\title{
Žanrovska obilježja Odiljenja sigetskoga Pavla Rittera Vitezovića
}

\section{Budišćak, Vanja}

Doctoral thesis / Disertacija

2020

Degree Grantor / Ustanova koja je dodijelila akademski / stručni stupanj: University of Zagreb, University of Zagreb, Faculty of Humanities and Social Sciences / Sveučilište u Zagrebu, Filozofski fakultet

https://doi.org/10.17234/diss.2020.163930

Permanent link / Trajna poveznica: https://urn.nsk.hr/urn:nbn:hr:131:239701

Rights / Prava: In copyright/Zaštićeno autorskim pravom.

Download date / Datum preuzimanja: 2023-04-26

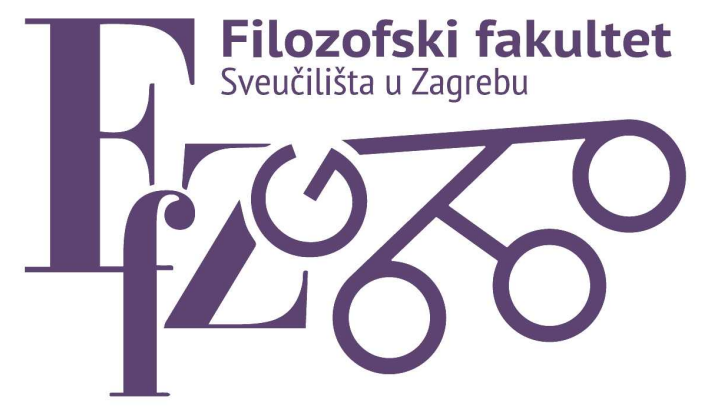

Repository / Repozitorij:

ODRAZ - open repository of the University of Zagreb Faculty of Humanities and Social Sciences
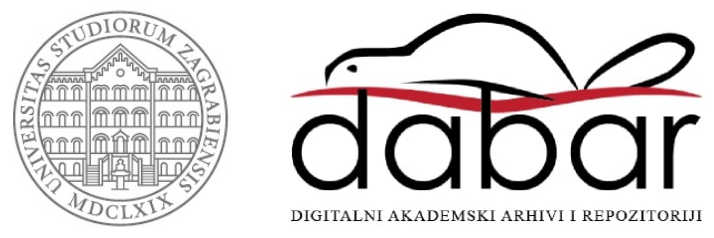
FILOZOFSKI FAKULTET

Vanja Budišćak

\section{ŽANROVSKA OBILJEŽJA ODILJENJA SIGETSKOGA PAVLA RITTERA VITEZOVIĆA}

DOKTORSKI RAD

Zagreb, 2020. 


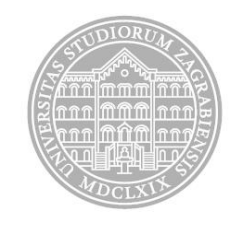

Sveučilište u Zagrebu

\title{
FILOZOFSKI FAKULTET
}

Vanja Budišćak

\section{ŽANROVSKA OBILJEŽJA ODILJENJA SIGETSKOGA PAVLA RITTERA VITEZOVIĆA}

\author{
DOKTORSKI RAD
}

\author{
Mentor: \\ akademik Pavao Pavličić, prof. emer.
}

Zagreb, 2020. 


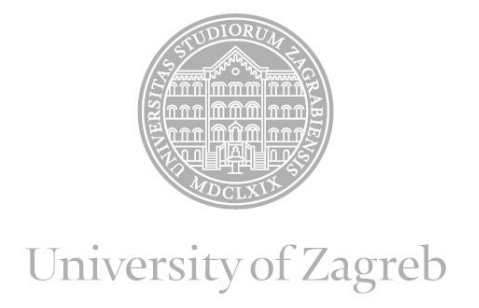

FACULTY OF HUMANITIES AND SOCIAL SCIENCES

Vanja Budišćak

\title{
GENRE CHARACTERISTICS OF PAVAO RITTER VITEZOVIĆ'S ODILJENJE SIGETSKO
}

\author{
DOCTORAL THESIS
}

Supervisor:

academician Pavao Pavličić, professor emeritus

Zagreb, 2020. 


\section{ŽIVOTOPIS MENTORA}

Akademik Pavao Pavličić hrvatski je književnik, prevoditelj, književni povjesničar te professor emeritus Filozofskoga fakulteta Sveučilišta u Zagrebu. Rođen je 1946. u Vukovaru, gdje je i završio osnovnu školu i gimnaziju. 1965. upisuje dvopredmetni studij komparativne književnosti te talijanskoga jezika s književnošću na zagrebačkome Filozofskom fakultetu, na kojemu 1969. stječe diplomu, a 1974. i doktorat obranivši tezu pod naslovom Sesta rima u hrvatskoj književnosti. Od 1970. radi kao asistent na Katedri za poredbenu povijest hrvatske književnosti Odsjeka za komparativnu književnost, a od 1985. i kao redoviti profesor, vodeći većinom kolegije iz komparativne povijesti domaće književnosti, književne teorije i metrike. Tijekom svoje znanstvene karijere objavio je zavidan broj rasprava i studija glavninom posvećenih našoj ranonovovjekovnoj književnosti, modernoj hrvatskoj lirici, književnoj genologiji i semantici stiha te redovito sudjelovao na znanstvenim skupovima u zemlji i inozemstvu. Ujedno je i autor više od stotinu neznanstvenih knjiga, čiji se žanrovski raspon proteže od zbirki pripovijedaka, preko fantastičnih i kriminalističkih romana te romana za djecu, pa sve do lirsko-memoarskih, feljtonističkih i esejističkih proza. Za svoj je rad primio niz nagrada, od kojih posebno vrijedi izdvojiti Nagradu „Vladimir Nazor“ za životno djelo za 2015. godinu. Član je Hrvatske akademije znanosti i umjetnosti, Matice hrvatske i Društva hrvatskih književnika. 


\section{SAŽETAK}

Zamišljena kao prvo sustavnije istraživanje generičkih posebnosti najpoznatijega književnog ostvarenja Pavla Rittera Vitezovića, ova disertacija nastoji detektirati karakteristična obilježja čitavog niza pisanoknjiževnih, usmenoknjiževnih, pučkoknjiževnih, poluknjiževnih i izvanknjiževnih žanrova od kojih je „sastavljeno“ Odiljenje sigetsko (Linz, 1684.), a sve s nakanom da za njegov kompleksan i do sada kojekako definiran žanrovski identitet pokuša iznaći što precizniju oznaku. Oslanjajući se na zapažanja suvremene književne genologije ili teorije žanr(ov)a, poglavito na ona utjecajne teorije govornih žanrova Mihaila Bahtina, analiza navedene žanrove motri kao podjednako tekstualne i kontekstualne konstrukte, slijedom čega i njihovu pojavu unutar korica Odiljenja dosljedno teži protumačiti kako unutartekstualnim i književnopovijesnim, odnosno poetičkim, tako i intertekstualnim, recepcijskim, ideološkim, pa čak i društvenopovijesnim razlozima. Zahvaljujući takvu pristupu, disertacija omogućuje puni uvid u dosad zanemarivanu generičku slojevitost Odiljenja sigetskog te pritom podastire mnoštvo opipljivih dokaza njegove uvjetovanosti raznim izvantekstualnim činiteljima, zbog udovoljavanja kojima ga Pavao Ritter Vitezović i jest držao najsvrsishodnijim realizirati kao kompozicijski i formalno rascjepkan višežanrovski sastavak koji će različite čitatelje biti u stanju navesti na posve različita generička očekivanja. Kao najvažniji rezultat provedenoga istraživanja stoga se i ispostavlja ta u potpunosti „osvježena“, iz novih spoznaja izrasla generička percepcija ovoga možda i najosebujnijeg književnog teksta naše barokne i ne samo barokne književnosti, koji zbog svojega „mozaičnog“ žanrovskog identiteta učinkovito izmiče svim pokušajima jednoznačnoga generičkog svrstavanja.

KLJUČNE RIJEČI: Pavao Ritter Vitezović, Odiljenje sigetsko, barokna književnost, žanrovi, književna genologija, teorija žanra. 


\section{SUMMARY}

The basic intention of the doctoral dissertation entitled Genre Characteristics of Pavao Ritter Vitezović's „Odiljenje sigetsko “ is to offer the first systematic genological analysis of one of the most difficultly genre-identifiable literary works in the history of Croatian literature in general - Pavao Ritter Vitezović's Odiljenje sigetsko (Linz, 1684.).

After the introductory part of the text, which briefly presents the problem orientation of the dissertation and its objectives, the second chapter establishes a theoretical framework within which the research will be conducted. Given that it is an exploration of the genre aspect of the selected text, it is precisely the literary genology or genre theory that has been shortly recalled as the most appropriate theoretical starting point. Among the various genealogical approaches, the theory of speech genres of the Russian literary theorist Mihail Bahtin is then chosen, especially because its postulates in contemporary genology have an important place and can therefore prove as extremely useful in the analysis of genre-intricate works such as Odiljenje sigetsko.

The genre and all other peculiarities of Vitezović's Odiljenje sigetsko are discussed in the next chapter, which also recalls the concerns encountered by his readers during its genre classification. Moreover, this chapter also points to the various definitions by which Pavao Ritter himself identified his first literary work in the Croatian language in the paratextual parts of three of its editions, published for his lifetime. Various - partly explicit and partly implicit - genre categorizations then followed the Odiljenje from the eighteenth century to the present day, when in literary historical accounts and studies it is possible to encounter extremely different attempts of its generic identification, but subsequently confirmed with insufficiently persuasive evidences.

The fourth chapter of the dissertation - which opens a detailed account of the complex genre system of Croatian baroque literature, within the framework of which Vitezović wrote his work - is fully devoted to exploring the specific genre characteristics of Odiljenje sigetsko. After the reconstruction of the baroque genre system, the following is an analysis of the genre characteristics of the very diverse origins by which Pavao Ritter has flowed Odiljenje from the first to the last of its verse, whereby the text does not only locate a number of peculiarities of baroque and pre-baroque literary genres ranging from fictitious epistle and lament to epitaph and allegory. Moreover, the analysis confirms that Odiljenje is filled with recognizable features and even complete examples of genres of folklore literature (bugaršćica, 
dirge, prayer, blessing, curse, proverb, riddle, etc.), as well as those of literary and even semiliterary and marginal literary such as instruction, war speech, oath, etc.

Starting from the insights from the previous section, in chapter five we approach Odiljenje as a unique (compact) literary text composed of features and complete examples of an unusually large number of literary and not just literary genres. In order to try to find as precisely and as comprehensively as possible genre determinant to such literary work, in this chapter it is viewed on the basis of the various contexts in which it is found, starting from that of the author's oeuvre, through intertextual and literary-historical context, to the context of the targeted and real audience. Here we also look for its possible genre patterns and eventual genre successors, and then we propose a completely new genre definition that best fits its hybrid, that is, "all-genre" identity.

In the concluding, sixth chapter of the dissertation, we briefly recall the most important results of our research into the genre characteristics of the Odiljenje sigetsko and point to the need for further genological studies of this extremely intriguing Pavao Ritter Vitezović's literary work, whose peculiarity is evident not only in the framework of the domestic baroque literature, but also in those of Croatian literature in general.

KEYWORDS: Pavao Ritter Vitezović, Odiljenje sigetsko, baroque literature, genres, literary genology, genre theory. 


\section{S A D R Ž A J}

1. UVOD 1

2. (KNJIŽEVNI) ŽANR KAO TEORIJSKA KATEGORIJA ...................................... 3

2. 1. (KNJIŽEVNI) ŽANR: TERMINOLOŠKE I DEFINICIJSKE NEDOUMICE ......... 6

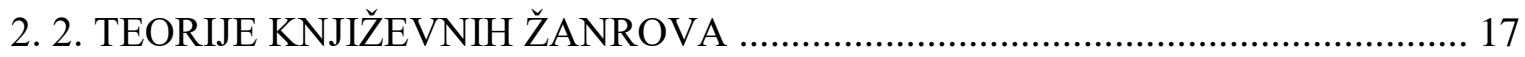

2. 3. BAHTINOVA TEORIJA GOVORNIH ŽANROVA I NJEZINI SUVREMENI

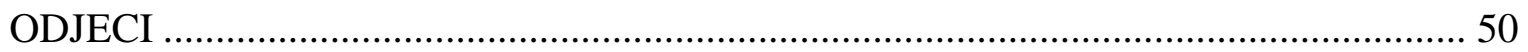

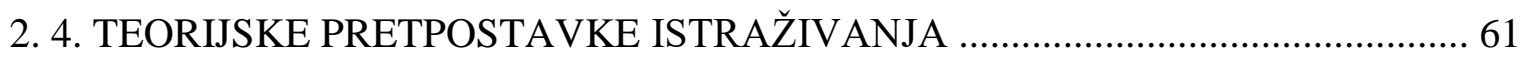

3. ODILJENJE SIGETSKO I PROBLEM ŽANROVSKOG ODREĐENJA ................ 70

3. 1. IDEJNE, SADRŽAJNE I FORMALNE POSEBNOSTI ODILJENJA ..................... 73

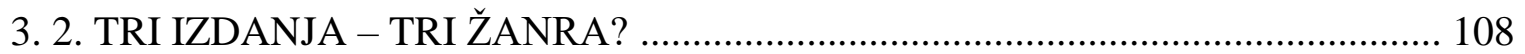

3. 3. ODILJENJE U OČIMA OSAMNAESTOSTOLJETNIH ČITATELJA ................. 119

3. 4. ROMANTIČKE ŽANROVSKE DVOJBE ...................................................... 125

3. 5. ŽANROVSKI STATUS ODILJENJA U KNJIŽEVNOPOVIJESNIM

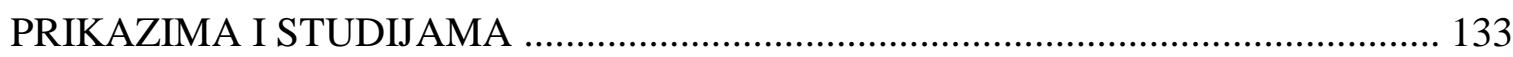

3. 6. NOVI ŽANR(OVI) NA VIDIKU? NAJRECENTNIJA ČITANJA ....................... 144

\section{PRIMARNI I SEKUNDARNI GOVORNI ŽANROVI I ŽANROVSKA OBILJEŽJA}

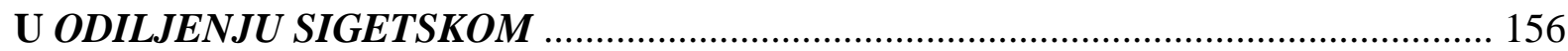

4. 1. POJAM I STATUS ŽANRA U BAROKU I ŽANROVSKI SUSTAV

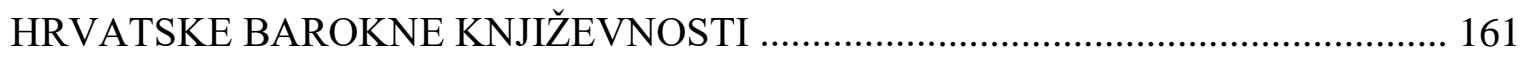

4. 2. PISANOKNJIŽEVNE ŽANROVSKE SASTAVNICE ODILJENJA

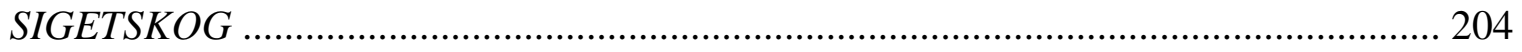

4. 2. 1. Odiljenje - barokni povijesni ep? .......................................................... 206

4. 2. 2. Poslanice (heroide) i konzolacija ............................................................. 231

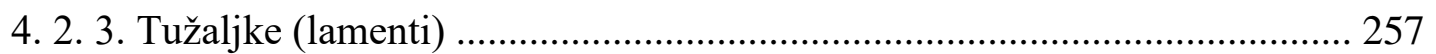

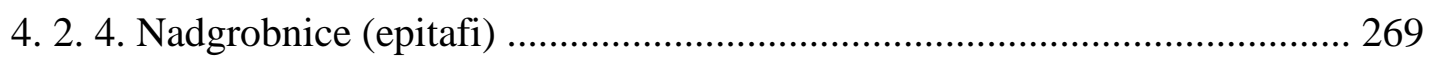

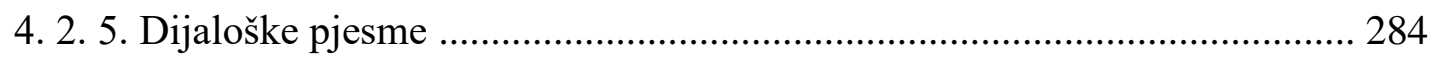

4. 2. 6. Lirske pohvalnice (panegirici) …............................................................. 297

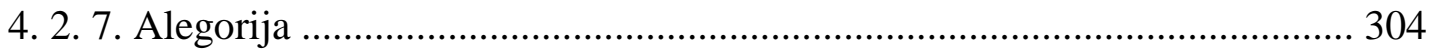

4. 2. 8. Dramska obilježja (Odiljenje kao barokna varijanta postajne drame?) ..... 312 


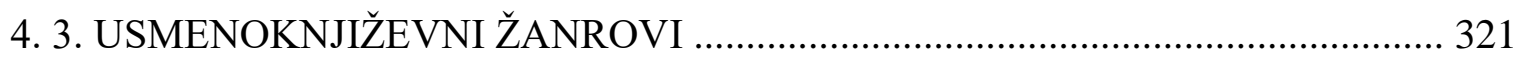

4. 3. 1. Žanrovski rekviziti usmene epske pjesme ............................................ 337

4. 3. 2. Naricaljke ............................................................................................ 358

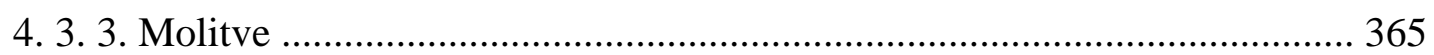

4. 3. 4. Usmenoknjiževne pohvalnice (,počasnice“) i hvale ................................ 369

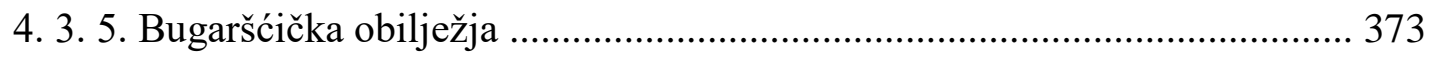

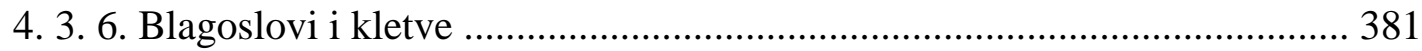

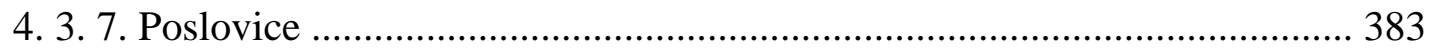

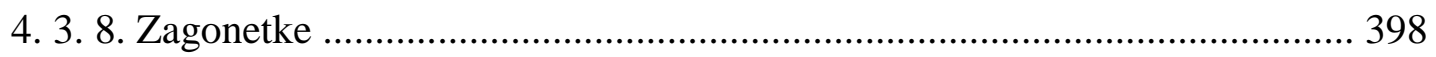

4. 4. POLUKNJIŽEVNI I IZVANKNJIŽEVNI ŽANROVI ..................................... 401

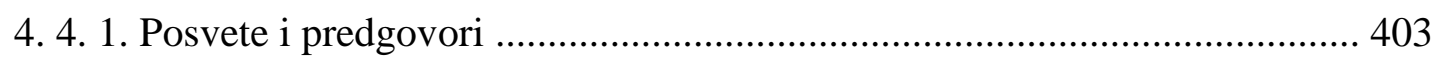

4. 4. 2. Ratni govor i zakletva (prisega) ............................................................. 418

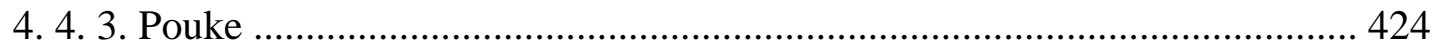

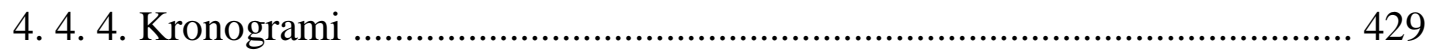

4. 5. ELEMENTI PUČKOKNJIŽEVNIH ŽANROVA U ODILJENJU SIGETSKOM

5. ODILJENJE SIGETSKO KAO SEKUNDARNI GOVORNI ŽANR ....................... 462

5. 1. ODILJENJE - BAROKNO DJELO (EUROPSKI I HRVATSKI KONTEKST) .. 463

5. 2. ODILJENJE - „VITEZOVIĆEVSKO“ DJELO (KONTEKST AUTOROVA

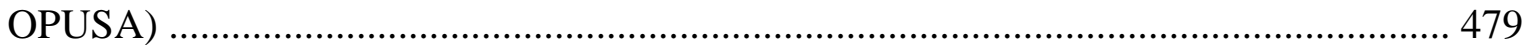

5. 3. ODILJENJE I ADRIJANSKOGA MORA SIRENA PETRA ZRINSKOG ............... 492

5. 4. „С̆TAVCI“ I „ŠTAVCI“ ILI KOMU I ČEMU ODILJENJE? ................................ 509

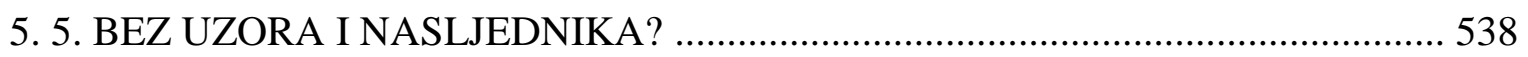

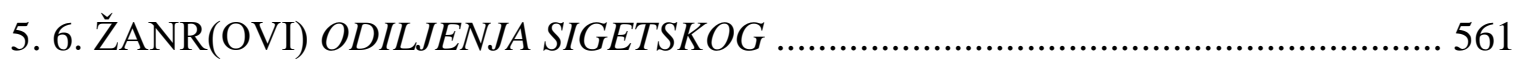

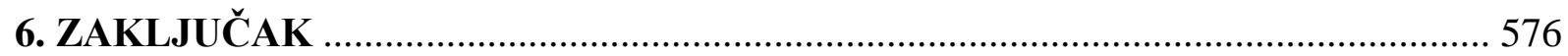

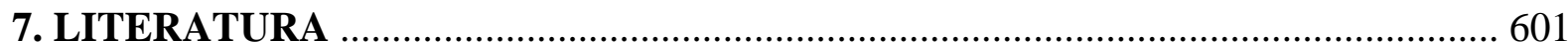




\section{UVOD}

Spoznaja da se baš svaki diskurs, pa tako i onaj o samim žanrovima, nužno oblikuje i razumijeva (tumači) u nekim žanrovskim „okvirima“ danas više ne predstavlja novost. Zahvaljujući kontinuiranoj istraživačkoj fasciniranosti kategorijom žanra, koja je u drugoj polovini prošloga stoljeća nadrasla okvire znanosti o književnosti prelivši se na čitav niz drugih disciplina, u posljednjih nekoliko desetljeća svjedoci smo naglog porasta teorijskih i praktičnih pristupa žanrovima iz svih područja čovjekove govorne i/ili pisane komunikacije. Jedno od tih, žanrovima „bogatih“ područja definitivno je i ono akademsko, a u zamišljenome sustavu akademskih žanrova svojom se važnošću, dugovjekošću i izrazitom postojanošću forme izdvaja upravo žanr doktorske disertacije, ${ }^{1}$ čija (ne)pisana poetika pred sve autore stavlja, između ostalih, i imperativ trodijelne strukture (uvod - središnji dio ili razrada teme zaključak). ${ }^{2} \mathrm{U}$ prvome, uvodnom dijelu teksta trebalo bi pritom - kako spomenuta ,poetika“ disertacije i nalaže - podastrijeti podrobnije objašnjenje same teme istraživanja, a kroz dosadašnju se, poglavito suvremenu praksu ovoga žanra to pojašnjenje uvriježilo izvoditi „seciranjem“ njegova uobičajeno kompleksnog naslova. Da bi unutar utvrđenoga akademskog konteksta uspješno postiglo temeljnu svrhu, ni ovomu doktorskom istraživanju ne preostaje, stoga, ništa drugo no u svojoj se problemskoj okrenutosti žanrovskim osobitostima odabranoga književnog teksta od samoga početka osloniti na specifične konvencije žanra disertacije. A to, drugim riječima, znači - poći upravo od naslova.

Ono što bi, kada je o naslovnom prizivanju kategorije žanra riječ, odmah na početku valjalo istaknuti jest to da da će se (i) naredno istraživanje temeljiti uglavnom na onim (književno)teorijskim predodžbama koje su, naročito od sredine 20. st., u najvećoj mjeri i potaknule rečenu višedisciplinarnu ,pomamu“ za žanrovima. Takvo teorijsko opredjeljenje, konkretno, iziskivat će napuštanje zastarjelih uvjerenja o „književnim vrstama“ kao svevremenskim i nepromjenjivim obrascima pisanja u korist modernih shvaćanja žanrova kao (povijesno) promjenjivih, dinamičnih i sveprisutnih entiteta koji usmjeravaju ne samo proizvodnju, već i recepciju diskursa, i to u skladu s određenom situacijom ili kontekstom.

\footnotetext{
${ }^{1}$ Detaljnije o (nekim) akademskim, odnosno žanrovima akademske ili znanstvene proze (među kojima i onome doktorske disertacije), s posebnim osvrtom na retoričko-strukturna pravila koja obvezuju njihove autore u: Oraić Tolić 2011. O pojedinim dosad neistraživanim značajkama disertacije, koju suvremeni proučavatelji zahvaljujući njezinu upijanju obilježja čitavog niza srodnih znanstvenih žanrova (npr. eseja, književne kritike, osvrta itd.) i sposobnosti funkcioniranja u različitim retoričkim situacijama ili kontekstima - vide kao multi-žanr ili hibridni žanr, naročito u: Paré, Starke-Meyerring i McAlpine 2009: 179-193.

${ }^{2}$ Primjerice, Dubravka Oraić Tolić u svojoj knjizi Akademsko pismo tako navodi da se u svim akademskim radovima - što, dakako, vrijedi i za doktorsku disertaciju - osnovni tekst mora sastojati od tri dijela, i to, redom: uvoda, tijela teksta (ili razrade teme) te zaključka (usp. Oraić Tolić 2011: 118).
} 
Potonju teorijsku zamisao dosad su već višestruko potvrdile kako nebrojene praktične analize kulturnih, tako i one akademskih, političkih, korporativnih, internetskih (elektroničkih) i mnogih drugih „svakodnevnih“ Žanrova, što će reći da se (ni) ovo istraživanje nipošto neće kretati nepoznatim, odnosno nimalo ili tek jedva prokrčenim teorijskim „terenom“. Naprotiv, pojavljuje se ono - a tako ga valja i shvatiti - kao jedna od neizbježnih „posljedica“ suvremenoga buđenja svijesti o prisutnosti i važnosti žanrova u baš svakome segmentu (među)ljudske komunikacije, i to bez obzira na činjenicu da se usredotočuje upravo na onu književnoumjetničku - sferu u kojoj ni o važnosti, a još manje o prisutnosti žanrova ozbiljnijega spora dosad zapravo i nije bilo.

Premda upućuje na jedno znatno arhaičnije poimanje književnih žanrova, naslovno njihovo „rastavljanje“ na specifična „obilježja“ također proizlazi iz uvažavanja suvremenih teorijskih pretpostavki o njihovoj povijesnosti, odnosno izraslosti iz stanovitoga (književno-, pa i društvenopovijesnog) okvira. O žanrovskim obilježjima navedena književnog djela u nastavku tako neće biti riječi samo zbog činjenice da je većina žanrova „zastupljena“ u njemu tek nekim svojim ,prepoznatljivim“ (sadržajnim, stilskim i/ili formalnim) značajkama, ali ni isključivo radi nemogućnosti da se utvrdi jesu li redom svi (ili koji to konkretno) uključeni Žanrovi u vrijeme nastanka djela doista i prepoznavani na isti način, odnosno jesu li tada uopće makar uživali status žanra kao takvog. Štoviše, iako se zbog potonjeg ograničenja doista i čini da bi najuputnije bilo (oprezno) govoriti o tek „obilježjima“ ovoga ili onoga žanra, treba znati da se upravo inzistiranjem na ,žanrovskim obilježjima“" najbolje može zahvatiti „bit“ vremena o kojemu je ovdje riječ, a koje je (književnim) žanrovima pristupalo na način korjenito drugačiji od onoga na koji se to činilo kasnije, pa i onoga na koji se to čini još i danas. Naime, u razdoblju u kojemu je spomenuto djelo i ugledalo svjetlo dana - a riječ je o drugoj polovini 17. stoljeća, odnosno o književnoumjetničkoj epohi baroka - žanrovi se ni u teoriji (tj. ni u poetičkim spisima, antologijama itd.) ni u praksi nisu (još) shvaćali kao cjeloviti, kompaktni entiteti, već upravo kao skupovi više ili manje postojanih (,karakterističnih“) obilježja koja su - ovisno o volji pisca - slobodno mogla prelaziti iz jednih žanrovskih okvira u druge. Baš s tim prošlim, baroknim shvaćanjem književnih žanrova - o kojemu će doskora biti i znatno više riječi - nužno je, dakle, računati želi li se žanrovskoj dimenziji odabrana djela uistinu pristupiti iz najsuvremenije moguće (književno)teorijske perspektive.

A „odabrano“ književno djelo u analizi kojega će se u nastavku iskuša(va)ti praktična primjenjivost ključnih postulata moderne teorije žanra bez ikakve bi se dvojbe moglo uvrstiti u red sadržajno i formalno najosebujnijih ostvarenja u povijesti hrvatske, a vrlo vjerojatno i 
europske (ranonovovjekovne) književnosti. Odiljenje sigetsko (1684.) u plodnome se i raznorodnom opusu našega baroknog polihistora, pjesnika, povjesničara, leksikografa, publicista, bakroresca i tiskara Pavla Rittera Vitezovića (Senj, 1652. - Beč, 1713.) izdvaja ne samo kao njegovo prvo hrvatsko tiskom objavljeno, već i - kako mu počesto danas tepaju književni povjesnici - najvažnije književno djelo na vernakularu, iako se pred neupitnom literarnom kvalitetom brojnih mu tekstualnih neobičnosti u našoj književnoj historiografiji (pre)dugo zatvaralo oči. Ni očita činjenica da specifičnost Vitezovićeva djela možda i do najvećeg izražaja dolazi baš na žanrovskoj razini pozornost naših stručnjaka nije dospjela privući desetljećima, zbog čega su se i prvi ozbiljniji pokušaji njegova žanrovskog tumačenja i određenja pojavili tek potkraj prošloga i početkom (n)ovoga stoljeća. O rezultatima tih će interpretacija više riječi biti na stranicama koje slijede, a da bi se istraživanju žanrovskih posebnosti Vitezovićeva Odiljenja sigetskog uopće i moglo pristupiti, potrebno je - za početak - predstaviti analitičku aparaturu, odnosno usustaviti teorijski okvir istraživanja. Tomu je zadatku, s posebnim osvrtom na najvažnije etape u razvoju suvremene teorije žanra, u cijelosti posvećeno sljedeće poglavlje.

\section{2. (KNJIŽEVNI) ŽANR KAO TEORIJSKA KATEGORIJA}

Žanrovska je klasifikacija samo jedan od mogućih, a ujedno i jedan od najstarijih načina razvrstavanja književnosti. ${ }^{3}$ Premda se, u praksi, ono neizbježno preklapa s drugim tipovima ili varijantama klasifikacije (zbog čega se tako, primjerice, govori o žanrovima pisane i žanrovima usmene književnosti ili, još preciznije, o žanrovima engleske romantičke književnosti, žanrovima (novo)latinske književnosti hrvatskoga baroka i sl.), svrstavanje književnih djela u „ladice“ konkretnih žanrova (a gdjekad i one rodova, vrsta i podvrsta) temeljna je predradnja svakoga - podjednako stručnog i „laičkog“ - bavljenja književnošću i zato mu se u okvirima književne znanosti i pristupa s osobitom pozornošću. Da je kategoriju žanra i žanrovske podjele doslovce nemoguće izbjeći kada je književnost u pitanju ponajbolje bi mogli posvjedočiti već i suvremeni književnoteorijski priručnici, u kojima se - kao svojevrsna „mantra“ - redovito ističe da bez razumijevanja žanrova ne može biti ni „razumijevanja književnosti, jer su oblici u kojima se pojavljuju književna djela često od presudne važnosti za shvaćanje i doživljavanje književnosti““ (Solar 1996: 128). Uistinu, baš svaki se (književni) tekst, prije svega, piše, čita i tumači sa sviješću o konkretnome žanru

\footnotetext{
${ }^{3} \mathrm{O}$ višestrukim mogućnostima klasifikacije književnosti, odnosno o njezinu razvrstavanju prema različitim načelima ili kriterijima (npr. žanrovskom, jezičnom, nacionalnom, (književno)povijesnom itd.) detaljnije u: Solar 1971: 61-75; 1996: 120-176 i 2014: 33-49.
} 
kojemu „pripada“ ili u kojemu, kako to običavaju naglasiti suvremene teorije žanrova, „participira“, a ta svijest ujedno sa sobom povlači i predodžbu ne samo o „karakterističnim“ tekstualnim značajkama koje to djelo uključuje ili ne uključuje, već i o njegovoj stanovitoj funkciji u danome književnom, odnosno kulturnom i društvenopovijesnom kontekstu.

Bilo je to, na neki način, piscima i čitateljima već poodavno jasno, pa se od samih početaka teorijskoga i kritičkog promišljanja književnosti kategorija žanra, odnosno problematika generičkoga razvrstavanja književne ,građe“ opravdano našla u samom središtu zanimanja. Na važnost koja se - od antike do danas - u književnoj teoriji i praksi pridavala žanrovskoj dimenziji tekstova tako upućuju ne samo eksplicitni teorijski iskazi o žanrovima, odnosno pokušaji da se u poetičkim traktatima p(r)opišu ključne i svevažeće značajke tada preferiranih žanrova ili, pak, naprosto utvrdi žanrovski sustav za dano razdoblje, nego i - na tada važećim teorijskim uvidima zasnovana - izravna generička određenja što su ih u paratekstualne segmente (naslove, podnaslove, predgovore, posvete, napomene, pogovore itd.) svojih djela kao putokaz čitateljima uključivali njihovi autori. Ne treba zaboraviti ni obiman korpus kritičkih tekstova i studija posvećenih istraživanjima žanrovskih posebnosti pojedinačnih (književnih) djela ili izdvojenih žanrova u kontekstu nacionalne i/ili svjetske književnosti, iscrpne prikaze čitavih književnopovijesnih razdoblja iz vizure njihovih generičkih sustava, ali ni organizirane napore pripadnika pojedinih književnih pokreta, škola i epoha (primjerice, onih okupljenih u različitim avangardnim pravcima) usmjerene na korjenito redefiniranje kategorije žanra, rušenje dotadašnjih generičkih normi i ustoličenje novih žanrovskih sustava sačinjenih od dotad posve nepoznatih (mahom hibridnih) žanrova.

Iako se pritom - zbog nedovoljne izgrađenosti žanrovske terminologije uopće $-\mathrm{s}$ identičnim problemima suočavaju gotovo sve inozemne znanosti o književnosti, u (ne odveć brojnim) žanrovskim čitanjima hrvatske književnosti kao najkrupniji se problem ispostavlja posve pogrešno korištenje pojedinih genoloških termina porijeklom iz novije teorije žanrova, koje ujedno daje do znanja da je sa suvremenom književnom genologijom naša znanost već odavno izgubila korak. Te i takve nedosljednosti u uporabi žanrovskoga nazivlja u nas su, kako se čini, možda i najočitija posljedica dugogodišnjega ignoriranja najrecentnijih teorija književnih žanrova, odnosno gotovo automatskoga pristajanja uz poodavno već nadvladana teorijska polazišta u kojima su se - umjesto (povijesno promjenjivoga) književnoga žanra ili vrste - kao temeljne genološke kategorije shvaćali (unaprijed zadani, a onda neizbježno i svevremenski) književni rodovi (lirika - epika - drama). Činjenica da je u posljednjih pola stoljeća i hrvatska književna znanost dočekala prijevode nekih od najutjecajnijih genoloških studija (između ostalih, i one Borisa Tomaševskog, Northropa Fryea i Hansa Roberta Jaussa) 
samo donekle može popuniti prazninu nastalu zbog posvemašnjeg izostanka teorijskih rasprava o žanru ili makar (samostalnih) pregleda najsuvremenijih spoznaja s područja književne genologije, naročito primjetnog od devedesetih godina 20. st., dok o apsolutnoj domaćoj nezainteresiranosti za (kako su pokazala inozemna iskustva, vrlo plodonosnu) primjenu aktualnih polazišta teorije žanrova i u znanosti o književnosti srodnim disciplinama (prije svega, u lingvistici i retorici) također ne treba trošiti previše riječi.

Da na samu praksu žanrovskih istraživanja u nas dosadašnji uistinu malobrojni i mahom tek uzgredni i ilustrativni osvrti na neke od recentnih teorija književnih žanrova nisu, nažalost, imali gotovo nikakvoga utjecaja posvjedočiti nam može već i izostanak eksplicitnoga teorijskog utemeljenja, koji u većini tih tekstova zapravo sugerira prešutno opredjeljenje za tradicionalnija shvaćanja kategorije žanra. To sustavno prešućivanje konkretnih teorijskih polazišta, koja pažljivijem čitatelju može ipak razotkriti upotrijebljena (redovito zastarjela) analitička aparatura, nipošto, međutim, nije produkt svjesnog odustajanja od postulata suvremene književne genologije, u koje su autori tih istraživanja ionako upućeni vrlo slabo ili gotovo nimalo. Naprotiv, ono je izravna posljedica pristajanja uz višekratno iskušane, kroz raniju praksu ovjerovljene teorijske premise starijih teorija žanrova koje se u našoj književnoj znanosti još uvijek poimaju kao neprikosnovene i samorazumljive, zbog čega na njih - vjeruju to naši stručnjaci - čitatelja nije potrebno posebno podsjećati. A da se distanciranje od pristupa koji su žanrove tretirali kao nadpovijesne klase s nepromjenjivim značajkama u korist njihova shvaćanja kao kontekstualno uvjetovanih entiteta nipošto ne bi smjelo pojmiti kao tek čin nekritičkoga pristajanja uz teorijska strujanja koja su trenutno „u modi“, nego kao nezaobilazan preduvjet znatno preciznijega dešifriranja i razumijevanja žanrovskih obilježja svih književnih ostvarenja, potvrditi ponajbolje može njihova primjena na djela poput Odiljenja sigetskog Pavla Rittera Vitezovića. Svedu li se spomenuta teorijska ishodišta suvremene književne genologije na interpretativno „najpotentnije“ premise, kao što će se i ovdje to učiniti u nastavku, moći će ona demonstrirati svoju izrazitu korisnost čak i u pristupu onim književnim tekstovima u žanrovskim tumačenjima kojih su tradicionalnije teorije žanrova redovito pokazivale svoju ograničenost, nedoraslost, pa i posvemašnju neuporabljivost, kao što je to nerijetko bio slučaj i s Vitezovićevim Odiljenjem. I premda ono zbog svoje (već na prvi pogled uočljive) žanrovske višeslojnosti s punim pravom nosi „stigmu“ djela koje izmiče gotovo svakoj dosad provedenoj klasifikaciji, upravo žanrovski se aspekt Odiljenja, kako će se i ovdje pokazati, definitivno nameće kao ključ njegova razumijevanja, $\mathrm{i}$ to poglavito stoga što se raspetljavanje zamršenoga klupka generičkih obilježja ispostavlja kao jedini mogući način da se ispravno odgovori i na dosad tek načeta 
pitanja njegovih vjerojatnih uzora, ciljane publike, konkretne namjene, a na koncu i „krovnoga“ žanrovskog određenja.

\section{1. (KNJIŽEVNI) ŽANR: DEFINICIJSKE I TEORIJSKE NEDOUMICE}

Termin „žanr“ (fra. i engl. genre; njem. Gattung) izvorno je francuske provenijencije (,genre“) i potječe od grčke riječi „genos“, odnosno latinske ,genus“, što doslovno znači: vrsta, rod, tip. Taj naziv - posuđen iz domene prirodnih znanosti - u književnoznanstvenim se istraživanjima rabi tek od 20. stoljeća, i to ponajprije zahvaljujući ruskim formalistima, koji su ga preuzeli iz francuske terminologije i njime sve češce počeli zamjenjivati dotad uvriježene pojmove „(književna) vrsta“ i „(književni) rod“. Poradi svojedobnoga snažnog ruskog (a kasnije i još snažnijega angloameričkog) utjecaja, u drugoj se polovini 20. stoljeća naziv ,žanr“ udomaćio i u našoj književnoj znanosti, i to usprkos nimalo nevažnoj činjenici da nije podudaran, kako je to na više mjesta opravdano upozorio Zdenko Škreb, fonološkome sustavu hrvatskog jezika. ${ }^{4}$

Kada se govori o žanru, svakako treba imati na umu da je riječ o jednomu od, upozorit će Zdenko Lešić, daleko „najkontroverznijih pojmova u povijesti književnokritičkog mišljenja“" (Lešić 2008: 289). Teorije 20. stoljeća, štoviše, zarana su spoznale da žanrovska pitanja nadilaze okvire znanosti o književnosti i uvelike se (do)tiču i područja lingvistike, filozofije, sociologije, povijest itd., što je - naposljetku - rezultiralo time da je kategorija žanra toliko proširena da se danas shvaća kao onaj teorijski pojam koji „uključuje, kroz prizmu problema koje obuhvaća, sve nesigurnosti, kontradikcije i zabune postmoderne epohe, bilo u kulturnim, intelektualnim ili političkim sferama“ (Duff 2000: 15). U naše vrijeme, nastavlja Duff, žanr tako najčešće služi kao ,alat za sve ambicioznije interdisciplinarne poslove, koji u mnogim slučajevima ne uspostavljaju nikakav odnos prema književnim strukturama bilo kakve vrste“ (Duff 2000: 16), što će reći da oni tradicionalni zaključci prema kojima je učenje o žanrovima isključivo temeljni dio ,svake poetike kao doktrine ili teorije književnosti, jer ono uključuje shvaćanje osnovnog principa klasifikacije književnih djela i

\footnotetext{
${ }^{4}$ Usp. Škreb 1976: 11 i 1985: 11-21. Škreb se iz toga razloga zalagao za uporabu termina „književna vrsta“, kojim je „pokrivao“ onu razinu genološke klasifikacije dotad obuhvaćanu nazivom „žanr“, izravno se tako nadovezujući na razmišljanja Pavla Pavličića, koji je (samo nekoliko godina ranije) ustvrdio kako bi temeljni književnogenološki pojam trebao biti upravo onaj vrste (usp. Pavličić 1983: 57). Pavličić, ipak, pritom nije želio u potpunosti isključiti uporabu naziva, žanr“, kojega vidi kao odrednicu za onu kategoriju koja se u hijerarhiji žanrovske klasifikacije nalazi na nižem stupnju od književne vrste.
} 
time određuje specifičnost književnosti u odnosu na druge oblike ljudske aktivnosti““ (Solar 1971: 61), sami od sebe naprosto vape za temeljitom revizijom i proširenjem. ${ }^{5}$

Usredotočimo li se, ipak, na uže područje književnosti, nepostojanje „stalne“ (,svevažeće“ ili „opće“) definicije žanra bit će moguće protumačiti mnogo jednostavnijim razlogom, i to činjenicom da mu se u različitim književnim razdobljima ili prostornovremenskim kontekstima pristupalo, u pravilu, na ne uvijek jednak način. Da je zaista tomu i bilo tako, trebao je nagovijestiti i već u uvodu navedeni primjer specifičnoga shvaćanja žanrova u baroknoj književnosti, u koje je proniknuo francuski filozof i teoretičar književnosti Jean-Marie Schaeffer, dokazavši u svojoj izvrsnoj studiji o pred- i (post)romantičkim pristupima književnim žanrovima da se prije romantizma žanr nije poimao kao pojam za tumačenje, već je služio kao mjerilo prema kojem su pojedinačna djela bila vrednovana. U predromantičkim su književnim razdobljima, konkretno, žanrovski pojmovi (tj. nazivi za određene žanrove) percipirani kao oznake za puke skupove kriterija uz pomoć kojih se procjenjivala usklađenost svakoga pojedinog književnog djela s tada vladajućom normom, a ne - kao što će se to uvriježiti kasnije - kao nazivi za klasifikacijske alate ili skupine. Iz toga su razloga žanrovske hijerarhije koje su u književnosti vrijedile do polovine 18. stoljeća redom bile zasnovane na nabrajanju i funkcionirale kao isključivo vrednujuće, a nisu težile uspostavljanju općega (,,logičkog“) žanrovskog sustava, što je, uostalom, i bilo u skladu s tadašnjim shvaćanjem književnosti kao djelatnosti zasnovane na ponavljanju, odnosno imitiranju idealnih, većinom antičkih modela (tu su zamisao o književnosti kao imitirajućoj aktivnosti zastupali podjednako branitelji antičkih teorija, kao i zagovornici onih modernih). Onodobna je teorija žanrova stoga i bila samo praktične naravi i svoje je opise predstavljala kao preskriptivne tvrdnje, pa su i u njoj (tj. u tadašnjim poetičkim traktatima) temeljna jedinica analize bila konkretna tekstualna obilježja (dakle, stabilna i nepromjenjiva pravila) koja su služila kao identifikacijski znakovi, a ne žanr kao cjelina. Ispitivao se, drugim riječima, odnos teksta prema tome skupu pravila, koji je zapravo bio onaj isti skup pravila kojega je bilo moguće naći u uzornim tekstovima što ih je valjalo imitirati.

No, potkraj 18. st. zbila se nagla i korjenita promjena u shvaćanju žanrova jer se književna teorija kao takva napokon prestala percipirati kao normativna, a počela razumijevati

\footnotetext{
${ }^{5}$ Isto se može reći i za onu pet godina „mlađu“ Škrebovu tvrdnju kako se „književni tekst bitno (...) razlikuje od neknjiževnoga tim što je svako književno djelo primjerak određene vrste“ (Škreb 1976: 41), tj. žanra. Danas, naime, prevladava shvaćanje kako je ne samo svaki tekst, već upravo svaki tip diskursa ,primjerak“ određenoga žanra, što znači da se ,razlučivost“ književnosti na žanrove više ne može držati jednom od njezinih i samo njezinih specifičnosti, kao što je to svojedobno mislio Škreb. Stoga ni proučavanje žanrova ili, kako reče Solar, „učenje o žanrovima“ više ne može biti (a i nije) ekskluzivnom svojinom teorije književnosti, već ga suvremena književna znanost neizbježno dijeli s čitavim nizom srodnih ili manje srodnih disciplina.
} 
kao objašnjavajuća aktivnost. Slijedom toga, ni svaki se pojedinačni žanr više nije mogao sagledavati kao „zbir normi“ izdvojivih iz „uzornih“ književnih djela koja je u svemu valjalo slijediti, nego isključivo kao kompaktna kategorija ili entitet koji osigurava „organsku cjelovitost“" književnoga teksta, odnosno koji utemeljuje njegovu bit, porijeklo i načelo prirodne uzročnosti, što onda znači da se - po prvi put u književnoj povijesti - počinje zamišljati „utjelovljenje“ konkretnoga žanra u danomu tekstu ili, obrnuto, ,pripadanje“ teksta pojedinome žanru. Već u romantizmu se tako, dakle, bitna obilježja književnosti težilo objasniti pomoću žanrovskih definicija, pa upravo otad i prevladava shvaćanje prema kojemu se žanr - kao samostalan i cjelovit (kompaktan) entitet - može „dodati“ nekom tekstu. Nije stoga nimalo neobično što se još i dan danas književna stvarnost najčešće zamišlja kao dvojna, pri čemu su na jednomu polu tekstovi, a na drugom žanrovi, pa se kao predmet generičkih istraživanja redovito nameće odnos između tekstova i žanrova (ponajprije odnos „uključivanja“ teksta u „njegov“ žanr), što je onda i razlog zbog kojega se teži(lo) stvaranju klasifikacijskih, žanrovskih sustava (jer se samo pomoću njih moglo objasniti to „pripadanje“ tekstova žanrovima). ${ }^{6}$

Kada je o različitim (povijesnim) shvaćanjima, a onda i definicijama kategorije žanra riječ, treba znati da se u suvremenoj književnoj genologiji sve glasnije ističe spoznaja kako žanr nema i ne može imati čvrsto određene granice jer „obuhvaća“ tekstove koji ne moraju nužno imati niti jedno obilježje zajedničko baš svima. Alaistar Fowler stoga napominje da je i definicija žanra kao takva nemoguća, pa se i ,ideje žanrova moraju mijenjati zajedno s njihovim djelovanjem u književnosti (Fowler 1982: 25), kao što je, uostalom, to i dosad bio slučaj. Žanr(ovi) se, tvrdi Fowler, definiciji snažno opiru na svim svojim razinama jer niti jedan žanr nije određen dovoljnim brojem specifičnih ili neophodnih obilježja koja bi se mogla pronaći kod apsolutno svih njegovih ,pripadnika“, a da bi se mogao dovoljno jasno i čvrsto oblikovati i izgraditi kao razred ili klasa. ${ }^{7}$ „Žanrovska imena ne posjeduju dovoljnu i nužnu definiciju“ (Schaeffer 1989: 177), ističe Schaeffer, premda postojanje žanra neizbježno pretpostavlja i postojanje prikladnoga (žanrovskog) termina koji je spojiv s tekstom, a kojega određuju sam pisac, kritičari i teoretičari. ${ }^{8}$ Schaeffer pritom naglašava kako ,žanrovsko imenovanje općenito pripisuje tekst jednoj žanrovskoj normi, dok je na razini njegove djelotvorne žanrovskosti često na presjecištu nekoliko normi““ (Isto: 179), što onda ujedno

\footnotetext{
${ }^{6}$ Detaljnije u: Schaeffer 1989: 167-187.

${ }^{7}$ Usp. Fowler 1982: 38-40.

${ }^{8}$ Usp. Schaeffer 1989: 179-180.
} 
znači da ni jedan književni tekst nije dovoljno precizno određen žanrovskom odrednicom koja mu se dodjeljuje. ${ }^{9}$

Bez obzira na sve neupitne manjkavosti žanrovskih definicija ili određenja, kao jedan se od najvećih, zasad nerješivih problema moderne književne genologije ispostavlja već spomenuto nepostojanje općeprihvaćenoga i svevažećeg žanrovskog nazivlja. Naime, tijekom čitavoga je prošlog stoljeća - a ne prestaje ona još ni danas, početkom (n)ovoga - u stručnim krugovima trajala neumorna potraga za jedinstvenom i prikladnom žanrovskom terminologijom, no, kako se zasad čini, još uvijek bez značajnijih, spomena vrijednih rezultata. Naročita pluralnost u uporabi žanrovske terminologije, uvelike potaknuta različitim kriterijima shodno kojima se u praksi provodi(o) opis i razvrstavanje žanrova, mogla se uočiti u drugoj polovini 20. stoljeća, kada se ujedno i spoznalo da je razvoj koncepcija o žanrovima i njegove terminologije zapravo proces koji teče paralaleno s evolucijom žanrova, zbog čega ni samo žanrovsko pojmovlje - ponajviše zbog svoje podložnosti povijesnim mijenama - ne može biti neograničena roka trajanja. Na neki je način stoga i razumljivo zašto je, s obzirom na sve veću prihvaćenost ovih činjenica, opći konsenzus o makar relativnome opsegu i stabilnosti kategorije koja se naziva „žanrom“ - a kamoli o onome pojedinih žanrova očigledno danas nemoguće postići, pa nesređenost genološkoga nazivlja (naročito primjetna, kako je već rečeno, u domaćim okvirima) naposljetku dovodi do toga da se još uvijek, čak i u najrecetnijim studijama, počesto rabe različiti nazivi za pojedini žanr ili, pak, jedan zajednički termin za više različitih žanrova. ${ }^{10}$ Jedna od zadaća teorije žanrova stoga bi trebala, između ostalog, biti i objašnjavanje žanrovske terminologije iz povijesne vizure, što će reći njezina statusa, značenja i konteksta u kojemu se pojavljuje, jer su, kao što se u novije vrijeme to često ističe, ,pojmovi za književne nadvrste, rodove $\mathrm{i}$ žanrove povezani kako $\mathrm{s}$ metaknjiževnom refleksijom i njezinim spoznajnim interesima, tako i sa »sustavima uporabe« (...), što će reći njihovim praktičnim korištenjem pri pisanju, čitanju, analiziranju, uređivanju ili posredovanju tekstova“"(Juvan 2006b: 161).

Govoreći, međutim, o temeljnim genološkim terminima, točnije o onima koji se odnose (ili bi se trebali odnositi) na hijerarhijski posložene razine žanrovske klasifikacije, pojam ,žanr“ definitivno bi najprije trebalo (jednom za svagda) što preciznije od njih razlučiti. Konkretno, posebno bi bilo bitno - poglavito za potrebe ove analize - napokon utvrditi razliku između termina ,žanr“" spram onih ,,podvrsta“, „,vrsta“ i „,rod“, tim više što su

\footnotetext{
${ }^{9}$ Podrobnije u: isto: 180-181. Upravo zato Tihomir Brajović i predlaže razlikovanje „žanrovskoga korpusa“, koji obuhvaća konkretna, žanrovski obilježena djela (tj. tekstove na osnovi kojih se gradi predodžba o žanru), od samoga pojma ,žanra“, koji iz spomenutoga korpusa i nastaje (usp. Brajović 1995: 9).

${ }^{10}$ Vrlo detaljno o tome u: Pavličić 1983: 22-30. Usp. i Pavličić 2017a: 11-22.
} 
sva četiri i danas još u opticaju te se počesto koriste za određivanje identičnih kategorija djela, odnosno za jednu te istu razinu klasifikacije. U nekim se slučajevima oni tako rabe kao sinonimi (naziv ,žanr“ u tom slučaju dolazi kao istoznačnica za „,(pod)vrstu“ ili, nešto rjeđe, „rod“), a u drugima kao oznake za različite stupnjeve klasifikacije (dakle, kao termini u već spomenutomu hijerarhijskom nizu: rod - vrsta - podvrsta - žanr), i to po očitoj analogiji s biološkim klasifikacijama živih organizama. Uz to, termin ,žanr“ pokatkad - osobito u posljednjih nekoliko desetljeća - biva upotrijebljen i sasvim „izvan odnosa subordinacije“ (Solar 1971: 61), pri čemu se sve kategorije ili stupnjeve klasifikacije - podjednako, dakle, i rodove, i vrste, i podvrste - redom proglašava ,žanrovima“, točnije shvaća kao žanrovima posve ravnopravne (a ne nadređene) entitete. Posve je razumljivo da to dovodi do izrazite pojmovne i terminološke zbrke, u pozadini koje stoji činjenica da je naša znanost o književnosti od svojih početaka primala utjecaje s različitih strana, što je na koncu i rezultiralo terminološkom šarolikošću, odnosno različitim uporabama jednoga te istog (osnovnog) genološkog termina. ${ }^{11}$ Čini se da bi, ipak, stvarne razlike između pobrojanih genoloških pojmova ponajprije trebale proizlaziti iz opsega definiranog skupa djela koja posjeduju neke zajedničke karakteristike, iz čega bi slijedilo da je „,rod“ najbolje prihvatiti kao najobuhvatniji pojam, „,vrstu“ kao pojam manjega opsega, a „podvrstu“ i/ili ,žanr“ kao još uži, odnosno pojam za skupinu djela u sklopu neke vrste, kao što je to, uostalom, u svojoj knjizi Književna genologija svojedobno već učinio i Pavao Pavličić.

Uočivši, naime, kako do početka 80-ih godina prošloga stoljeća genološka terminologija u nas nije (bila) uopće razrađena, Pavličić tako predlaže razlikovanje četiriju osnovnih razina genološke klasifikacije, i to: rodove, vrste, podvrste i žanrove. Pritom bi rodovi (epika - lirika - drama ili poezija - proza - drama) označavali najopćenitiju klasifikacijsku razinu, odnosno najobuhvatniju skupinu podudarnih književnih tekstova, vrste bi, pak, podrazumijevale grupu tekstova različitu od drugih grupa po nekome bitnom aspektu, dok bi se podvrste mogle definirati kao skupine djela „koja sva posjeduju važan formalni ili sadržajni aspekt koji svako od njih bitno određuje, a po kojemu se ta djela razlikuju od ostatka vrste“ (Pavličić 1983: 20). Žanrovi bi, naposljetku, obuhvaćali najnižu klasifikacijsku razinu, dakle onu na kojoj se djela najuočljivije razlikuju, $i$ to zahvaljujući činjenici da podrazumijevaju čitav niz osobina koje stanoviti tekst ili skupinu njih vidno razlikuju od ostalih tekstova uključenih u (pod)vrstu. ${ }^{12}$ Ukratko, za razliku od žanra, vrsta bi bila skupina

\footnotetext{
${ }^{11} \mathrm{O}$ neujednačenoj uporabi termina ,žanr“ u našoj i susjednim znanostima o književnosti, a osobito o njegovu čestom miješanju s nazivima ,rod“ i ,vrsta“ znatno detaljnije u: Popov 2003: 457-471.

${ }^{12}$ Usp. Pavličić 1983: 16-21. Spomenuto su Pavličićevo razlučivanje četiriju razina žanrovske klasifikacije u svojoj knjizi prihvatile i pri razvrstavanju žanrova srednjovjekovne drame (uspješno) primijenile Danijela Bačić-
} 
književnih tekstova čija podudarnost proizlazi iz nekoga temeljnog zajedničkog obilježja, dok bi rod, kao pojam širi i obuhvatniji od onog vrste, trebao predstavljati neke osnovne načine književnoga izražavanja. Termin „rod“, pak, potječe tek iz 18. stoljeća, kada je u njemačkoj sredini razrađena podjela na tri roda: epiku, liriku i dramatiku, koju je u 20. st. (samo donekle uspješno) pokušala zamijeniti rodovska kategorizacija književnosti bazirana na tri temeljna načina književnoga izražavanja: poeziji, prozi i drami, najprije prihvaćena u anglosaksonskim zemljama, a nedugo zatim i u francuskoj i talijanskoj znanosti o književnosti. Te se rodovske podjele, međutim, zasnivaju na dvjema posve različitim književnim poetikama o kojima je na ovome mjestu posve izlišno govoriti, pa pripomenimo tek da - makar kada je riječ o hrvatskoj književnoj znanosti - niti jedna od njih (još) nije dospjela preuzeti primat. ${ }^{13}$

Kako bilo, u pristupima konkretnome književnom materijalu, naročito djelima iz starijih, predromantičkih razdoblja, najuputnijom bi se i najtočnijom ispostavila upravo uporaba termina ,žanr“, ponajviše zato što ni pisci, ni autori poetičkih traktata, a još manje čitatelji prije 19. st. nisu ni bili svjesni mogućnosti klasificiranja književnih djela (i) u kategorije obuhvatnije od one žanra. Te mogućnosti, dakako, nisu oni ni mogli biti svjesni budući da se o književnim rodovima, vrstama i podvrstama (dakle, „žanru“ nadređenim entitetima) u teoriji žanra počelo govoriti upravo u 19. i 20. st., a do tada razmišljalo se o isključivo zasebnim žanrovima (koji se, doduše, nisu uvijek i posvuda upravo tako zvali) kao praktičnim kategorijama, odnosno o konkretnim skupovima propisanih obilježja obuhvaćenih nekim žanrovskim imenom. Naime, s obzirom na to da se prije romantizma, ponovimo, predodžba o svakome pojedinačnom žanru svodila na poznavanje „karakterističnih“, poetički propisanih njihovih obilježja, u sklopu takvih razmišljanja kategorije roda, vrste i podvrste čak i da su dotad već bile skovane - ne bi imale gotovo nikakav (praktični) značaj jer njihovi skupovi suviše općenitih i malobrojnih ,ključnih“ značajki nikako nisu mogli funkcionirati kao dovoljno precizni „recepti““ za pisanje konkretno žanrovski obilježenih djela. Hijerarhiju „rod - vrsta - podvrsta“ (kao nužnu nadopunu primarnim žanrovskim određenjima) stoga je moguće, ako se baš želi, (is)koristiti tek u pristupima modernijim, postromantičkim književnim ostvarenjima (dakle, onima nastalima nakon što su te kategorije u književnoj genologiji doista i zaživjele), iako je njezina uporaba zapravo najopravdanija tek u općoj ili teorijskoj žanrovskoj klasifikaciji, odnosno onda kada se, s povijesne distance i s nužno

Karković i Adriana Car-Mihec, za koje „rod“ također predstavlja najopćenitiju razinu, „vrsta“ manje općenitu, „podvrsta“ manju skupinu unutar vrste, a ,žanr“ posljednju razinu klasifikacije (podrobnije u: Bačić-Karković i Car-Mihec 2000: 23-25 i 61-64). O navedenim četirima klasifikacijskim razredima usp. i Meić 2017: 23-37.

${ }^{13}$ O konkretnim razlikama među dvjema spomenutim koncepcijama književnih rodova osobito u: Pavličić 1983: 33-58 i Solar 1996: 133-136. Detaljnije, pak, o distinkcijama između kategorija „roda“, „vrste“, „podvrste“ i „Žanra“ u: Solar 1971: 61-75 i 1996: 128-136, Škreb 1985: 11-21, Popov 2003: 457-471, Juvan 2006b: 153-169. 
akumuliranim znanjem o njegovim povijesnim mijenama, svaki pojedinačni žanr teži smjestiti u neki zamišljeni (opći i nadpovijesni) žanrovski sustav.

Poglavito se ta ograničena uporabljivost $\mathrm{u}$ žanrovskim klasifikacijama konkretnih književnih djela odnosi na kategoriju roda, koju je - zbog spomenute (pre)kasne književnoteorijske evokacije - izrazito neprikladno i suvišno „nakalemiti“ na tekstove porijeklom iz razdoblja u kojima o njoj nije još bilo ni najmanjega spomena. To je, na kraju krajeva, ispravno uočio već i Pavličić, zaključivši kako u kategoriji roda ne treba opisivati genološku situaciju starijih književnih epoha jer se ,poetike pojedinih književnih razdoblja i, u vezi s njima, odgovarajući žanrovski sistemi, ne izgrađuju (...) s obzirom na rodove, nego s obzirom na vrste“ (Pavličić 1983: 50), tj. žanrove, razlikama među kojima se svaka poetika ponajviše zapravo i bavi. ${ }^{14}$ Štoviše, nepouzdana je, upozorava na drugom mjestu Pavličić, i uporaba nekih drugih kategorija generičke klasifikacije - naročito želimo li tumačiti književna djela iz povijesne perspektive - jer treba znati da su i „neki od oblika koje danas doživljavamo kao podvrste (dakle kao veće skupine) u žanrovskome sistemu u kojemu su nastale zapravo bivale shvaćene kao žanrovi, dakle kao takvi oblici kod kojih je bio konvencionaliziran i sadržaj i način njegove obrade“ (Pavličić 1979a: 170).

Znanost o književnosti zato bila i jest, naglašava Pavličić, najsklonija upravo pojmu književne vrste, i to ne vrste koja se (hijerarhijski) izvodi iz pojma roda (koji je, kao što je pokazano, u cijelosti izvanknjiževna, većinom filozofska kategorija osmišljena neovisno od spoznaje o vrstama), već one koja proizlazi iz konkretnoga opisa ili poetike određenoga razdoblja, odnosno iz predodžbi na kojima se i temelje pristupi tadašnjih autora i čitatelja književnim tekstovima (na podlozi kojih se, dakle, to djelo i shvaća(lo) kao član vrste i, kao takvo, impliciralo vladajući vrstovni sustav svojega vremena). Zbog toga bi, nastavlja, i istraživanja u književnoj genologiji svakako trebala polaziti od književne vrste kao takve, tim više što ona uvijek neizbježno uključuje i svoju povijesnu komponentu budući da je riječ o povijesno promjenjivoj, relativnoj kategoriji ovisnoj o poetičkim mijenama, odnosno promjenama u sustavu vrsta. Štoviše, književne su poetike pojedinih epoha ponajviše i bile

\footnotetext{
${ }^{14}$ Ovom izbacivanju književnoga roda iz genoloških interpretacija svojedobno se suprotstavio Zdenko Škreb istaknuvši kako bi se termin „rod“ mogao ipak prihvatiti pod uvjetom da se „oslobodi značenja prvotne i iskonske mogućnosti umjetničkoga oblikovanja“ te da se „shvati kao uvjetni grupni pojam“ (Škreb 1985: 18), primjerice, da se tako sve književne vrste utemeljene na naraciji skupe u jednu (uvjetnu) obuhvatniju rodovsku grupu. Škreb tom prilikom ujedno predlaže i utemeljivanje dodatnoga, četvrtog književnog roda - „didaktike“ ili „refleksije“ - u koji bi, drži, trebalo uvrstiti vrlo kratke književne oblike (zagonetke, poslovice, aforizme, gnome itd.). Relativno je nedavno i Marko Juvan, pišući o problematici književne genologije, tako ustvrdio da su rodovi, shvaćeni prema njemačkom modelu (lirika - epika - drama), pretežno „stvar teorije, a ne pisanja, distribucije i čitanja književnih tekstova“, dok, za razliku od nje, novija, anglosaksonska trijadna razdioba (poezija - proza - drama) zapravo izvrsno „funkcionira podjednako u svijesti i kroz djelatnost pisaca, urednika, u preferencijama čitatelja: neki vole poeziju, drugi ne otvaraju knjigu ukoliko nije u prozi, treći, pak, najradije zalaze u kazališta itd.“ (Juvan 2006b: 152, bilješka 74).
} 
zaokupljene upravo statusom, hijerarhijom (međuodnosima), funkcijama i značajkama vrsta koje su u tim periodima i shvaćane kao najvažnije, a znamo li da smjenjivanje književnih razdoblja zapravo podrazumijeva smjenjivanje poetika, jasno je da bi se, u tom slučaju, ono moglo (i moralo) motriti upravo kao smjenjivanje sustava književnih vrsta. Smjena književnih perioda, ukratko, tako i počiva na (postupnoj) zamjeni jednoga sustava preferiranih književnih vrsta drugim vrstovnim ili - ne bi li ipak bilo ispravnije reći? - žanrovskim sustavom. ${ }^{15}$

Premda ovakvo opredjeljenje za kategoriju književne vrste $u$ genološkim istraživanjima na prvi pogled isključuje ne samo one roda i podvrste, već, dakako, i onu žanra, čini se da bi se sve netom rečeno s daleko većom uvjerljivošću i moglo primijeniti upravo na sam žanr. Naime, u genološkim bi se čitanjima, s književnopovijesnoga gledišta, znatno opravdanije bilo fokusirati na kategoriju žanra, i to ponajprije zato što on označava najnižu točku žanrovske klasifikacije, odnosno uključuje najpreciznije generičke odrednice s predznanjem o kojima sudionici u književnoj komunikaciji (pisci, kritičari, poetičari, „obična“ publika itd.) i pristupaju književnom činu, a koja su iz toga razloga ujedno i neizbježno povijesna (točnije, povijesno i kontekstualno određena), za razliku od suviše obuhvatnih i samo rubno povijesnih vrstovnih određenja. Uostalom, i sam će Pavličić opravdano napomenuti da žanr, kao manja grupa tekstova u okrilju vrste, zapravo „predstavlja interpretaciju vrste svojstvenu nekoj književnoj struji ili nekome razdoblju“ (Pavličić 1983: 101), što će reći ne samo da književna vrsta uvijek nužno pretpostavlja i svoj(e) žanr(ove), već i da bi - u povijesnoj perspektivi - najveću važnost stoga trebalo pridavati upravo žanru (kao povijesno određenoj ,,interpretaciji vrste“). Pavličić nadalje ističe kako (i) iza žanra stoji poetika razdoblja u kojemu se on pojavljuje i izravno određuje njegova obilježja i poziciju u žanrovskome sustavu, a ta ista poetika književnim tekstovima i propisuje upravo žanrovska (a ne vrstovna) obilježja, što onda znači da se u svakome periodu ,pripadnici“ pojedine vrste i ponašaju kao „pripadnici“ žanra. Štoviše, presudan dio svakoga književnog iskustva, zaključuje, i jest upravo žanr, u obliku kojega se to iskustvo i pohranjuje, pa bez pojma žanra, koji „nastaje iz neposrednoga odnosa prema književnim djelima“, mi „,ne možemo biti ni čitatelji, kao ni bez pojma stiha ili rime“" (Pavličić 1983: 127). ${ }^{16}$

Potonje saznanje o književnim žanrovima stoga najuvjerljivije potvrđuje već izrečen zaključak kako je primjena kasnijih, (post)romantičkih kategorija žanrovske klasifikacije na književne tekstove iz starijih razdoblja ne samo nepotrebna, već i ne odveć poželjna, tim više što su pisci do 19. st. žanrove jasno razlikovali i rabili slijedeći konkretne uzore iz tradicije

\footnotetext{
${ }^{15}$ O tome podrobnije u: Pavličić 1979a i 1983: 33-58 i 59-96.

${ }^{16}$ Opširnije u: Pavličić 1983: 97-128 i 2017a: 13-14.
} 
(najčešće propisane u brojnim poetičkim traktatima), a ne oslanjajući se na apstraktne teorijske, svevažeće klasifikacijske kategorije ili razrede. ${ }^{17}$ Unatoč činjenici da je sam termin ,žanr“ skovan tek znatno kasnije te da izgrađeno i općeprihvaćeno nazivlje za različite žanrove u mnogim književnostima prije 19. st. nije uopće ni postojalo, već u predromantičkoj je književnosti vrijedilo, a vrijedi ono još i danas, zapažanje da su ,prava realnost diskursa žanrovi, da su upravo oni ti modusi koji uistinu reguliraju komunikaciju“, dok se to samo donekle ili gotovo uopće ne može reći i ,za rodove/vrste, koji, naime, funkcioniraju u razmjenama između književne prakse i njezina teorijsko-povijesnog promatranja“ (Juvan 2006b: 152, bilješka 74). Pa iako su - na terminološkoj razini - pisci iz predromantičkih epoha često brkali žanrove, nejasno žanrovski određivali svoja djela, pa i rabili više naziva za jedan te isti žanr (ili obrnuto), poprilično su jasno - čak i kada to poetički nije izrijekom bilo propisano - uviđali njihove razlike, (pre)poznavali repertoare njihovih specifičnih obilježja, itekako bili svjesni različitih praktičnih funkcija (svrha) koje su njima mogli postići, odnosno točno znali kakav će tip publike svakim od njih privući i kakav će utjecaj na konkretan tip publike tim i takvim žanrom i ostvariti (kao što to, vidjet ćemo, ponajbolje svjedoči i primjer Odiljenja sigetskog). Baš zato se u analizama žanrovskih osobina djela iz predromantičke, ali i onima iz romantičke, pa i postromantičke književne povijesti valja odlučno opredijeliti za kategoriju žanra, i to upravo onog žanra (ili žanrova) shvaćenog na podlozi konkretne (pisane ili implicitne) poetike danoga razdoblja, specifičnoga žanrovskog sustava toga vremena (kojemu bi, dakako, trebalo priključiti čak i one žanrove koji su ostali izvan fokusa spomenutih eksplicitnih poetika), uopće stanovitih književno- i društvenopovijesnih okolnosti koje su uvjetovale njegovu tekstualnu i kontekstualnu dimenziju; dakle, ukratko, žanra kao povijesne, a ne teorijske kategorije, kako je to svojedobno formulirao francuski teoretičar književnosti Tzvetan Todorov. I premda je, naravno, bilo kojemu žanru nemoguće pristupiti iz „čisto“ povijesne vizure, odnosno one koja bi u potpunosti isključivala sve moguće suvremen(ij)e teorijske „intervencije“ (na kraju krajeva, kao što smo vidjeli, i sam je termin ,žanr“ već sam po sebi produkt teorijskoga domišljanja), to nipošto ne smije biti izgovor za odustajanje od žanrovskih interpretacija, a poglavito ne od kategorije žanra, koja u znanstvenim proučavanjima s punim pravom danas uživa gotovo nevjerojatnu popularnost.

Usprkos tomu što on, kada su književnopovijesna istraživanja u pitanju, nipošto ne bi smio biti presudan, jedan od podstreka opredjeljenju za termin ,žanr“ svakako bi mogla dati i suvremena književna kritika, u kojoj je (u nas, a poglavito drugdje) već desetljećima u uporabi samo pojam žanra, iako polagano on stječe prevlast u svim područjima znanosti o

\footnotetext{
${ }^{17}$ Uvjerljivo o tome u: Schaeffer 1989: 167-187.
} 
književnosti (poglavito teoriji, no i u književnoj povijesti), ali i ne samo u njoj, već i u nizu drugih, ovdje već pobrojanih disciplina zaokupljenih (i) proučavanjima žanrova i njihovih učinaka. Važno je pritom znati da se u definicijama (većinom) starijih datuma književni žanr - iako se pokatkad čini to i danas - obično svodio na „golu“ formu, što je za svoju posljedicu imalo to da su u kritičkim interpretacijama književnih djela njihove žanrovske osobitosti obično motrene zajedno s drugim formalnim značajkama (metričkim kalupom, jezikom teksta itd.). Ipak, novija su teorijska promišljanja nepobitno utvrdila (iako je to bilo očito oduvijek) kako žanr obuhvaća i organski povezuje sve tekstualne razine danoga djela (podjednako, dakle, sadržajnu, formalnu, ali i stilsku) usmjerujući ujedno i kontekstualni njegov značaj i recepciju, i to u skladu s književnim i društvenim okružjem iz kojega proizlazi i u koji se vraća (iz)vršiti neke specifične funkcije. Žanr na taj način implicira cjelokupan žanrovski sustav određenoga razdoblja, pa, dakle, neizbježno i svoje (eventualno) poetičko određenje, svoje manifestacije $\mathrm{u}$ djelima drugih autora konkretnoga vremenskog trenutka, kontekst autorova opusa u kojemu se pojavljuje i u kojemu dolazi u međuodnos s drugim žanrovima, ali i cijelu svoju dotadašnju (žanrovsku) povijest (prethodne uporabe u nekim prošlim kontekstima). Da bi to, jasno je, uopće bio u stanju, žanr nipošto ne može biti puka „književna forma“", pa ga, kako je to još 1965. ispravno učinio utjecajni španjolski komparatist Claudio Guillén, valja motriti kao povijesno promjenjivoga posrednika ili svojevrsno „vezivno tkivo“ između sadržaja i forme, tj. kao element koji vrši usklađivanje sadržaja i forme omogućujući na taj način jedinstvenost književnoga (i uopće svakoga umjetničkog) djela, odnosno osposobljavajući ga za obavljanje stanovitih izvanknjiževnih ,zadaća“. ${ }^{18}$ Upravo svaki žanr bez obzira na to bio on književni ili neknjiževni - mora postići tu fuziju ili stapanje (karakteristične) forme i (karakterističnog) sadržaja (ili, pojednostavljeno rečeno, ostvariti podudarnost sadržaja i forme) ne bi li stekao (i) praktičnu komponentu, odnosno mogao uspješno izvršiti svoju izvantekstualnu ili društvenu svrhu, zbog čega se teško složiti s onim proučavateljima koji rezolutno tvrde kako se forma i sadržaj u žanru nalaze u hijerarhijskom odnosu. Naime, samo i isključivo „ravnopravnim“ stapanjem sadržaja i forme žanr može pokrenuti neku - kako to često vole reći suvremeni genolozi - društvenu akciju, ostvariti neko značenje u konkretnome društvenom (kulturnom) kontekstu, odnosno uslijed neke (kulturne i društvene) situacije funkcionirati kao prikladan „odgovor“ na tu situaciju, kako je to već u svome utjecajnom tekstu još osamdesetih godina prošloga stoljeća zaključila američka teoretičarka žanra Carolyn Miller. ${ }^{19}$

\footnotetext{
${ }^{18}$ Usp. Guillén 1982: 106-129.

${ }^{19}$ Opširnije u: Miller 1984: 151-167.
} 
Dospjevši do ovakvih shvaćanja o žanru kao entitetu koji - povezivanjem različitih njegovih dimenzija ili razina - tekstu omogućuje djelovanje u stanovitom kontekstu, teorijski su pristupi vrata genoloških istraživanja širom otvorili i mnogobrojnim već rečenim znanostima koje su se otad sve intenzivnije počele baviti različitim neknjiževnim (,praktičnim“) žanrovima. Svijest o žanru tako je prerasla granice znanosti o književnosti, a da se i izvan uskih znanstvenih krugova žanr definitivno prestao poimati „eksluzivno“ književnom svojinom dokazuju - od početka (n)ovoga stoljeća sve učestaliji - „obični“ razgovori i diskusije o mnogobrojnim kulturnim, retoričkim i njima srodnim žanrovima: kako onim književnim, tako i onim likovnoumjetničkim, filmskim, glazbenim, historiografskim, filozofskim, akademskim, televizijskim, radijskim, internetskim, političkim itd. Važno je, štoviše, primijetiti i to da su stručni napori u nekim disciplinama u posljednjih pola stoljeća dospjeli čak i znatnije nadmašiti one što su ih u proučavanja žanrova (i, dakako, drugih genoloških kategorija) dosad uložili i još uvijek ulažu književni genolozi, zahvaljujući čemu žanr danas ima gotovo središnje mjesto u studijima filma ili filmologiji, ${ }^{20}$ a i najsuvremenija istraživanja u lingvistici i retorici također su ponajviše zaokupljena analizom mehanizama funkcioniranja različitih svakodnevnih žanrova. Povrh toga, i u pedagogiji već se desetljećima sustavno istražuje uloga žanrova u poučavanju stranih jezika, dok sve veće zanimanje za žanrovsku problematiku bilježe i discipline u rasponu od historiografije i politologije do religijskih (teologije) i ženskih (feminističkih) studija, što je i više nego uvjerljiv dokaz široke prihvaćenosti i nezanemarive važnosti što ju početkom 21. stoljeća uživa koncept žanra. Ta sveopća zaokupljenost žanrom ujedno je i najbjelodanije svjedočanstvo o tome kako je razmišljanje o žanrovima kao o svojevrsnim okvirima proizvodnje i recepcije diskursa zapravo duboko ukorijenjeno u svakodnevni govor i pisanje te sustave koji klasificiraju tekstove, odnosno da upravo žanrovske klasifikacije, kojih najčešće nismo ni svjesni, neizbježno organiziraju gotovo svaki aspekt našega svakodnevnog života. ${ }^{21}$

Ovome suvremenom višedisciplinarnom zanimanju i brojnim do danas više ili manje uspješno provedenim istraživanjima žanrova usprkos, ne samo (zadovoljavajuća) obuhvatna definicija, već ni čvrst pojam samoga žanra još uvijek, nažalost, nisu iznađeni, što za svoju posljedicu ima to da se u različitim znanostima počesto on i shvaća nejednako, zbog čega su i eventualni pokušaji osmišljavanja njegove svevažeće definicije nužno „osuđeni“ na krajnja poopćavanja. U novijim se studijama žanr tako određuje kao „genološki fenomen koji nadilazi

\footnotetext{
${ }^{20}$ Da je i u nas tomu zaista tako ponajbolje svjedoče dvije recentne (i teorijski izuzetno inovativne) studije o filmskim žanrovima što ih potpisuju dvojica naših najistaknutijih filmologa: Hrvoje Turković (Nacrt filmske genologije, Zagreb, 2010.) i Nikica Gilić (Filmske vrste i rodovi, Zagreb, 2007.).

${ }^{21}$ Naročito o tome u: Frow 2015: 12-13.
} 
okvire samo jedne umjetnosti ili diskurzivne prakse i predstavlja elementarnu semiološku kategoriju na osnovi koje se vrši razvrstavanje tekstova po zajedničkim osobinama“" (Milutinović 2009: 12), no sve češće se napominje i to da on zapravo „nije instrument klasifikcije ili propisivanja pravila, već značenja“ (Fowler 1982: 22), odnosno, kao što to čini John Frow, „skup konvencionalnih i visoko organiziranih okvira proizvodnje i tumačenja značenja“ (Frow 2015: 10) ili, još preciznije, „povijesno uvjetovan okvir organizacije semantičkog materijala kroz nekoliko dimenzija u specifičnom mediju i u odnosu prema pojedinim tipovima situacijskih granica koje pomažu oblikovati taj okvir" (Isto: 80). Na najnačelnijoj je razini žanrove danas možda najprikladnije motriti - a sve češće to se i čini ${ }^{22}$ kao naučene obrasce razumijevanja svijeta, tim više što su, dajući svojim istraživanjima svaka svoj doprinos općem porastu svijesti o važnosti žanrova u različitim aspektima ljudske svakodnevice, pojedine znanstvene discipline zajednički rasvijetlile činjenicu da „kroz uporabu žanra učimo tko smo i spoznajemo granice našega svijeta“ (Isto: 166). Jedna od, za naše istraživanje, najvažnijih posljedica te multidisciplinarne zaokupljenosti žanrovima bila je (i) ta da su noviji književnogenološki pristupi sve veću pažnju napokon počeli poklanjati i dotad zanemarenim usmenoknjiževnim, pučkoknjiževnim i rubno književnim žanrovima te, $u$ vezi s njima, i nezaobilaznim pitanjima mjesta književnih žanrova u življenoj svakodnevici te njihova preklapanja sa žanrovima iz ostalih ljudskih sfera, no time se već otvara ,područje“ teorija (književnih) žanrova, o povijesti kojih nam sada i predstoji reći nekoliko riječi.

\section{2. TEORIJE KNJIŽEVNIH ŽANROVA}

Unatoč tomu što do današnjega dana nije (još) dočekao svoju opću ili, bolje rečeno, općeprihvaćenu definiciju, o žanru ili žanrovima (,vrstama“, „rodovima“, „tipovima“, „oblicima“, „formama“ itd.) konstantno se kroz povijest raspravljalo kao o stvarno postojećim praktičnim kategorijama, $\mathrm{i}$ to neovisno od toga kako ih je u danome trenutku književna teorija konkretno određivala. ${ }^{23}$ Taj, pak, dio teorije književnosti zadužen za žanrovska pitanja, kako je već višestruko istaknuto, naziva se književna genologija (grč. génos - rod / vrsta; lógos govor, riječ) $)^{24}$ ili teorija žanrova (engl. genre theory; njem. Gattungspoetik) i, za razliku od

\footnotetext{
${ }^{22}$ Usp. npr. isto: 161-167.

${ }^{23}$ Itekako svjesni te činjenice, pojedini genolozi danas s punim pravom ističu kako je povijest (književnog) teoretiziranja zapravo ,velikim dijelom povijest teoretiziranja o pojedinim vrstama, o onome što ih razlikuje od »susjednih« vrsta i o onome što ih ključno obilježava“ (Turković 2010: 10).

${ }^{24}$ Termin ,genologija“ još 1938. upotrijebio je francuski komparatist Philippe van Tieghem, a on će se kasnije kao drugo ime za teoriju žanrova - najviše uvriježiti u poljskoj znanosti o književnosti. U nas, pak, sve do knjige Književna genologija Pavla Pavličića taj naziv nije imao gotovo nikakvu tradiciju, što znači da se tek od ranih osamdesetih godina počeo on sve učestalije rabiti. Da u našoj sredini on još uvijek ima prednost pred frazom
} 
žanra, vrlo se precizno može definirati kao središnja disciplina „tradicionalne poetike, koja se bavi uspostavljanjem, definiranjem i proučavanjem književnih generičkih entiteta i kategorija kao što su modusi, rodovi, vrste ili žanrovi, podvrste, razredi, tipovi, oblici i sl.“ (Biti 2000: 153). Riječima Marka Juvana, moderna književna genologija ,proučava tipične, ponovljive književne strukture, perspektive, odnosno oblike“ nastojeći, „,iz književnih djela nastalih u različitim sredinama i razdobljima, izlučiti zajednička obilježja, invarijante, te ih na toj osnovi razvrstati u razrede (tj. u nadrodove, vrste, žanrove, tipove), određene jedinstvenim pojmovima i identičnim opisima“" (Juvan 2006b: 151). Ono što je pritom nužno imati na umu jest to da su kroz povijest genologije u opticaju bila različita mjerila na osnovi kojih se pristupalo žanrovskim razvrstavanjima književnih djela te da su ona proizlazila iz različitih položaja što ih je književnost u određenome vremenskom trenutku zauzimala, ali i iz primjene različitih konceptualnih okvira unutar kojih se klasifikacija provodila (drugačiji pristup generičkoj klasifikaciji gajile su, primjerice, retorika, poetika, kritika, književna povijest itd.).

Teorija književnih žanrova mogla bi se shvatiti kao jedan od „kamena temeljaca“ znanosti o književnosti u cijelosti, tim više što je od samih svojih početaka bila fokusirana na rješavanje možda i najosnovnijega književnoznanstvenog problema: onaj razvrstavanja tekstova. Ta je problemska orijentacija genologije bila očita već u antici, kada su i udareni njezini temelji, i to ponajprije zahvaljujući tekstovima Platona (treća knjiga Države) te Aristotela (Poetika), koji razvijaju prve (normativne) teorije žanrova, i to razlikujući ih kako prema načelima, sredstvima i predmetima oponašanja, tako i prema učincima što ih oni imaju na čitatelje ili publiku općenito. Platon i Aristotel žanrove prvi shvaćaju kao nepromjenjive konstrukte, slijedom čega se u svojim spisima ponajviše i usredotočuju na p(r)opisivanje pravila za koja očekuju da će ih svi „dobri“ žanrovi, točnije u njima realizirani tekstovi, u cijelosti i slijediti. Njihove esencijalističke predodžbe postale su tako ishodištem svih budućih književnogenoloških proučavanja, odnosno cjelokupnoga kasnijeg razvoja teorije žanrova, koji je, kako sumiraju pojedini proučavatelji, od srednjega vijeka do danas tekao u tri ključne faze $^{25}$ određene trima različitim pristupima književnim žanrovima ${ }^{26}$ izraslima iz sasvim različitih književno- i društvenopovijesnih konteksta i obilježenih ne samo nejednakim poetičkim gledištima, već i drugačijim ideologijama, svjetonazorima itd.

Prvu je tako fazu (ili retoričko-normativni, ,,aristotelovski“ pristup) - koja je trajala od srednjega vijeka do polovine 18. stoljeća - presudno obilježilo shvaćanje žanrova kao

\footnotetext{
„teorija žanrova“ dokazuju, primjerice, i mnogi tekstovi iz nedavno objelodanjena zbornika „Vrsta ili žanr“ (usp. npr. Pavličić 2017a: 11-22, Meić 2017: 23-37, Coha 2017: 64-83 i dr.).

${ }^{25}$ Usp. Milutinović 2009: 14-26.

${ }^{26}$ Detaljnije u: Bačić-Karković i Car-Mihec 2000: 8-16.
} 
esencijalističkih, nadpovijesnih fenomena, što će reći da su oni tada percipirani kao kategorije ili fizički objekti u kojima je utjelovljena istina (bit) i čije su porijeklo i priroda transcedentalni. Vjerovalo se, drugim riječima, da su žanrovi svojevrsne metafore Biblije, da svaki od njih posjeduje unaprijed zadan, jedinstven i nepromjenjiv smisao te da je svaki točno određen specifičnom prilikom zbog koje i postoji, a to je ujedno podrazumijevalo da svi žanrovi moraju biti maksimalno kanonizirani, da njihov sadržaj mora biti usklađen s njihovom formom, da nikako među njima ne smije biti miješanja ni preklapanja (posebno se inzistira na „čistoći“ žanrova), da su tim bolji što su bliži svojim uzorima (odnosno, da je svako njima „pripadajuće“ djelo automatski kvalitetnije ukoliko je - formalno i sadržajno - posve nalik svome zadanom uzoru) te da ih je nužno neprestano poetički „braniti“ i potvrđivati (jer su onodobni književni tekstovi svojim značajkama kontinuirano dovodili u pitanje ta njihova poetički propisana pravila). ${ }^{27}$ Od književnih se djela, ukratko, tada očekivalo da se što više približe žanru jer je on idealan oblik, tj. uzor kojega valja slijediti, što onda znači da je svaki tekst zapravo „pripadao“ žanru po načelu odnosa između općega tipa i pojedinačnog primjera, zbog čega su se rasprave o žanrovima većinom i svodile na pitanje klasificiranja djela shodno njihovim sadržajnim i formalnim obilježjima - u te unaprijed zadane, ,idealne“, nadpovijesne klase. Teorije su žanrova, dakle, u ovoj prvoj fazi bile striktno preskriptivne jer su žanrovima propisivale „poželjne“, a ujedno i „,svevažeće“ karakteristike kojih su se morali pridržavati, i to vodeći se uvjerenjem kako se ta obilježja zasnivaju na vječno važećim normama ljepote i razuma. Te je ,žanrovske okvire“ još u 1. st. n. e. prvi odredio Horacije svojim Pjesničkim umijećem, u kojemu se uvelike naslanjao na Aristotelove i (u nešto manjoj mjeri) Platonove teze, a zatim su ta utvrđena žanrovska pravila naprosto ponavljali i samo ponešto nadopunjavali i korigirali i teoretičari (retoričari) od renesanse do početka 18. st.

Doduše, Aristotelova teorija žanrova ne samo što je preuzimana i dopunjavana već u nekim antičkim poetičkim traktatima, nego se njezini poetički zahtjevi - usprkos činjenici da žanrovska kritika tada nije bila osobito razvijena - ponešto dorađuju u srednjemu vijeku, kada ujedno dolazi i do zamjenjivanja mnogih žanrovskih termina novima. Ipak, početkom 16. st. ponovno se otkriva i reinterpretira, „izvorna“ Aristotelova Poetika, pri čemu na važnosti dobivaju mnogi žanrovi koje je Aristotel naprosto ignorirao (poglavito se to odnosi na lirsku pjesmu), no i dalje se tvrdi kako su antički žanrovi svojevrsni „,prirodni oblici“ i uzor književne vrijednosti, zbog čega ih je nužno u cijelosti nasljedovati. Renesansni, ali i kasniji su poetičari (Dante, Ariosto, Sidney, Dryden, Pope i dr. ${ }^{28}$ ), slijedom Aristotelovih zapažanja,

\footnotetext{
${ }^{27}$ To i jest razlog zbog kojega se ta prva faza razvoja književne genologije nerijetko i naziva „dobom poetika“.

${ }^{28}$ Teorija žanrova u rasponu od 16. do 18. st., podsjetimo, naročito je bujala u Italiji i Engleskoj.
} 
Žanrove prihvaćali kao statične, fiksne konstrukte, držeći svojom zadaćom pisanje preskriptivnih poetika u kojima su inzistirali na „čistim“ žanrovima strogo zabranjujući njihovo eventualno miješanje. Izuzev Scaligera, koji je u svojim poetičkim spisima (p)opisao više od stotinu književnih žanrova, većina ostalih se renesansnih i postrenesansnih (osobito klasicističkih) poetičara odlučila fokusirati na tek nekoliko žanrova (većinom na ep, pastoralu, komediju i tragediju) svjesno ignorirajući mnoge koji su u njihovo vrijeme u praksi ipak bili vrlo česti, a ujedno su izbjegavali i sistematizaciju - tj. kreiranje žanrovskoga sustava zadovoljavajući se tek njihovim pobrojavanjem i navođenjem ,neizbježnih“ pravila. Isto će 1674. (u)činiti i klasicist Boileau u svome Pjesničkom umijeću, u kojemu piše o „malim“ i „velikim“ pjesničkim formama prikazujući njihove karakteristike kao univerzalne i apsolutne, a pukom izlistavanju književnih (pjesničkih) vrsta bit će sklona i većina poetika prve polovine 18. stoljeća. Pritom će naročito francuski i engleski klasicistički teoretičari s osobitim žarom zagovarati nepromjenjivost žanrova te ih $-\mathrm{u}$ tipično klasicističkome duhu slijeđenja Aristotelovih zapažanja - definirati kao norme, tj. skupove nepobitnih pravila s univerzalnom vrijednošću koje valja slijediti.

No, tek u drugoj su fazi razvoja književne genologije (obilježenoj povijesnofilozofskim ili tzv. „hegelovskim“ pristupom žanrovima) - protegnutoj od druge polovine 18. do početka 20. stoljeća - zapravo udareni pravi temelji moderne teorije žanra. ${ }^{29}$ Do promjene u shvaćanju književnih žanrova ponajprije je tada došlo zahvaljujući prijelazu iz aristokratske u građansku kulturu te, slijedom toga, napuštanju dotadašnjih (klasicističkih) poetika zasnovanih na nepromjenjivim, „vječnim zakonima“ razuma, ljepote i prirode. Taj važni društveno- i kulturnopovijesni prijelom dubokog je traga ostavio i na, dakako, književnosti, koja se od tada počinje shvaćati kao spontani izraz slobodnoga stvaratelja što ne priznaje unaprijed zadana pravila i ne teži postići savršenstvo forme, već svoje djelo vidi kao autonomni organizam koji stječe svoje mjesto u beskonačnoj povijesti obilježenoj neprestanom promjenom vrijednosti. $U$ to vrijeme stoga dolazi do postupnog napuštanja preskriptivnih koncepcija (statičnih shvaćanja) književnih žanrova i ustoličenja otvorenih žanrovskih sustava u potpunosti ovisnih od povijesnih mijena, odnosno do apsolutnog opredjeljenja za deskriptivne poetike koje uvažavaju povijesnost žanrova, tj. njihovu neizbježnu privremenost. Za razliku od spomenutoga dotadašnjeg inzistiranja na poimanju žanrova kao nepromjenjivih, vječno važećih i „,̌cistih“ kategorija, u drugoj se oni fazi napokon počinju motriti „kako u međusobnoj tako i interakciji sa svojim okruženjem i promjenama koje su uvjetovane protokom vremena“ (Milutinović 2009: 16), što onda ujedno znači da je 
jednom za svagda osviještena i prihvaćena činjenica kako svako književno djelo samo za sebe stvara žanrovske norme, a ne podvrgava se onim unaprijed zadanim.

$\mathrm{S}$ obzirom na to da se u ovoj fazi izdvajaju dva bitno različita pristupa ili etape $\mathrm{u}$ razmatranju problematike književnih žanrova, treba znati da rečena zamisao o žanrovima kao povijesno promjenjivim konstruktima u onoj prvoj (ranijoj) još uvijek nije bila prisutna u toliko izrazitoj mjeri. Naprotiv, prvi pristup ili prva struja proučavatelja, u koju valja ubrojiti njemačke estetičare kasnoga 18. i prve polovine 19. stoljeća (Herder, Goethe, Hegel, braća Schlegel, Jean Paul Richter, Schelling, Novalis i dr.), u svojim je promišljanjima književnih žanrova spajala povijesni i filozofski pristup, što je na koncu urodilo idejom o trima književnim rodovima ili - kako ih u svojoj knjizi Zapadno-istočni divan (1819.) prozvao Goethe - „prirodnim oblicima“ pjesništva koji, na različite načine, izražavaju njegovu nepromjenjivu bit (ili duh) kroz tri različita tipa umjetničkoga izlaganja. Za njemačke estetičare ti su rodovi apsolutne kategorije protumačive isključivo pomoću metafizičkih pojmova, pa ih oni tako i definiraju kao unutarnje forme ili esencije iz kojih se djela izvode, tvrdeći pritom kako forma i značenje svakoga teksta organski proistječu iz svoga rodovskog izvorišta, što je onda i razlog zbog kojega valja iznaći „srž“ svakoga od triju rodova, i to s obzirom na subjekt, objekt, vrijeme i/ili mjesto. Budući da bi, naglašavaju oni, književni tekst trebao biti bitno obilježen imaginativnim, estetskim i inim unutarnjim obilježima, literarnima valja držati samo ona djela koja se mogu kategorizirati u neku od pobrojanih rodovskih kategorija (lirika, epika ili drama), a to će onda reći da se odnos između pojedinoga djela prema žanru i književnosti općenito u kontekstu ovih tumačenja shvaća strogo hijerarhijski. Iako spomenuti proučavatelji ovim svojim razmatranjima, kako se čini, utemeljuju „nešto poput doktrine svetoga trojstva u modernoj žanovskoj kritici“ (Hernadi 1972: 55), nužno je znati da njihova trojna rodovska razdioba nije ništa drugo no tek produkt dubinskoga preispitivanja čuvene Aristotelove trodiobe načina oponašanja ( $u$ to se doba ona, naime, po prvi put zaista ozbiljno pretresa i razrađuje) te da su se, uostalom, na ponešto modificiranoj antičkoj trodiobi stilova zasnivale već i brojne žanrovske razdiobe nastale u periodu između renesanse i ranoga 18. stoljeća (one, primjerice, Miltona, Drydena, Batteauxa i dr.). ${ }^{30}$ Štoviše, moderna se trojna razdioba žanrova (rodova) - na liriku, epiku i dramu - najčešće zapravo pripisuje španjolskomu piscu i poetičaru Franciscu Cascalesu (Tablas poéticas, 1617.), no najvjerojatnije ona potječe još od talijanskoga pjesnika Antonia Minturna i njegova znamenitog poetičkog traktata $L^{\prime}$ arte poetica (1563.). ${ }^{31}$

\footnotetext{
${ }^{30}$ Usp. o tome u: Hernadi 1972: 54-55.

${ }^{31}$ Usp. Fowler 1982: 236.
} 
Svoju teoriju književnih žanrova, zasnovanu na navedenoj ideji o trima osnovnim rodovima, u nešto novije je vrijeme - polovinom 20. stoljeća - predstavio i glasoviti švicarski povjesničar književnosti Emil Staiger, koji u knjizi Osnovni pojmovi poetike (1946.) epiku, liriku i dramu shvaća kao tri temeljne mogućnosti čovjekova odnosa prema svijetu. Za Staigera književni rodovi predstavljaju, konkretno, idealne, nepovijesne tipove književnoga izražavanja ili stilove, pri čemu se, napominje, u pojedinačnim književnim tekstovima ni jedan od tih stilova ne manifestira u svojoj punini. Stilski „destilirano“ pjesništvo, naime, u praksi ne postoji jer svako djelo u većoj ili manjoj mjeri ima udjela u svim pobrojanim stilovima ili rodovima, a tek pretežitost nekoga stila u određenome tekstu zapravo navodi na to da se ono definira ili kao lirsko, ili kao epsko, ili, pak, kao dramsko. ${ }^{32}$

Nakon opisanih romantičkih pokušaja uspostavljanja trojne rodovske podjele književnosti, druga će se postromantička struja proučavatelja - koja je „djelovala“ u drugoj polovini 19. stoljeća - u svojim istraživanjima odrješito opredijeliti za shvaćanje književnih rodova (žanrova) kao povijesno promjenjivih, privremenih konstrukata ili fenomena. Zadržavajući ranije uspostavljenu rodovsku trijadu, ova će grupa književnih genologa - u kojoj se utjecajnošću svojih zapažanja ponajviše istaknuo ruski teoretičar književnosti Aleksandr Nikolajevič Veselovski, autor prijelomne studije Tri poglavlja o povijesnoj poetici $(1899 .)^{33}-$ u potpunosti odbaciti statično shvaćanje književnih rodova (kakvomu su, kao što je pokazano, težili teoretičari prethodne etape) naglašavajući kako rodovi kroz povijest prolaze kroz neprekidnu i nezaustavljivu transformaciju. S druge strane, potkraj 19. st. pojavit će se i otvoreni pokušaji primjenjivanja spoznaja tada posebno aktualne teorije evolucije na književnost, a da je, prije svega, Porijeklo vrsta (1859.) Charlesa Darwina imalo itekako važan utjecaj na formiranje novih teorijskih uvida o žanrovima ponajbolje nam može posvjedočiti rad francuskoga književnog kritičara Ferdinanda Brunetièrea. Brunetière će, naime, u svojoj najznačajnijoj knjizi znakovitoga naslova Evolucija žanrova u povijesti književnosti (1890.) književne žanrove tako pokušati sagledati iz vizure darvinističke teorije,

\footnotetext{
32 Emil Staiger, naime, u svojoj studiji razlikuje imenice „ep“, „lirika“ i „drama“ kao pretince (ili „fundamentalne rodove“) u koje se svrstavaju konkretna književna djela od pridjeva „epsko“, „lirsko“ i „dramsko“ koji označavaju stilove ili moduse, odnosno „kvalitete u kojima određeno pjesništvo može imati udjela, ali i ne“ (Staiger 1996: 203). Upravo tim trima stilovima Staiger i posvećuje svoju knjigu u kojoj ujedno zagovara isključivo njihovu uporabu u proučavanju književnosti, tj. tvrdi da bi se upravo oni odlučno morali razdvojiti od pojmova epa, lirike i drame (usp. Staiger 1996). Inače, ovoj se Staigerovoj zamisli prvi oštro suprotstavio njemački književni teoretičar Wolfgang Kayser, koji u važnoj svojoj knjizi Jezična umjetnina (1948.), u kojoj brani autonomiju književnosti i također razvija trijadnu podjelu rodova (stilova), tvrdi da je pri tumačenju pojedinačnoga književnog teksta nužno u obzir uzeti sve njegove elemente (tematsko-motivske, formalne, jezične ili stilske itd.) u njihovoj povezanosti, pri čemu žanrove (rodove) treba shvatiti i proučavati kao isključivo ,gole“ jezične pojave.

33 Detaljnije o ,povijesnoj poetici“ Aleksandra Veselovskog kao temelju (i) većine najrecentnijih pristupa književnim žanrovima u: Brajović 1995: 20-27 i 95-133.
} 
odnosno njihov razvoj protumačiti kao biološki proces, zaključivši kako su su žanrovi (rodovi), nalik drugim živim organizmima, zapravo fenomeni koji se rađaju (tj. proizlaze jedni iz drugih), prolaze kroz razdoblja mladosti i zrelosti te naposljetku ulaze u fazu starenja i konačne smrti, a za čitavoga su svojeg života prisiljeni međusobno se boriti za prevlast u sferi književnosti. Drugim riječima, u Brunetièreovoj se optici rodovi motre kao sasvim autonomni entiteti čije promjene ne uvjetuju ni individualno djelovanje, a još manje kreativna volja $^{34}$, što se, na samom kraju 19. st., svakako moglo - i jest - shvatiti kao prilično inovativna predodžba o jednoj (,,papirnatoj“) klasifikacijskoj kategoriji.

Još uvijek aktualnu, treću fazu (ili strukturno-funkcionalni pristup književnim žanrovima) - otpočelu s prvim desetljećima 20. stoljeća - presudno je, pored ideja književne evolucije što su ih zastupali Veselovski i Brunetière, obilježila pojava ruskog formalizma i strukturalizma Ferdinanda de Saussurea. Pojačan interes što su ga tadašnji teoretičari počeli iskazivati za njegovu tekstualnu dimenziju urodio je naposljetku definitivnim ustoličenjem predodžbe o žanru kao funkcionalnoj kategoriji, zbog čega se s punim pravom može reći kako moderna genologija zapravo i počinje s ruskim formalistima, koji odlučno odbacuju romantičku teoriju zasnovanu na ideji o trima književnim rodovima kao univerzalnim, a ne povijesno određenim kategorijama. Zahvaljujući ponajprije Saussureovim strukturalističkim konceptima, ruski su formalisti - a poglavito se tu misli na Viktora Šklovskog, Borisa Tomaševskog i Jurija Tinjanova ${ }^{35}$ - u dvadesetim godinama prošloga stoljeća žanrove prvi počeli motriti u okrilju većega sustava dokazavši pritom kako obilježja (,postupci“), učinci i status svakoga pojedinačnog žanra presudno ovise o trenutnome stanju žanrovskog sustava podložnog neprekidnim promjenama, u kojemu se paralelno odvijaju i procesi potvrđivanja i oni opovrgavanja i transformiranja utvrđenih žanrovskih pravila. Imajući to na umu, Šklovski i suradnici ponajviše su istraživali sinkronijsku i dijakronijsku promjenjivost samih žanrova i njihovih međuodnosa u žanrovskom sustavu, posebno se usredotočujući na tzv. dominantne žanrove, koji u svakoj pojedinoj epohi zauzimaju mjesto na vrhu žanrovske hijerarhije da bi potom, u fazi raspadanja, svoje mjesto bili prisiljeni prepustiti drugome žanru. ${ }^{36}$ Formalisti stoga zaključuju da su, zahvaljujući međusobnoj povezanosti žanrova unutar sustava, i promjene u strukturi svakoga pojedinačnog žanra (odnosno, kako to oni običavaju reći,

\footnotetext{
${ }^{34}$ Usp. Duff 2000: 4.

35 Definitivno najveći prilog formalističkoj teoriji žanrova dali su Jurij Tinjanov svojim esejom „Književna činjenica“ (1924.) te, dakako, Boris Tomaševski čuvenom Teorijom književnosti (1925.).

${ }^{36}$ Formalisti ističu da do smjene na vrhu hijerarhije žanrova dolazi kada se, uslijed svoga raspadanja, dotad dominantni žanr postupno seli iz središta žanrovskoga sustava na njegove margine, dok drugi žanr, koji je dotad bio percipiran kao manje važan (pa čak pokatkad i posve nevažan i marginalan), s ruba sustava dolazi u njegov centar, zauzima mjesto na vrhu hijerarhije i time postaje dominantnim žanrom konkretne književne epohe.
} 
njegovih karakterističnih postupaka) ponajviše uvjetovane izmjenama u poretku žanrova u sustavu, čime ujedno nepobitno potvrđuju da su svojstva književnosti u stalnoj mijeni te da na to utječu ne samo unutarknjiževne (unutartekstualne) promjene, već i one konteksta (samoga književnog razdoblja), odnosno da je značenje tekstova uvelike uvjetovano nepostojanim književnim okvirom unutar kojega su oni i ostvareni.

Formalistička je teorija, kao takva, izravno utjecala i na utemeljenje semiotičkoga pristupa književnosti, čije je predstavnike - počevši od američkih filozofa Charlesa Morrisa i Charlesa Sandersa Peircea - ponajviše zaokupljao proces semioze ili upotrebe bilo kojega znaka ili znakovnog događanja. Njihova istraživanja, dakako, nisu mogla mimoići ni same književne žanrove, a semiotički je pristup žanrovima urodio i daljnjim promjenama u njihovu shvaćanju, koje će naročito postati uočljive u kontekstu iduće, strukturalističke teorijske paradigme. U tom je smislu kao svojevrsnu ,predigru“ strukturalizma, osim semiotike, moguće označiti i sociološka, marksistička razumijevanja književnosti, koja će uvelike slijediti smjer što su ga u svojoj knjizi Formalna metoda u znanosti o književnosti već 1927. zacrtali ruski teoretičari Mihail Bahtin i Pavel Medvedev, a u kojoj se - između ostaloga - i književni žanr po prvi put počeo motriti na podlozi društvenopovijesnih mijena, odnosno iz vizure „sociološke poetike“ koja je posebno isticala njegovu dotad sustavno zanemarivanu ideološku dimenziju. Bahtinovi i Medvedevljevi zaključci snažnoga su odjeka imali tijekom cijeloga 20. stoljeća, pa su se na njihova sociološka shvaćanja žanrova u znatnoj mjeri naslanjali i brojni (drugi) marksistički teoretičari književnosti poput, primjerice, Györgyja Lukácsa, Raymonda Williamsa, Johna Frowa, Tonyja Bennetta i Fredrica Jamesona.

Ipak, možda i najuvjerljivija, a svakako najutjecajnija (i, usudili bismo se reći, do danas nenadmašena) zapažanja o sociologiji žanrova doći će upravo iz pera (zreloga) Mihaila Mihailoviča Bahtina, koji u svome eseju „Problem govornih žanrova“ iz 1953. (o kojemu će znatno više riječi biti u nastavku) razgraničuje „primarne“ od „sekundarnih“ govornih žanrova, napominjući pritom kako i jedni i drugi u cijelosti proizlaze iz svakodnevice i presudno su određeni svojom specifičnom uporabom ili ulogom $u$ danome društvenopovijesnom kontekstu. ${ }^{37} \mathrm{Za}$ Bahtina svi su tako žanrovi ,književnosti i govora, ne samo skupovi sredstava i konvencija, nego i »forme promatranja i interpretiranja pojedinih aspekata svijeta«, načini »osmišljavanja stvarnosti« pohranjenih u »žanrovskom pamćenju«“ (Duff 2000: 10). Pritom je, dakako, očito da se u razvijanju ovih svojih zapažanja uvelike on nadovezivao na mnoge genološke spoznaje što su ih u svojim radovima nagovijestili već ruski formalisti, no usprkos takvim je idejnim uzorima inovativnim zamislima o žanrovima kao

\footnotetext{
${ }^{37}$ Usp. Bahtin 1986: 60-102. Pregledno o tome i u: Holquist 1986: IX-XXIII.
} 
sveprisutnim entitetima izvršio i više nego jak utjecaj na gotovo sve teorije žanra od druge polovine 20. st. do danas. Štoviše, upravo Bahtinov koncept govornih žanrova i predstavlja temelj suvremene (književne) genologije i žanrovskih analiza kako u znanosti o književnosti, tako i u gotovo svim drugim znanostima u kojima je kategorija žanra bila i još uvijek jest jedan od središnjih predmeta sustavnoga proučavanja. ${ }^{38}$

Međutim, o „osnovnim“ i ,složenim“, tj. ,,jednostavnim“ i ,kompleksnim“ Žanrovima književni su genolozi, kako se čini, razmišljali već desetljećima prije Bahtina, što i potvrđuje sličan pokušaj razlikovanja kojega je već 1930. u svojoj studiji o devet jednostavnih (pretknjiževnih) oblika predstavio nizozemski povjesničar umjetnosti i komparatist André Jolles. U knjizi naslovljenoj Jednostavni oblici Jolles tako razmatra devet žanrova usmene književnosti (legendu, predaju ili sagu, mit, zagonetku, izreku, kazus, memorabile, bajku i vic), koje definira kao pretknjiževne oblike, u opreci spram „složenih“ oblika ili žanrova, koji su se, ističe, razvili u kasnijoj, pisanoj književnosti. Pobrojani jednostavni oblici produkt su, napominje Jolles, autohtone, izvorne jezične proizvodnje i „događaju“ se - u obliku gesta sami u jeziku, što će reći da se, bez kreativnoga posredovanja bilo kojega pojedinca, „ostvaruju i u životu i u jeziku“ (Jolles 2000: 244), dok, za razliku od njih, ,posredovani““ ili složeni oblici (tj. književni žanrovi u punom smislu riječi) upravo i nastaju posredstvom pojedinčeve naknadne jezične djelatnosti. Jednostavni su oblici, dakle, prvobitni ili temeljni načini izražavanja, koji egzistiraju neovisno od određenoga prostorno-vremenskog konteksta (zahvaljujući čemu ih je moguće pronaći čak i u vremenski i prostorno prilično udaljenim kulturama) i posredstvom kojih - u stvaralačkom činu pojedinca - nastaju ili se razvijaju složeni oblici što ih potom i percipiramo kao književne žanrove. Jollesovo zapažanje kako, zbog takvoga „ugrađivanja“ u književne žanove, jednostavni oblici nužno propadaju, pa u složenim oblicima ili žanrovima stoga zatječemo tek njihove ostatke ${ }^{39}$ itekako je usporedivo s Bahtinovim objašnjenjem procesa stapanja primarnih sa sekundarnim žanrovima uslijed kojega oni primarni u cijelosti bivaju „usisani“ u sekundarne, gdje gube svoju prvobitnu jezičnu svrhu, odnosno prestaju, na neki način, u tome novom okviru postojati kao takvi. ${ }^{40}$

\footnotetext{
${ }^{38}$ Genološka teorija Mihaila Bahtina, a naročito njezino naglašavanje društvene utemeljenosti žanrova, u izrazito velikoj će mjeri, kao što ćemo vidjeti kasnije, obilježiti i one pristupe koji će fokus svojih istraživanja usmjeriti na propitivanje dinamičkog odnosa između žanrova, tekstova i kulturnih (društvenopovijesnih) okolnosti ili društvenih akcija, odnosno načina na koje se žanrovi (ili žanrovske konvencije) nameću kao zakonite opcije kojima se mogu (i moraju) služiti čitatelji i/ili kritičari. Ti pristupi, ponajviše slijedeći upravo Bahtinova razmišljanja, polaze od pretpostavke da je stvaranje i rastvaranje (mijenjanje) žanrova izravno povezano $\mathrm{s}$ društvenim stvaranjima i rastvaranjima, i to na ideološki način. Naime, žanrovi ne samo što, tvrde oni, oblikuju tekstove, već i društvene akcije, a to čine tako što mijenjaju diskurse u društveno prepoznatljive i svrhovite tekstove, čime ujedno utječu i na proizvodnju i organizaciju društvenih praksi, struktura i događaja.

${ }^{39}$ Podrobnije u: Jolles 2000.

${ }^{40}$ Usp. Bahtin 1986: 60-102.
} 
Kako bilo, ruski je formalizam u najvećoj mjeri i „pripravio put“ za skori dolazak strukturalizma, a prve se naznake strukturalističke teorije žanrova donose već u knjizi Morfologija bajke (1927.) ruskoga folklorista i utemeljitelja morfologije Vladimira Proppa, u kojoj je - između ostalog - riječ i o nekim ustaljenim „funkcijama“ žanra bajke (tipovima gradnje priče, stalnome repertoaru akcija, karakternih uloga itd.). Nedugo nakon Proppa, ruski će semiotički strukturalist Jurij Lotman književni tekst motriti kao neodvojiv od njegova okružja tvrdeći da on „u tijeku svoga povijesnog postojanja ili prelaskom iz jednog u drugi kulturni kontekst može doživjeti preraspodjelu funkcija i promjenu žanra“ (Milutinović 2009: 21), zbog čega se onda i sam autorski izbor žanra zapravo ispostavlja kao u cijelosti informativan i motiviran čitateljevim očekivanjem jasnih tekstualnih signala koji bi ga trebali uputiti na konkretna žanrovska pravila. Propp, Lotman i drugi su strukturalistički teoretičari, slijedeći i produbljujući zapažanja formalista i semiotičara, u proučavanje književnosti tako uveli shvaćanja prema kojima se književna djela nužno moraju motriti kroz prizmu svoje tekstualnosti, ali nipošto bez analize čitateljeve uloge u stvaranju značenja te utjecaja izvanknjiževnoga okružja na to značenje. I žanrovima se, slijedom takvih predodžbi, od strukturalizma počinje pristupati kao kategorijama obilježenim snažnim utjecajem izvantekstualne stvarnosti, što će reći da se pitanja žanra sve češće počinju povezivati s pitanjima estetskih normi (tj. književnoga i kulturnog sustava u cijelosti), a sve veći značaj u teorijskim tekstovima dobiva $\mathrm{i}$ ideja kako žanrovi utječu ne samo na književne pojave, već $\mathrm{i}$ na društvene prakse i stvarnost općenito. ${ }^{41}$

Jednim od specifičnih se izdanaka strukturalističke teorije žanra može shvatiti i tzv. „arhetipska kritika“, čija će polazišta njezin osnivač - Northrop Frye - predstaviti u glasovitoj knjizi Anatomija kritike iz 1957. U fokusu te su studije, konkretno, predžanrovske strukture, odnosno čisto unutartekstualni i nadpovijesni arhetipovi ili svojevrsni oblici književne simbolike (simboličke jedinice) što ih - u najrazličitijim mogućim kombinacijama - svi pisci uključuju u svoja djela, čime ujedno oni postaju svojinom apsolutno svih književnih žanrova. Frye pritom, usporedivši ih s četirima fazama prirodnoga ciklusa, ponajprije izdvaja četiri temeljna narativna tipa, tj. „mita“ ili arhetipska načina pripovijedanja - tragediju, komediju, romansu i ironiju (satiru) - koje razlikuje prema obilježjima njihovih „svjetova“, a potom ispituje na koji se način te književne forme razvijaju kroz različite (arhetipske) stupnjeve literarnosti ili moduse - i to njih, sveukupno, pet (mitski, romancesni, visokomimetski, niskomimetski, ironijski) - definirane s obzirom na „moć akcije“ pridanu središnjem junaku,

\footnotetext{
${ }^{41}$ Pregledno o semiotičkoj i strukturalističkoj teoriji žanra i njezinim zastupnicima npr. u: Winner 1978: 254-268 i Dijk 1985: 1-9.
} 
ali ujedno određene i nizom povijesnih, psiholoških i antropoloških faktora. Osim toga, Frye razlučuje još i pet konteksta ili faza u okvirima kojih je moguće tumačiti značenje svakoga teksta (doslovnu, opisnu, oblikovnu, mitsku i anagogijsku fazu), da bi - naposljetku - izlučio sveukupno četiri temeljna književna roda - epos (u koji uključuje narativna djela u stihu: epove i balade), prozu, dramu i liriku - koje razlikuje shodno prezentacijskim i retoričkim kriterijima, odnosno prema (pretežno) jezičnim kriterijima i formalnim značajkama. ${ }^{42}$

Posebnom (i posebno utjecajnom) varijantom strukturalizma definitivno valja držati i teoriju recepcije (ili, kako se u sekundarnoj literaturi često naziva, pristup tzv. škole u Konstanzu), čijim se ključnim ishodištima u svome nezaobilaznom tekstu „Teorija žanrova i srednjovjekovna književnost“ iz 1970. pozabavio njemački filolog Hans Robert Jauss. Teorija recepcije, naime, fokus u proučavanju žanra u cijelosti premješta s pola proizvodnje na pol recepcije - usredotočujući se na mehanizme pomoću kojih se književna djela prihvaćaju i vrednuju - te pritom zagovara poimanje žanrova kao događaja, odnosno povijesnih kategorija koje provociraju promjenjive horizonte značenja i očekivanja. Stoga i Jauss, pišući o srednjovjekovnim književnim žanrovima, naglašava da se žanrovski ,identitet“ svakoga novog djela utvrđuje isključivo na podlozi tzv. „horizonta očekivanja“, kojega sami žanrovi i impliciraju i kojega u procesu recepcije aktivira publika, što onda znači da će to djelo ili gotovo u potpunosti potvrditi postojeće norme žanra ili, pak, svojim inovativnim obilježjima isprovocirati pomicanje „,horizonta očekivanja“.

Beziznimno je svako književno djelo, nastavlja Jauss, upućeno na povijesno obilježenu situaciju razumijevanja koja čin recepcije i usmjerava, odnosno na povijesno promjenjivi ,horizont očekivanja“ koji implicira skup (žanrovskih) pravila poznatih iz ranije čitanih tekstova koja čitatelj nužno evocira pri susretu sa svakim novim tekstom i koja na taj način i usmjeruju njegovo razumijevanje toga teksta. „Horizont očekivanja“ ujedno, dakle, uključuje kako ono što tekst iziskuje od čitatelja (ono što je utkano u tekst kao „horizont očekivanja“ implicitnog čitatelja), tako i očekivanja s kojima čitatelj pristupa tome tekstu (tj. „horizont očekivanja“ eksplicitnog čitatelja), pa upravo te dvije razine ili sustava očekivanja uzajamno i oblikuju recepciju. Svako novo djelo te čitatelju od ranije poznate norme samo reproducira ili korigira, varira ili sasvim mijenja, iziskujući od njega da prilagodi i svoja očekivanja, a to onda znači da je razumijevanje ili recepcija teksta moguća jedino pod uvjetom da prizivanje određenoga ,horizonta očekivanja“ što ga tekst i pokreće u stopu prati i odgovarajući „horizont očekivanja“ kojim raspolaže čitatelj, ili, drugim riječima, samo ukoliko se ta dva horizonta na koncu i stope. Jauss pripominje i da se sa svakim novim djelom

\footnotetext{
${ }^{42}$ Detaljnije o Fryevu arhetipskom pristupu književnim žanrovima i u: Hernadi 1972: 131-151.
} 
„horizont očekivanja“ sve više širi i nadopunjuje, što je proces u kojemu su, osim unutarknjiževnih situacija (npr. mijene poetika ili hijerarhije žanrova u žanrovskom sustavu), od presudne važnosti i povijesne i društvene situacije koje bitno utječu na svaki žanr. To vrlo često rezultira i time da se žanrovi u kasnijim fazama svoga, života“ rabe u sasvim različite estetske i društvene svrhe od onih kojima su služili ranije, ali i da mogu postati nositeljima raznoraznih, ne uvijek identičnih funkcija unutar žanrovskoga sustava istoga perioda (mnogi od njih tako, primjerice, mogu imati podjednako društvenu i književnu funkciju). Žanrovi su kao društvenopovijesne pojave - tako u konstantnoj mijeni, no ono što u njihovu slučaju doista i jest podložno mijeni zapravo je ,horizont očekivanja“ od kojega njihovo postojanje jedino i ovisi. Baš zato bi, kako zaključuje Jauss i time ujedno anticipira i neka od najsuvremenijih shvaćanja žanrova, genološkim istraživanjima ponajprije i trebao biti cilj istražiti „funkciju, recepciju i djelovanje književnih djela i rodova (žanrova, op. V. B.) u njihovoj povijesnoj stvarnosti i društvenoj okolini“ (Jauss 1970: 351), i to imajući na umu da žanrovi zapravo nisu logične skupine, već povijesne obitelji čiji je poredak nestabilan i koje stoga i jest moguće opisati isključivo iz povijesne perspektive. ${ }^{43}$

Teze što su ih zastupali Jauss i teoretičari recepcije definitivno bi se mogle povezati is idejama što ih je 1967. iznio američki hermeneutički kritičar Eric Donald Hirsch, koji, pišući o ,načelima interpretacije“ književnih tekstova, upravo žanr vidi kao nositelja tumačenja, ${ }^{44}$ ali i s mnogobrojnim relativno novijim teorijama koje, polazeći od zapažanja da njegova moć ne izvire iz same proizvodnje nego recepcije književnosti, žanru prilaze iz pozicije čitatelja shvaćajući ga kao alat za razumijevanje književnih djela. Tako, primjerice, i Adena Rosmarin u knjizi Moć žanra (1985.), definiravši ga kao argument što ga kritičar iznosi o danome tekstu, žanr poima kao praktičnu kategoriju, odnosno kao osnovno kritičarevo „oruđe“ za objašnjavanje (vrednovanje) književnoga djela, njegovo sredstvo uvjeravanja publike. Iako upravo žanr daje književnome tekstu značenje i vrijednost, nikada se s tim tekstom on ne može savršeno podudarati i baš zato su tekstovi ujedno i nalik žanru, ali i različiti od njega. To, napominje Rosmarin, nipošto nije njegov nedostatak jer svrha žanra i nije da odgovara teorijskoj ili povijesnoj stvarnosti, već kritičarevoj praktičnoj svrsi, što upravo i jest razlog

\footnotetext{
${ }^{43}$ Opširnije u: Jauss 1970: 327-352 i 1978: 349-376.

${ }^{44}$ U svojoj knjizi Načela tumačenja i Hirsch, baš poput Jaussa, ističe važnost „,generičkih očekivanja“ što ih čitatelji, zahvaljujući usvajanju - kroz recepciju prethodnih djela - njegovih specifičnih normi i konvencija, imaju od pojedinoga žanra. Upravo ta su očekivanja (a onda i shvaćanja žanrova) presudna pri svakoj interpretaciji jer, napominje Hirsch, usmjeravaju razumijevanje djela u cjelini i zato je posebno bitno da autori i tumači (kritičari) dijele isti sustav žanrovskih očekivanja, tj. identičnu žanrovsku koncepciju (ili „unutarnji žanr“ određenoga iskaza). Svako ispravno tumačenje, poentira Hirsch, tako se zapravo svodi na ispravno detektiranje žanra (usp. Hirsch 1983: 87-147).
} 
zbog kojega tekst može postati objektom različitih žanrovskih objašnjenja, a da pritom ne izgubi ništa od svoje cjelovitosti. ${ }^{45}$

U strukturalističkim je promišljanjima genoloških dilema važnu ulogu odigrala $i$ izvorno marksistička teorija o žanru kao ugovoru, koje će se u drugoj polovini 20. stoljeća dotaknuti brojni ugledni genolozi, među kojima posebno vrijedi izdvojiti američkoga književnog teoretičara Jonathana Cullera. Dospjevši u jednom od poglavlja svoje knjige Strukturalistička poetika (1975.) i do problematike književnih žanrova, Culler ustvrđuje da određivanje žanrovskoga okvira svakoga teksta proizlazi iz tzv. književne kompetencije, koja „definira sposobnost nas kao čitatelja da prepoznamo i interpretiramo kodove danoga žanra, pa odatle i »izvedemo« čitanja pojedinih primjera žanra“ (Duff 2000: 15), što će reći da „književna kompetencija“ podrazumijeva ovladavanje skupom konvencija neophodnih za čitanje književnih djela. Te su konvencije, pojasnit će Culler, i omogućene ponajprije zahvaljujući postojanju pojedinih žanrova, a budući da svaki književni tekst stječe značenje jedino oslanjanjem na sustav konvencija koje su čitatelji upili, ali i s predznanjem o kojima i pisci pišu svoja djela, s punim se pravom može reći da one konstituiraju instituciju književnosti. Žanrovske se konvencije, nastavlja Culler, s vremena na vrijeme mijenjaju, a ta promjena konvencija - a zajedno s njima i očekivanja čitatelja - ujedno znači i promjenu u instituciji književnosti u cijelosti. A da bi se (i) te promijenjene konvencije žanrova uopće mogle aktivirati i tako omogućiti značenje književnih djela, potreban je, napominje Culler, (nepisani) ugovor između pisca i publike na temelju kojega i konkretna (žanrovska) očekivanja čitatelja mogu postati djelotvorna. Iz svega toga, konačno, slijedi da književni žanrovi zapravo nisu tek spletovi konvencija, već ujedno i očekivanja, koja su - zajedno s konvencijama - od presudne važnosti za razumijevanje svakoga književnog djela, točnije njegovo prihvaćanje kao takvog. ${ }^{46}$ Inače, pitanjima čitateljskoga prihvaćanja žanrova u svojoj je studiji Logika književnosti još 1957. izrazito veliku pažnju posvetila i njemačka filozofkinja Käte Hamburger, koja naglašava kako unutar strukture žanra „sudionici u diskursu utjelovljuju određene akcije, identifikacije i reprezentacije u odnosu jednih spram drugih“ (Bawarshi i Reiff 2010: 19). Hamburger je, treba znati, bila i jedna od prvih teoretičarki žanra koja se s osobitim zanimanjem osvrnula i na „mješovite“, odnosno „granične“ žanrove, dok se njezino zapažanje kako čitatelji posve različito reagiraju na različite skupine književnih djela svakako može držati nagovještajem nekih znatno ,mlađih“ genoloških zamisli. ${ }^{47}$

\footnotetext{
${ }^{45}$ Podrobnije u Rosmarin 1985: 23-51.

${ }^{46}$ Usp. Culler 1990: 171-196.

${ }^{47}$ O ključnim genološkim opservacijama K. Hamburger pregledno u: Hernadi 1972: 46-53.
} 
Teorijsko „nasljeđe“ strukturalističkoga će bavljenja književnim žanrovima u velikoj mjeri usmjeriti i genološka proučavanja u posljednjim desetljećima 20. stoljeća, pa će i tzv. poststrukturalistički pristupi redom polaziti od već dobro utvrđene spoznaje o tome kako je svaki žanr presudno određen (i) međužanrovskim, dakle odnosima spram drugih supostojećih žanrova, a ne tek pukim repertoarom svojih unutaržanrovskih obilježja. Za razliku od esencijalističkih pristupa žanrovima, koji su vjerovali da svi književni tekstovi nose stanovitu „bit““ (esenciju) koja ih nužno - i jednom za svagda - svrstava u neki od triju općih rodova ili u konkretnu književnu vrstu, ${ }^{48}$ antiesencijalističke (relativističke) teorije poststrukturalizma i historizma drže da je svaki žanr neodrediv, nepostojan književni fenomen koji ne posjeduje stabilan, a poglavito ne unaprijed zadan sadržaj i, shodno tomu, ne predstavlja ni jedinu kategoriju niti tip. Generički „identitet“ svakoga književnog djela, uvjereni su poststrukturalisti, dinamičan je i otvoren zato što je bitno određen (trenutnim) odnosom žanra spram drugih sličnih fenomena, čitateljevom društveno-kulturnom, spoznajnom i psihološkoideološkom perspektivom, kao i povijesno obilježenom ulogom koju to djelo igra u određenoj kulturi. „Ni književnost ni žanrovi zato nisu kategorije s permanentnom i nepromjenjivom esencijom“ (Milutinović 2009: 24), kao što su to mislili esencijalisti, poimajući žanrove transcedentalnim, čvrstim i statičnim konstruktima, već, upravo suprotno, varijabilni entiteti na koje presudno utječu mnogobrojni promjenjivi vanjski čimbenici.

Šezdesetih se godina 20. stoljeća u okrilju dekonstrukcije, koja se dotad najodlučnije suprotstavila tradiciji esencijalizma i njegovih klasifikacija, pojavljuje tako intrigantna teorija intertekstualnosti, a uz nju i zamisao o književnosti kao instituciji, koje će dubokoga traga ostaviti osobito u književnoj genologiji. Žanr se, naime, otad sve češće počinje promišljati kao intertekstualna i transtekstualna kategorija, što rezultira spoznajom kako generičko određenje svakoga teksta nužno ovisi o intertekstualnim sponama koje čitatelju pomažu da ga shvati kao izraz komunikacijske strategije pisca. Budući da je - tvrde poststrukturalistički teoretičari dekonstrukcije - granica između umjetničkih i neumjetničkih žanrova zapravo stvorena u okviru različitih institucija (književne povijesti, izdavaštva, obrazovnoga sustava itd.), potrebno je shvatiti da su u ,posao“ prepoznavanja i utvrđivanja žanrovskih obilježja upleteni ne samo autor, „obični““ čitatelji te književni kritičari, teoretičari i povjesničari, već i svi oni koji su na bilo koji način uključeni u prezentaciju tekstova i njihovo (kritičko) tumačenje (urednici, novinari, mediji itd.), a to su, dakle, redom svi sudionici književne komunikacije. ${ }^{49}$ Baš zato poststrukturalisti i plediraju za to da se žanrovi „ne shvaćaju više kao unutarnje

\footnotetext{
${ }^{48}$ Esencijalizam se, podsjetimo, bazirao na stajalištu da svaki tekst počiva na jasno određenoj biti koja mu i osigurava prikladan sadržaj i strukturu, i to u okvirima pripadnosti nekoj žanrovskoj kategoriji.

${ }^{49} \mathrm{O}$ tome u: Milutinović 2009: 26.
} 
forme zatvorene u konkretnim objektima iste klase, već kao rezultat intertekstualnih i metatekstualnih procedura koje u potpunosti obuhvaćaju i određuju pisanje i čitanje“ (Milutinović 2009: 26), a inzistiranje na takvom poimanju žanrova u genologiji je naposljetku urodilo uvažavanjem intertekstualnosti kao fenomena koji najsnažnije oblikuje, mijenja i/ili održava žanrove na životu, odnosno u svijesti autora i recipijenata književnih tekstova.

Žanrovskoj intertekstualnosti posvećen je, između ostalih, i iznimno velik broj studija Gérarda Genettea, u kojima je ovaj čuveni francuski teoretičar književnosti uspješno dokazao da je svaki (književni) tekst sazdan od generičkih signala koji se različito prepoznaju, odnosno koji su smješteni na različitim unutartekstualnim i izvantekstualnim razinama (arhitekstovi, paratekstovi, metatekstovi, intertekstovi, hipertekstovi, hipotekstovi). Svi su ti signali, pojašnjava Genette, bjelodan dokaz intertekstualnosti književnoga teksta jer svaki od njih čitatelje upućuje na druge tekstove i žanrove, odnosno podsjeća ih na to da je tekst nužno čitati intertekstualno, evocirajući određene žanrovske tradicije i matrice (žanrovske predloške), a onda i konkretna žanrovska očekivanja. ${ }^{50}$ Samo područje žanrova kao takvih, ipak, neposredno se tiče onoga tipa odnosa kojeg Genette naziva arhitekstualnošću, a riječ je o odnosu uključivanja „koji povezuje svaki tekst s različitim tipovima diskursa iz kojih on proizlazi“(Genette 1985: 189).

Novonapisani se tekstovi neizbježno, dakle, (intertekstualno) nadovezuju na one stare, no žanrovska pravila rabe oni pritom na sebi svojstven način, što ujedno znači da svaki novi tekst u većoj ili manjoj mjeri preoblikuje stari (dotadašnji) žanr, mijenja ga, posve transformira, opire mu se ili proširuje ,inventar“ njegovih „karakterističnih“ obilježja. To, na koncu, dovodi i do pomicanja granica žanra, koji - u sasvim novome povijesnom trenutku i pod drugačijim okolnostima - biva redefiniran, slijedom čega se pred njega počinju postavljati i novi zahtjevi i nove funkcije. Baš zato književni tekstovi nikada pasivno ne „pripadaju“ nekome žanru, već su njegova „uporaba“ u mreži intertekstualnih odnosa i u određenome okviru ili kontekstu. Ipak, poneki teoretičari žanra (ponajprije David Fishelov i Jean-Marie Schaeffer) ističu kako bi se unutar svakoga pojedinog žanra mogla prepoznati i izdvojiti (reprezentativna) književna djela koja funkcioniraju kao svojevrsni žanrovski prototipovi, odnosno kao tekstovi koji pravila danoga žanra ,iskazuju na tako tipičan način, da je na njih moguće uputiti kad god se uz nove književne proizvode provjerava prikladnost konkretnoga genološkog pojma“ (Juvan 2006b: 175). Žanrovski prototip, dakle, najčešće ne

\footnotetext{
${ }^{50}$ Usp. Genette 1985: 189-191 i Rasmussen 2015: 130-133. Primjerice, očiti ili manje očiti žanrovski se signali, kako će pokazati i primjer Vitezovićeva Odiljenja, mogu tako kriti u prijelaznom „teritoriju“ između unutartekstualnoga i izvantekstualnoga, odnosno u paratekstu (u naslovu, posveti, predgovoru itd.). Detaljnije u: Genette 1997, a pregledno o tome i u: Fowler 1982: 88-105 i Rasmussen 2015: 125-152.
} 
uključuje samo jedno djelo, već obično nekolicinu njih, koja - zahvaljujući obilnoj premreženosti nekim „tipičnim“ njegovim značajkama - čine svojevrsnu ,jezgru“ konkretnoga žanra. Ti „najčišći“ (,kanonski“) predstavnici svoje žanrovske kategorije zato najčešće i vrše funkciju tzv. žanrovskih referenci, na koje se najveći broj novih tekstova oslanja, nadovezuje ili ih priziva intertekstualnim signalima - kako onim potvrdnim, tako i onim polemičkim. ${ }^{51}$

Poststrukturalisti su se, međutim, s osobitim žarom usredotočili i na dekonstruiranje tradicionalne, dugo uvriježene i već gotovo samorazumljive hijerarhije rodova / vrsta / žanrova dokazavši, konačno, kako baš svaki književni tekst nužno upija, miješa i preobražava različite žanrovske obrasce, iz čega onda proizlazi da pretpostavljeni ,čisti“ žanrovi i/ili vrste nisu zapravo ništa drugo no puka teorijska apstrakcija. Na tragu su te spoznaje bili već i neki raniji proučavatelji - primjerice, Bahtin i marksisti - koji su također ustrajno upozoravali na hibridan i heterogen značaj teksta tvrdeći kako je, zahvaljujući njemu, svako književno djelo moguće nejednako, a pokatkad i sasvim proturječno žanrovski kategorizirati. Imajući to na umu, književni genolozi u drugoj polovini 20. st. zato neprekidno ističu da su presudan čimbenik u formiranju žanrova i osiguravanju njihova kontinuiteta u svijesti svih sudionika književne komunikacije (ali ujedno i njihovu mijenjanju kroz povijest) intertekstualne poveznice na prototipska djela, odnosno na sadržajno-formalne osobine sličnih tekstova, iz čega slijedi da žanrovi zapravo „postoje na društvenim praksama koje okružuju, obuhvaćaju i određuju intertekstualne i metatekstualne reference na prototipske tekstove ili nizove tekstova“ (Milutinović 2009: 27) te su, kao takvi, u cijelosti socijalne kategorije jer pokreću repertoar društvenih diskursa. Pod utjecajem ovih spoznaja o kulturnoj određenosti (književnih) žanrova u recentnoj se teoriji žanrova gotovo posve odustalo od klasifikacijskog razvrstavanja tekstova u ,čiste“, hijerarhijski predočene žanrove te se, umjesto toga, sve glasnije zagovara primjena modela mnoštvenosti povijesnih žanrova. Razmišljanje o tome kako „temeljna vrijednost žanrova nije klasifikatorska“ (Fowler 1982: 37), već se njihov značaj krije u isključivo komunikaciji i identifikaciji (identifikaciji, dakle, žanra u svrhu interpretacije književnoga teksta, jer svako žanrovsko određenje ujedno uspostavlja i njegovo značenje), u najsuvremenijoj književnoj genologiji stoga nije novo, već se u teorijskim radovima elaborira punih nekoliko desetljeća. ${ }^{52}$

Iz zapažanja o žanrovima kao hibridnim kategorijama koje zapravo potkopavaju čvrste i jednoznačne klasifikacije književne građe proizišli su i nov(ij)i pokušaji redefiniranja

\footnotetext{
${ }^{51}$ Opsežnije u: Juvan 2006b: 174-179.

${ }^{52} \mathrm{O}$ hibridnim žanrovskim značajkama svih (književnih) tekstova posebno u: Schaeffer 1989: 167-187.
} 
samoga koncepta žanra, odnosno preispitivanja temeljnih pretpostavki na kojima su shvaćanja žanra dotad i počivala. Promišljajući iznova što to žanr doista i čini žanrom, neki su suvremeni teoretičari ustaljenu predodžbu o žanru kao kategoriji koja nužno implicira unaprijed definirana i točno određena (tipična) tekstualna obilježja (ili repertoar značajki) pokušali zamijeniti viđenjem žanrova kao entiteta koji se temelje na tzv. obiteljskim podudarnostima, o kojima je svojedobno pisao već Ludwig Wittgenstein, a koje je na umu jamačno imao i Hans Robert Jauss kada je, kao što smo vidjeli, pledirao za razumijevanje žanrova kao povijesnih obitelji, a ne logičnih skupina ili razreda. ${ }^{53}$ Kao jedan od najglasnijih zastupnika takvoga „olabavljenog“ koncepta književnog žanra nametnuo se škotski književni kritičar Alaistar Fowler, koji pojmom „obiteljskih podudarnosti““ označava mrežu sličnosti između različitih elemenata (odnosno tekstova) koji potpadaju pod isti žanrovski naziv, ali pritom ne moraju nužno dijeliti ni jednu zajedničku osobinu. ${ }^{54}$ Žanrovi se pritom, posve u skladu s poststrukturalističkim razmišljanjima, motre kao isključivo određeni načini uporabe književnih tekstova, tj. kao svojevrsni sustavi razlika bez nekakve zajedničke strukture, odnosno kao institucije ili ugovori između autora i publike koji propisuju „ispravnu“ uporabu književnoga djela, iz čega proizlazi da oni ne postoje kao svojina teksta, već isključivo kao odnos između publike i djela, posredstvom kojega se „dogovara“ njegov žanrovski identitet.

Tezu o žanru kao instituciji, inače, prvi su u svojoj čuvenoj Teoriji književnosti dakle, već 1949. - predstavili američki književni kritičari René Wellek i Austin Warren, ustvrdivši kako je žanr - upravo kao što su to i, primjerice, država, Crkva i sveučilište - jedna od (povijesno promjenjivih) institucija, kroz koje ljudi mogu djelovati, izražavati se, pristupati im u želji da ih preoblikuju, stvarati nove ili se naprosto, ukoliko u njima ne žele participirati, od njih (koliko je to moguće) distancirati. ${ }^{55}$ Od sedamdesetih godina prošloga je stoljeća ovakvim shvaćanjima osobito bila sklona sociologija, koja je žanrove motrila iz vizure procesa institucionalizacije i deinstitucionalizacije tvrdeći kako su oni - nalik ostalim institucijama - „dio one društvene cjelovitosti koja ih institucionalizira“, ali na koju ujedno „, oni mogu utjecati regulirajući kretanje ove cjelovitosti“ (Konstantinović 1985: 31), zbog čega su u nezaustavljivom procesu stvaranja i rastvaranja. Zahvaljujući utjecajnim studijama Fredrica Jamesona ${ }^{56}$ i Jonathana Cullera, ${ }^{57}$ razumijevanje žanrova kao institucija potvrdilo je

\footnotetext{
${ }^{53}$ Usp. Jauss 1970: 330-331. O tome Jaussovu konceptu ukratko i u: Novaković 1986: 328-329.

${ }^{54}$ Usp. Fowler 1982; Juvan 2006b: 158-159; Frow 2015: 58-59. O tome kako većina djela unutar okvira nekoga žanra biva podvedena samo na temelju stanovitih „obiteljskih sličnosti“ pisao je i Jean-Marie Schaeffer, ističući kako se sve žanrovske grupe zbog toga i konstituiraju samo privremeno (usp. Schaeffer 1989: 167-187).

${ }^{55}$ Podrobnije u: Wellek i Warren 1974: 272-285.

${ }^{56}$ Usp. Jameson 1984: 122-181.

${ }^{57}$ Usp. Culler 1990: 171-196.
} 
svoju važnost obogativši književnu genologiju shvaćanjem prema kojemu identitet žanra u cijelosti ovisi od njegove „uporabne vrijednosti“ ili funkcije koju vrši unutar društvenih praksi, ${ }^{58}$ a onda i od relacije spram drugih žanrova u danome vremenskom trenutku, odnosno o sličnostima i razlikama prema njima.

U sedamdesetim je godinama 20. st. zamisao o žanru kao (društvenopovijesnoj) instituciji svoje mjesto našla i u radovima dvojice znamenitih (post)strukturalističkih književnih povjesnika - Gérarda Genettea ${ }^{59}$ i osobito Tzvetana Todorova. Za potonjega žanrovi su tako kodifikacije ponovljivih tekstualnih - semantičkih, sintaktičkih i pragmatičkih - obilježja koji funkcioniraju kao „modeli pisanja“ za autore, odnosno kao „horizonti očekivanja za čitatelje, a riječ je o skupinama tekstova koje se povijesno shvaćaju kao takve i čije je postojanje presudno određeno društvenim mijenama. ${ }^{60}$ Todorov će, međutim, u svojoj čuvenoj knjizi Uvod u fantastičnu književnost (1970.) ipak ustvrditi da književna genologija nije i ne može biti usredotočena samo na proučavanje ovakvih „povijesnih“ žanrova jer se, paralelno s njima, neprekidno pojavljuju i oni koji svoje porijeklo ne vuku iz književne povijesti i za koje se stoga najs(p)retnijim ispostavlja naziv „teorijski“ žanrovi.

I dok povijesne žanrove Todorov tako definira kao ,proizvod promatranja književne stvarnosti“ (Todorov 1987: 18), za one teorijske upozorava da su tek (nus)produkt „dedukcije teorijskog reda“ (Isto: 18), odnosno svojina teorije književnosti, pa ako je prve moguće iskristalizirati jedino sagledaju li se djela na podlozi (književno)povijesnoga konteksta unutar kojega su nastala, za oblikovanje ovih potonjih bili su većinom „,zaduženi“ teorijski (poetički) tekstovi (ponajprije poetički traktati u kojima su poetičari, polazeći od apstraktnih hipoteza, tj. od stanovitih predodžbi o književnim djelima i književnosti općenito, razlikovali određen broj logički konstruiranih žanrova s „neizbježnim“ i svevažećim apstraktnim obilježjima), u kojima su oni shvaćani kao trajne, nadvremenske kategorije. Dodatno je pritom moguće, nastavlja Todorov, razlikovati elementarne (određene samo jednom, presudnom značajkom) od složenih teorijskih žanrova (određene nizom neizostavljivih obilježja), pri čemu valja znati da se za njihovo usustavljivanje rabe zapravo povijesni žanrovi (tj. da se teorijski žanrovi „grade“ upravo na temelju promatranja povijesnih žanrova i izlučivanja nekih „bitnih“ njihovih karakteristika kao važećih za sva vremena), što će onda reći da su „povijesni žanrovi podskup skupa složenih teorijskih žanrova“ (Isto: 25). Unatoč tomu što ih je (naizgled) prilično snažno razgraničio, u nastavku će svoje studije Todorov tako ipak priznati da svako proučavanje žanrova istodobno mora udovoljiti podjednako praktičnim i teorijskim

\footnotetext{
${ }^{58}$ Detaljnije u: Juvan 2006b: 160.

${ }^{59}$ Usp. Genette 1985: 188.

${ }^{60}$ Podrobnije u: Todorov 1990: 13-26.
} 
zahtjevima, što znači da se ,žanrovi koje izvodimo polazeći od teorije moraju (...) potvrditi na tekstovima“, dok ,žanrovi koje nalazimo u povijesti književnosti moraju biti podvrgnuti objašnjavanju uz pomoć jedne cjelovite teorije“ (Isto: 25-26), iz čega je očito da Todorov želi implicirati kako su povijesni i teorijski žanrovi u „stvarnosti“ zapravo čvrsto isprepleteni. ${ }^{61}$

Svoja je intrigantna zapažanja o književnim žanrovima iznijeta u Uvodu u fantastičnu književnost dodatno Todorov razradio u studiji „Porijeklo žanrova“, u kojoj se - upućuju na to u njoj iznijeti zaključci - u nezanemarivoj mjeri naslanjao na već spomenutu Bahtinovu raspravu „Problem govornih žanrova“.$^{62} \mathrm{U}$ toj svojoj studiji objelodanjenoj 1976., konkretno, Todorov ponajviše raspreda o procesu nastajanja žanrova dokazujući kako svaki novi žanr nastaje iz drugih žanrova, odnosno preobrazbom prethodnih (ranijih) žanrova. Pritom ne propušta ponoviti ni svoju šest godina stariju tezu kako se žanrovi moraju opisivati podjednako na temelju empirijskoga promatranja (utvrđivanja njihovih književnopovijesnih mijena) te apstraktne analize (uvažavanja književnoteorijskih, tj. poetičkih predodžbi o njima), pa u nastavku napominje kako žanrovima stoga valja definirati „grupe tekstova koje su se povijesno percipirale kao takve“ (Todorov 1990: 17) i čije je književnopovijesno postojanje bilo (i jest) potvrđeno specifičnim diskursom o njima (dakle, teorijskim razmatranjima). Kao takvi, žanrovi nisu ništa drugo no „kodifikacija diskurzivnih svojstava“ (Isto: 18) - koja se sastoje od semantičkog, sintaktičkog i jezičnog aspekta teksta - a budući da je u svakom društvu uporaba diskurzivnih svojstava kodificirana ili institucionalizirana, žanrovi zapravo postoje kao institucije. Oni tako ujedno funkcioniraju i kao „modeli pisanja“ za autore i kao „horizonti očekivanja“ za recipijente (budući da autori pišu, a čitatelji čitaju u okvirima funkcije postojećega žanrovskog sustava) te - nalik svakoj drugoj instituciji ujedno osvjetljavaju i neke osnovne značajke društva u kojemu djeluju. Žanrovski sustavi različitih razdoblja i kultura, pojašnjava Todorov, tijesno su vezani uz kulturni kontekst kojega su dio i čija ih ideologija presudno određuje, iz čega slijedi da prisustvo ili odsustvo žanrova u konkretnome vremenskom trenutku i na konkretnome prostoru ujedno nepogrešivo (raz)otkriva i ideologiju društva (jer odabir žanrova uvijek i svugdje podliježe ideološkim silnicama). Stoga on ističe kako su žanrovi paralelno određeni povijesnom i diskurzivnom stvarnošću, radi čega ih valja motriti kao „mjesta na kojima se susreću opća poetika i književna povijest utemeljena na događajima“ (Isto: 19-20), a potom zaključuje - u prepoznatljivo bahtinovskom „,tonu“ - tvrdnjom kako književne žanrove proizvode govorni

\footnotetext{
${ }^{61}$ Znatno detaljnije o ,povijesnim“ i „teorijskim“ žanrovima u: Todorov 1987: 7-27.

${ }^{62}$ Iako je Bahtinov tekst danje svjetlo ugledao pune tri godine (1979.) nakon objelodanjivanja Todorovljeve studije, treba znati da je bio on dogotovljen već desetljećima ranije, pa nije neopravdano pretpostaviti da je njegov rukopis u svojim rukama pri pisanju „Porijekla žanrova“ imao Tzvetan Todorov.
} 
činovi, pa s obzirom na to da oni potječu od ljudskoga diskursa, može se reći da ne postoji opreka između književnosti i onoga što nije književnost. ${ }^{63}$

Svojim je opservacijama Todorov uvelike išao ukorak s općom težnjom promišljanju književnih žanrova iz spolne, rasne, političke i uopće ideološke vizure, za koje su - naročito od početka osamdesetih godina prošloga stoljeća - sve glasnije počele pledirati marksistička, feministička i postkolonijalna kritika. Kao što je to donekle bio slučaj i u Todorova, i ovi će se pristupi redom opredijeliti za istraživanje suodnosa između žanrova i institucija vjerujući da (književni) žanr nije ništa drugo no izravni proizvod uvriježenih društvenih praksi i interakcija te da, slijedom toga, čitatelji nužno i aktiviraju svijest o svakome pojedinačnom žanru uvijek pod nekim određenim okolnostima. Uz (djelomično) Todorovljeve studije, jedan od temeljnih idejnih će podstreka ovim pristupima dati razmišljanja o govornim žanrovima koji se konkretiziraju isključivo kroz svoju uporabu (tj. posredstvom svoje specifične „aktivnosti“ u konkretnome kontekstu), a koja je, podsjetimo, još polovinom 20. stoljeća izrekao Mihail Bahtin ${ }^{64}$ i na koja se izravno nadovezala i američka teoretičarka žanra Carolyn Miller pišući u svome vrlo utjecajnom tekstu iz 1984. o žanrovima kao o tipiziranim retoričkim odgovorima na ponavljajuće retoričke situacije, odnosno kao o posrednicima između teksta i stanovitoga (društvenog) konteksta. Studija C. Miller, doduše, gotovo se u cijelosti odnosi na svakodnevne, retoričke žanrove i iz toga razloga ne čudi što se još i dan danas uzima kao ključni teorijski tekst u okvirima retoričkih studija, no osnovni njezini zaključci (među kojima se posebno izdvaja onaj prema kojemu je retoričko djelovanje ili učinak svakoga teksta izravno povezano s njegovim žanrom) itekako se - uz, naravno, stanovite prilagodbe - mogu pokazati korisnima i u analizama književnih žanrova, tim više što ih je s punim pravom moguće razumjeti kao produbljenje nekih ključnih Bahtinovih teza.

Polazeći od tvrdnje kako se u proučavanju žanrova nužno, prije svega, posvetiti njihovoj povijesnoj i društvenoj dimenziji, C. Miller u tekstu „Žanr kao društvena akcija“ tako naglašava da bi se (i) retorička definicija žanra ponajprije trebala fokusirati na samo njegovo djelovanje, odnosno akciju koju je njime moguće postići i koja se njegovom uporabom, na koncu, i postiže. Žanr je, precizira Miller, zapravo ,kompleks formalnih i sadržajnih obilježja koja stvaraju poseban učinak u danoj situaciji“ (Miller 1984: 153), a s obzirom na to da je svaka od tih (retoričkih) situacija ponovljiva (tj. povratna), žanrovi bi se u tom smislu mogli shvatiti kao konvencionalne, pravilima određene, „tipizirane retoričke akcije utemeljene na povratnim situacijama“ (Isto: 159), koje i stječu značenje na podlozi same te situacije,

\footnotetext{
${ }^{63}$ Opširnije u: Todorov 1990: 13-26.

${ }^{64}$ Usp. Bahtin 1986: 60-102.
} 
odnosno širega društvenog konteksta u okrilju kojega se ona i odvija. Žanrovi su, kao takvi, neizdvojivi iz konkretnoga prostorno-vremenskog okvira ili - bahtinovski rečeno kronotopa,${ }^{65}$ odnosno pojavljuju se u točno određenim povijesnim momentima i u određenim kulturama, zahvaljujući čemu je upravo na njima (tj. na „sustavu“ žanrova koji su bili u „uporabi“ na danome mjestu i u dano vrijeme) moguće temeljiti predodžbu o karakteru stanovitoga razdoblja i/ili kulture. Zbog te se svoje vezanosti za kontekst žanrovi, tumači u nastavku Miller, neizbježno „mijenjaju, razvijaju i propadaju; broj žanrova koji su u opticaju u bilo kojem društvu je neodređen i ovisi o složenosti i raznolikosti društva“, no baš u svakome društvu, kao ,povratni obrasci uporabe jezika, žanrovi pomažu konstituirati sadržaj našega kulturnog života“ (Isto: 163) jer posreduju između privatnih namjera i društvenih potreba. Baš zato, kako zaključuje Miller, pri učenju žanra ne usvajamo samo njegov konkretni formalni obrazac, već i „učimo bolje razumjeti situacije u kojima smo se našli i potencijale za neuspjeh i uspjeh u zajedničkom djelovanju“ (Isto: 165). ${ }^{66}$

Pored Bahtina i njegove teorije (primarnih i sekundarnih) govornih žanrova, upravo Carolyn se Miller danas priznaju daleko najveće zasluge za uspostavu suvremenoga razumijevanja žanra kao društvene djelatnosti, a brojne kasnije razrade njezinih teza i više su nego očit dokaz da bi „Žanr kao društvenu akciju“ trebalo shvaćati kao jedan od temelja modernih empirijskih pristupa (književnim) žanrovima. ${ }^{67}$ Genološka promišljanja Mihaila Bahtina i Carolyn Miller na najsuvremenija su dinamička shvaćanja žanrova tako imala

\footnotetext{
${ }^{65}$ Detaljnije u: Bahtin 1989: 193-195. Bahtin, doduše, kronotop definira kao isključivo u književnosti (poglavito u pripovjednom tekstu) ostvarenu uzajamnu vezu prostornih i vremenskih odnosa, dakle kao sadržajno-formalnu kategoriju književnosti ili sklop koji u smislenu cjelinu zbija prostorne i vremenske oznake u književnome djelu. Taj se termin, međutim, definitivno može koristiti i za označavanje spleta vremenskih i prostornih koordinata unutar kojih se (i) književnost - zajedno sa svojim žanrovima - ostvaruje, tim više što je i povijesni diskurs posvećen opisu toga „kronotopskog“ konteksta već i sam po sebi neizbježno narativan. Uostalom, u identičnom ga značenju, primjerice, u svome recentnom povijesnom prikazu razvoja izvedbenoga žanra performansa u nas koristi i Suzana Marjanić, ujedno i naslovljujući svoju monumentalnu monografiju - Kronotop hrvatskoga performansa (Zagreb, 2014.).

${ }^{66}$ O tome opširnije u: Miller 1984: 151-167 i Simčič 2008: 56-63.

${ }^{67}$ Itekako svjesna popularnosti svoje studije, ali i činjenice da se poslije 1984. istraživački fokus postupno počeo širiti i na one žanrove za pojavu kojih je najzaslužniji munjeviti razvoj tehnologije u posljednjih nekoliko desetljeća, Miller se točno trideset godina (2014.) nakon njezina objavljivanja, želeći ih prilagoditi idejama na kojima počivaju najrecentnije studije žanra, odlučila ponešto korigirati i nadopuniti svoja ranija razmišljanja. U tekstu „Žanr kao društvena akcija: revidiran 30 godina kasnije“ ona tako podsjeća na brojne odjeke što ih je izazvala njezina pomalo revolucionarna teorija žanrova, a potom svoje tadašnje zaključke pokušava uskladiti i pomiriti s nekim od najsvježijih teorijskih zamisli o kategoriji žanra, posebno pritom propitujući mogućnosti njihove primjene u danas vrlo čestim istraživanjima žanrova elektroničke komunikacije. Usto primjećuje da su, početkom 21. st., istraživanja žanrova usmjerena na njihove najrazličitije moguće manifestacije (duž različitih medija, zajednica, povijesnih trenutaka i kultura), zbog čega se i kategoriji žanra u sve većoj mjeri priznaju različite funkcije i značenja u različitim teorijskim kontekstima i kontekstima različitih disciplina (npr. znanosti o književnosti, retoričkih studija, lingvistike, pedagogije, kulturnim studijima, muzikologiji, filmologiji, povijesti umjetnosti, antropologiji, studijima medija i televizije, bibliotekarstvu itd.), koje onda i promoviraju različite pristupe žanru. Danas se, zaključuje Miller, žanr tako pretežno razumijeva kao kompleksan, višedimenzionalni društveni fenomen, i to ponajviše zahvaljujući dosezima mnogobrojnih znanstvenih disciplina unutar kojih se $\mathrm{s}$ vremenom on prometnuo u jedan od ključnih istraživačkih problema. Više u: Miller 2015: 56-72.
} 
daleko najsnažniji utjecaj, ${ }^{68}$ a upravo tom bi utjecaju valjalo pripisati najveće zasluge za to što se žanr danas više ne promatra kao puki klasifikacijski alat, već kao ideološki obilježena i povijesno promjenjiva „forma kulturnog znanja koja koncepcijski uokviruje i posreduje načine na koje razumijemo određene situacije i prikladno se u njima ponašamo“ (Bawarshi i Reiff 2010: 4). Počevši od Bahtina i C. Miller, žanrovi se, drugim riječima, u različitim znanostima sve tješnje povezuju s kontekstom u kojemu se pojavljuju, slijedom čega se i njihove tekstualne značajke pokušavaju objasniti na podlozi određenih društvenih akcija što ih oni izazivaju i kojima su i bili izazvani. Proučavatelji to čine vođeni uvjerenjem kako žanrovi odražavaju i uvjetuju društvene načine na koje spoznajemo svijet i ponašamo se u njemu, odnosno na koje participiramo u nekim ponovljivim, povratnim (recurrent) situacijama, a to što „strateški utjelovljuju stavove, vrijednosti i načine ponašanja“ (Coe i sur. 2002: 3) ujedno znači da u procesu „učenja“ žanrova pojedinac upija i stavove te vrijednosti određene kulture. Upravo ta spoznaja ima posebnu važnost u svim suvremenim retoričkim pristupima žanru.

Moderni genolozi stoga neprekidno naglašavaju da rad svakoga žanra podrazumijeva „posredovanje između društvene situacije i teksta koji ostvaruje pojedina obilježja te situacije ili koji strateški odgovara njezinim zahtjevima“ (Frow 2015: 14-15), što žanr čini pomičnim diskursom „koji u složenom polju uvjeta, pretpostavki i pravila neprestance preuređuje i prilagođuje svoje žanrovske granice“ (Biti 2000: 159). Žanr je, drugim riječima, „kombinatoran, a ne monolitan“ (Cohen 1991: 91), on je samo privremeno stabiliziran entitet, zbog čega se, tvrde najrecentnije genološke teorije, ,,cilj genoloških proučavanja ne bi (...) trebao iscrpljivati utvrđivanjem žanrovske sheme, već se mora težiti određivanju dominantnih elemenata u shemama koje se smjenjuju kroz povijest“ (Milutinović 2009: 35). Shodno najrecentnijim shvaćanjima, žanrovska analiza zato ne bi trebala biti ništa drugo nego svojevrsno pomoćno sredstvo širega „književnokritičkog, hermeneutičkog, književnopovijesnog ili kulturno-povijesnog postupka“" (Biti 2000: 159-160), pa se suvremena teorija žanra zato najviše i koncentrira na pragmatičko pitanje: „Tko postavlja i rješava $\mathrm{s}$ pomoću klasifikacijskih koncepata u kojoj situaciji koju vrstu problema?““(Isto: 594). Budući da su žanrovi, kao takvi, svojevrsan skup tumačenja svijeta ( $\mathrm{tj}$. specifične forme organizacije znanja), oni kreiraju „obrasce značenja koji se odnose na pojedine komunikacijske funkcije i situacije“ (Frow 2015: 91), pa to i jest razlog zbog kojega se treba (poza)baviti pitanjima njihove uporabe (,Koji modeli klasifikacije su u to vrijeme postojali i kako su ih ljudi koristili u pojedinim okolnostima?“; Isto: 60), a ne - kao dosad - njihovom klasifikacijom.

\footnotetext{
${ }^{68}$ Poglavito se to odnosi na ona shvaćanja što ih zastupaju suvremeni retorički studiji žanrova, posebno njihov sjevernoamerički ,odvjetak“. Podrobnije o tome u: Freedman i Medway 2005: 9.
} 
Vođeni ovim najaktualnijim, poststrukturalističkim predodžbama o (književnim) žanrovima, teorijski će se pravci poput novoga historizma i empirijske znanosti o književnosti stoga gotovo u potpunosti usredotočiti na što preciznije opisivanje konteksta, točnije okolnosti ili situacija u kojima se vrši(lo) pojedino identificiranje žanrova, a sve to ne bi li objasnili uvjete u kojima je do svake takve identifikacije došlo. Budući da takav pristup na koncu vodi do „seciranja“ cjelokupne institucije književnosti $\mathrm{u}$ određenome povijesnom trenutku, $\mathrm{u}$ sklopu takvih se istraživanja obično ispituju ne samo načini na koje su neko književno djelo žanrovski definirali autor, kritičari, izdavači i „obični“ čitatelji, već se u obzir uzimaju i njegovi ekonomski, odgojni, pravni, estetički i drugi učinci jer se, drže proučavatelji, cjelokupna ta recepcija i sva ta poimanja književnoga teksta dubinski upisuju u njegovo razumijevanje i valorizaciju. S obzirom na to da je potkraj 20. st. i definitivno postalo ,jasno da nema homogene žanrovske svijesti (...), već je ona ispresijecana klasnim, rasnim, spolnim, civilizacijskim, kulturalnim i institucijskim razlikama“ - što će reći da su žanrovi napokon prihvaćeni kao „složeni povijesni, ideologijski i politički konstrukti“ (Biti 2000: 594) - kao neodgodiva se nužnost ispostavilo proučavanje ideoloških funkcija žanra, istraživanje uvjeta koji su omogućili njihovo postojanje te konkretnih razloga njihove evokacije, uspona i/ili pada. Ukratko, u okrilju (n)ovih je pristupa tako postalo gotovo neizbježno žanr motriti na pozadini njegovih ,raznolikih odnosa spram političkih i društvenih ciljeva“ (Cohen 1991: 91), pa je pitanje kontekstualne uvjetovanosti apsolutno svih žanrova ono koje istraživače iz svih područja žanrovskih studija i dan danas intrigira u definitivno najvećoj mjeri. ${ }^{69}$

Poststrukturalistički genolozi, imajući na umu tu trajnu nestabilnost i privremenost žanrova, u svojim se istraživanjima nisu propustili osvrnuti ni na promjene $u$ percepciji pojedinih žanrova uvjetovane promjenama njihovih naziva, pri čemu su uočili kako su ti nazivi ovisni ne samo od konkretnoga vremenskog trenutka, već i od dane kulturne sredine ili jezika. ${ }^{70}$ Naime, kako među terminima za određene žanrove najčešće ne postoje dovoljno precizni ekvivalenti u drugim jezicima i kulturama, a i književne su konvencije redovito čvrsto isprepletene s kulturom svake pojedine nacije, za svoju posljedicu to obično ima

\footnotetext{
${ }^{69}$ Novi se historizam, između ostalog, stoga zalaže i za tumačenje žanrova kao kulturnih artefakata, odnosno kulturnih konstrukata koji uzajamno sudjeluju u ,gradnji“ kulture u cjelini, pa će tako i jedan od najistaknutijih novohistoričara - američki povjesničar književnosti Stephen Greenblatt - u jednoj od svojih studija ustvrditi kako je „proučavanje žanra zapravo istraživanje poetike kulture“ (Miller 2005: 59). Ponajviše se u slijedu ovih novohistorističkih razmišljanja žanrovi danas obično i poimaju kao „kulturni artefakti“ (poglavito to vrijedi za područje retoričkih studija), a s time se u vezi ističe i da se pojedina kultura kao takva ponajbolje može definirati, kako je već rečeno, s obzirom na u njoj ,upotrijebljen“ skup žanrova. Naime, budući da su žanrovi, vjeruje se danas, središnji aspekt komunikacijske strukture kulture, a u različitim su vremenskim trenucima i na različitim mjestima u „uporabi“ više ili manje različite „palete“, dijapazoni ili sustavi žanrova, posve je jasno da isti žanr koji se pojavljuje u različitim momentima i/ili na različitim mjestima zato nipošto ne može biti isti (usp. o tome u: Miller 2005: 57-66).

${ }^{70} \mathrm{O}$ tome naročito u: Fowler 1982: 130-148.
} 
činjenicu da se u svakoj pojedinoj kulturi druge značajke i funkcije najčešće kristaliziraju kao dominantne za svaki žanr. Povrh toga, spoznalo se i da su sami kriteriji razlikovanja žanrova podložni stalnoj promjeni, zbog čega i identitet svakoga žanra presudno ovisi od varirajućih razlika spram drugih žanrova, što, pak, nerijetko rezultira time da konkretna generička oznaka u promijenjenim kontekstima može zadobiti i sasvim novi pojmovni sadržaj. ${ }^{71}$ Kontinuitet žanrovskoga imena u tim slučajevima tako zapravo prikriva diskontinuitet u njegovu sadržaju do kojega je došlo prilikom prelaska iz jednoga žanrovskog sustava u drugi.

Paralelno, međutim, s ovim kontinuiranim naporima (pretežno) književnih teoretičara da redefiniraju pojam žanra i tako dodatno istaknu njegovu važnost za tumačenje samoga književnog materijala, kroz čitavo su se 20. stoljeće povremeno mogli čuti i glasovi onih proučavatelja koji su se u svojim tekstovima rezolutno odupirali pokušajima žanrovskoga razvrstavanja književnosti tvrdeći kako književna djela mogu steći svoj status jedino kroz nadilaženje generičkih pravila. Prve naznake toga otvorenog otpora spram žanrova datiraju još iz kasnoga 18. st. - tj. iz razdoblja njemačkoga romantizma - kada Friedrich Schlegel u svojim Fragmentima o književnosti $i$ poeziji (1797.) iznosi ideju kako svaka pjesma predstavlja žanr za sebe, zbog čega bi, nastavlja, i uvriježena, tradicionalna razlikovanja među žanrovima napokon trebalo odbaciti kao suvišna i zastarjela. ${ }^{72}$ Nešto više od stotinu će godina kasnije i čuveni talijanski filozof Benedetto Croce u Estetici (1900.) predstaviti mišljenje o posvemašnjoj beskorisnosti žanra, koji je - ističe - tek puka obmana jer unaprijed poništava individualnost svakoga teksta, o kojoj zapravo i ovisi njegova estetska vrijednost. Croce, naime, misli da kategoriziranje bilo kojega djela $\mathrm{u}$ žanrovske ladice negira njegovu istinsku prirodu jer je temelj svakoga književnog ostvarenja u intuiciji, a ne u logici, a s obzirom na to da su žanrovi upravo logičke kategorije, oni se nipošto ne mogu primijeniti na književne tekstove, koji se - zbog svoje krajnje neodređenosti - otvoreno opiru kategorizacijama.

Vrlo slične teze nekoliko će desetljeća kasnije iznijeti i francuski književni teoretičar Maurice Blanchot, koji razlučuje kategoriju knjige od kategorije žanra ističući pritom da jedino knjiga kao takva doista izrasta iz same književnosti i opire se svim eventualnim klasifikacijama što u njoj pokušavaju fiksirati njezino mjesto, tim više što književnost kao takva i nije ništa drugo no svojevrsna transcedentalna sfera koja postoji onkraj nakane

\footnotetext{
${ }^{71}$ Tako je, primjerice, u Danteovo vrijeme naziv „commedia“ označavao pripovijetku sa sretnim završetkom, dok je pojam „drama“ tek u 18. i 19. st. prihvaćen kao odrednica za žanr suprotan žanrovima komedije i tragedije, iako je još u antici on obuhvaćao sve tekstove namijenjene izvođenju na pozornici (podrobnije npr. u: Juvan 2006b: 165). Ponajbolji je - i u književnoj genologiji daleko najisticaniji - primjer nedvojbeno onaj žanra elegije, koja se u staroj Grčkoj i Rimu definirala i prepoznavala u potpunosti metrički (kao pjevanje u elegijskim distisima), dok od 17. st. elegiju određuje isključivo njezin sadržaj, pa se ona otad definira kao sjetna, odnosno pjesma tugaljivoga raspoloženja (o tome u: Brajović 1995: 12 i Frow 2015: 141-145).

${ }^{72}$ Detaljnije u: Duff 2000: 4-5.
} 
žanrova da kategoriziraju i strukturiraju baš sva književna djela. To je (prešutno) odbijanje žanra, štoviše, (bilo) uočljivo čak i u jednome dijelu poststrukturalističkih pristupa književnosti, koji su pojam žanra ionako vrlo često skloni zamijeniti terminima kao što su „tekstualnost“, „diskurz“, „medij“, „pisanje“ i sl., dakle znatno općenitijim, globalnim genološkim pojmovljem. S obzirom na to da pojam, „̌aanr“ već sam po sebi nosi jake aluzije na unaprijed zadana pravila i autoritet, u književnoznanstvenim je krugovima oko polovine prošloga stoljeća - uvelike pod utjecajem postmodernističkoga svjetonazora $-\mathrm{u}$ jednome trenutku prevladalo mišljenje da žanrovi nezaustavljivo idu prema svome definitivnom nestanku, a kao posljedica se toga javila otvorena sumnja u ispravnost interpretacija zasnovanih na detektiranju generičkih osobitosti književnih tekstova, odnosno u samu održivost žanrovskih klasifikacija. Štoviše, kao što je i rečeno maločas, u brojnim se genološkim studijama od druge polovine 20. st. tvrdi(lo) kako ni jedno književno djelo koje biva „pridruženo“ nekome konkretnom žanru nipošto ne uključuje redom sve njegove značajke, već je „sazdano“ od mnoštva različitih i suprotnih generičkih obilježja, slijedom čega se ono može (pa čak, naprotiv, i mora) različito žanrovski klasificirati.

Hibridni žanr - o kojemu je svojedobno pisao već i Bahtin - zahvaljujući dvadesetostoljetnim se teorijskim istraživanjima tako nametnuo ne kao izuzetak, već kao norma, a ta je činjenica ujedno bacila sjenu i na dotad često isticanu kompaktnost $\mathrm{i}$ neprikosnovenost zamišljenoga žanrovskog sustava pojedine književnopovijesne epohe. Ideje o žanrovskoj hibridnosti književnih tekstova posebno je razradio francuski filozof Jacques Derrida u glasovitoj svojoj raspravi „Zakon žanra“ iz 1980., osmišljenoj kao odgovor Blanchotu, u kojoj tvrdi kako beziznimno sva obilježja nekoga žanra istodobno već pripadaju (i) nekome drugom žanru ili žanrovima, što ujedno znači da ga „kontaminiraju“, odnosno da je baš svaki žanr unaprijed nečist. Derrida stoga upozorava da bi se u književnogenološkim analizama trebalo govoriti o tome kako neki konkretni književni tekst „sudjeluje“ u jednom ili više žanrova, a ne o tome da - kao što se to činilo dosad - „pripada“ stanovitomu žanru, jer tekstovi zapravo „rade“ na pojedinim žanrovima u jednakoj mjeri u kojoj su njima i „oblikovani“, iz čega onda slijedi da su žanrovi otvorene i promjenjive kategorije, ali ujedno i preduvjeti za svaku tekstualnu ,izvedbu“ ${ }^{73}$

Potkraj 20. i naročito početkom 21. stoljeća spomenute su se antižanrovske tendencije, ipak, znatno prorijedile, a taj otvoreni teorijski skepticizam na koncu se ispostavio tek svojevrsnim zatišjem pred ,prolom“ ne samo obnovljenoga, već ujedno i bitno proširenoga zanimanja za žanr i genološka istraživanja. Do toga definitivnog ,povratka žanru“ došlo je

\footnotetext{
${ }^{73}$ Usp. Derrida 1988: 132-144.
} 
sredinom osamdesetih te posebno u devedesetim godinama prošloga stoljeća, čemu poticaje valja tražiti ponajprije u pojavi novih retoričkih (mahom elektroničkih) žanrova, koji su sa sobom „donijeli“ i potrebu preispitivanja i temeljitog redefiniranja dotad uvriježenih genoloških uporišta, a onda i u širenju suvremenih (poststrukturalističkih) književnih i kulturnih teorija, koje su, vidjeli smo, iznimnu pažnju pridale upravo kategoriji (književnoga) žanra, promovirajući njegovo dinamično i pragmatičko (praktično) shvaćanje utemeljeno na spoznaji o neizbježno promjenjivom, o konkretnome kontekstu ovisnom njegovu „identitetu“. Širenje interesa za žanrovsku problematiku na različite humanističke i društvene znanosti znatno je, povrh toga, ubrzao i streloviti uspon (najčešće generički jasno određene) popularne kulture, koji je, na koncu, urodio apsolutnom dominacijom prepoznatljivih popularnih žanrova, a onda i nužnošću da se (i) njima napokon posveti dostojna istraživačka pozornost. Iz potrebe da se osmisli prikladna teorijsko-analitička aparatura i za pristup različitim žanrovima popularne produkcije proizišlo je i odlučno teorijsko opredjeljenje za žanr kao praktičnu, a ne valorizacijsku kategoriju, odnosno za ,žanr kao sredstvo mogućnosti, kao sredstvo stjecanja kompetencije“ (Duff 2000: 2) i kao, na koncu, kulturni konstrukt, na kojemu će se temeljiti empirijska genološka proučavanja popularnih žanrova u znanosti o književnosti i drugim srodnim disciplinama. ${ }^{74}$

Jednim od zacijelo najuvjerljivijih dokaza definitivnoga ,povratka žanru“ - ili, kako tu „pojavu“ naziva David Duff, ,žanrovskoga obrata“ (Duff 2000: 16) - svakako bi trebalo označiti i recentnija pretresanja vrlo intrigantnih pitanja žanra kao pamćenja i žanrovskoga pamćenja, kojima se, kombinirajući spoznaja teorije žanrova i suvremenih istraživanja (književnoga) pamćenja i sjećanja, književni genolozi u posljednja dva desetljeća vrlo intezivno bave. Koncept žanrovskoga pamćenja po prvi se puta pojavio još u radovima Mihaila Bahtina, koji već u studiji „Oblici vremena i kronotopa u romanu“ iz tridesetih godina prošloga stoljeća svoju zamisao o kronotopu - kao prostorno-vremenskom sklopu koji je, kao sadržajno-formalni element, ,ugrađen“ u svaki (pretežno narativni) književni tekst - promišlja u generičkim okvirima. Kronotop je, pojašnjava ondje Bahtin, u cijelosti i određen žanrovski jer se ,žanr i žanrovski oblici obrađuju upravo kronotopom“ (Bahtin 1989: 194), što će reći da svaki žanr „pamti““ svoj kronotop, odnosno da je kronotop - kao takav - jamstvo žanrovskog pamćenja budući da se vezuje za žanr kao „upamćeni moment“ (ili shema pamćenja). ${ }^{75}$ Te će svoje teze Bahtin ponešto razraditi u knjizi Problemi poetike Dostojevskog iz 1963., u kojoj navodi da baš svaki žanr pamti svoje načelo, odnosno svoja obilježja, a samim time i svoju

\footnotetext{
${ }^{74}$ Detaljnije u: Duff 2000: 1-2.

${ }^{75}$ Usp. Bahtin 1989: 193-195.
} 
prošlost jer, iako živi u sadašnjosti, kroz svoj se ,život“ neprekidno (pri)sjeća te vlastite prošlosti. Svaki se, naime, žanr, bez obzira na promjene koje neprekidno doživljava, sa svakim novim djelom iznova obnavlja i kroz to djelo ,pamti“ neke svoje specifične značajke iz ranijih djela (,tipične“ motive, teme, kompozicijske strukture, kronotope itd.), zbog čega svako takvo novo djelo predstavlja obogaćivanje toga žanra. Žanr tako zrcali vječne tendencije razvoja književnosti jer su u njemu konzervirani i žive elementi arhaičnosti (upravo ti elementi i jesu ono što žanr ,pamti“), pa se kroz neprekidno obnavljanje žanra ujedno obnavlja i ta u njemu konzervirana arhaičnost. ${ }^{76}$ Poslije Bahtinova zaključka kako žanr predstavlja stvaralačko pamćenje u procesu razvoja književnosti i kao takav tome razvoju osigurava kontinuitet i jedinstvo, ideji žanrovskoga pamćenja tek će se nekoliko desetljeća kasnije - definirajući to pamćenje kao svojevrsni rezervoar određenih žanrovskih (sadržajnih i formalnih) značajki - vratiti i Gérard Genette u svojoj čuvenoj studiji „Uvod u arhitekst“ ${ }^{* 7}$ a mnogo će veću popularnost doživjeti ona potom tek relativno nedavno.

Uvažavajući rezultate ovih najranijih istraživanja žanrovskoga pamćenja, suvremeni genolozi dospjeli su do zaključka kako svaki žanr u procesu čitanja tijesno povezuje tekst s upamćenim generičkim okvirima i shemama ne bi li olakšao čitatelju njegovo razumijevanje i spoznavanje, čime se ujedno nameće kao svojevrsni neizostavni posrednik između „novoga“ teksta i upamćenih žanrovskih obrazaca (tj. iskustva čitanja sličnoga žanra), odnosno kao jedan od najpouzdanijih čitateljevih vodiča u interpretaciji. Prema Bahtinu i Genetteu, osnovica je žanrovskoga pamćenja ponavljanje tema, motiva, stilskih i drugih značajki „tipičnih“ za konkretni žanr, na kojima se zasnivaju kasniji tekstovi imitirajući, prerađujući ili parodirajući kanonizirana djela ili tzv. ,žanrovske prototipove“, čime ujedno i konzerviraju ta obilježja ili žanrovske ,šablone“, no istovremeno ih i osuvremenjuju i nadograđuju te tako održavaju to ,žanrovsko pamćenje“. I u najrecentnijim se analizama žanrovi stoga poimaju kao svojevrsne sheme pamćenja koje „kognitivno organiziraju pisanje i recepciju tekstova i suoblikuju pogled na svijet više rodova (žanrova, op. V. B.) u nizu““ (Juvan 2006a: 282), pri čemu se ističe kako se oni ujedno mogu motriti i kao skladišta kulturnoga pamćenja s obzirom na to da njihove memorijske sheme nadilaze vremensko okružje u kojemu su nastali žanrovski prototipovi i uključuju se u nov(ij)e tekstove. ${ }^{78}$

\footnotetext{
${ }^{76}$ Podrobno u: Bahtin 2000.

${ }^{77}$ Usp. Genette 1985: 139-191.

${ }^{78}$ Podrobnije o tome u: Juvan 2006a: 195-205, Gorp i Musarra-Schroeder 2000: I-IX i uopće u tekstovima iz zbornika Genres as Repositories of Cultural Memory (Amsterdam - Atlanta, 2000.), u kojem je niz autora zaokupljen istraživanjem vrlo indikativnoga i zanimljivog odnosa između književnih žanrova i kulturnoga pamćenja. Najvećim se pritom dijelom proučavatelji usredotočuju na one žanrove koji su se kroz povijest pokazali važnima za upamćivanje i transformiranje prošlih iskustava - od povijesnoga romana, autobiografije i
} 
Da se genološka problematika - ako uopće u nekome trenutku ona to nije bila ponovno našla u žarištu zanimanja književne teorije posvjedočiti nam može i sve veća pažnja što su je genolozi (točnije, folkloristi-genolozi) u posljednjih nekoliko desetljeća počeli posvećivati (i) žanrovima usmene književnosti. Premda su i usmenoknjiževni žanrovi, kao što je to nedavno utvrđeno i za one pisanoknjiževne, bili već poodavno prepoznati kao svojevrsni socijalni konstrukti koji - svaki ponaosob - ovise o nekim konkretnim (praktičnim) društvenim svrhama, ${ }^{79}$ ne samo drugačija sfera iz koje potječu, već i činjenica da je riječ o relativno postojanim, povijesno vrlo sporo mijenjajućim kategorijama od proučavatelja su iziskivali i iziskuju da ih razmatraju odjelito od žanrova pisane književnosti. Štoviše, kako su ispravno uočili pojedini genolozi, upravo se u pogledu žanrova u najvećoj mjeri i očituje razlika između usmene i pisane (,umjetničke“) književnosti, poglavito stoga što se žanrovske konvencije u usmenoj književnosti ne mijenjaju od razdoblja do razdoblja, ali i zato što u njoj žanrovi postoje ravnopravno kao zasebni entiteti i gotovo nikada ne dolazi do njihova miješanja. Nije, jednako tako, nevažno ni to što je hijerarhija među žanrovima u usmenoj književnosti uspostavljena isključivo na temelju društvene funkcije određenih žanrova, a ne, kao što je to slučaj u onoj pisanoj, (i) poetike dane epohe, kao ni to što umjetnička književnost - zahvaljujući svojoj dinamičnosti i oslanjanju na znatno otvoreniju poetiku - mnogo lakše i češće preuzima žanrove usmene književnosti, koja, pak, iz one pisane samo u iznimnim slučajevima posuđuje tek neke žanrovske značajke, a nipošto žanrove u cijelosti. ${ }^{80}$ Te razlike, međutim, folkloriste nisu priječile da i folklornim književnim žanrovima pristupe s posve jednakih teorijskih gledišta kojima se pristupa i onim pisanoknjiževnim te da na taj način dođu do izuzetno zanimljivih i inovativnih zapažanja.

Iako su se postulati književne genologije na folkloristička istraživanja žanrova pokušali primijeniti i još prije više od dva stoljeća, ${ }^{81}$ podrobnije analize usmenoknjiževnih se žanrova u folkloristici provode tek od dvadesetih godina prošloga stoljeća, a poseban će zamah one doživjeti od šezdesetih godina, od kada folkloristi iskazuju sve češće i sustavnije zanimanje za genološku problematiku. U povijesti književne je genologije usmenoknjiževnim žanrovima prvi značajniju pažnju posvetio već spomenuti André Jolles u svojim čuvenim

biografije, sve do lirske pjesme, drame, epske pjesme, bajke, poslovice i usmene priče - redom dokazujući da žanrovi igraju važnu, ako ne i presudnu ulogu u upijanju i aktiviranju kulturnoga pamćenja.

79 Tako, primjerice, već Maja Bošković-Stulli u svome povijesnom pregledu hrvatske usmene književnosti naglašava kako sve usmenoknjiževne žanrove presudno određuje njihova praktična (društvena) primjenjivost, odnosno kako „,izvanknjiževna životna upotreba uvjetuje i književna obilježja folklornih žanrova“, koja nužno moraju biti „funkcijski djelotvorna“ (Bošković-Stulli 1978: 23).

${ }^{80}$ O ovim pitanjima naročito u: Pavličić 1983: 129-155.

${ }^{81} \mathrm{O}$ tomu ponajprije svjedoče interesantna zapažanja braće Grimm o sličnostima i razlikama između legende, bajke i mita (usp. Honko 1989: 14). 
Jednostavnim oblicima, gdje, podsjetimo, istražuje „,pretknjiževne“ ili ,jednostavne“ oblike koji nastaju sami iz jezika, odnosno bez posredovanja konkretnoga autora i iz kojih se, u pravilu, razvijaju kompleksniji (pisano)književni žanrovi. ${ }^{82}$ To što Jolles pritom najveću pažnju pridaje njihovu jezičnom aspektu - jer se, tvrdi, ,jednostavni oblici“ ostvaruju upravo u jeziku, tj. posredstvom jezičnih gesta - itekako je usporedivo i s nekoliko stoljeća „mlađom“ Bahtinovom teorijom govornih žanrova, čiji bi se „primarni žanrovi“ također djelomice mogli shvatiti (i) kao usmenoknjiževni, tim više što je znatan dio njih proizišao upravo iz folklorne sfere (npr. poslovice, zagonetke, zdravice, blagoslovi itd.).

Istodobno s razvojem suvremene teorije (pisanoknjiževnih) žanrova, i folkloristi su poglavito u drugoj polovini 20. stoljeća - sve veći značaj u svojim istraživanjima počeli pridavati izvedbenome (performativnom) aspektu usmene književnosti, što je, naposljetku, rezultiralo definitivnim napuštanjem predodžbe o usmenoknjiževnim ostvarenjima kao fiksiranim tekstovima u korist njihova shvaćanja kao „proizvoda“ složene izvedbene aktivnosti. Kao i u „domeni“ pisane, tako i u onoj usmene književnosti žanrovi su se tako postupno prestali razumijevati kao unaprijed (za)dani okviri unutar kojih usmeni stvaratelj oblikuje svoje folklorno ostvarenje te je na koncu prevladalo njihovo shvaćanje kao samo u određenoj mjeri kulturno naučenih proizvoda trenutka koji presudno ovise od konteksta, odnosno konkretnoga mjesta, vremena, publike i osobito društvenih okolnosti prilike u sklopu koje se djelo u danome žanru i izvodi. ${ }^{83}$ To je, konačno, vodilo i k spoznaji o posvemašnjoj nestabilnosti, nekonzistentnosti, privremenosti i situacijskoj ovisnosti žanrovskih klasifikacija usmenoknjiževnoga „materijala“, pa su one - kao što je to već ranije bio slučaj i u teoriji pisanoknjiževnih žanrova - shvaćene kao dio procesa tumačenja, u koji su u podjednakoj mjeri uključeni izvođači te („obična“ i stručna) publika. Budući da se i u folkloristici žanr u novije vrijeme definira kao podjednako tekstualni entitet i društvena praksa (tj. intertekstualna kategorija), nimalo ne čudi što se i u proučavanjima usmene književnosti sve češće iskazuje

\footnotetext{
${ }^{82}$ Detaljno u: Jolles 2000. Inače, još se i dan danas Jollesova studija nerijetko shvaća kao prikaz pojedinih žanrova usmene književnosti.

${ }^{83}$ Istaknuti suvremeni folkloristi poput Rogera Abrahamsa, Dana Ben-Amosa, Kennetha Burkea, Roberta Kellogga i dr. u svojim se istraživanjima ponajviše stoga i fokusiraju na konktekst u kojemu se pojedini usmenoknjiževni žanr evocira, redovito pritom ističući kako upravo okolnosti određuju na koji će se način sama izvedba (žanr) tumačiti i razumjeti te kako na taj žanr valja odgovoriti. Kao i kod žanrova pisane književnosti, tako i kod onih usmenoknjiževnih, utvrđeno je, žanrovske značajke proizlaze iz interakcije publike, izvođača, situacije i konteksta, zbog čega je nužno imati na umu da u pozadini svakoga usmenoknjiževnog žanra stoji tradicija, odnosno izvedba uvjetovana razumijevanjem zajednice. Žanr sam po sebi, zaključuju folkloristi, stoga bi valjalo motriti kao tek puku apstrakciju koja ne postoji u fiksiranoj formi i koja ne mora ni biti ostvarena, što će onda reći da su i usmenoknjiževni žanrovi, baš poput onih pisanoknjiževnih, tako napokon prepoznati i prihvaćeni kao promjenjive, nestabilne, fluidne, o mnogim kontekstualnim činiteljima - ponajprije o kulturnom kontekstu, društveno-političkim i uopće povijesnim okolnostima i prevratima - ovisne kategorije, odnosno entiteti čiji su „,identitet“ i status „,proizvod“ dane situacije, izvođača, proučavatelja, ali i odnosa spram drugih folklornih žanrova u konkretnome okružju.
} 
težnja za interdisciplinarnošću, koja dovodi do toga da se pri tumačenjima folklornih žanrova nerijetko sljubljuju književnopovijesne, sociološke, lingvističke, antropološke i povijesne spoznaje koje potvrđuju da je žanr u najvećoj mjeri društveno proizvedena kategorija, a ne tek puka forma ili klasifikacijski princip. Danas se, ukratko, ni proučavanje usmenoknjiževnih žanrova tako ne svodi (samo) na klasificiranje zapisa usmene književnosti, već se ponajčešće promeće (i) u istraživanje ljudskoga diskursa i ponašanja, izvedbe tih žanrova, ,ispitivanje frekventnosti i raspodjele različitih žanrova u zajednici i procjenjivanje stoje li oni u središtu ili na marginama proučavane kulture“ (Honko 1989: 20). Drugim riječima, i na području fokloristike sve više ,žanrovska analiza traži postojanje svojevrsnoga osjećaja za formu kao empirijsku stvarnost unutar istraživane kulture“ (Isto: 24). ${ }^{84}$

Neupitno najbolji dokaz definitivnoga stručnog ,povratka žanru“ i sveopćega jačanja svijesti o njegovoj nezaobilaznosti svakako je već višekratno spomenuto širenje genoloških istraživanja daleko onkraj granica povijesti i teorije književnosti. Osim na područje folkloristike, a naročito na proučavanje usmenoknjiževnoga stvaralaštva, spoznaje suvremene teorije (književnih) žanrova snažno su utjecale i na niz drugih znanosti, posljedica čega je činjenica da se u posljednjih nekoliko desetljeća o žanrovima pretežno govori izvan same znanosti o književnosti. Naime, (izvorno) književnoteorijskim su se predodžbama o kategoriji Žanra naročito od konca osamdesetih godina 20. st. u sve većoj mjeri počele koristiti i druge, književnoj znanosti isprva vrlo srodne discipline, čiji je entuzijazam i ustrajnost u ispitivanju žanrovske obilježenosti njihovih područja bio tolik da su svojim teorijskim i praktičnim doprinosom studijima žanra uskoro prestigle književnu genologiju, zbog čega treba imati na umu da najkonkretniji pokušaji promišljanja i domišljanja teorije žanra posljednjih godina dolaze upravo iz njihova „smjera“, dok književna teorija u tom pogledu pomalo stagnira. Vođeni književnoteorijskim (Bahtin) analizama inspiriranom spoznajom da su žanrovi zapravo tipizirani retorički načini posredstvom kojih sudionici u procesu komunikacije mogu prepoznati različite tipove (književnih i izvanknjiževnih) situacija te u njima participirati na prikladan način (tj. da su žanrovi svojevrsna retorička „okružja“ unutar kojih prepoznajemo i dosljedno reproduciramo stanovite odnose, prakse, situacije i identitete), proučavatelji su u mnogobrojnim disciplinama shvatili da svrha žanrova nije tek puko klasificiranje različitih tekstova, već ujedno (i) definiranje i organiziranje tipova društvenih akcija što ih ti tekstovi retorički i omogućuju. ${ }^{85}$ Zahvaljujući „otkriću“ da žanrovi „grade“ apsolutno sve

\footnotetext{
${ }^{84} \mathrm{O}$ primjeni postulata književne genologije i u folkloristici poglavito u: Rosenberg 1978: 150-165; Honko 1989: 13-28 (Honko posebno upozorava na iznimnu plodonosnost uporabe brojnih koncepata teorije žanrova i u folklorističkim žanrovskim razmatranjima); Shuman i Hasan-Rokem 2012: 55-74.

${ }^{85}$ Usp. Bawarshi 2000: 335-336.
} 
komunikacijske akcije danas su stoga iznimno proširena i proučavanja rubno književnih i izvanknjiževnih, pa čak i izvanumjetničkih (,svakodnevnih“) žanrova, a u zapadnim zemljama to je razvedeno i interdisciplinarno područje proučavanja najrazličitijih mogućih generičkih entiteta prozvano na koncu tzv. žanrovskim studijima ili studijima žanrova (genre studies), što će reći da se književna genologija razdvojila u istraživanja različitih žanrova $\mathrm{i}$ njihovih funkcija u okrilju žanrovskih studija. Žanrovski studiji, konkretno, iskušavaju praktičnu primjenjivost zamisli izniklih u teoriji žanra na nekoliko (osnovnih) polja književnom (točnije, šire umjetničkom), lingvističkom, retoričkom i pedagoškom - i to istražujući ne samo kontekstualnu obilježenost (književno)umjetničkih žanrova, već i mjesto i funkcije retoričkih žanrova u okvirima življene svakodnevice ili kulture u cjelini, kao i eventualne pedagoške implikacije žanra shvaćenog kao medij poučavanja (tj. ulogu pojedinih žanrova u podučavanju stranih jezika ili, pak, podučavanja pismenosti).

Zahvaljujući kontinuiranim interdisciplinarnim naporima stručnjaka uključenih $\mathrm{u}$ žanrovske studije, na konkretnim je primjerima već višestruko dokazano da žanrovi nipošto nisu određeni tek svojom tekstualnom formom, nego i da ,značajno utječu na to kako ljudi koriste jezik, čitaju književnost te pišu i čitaju neknjiževne tekstove“ (Devitt 2004: 2). Povrh toga, žanrovski su studiji potvrdili i teorijsku pretpostavku da žanrovi ne sudjeluju samo u konstituiranju konkretnih tekstova, već ujedno i konteksta koji ih okružuju, a budući da oni na taj način i stvaraju uvjete unutar kojih funkcioniraju tekstovi, i ujedno osluškuju društvenu stvarnost svojih autora i čitatelja (tj. oblikuju i nas same dok mi njima dajemo oblik), to znači da su i sudionici u procesu komunikacije i njihovi konteksti zapravo dio tih tekstova što ih pišu. ${ }^{86}$ Ti su raznoliki pristupi u okviru žanrovskih studija, odnosno višedisciplinarna istraživanja književnih i izvanknjiževnih žanrova tako i definitivno potvrdila da osnovna funkcija proučavanja žanrova nipošto ne bi trebala biti opis i klasifikacija tekstova, već upravo njihovo pojašnjavanje ili tumačenje.

Studije žanra ili žanrovske studije posebno je „osokolilo“ i usmjerilo teorijsko „otkriće“ kako svaki žanr ,projicira određenu vrstu svijeta, zajedno s učincima stvarnosti, istine, vjerojatnosti i autoriteta, koji ga pomažu organizirati u koherentnu cjelinu“ (Frow 2015: 108), iz kojega je bilo i više nego jasno da se ponajviše odnosi na izvanknjiževne žanrove, a među njima i one koji podržavaju discipline formalnoga znanja (primjerice, filozofiju, povijest itd.). Različiti su pristupi žanrovskih studija - lingvistički, retorički, pedagoški - stoga pristupili dubinskom istraživanju poslovnih, akademskih, znanstvenih, političkih i uopće „svakodnevnih“ žanrova, među kojima su posebno mjesto imali i još uvijek

\footnotetext{
${ }^{86}$ Podrobnije u: Isto: $335-360$.
} 
imaju elektronički (internetski) žanrovi, kojima daleko najveću pažnju posvećuju retorički genolozi. Temeljita proučavanja elektroničkih žanrova, koja je također moguće istaknuti kao jedan od „simptoma“ spomenutoga ,žanrovskog obrata“, dosad su se većinom svodila na to da su se u tim internetskim načinima ili oblicima komunikacije prepoznavali tragovi starijih (pisanih) žanrova, odnosno pokušavalo istražiti njihovo prilagođavanje na nov medij. Pritom su posebno zanimanje izazivali (i još uvijek izazivaju) internetski žanrovi poput elektroničke poruke (e-maila), bloga, i micro-bloga - redom, kako su utvrdili proučavatelji, nastali preoblikovanjem ranije postojećih žanrova (dnevnika, pisma, replike itd.) - a u posljednjih nekoliko godina $u$ istraživačkom će se fokusu sve češće naći i žanrovi mobilnih telefona (poput, primjerice, osobnoga digitalnog asistenta). ${ }^{87}$ Zahvaljujući tim i raznim drugim tumačenjima što ih revno provode stručnjaci u žanrovskim studijima, žanr je, kako se često navodi, s vremenom tako ,postao dijelom pravoga metajezika interdisciplinarnosti, stapanja disciplina“ (Duff 2000: 16). Mnogobrojna najrecentnija istraživanja žanrova danas žele ispitati na koji to način žanrovi funkcioniraju kao „mjesta interakcije koja omogućuju pristup, strukturiraju i uokviruju djelovanja sudionika unutar grupa ili organizacijskih konteksta“ (Bawarshi i Reiff 2010: 107), a to, dakako, podrazumijeva povijesno proučavanje žanrova koje, pak, iziskuje dijalog s drugim disciplinama i najrazličitijim tipovima analiza - od onih socioloških, pa sve do lingvističkih i psiholoških.

Zbog činjenice da u posljednjih nekoliko desetljeća nastaju u okrilju različitih maločas pobrojanih znanstvenih disciplina, teorije žanrova i uopće razumijevanja (definicije) žanrova postala su, kako je već zamijećeno, sve kompleksnija i raslojenija. Brojna, ipak, shvaćanja što su ih zastupali i praktičnim analizama potkrijepili različiti pristupi unutar žanrovskih studija itekako su - uz neznatne, dakako, korekcije - primjenjive i u proučavanju književnoga materijala, čemu razlog treba tražiti u činjenici da su baš sva kasnija genološka istraživanja od već razrađenih teorija književnih žanrova zapravo, na kraju krajeva, i pošla. Uostalom, osim spoznaje o sveprisutnosti žanrova, kojom daju do znanja da je žanr nezaobilazna kategorija vrijedna istraživačkoga truda, kao najvažniji doseg studija žanra može se označiti spoznaja da žanrovi uokviruju svijet kao stanovite „vrste stvari“, odnosno da oni „oblikuju našu komunikaciju i pomažu nam prepoznati njezine ciljeve, uključujući i to zašto ti ciljevi postoje, kojim i čijim svrhama oni služe te kako ih je najbolje postići“" (Bawarshi 2000: 339), iz koje očito proizlazi da su različiti (književni, znanstveni, elektronički, politički itd.) žanrovi u suštini ipak srodni i da se u „sustavu“ društva ili kulture međusobno podrazumijevaju, što i otvara mogućnost pristupa tim naizgled nepodudarnim žanrovima iz istoga teorijskog očišta.

\footnotetext{
${ }^{87}$ Usp. o tome u: Frow 2015:150-161.
} 
Proučavanje žanrova danas je interdisciplinarno područje, a uvidi drugih disciplina stoga mogu i moraju biti od velike koristi i u analizi književnih žanrova, što će u velikoj mjeri nadajmo se - potvrditi i ovo istraživanje. Pritom se ni u jednome trenutku ne smije smetnuti s uma da je „svaka teorija (...) krajnje relativna i važeća samo za kontekst u kome se pojavljuje“ (Milutinović 2009: 35), što će reći i da trenutno aktualne teorije književnih žanrova nužno treba shvatiti kao uvjetovane trenutkom, kontekstom, situacijom, odnosno kao promjenjive, trenutne i podložne modifikacijama. S obzirom na to da, kako ističe Todorov, „žanrovi postoje na različitim razinama općenitosti“, nama - njihovim proučavateljima - stoga ne preostaje ništa drugo nego da ,sadržaj tog pojma određujemo sa stajališta koje smo sami izabrali“ (Todorov 1987: 9), ali nužno uvijek sa sviješću o neizbježnoj ograničenosti i nepotpunosti toga određenja. ${ }^{88}$

Kako bilo, posredstvom mnogobrojnih je poetičkih očitovanja, teorijskih i kritičkih tekstova, ali i genoloških interpretacija nastalih u rasponu od antike do danas žanr potvrdio da je ne samo „neizostavna komponenta književne komunikacije“ (Brajović 1995: 7), već i sveprisutna i nezaobilazna kategorija u znatno širem kontekstu od onoga književnog, tj. konstrukt koji bi se trebao prihvatiti kao osnovno polazište svakog istraživanja književnoga ili bilo kojega drugog umjetničkog diskursa ili medija. Ako je pretpostavka razumijevanja apsolutno svakoga diskursa poznavanje žanr(ov)a u kojima se taj diskurs odvija, onda se s punim pravom može reći da je žanr ,,preduvjet za stvaranje i čitanje tekstova“ (Frow 2015: 110) nastalih (i) u okrilju književnosti, a onda i da je on ključan usmjeravatelj svake intepretacije i svojevrsna funkcija čitanja, jer, podsjetimo, određuje koja su značenja prikladna u pojedinome kontekstu. Bez obzira na sve teorijske varijacije o kojima je dosad bilo riječi, jedinom doista neprijepornom ostaje činjenica da svako djelo pripada ili participira u najmanje jednome književnom žanru, odnosno da, kao što navodi Alaistar Fowler, posjeduje makar neko „značajno žanrovsko obilježje“ (Fowler 1982: 20), a ta spoznaja onda otvara i pitanja posebno važna upravo u suvremenoj književnoj genologiji, što će reći u jednakoj mjeri ona koja se tiču teksta i (što je još važnije) konteksta. U transformaciji se žanrova tako zapravo ogleda i transformacija književnosti u cijelosti, točnije, ona - s(p)retnije rečeno - kao takva s promjenama žanrova i započinje, pa ,iako se književnost može distancirati od starih žanrova, ona se ne može udaljiti od žanra kao takvog, a da ne prestane biti književnošću“

\footnotetext{
${ }^{88} \mathrm{Za}$ detaljniji, potpuniji pregled povijesti književne genologije, odnosno teorija književnih žanrova usp. Hernadi 1972, Dijk 1985: 1-9, Konstantinović 1985: 22-36, Schaeffer 1989: 167-187, Biti 2000: 153-160 i 591594, Duff 2000: 1-24, Lešić 2008: 287-302, Milutinović 2009: 11-37, Bawarshi i Reiff 2010: 11-104, Avsenik Nabergoj 2011: 27-131, Frow 2015: 55-78. Ponajbolji, pak, pregled najsuvremenijih (,antiesencijalističkih“) teorija književnih žanrova, odnosno onih evociranih od sedamdesetih godina prošloga stoljeća do danas u svojoj je knjizi donio Marko Juvan (usp. Juvan 2006b: 149-180).
} 
(Isto: 278) s obzirom na to da, kao takva, ne bi ni bila u stanju ostvariti komunikaciju sa svojim čitateljima, a još manje utjecati na trenutno postojeće vrijednosti. Neovisno od svih ovih spoznaja o važnosti žanrova u književnosti, jednako tako neprijepornom i neprešutnom ostaje, međutim, i činjenica kako ,zbog živoga procesa transformacije žanrova je moguće tvrditi da ni jedan opis ni razdioba književnih rodova i žanrova nisu prikladni““ (Avsenik Nabergoj 2011: 39), no ona se, svojoj točnosti unatoč, nipošto ne smije koristiti kao izlika za odustajanje od prijeko potrebnih genoloških analiza književnih tekstova, pa čak i kada se zna da će neizbježno svaka od njih - a odnosi se to, dakako, i na ovu našu - stoga nužno ostati krajnje subjektivnom, nepotpunom i vidno nedorečenom.

\section{3. BAHTINOVA TEORIJA GOVORNIH ŽANROVA I NJEZINI SUVREMENI ODJECI}

Netom opisani ,žanrovski obrat“ u suvremenoj znanosti o književnosti, paralelno s kojim je žanr prepoznat kao fenomen koji iziskuje multidisciplinarni istraživački tretman, vrlo se vjerojatno ne bi ni zbio - ili, u nešto povoljnijem slučaju, nikada ne bi ni izišao onkraj granica književne znanosti - da svoju (doduše, nedovršenu) teoriju žanrova polovinom prošloga stoljeća nije razradio (i) glasoviti ruski filozof i teoretičar književnosti Mihail Mihailovič Bahtin (1895. - 1975.). Učinio je on to u već spomenutom eseju „Problem govornih žanrova“ - dogotovljenom između 1952. i 1953., ali prvi puta tiskom objavljenom tek četiri godine iza njegove smrti (1979.) - kojega je prvotno zamislio kao uvod u znatno opsežniju studiju posvećenu genološkoj problematici pod (radnim) naslovom Govorni žanrovi. Bahtin, međutim, dalje od uvoda svojoj planiranoj knjizi nije, nažalost, dospio, pa se i njegova intrigantna teorija o govornim žanrovima svela na tek odulji esej u kojemu predstavlja neke njezine ključne postulate pledirajući pritom za shvaćanje žanrova kao podjednako književnih i neknjiževnih „tipova iskaza“ čije su unutarnje osobitosti u potpunosti određene stanovitim izvanjskim (kontekstualnim) čimbenicima.

Usprkos činjenici da u „Problemu govornih žanrova“ Bahtin zapravo donosi prilično nedorečene i nedovoljno oprimjerene zaključke o žanrovima iz različitih područja ljudske komunikacije, njegove su genološke teorijske smjernice neki teoretičari žanra oduševljeno prihvatili već i nekoliko godina prije no što je esej uopće otisnut, a zatim će - sve do danas one (p)ostati temeljem svih istraživačkih (teorijskih i praktičnih) pristupa književnim, a još više neknjiževnim (mahom retoričkim) žanrovima. ${ }^{89}$ Štoviše, bit će da je upravo nedovoljna

\footnotetext{
${ }^{89}$ Pored ideja dekonstrukcijske kritike, upravo se na Bahtinovoj teoriji govornih žanrova temelji najveći broj najsuvremenijih pristupa žanru, i to poglavito oni lingvistički, retorički i pedagoški. Podrobnije o tome u: Devitt 2004, Freedman i Medway 2005: 2-18, Bawarshi i Reiff 2010 itd.
} 
razrađenost i općenitost Bahtinovih predodžbi, koja otvara mogućnost njihova tumačenja iz najrazličitijih mogućih vizura, ponajviše i doprinijela vrlo širokoj, višedisciplinarnoj prihvaćenosti teorije govornih žanrova, koja se na taj način pokazala dovoljno fleksibilnom, odnosno podložnom „modeliranju“ po potrebi svake konkretne znanosti zaokupljene genološkim - teorijskim i praktičnim - proučavanjima, a ujedno i dovoljno otvorenom za eventualna preplitanja s većinom drugih dvadesetostoljetnih teorija (književnih) žanrova. Kao takva, Bahtinova se razmišljanja o govornim žanrovima ukazuju kao daleko najprikladnije, a ujedno i (još uvijek) najsuvremenije teorijsko polazište analiza žanrovski teško odredivih, hibridnih književnih djela kakvo je i Odiljenje sigetsko Pavla Rittera Vitezovića, zbog čega nam ne preostaje ništa drugo nego u nastavku predstaviti ključne teze - u nas, nažalost, neprevedenoga i nepravedno zapostavljenog ${ }^{90}$ - eseja „Problem govornih žanrova““.

Jedan će od svojih najutjecajnijih teorijskih radova Mihail Bahtin otvoriti zapažanjem kako se jezik realizira posredstvom individualnih - pisanih i usmenih - iskaza što ih u svakoj sferi ljudske djelatnosti izmjenjuju sudionici (sugovornici) u tom području, pri čemu svaki od tih iskaza - svojim sadržajem, jezičnim stilom i kompozicijskom strukturom - odražava specifične uvjete i ciljeve konkretne sfere. Premda je, napominje se u nastavku, pojedinačni iskaz individualan, svako područje ljudske djelatnosti razvija svoj vlastiti - izrazito raznolik repertoar (donekle stabilnih) tipova iskaza, koje je moguće nazvati „govornim žanrovima“. S obzirom na to da su i mogućnosti ljudske djelatnosti neiscrpne te da se svaka zasebna sfera djelatnosti sastoji od vrlo široke palete iskaznih tipova, govorni su žanrovi (usmeni i pisani) iznimno raznorodni, pa oni obuhvaćaju podjednako, primjerice, replike svakodnevnih razgovora, pisma, vojne naredbe, poslovne dokumente, publicistička i znanstvena izlaganja, ali i, dakako, sve književne žanrove, i to u rasponu od poslovice do višesveščanoga romana.

Svi govorni žanrovi - bez obzira na područje ljudske djelatnosti u kojem ih nalazimo razlikuju se po svojoj kompleksnosti i porijeklu, slijedom čega je nužno, tvrdi Bahtin, razlikovati primarne (jednostavne) od sekundarnih (složenih) govornih žanrova. Primarni se žanrovi (primjerice, replike svakodnevnoga razgovora, pismo, vic i sl.) formiraju u uvjetima neposred(ova)ne govorne komunikacije, ali ih zatim (u pravilu) apsorbiraju sekundarni žanrovi, unutar kojih bivaju podvrgnuti transformaciji te tako gube svoj neposredan odnos

\footnotetext{
${ }^{90}$ U hrvatskoj kulturi, u kojoj je uopće prevođeno malošto od brojnih (i neobično utjecajnih) Bahtinovih teorijskih i književnopovijesnih radova, tekst „Problem govornih žanrova“ do danas nije (još) dočekao svoj prijevod. Za njega su se, međutim, promptno ,pobrinuli“ u Srbiji, gdje je svjetlo dana on ugledao samo godinu dana nakon svoga objelodanjivanja - dakle, 1980., i to u 47. broju čuvenoga zbornika Treći program Radio Beograda (usp. Bahtin 1980: 233-237). U nastavku će se citati i referiranja na Bahtinov esej stoga paralelno donositi prema tomu, ali i prema njegovu engleskom prijevodu, kojega je 1986. učinio Vern W. McGee (usp. Bahtin 1986: 60-102).
} 
spram konkretne realnosti i stvarnih iskaza drugih govornika. Primarni žanrovi pritom će u okrilju onih sekundarnih zadržati svoju formu, no u konkretnu stvarnost više neće ulaziti kao manifestacije svakodnevnoga života, već isključivo kao književni (umjetnički) produkti. Za razliku od njih, kompleksni ili sekundarni govorni žanrovi (drame, romani, znanstvena istraživanja, publicistički žanrovi itd.) pojavljuju se u uvjetima mnogo složenije, visoko razvijene i organizirane - umjetničke, znanstvene, društveno-političke itd. - komunikacije, a proces njihova formiranja temelji se na rečenu upijanju i sažimanju raznih primarnih žanrova izniklih iz sfere svakodnevne komunikacije. Ponajbolji primjer tipičnoga sekundarnog žanra je, ističe Bahtin, roman, koji se doima kao svojevrsna fuzija niza primarnih govornih žanrova, naročito najrazličitijih mogućih tipova svakodnevne usmene komunikacije, i to u rasponu od pukih replika do, primjerice, pisama. $^{91}$ Ukratko, kako o jednostavnim i kompleksnim žanrovima - slijedeći Bahtinove sudove - izvrsno sumira Marko Juvan, ako su ,jednostavni žanrovi sadržani u jezičnoj sposobnosti većine korisnika jezika, tada su složeni rodovi, koji se ponajprije razvijaju u pisanom mediju i tisku, za svladavanje njihovih konvencija nedvojbeno zahtjevniji - oni su već bitna sastavnica kulturne pismenosti“ (Juvan 2006b: 167).

U svakom su području ljudske djelatnosti, nastavlja Bahtin, prisutni, odnosno rabe se žanrovi koji odgovaraju posebnim uvjetima konkretne sfere, što će reći da pojedinom području svojstveni uvjeti govorne komunikacije i prikladna funkcija (tehnička, znanstvena, poslovna, publicistička, svakodnevna itd.) rađaju i posve određene govorne žanrove, tj. donekle stabilne tematske, kompozicijske i stilske tipove iskaza. Različiti govorni žanrovi, štoviše, pretpostavljaju i različite ciljeve, odnosno govorne zamisli govornika ili pisaca, no oni, uz to, pretpostavljaju i cjelokupnu govornu zajednicu ili kontekst u cijelosti. Kroz vrijeme - ovisno, dakako, o društvenim promjenama - dolazi do korjenitoga prestrukturiranja i obnavljanja govornih žanrova, njihova razvijanja i množenja, zbog čega se može reći kako povijest govornih žanrova zrcali zapravo sve mijene koje su se zbile u pojedinačnim vremenskim razdobljima u društvenoj i kulturnoj stvarnosti. Iz ovoga je očito da Bahtin žanrove tumači ustvari vrlo pragmatično jer su (već) za njega oni sredstva za „,egzistencijalno i društveno razumijevanje, osmišljavanje i vrednovanje stvarnosti““ (Juvan 2006b: 282).

S obzirom na to da su govorni žanrovi tipične forme iskaza, a iskaz kao takav je prava jedinica govorne komunikacije (jer u stvarnosti govor može egzistirati isključivo u formi konkretnih iskaza govorećih ljudi), iz toga slijedi i da su, pojašnjava dalje Bahtin, granice

\footnotetext{
$91 \mathrm{Tu}$ je složenost na primjeru hrvatskih realističkih romana u svojoj disertaciji uvjerljivo dokazao Vilko Endstrasser (usp. Endstrasser 1997). O (žanrovskoj) kompleksnosti romana i njegovu neizbježnom upijanju brojnih izvanknjiževnih, ali i književnih (,sekundarnih“) žanrova podrobnije je Bahtin pisao (i) u svojoj knjizi $O$ romanu (usp. naročito: Bahtin 1989: 435-474).
} 
svakoga pojedinačnog iskaza - u rasponu od kratke replike do obimne znanstvene rasprave ili višesveščanoga romana - određene smjenom govornika, odnosno predavanjem riječi drugome govornom subjektu. Činjenica da ,iskaz prestaje ondje gdje riječ preuzima drugi govornik ili autor“ (Užarević 2012: 10), i to zato što govornik drži da je u određenome trenutku ili pod određenim uvjetima izrekao sve što je želio izreći, ne znači stoga ništa drugo nego da je žanr isto što i iskaz, a to će reći $\mathrm{i}$ isto što i replika. U različitim sferama ljudske djelatnosti $\mathrm{i}$ svakodnevice to smjenjivanje govornika stječe različite oblike i različit karakter, $i$ to ovisno od različitih funkcija jezika te uvjeta i situacija komunikacije, no i u sekundarnim i u primarnim govornim žanrovima svih sfera riječ je tako o pojedinačnim, jedinstvenim iskazima. Naime, iako su u složene žanrove uključeni (naizgled) mnogostruki iskazi različitih govornika (pitanja, odgovori, replike pripovjedača, likova, subjekata, adresata itd.), i najsloženiji tekst sekundarnoga žanra u svojoj je cjelini zapravo jedan i jedinstven iskaz zato što sekundarni žanrovi unutar svojih okvira zapravo tek „odigravaju“, „glume“ ili hine (play out) primarne govorne žanrove, a time i svakodnevnu govornu komunikaciju kao takvu.

Drugim riječima, svi sekundarni žanrovi u konstrukciju svojega iskaza unose primarne govorne žanrove i odnose među njima, no s obzirom na to da u sekundarnom žanru izostaje stvarno smjenjivanje govornih subjekata, primarni su govorni žanrovi - iako ne podliježu gramatikalizaciji i stoga uspijevaju očuvati svoju specifičnu prirodu drugačiju od prirode odnosa između riječi i rečenica unutar iskaza - neizostavno podvrgnuti transformaciji, čime postaju dijelom jedinstvenoga iskaza sekundarnoga žanra. Upravo zahvaljujući toj nužnoj preobrazbi i stapanju u kompaktan iskaz, i najsloženiji će se tekst nekoga sekundarnog žanra kao cjelina biti tako očuvan kao pojedinačna izjava, a tu je spoznaju neophodno imati na umu uvijek kada se sretnemo (i) sa žanrovski izrazito hibridnim književnim djelima. Prema tome, kompleksni tekstovi znanstvenih i umjetničkih žanrova ne predstavljaju stoga ništa drugo no posve identične jedinice govorne komunikacije kao i npr. replike svakodnevnoga dijaloga, jer su i jedni i drugi jasno određeni smjenjivanjem govornika, odnosno usmjerenjem na odgovor drugoga (drugih) govornika, tj. njihovo aktivno uzvratno razumijevanje. Poput replike dijaloga, i književno je djelo karika u lancu govorne komunikacije jer je također povezano s drugim iskazima, odnosno djelima na koje „odgovara“ i koja na njega „odgovaraju“.

Izbor konkretnoga (govornog) žanra uvjetovan je, ponavlja u nastavku Bahtin, isključivo kontekstom, $i$ to specifičnom prirodom područja govorne komunikacije, tematskim razlozima, stanovitom situacijom govorne komunikacije, osobnim sastavom sudionika govorne komunikacije itd. Ljudska komunikacija u cijelosti je, naime, „sazdana“ od govornih žanrova, što će reći da apsolutno svaki govornik komunicira isključivo žanrovima, odnosno 
da se njegova govorna zamisao - zajedno s njegovom individualnošću i subjektivnošću mora prilagoditi konkretnome žanru ili se, bolje rečeno, razviti u nekome žanrovskom obliku. Iako ih teorijski nismo svjesni, u praksi vješto raspolažemo bogatim repertoarom pisanih i usmenih govornih žanrova, zbog čega čak i u najslobodnijem razgovoru sa sugovornikom izmjenjujemo same žanrove, odnosno baš sve naše zamisli, ideje i replike pretačemo u žanrovske kalupe. Te govorne žanrove usvojili smo tijekom procesa učenja govora jer naučiti govoriti - zato što komuniciramo iskazima, a ne pojedinačnim riječima i rečenicama - znači naučiti graditi iskaze, pa onda iz toga i proizlazi da naš govor organiziraju upravo govorni žanrovi ili žanrovski oblici, u čemu se onda i krije razlog njihove iznimne raznolikosti.

Kratki svakodnevni žanrovi (npr. pozdravi, rastanci, čestitanja, raspitivanja o zdravlju i sl.) raznovrsni su zato što se razlikuju ovisno od konkretne situacije, društvenoga položaja i osobnih odnosa sudionika govorne komunikacije, no oni ujedno posjeduju i vrlo visok stupanj stabilnosti i prisilnosti (prinudnosti). Ipak, moguće je - kao što je to slučaj u govornoj komunikaciji uopće - ove žanrove čak i preakcentuirati, pa prenijeti, primjerice, žanr pozdrava iz službene sfere u onu privatnu, odnosno upotrijebiti ga s parodijsko-ironičnom preakcentuacijom, što pokazuje da se žanrovi različitih područja ljudske djelatnosti ili komunikacije (pod određenim, naravno, uvjetima) relativno lako mogu i „seliti“. Pored ovih vrlo standardnih žanrova, postoje i mnogo slobodniji i kreativniji žanrovi usmene govorne komunikacije (npr. žanrovi svakodnevnih salonskih razgovora, žanrovi razgovora za stolom, privatnih obiteljskih razgovora i sl.), koji su otvoreni slobodno-kreativnom preoblikovanju, iako i njihovo korištenje počiva na pretpostavci da se njima vrlo dobro ovladalo. Nužno je, drugim riječima, praktično ovladati govornim žanrovima različitih sfera kako bi se moglo participirati u tim područjima komunikacije, pa što bolje žanrove „naučimo“ i „uvježbamo“, to ćemo i bolje moći odraziti neponovljivu situaciju komunikacije, odnosno lakše i savršenije ostvariti našu slobodnu govornu zamisao. Za svakoga govornika unaprijed su dani obavezni, relativno stabilni i normativni oblici iskaza neophodni za uzajamno razumijevanje, a to je onda i razlog zbog kojega nas u procesu našega govorenja vodi ideja o formiranju iskaza u cijelosti ili, dakako, konkretnoga govornog žanra.

Sudionici u procesu komunikacije razmjenjuju govorne žanrove koji imaju tipičnu ekspresiju, što znači da govornik u njima - ovisno od područja govorne komunikacije u kojemu participira - uspostavlja subjektivan, emocionalno vrednujuć odnos spram sadržaja svoga iskaza. Iako su jedinice ili elementi jezika (riječi, rečenice) sami po sebi neutralni, iskaze kao takve govornici recipiraju kao govorne žanrove s izraženom ekspresijom, i to zahvaljujući činjenici da se značenje jedinica jezika naslanja na konkretnu stvarnost u točno 
određenim uvjetima govorne komunikacije, zbog čega svaki govornik spram njih zauzima aktivno emocionalan stav. Bahtinovim riječima, „kontakt između jezičnog značenja i konkretne stvarnosti, koji se događa u iskazu, u stanju je stvoriti iskru ekspresije“ (Bahtin 1980: 250 i 1986: 86-87), a ona ne postoji ni u samom sustavu jezika, ali ni u objektivnoj stvarnosti koja nas okružuje. Budući da je govorni žanr tipična forma iskaza, a ne forma jezika, on - kao takav - u sebe uključuje i tipičnu vrstu ekspresije svojstvenu tom žanru, pa žanrovi zapravo odgovaraju nekim tipičnim situacijama govorne komunikacije, tipičnim sadržajima (temama), a onda i tipičnim kontaktima što ih značenja riječi ostvaruju $s$ određenom stvarnošću uslijed nekih tipičnih okolnosti.

Stil i kompozicija iskaza određeni su, dakle, govornikovim emocionalno-vrednujućim odnosom prema sadržajnome (semantičkom, predmetno-tematskom) elementu iskaza. Pritom, baš je svaki iskaz samo jedan dio govorne komunikacije svakoga pojedinačnog područja ljudskog djelovanja, a budući da se iskazi unutar te sfere međusobno odzrcaljuju, to i jest razlog zbog kojega se svaki zasebni iskaz sastoji od replika ili uzvratnih reakcija na druge iskaze dane komunikacijske sfere. Pojedini je iskaz svojevrsni odgovor na druge (prethodne) iskaze u danome području, ali je ujedno i adresiran na drugoga govornika i gradi se - kao i oni prije njega - poradi njegove moguće uzvratne reakcije, što znači da svaki iskaz mora imati i autora i adresata ili naslovljenika. Uz to, Bahtin napominje kako ne treba zaboraviti ni činjenicu da se i pojedinačno govorno iskustvo svakoga govornika gradi posredstvom neprestane interakcije $\mathrm{s}$ individualnim iskazima drugih sudionika, zbog čega su svi individualni iskazi ujedno i tuđi jer se sastoje od „tuđih“ riječi nadograđenih „tuđom“ ekspresijom ili vrednujućim tonom. Na kraju krajeva, u svakome vremenskom razdoblju u ljudskoj povijesti i u svakome društvenom krugu postojala su i postoje autoritativna ili kanonska znanstvena, umjetnička i druga djela koja se citiraju i slijede, a koja su odredila ton (ekspresiju) nekim iskazima, ali i iskazi koji se sastoje od samo jedne, tipske rečenice ili čak jedne jedine riječi sa specifičnom ekspresijom poput, primjerice, kratkih vojnih naredbi (,Pozor!“”, „Voljno!“‘ itd).

Baš svaki žanr, i to u bilo kojemu području ljudskoga djelovanja, razvija svoju vlastitu tipičnu zamisao o adresatu (ili, kao što bi rekli Jauss i teoretičari recepcije, svoj horizont očekivanja ili predodžbu o implicitnom čitatelju), a upravo ona ga u najvećoj mjeri i određuje kao žanr. Naime, tip iskaza ili žanr - tj. izbor njegovih jezičnih sredstava, kompozicijskih postupaka i uopće njegov stil kao takav - određen je upravo razumijevanjem adresata, a to znači da autor, odabirući ga, neminovno mora računati s upućenošću ili upoznatošću adresata sa situacijom o kojoj se ili unutar koje se govori (dakle, s kontekstom o kojemu se u iskazu 
govori), s adresatovim svjetonazorom i uvjerenjima, s njegovim preduvjerenjima, s njegovim predznanjem (posjeduje li ili ne znanja iz konkretnoga kulturnog područja), njegovim simpatijama i antipatijama, sa stupnjem (osobne) bliskosti $\mathrm{s}$ adresatom, s njegovim društvenim položajem (rangom, tj. mjestom na društvenoj ljestvici ${ }^{92}$ ) itd., zato što su redom sve to činitelji koji presudno utječu na aktivno razumijevanje autorova iskaza, pa onda i na njegovu reakciju, točnije odgovor u uzvratnome iskazu ili žanru. Upravo iz toga razloga i postoji tolika razlika između, primjerice, poslovnih i privatnih (obiteljskih) žanrova, iz kojih je jasno da su upućeni adresatu izvan društvene hijerarhije i društvenih normi, što katkad za svoju posljedicu ima i otvaranje („oslobađanje“) govora. Dakle, „svako razdoblje, svaki književni pravac i književno-umjetnički stil, svaki književni žanr unutar nekoga razdoblja ili pravca tipiziran je svojim vlastitim posebnim koncepcijama adresata književnoga djela, posebnim osjećajem i razumijevanjem čitatelja, slušatelja, publike ili ljudi““ (Bahtin 1980: 268 i 1986: 98). Svako djelo primarnoga ili sekundarnoga govornog žanra stoga je jedinstven iskaz kojega stvarni autor upućuje stvarnom adresatu ili adresatima, a raznolike tipične forme toga adresiranja, kao i različite zamisli ili koncepcije adresata, konstitutivne su, odnosno presudno određujuće značajke svih govornih žanrova. ${ }^{93}$

Mihail Bahtin u svome „Problemu govornih žanrova“ prvi je tako, dakle, uvjerljivo pokazao i dokazao da su govorni žanrovi zapravo ,,jezično-komunikacijske strategije i taktike koje nastaju kao izraz različitih ljudskih socijalno-duhovnih potreba, aktivnosti, interesa, svjetonazora“" (Užarević 2012: 9). Ni u jednome trenutku u svome tekstu on stoga ne prestaje naglašavati važnost (društvenopovijesnoga) konteksta za pojavu, izgled i funkciju govornih žanrova, pa tako višekratno ističe kako redom svi žanrovi proizlaze iz neke dane situacije, odnosno kako je svakoj situaciji prikladan ili svojstven točno određeni skup ili kombinacija žanrova. Sudionici u komunikaciji uvijek se, naime, orijentiraju s obzirom na konkretnu situaciju, ali i ranije iskaze o određenome sadržaju, pa upravo na taj način i odabiru ili grade iskaz, odnosno odlučuju se za konkretni, ,prikladni“ govorni žanr. Budući da svaki takav određeni žanrovski oblik na taj način reflektira vanjske čimbenike, ponajprije značajke komunikacijskoga područja i odnose među sudionicima u komunikaciji, Bahtin s punim pravom upozorava da je u svim genološkim istraživanjima govorne žanrove - bili oni primarni ili sekundarni - nužno motriti na podlozi specifične situacije u sklopu koje oni i egzistiraju, točnije da je napokon potrebno shvatiti da beziznimno sve žanrove presudno

\footnotetext{
${ }^{92}$ Posebno je to bilo važno u uvjetima staleško-klasnoga sustava, gdje je bila na snazi jasna diferencijacija žanrova i njima primjerenih stilova, jer su oni ovisili od ranga ili društvenoga položaja adresata, ali i položaja samoga pisca.

${ }^{93}$ Znatno opsežnije u: Bahtin 1980: 233-270 i 1986: 60-102.
} 
oblikuje njihov kontekst. Upravo zbog promjenjivih konteksta kojih su dio i zato što su proizvodi jezične djelatnosti, Bahtin žanrove i vidi kao dinamičnu kategoriju, napominjući kako „stari nestaju, novi se stvaraju ili transformiraju iz starih, isprepliću se jednostavni i složeni, a najzanimljiviji vid u kojemu nam se pokazuju jeste njihova aktualizacija, konkretna primjena u komunikacijskom procesu“ (Endstrasser 1997: 30), što je zapažanje od kojega će nastaviti polaziti i sva kasnija, suvremen(ij)a (književno)genološka istraživanja. ${ }^{94}$

Kao što je iz ovoga kratkog pregleda najvažnijih polazišta teorije govornih žanrova postalo i više nego jasno, riječ je o nepobitno inovativnim, no istodobno vidno nedorečenim teorijskim predodžbama, čija „nabačenost“ jamačno proizlazi iz već spomenute činjenice da je „Problem govornih žanrova“ prvotno osmišljen kao uvodni dio znatno obimnije studije u kojoj su pitanja kojih se Bahtin ovdje tek dotiče trebala biti podrobnije razrađena $\mathrm{i}$ potkrijepljena konkretnim književnim primjerima. Unatoč tomu što nedovoljna preciziranost tih temeljnih Bahtinovih zamisli dopušta, kako je već primijećeno, njihovu znatno slobodniju interpretativnu primjenu, ona neizbježno otvara i niz (teško rješivih) nedoumica, pri čemu daleko najveće još i danas provocira čuvena razdioba primarnih od sekundarnih žanrova, koja spada u možda i najmanjkavije objašnjene teze ovoga teksta. S obzirom na odveć štura Bahtinova razjašnjenja te neupitno važne distinkcije, i dalje tako ostaje nejasno koje to konkretno žanrove valja pojmiti kao primarne, a koje kao sekundarne, a ujedno se i ništa ne govori o (u praksi vrlo čestim) slučajevima kombiniranja primarnih žanrova, odnosno o situacijama u kojima određeni primarni žanrovi „,apsorbiraju“ druge primarne žanrove. ${ }^{95}$ Nije, povrh toga, do kraja jasno ni to nastaju li sekundarni žanrovi samo i isključivo ulančavanjem ili sažimanjem određenoga broja onih primarnih ili, pak, proces njihove ,gradnje“ započinje izdvajanjem nekoga već postojećeg primarnog žanra kao svojevrsnoga okvira u koji se potom „ulijevaju“ drugi jednostavni žanrovi formirajući na koncu složen(ij)i žanr. Ništa, s druge strane, u Bahtinovu eseju ne daje naslutiti ni to da su sekundarni žanrovi već od samoga početka zamišljeni kao takvi, odnosno da proces njihova formiranja otpočinje uspostavljanjem kompleksnoga okvira koji potom postupno biva ispunjen obiljem primarnih žanrova, a sasvim

\footnotetext{
${ }^{94}$ Pregledno o Bahtinovoj teoriji govornih žanrova i (nekim) njezinim odjecima u: Holquist 1986: IX-XXIII, Endstrasser 1997: 27-36, Simčič 2008: 40-55, Užarević 2012: 9-28, Frow 2015: 32-54, Grübel 2015: 215-225.

95 Bahtin tako, primjerice, privatno pismo shvaća kao primarni žanr, no pritom ne spominje da ono redovito uključuje i čitav niz drugih (još jednostavnijih) primarnih žanrova poput oslovljavanja, pozdrava, pokatkad čak i poslovica, viceva itd. Budući da gotovo svako pismo - ili, kada je riječ o novim elektroničkim žanrovima, elektronička poruka ili e-mail - neminovno upija razne druge primarne žanrove, bi li to onda trebalo značiti da valja razlikovati pismo kao primarni i pismo kao sekundarni žanr ili je naprosto riječ o prožimanju nekolicine primarnih žanrova? Inače, tu je nejasnoću vezanu uz mogućnost kombiniranja primarnih žanrova (tek nedavno) u svojoj knjizi Književni minimalizam pokušao donekle razriješiti Josip Užarević, koji - polazeći valjda od svoga iskustva s brojnim takvim slučajevima - smjelo ustvrđuje kako ne postoje nikakve zapreke za moguća uzajamna prožimanja malih (dakle, primarnih) govornih žanrova (usp. Užarević 2012: 14).
} 
su zaobiđeni i oni (ne tako rijetki) slučajevi - jednom od kojih ćemo svjedočiti i u Vitezovićevu Odiljenju ${ }^{96}$ - u kojima sekundarni žanrovi prodiru u okvire drugoga sekundarnog žanra, pa je iz Bahtinova izlaganja moguće tek pretpostaviti da oni, nakon što bivaju upijeni u taj još kompleksniji žanr, najvjerojatnije ne prolaze kroz (toliko dubinsku) preobrazbu kao oni primarni, koji u okrilju sekundarnoga žanra sasvim gube svoj doticaj s kontekstom konkretne stvarnosti. ${ }^{97}$

Bile kakve bile, Bahtinove ideje o govornim žanrovima presudno su utjecale na moderna žanrovska istraživanja, pa je među genološkim pristupima kasnoga 20. i početka 21. stoljeća gotovo nemoguće izdvojiti i jedan u čijim temeljima nije makar poneka od teza iznesenih u eseju „Problem govornih žanrova“. Nipošto to, dakako, ne bi smjelo biti neobično ima li se na umu da je svojim izrazito općenitim (sveobuhvatnim) razumijevanjem govornih žanrova - kao najrazličitijih mogućih iskaznih tipova u živome jeziku (i čvrsto povezanih, jer su načinjeni od istoga materijala: riječi) - Bahtin zapravo otvorio istraživački prostor kako znanosti o književnosti i lingvistici, tako i mnogim drugim (srodnim) humanističkim znanstvenim disciplinama, što je, na koncu, dovelo do temeljitog korigiranja dotadašnjih shvaćanja žanra, koji se danas više ne motri kao usko književna ili umjetnička kategorija. Upravo je Bahtinova predodžba o govornim žanrovima, kako izvrsno sumira David Duff, omogućila „daljnje širenje koncepta sugerirajući kako svi činovi komunikacije, čak i oni gestualni, mogu biti oblikovani u terminima žanra, sve dok su djelomice ovisni o kodovima i konvencijama“ (Duff 2000: 16), pa cjelokupni suvremeni žanrovski studiji - poglavito njihova lingvistička, retorička i pedagoška struja - stoga u potpunosti počivaju na tezama predstavljenima u radu „Problem govornih žanrova“. Njihovoj „popularizaciji“, dakako, bitno je pridonijela i ,intervencija“ Carolyn Miller, u čijoj su ranije spomenutoj - još i danas utjecajnoj - studiji iz polovice osamdesetih godina prošloga stoljeća temeljne Bahtinove ideje doživjele bitnu doradu nametnuvši se tako kao izrazito suvremen i koristan teorijski alat (i) za niz izvanknjiževnih (poglavito retoričkih) istraživanja govornih žanrova. ${ }^{98}$

\footnotetext{
${ }^{96}$ Spomenuto je preklapanje sekundarnih žanrova vidljivo tako već u proznim predgovorima prvih dvaju izdanja Odiljenja sigetskog, u svaki od kojih Vitezović uključuje i sekundarni žanr lirske pjesme, u kojem, pak, nalazimo i po nekoliko primjera primarnoga žanra (usmenoknjiževne) poslovice. Više o tome, dakako, u nastavku.

${ }^{97}$ Upitno je, doduše, i nedovoljno objašnjeno već i to kroz koliko snažnu i dubinsku preobrazbu doista prolaze primarni žanrovi nakon što ih „usisa“ sekundarni žanr. Tako, primjerice, Josip Užarević ispravno uočava kako „kvalitativno-funkcionalnu preobrazbu“ nakon uvrštavanja u sekundarni žanr (ponajčešće roman) ne doživljavaju poslovica ili aforizam „, obzirom na to da oni u trenutku inkorporiranja u roman već imaju status umjetničkih djela“ (Užarević 2012: 11), premda su, prema Bahtinovoj rašlambi, oni neosporno primarni žanrovi. Iz toga razloga oni ne prolaze kroz onu istu transformaciju kao žanrovi životne svakodnevice (pozdravi, pisma, zahvale ili psovke) jer je njihova svrha u sekundarnom žanru oblikovati umjetničku sliku umjetnosti, a ne umjetničku sliku svakodnevice. Doduše, i poslovice su dio životne svakodnevice i u njoj se rabe, pa itekako u romanu mogu sudjelovati u oblikovanju slike svakodnevice (primjerice, posredstvom motiva uporabe poslovice). ${ }^{98}$ Usp. o tome u: Coe i sur. 2002: 1-10.
} 
Dubok su trag Bahtinova zapažanja, zajedno s onima Andréa Jollesa o jednostavnim i složenim oblicima, ostavila i na recentnija proučavanja malih i najmanjih govornih žanrova, odnosno tzv. književnog minimalizma, s kojima se može podičiti čak i domaća nam književna znanost. Oslanjajući se tako na Jollesovu studiju (tj. uključivši u svoj popis „,malih“ žanrova redom sve one „oblike“ što ih je pobrojao i Jolles), a uz nju posebno i na Bahtinovu teoriju govornih žanrova, Josip Užarević nametnuo se kao jedan od prvih genologa koji je svoju punu istraživačku pozornost usmjerio i na sferu najjednostavnijih, sitnih žanrova, koji (u pravilu) kao što je to primijetio i Bahtin - ulaze u složenije žanrove kao njihovi elementi i tamo doživljavaju funkcionalnu preobrazbu (preciznije, gube vezu sa stvarnošću i konkretnim adresatom) ne bi li u njima mogli sudjelovati u kreiranju slike svakodnevice i umjetnosti, kao što je to slučaj i u romanu. Držeći se Bahtinovih postulata, Užarević uzima u obzir uistinu širok raspon malih govornih žanrova, i to iz najrazličitijih područja ljudske djelatnosti (kako, dakle, one književne i književnoznanstvene, tako i one religijske, vojno-redarstvene, novinske, pravne, medicinske, kulinarske, svakodnevno-komunikacijske itd. $)^{99}$ te pritom dokazuje kako je njihovu veličinu - kao najvažniji kriterij za njihovo određivanje - moguće definirati iz konteksta (zbog čega ona može varirati od djela koja se sastoje od tek jedne riječi - jednorječja - do onih od desetak stranica, kao što su to, primjerice, bajka ili pripovijetka), a ujedno i podsjeća na to da ih je okupljene najčešće moguće naći u raznoraznim zbirkama (poslovica, viceva, lirskih pjesama) ili, pak, zbornicima (eseja, znanstvenih članaka itd.). ${ }^{100}$

Nažalost, izuzev spomenute Užarevićeve knjige, u kojoj je podosta prostora posvećeno ključnim idejama teorije govornih žanrova, zatim doktorske disertacije i kasnijih znanstvenih radova Vilka Endstrassera o primarnim žanrovima u romanima hrvatskoga realizma ${ }^{101}$, kraće rasprave o statusu kategorije žanra u folklorističkim istraživanjima usmenoknjiževnih zapisa iz pera Ivana Lozice ${ }^{102}$ te - na stranicama našega najvažnijeg književnoznanstvenog časopisa Umjetnost riječi - relativno nedavno objavljene studije njemačkoga teoretičara književnosti Rainera Grübela u kojoj se Bahtinovi genološki koncepti motre iz vizure nekih od najrecentnijih književnoteorijskih zamisli, ${ }^{103}$ značajnijih rasprava o teoriji Mihaila Bahtina, a kamoli sustavijih pokušaja njezine primjene na konkretan (književni) materijal, u nas do danas gotovo da i nije bilo. S druge, pak, strane, u susjednoj su, slovenskoj kulturi zabilježeni već i (prilično uspješni) pokušaji proučavanja korporativnih, odnosno žanrova poslovne

\footnotetext{
${ }^{99}$ Usp. Užarevićev detaljni popis tih malih govornih žanrova u: Užarević 2012: 12-13.

${ }^{100}$ Detaljnije u: Isto: 9-28.

${ }^{101}$ Usp. Endstrasser 1997 i 2000: 163-180.

102 Usp. Lozica 1990: 111-119.

${ }^{103}$ Usp. Grübel 2015: 215-238.
} 
komunikacije iz očišta teorije govornih žanrova i njezinih kasnijih dorada (Miller), ${ }^{104}$ što pokazuje da su pojedini znanstvenici iz neposrednoga nam okružja napokon uvidjeli kakve se istraživačke perspektive otvaraju osvijesti li se (bahtinovska) činjenica da žanrovi - „kao jezične (govorne) forme - odgovaraju različitim područjima ljudskoga socijalnoga i kulturnoga života“ (Užarević 2012: 9), odnosno da su, drugim riječima, prisutni u doslovno svim sferama ljudske komunikacije. Uostalom, već desetljećima je Bahtinova teorija, podsjetimo još jednom, u srži retoričkih, lingvističkih, pedagoških, ali i (velike većine) književnoteorijskih pristupa žanrovima, a kakve ona doista rezultate može polučiti aplicira li se na literarnu građu - pa $\mathrm{k}$ tome još i žanrovski izrazito hibridno djelo iz naše ranonovovjekovne književnosti - pokušat će se provjeriti upravo na stranicama koje slijede.

Za Bahtinovu teoriju govornih žanrova kao ključno se teorijsko polazište, valja odmah istaknuti, u ovome istraživanju pritom nipošto nećemo opredijeliti iz nekakvih eventualnih pomodnih razloga, odnosno činjenice da je riječ o jednoj od još uvijek najutjecajnijih - ako ne i najutjecajnijoj - teoriji žanrova; teoriji na kojoj se, u većoj ili manjoj mjeri, baziraju sva aktualna književnogenološka istraživanja. Naprotiv, Bahtinove se teorijske postavke najkorisnijima i mogu pokazati upravo apliciraju li se na djela poput Odiljenja sigetskog Pavla Rittera Vitezovića, poglavito zato što je riječ o tekstu koji miješa „karakteristična“ obilježja izuzetno velikog broja (baroknih) žanrova koja je upio u sebe na isti način na koji to, podučio nas je Bahtin, čine i (svi) sekundarni žanrovi, iz čega onda proizlazi da aktiviranje teorije govornih žanrova, na neki način, Odiljenje - odnosno njegova „napadna“ žanrovska mješovitost svojstvena „tipičnom“ sekundarnome govornom žanru - iziskuje već „samo od sebe“. Uz pomoć Bahtinovih ćemo teorijskih alata u nastavku stoga razmotriti na koji to način ovo neobično Vitezovićevo ostvarenje upija žanrovske osobitosti primarnih i (drugih) sekundarnih žanrova te na koncu pokušati utvrditi može li se ono uopće definirati kao jednoznačan sekundarni žanr. Iako se pritom nećemo odveć „spuštati“ u dubine primarnih govornih žanrova (sve do, dakle, razine najelementarnijih ili najmanjih govornih žanrova poput oslovljavanja, pozdrava itd.), Bahtinova će nam zapažanja bitno olakšati poslove razlučivanja konkretnih žanrovskih komponenata zastupljenih $\mathrm{u}$ tekstu, istraživanja međuodnosa uvrštenih (primarnih i sekundarnih) žanrova (odnosno njihovim značajkama obilježenih dionica), utvrđivanja načina na koji su u tekst uklopljeni oni „najniži“ (književni) žanrovi (poslovica, zagonetka itd.), a posebno posao traženja odgovora na pitanje kojem to (sekundarnom) žanru Vitezovićevo Odiljenje uopće pripada, ako bilo kojemu uopće i pripada

\footnotetext{
${ }^{104}$ Misli se na, konkretno, magistarski rad Mihe Simčiča Analiza komunikacijskih žanrov podjetniških spletnih mest (usp. Simčič 2008).
} 
ili u njemu, suvremenije rečeno, participira. Premda je posebno važno praktično upotrijebiti Bahtinova zapažanja i zato što u Odiljenju sigetskom imamo posla ne samo s književnim, već i poluknjiževnim te izvanknjiževnim žanrovima, naredno se istraživanje, dakako, nipošto neće zasnivati samo i jedino na postulatima te još uvijek silno utjecajne teorije govornih žanrova.

\section{4. TEORIJSKE PRETPOSTAVKE ISTRAŽIVANJA}

Posve je razumljivo - pa čak, štoviše, i očekivano - da genološko istraživanje koje se neprekidno diči suvremenošću svojega pristupa i pritom obećava iznjedriti neke dosad nepoznate spoznaje o predmetu svoje analize (naročito njegovo novo, preciznije generičko određenje) pođe upravo od onih zamisli koje su u teoriji žanrova od polovine prošloga stoljeća do danas odigrale i još uvijek igraju najvažniju, središnju ulogu. O kojim bi to teorijskim konceptima, u mnoštvu onih osmišljenih u posljednjih pet ili šest desetljeća, doista trebalo biti riječi, dade se lako razabrati već iz prethodnoga letimičnog osvrta na povijest razvoja (književne) genologije, pa nam ovdje predstoji tek ukratko na njih podsjetiti i na taj način ustanoviti konkretni teorijski okvir, odnosno zacrtati teorijska ishodišta naredne analize.

Ponajprije, neće biti izlišno još jednom naglasiti da će - kao što je, uostalom, to slučaj i u suvremenoj teoriji žanra i u najrecentnijim (književno)genološkim proučavanjima uopće (i) u ovoj analizi riječi biti isključivo o ,žanrovima“ i ,žanrovskim“ obilježjima Odiljenja sigetskog, slijedom čega se za uporabom genoloških kategorija „,rod“, „vrsta“ i „podvrsta“, odnosno eventualnim uklapanjem lociranih žanrova u njima hijerarhijski nadređene razine žanrovske klasifikacije neće ovdje ukazati ni najmanja potreba. Bit će tomu ponajprije tako zato što, ponovimo, ni u poetičkim traktatima, a još manje u drugim autoreferencijalnim ili metatekstualnim iskazima samih autora iz vremena u kojemu je Odiljenje nastalo i ugledalo danje svjetlo - potkraj, dakle, 17. stoljeća - te termine nigdje ne nalazimo, a kamoli makar tragove bilo kakve svijesti o tome da se oni odnose na kategorije pripadne razrađenoj žanrovskoj hijerarhiji ustanovljenoj - ponovimo i to - tek mnogo kasnije. Iako, doduše, u to vrijeme nije još u opticaju bio ni termin ,žanr“ - kao, uostalom, ni bilo koji drugi njemu ekvivalentan i općeprihvaćen genološki pojam - iz današnje se perspektive on ipak nameće kao daleko najsretnije rješenje za označavanje pojedinačnih tipova književnih djela o kojima su pisali poetičari i s predodžbom o kojima su i sami pisci sastavljali svoja ostvarenja, najčešće budno pazeći da se ne ogriješe o unaprijed zadane njihove norme. Da se u genološkim analizama - poglavito književnih djela iz nešto dublje prošlosti - najispravnije (ili makar najmanje pogrešno) odlučiti za termin ,žanr“, zamijetio je već i Vilko Endstrasser, 
naglasivši kako to valja učiniti ponajprije zato što „termini rod i vrsta impliciraju pristup književnosti preko nadređenih struktura različitih (većinom romantičkih i postromantičkih, op. V. B.) poetika, zanemarujući manje oblike koji su isto tako konstituenti književnoga djela, a koji ne pripadaju isključivo književnosti nego su sastavni dio »prirodnog« jezika i svakodnevnog govora“ (Endstrasser 1997: 5). Drugim riječima, opredijelimo li se za pojam „Žanr“ i pritom isključimo ostale razine genološke klasifikacije, to će značiti da smo pristali uz kategoriju koja se, utvrdile su to moderne genološke teorije, odnosi na ,jezične oblike kao što su pozdravi, izreke, poslovice, vicevi i uopće razne oblike diskursa svakodnevne komunikacije, i sve one oblike koji pripadaju književnoj proizvodnji: roman, pripovijetku, novelu i ostale“ (Isto: 5-6), a ta će se njome implicirana sveobuhvatnost pokazati i više nego poželjnom primijenimo li je u analizi žanrovski izrazito slojevitih i mješovitih djela kakvo je definitivno i Odiljenje sigetsko.

Ni u jednome se trenutku pritom neće smjeti smetnuti s uma da svaki pojedinačni (književni) žanr kao takav - na što nas u svojim radovima ne propuštaju počesto podsjetiti i brojni suvremeni genolozi - „stvara“ zapravo tek drugi tekst ili iskaz sastavljen od (većinom) identičnih obilježja i usklađen sa sličnim (ako ne i posve jednakim) kontekstom ili situacijom kao što je to bio i njegov prototip, odnosno tekst ili iskaz koji je u (književnoj) povijesti prvi donio kombinaciju danih tekstualnih značajki ispunjavajući pritom i stanovite izvantekstualne funkcije. Da bi, pojednostavljeno rečeno, konkretni generički predložak tako doista mogao postati žanrom nužno je da „proizvede“ više od jednoga primjera, odnosno da bude prepoznat i identificiran prvom, a zatim i svim sljedećim imitacijama, a možda i eventualnim kritičkim analizama te da se - skupom svojih „karakterističnih“, (samo) njemu svojstvenih značajki razgraniči ili izdvoji u odnosu spram drugih, u tom trenutku i na tom mjestu (su)postojećih žanrova. ${ }^{105} \mathrm{Ne}$ ispuni li taj preduvjet i tako ostane na samo jednom jedinom svom primjerku ili prototipu, u tom je slučaju o postojanju konkretnoga žanra ne samo neutemeljeno, već i posve nemoguće govoriti, pa je najvjerojatnije riječ o tek više ili manje uspjelom (jednokratnom) pokušaju kombiniranja obilježja nekolicine postojećih žanrova ili, pak, o preoblikovanju jednoga već afirmiranog žanra koje - eto - nije privuklo potencijalne nasljedovatelje. Kolika je doista važnost ovoga svojstva žanra pokazat će se, na kraju krajeva, i u ovome našem istraživanju.

Odabir kategorije žanra kao svojevrsnoga nosivog stupa narednoga proučavanja ujedno tako i jasno upućuje na to da će se genološka analiza Odiljenja u cijelosti bazirati upravo na onim teorijskim dosezima koji su poslužili kao izvorište najaktualnijih pristupa 
okupljenih u tzv. žanrovskim studijima. To, konkretno, ne znači samo da će se u širokome luku ovdje zaobići tradicionalne i već nadvladane predodžbe o žanru kao esencijalnoj i svevažećoj kategoriji, kao i (post)romantičko inzistiranje na trijadi rodova te hijerarhijskim odnosima između žanrovskih entiteta, nego i da će ranije obećan suvremeni pristup podrazumijevati već višestruko najavljeno interpretativno inzistiranje na utjecajnoj Bahtinovoj distinkciji između primarnih i sekundarnih govornih žanrova, a uz nju i shvaćanjima o žanru kao situacijskom konstruktu, poteklima od Carolyn Miller, ${ }^{106}$ koji su se, kako je spomenuto, u već nebrojeno mnogo navrata potvrdili kao kameni temeljci recentne (književno)genološke misli. Pritom će se daleko najvažnijima ispostaviti, dakako, Bahtinove genološke spoznaje, iz kojih će u suvremenoj genologiji proizići i danas neprikosnoveno razumijevanje žanra kao u potpunosti nestabilne - tj. privremeno stabilizirane - te neizbježno hibridne kategorije, a ta - u suštini bahtinovska - ideja o mješovitim žanrovima koja je rezultirala potrebom istraživanja procesa žanrovskih stapanja i pretapanja itekako će se važnom ispostaviti upravo u pristupu tekstovima poput Odiljenja, koji u sebe uključuju raznorazne žanrove i njihova „prepoznatljiva“ obilježja stvarajući tako specifične i rijetko ili gotovo čak nikad ponovljene hibride.

Osim Bahtinovih zamisli, ovo će genološko čitanje Vitezovićeva Odiljenja u znatnoj mjeri počivati i na čuvenom razlikovanju povijesnih i teorijskih žanrova Tzvetana Todorova, inače jednoga od prvih nasljedovatelja teorije govornih žanrova, bez očitog utjecaja koje bi vjerojatno i brojni njegovi zaključci na koncu izgledali znatno drugačije no što to izgledaju danas. ${ }^{107}$ To, drugim riječima, znači da će se u ispitivanju generičkih značajki Vitezovićeva djela ponajviše ustrajati - kada i koliko god će to biti moguće - na povijesnim žanrovima, što će reći da će se svakome od lociranih žanrova (pokušati) pristupiti kao povijesnome entitetu izraslome iz danoga povijesnog trenutka i zastupljenom u književnosti hrvatskoga i/ili europskog baroka. Iz toga će se razloga neprekidno imati na umu da su (ti) žanrovi, kao što je utvrđeno, neizbježno nestabilne, nepostojane i nedovoljno čvrsto definirane kategorije, a to će, pak, neminovno nositi sa sobom potrebu odustajanja od - brojnim domaćim (a i nekim inozemnim) povjesničarima književnosti još uvijek osobito drage - predodžbe o žanru „kao o stabilnoj, nepovijesnoj kategoriji koja se na isti način manifestira $u$ bilo kojem književnopovijesnom razdoblju“ (Brajović 1995: 131). Međutim, kao što je u svojim radovima i sam Todorov to višekratno istaknuo, svako proučavanje (književnih) žanrova nužno mora uključivati ne samo razmatranje povijesnoga žanra, već i njegovo objašnjenje iz

106 Usp. Miller 1984: 151-167. Pregledno o teoriji žanra kao (retoričkog) odgovora na stanovitu društvenu situaciju u: Simčič 2008: 56-66.

${ }^{107}$ O Todorovljevu oslanjanju na teze Bahtinove teorije govornih žanrova pregledno u: Duff 2000. 
vizure neke cjelovite teorije, iz čega slijedi da su teorijski i povijesni žanrovi isprepleteni mnogo čvršće no što bi se to na prvi pogled dalo zaključiti. Na kraju krajeva, za usustavljivanje teorijskih se žanrova rabe upravo povijesni žanrovi, dok je apsolutno svaki analitički i/ili praktični - pristup povijesnim žanrovima nužno opterećen većom ili manjom količinom teorijskoga „balasta“, zbog čega ni u ovome istraživanju neće moći biti riječi o „čisto“ povijesnim žanrovima, jer će i njihovo ispitivanje neizbježno morati polaziti od nekih njihovih unaprijed utvrđenih teorijskih (poetičkih, književnoteorijskih) predožbi. ${ }^{108}$

Drugim riječima, premda će se i ova analiza, dakle, u cijelosti (pokušati) usredotočiti na povijesne žanrove, što će reći na praktično shvaćanje prepoznatih žanrova iz perspektive točno određenoga vremenskog trenutka, teorijskim predodžbama o njima - i to u potpunosti, dakako, onim suvremenim, književnoznanstvenim - ni uz najveće napore ipak neće moći umaći, što joj s obzirom na sve dosad rečeno, ali i na brojna ograničenja s kojima se suočava, možda ipak ne bi trebalo uzeti za (veće) zlo. Iznimno je teško, naime, ako ne i sasvim nemoguće utvrditi kako je konkretne žanrove čijim je obilježjima premrežio svoje Odiljenje sigetsko Pavao Ritter Vitezović doista shvaćao, a još manje kako su ih shvaćali ostali naši sedamnaestostoljetni pisci i njihova publika, i to ponajprije „zahvaljujući“ posvemašnjem nedostatku eksplicitnih poetičkih očitovanja u domaćoj nam baroknoj književnosti. Poradi nepostojanja tekstova iz kojih bi se moglo utvrditi kakav su doista status uživali žanrovi čije značajke zatječemo u Odiljenju sigetskom danas nije moguće dati posve precizan odgovor na pitanje jesu li baš svi oni redom u drugoj polovini 17. stoljeća postojali u nas kao samostalni, jasno prepoznatljivi žanrovi, odnosno jesu li njihova „karakteristična“ obilježja uopće bila shvaćana i prihvaćana kao svojstvena upravo tim žanrovima. S obzirom na to da, povrh toga, nismo u stanju utvrditi čak ni to kako su ti žanrovi - ako su tada uopće i imali svoj ,identitet“ - uopće nazivani, već samim ih činom imenovanja mi, suvremeni genolozi, zapravo neizbježno teorijski domišljamo i prekrajamo tako da odgovaraju aktualnim nam genološkim shvaćanjima, a iz toga onda proizlazi da je - ne samo u ovome našem slučaju - teorijska dimenzija zapravo neodvojiva komponenta svakoga povijesnog žanra, naročito kada tragamo za žanrovskim obilježjima djela iz nešto dublje književne povijesti. U takvim prigodama, drugim riječima, dijakronijski pristup analiziranim žanrovima ispostavlja se posve nemogućim ne sagledamo li ih i iz nadpovijesne, odnosno sinkronijske perspektive.

\footnotetext{
108 Svakako, pritom, treba znati da teorijski žanrovi neizbježno moraju uključivati i svijest o povijesnoj promjenjivosti žanrova te mijeni njihovih značajki i funkcija, dok povijesni žanrovi mogu, ali i ne moraju uključivati i svoje teorijsko (poetičko) poopćenje jer se - čak i njegovu odsustvu usprkos - konkretni zaključci o njima ionako izvlače iz promatranja njihova (književno)povijesnog trajanja.
} 
Bilo kako bilo, svakome će se pojedinačnom žanru u okvirima narednoga istraživanja - posve u skladu s pobrojanim suvremenim teorijskim postavkama - pristupiti kao podjednako tekstualnoj i kontekstualnoj kategoriji, odnosno kao posredniku između teksta i stanovite situacije, kao tekstualnom entitetu koji je uvijek i neizbježno uronjen u specifičan bahtinovski rečeno - kronotop, a u našemu slučaju to će, konkretno, biti onaj hrvatske barokne (naročito sjevernohrvatske) književnosti. Polazeći od shvaćanja da ,žanrovi nemaju nepovijesnu esenciju, već samo povijesno promjenjive uporabne vrijednosti“ (Frow 2015: 167), ponajprije će se tako razmatrati (kontekstualnim zahtjevima uvjetovane) tekstualne značajke svakoga od lociranih žanrova, i to - baš kao što je u svojim genološkim studijama učinio to i Gérard Genette ${ }^{109}$ - kako one uključene u sam tekst djela, tako i one zastupljene u paratekstu, no u konačnici svima će njima redom biti potvrđeno arhitekstualno, odnosno intertekstualno porijeklo. Značit će to, konkretno, da će se signali pojedinih žanrova najprije pokušati locirati u samome tekstu Odiljenja sigetskog, a potom i u njegovim (relativno opsežnim) popratnim, paratekstualnim dionicama (predgovorima i posvetama svih triju Vitezovićevih izdanja „spjeva“), a sve to slijedeći Genetteov i primjer brojnih drugih suvremenih genologa, koji su uvjerljivo potvrdili kako se autorova žanrovska određenja djela počesto kriju i u tim - dosad, u pravilu, zanemarivim - segmentima knjige. ${ }^{110}$ Utvrđivanje te tekstualne dimenzije pojedinih žanrova neizbježno će, u skladu s recentnim genološkim shvaćanjima, povlačiti sa sobom i nužnost definiranja njihova odnosa spram interteksta, točnije razmatranja vjerojatnoga intertekstualnog (međutekstualnog) slijeđenja žanrovskih značajki iz djela ranijih ili Vitezoviću suvremenih, baroknih autora, a u vezi s tim i potrebu da se zaviri i u književno te uopće kulturno i društveno okružje autorova vremena.

Svaki će se zasebni žanr tako, ukratko, motriti kao izravna posljedica konteksta, kao kategorija koja ovisi od različitih instanci koje se njome koriste (autor, onodobna publika, kasniji recipijenti, poetičari, izdavači itd.), što će reći kao entitet nerazdruživo povezan $\mathrm{s}$ određenom kompleksnom društvenom stvarnošću te potrebama i očekivanjima sviju sudionika književne komunikacije. Svaki zasebni kontekst ili situacija, poučili su nas suvremeni genolozi, iziskuje drugačije žanrove koji odgovaraju njezinu okviru, odnosno kreiraju danoj situaciji prikladne načine razumijevanja teksta, slijedom čega je i ovdje žanrove nužno shvaćati kao, ponovimo, posrednike između teksta i situacije, dakle kao entitete koji ostvaruju specifična situacijska značenja i koji su stoga u najvećoj mjeri definirani svojom namjenom. Jer, žanr ne „pripada“ tekstu, već je okosnica koju tekstu nameće kontekst,

\footnotetext{
${ }^{109}$ Detaljnije u: Genette 1997.

${ }^{110}$ Usp. naročito u: Fowler 1982 i Rasmussen 2015: 125-152.
} 
navlastito članovi neke (diskursne, komunikacijske) zajednice u određenome povijesnom trenutku, a to onda znači da žanrovi nisu ništa drugo nego „kulturne tvorevine“, odnosno kategorije tijesno isprepletene s danim kulturnim okolnostima koje „utječu na razmišljanje, osjećanje i znanje njihove publike“ (Cohen 1991: 90). Bit će, drugim riječima, neophodno locirane žanrove stoga promotriti iz vizure točno određenoga kronotopa, i to imajući u svakom trenutku na umu da baš svaki žanr, uronjen u određene kronotopske ili prostornovremenske odnose koje upija u sebe, ujedno s njima upija i (privremeni) društveni svjetonazor, uvjerenja, uopće sustav vrijednosti neke zajednice, njezinu ideologiju itd. Kao što je već više puta istaknuto, žanr se - želi li uopće egzistirati - nužno prilagođava stanovitome prostoru i vremenu (tj. situaciji), vršeći u tome okviru neke specifične funkcije povezane $\mathrm{s}$ tada dominantnom ideologijom i svjetonazorom te tako odgovarajući na specifične zahtjeve i potrebe konteksta ili situacije, a time ujedno i sudjelujući u suoblikovanju te situacije.

Znajući sve to, posebnu ćemo pozornost u ovome istraživanju stoga posvetiti i rekonstruiranju žanrovskoga sustava analiziranog razdoblja - onoga, dakle, hrvatske barokne književnosti - jer žanrovi neminovno postoje isključivo posredstvom svoga odnosa spram drugih žanrova u nekome (kronotopskom) okružju, iz kojega, na kraju krajeva, u najvećoj mjeri i proizlazi njihov privremeni unutarnji, tekstualni identitet (zbir njihovih sadržajnih, formalnih, stilskih i drugih tekstualnih značajki ili posebnosti važećih u određenome povijesnom trenutku). Naime, u svakome se žanrovskom sustavu žanrovi ili vrste uzajamno „podrazumijevaju tako da između sebe nekako dijele krug raspoloživih sadržaja, stilova, shvaćanja svijeta, društvenih pozicija itd., pa ono što usvaja jedna, to druge obično zaobilaze“ (Pavličić 1979a: 148), a kada - i ukoliko - dođe do seljenja žanra iz konteksta jednoga sustava u drugi, u tom slučaju dolazi i do promjene njegovih tekstualnih čimbenika, ali i, što je još važnije, njegove funkcije, vrijednosti i uopće statusa. Nije iz toga razloga nimalo neobično to što tu važnost - vremenski i mjesno određenoga - sustava ili dijapazona žanrova naglašavaju i brojni recentni genolozi (poglavito S. Greenblatt i C. Miller), glasno pledirajući za razumijevanje žanrova kao kulturnih artefakata koji svojim uzajamnim djelovanjem sudjeluju u konstituiranju i održavanju kulture u cjelini. Shvativši da je identitet svake kulture određen zapravo specifičnim setom ili sustavom žanrova koji su u njoj u (trenutnoj) uporabi, teoretičari žanra s pravom upozoravaju da je i (naizgled) isti žanr koji se pojavljuje u dvjema različitim kulturama u suštini zapravo korjenito različit jer u svakoj od njih (najvjerojatnije) vrši neke sasvim različite funkcije i stoga i biva shvaćen na nezanemarivo drugačiji način. „Žanr“ Odiljenja za to, vidjet ćemo, može poslužiti kao i više nego dobar primjer. 
Iz istoga će se, nadalje, razloga - kontekstualne ili situacijske uvjetovanosti svakoga žanra - nezaobilaznim ispostaviti i pitanje (vjerojatne) publike Vitezovićeva Odiljenja, što znači da će u narednom istraživanju bitnu ulogu (od)igrati i utjecajna teorijska predodžba o žanru kao ugovoru između autora i publike, odnosno genološka zapažanja Hansa Roberta Jaussa, na kojima počiva i cjelokupno shvaćanje žanrova u estetici recepcije. Pretpostavit će se tako u nastavku da je (i) publika u drugoj polovini 17. stoljeća (ili makar jedan znatan dio onodobne - opismenjene - publike) imala već razvijenu svijest, odnosno znanje o pojedinim žanrovima te njihovoj „uporabnoj vrijednosti“ i svrsi, zahvaljujući kojem je bila u stanju prepoznati ih i ,poduzeti“ prikladno čitanje svakoga od njih, odnosno razabrati koje on funkcije ispunjava te u skladu s njima i „djelovati“. Vjerovat će se, ukratko, da je znanje o konkretnim žanrovima - iako najvjerojatnije tomu nije (uvijek) bilo tako - duboko bilo usađeno i u strukture svakodnevice u našemu 17. stoljeću, a s obzirom na to da su njihove konvencije (u tom slučaju) dijelili članovi tadašnje diskurzivne zajednice (pisci, čitatelji, tiskari itd.), nužnim će se ispostaviti i utvrđivanje vjerojatnih recipijenata Odiljenja, koji su spram svih ili makar nekih u nj uvrštenih žanrova gajili stanovita očekivanja, a onda zacijelo u njima i „sudjelovali“. To što su, međutim, potencijalni sedamnaestostoljetni čitatelji Vitezovićeva djela posjedovali jasnu ili manje jasnu svijest o pojedinim (književnim) žanrovima i njihovim razlikama neće, međutim, istodobno podrazumijevati i to da su bili oni svjesni i čitavoga žanrovskog sustava hrvatske barokne književnosti ili kulture domaćeg nam baroka u cijelosti, tim više što su među njima postojale gdjekad i vrlo krupne razlike u porijeklu, društvenom statusu, dosegnutom stupnju obrazovanja, prethodnome književnom iskustvu, afinitetima, potrebama itd. Kao što su već upozorili pojedini genolozi, prosječni čitatelj - a vrijedit će to i za najnačitanije i najstručnije povjesničare književnosti - u svojoj svijesti ne nosi cjelokupan žanrovski sustav konkretnoga (književno)povijesnog razdoblja na temelju kojega bi bio u stanju detektirati žanr nekoga književnog ostvarenja razgraničujući ga pritom od apsolutno svih drugih, u tom trenutku supostojećih žanrova koji tvore sustav. Naprotiv, svaki čitatelj - a odnosit će se to i na vjerojatne recipijente Odiljenja sigetskog posjeduje znanje o konkretnim, pojedinačnim žanrovima $s$ kojima se dotad imao prilike susresti i koji u njegovoj čitateljskoj svijesti tvore tek provizorni skup poznatih mu žanrova na temelju kojega je on i osposobljen - ili nije osposobljen - žanrovski odrediti književni tekst koji mu je u nekom trenutku dospio u ruke. ${ }^{111}$ Budući da je taj provizorni žanrovski skup

\footnotetext{
111 Pišući o žanrovima i načinima na kojih ih recipijenti (pre)poznaju, i Zdenko Škreb tako je već ispravno utvrdio da svaki „(...) gledalac, slušalac, čitalac ne nosi »prirodno« u sebi podsvjesni sistem vrsta koji bi mu dopuštao da u predloženom tekstu prepozna književnu vrstu i da taj tekst na osnovi toga podsvjesnog sistema odijeli od neknjiževnoga teksta kao književno djelo: pojedinci se uče poznavanju vrsta čistim empirijskim
} 
posve indivudualan i ovisi o nizu maločas spomenutih faktora $-\mathrm{u}$ rasponu od društvenoga statusa do osobnih afiniteta - nipošto ne možemo govoriti o čitateljevu poznavanju sveopćega žanrovskog sustava nekoga razdoblja, zbog čega se ni rekonstruiranje sustava žanrova barokne književnosti neće ovdje poduzeti da bi se sugeriralo s kakvim se bogatim izborom suočavao svaki pojedinačni onodobni čitatelj i s kakvim je u svakome trenutku računao, već, naprotiv, da bi se pokazalo iz kakvoga je to obilnog žanrovskog ,izvora“ svoje djelo „napajao“ sam Pavao Ritter Vitezović pokušavajući ispisati tekst koji će biti po mjeri svakoga, pa čak i jedva pismenoga čitatelja.

U svakom slučaju, u našem ćemo istraživanju, slijedeći pretežno teorijske zamisli estetike recepcije, ispitati i kakve su to konkretno - jaussovski rečeno - ,horizonte očekivanja“ provocirali i iziskivali različiti žanrovi utkani u tkivo Vitezovićeva Odiljenja sigetskog te kakvu je, slijedom toga, publiku ono uopće prizivalo. Bez obzira na vrlo škrte dokaze što nam ih nude neka ranija istraživanja našega sedamnaestostoljetnog čitateljstva, pokušat ćemo, dakle, proniknuti u „funkciju, recepciju i djelovanje“ Odiljenja, odnosno u funkciju u nj uključenih žanrova „u njihovoj povijesnoj stvarnosti i društvenoj okolini“ (Jauss 1970: 351), slijedom čega bi trebalo postati jasnije i u kolikoj su to mjeri žanrovi što ih je Vitezović rabio bili povijesno, pa čak i geografski određeni, koju su funkciju unutar tih granica oni imali, u kolikoj je mjeri ta funkcija odgovarala onoj koju je naš autor želio postići svojim djelom te kakav je (vjerojatni) utisak na (potencijalne) recipijente ono ostavljalo. Posebno će se intrigantnim pritom ispostaviti pitanje mijene ciljanoga čitateljskog kruga, do kojega je došlo s trećim Vitezovićevim izdanjem Odiljenja, a zbog te će činjenice i s osobitom pomnjom valjati ispitati kakav je tretman ono imalo kod kasnije svoje publike, ponajprije one u 18. i 19. stoljeću, ali i na koji su ga način percipirali (i još uvijek percipiraju) književni povjesničari i kritičari u 20. i 21. stoljeću. Utvrđivanje načina na koje su Odiljenju pristupali „obični“ i stručni čitatelji u različitim povijesnim momentima od njegova prvog izdanja do danas ispostavit će se ujedno i jednim od najvažnijih vodiča u traženju odgovora na pitanje o eventualnome sekundarnom žanru Vitezovićeva teksta, tim više što će se upravo na

putem. Što je tko od malih nogu naučio recipirati kao književnu vrstu, koliko je zatim poznavanje vrsta razvio školovanjem ili kasnijim životnim iskustvom, to će u njegovoj svijesti stvoriti inventar književnih vrsta koje će on biti kadar prepoznati u novim tekstovima ako mu dopadnu ruku, ako ih negdje može čuti, čitati ili gledati inventar, ali ne sistem. Da svaki član određene društvene zajednice u sebi nosi sistem književnih vrsta kao što nosi sistem jezika, svi bi se članovi te zajednice mogli sporazumijevati u svom odnosu prema književnosti kao što se mogu sporazumijevati sistemom zajedničkoga jezika, koji nose u svijesti. Međutim velike razlike između pojedinaca u njihovu porijeklu, njihovoj klasnoj pripadnosti, u njihovu obrazovanju i njihovu kulturnom stavu, omogućuju bar djelomično sporazumijevanje o književnosti u pravilu tek između ljudi koji žive u jednakim ili vrlo srodnim društvenim uvjetima“ (Škreb 1976: 41). Primijetimo kako je ovo gledište ujedno i vrlo blisko najsuvremenijim teorijama žanra koje ističu kako je žanr zapravo mentalni konstrukt ili predodžba, a ne (fizički) postojeća kategorija, kako se to dosad često mislilo. 
njegovu primjeru potvrditi da je ,horizont očekivanja“ - kao što je to prije nekoliko desetljeća ispravno uočio Jauss - povijesno promjenjiv te da ovisi ponajprije o kontekstualnim čimbenicima, o gomilanju književnopovijesnoga materijala i znanja, o mijenama književnoteorijskih perspektiva te o nizu drugih činitelja koji utječu na to da se u različitim vremenskim momentima jedno te isto djelo posve različito percipira. I više nego zanimljiva činjenica da se tri Vitezovićeva izdanja Odiljenja sigetskog zapravo nisu obraćala istom tipu publike tako će potvrditi ono teorijsko zapažanje prema kojemu i sam autor raznim svojim postupcima nerijetko provocira posve različite horizonte očekivanja za svoje djelo, što se, kada je riječ o Odiljenju, zapravo i ne bi trebalo učiniti toliko neobičnim znamo li da su u 17. stoljeću različiti tipovi publike razvijali posve različite horizonte očekivanja nejednako tako pristupajući često i jednom te istom književnom djelu.

Poradi izrazite brojnosti i različitosti žanrova u Odiljenju sigetskom iznimno će se važnima, pa čak, štoviše, i nezanemarivima ispostaviti i recentne genološke predodžbe o usmenoknjiževnim žanrovima, i to upravo one proizišle iz rečenih folklorističkih aplikacija suvremenih teorija žanrova, o kojima je maločas bilo znatno više riječi. Pridodamo li toj činjenici još i onu da će nas susret s pojedinim obilježjima pučkoknjiževnih žanrova $\mathrm{i}$ njihovim prepoznatljivim populističkim mehanizmima - od kojih Vitezović u Odiljenju također nije zazirao - suočiti i s potrebom uključivanja čak i generičkih klasifikacija pučke književnosti, jasno je da će se u ovome istraživanju miješati nekoliko različitih klasifikacija književnih djela, i to, konkretno, one prema žanrovskom, književnopovijesnom, medijskom (pisana / usmena književnost), ali i klasifikacija prema kriteriju populističnosti (,visoka““ / popularna, tj. pučka književnost). Kada je riječ o usmenoknjiževnim (pa i, donekle, pučkoknjiževnim) žanrovima Odiljenja, bez obzira na njihovu će im se nezanemarivu različitost u okvirima ovoga istraživanja pristupiti, ipak, iz posve jednakih teorijskih očišta kao i onim pisanoknjiževnim, za što nam valja zahvaliti Bahtinovoj (univerzalnoj) teoriji govornih žanrova, primjenjivoj u proučavanju apsolutno svih poznatih, pa tako i folklornih žanrova, kao što su to, uostalom, dosad već i potvrdile mnogobrojne studije. ${ }^{112}$

Istraživanje žanrova u Odiljenju sigetskom Pavla Rittera Vitezovića u najvećoj će se mjeri stoga usredotočiti upravo na utvrđivanje njihove „uporabne vrijednosti“ u kontekstu hrvatske barokne književnosti, što znači da će (tekstualno) identificiranje pojedinih generičkih obilježja zastupljenih u Vitezovićevu djelu poslužiti tek kao polazište mnogo ekstenzivnijem razmatranju njihove situacijske uvjetovanosti, a sve u cilju možebitnoga definiranja „krovnoga“" sekundarnog žanra ovoga po mnogočemu neobičnog književnog ostvarenja, koje

${ }^{112} \mathrm{O}$ mogućnostima primjene Bahtinove teorije na proučavanje usmenih žanrova npr. u: Lozica 1990: 111-118. 
su dosadašnji njegovi proučavatelji žanrovski određivali doista kojekako. Ukratko, kako to u jednoj od svojih recentnijih studija izvrsno sažima Claudio Guillén, u svakoj bi - pa i ovoj iole ozbiljnijoj genološkoj analizi trebalo razmotriti ni manje ni više nego sveukupno šest aspekata književnog žanra, i to: povijesni (jer žanrovi podrazumijevaju dinamičke, promjenjive modele koji kroz povijest bivaju podvrgnuti nebrojenim imitacijama i preoblikovanjima), sociološki (jer su žanrovi zapravo društvene institucije, kao, uostalom, i književnost u cjelini), praktični (jer svaki žanr pretpostavlja ugovor s publikom koji ga obvezuje da ispuni čitateljev ,horizont očekivanja“), strukturalni (jer je žanr dio dinamičnoga žanrovskog sustava u kojemu u svakom trenutku egzistira niz žanrovskih modela), konceptualni ili logički (jer, naročito s gledišta autora, žanr funkcionira ponajprije kao mentalni model, ideja ili koncept, koji se potvrđuje kada čitatelj - većinom kritičar žanrovski klasificira njegovo djelo) te komparativni (jer je potrebno utvrditi i je li žanr „univerzalan“ ili je, pak, bio i ostao svojinom neke određene nacionalne književnosti). ${ }^{113}$ Samo ono generičko istraživanje koje ne propušta ispitati niti jedan od ovih šest žanrovskih aspekata s punim se pravom može dičiti suvremenošću svojega pristupa, dostojno pokazujući na vlastitom primjeru kako fokusiranje na „tek“ žanrovsku dimenziju jednoga jedinog književnog djela - shvati li se ona, dakako, kao tekstualno odzrcaljenje kontekstualnih ili situacijskih imperativa - analitičku perspektivu može otvoriti do uistinu neslućenih razmjera.

\section{ODILJENJE SIGETSKO I PROBLEM ŽANROVSKOG ODREĐENJA}

Ne tako davno određeni su proučavatelji golemoga stvaralačkog opusa Pavla Rittera Vitezovića, utvrdivši da je „o različitim aspektima njegova književnog i političkog djelovanja napisana (...) čitava biblioteka“ (Blažević 2002: 31), predložili da se korpus stručnih tekstova posvećenih Vitezovićevu „liku i djelu“ obuhvati nazivom „ritterološka literatura“. 114 Štoviše, budući da je riječ o ,autoru koji je već gotovo dvije stotine godina omiljen predmet istraživanja različitih disciplinarnih usmjerenja“ (Blažević 2008b: 295), istim se proučavateljima (s pravom) učinilo da tu kontinuiranu višestoljetnu i višedisciplinarnu zaokupljenost Vitezovićem i njegovom sveukupnom kreativnom ostavštinom napokon valja svesti u okvire neke nove, posebne znanosti ili discipline, koju su tom prilikom prozvali, dakako, „ritterologijom“. Prihvatimo li tu njihovu i više nego dobrodošlu inicijativu, sama će se od sebe u tom slučaju nametnuti i pomisao da „ritterološkoj“ pažnji, između ostalih, dosad

\footnotetext{
${ }^{113}$ Detaljnije u: Guillén 2005: 137-145.

114 Taj je prijedlog u svojoj studiji posvećenoj analizi Vitezovićeve spomenice Oživljena Hrvatska iznijela Zrinka Blažević (usp. Blažević 2002: 31-38).
} 
nije izmaknulo ni Vitezovićevo najpoznatije književno djelo na hrvatskom jeziku - „spjev“ Odiljenje sigetsko. I, doista, ovaj osebujni četverodijelni sastavak, koji ulazi u red ponajboljih baroknih ostvarenja naše književnosti, od početka prošloga se stoljeća do danas u više navrata našao u fokusu istraživanja mnogih „ritterologa“, što je urodilo s otprilike stotinjak ispisanih stranica njegovih - više ili manje uspjelih - književnopovijesnih analiza. Unatoč tomu što je u gotovo svakoj od tih analiza konstatirano da ga karakterizira izrazita generička slojevitost ili šarolikost, pitanjem žanrovske (ne)odredivosti Odiljenja sigetskog ozbiljnije su se pozabavila tek (neka) recentnija čitanja, napokon shvativši da se radi o jednoj od njegovih najvažnijih, ako ne i najvažnijoj (tekstualnoj) dimenziji.

Povećani interes za žanrovske specifičnosti Vitezovićeva teksta, ipak, nije (još) rezultirao konačnim razrješenjem dilema vezanih uz njegovu generičku pripadnost, a i znatnom dijelu žanrovskih mu obilježja dosadašnji proučavatelji nisu pridali zasluženu pozornost, jamačno ih ni ne prepoznavši. To, međutim, i ne treba suviše čuditi znamo li da su analitičku (genološku) aparaturu redom oni baštinili iz tradicionalni(ji)h književnih teorija, u kojima je središnju važnost imala genološka kategorija (nadpovijesnoga) roda, a ne ona (povijesnoga) žanra, što je problem s kojim se domaća nam znanost o književnosti suočava, nažalost, još i početkom (n)ovoga stoljeća. Upravo zato, kako je u svojoj studiji ispravno primijetio i Davor Dukić, ni do danas naša „književna povijest nije čak u slučaju Odiljenja učinila posao svođenja nepoznatog na poznato, tj. opisa teksta kao kombinacije elemenata poznatih žanrova“, već se, namjesto toga, najčešće ,pribjegavalo apstraktnijim tipološkim opisima, uz pomoć pojmova poput »epsko« i »lirsko«“", dok ,pitanja poetičkih izvora Vitezovićeva Odiljenja i konkretnih književnih djela koja je Vitezović u Odiljenju mogao slijediti nisu zapravo ni postavljena“" (Dukić 2002: 69). Da je zbog zastarjelih teorijskogenoloških polazišta u gotovo svim njegovim interpretacijama sustavno bio zanemarivan niz izrazito bitnih tekstualnih, a poglavito kontekstualnih signala žanrovskoga mu identiteta, ponajbolje će razotkriti ovo istraživanje, dokazujući pritom da je upravo fluidni generički okvir koji otvara mogućnost njegova raznolikog određenja onaj faktor koji je Odiljenju omogućio i lake promjene statusa što ih je ono uživalo od vremena nastanka do danas.

Ritterovu nakanu da svoje Odiljenje sigetsko - očigledno ohrabren baroknom „modom“ stvaranja generičkih hibrida - „komponira“ kao žanrovski izrazito mješovit tekst moguće je razabrati već pri letimičnom prelistavanju ovoga neobičnog „spjeva“, no pritom ipak nipošto ne bi trebalo izgubiti iz vida da je istodobno riječ i o djelu čijem se (mogućem) jedinstvenom žanrovskom određenju i sam autor u nekoliko navrata pokušavao dovinuti te na njega na više mjesta i jasno ukazati. Da je Vitezoviću uistinu bilo stalo do toga da ga 
prezentira (i) kao žanrovski konkretan, kompaktan tekst potvrditi nam može čitav niz unutartekstualnih i (dosad sustavno previđanih) izvantekstualnih signala, što će reći da bi svaka - pa tako i ova - potraga za najprikladnijom mu generičkom odrednicom neizbježno u obzir morala obratiti pozornost i na nemali broj onih činitelja žanrovske predodžbe razbacanih onkraj njegova tekstualnog okvira. To bi, kao što u svojoj izvrsnoj genološkoj studiji navodi i Alaistar Fowler, trebalo - ukratko - značiti da čimbenike žanrovskoga identiteta (ili „dokaze za žanr") svakoga pojedinačnog književnog djela valja tražiti kako među autorovim svjesnim ili nesvjesnim žanrovskim „operacijama“ izvedenima u samome tekstu djela te kasnijim eksplicitnim generičkim definicijama (sadržanima u, primjerice, usmenim ili pisanim izjavama autora, paratekstualnim dionicama knjige, reklamnim njezinim prezentacijama itd.), tako i u specifičnim žanrovskim praksama razdoblja u kojemu je djelo napisano i objelodanjeno (eventualnim imitacijama njegova žanra), ali i isprovociranomu čitateljskom odjeku, navlastito u komentarima (prvih) - većinom stručnih, no i „običnih“ - čitatelja. ${ }^{115}$

Fowler pritom osobitu važnost pridaje, a i mi ćemo ovdje učiniti isto, onim generičkim signalima pozicioniranima u uvodnim dionicama knjige - poglavito onima sadržanim $u$ naslovu i podnaslovu (tim više što su se konvencije naslovljivanja u svakoj književnopovijesnoj epohi razlikovale od žanra do žanra), u početnim dijelovima teksta (gdje su vrlo često smještene žanrovski prepoznatljive uvodne formule i toposi) te jasnim aluzijama na ranije predstavnike žanra, najčešće uključenima u predgovore, uvode, prologe itd. - budući da se radi upravo o onim znakovima koji, zahvaljujući činjenici da ih susreće na samome početku djela, čitatelja potiču na aktiviranje konkretnoga generičkog „mentalnog sklopa“, odnosno na to da se što prije prisjeti određenih žanrovskih kodova nužnih (i) za recepciju toga književnog ostvarenja u cijelosti. ${ }^{116}$ Tek nakon detektiranja tih iznimno bitnih uvodnih tekstualnih signala genologu se otvara put i za istraživanje inih unutarnjih žanrovskih obilježja danoga djela, no prije toga svakako je još uputno ispitati i je li ga te kojim to konkretno žanrovskim odrednicama u nekim drugim svojim iskazima obilježavao njegov autor, a onda i kako su ga „doživljavali“ njegovi čitatelji od vremena u kojem je ono ugledalo danje svjetlo do ovoga trenutka. Kada je riječ o ostvarenju poput Odiljenja sigetskog, taj će posao neizbježno iziskivati još i osvrt na njegova generička određenja u književnopovijesnim studijama i prikazima ispisanima unatrag otprilike stotinu godina, tim više što je i iz nejednakoga tretmana kojeg je ono u tim tekstovima uživalo također moguće naslutiti da je

\footnotetext{
115 Podrobnije u: Fowler 1982: 52-53.

${ }^{116}$ Usp. Isto: 88-105.
} 
definitivno riječ o djelu koje, po pitanju svojega žanrovskog identiteta, prilično visoko „strši“ iz korpusa hrvatske, ali i, donekle, europske sedamnaestostoljetne književne produkcije.

\section{1. IDEJNE, SADRŽAJNE I FORMALNE POSEBNOSTI ODILJENJA}

Bez obzira na konkretnu poziciju koju u njegovu opusu zauzima ili bi - prema mišljenju pojedinih ,ritterologa“ - trebalo zauzimati, ${ }^{117}$ ono što se za Odiljenje sigetsko sa sigurnošću može ustvrditi jest to da je riječ o jednome od prvih djela Pavla Rittera Vitezovića na hrvatskom jeziku, a ujedno i njegovu prvom hrvatskom tiskom objavljenom književnom tekstu uopće. U godinama prije njegova objelodanjivanja Ritter je narodnim jezikom ili vernakularom, naime, ispisao uistinu skroman broj stranica, a s kojim se to hrvatskim tekstovima mogao on podičiti prije 1684. otkriti možemo zavirimo li u njegov zbornik rukopisnih i tiskanih djela Otia metrica manuscripta et impressa, koji sadržava najveći dio pisane mu ostavštine iz razdoblja između 1682. i 1684. ${ }^{118}$ Doduše, prema Ritterovu vlastitom priznanju, koje je iznio u nekolicini svojih latinskih pjesama uvrštenih u nešto stariju rukopisnu zbirku Epistolae metricae, ${ }^{119}$ stihove i druga djela na latinskom jeziku počeo je, umjesto hrvatskih, pisati tek za svojega boravka u Sloveniji (dakle, tijekom 1676. i 1677.), i to zato što su - pojašnjava - u slovenskim zemljama u to vrijeme osnovni jezici komuniciranja bili latinski i njemački. ${ }^{120}$ Iako bi to, dakle, značilo da je stanovit broj pjesama na hrvatskom jeziku Vitezović ispjevao već i prije 1676., od njih se do danas nisu sačuvali čak ni naslovi, a kamoli cjeloviti tekstovi, zbog čega nam ne preostaje ništa drugo no njegovim jedinim hrvatskim ostvarenjima ispisanima do izlaska Odiljenja iz tiska držati isključivo ona razasuta zbornikom Otia metrica, veći dio kojih je, k tome, još i nepotpun.

U mnoštvu (pretežno latinskih) tiskanih i rukopisnih tekstova uvezanih u rečeni zbornik zateći ćemo tako - već na prvoj njegovoj stranici - Ritterov vlastoručni zapis odlomka jedne (vjerojatno izvorne) folklorne pjesme, i to bugaršćice naslovljene Sužanjstvo Krbave, koja se svojim sadržajem, kako je to svojedobno ispravno pretpostavio Đuro Šurmin,

\footnotetext{
117 O biografskim pojedinostima iz života Pavla Rittera Vitezovića i njegovim najvažnijim djelima znatno detaljnije u: Lopašić 1897: 39-55, Klaić 1914, Bratulić 1994: 5-17 i 1997: 9-40, Vajs i Meštrović 2009: V-LXIII, Ušković Croata 2015: 7-13, Jembrih 2015: 489-612, 2016a: 13-81, 2017b: 11-82 itd.

118 Navedeni se zbornik - pod signaturom R 3461 - danas čuva u zagrebačkoj Nacionalnoj i sveučilišnoj knjižnici. Usp. njegov sadržaj u: Kosić 2013: 23-29. Inače, o Vitezovićevu je hrvatskom pjesništvu iz zbornika Otia metrica - dakle, o onom nastalom do 1684. - prvi u nas pisao Đuro Šurmin, i to već prije punih 115 godina (usp. Šurmin 1902: 531-538).

119 Riječ je, pak, o Vitezovićevoj rukopisnoj zbirci u kojoj su okupljeni njegovi latinski pjesnički sastavci napisani između 1676. i 1677. i koja je danas pohranjena u Arhivu HAZU.

${ }^{120}$ Usp. Novaković 2010: 39-40.
} 
zacijelo referira na hrvatski poraz od Turaka na Krbavskom polju $1493 .{ }^{121}$ Pored nje, u isti je zbornik Vitezović upisao i osmeračku lirsku minijaturu pod naslovom Hroma pravica ${ }^{122}$ te još jednu (nepotpunu) kraću pjesmu u dvostruko rimovanim dvanaestercima južnoga tipa i prepoznatljivo petrarkističke ljubavne tematike. ${ }^{123}$ Od (najvjerojatnije) četvrte hrvatske pjesme u Otia metrica sačuvao se tek njezin naslov - Mesopušćica aliti čin od mesopusta koju je, kako pretpostaviše naši književni povjesnici, Vitezović ispjevao za posebnu priliku, i to kada su, u sklopu hrvatskoga kolegija u Beču, mladi svećenici koji su ondje studirali 9. veljače 1682. upriličili pokladnu zabavu. ${ }^{124} \mathrm{~S}$ Mesopušćicom, međutim, hrvatski Ritterovi stihovi u navedenome zborniku nipošto ne prestaju, no one sljedeće nećemo više naći izdvojene u samostalne lirske minijature.

Imperativ sastavljanja pjesničkih poslanica na latinskom jeziku, koji je u najvećem dijelu svoga epistolografskog korpusa „poslušno“ slijedio, Pavla Vitezovića u mladosti ipak nije spriječio u naumu da $\mathrm{u}$ nekolicinu svojih stihovanih pisama upućenih prijateljima $\mathrm{i}$ poznanicima u Hrvatskoj uvrsti i stihove na narodnom jeziku. Oveći ciklus poslanica u Otia metrica sadrži tako nekoliko primjera te Vitezovićeve mladenačke prakse, od kojih je kronološki - najraniji onaj (pretežno) latinske poslanice vijećniku Jurju Mihajlu Kiševiću (odaslane iz Beča 12. veljače 1682.), u koju, žaleći se na besparicu što ga je zatekla tijekom njegova boravka u habsburškoj prijestolnici, uključuje jedan hrvatski distih u dvostruko rimovanom dvanaestercu („Al je zakon stari u ovomu gradu, / Da prez pinez stvari najmanje ne dadu“). ${ }^{125}$ Prvih osam stihova - također većim dijelom latinske - poslanice zagrebačkome podžupanu Stjepanu Jelačiću od 17. svibnja 1682. Vitezović piše na hrvatskom u dvostruko rimovanim dvanaestercima sjevernoga tipa, a u istome će stihu samo nekoliko dana kasnije 21. svibnja 1682. - ispjevati i hrvatski dio poslanice kapetanu Franji Ivanoviću. Ta epistola, štoviše, predstavlja svojevrsnu kulminaciju ove Vitezovićeve prakse ne samo s razloga što je

${ }^{121}$ Usp. Šurmin 1902: 537-538. Autor na istome mjestu donosi i cjelovit tekst rečene bugaršćice, a u novije vrijeme nju će u svoju antologiju Bugaršćcice uvrstiti i Josip Kekez, i to pod izmijenjenim naslovom Ban Derenčin boja bije (usp. Kekez 2000: 114-115).

${ }^{122}$ Hroma pravica u cijelosti glasi: „Gdi je Juno dare vrgla, / Pravica je nogu vtrgla; / Al kakogod ide hroma, / Dojt će jošće nigda doma!““ (cit. prema: Klaić 1914: 53).

${ }^{123}$ Pjesma je trebala brojiti dvanaest stihova, no nedostaje joj onaj četvrti, pa tako glasi: „Primi mi ljubljeno, vilo, pozdravljenje, / Pri koj mi srčeno stoji ozdravljenje. / Dobru si lovinu zaisto vlovila, / ---------- / Jer su ulovile tvoje oči, vilo, / I jur posvojile moje srce milo. / Kada sam zapazil on lipi obraz tvoj, / Sebi sam omrazil, niti sam već sam svoj, / Nego vas tvoj biti i želim i hoću / I za te trpiti vse zlo i teškoću, / Da me ljubav tvoja i tvoj obraz lipi / Do moga pokoja dobrom voljom kripi“ (cit. prema: Šurmin 1902: 533).

${ }^{124}$ O tome „hrvatskom spisku“ pisao je u Vitezovićevoj biografiji još Vjekoslav Klaić 1914. (usp. Klaić 1914: 45), a da je najvjerojatnije bila riječ o još jednoj hrvatskoj Ritterovoj pjesmi u svojem će pregledu povijesti hrvatske i srpske književnosti odlučno zatim pretpostaviti David Bogdanović (usp. Bogdanović 1932: 452). Treba, međutim, imati na umu da taj svoj nesačuvani tekst Vitezović podnaslovljuje kao „predgovornik“, što bi pretpostavku o Mesopušćici kao pjesmi moglo donekle dovesti u pitanje, tim više što se - misli Đuro Šurmin vro vjerojatno radilo o (kajkavskoj) pokladnoj drami (usp. Šurmin 1902: 536-537).

${ }^{125}$ Navedeni distih citirao je u Ritterovoj biografiji i Vjekoslav Klaić (usp. Klaić 1914: 50). 
riječ o jedinoj njegovoj poslanici s naslovom na hrvatskom jeziku (,Dobro-plemenitomu, i viteškomu gnu Ferencu Ivanoviću od Šćitara..." $\left.{ }^{126}\right)$, već i stoga jer hrvatska dionica u njoj daleko nadmašuje onu latinsku (od sveukupno 120 njezinih stihova, na latinskom jeziku ispisano je njih tek šest zaključnih), a za naše će istraživanje posebno ona biti važna i zato što u njoj Ritter Ivanovića, između ostalog, izvještava i o svojemu radu na Odiljenju sigetskom. ${ }^{127}$ Nedugo nakon nje, hrvatski katren u dvostruko rimovanome dvanaestercu sjevernoga tipa naš je autor - ne bi li poetski opisao razuzdano slavlje Bečana u povodu rođenja kraljeva sina (,Tad ljudi duhovni po noći hodjahu, / Povsud se telovni s' ženami vodjahu; / U gusle igrahu, v bubnje i trumbite, / Zastave višahu 'z oblokov razvite!“(128) - inkorporirao i u prozno latinsko pismo Stjepanu Jelačiću od 7. lipnja 1682., a u cijelosti će na hrvatskom jeziku potom sastaviti i kratku epistolu Martinu Kostisu (datiranu na 14. lipnja 1682.), u kojoj adresata „moli, da mu po pošti otpravi neka pisma, što mu ih je (...) poslao (svega 7 dvanaesteraca)“ (Šurmin 1902: 536). Potonja je bila i posljednja (do danas nam poznata) Ritterova poslanica sa stihovima na vernakularu.

Stihotvoračku svoju umješnost Ritter je, dakle, u godinama prije objelodanjivanja Odiljenja iskaz(iv)ao ponajvećma u svojim latinskim pjesničkim ostvarenjima, kojih je - za razliku od onih hrvatskih - do 1684. ispisao već uistinu zavidan broj. Ostavimo li po strani prvo njegovo tiskom objavljeno djelo - historiografsku raspravu o plemićkoj porodici Gušić Apographum ex Joanne Lucio (1681.) - i niz već spomenutih pjesničkih poslanica iz zbornika Otia metrica, korpus mladenačkih Vitezovićevih poetskih tekstova obuhvaćao bi tako još i veći broj epistola okupljenih u dvjema rukopisnim zbirkama naslovljenima Equitis Pauli Ritter epistolarum metricarum (liber primus i liber secundus), koje datiraju iz razdoblja 1676. - 1677., ${ }^{129}$ potom pjesmu prigodnicu uvrštenu u djelo Topographia ducatus Carnioliae modernae (Topografija suvremene vojvodine Kranjske, 1679.) njegova velikog prijatelja, slovenskog baruna i polihistora Janeza Vajkarda Valvasora, ali i rukopisnu lamentaciju Lamentatio Segniae (1681.), u kojoj jadikuje nad brojnim nevoljama što su tih godina snašle građane rodnog mu Senja. U korpus njegova latinskog pjesništva nastalog do 1684. ulaze još i mnogobrojne prigodne pjesme što ih je, u duhu svoga vremena, tih godina - a i kasnije gotovo opsesivno ispisivao potaknut kojekakvim važnim događajima, a od njih vrijedi

\footnotetext{
${ }^{126}$ Usp. naslov poslanice u: Kosić 2013: 24. Na istome je mjestu donesen i reprint njezina rukopisa, a tiskana je ona po prvi put u cijelosti u: Šurmin 1902: 534-536. U novije ju je vrijeme u svoj izbor iz Vitezovićeva stvaralaštva uvrstio Marko Samardžija, no izostavivši pritom njezinih zaključnih šest stihova na latinskom jeziku (usp. Ritter Vitezović 1999: 98-100), a fragmentarno je ona objavljena i u: Ritter Vitezović 1994: 118-120.

127 Usp. Klaić 1914: 51.

${ }^{128}$ Rečeni katren u svome je životopisu Pavla Vitezovića također donio Vjekoslav Klaić (usp. Isto: 53).

${ }^{129}$ Podrobnije o ovim zbirkama u: Moretti 2014. O intrigantnim ljubavnim elegijama (tj. poslanicama ženskim adresatima) iz obiju ovih zbirki te onih iz zbornika Otia metrica znatno opširnije i u: Novaković 2010: 39-54.
} 
izdvojiti, primjerice, dvije prigodnice posvećene zagrebačkome kanoniku Aleksandru Mikuliću objelodanjene u sklopu knjižice Vinculum ex pindiis hortis (1681.), zatim prigodnicu Novus Skender-beg (1682.) ispjevanu u čast grofa Petra Ricciardija koji je stekao plemićku titulu, potom opsežnu prigodnu pjesmu posvećenu kralju Leopoldu I. u povodu njegova uspješnog zaključenja sabora u Šopronu potkraj prosinca 1681. itd. Sve značajnije prigodnice što ih je ispjevao 1682. Vitezović je potom, zajedno s još nekim drugim latinskim pjesmama, skupio u svoju zbirku Nova Musa, koja je svjetlo dana ugledala u Beču 1683., no bit će da time njegov mladenački latinski pjesnički opus nipošto nije bio zaokružen jer je, kako tvrdi Vjekoslav Klaić, nemali broj svojih ranih stihovanih tekstova na latinskom jeziku (a vjerojatno i pokoje hrvatsko) vlastoručno kasnije uništio. ${ }^{130}$

Ako je u pobrojanim latinskim i hrvatskim pjesničkim radovima Vitezović, na neki način, samo ,(iz)oštrio pero“ za svoj vernakularni književni prvijenac, onda i samo Odiljenje doista zaslužuje da ga se shvati kao svojevrsno prekretničko djelo u njegovu stvaralačkom opusu, i to ponajmanje zato što je poslije njega veći dio svoje kreativne pozornosti usmjerio on nekim drugim područjima. Konkretno, ukoliko je mladenačku etapu Vitezovićeva stvaralaštva obilježila njegova gotovo definitivna zaokupljenost elitnom književnošću i historiografskim raspravama na latinskom jeziku, u onoj zreloj - poslije 1684. - važno će (iako ne i dominantno) mjesto imati i njegova iznimna posvećenost sastavljanju i tiskanju pučkoknjiževnih ostvarenja na hrvatskom jeziku namijenjenih širem čitateljstvu, u red kojih bi se, kao što će se pokazati nešto kasnije, lako moglo uvrstiti već i samo Odiljenje. Doduše, na prve sljedeće Ritterove pjesničke pokušaje na vernakularu nakon prvoga je izdanja Odiljenja valjalo čekati punih pet godina, no te 1689. u monumentalnom će Valvasorovu djelu Die Ehre des Herzogthums Crain (Slava vojvodine Kranjske) - u sastavljanju kojega je, za svoga boravka u Kranjskoj u sedamdesetim godinama 17. st., Vitezović predano pomagao Valvasoru - danje svjetlo ugledati pohvalnice Hrvatkinja i Dalmacija, ispjevane dvama najvažnijim stihovima ranonovovjekovne hrvatske književnosti - dvostruko rimovanim dvanaestercem, odnosno osmercem. Izuzmemo li izgubljenu njegovu (pučku) prigodnu pjesmu Novljančica iz, kako pretpostavlja Klaić, iste godine, u kojoj je najvjerojatnije opjevao trijumf hrvatske vojske nad Osmanlijama kod Novoga na Uni, ${ }^{131}$ Valvasorova sjena nastavit će, na određeni način, lebdjeti i nad sljedećim Ritterovim hrvatskim (pučko)književnim pokušajima, koji će se pred publikom naći tek u drugoj polovini devedesetih godina 17. st.

\footnotetext{
${ }^{130}$ Detaljnije u: Klaić 1914: 9-70.

${ }^{131}$ Usp. Isto: 78-79.
} 
Naime, četiri godine nakon njegova definitivnog dolaska u Zagreb i neočekivanog otkrića tiskarskog stroja koji je, posve nekorišten, propadao u biskupskom dvoru na Kaptolu, Hrvatski sabor će - u studenom 1694. - Pavlu Ritteru Vitezoviću napokon dodijeliti na upravljanje dotad zanemarenu Zemaljsku tiskaru. Sjetivši se odmah baruna Valvasora, koji je u svome kranjskom dvorcu Bogenšperku (Wagensperg) uredio privatni muzej s golemom bibliotekom i tiskarom, u kojemu su se okupljali neki od najvažnijih intelektualaca iz ovoga dijela Europe, Ritter je već 1695. „instituirao hrvatsku inačicu Valvasorova muzeja u svojoj kući na Griču, smjestivši onamo i kraljevinsku tiskaru koju su mu na upravu povjerili hrvatski staleži“ (Blažević 2014a: 285), te odmah prionuo na posao tiskanja prijeko potrebnih knjiga na hrvatskom i latinskom jeziku. Iste će godine, pored niza tuđih ostvarenja, na svjetlo dana tako izaći i Vitezovićev pučki kalendar Kalendarium aliti misečnik hervatski te ponovljeno izdanje Odiljenja sigetskog, a već sljedeće godine i kronikalni prikaz domaće i svjetske povijesti Kronika aliti spomen vsega svieta vikov. Pored kalendara, koji će u narednim godinama nastaviti redovito izlaziti, u Zemaljskoj tiskari, odnosno Vitezovićevu „muzeju“ 1701. najvjerojatnije je objelodanjena i (djelomično sačuvana) knjiga gatalica Lado horvatski iliti Sibila, a od hrvatskih će njegovih (pučkoknjiževnih) ostvarenja ondje još biti otisnuta i zbirka stihovanih poslovica Priričnik aliti razliko mudrosti cvitje (1703.) te prigodna pjesma Senjčica (1704.), u kojoj se proslavljaju ratni podvizi neustrašivih Senjana. Premda će do lipnja 1706., kada je znatan dio Zemaljske tiskare oštećen u velikom požaru, Vitezović (vjerojatno) otisnuti još i kalendare za 1705. i 1706., ${ }^{132}$ upravo se sa Senjčicom zaokružuje Vitezovićeva (uvjetno rečeno) dvadesetogodišnja „hrvatska““ kreativna faza, u kojoj su počevši s Odiljenjem - objavljena redom sva njegova (pučko)književna djela. Pretpostavimo li da je još 1706. iz tiska izišao posljednji njegov Misečnik hervacki, to će značiti da je u završnim godinama svojega života Ritter u potpunosti „digao ruke“ od stvaralaštva na narodnom jeziku, no za to je, kako se čini, imao i više nego opravdane životne razloge. ${ }^{133}$

Da je kucnuo čas za objelodanjivanje Odiljenja sigetskog Pavao Vitezović osjetio je, konkretno, za svoga četveromjesečnog boravka u privremenoj habsburškoj prijestolnici u Linzu, ${ }^{134}$ u proljeće 1684., kamo ga je kao svoga poklisara kod kralja Leopolda I. poslao ban Nikola Erdödy. ${ }^{135}$ Samo godinu dana kasnije, boraveći u „izvornome“ sjedištu habsburškoga

\footnotetext{
132 Od tih se dvaju vjerojatnih kalendara dospio sačuvati tek Misečnik hervacki za 1705., danas pohranjen u Zbirci rukopisa i starih knjiga zagrebačke Nacionalne i sveučilišne knjižnice (usp. Kosić 2013: 343-343).

$133 \mathrm{O}$ nevoljama s kojima se Vitezović suočavao u posljednjem desetljeću svojega života najdetaljnije u: Klaić 1914: 189-292.

${ }^{134} \mathrm{U}$ to je vrijeme, podsjetimo, trajala turska opsada Beča, zbog koje se habsburški dvor i bio povukao u Linz.

135 Pretisak toga izdanja Vitezovićeva je Odiljenja objavljen 1971. u sklopu edicije Opsada Sigeta, u kojoj su objelodanjeni još i reprint prvoga izdanja povijesnog epa Barne Karnarutića Vazetje Sigeta grada (1584.) te kronika Podsjedanje i osvojenje Sigeta Ferenca Črnka.
} 
dvora u Beču, Vitezović tiska „drugo“ izdanje svojega pjesničkog djela, koje se u „ritterološkoj“ i uopće književnopovijesnoj literaturi podugo označavalo kao ujedno i posljednje objavljeno za autorova života. Trećim njegovim izdanjem u više je, pak, navrata proglašavano ono prvo postumno, koje je priredio i 1836. u Zagrebu izdao znameniti biskup Stjepan Moyses, ${ }^{136}$ no stvarno treće izdanje Odiljenja Vitezović je imao prilike ne samo držati u svojim rukama, već ga i vlastoručno otisnuti. Čitavo, naime, desetljeće nakon što je objavljeno „drugo“, bečko izdanje Odiljenja, iz tiska će - u Zemaljskoj tiskari u Zagrebu, kojom je tada upravljao sam Ritter - izaći ponovljeno, tek neznatno izmijenjeno njegovo izdanje, o čijem su se postojanju sve do nedavno pojedini „ritterolozi“ usudili tek nagađati. Nagađanja su se, međutim, ispostavila posve opravdanima kada je - polovinom 2016. - u budimpeštanskoj Sveučilišnoj knjižnici napokon pronađen primjerak trećega Vitezovićeva izdanja Odiljenja sigetskog, otisnut u onoj istoj zagrebačkoj tiskari u kojoj će biti objelodanjena i sva preostala njegova (pučko)književna djela na hrvatskom jeziku te, pored njih, još i niz - što Ritterovih, a što tuđih - latinskih zbirki anagrama i prigodnica, govora, proglasa, povijesnih i jezikoslovnih djela, izvoda iz saborskih spisa i zapisnika, a k tome još i brojna nabožna djela i molitvenici na hrvatskom jeziku, zbirke propovijedi, školske knjige itd. ${ }^{137}$ Iako treće njegovo izdanje Odiljenja sigetskog, kako se čini, nije (još) bilo u službi propagandističkih ciljeva, razlog kasnije Vitezovićeve zauzetosti pisanjem i tiskanjem velikog broja pučkoknjiževnih djela na hrvatskom jeziku krio se, pokazala su neka od najrecentnijih istraživanja, u nužnosti predstavljanja nove politike hrvatskih staleža, odnosno njezina širenja na što je moguće veću publiku, i to upravo posredstvom vernakularnih pučkih ostvarenja unutar kojih su njezine ideološke silnice i bile uklopljene. ${ }^{138}$ Zadaća je, drugim riječima,

\footnotetext{
136 Trećim ga je izdanjem Odiljenja najprije proglasio već Đuro Šurmin (usp. Šurmin 1898: 136), a to će zatim učiniti i niz kasnijih „ritterologa“ (usp. Matić 1968: 106, Bratulić 1997: 16, bilješka 4, Blažević 2011: 252). Štoviše, Anđelko će Mijatović, slijedeći posve netočan (Vodnikov) podatak o drugome, bečkom Vitezovićevu izdanju Odiljenja (1685.) kao prvom cjelovitom, pogrešno zaključiti kako je Stjepan Moyses zapravo objavio „drugo izdanje cjelovitoga Vitezovićeva djela Odiljenje sigetsko“ (Mijatović 2010: 120). Vrlo detaljno o tom Moysesovu izdanju u: Jembrih 2008: 41-58 i 2016b: 161-169.

${ }^{137}$ O Ritterovu upravljanju Zemaljskom tiskarom te konkretnim (do danas poznatim) naslovima koji su u njoj u tom razdoblju (1695. - 1706.) otisnuti detaljno u: Klaić 1914: 93-126, Dobronić 1994: 117-126 i 1995: 171-178, Stipčević 1995: 187-190, Marković 1987: 71-99, Janković 2016: 97-120, Jembrih 2015: 537-546, 2016a: 46-52 i 2017b: 44-50. Da je Vitezović, međutim, već 1690. - nedugo, dakle, nakon svoga preseljenja u Zagreb - na tek otkrivenomu tiskarskom stroju otisnuo propovijed Sermo Funebris kanonika Petra Češkovića, u svojim su spomenutim studijama naveli M. Marković, L. Dobronić te A. Jembrih. O tome više i u: Budišćak 2016b: 94-96. 138 Naime, kako je u nizu svojih studija uvjerljivo dokazala Zrinka Blažević, nakon slamanja zrinskofrankopanske, odnosno hrvatsko-ugarske magnatske urote 1671., hrvatski su se staleži postupno počeli distancirati od otvoreno protuhabsburške ugarske politike istodobno se okrećući u sve većoj mjeri bečkome dvoru. Iako su hrvatski staleži, međutim, sve intenzivnije počeli iskazivati lojalnost habsburškom vladaru i njegovoj apsolutističkoj politici, u devedesetim godinama 17. stoljeća nimalo se nisu oni libili glasno zatražiti reintegraciju nekadašnjih hrvatskih područja netom oslobođenih od turske vlasti. Bez obzira na neprikriveno iskazivanje odanosti kralju, drugim riječima, domaći staleži iziskivali su da se osvojena područja pripoje Hrvatskom Kraljevstvu, odnosno vrate pod njegovu upravu, što znači da su - priželjkujući ostvariti partnerski
} 
velikog dijela Ritterove tiskarske produkcije bila „osigurati pedagošku formaciju i političku mobilizaciju širih slojeva“" (Blažević 2012: 435), no izdanje Odiljenja iz 1695. vrlo je vjerojatno nije još moralo ispunjavati.

Izuzmemo li promjenjive popratne, paratekstualne njihove segmente (naslovnicu, posvetu, predgovor), za sva se tri izdanja može konstatirati da su sadržajno - uz zanemarive korekcije što ih je Vitezović proveo u onom zagrebačkom ${ }^{139}-u$ potpunosti identična, što će reći da se u svakom od njih sam tekst Odiljenja sigetskog proteže na sveukupno četiri duljinom nejednaka dijela ili „dila“. Dapače, ni izdanju iz Linza tako ne samo da - u usporedbi s onim godinu dana „mlađim“ - ne nedostaju tri dijela, nego je ono, kako sam Vitezović navodi u njegovu predgovoru, u takvom obliku bilo čak dovršeno punih pet godina ranije, što će reći potkraj sedamdesetih godina 17. st. Naime, da je u drugoj polovini sedamdesetih naš autor uistinu radio na nekom hrvatskom tekstu, pa čak i da ga je do 1679 . bio već i dogotovio, posvjedočiti nam može niz informacija što ih je u pjesničkim poslanicama odaslanima različitim adresatima između 1676. i 1679. Ritter sam donio. Tako već 1676. u pismu opatu Tomi Hreljanoviću otkriva kako je napisao (nenaslovljeno) stihovano djelo u kojem opjevava junaštva hrvatskih branitelja, a samo godinu dana kasnije $u$ poslanici će nekom kranjskom znancu tek usputno spomenuti neku svoju pjesmu ispjevanu na

odnos s bečkim dvorom - nad njima bili spremni priznati tek formalnu habsburšku vlast, uz uvjet da jurisdikcija nad njima, točnije upravljanje cjelokupnim „povijesnim“ teritorijem Hrvatske, u potpunosti bude u njihovoj nadležnosti (usp. Blažević 2002: 67-82 i 2008b: 291-296, a o odnosu između hrvatske političke elite i bečkoga dvora u drugoj polovini 17. st. pregledno i u: Budak 2007: 158-162). Svjestan da je time došlo do presijecanja habsburške apsolutističke politike i one hrvatske staleške, obilježene sustavnim inzistiranjima na političkom utjecaju staleža, Pavao Ritter Vitezović pokušao ih je - u svojim historiografsko-političkim djelima iz tzv. postkarlovačkoga ciklusa (nastalima između 1699. i 1701., odnosno u vrijeme njegova sudjelovanja u Komisiji za razgraničenje koju je - nakon sklapanja habsburško-turskoga Mira u Srijemskim Karlovcima u siječnju 1699. - vodio talijanski grof Luigi Ferdinando Marsigli; o tim tekstovima podrobnije u: Blažević 2002 i 2012: 435 437) - pomiriti u novom političkom programu hrvatskih staleža, koji je kralja Leopolda I. zapravo trebao ponukati na „oživljavanje“ cjelokupne Hrvatske pod njegovom vlašću. Taj je program, naime, kralja trebao potaknuti na uspostavljanje staleškoga pravnopolitičkog uređenja pod argumentom da su hrvatski staleški interesi ujedno i primarni habsburški politički interesi, a to je ujedno trebalo značiti da se njegova vlast time formalno neće umanjiti, što je - očito je iz današnje perspektive - bila itekako dvojbena, pa čak i utopijska zamisao. Uvidjevši da bi od njegova rada mogli imati itekakve (političke) koristi, staleži su svojom saborskom odlukom Ritteru na upravljanje i povjerili zagrebačku Zemaljsku tiskaru, pri čemu su, shodno „aktualnoj emancipacijskoj političkoj platformi hrvatskih staleža čijem je kreiranju i sam značajno pridonio, glavni ciljevi Vitezovićeve izdavačke strategije bili (...) s jedne strane kreirati odgovarajući nacionalni historiografski i književni kanon u djelima pisanim latinskim jezikom, a s druge strane osigurati njihovu širu recepciju u popularnim vernakularnim kalendarima“" (Blažević 2016: 152). Tiskarska djelatnost u Zagrebu koncem 17. i početkom 18. stoljeća na taj je način stekla snažno propagandno-političko značenje, pa je od 1696. (kada je tiskana Vitezovićeva Kronika), u okviru novoga političkog programa domaćih staleža, jedan od njezinih najvažnijih funkcija bila (i) ,što obuhvatnije vertikalno mobiliziranje javnog mnijenja posredstvom jezično i žanrovski prilagođenih djela" (Blažević 2002: 178) pučkoknjiževne provenijencije (zbog čega, između ostalog, Vitezović već i Kronici dodaje „Pridavak“, u kojem piše o proširenosti slavenskoga imena i jezika, a kalendaru za 1699. popis hrvatskih kraljeva, ne bi li propagirao novu politiku i mobilizirao javno mnijenje). Detaljnije u: Blažević 2002: 174-196 i 2016: 151-152 i Hrgić 2015: 59-65.

139 Riječ je o tek nekolicini ispravaka nezgrapnih stihova, nespretnijih interpunkcijskih rješenja i tiskarskih pogrešaka iz prethodnih dvaju izdanja (podrobnije u: Budišćak 2016b: 87-88). 
„dalmatinskom“ jeziku. Vraćajući se koncem 1678. iz Kranjske u rodni Senj, Vitezović zastavši u Rijeci - ispisuje pjesničku poslanicu kranjskom plemiću Ivanu Krstitelju Locatelliju, u kojoj, između ostalog, ističe i kako u rodnom gradu kani dovršiti jedno svoje započeto djelo za koje je uvjeren da će biti iznimno drago hrvatskom (,ilirskom“) narodu (implicirajući valjda da bi tomu trebalo biti tako zato što ga piše na hrvatskom jeziku), ${ }^{140}$ dok Ivana Despotovića mlađeg u epistoli iz 1679. već obavještava da je - ne navodeći pritom njihove naslove - dovršio slavenske (tj. hrvatske) „knjižice“ (libelli) te da ih planira izdati tijekom svoga skorog putovanja u Veneciju. ${ }^{141}$ Potonja Vitezovićeva namjera - da svoje neimenovano hrvatsko ostvarenje tiska upravo u Mlecima, a ne drugdje u Habsburškoj Monarhiji - mogla bi se, kako predmnijeva Vjekoslav Klaić, možda opravdati činjenicom da je ondje 1660. „štampano u krasnoj opremi djelo grofa Petra Zrinskoga »Adrianskoga mora Sirena«, koju bijaše Ritter dobro proučio, pa (...) ga je želja vukla, da u istoj tiskari bude u svijet opremljeno njegovo djelo, koje je i po sadržaju i obradbi kao neki zaglavak zrinijadi““ (Klaić 1914: 34), no s obzirom na to da u Veneciju na koncu i nije otputovao, ne samo Odiljenje, već ni bilo koje drugo njegovo (eventualno) hrvatsko djelo svjetlo dana na koncu ondje i nije dobilo prilike ugledati.

Informacijama o radu na stanovitu hrvatskom pjesničkom djelu ni blizu tu nije kraj jer već u prosincu sljedeće godine, zaustavivši se na svome putovanju u Ljubljanu - u kojoj će početkom 1681. objelodaniti latinsku povijesnu raspravu o porodici Gušić (Apographum ex Joanne Lucio) - $\mathrm{u}$ dvorcu Bogenšperku, Vitezović prijatelju Valvasoru najavljuje kako „planira napisati dulji ep o bitci za Siget, i to na hrvatskom jeziku“ (Kovač 1973: 118), očigledno pritom misleći upravo na Odiljenje sigetsko. Razlog zbog kojega Valvasoru tom prilikom Ritter taji da je ,slavenske knjižice“ već dogotovio nije do kraja jasan, no spominjanje planova o pisanju vernakularnoga pjesničkog djela sa sigetskom tematikom možda bi dalo naslutiti kako prvom njegovom inačicom nije bio posve zadovoljan, pa je ili prionuo na njezino dorađivanje, ili se, pak, sprema ispjevati ga ispočetka. Posrijedi bi, zaključili bi skeptici, mogla biti i nimalo nevjerojatna činjenica da u svojim navedenim pjesničkim poslanicama iz prethodnih godina Vitezović uopće nije aludirao na Odiljenje, već neko drugo (do danas zagubljeno ili nesačuvano) djelo na hrvatskom jeziku, no takva bi se pretpostavka onda kosila s navedenim podatkom iz predgovora prvome izdanju, prema kojem

\footnotetext{
${ }^{140}$ Ili, riječima samoga Vitezovića: „Illic proposui coeptos finire libellos, / Illyricis grateum gentibus fiet opus“ (cit. prema: Klaić 1914: 33).

${ }^{141}$ Za sve ove podatke zahvalnost dugujemo Vitezovićevu biografu Vjekoslavu Klaiću, koji je prvi i pretpostavio da naš autor u svim navedenim poslanicama aludira upravo na Odiljenje (usp. Klaić 1914: 32-35). Štoviše, posebno se osvrćući na poslanicu Ivanu Despotoviću, Klaić i napominje da se „sve (...) namiće misao, da je on već tada imao »Odiljenje sigetsko« priredjeno, i da se je radilo o izdanju ovoga djela“ (Isto: 34).
} 
je tekst bio dovršen punih pet godina prije svoga objelodanjivanja - dakle, upravo 1679. Shvatimo li ovaj detalj kao (što je možda i najbliže istini) puki fikcionalni dodatak biografiji Janeza Vajkarda Valvasora ${ }^{142}$ - kao, drugim riječima, najvjerojatnije netočan - naše nedoumice nipošto time neće biti razrješene jer već u svibnju 1682. u glavninom hrvatskoj će pjesničkoj poslanici kapetanu Franji Ivanoviću, o kojoj je maločas već bilo riječi, Vitezović (iznova) pripomenuti kako namjerava opjevati ratne podvige hrvatskih branitelja.

I dok bi se iz „ključne“ dionice epistole Ivanoviću možda još i moglo iščitati da djelo posvećeno hrabrim hrvatskim ratnicima nije tek u planu, nego da je rad na njemu već i otpočeo (,Što je meni znati dala narav moja, / Ne ću prepušćati truda ni pokoja; / Il mira il boja hrvatsko držanje / Dati ću ništo ja svitu na poznanje“(143), ni u jednome trenutku neće biti sporno to da Vitezović u tim stihovima „misli na svoje »Odiljenje sigetsko«, u kome je iznio primjer hrvatskoga junaštva“ (Kombol i Prosperov Novak 1995: 315), što znači da ono (ni) u proljeće 1682. nije još bilo dovršeno, iako je još u svojoj tri godine starijoj pjesničkoj poslanici Ivanu Despotoviću bio on tvrdio suprotno. Potvrdu o - valjda definitivnom dogotovljenju Odiljenja (ili, možda, samo jednoga njegova dijela) Vitezović će donijeti tek koncem 1683., i to u latinskoj prigodnici sastavljenoj u čast grofa Adama Zrinskog, kojega je imao prilike upoznati na svečanom objedu upriličenom u kuriji bana Nikole Erdödyja u turopoljskom Obrežu. Fasciniran posljednjim potomkom čuvene magnatske obitelji, Ritter dan nakon toga upečatljivog susreta u dahu piše prigodnu pjesmu u kojoj otkriva kako je, cijeneći junaštva njegova možda i najslavnijeg pretka, o Nikoli Šubiću Zrinskom ispjevao pjesmu na hrvatskom jeziku koju bi svakako vrijedilo otisnuti, pa ga na koncu moli ne samo da taj pothvat financijski potpomogne, već i da (p)ostane njegovim trajnim mecenom. ${ }^{144}$ Našem autoru potonja se želja, po svemu sudeći, nije ostvarila, no Adam je ipak pristao biti pokroviteljem prvoga izdanja Odiljenja, otisnutog samo nekoliko mjeseci nakon njihova „sudbonosnog“ susreta, koje će se - iako nerasprodano - već iduće godine Vitezović potruditi promptno nadomjestiti „drugim“, bečkim izdanjem. U njemu će raniju posvetu Adamu Zrinskom istisnuti posveta opatu i kapetanu Matiji Ignaciju Radanoviću, čemu bi razlog

\footnotetext{
142 „Podatak“ kako je Vitezović Valvasoru, za spomenutoga posjeta Bogenšperku, otkrio svoje planove o pisanju stanovitoga „epa“ o Sigetu u svojoj je (polu)biografskoj knjizi Spomini barona Valvasorja donijela Tita Kovač (usp. Kovač 1973). Da je taj ,podatak“, međutim, nužno uzeti s ovećom zadrškom jasno je već iz činjenice da autorica nigdje ne precizira odakle je on konkretno crpljen, a iako na više mjesta ističe kako se pri pisanju svojega teksta ponajvećma oslanjala na Valvasorove autobiografske zapise razasute njegovim monumentalnim djelom Slava vojvodine Kranjske, Kovač ipak ne taji da su podaci iz njih - zbog njihove izrazite fragmentarnosti - obilno nadopunjeni fikcionalnim materijalom. To, drugim riječima, znači da su Spomini ni manje ni više nego mješavina biografskih detalja (a onda i povijesnih činjenica) te fikcionalnih dodataka, iz čega slijedi da se ni „,podatak“ o Vitezovićevu Odiljenju nipošto ne može prihvatiti „zdravo za gotovo“.

${ }^{143}$ Cit. prema: Šurmin 1902: 535.

${ }^{144}$ Usp. Klaić 1914: 56-57, Jembrih 2015: 546-551, 2016a: 52-55 i 2017b: 50-52..
} 
možda valjalo tražiti u činjenici da je - kako su „ritterolozi“ najskloniji tvrditi - Vitezović „doživio kritiku i osudu zbog nepromišljene posvete jednom Zrinskome koji je očevidno bio persona non grata“ (Blažević 1997: 40) u čitavoj onodobnoj Habsburškoj Monarhiji. ${ }^{145}$

Kao jedini se donekle opravdan - ili makar najmanje nevjerojatan - zaključak, nakon svih ovih Ritterovih (oprečnih) iskaza o radu na stanovitom vernakularnom djelu posvećenom junaštvima hrvatskih branitelja, stoga nameće onaj da je Odiljenjem sigetskim naš autor - s duljim ili kraćim prekidima - svakako bio zaokupljen najmanje osam godina prije no što je ono otisnuto, pri čemu je prvu njegovu inačicu zacijelo (kako, uostalom, i sam priznaje) dospio završiti do 1679., no zatim ju je u sljedećih nekoliko godina prepravljao, dopisivao, a možda i sasvim preispisao, čekajući usput pravi trenutak za njezino objelodanjivanje. Želju za dodatnim radom na rukopisu Odiljenja Vitezović je jamačno osjetio nakon povratka u ratnu sredinu rodnoga Senja početkom 1679., „užarena“ atmosfera koje ga je vrlo lako mogla potaknuti na to da se vrati tekstu o hrvatsko-turskom okršaju pod Sigetom i da u njemu doradi, odnosno jače naglasi i dotjera neke ratne, ali i poratne momente, osobito motive neutješnih majki i supruga izginulih sigetskih branitelja. ${ }^{146}$ Povremeno tako „bruseći“ svoje pjesničko ostvarenje, Vitezović u sljedećih nekoliko godina nikako nije mogao dočekati prikladan trenutak da ga napokon dade u tisak, a i nedvojbeno je - pored neprekidne

${ }^{145}$ Doduše, unatoč tomu što se u stručnoj literaturi počesto inzistira na tim vjerojatnim neugodnostima s kojima se Vitezović bio prisiljen suočiti radi „,nepromišljene“ posvete prvoga izdanja potomku „urotničke“ porodice Zrinski, treba znati da je devet godina prije Odiljenja (odnosno samo četiri nakon smaknuća njegova strica Petra u Bečkome Novom Mjestu) svoju prevedenu zbirku fiktivnih poslanica ili heroida Listi heroov (1675.) istome Adamu Zrinskom posvetio i varaždinski pjesnik Gabrijel Jurjević, također pritom istaknuvši kako to čini jer je riječ ne samo o nasljedniku sigetskoga kapetana koji se odvažno suprotstavio Sulejmanu i njegovoj daleko moćnijoj vojsci, već i o potomku obitelji koja ima dugogodišnju „tradiciju“ uspješnoga ratovanja protiv turskih osvajača. Koliko je poznato, Jurjevića zbog njegova čina nisu snašle nikakve (značajnije) nevolje, pa je prilično vjerojatno da se Adamu za pokroviteljstvo Vitezović i obratio upravo znajući za taj prethodni, Jurjevićev slučaj, odnosno (slijepo) vjerujući da ni njegova posveta posljednjem Zrinskom neće potaknuti nikakve negativne reakcije. Znao je, povrh toga, Ritter i da su ranija djela sa sigetskom tematikom - redom, doduše, objelodanjena prije neslavnog svršetka zrinsko-frankopanske urote - bila posvećena pojedinim članovima obitelji Zrinski ili, pak, da s njima na bilo koji drugi način bijahu povezana, pa je tako, pored (rukopisne) kronike Ferenca Črnka (napisane na poticaj Jurja Zrinskog) te Adrijanskoga mora Sirene iz pera samoga (Petra) Zrinskog, Vazetje Sigeta grada Barne Karnarutić posvetio sinu sigetskoga junaka Jurju, a svoju prigodnu pjesmu Trublja slovinska Vladislav Menčetić ispjevao u čast Petra Zrinskoga i njegove tek objavljene Sirene. Objavljujući i sam djelo o opsadi i padu Sigeta, Vitezović je jamačno držao da mu je - bez obzira na ponešto promijenjene društvenopolitičke okolnosti - dužnost učiniti isto, pa kada mu se napokon i ukazala prilika da stupi u kontakt s jednim Zrinskim i privoli ga da bude pokrovitelj njegovu Odiljenju, objeručke ju je prihvatio ne misleći odveć na eventualne posljedice takvoga čina. Kakve su zaista te posljedice i bile, danas nam je moguće tek nagađati, no konkretne dokaze o negativnim reakcijama što ih je (eventualno) isprovociralo to vezivanje njegova djela uz posljednjega Zrinskog - izuzev spomenutog odacivanja posvete Adamu u bečkom izdanju - u našoj (književnoj) povijesti nijedan „ritterolog“ nije još dospio pronaći. Štoviše, da Adamovo pokroviteljstvo nad prvim izdanjem Odiljenja diljem Habsburške Monarhije očito nije neugodno odjeknulo potvrditi nam može i činjenica da u Vitezovićevim odnosima sa samim kraljem Leopoldom poslije 1684. nije došlo ni do kakvoga (vidnog) zahlađenja, pa bi „brzopotezno“ njegovo odbacivanje posvete Adamu možda bilo ispravnije tumačiti nekim drugim, mnogo osobnijim razlozima, o kojima će više riječi biti nešto kasnije.

${ }^{146} \mathrm{O}$ mogućem utjecaju ratne atmosfere Vitezovićeva rodnog grada na njegove pjesničke ambicije iskazane u Odiljenju podrobnije u: Putanec i dr. 1952: 7-8. 
okupiranosti daleko važnijim poslovima (kontinuiranim radom na drugim pjesničkim i historiografskim djelima, sudjelovanjem na ugarskom Saboru 1681., obavljanjem pravnih i drugih obaveza u Beču 1682. i 1683., sudjelovanjem u protuturskim ratovima 1683. itd.) razlog u odgađanju njegova objelodanjivanja u velikoj mjeri bio i financijske naravi. Povoljne okolnosti za objavljivanje Odiljenja ukazale su se napokon u proljeće 1684. u Linzu, gdje Ritter iznova susreće Adama Zrinskog, koji se ondje spremao vjenčati s groficom Marijom Katarinom Lamberg i koji je očito tada i pristao financirati tiskanje toga pjesničkog djela što proslavlja vrline znamenitog mu pretka. Da je svjetlo dana Odiljenje ugledalo ne samo u pravi čas, već i na pravom mjestu dokazuje i povijesni ep o turskoj opsadi habsburške prijestolnice Beča grada opkruženje dubrovačkoga pjesnika Petra Bogašinovića, koji je u Linzu kod istoga tiskara objelodanjen nešto ranije iste godine i koji je i Vitezoviću - kako pretpostavljaju neki „ritterolozi“ - mogao dati dodatan „vjetar u leđa“ da se baš u privremenome sjedištu habsburškoga dvora konačno odvaži i na tiskanje svojega „spjeva“. ${ }^{147}$ Uostalom, nije li najbolji trenutak za izdavanje djela poput Odiljenja sigetskog bilo razdoblje nakon bolnoga poraza Osmanlija pod Bečom 1683., kada je napisan i objavljen velik broj tekstova posvećenih pobjedi kršćanske vojske pod zapovjedništvom poljskoga kralja Jana Sobjeskog, ali i u kojemu su sve brojniji ratni trijumfi nad poljuljanim muslimanskim snagama i njihovo postupno povlačenje iz okupiranih područja sve jasnije nagovještavali da se vrijeme turske opasnosti ubrzano približava kraju?

Upravo uslijed takvih okolnosti, dakle, prvo je izdanje Odiljenja sigetskog napokon ugledalo svjetlo dana, pojavivši se na europskom „književnom horizontu“ paralelno s brojnim književnim ostvarenjima koja su euforično proslavljala turski poraz pod zidinama Beča, dok je na onom hrvatskom „,zabljesnulo“ kao „tek“ nova, ali i po mnogočemu neobična „karika“ u lancu (pjesničkih) tekstova posvećenih opjevavanju herojskog otpora šačice hrvatskih branitelja Sigeta na čelu s Nikolom Šubićem Zrinskim brojčano daleko nadmoćnijoj osmanlijskoj vojsci predvođenoj sultanom Sulejmanom Veličanstvenim u ljeto 1566. Niz tih mahom epskopjesničkih - djela na temu opsade i pada Sigeta, koja se u najrecentnijoj književnopovijesnoj literaturi uvriježilo nazivati ,zrinijadama““ ${ }^{418}$ započeo je još $s$

\footnotetext{
${ }^{147}$ Detaljnije u: Jembrih 2015: 548, 2016a: 53 i 2017b: 50..

148 Odrednica „zrinijada“, treba znati, isprva se rabila gotovo isključivo u vezi s povijesnim epom Obsida sigecka iz zbornika Adrijanskoga mora Sirena Petra Zrinskoga te njezina mađarskog predloška iz pera Petrova brata Nikole (usp. Ljubić 1869: 505-507, Šrepel 1902: 105, Klaić 1914: 34, Novalić 1967b i 1968: 712-730, Vončina 1976b: 7-20). Iako je pojedini - mahom stariji - književni povjesnici i dan danas još koriste u identičnom značenju [Zrinijadama tako, primjerice, epskopjesnička ostvarenja obojice braće Zrinski naziva Josip Bratulić (usp. Bratulić 2016a: 5-58), a istu odrednicu za isključivo mađarsku Sirenu Nikole Zrinskoga, točnije njezin najdulji tekst - povijesni ep Szigeti veszedelem, navodi i István Lőkös, nastavljajući tako dugogodišnju praksu mađarskih povjesničara književnosti, među kojima se ona uvriježila kao oznaka za Nikolin ep (usp. Lőkös 2008:
} 
ostvarenjima nastalima neposredno nakon junačke pogibije „sigetskoga Leonide“ (Šrepel 1902: 81), ${ }^{149}$ kada su vijesti o tome nemilom događaju - koje su se ubrzano proširile Hrvatskom i čitavom Europom - na pjesničku njegovu obradu potaknule najprije narodne, bespismene stvaratelje. Nedugo nakon što su desetkovane turske čete trijumfalno stupile u gotovo sasvim razrušeni Siget, diljem Hrvatske su se (a i šire) počele tako pjevati mnoge lirske i epske pjesme te bugaršćice, od kojih je do našega vremena - zahvaljujući njihovu neprekidnom, dugogodišnjem cirkuliranju u narodu i konačnom bilježenju - dospio „preživjeti“ niz uistinu zanimljivih primjeraka, podjednako onih izniklih u kršćanskoj, tako i onih s porijeklom u muslimanskoj usmenoknjiževnoj tradiciji. ${ }^{150} \mathrm{Za}$ (kronološki) prvi pisani tekst o padu Sigeta, nastao samo godinu-dvije nakon što se on i zbio, pobrinuo se jedan od tek nekolicine preživjelih sigetskih branitelja, i to tajnik i komornik samoga Nikole Šubića Zrinskog - Ferenc Črnko, koji se pera laća na poticaj Nikolina sina Jurja. Nemajući većih literarnih pretenzija, Črnko se u svome tekstu opredjeljuje za puko kronikalno nizanje ključnih događaja koji su se u Sigetu i oko njega zbivali u razdoblju između 15. lipnja i 7. rujna 1566., što je na koncu rezultiralo time da će njegovo Podsjedanje i osvojenje Sigeta iako kružeći u rukopisima i raznim tiskom objavljenim prijevodima - u narednim desetljećima i stoljećima (p)ostati najpouzdanijim izvorom informacija o tijeku kršćanskoosmanlijske bitke za tu strateški važnu ugarsku utvrdu. ${ }^{151}$

\footnotetext{
113-130)], od konca prošloga stoljeća počela se ona sve češće protezati na sva ostvarenja posvećena bitci pod Sigetom 1566., pa čak i na ona usmenoknjiževna te anonimna, poput Pjesme o sigetu zapisane u Prekomurskoj pjesmarici s kraja 16. st. Na tom je „valu“ kao „posljednja u nizu velikih zrinijada u staroj hrvatskoj književnosti“ (Dukić 2002: 67) označeno i Vitezovićevo Odiljenje sigetsko, no premda se u književnopovijesnoj literaturi za nj taj termin do danas već uobičajio (usp. Prosperov Novak 1999: 698, Dukić 2002: 67 i 2004b: 131, Blažević 2012: 435, Budišćak 2016a: 263 i 2016b: 82), zateći ćemo ipak i primjere otvorenog zaobilaženja takvoga njegova određenja, uslijed kojega se Odiljenje navodi tek kao djelo pripadno ,sigetskomu tematskomu krugu“, odnosno „sigetskoj tradiciji“ (Samardžija 1999: 9-10).

149 Kao „Leonidas sigetski“ Nikola je Šubić Zrinski prozvan zapravo već u predgovoru prvoga postumnog izdanja Odiljenja - onomu, dakle, što ga je 1836. za tisak priredio i objelodanio biskup Stjepan Moyses (usp. Ritter Vitezović 1836: 3; spomenuti je predgovor nedavno pretiskan i u: Jembrih 2016b: 343-369) - no, kako se čini, slavnoga su sigetskog kapetana već i mnogobrojni suvremenici i svjedoci toga kršćansko-turskog okršaja uspoređivali sa spartanskim kraljem Leonidom, koji je 480. g. pr. n. e. poginuo braneći Termopilski tjesnac sa samo tristotinjak grčkih vojnika pred naletom daleko moćnije perzijske vojske (usp. Mijatović 2010: 98 i Bratulić 2016a: 6). Inače, u ranomu je 19. stoljeću kao „Leonida“ - ali, dakako, mađarski (,der ungarische Leonida“) - Zrinski apostrofiran (i) u Mađarskoj, pa i drugdje, osobito u zemljama njemačkoga govornog područja (usp. o tome u: Bitskey 2012: 243 i Zvonar 2016: 61).

${ }^{150}$ O tim usmenoknjiževnim ,zrinijadama“ vrlo detaljno u: Novalić 1967b: 22-46.

151 Podsjedanje $i$ osvojenje Sigeta, naime, dugi je niz godina diljem sjeverne Hrvatske kružilo u različitim prijepisima (od kojih se ni u jednome, doduše, ne navodi Črnkovo ime), a jedan od njih je 1568. dospio i u ruke slovenskome piscu Samuelu Budini. Iste godine Budina sastavlja te u Beču objavljuje njegov latinski prijevod naslovljen Historia Sigethi, koji će - zahvaljujući iznimnome interesu što su ga diljem Europe pobudile vijesti o hrabrome otporu malobrojnih kršćanskih branitelja Sigeta moćnoj Sulejmanovoj vojsci - ubrzo doživjeti i prijevode na njemački i talijanski. Sve do početka 20. stoljeća Historia Sigethi uzimala se kao jedini sačuvani tekst Črnkova ljetopisa, a zatim je - točnije, 1911. godine - u arhivu u austrijskom gradu Losensteinhaltenu profesor Antun Kaspret pronašao njegov original, odnosno jedan od glagoljskih hrvatskih prijepisa njezina (vjerojatno) latinički pisanoga izvornika, koji će već sljedeće godine izdati Franjo Kidrič (usp. o tome u: Novalić
} 
I dok bi se o eventualnom oslanjanju anonimnoga autora četverodijelne dvanaesteračke kajkavske epske Pjesme o Sigetu (ili, kako je proučavatelji također pokatkad naslovljuju, Pesem od Sigeta grada ${ }^{152}$ ), zabilježene - najvjerojatnije - potkraj 16. stoljeća u Prekomurskoj ili Martjanskoj pjesmarici, na Črnkov ljetopis definitivno još moglo diskutirati, u povijesnom epu Vazetje Sigeta grada Barne (Bernardina) Karnarutića - izišlog iz tiska 1584. u Veneciji - o obilnom (sadržajnom) nasljedovanju Podsjedanja i osvojenja Sigeta nema više ni najmanjega spora. Makar posredno - zahvaljujući ugledanju na Vazetje - u vezu s kronikom Ferenca Črnka stupit će i Nikola Zrinski u svome epu Szigeti veszedelem, čiji će prepjev i preradu 1660. - pod naslovom Obsida sigecka - u sklopu zbornika Adrijanskoga mora Sirena objelodaniti njegov brat Petar, izmamivši tim činom oduševljenu pjesničku reakciju dubrovačkog pjesnika Vladislava Menčetića, koji njemu i njegovu djelu u čast sastavlja odulju prigodnicu Trublja slovinska (1665.). Da „zrinijade“ uistinu tvore lanac tematski srodnih književnih djela dodatno učvršćen brojnim sadržajnim i formalnim poveznicama na prethodne tekstove dokazuje i samo Odiljenje sigetsko, premreženo obiljem motiva i formalnih rješenja posuđenih ponajviše iz Petrove Sirene, a mnoštvo elemenata baštinjenih iz ranijih usmenoknjiževnih i pisanoknjiževnih obrada opsade Sigeta jamačno bi se moglo izlučiti i iz (nažalost, nesačuvanih) sedamnaestostoljetnih isusovačkih školskih drama o sigetskim događajima, uprizorivanih u povodu završetka školske godine na kolegijima u Zagrebu i Trnavi, u kojima su se ban Zrinski i njegova vojska ustrajno isticali kao uzori ratnika i mučenika koji se žrtvuju za vjeru i domovinu. ${ }^{153}$ Temi Sigeta periodički će se vraćati i naši autori narednih stoljeća, pa će tako, nakon osvrta na junaštva Nikole Šubića Zrinskog u Kačićevu Razgovoru ugodnom naroda slovinskog (1756.), posebno velik interes za nju vladati i u šezdesetim godinama 19. st. - ponajvećma zahvaljujući obilježavanju tristote obljetnice sigetske katastrofe (1866.) - kada ona biva obrađena u gotovo svim tada važnijim književnim žanrovima: od lirske pjesme i povijesnoga epa do drame i libreta. ${ }^{154}$

1967b: 16-22 i Zvonar 2016: 58-72). Premda bi se, na prvi pogled, moglo zaključiti kako je Podsjedanje tek suhoparni kronikalni prikaz sigetskih događaja, nastao najvjerojatnije na temelju autorovih dnevničkih zapisaka, kasnije su analize toga njezina hrvatskog prijepisa pokazale da je C̆rnku, u određenoj mjeri, ipak bilo stalo i do literarizacije vlastitoga svjedočanstva, na što upućuje čitav niz u njemu lociranih književnih obilježja poput različitih stilskih figura, usmenoknjiževnih elemenata, učestalih ponavljanja itd. Detaljnije o Črnkovoj kronici i njezinim literarnim kvalitetama u: Ratković 1971: 27-34 (usp. i nedavni pretisak Ratkovićeve studije u: Pranjić 2016: 9-16), Zvonar 2008: 24-30 i 2016: 58-72.

152 Usp. Zvonar 2008: 30.

${ }^{153}$ Detaljnije u: Bratulić 2016a: 19 i 2016b: IV.

${ }^{154}$ O književnim obradama bitke pod Sigetom ili „zrinijadama“ napisan je do danas poveći broj studija, pa bi, pored pionirskoga teksta Milivoja Šrepela o toj problematici „Sigetski junak u povijesti hrvatskoga pjesništva“ (1902.), u kojemu je donesen pregled književnih djela posvećenih pogibiji bana Zrinskog u rasponu od prvih usmenih (bugaršćičkih) pokušaja do konca 19. st. (usp. Šrepel 1902: 81-173), u taj niz tako ponajprije valjalo ubrojiti još i prikaz Miroslava Vaupotića „Sigetski junak u novijoj hrvatskoj književnosti (kratki povijesni pregled)“, koji se - zamišljen kao svojevrsna nadopuna Šrepelova rada - osvrće isključivo na „zrinijade“ 
Da u navedenome slijedu književnih tekstova Odiljenje nipošto ne „strši“ posve bezrazložno uviđa se već i iz njegova osebujnog naslova, poprilično neočekivanog za jednu (ranonovovjekovnu), ,zrinijadu“. I dok druga riječ naslovne fraze čitatelju tako najavljuje (novu) literarnu obradu u nas možda i najopjevanije kršćansko-turske bitke iz hrvatske povijesti, ona mu prva, pak, nepogrešivo sugerira da u nastavku ne treba očekivati uobičajenu prezentaciju njezina tijeka. Naprotiv, mjesto naslovnog isticanja „,vazetja“ (zauzeća), „obside“ (opsade) ili propasti (veszedelem), ${ }^{155}$ kojim su autori prethodnih pisanoknjiževnih ,zrinijada“ jasno davali do znanja kako će u njihovu fokusu biti sam sigetski događaj koji iziskuje, dakako, narativnu (epskopjesničku) obradu, Ritter naslovom svojega ostvarenja zacrtava sasvim drugačiji smjer, odnosno otkriva da će ga u temi Sigeta zanimati njezina (dotad većinom zanemarivana) privatna dimenzija, koja traži i bitno drugačiji, njoj primjeren literarni pristup. Iz perspektive prethodnih se ,zrinijada“ takva naslovom nagoviještena sadržajna orijentacija opjevavanju sigetskoga „odiljenja“ - a ne kronologije sigetskoga poraza - zacijelo mora(la) doimati i više nego dvojbenom, tim više što već samo navođenje „odiljenja“ kao teme književnoga teksta povlači sa sobom i još nekoliko nimalo nevažnih pitanja.

Upitamo li se, ponajprije, kako su ovako sročen naslov sedamnaestostoljetni, ali i kasniji čitatelji Ritterova teksta razumijevali te kakva su, posljedično, očekivanja od njega oni imali, shvatit ćemo da su - stvorena samo na temelju naslova - ta očekivanja najvjerojatnije bila nejednaka. Ne samo što iz naslova, naime, nije sasvim jasno na koga bi se ,sigetsko odiljenje“ uopće trebalo odnositi (na sam Siget, na neposredne sudionike sigetske katastrofe, na njezine svjedoke i suvremenike ili, pak, na sve njih zajedno), već je i sama riječ „odiljenje“

napisane od početka 19. do sredine 20. stoljeća (usp. Vaupotić 1969: 44-62), kao i tri godine stariju studiju Zvonimira Matagića „Nikola Šubić Zrinski i sigetska bitka u književnosti, umjetnosti i politici“ (usp. Matagić 1966: 906-918), u kojoj je pažnja posvećena ne samo domaćim i inozemnim literarnim ostvarenjima na temu Sigeta nastalima od polovine 16 . do polovine prošloga stoljeća, već i odjecima toga važnog događaja u drugim umjetnostima i politici. Osamdesetih godina 20. st. o „sigetskoj epopeji od manirizma do kasnog baroka“ točnije, o pisanoknjiževnim obradama opsade Sigeta nastalim u ,stoljeću“ između 1584. (Vazetje) i 1684. (Odiljenje) - pisao je Nikica Kolumbić [prvi put objavljen 1986., navedeni je Kolumbićev tekst iznova tiskan dva desetljeća kasnije u njegovoj knjizi Poticaji i nadahnuća (usp. Kolumbić 2005: 309-326)], na domaće i strane književne (ali i likovnoumjetničke te glazbene) odjeke sigetske katastrofe u svojoj se izvrsnoj monografiji posvećenoj bitci pod Sigetom nije zaboravio osvrnuti ni Anđelko Mijatović (usp. Mijatović 2010: 107-161), a u posljednjih nekoliko godina za najsvježije su se preglede ,zrinijada“ pobrinuli i neki od naši najeminentnijih književnih povjesnika poput Stjepana Hranjeca (usp. Hranjec 2011: 91-108 i 2016: 22-32) te Josipa Bratulića (usp. Bratulić 2016a: 5-58 i 2016b: I-XXV). Veći dio potonjih je tekstova, valja naglasiti, nastao u povodu obilježavanja 450. obljetnice Sigetske bitke 2016., zahvaljujući kojoj je svjetlo dana ugledalo i još nekoliko izbora iz (pre)bogatoga korpusa naših ,zrinijada“ [obimna antologija književnih tekstova sigetske tematike Nikola Šubić Zrinski u hrvatskom stihu (2016.) te knjiga Sigetski boj u hrvatskoj epici (usp. Pranjić 2016), u koju su uvršteni anonimna Pjesma o Sigetu iz Prekomurske pjesmarice, Črnkovo Podsjedanje i osvojenje Sigeta, Karnarutićevo Vazetje Sigeta grada, Vitezovićevo Odiljenje te povijesni ep Vladislava Vežića Sigetski junak Nikola Zrinjski, objelodanjen u povodu 300. obljetnice pada Sigeta 1866.], a uz njih i izbor iz Adrijanskoga mora Sirene Petra Zrinskoga, što ga je priredio te predgovorom i komentarima popratio Josip Bratulić (2016.).

${ }^{155}$ Misli se, dakako, na naslov mađarskoga povijesnog epa Nikole Zrinskog Szigeti veszedelem, koji bi se doslovno mogao prevesti kao „Propast Sigeta“. 
u takvome kontekstu vrlo lako mogla isprovocirati niz dilema. Te su (vjerojatne) dileme glavninom proizlazile iz dvojakoga - iako u srži srodnog - značenja pojma „odiljenje“, s primjerima kojega se možemo već susresti i zadržimo li se unutar granica Vitezovićeva stvaralačkog opusa. Što je recipijentima druge polovine 17. st. danas arhaična riječ „odiljenje“ zaista predstavljala ponajbolje se možemo uvjeriti zavirimo li u (nasreću, nedavno napokon objelodanjen) rukopis Vitezovićeva monumentalnog latinsko-hrvatskog rječnika Lexicon Latino-Illyricum, u kojemu se ona pojavljuje kao prijevod triju latinskih pojmova „disjunctio“, „discessus“ i „separatio“. 156 Riječ „discessus“ ondje je tako prevedena trima hrvatskim istoznačnicama ${ }^{157}$ („odhodak“, „odšastje“ i „odiljenje“), „disjunctio“ sveukupno četirima (,razdruženje“, „razlučenje“, „odiljenje“ i „odiljanje“), a „separatio“ opet trima (,razlučenje“, „rastavljenje“ i „odiljenje“), iz čega proizlazi da se pod pojmom „odiljenje“ u Ritterovo doba, dakle, mislilo na rastanak i odlazak, ali i na rastavljanje, razdvajanje. ${ }^{158}$

Premda na prvi pogled značenjem identične, pobrojane se riječi ne odnose na jedno te isto, a da to onda podrazumijeva kako je i riječ „odiljenje“ višeznačna, potvrdit će nam i uvid u samo Odiljenje sigetsko. Činjenica kako u tekst svoje „zrinijade“ riječ „odiljenje“ (,odiljen“) uklapa svega tri puta - i to sva tri puta u iskaze personificiranoga grada Sigeta Vitezovića nije spriječila u tome da je uporabi u dva slična, ali ipak vidljivo različita značenja, pa dok tako u prvoj pjesmi prvoga dijela - Siget hrvatskim gospojam (I: 1-477) ${ }^{159}$ - Siget, opraštajući se u ime poginulih hrvatskih branitelja s ožalošćenim članicama njihovih obitelji, ističe kako to čini jer je oproštaj primjeren ovakvom „odiljenju“ (rastanku), a punih dvjesto stihova kasnije (iznova) izražava svoju ojađenost ishodom opsade, zbog kojega je - i sam u vrlo jadnom stanju - prisiljen obznaniti „odiljenje“ (definitivni rastanak) obiteljima izginulih kršćana, u pjesmi Siget zvrhu samoga sebe iz drugoga dijela, pak, porobljeni (poturčeni) Siget lamentira nad svojom nevoljom jadajući se, između ostaloga, i kršćanskoj vjeri zato što je „odiljen“ (nasilno razdvojen) od njezine ljubavi. ${ }^{160}$ Ako se, dakle, u prva dva slučaja „odiljenje“ odnosilo na (u suštini također prisilni) rastanak hrvatskih vojnika s njihovim najmilijima, prouzročen nepovoljnim ishodom bitke iz koje se nikada neće vratiti, u onome drugom riječ je „odiljenju“ kao činu nasilnoga razdvajanja - u ovome slučaju Sigeta od

\footnotetext{
156 Usp. Vitezović 2009 i 2010.

${ }^{157}$ U Vitezovićevu su rječniku, naime, gotovo sve latinske riječi prevedene istoznačnicama iz svih triju hrvatskih narječja (o tome u: Vajs i Meštrović 2009: XI-XII).

${ }^{158}$ Usp. i hrvatske prijevode triju navedenih latinskih riječi u: Divković 2006.

${ }^{159}$ Rimske znamenke označavat će dio, a arapske stihove unutar konkretnoga „dila“ Odiljenja. Rečena mjesta iz navedene pjesme glase: „Ne mogahu, vilo, od vas zet prošćenje, / kot bi dužno bilo na 'vo odiljenje“ (I: 249250), odnosno „Ja dospih u sinžir od dragih razdiljen, / naslidnik turskih vir ah ljuto prisiljen, / klikujem razcviljen vojstva odiljenje, / od ognja razbiljen uzimljuć prošćenje“ (I: 447-450).

160 „Odiljen sasvime od tvoje ljubavi / turačkoga brime robstva Siget bavi“ (II: 527-528).
} 
kršćanske vjere i njezinih „zastupnika“ (ponajprije kršćanskih njegovih branitelja i kršćanske vlasti uopće) - neusporedivoga s pukim rastankom do kojega je u prethodnom slučaju došlo voljom jedne od rastavljajućih strana, odnosno njezinim prihvaćanjem rizika „vječnoga odlaska“. Ta je značenjska dvostrukost i sa sadržajnoga aspekta tako potkrijepljena logičnim i opravdanim razlozima jer spomenuta dva se tipa „odiljenja“, doduše, mogu usporediti po tomu što su rastanci, no dok je Siget - iako „oživljen“ - tek objekt koji može prelaziti iz ruke u ruku (i koji, slijedom toga, može biti i osvojen ili otet, tj. silom razdvojen od ranijih svojih „vlasnika“), hrvatski su branitelji i njihove obitelji itekako aktivni sudionici (međuljudskih) rastanaka, svjesni da do njih - poglavito iz ratnih razloga - katkada neizbježno mora doći.

Dvojakost značenja riječi ,odiljenje“ u konačnici se tako upisuje i u naslov ovoga Vitezovićeva ostvarenja, hotimice uzrokujući dvojbe u pogledu njegova stvarnog smisla, ali ujedno tako i aludirajući na različitost rastanaka do kojih u Sigetu dolazi, odnosno onih kojima Siget svjedoči (i u nekima od kojih je čak i posrednik) te onih na koje je i sam na koncu primoran. A to će onda reći i da se naslovno „odiljenje“ i potvrđuje kao „sigetsko“ ponajvećma po tome što uključuje različite rastanke različitih sudionika i svjedoka sigetskih događanja - kako onih živih, tako i personificiranih - te da se stoga odnosi baš na sve posredno ili neposredno u njih upletene aktere: na sve one za koje je pad Sigeta bio gubitak u bilo kojem smislu riječi. S obzirom na to da od prvoga do posljednjeg stiha Odiljenja sigetskog tako i nije riječ ni o čemu drugome no o raznolikim „odiljenjima“, možda neće biti slučajno ni to što njegove dijelove Vitezović naziva upravo „dilovima“ (iako „dilove“ nalazimo već i u Karnarutićevu Vazetju, a „delove“ u Obsidi sigeckoj Petra Zrinskoga), želeći možda i na taj način sugerirati, odnosno jače istaknuti kako baš svaki segment njegova teksta donosi nova (sigetska) „diljenja“ i ,odiljenja“, rastanke i prisilna razdvajanja, po tipu različita, no zapravo potaknuta identičnim, jednako nesretnim razlogom. Znamo li da je Vitezović itekako bio sklon (baroknom vremenu iznimno dragim) igrama riječima, na kojima se zasnivaju i mnoga njegova (mahom latinska) književna ostvarenja, ovakvu pretpostavku nipošto ne bi trebalo odbaciti kao neutemeljenu, a kamoli kao sasvim nevjerojatnu.

Ukratko, baš kao što je Odiljenje sigetsko - kako će se doskora pokazati - u cijelosti realizirano kao djelo koje spreže mnogobrojne (poglavito žanrovske) raznolikosti, kao „zrinijada“ posvećena opjevavanju najrazličitijih mogućih, padom Sigeta uzrokovanih „odiljenja“, kao književni tekst koji je zahvaljujući mnogim svojim raznolikostima i protuslovljima s lakoćom privlačio pažnju domaćih čitatelja različitih profila, tako mu je i posve očekivano - nadjenut upravo naslov čija višeznačnost ciljano provocira i nejednaka (iako srodna) njegova shvaćanja, navodeći čitatelje na to da razviju i raznolika očekivanja 
koja sam tekst, na koncu, sva odreda „potvrđuje“ kao ispravna. No, iako - kao takav - naslov Vitezovićeve „zrinijade“ ujedno zrcali i nagovješćuje njezine najvažnije osobitosti, implicirajući da je upravo različitosti od kojih je ona sazdana i čine takvom kakva ona i jest te da u njezinu „svijetu“ jedne bez drugih one ne mogu, iz njega ipak o konkretnoj žanrovskoj podlozi Odiljenja eksplicitno nećemo dospjeti utvrditi gotovo ništa. Dobro nam znana činjenica da - kao jedan od ,pobočnih“, paratekstualnih elemenata - i sam naslov književnoga djela često može uključivati precizna žanrovska određenja, ${ }^{161} \mathrm{u}$ ovome nam slučaju tako, nažalost, neće biti od veće pomoći, no to što su u naslovu Ritterove ,zrinijade“ takva žanrovska određenja izostala ne znači, međutim, istodobno $i$ to da se njime $u$ generičkome pogledu baš ništa ne pokušava sugerirati. I time upravo dolazimo i do drugoga ključnog prijepora vezanog uz naslovnu frazu, koja - kako su u svojim studijama to već i uočili pojedini „ritterolozi“ - zapravo sljubljuje motiv dotad obrađivan u žanrovima lirske pjesme s osnovnim tematskim kompleksom na kojega su još i u drugoj polovini 17. st. „pravo“ polagali većinom povijesni epovi i usmene epske pjesme.

Kao što je maločas već uočeno, poprilično osebujni naslov Vitezovićeva teksta upućuje na to da je riječ o djelu koje se u isti mah nadovezuje na dotadašnju tradiciju „Zrinijada“, ali i od te tradicije - sačinjene od isključivo narativnih obrada pada Sigeta nepokolebljivo i otvoreno odmiče. Zaokupljen motivom višestrukih „odiljenja“, isprovociranih krvavim sukobom pod zidinama Sigeta, naš autor tako već naslovom daje do znanja kako ono što slijedi neće biti (glavninom) epskopjesnička razrada tijeka sigetske katastrofe, pa i usprkos činjenici da će - tematski - biti riječ upravo o onom gradivu koje je dotad iziskivalo „,̌isto“ pripovjedni, „epski“ pristup. Štoviše, za razliku od svojih neposrednih prethodnika - Barne Karnarutića i Petra Zrinskoga - Ritter taj isti naslov koristi kako bi uvriježenu „epskost“" svoje teme olabavio podsjećanjem na njezin podugo negirani emocionalni aspekt, pa dok tako, kao što uočava i Nikica Kolumbić, „riječi »vazetje« (zauzeće) i »opsida« (opsada) upućuju na vizuelnu predodžbu, »odiljenje« (rastanak) spada više u domenu emocionalnih kategorija i govori nam o pjesnikovu lirskom doživljaju“ (Kolumbić 2005: 333), koji će vidljivo dominirati cjelokupnim Odiljenjem. Da bi od samoga parateksta pripremio čitatelje na takav neuobičajeni pristup dobro znanoj temi, „epskim“ konotacijama nabijeno spominjanje Sigeta on tako kombinira s pojmom (motivom) nespojivim s ranijim literarizacijama sigetskoga okršaja, tim više što ni u novijoj tradiciji povijesne epike (od Tassa nadalje) - njezinoj napadnoj romantiziranosti usprkos - „odiljenja“

${ }^{161}$ O tome poglavito u: Genette 1997: 55-103. 
motivirana ratnim zbivanjima nisu imala veći značaj. ${ }^{162}$ Budući da književnopovijesne činjenice doista potvrđuju da je još i tijekom čitavoga 17. stoljeća „odiljenje“ - premda se ono u nas tek zgodimice javljalo kao književna tema - opjevavano isključivo u sklopu (pretežno ljubavnih) lirskih pjesama, ${ }^{163}$ to bi onda značilo da je literarno iskusnije recipijente Odiljenje svojim naslovom jamačno zbunjivalo, skrećući im pozornost na „lirske“ momente jednoga punokrvno „epskog“ događaja. A to, na koncu, ujedno znači i da je iz samoga naslova Vitezovićeve „zrinijade“ - iako se na prvi pogled tomu ne čini tako - itekako moguće iščitati i konkretn(ij)e žanrovske aluzije, odnosno na temelju njih makar naslutiti da će se, združujući generički dotad teško spojivo, žanrovski karakter ovoga teksta zasnivati na očitoj raznovrsnosti: raznovrsnosti kojoj i ovako višeznačan naslov nedvojbeno ponajbolje pristaje.

Naslov, međutim, nije i jedini paratekstualni element Odiljenja sigetskog u kojem se ogledaju sve njegove raznovrsnosti, pa i proturječja. Naprotiv, vrijedi to i za preostale segmente parateksta Odiljenja, koje je u drugom i trećem njegovu izdanju Vitezović držao nužnim i svrsishodnim izmijeniti, a u potonjem neke od njih čak i sasvim izostaviti. Misli se pritom, dakako, na hrvatske prozne predgovore čitateljima (s uklopljenim kraćim lirskim vernakularnim pjesmama) te latinske posvete, odnosno posvetne pjesme, prva od kojih je - u izdanju iz 1684. - bila adresirana na grofa Adama Zrinskog, ${ }^{164}$ a ona druga - u samo godinu

162 U Tassovu, doduše, Oslobođenom Jeruzalemu, ali i u - primjerice - Opsidi sigeckoj Petra Zrinskoga, zatječemo motiv zaljubljenika koji se rastaju jer muškarcu valja poći u rat, no ni u jednome ranijem epu ne prerasta on u značajniji, a kamoli središnji motiv cjelokupnoga teksta.

${ }^{163} \mathrm{U}$ našoj ranonovovjekovnoj književnosti „odiljenje“ ili rastanak izuzetno je rjedak već kao motiv, a i kao temu ga u njoj nalazimo u svega nekoliko navrata. Početkom 16. st. u Zbornik Nikše Ranjine zapisana je tako, između ostalih, i anonimna ljubavna lirska pjesma - ispjevana u formi usmenoknjiževnih bugaršćica (usp. Kekez 2000: 33) - naslovljena Odiljam se, u kojoj se lirski subjekt, odlazeći na neodgodivo (vjerojatno ratničko) putovanje, dirljivim riječima oprašta od voljene ,vile“. Potkraj 17. ili početkom 18. st., pak, osmeračku ljubavnu lirsku pjesmu slične tematike - u kojoj se neutješni kazivač, zbog povratka u „rodne strane“, rastaje sa zaručnicom - pod naslovom Odijeljenje vjerenika ispjevao je i Ignjat Đurđević, uvrstivši je kasnije u svoj rukopisni kanconijer Pjesni razlike. Između ove dvije lirske obrade teme (ljubavnih) rastanaka „ugurao“ se još i motiv „odiljanja“ junaka od rodnoga mu grada, kojim se otvara bugaršćica poznata kao Vojevode Radosav Siverinski $i$ Vlatko Udinski (usp. Isto: 109-111) što ju je u svoje Ribanje i ribarsko prigovaranje (1568.) uvrstio Petar Hektorović (njezin početak, konkretno, glasi: „Kada mi se Radosave vojevoda odiljaše / Od svojega grada divnoga Siverina, / Često mi se Radosav na Siverin obaziraše, / Tere to mi ovako belu gradu besijaše: / - Ovo mi te ostavljam, beli grade Siverine, / Moj divni grade, / Ne znam veće viju li te, ne znam veće vidiš li me!“), a „odiljenje“, kao (značajniji) literarni motiv, otad se - sve do Vitezovićeva Odiljenja - neće u našoj književnosti više javljati. Doduše, u Frankopanovoj rukopisnoj pjesničkoj zbirci Gartlic za čas kratiti nalazimo, između ostalih, i ljubavnu pjesmu Vzimanje dobre noči, u kojoj se motiv „odiljenja“ izrijekom ne pojavljuje, no lirski subjekt koje se također zauvijek rastaje od ljubljene mu „vile“. Tu su pjesmu, inače, neki književni povjesnici odredili kao „,invertiranu albu“, prepoznajući u njoj utjecaje kasnosrednjovjekovnoga, trubadurskog pjesništva, u sklopu kojega su pjesme u kojima se muški lirski subjekt neposredno prije odlaska u Križarski rat emotivno rastaje od voljene žene shvaćane kao izdanci posebnoga lirskopjesničkog žanra - albe (usp. Kravar 1993: 95-96; o tragovima trubadurskoga pjesništva u Frankopanovoj lirici detaljno i u: Angyal 1961: 165-169). Samo „odiljenje“ ili rastanak, drugim riječima, kao književna je tema izvorno trubadurske provenijencije, pa ne čudi što ga i u većini - od onih tek nekoliko - njegovih primjera prisutnih u našoj literaturi također nalazimo u sklopu ljubavnih lirskih pjesama kazivači kojih se nevoljko rastaju od svojih ljubavnica, a i u samome se Odiljenju na više mjesta (doduše, s odgodom) rastaju upravo ljubavnici i zaručnici.

164 O Adamu (1662. - 1691.), kao posljednjem muškom potomku Zrinskih, podrobno u: Hausner 2012: 447-461. 
dana „mlađem“, bečkom izdanju - na opata i vrhovnog kapetana u Szalaváru na mađarskom Blatnom jezeru Matiju Ignacija Radanovića, ${ }^{165}$ zahvaljujući čijoj je valjda potpori Odiljenje (točnije, njegova paratekstualna dionica) ponovno $\mathrm{i}$ otisnuto. $\mathrm{U}$ paratekstualno najizmjenjenijemu, trećem izdanju (Zagreb, 1695.), mjesto latinske posvetne pjesme i hrvatskoga proznoga predgovora zauzela je odulja prozna posveta na hrvatskom jeziku (očevidno) novom meceni i zaštitniku - pukovniku Ivanu Andriji Makaru ${ }^{166}-\mathrm{u}$ kojoj, pored uobičajenih posvetnih glorifikacija adresatovih vrlina, njegova ugleda i dotadašnjih profesionalnih uspjeha (u ovom slučaju osobito Makarovih mnogobrojnih ratničkih podviga), ${ }^{167}$ Ritter podastire i pojedine informacije o svojemu djelu te razlozima njegova (ponovnog) objelodanjivanja, koje je u oba prethodna izdanja donio u vernakularnim svojim predgovorima. Iako zbog izostanka predgovora, dakle, čitatelji nisu ostali uskraćeni (i) za neke podatke o samome Odiljenju što ih je Vitezović ondje obično otkrivao, u posveti Makaru neće oni ipak moći pročitati i napomenu kojom je naš autor u prethodnim dvama izdanjima svoju ,zrinijadu“ predstavio kao specifično djelo, priznajući da je ono zapravo - nedovršeno.

I dok tako predgovor $K$ čtavcu prvoga izdanja Vitezović tek zaključuje obećanjem kako će „druga tri dila, koja još nesvršena zaostahu, u kratko vrime na svitlo dati““ (Ritter Vitezović 1684), onaj naslovljen Prijaznivi štavče! „drugoga“ izdanja gotovo u cijelosti posvećuje razlozima (,divjim uzrokima“) zbog kojih je bio prisiljen i u (n)ovome izdanju donijeti jednako krnj, nedogotovljen tekst Odiljenja. To što nisu ,jošće ona tri dila (...) dovršena“" naš autor pravda činjenicom da mu u međuvremenu nije pošlo za rukom pronaći „gospodara, koji bi ih u darežljivi milošće svoje naručaj veselo prijel“", a samome mu, pak, „, trude činiti, i stroške gubiti, ni uhara“ jer - kako vlastitim riječima priznaje - „nisam tako

\footnotetext{
${ }^{165} \mathrm{O}$ (vjerojatnom) pokrovitelju bečkoga izdanja Odiljenja - Matiji Ignaciju Radanoviću (ili, mađarski, Mátyásu Ignácu Radonayu; 1630. - 1703. - moguće je danas pronaći tek nekoliko vrlo šturih podataka, raspršenih u nizu hrvatskih, ali i mađarskih izvora. Zna se tako o njemu to da je rođen u blizini Desinića (pored Varaždina), da je kao sedamnaestogodišnjak - srednjoškolsko obrazovanje nastavio u Mađarskoj te da je studirao u Grazu, gdje je i doktorirao teologiju i filozofiju. U Salzburgu je potom zaređen za svećenika, nakon čega je putovao u Rim i brojne naše primorske gradove, u kojima se bavio poučavanjem djece iz plemićkih obitelji. Od 1687. do smrti obnašao je dužnost rimokatoličkoga biskupa u Pečuhu, a vrijeme njegova biskupovanja ponajviše se pamti po tome što je neumorno poticao doseljavanje bosanskih Hrvata u predjele pod ingerencijom svoje biskupije ne bi li tako u njoj povećao broj katolika. 1685., kada iz tiska i izlazi „drugo“ izdanje Odiljenja, Radanović je vršio funkciju svećenika i vrhovnog kapetana u mađarskom gradiću Szalaváru na obalama Balatona, a to što se Vitezović odlučio upravo njemu posvetiti svoju ,zrinijadu“ upućivalo bi ne samo na to da je već tada bio izrazito utjecajan ( $\mathrm{pa}$ je svojim autoritetom mogao zaštiti Odiljenje od eventualnih kritika što ih je - možda isprovocirala prošlogodišnja njegova posveta Adamu Zrinskom), već i da je imao mogućnosti - a možda i da je to već u nekoliko ranijih navrata velikodušno učinio - financijski potpomagati tiskanje vrijednih (domaćih) izdanja, zbog čega je naš autor najvjerojatnije vidio u njemu trajnoga svog mecenu. Koliko je do danas poznato, Radanović nakon bečkoga izdanja Odiljenja nije više financirao tiskanje ni jednoga Ritterova djela, što će reći da su se možebitne njegove nade o pronalasku stalnoga pokrovitelja ubrzo rasplinule kao mjehurić od sapunice.

166 Detaljnije o Ivanu Andriji Makaru (1640. - 1700.), glasovitomu hrvatskom pukovniku koji je sudjelovao i u konačnom protjerivanju Turaka iz Sigeta u listopadu 1686., a uz to je zaslužan i za kasnije oslobađanje velikih dijelova Ugarske i Slavonije od osmanlijske vlasti, u: Mažuran 1998: 243-275 i Bogdanović 2011: 29-30.

${ }^{167}$ Usp. prijepis posvete Ivanu Andriji Makaru u: Budišćak 2016b: 99-102.
} 
bogat, da gore s mosti za drugih lahkoću vežem, ni tako ubog, da s tim življenja uzdržanje išćem, niti tako skazljiv, da tašću otuda slavu radim zadobiti““ (Ritter Vitezović 1685). Bez obzira na to što ni u trećem izdanju, objelodanjenomu punih deset godina nakon onoga bečkog, Odiljenje nije (još) dopunjeno ni jednim jedinim novim stihom (a kamoli ranije obećanim trima dodatnim dijelovima), u proznoj posveti Ivanu Andriji Makaru njegovu će nedovršenost Ritter u potpunosti prešutjeti, a zajedno s njom i svoja ranija obećanja o dopisivanju „drugih triju dilova“. Ako je, dakle, naš autor prvotno zaista i namjeravao proširiti svoju četverodijelnu ,zrinijadu“, iz posvete zagrebačkoga je izdanja postalo bjelodano da je od toga nauma u međuvremenu ipak odustao, a razlog tomu mogao se - kako se čini - kriti u odveć povoljnoj recepciji prethodnih dvaju izdanja i/ili u činjenici da samim isticanjem njegove nedovršenosti te poglavito njezinih razloga među (nekim) svojim čitateljima nije ipak dospio isprovocirati reakciju kakvu je priželjkivao.

Naime, novo izdanje Odiljenja sigetskog, što ga je 1695. Vitezović pripremio za tisak i osobno otisnuo u zagrebačkoj Zemaljskoj tiskari, ne sugerira nam samo to da je i deset godina nakon njegova posljednjeg izdanja među publikom - ili makar jednim njezinim dijelom - još uvijek za nj postojao interes, već ujedno i to da taj interes nije mogao biti zadovoljen naprosto zato što je deset godina starije izdanje do toga trenutka bilo rasprodano. Uočivši, dakle, da su prethodna dva izdanja čitatelji izvrsno prihvatili i njihovoj (vjerojatnoj) nedovršenosti usprkos, Ritter je i sam vrlo lako mogao uvidjeti kako njegovoj „zrinijadi“ - u strukturnom smislu - zapravo ništa i ne nedostaje, odnosno kako su dosadašnji recipijenti dospjeli steći dojam zaokruženosti i usprkos svim njezinim sadržajnim, formalnim, stilskim i uopće žanrovskim raznolikostima, unatoč mnogobrojnim njezinim govornicima, konstantnim prostorno-vremenskim skokovima i višestruko naglašenom ,izostanku“ punih triju još nenapisanih dionica. Štoviše, ako su „obični“ recipijenti Odiljenju pristupali kao ostvarenju kojemu ne manjka ni jedan jedini stih, onda mora da je identičan utisak ostavilo ono i na čitatelje iz viših društvenih slojeva među kojima se Ritter uzaludno nadao pronaći pokrovitelja zainteresiranog za financiranje njegova budućeg „cjelovitog“ izdanja, ali i drugih svojih književnih i neknjiževnih radova. Znamo li, naime, da se Vitezović i brojna druga svoja ostvarenja (ponajvećma bezuspješno) trudio predstaviti kao tek puke „,nacrte“, „priprave“6168 ili naprosto nedovršene tekstove ne bi li potaknuo njihove - ili, pak, zaintrigirao i neke sasvim nove - pokrovitelje da novčano potpomognu tiskanje njihovih potpunih izdanja (pa i - ako je ikako moguće - ostanu trajnim njegovim mecenama), neće biti neopravdano pretpostaviti da

\footnotetext{
168 Ritter će, uostalom, i svoje Odiljenje sigetsko u predgovoru njegova bečkog izdanja na jednome mjestu također označiti kao pripravu, odnosno „spravu“ (usp. Ritter Vitezović 1685).
} 
je za identičnom „strategijom“ posegnuo on već i u Odiljenju sigetskom, u predgovoru prvoga izdanja kojeg potencijalne „financijere“ $\mathrm{k}$ tome još obavještava i kako doskora kani napisati lingvističku raspravu o pravopisnim pitanjima kojih se ondje tek dotaknuo. ${ }^{169}$ Budući da ni Adam Zrinski, ni Matija Ignacije Radanović, a ni drugi mogući pokrovitelji, čiji se interes svojim ,Žalopojkama“ nad nedovršenim tekstom nadao privući, najvjerojatnije Odiljenje također nisu vidjeli kao „krnji“ tekst te svakako nisu bili voljni financirati objavljivanje njegova eventualnog potpunog izdanja (a ni drugih Ritterovih djela), ${ }^{170}$ prilično je moguće da je od iluzije o nenapisanim trima dijelovima u zagrebačkom izdanju naš autor odustao pomirivši se s činjenicom da za takav ,pothvat“ neće naći zainteresiranoga patrona, a možda mu ni samome više nije bilo do povratka jedanaest godina „starome“ pjesničkom tekstu za čije je novo izdanje ionako dospio „osigurati““ (privremenoga) mecenu.

Ako je, dakle, u proznoj posveti trećega izdanja najviše prostora Vitezović posvetio oduševljenom nabrajanju Makarovih ratnih zasluga, a u predgovoru onoga drugog razlozima radi kojih je pred ,štavce“ iznova morao donijeti „nepotpun“ svoj tekst, u predgovoru prvoga izdanja najviše će on tinte potrošiti ne bi li upozorio na sve veću prisutnost (bespotrebnih) tuđica $\mathrm{u}$ hrvatskom jeziku te predstavio svoja vlastita, nova pravopisna rješenja, koja je primijenio i u Odiljenju i o kojima je namjeravao napisati čitavu jezikoslovnu raspravu naslovljenu Početak i temelji jezika slovinskoga. Potonju raspravu Ritter na koncu nije

\footnotetext{
169 Odnosno, Vitezovićevim riječima: „od česa svega, to jest i načina za dobro pisati, i od nauka za pravo govoriti, u Početku i temeljih jezika slovinskoga obilnije naskorom kazati hoću“ (Ritter Vitezović 1684).

${ }_{170} \mathrm{Da}$ se Vitezović na tako skoro ponovljeno izdanje Odiljenja sigetskog - koje, kao što ćemo uskoro vidjeti, uopće i nije bilo drugo u punom smislu riječi - odlučio ponajprije zato što su mu se, ubrzo nakon objelodanjivanja njegova prvog izdanja, izjalovili planovi o Adamu kao trajnom meceni, razabiremo iz (relativno kratke) „kronologije“ njihova prijateljevanja. Naime, samo pola godine nakon upečatljivoga susreta $\mathrm{s}$ posljednjim Zrinskim u Obrežu, Vitezoviću u Linzu Adam financira tiskanje Odiljenja, hotimice predstavljenog kao „nedovršeno“ djelo. S obzirom na to da na kraju svojega predgovora Ritter hrabro obećaje zaostala „druga tri dila“" ubrzo objelodaniti, moguće je da je već tada - dakle, u svibnju 1684. - od Adama dospio izmamiti obećanje kako će mu u skorije vrijeme udijeliti novčanu potporu kako bi mogao i to „dovršeno“ djelo napokon objaviti. Ukoliko je tomu doista i bilo tako, lako je pretpostaviti da se Vitezović - kao stvaratelj koji je već tada bio u neprekidnoj grčevitoj potrazi za stalnim mecenom - ponadao da bi Adam bio voljan financirati i tiskanje drugih njegovih ostvarenja, slijedom čega ga je jamačno krenuo salijetati s odveć čestim i „,nasrtljivim“ molbama koje je ovaj sustavno odbijao ispuniti. Da bi ova pretpostavka mogla biti vrlo blizu istini svjedoči nam i Ritterova pjesnička poslanica Adamu iz rujna 1684., u kojoj ga otvoreno moli za financijsku pomoć, a iz listopada iste godine datira i njegova posljednja epistola Zrinskom, nakon koje se - kako se čini - komunikacija između ove dvojice prekinula (usp. Klaić 1914: 60). Premda se iz sadržaja spomenutih poslanica ne nazire nikakav konflikt između Vitezovića i Adama Zrinskog, činjenica da je nakon listopada 1684. pisani kontakt između njih prekinut (u obzir, naravno, treba uzeti i mogućnost da kasnija njihova korespondencija naprosto nije sačuvana) upućuje na pucanje prijateljskih spona, odnosno udaljavanje koje je vrlo vjerojatno moglo biti motivirano Adamovim sustavnim oglušivanjem na Vitezovićeve molbe za financijskom potporom. U svojoj biografiji, naime, Klaić napominje kako nije poznato je li Adam Ritteru uistinu poslao onu novčanu pomoć koju je ovaj zatražio u rujnu 1684., no lako je moguće da je upravo Adamovo odbijanje njegovih zahtjeva dovelo do toga da je naš autor napokon shvatio kako u posljednjemu Zrinskom jamačno neće naći onoga toliko žuđenog trajnog pokrovitelja te da mu se stoga valja okrenuti drugim mogućnostima. Čini se da je upravo tada Vitezović i donio odluku da potraži novoga mecenu (i) za svoje Odiljenje, no - kao što smo vidjeli - ni pokroviteljstvo Matije Ignacija Radonaya neće se, nažalost, pokazati dugoročnim rješenjem za njega u tom pogledu.
} 
napisao ili do danas ona naprosto nije pronađena, no ponajprije iz predgovora Odiljenja, a zatim i iz predgovora Kronike (1696.), latinskoga „spjeva“ Dva stoljeća ucviljene Hrvatske (1703.) te zbirke osmeračkih poslovica Priričnik aliti razliko mudrosti cvitje (1703.) ${ }^{171}-\mathrm{u}$ kojima se iznova dotiče istih pravopisnih pitanja - lako razabiremo da se njegova grafijska reforma bazirala na razračunavanju s dotadašnjim bilježenjem pojedinih glasova digramima, odnosno na pisanju svakoga glasa isključivo jednim slovom ili monogramom, dok ,za one kojih latinski jezik nema uvodi latinska slova s dijakritičkim znakovima iznad ili ispod njih“ (Katičić 2013: 32). Pritom on ima na umu kako nezgrapne digrame koji su tada bili u uporabi na našem sjeveru, tako i one kojima su isti glasovi bilježeni u južnoj nam književnosti, što će reći da svojim prijedlogom monogramskoga bilježenja glasova u jednakoj mjeri pokušava doskočiti nedostacima latinskoga i talijanskog pravopisa kojima su se služili naši pisci na jugu, kao i onoga mađarskog na koji su se, pak, oslanjali sjevernohrvatski autori. ${ }^{172}$ Vitezović, drugim riječima, identična grafijska rješenja nudi objema hrvatskim sredinama, iskušavši ih najprije u tekstu ispisanom od prvoga do posljednjeg stiha trodijalektalnim hrvatskim jezikom, čime pokušava postaviti temelje za ostvarenje ne samo svoje vizije jedinstvene književnosti za sve Hrvate, već i ideje ujedinjene Hrvatske uopće, čije bi razjedinjene krajeve i pokrajine najprije trebao povezati upravo svehrvatski jezik sa zajedničkim pravopisom.

Ortografske Vitezovićeve zamisli prezentirane u predgovoru prvoga izdanja Odiljenja sigetskog mogle bi se tako držati „nadogradnjom“ njegova trodijalektalnog, odnosno mješovitog jezika sastavljenog od elemenata iz svih triju hrvatskih narječja kojim ispisuje svoju „zrinijadu“, ali i sva preostala svoja vernakularna ostvarenja. Našem bi autoru, međutim, pogrešno bilo pripisati zasluge za stvaranje ovoga višenarječnog jezika budući da nije zapravo riječ ni o čemu drugome no o tek jednoj inačici naddijalektalnoga jezičnog tipa $^{173}$ kojega su u 17. stoljeću koristili pisci tzv. ozaljskoga književnojezičnog kruga, i to oni u rasponu od Jurja Rattkaya, Ivana Belostenca i Frana Krste Frankopana do Katarine i Petra Zrinskoga, ${ }^{174}$ koji upravo njime ispisuje svoju Adrijanskoga mora Sirenu, iz koje je Ritter

\footnotetext{
${ }^{171}$ U Dva stoljeća i Priričniku Vitezović je otvoreno istaknuo kako je njegova grafijska reforma dovršena, što bi onda značilo kako ju je konačno uspio dogotoviti oko prijelaza stoljeća.

172 Podrobnije o Vitezovićevoj pravopisnoj reformi u: Putanec 1986: 350-352, Vončina 1988: 244-246, Moguš 1974: 73-79 i 2009: 99-103.

${ }^{173}$ Taj naddijalektalni jezični tip naši su filolozi nazivali doista kojekako, pa ćemo u stručnoj literaturi, između ostalih, tako zateći i termine „hibridni književnojezični tip“ (usp. Vončina 1988: 187-195) i „trojna hibridna koiné" (Prosperov Novak 1999: 443). O problematičnosti ovakvih naziva opširnije u: Bratulić 2011: 267.

${ }^{174}$ Pojedini su naši književni povjesničari u ozaljski književnojezični krug uvrštavali čak i Jurja Križanića, koji je - kako tvrde - upravo na temelju dijalektalno mješovitoga hrvatskog jezika razvio svoj koncept zajedničkoga slavenskog jezika sastavljenog od riječi iz pojedinačnih slavenskih „narječja“ (usp. Posavac 1994: 849-857).
} 
baštinio i više no što bi se to na prvi pogled dalo naslutiti. ${ }^{175}$ Kombiniranje obilježja svih triju hrvatskih narječja u književnim djelima „Ozljana“ posljedica je, prije svega, jezične situacije ozaljskoga područja, na kojemu su se - u svakodnevnoj komunikaciji - fizički preklapala sva tri dijalekta tvoreći poseban jezični hibrid, no na opredjeljenje za naddijalektalni tip jezika najvjerojatnije je - naročito u Katarine i Petra Zrinskog te Frana Krste Frankopana - utjecala i činjenica velike rasprostranjenosti posjeda njihovih magnatskih obitelji, ali jamačno i svjesna želja svih (ili većine) autora ovoga kruga da njihova djela nađu svoje čitatelje u svim dijelovima Hrvatske. ${ }^{176}$ Čini se da su, kako je svojedobno odlučno pretpostavio Josip Vončina, već autori ozaljskoga književnojezičnog kruga upravo tu svoju naddijalektalnu jezičnu kovanicu vidjeli kao najsretnije rješenje problema nepostojanja standardnoga hrvatskoga jezika, ${ }^{177}$ u čemu su zapravo slijedili ideje o identično koncipranome jeziku kao zajedničkom što su ih još u prethodnom stoljeću zastupali naši protestantski pisci. ${ }^{178}$

Da su odjeci (izvorno) protestantskih razmišljanja o mješovitom (jedinstvenom) jeziku kao najpogodnijem za hrvatski jezični standard doprli i do samoga Vitezovića sugeriraju nam upravo njegove kritike uperene protiv suvišne uporabe tuđica, zbog kojih izvorni hrvatski jezik u tolikoj mjeri biva zaboravljen da ,skoro vikovični (na jedno rečenje) domoroci materinskim jezikom dobro općiti i svaku rič pravi nje imenom spovidati ne mogu“ (Ritter Vitezović 1684). Donijevši u nastavku nekoliko primjera izlišnih tuđica kojima se zakriva „slovinskoga jezika obilnost“, Ritter naglašava da je hrvatski jezični fond dovoljno bogat da bi domaće riječi mogle i morale imati prednost ispred posuđenica, zbog čega u nastavku dakle, u samome Odiljenju - obećaje jezičnu čistoću, pa čak i usprkos tomu što bi neke čitatelje odveć navikle na strane istoznačnice pojedine njima nepoznate (domaće) riječi mogle dovesti u nedoumice po pitanju njihova porijekla. Svojim obećanjem da će u Odiljenju izbjegavati tuđice, odnosno držati se izvornoga bogastva hrvatskoga jezika i svih njegovih narječja, Vitezović tako zapravo implicira da bi jezik vernakularnih književnih djela morao biti razumljiv svima, što znači da bi se morao bazirati na autohtonome, „običnom“ leksiku koji se svakodnevno rabi u svim hrvatskim krajevima, čime nije daleko ni od Petra Zrinskoga, koji u predgovoru Adrijanskoga mora Sirene - obraćajući se svojim suborcima - navodi kako

\footnotetext{
175 Osnovica Petrova jezika u Sireni je čakavsko-ikavska, baš kao što će to biti i ona jezika kojim je ispisano i Odiljenje sigetsko. Inače, u djelima pisaca ozaljskoga književnojezičnog kruga najviše se - kao i u Odiljenju miješaju čakavsko i kajkavsko narječje, poglavito zato što je u 17. stoljeću postojalo mnogo zajedničkih crta između kajkavštine i čakavštine, a upravo je „velik broj zajedničkih elemenata omogućio (...) prisan kontakt tih dvaju dijalekata“" (Vončina 1968: 197).

176 Usp. Dukić 2003: 491.

177 Usp. Vončina 1968: 195.

${ }^{178} \mathrm{O}$ naddijalektalnome tipu hrvatskog jezika - o kojemu će nešto kasnije biti i više riječi - detaljnije u: Vončina 1968: 195-205, 1973: 203-237, 1977: 191-204, 1988: 187-195; Moguš 2009: 91-99; Jembrih 2011: 109-117; Bratulić 2011: 229-273, Pajur 2014: 55-68.
} 
je svoje djelo napisao „ne kako dijak, nego kako krajinski vaš tovariš““ (Zrinski 1957: 19), a ni od Frana Krste Frankopana, koji, pak, u predgovoru svoje rukopisne zbirke lirskih pjesama Gartlic za čas kratiti tvrdi kako se - u jezičnom pogledu - trudio u svojim pjesmama „na sridnjem putu ostat, da znam kaj govorim i drugi razumit me more“ (Frankopan 1999: 82). Potonje težnje za jezičnom jednostavnošću i razumljivošću, koje su isticali „Ozljani“, a nakon njih i Pavao Ritter Vitezović, nisu zapravo ništa drugo no „,produžetak“ protestantskih nakana da miješanjem svih triju dijalekata kreiraju dovoljno jednostavan, a onda i razumljiv jezični standard kako bi doprli do recipijenata iz svih krajeva Hrvatske i tako lakše proširili svoja religijska gledišta, pa u ovim formulacijama Zrinskoga i Frankopana stoga i možemo razabrati svojevrsni nastavak otvorenog inzistiranja na jezičnoj razumljivosti, kojom su se već u predgovoru glagoljskome izdanju Prvoga dela Novoga testamenta (1562.) - dakle, prijevoda Novoga zavjeta - dičili protestantski pisci Antun Dalmatin i Stjepan Konzul Istranin. ${ }^{179}$

U otvorenom otporu spram tuđica, odnosno nastojanjima na jezičnom purizmu ustrajat će Vitezović i u kasnijim svojim djelima na hrvatskom jeziku, pa tako već i u predgovoru Kronike one „koteri budu čtali ove knjige“ izrijekom upozorava: „nemojte se čuditi da negdi čete slovensku, negdi majdačku, negdi posav(s)ku, negdi podravsku, negdi pako primorsku a negdi i krajinsku reč, budući i ja tako pisane našel, i to vse slovenski jeziki, od kojih vsakoga lipše se pristoji uzeti reči neg od tujega kogagoder, dijačkoga, nemškoga ali ugerskoga posudjavati“ (Ritter Vitezović 2015: 21). Da posezanje za riječima iz različitih dijalekata vidi kao najpouzdaniju „metodu“ za iskorjenjivanje suvišnih posuđenica u hrvatskom jeziku sedam će godina kasnije potvrditi on i u predgovoru Priričnika, u kojemu ističe kako sve u tekstu navedene riječi „hrvatske jesu, ako ne povsud općinske, ar vnoge hrvatskoga orsaga strane s dijačkim, ugrskim i nimškim jezikom pomutiše se, navlastito u slovinskih varaših, gdi se s dijačkim jezikom u duhovnih i pravdenih stvarjah najveć služe i gdi Ugri, Nimci, Latini najveć obujahu“ (Zrinski, Frankopan i Ritter Vitezović 1976: 475). Upravo pučkoknjiževnim Priričnikom možda se Vitezović ponajviše i dospio približiti (protestantskom) idealu opće jezične razumljivosti i jednostavnosti, i to ne samo time što u njemu u potpunosti odbacuje tuđice, već i time što su u njemu ,nikoje riči (...) naravskim imenom izrečene“ (Isto: 476), što je ništa drugo no izravna posljedica činjenice da je povelik broj ondje uvrštenih poslovica uistinu folklorne, usmenoknjiževne provenijencije. Drugim riječima, „kratke oblike usmene književnosti shvaća Vitezović kao one žive primjere koji pokazuju kakav bi zapravo morao biti jezik pisane književnosti““ (Vončina 1988: 246), pa stoga i ne čudi zašto je obilježjima (tuđicama „nezagađene“) folklorne književnosti, pa i stanovitim usmenoknjiževnim

\footnotetext{
${ }^{179}$ Usp. o tome u: Bratulić 2011: 244-261.
} 
žanrovima u cijelosti premrežio već i Odiljenje, ali i sva druga svoja ostvarenja na hrvatskom jeziku, redom napisana naddijalektalnom jezičnom kovanicom, ${ }^{180}$ u kojoj je samo omjer zastupljenih elemenata iz pojedinih narječja od teksta do teksta ponešto varirao. ${ }^{181}$

Nevjerojatnu okretnost u sastavljanju stihova na tronarječnoj varijanti hrvatskoga jezika Pavao Ritter Vitezović stekao je, kako ističu „ritterolozi“, ne samo stoga što je vrlo dobro poznavao onodobna, ,štampana djela hrvatskih pisaca od Dubrovnika na jugu do Varaždina na sjeveru“ (Klaić 1914: 107), već i poglavito zahvaljujući činjenici što se „i sam kretao po različitim krajevima Hrvatske te je svladao njihove dijalekte“ (Kravar 1991: 236). Ne treba, osim toga, zaboraviti ni to da je rođen on upravo u Senju, na svojevrsnoj granici između sjevernih kajkavskih i primorskih čakavskih krajeva, te da je veći dio života doslovno proveo na relaciji između kajkavskoga Zagreba i (pretežno) čakavskoga rodnog grada, a ponajprije zahvaljujući svojim vojnim službama u pograničnim područjima dospio je, k tome, stupiti i u izravni kontakt sa štokavštinom. Imajući zacijelo u uhu i dijalektalno mješoviti jezik kojim se u 16. i 17. st. govorilo u neposrednoj okolici Senja, mogao je Ritter s priličnom lakoćom usvojiti koncept interdijalekta kakav su propagirali autori ozaljskoga književnojezičnog kruga (a poglavito njegov najveći literarni uzor - Petar Zrinski), znajući da će njegovim prihvaćanjem tako ujedno pristati i uz same „Ozljane“ te njihove ideje o zajedničkom jeziku kao ključnom ujedinitelju hrvatskih regija. Osim što se opredjeljenjem za

\footnotetext{
${ }^{180}$ Mješavinom narječja (is)pisao je, dakle, Ritter i preostale svoje (pučkoknjiževne) tekstove na hrvatskom jeziku - kalendare, knjigu gatalica Lado horvatski iliti Sibila, prigodnicu Senjčicu, a jamačno i (danas izgubljenu) Novljančicu. Osim njih, tronarječnim hrvatskim jezikom napisane su i dvije već spomenute njegove lirske pohvalnice, objelodanjene 1689. u sklopu Valvasorove Slave vojvodine Kranjske pod naslovima Hrvatkinja i Dalmacija, i to usprkos tome što je različite identitete dviju hrvatskih regija kojima su one posvećene naglasio odabirom različitih stihova (dvostruko rimovanoga dvanaesterca u Hrvatkinji te osmerca u Dalmaciji) i grafija, što pokazuje da ga je već tada zaokupljala ideja ujedinjenja razjedinjenih hrvatskih regija u zajedničku državu čije bi žitelje povezivao (i) jedinstveni, naddijalektalni hrvatski jezik (detaljnije u: Bogović i Pavić 2016: 243-261). Štoviše, naddijalektalni jezični tip iskušavao je Ritter i u godinama prije objelodanjivanja Odiljenja, što nam uvjerljivo potvrđuju brojni hrvatski stihovi uvršteni u maločas spomenuti zbornik rukopisnih i tiskanih njegovih djela Otia metrica manuscripta et impressa, među kojima preklapanje narječja uočavamo već u minijaturi Hroma pravica te nedovršenoj ljubavnoj pjesmi čiji prvi stih glasi „Primi mi ljubljeno, vilo, pozdravljenje“. Mnogo uočljivije to će miješanje elemenata iz različitih dijalekata biti u stihovanim hrvatskim umetcima latinskih Vitezovićevih pjesničkih poslanica uvrštenih u rečeni zbornik, među kojima se, dakako, izdvaja ona Franji Ivanoviću od 21. svibnja 1682., u kojoj višenarječnost najviše i dolazi do izražaja jer je podsjetimo - riječ o epistoli čija dionica na hrvatskom jeziku kvantitativno daleko nadmašuje onu latinsku. $\mathrm{S}$ obzirom na to da je u toj poslanici - u kojoj je, ponovimo, po prvi puta kroatizirao svoje njemačko prezime ispjevanoj u dvostruko rimovanim dvanaestercima sjevernoga tipa naš autor kapetanu Ivanoviću pripomenuo kako je trenutno zaokupljen radom na (najvjerojatnije) Odiljenju sigetskom, nema sumnje da je u njoj za rješenjima kojima će pribjeći i u svome „spjevu“ (kroatizirano prezime, identični dominantni stih) - pa tako i za naddijalektalnim hrvatskim jezikom - posegnuo očito želeći iskušati njihove „efekte“ prije no što ih prezentira (široj) hrvatskoj publici. U tom je smislu i trodijalektalna jezična mješavina na kojoj i piše najveći dio epistole Ivanoviću najvjerojatnije trebala biti svojevrsni (po svemu sudeći, uspješni) „test“ za Odiljenje, odnosno pokušaj kojim je Ritter želio istražiti kakav učinak njegov „svehrvatski“ jezik ostavlja u praksi i može li upravo on biti jedan od čimbenika pomoću kojih će osigurati toliko željeni interes čitatelja iz svih hrvatskih regija.

${ }^{181}$ O konkretnim štokavskim, čakavskim i kajkavskim slojevima jezika Vitezovićevih hrvatskih djela poglavito i u: Isto: 145-153 i Vončina 1988: 237-238.
} 
višenarječni hrvatski jezik otvoreno želio svrstati uz bok stvarateljima koji su dali neposredni poticaj i njegovu književnom radu, bio je ujedno Vitezović i više nego svjestan činjenice da će se upravo inzistiranjem na dijalektalno „nečistom“ jeziku (i) s formalne strane nadovezati na tradiciju domaćih (literarnih) obrada sigetske katastrofe, u kojoj do toga trenutka nije bilo niti jednoga teksta ispisanog isključivo jednim, „destiliranim“ narječjem. Već je sjevernočakavska jezična osnovica Črnkova Podsjedanja i osvojenja Sigeta bila tako prožeta kajkavskim i štokavskim elementima, ${ }^{182}$ a zahvaljujući ugledanju u tu će kroniku i Barne Karnarutić (zadarsku) čakavštinu svojega Vazetja „obogatiti“ ne samo Marulićevom čakavštinom, nego i dubrovačkom štokavštinom te jasnim kajkavskim tragovima. ${ }^{183}$ Znamo li da, štoviše, čak ni glavninom kajkavska anonimna Pjesma o Sigetu zapisana u Prekomurskoj pjesmarici nije ostala „pošteđena“ od (doduše, vrlo malog broja) štokavskih i čakavskih elemenata, ${ }^{184}$ postat će i više nego jasno da se - nedugo nakon kulminacije ovoga dijalekatskog „šarenila“ u jeziku Petrove Adrijanskoga mora Sirene - Vitezović svojim Odiljenjem (makar) u jezičnom smislu izvrsno uklopio u dotadašnji niz ,zrinijada“.

Ipak, za razliku od Črnka, Karnarutića i anonimnog autora Pjesme o Sigetu, koji su po svemu sudeći - za riječima iz drugih narječja i/ili njihovih lokalnih inačica posezali bez (svjesne) namjere da se svojim ostvarenjima približe i recipijentima iz svih hrvatskih sredina, Vitezović je - slijedeći u tome Petra i druge ozaljske autore - upravo dijalektalnom jezičnom mješavinom ciljano i „mamio“ publiku s područja cijele Hrvatske, i to nipošto (samo) iz puke želje da time podigne čitanost vernakularnoga prvijenca. Naprotiv, ako je vjerovati njegovim izjavama iz predgovora prvom izdanju, ovako je napisano Odiljenje trebalo pridonijeti tomu „da slavni hrvatski jezik naš u (...) pozabljenje ne dohodi“ (Ritter Vitezović 1684), što se čini(lo) kao dovoljno valjan razlog maksimalnog proširivanja njegove publike, koje je, pak, (bilo) moguće postići samo jezičnim prilagođavanjem svim potencijalnim recipijentima, odnosno iznalaženjem takvoga jezika koji će sprezati baš sve dijalektalne različitosti razjedinjenih hrvatskih krajeva. Naravno, sastavljajući svoju „zrinijadu“ upravo tim naddijalektalnim jezičnim tipom Ritter nipošto nije priželjkivao tek jednokratno njezino razumijevanje duž čitavoga prostora nekad jedinstvene Hrvatske, nego je na umu - već tada imao i povezivanje hrvatskih regija posredstvom ovako osmišljenoga zajedničkog jezika,

\footnotetext{
${ }^{182}$ Usp. Ratković 1971: 29. Alojz Jembrih je - na temelju nekolicine sačuvanih Nikolinih pisama nastalih u godinama uoči Sigetske bitke - utvrdio kako je Črnkov kronikalni prikaz pada Sigeta zapravo napisan onim istim dijalektalno mješovitim tipom jezika kakav je u svojoj komunikaciji rabio i sam Nikola Šubić Zrinski i koji je potom postao osnovicom koiné kojom će se služiti i pripadnici ozaljskoga ili zrinsko-frankopanskog književnojezičnog kruga (usp. Jembrih 2011: 116-117).

${ }^{183}$ Podrobnije u: Vončina 1986: 119-127.

${ }^{184}$ Usp. Zvonar 2008: 30-39.
} 
vidjevši u njemu jamca buduće teritorijalne cjelovitosti iznova ujedinjene (,oživljene“) Hrvatske, čime je samo nastavljao i bitno produbljivao ideje iz ozaljskoga književnojezičnog kruga. S obzirom na to da će se ova trodijalektalna jezična „stopljenica“ nametnuti kao „jezični preslik njegove integracionističke ideološke koncepcije“ (Blažević 2012: 436), razradom koje je posebno bio zaokupljen u godinama na prijelazu iz 17. u 18. st., to bi ujedno onda značilo i da je već u prvoj polovici osamdesetih godina 17. st. Vitezović - očito ponukan sve zamjetnijim opadanjem osmanlijske ratne moći - razmišljao o oslobođenoj „čitavoj“ Hrvatskoj (tota Croatia), čije će „oživljavanje“ pod habsburškom vlašću za petnaestak godina predložiti samome kralju Leopoldu. ${ }^{185}$

Vjera u jezično-kulturno, a onda i geografsko sjedinjenje hrvatskih regija, koja će kasnije prerasti u politički program (ponovnog) združivanja svih - turske vlasti lišenih „slovinskih“ zemalja i pokrajina u zajedničku državu nazvanu hrvatskim imenom (i) u Vitezovićevu je slučaju ništa drugo no tek jedan od refleksa ideologije tzv. baroknoga slavizma, koja je u 17. st. svoje zastupnike imala u mnogim intelektualcima sa slavenskoga govornog područja, ali i šire. Vukući svoje korijene još od ideje slavenskoga zajedništva začete u humanizmu, kada i dolazi do jačanja osjećaja nacionalnosti i potrebe za definiranjem specifičnosti nacionalne kulture, ${ }^{186}$ sedamnaestostoljetni ili barokni slavizam uglavnom je podrazumijevao „opisivanje i veličanje slavenstva, slavenske etničke, društvene, političke i jezične zajednice kao nadnacionalnog fenomena, pri čemu se sadržaj pojma najčešće argumentira jedinstvenim jezikom i slavnom prošlošću slavenskih naroda, kadikad njihovom vjerskom pripadnošću (katolicizam), a isto tako vjerom da će upravo slavenski narodi osloboditi Europu od Turaka“ (Fališevac 2010a: 116). Kao ideološki koncept uvelike izrastao

\footnotetext{
${ }^{185}$ Svoje pankroatističke političke zamisli, odnosno (utopijsku) viziju o tome kako bi se sve (južno)slavenske zemlje koje se prostiru na području nekadašnjega Ilirika - u najoptimističnijem slučaju, dakle, sve one što se nalaze na prostoru od Baltičkoga i Crnog mora do Jadrana - trebale ujediniti u zajedničku državu nazvanu „čitava (cjelovita) Hrvatska“ (tota Croatia) kojom bi vladao habsburški kralj, predstavio je on u historiografskim i pravnopovijesnim djelima tzv. postkarlovačkoga ciklusa, glavninom nastalima između 1699. i 1701., odnosno u razdoblju nakon sklapanja Mira u Srijemskim Karlovcima između Habsburške Monarhije i Turske potkraj siječnja 1699. (točnije, u vrijeme svojega sudjelovanja u Komisiji za razgraničenje pod vodstvom grofa Luigija Ferdinanda Marsiglija). Jezgru spomenutoga ciklusa čini pet latinskih spomenica - Responsio ad postulata comiti Marsiglio (Odgovor na potraživanja grofa Marsiglija, 1699.), Croatia (Hrvatska, 1699.-1700.), Dissertatio Regni Croatiae (Rasprava o Kraljevstvu Hrvatske, 1699.-1700.), Croatia rediviva (Oživljena Hrvatska, 1700.) i Regia Illyriorum Croatia sive Croatia rediviva (Kraljevska ilirska Hrvatska ili oživljena Hrvatska, 1701.) - no pripadaju mu još i heraldička zbirka Stemmatographia (Grboslovlje, 1701.), neobjavljena rasprava Banologia, hagiografski rukopisni tekst Ilirski domoroci ili životi svetaca Ilirika te nedovršeno enciklopedijsko djelo $O$ žrtvenicima $i$ ognjištima Ilira (podrobnije o ovim djelima te o Vitezovićevoj pankroatističkoj ideološkoj koncepciji u: Blažević 2002 i 2012: 435-437). Postkarlovačkim je ciklusom, inače, prva ovaj niz tekstova u svojoj doktorskoj disertaciji posvećenoj Ritterovim naporima oko simboličkoga osmišljavanja hrvatskoga nacionalnog identiteta prozvala Catherine Anne Simpson (usp. Simpson 1991), a u nas ga je - kao oznaku za isti segment njegova opusa - potom preuzela Zrinka Blažević (usp. Blažević 2002).

${ }_{186}$ Usp. o tome u: Simpson 1991: 11-38.
} 
upravo iz snažnoga protuturskog raspoloženja ${ }^{187}$ te dodatno osnažen protureformacijskim nastojanjima Katoličke crkve da na vjerskoj i kulturnoj podlozi ujedini (južno)slavenske narode u svrhu obrane od prijeteće islamizacije čitava jugoistoka Europe, barokni se slavizam i u našoj sedamnaestostoljetnoj kulturi iskazivao različito, uključujući ne samo brojne inačice slavenofilske ideologije (rusofiliju, polonofiliju itd.), ${ }^{188}$ već i zagovaranje raznolikih strategija kojima se trebalo osigurati nacionalno, a onda i nadnacionalno (sveslavensko) zajedništvo. Između ostalog, manifestirao se on tako u nas i predanim radom na normiranju hrvatskoga jezika, na sastavljanju prvih naših gramatika i rječnika, a poglavito u kontinuiranim težnjama - prisutnima još od humanizma - za iznalaženjem zajedničkoga, svehrvatskog jezika, uvelike potaknutima uvjerenjem o postojanju isključivo jednoga - jedinstvenog - slavenskog (,slovinskog“) jezika u usporedbi s kojima su svi ostali narodni jezici tek njegovi dijalekti ili žargoni. ${ }^{189} \mathrm{U}$ tom bi, dakle, smislu i Vitezovićevo propagiranje naddijalektalnoga jezičnog tipa kao idealnog rješenja problema onodobne jezične razjedinjenosti hrvatskih regija valjalo motriti kao tek jedan od izdanaka višestoljetnoga, (barokno)slavističkim idejama vođenoga procesa traganja za zajedničkim (standardnim) hrvatskim jezikom, koji je dotad tekao ili u smjeru zagovaranja jednog - većinom štokavskog - narječja kao hrvatskoga standarda, ili, pak, u smjeru kreiranja višedijalektalne jezične stopljenice prihvatljive svim Hrvatima. ${ }^{190}$ Otvoreno se tako priklonivši ovoj drugoj mogućnosti, Ritter već formalnom dimenzijom Odiljenja nepogrešivo signalizira svoju baroknoslavističku ideološku orijentaciju, no podjednako će važne - a k tome još i znatno uočljivije - biti one silnice ideologije

\footnotetext{
${ }^{187}$ Isto je - antitursko - raspoloženje u baroku iznjedrilo i sve druge, slavizmu podudarne nadregionalne osjećaje zajedništva (općekršćanski, prohabsburški, promletački i sl).

${ }^{188}$ U sklopu baroknoslavističkih se razmišljanja najčešće glorificirao onaj slavenski narod koji se u danome vremenskom trenutku vojno bio sposoban oduprijeti Turcima, pa se, kao svojevrsna alternativa Vitezovićevim svehrvatskim i sveslavenskim koncepcijama te zamislima o jedinstvenomu južnoslavenskom geokulturnom prostoru što ih je zastupao Vladislav Menčetić, u 17. st. u našoj književnosti tako pojavljuju i rusofilske ideje Jurja Križanića te Gundulićeva polonofilska koncepcija, razvidna, dakako, u njegovu Osmanu. Mitologemima i ideologemima slavizma ili „slovinstva“, kako su već višestruko dokazali književni povjesnici, „prošaran“ je zapravo najveći dio domaće nam barokne književnosti (o baroknom slavizmu i njegovim manifestacijama u hrvatskoj književnosti 17. st. vrlo detaljno u: Bogišić 1991: 9-38, Maleković 1993: 22-23, Dukić 2003: 496-498, Golub 2003: 123-140, Kravar 2003b: 120-121, Fališevac 2010a: 116).

189 Usp. Slamnig 1965: 167-174 i Bogišić 1991: 9-38.

190 Konkretno, tijekom 16. i 17. stoljeća - napajajući se podjednako na baroknoslavističkome ideološkom „,izvoru“ - iskristalizirale su se dvije struje jezikoslovaca zaokupljenih pitanjem nepostojanja hrvatskoga jezičnog standarda: južna i sjeverna. Južna je pritom struja - kojoj su najbliži bili dubrovački književnici te autori zadarskoga, splitskog i hvarskog književnog kruga u 16. i 17. st. - pod idejnim vodstvom Bartola Kašića i Jakova Mikalje - inzistirala na odabiru štokavskoga dijalekta kao temelja hrvatskome standardnom jeziku, dok je ona sjeverna - čije su zamisli u praksi provodili već protestantski pisci, a zatim i autori ozaljskoga književnojezičnog kruga - vjerovala da je problem hrvatskoga standarda moguće riješiti prožimanjem štokavskoga, kajkavskoga i čakavskoga narječja, kao što su to u svojim jezikoslovnim radovima predlagali i Ivan Belostenec te Juraj Križanić (usp. Moguš 1974: $75-76$ i 1986: 147-148). Vrlo detaljno o ovoje problematici i u: Slamnig 1965: 167-174, Vončina 1977: 191-204, Bogišić 1991: 9-38, Fališevac 2010a: 116, Golub 2003: 123140, Katičić 2013: 13-44.
} 
„slovinstva“ što ih nalazimo na njegovoj sadržajnoj razini: po mnogočemu - govoreći iz perspektive ciklusa „zrinijada“ - također specifičnoj, pa i neobičnoj.

Ako, drugim riječima, sama idejna podloga i ne čini Odiljenje sigetsko odveć osebujnim ostvarenjem, isto ipak nije moguće ustvrditi i za formalne njegove, a još manje sadržajne značajke. Naprotiv, da je Vitezovićeva „zrinijada“ - motrena kroz prizmu (književnog) razdoblja kojemu pripada, ali i dotadašnjih djela posvećenih sigetskoj tematici po svojim unutarnjim obilježjima tekst koje odskače od zamišljenoga „literarnog prosjeka“ i ciljano provocira višestruka (žanrovska) određenja, ponajbolje se i razabire iz njezina pristupa središnjoj temi, utemeljenog na naglašavanju onih motivskih aspekata kojima je u ranijim obradama pridavana tek minorna pozornost, pri čemu se ti aspekti ujedno prezentiraju i u posve neočekivanome (neuvriježenom) formalnom okviru. Umjesto dosljedne epskopjesničke naracije, odnosno kompaktne priče bazirane na kronološkom nizanju čitateljima dobro poznatih ratnih događaja pod Sigetom i u njemu iz ljeta 1566. i protegnute kroz manji ili veći broj - kvantitativno otprilike podudanih - pjevanja, četiri „dila“ Odiljenja rascjepkana su (svaki od njih ponaosob) u zasebne pjesme nejednake duljine, u kojima različiti - živi, mrtvi i personificirani - govornici („likovi“) iznose svoje viđenje sigetske katastrofe, koja je presudno usmjerila i njihovu sudbinu, prisilivši ih u konačnici na neizbježna i povišenim emocijama nabijena „odiljenja“ ili rastanke. U ranijim „zrinijadama“ neizostavan (redo)slijed zbivanja u rasponu od dolaska turske vojske do junačke pogibije Nikole Šubića Zrinskog pod gotovo već sasvim razrušenim bedemima Sigeta Ritter tako zamjenjuje „tek“ nizom „reminiscencija“ (Vončina 1976a: 341), točnije „epsko-lirskih varijacija o temi Sigetske bitke“ (Dukić 2003: 497), čime iskazuje ne vlastitu literarnu nevještost u pristupu ovoj toliko već puta opjevanoj temi, nego - upravo suprotno - jasnu svijest o tome kako će literarizacija sigetskih „odiljenja“ daleko bolji učinak postići ostvarena kao ,zbirka slika uzetih iz samoga boja i zamišljena duševnog stanja onih, koju u boju sudjeluju“ (Putanec i dr. 1952: 7 i Jembrih 2008: 54) no u formi (barokne) povijesne epske pjesme, u kojoj tom motivu ni dotad nije pripadalo neko osobito važno mjesto.

Očitu sadržajno-formalnu distancu spram neposrednih svojih tematskih prethodnica Odiljenje sigetsko, štoviše, produbljuje i time što ove - kako su ih prozvali stariji naši književni povjesnici - „momentne slike iskinute iz sigetskoga boja“ (Šrepel 1902: 106) niti su $\mathrm{u}$ njemu donesene u okviru iskaza tradicionalnoga epskog pripovjedača (koji u tekstu u potpunosti izostaje), niti se nižu (pretpostavljenim) pravocrtnim kronološkim slijedom, ${ }^{191}$ pa dok tako, konkretno, u prvoj pjesmi prvoga dijela Siget, koji je već pao u turske ruke, o

${ }^{191}$ Usp. kratki pregled sadržaja svih segmenata Odiljenja sigetskog u: Pavličić 2007: 257-269. 
ishodu opsade izvještava udovice i majke poginulih branitelja, već u sljedećim dvjema - u kojima se jedan od drugog opraštaju ban Zrinski i sin mu Juraj - vraćamo se u razdoblje koje je prethodilo trijumfu Osmanlija i konačnom zauzeću utvrde. U drugome „dilu“, pak, miješaju se pjesme vremenski „smještene“ $u$ trenutke neposredno prije posljednjega okršaja i pogibije Nikole Šubića Zrinskog s onima iz razdoblja nakon završetka opsade, a potonjoj vremenskoj perspektivi - iako pretpostavljaju nešto veći temporalni odmak od trenutka poraza sigetskih branitelja - pripadaju i pjesma Putnik i Jeka trećega dijela te redom sve pjesme zaključnoga „dila“ Odiljenja, koje imitiranjem natpisa na nadgrobnim pločama razasutima grobljem pored Sigeta aludiraju na to da se vrijeme od turske pobjede do trenutka njihova „čitanja“ mjeri već zacijelo u tjednima, a možda i mjesecima. ${ }^{192}$

Sadržajno-formalna i kompozicijska razmrvljenost, međutim, ne znače ujedno i to da Odiljenju nedostaju sadržajna povezanost i uopće smisaona zaokruženost, kao ni to da bi jedini njihov eventualni jamac trebala biti jedinstvena tema. Štoviše, iako segmente Vitezovićeve „zrinijade“ u kompaktnu cjelinu najpresudnije doista i veže „krovna“ sigetska tematika, nipošto se ne bi smjela previdjeti ni Vitezovićeva nakana da i u ovako (naizgled) razbarušenom tekstu primarno usredotočenom na opjevavanje reperkusija bitke pod Sigetom podastre ipak i informacije o samome tijeku kršćansko-osmanlijskog okršaja, pa čak i o podvizima pojedinih njezinih sudionika, koje uključuje u pjesme svih četiriju dijelova - od uvodne poslanice Sigeta do nadgrobnica posljednjega „dila“ - ne bi li (i) na taj način učvrstio njihove sadržajne konekcije. Mnogobrojne pjesme - naročito u prva dva dijela - ne samo što su, povrh toga, realizirane kao obraćanja i replike (npr. Ban sinu i Sin banu), odnosno pisma i odgovori (primjerice, Ban kralju i Kralj banu), čime - kao svojevrsne „parne“ pjesme sadržajno i formalno upućuju jedna na drugu, nego se, k tome, još i neke od njih mogu shvatiti kao izravne reakcije na momente o kojima je bilo riječi u ranijim pjesmama ili, pak, tim istim momentima izazvane akcije, ${ }^{193}$ što također rezultira jačim povezivanjem pojedinih

\footnotetext{
192 O izostanku kronološkoga reda u Odiljenju vrlo pregledno u: Kolumbić 2005: 335-337.

193 Tako bi se, primjerice, pjesma Putnik $i$ Jeka trećega dijela Odiljenja, u kojoj o detaljima sigetske katastrofe putnik-slučajnik razgovara s vilom Jekom, lako mogla dovesti u smisaonu vezu s obećanjem što ga Siget daje „gospojama hrabrenim i hrvatskim vilama“ pri kraju uvodne pjesme prvoga dijela, gdje ističe kako će - nipošto ne želeći da se uspomena na njegov pad izgubi - o kršćansko-muslimanskoj bitci pod svojim zidinama pričati čak i putnicima (,Ni noći ni danka ne ću ja pustiti / od toga rastanka spomen ne imiti. / I ki bude iti putnik mimo mene, / š njim ću govoriti od rati hrabrene“; I: 471-474). Jednako tako, pismo Sigeta koje u pretposljednjoj pjesmi drugoga „dila“ - Vila Hrvatkinja nad Sigetom (II: 614-734) - u čak dva navrata spominje vila Hrvatkinja (,Kot što duha nima, srca nis' ćutila, / suznimi očima gda sam knjigu čtila, / kako turska sila bana i vojnike / ljuto je pobila rad sigetske dike“, II: 632-635; „Al' mi zvrhu toga zlo sad Siget piše, / da smrt od turskoga meča svi podniše“, II: 658-659) ne referira se, dakako, ni na koje drugo „pismo“ nego ono Sigeta, s kojim se Odiljenje i otvara (I: 1- 477), dok, pak, posljednja pjesma toga istog - drugog - dijela (Gospodična Sofija i oral, II: 735906), u kojoj o tragičnom ishodu bitke i pogibiji svoga zaručnika Sofija doznaje od personificirana orla, sadržajem sugerira da pismo Sigeta (najvjerojatnije) nije ni napisano, a kamoli odaslano, jer „službene“ vijesti o dovršetku bitke do ,gospoja i vila“ još uvijek nisu stigle.
} 
dionica, a u krajnjoj konzekvenci i svih komponenata teksta u cijelosti. Da je Vitezoviću itekako bilo stalo do toga da Odiljenje sigetsko ipak pobuđuje dojam sadržajno i smisaono zaokruženog ostvarenja ne otkriva nam samo činjenica da se pojedinim pjesmama pokušavaju predočiti posljedice što ih je pad Sigeta imao na sve moguće životne dimenzije (povijesnopolitičku, religijsku, kulturnu, privatno-obiteljsku, pa čak i prirodno-ekološku), već i jasna nakana da se te reperkusije sigetske katastrofe prikažu - u određenoj mjeri - stupnjevito, odnosno dosljedno se krećući - u svakom od četiriju dijelova teksta - od javnih do privatnih aspekata bitke. ${ }^{194}$ Jasnu dubinsku organizaciju naizgled „nabacanoga“ sadržajnog materijala odaje i svojevrsni okvir djela, ,izgrađen“ od pjesama u kojima se Siget pojavljuje ili kao govornik (u prvoj pjesmi prvoga „dila“ - Siget hrvatskim gospojam te pretposljednjoj nadgrobnici - Sigeta grada) ili, pak, kao središnji motiv (u zaključnoj nadgrobnici Sigetu Druga istoga grada, u kojemu rat govori), dok upravo finalni ciklus nadgrobnica, koji zaprema čitav četvrti „dil““ teksta, dolazi kao „idejna rekapitulacija teksta“ (Dukić 2002: 68), sugerirajući podjednako svojom motivskom i generičkom određenošću da mu ponajbolje kao takvom - upravo i pristaje mjesto na „začelju“ ovako koncipirana djela.

Sličnu raspršenost - iza koje također stoje mnogo dublji tekstualni i izvantekstualni razlozi - zamijetit ćemo i na drugim razinama formalne dimenzije Odiljenja sigetskog. $\mathrm{O}$ dijalektalnoj mješovitosti njegove jezične razine, motiviranoj Vitezovićevom željom da iznađe rješenje problema hrvatskoga jezičnog standarda, dosad je već bilo podosta riječi, što se, pak, ne može reći i za onu metričku, obilježenu (u našoj dotadašnjoj književnosti) nezapamćenim brojem varijacija, zahvaljujući kojima su neki naši književni povjesnici Odiljenje čak prozvali ,svojevrsnom stihovno-strofičkom enciklopedijom starije hrvatske književnosti““ (Kravar 1993: 155, bilješka 37). Dvostruko rimovani dvanaesterac sjevernoga ili Marulićeva tipa ( $\mathrm{u}$ kojemu se rima s kraja jednoga distiha prenosi u sredinu drugoga distiha), kojim će biti ispjevane sve pjesme prvoga te one - izuzev Gospodične Sofije i orla (dvostruko rimovani dvanaesterački katreni s neprijenosnom rimom) - drugoga „dila“, u trećem će tako dijelu smijeniti dvostruko rimovani dvanaesterac južnoga tipa (bez prijenosne rime), dok je u nadgrobnicama četvrte dionice teksta moguće susresti čitav niz stihova nejednakoga porijekla, raspoređenih u strofe različite duljine i tipa te pritom još i vezanih različitim kombinacijama rime. U tom zaključnom ciklusu epitafa, štoviše, Vitezović nije uporabio samo sve dotad poznate stihove hrvatske književnosti, već je neke od pjesama

\footnotetext{
${ }^{194}$ Vitezovićevu težnju da se u Odiljenju sigetskom osvrne podjednako na privatne i društvene aspekte opsade Sigeta uočio je već i Pavao Pavličić, koji drži da se u svakom od četiriju dijelova teksta fokus prebacuje s jednoga na drugi aspekt. Prema njegovu mišljenju, u prvome tako „dilu“ dominira privatni (obiteljski) aspekt, u drugome i četvrtom onaj društveni, dok se samo u trećoj dionici Odiljenja - u razgovoru putnika i vile Jeke oba ta aspekta na neki način nastoje pomiriti, odnosno spojiti (usp. Pavličić 2007: 278).
} 
(nadgrobnicu Sulejmanu Četrta istoga te Drugu istoga grada, u kojemu rat govori, posvećenu Sigetu) metrički realizirao čak i u heksamestru ${ }^{195}$ - doduše, u njegovoj pseudokvantitativnoj varijanti ${ }^{196}$ - dok se, pak, u nekim drugima nije libio čak ni polimetrijskih rješenja (u trećoj Sulejmanovoj - Treta istoga, potom u Istoga Deli-Vida i Julijane drugarice te Alderana, vojvode harapskoga). Bez obzira, ipak, na to stihovno, strofičko, pa i srokovno „dinamiziranje“ generički vrlo ujednačena četvrtog „dila“, u najvećem će se dijelu svojega teksta - kako primjećujemo - naš autor ipak držati prokušanoga metričkog „recepta“, ispisujući redom sve pjesme prvih triju dionica u jednoj od dviju dobro mu poznatih varijanata „stožernoga“ stiha (južno)hrvatske renesansne književnosti, kojeg je u vrijeme kada je Odiljenje objavljeno u književnosti našega juga gotovo već sasvim bio istisnuo osmerac. ${ }^{197}$

Kada se u ovakvome, relativno kratkom i tematski kompaktnom tekstu pojavi tolik broj metričkih (stihovno-strofičkih) rješenja različite provenijencije, pa k tome i još prilično

\footnotetext{
${ }^{195}$ Sastavljanjem pojedinih pjesama nadgrobničkoga dijela u (pseudo)heksametru - iako to ponajprije čini ne bi li istaknuo u njemu opjevane sadržaje - Vitezović kao da na neki način želi podsjetiti na antičku tradiciju, u sklopu koje su epitafi također velikom većinom bili ispisivani upravo u heksametrima, odnosno elegijskim distisima (usp. Rendić-Miočević 1987: 22). Vrlo dobro poznajući tu tradiciju, ali i svjestan činjenice da heksametar u hrvatskom pjesništvu dotad nije imao osobito važno mjesto (budući da je shvaćan kao isključivo stih novolatinske književnosti), Ritter je poticaj za svoje vernakularne heksametarske pokušaje mogao naći samo u dva ranija ostvarenja naših baroknih autora. Prvo je od njih heksametarska pohvalnica Davorija Jurja Križanića, koja je - uz još nekoliko njegovih hrvatskih pjesama - uvrštena u knjigu Oedipus Aegyptiacus (1652.) Athanasiusa Kirchera, a drugo dvostruko rimovani elegijski distih kojim njegov najveći literarni uzor - Petar Zrinski - zaključuje posvetu svoje Adrijanskoga mora Sirene („V šišaku Marčenom učiniše gnijezdo golubi, / da se zna, načinom kim Venus Marča ljubi“; Zrinski 1957: 20) i gdje, kako je primijećeno, metričku ulogu također nema samo duljina sloga, već i akcent (detaljnije u: Slamnig 1981: 48-52 i Kravar 1986: 129). Premda nakon Odiljenja Ritter, kako je već rečeno, neće prestati pjevati na vernakularu, ostat će ono ipak njegovim jedinim hrvatskim djelom u kojemu je heksametar pokušao uvesti u domaću pjesničku tradiciju, ali ne ujedno i jedinim njegovim ostvarenjem u kojemu će se odvažiti na miješanje antičke metričke tradicije s onom domaćom. Naprotiv, u latinskom Vitezovićevu pjesništvu na pojedinim je mjestima moguće zateći pokušaje „nadograđivanja“ kvantitativnih stihova elementima onih izvorno hrvatskih, kao što će to, između ostalog, biti slučaj i s nekolicinom njegovih prigodnica realiziranih u dvostruko rimovanim heksametrima. Usprkos dobro mu znanoj činjenici da kvantitativnom klasičnom pjesništvu rima uopće nije svojstvena (a kamoli još srok ovakvoga tipa), Ritter će tako, primjerice, u prigodnoj pjesmi Corona Lauro-palmaris (1682.) rimovanje heksametra provesti ,po modelu tzv. sjevernog tipa dvostruko rimovanog dvanaesterca, tako da se rima s kraja distiha prenosi u sredinu idućeg distiha" (Stepanić 2016: 345), a po istoj će shemi rimovati i završne heksametre prigodnice napisane povodom tridesetoga svog rođendana De natali die sui ipsius 7. Januarii iz iste godine. I dok je, naime, u prvih 46 stihova te elegije - u kojima lirski subjekt opisuje nesretnu svoju sudbinu - riječ o „standardnim“, nerimovanim elegijskim distisima, u posljednjih 10 stihova - u kojima kazivač samomu sebi čestita rođendan i izriče dobre želje - nižu se dvostruko rimovani heksametri, iz čega proizlazi da je naš pjesnik dvije tematsko-motivske cjeline u ovoj pjesmi zapravo ciljano razgraničio i metričkom ,izmjenom“, što je „strategija“ za kojom će, u određenoj mjeri, posegnuti i u Odiljenju sigetskom. Podrobnije o ovome u: Stepanić 2016: 345-346. O rimovanju kvantitativnih stihova u Vitezovićevu latinskom pjesništvu - kao „pojavi“ koja je ranije zabilježena još samo u opusu riječkoga pjesnika Kajetana Vičića - posebno u: Isto: 207-209

${ }^{196}$ U spomenutim dvjema nadgrobnicama, kako su to u već više navrata potvrdile metričke analize, ne zatječemo „originalni“, kvantitativni heksametar, već „tek“ onaj građen po klasičnom uzoru, u kojemu akcent dolazi u ulozi iktusa. Drugim riječima, Vitezovićevi heksametri u Odiljenju, bez obzira na svoju kvantitativnu podlogu, temelje se zapravo na naglasku, po čemu u našoj književnosti - ističe Zoran Kravar - upravo Pavlu Ritteru Vitezoviću „pripada prvenstvo na području hrvatskoga heksametra na osnovi akcenta“ (Kravar 1986: 141). Detaljnije o ovim Vitezovićevim pseudoheksametrima u: Slamnig 1981: $52-53$ i Kravar 1986: 129-144.

${ }^{197}$ O najvažnijim stihovima naše sedamnaestostoljetne književnosti podrobno u: Slamnig 1981: 34-43, Pavličić
} 1995: 7-29 i 169-188. 
ravnomjerno raspoređenih, posve je opravdano najprije pomisliti na to da su na njihovu pojavu i utvrđen redoslijed najvjerojatnije utjecali stanoviti sadržajni, odnosno tematskomotivski imperativi. Na mogućnost da su i različiti stihovi u Odiljenju sigetskom upotrijebljeni funkcionalno, odnosno da metričke izmjene u njemu zapravo slijede i određene promjene na sadržajnoj razini, prvi se - tek nedavno - osvrnuo Davor Dukić, zaključivši kako je u Vitezovićevoj „zrinijadi“ zaista prisutna „funkcionalna specijaliziranost stiha; marulićevski dvanaesterci imaju funkciju pripovjednog, monološkog stiha (prvi dio, drugi dio do Gospodične Sofije i orla), drugi oblici dvanaesterca pojavljuju se kao dijaloški stihovi (Gospodična Sofija i oral, treći dio Putnik i Jeka), a različiti stihovi i polimetrija dolaze u nadgrobnicama kao izrazito lirskim dijelovima teksta“ (Dukić 2002: 69). Provjerimo li ih (i) s „čisto“ Žanrovskoga aspekta Odiljenja, Dukićeva se zapažanja pokazuju i više nego ispravnima, tim više što su u sjevernom tipu dvostruko rimovanoga dvanaesterca donesena sva pisma, govori i tužaljke prvih dvaju dijelova teksta, u njegovu južnom tipu organiziranom u katrene dijaloška (i ujedno posljednja) pjesma drugoga „dila“ Gospodična Sofija i oral, u distisima ispjevanima $\mathrm{u}$ istom stihu poludijaloška pjesma s figurom jeke Putnik i Jeka iz trećega dijela, dok su nadgrobnice posljednjega dijela ostvarene kojekakvim metrima, među kojima će značajno mjesto (još uvijek) imati južni tip dvostruko rimovanoga dvanaesterca. ${ }^{198}$ Metrička raznovrsnost zaključne dionice Odiljenja pritom je, kako se čini, motivirana nejednakom važnošću junaka pokopanih pod bedemima sada već turskog Sigeta, različitom pozicijom koju su imali u vojnoj hijerarhiji, različitom ulogom koju su odigrali u kršćanskomuslimanskom okršaju (odatle najveći broj nadgrobnica - pa k tome još i pozicioniranih na samome početku ciklusa - pripada upravo Nikoli Šubiću Zrinskom i sultanu Sulejmanu), a jamačno i njihovim nejednakim porijeklom. Forma epitafa svakome pojedinačnom junaku stoga i jest u toliko mjeri „,individualizirana“ - odnosno prilagođena duljinom, stihom, strofičkim i srokovnim rješenjima - ne bi li odgovarala svim pobrojanim parametrima, dok na različito podrijetlo poginulih očito ukazuje činjenica da nadgrobni natpisi važnijim, a onda i obrazovanijim pojedincima (primjerice, Sulejmanu, Zrinskom, Delimanu, Andrijinu Radovanu itd.) dolaze u duljim pjesmama realiziranima „knjiškim“ stihovima (dvostruko rimovani dvanaesterac, heksametar itd.), dok su oni manje važnim i (kako je moguće pretpostaviti) slabije obrazovanim ratnicima (iz „puka“) ne samo znatno kraći, već i nerijetko

\footnotetext{
198 Od sveukupno 428 stihova četvrtoga „dila“, u dvostruko rimovanim dvanaestercima bez prijenosne rime ispisano je njih čak 250 (u što nije uračunato još i šest stihova u dvostruko rimovanim dvanaestercima, raspoređenih u tri kraće nadgrobnice u distisima - Stipana Oršića, Petra Patačića i Ilije Golema), iz čega proizlazi da je veći dio zaključnoga ciklusa realiziran u onome istom stihu kojim su ispjevane i pjesme Gospodična Sofija i oral te Putnik i Jeka.
} 
ostvareni mješavinama kraćih stihova očigledno folklornoknjiževne provenijencije (nadgrobnice Murtuzanu i sinu mu Ahmetu, potom Alderanu, Andriji Gusiću itd.).

Složimo li se - a nema razloga da to ne učinimo - s ovakvim tumačenjem metričke šarolikosti Vitezovićeve „zrinijade“, to će onda ujedno značiti da smo uvjereni kako u njoj (pojedini) stihovi posjeduju vrlo izrazitu tzv. metametričku funkciju, odnosno upravo onaj aspekt „po kojemu metar, stih ili oblik uopće - sam za sebe, kao goli oblik, kao samostalan simbol, odvojen od pjesme i prije pjesme u kojoj ga zamjećujemo - može imati neko značenje i može neposredno postati dio »sadržaja«, »pjesničke poruke« ili smisla djela“" (Petrović 1968: 93). Kao što je to još prije punih pola stoljeća u svojoj još nenadmašenoj studiji pokazao Svetozar Petrović, metametrički aspekt ili funkcija konkretnoga stiha ili oblika može biti prepoznata na razini čitave jedne književne kulture (poput, primjerice, soneta, kojega su naši pjesnici 16. i 17. st. metametrički povezivali s isključivo talijanskim ljubavnim, petrarkističkim pjesništvom libeći se rabiti ga i u vlastitoj poeziji na hrvatskom jeziku, jer je prema njihovu mišljenju - taj čin ujedno iziskivao i uporabu talijanskoga jezika ${ }^{199}$ ), no danom stihu može ona biti pridana i u okvirima samo jednoga jedinog djela, gdje on dosljedno biva upotrijebljen na specifičan način i najčešće u suglasju s konkretnim sadržajnim ili uopće idejnim ,zahtjevima“ teksta. U ranonovovjekovnoj našoj književnosti daleko najuvjerljiviji primjer potonje metametričke uporabe pojedinih stihovnih rješenja nalazimo u hibridnoj epskoj pjesmi Vila Slovinka Jurja Barakovića - čije je prvo izdanje svjetlo dana ugledalo točno sedam desetljeća prije Odiljenja, a ono treće samo dvije godine ranije ${ }^{200}$ - ispjevanoj u „,̌etare vrsti petja“, odnosno četirima različitim tipovima stihovno-strofičkih okvira, i to, Barakovićevim riječima: „pismima skupnim“, „osmoretkama“, „poluretkama“ te „Zučnopojkama“. Svaku od navedenih „,vrsti petja“ - kako je to ispravno utvrdio Petrović Baraković pritom rabi za opjevavanje posve različitih sadržaja ili sadržajnih razina, pa se tako u ,pismima skupnim“ - koje funkcioniraju kao „nulta razina“ djela - donose uvodne, posvetne i pohvalne pjesme, u njima se pripovijedaju ratne kronike i povijesna prošlost Zadra, govori o pretcima glavnoga junaka - Pisnika, opisuje njegov susret s drugim važnim likovima (Vilom i pustinjakom) te pripovijeda o njegovu putovanju morem i vilinskom skupu na Velebitu. „Osmoredke“, pak, funkcioniraju kao „mitološka razina“ teksta jer u njima Vila pripovijeda o svome porijeklu i mitološkom postanku Zadra te se u njima donose još i uvodna pjesma, Pisnikova polemika s Vilom i epizoda s paklom, „poluretke“ donose „razinu realističnosti“ $\mathrm{s}$ obzirom na to da u njima dominira lik Poklisara te je u njih uključena $i$

\footnotetext{
${ }^{199}$ Detaljnije u: Petrović 1968.

${ }^{200}$ Izuzev prvoga izdanja iz 1614. i trećega iz 1682., Vila Slovinka doživjela je 1626. još i drugo svoje izdanje.
} 
bugaršćica o majci Margariti, dočim se u zučnopojkama podastire Pisnikov monolog o osjećajima i sudbini, poradi čega je njih moguće označiti kao „razinu lirskoga komentara“. ${ }^{201}$

O iznimnoj sedamnaestostoljetnoj popularnosti Vile Slovinke ponajbolje svjedoče tri njezina izdanja objelodanjena između 1614. i 1682., ${ }^{202}$ no je li jedno od njih i sam Vitezović imao u svojim rukama te je li ga upravo ono potaknulo na to da i stihove u svojoj ,zrinijadi“ upotrijebi funkcionalno, s potpunom sigurnošću danas, nažalost, nije moguće utvrditi. Ono što je, međutim, i više nego sigurno jest to da se pojedini stihovi i stihovno-strofički oblici u Odiljenju sigetskom doista pojavljuju kao nositelji konkretnih metametričkih funkcija, i to ne samo onih koje se svode na signaliziranje različitih načina izlaganja (pripovjedne, dijaloške, lirske dionice) ili, pak, generički različito realiziranih segmenata teksta, već i onih čiji je cilj istaknuti ne samo drugačiji vremenski okvir, nego i uvođenje govornika koji su u događaj o kojemu je u tekstu riječ upleteni na sasvim drugačiji način od onih ostalih. Drugim riječima, dvostruko rimovane dvanaesterce sjevernoga tipa Vitezović tako „rezervira“ za pjesme čiji su govornici nesporedni sudionici bitke te njome izravno ,pogođene“ institucije (kralj, katolička Crkva) ili kolektiv (sunarodnjaci, vila Hrvatkinja kao predstavnica obitelji izginulih branitelja) i koje temporalno pripadaju razdoblju pred sam kraj bitke te trenucima neposredno nakon njezina okončanja. Južnim, pak, tipom dvostruko rimovanoga dvanaesterca naš je autor ispjevao pjesme u kojima riječ uzimaju „obični“ govornici - Sofija i putnik - željni doznati pojedinosti o ishodu bitke pod Sigetom, o kojoj ne znaju ništa ili tek ponešto, i koji te informacije dobivaju od personificiranih životinja (orao) ili mitoloških likova u obličju prirodnih pojava (vila Jeka), pri čemu te pjesme pripadaju vremenu nakon pada Sigeta, od kojega je (kako je moguće pretpostaviti) prošlo već dotad najmanje jedan ili više dana.

Dominacija istoga tipa dvanaesterca i u nadgrobničkome ciklusu, kako se čini, također se može pravdati činjenicom da je riječ o pjesmama koje pretpostavljaju vrijeme nakon pada utvrde, no metričke varijacije na kojima četvrti „dil“" u cijelosti počiva zapravo bi trebale biti $\mathrm{u}$ vezi sa stanjem u kojima se govornici tih pjesama nalaze, a onda i temporalne perspektive kojoj one pripadaju. Budući da se na svoje sudioništvo u sigetskoj katastrofi njihovi kazivači osvrću s „onoga svijeta“ te da se ti njihovi iskazi, kao takvi, sada nalaze onkraj protoka vremena (jer pretpostavljaju vječnost stečenu herojskim ovozemaljskim djelima), na formalnoj razini taj se sadržajni ,rez“ najuvjerljivije i mogao naglasiti upravo olabavljivanjem dotadašnjih prilično strogih metričkih kalupa i uvođenjem onih stihovnih, strofičkih i srokovnih rješenja koja bi morala aludirati na značaj, ratne zasluge, ali i porijeklo svakoga

${ }^{201}$ Opširnije o metametričkim funkcijama različitih stihovno-strofičkih rješenja u Vili Slovinki u: Petrović 1968: 44-65 i 178-212.

${ }^{202}$ Usp. Isto: 210, bilješka 37. 
pojedinog pokojnika, no ujedno na taj način i zadržati pažnju čitatelja na ovome generički i sadržajno najmonotonijem „dilu“ Odiljenja. Ovo posljednje Ritteru je, kako će se pokazati, bilo posebno važno budući da je računao na vrlo širok krug čitatelja, a među njima poglavito $i$ na one čiji je interes mogao privući jedino intrigantnim formalnim postupcima, pa tako i - za jednu ,zrinijadu“ svakako iznenađujućom - izrazitom metričkom šarolikošću.

Bilo kako bilo, Vitezovićevo Odiljenje sigetsko - ne dvoje u to više naši književni povjesnici - definitivno predstavlja ,po elegično-nostalgičnom tonu, po fragmentarnoj kompoziciji, ciklički organiziranoj, kao i po nekim obilježjima folklorne književnosti (...) novum u hrvatskoj književnosti“ (Fališevac 2013: 12), u što su se, dodajmo, na „vlastitoj koži“ dosad ponajbolje mogli uvjeriti oni „ritterolozi“ zaokupljeni pokušajima njegove žanrovske kategorizacije. Sagleda li se ono makar na podlozi svojih neposrednih tematskih prethodnica, odnosno iz očišta tada već prilično bogate tradicije „zrinijada“, već na prvi će se pogled uvidjeti da se izdvaja ono u njoj poput svojevrsnoga - lotmanovski rečeno - „minuspostupka“, ${ }^{203}$ dakle teksta koji, ispuštanjem dotad „ključnoga“ (uvriježenog) obilježja ili više njih, iznevjeruje očekivanja publike provocirajući - kazano u terminima estetike recepcije promjenu ili pomicanje njihova horizonta očekivanja. Umjesto onoga što su (makar načitaniji) recipijenti očekivali od još jednoga ostvarenja posvećenog proslavljanju junaštava sigetskih branitelja, Vitezovićeva je „zrinijada“ ponudila čitav niz neočekivanih sadržajnih i formalnih posebnosti, a sve u žanrovski izrazito hibridnom okviru unutar kojega je - iako mu se na prvi pogled zacijelo to i nije činilo tako - baš svaki pojedinačni čitatelj mogao pronaći barem neki moment dostojan njegove pozornosti. Da bi sastavio baš takvo, univerzalno „primamljivo“ djelo - pa i pored otvorenog fingiranja njegove nedovršenosti - Vitezović je morao iznaći način na koji će u njemu sažeti ne samo obilježja nekolicine žanrova, već - kao što će se pokazati nešto kasnije - gotovo svih žanrova koji su sačinjavali generički sustav sedamnaestostoljetne, dakle barokne naše književnosti. Iako mu je na koncu to doista i pošlo za rukom, rezultat je bilo ostvarenje s upitnim žanrovskim identitetom, odnosno lišeno jednoznačnoga generičkog određenja, kojega se naš autor ni sam nije bio u stanju domisliti, a kamoli na njemu inzistirati u paratekstualnim segmentima svih triju njegovih izdanja.

\section{2. TRI IZDANJA - TRI ŽANRA?}

Nasuprot prvom i posljednjem Vitezovićevu izdanju Odiljenja sigetskog objelodanjenima 1684. u Linzu, odnosno 1695. u Zagrebu - ono bečko iz 1685., koje se 
uvriježilo poimati kao njegovo drugo, samo bi se uvjetno moglo nazvati izdanjem u punom smislu riječi. Motrimo li ga, doduše, s čisto „tehničke“ strane, utvrdit ćemo da je posrijedi „tipično“ izdanje Odiljenja, u kojemu - kao što je to slučaj i u preostala dva - iza osam nepaginiranih stranica paratekstualnih dijelova (naslovnica, posveta, predgovor u 1. izdanju) slijedi sveukupno 88 stranica samoga teksta ,zrinijade“, do u detalj otisnutih identično onima iz prvoga izdanja. Unatoč činjenici da se od onoga prošlogodišnjeg bečko izdanje razlikuje novom naslovnicom, posvetnom pjesmom i predgovorom, te da mu nedostaje još i posljednja (neobrojčana) stranica s popisom tiskarskih pogrešaka i njihovih ispravaka, neobično velika tipografska podudarnost njihovih središnjih dijelova još je polovinom prošloga stoljeća pojedine ,ritterologe“ ponukala na to da izdanja iz 1684. i 1685. napokon podvrgnu temeljitoj usporedbi. Rezultati njihovih istraživanja pokazali su da, izuzev arka s novim paratekstualnim komponentama (izmijenjenom naslovnicom, posvetom Matiji Ignaciju Radanoviću te predgovorom Prijaznivi štavče!), iz bečke tiskare Johanna van Ghelena - ili, kako ga sam Vitezović proziva, Ivana Gelenića - te 1685. nije izišla ni jedna jedina iznova tiskana stranica Odiljenja, a kamoli poneki arak ili, pak, njegov tekst u cijelosti. To što su u bečkom izdanju „sve (...) štamparske pogreške netaknute i čitav je slog nepromijenjen“ (Putanec i dr. 1952: 8) upućivalo bi, prema tome, ni na što drugo nego na to da su arci sa samim tekstom Odiljenja sigetskog naprosto „posuđeni“ iz godinu dana starijega izdanja, a potom - u spomenutoj tiskari u Beču - uvezani s osam tek otisnutih stranica izmijenjenoga parateksta, koji je trebao sugerirati da je doista riječ o posve novom izdanju. ${ }^{204}$ Štoviše, da bi iluzija o njegovoj novosti bila potpuna, Ritter je iz svih neprodanih primjeraka prošlogodišnje naklade - osim parateksta - uklonio još i stranicu s ispravcima tiskarskih pogrešaka, očito bojeći se „da se čitatelj ne bi dosjetio, da pogleda, da li su izvršene u ovom »drugom« izdanju korekture štamparskih pogrešaka 1. izd.“(Isto: 8), iako su se recipijenti koji su već posjedovali prvo izdanje - a njih je, po svemu sudeći, bio ne odveć zamjetan broj - pukom usporedbom i sami mogli uvjeriti da je riječ o izdanjima otisnutima identičnim slogom. ${ }^{205}$

\footnotetext{
${ }^{204}$ Vitezović je, ne želeći ništa prepustiti slučaju, tu „drugost“ bečkoga izdanja Odiljenja višestruko istaknuo u svim segmentima njegova parateksta, počevši od naslovnice, na kojoj podnaslov djela otkriva kako su njegova „prva četiri dila“" sada „drugoč na svitlo dana“ (Ritter Vitezović 1685). Na samom početku latinske posvetne pjesme Matiji Ignaciju Radanoviću, pak, Ritter naglašava kako svoju „novu tiskanu knjigu“ objelodanjuje ponajprije potaknut ustrajnim molbama prijatelja (s obzirom na to da je, implicira, prvo izdanje već sasvim rasprodano), dok u vernakularnom predgovoru Prijaznivi štavče! samo podsjeća na prošlogodišnje prvo izdanje Odiljenja, pravdajući njegovu nedovršenost - odnosno (kvantitativnu) identičnost s prethodnim izdanjem nedostatkom adekvatne financijske potpore koja bi mu omogućila da se posveti pisanju zaostalih triju „dilova“.

${ }^{205}$ Čitatelji koji u svojim rukama nisu imali izdanje Odiljenja iz 1684., s druge strane, vrlo su se teško mogli uvjeriti u to da nije riječ o izdanju koje je iznova tiskano od korica do korica. Osim neznatnih tipografskih nepodudarnosti (ponešto drugačiji tip slova) između arka s paratekstualnim dijelovima i onih na kojima je otisnut sam tekst „,zrinijade“, razliku između (,stare“) tekstualne i (,nove“) paratekstualne dionice bečkoga izdanja odaju još samo nejednaka kvaliteta papira (izmijenjeni je paratekst tako otisnut na nešto tvrđem, kvalitetnijem
} 
Budući da je (naj)većim svojim dijelom bečko ,izdanje“ Odiljenja sigetskog tako zapravo sastavljeno od araka onoga koje mu je neposredno prethodilo, egzistirajući prije kao svojevrsna inačica prvog izdanja zaogrnuta u „osvježeno“ paratekstualno ruho nego kao stvarno novo izdanje, posve je jasno da ga nije u potpunosti ispravno okarakterizirati kao drugo izdanje, iako se u „ritterološkoj“ literaturi dosad ustrajno to činilo i još se uvijek - pa i na ovome mjestu - to čini. S obzirom na ovo potonje, ali i na činjenicu da ga je i sam Vitezović u paratekstualnoj dionici toga, a potom i zagrebačkog izdanja iz 1695. izrijekom naveo kao drugo izdanje Odiljenja, ,ritterolozima“ u pogledu njegova određenja zapravo i nije ostavljen naročito velik izbor, no to ujedno ne znači i da je nužno u potpunosti zanijekati navedene mu posebnosti. Nipošto se, konkretno, pritom ne bi trebalo propustiti naglasiti da bečkome izdanju tek formalno pripada status drugoga, dok se - imajući na umu tu njegovu fingiranost - najtočnije ono može odrediti „samo“ kao „fiktivno »drugo« izdanje Odiljenja“ (Putanec i dr. 1952: 8), kao što su to već i pokušali učiniti urednici kataloga obljetničke izložbe Djela Pavla Vitezovića (1652 - 1952), a za njima i pojedini naši književni povjesnici. ${ }^{206}$ Dobro je, k tomu, pripomenuti još i to da Odiljenje sigetsko u tom pogledu u opusu našega autora nije usamljen primjer, jer upravo kao što je - želeći zaintrigirati potencijalne pokrovitelje - u nekoliko kasnijih navrata Ritter pribjegao ondje iskušanoj strategiji stvaranja iluzije nedovršenosti, tako je i u desetljećima koja su uslijedila priredio (a potom i vlastoručno „otisnuo“) više „drugih“ izdanja u kojima su jedini iznova tiskani (i, dakako, izmijenjeni) segmenti bili tek oni paratekstualni. ${ }^{207}$

papiru u usporedbi s tekstom preuzetim iz prvoga izdanja) te - samo pažljivijim promatračima uočljiv - drugačiji uvez paratekstualnoga arka, koji nije iznova uvezan s arcima iz prethodnoga izdanja, već je na njih naprosto nalijepljen (usp. detalje u: Ritter Vitezović 1685). S obzirom na to da se ovi uistinu teško zamjetni detalji čak i dobro upućenim ,ritterolozima“ otkrivaju tek nakon poduljega i pažljivog promatranja sveska bečkoga „izdanja“, nije ishitreno zaključiti da sedamnaestostoljetni čitatelji - podjednako oni koji su možda posjedovali godinu dana starije izdanje iz Linza, kao i oni koji nisu - ovim materijalnim pojedinostima nisu posvećivali ni najmanju pozornost, slijedom čega i nisu mogli razabrati da je glavninom riječ o dvama inačicama - u suštini jednoga te istog izdanja. Stoga i ne čudi da se na spoznaju o fiktivnosti bečkoga izdanja zapravo i moralo čekati tek do polovice prošloga stoljeća, kada su i poduzeta detaljnija istraživanja u tom smjeru.

${ }^{206}$ Nakon što je to učinjeno u spomenutom katalogu, fiktivnim će drugim izdanjem bečko izdanje Odiljenja u svome književnopovijesnom prikazu proglasiti i Krešimir Georgijević (usp. Georgijević 1969: 132), a u posljednjih nekoliko desetljeća takvo je određenje u ,ritterološkim“ studijama sve češće (usp. Samardžija 1999: 8; Jembrih 2015: 549, 2016a: 54 i 2017b: 52; Budišćak 2016b: 84).

${ }^{207}$ Sva kasnija je „fiktivna“ druga izdanja pojedinih svojih ostvarenja Pavao Vitezović zapravo osobno „otisnuo“ u vrijeme upravljanja zagrebačkom Zemaljskom tiskarom. Zanemarimo li čuvenu njegovu latinsku spomenicu Oživljena Hrvatska (1700.), koje je prvo izdanje tiskao u tri (paratekstualno) različite inačice namijenjene posve različitim čitateljima (usp. o tome u: Blažević 1999 i 2002: 92-94), za prvo sljedeće fiktivno „drugo“ izdanje (nakon onog Odiljenja iz 1685.) pobrinuo se Vitezović 1699., kada iz Zemaljske tiskare izlazi zbirka latinskih anagrama Fata et vota, opremljena novom posvetom i predstavljena kao novo izdanje, ali tekstualno sastavljena od araka iz prošlogodišnjega (također zagrebačkog) izdanja. Samo dvije godine kasnije Ritter u Beču objelodanjuje heraldičku zbirku Stemmatographia posvećenu austrijskom kancelaru Bucelleniju, no već sljedeće će godine - nezadovoljan (i) reakcijama čitatelja - u zagrebačkoj tiskari otisnuti novu naslovnicu, posvetu (hrvatskim staležima i redovima) i posljednji arak knjige (str. 73-81), a potom - uvezavši ih s preostalim arcima prošlogodišnjeg izdanja - predstaviti kao novo izdanje uz (dobro nam poznatu) napomenu da je ,bečko izdanje 
Ovo potonje ne odnosi se, međutim, i na zagrebačko izdanje Odiljenja sigetskog, koje bi - s obzirom na sve dosad rečeno - možda mnogo točnije bilo označiti kao (,punokrvno“) drugo, a ne treće Vitezovićevo izdanje. Premda ovaj u cijelosti iznova tiskan svezak takvo određenje nesumnjivo zaslužuje, inzistiranje na njemu za svoju bi posljedicu imalo sasvim nepotrebnu pomutnju, kako radi toga što se u ,ritterološkoj“ literaturi bečko izdanje poodavno već shvaća kao ono drugo, tako i zbog toga što ga u paratekstualnoj dionici i sam Ritter izrijekom predstavlja kao treće, ${ }^{208}$ a takvim su ga pristali obilježavati i pojedini (zasad još malobrojni) njegovi proučavatelji. ${ }^{209} \mathrm{U}$ svakom slučaju, radi se o najmlađem Vitezovićevu izdanju Odiljenja, i to ne samo iz razloga što je - za autorova života - ono kronološki posljednje objavljeno (1695.), već i zbog toga što je - od svih danas nam poznatih izdanja ove „zrinijade“ - najkasnije ono pronađeno, i to tek polovinom 2016. u fondu budimpeštanske Knjižnice Sveučilišta Eötvösa Loránda. ${ }^{210}$ Kao jedan od uopće prvih tekstova što ih je Ritter otisnuo u vrijeme (službenoga) upravljanja zagrebačkom Zemaljskom tiskarom (1694. 1706.), treće izdanje Odiljenja sigetskog najkrupnije je izmjene - kao i ono fiktivno „drugo“doživjelo tek u paratekstualnome svom segmentu, no da je (pored parateksta) ovoga puta pretiskano i svih 88 stranica samoga teksta ,zrinijade“ potvrdit će nam niz grafičkih (tipografskih) i sadržajnih preinaka poput onih u tiskarskom slogu, uporabe nekih drugačijih slova, izmijenjenih florealnih ornamenata u zaglavljima svakoga pojedinog dijela, otklonjenih tiskarskih pogrešaka iz prethodnih izdanja, nekolicine prepravljenih nezgrapnih stihova i lošijih interpunkcijskih rješenja itd. ${ }^{211}$ Pored iznova otisnutoga (i samo neznatno dorađenog) tekstualnog dijela Odiljenja te njegova posve izmijenjenog parateksta, koji - kao što će se kasnije pokazati - sugerira da je bilo ono namijenjeno znatno užem krugu publike od prethodnih dvaju, treće izdanje donijet će i još jedan, sasvim nov (no jednako neuvjerljiv) Vitezovićev pokušaj da za svoju ,zrinijadu“ iznađe prikladnu žanrovsku odrednicu.

„Povijest“ Vitezovićeva traganja za dovoljno preciznim, a ujedno i dovoljno fleksibilnim generičkim okvirima unutar kojih bi mogao smjestiti i svoje Odiljenje sigetsko seže, kako se čini, još u vrijeme njegova rada na ovoj „zrinijadi“, odnosno na nekoj od njezinih (vjerojatnih) ranijih inačica. Da je već u drugoj polovini sedamdesetih godina 17. st. bio on u ozbiljnim dilemama po pitanju žanrovske klasifikacije svoga budućeg hrvatskog

\footnotetext{
tiskano i objavljeno u velikom broju primjeraka, da je rasprodano i da postoji velik interes, pa se zato odlučio za ovo drugo izdanje“ (Ljubović 2002: 1193) s novom posvetom (detaljnije u: Blažević 1999: 86).

${ }^{208}$ Posvetu zagrebačkoga izdanja pukovniku Ivanu Andriji Makaru naš autor, naime, i otvara napomenom: „Tretič sloga ova moja, zvrh' rasutja sigetskoga učinjena, dojti na svitlo jest morala (...)“ (Ritter Vitezović 1695). Usp. prijepis spomenute posvete u: Budišćak 2016b: 99-102.

${ }^{209}$ Usp. Budišćak 2016b.

${ }^{210}$ Jedan njegov primjerak u spomenutoj je knjižnici pohranjen pod signaturom RMK III 574 b.

${ }^{211}$ Detaljnije o ovim preinakama u: Budišćak 2016b: 87-88.
} 
prvijenca razvidno je već iz nekolicine sačuvanih latinskih pjesničkih poslanica iz toga razdoblja, u kojima - podsjetimo - različitim adresatima (Tomi Hreljanoviću, Ivanu Krstitelju Locatelliju, Ivanu Despotoviću mlađem i dr.) otkriva kako trenutno radi na (još nenaslovljenomu) vernakularnom stihovanom ostvarenju posvećenom junačkim djelima hrvatskih branitelja. Ritter pritom to svoje ostvarenje generički određuje doista kojekako kao „djelo“, „pjesmu“, „knjižice“ itd. - ne libeći ga se čak ni unutar tek nekoliko stihova jedne jedine poslanice - one, konkretno, Ivanu Krstitelju Locatelliju iz 1678. - predstaviti i kao (kompaktno) „djelo“ (opus), i kao (unutar istih korica kompilirane) „knjižice“ (libellos). Već će 1680. Vitezović - ako je vjerovati Titi Kovač ${ }^{212}$ - iz temelja promijeniti žanrovsko viđenje svoga hrvatskog pjesničkog teksta, opisavši ga tako Janezu Vajkardu Valvasoru kao ep o padu Sigeta, dok će samo godinu i pol kasnije - u pretežno hrvatskoj poslanici kapetanu Franji Ivanoviću - u potpunosti odustati od njegovih eksplicitnih žanrovskih kategorizacija, najavljujući adresatu tek da će doskora o neustrašivom otporu Hrvata turskim osvajačima dati „ništo (...) svitu na poznanje“ (Šurmin 1902: 535). Naposljetku, u latinskoj prigodnoj pjesmi koju je potkraj 1683. sastavio u čast Adama Zrinskog, Ritter Odiljenje - ili makar ono što je od njega dotad dospio ispjevati - označava kao pjesmu (,„pjesan“) ${ }^{213}$ na hrvatskom jeziku, navodeći svoga „novopečenog“ prijatelja na pomisao kako se doista radi o čvrsto povezanom, kompaktnom pjesničkom sastavku, a ne o tek pukoj zbirci samostalnih pjesama ili „knjižica“.

Pobrojana Vitezovićeva generička kolebanja - sva redom iz vremena prije 1684. nipošto nisu morala biti tek posljedica autorove nemogućnosti da se dosjeti najpreciznijega određenja za svoje žanrovski izrazito šaroliko ostvarenje. Naprotiv, znamo li da Odiljenje najvjerojatnije ni krajem 1683. nije još poprimilo svoj „današnji“ oblik, raznolike njegove žanrovske (pred)kategorizacije naprosto bi se mogle (i očigledno trebale) tumačiti kao rezultat posve uobičajenih dilema autora koji u trenucima dok piše o svome budućem djelu ni sam još nije posve siguran na što će - dogotovljeno - ono doista (s)ličiti. Ritterov otvoreni zazor od konkretnijih žanrovskih odrednica, koji se ogleda u inzistiranju na općenitim oznakama kao što su „djelo“ i „knjižice“, stoga bi očito morao biti motiviran činjenicom da njegova „Zrinijada“ još uvijek nije bila dovršena, iako ne treba odbaciti ni mogućnost da je njima naš autor obilježio neke (već dogotovljene i nama danas nepoznate) ranije inačice Odiljenja, višestrukom preradom (i najvjerojatnijim širenjem) kojih je naposljetku došao do njegova teksta kakav nam je i danas poznat. Jednako tako, ne smije se zaboraviti ni to da u razdoblju baroka, kojemu makar po vremenu svoga nastanka Odiljenje i pripada, nije još u nas postojala

\footnotetext{
${ }^{212}$ Usp. Kovač 1973: 118.

${ }^{213}$ Usp. Klaić 1914: 57.
} 
u potpunosti razrađena, poetičkim tekstovima utvrđena i propisana genološka terminologija, što je - kao što ćemo vidjeti i nešto kasnije - u najvećem broju slučajeva rezultiralo ne odveć preciznim određenjima konkretnih književnih djela. Za generičkim oznakama kao što su „pisma“, „knjižice“, „dilo“ i njima sličnim posezali su stoga - u nedostatku razrađenoga i općeprihvaćenog nazivlja - mnogi naši sedamnaestostoljetni pisci, što ni Pavla Rittera Vitezovića u tom pogledu ne čini ni najmanjom iznimkom. Ipak, da su i uslijed takve terminološke općenitosti domaći barokni autori itekako bili u stanju razabrati kojem tipu književnih djela više pristaje odrednica „pisma“, a kojem „knjižice“ potvrditi nam može nemali broj slučajeva, iz čega bi onda slijedilo da ni Ritterovo ,žongliranje“ (i) tim generičkim oznakama definitivno ne treba okarakterizirati kao u potpunosti slučajno. A da se Vitezovićeva žanrovska „lutanja“ iz godina uoči objelodanjivanja Odiljenja sigetskog svakako ne mogu protumačiti kao tek proizvoljno nizanje naoko različitih, a zapravo sinonimskih generičkih odrednica potvrdit će nam i uvid u sva tri njegova sedamnaestostoljetna izdanja, paratekstualne dionice kojih je moguće izdvojiti kao možda i najuvjerljivija svjedočanstva autorove neodlučnosti po pitanju utvrđivanja žanrovskoga identiteta ove osebujne ,zrinijade“.

$\mathrm{Da}$ je u nepunih šest mjeseci, koliko je proteklo od njegova oduševljenog prigodničarskog proslavljanja „lika i djela“ Adama Zrinskog do objelodanjivanja prvog izdanja Odiljenja sigetskog sredinom proljeća 1684., Ritterovo generičko poimanje hrvatskog mu prvijenca načelno ostalo nepromijenjeno, posvjedočiti nam ponajprije može latinska posvetna pjesma posljednjem Zrinskom, smještena $u$ samo središte parateksta toga „premijernog“ izdanja. Iako se na istu žanrovsku odrednicu (vrlo vjerojatno) upućuje već i na naslovnici, na kojoj je Odiljenje podnaslovljeno kao (djelo) „tuliko različitom, kuliko nečujenom dosle hrvatske rišme lipotom spravljeno“ (Ritter Vitezović 1684; istaknuo V. B.), ${ }^{214}$ Vitezović tek u posveti, slaveći Adama kao „baštinika imena i djedovske vrline“ (Zrinski, Frankopan i Ritter Vitezović 1976: 360), za svoju „zrinijadu“ donosi prvu

\footnotetext{
214 Što je pod riječju „rišma“ Vitezović u citiranome podnaslovu najvjerojatnije podrazumijevao lako ćemo otkriti zavirimo li - iznova - u njegov Lexicon Latino-Illyricum (usp. Ritter Vitezović 2010), gdje dolazi ona kao hrvatski prijevod nekolicine latinskih riječi, između ostalih i onih „,carmen“ (pjesma), ,,epos“ (epska pjesma, ep), „rhythmus“ (ritam) te „versus“ (stih). Napominjući, drugim riječima, čitatelju već na naslovnici da je njegovo Odiljenje sastavljeno raznolikom, a k tome još i dosad „nečujenom“ ljepotom hrvatske ,rišme“, Ritter je tako istodobno želio ukazati ne samo na to da je riječ o hrvatskome djelu ispjevanom u različitim metrima (od kojih će - makar dijelu publike - neki od njih biti nepoznati), već i da se radi o tekstu sastavljenom od - generički gledano - pjesama različitoga tipa, odnosno - da budemo do kraja precizni - od raznovrsne, ali podjednako lijepe pjesme na vernakularu (točnije, različito ispjevane hrvatske pjesme). Zanimljivo je, naime, da naš autor na ovome mjestu inzistira upravo na riječi „rišma“ (u jednini), a ne „rišme“, očigledno želeći dati do znanja da stihovno-strofičkim i generičkim raznolikostima usprkos - Odiljenju valja pristupiti kao jedinstvenom djelu, a ne možebitnoj zbirci metrički raznoliko ispjevanih pjesničkih sastavaka okupljenih oko jedne te iste teme. Tu će jedinstvenost, kao što ćemo vidjeti, nastaviti on potom zagovarati i u narednim paratekstualnim segmentima ovoga izdanja.
} 
eksplicitnu oznaku, i to camoena, odnosno pjesma. ${ }^{215}$ Znajući, međutim, da će doći ona i u ruke čitatelja koji latinskim jezikom nisu (još) dospjeli ovladati ili ga poznaju tek vrlo slabo, Vitezović - za svaki slučaj - identičnu žanrovsku oznaku zatim ponavlja i u (proznomu) hrvatskom predgovoru $K$ čtavcu, gdje, pak, izričito spominje ,pisam ovu Odiljenja sigetskoga“ (Ritter Vitezović 1684), premda ga je u prethodnoj rečenici ponešto općenitije već okrstio kao „dilo“. Generičkim odrednicama u ovome posljednjem paratekstualnom segmentu prvoga izdanja, međutim, tu još ni izbliza nije kraj jer samo nekoliko redaka kasnije, pojašnjavajući razloge svoga inzistiranja na trodijalektalnoj jezičnoj mješavini, Ritter čitatelja upozorava da će se zasigurno u „knjižicah ovih“ susresti i s riječima koje još nikada nije čuo, dok pridodanu osmeračku lirsku pjesmu, kojom se predgovor i zaključuje, otvara stihom u kojemu Odiljenje (iznova) definira kao „pisam knjige moje“ (Isto).

Izuzmemo li, ukratko, „usamljeno“ generičko podsjećanje na to da se Odiljenje sigetsko sastoji od „knjižica“ (pod kojima se zacijelo misli na njegove „dilove“), sva tri paratekstualna odsječka njegova prvog izdanja svojim prilično jasnim žanrovskim odrednicama - među kojima prednjači, dakako, ona pjesme ili „pisme“ - potencijalnim recipijentima sugeriraju da je ovu ,zrinijadu“ nužno razumjeti kao homogeno, kompaktno ostvarenje, pa i unatoč tome što ga, kako je i podnaslovom nagovješteno, karakterizira nezanemariva formalna i žanrovska heterogenost. Ustrajući upravo na generičkoj odrednici „pisam“ (pjesma) Vitezović kao da - mnogobrojnim njegovim tekstualnim neobičnostima usprkos - svoje ostvarenje želi čvršće vezati uz (do toga trenutka glavninom epskopjesničku) tradiciju „zrinijada“, tim više što i nekolicina motiva pjevanja „pisama“ u čast sigetskih branitelja, razasutih duž drugoga i trećeg dijela teksta, ${ }^{216}$ snažno ukazuje na to da bi ova oznaka zapravo trebala podrazumijevati žanr epske pjesme. Bez obzira na maločas utvrđeno

\footnotetext{
${ }^{215}$ Riječ „camoena“, odnosno „camena“ u latinskom je pjesništvu nerijetko označavala i muzu, no iz konteksta same posvete jasno je da Vitezović njome misli ponajprije na pjesmu, odnosno Odiljenje kao cjelinu (u prijevodu Vladimira Vratovića spomenuto mjesto glasi: „TEBE uključujući, ova je Kamena (pjesma, op. V. B.), zapjevavši istinsku bol, s jednakim pravom posvećena TEBI“; Zrinski, Frankopan i Ritter Vitezović 1976: 360). Uzgred budi rečeno, riječ „,camena“ u istom se značenju pojavljuje i u brojnim stihovima čuvenih Horacijevih Epistola (između ostalih, i na samom početku njegove prve poslanice, upućene Mecenatu), odakle je naš autor - rabeći je upravo u takvom značenju - jamačno i preuzima.

${ }^{216}$ Prvi takav motiv zatječemo u posljednjem stihu pjesme Orsag banu (II: 118-146), u kojoj personificirana domovina, otpisujući na njegovu oproštajnu poslanicu, Zrinskom otkriva da se u čast njegovih herojskih podviga pod Sigetom već sastavljaju (epske) pjesme (,pisme ti se čine na sve svita strane“). Siget, pak, u nešto kasnijoj pjesmi Siget banu i vojnikom (II: 361-449), obraćajući se već poginulomu banu i njegovim suborcima, naglašava kako - poradi svoje neustrašivosti u njegovoj obrani - svi oni redom „svakoga jezika pisam zaslužiste“ (II: 415), dok se u pjesmi Putnik i Jeka trećega dijela navodi kako je poginulim kršćanskim junacima sama Vila (vjerojatno vila Hrvatkinja) neposredno nakon svršetka bitke ,pisam od boja njim spravila“(III: 364). S obzirom na to da se u sva tri slučaja pretpostavljaju upravo pjesme o padu Sigeta - dakle, narativna stihovana ostvarenja koja donose kronologiju opsade i osvajanja sigetske utvrde te proslavljaju junaštva kršćanskih (hrvatskih) branitelja - nema sumnje da citiranim stihovima Vitezović aludira upravo na epske pjesme, kako one pisanoknjiževne, tako jamačno i na one usmene.
} 
sedamnaestostoljetno nepostojanje jedinstvene i općeprihvaćene genološke terminologije u nas, onodobni su pisci - u rijetkim prilikama kada su to činili - pri (žanrovskom) definiranju svojih djela za terminima „pisma“ ili „pisan“ obično posezali ukoliko se radilo o zaokruženom, koherentnom (tematski i formalno jedinstvenom) tekstu u stihovima, neovisno od toga je li bila riječ o lirskoj pjesmi (redovito uvrštavanoj u kanconijere naslovljivane „pjesni ljuvene“, „pjesni razlike“ i sl.), epu ili makar jednome njegovu pjevanju, ${ }^{217}$ dok je naziv ,popivka“, s druge strane, bio ,rezerviran“ za isključivo (kraće) lirske pjesme, nerijetko upravo one namijenjene pjevanju, iako su zabilježeni i slučajevi njegove ponešto slobodnije uporabe. ${ }^{218}$ I Vitezovićevo opredjeljenje za žanrovsku kvalifikaciju „,pisam“ stoga ne može upućivati ni na što drugo nego da je Odiljenje sigetsko bilo isprva zamišljeno (ili da je makar iziskivalo da ga se tako shvati) kao čvrsto povezano djelo, i to - s obzirom na osnovnu svoju tematsku orijentaciju - najvjerojatnije kao ona ista vrsta „,pisme“ kojoj su generički pripadale i gotovo sve literarne „zrinijade“ napisane u prethodnih stotinjak godina. No, i to očito ili manje očito žanrovsko približavanje ranijim epskopjesničkim obradama sigetske katastrofe već će u paratekstu fiktivnoga „drugog“ izdanja zamijeniti daleko konfuznija određenja.

Sastavljajući novi paratekstualni odsječak za tek godinu dana „mlađe“ izdanje Odiljenja, Vitezović iznova nije mogao izbjeći obvezu da to svoje djelo žanrovski nekako i precizira, no odrednice kojima ga je tom prilikom okrstio pokazuju da je generički njegov identitet $\mathrm{u}$ tom trenutku shvaćao on ponešto drugačije. Indikativno je, ponajprije, već to što su na naslovnom listu bečkoga izdanja izostale bilo kakve (eksplicitne) žanrovske oznake, pa se u podnaslovu tako navodi tek to da se četverodijelno Odiljenje objelodanjuje sada po drugi put te da pojedinosti o njegovu sadržaju valja potražiti u kazalu otisnutom na drugoj stranici knjige. U posvetnoj, pak, latinskoj pjesmi - adresiranoj na Matiju Ignacija Radanovića ${ }^{219}$ - o Odiljenju kao camoeni nema više ni riječi, ali ondje zato nalazimo jedno njegovo određenje kao „djela“ (opus) te još dva kao „(herojske) pjesme“ (heroum melos, odnosno melos) koju je ispjevala Talija - jedna od, podsjetimo, devet (starogrčkih) muza te zaštitnica bukolike i komedije, a ujedno i boginja plesa, glazbe i pjesme. I dok smo žanrovski naziv melos (pjesma) - u kontekstu iz kojega, doduše, nije baš posve jasno na što se on konkretno

\footnotetext{
217 Zanimljiv je - u tom pogledu - primjer Jurja Barakovića, koji svako „petje“ (pjevanje) Vile Slovinke podnaslovljuje kao „pismu“, očito u želji da naglasi sadržajno-formalnu ,individualnost“" svake dionice teksta. 218 „Popivkama“ će tako, primjerice, svoje lirske pjesme okupljene u (rukopisnoj) zbirci Gartlic za čas kratiti u jednom od dvaju njezinih predgovora označiti Fran Krsto Frankopan, dok informaciju o tome kako je „nekuliko popivki od ljubavi knjigam ovim privrgal“" (Zrinski 1957: 20) u posveti Adrijanskoga mora Sireni donosi i Petar Zrinski. U nastavku on, ipak, nekima od spomenutih ,popivki“ dodjeljuje naslov Pisam, dok u posljednjoj strofi Obside sigecke svoju epsku pjesmu klasificira kao „popivkinju“ („,Ti, Bože, u svemu popivkinju ovu / primi, po krvnomu ku popisah slovu“; XV: 118), što u našoj književnosti predstavlja jedini (poznati) slučaj označavanja epskopjesničkoga ostvarenja popijevkom.

${ }^{219} \mathrm{Na}$ prijevodu spomenute posvete s latinskog od srca zahvaljujem prevoditeljici Zvjezdani Timet.
} 
odnosi $^{220}$ - mogli već zateći i u posvetnoj pjesmi prvoga izdanja Odiljenja, isto se ne može reći i za sve one oznake što ih Vitezović uvrštava u naredni (i ujedno posljednji) paratekstualni segment ovoga fiktivnog „drugog“ izdanja. Riječ je o, dakako, vernakularnome predgovoru Prijaznivi štavče! s pridodanom dvanaesteračkom lirskom pjesmom, u kojemu se pri samom kraju proznoga dijela piše o - dobro nam već znanim - „knjižicama“ Odiljenja, dok se u naslovu pjesme, kojom se personificirani Siget potiče da hrabro otpočne svoje izlaganje, jasno naznačuje da naredne stihove „učinitelj“ (autor) upućuje svojim „knjigam“. Pored ovoga očitog i nimalo novog naglašavanja njegove strukturne heterogenosti (višedijelnosti), naš će autor u svome predgovornom obraćanju publici dijelove Odiljenja označiti ujedno i kao „pisma mojega sprave“ (Ritter Vitezović 1685), dajući do znanja da je zapravo ono ništa drugo no tek „sprava“ (priprava, nedovršeni literarni sastavak ${ }^{221}$ ) sazdana od stanovitog broja zaokruženih tekstova ili pisanih (književnih) djela (pa i - doslovno poslanica $)^{222}$ te da mu - kao takvom - (više) ne pristaje generička odrednica koja bi aludirala na možebitnu njegovu (sadržajnu, idejnu, formalnu, a onda i žanrovsku) kompaktnost.

Ovo posljednje definitivno valja izdvojiti kao najkrupniju novost u odnosu na žanrovska očitovanja sadržana u paratekstualnim komponentama prvoga izdanja Odiljenja sigetskog, kojima je - ponovimo - Vitezović pokušavao izgraditi dojam čvrste povezanosti, odnosno generičke jedinstvenosti svoje ,zrinijade“. Odbacivanje Adama Zrinskog kao zaštitnika prve mu objelodanjene hrvatske ,pjesme“ našega autora kao da je ujedno potaknulo

\footnotetext{
${ }^{220}$ Veličajući ratna junaštva Adamova slavnog pretka, Ritter tako u osmom elegijskom distihu svoje posvete prvoga izdanja - misleći na Odiljenje - naglašava: „Njega je moja Muza opisala hrvatskim stihom, i posmrtna pjesma (melos, op. V. B.) podigla mu sveti grobni spomenik“ (Zrinski, Frankopan i Ritter Vitezović 1976: 360). S obzirom na to da je prijevod Vladimira Vratovića uistinu vjeran originalu, iz ovoga je segmenta pjesme teško razabrati proteže li odrednicu „pjesma“ (melos) Vitezović na svoju „zrinijadu“ u cijelosti ili, pak, misli tek na nadgrobnice posvećene samome Nikoli Šubiću Zrinskom donesene u završnom epitafskom ciklusu. Ipak, budući da u prethodnom distihu Vitezović piše kako je mrtvo Nikolino tijelo ,žalosni rat nakon propasti grada odnio u sveti grob" (Isto: 360) - čime očito aludira na motiv personificiranoga rata, koji u posljednjoj nadgrobnici četvrtoga „dila“ preuzima odgovornost za pad Sigeta i pogibiju njegovih branitelja - bit će da je „pjesma koja je banu podigla grobni spomenik" ipak trebala aludirati isključivo na epitafe posljednje dionice Odiljenja sigetskog, a ne na njegov tekst u cijelosti.

${ }^{221}$ U njegovu rječniku Lexicon Latino-Illyricum „spravu“ nalazimo - pored onih „,collectum“ (zbirka), „,compositura“ (sastavak) itd. - (i) kao prijevod riječi „,apparatus“ i „paratus“, koje obje znače upravo pripremu, odnosno pripravu (usp. Ritter Vitezović 2010).

${ }^{222}$ Osim kao hrvatski prijevod imenice „epistola“ (poslanica), sam Vitezović u Lexiconu (usp. Ritter Vitezović 2010) riječ „pismo“ donosi i kao prijevod latinskih imenica kao što su „litera“, „literatura“ itd., iz čega slijedi ne samo da se njezino značenje u drugoj polovini 17. st. odnosilo na žanr poslanice (u stihu ili prozi), već i da je njome zapravo označavano bilo koje (pisano)književno djelo, pisani sastavak uopće, ali i ukupnost svih književnih tekstova (književnost u cjelini). „Pismo“ je u tom slučaju - osim ako se njime nije podrazumijevao žanr poslanice - predstavljalo najopćenitiju odrednicu nekoga teksta, identičnu, primjerice, onoj „dila“ (,dela“), a vrijedi reći da istu riječ u paratekstu (posveti) svoje Adrijanskoga mora Sirene rabi i Vitezovićev najveći književni uzor - Petar Zrinski - označavajući njome svoje djelo u cjelini (usp. Zrinski 1957: 20). Doduše, kao što je rečeno maločas, Zrinski već u nastavku precizira da se njegovo „pismo“ sastoji od „versi“, „rišma“, „popivki“ i „knjiga“, što pokazuje da nipošto ne teži ustrajati na viđenju Sirene kao zaokruženoga, odnosno sadržajno i formalno jedinstvenog teksta.
} 
i na novo, temeljito promišljanje i domišljanje najprikladnijeg joj žanrovskog određenja, što je na koncu rezultiralo i znatno šarolikijom paletom oznaka uključenih u stihove latinske posvete, a naročito onih razasutih nevelikim tekstom predgovora i njemu pridružene lirske pjesme. Ako je u godinu dana starijem izdanju Odiljenje Ritter žanrovski težio prezentirati kao homogenu i jedinstvenu, očigledno epsku pjesmu, u fiktivnom će ga tako „drugom“ okarakterizirati kao možda i ponajmanje epskopjesničko ostvarenje, a i kada ga - u stihovanoj posveti - napokon i označi kao „herojsku pjesmu“, učinit će on to rabeći termin melos, stavljajući tu (pjevanu ${ }^{223}$ ) pjesmu o herojima u usta muze zaštitnice komedije. Vidno se dvoumeći između nekoliko različitih - i jamačno podjednako primjerenih i neprimjerenih odrednica za svoju ,zrinijadu“, Vitezović je u nastavku najprije proglašava zaokruženim „delom“ da bi je zatim definirao kao tek krnju „spravu“, a sve ne bi li u čak tri navrata na koncu ponovio da je ona tek kompilacija „pisama“ i „knjižica“, baš kao što su to bila i hibridna djela pojedinih naših sedamnaestostoljetnih pjesnika. ${ }^{224}$ Zamjetno neodređeniji po pitanju njegova žanrovskog identiteta Ritter u bečkom izdanju Odiljenja sigetskog tako zapravo podastire njegovo svojevrsno „svežanrovsko“ određenje, ne želeći se odreći ni njegove dotadašnje (epskopjesničke) kompaktnosti, a ni posve opredijeliti za predodžbu o složenom, odnosno kompiliranom ostvarenju, do koje će ga, pak, ova njegova žanrovska „lutanja“" konačno dovesti punih deset godina kasnije.

Raznolikih, naizgled i sasvim disparatnih generičkih odrednica, bliskih onima koje je Vitezović svome djelu „prišio“ u prvim dvama izdanjima, neće manjkati ni u onomu njegovom trećem, najpresudnije ipak obilježenom jednom jedinom, višestruko specifičnom oznakom, koja odaje da je problemu žanrovskog identiteta Odiljenja naš autor napokon pokuša(va)o doskočiti jedinstvenim, a opet najkompleksnijim mogućim rješenjem. U poduljem tekstu hrvatske prozne posvete pukovniku Ivanu Andriji Makaru, koji će protegnut na svih sedam preostalih stranica paratekstualnoga segmenta zagrebačkog izdanja uslijediti nakon krajnje pojednostavljenoga i informacijama siromašnog naslovnog lista, ${ }^{225}$ od „starih“ je generičkih oznaka svoje mjesto našla ona „knjižica“, a uz nju i ona „knjiga“, pa i „knjižice“, kojom Ritter zapravo proziva sam tiskani svezak Odiljenja u cijelosti,

\footnotetext{
${ }^{223}$ U svome latinsko-hrvatskom rječniku „melos“ Vitezović prevodi kao „ljubkopojku“, „slatku pesan“ i „,slast popevke“ (Ritter Vitezović 2010: 283), odnosno upravo kao pjesmu namijenjenu pjevanju.

${ }^{224}$ Izuzev Petra Zrinskoga, koji u posveti Sirene svoje djelo na jednome mjestu također opisuje kao kolekciju „knjiga“ (usp. Zrinski 1957: 20), o „(malim) knižicama“ od kojih je sastavljen njegov zbornik pisat će također i Matijaš Magdalenić u posveti svoga Zvončaca (1670.) Nikoli Erdödyju. Za razliku, međutim, od Petra Zrinskog, Magdalenić u rečenomu paratekstualnom odsječku ne rabi ni jedno drugo generičko određenje, očito svjestan da njegovo sadržajno, formalno i žanrovski heterogeno djelo ne može podnijeti nikakvu „strožu“ žanrovsku kvalifikaciju. Usp. posvetu Zvončaca u: Šojat 1977b: 169-171.

${ }^{225}$ Otisnut je na njoj samo naslov Vitezovićeva djela - „ODDILYENJE SIGETSKO“.
} 
pripominjući Makaru da je ona, iako opsegom mala, zapravo „velikoga spomenka“ (Ritter Vitezović 1695). Pođemo li od kraja posvete prema njezinu početku, identificiranje Odiljenja sigetskog „viteškim spomenkom“ susrest ćemo već u sljedećoj rečenici, premda je znatno ranije - već u četvrtoj rečenici posvete - Vitezović precizirao kako njegova „zrinijada“ sadrži „pravične imenitoga vojništva i slavnoga viteštva spomenke“ (Isto). I „stare“ će „knjižice, i „nove“ ove „spomenke“, međutim, u potpunosti zasjeniti ili - možda bolje rečeno - natkriliti ona žanrovska odrednica što ju je naš autor iznio na samom početku ovoga paratekstualnog odsječka, odmah nakon uvodnog adresiranja Makara i nizanja brojnih njegovih dužnosti i titula, gdje otkriva kako se - potaknut zahtjevima mnogih prijatelja - još jednom, po (sveukupno) treći put, na danje svjetlo odvažio donijeti ovu svoju ,slogu“.

Pored svih ostalih njome premreženih oznaka, već u prvoj će rečenici vernakularne posvete zagrebačkoga izdanja Odiljenja sigetskog Ritter tako podastrijeti najobuhvatnije i značenjem daleko najprikladnije - a k tome još i dosad neiskušano - generičko njegovo određenje, koje dovoljno precizno, no ujedno i dovoljno poopćeno ukazuje na kompiliranost ove ,zrinijade“ na svim njezinim razinama. Kolika je - ne samo u ovomu konkretnom slučaju - doista (bila) značenjska protežnost imenice „sloga“ najbolje je uvjeriti se uvidom u Lexicon Latino-Illyricum našega autora, u kojemu je zatječemo kao hrvatski prijevod latinskih riječi „,compages“ (sklop), „compositura“ (sastavak) i „synthesis“ (sinteza, združivanje), a vrijedi pripomenuti i da su srodnom riječju „složenje“ prevedene ondje riječi „coagmentatio“ (sklapanje), „compactio“ (sklop) i „,compositio“ (spoj, sastavak). Znamo li da je u istome rječniku Ritter ,poesis“ (pjesništvo) preveo kao „složnoričje“, a riječ „poeta“ (pjesnik) - osim kao „pisnik“ i „spravorečnik“ - i kao „složnoričnik“, ${ }^{226}$ postat će i više nego bjelodano da je oznaka „sloga““ u posveti trećega izdanja podrazumijevala složeno, kompilirano književno (ponajprije pjesničko) djelo, odnosno stihovani tekst koji se sastoji od više (zasebnih) dijelova i kojega karakterizira formalna, donekle sadržajna, ali iznad svega žanrovska heterogenost. Napokon spoznavši da se, u generičkom pogledu, Odiljenje sigetsko nipošto (više) ne može predstaviti kao zaokružena (epska) „pisma“ - odnosno da je uopće riječ o djelu koje ne trpi odveć stroge, a kamoli jednostrane kategorizacije - Vitezović odabire upravo ono žanrovsko određenje koje, usprkos prividnoj svojoj neutralnosti i općenitosti, ponajbolje pristaje više ili manje zaokruženom ostvarenju kompilatorskoga tipa, koje sve te silne „knjižice“ i „spomenke“ okuplja oko jedne zajedničke teme (i svrhe). U tom smislu, ako je u prvom izdanju Ritter implicirao da bi njegovu ,zrinijadu“ valjalo pojmiti kao (žanrovski) jedinstvenu epsku pjesmu, a u drugome jasno dao do znanja da se može ona čitati i razumjeti u gotovo 
bilo kojemu generičkom ključu (u rasponu, dakle, od cjelovitoga do kompiliranoga sastavka), u onom će je trećem eksplicitno označiti kao žanrovski hibrid, odnosno kao složeno, sabrano djelo sklopljeno od većeg broja sadržajno i formalno - a onda i žanrovski - različitih „knjižica“, koje se, zahvaljujući ponajprije činjenici da govore o jednome te istom (povijesnom) događaju te tako zapravo vrše - jasno naznačenu - memorijalnu funkciju (one su „,viteštva spomenki“), združuju u kompleksnu, no ujedno i čvrsto povezanu „slogu“, odnosno „knjigu“ ili ,spomenek“.

To što u prvom i posljednjem Vitezovićevu izdanju Odiljenja sigetskog pretežu tako dva više ili manje jasno naznačena (i iz temelja različita) njegova generička shvaćanja - kao „pisme“, odnosno „sloge“ - nipošto, kao što smo vidjeli, ne znači ujedno i to da su iz njih eliminirane sve možebitne njima nepodudarne žanrovske oznake. Naprotiv, baš sva će tri netom analizirana parateksta - a ne samo onaj fiktivnoga „drugog“ izdanja - naš autor „opskrbiti“ stanovitim brojem različitih, gdjekad i nepomirljivih generičkih određenja, no s tom razlikom što će u izdanjima iz 1684. i 1695. svojom kvantitetom ili kvalitetom jedno od njih ipak prilično očigledno „odskakati“. Ovo ustrajno paratekstualno supostavljanje kojekakvih žanrovskih odrednica stoga najvjerojatnije ne svjedoči o Ritterovu ciljanom i definitivnom odustajanju od traženja najprimjerenije generičke definicije za svoje djelo, već prije o njegovoj itekako dobro razvijenoj svijesti o tome kako je baš svaka pojedinačna oznaka nedovoljna da bi zahvatila generički identitet ovako kompleksnoga teksta u njegovoj cijelosti. Baš kao što nizanjem različitih odrednica u paratekstualnoj dionici fiktivnoga „drugog“ izdanja Vitezović aludira na to da Odiljenju podjednako pristaje i ne pristaje bilo koji od navedenih - pa i mnogih još drugih - žanrovskih identiteta, tako i uključivanjem generičkih oznaka različitih od onih „pisme“ i „sprave“ u paratekstovima preostalih dvaju izražava on otvorenu sumnju u odabrano određenje, očito ni sam ne vjerujući u to da je dovoljno ono primjereno (provizornom) ,tipu“ djela kojem pripada i njegova „zrinijada“.

\section{3. ODILJENJE U OČIMA OSAMNAESTOSTOLJETNIH ČITATELJA}

Osim činjenice da su do 1695. godine - kada će u Zemaljskoj tiskari iznova ono biti otisnuto - očito bili rasprodani apsolutno svi primjerci prethodnih dvaju izdanja Odiljenja sigetskog, nikakve detaljnije informacije o njegovoj čitanosti krajem 17. i početkom 18. st. do nas, nažalost, nisu doprle. Snažna, ipak, potreba da se ono - svega deset godina nakon objelodanjivanja fiktivnoga „,drugog“ izdanja - ponovno nađe na „književnom tržištu“ i više je nego jasan indikator postojanja nezanemarivoga čitateljskog interesa, o kojemu, uostalom, 
u posveti Ivanu Andriji Makaru piše i sam Vitezović, ističući kako ovim zagrebačkim izdanjem zapravo udovoljava „volji i željenju prijateljov“ (Ritter Vitezović 1695). U potonjemu će svom paratekstualnom očitovanju Ritter, povrh toga, otkriti i kako novo izdanje Odiljenja šalje u ruke „navlastito viteških i razumnih ljudi“ (Isto), ali i to da je prethodna dva dao otisnuti u (sasvim raspačanoj) nakladi od „nikuliko stotin“ primjeraka, iz čega bi onda slijedilo da je publika toliko rado posezala za njegovom „zrinijadom“ da je već i treće izdanje imalo osigurane čitatelje, i to - kako se čini - mahom one iz najviših društvenih slojeva. Ukoliko na temelju svih ovih posredno izvučenih pokazatelja doista i možemo zaključiti da je Odiljenje među Vitezovićevim suvremenicima bilo itekako obljubljeno literarno ostvarenje, time zapravo nećemo reći baš ništa o njegovoj onodobnoj žanrovskoj percepciji jer - ni neposredni, a kamoli posredni - tragovi načina na koje su ga sedamnaestostoljetni recipijenti generički razumijevali naprosto ne postoje ili su već poodavno izbrisani.

To, nasreću, ne vrijedi i za razdoblje druge polovine 18. stoljeća, kada će se među njegovom publikom naći i stanovit broj nasljedovatelja, zahvaljujući kojima štošta možemo zaključiti i o tadašnjem njegovu žanrovskom tretmanu. Premda će o konkretnim sadržajnoformalnim paralelama između Vitezovićeve ,zrinijade“ i djela pojedinih osamnaestostoljetnih naših pisaca znatno više riječi biti nešto kasnije, na ovome mjestu valja tek primijetiti kako su za određenim motivima i formalnim postupcima iz Odiljenja potonji autori redom posezali u svojim žanrovski vrlo bliskim ostvarenjima, što nedvojbeno upućuje i na to da je „pisma“ našega autora $u$ to vrijeme očigledno poimana kao njihovim ostvarenjima generički srodan, odnosno jasno i jednoznačno žanrovski definiran tekst. $\mathrm{S}$ obzirom na to da, nažalost, ne raspolažemo podacima o sveukupnom opsegu, a kamoli konkretnom „sastavu“ onodobne publike Odiljenja, jasno je da s potpunom sigurnošću ne možemo tvrditi da su mu apsolutno svi čitatelji iz toga razdoblja generički pristupali na jednak način, no da je hrvatski Vitezovićev prvijenac itekako visoko kotirao makar među domaćim literatima druge polovine 18. stoljeća, u stručnoj je literaturi dosad već višestruko potvrđeno. Stoga nam ne preostaje ništa drugo no posve se osloniti na rezultate spomenutih književnopovijesnih studija koje su, između ostalog, (i) pretpostavku o utjecaju Vitezovićeve „zrinijade“ na osamnaestostoljetne hrvatske pjesnike potkrijepile čitavim nizom tekstualnih argumenata, pri čemu se $-\mathrm{u}$ tom smislu - podjednako korisnima mogu pokazati kako punih stotinu godina „stara“ analiza stvaralačkog opusa Jurja Malevca što ju je ispisao Vladoje Dukat, ${ }^{227}$ tako i znatno „mlađi“ prikaz cjelokupne epskopjesničke produkcije našega 18. stoljeća iz pera Davora Dukića. ${ }^{228}$

\footnotetext{
${ }^{227}$ Usp. Dukat 1915: 137-261.

${ }^{228}$ Usp. Dukić 2002.
} 
Prije svega, dokaze o recepciji Odiljenja - one, dakako, u obliku (najvjerojatnijih) različitih kreativnih posudaba - naši su književni povjesnici tako detektirali u nemalom broju danas vrlo slabo poznatih narativnih (,epskih“) prigodnih pjesama Mateše Antuna Kuhačevića, rodom Vitezovićeva sugrađanina. ${ }^{229}$ Riječ je o mahom motivskim i formalnim podudarnostima poput pojave personificiranih kazivača (i u Kuhačevića tako počesto riječ preuzimaju gradovi, pokrajine i vile), potom motiva putnika koji odgovara na lamentaciju pokrajine, naglašenoga tužbalačkog tona koji prožima čitave tekstove, ali i inzistiranja na (jednostruko rimovanom) dvanaestercu, za kojim je ovaj senjski prigodničar lako mogao posegnuti po uzoru na također pretežno dvanaesteračku Vitezovićevu „,zrinijadu“. Očito na Ritterovu tragu Kuhačević u svojim pjesmama, štoviše, provodi funkcionalnu specijalizaciju pojedinih tipova stihova, pa dok tako parno rimovani dvanaesterac većinom rabi u funkciji pripovjednoga stiha (kao što to u Odiljenju čini i naš autor s dvostruko rimovanim dvanaestercem sjevernoga tipa), osmeračku sestinu sa shemom rimovanja ABABCC - dakle, sestu rimu - donosi on u isključivo njihovim lirskim dionicama, ${ }^{230}$ a bit će $\mathrm{i}$ da je, uz to, $\mathrm{i}$ poticaj za brojne kronograme dobio on također čitajući Odiljenje, gdje ih također nalazimo na nekoliko mjesta. Iako je Kuhačević, kako ispravno zamjećuju malobrojni njegovi proučavatelji, ${ }^{231}$ ključni podstrek za svoj pjesnički rad jamačno dobio iz njemačke književnosti austrijskih zemalja, u kojoj su u njegovo vrijeme kružile mnogobrojne prigodnice i pohvalne pjesme - najčešće u obliku anonimno sastavljenih i otisnutih letaka - posvećene Sedmogodišnjem ratu, za većinu pobrojanih formalnih i sadržajnih momenata teško je on u njoj mogao naći uzora, kao i u dotadašnjoj - podjednako pisanoj i usmenoj - hrvatskoj književnosti, u kojoj je jedinim njihovim izvorom bilo dotad upravo Odiljenje sigetsko.

$\mathrm{S}$ istoga se literarnog izvora, kako se čini, napajao i osječki osamnaestostoljetni pjesnik Antun Ivanošić, i to poglavito u svojoj kraćoj deseteračkoj epskoj pjesmi Pisma od uzetja Turske Gradiške iliti Berbira grada (1789.), u kojoj opjevava još uvijek „vruć“ povijesni događaj - austrijsko oslobođenje Gradiške. Ovaj izrazito zanimljiv pjesnički tekst, naime, počinje upravo u trenutku kada sa slavonskoga bojišta u Banju Luku dolijeće ranjeni personificirani orao, koji potom Fatimu - nećakinju turskoga zapovjednika u Gradiški izvještava o kršćanskom osvajanju grada. Da se, kako zamjećuje Dukić, ${ }^{232}$ u svojoj Pismi Ivanošić vidno (motivski) oslanjao na Vitezovićevu ,zrinijadu“, i to ponajvećma na dijalošku pjesmu Gospodična Sofija i oral, koja uključuje identičan motiv orla što djevojci donosi

\footnotetext{
${ }^{229}$ Rođen je Kuhačević, naime, upravo u Senju, no gotovo punih pola stoljeća nakon Rittera - 1697. godine. Inače, njegove prigodnice danje će svjetlo ugledati tek 1878., odnosno stotinu godina nakon njegove smrti.

${ }^{230}$ Detaljnije u: Dukić 2002: 171.

${ }^{231}$ Usp. Isto: 73-84.

${ }^{232}$ Podrobnije u: Isto: $125-126$.
} 
nesretne vijesti iz netom završena rata, najuvjerljivije će potvrditi prvi dio teksta, u kojemu stihove iz uvodnoga dijela Sofije (,,Orle moj, orle moj, nemoj dalje litat, / padi na hrast ter stoj: ništo ću te pitat. / Ni v dubravi evoj ki će te se hitat / niti se dice boj, da te hte pruglo splitat. / (...) / Ne govori toga, nemoj se gubiti, / neg sedi ovoga hrasta na koj kiti / ter pomena tvoga nemoj mi kratiti, / od znanja ti moga neće teže biti. / Otkud lićeš sada, gdi si dosad služil, / s kim si se najzada, moj orle, razdružil? / Cić koga li jada tako se rastužil? / Povij, to bih rada da bi mi poslužil“; II: 735-738 i 751-758) Ivanošić i više nego očito parafrazira (,Orle dragi, kakva ti je sila? / Sidi ovdi na kojojgod grani / pak mi kaži tiho po teani, / kakova te ovud nužda nosi, / odkud letiš, što tražiš i tko si. / Nejma ovom u bostanu dice, / da se iz preče hitaju na ptice. / Ne boj mi se, već pristani litat, / ter mi kaži, što ću te upitat"; Kanižlić, Ivanošić i Katančić 1940: 246), na što je - još prije četvrt stoljeća - prvi u svojoj barokološkoj studiji upozorio Zoran Kravar. ${ }^{233}$

Bit će da su Odiljenje pri sastavljanju svojih (epsko)pjesničkih ostvarenja na umu imali čak i neki sjevernohrvatski (kajkavski) osamnaestostoljetni literati, među kojima se naročito izdvaja književnik pater Gregur Kapucin ili - rodnim imenom - Juraj Malevac, koji je pojedina sadržajna, formalna i napose žanrovska rješenja Vitezovićeve „zrinijade“ ugradio u svoju stihovanu (epsku) kroniku Nestrančno vezdašnjega tabora izpisivanje, objelodanjivanu između 1789. i 1791., u kojoj opjevava ratne događaje iz austrijsko-ruskoturskoga rata. O tekstualnim podudarnostima između Malevčeva i Vitezovićeva djela pisali su povjesničari naše književnosti već potkraj 19. stoljeća, a relativno nedavno istim se pitanjem pozabavio i Davor Dukić, koji u svojoj studiji signalima Malevčeva ugledanja na Odiljenje vidi sličan tip stiha (pretežno parno rimovani, astrofični dvanaesterac), motiv vile, ali i uključivanje pisama, tužbalica te nadgrobnica (napizki) u pretežno ,epski““, pripovjedni tekst. Kreativno naslanjanje na Vitezovića potvrditi nam, precizira Dukić, tako može ne samo primjer sadržajno iznimno interesantne nadgrobnice austrijskome maršalu Laudonu, ${ }^{234}$ koja se u cijelosti sastoji od dijaloga između pokojnika i slučajnog putnika, već i činjenica da je Izpisivanje - $\mathrm{u}$ formalnom pogledu - metrički vrlo šarolik tekst, iako u znatno manjoj mjeri nego što je to Odiljenje. Metričke su varijacije, povrh toga, u Malevčevu tekstu ni manje ni više nego posljedica funkcionalne uporabe pojedinih stihova, pa dok se tako parno rimovani dvanaesterac nameće kao njegov temeljni narativni stih, žanrovski drugačije obilježeni njegovi segmenti (nadgrobnice, poslanice, pohvalnice) većinom bivaju realizirani kraćim i strofički organiziranim stihovima, što neodoljivo podsjeća kako na sličnu strategiju koju smo

\footnotetext{
${ }^{233}$ Usp. Kravar 1993: 155, bilješka 37.

${ }^{234}$ Odnosno Ernstu Gideonu von Laudonu, osvajaču Beograda 1789.
} 
uočili i u Kuhačevićevim prigodnicama, tako i na Ritterovo inzistiranje na tome da sadržajne „rezove“ u svojoj ,zrinijadi“ naglasi i promjenom formalnoga, stihovnog okvira. ${ }^{235}$

Istražujući obiman korpus „epskih“ (epskopjesničkih) tekstova osamnaestostoljetne naše književnosti Davor Dukić pojedina je - većinom motivska i žanrovska - rješenja koja zauzimaju istaknuto mjesto u Odiljenju locirao i u djelima mnogih drugih onodobnih pisaca, na što je i u svojoj studiji s punim pravom držao nužnim upozoriti. Tako se, primjerice, u posljednjoj epskoj pjesmi Kačićeva Razgovora ugodnog naroda slovinskog (1756.) personificirana Bosna obraća starcu Milovanu, u nekoliko, pak, narativnih pjesama Jose Krmpotića kao jedna od govornica pojavljuje se vila, ${ }^{236}$ dok u jednome deseteračkom (epskom) pjesničkom sastavku franjevačkoga dalmatinskog pjesnika Luke Vladimirovića iz nedovršene zbirke Pripisanje Neretve $i$ njezina početka i naseljenja do sadašnjega vrimena riječ uzima rijeka Neretva te pritom izrijekom optužuje Turke za trenutne svoje nevolje. U potonjem motivu, međutim, Vladimirović ne samo što izravno nasljeduje Kačića (a ne Vitezovića), nego valja imati na umu i to da je govor personificiranih rijeka i gradova bio vrlo čest sadržajni moment u tadašnjoj njemačkoj književnosti - poglavito u tzv. ratnoj literaturi, odnosno u stihovanim (,epskim“) izvještajima o aktualnim ratnim događanjima ${ }^{237}$ - iz koje ga je jamačno baštinio i makar poneki naš onovremeni autor. Izrazito je, u pogledu mogućih sadržajnih paralela s Odiljenjem, zanimljiva još i prigodna epska pjesma slunjskoga pjesnika i župnika Šimuna Štefanca pod naslovom Pisma od Ivana Salkovića (1781.), koja tematizira događaje iz Bavarskoga rata (1778.-1779.) i u kojoj ne samo što poziciju govornika (pripovjedača) u više navrata preuzima vila, već je u nju uklopljena čak i nadgrobnica Mijata Salkovića s motivom putnika koji prolazi pored njegova groba. Bez obzira na njezinu frapantnu sadržajnu podudarnost - napose sličnost u konkretnim motivima $\mathrm{i}$ frazama $-\mathrm{s}$ mnogim pjesmama iz nadgrobničkoga ciklusa Odiljenja sigetskog, ${ }^{238}$ ne treba zaboraviti da su motivom natpisa na nadgrobnoj ploči u kojem se pokojnik izravno obraća putniku-prolazniku te uopće generičkim obilježjima epitafa svoje epskopjesničke sastavke premreživali i mnogi onovremeni njemački pjesnici, ${ }^{239}$ čija djela je i sam Štefanac zasigurno imao priliku čitati.

\footnotetext{
235 Opširnije u: Dukić 2002: 137-143. O tome više i u: Dukat 1915: 137-261.

${ }^{236}$ Usp. Dukić 2002: 101-123.

${ }^{237}$ Riječ je o tzv. novinama u stihu ili letcima, koji su se u njemačkoj književnosti pojavili još u 17. stoljeću i u kojima nerijetko susrećemo motiv obraćanja zapovjednika neprijateljske, osvajačke vojske opsjednutomu gradu. Grad pritom nije tek pasivni slušatelj zapovjednikovih riječi, već mu na njih, u pravilu, replicira, što se obično ispostavlja kao otponac za razvijanje čitavoga dijaloga. O ovome sadržajnom momentu u kontekstu ranonovovjekovne njemačke ratne literature detaljnije u: Dukat 1915: 189-190. Usp. i Dukić 2002: 172-173.

${ }^{238}$ U tom je smislu dovoljno - ilustracije radi - citirati tek nekoliko stihova nadgrobničke dionice Štefančeve pisme: „Moj putniče, kada onud projdeš, / i pram crkve putujući dojdeš, / silni junak ovd' u grobu leži, / za takva ga sva krajina drži. / Pokoj vičnji spomeni mu brže / jer Bog ovde tog junaka vrže“ (cit. prema: Dukić 2002: 98). ${ }^{239}$ Detaljnije u: Dukić 2002: 95-100.
} 
S obzirom na to da - Dukićevim riječima - Vitezovićev hrvatski prvijenac, „kao nezaobilazan dio lektire osamnaestostoljetnih pisaca iz sjeverne Hrvatske, sadrži čitav niz artificijelnih postupaka (polimetrija, lirizam, govor neživog, razgovor putnika i jeke, putnika i groba, grobni natpis, stiliziran folklorni motiv ptice-glasnika)“, posve je očekivano to što će se mnogi od njih „kao nesumnjiv dokaz produktivne recepcije Odiljenja, naći i u tekstovima nekolicine sjevernohrvatskih epika (Kuhačević, Kapucin, Štefanac, Krmpotić, Ivanošić)“ (Dukić 2002: 177). To što je, dakle, redom riječ o autorima narativnih (,epskih“) pjesama, odnosno epskopjesničkih sastavaka, značilo bi onda ništa drugo nego da je - kako s pravom konstatira Dukić - i utjecaj što ga je Odiljenje sigetsko izvršilo na njihov pjesnički rad morao izvirati iz činjenice da su oni „razumjeli to djelo kao epsko ili barem u neku ruku kao epsko djelo“ (Isto: 69) jer im se, u suprotnom, ni asimiliranje tekstualnih njegovih rješenja zacijelo ne bi učinilo primjerenim žanru vlastitih ostvarenja. Da su, drugim riječima, naši pisci 18. stoljeća Odiljenju nesumnjivo generički pristupali na većinom ili gotovo u potpunosti jednak način na koji su to činili i s, primjerice, epskim pjesmama iz Kačićeva Razgovora ugodnog, za formalnim i sadržajnim momentima kojih su neki od njih također rado (i često) posezali, ponajbolje nam dokazuje njihova jasno izražena nakana da iz Vitezovićeve ,zrinijade“ baštine isključivo one postupke i literarne strategije koje su očito držali „tipično“ ili pretežno „epskima“ (personificirani govornici, nadgrobnički motiv razgovora putnika i pokojnika, generička obilježja epitafa i lamentacije, funkcionalna uporaba različitih stihova i sl.), vrlo vjerojatno zato što su ih bili već susreli i u nekim drugim, njima dobro znanim epskopjesničkim ostvarenjima (prisjetimo se samo, primjerice, personificiranih kazivača u Kačićevoj pjesmarici). Uvjerenje da je Odiljenje sigetsko upravo epska „pisma“, koja se zahvaljujući „epskim“ svojim obilježjima može i mora nametnuti kao jedan od uzora njihovim narativnim stihovanim sastavcima, možda je dodatno osnaživalo i to što su u svojim rukama imali oni jedno od prvih dvaju njegovih izdanja, u paratekstualnim segmentima kojih je Vitezović - podsjetimo - (još) pledirao za žanrovski homogeno (epskopjesničko) određenje svojega djela, odnosno takvo određenje - u fiktivnom „drugom“ izdanju - donio uz bok oznakama koje su njegovu ,zrinijadu“ predstavljale kao žanrovsku kompilaciju. Bez obzira na to jesu li i u kojoj mjeri i ova Ritterova autoreferencijalna očitovanja utjecala na njegovu onodobnu generičku predodžbu, može se konstatirati da je, kao djelo drugoga najutjecajnijeg autora - poslije, dakako, Andrije Kačića Miošića - u osamnaestostoljetnoj hrvatskoj književnosti, ${ }^{240}$ Odiljenje sigetsko uživalo tada status žanrovski „„čistoga“ teksta, kojega će u pitanje dovesti tek njegovo sljedeće, prvo postumno izdanje. A ono će svjetlo dana ugledati u 
jeku hrvatskoga narodnog preporoda, otvarajući tako i posve novu - devetnaestostoljetnu etapu žanrovskog promišljanja Vitezovićeva djela, obilježenu daleko neujednačenijim, pa i konfuznijim shvaćanjima od onih koja su prevladavala u prethodnom stoljeću.

\section{4. ROMANTIČKE ŽANROVSKE DVOJBE}

Koliki doista utjecaj može imati povoljan društvenopovijesni, a onda i kulturni kontekst na recepciju pojedinoga (književnog) djela izvrsno se pokazuje upravo na primjeru Odiljenja sigetskog, čijem su iznimno dobrom odjeku među devetnaestostoljetnom publikom ponajvećma doprinijele specifične povijesne okolnosti. Naime, izrazit čitateljski interes za literarne obrade teme junačke smrti Nikole Šubića Zrinskog pod sigetskim zidinama polovinom je 19. stoljeća bio, prije svega, potaknut svečanim obilježavanjem tristote obljetnice pada Sigeta (1866.), no i u desetljećima uoči njega Vitezovićevu je stvaralaštvu pa tako i samom Odiljenju - posebna pozornost posvećivana napose zbog činjenice što su upravo njegove pankroatističke (baroknoslavističke) zamisli shvaćane kao jedno od ishodišta ideologije hrvatskoga narodnog preporoda. ${ }^{241}$ Zahvaljujući tim uvelike mu naklonjenim okolnostima, lik Pavla Rittera Vitezovića i njegovo djelo poprilično će visoko kotirati kroz čitavo romantičko razdoblje, što će - između ostalog - možda i najuvjerljivije potvrditi upravo reizdanje Odiljenja, objelodanjeno nešto manje od stoljeća i pol nakon njegova posljednjeg (zagrebačkog) izdanja. Ritterovoj „zrinijadi“ put do čitatelja pritom nije olakšavala samo poticajna „,atmosfera“, već i činjenica da će ovo postumno izdanje biti ujedno i prvo čiju će pojavu na „književnom tržištu“ razglasiti i reklame u pojedinim časopisima, kao i to što su sastavljači (prvih naših) pjesničkih antologija zanimanje za nju pokušavali osnažiti uvrštavanjem pojedinih njezinih dionica u svoje izbore. U drugoj polovini stoljeća po prvi će put Odiljenje postati i predmetom stručnoga interesa, a sve češće će sagledavanje iz književnopovijesne vizure ujedno rezultirati i porastom - podjednako eksplicitnih i implicitnih - žanrovskih njegovih određenja, koja, ipak, predstavljaju samo jedan dio njegove vrlo šarolike i neujednačene devetnaestostoljetne generičke percepcije.

Temelj romantičkoga žanrovskog razumijevanja Odiljenja sigetskog bilo je, dakako, njegovo već spomenuto novo izdanje, koje je u Zagrebu 1836. - na 270. obljetnicu pada Sigeta - ugledalo svjetlo dana ponajviše zaslugom glasovitoga, porijeklom slovačkog biskupa Stjepana (Štefana) Moysesa. ${ }^{242}$ Osim što će u povijesti hrvatskoga jezika i književnosti ovo

\footnotetext{
${ }^{241}$ Pregledno o tome npr. u: Fališevac 2013: 12 i Bratulić 2018: 67-72.

${ }^{242}$ O Stjepanu Moysesu - slovačkom biskupu, profesoru na Kraljevskoj akademiji u Zagrebu i kanoniku zagrebačkoga Kaptola u razdoblju od 1847. do 1851. - detaljnije u: Jembrih 2008: 41-58 i naročito 2016 b.
} 
izdanje ostati zabilježeno kao „prva hrvatska knjiga tiskana novim, Gajevim, pravopisom“ (Bratulić 1997: 16, bilješka 4), točnije „reformiranom latinicom“ (Bratulić 2018: 71), u kontekstu našega istraživanja izdvaja se ono (i) kao (kronološki) prvi izvor za utvrđivanje generičkoga statusa što ga je u 19. st. imala Ritterova „zrinijada“, odnosno kao prvi tekst u kojem nalazimo žanrovske oznake za Odiljenje iz pera jednoga od njegovih devetnaestostoljetnih recipijenata. Priređujući - zajedno s (nepotpisanim) jezikoslovcem Vjekoslavom Babukićem - njegovo prvo postumno izdanje, Stjepan Moyses opremio ga je, naime, vrlo bogatim paratekstualnim odsječkom, koji se - izuzev naslovnice na kojoj je navedeno da četverodijelnome Odiljenju u ovome svesku prethodi uvod s kratkim životopisom Nikole Šubića Zrinskog - sastoji od čak tri (prozna) teksta nejednake duljine. U sva ta tri paratekstualna segmenta Moyses, međutim, kao da teži izgraditi dojam poprilične suzdržanosti kada je u pitanju konkretan žanrovski identitet Vitezovićeva djela, pa dok ga tako u kraćoj uvodnoj napomeni naslovljenoj Dobrovoljnomu Čitatelju - u kojoj pojašnjava neke pravopisne posebnosti ovoga izdanja - definira samo kao „djelo“, u znatno duljem ga predgovoru Ljubezni i slavni Narode Ilirski! - napisanome u koautorstvu s Babukićem ${ }^{243}$ najprije vidi kao „knjižicu“, a potom i kao „pjesmotvor“ te - iznova - „djelo“. ${ }^{244}$ Da je Moyses uistinu zazirao od pobližega (eksplicitnog) generičkog određenja Ritterove „Zrinijade“ potvrdit će i treća, daleko najobimnija paratekstualna komponenta izdanja iz 1836. - već spomenuti uvod ili predgovor Nikola knez Zrinjski i Obsjedjenje Sigetsko ljeta 1566., ${ }^{245}$ posvećen junaštvima sigetskog kapetana - u kojem se konstatira tek to da u Odiljenju ,izpjeva Vitezović ilirskim jezikom branjenje sigetsko“ (Ritter Vitezović 1836: 37), u čemu je ipak moguće nazrijeti i implicitne naznake stvarnoga Moysesova žanrovskog poimanja Odiljenja.

Opisujući ga kao djelo u kojemu je opjevano „branjenje sigetsko“ Stjepan će Moyses Ritterov tekst tako zapravo prezentirati kao (kompaktno) pjesničko ostvarenje posvećeno zbivanjima pod Sigetom u ljeto 1566., čime jasno sugerira da je riječ o „pjesmi““ sadržajno fokusiranoj na sam tijek opsade i pada utvrde, odnosno stihovanom djelu koje sigetske događaje obrađuje u narativnomu obliku. Ovakvo je implicitno njegovo poimanje pritom posve u skladu i sa svim preostalim paratekstualnim generičkim oznakama - „djelo“, „knjižica“, „pjesmotvor“ - kojima, njihovoj prividnoj neodređenosti i općenitosti usprkos, Moyses odaje da Odiljenju sigetskom pristupa kao žanrovski jedinstvenom, odnosno (sadržajno, formalno i strukturno) homogenom ostvarenju te da je ujedno uvjeren u to i da će ga (preostali) njegovi devetnaestostoljetni čitatelji razumjeti na jednak način. Usprkos, dakle,

\footnotetext{
${ }^{243}$ Detaljnije o tome u: Jembrih 2008: 45.

${ }^{244}$ Usp. Ritter Vitezović 1836: I-IX i Jembrih 2016b: 345-349.

${ }^{245}$ Usp. Ritter Vitezović 1836: 1-39.
} 
fingiranoj nepreciznosti u pogledu njezina žanrovskog određenja, Stjepan Moyses sve paratekstualne elemente reizdanja Vitezovićeve „zrinijade“ tako ustvari prožima signalima vrlo konkretnoga generičkog razumijevanja, no da to (najvjerojatnije) shvaćanje Odiljenja epskom pjesmom s njime ipak nisu dijelili i (pojedini) onodobni čitatelji ponajprije će pokazati primjer jednoga časopisnog oglasa, kojim se nedugo nakon njegova izlaska iz tiska pokušavala privući pozornost potencijalnih kupaca.

Naime, u svome će 33. broju iz 1836. zadarske novine na talijanskom jeziku Gazzetta di Zara donijeti, između ostalog, i kraći oglas o tek objavljenim naslovima, među kojima će se naći i prvo postumno izdanje Odiljenja sigetskog, koje je nešto ranije iste godine izišlo u Zagrebu. ${ }^{246}$ Sastavljač ove reklame, dakako, za ovu je priliku Vitezovićevo ostvarenje bio prisiljen i nekako žanrovski precizirati, slijedom čega će - čini se, „moysesovski““ - navesti tek da je ono operetta, što bi se moglo prevesti kao „djelo“, odnosno - da budemo do kraja precizni - „djelce“ (kraće djelo). Iako bi ovakvo određenje isprva zaista moglo navesti na pomisao da se ovdje radi o tek običnom prihvaćanju Moysesovih žanrovskih oznaka ili makar slučajnom podudaranju s njima, ne zaboravimo da je riječ opera - koje je umanjenica upravo operetta $^{247}$ - na talijanskom podrazumijevala (i još uvijek podrazumijeva) ne samo kompaktno književno djelo ili čitav opus jednoga autora, već i složeno književno ostvarenje komponirano od više (zasebnih) dijelova (kompoziciju, sastavak ili - vitezovićevski rečeno „slogu“) koje je žanrovski vrlo teško, ako ne i posve nemoguće preciznije odrediti. U tom bi slučaju i Odiljenje - identificirano i shvaćeno kao operetta - predstavljalo ništa drugo no (žanrovski hibridan) kraći književni sastavak kompilacijskoga tipa, premda ne smijemo posve isključiti ni mogućnost da je navedena oznaka - upotrijebljena u svome prvom značenju trebala upućivati upravo na to da je Ritterov tekst (žanrovski) homogeno literarno djelo, kakvim ga je vidio i biskup Moyses. Kako bilo, ova novinska reklama za novoobjavljeno ponovljeno izdanje Odiljenja sigetskog predstavlja ujedno i prvi devetnaestostoljetni slučaj generički dvojbenoga njegova određenja, ali nipošto pritom i posljednji. Naprotiv, do kraja će se stoljeća zaredati još uistinu kojekakvi pokušaji žanrovskoga identificiranja Ritterove „zrinijade“, no odsada će to redom biti isključivo oni (književnih) povjesničara i antologičara.

Ako generičko razumijevanje Odiljenja u potonjem oglasu označava djelomičan odmak od onoga za koje se u paratekstu njegova reizdanja opredijelio Stjepan Moyses, onda je i ono što ga zatječemo u (kronološki) sljedećem izvoru moguće shvatiti kao njegov samo naoko vjerni produžetak. Riječ je o, konkretno, tri i pol desetljeća „mlađem“ pregledu

\footnotetext{
${ }^{246} \mathrm{Na}$ ovu je reklamu za Odiljenje prvi u svojoj studiji upozorio Nikica Kolumbić (usp. Kolumbić 2005: 481).

${ }^{247}$ Nije, dakle, riječ - kako bi se na prvi pogled moglo pomisliti - o žanrovskom terminu za istoimeno glazbenoscensko djelo izvedeno iz opere.
} 
povijesti hrvatske književnosti Šime Ljubića, u kojem je Vitezovićev hrvatski prvijenac ponešto neodređeno - iznova predstavljen kao „knjiga“ i „dielo“. Da pod tim oznakama, međutim, Ljubić gotovo sigurno nije mislio na epsku pjesmu, sugeriraju nam identične žanrovske odrednice kojima je okrstio i Petrovu Sirenu- Vitezovićeva najvećeg literarnog uzora - ne zaboravivši pritom napomenuti kako najveći dio Petrova „diela“ ili „knjige“ otpada na epsku, odnosno „piesmu junačku“ Obsidu sigecku. ${ }^{248}$ Ignorirajući ovu Ljubićevu, ali i sve prethodne njegove identifikacije, svega nekoliko će godina kasnije Velimir Gaj - sastavljajući bibliografski popis knjiga iz knjižnice svoga oca Ljudevita - Odiljenju uskratiti čak i status „običnoga“" književnog djela, uvrstivši ga tom prilikom u „ladicu“ Historia, antiquitates, biographia et chronologia slavicae, odnosno povijesnih tekstova, i to uz bok drugih Ritterovih historiografskih i pretežno historiografskih djela (Kronike, Oživljene Hrvatske, Stemmatographije, Dva stoljeća uplakane Hrvatske i dr.). ${ }^{249}$ Nije pritom posve jasno kojim to kriterijima Vitezovićeva „zrinijada“ nije udovoljavala, a jesu druga strana (Tassova, Puškinova, Schillerova i dr.) i domaća pjesnička djela (primjerice, Barakovićeva Vila Slovinka, Gundulićev Osman, Relkovićev Satir itd.) smještena u kategoriju Literae slavicae et historia literarum slavicarum in genere, u odjeljak Artes liberalen, poesis (dakle, književnih, pjesničkih tekstova), no da je i među njima bilo žanrovski „sumnjivih“ uradaka koji su obrađivali identične - povijesne - zgode kao i Odiljenje, dokazuje nam i Sirena, koja je u ovoj „niši“ ‘ također našla svoje mjesto. S obzirom još i na to da će, od svih Ritterovih radova što ih je zatekao u očevoj knjižnici, u nju Gaj tako uključiti samo dvije zbirke njegovih anagrama (Anagrammaton liber tertius i Fata et vota: sive opera anagrammaton), ${ }^{250}$ dok će rukopisna mu djela - korespondenciju, poslanice i neke latinske spise - klasificirati kao Codices manuscripti, očito je da svoje razvrstavanje nije u potpunosti provodio ni isključivo po sadržajnom, ni po formalnom, ali ni - kako se čini - prema žanrovskom kriteriju, slijedom čega bi i obilježavanje Odiljenja povijesnim djelom predstavljalo jednu od njegovih najneutemeljenijih, a onda i - do danas - najdvojbenijih generičkih identifikacija uopće.

Krajnje upitnim, pa i sasvim neargumentiranim devetnaestostoljetnim žanrovskim određenjima nije tu bio i kraj jer samo četiri godine nakon Gaja - 1879. - August će Šenoa Ritterovu „zrinijadu“ implicitno proglasiti ni manje ni više nego - svojevrsnim prototipom stihovanih novina. Nagađajući, naime, u jednom od svojih tekstova o sadržajnim i žanrovskim osobitostima izgubljene Vitezovićeve pjesme Novljančica, koja je - po svemu sudeći opjevavala aktualna ratna zbivanja, Šenoa (naslijepo) dolazi do zaključka kako je upravo ona

\footnotetext{
${ }^{248}$ Usp. Ljubić 1869: 505-514.

${ }^{249}$ Detaljnije u: Gaj 1875: 43-61.

${ }^{250}$ Usp. Isto: $145-161$.
} 
morala poslužiti kao predložak kasnijim novinskim brošurama, odnosno novinama koje će potkraj 18. st. cirkulirati našim prostorima te u dvanaestercima izvještavati o ishodima tadašnjih ratnih okršaja. Primjer toga žanra vidi on u kajkavskoj knjižici Nestrančno vezdašnjega tabora izpisivanje, koja je redovito izlazila u razdoblju između 1789. i 1791., donoseći najsvježije vijesti iz austrijsko-turskoga i rusko-turskoga rata ${ }^{251}$ opjevane u dvanaesteračkim pjesmama u koje je njihov autor - već spomenuti pater Juraj Malevac ili Gregor Kapucin - ugradio niz motiva, formalnih i žanrovskih rješenja što ih je mogao zateći upravo unutar korica Odiljenja sigetskog (vile koje govore o ratnim događanjima, dijalog između putnika i pokojnika, metričke paralele, dijaloške pjesme, nadgrobnice itd.). Budući da je, nastavlja Šenoa, u žanrovskom smislu Izpisivanje zapravo „sljedbenik“ Novljančice - kao prvih hrvatskih novina u stihovima - te da Malevac u njemu rabi brojna tekstualna obilježja kojima je svoju „zrinijadu“ premrežio Ritter, nema dvojbe da je - zaključuje - i sama Novljančica bila očito ispjevana na tragu „načina, kojim je Vitezović pisao svoje Odilenje Sigetsko“ (Šenoa 1879: 719), što je prilično dvojbena konstatacija koja, izuzev pukih autorovih pretpostavki, ne počiva zapravo ni na kakvim čvršćim, a kamoli konkretnim dokazima. Upitna je, štoviše, ona poglavito i stoga jer aludira na to da bi i samo Odiljenje zahvaljujući „tipičnim“ motivskim, formalnim i žanrovskim karakteristikama - valjalo shvatiti kao svojevrsni predložak ili prototip novina u stihu, no takvo njegovo (implicitno) shvaćanje, nasreću, nije - izuzev Šenoe - ni u 19. st., a ni kasnije našlo svoje zastupnike. ${ }^{252}$

O tome kako Vitezović „o njekih sgodah pokuša po običaju svoga vremena novine izdavati pod imenom »Novljančica«" (Smičiklas 1879: 265) pisao je - iste godine kada i Šenoa - u svojoj Poviesti hrvatskoj i Tadija Smičiklas, ne pokušavajući ipak - ni implicitno, a kamoli eksplicitno - pod istu žanrovsku oznaku podvesti i Odiljenje. Kratko se osvrnuvši i na Ritterov (književni) rad, Smičiklas je tako hrvatski njegov prvijenac okarakterizirao prilično neodređeno, tek kao „pjesmu“, ${ }^{253}$ no nipošto time ne želeći sugerirati da je riječ o epskopjesničkom tekstu, kao što su to činili pojedini njegovi prethodnici. Naprotiv, da je usprkos ovome određenju kojim kao da upućuje na zaokruženost, odnosno generičku kompaktnost Odiljenja - o njemu on stvorio neku posve drugačiju žanrovsku predodžbu uvidjet ćemo iz njegova pristupa punokrvn(ij)im epskopjesničkim ostvarenjima poput, primjerice, Gundulićeva Osmana, kojega i više nego jasno označava kao „epos“, odnosno „velepjesan“, čime ujedno na vlastitom primjeru pokazuje da u drugoj polovini 19. stoljeća nije manjkalo konkretnih genoloških termina za žanr epske pjesme. Upravo za nekima od tih

\footnotetext{
${ }^{251}$ Oba rata započela su 1787., no dok je prvi završio 1791., onaj se drugi oduljio još punih godinu dana. ${ }^{252}$ Usp. Šenoa 1879: 719-720 i 738-739.

${ }^{253}$ Detaljnije u: Smičiklas 1879: 265.
} 
termina u narednim su godinama posezali i čitatelji iz književnih krugova želeći pobliže odrediti i Vitezovićevu ,zrinijadu“.

I dok se tako Tadija Smičiklas suzdržao od obilježavanja Odiljenja sigetskog epskopjesničkim ostvarenjem, to nije pošlo za rukom i dvojici (prvih) antologičara hrvatskog pjesništva - Augustu Šenoi i Hugi Badaliću, od kojih će fragmente iz Vitezovićeva djela u poetski svoj florilegij uvrstiti tek ovaj potonji. Premda će ga, kao što smo vidjeli, svega tri godine kasnije dovesti u možda i odveć blisku vezu sa žanrom novina u stihu, još 1876. za Šenou Ritterova je „zrinijada“, u generičkom pogledu, predstavljala nešto sasvim drugo, što je moguće razabrati iz uvodne napomene te opsežnoga predgovora $O$ poetici, ${ }^{254}$ prirodanima čuvenoj njegovoj Antologiji pjesničtva hrvatskoga i srbskoga. Usprkos činjenici da se u florilegijskome njezinu dijelu nije našlo mjesta ni za jedan jedini stih iz Odiljenja - kao, uostalom, ni iz Obside sigecke Petra Zrinskoga ${ }^{255}$ - Šenoa se na Vitezovićev hrvatski prvijenac nije zaboravio osvrnuti u napomeni Štiocu, u kojoj, pravdajući svoj vrlo selektivan odabir iz korpusa dotadašnjega hrvatskog pjesništva suženošću prostora, ističe kako naprosto nije „mogo staviti sve epose o Zrinjskom (Karnarutićev, Petra Zrinjskoga, Vitezovićev i Vezićev) u ovo djelo“ (Šenoa 1876), iz kojega je ionako bio prisiljen štošta ispustiti. ${ }^{256}$ Pridoda li se ovoj „tehničkoj“ pripomeni još i to da će, dotaknuvši se u predgovoru $O$ poetici i pitanja metrike našega pisanoknjiževnog epskog pjesništva, kao pisce dvanaesteračke epike on izdvojiti „Dubrovčane starije“ te potom istaknuti kako su u istom stihu pisali „uz njih i ovostrani Hrvati Vitezović i Zrinjski slikovane dvanajsterce“ (Šenoa 1876: XXXV), postat će i više nego očito da je Šenoa za Odiljenje sigetsko imao na umu vrlo preciznu žanrovsku odrednicu. Njegova Antologija, drugim riječima, u kontekstu 19. stoljeća predstavlja zapravo prvi pokušaj da se Vitezovićeva „zrinijada“ deklarativno (izrijekom) proglasi epskom pjesmom, odnosno - šenoinski rečeno - „eposom“, a kada znamo da je ta kvalifikacija proizišla iz pera možda i najvećega onodobnog literarnog autoriteta, neće čuditi to što su je u desetljećima koja su slijedila prihvatili i (neki) drugi naši stručnjaci za književna pitanja.

Implicitni dokaz o prihvaćanju takva njezinog - doduše, ipak ponešto modificiranog žanrovskog shvaćanja u svojoj je antologiji domaćega pjesništva donio Hugo Badalić, no, za razliku od svoga neposrednog prethodnika na istomu poslu, ne u predgovornoj dionici, koja je u ovome izdanju u potpunosti izostala. Badalićevo se, naime, razumijevanje Odiljenja naslućuje upravo iz same prezentacije odabrane pjesničke građe, među kojom se u Hrvatskoj

\footnotetext{
${ }^{254}$ Usp. Šenoa 1876: I-XLVIII.

255 Šenoa je, naime, u Antologiji donio tek jedan jedini epitaf iz zaključnoga dijela Petrove Adrijanskoga mora Sirene, i to onaj Nikoli Šubiću Zrinskom (usp. Isto: 327).

${ }^{256}$ Hrvatski dio Vitezovićeva književnog opusa, ipak, u Antologiji zastupaju pjesma Hrvatkinja (iz Valvasorove Slave vojvodine Kranjske) te nekolicina poslovica iz njegova Priričnika (usp. Isto: 142-143 i 327).
} 
antologiji napokon našla i dionica iz Vitezovićeve „zrinijade“, i to pjesma Ban orsagu, kojoj je za ovu priliku dodijeljen ponešto izmijenjen naslov - Ban Nikola Šubić-Zrinjski Hrvatskoj. ${ }^{257}$ Spomenutom fragmentu Odiljenja, smještenomu na samom početku odjeljka knjige u kojem se donose poslanice (kao žanr „didaktičnog pjesničtva“"258), Badalić pritom odmah ispod naslova pridodaje napomenu kako je riječ o stihovima izlučenima ,iz pjesme »Odiljenje Sigetsko«“ (Badalić 1892: 277), i to posve jednaku onoj kojom je, primjerice, stotinjak stranica ranije čitateljima otkrio da je pjesnički segment naslovljen Starac major preuzeo „,iz I. pjevanja pjesme »Dom i sviet«“ (Isto: 182) Franje Markovića. Budući da je fragment iz Markovićeva epa još pritom uključen i u ciklus „epskoga pjesničtva“, posve je očito da Badalić odrednicom „pjesma“ - osim ako se ona ne odnosi, dakako, na kraće lirske sastavke okupljene u prvome dijelu antologije - podrazumijeva upravo epskopjesničke tekstove, iz čega bi onda slijedilo da i Odiljenje sigetsko vidi kao cjelovito, premda ne i žanrovski jedinstveno epsko djelo. Da je Badalić itekako bio svjestan generičke hibridnosti Ritterove „zrinijade“ ponajbolje odaje već sam čin uvrštavanja jednoga njezina dijela uz bok drugim - redom samostalnim (lirskim) - epistolama (Bruerevićevoj, Kaznačićevoj, Pavlinovićevoj i dr.), a ne među fragmente tekstova koji pripadaju nekome od brojnih žanrova epskoga pjesništva („heroički epos“, „,romantički epos“, „,idilski epos“ itd.), kojim je ujedno i jasno dao do znanja da Odiljenje vidi kao ,pjesmu“ čije se dionice žanrovski različito mogu odrediti, a da ona - kao cjelina - pritom ne (iz)gubi ništa od svoje pretpostavljene „epskosti““. $\mathrm{Na}$ kraju krajeva, romantički su epici ionako bili skloni generički „složenim“, mješovitim epskopjesničkim ostvarenjima, što je i samome Badaliću morao očito biti najveći poticaj da očito na tragu Šenoe - ustraje u poimanju Odiljenja kao zaokruženoga, no u srži ipak generički kompiliranoga pjesničkog teksta.

Identično Badalićevo žanrovsko tretiranje Odiljenja sigetskog i (pojedinih) epskopjesničkih ostvarenja iz njegova vremena neopravdano je, dakle, držati posve slučajnim ako znamo na koji se način u razdoblju romantizma u nas pristupalo žanru epske pjesme. Da bi smo to doznali, dovoljno je zaviriti u već spomenuti tekst $O$ poetici, kojim Šenoa otvara svoju Antologiju i u kojem se, između ostalog, dotiče i pojedinih „karakterističnih“ obilježja niza književnih žanrova, pa tako i onih (povijesne) epske pjesme. Epsko bi tako pjesništvo, pojašnjava Šenoa, moralo opjevavati prošle događaje - i to najčešće borbu između dvaju naroda, država ili vlasti ili naprosto borbu protiv sile - pri čemu nije u njemu zabranjeno „premetati kronologični red sgodjaja, te pripoviedati sgodnom prilikom poslije, što se prije

\footnotetext{
${ }^{257}$ Usp. Badalić 1892: 277-278.

${ }^{258}$ Pjesničke poslanice su - uzgred budi rečeno - kao (pod)žanr „didaktičnog i opisnog pjesničtva“ bile prisutne i u Šenoinoj antologiji (usp. Šenoa 1876: 316-320).
} 
dogodilo“ (Šenoa 1876: XXXV), kao ni - bez obzira na poželjnu objektivnost - upustiti se u opisivanje doživljaja pojedinih junaka, pa čak i pod cijenu generičkoga približavanja lirskoj poeziji. Ovakvo shvaćanje žanra epske pjesme (ili, konkretnije, povijesnoga epa) Šenoa pritom oblikuje isključivo na temelju akumuliranih književnopovijesnih spoznaja, odnosno naprosto popisujući „karakteristična“ epskopjesnička obilježja koja su dijelili pripadnici žanra kroz dulji (višestoljetni) vremenski period, što će reći da je ep u romantičkoj optici - a to se odnosi i na sve ostale žanrove koji su u to vrijeme bili „u opticaju“ - zapravo kotirao kao izvanpovijesna i statična kategorija s jasno definiranom i nepromjenjivom paletom tekstualnih značajki. S obzirom na to da su, osvrćući se iza sebe, devetnaestostoljetni autori tako uvidjeli i da su u književnoj povijesti - navlastito od 16. stoljeća - sve veći značaj počela dobivati epska ostvarenja prožeta prepoznatljivo ,neepskim“ osobinama, tu su žanrovsku hibridnost (povijesnoga) epa i oni prihvatili kao njegovu specifičnu „karakteristiku“, ne libeći se pisanja generički izrazito mješovitih epskopjesničkih sastavaka, ${ }^{259}$ odnosno prihvaćajući tekstove s raznolikim generičkim obilježjima kao punokrvna epska djela. Slijedom toga, ni pojedini naši književni povjesnici iz (ponajvećma) druge polovine 19. stoljeća - generički ga procjenjujući na podlozi tada aktualne epskopjesničke produkcije - nisu se suočili ni s najmanjom preprekom u svojim nastojanjima da Odiljenje - eksplicitno ili manje eksplicitno klasificiraju kao epsku ,pjesmu“, odnosno - kao što je to 1897. u svojoj biografskoj studiji o Vitezoviću učinio Radoslav Lopašić - „krasni spjev“ (Lopašić 1897: 54), ${ }^{260}$ čime su ujedno i u velikoj mjeri usmjerili dvadesetostoljetna njegova žanrovska shvaćanja.

Budući da konkretni podaci o njegovoj čitanosti, kao ni dokazi o tome kako su ga žanrovski poimali „obični“ čitatelji ne postoje ili do nas naprosto nisu dospjeli, informacije o devetnaestostoljetnom generičkom tretmanu Odiljenja sigetskog iznova je - kako se pokazalo - bilo nužno potražiti pretežno u tekstovima njegovih „stručnih“ recipijenata. Velik ugled što su ga Pavao Ritter Vitezović i njegove ideje tih godina uživali, reizdanje Odiljenja iz 1836. praćeno reklamama u književnim časopisima, uvrštavanje njegovih fragmenata u pojedine pjesničke antologije i pažnja koju su mu povremeno poklanjali onodobni književni povjesnici sugeriraju ne samo to da je za Ritterovu ,zrinijadu“ interes u 19. stoljeću doista i postojao, već i to da je on očito bio vrlo širok, kao što su - uostalom - široke bile i generičke granice

\footnotetext{
${ }^{259}$ Usp. o tome u: Fališevac 1997: 16-20, 293-337 i Brešić 2015: 107-108.

${ }^{260}$ Da su u drugoj polovini 19. stoljeća odrednice „ep“ [„,epos“, (epska) „pjesma“ itd.] i „spjev“ shvaćane isključivo kao sinonimi potvrditi nam može već sam Lopašićev tekst, u kojemu je spomenutom određenju Odiljenja „spjevom“ prethodila upravo njegova klasifikacija „epom“ (usp. Lopašić 1897: 42). U narednom će se stoljeću, kao što će biti pokazano u nastavku, to sinonimsko povezivanje oznaka „ep“ i ,spjev“ provoditi ipak sve rjeđe, pa će tako općenitom odrednicom „spjev“ mnogi proučavatelji obilježavati žanrovski dvojbena ili gotovo posve neodrediva pjesnička djela nalik samomu Odiljenju sigetskom.
} 
unutar kojih su ga tadašnji književni i književnopovijesni eksperti (najprije implicitno, a zatim i sve eksplicitnije) smještali. Trudeći se proniknuti u njegov (izrazito kompleksan) žanrovski identitet, potonji su mu devetnaestostoljetni recipijenti pridavali, kako smo pokazali, poprilično raznolike generičke oznake, no dok se u onih čiji pristupi datiraju iz - otprilike prve dvije trećine stoljeća može još nazrijeti stanovit oprez u pogledu njegove žanrovske identifikacije (za njih je, podsjetimo, bilo ono „pjesmotvor“, „dielo“, operetta, „knjiga“, povijesno djelo ili - samo implicitno - epska pjesma), oni iz posljednjih dvaju i pol desetljeća po tom su pitanju bili ipak daleko precizniji i odrješitiji, ne dvojeći u to da mu ponajbolje pristaje upravo odrednica epske pjesme. To će, ukratko, značiti da su - iako je epskopjesničko razumijevanje Vitezovićeve ,zrinijade“ na koncu prevladalo te (isprva) nastavilo dominirati i u idućem stoljeću - devetnaestostoljetnu (,stručnu“) recepciju Odiljenja sigetskog u najvećoj mjeri usmjerile žanrovske dvojbe, odnosno - sve do potkraj stoljeća - sveopći izostanak konsenzusa u pogledu najprimjerenijega njegova generičkog određenja, zbog kojega je pokatkad ono identificirano ne samo kao „pripadnik“ poluknjiževnih (,novine u stihu“), već i sasvim izvanknjiževnih žanrova (,povijesno djelo“). Neovisno, dakle, od načelnoga opredjeljenja (dijela) književnih povjesnika za njegov epskopjesnički identitet, očito je da su (i) generička lutanja dvadesetostoljetnih proučavatelja Odiljenja svoj korijen imala u romantičkim klasifikacijskim nedoumicama, koje će se u novome stoljeću - zahvaljujući činjenici da su ga se u većoj ili manjoj mjeri tada dotaknuli mnogobrojni „ritterolozi“ i ini književni, pa i izvanknjiževni stručnjaci - vidno intenzivirati, odnosno produbiti.

\section{5. ŽANROVSKI STATUS ODILJENJA U KNJIŽEVNOPOVIJESNIM PRIKAZIMA I} STUDIJAMA

S punim bi se pravom moglo reći da je s početkom 20. stoljeća otpočela ujedno i posve nova etapa u literarnom životu Vitezovićeva Odiljenja sigetskog. Stoljeće je to, naime, u kojem ovoj ,zrinijadi“ neće manjkati (većinom stručnoga) čitateljskog interesa, a povremena njezina tumačenja iz književnopovijesne vizure pratit će tada - naročito u drugoj njegovoj polovini - i opetovana cjelovita reizdanja te niz izbora, ${ }^{261}$ ali i uvrštavanje u gotovo

\footnotetext{
261 Prvo cjelovito dvadesetostoljetno izdanje Odiljenja sigetskog priredio je i u 29. knjizi Građe za povijest književnosti hrvatske JAZU 1968. objavio Tomo Matić, samo tri godine kasnije - 1971. - pretisak njegova prvog izdanja i tekst u suvremenoj transkripciji objelodanjeni su u knjizi Opsada Sigeta (zajedno s Črnkovim Podsjedanjem i osvojenjem Sigeta te Karnarutićevim Vazetjem Sigeta grada), a 1976. cjelovit je njegov tekst uz izbor iz drugih hrvatskih Vitezovićevih, ali i Frankopanovih te djela Petra Zrinskoga - uvršten i u 17. knjigu edicije Pet stoljeća hrvatske književnosti. Odabrane dionice iz Odiljenja sigetskog, pak, u svojoj je povijesnoj monografiji Obrana Sigeta 1987. donio Anđelko Mijatović, a pojedini će njegovi fragmenti svoje mjesto potom naći i u vrlo preglednim izborima iz Vitezovićeva stvaralačkog opusa što su ih priredili Josip Bratulić (1994.),
} 
sve književnopovijesne priručnike, pa čak i na (šire) popise lektirnih naslova za učenike srednjih škola i studente koji pohađaju fakultetske kolegije iz starije hrvatske književnosti. To što su, međutim, tadašnje književnopovijesne studije i pregledi posvećivanjem zaslužene (iako ni izbliza dovoljne) pozornosti Ritterovu hrvatskom prvijencu jednom za svagda potvrdile da je riječ o nezaobilaznom djelu u povijesti naše književnosti neće ipak značiti i to da su ga ujednačeno, a kamoli identično vrednovale, premda je velika većina proučavatelja desetljećima dijelila mišljenje kako se ne radi o ostvarenju od krupnijega pjesničkog značaja. ${ }^{262}$ Ako o literarnim njegovim (ne)kvalitetama među književnim našim povjesnicima dugi niz godina tako i nije bilo većega spora, nipošto se isto neće moći reći i za - nama najzanimljiviji - žanrovski dvadesetostoljetni tretman Odiljenja, koji prilično jasno pokazuje da u stručnim krugovima ni kroz čitavo prošlo stoljeće nije (još) postignut dogovor o njegovu žanrovskom statusu, a kamoli iznađena konkretna i općeprihvaćena generička oznaka koja bi u potpunosti pristajala takvu izrazito hibridnom (višežanrovskom) tekstu.

Suvremeni povjesničari hrvatske književnosti u svojim su pokušajima žanrovske kategorizacije Vitezovićeve „zrinijade“ nekim određenjima, ipak, davali nešto veću prednost nego onima drugim, pri čemu je kao jednu od najpreferiranijih generičkih odrednica za Odiljenje definitivno pritom moguće izdvojiti upravo onu epske pjesme. Očigledno se nadovezujući na dominantna generička shvaćanja s konca prošloga stoljeća, i pojedini su dvadesetostoljetni stručnjaci za literarna pitanja u Odiljenju, dakle, vidjeli punokrvni epskopjesnički tekst, pa će tako i sastavljač jednoga od prvih (kratkih) pregleda povijesti hrvatske književnosti - Cherubin Šegvić - već 1911. pripomenuti kako se Ritterovo djelo

odnosno Marko Samardžija (1999.). Dodamo li ovome još i to da Ritterovu „zrinijadu“ nisu zaboravili ni priređivači izdanja objavljenih u povodu 450. obljetnice pada Sigeta - Ivan Pranjić, koji njezin cjelovit tekst uključuje u knjigu Sigetski boj u hrvatskoj epici (2016.), te Josip Bratulić, Vladimir Lončarević i Božidar Petrač, u čijoj su antologiji Nikola Šubić Zrinski u hrvatskom stihu (2016.) predstavljeni odabrani njezini segmenti postat će i više nego očito da Odiljenje sigetsko zaslužuje epitet najizdavanijega Vitezovićeva ostvarenja ne samo u posljednjih (dvje)stotinjak godina, nego i uopće.

${ }^{262}$ Već 1932. Mate je Ujević tako ustvrdio da Odiljenje „nema nikakve umjetničke vrijednosti“ te da - kao takvo - pokazuje da je Vitezovićeva „pjesnička sposobnost bila (...) malena“ (Ujević 2009: 78). Nešto više od desetljeća kasnije Mihovil Kombol u čuvenoj svojoj Povijesti hrvatske književnosti do narodnog preporoda zaključuje kako Odiljenje ne svjedoči o Ritterovoj „velikoj pjesničkoj invenciji“ (Kombol 1961: 280), a i za Krešimira Georgijevića ono pokazuje da njegov autor „,nije bio osobiti pjesnički talent“ (Georgijević 1969: 123) jer, sve u svemu, „nije unio u književnost ništa novo“ (Isto: 67). I Tomo Matić će, priređujući kritičko izdanje Odiljenja i Senjčice, 1968. zaključiti kako „hrvatski stihovi Vitezovićevi nijesu svjedoci pjesničkog talenta“ (Matić 1968: 103), Franjo Švelec će, pak, potvrditi kako Odiljenjem naš autor „nije dostigao visok domet“ (Švelec 1974: 257), dok će Josip Vončina u uvodnoj studiji kojom je popratio izdanje Vitezovićevih izabranih djela ustvrditi da se u većini njegovih zrelih radova - a tu misli i na Odiljenje - očituje tek ,prazna rječitost““ (Vončina 1976a: 339). Premda je o njegovoj „zrinijadi“ iznio neke znatno pozitivnije opservacije od svojih prethodnika, i Slobodan Prosperov Novak će konstatirati kako ,ton svoga najvažnijeg književnog djela ponavlja Vitezović u svim svojim latinskim i hrvatskim cjelinama“, čime se potvrđuje kao „pjesnik lamentacija, pisac dugih i zamornih stihova u kojima su se najčešće gradovi ili simbolični značajevi pojavljivali kao razgovornici“ (Prosperov Novak 1999: 704), dok Dubravko Jelčić o Odiljenju sudi znatno strože i jezgrovitije, videći ga kao tek dokaz Ritterovih „skromnih pjesničkih mogućnosti“ (Jelčić 2004: 117). 
proteže „u četiri pjevanja“ (Šegvić 1911: 82), čime i više nego bjelodano aludira na to da mu valja pristupiti kao i svakomu drugom - u pjevanja razdijeljenom - „epskom“ ostvarenju. Od Šegvićevih se konstatacija samo djelomično odmaknuo David Bogdanović, koji, pak, u svojoj književnopovijesnoj „panorami“ Odiljenje definira kao „pjesan“ ili „pjesmu“ (Bogdanović 1932: 452), i to svega nekoliko redaka nakon što je utvrdio da mu nedostaje cjelovito pripovijedanje o padu Sigeta, odnosno da se u njemu donose ,pojedine slike iz sigetskoga boja“ zaogrnute „u ruho govora, pisama, apostrofa, epitafija, razgovora“ (Isto: 452). U svome paralelnom poimanju Vitezovićeve, „zrinijade“ kao žanrovski homogenoga (dakle, (epsko)pjesničkog), a ujedno i heterogenoga (višežanrovskog) teksta Bogdanović, međutim, neće ostati usamljen budući da koncem prošloga stoljeća vrlo slične zaključke o Odiljenju u svoja čak dva prikaza povijesti hrvatske književnosti izriče i Slobodan Prosperov Novak.

Vidno zatečen njegovom nimalo uobičajenom sadržajnom, formalnom, kompozicijskom te - iznad svega - žanrovskom „fakturom“, Prosperov će Novak tako najprije u knjizi Hrvatska književnost do Narodnog preporoda (koju je zamislio kao svojevrsnu nadopunu čuvene Kombolove dopreporodne povijesti domaće književnosti) Odiljenje sigetsko odlučno proglasiti „baroknim epom“ (Kombol i Prosperov Novak 1995: 309), da bi ga potom - samo nekoliko stranica kasnije - (generički) opisao citatom što ga je u svojem književnopovijesnom priručniku donio Krešimir Georgijević263 i shodno kojem Ritter u Odiljenju „,ne želi pjevati ep ili epopeju, jer zna da je to prije njega učinio Petar Zrinjski“, te ga zato i realizira kao „niz elegičnih razgovora i oproštaja sa Sigetom i njegovim junacima“ (Isto: 317). Georgijevićevo određenje Odiljenja kao „niza elegičnih razgovora“ Prosperov Novak pritom još - vidimo - dodatno naglašava kurzivom, a zatim ga u nastavku potvrđuje i citatom Josipa Vončine, koji je u jednoj od „ritteroloških“ svojih studija utvrdio kako se Vitezović u svome djelu ,lišio (...) ponajprije epske osnove djela“, a pojačao njegovu liričnost, što je rezultiralo time da lirska koncepcija Odiljenja „kao temeljna nit drži na okupu njegove prividno nepovezane dijelove“ (Isto: 319). Da je prije ovdje riječ o očitoj pomutnji u pogledu žanrovske definicije Odiljenja nego o tek hotimičnom (iako nezgrapno izvedenom) pokušaju da se na vlastitom primjeru ukaže na problem nemogućnosti jednoznačnoga njegova generičkog određenja potvrdit će i slučaj samo četiri godine „mlađe“ Povijesti hrvatske književnosti, u kojoj na nekoliko mjesta u tekstu Prosperov Odiljenje proziva epom (jednom čak i „spjevom“‘264), da bi na koncu hladnokrvno ustvrdio kako je u svome djelu Vitezović „shvatio da više nema smisla pisati narativni ep o Sigetu“ (Prosperov Novak 1999: 699). Ove

\footnotetext{
${ }^{263}$ Riječ je o, dakako, Georgijevićevoj knjizi Hrvatska književnost od 16. do 18. stoljeća u sjevernoj Hrvatskoj i Bosni (Zagreb, 1969).

${ }^{264}$ Usp. Prosperov Novak 1999: 698.
} 
- očigledno - nerazriješene Prosperovljeve žanrovske dvojbe, koje su dovele do čak dvostrukoga paralelnog identificiranja Odiljenja sigetskog epom, ali i tekstom kojemu nedostaju neke „temeljno epske“ značajke, nisu zapravo ništa drugo no tek jedan od najilustrativnijih primjera generičkih „nevolja“ s kojima su se redovito suočavali prošlostoljetni ,ritterolozi“ i povjesničari hrvatske književnosti prisiljeni pobliže odrediti ovo neobično Ritterovo literarno ostvarenje.

Klasifikacijske nedoumice izazvane heterogenim žanrovskim identitetom Vitezovićeve ,zrinijade“ nisu, dakako, mimoišle ni mnogobrojne autore književnopovijesnih studija, među kojima ponajprije vrijedi izdvojiti one koji su joj također više ili manje rezolutno pristupali kao epskopjesničkom ili pretežno „epskom“ djelu. Redom je pritom riječ o tekstovima nastalima u drugoj polovini prošloga stoljeća, kojih najveći broj otpada na studije posvećene korpusu baroknoga epskog pjesništva, u kontekstu kojega su njihovi autori promatrali i žanrovski „dvojbeno“ Odiljenje sigetsko. U svojoj je tako knjizi Rasprave o hrvatskoj baroknoj književnosti Pavao Pavličić još 1979. neke sadržajne i formalne specifičnosti Vitezovićeva teksta prepoznao kao „tipične“ - čak, štoviše, i primjerne - za naš povijesni ep baroknoga razdoblja, ${ }^{265}$ a isto će potom - u studiji „Tasso i hrvatski ep“ - 1997. učiniti i Dunja Fališevac, ${ }^{266}$ koja nekoliko godina kasnije Odiljenje čak uvrštava i u krug najreprezentativnijih domaćih sedamnaestostoljetnih epskih djela. ${ }^{267}$ Odiljenje sigetsko 1991. u doktorskoj je svojoj disertaciji posvećenoj Vitezovićevu stvaralačkom opusu „epom“ (epic) označila i jedna od rijetkih inozemnih ,ritterologinja“ - engleska povjesničarka Catherine Anne Simpson - pripomenuvši kako se „priča“ (telling) u njemu (priča, naracija) o bitci pod Sigetom, ${ }^{268}$ a njezinim će stopama zatim poći i naš povjesničar Ivo Banac, koji Ritterov vernakularni prvijenac također vidi kao „epsku pjesmu“. 269

Što se pobrojanih dvadesetostoljetnih identifikacija Odiljenja epskopjesničkim tekstom tiče, nema dvojbe da su one, ako ne već izravno preuzete iz prošlostoljetnih (romantičkih) izvora, onda svakako pod utjecajem generičkih shvaćanja iz 19. stoljeća, odnosno - preciznije rečeno - romantičkih koncepcija književnih žanrova. To će, drugim riječima, značiti da su pojedini naši književni povjesnici, tragajući za najprikladnijom generičkom odrednicom za Ritterovo ostvarenje, žanrovima pristupali na isti način na koji su to činili i romantički njihovi prethodnici - dakle, kao statičnim i za svagda definiranim

\footnotetext{
${ }^{265}$ Detaljnije u: Pavličić 1979b: 13-16.

${ }^{266}$ Studija je objelodanjena u knjizi Kaliopin vrt: studije o hrvatskoj epici (usp. Fališevac 1997: 161-175).

${ }^{267}$ Usp. Fališevac 2003: 503.

268 Podrobnije u: Simpson 1991: 55.

${ }^{269}$ Citirajući poslovicu iz Vitezovićeva predgovora prvome izdanju Odiljenja Banac u svome tekstu, naime, tako pripominje da je ona zabilježena „u stihovima jedne od njegovih epskih pjesama“ (Banac 1996: 18).
} 
kategorijama - u čemu ih je uvelike poticala i (naročito u nas) vrlo utjecajna teorija žanrova Emila Staigera, glavninom izrasla upravo iz romantičkih genoloških temelja. Pretežno se iz toga razloga mnogima od njih i učinilo da Odiljenju može pristajati jedino žanrovski okvir epske pjesme jer - na kraju krajeva - ipak je riječ o stihovanom djelu koje opjevava stvarne, povijesno provjerljive ratne događaje i koje je, kao takvo, blisko isključivo epskopjesničkim ostvarenjima, čiji je sadržaj neizbježno - dakle, u svim razdobljima i svim nacionalnim književnostima - uključivao upravo prikaze stvarnih ratnih zbivanja. Da se tematska posvećenost opisivanju bojnih okršaja u versificiranoj formi još i danas - u prvim desetljećima 21. stoljeća - proučavateljima pokatkad zna učiniti dovoljno valjanim razlogom da neko djelo - bez dodatne književnopovijesne i generičke provjere - kategoriziraju kao epsku pjesmu pokazuje nam i primjer obljetničke antologije Sigetski boj u hrvatskoj epici, u sklopu koje je i samo Odiljenje doživjelo svoje novo cjelovito reizdanje. ${ }^{270}$ Očito polazeći od činjenice da se u njoj Vitezović latio događaja koji je prije i poslije njega bio temom mahom epskih tekstova, priređivač antologije Ivan Pranjić i njegovu je ,zrinijadu“ ne samo uvrstio među ina epska ostvarenja posvećena sigetskoj katastrofi, već i - kako vidimo iz sama naslova - izrijekom okrstio kao ep, proglasivši je nešto kasnije i ,spjevom“ (Pranjić 2016: 6), no pod time očito misleći - u romantičkomu duhu - upravo na žanr epske pjesme.

Nasuprot ovim - nerijetko i prilično samouvjerenim - svrstavanjima Odiljenja sigetskog u „ladicu“ epske pjesme stoje, ipak, oni književnopovijesni pregledi i studije iz prošloga stoljeća u sklopu kojih neće biti ni riječi o njegovu eventualnom epskopjesničkom žanrovskom identitetu, kao i oni u kojima će se - na temelju ovih ili onih argumenata - takva njegova kategorizacija otvoreno pokušati osporiti. I više nego svjesni njegove generičke kompleksnosti, književni povjesnici koji stoje iza ovih tekstova za Vitezovićevo su se ostvarenje tako pokušavali domisliti što neutralnije žanrovske odrednice, a u najvećem broju slučajeva rezultat njihovih je napora bilo općenito određenje Odiljenja kao „djela“. Već u kasnodevetnaestostoljetnom prikazu povijesti hrvatske i srpske povijesti iz pera Đure Šurmina proglašeno je tako ono „pjesničkim radom“ i „djelom“ (Šurmin 1898: 135), a za sličnim će oznakama petnaest godina kasnije posegnuti i Branko Vodnik u prvoj knjizi svoje Povijesti hrvatske književnosti, identificirajući ga ondje tek kao „pjesničko djelo“. ${ }^{271}$ Libeći se preciznijega njegova žanrovskog definiranja, i Vitezovićev će biograf Vjekoslav Klaić Odiljenje kvalificirati „samo“ kao „pjesničko djelo“, odnosno „pjesmotvor“, 272 1932. u svome

\footnotetext{
${ }^{270}$ Usp. Pranjić 2016: 105-202.

${ }^{271}$ Usp. Vodnik 1913: 298.

272 Detaljnije u: Klaić 1914: 57-62.
} 
će ga Pregledu hrvatskih pisaca i knjiga i Mate Ujević predstaviti kao „djelo“, ${ }^{273}$ dok će Slavko Ježić, pak, 1944. u prvome cjelovitom pregledu povijesti domaće književnosti konstatirati kako je ono „prvo veće pjesničko djelo Pavla Vitezovića“ (Ježić 1993: 147). I Antun Barac Ritterovu „zrinijadu“ vidi kao „hrvatsko djelo u stihovima“ (Barac 1963: 52), 274 dok je nešto rječitiji i konkretniji Franjo Švelec najprije proziva „djelom“, da bi potom pripomenuo kako je to „djelo“ zapravo koncipirano kao „niz monologa i dijaloga“ (Švelec 1974: 257 i 259), pri čemu valja znati da i žanrovski dvojbenu Ritterovu latinsku kroniku u stihovima Dva stoljeća ucviljene Hrvatske također on definira kao „,povijesno-pjesničko djelo u heksametrima“ (Isto: 260), kao, uostalom, i generički složeno „djelo“275 Petra Zrinskoga Adrijanskoga mora Sirena. S obzirom na to da je - zbog izostanka tipične „epske niti“ - za njega očito da Vitezović nije namjeravao napisati ep, i Krešimir će se Georgijević u svome pregledu ranonovovjekovne sjevernohrvatske i bosanske književnosti za Odiljenje kao najpreciznije dosjetiti upravo oznake ,,pjesničkoga djela“ ${ }^{276}$ dok će ga Ivo Frangeš - izrazito kritički nastrojen spram Vitezovića i njegova stvaralaštva u cijelosti - u jedva jednoj jedinoj rečenici koju mu posvećuje nazvati „običnim“ tek „djelom“. 277

Za najvećega našeg dvadesetostoljetnog književnopovijesnog autoriteta za stariju hrvatsku književnost - Mihovila Kombola - Odiljenje sigetsko neće biti samo Vitezovićevo „glavno pjesničko djelo“, nego ujedno i (formalno i generički) kompleksan tekst sačinjen od „niza samostalnih spjevova u obliku monologa, dijaloga, poslanica i epitafija“ (Kombol 1961: 280). Za razliku od Adrijanskoga mora Sirene, koju će također odrediti kao „djelo“,278 Kombol u Ritterovoj ,zrinijadi“ tako zapravo prepoznaje i razlučuje različite žanrovske „slojeve“ - dijaloge, monologe, epistole, nadgrobnice, pa i oproštajne govore - u čemu ipak nije bio i prvi budući da su nekoliko desetljeća prije njega o konkretnim žanrovima na „prostoru“ Odiljenja pisali već Branko Vodnik ${ }^{279}$ te - još ranije - Milivoj Šrepel, ${ }^{280}$ na zapažanja kojih se $\mathrm{i}$ on sam ponajviše naslanja. Potonji pokušaji da se u hibridnom

\footnotetext{
${ }^{273}$ Usp. Ujević 2009: 78.

${ }^{274}$ Već je Slavko Ježić i Sirenu Petra Zrinskoga odredio podjednako neprecizno kao i Odiljenje - kao „knjigu“ (Ježić 1993: 142-143) - a nakon njega to će učiniti i sam Barac, koji i Sireni također dodjeljuje općenite generičke oznake: „djelo“ i „knjiga“( (usp. Barac 1963: 50).

${ }^{275}$ Usp. Švelec 1974: 245.

${ }^{276}$ Usp. Georgijević 1969: 132. „Djelom“ Georgijević proglašava i Sirenu Petra Zrinskoga (usp. Isto: 94).

277 Detaljnije u: Frangeš 1987: 106.

${ }^{278}$ Usp. Kombol 1961: 273-274.

${ }^{279}$ U svojoj Povijesti hrvatske književnosti iz 1913. Vodnik tako piše da je Odiljenje „pjesničko djelo“ u kojem zatječemo govore, dijaloge, poslanice i epitafe, a sve te žanrove pritom vidi kao oblike uvriježene u prigodnome pjesništvu kojem je Vitezović itekako bio sklon (usp. Vodnik 1913: 299).

280 Šrepel će, naime, u čuvenoj svojoj studiji „Sigetski junak u povijesti hrvatskoga pjesništva“ u Vitezovićevu hrvatskom prvijencu detektirati govore, apostrofe, poslanice (,listove“), razgovore i epitafije (usp. Šrepel 1902: 105), a upravo na te će se njegove zaključke desetljeće kasnije osloniti i Vodnik, koji ih u svojoj Povijesti - a nakon njega će to učiniti i sam Kombol - većim dijelom tek doslovno ponavlja.
} 
Vitezovićevu „djelu“ lociraju konkretni (samostalni) žanrovi ili njihovim značajkama obilježene dionice predstavljaju, nažalost, raritet u korpusu književnopovijesnih prikaza, dok u malobrojnim studijama u kojima se Odiljenju pristupa kao (pjesničkom) „djelu“ - kao u, primjerice, onoj Tome Matića, u kojoj je ono predstavljeno kao „djelo zaodjenuto u stihove“ (Matić 1968: 104) - takvi pokušaji nisu zabilježeni uopće. Rijetkost, s druge strane, u istim tim pregledima povijesti domaće književnosti ne predstavljaju, kao što smo vidjeli, (provizorna) generička izjednačavanja Odiljenja sigetskog i - njegova izravnog literarnog (pa i generičkog) uzora - Adrijanskoga mora Sirene Petra Zrinskoga, koje je znatan broj naših povjesnika paralelno identificirao kao „djelo“, a katkad i kao „knjigu“. Označavanjem ovih dvaju ostvarenja identičnim - prilično općenitim i nepreciznim - žanrovskim odrednicama potonji proučavatelji pritom nipošto nisu (svjesno) težili sugerirati da je doista riječ o generički istovrsnim tekstovima, već bi to njihovo terminološko generičko zbližavanje trebalo shvatiti kao izravnu posljedicu podjednakih nedoumica u koje su ih - poradi slične žanrovske složenosti - dovodila oba (generički zapravo prilično različita) teksta. Izazvavši im ozbiljne glavobolje u pogledu svojega žanrovskog statusa, oba su ova ostvarenja u pregledima povijesti hrvatske književnosti pojedinih autora tako ponijela jednako općenitu oznaku „djelo“, dok su im, pak, iz istih razloga neki drugi povjesnici u svojim „panoramama“ i studijama dodjeljivali ponešto precizniju odrednicu „spjev“, koja kotira kao sljedeća najčešća identifikacija Odiljenja sigetskog u sekundarnoj - književnopovijesnoj - literaturi.

To što je, dakle, u (kronološki) posljednjoj cjelovitoj povijesti nacionalne nam književnosti - onoj Dubravka Jelčića iz 2004. ${ }^{281}$ - Vitezovićeva „zrinijada“ napokon prezentirana kao „spjev“ ne znači da je u generičkom njezinu poimanju u međuvremenu došlo do naročitoga obrata, a kamoli do krupnijega pomaka ka većoj preciznosti. Naprotiv, iako se kao što ćemo doskora vidjeti - o Odiljenju sigetskom kao „spjevu“ unatrag već nekoliko desetljeća sustavno piše u brojnim „ritterološkim“ raspravama, riječ je zapravo o tek za nijansu manje neutralnoj i općenitoj oznaci, koja - u slučajevima kada se ne rabi kao sinonim za epskopjesničko djelo - najčešće podrazumijeva odulji versificirani (u cijelosti ili samo djelomično) narativni tekst koji se, zahvaljujući mješovitim svojim žanrovskim karakteristikama, ne može bez ostatka kategorizirati kao „epski“ sastavak. Drugim riječima, ni priklanjanje odrednici ,spjev“ u tom smislu obično ne ukazuje ni na što drugo nego da je posrijedi generički upitno stihovano ostvarenje kojemu se njegovi tumači nisu bili u stanju domisliti konkretnije žanrovske identifikacije, što, uostalom, dokazuje i sam Jelčićev primjer,

\footnotetext{
${ }^{281}$ Riječ je, zapravo, o drugom, znatno dopunjenom izdanju Jelčićeve Povijesti hrvatske književnosti, koja je svjetlo dana prvi puta ugledala još 1997.
} 
u čijem se književnopovijesnom priručniku Odiljenje naizmjence obilježava kao „spjev“ i kao „pjesničko djelo“. ${ }^{282} \mathrm{Da}$ među terminima „spjev“ i „(pjesničko) djelo“, u pravilu, i nema krupnije razlike svjedoči i Jelčićevo proglašavanje Adrijanskoga mora Sirene Petra Zrinskoga „spjevom“, 283 koje, međutim, ne prati i identična kategorizacija drugih baroknih epskopjesničkih tekstova, iz čega slijedi da je - identično kao što su neki od njegovih prethodnika to činili s odrednicom „(pjesničkoga) djela“ - oznaku „spjev“ koristio on za isključivo žanrovski problematična ostvarenja.

Iako je u otprilike sličnome značenjskom ključu u svome književnopovijesnom prikazu rabi i Mihovil Kombol za odrednicom „spjev“ u posve istom su značenju kao i onom „pjesničkoga djela“ već tridesetih godina prošloga stoljeća posegnuli srpski književni povjesnici Momir Veljković i Miloš Savković, ${ }^{284}$ također želeći što preciznije identificirati Vitezovićevu ,zrinijadu“. Ako su, dakle, u tim pokušajima bili oni sasvim na tragu dvojice svojih sunarodnjaka - Pavle Popovića i Đorđe Anđelića - u čijim je povjesnicama „jugoslovenske“ književnosti Odiljenje ništa manje neprecizno okršteno kao „pjesničko djelo“" ${ }^{285}$ onda su, primjerice, naši (književni) povjesničari Zvonimir Matagić i Miroslav Vaupotić u svojim proglašavanjima Vitezovićeva djela „spjevom“ od istih tih kategorizacija bili poprilično daleko, $\mathrm{i}$ to nipošto zato što nisu ona bilo dijelom književnopovijesnih priručnika, nego tek pukih kraćih studija. Naprotiv, Matagić i Vaupotić nisu se u svojim tekstovima zaustavili samo na tome da ,spjevom“ obilježe Odiljenje te - možda - uz njega još i Sirenu Petra Zrinskoga, već su u istu generičku kategoriju uvrstili još i Karnarutićevo Vazetje Sigeta grada i („samo“) Petrovu Opsidu, sugerirajući time da je - u romantičkome duhu - kategorija „spjeva“ za njih isto što i ona „epske pjesme“. ${ }^{286}$ Samo nekoliko će godina kasnije svoga ,istomišljenika“ po tom pitanju naći oni u liku Josipa Vončine, koji se u predgovoru izdanju s izabranim Vitezovićevim djelima koleba između određenja Odiljenja kao „spjeva“ i onoga kao - dobro nam već znanog - „pjesničkog djela“. ${ }^{287}$ Bez obzira na to što ga je u spomenutomu tekstu izbjegao eksplicitno označiti epom, svega nekoliko stotina

\footnotetext{
282 Usp. Jelčić 2004: 116-117.

${ }^{283}$ O Sireni kao „spjevu“ u: Isto: 94.

284 Veljković i Savković, naime, u prvom su dijelu svoje Jugoslovenske književnosti (1932.) Vitezovićevo Odiljenje prezentirali tek kao četverodijelni „spjev“. Da pritom jamačno nisu imali na umu žanr epske pjesme pokazuje već činjenica da su i prigodnu njegovu pjesmu Senjčica iz 1704. uvrstili u istu generičku kategoriju, što će reći da su „spjevom“ očito shvaćali isključivo žanrovski teško odrediva djela u stihovima (detaljnije u: Veljković i Savković 1932: 242).

${ }^{285}$ U književnopovijesnim su se svojim prikazima Pavle Popović (1918.) i Đorđe Anđelić (1933.) zadovoljili tek neutralnim određenjem Odiljenja kao ,pjesničkoga djela“, no ovaj je potonji tom prilikom držao nužnim još pripomenuti kako je to „djelo“, s formalno-žanrovskog aspekta, zapravo „niz pjesama, priča, dijaloga i nadgrobnica bez jače organske veze“ (Anđelić 1933: 132). Opširnije u: Anđelić 1933: 132 i Popović 1999: 33.

${ }^{286}$ Usp. Matagić 1966: 908 i Vaupotić 1969: 49.

${ }^{287}$ Usp. Vončina 1976a: 339-343.
} 
stranica ranije - u uvodu u odabrana djela Petra Zrinskog - Adrijanskoga mora Sirenu i njezin epskopjesnički segment - Opsidu sigecku - također će on višekratno proglasiti „spjevom“, a zatim još nekoliko puta i „epom“, odnosno „epopejom“, očigledno želeći na taj način dati do znanja da termin „spjev“ u njegovim očima nije ništa drugo no tek sinonim za epsku pjesmu. ${ }^{288} \mathrm{U}$ tom bi, dakako, smislu i identičnu kategorizaciju Odiljenja sigetskog u ovome kontekstu trebalo razumjeti na isti način, što će reći da je i Vončininoj „ritterološkoj“ studiji mjesto među onim ne odveć brojnim prošlostoljetnim tekstovima u kojima prizivanje odrednice „spjev“ ipak nije trebalo implicirati neuspješna proučavateljeva nastojanja da se za neobičnu Ritterovu „zrinijadu“ dosjeti najprimjerenije ili makar najmanje neprikladne generičke kvalifikacije.

Preskočimo li čuveni književnopovijesni priručnik Vinka Lozovine Dalmacija $u$ hrvatskoj književnosti (1936.), u kojemu, usprkos činjenici da je Vitezoviću i njegovu stvaralaštvu posvećeno ondje čak čitavih nekoliko stranica, ${ }^{289}$ o Odiljenju sigetskom - iz ne odveć jasnih razloga - nema ni riječi, muke dvadesetostoljetnih književnih povjesnika suočenih s nužnošću definiranja generičkoga identiteta Ritterove „Zrinijade“ posvjedočit će nam i dva prikaza povijesti hrvatske, odnosno slavenske barokne književnosti, u kojima se predlažu poprilično interesantna rješenja ovoga problema. Premda je objelodanjen nekoliko desetljeća kasnije, prvomu od njih pažnju valja posvetiti pregledu stvaralaštva hrvatskoga književnog baroka Das Barock in der kroatischen Literatur, kojega je - pretežno za čitatelje s njemačkoga govornog područja - 1991. objavio jedan od najznačajnijih naših barokologa Zoran Kravar. Pišući o (pre)bogatomu Vitezovićevu opusu, Kravar se s posebnom pozornošću osvrće i na hrvatski njegov književni prvijenac, kojemu - i više nego svjestan njegove upitne žanrovske pripadnosti - dodjeljuje pomalo romantičku, gotovo „smičiklasovski“ neodređenu oznaku „hrvatske pjesme“ (kroatische Dichtung), nemajući pritom ni u primisli možebitne aluzije na žanr epa. Naprotiv, da je opredjeljenjem za navedenu odrednicu bio on mnogo bliži onim shvaćanjima u kontekstu kojih je Odiljenje proglašavano „djelom“ i „knjigom“ potvrdit će već sljedeći retci njegova pregleda, u kojima odlučno ustvrđuje da ono nipošto nije ep, nego „slobodan slijed izravnih govora koje redaju jedan za drugim junaci bitke kod Sigeta“ (Kravar 1991: 237), poradi čega bi ga, u generičkom smislu, valjalo shvatiti - s izuzetkom četvrtoga „dila“, u kojemu ih istiskuju epitafi - kao ciklus ili zbirku tzv. sermocinatia,

\footnotetext{
${ }^{288}$ Podrobnije u: Vončina 1976b: 7-20.

${ }^{289}$ Usp. Lozovina 1936: 183-185.
} 
odnosno iskaza u upravnom govoru, od kojih svaki u svome naslovu donosi ime govornika i adresata (primjerice, Ban sinu, Kralj banu itd.). ${ }^{290}$

Općenitim, dakle, njegovim određenjem kao „hrvatske pjesme“ Kravar Odiljenju tako ustanovljuje tek provizoran identitet, dajući istovremeno do znanja da je to - naizgled generički kompaktno ostvarenje u suštini ipak heterogen tekst čije je dionice nemoguće svesti pod isti žanrovski nazivnik. Jednoznačno, štoviše, pritom nije moguće definirati čak ni formalne njegove komponente, $\mathrm{i}$ to ne samo zato što su neki od njih epitafi, a drugi sermocinatia, već poglavito zbog toga što kategorija ovih potonjih uopće ne posjeduje status (književnoga) žanra. Iako se, naime, doslovno on može odrediti upravo kao „dijalog“ ili „razgovor“ (slijedom čega bi ga - u optici Bahtinove teorije govornih žanrova - svakako valjalo poimati generički), sermocinatio je - prema tumačenju Krešimira Bagića - ništa drugo no tek figura misli, koja se pojavljuje ili kao „digresija u iskazu kojom pripovjedač ili govornik izriče svoje misli tako da ih stavlja u usta komu drugom“, koji „može biti odsutna ili mrtva osoba, životinja, pojava ili apstraktna kategorija“, ili kao „fiktivni razgovor dvaju sugovornika od kojih je najmanje jedan izmišljen“ ili, pak, kao govornička vježba, odnosno „oponašanje različitih tipova ljudi“ (Bagić 2012: 282). Segmente svih četiriju „dilova“ Odiljenja (pa čak i onoga epitafskog, u kojemu se ,govori“ uime poginulih aktera) pritom je $\mathrm{u}$ ponešto fleksibilnijoj interpretaciji - uistinu moguće sagledati kao svojevrsne primjere svake od netom pobrojanih pojavnih varijanata sermocinatia, no s obzirom na to da je riječ o figuralnom (a ne generičkom) rješenju u okviru kojega se osobni iskaz predstavlja kao iskaz drugoga govornika uz neizbježno oponašanje njegovih govornih posebnosti, jasno je da takvo identificiranje dionica Vitezovićeve „zrinijade“ ni najmanje ne rješava problem generičke njihove pripadnosti. U tom je smislu i ovaj Kravarov prijedlog - iako nepobitno vrijedan i originalan - nužno prihvatiti sa stanovitom dozom opreza kada se govori o žanrovskim osobitostima pojedinih pjesama, a naročito Odiljenja sigetskog u cijelosti, tim više što on otvara i čitav niz drugih neizbježnih pitanja, i to mahom onih teorijske, odnosno (književno)poetičke prirode.

Točno trideset godina prije Kravarova prikaza sedamnaestostoljetne hrvatske književnosti, iz tiska je - namijenjena većinom publici s istoga jezičnog područja - izašla opsežna studija posvećena baroknoj kulturi slavenskih zemalja Die slawische Barockwelt (1961.) iz pera glasovitoga mađarskog slavista Andreasa Angyala. Motreći književno stvaralaštvo 17. stoljeća kao dio znatno širega (baroknog) kulturnog i društvenog okružja,

\footnotetext{
${ }^{290}$ Više o tome u: Kravar 1991: 237-238. Iste će zaključke Kravar ponoviti i nepunih deset godina kasnije u natuknici posvećenoj Ritterovu opusu u Leksikonu hrvatskih pisaca (usp. Kravar i Novaković 2000: 766-769).
} 
Angyal u svojoj knjizi uvjerljivo dokazuje da su literarne manifestacije baroka $\mathrm{u}$ književnostima slavenskih naroda bile ništa drugo no izravan produkt specifičnih društvenopovijesnih okolnosti te idejnih, odnosno svjetonazorskih strujanja koja su presudno obilježila sve aspekte društva, pa tako i (književno)umjetničku njegovu sferu u potpunosti. Takvim shvaćanjem barokne književnosti nametnuo se Angyal kao svojevrsni prethodnik kasnijih barokologa, koji su posebnosti sedamnaestostoljetnoga pisanog stvaralaštva ustrajno tumačili kao odzrcaljenje karakterističnih kontekstualnih silnica toga razdoblja, ${ }^{291}$ no ono u čemu ga se ipak nitko od njih nije usudio - ili želio - slijediti jest njegova sklonost da pojedina književna ostvarenja iz toga vremena razvrsta u „umjetne“ žanrovske kategorije skrojene prema isključivo nekim konktekstualno-sadržajnim kriterijima.

Spoznavši, konkretno, da su sve slavenske zemlje u 17. stoljeću zauzimale položaj svojevrsne granice spram teritorija koje je osvojila turska vojska, što - uostalom - potvrđuje i lanac graničnih utvrda koje su se u to vrijeme protezale na potezu od Volge do Jadrana, Angyal tako cjelokupno slavensko barokno društveno i kulturno okružje naziva „svijetom graničnih utvrda“, u kojemu su - između ostalog - dominirala i književna djela s naglašeno ratnim motivima, koja su ponajbolje odražavala specifičan „duh vremena“, odnosno neposredno odgovarala na tadašnje ratne okolnosti. Na umu Angyal pritom nema samo pisanoknjiževnu baroknu produkciju, već i folklorno stvaralaštvo toga vremena (poglavito usmenu epiku na temu kršćansko-muslimanskih okršaja), a u hrvatskome i srpskom usmenoknjiževnom epskom pjesništvu, štoviše, vidi čak balkansko-slavensku inačicu barokne europske (pisane) književnosti. ${ }^{292} \mathrm{Za}$ sveukupan korpus tih - glavninom epskih - ostvarenja posvećenih opjevavanju kršćanskoga otpora turskim osvajačima, koja su u 17. stoljeću nastajala diljem slavenskoga svijeta (odnosno $u$ istočnoeuropskim nacionalnim književnostima), smišlja on i poseban generički naziv - „pjesništvo graničnih utvrda“ (Grenzfestungen-Dichtung) - ustanovivši tako sasvim novu (polu)žanrovsku odrednicu, koju će se (pa i u nas) poslije njega odvažiti rabiti tek malokoji književni povjesnik. Ipak, kada je riječ o hrvatskoj onovremenoj književnosti, tu su oznaku - shodno Angyalovu mišljenju ponajprije zaslužile ponijeti obje ,zrinijade“ (Nikolina mađarska i Petrova hrvatska) braće Zrinski, koje ujedno izdvaja kao možda i najuspjelije literarne izraze burne atmosfere „svijeta graničnih utvrda“, proglašavajući njihove autore tipičnim predstavnicima kulture europskoga

\footnotetext{
${ }^{291}$ Nalik Angyalu, i mnogi su od tih kasnijih stručnjaka dominaciju ratnih tema i motiva u sedamnaestostoljetnoj književnosti tako objašnjavali kao izravnu posljedicu opće društvene atmosfere obilježene stalnom ratnom uznemirenošću, odnosno sveopćim strahom pred gotovo svakodnevnim oružanim sukobima koji su se tada vodili diljem „staroga kontinenta“. Usp. npr. Warnke 1972 i Segel 1974.

292 Podrobnije u: Angyal 1961: 246.
} 
baroka. ${ }^{293}$ Bez obzira na to što, pored drugih pripadnika žanra „pjesništva graničnih utvrda“, Angyal navodi i Odiljenje, u nekoliko će mu navrata dosljedno pridružiti oznaku ,junačka (epska) pjesma“ (Heldengedicht), ${ }^{294}$ čime ipak nipošto nije želio sugerirati da Vitezovićevu tekstu nije mjesto u kategoriji kojoj pripada i njegov najveći literarni uzor - Petrova Sirena.

Potonje implicitno Angyalovo uvrštavanje Odiljenja u provizornu - ili, todorovljevski rečeno, teorijsku - generičku kategoriju ,pjesništva graničnih utvrda“ zacijelo ponajbolje zaokružuje opisana dvadesetostoljetna kolebanja književnih povjesnika u pogledu konkretnoga žanrovskog identiteta ove po koječemu osebujne „zrinijade“. Osjetno širenje kruga njezinih (stručnih) čitatelja, potaknuto objelodanjenim joj reizdanjima, ali i sigurnim mjestom u svim književnopovijesnim priručnicima, kojim je napokon potvrđen njen status kanonskoga literarnog teksta, u prošlom je stoljeću, naime, rezultiralo i sve većom pažnjom koju su „ritterolozi“ i drugi stručnjaci počeli posvećivati žanrovskim njezinim posebnostima, no ne i posebno opipljivim rezultatima u tom pogledu. Štoviše, iako će neka određenja među proučavateljima steći nešto više zagovornika od onih drugih, sumarno se može reći da njihova lutanja po pitanju žanrovske pripadnosti Odiljenja sigetskog nisu - u načelu - ništa drugo no tek produžetak onih istih klasifikacijskih nedoumica što su ih u svojim studijama i pregledima iskazivali i devetnaestostoljetni književni povjesnici, tim više što se na pojedine romantičke konstatacije neki od njih - kao što smo vidjeli - izravno i nadovezuju. Ako, dakle, generički tretman Vitezovićeva djela u većem dijelu 20. stoljeća ne pokazuje naročit odmak od onoga romantičkog, onda se za pojedine ,ritterološke“ studije ispisane u posljednjim desetljećima prošlog i na samom početku ovoga stoljeća definitivno može ustvrditi da unose bitan pomak u njegovo žanrovsko shvaćanje, pa i usprkos činjenici da ni njihovi pokušaji iznalaženja jedinstvene generičke oznake za Odiljenje nisu (još) dosad polučili naročit uspjeh.

\section{6. NOVI ŽANR(OVI) NA VIDIKU? NAJRECENTNIJA ČITANJA}

Tijekom - otprilike - posljednjih dvaju desetljeća 20. i poglavito u prvim godinama tekućeg stoljeća zaredale su se interpretacije Odiljenja sigetskog u kojima se, između ostalog, iznova težilo dubinski preispitati i njegovo dosadašnje žanrovsko poimanje. Velik broj tih

\footnotetext{
${ }^{293}$ Detaljnije o tome u: Angyal 1961. O ovoj Angyalovoj „žanrovskoj“ odrednici pregledno i u: Blažević 2003: 203. Valja znati i da je niz povijesnih epova na temu osmanlijskog osvajanja graničnih utvrda već u drugoj polovini 16. stoljeća napisan i u slovačkoj književnosti. Među njima posebno se izdvaja anonimna Piseň o sigetském zámku (Pjesma o sigetskoj tvrđi), nastala nedugo nakon što je Siget pao u ruke Turaka, koja - zajedno s mnogim drugim literarnim obradama sigetske katastrofe iz mađarske, pa i češke književnosti - svjedoči o golemom odjeku što ga je herojski otpor šačice sigetskih branitelja višestruko nadmoćnijoj muslimanskoj vojsci imao diljem čitave ranonovovjekovne Europe. Usp. o tome u: Serdarević 1995: 71-78.

${ }^{294}$ Usp. Angyal 1961: 170-171.
} 
„ritteroloških“ i književnopovijesnih studija, bez obzira na to jesu li posvećene njegovu čitanju u cijelosti ili ga se tek usputno dotiču, pristupat će mu pritom iz bitno drugačije perspektive, otkrivajući u njegovoj generički izrazito kompleksnoj „fakturi“ dotad neprepoznate ili posve zanemarene elemente, a ujedno i pokušavajući posredstvom tih novih spoznaja izvesti njegovo najprihvatljivije (najčešće ne i odveć inovativno) žanrovsko određenje. Najkrupniji napredak u odnosu na većinu ranijih tumačenja vidljiv je poglavito u njihovu ustrajanju na temeljitoj analizi, odnosno na potrazi za konkretnim generičkim signalima unutar samoga teksta, na osnovi kojih zatim predlažu i prikladnu kategorizaciju Vitezovićeve ,zrinijade“, dakle onu koja - prema mišljenju njihovih autora - odgovara ili bi najviše trebala odgovarati njezinu ,stvarnom“ (izvornom) žanrovskom identitetu, premda se u mnogima od njih istovremeno i jasno upozorava na njen hibridni karakter, a katkad čak i otvoreno ističe izrazita žanrovska višeslojnost kao najveća prepreka njezinu jednoznačnom klasificiranju. Ipak, suvremeni su proučavatelji i usprkos potonjoj prepreci Odiljenje redovito nekako (i nekamo) svrstavali, a iako su se pritom - u najvećem broju slučajeva - o njemu klonili izricati odviše načelne sudove, njihove generičke identifikacije u potpunosti počivaju na dubinskoj, no ipak ograničenoj tekstualnoj analizi, često lišene i najmanjega osvrta na književno-kulturni i društvenopovijesni kontekst razdoblja u kojemu je ono nastalo i koji je u velikoj mjeri isprovocirao i specifičan njegov žanrovski ,izgled“. Vođeni imperativom iznalaženja što primjerenije žanrovske mu oznake, ali i suočeni s njegovom izrazito zamršenom generičkom „pojavnošću“, autori ovih recentnih tumačenja Odiljenja mahom su svjesni manjkavosti bilo kojega konkretnijeg određenja - stoga posezali za prilično općenitim, iz ranijih im studija i književnopovijesnih pregleda dobro znanim odrednicama, samo pokatkad proširenima ponešto preciznijim generičkim atributima, premda je među njima bilo ipak i onih koji se - temeljem rezultata svojih istraživanja - Ritterov tekst nisu ustručavali identificirati i znatno drugačije, a k tome i daleko preciznije.

Što se one prve - najbrojnije - skupine proučavatelja tiče, nju bi svakako valjalo držati „odgovornom“ za sve one, i više nam nego dobro poznate identifikacije Odiljenja kao „(pjesničkoga) djela“, „knjige“ i „spjeva“, kojih u književnopovijesnoj i drugoj sekundarnoj literaturi ni u posljednjih nekoliko desetljeća u nas nije manjkalo. I dok u enciklopedijskim tako opisima Vitezovićeva hrvatskog prvijenca „književnim djelom“295 - zbog nužnoga pojednostavljivanja - ne bi trebalo vidjeti ništa sporno, inzistiranje na istoj, suviše nepreciznoj oznaci u najrecentnijim studijama iz pera samih ,ritterologa“ i povjesničara (starije) hrvatske književnosti na prvi se pogled ne doima u potpunosti jasnim, tim više što su razrješavanju 
problema žanrovskog identiteta Odiljenja neki od njih u ne tako davnoj prošlosti i sami pokuša(va)li dati svoj (značajniji) doprinos. Suzdržavajući se od njegova preciznijeg označavanja, Stjepan će Hranjec tako uočiti „lirsku intonaciju“ Ritterova „djela“, 296 Alojz Jembrih definirati ga kao „pjesničko djelo“ u kojemu se „na lirski način opisuje rastanak glavnih protagonista od Sigeta koji su branili“ (Jembrih 2016a: 28), dok će - ponešto proširenije i za nijansu preciznije - isto određenje u dvama svojim tekstovima varirati i Dunja Fališevac, predstavljajući Odiljenje sigetsko najprije kao „djelo epsko-lirske strukture“ (Fališevac 2003: 503), a zatim i kao „lirsko-epsko djelo“ (Fališevac 2010b: 486). Nesigurnost $\mathrm{u}$ pogledu njegove žanrovske kategorizacije u dvije će svoje nedavno objelodanjene (obljetničke) studije iskazati i poslovično samouvjereni Josip Bratulić, koji, pak, Odiljenju dodjeljuje ništa manje općenitu odrednicu „knjige“, 297 nastavljajući se tako na višestoljetni „lanac“ generičke definicije koji je - podsjetimo - još u predgovoru $K$ čtavcu prvoga njegova izdanja identičnim određenjem započeo „kovati“ sam Vitezović. Pripomenimo i da se vrlo posebne, ništa manje neutralne žanrovske oznake za nj u svome izvrsnom pregledu povijesti hrvatskoga pjesništva dosjetio i češki kroatist Dušan Karpatský, koji ga ondje označava kao „skladbu“, ali uz to ipak ne propušta istaknuti i da je riječ o tekstu skrojenom od „niza »lamentacija« sudionika i svjedoka sigetske bitke“ (Karpatský 2008: 627).

Oklijevajući s preciznijim njegovim žanrovskim identificiranjem, višestruko će se već iskušane, uopćene oznake za Vitezovićevu „zrinijadu“ držati i oni suvremeni „ritterolozi“ kojima će se za nj najprikladnijom - ili možda najmanje neprikladnom - učiniti ona „spjeva““. Valja pritom znati da je riječ o uvjerljivo najfrekventnijoj generičkoj odrednici za Odiljenje u posljednjih tridesetak godina, za koju će se u (pojedinim) svojim čitanjima opredijeliti većina domaćih stručnjaka za ranonovovjekovnu našu književnost - između ostalih, i Franjo Švelec, Josip Bratulić, Alojz Jembrih, Pavao Pavličić, Dunja Fališevac, Radoslav Katičić, Davor Dukić i dr. ${ }^{298}$ - ali i sastavljači recentnih književnih leksikona, odnosno autori priloga u enciklopedijskim i leksikonskim pregledima hrvatske književnosti. ${ }^{299}$ Kao što je to bio slučaj i s ranijim proučavateljima, i za autore će ovih najsvježijih književnopovijesnih studija kategorija „spjeva“ pokatkad podrazumijevati (punokrvno ili većim dijelom) epskopjesničko ostvarenje, a ponekad tek generički teško odrediv stihovani tekst s „,epskim“, ali i „,neepskim“

\footnotetext{
${ }^{296}$ Usp. Hranjec 2016: 27-28.

${ }^{297}$ Detaljnije u: Bratulić 2016a: 38 i 2016b: VII. Zanimljivo, u prvom će od ovih dvaju tekstova istu oznaku (,knjiga“) Bratulić upotrijebiti i za obje - mađarsku i hrvatsku - Sirene braće Zrinski, dok će im u onome drugom pridati - po neodređenosti gotovo ekvivalentnu - odrednicu „djela“, očito time želeći ukazati na to da su i Odiljenje, i Sirena, i Syrenaia generički podjednako složena, a možda i posve ,istovrsna“ ostvarenja.

${ }^{298}$ Usp. Švelec 1990: 187, Posavac 1994: 867, Bratulić 1994: 9 i 1997: 16, Dukić 2003: 491, Fališevac 2003: 503, Pavličić 2007: 253-284, Jembrih 2008: 54, Katičić 2013: 32, Sršen i Piskač 2016: 221.

${ }^{299}$ Usp. Bogišić i sur. 1998: 384, Kravar i Novaković 2000: 767; Pavličić 2008b: 536, Solar 2011: 501.
} 
značajkama, pa dok će tako, primjerice, priređivači zbornika posvećenog obitelji Zrinski ${ }^{300} \mathrm{u}$ njegovu predgovoru odrješito ustvrditi kako je - ugledajući se na „zrinijade“ Nikole i Petra Zrinskog - Vitezović ispjevao „hrvatski nacionalni junački spjev“ (Bene, Hausner i Ladić 2012: 8), dakle ep, Davor će Dukić u svome kratkom osvrtu na temeljne značajke sedamnaestostoljetne naše književnosti napomenuti da je - sadržajno se oslanjajući na epove braće Zrinski - Ritter napisao „spjev“ Odiljenje sigetsko, ${ }^{301}$ jasno time dajući do znanja da, (i) u žanrovskom pogledu, Petrovu i Nikolinu djelu nije ono ipak nalik. Mnogo eksplicitniji u ovoj će potonjoj uporabi oznake „spjev“ biti Zoran Kravar i Darko Novaković u natuknici posvećenoj liku i djelu Pavla Rittera Vitezovića u Leksikonu hrvatskih pisaca, gdje njegov tekst izrijekom najprije proglašavaju „,spjevom“ da bi svega nekoliko redaka kasnije upozorili kako on - uprkos svome sadržajnom nadovezivanju na ranije epove sa sigetskom tematikom „nije ep“, već „niz sermocinacija“ ili iskaza u upravnom govoru, ${ }^{302}$ što će reći da ga shvaćaju kao formalno i generički složeno pjesničko djelo karakteristično epske tematike kojega je žanrovski očito nemoguće jednoznačno kategorizirati.

Da su, uostalom, mnogi naši književni povjesnici u generičkim pristupima ostvarenju kakvo je (i) Odiljenje sigetsko oznaku „spjev“ preferirali isključivo zbog izrazite značenjske fluidnosti i općenitosti, a ne zbog eventualnoga sinonimskog prizivanja žanra epske pjesme, ${ }^{303}$ ponajbolje se da naslutiti iz načina na koji je ona uporabljena u drugim književnopovijesnim radovima novijih datuma. S obzirom na to da se - zahvaljujući toj svojoj nepreciznosti odrednica „spjev“ u najvećem broju slučajeva proteže na niz versificiranih djela iz starije i novije hrvatske književnosti u kojima se presijecaju raznolike žanrovske značajke, odnosno protkana karakteristikama koje se uvriježeno shvaćaju kao „epske“, „lirske“ i „dramske“, posve je jasno da se i u pogledu Odiljenja proučavatelji za nju opredjeljuju mahom poradi nemogućnosti da iznađu jednoznačnu i konkretnu generičku identifikaciju koja bi Vitezovićevu tekstu pristajala $u$ potpunosti, a ujedno $\mathrm{i}$ da na taj način već samom klasifikacijskom oznakom daju do znanja da je riječ o žanrovski izrazito dvojbenom tekstu. To će, pišući o problemu sve češćega (pre)općenitog definiranja Mažuranićeve Smrti Smailage Čengića identičnom žanrovskom oznakom, primijetiti i Pavao Pavličić, koji ističe kako je u našoj književnoj znanosti proglašavanje nekoga pjesničkog djela „spjevom“ najčešće signal

\footnotetext{
${ }^{300}$ Riječ je o zborniku Susreti dviju kultura: obitelj Zrinski u hrvatskoj i mađarskoj povijesti (Zagreb, 2012.), što su ga priredili Sándor Bene, Gábor Hausner i Zoran Ladić.

${ }^{301}$ Detaljnije u: Dukić 2003: 491.

${ }^{302}$ Usp. Kravar i Novaković 2000: 766-769.

${ }^{303} \mathrm{Ne}$ treba zaboraviti ni one - doduše, ne baš česte - slučajeve u kojima se obilježavanje Odiljenja sigetskog „spjevom“ provodi po analogiji s identičnim određenjem Adrijanskoga mora Sirene Petra Zrinskog, no i tada je riječ ni o čemu drugome no o naglašavanju podjednake žanrovske neodredivosti oba djela, a ne impliciranju njihova možebitnoga identičnog (epskopjesničkog) generičkog identiteta. Usp. npr. Blažević 2012: 435.
} 
svjesnoga izbjegavanja možebitnih generičkih nesporazuma, odnosno otvorenoga zaziranja od kategoriziranja pojedinoga teksta u neki čvrsti žanrovski „pretinac“. Kada povjesničari naše književnosti to čine (i) s Mažuranićevim ostvarenjem, napominje Pavličić, tada su itekako „svjesni da je termin koji upotrebljavaju toliko širok da se njime, doduše, može ispravno kvalificirati Smrt Smail-age Čengića, ali da on obuhvaća i djela sasvim drugačije naravi: od, recimo, Judite, preko Vile Slovinke, Suza sina razmetnoga ili Odiljenja sigetskoga, pa do Doma i svijeta, Medvjeda Brunda ili Jame“, iako je pritom očito „da su ti tekstovi između sebe žanrovski izrazito različiti“. U tom smislu, poentira Pavličić, posezanje za tim i takvim žanrovskim određenjem samo ,potvrđuje svijest naših proučavalaca o žanrovskoj problematičnosti toga pjesmotvora, pa onda i o tome da bi njegov status trebalo generički preciznije definirati“ (Pavličić 2003: 197-198), što se itekako odnosi i na najveći broj identičnih generičkih definicija i same Vitezovićeve „zrinijade“، 304

Čini se, međutim, da se pri takvom apostrofiranju Odiljenja neki ,ritterolozi“ ipak nisu mogli otresti dojma da termin ,,spjev“ neizbježno konotira (i) žanr epske pjesme, ${ }^{305}$ slijedom čega su - strepeći od mogućih pogrešnih shvaćanja ovakvoga kategorizacijskog „rješenja“ toj odrednici vjerojatno i pridavali dodatne generičke oznake ne bi li je precizirali, odnosno što je moguće više udaljili od neželjenih žanrovskih konotacija. Jedan od prvih primjera ovakvog modificiranja oznake „spjev“ proizišao je iz pera Nikice Kolumbića, koji - pišući o osobitostima žanrova hrvatskoga književnog baroka - Vitezovićevu ,zrinijadu“ najprije smjelo proglašava „lirskom dramom“, odnosno pripadnikom izvorno baroknoga žanra u kojemu se susreću dramske i lirske generičke značajke, da bi ga već u istoj rečenici ništa manje hrabro okrstio „spjevom“, definirajući ga u nastavku kao ,jedinstveni primjer lirskog doživljaja tipične epske građe u hrvatskoj književnosti, ali ujedno i spoj lirske i dramske

\footnotetext{
${ }^{304}$ I Dunja Fališevac u natuknici „Ep“ u Hrvatskoj književnoj enciklopediji napomenut će tako da je termin „spjev“ u našoj književnopovijesnoj tradiciji dugo značio (isključivo) isto što i pojam „ep“, ali i da se u posljednje vrijeme sve češće on rabi za identificiranje ranonovovjekovnih pjesničkih ostvarenja specifične strukture koja odskaču od žanrovskoga okvira povijesne epske pjesme (pored Barakovićeve Vile Slovinke navodi ona i primjer Ritterova Odiljenja), ali i romantičkih narativnih djela u stihu, u kojima također izostaju „klasične“ značajke epa što svoje podrijetlo vuku još iz antičke književnosti (poput, primjerice, Demetrova Grobničkog polja ili Mažuranićeva Smail-age). Usp. Fališevac 2010b: 484-488.

${ }^{305}$ Podsjetimo, još je 1897. u kratkoj Vitezovićevoj biografiji Radoslav Lopašić Odiljenje naizmjence prozivao „epom“ i „spjevom“ (usp. Lopašić 1897: 39-55), no s obzirom na to da je pojam „spjev“ u njegovo vrijeme većinom shvaćan kao sinonim za ep, „epos“, (epsku) ,pjesmu“ itd., jasno je da takvo određenje nije tada (još) izazivalo (veće) nedoumice. Eksplicitno „lopašićevsko“ žongliranje oznakama „,ep“ i ,,spjev“" pokatkad se - iako zaista rijetko - može susresti još i danas, što potvrđuje i primjer recentnoga teksta Andreje Sršen i Davora Piskača posvećenog Vitezovićevu opusu (usp. Sršen i Piskač 2016: 221-222), no generalno se može reći da je u najsuvremenijoj domaćoj znanosti o književnosti naposljetku ipak prevladalo ono poimanje termina „spjev“ koje ga ne dovodi u izravnu značenjsku vezu s (isključivo) žanrom epske pjesme. Terminološko i značenjsko izjednačavanje ovih dvaju kategorija početkom 21. stoljeća predstavljalo bi stoga eksces, a ne pravilo, i stoga se - naročito kada je riječ o Vitezovićevu Odiljenju - može tumačiti prije kao posljedica klasifikacijske pomutnje najvjerojatnije potaknute (i) pokušajem uvažavanja različitih generičkih pristupa, nego ciljanoga „oživljavanja“ tradicionalnih, već prevladanih shvaćanja.
} 
strukture“ (Kolumbić 1991: 48). Za Kolumbićevom identifikacijom Odiljenja kao „spjeva“ koji spreže „epsku građu“ te „lirsku i dramsku strukturu“ uslijedit će potom niz vrlo sličnih iako jezgrovitijih - njegovih određenja, među kojima se - pored Kravarova prozivanja Vitezovićeva djela „vrstovno mješovitim spjevom“ (Kravar 2010: 113) te njegova obilježavanja ,pjesničkim spjevom“ $u$ jednom od tekstova Zrinke Blažević ${ }^{306}$ - posebno ističe ona „lirsko-epskoga“ ili „epsko-lirskoga spjeva“, koju nalazimo u više različitih književnopovijesnih studija i osvrta, redom onima D. Fališevac, Z. Blažević i D. Dukića. ${ }^{307}$

Pristupajući Odiljenju kao „lirsko-epskom spjevu“ - žanrovskomu, dakle, hibridu u kojem „epske“ karakteristike ne odnose primat nad svim drugim (poglavito onim „lirskim“) navedeni se „ritterolozi“, kako se čini, ustvari priklanjaju odrednici u kojoj je osnovna generička kategorija (,spjev“, za koji se pretpostavlja da će biti shvaćen kao barokni povijesni ep) oplemenjena ili konkretizirana oznakom žanrovskoga čimbenika (i to njih dvaju: ,epskog“ i „lirskog“"), i to onoga što ga neki moderni književni genolozi nazivlju modusom. Modus bi, shodno njihovu tumačenju, valjalo razumjeti kao (djelomično generički) aspekt djela, odnosno puki ,izbor iz pripadajućih značajki vrste“, koji sugerira da su se „neka od nestrukturalnih obilježja vrste proširila kako bi modificirala drugu vrstu“, što bi onda značilo da, ,kada se modalni termin poveže s imenom vrste, on referira na kombinirani žanr u kojem je cjelokupna forma određena vrstom samom“ (Fowler 1982: 107). Modusi, ukratko, najčešće uključuju stanovite sadržajne momente (primjerice, pojedine motive, „tipične“ dionice, formule i sl.) i funkcioniraju kao dodatak, odnosno (sadržajna) primjesa temeljnom žanru kojega na taj način dodatno usmjeruju, premda - $u$, doduše, vrlo rijetkim slučajevima pokatkad mogu prožimati i veći dio teksta. ${ }^{308}$ Budući da su modusi nekada bili (a neki od njih još uvijek jesu) žanrovi, iz kojih su se zatim izdvojile pojedine općenitije (tematsko-motivske) posebnosti prikladne za ulazak u druge žanrove, ali bez da ih pritom generički „kontaminiraju“, oni - kao takvi - uvijek neodoljivo podsjećaju na „svoje“ Žanrove, odnosno na njih aludiraju koristeći prepoznatljive (povijesno otpornije, nepromjenjiv(ij)e) značajke iz njihovih generičkih repertoara, koje se u druge (cjelovite) žanrove mogu uklapati u gotovo svim književnopovijesnim razdobljima. ${ }^{309}$ Iako u iznimnim slučajevima mogu dovesti i do

\footnotetext{
306 Usp. Blažević 2011: 252.

${ }^{307}$ Pored nekoliko godina starijega određenja ,lirsko-epskim djelom“ (Fališevac 2010b: 486), Dunja Fališevac će Odiljenje sigetsko u svome relativno nedavnom obljetničkom tekstu tako definirati kao „lirsko-epski spjev“ (Fališevac 2013: 12), na istoj će oznaci u nizu svojih radova inzistirati i Zrinka Blažević (usp. Blažević 1997: 39 i 2012: 435), a kao „epsko-lirski spjev“ Vitezovićevo će ostvarenje u izvrsnoj imagološkoj studiji Sultanova djeca obilježiti i Davor Dukić (usp. Dukić 2004b: 156).

${ }^{308}$ Opširnije u: Guillén 2005: 158-159.

${ }^{309}$ Pojedini genolozi, međutim, osporavaju ovo uopćeno shvaćanje prema kojem se modusi nužno izvode iz konkretnih povijesnih žanrova. Darko Novaković tako, primjerice, navodi slučaj grotesknoga modusa, za koji je
} 
formiranja posve novih žanrova, primarna je njihova „zadaća“ pridati specifičnu „,boju“ žanru u koji bivaju uključeni, odnosno pobliže odrediti sadržajna mu obilježja, a u književnoj povijesti taj su zadatak u čitavom nizu žanrova najčešće vršili epski, tragički, komični, pikarski, satirični, groteksni, gotski i drugi modusi. ${ }^{310}$

Višestruko identificiranje Odiljenja sigetskog ,lirsko-epskim spjevom“ u tom bi onda smislu, kao da sugeriraju spomenuti „ritterolozi“, trebalo proizlaziti iz činjenice da je - u žanrovskom pogledu - riječ o „spjevu“ ili (pretpostavljeno) baroknoj epskoj pjesmi modificiranoj (tradicionalnim) „epskim“ i „lirskim“ sadržajnim momentima, pa ako bi se samo tematsko opredjeljenje za stvaran povijesni (ratni) događaj tako moglo izdvojiti kao jedna od njemu dodanih značajki „epskoga“ modusa, onda bi motiv povišenim emocijama nabijenih (po)ratnih rastanaka trebalo shvatiti kao u nj uvršteno obilježje „lirskoga“ modusa. Ukoliko, međutim, ovako skovana oznaka uistinu želi implicirati takvo generičko poimanje Vitezovićeva ostvarenja, tada ono nije suviše daleko od pojedinih tradicionalnijih shvaćanja Odiljenja, uslijed kojih se - kao u slučaju njegove definicije iz pera Franje Šveleca naglašavalo da je ono glavninom „lirski intonirano, ali kako je u njemu ipak ispripovijedana sigetska katastrofa, ulazi ono i u područje epskoga“" (Švelec 1990: 186). Izbjegavajući za nj pritom osmisliti žanrovsku identifikaciju koja bi - nalik onoj „lirsko-epskoga spjeva“ eksplicitno upućivala na eventualnu njegovu generičku modificiranost, autori ovih potonjih pristupa jasno daju do znanja da im na umu nije viđenje Odiljenja sigetskog kao pripadnika nekoga konkretnog žanra „obojanog“ karakteristikama stanovitih modusa, već kao teksta skrojenog od karakteristika različitih žanrova, i to onih „epskog“, „lirskog“, ali i „dramskog““ žanra (ili „Žanra“). Tako će, primjerice, i Zrinka Blažević - usprkos činjenici da ga je u pojedinim radovima dosljedno proglašavala „lirsko-epskim spjevom“ - u jednom od recentnijih svojih tekstova za Odiljenje konstatirati kako bi se, „u žanrovskom i poetičkom pogledu spjev (...) mogao nazvati hibridnim oblikom, s lirskim, epskim i dramskim elementima“ (Blažević 2011: 252), čime se zapravo nadovezuje na gledišta mnogih „ritteroloških“ svojih prethodnika, koji - počevši još od Milivoja Šrepela, koji je još 1902. odlučno ustvrdio kako je ,glavni (...) značaj Vitezovićeva 'Odiljenja' lirski, epska se gragja obragjuje u obliku lirike“ (Šrepel 1902: 116) - još i u najnovije vrijeme inzistiraju na shvaćanju Vitezovićeva djela kao mješavine „epskih“, „lirskih“ i (nešto rjeđe) „dramskih“ žanrovskih komponenata $\mathrm{u}$, doduše, različitom omjeru.

\footnotetext{
- napominje - teško utvrditi iz kojega je to stvarnoga (povijesno postojećeg) žanra (ukoliko iz nekoga uopće i jest) doista on deriviran (usp. Novaković 1986: 337-338).

310 O modusima kao genološkoj kategoriji podrobnije u: Fowler 1982: 106-111 i Frow 2015: 69-74.
} 
Navedeni nas primjer, međutim, i više nego uvjerljivo upozorava na to da su i određenja Vitezovićeva Odiljenja kao „epsko-lirskoga spjeva“ u najvećoj mjeri ipak izrasla iz višegodišnjih pokušaja književnih povjesnika da u njemu razluče „lirske“ od „epskih“ i „dramskih“ posebnosti, a ne iz svjesnoga prepoznavanja „lirske“ i „epske“ modificiranosti njegova temeljnog žanra prozvanog ,spjevom“, tim više što bi se uslijed takvoga shvaćanja i samo njegovo prozivanje „epskim spjevom“ (dakle, epom s pridodanim epskim obilježjima) doimalo poprilično oksimoronski. U tom bi smislu fraza „lirsko-epski spjev“ podrazumijevala ništa drugo nego generički teško odredivo djelo u stihovima (,spjev“) koje uključuje prepoznatljivo „epska“ i prepoznatljivo „lirska“ žanrovska obilježja, i to upravo ona koja se mogu izdvojiti kao svevremenska ili „standardna“, odnosno ona koja su kroz književnu povijest pružala najveći otpor periodičkim mijenama svojih žanrova - točnije, njihovih žanrovskih repertoara - potvrdivši se kao (uvjetno rečeno) temeljna. Kada, drugim riječima, Zrinka Blažević, Dunja Fališevac i Davor Dukić Odiljenju tako dodijele identifikaciju „lirskoepski spjev“, kada se „lirskih“, „epskih“ i „dramskih“ njegovih karakteristika u „ritterološkim“ svojim studijama dotaknu Nikica Kolumbić i Pavao Pavličić ${ }^{311}$ ili kada, primjerice, Josip Bratulić zaključi da je ono ,prema vrstovnom određenju više lirskog nego epskog karaktera“ (Bratulić 1994: 9), a Marko ga Samardžija odredi kao „pjesnički, pretežito lirski prikaz pojedinih ulomaka stanja poslije sigetskoga poraza, a ne epsko veličanje bitke i u njoj prikazanoga junaštva“ (Samardžija 1999: 10), ${ }^{312}$ nitko od njih na umu pritom neće imati konkretne (povijesne) žanrove sazdane od kombinacije specifičnih i povijesno promjenjivih obilježja, već upravo neke načelne osobitosti općih (teorijskih) žanrovskih kategorija, koje su pojedini genolozi nazivali stilovima. Ukratko, svjesno će se oni ili nesvjesno u ovim čitanjima zapravo nadovezivati na genološka shvaćanja što ih je u svojoj - u hrvatskoj književnoj znanosti prilično utjecajnoj - studiji Temeljni pojmovi poetike polovinom prošloga stoljeća razradio Emil Staiger, ${ }^{313}$ pišući ondje o trima nadpovijesnim stilovima ili - kako ih sam katkad proziva - „modusima“: ,,lirskom“, „,epskom“ te „,dramskom“.314

\footnotetext{
${ }^{311}$ Usp. Kolumbić 1971: 85-92, 2005: 322-325 i 327-353; Pavličić 2007: 253-284.

312 Osim Bratulića (usp. Bratulić 1994: 9 i 1997: 16) i Samardžije, već 1976. o pretežno „lirskoj osnovi“, odnosno „lirskoj koncepciji“ Odiljenja pisao je i Josip Vončina (usp. Vončina 1976a: 339-343), na činjenicu kako u svojoj „zrinijadi“ Vitezović „,iz epskog kompleksa izvlači njegov, inače u epu uvijek prisutni, lirski dio i samo taj vidi, samo o njemu pjeva“" (Bogišić 1995: 195) upozorio je potom i Rafo Bogišić, dok Andreja Sršen i Davor Piskač u jednom od najsvježijih „ritteroloških“ radova također naglašavaju kako je to njegovo „djelo žanrovski više lirsko nego epsko“"(Sršen i Piskač 2016: 221).

${ }^{313}$ Usp. Staiger 1996.

${ }^{314}$ Staiger, podsjetimo, u svojoj knjizi tri nabrojana stila izvodi iz triju ništa manje općenitih generičkih entiteta: „osnovnih rodova“ - epike, lirike i drame - od kojih svaki ponaosob, tvrdi, sadrži niz svevremenskih kvaliteta ili karakteristika koje su obilježile baš sva književna djela ispisana kroz povijest. I dok tako „lirski stil“, prema njegovu mišljenju, karakteriziraju nepovijesnost, kratkoća i sklonost ponavljanju, „epski stil“, s druge strane, prepoznaje se upravo po svojoj povijesnoj funkciji (sadržajnoj okrenutosti nepromjenjivoj prošlosti) i
} 
Ponešto temeljitije generičke analize Odiljenja sigetskog određen su broj „ritterologa“, ipak, navele na bitno drugačiju njegovu žanrovsku percepciju, o kojoj svjedoči i nekolicina sasvim novih određenja pridanih mu u pojedinim studijama ispisanima unatrag posljednjih nekoliko desetljeća. Ne računajući u njih i - samo naizgled inovativne - pokušaje Rafe Bogišića da Vitezovićevu „zrinijadu“ generički definira kao „poemu“, 315 najvećim se dijelom pritom misli na čitanja Odiljenja uslijed kojih ono biva identificirano kao ciklus ili zbirka lirskih pjesama, i to obično na temelju utvrđivanja stanovitih „lirskih“ njegovih tekstualnih posebnosti. Već 1990. u jednomu će svom radu Josip Bratulić tako istaknuti da se Odiljenjekao Ritterovo najbolje hrvatsko „djelo“ - zapravo sastoji „od nekoliko samostalnih pjesama o sigetskoj tragediji“ (Bratulić 1990: 188), implicirajući potom da bi ih - s obzirom na to da u njima preteže „lirsko raspoloženje“ - valjalo motriti kao lirske pjesme, dok dva i pol desetljeća kasnije i Radoslav Katičić Vitezovićevu „zrinijadu“ proglašava „knjigom pjesama“, i to usprkos činjenici da ju je u prethodnoj rečenici već predstavio kao „spjev“. ${ }^{316}$ Tim su (većinom uzgrednim) pokušajima njegove identifikacije prethodila, pak, znatno ekstenzivnija razmatranja izrazite „lirske“ obilježenosti Odiljenja iz pera Nikice Kolumbića, komu se pretresajući u svojoj interpretaciji hrvatskoga Vitezovićeva prvijenca ista pitanja - $\mathrm{u}$ zagovaranju njegove „liričnosti““ ubrzo pridružio i Pavao Pavličić.

Još sedamdesetih godina prošloga stoljeća ozbiljnoga se propitivanja generičkog identiteta Odiljenja latio najprije Nikica Kolumbić, koji u nizu svojih „ritteroloških“ radova

predočavanju, odnosno upućivanju na nešto, dok, pak, „dramski stil“ u najvećoj mjeri počiva na napetosti, pri čemu je - napominje - riječ o trajnim značajkama što ih (u jedinstvenom omjeru) uključuje zapravo svaki pojedinačni književni tekst. Premda, kao što vidimo, ovakvo shvaćanje stilova ima pojedinih dodirnih točaka (i) s kasnijom, maločas spomenutom koncepcijom modusa, nije naodmet još jednom ponoviti da su modusi skupine (većinom) sadržajnih značajki koje su prerasle granice „svoga“ žanra i tako - kao izdvojena obilježja „dugoga trajanja“ - stekle „sposobnost“ uključivanja u druge žanrove, dok Staigerovi stilovi - kojih je, za razliku od čitavog niza modusa, moguće razlikovati svega tri - proizlaze iz mnogo obuhvatnijih, teorijskih kategorija (rodova, a ne konkretnih žanrova) te su svojina apsolutno svih dosad realiziranih literarnih ostvarenja. Upravo iz perspektive ovih drugih mnogi su naši književni povjesnici i pristupali Vitezovićevu Odiljenju, svojski se trudeći izmjeriti koliki je u njemu udio „lirskih“, koliki „,epskih“, a koliki - naposljetku - „dramskih“ značajki, ali ne i utvrditi koja to obilježja kojih konkretnih (povijesnih) žanrova grade njegov tekstualni svijet te što to uopće govori o žanrovskom mu identitetu u cijelosti. Štoviše, u zamku tih - danas već poprilično zastarjelih, no u nas itekako još „optjecajnih“ - staigerovskih shvaćanja pokatkad će upasti čak i oni proučavatelji koji se otvoreno diče inovativnošću svojih genoloških pristupa, a potom upuštaju u razmatranja (načelno) ,epskih“ karakteristika Vitezovićeve „zrinijade“, što je i više nego jasan pokazatelj ne samo duboke uraslosti ovih tradicionalnih genoloških predodžbi u našu književnu znanost, već i bjelodan dokaz utjecaja što ga one (još uvijek) imaju na našu žanrovsku percepciju književnosti uopće.

${ }^{315}$ Iako Bogišić izrijekom ustvrđuje kako je u Odiljenju sigetskom Pavao Ritter Vitezović ispjevao „,poemu o Zrinjskomu“ (Bogišić 1995: 195), odnosno učinio „poemični zahvat u sigetsku temu“ (Bogišić 2007: 215), nipošto on pritom neće misliti na - Vitezovićevu vremenu svojstven i tada izrazito popularan - žanr (religiozne ili komične) poeme (usp. o baroknoj poemi u: Isto: 212-219). Naprotiv, s obzirom na to da će u istim tekstovima ustrajno „poemom“ prozivati i Karnarutićevo Vazetje, Szigeti veszedelem Nikole te Obsidu sigecku Petra Zrinskog, ali i anonimnu Pjesmu o Sigetu zapisanu u anonimnoj Prekomurskoj pjesmarici s kraja 16. st., i više je nego očito da navedenu oznaku rabi on (na posve neopravdan način) kao sinonim za odrednicu „ep“, odnosno „epska pjesma“, iz čega bi onda slijedilo da i samo Odiljenje generički on shvaća poprilično tradicionalno.

${ }^{316}$ Usp. Katičić 2013: 32. 
na temelju brojnih argumenata zaključuje kako je u Vitezovićevoj „zrinijadi“ najizrazitija upravo „lirska, a ne epska doživljajna osnova“ (Kolumbić 2005: 323). Naime, Ritter se pojašnjava - u svome djelu odlučio u potpunosti usredotočiti na sama raspoloženja što ih $u$ izravnim i neizravnim sudionicima sigetske katastrofe izaziva nužnost rastanka od Sigeta i jednih od drugih, slijedom čega isticanju emocionalnosti i sentimentalnosti - kao „tipično“ lirskih sadržajnih momenata - i podređuje redom sve slojeve teksta, odnosno cjelokupnu njegovu strukturu. Na temeljno „lirsko nadahnuće“ upućivat će u njemu tako već sam „lirični“ naslov, zatim njegov dijaloško-monološki oblik (kao najprimjereniji za neposredno izražavanje tuge izazvane mnogobrojnim rastancima), ali i vremenski rastrgano (asocijativno) nizanje događaja uzrokovano svjesnim odustajanjem od naracije, simbolično-lirski karakter ožalošćenih likova i stanja u kojemu se nalaze, izrazito suosjećajni odnosi među njima te, naposljetku, povišenom osjećajnošću prožeta formalna razina (koju obilježavaju emocionalno obojene riječi i izrazi, tečna rima koja ostavlja dojam spontanosti i metričke varijacije kojima se teži naglasiti raznolikost doživljaja pojedinih likova). ${ }^{317}$ Paralelno, međutim, s ovim poprilično uvjerljivim dokazivanjem dominantne „lirskosti“ Odiljenja, odnosno opetovanim isticanjem kako Vitezovićev „doživljaj“ bitke pod Sigetom nije u njemu „ni epski ni dramski jer su u djelu i naracija i radnja isključeni kao umjetničke komponente“ (Isto: 336), Kolumbić će se prilikom svakoga njegova određenja čvrsto ipak držati (neutralne) oznake „spjev“, pripominjući pokatkad da ono - strukturnoj fragmentarnosti usprkos - „uglavnom počiva na temeljima kompozicijskoga jedinstva“ (Isto: 348). To će, dakle, reći da Vitezovićevu „zrinijadu“ on ne poima kao žanrovski heterogeno, kompilirano djelo, a onda ni kao možebitnu zbirku lirskih pjesama, već upravo kao cjelovit - iako (jednoznačno) generički posve neodrediv - tekst s naglašeno lirskim obilježjima, i to ne onima svojstvenima „samo“ korpusu sedamnaestostoljetnoga, odnosno baroknog lirskog pjesništva.

Tragom Kolumbića, koji se u svojim studijama opredijelio za poprilično tradicionalnu generičku odrednicu za Odiljenje, i Pavao Pavličić u nešto recentnijoj će njegovoj interpretaciji posegnuti za posve identičnom žanrovskom oznakom, no čineći to u knjizi poprilično indikativna naslova - Epika granice. ${ }^{318}$ Bez obzira na činjenicu što je - temeljem (pomalo „kolumbićevskoga“) razmatranja njegovih (načelnih, odnosno nadvremenskih) „epskih“ i „lirskih“ značajki - kao najs(p)retniju za nj odabrao upravo značenjski fluidnu oznaku ,spjev“, u kontekstu spomenuta je rada, a onda ni knjige u cjelini, neće on koristiti

\footnotetext{
317 Usp. Kolumbić 1971: 85-92 (pretisak ovoga teksta nedavno je uvršten i u: Pranjić 2016: 97-104), 2005: $322-$ 325 (riječ je o segmentu rasprave prvotno objelodanjene u zborniku radova Sigetska epopeja od Karnarutića do Vitezovića, Zadar 1986.) i 327-353 (ova je studija - naslovljena „Vitezovićev lirski doživljaj sigetske tragedije“ - svjetlo dana prvi put ugledala u 4. broju godišnjaka Senjski zbornik iz 1970. godine).

${ }^{318}$ Usp. Pavličić 2007: 253-284.
} 
kao sinonim za žanr epske pjesme, na što, uostalom, i sam upozorava konstatirajući kako čitatelj Odiljenje „,ne može čitati kao ep, jer ono ep nije, ne može ga primiti kao dramu, jer ono ni to nije, a ni kao zbirku pjesama, jer se Odiljenje ni tako ne deklarira“ (Pavličić 2007: 257). Ustrajno ga proglašavajući „spjevom“, Pavličić će u Vitezovićevu ostvarenju ipak dospjeti utvrditi bitnu prevlast onih - „lirskih“ - obilježja koja nepogrešivo sugeriraju kako je Odiljenje „htjelo biti zbirkom lirskih pjesama objedinjenih temom sigetske bitke i vezanih za Sirenu kao svoj matični tekst“ (Isto: 277), i to počevši od formalne kratkoće zasebnih njegovih segmenata i njihove metričke podudarnosti, preko dominacije prvoga lica i pretežno ispovjednoga - a ne narativnoga - njihova tona, sve do sadržajne usmjerenosti opjevavanju emocija što ih je potaknuo imperativ rastanka od osvojenoga Sigeta, koja ih sve zajedno tematski i motivski povezuje. Ustanovit će on, ukratko, da se sve pojedinačne dionice teksta odnosno svaka individualna pjesma ponaosob - ,prema svome sadržaju ne odnose epski nego lirski“ (Isto: 277), a iako se pjesme iz svakoga od četiri „dila“ osvrću na različite momente propasti Sigeta, u svima je njima Vitezović dosljedno „nastojao pokazati lirske aspekte epske priče“ (Isto: 279), iz čega bi onda slijedilo da i odrednicu „spjev“ kojom identificira Odiljenje valja shvatiti ne kao oznaku za homogeno (epskopjesničko) djelo, nego onu za (tematski) zaokruženo versificirano ostvarenje kompilacijskoga tipa, mnogo bliskije upravo zbirci lirskih pjesama nego epskoj pjesmi.

Za razliku od identifikacija koje se zasnivaju na prepoznavanju u njemu zastupljenih značajki nekih vrlo općenitih - „epskih“, „lirskih“, a katkad i „dramskih“ - genoloških kategorija, umjesto na usporedbi njegovih generičkih obilježja s repertoarima konkretnih sedamnaestostoljetnih žanrova, u najrecentnijim će se književnopovijesnim prikazima i „riterološkim“ studijama Odiljenju sigetskom sve češće pridavati (teorijska) oznaka „zrinijada“, kojom se teži naglasiti isključivo sadržajna (tematsko-motivska) njegova bliskost obimnom korpusu domaćih književnih ostvarenja koja tematiziraju opsadu i pad Sigeta te herojsku pogibiju Nikole Šubića Zrinskog. Ova odrednica - o kojoj je već nešto ranije bilo podosta riječi - u značenjskom smislu zapravo predstavlja svojevrsno proširenje identičnoga pojma što su ga naši književni povjesnici sve do sedamdesetih i osamdesetih godina prošloga stoljeća rabili za isključivo ep Obsida sigecka Petra Zrinskoga, a nerijetko i za njegov mađarski epskopjesnički predložak iz pera Petrova brata Nikole, ${ }^{319}$ pri čemu valja naglasiti da se ni u jednom od ovih dvaju značenja ,zrinijada“ ne pojavljuje kao punokrvna, povijesna generička oznaka, pa čak ni kao teorijska žanrovska ladica u koju su se retrogradno

\footnotetext{
319 O pojmu „zrinijada“ i njegovoj uporabi u domaćim književnopovijesnim pregledima i studijama detaljnije u bilješci 181 .
} 
pokušavali i još uvijek pokušavaju svrstati konkretni literarni tekstovi. Naprotiv, dok se u svome starijem značenju koristila kao pomalo kolokvijalna oznaka za povijesne epove braće Zrinski, u ovomu novijem - u kojem često biva navedena i u našem istraživanju - odnosi se ona na svako pojedinačno djelo iz hrvatske književnosti koje obrađuje kršćansko-muslimanski sukob pod sigetskim zidinama, i to neovisno od stvarnoga žanra u kojemu je to djelo realizirano, odnosno konkretnih generičkih značajki koje se u njemu sljubljuju. ${ }^{320}$ Upravo kao takvu, nežanrovsku ili nadžanrovsku odrednicu kadru da jedino na temelju tematskih podudarnosti zbliži katkad i žanrovski izrazito raznolika djela rabit će je i mnogi suvremeni (književni) povjesnici - primjerice, Slobodan Prosperov Novak, Davor Dukić, Zrinka Blažević i dr. ${ }^{321}$ - u svojim osvrtima (i) na Ritterov vernakularni književni prvijenac.

Unatoč, dakle, sve većim naporima što ih u posljednjih nekoliko desetljeća proučavatelji ulažu u istraživanje žanrovskih posebnosti Odiljenja, većina njihovih pokušaja da se ovome specifičnom Vitezovićevu tekstu domisle najprikladnije generičke odrednice ostala je - nažalost - na tragu onih identifikacija za kojima su posezali još devetnaestostoljetni naši književni povjesnici. Propitujući njezina dosadašnja žanrovska shvaćanja, pojedini su se suvremeni „ritterolozi“ napokon odvažili na znatno temeljitije analize Ritterove ,zrinijade“, no iako im je redovito pritom polazilo za rukom locirati u njoj neke ranije previđane generičke značajke, njih obično nisu motrili na podlozi poetički propisanih obilježja konkretnih povijesnih (baroknih) žanrova, već pojmili kao nadvremenske osobitosti triju općih genoloških kategorija ili - staigerovski rečeno - stilova: „epskog“, „lirskog“ i „dramskog“. S obzirom na ova prilično anakrona teorijska (genološka) polazišta, ni samo generičko definiranje Odiljenja nije moglo uroditi naročito inovativnim rezultatima, pa će najveći broj proučavatelja i dalje posezati za odrednicama kao što su „djelo“ i „spjev“, pri čemu će ovu potonju - u želji da je preciziraju - neki od njih pokatkad nadopunjavati dodatnim, no odveć načelnim generičkim oznakama („lirsko-epski spjev“). I na samom će se kraju 20., odnosno početku 21. stoljeća u književnopovijesnim pristupima Vitezovićevu ostvarenju nastaviti tako množiti kojekakve njegove generičke definicije, i to bez i najmanjih naznaka da će se u kompleksan njegove generički identitet u skorije vrijeme napokon dospjeti proniknuti, a onda i za nj iznaći najprimjerenija (ili makar najmanje neprimjerena) jednoznačna žanrovska odrednica oko čije bi uporabe „ritterolozi“ konačno bili voljni postići nasušno potreban konsenzus. Ne gajeći nade da bi baš njemu takvo što ipak moglo poći za rukom, ovo će istraživanje na stranicama koje slijede najprije pristupiti - dosad tek napola

\footnotetext{
${ }^{320}$ Podrobnije o književnim djelima koja potpadaju po oznaku ,zrinijada“ u bilješci 187.

${ }^{321}$ Usp. Prosperov Novak 1999: 698, Dukić 2004b: 131, Blažević 2012: 435, Budišćak 2016a: 263 i 2016 b: 82.
} 
obavljenom - poslu detektiranja različitih generičkih slojeva Odiljenja sigetskog, odnosno razlučivanja u nj utkanih značajki konkretnih povijesnih žanrova, a potom se - slijedom novootkrivenih spoznaja - usredotočiti i na traganje za odgovarajućom generičkom definicijom Vitezovićeva djela, i to s punom sviješću o tome da je taj njegov pothvat možda unaprijed već osuđen na propast.

\section{PRIMARNI I SEKUNDARNI GOVORNI ŽANROVI I ŽANROVSKA OBILJEŽJA U ODILJENJU SIGETSKOM}

Pišući o žanrovskoj klasifikaciji kao jednoj od mogućih varijanata razvrstavanja književnih tekstova, Milivoj Solar u svojoj će do danas nenadmašenoj Teoriji književnosti s pravom naglasiti kako bez ,razumijevanja književnih rodova i vrsta, naime, nema razumijevanja književnosti, jer su oblici u kojima se pojavljuju književna djela često od presudne važnosti za shvaćanje i doživljavanje književnosti“" (Solar 1996: 128). Premda bi se Solarovu inzistiranju upravo na književnim rodovima i vrstama - umjesto na (povijesnim) žanrovima - iz perspektive suvremene genologije moglo štošta prigovoriti, o presudnom utjecaju generičke predodžbe na razumijevanje književnih djela nema danas više ni najmanjega spora, tim više što se od polovine prošloga stoljeća sve glasnije, kao što smo vidjeli u pretprošlom poglavlju, govori i o razvijanju žanrovske svijesti kao neophodnom preduvjetu čovjekova participiranja u različitim općeživotnim tipiziranim (retoričkim) situacijama. Da Solarove riječi nipošto nisu tek puka naklapanja potvrdit će nam ne samo moderna teorija žanrova sa svojom praktičnom izvedenicom u vidu žanrovskih studija, već i povijest književnih teorija, koje su se još od Aristotelove Poetike većinom fokusirale na propisivanje „nužnih“ obilježja za pojedine žanrove, ali i najsuvremeniji autorsko-čitateljski pristup književnim djelima, koji najvećim dijelom također počiva upravo na „generičkom predumišljaju“, točnije na kreativnom udovoljavanju ili odupiranju nekim žanrovskim „kalupima“, odnosno na prilagođavanju recepcije shodno nekim žanrovskim očekivanjima. Kakve doista posljedice na razumijevanje svakoga pojedinačnog književnog djela ostavlja stanovita žanrovska predodžba o njemu - odnosno bilo koji pokušaj njegove generičke klasifikacije - posvjedočiti nam i više nego zorno može upravo primjer Vitezovićeve „zrinijade“, koju su, kao što smo vidjeli, različiti njezini (većinom stručni) čitatelji od konca 17. stoljeća do danas u žanrovskom smislu shvaćali poprilično različito, što se automatski odrazilo i na rezultate njihovih interpretacija, većinom svedenih na utvrđivanje prevlasti ovih ili onih generičkih silnica na tekstualnom prostoru Odiljenja. I baš kao što se žanrovski ono 
dosad definiralo poprilično općenitim odrednicama, tako je i čitanjima u sklopu kojih su te definicije predstavljane redovito nedostajala znatno veća preciznost pri detektiranju pojedinih njegovih žanrovskih osobina, što će reći da se ni jedna od dosadašnjih analiza locirane mu tekstualne posebnosti nije usudila motriti kao tragove konkretnih povijesnih žanrova.

Ni maločas razmatrana recentn(ij)a generička tumačenja Ritterova djela - ona Nikice Kolumbića, Davora Dukića i Pavla Pavličića ${ }^{322}$ - ne predstavljaju u tom pogledu značajniju iznimku, pa - usprkos hvalevrijednoj analitičkoj temeljitosti, zahvaljujući kojoj dolaze do mnogih neosporno inovativnih zapažanja - sadržajne i formalne njegove posebnosti ustrajno sagledavaju ne kao obilježja ranonovovjekovnih žanrova, već kao svevremenske osobitosti nekih daleko načelnijih - očito staigerovskih - teorijskih genoloških kategorija. Bez obzira na to što se Odiljenje sigetsko zaslugom tih i takvih interpretacija ipak izdvaja kao jedno od rijetkih Vitezovićevih ostvarenja koja su do danas dospjela dočekati (makar donekle) minuciozniju generičku analizu, ${ }^{323}$ neobično je da se (nekim) pojedinačnim žanrovima od kojih je ono satkano daleko veća pažnja sustavno posvećivala u kratkim njegovim prikazima ispisanima na stranicama preglednih radova ili književnopovijesnih priručnika no u ovim znatno duljim, odnosno problemskim ,ritterološkim“ studijama. U svome iscrpnom osvrtu na domaća književna djela u kojima se proslavlja herojski otpor „sigetskog junaka“, Milivoj Šrepel prvi je - već 1902. - tako uočio da je u svojoj „zrinijadi“ Vitezović „upotrijebio apostrofe, govore, listove, razgovore i epitafije“ (Šrepel 1902: 105), a svega nekoliko godina kasnije iste će žanrove u Odiljenju - govore, dijaloge, poslanice (pisma) i epitafe - u svome književnopovijesnom priručniku detektirati i Branko Vodnik, pripominjući uz to kako je redom riječ o „oblicima“ udomaćenima u prigodnom pjesništvu, ${ }^{324}$ kojemu je Ritter ionako izrazito bio sklon. Očevidno slijedeći Šrepelova i Vodnikova zapažanja, i David Bogdanović u prvoj knjizi svoga Pregleda književnosti hrvatske $i$ srpske nabraja identične žanrove sadržane u Odiljenju (govori, pisma, apostrofe, epitafiji, razgovori), ${ }^{325}$ nešto više od desetljeća potom Slavko Ježić u književnopovijesnome svom pregledu Vitezovićev tekst žanrovski opisuje kao „niz pjesama u obliku monologa, dijaloga, poslanica i nadgrobnica“ (Ježić 1993:

\footnotetext{
${ }^{322}$ Usp. Kolumbić 2005: 327-353, Dukić 2002: 67-70 i Pavličić 2007: 253-284.

${ }^{323}$ Ozbiljnijom se generičkom interpretacijom mogu tako dosad „pohvaliti“ jedino Vitezovićev najznačajniji historiografski latinski spis Oživljena Hrvatska, o kojemu je - kao primjeru žanra barokne spomenice ili memoranduma - pisala Zrinka Blažević (usp. Blažević 2002: 100-113), potom njegova latinska kronika u stihovima Dva stoljeća ucviljene Hrvatske, čijim su se epskopjesničkim značajkama pozabavili Pavao Knezović (usp. Knezović 2016: 229-241) i Zrinka Blažević (usp. Blažević 2019: 5-21), te korpus njegovih (glavninom također latinskih) pjesničkih poslanica, koji je - u sklopu rada na doktorskoj svojoj disertaciji - temeljito istražila Violeta Moretti (usp. Moretti 2014 i Moretti i Stepanić 2019: 9-116). O drugim se Ritterovim tekstovima iz žanrovske perspektive pisalo dosad većinom uzgredno i najčešće bez (ozbiljnijih) pretenzija da se njihove značajke povežu s repertoarima konkretnih baroknih književnih žanrova.

${ }^{324}$ Usp. Vodnik 1913: 299.

${ }^{325}$ Detaljnije u: Bogdanović 1932: 452.
} 
147), dok u Povijesti hrvatske književnosti do narodnog preporoda Mihovil Kombol napominje kako Odiljenje sačinjavaju dijalozi, monolozi, epitafiji, poslanice te oproštajni govori. ${ }^{326}$ Pišući kratku popratnu studiju uz svoje kritičko izdanje Odiljenja sigetskog Tomo će Matić 1968. naglasiti kako u Vitezovićevu tekstu možemo zateći („samo“) govore, razgovore i nadgrobnice, ${ }^{327}$ Krešimir Georgijević u jedva godinu će dana mlađem prikazu sjevernohrvatske i bosanske ranonovovjekovne književnosti uočiti u njemu ne samo primjerke žanra poslanice i oproštajnoga govora, već i „elegične tugovanke“ te „dijalogizirane elegije“, ${ }^{328}$ a u svomu će nedavnom obljetničkom pregledu domaćih „zrinijada“ i Stjepan Hranjec - slijedom ranijih naših književnih povjesnika - konstatirati kako je Odiljenje žanrovski skrojeno „od niza monologa, dijaloga, poslanica i epitafija“ (Hranjec 2016: 27).

Snažnu, dakle, svijest o tome da je Vitezovićevo Odiljenje sigetsko višežanrovsko pjesničko ostvarenje, odnosno da je njegova struktura protkana stanovitim brojem individualnih (,manjih“) žanrova pojedini su povjesničari hrvatske književnosti otvoreno iskazivali već početkom prošloga stoljeća, od kada - kao što smo vidjeli - i datiraju prvi pokušaji preciziranja njegova generičkog sastava. Iako je zapravo riječ o pobrojavanju očitih žanrovskih komponenata Odiljenja (epitafi, poslanice), kao i nabrajanju onih koje se među književne žanrove mogu uvrstiti samo uvjetno ili čak ne mogu uopće (monolozi, dijalozi, oproštajni govori, „elegične tugovanke“, „dijalogizirane elegije“ itd.), ostaje poprilično nejasno zašto se na njih nije držao svrsishodnim referirati niti jedan od maločas pobrojanih recentnijih „ritterologa“, redom zaokupljenih odveć apstraktnim definicijama generičkih sastavnica Vitezovićeva teksta („epska“" vs. „lirska“ obilježja). S obzirom na to da su navedene (pod)žanrove svjesno ili hotimice oni odbijali uzeti u obzir, dok, pak, o konkretnim njihovim obilježjima u Odiljenju ništa više nisu mogli (a ni željeli) reći ni sami književni povjesnici koji su ih locirali, pitanje konkretnih njegovih žanrovskih sastavnica, a kamoli ono njihove podudarnosti stvarnim - sedamnaestostoljetnim - povijesnim žanrovima i njima svojstvenim tekstualnim značajkama i izvantekstualnim funkcijama u ,ritterološkoj“ se literaturi do danas nije načinjalo, premda se, s vremena na vrijeme, događalo da na nužnost ekstenzivnije žanrovske analize Ritterove ,zrinijade“ podsjeti pokoji izdvojeni proučavatelj, no čineći to bez stvarne namjere da se tim problemom sam ozbiljnije pozabavi. ${ }^{329}$ To očito izbjegavanje temeljite i što preciznije generičke raščlambe, odnosno interpretativni pristupi koji se - još i početkom 21. st. - zasnivaju na već prilično zastarjelim teorijskim (genološkim)

\footnotetext{
${ }^{326}$ Usp. Kombol 1961: 280.

${ }^{327}$ Usp. Matić 1968: 104.

${ }^{328}$ Podrobnije u: Georgijević 1969: 132-134.

${ }^{329}$ Usp. npr. Dukić 2002: 69.
} 
ishodištima ne predstavljaju - nasreću ili nažalost - isključivo „ritterološki“ problem, tim više što se (fokusiramo li se samo na Vitezovićevo razdoblje) u izrazito bogatom i raznolikom korpusu barokne književnosti jedva da i može naći literarno ostvarenje kojemu se do danas „posrećilo“ biti predmetom minucioznije, pa i teorijski osuvremenjene (žanrovske) analize.

Naslućujući izrazito složenu generičku ,prirodu“ Odiljenja sigetskog, u razmatranju koje se nije moguće u potpunosti osloniti na tek puku potragu za pojedinim „tipičnim“ i nadvremenskim tekstualnim karakteristikama sveobuhvatnih genoloških kategorija, naredno je istraživanje stoga prisiljeno kročiti upravo tim dosad neutabanim putovima želi li makar pokušati razmrsiti klupko žanrovskoga identiteta Vitezovićeve ,zrinijade“, odnosno doći u priliku da na pitanje o njegovoj žanrovskoj (ne)pripadnosti podastre - po njegovu sudu najprikladniji mogući odgovor. Da bi mu takva prilika uopće mogla biti ponuđena, naše istraživanje Odiljenju sigetskom svakako mora pristupiti kao svojevrsnome povijesnom literarnom artefaktu, što će reći kao ostvarenju čiji se generički identitet mogao izgraditi jedino - podjednako svjesnim i nesvjesnim - ugledanjem na točno određene povijesne (onodobne i/ili starije) književne žanrove, i to kako na praktično ostvarene njihove primjer(k)e, tako i na tadašnje njihove poetičke opise (ako su, dakako, oni uopće postojali). Isključivo pod uvjetom da Vitezovićevo Odiljenje prihvati kao književnopovijesni, a ne nadpovijesni ostvaraj, ovo će istraživanje biti u stanju u njemu prepoznati upravo obilježja konkretnih povijesnih - dakle, sedamnaestostoljetnih - književnih, pa i ne samo književnih žanrova, a ne - kao što je to dosad bio slučaj - za sva vremena zadane „tipične“ tekstualne značajke univerzalnih teorijskih entiteta, na temelju kojih se suviše fluidno ono jedino i moglo definirati kao „epsko“, „lirsko“ ili, pak, „lirsko-epsko“ djelo.

Umjesto uobičajenoga prešutnog nadovezivanja na zastarjele teorijske uvide, posve usredotočene na „vječne“ karakteristike ovih odveć apstraktnih genoloških kategorija, naše će istraživanje u svome poslu dubinskog raščlanjivanja pojedinih žanrovskih slojeva Odiljenja sigetskog daleko najpouzdanijega vodiča pronaći u suvremenim teorijama književnih žanrova, i to navlastito u onima koje otvoreno ukazuju na izrazitu složenost većine žanrova, odnosno na njihovu neizbježnu hibridnost. Budući da pred sobom ima upravo jedno takvo - generički vrlo kompleksno - književno ostvarenje, kao definitivno najprikladnije teorijsko ishodište gotovo mu se sama od sebe nameću nešto ranije detaljno predstavljena genološka promišljanja Mihaila Mihailoviča Bahtina, koja je ovaj utjecajni ruski filozof iznio u svome eseju „Problem govornih žanrova“. ${ }^{330}$ Podstrek temeljitoj analizi različitih generičkih obilježja što premrežuju Odiljenje doslovno od korica do korica pritom neće dati samo čuveno

\footnotetext{
${ }^{330}$ Usp. Bahtin 1980: 233-270 i 1986: 60-102.
} 
Bahtinovo zapažanje kako su gotovo svi (pisano)književni žanrovi zapravo složeni (sekundarni) govorni žanrovi satkani od mnoštva onih jednostavnijih (primarnih), otrgnutih iz sfere svakodnevne govor(e)ne komunikacije, već naročito njegovo uvažavanje najrazličitijih mogućih - podjednako umjetničkih i izvanumjetničkih - govornih žanrova, koje i pred ovu interpretaciju postavlja imperativ posvećivanja podjednake pažnje kako pisanoknjiževnim, tako i usmenoknjiževnim, pučkoknjiževnim, poluknjiževnim i izvanknjiževnim žanrovima, čijim je obilježjima, a pokatkad i cjelovitim primjerima, Ritter svoju „zrinijadu“ obilno napučio. To, međutim, neće automatski značiti i da će se u poslu detektiranja konkretnih (povijesnih) žanrova i/ili zasebnih njihovih značajki naredna analiza spuštati sve do razine $-\mathbf{u}$ Odiljenju također obilato zastupljenih - najelementarnijih primarnih govornih žanrova poput, primjerice, oslovljavanja ${ }^{331}$ ili pozdrava, ${ }^{332}$ osim u slučajevima kada se utvrdi da je riječ o prepoznatljivim odlikama (ili uvriježenim toposima) stanovitih u tekstu prisutnih (baroknih) sekundarnih žanrova (primjerice, poslanica ili nadgrobnica). Također, s obzirom na maločas zamijećena manjkava Bahtinova razjašnjenja distinkcije između primarnih i sekundarnih govornih žanrova, ${ }^{333} \mathrm{u}$ samome se istraživanju neće posebno precizirati o obilježjima ili cjelovitim primjercima kojega je konkretno tipa žanra riječ, iako će za većinu njih već na prvi pogled biti jasno radi li se o jednostavnijem ili kompleksnijem generičkom „rješenju“. U najvećem broju slučajeva bit će ipak riječi upravo o složenijim (sekundarnim) govornim žanrovima, $\mathrm{i}$ to posve usprkos činjenici da, kako implicira Bahtin, fakturu jednoga sekundarnog žanra - kakav bi, uostalom, trebalo biti i Odiljenje sigetsko kao cjelina - tvore isključivo (transformirani) primarni govorni žanrovi.

Proglašavajući ove ili one sadržajne $\mathrm{i} / \mathrm{ili}$ formalne osobitosti utkane $\mathrm{u}$ Vitezovićev tekst ,žanrovskim obilježjima“, na umu ćemo zapravo neprestano morati imati cjelokupan „raspon potencijalnih točaka sličnosti što ih žanr može izložiti““ (Fowler 1982: 55), kojega pojedini moderni književni genolozi nazivaju ,žanrovskim repertoarom“. Svjesni činjenice da baš svaki žanr posjeduje ,jedinstven repertoar iz kojega njegovi predstavnici odabiru obilježja“ (Isto: 55), s uma - jednako tako - ni u jednome trenutku nećemo smjeti smetnuti ni to da pojedinačne značajke u svakome repertoaru stoje u snažnom međuodnosu, no s obzirom na to da se njihove funkcije kroz vrijeme ipak mijenjaju, periodički dolazi i do promjene $u$ sastavu čitavih repertoara, odnosno do odbacivanja starih te asimiliranja nekih sasvim novih

\footnotetext{
${ }^{331}$ Npr. „Jurju, dite moje“ (I: 478), „Kralju, kruno sveta“ (II: 1), „Braćo draga moja“ (II: 269) itd.

${ }_{332}$ Primjerice, pozdrava „Zdravo“ (III: 12) ili - znatno češće - onoga „Sbogom“ (II: 435, 903; III: 376).

${ }^{333}$ Usp. poglavlje 2. 3.
} 
žanrovskih karakteristika. ${ }^{334}$ Premda te promjene u žanrovskim repertoarima katkada bivaju potaknute (naizgled) „čisto“ unutarknjiževnim razlozima, do njih ipak najčešće dolazi zbog određenih izvanknjiževnih (kontekstualnih) mijena, kao što je to, uostalom, bio slučaj i s većinom žanrova što ih je barok baštinio iz renesansnoga razdoblja, čije bitno izmijenjene sadržajne, formalne i stilske značajke prilično jasno ukazuju i na promjenu okolnosti, s kojima je ujedno došlo i do promjene njihovih funkcija (primjerice, zamjena dvostruko rimovanoga dvanaesterca „narodnim“ osmercem u baroknomu je epu i lirskoj pjesmi tako očit signal želje autora da svoja ostvarenja približe i sustavno dotad zanemarivanoj publici ne bi li tako u njima sadržane - mahom ideološke - poruke doprle do što je moguće većeg broja recipijenata). Ne sumnjajući u točnost ove višestruko potvrđene spoznaje, ni u narednom nam istraživanju stoga ne preostaje ništa drugo no inzistirati upravo na obilježjima povijesnih žanrova, odnosno iznađene generičke značajke ustrajno motriti na podlozi repertoara stanovitih sedamnaestostoljetnih žanrova, pokušavajući tako utvrditi za kojim je to konkretnim generičkim rješenjima iz svoga vremena Vitezović posezao ispisujući Odiljenje sigetsko. A da bismo uopće bili u stanju steći predodžbu o tome s kakvim se žanrovskim izborom tijekom svoga rada na Odiljenju naš autor suočavao, bit će potrebno prisjetiti se svih mogućih generičkih opcija koje je u tome trenutku (najvjerojatnije) on imao na raspolaganju, odnosno „rekonstruirati“ cjelokupni žanrovski sustav hrvatske barokne književnosti, u okrilju kojega je, uostalom, njegova generički osebujna „zrinijada“ i ugledala danje svjetlo.

\section{1. POJAM I STATUS ŽANRA U BAROKU I ŽANROVSKI SUSTAV HRVATSKE BAROKNE KNJIŽEVNOSTI}

Promatrano iz književnopovijesne perspektive, Odiljenje sigetsko Pavla Rittera Vitezovića ispjevano je i objelodanjeno - kako smo već više puta napomenuli - duboko u razdoblju hrvatskoga književnog baroka. Premda taj podatak nipošto ne mora sugerirati da je, kao djelo iz druge polovine 17. stoljeća, Odiljenje po unutarnjim karakteristikama i literarnoj svojoj funkciji ujedno i „tipično“ barokno ostvarenje, već sama činjenica da se svojom pojavom uključilo u dominantno barokno okružje, odnosno stupilo u krug domaćih književnih tekstova presudno obilježenih (i) „prepoznatljivo“ baroknim - poglavito žanrovskim silnicama, podrazumijeva da je ono spram tada prevladavajuće književne poetike nužno razvilo neki odnos, bez obzira na to je li (bila) riječ o odnosu (djelomičnoga ili potpunog)

\footnotetext{
334 Genolozi pritom napominju da repertoar niti jednoga žanra nije beskrajno obnovljiv jer svako zasebno obilježje mora u njemu biti prepoznatljivo, što ujedno u svakome trenutku života konkretnoga žanra bitno ograničava mogućnost promjena u njegovu repertoaru. Detaljnije u: Fowler 1982: 73.
} 
uvažavanja, otvorenog odbacivanja ili (svjesnoga ili nesvjesnog) ignoriranja. Poprilično ishitreno, ako ne i posve promašeno bilo bi pritom ustvrditi kako Vitezović u vrijeme rada na svojoj ,zrinijadi“ nije bio ni ovlaš upućen u barokne poetičke (pr)opise - neovisno od toga je li ih usvojio kroz recepciju baroknih književnih djela, čitajući same poetičke traktate ili preko oba „kanala“ - tim više što je, podsjetimo, riječ o izrazito obrazovanu autoru koji je, po završetku svoga školovanja $\mathrm{u}$ isusovačkoj gimnaziji, doslovno do kraja života nastavio predano proučavati povijesne izvore, iščitavati domaća i strana književna djela na više jezika, ali i zanimati se za usmenoknjiževno stvaralaštvo i folklorne običaje. Drugim riječima, kao tipični barokni polihistor Ritter je o mnogočemu znao makar ponešto, a s obzirom na vlastite literarne ambicije naprosto je morao biti dobro „potkovan“ i po pitanju tada aktualnih književnopoetičkih imperativa, što će reći da je i svoje Odiljenje sigetsko - kao djelo kojim se, kao što će se doskora pokazati, težio približiti publici najrazličitijih mogućih profila - bez sumnje prožeo (i) nemalim brojem baroknih karakteristika, od kojih su daleko najbrojnije i najznačajnije bile upravo one žanrovski određene.

Pretpostavimo li da bi tomu zaista trebalo biti tako, u tom se slučaju i pred našu analizu postavlja imperativ jednako dobroga poznavanja cjelokupna raspona u (hrvatskom) baroku dostupnih literarnih - pa i ne samo literarnih - žanrova te poglavito njihovih specifično kombiniranih „generičkih repertoara“, koji su, ponovimo, za čitava ranonovovjekovlja i shvaćani kao kriteriji na podlozi kojih je procjenjivano odgovaraju li pojedini tekstovi (eksplicitno ili implicitno) ustanovljenim žanrovskim normama. Uvid u iznimno bogatu paletu sedamnaestostoljetnih generičkih rješenja nužan je, međutim, ne samo kako bismo stekli jasnu predodžbu o tome za značajkama kojih to uopće baroknih pisanoknjiževnih žanrova nam u nastavku valja tragati - zahvaljujući kojoj ćemo ujedno i moći prionuti na posao razlučivanja njihovih osobitosti od eventualnih (tekstualnih) specifičnosti onih predbaroknih, kao i usmenoknjiževnih, pučkoknjiževnih i izvanknjiževnih žanrova, koji ne podliježu mijenama poetičkih propisa kao oni pisane književnosti - već i da bismo osvijestili punu širinu generičkoga konteksta ili sustava naše barokne književnosti, u kojemu žanrovi nisu ,tek“ supostojali jedni pored drugih, već su - a to se naročito odnosi na one pisanoknjiževne - jedni na druge međusobno i računali, tim više što su vršili ne uvijek jednake izvanknjiževne funkcije i obraćali se ne uvijek istim tipovima čitatelja. Štoviše, razmatranje žanrovskoga sustava sedamnaestostoljetne hrvatske književnosti ujedno će pripomoći i da spoznamo punu njezinu kompleksnost, glavninom proizišlu iz snažne joj regionalne rascjepkanosti, a onda i da utvrdimo koju su to i kakvu konkretnu publiku 
najvjerojatnije trebali prizivati ti različiti generički elementi što ih Vitezović - kako se čini - s i više nego pomno isplaniranom svrhom uključuje u svoje Odiljenje sigetsko.

Kao prvi i zacijelo najvažniji kontekst svakoga pojedinačnog literarnog žanra, generički je sustav, podsjetimo, u skladu s tada dominantnom (implicitnom ili eksplicitnom) poetikom iz temelja gradilo baš svako razdoblje književne povijesti, pokatkad se pritom snažno nadovezujući na onaj prethodne epohe, a pokatkad se trudeći od njega što više odmaknuti. Ni barok, dakako, u tome nije bio izuzetak, premda su na sastav njegova žanrovskog sistema - skrojenog od pojedinih naslijeđenih (no bitno modificiranih) renesansnih žanrova, ali i onih novostvorenih - znatno presudnije djelovale stanovite izvanjske, društvenopovijesne okolnosti, koje su i iziskivale - u odnosu na renesansno razdoblje - bitno proširenje palete dostupnih generičkih rješenja. U prilog baroknomu žanrovskom obilju svakako su morale ići i relativna dugotrajnost baroka kao (književnog) perioda, njegovo paralelno manifestiranje u različitim sedamnaestostoljetnim umjetničkim praksama (književnoj, likovnoj, glazbenoj itd.), kao i sve čvršće veze između različitih nacionalnih književnosti, koje su - između ostalog - poticale i međuknjiževne žanrovske razmjene. Pri tomu je nužno imati na umu da se barok - kao epoha koja je u europskim književnostima (okvirno) trajala od 1575. do 1690., ${ }^{335}$ a u nas i znatno dulje $\mathrm{e}^{336}$ - nije posvuda manifestirao jednako, odnosno da barokne silnice ne samo što se nisu počele javljati istodobno u apsolutno svim europskim književnostima, već ni unutar jedne nacionalne književnosti nisu one odjednom ušle u fakturu redom svih u njoj tada zastupljenih žanrova.

Svjesni ovoga potonjeg, pojedini su barokolozi u posljednjih nekoliko desetljeća odustali od tradicionalnoga književnopovijesnog poimanja baroka - utemeljenog na uvjerenju da mu valja pristupati kao isključivo periodizacijskoj kategoriji ${ }^{337}$ - te otvoreno počeli zagovarati viđenje baroka kao specifičnoga stila, odnosno stilskopovijesne kategorije. ${ }^{338}$ Polazeći od činjenice kako je „europska književnost oko g. 1600. i nakon nje skup (...) manje ili više odvojenih književnih kultura i tradicija među kojima je koliko-toliko posredovao jedan stil“ (Kravar 1993: 37), ovi se književni povjesnici u svojim analizama sedamnaestostoljetnih literarnih ostvarenja stoga usredotočuju na prisutnost ili odsutnost prepoznatljivo baroknoga,

\footnotetext{
${ }^{335}$ Usp. Segel 1974: 3 i Johnson 2012: 121.

336 Pojedini naši barokolozi tako navode da se barok u hrvatskoj književnosti vremenski protezao od 1600. do 1750. godine (usp. npr. Kravar 2010: 110), pri čemu ta domaća njegova dugotrajnost ne bi smjela odveć čuditi s obzirom na to da je, primjerice, u poljskoj književnosti - kako navode neki književni povjesnici - trajao on sve do 1764., kada se na prijestolje popeo posljednji poljski kralj (usp. o tome u: Segel 1974: 31).

${ }^{337}$ Baroku kao (punokrvnomu) književnom razdoblju pristupali su, između ostalih, i Frank Warnke (usp. Warnke 1972), Harold Segel (usp. Segel 1974) te Pavao Pavličić (usp. Pavličić 1979b: 31-67).

338 Takvo shvaćanje baroka najglasnije je u nas zagovarao Zoran Kravar (usp. Kravar 1978: 223-241 i 1993: 738).
} 
figuralno naglašenog stila, koji se, prema njihovu mišljenju, može izdvojiti kao jedini čimbenik onodobne književnosti što su ga - bez obzira na svoje podrijetlo - posjedovali odreda svi oni tekstovi koji (jedini) zaslužuju ponijeti epitet baroknih. Za razliku, dakle, od proučavatelja koji su inzistirali na univerzalnome „,baroknom iskustvu“, manifestiranom kroz specifičan svjetonazor i zajedničke estetičke sklonosti velike većine europskih - pa i naših baroknih literata, ovi suvremen(ij)i eksperti za baroknu književnost ističu kako se međunarodnost baroka može dokazati samo i jedino na razini prepoznatljivih stilskih preferencija, o poznavanju i uvažavanju kojih svjedoči i niz ostvarenja domaćih sedamnaestostoljetnih (ponajprije južnohrvatskih) pisaca.

$\mathrm{Na}$ odrješito odbacivanje uvriježenih predodžbi o baroku kao književnopovijesnom periodu nov(ij)u je generaciju barokologa, kako rekosmo, ponajviše navela spoznaja o njegovoj izrazitoj pluralnosti, s kojom ćemo se i sami suočiti pri razmatranju žanrovskoga sustava naše barokne književnosti. Nezanemarive različitosti literarnih ostvarenja nastalih tijekom 17. stoljeća prema njihovu tako mišljenju proizlaze iz činjenice da se sve onodobne europske književnosti u vrijeme nastupanja „baroka“ nisu nalazile na istome stupnju razvoja budući da im nije svima bilo omogućeno $\mathrm{u}$ istome trenutku proći kroz renesansu $\mathrm{i}$ posredstvom nje se jednom za svagda osamostaliti od književne kulture srednjega vijeka. Emancipacija od srednjovjekovlja u različitim se europskim sredinama, naime, odvijala u različitim trenucima višestoljetnoga razdoblja između 14. i druge polovine 18. stoljeća, pa dok tako u Italiji i Dubrovniku renesansa počinje već u 16. st., u Habsburškoj će Monarhiji i na istoku Europe književnost i u 17. stoljeću - kako u žanrovskom, tako i u smislu društvenoga statusa kojega tada uživa - još uvijek pokazivati veću bliskost predrenesansnoj, odnosno srednjovjekovnoj književnoj kulturi, pa će i tada u njoj (još uvijek) uvelike biti zastupljeni religiozno lirsko pjesništvo te propovjedni tekstovi. Drugim riječima, u sedamnaestostoljetnoj su Europi jedna uz drugu supostojale predrenesansna i postrenesansna književna kultura, što je za svoju posljedicu imalo nezanemarivu nepodudarnost lokalnih obilježja njihovih varijanata baroka, tj. činjenicu da su nacionalne crte „barokne“ književnosti u njima bile znatno izrazitije od onih nadnacionalnih, odnosno općeeuropskih. Upravo iz toga će razloga zagovornici stilskoga pristupa baroku neprekidno i izražavati sumnju u to da se onodobno literarno stvaralaštvo u cijelosti uopće može označiti kao „barokno“, napominjući pritom da europski književni barok nije bio cjelovita književna pojava jer naprosto nije ni dospio steći status književnopovijesnoga razdoblja u punom smislu te riječi. 339

\footnotetext{
339 Ili, Kravarovim riječima, „dok je zapadnoeuropska kultura 17. stoljeća razvijala svoj književni život na tekovinama renesanse, u srednjoj i istočnoj Europi nalazimo i nakon g. 1600. oblike književne komunikacije
} 
Da se, međutim, nipošto ne bi smjelo olako odreći i viđenja baroka kao više ili manje kompaktnoga književnopovijesnog, ali i kulturnog perioda sugerirat će nam ne samo brojni zajednički nestilski čimbenici „baroknih“ literarnih ostvarenja, već poglavito kontekstualne okolnosti, odnosno specifično društvenopovijesno okružje, koje je u nacionalnim sedamnaestostoljetnim kulturama diljem „staroga kontinenta“ uistinu rezultiralo uspostavljanjem relativno bliskoga svjetonazora uvelike manifestiranoga i unutar mnogih onodobnih književnih djela. Epohu koju nazivamo baroknom, podsjetimo, presudno je u Europi obilježio niz prijelomnih političkih, religijskih i znanstvenih događaja poput pojave reformacije i protureformacije, neprekidnih kršćansko-turskih ratnih okršaja, brojnih manjih vojnih akcija i nacionalnih sukoba (Englesko-španjolski rat, Tridesetogodišnji rat), ${ }^{340}$ uspostave apsolutne monarhije kao tipičnoga sedamnaestostoljetnog oblika vlasti, osnivanja znanstvenih društava ili akademija, odvajanja filozofije od teologije i njezina razvijanja u kontekstu znanosti, mnogobrojnih velikih znanstvenih dostignuća (Kopernikova vizija heliocentričkoga astronomskog sustava, pojava novih ideja o anatomiji ljudskoga tijela itd.) te uopće nametanja nove slike svijeta na koju su bitno utjecala i nova znanstvena otkrića te sve intenzivnije kolonijalno širenje na novootkrivena područja. S obzirom na to da su barokno razdoblje diljem europskoga kontinenta dubinski usmjerili kako strelovit napredak znanosti i povišena duhovnost, tako i prisutnost sukoba u svim sferama života te česte društvene i prirodne katastrofe, očito je da je - riječima Franka Warnkea - 17. stoljeće i više nego opravdano opisati kao „razdoblje sukoba, ratova i nereda“, u kojemu je „novi znanstveni i racionalistički svjetonazor postupno istisnuo stari religijski i simbolički svjetonazor koji je uvjetovao europsku misao i umjetnost još od srednjega vijeka“ (Warnke 1972: 16).

Poredbenom povjesničaru književnosti pritom teško može promaći činjenica da je ta (sve)opća atmosfera nestabilnosti, nesigurnosti, uskomešanosti, tjeskobe, pa i straha bitnoga traga - ovakvog ili onakvog - ostavila u apsolutno svim sedamnaestostoljetnim nacionalnim književnostima, slijedom čega se nimalo ne bi trebao ustručavati od toga da baroknu književnost kao (makar provizornu) cjelinu - kao što su dosad to već (u)činili i mnogi raniji proučavatelji - odlučno označi kao „tipičan“ izraz njezina vremena. ${ }^{341}$ Suočeni s gotovo neprekidnim sukobima i dubokim protuslovljima svoga doba, i barokni su književnici - kao,

\footnotetext{
kakvi su na zapadu dominirali u srednjem vijeku, a poslije su iščezli ili su ostali vezani uz estetički nereprezentativnu pučku kulturu i za nabožnu literaturu“ (Kravar 1993: 24). Opširnije u: Kravar 1993: 7-38; 161-191 i 2010: 110-115.

${ }^{340} \mathrm{O}$ konstantnim ratovima i bunama koje su se tijekom 17. st. odvijale i na hrvatskim prostorima (uključujući i međusobne oružane sukobe domaćih magnatskih obitelji zbog posjeda), ali i daleko većim ratnim sukobima u kojima su - duž cijele Europe - tada sudjelovali Hrvati detaljnije u: Maleković 1993: 12-16 i Budak 2007.

${ }^{341}$ Detaljno o tome u: Segel 1974: 66-101.
} 
uostalom, i drugi onodobni umjetnici - u svojim ostvarenjima ponajprije težili sintezi, odnosno usklađivanju i pomirivanju raznoraznih - sadržajnih, stilskih, formalnih, ideoloških i mnogih drugih - opreka, a ta će se njihova snažna sklonost sprezanju i nadilaženju različitosti možda i najočitije iskazati upravo na žanrovskomu planu - kako na onomu pojedinačnom, tako i (još više) na onomu općem. To će, konkretno, značiti da će do dubinskih promjena s nastupom „specifičnih“ (sedamnaestostoljetnih) okolnosti, iz njega proizišlog „karakterističnog“ (baroknog) svjetonazora te kontekstualnim silnicama presudno obilježenih novih poetičkih imperativa postupno doći kako u pogledu „repertoara“ i funkcije pojedinih naslijeđenih žanrova, tako i u pogledu sastava čitavoga žanrovskog sustava književnosti 17. stoljeća, u kojemu se možda neće zbiti odveć krupne hijerarhijske promjene, no koji će uslijed već spomenutoga priljeva novih generičkih rješenja svoje ,granice“ ipak bitno „rastegnuti“.

Naime, kao (književnopovijesno) razdoblje izraslo iz nestabilnih društvenih uvjeta, čija se poetika zasnivala na iskazivanju snažnoga nepovjerenja u naslijeđene koncepcije, književni je barok i svoj žanrovski sustav pokuša(va)o u što većoj mogućoj mjeri „pročistiti“ od njemu mrskoga renesansnog „balasta“. S obzirom na to da je - paradoksalno - glavninom on bio sazdan upravo od renesansnih generičkih rješenja te da, $\mathrm{k}$ tome, ni $\mathrm{u}$ njihov hijerarhijski poredak također nije želio odviše dirati, nije mu preostalo ništa drugo no da tim baštinjenim žanrovima izmijeni generičke repertoare, odnosno da ih makar liši načina na koji ih je shvaćala i rabila renesansa, a onda i da im sup(r)o(t)stavi neke sasvim nove žanrovske varijante. Osim što je, dakle, svoj žanrovski sustav uvelike popunio nizom novoosmišljenih, redom hibridnih žanrova, barok je na „korištenje“ onodobnim literatima ipak ponudio i popriličan broj onih naslijeđenih iz prethodne epohe, no izgledom i funkcijom posve prilagođenih zahtjevima novoga književnog i društvenopovijesnog okružja.

Iako je, međutim, barok pokazivao naročitu sklonost zamućivanju žanrovskih distinkcija, neprekidno sastavljao nepravilne i asimetrične žanrove te se otvoreno klonio čvrstih formi i inzistirao na onim visokoindividualiziranim, književna su kritika i teorija u njegovo vrijeme bile još uvijek antički usmjerene, što znači da je - kao što je to bio slučaj i u renesansi - i u 17. stoljeću (makar u teoriji) tako zapravo poštivana žanrovska hijerarhija na čijem su vrhu stajali epska pjesma (povijesni ep) i tragedija. Neovisno, ipak, od ove teorijske perspektive, izrazita barokna zadivljenost generičkim mješavinama u praksi je ipak rezultirala zanemarivanjem hijerarhijske žanrovske čistoće, pa se tako, primjerice, ni mnogi epski pjesnici diljem sedamnaestostoljetne Europe nisu libili pisati žanrovski pomalo bizarne hibridne epove, a katkad i posve kvazi-epska djela, radikalno se pritom udaljujući od 
uvriježenih epskopjesničkih konvencija, ${ }^{342}$ pa i pored toga što su ih neki od njih u svojim teorijskim raspravama i sami nastavili otvoreno zastupati. Štoviše, neobično raznolik barokni žanrovski se sustav nije sastojao samo od ovih modificiranih renesansnih generičkih varijanata te kojekakvih žanrovskih inovacija, već su u njemu važnu ulogu igrali i srednjovjekovni žanrovi, također pokatkad zamjetnije hibridizirani, odnosno „nadograđeni“ povećim brojem inih generičkih obilježja. Iako je riječ o žanrovima koji vuku svoje podrijetlo iz predrenesansne književne kulture, odnosno vrše pretežno pragmatičko-ideološke funkcije i izravno nastavljaju srednjovjekovne generičke tradicije, ${ }^{343}$ njih nipošto ne bi trebalo izdvajati u odnosu na ostale u baroknom generičkom sustavu zastupljene žanrove, tim više što je srednjovjekovni moment $\mathrm{u}$ europskoj baroknoj kulturi bio u tolikoj mjeri važan da pojedini barokolozi smjelo tvrde kako u kulturi 17. st. zapravo svjedočimo ,preporodu srednjega vijeka“ (Angyal 1964: 100). ${ }^{344} \mathrm{U}$ tom smislu i srednjovjekovne žanrove - iako njihova uporaba vrlo često nije bila u službi (pretežno) estetskih ciljeva - valja shvaćati kao integralni dio europske barokne književne kulture, što će reći kao generička rješenja koja su i u baroknome žanrovskom sustavu imala svoje čvrsto, dakle nimalo upitno mjesto. ${ }^{345}$

To što je mjesto srednjovjekovnih, a uz njih i čitava niza drugih - novih ili manje novih - žanrova u generičkome sustavu sedamnaestostoljetne književnosti bilo neprijeporno, nipošto samo po sebi neće značiti i to da su pojedine tada dostupne žanrovske varijante bile jasno i nedvosmisleno (poetički) definirane, a kamoli to da su i u samoj teoriji i praksi bile one precizno - dakle, jednoznačno - terminološki označivane i razlučivane. Naprotiv, kroz čitavo su barokno doba pomutnje proizlazile ne samo iz odviše nepreciznih poetičkih određenja i razlikovanja konkretnih žanrova, već i iz same prakse njihova imenovanja, uslijed koje su i literati, a nerijetko i pokoji poetičar, pribjegavali uistinu vrlo šarolikim, iako najčešće ne i dovoljno konkretnim terminološkim rješenjima. Bez obzira na to što su adekvatn(ij)i i precizn(ij)i generički nazivi - u što je moguće uvjeriti se već uvidom u neke

\footnotetext{
342 Podrobnije u: Warnke 1972: 158-186.

${ }^{343}$ Usp. Kravar 1993: 162-163.

344 Vrlo detaljno o tome u: Angyal 1964: 97-118, Kravar 1991 i 1993 i Curtius 1998.

345 To barokno uvažavanje srednjovjekovnih žanrova, ali i uopće prepoznatljivih srednjovjekovnih ideja i literarnih postupaka Andreas Angyal naziva „baroknom gotikom“, aludirajući pritom na kasnosrednjovjekovni umjetnički period, koji je trajao između 13. i 14. stoljeća. Osim prihvaćanja nemalog broja žanrova porijeklom iz srednjega vijeka (legenda, lament, religiozni žanrovi itd.), barok je od ,gotike“ baštinio i niz specifičnih motiva (primjerice, mračne i demonske motive, potom motiv prevrtljive sreće, motiv Boga-suca i strašnoga nebeskog suda, uopće motive smrti i prolaznosti, misticizam uopće, ali i ideju pustinjaštva i asketizma, motiv hodočašća, donekle čak i figuru mučenika - odnosno patos mučeništva - i duh herojsko-viteške tradicije itd.), pa čak i ustvrđuje Angyal - naslijedio posebnu sklonost za folklorno, koja je vrlo izrazita bila već u srednjovjekovnome razdoblju (opširnije o „baroknoj gotici“ u: Angyal 1961: 19-79). To će, pak, onda značiti ništa drugo nego da je i sam srednji vijek - gotovo na isti način na koji je to bila i renesansa - nizom svojih čimbenika bio ,ugrađen“ $u$ barok, iz čega slijedi da ni njegove generičke varijante prisutne u sedamnaestostoljetnoj književnosti nije opravdano izdvajati kao predbarokne, a kamoli kao nebarokne.
} 
sedamnaestostoljetne poetičke priručnike, rječnike, pa i gdjekoji književni tekst - već tada postojali i bili u opticaju, onodobni su autori u svojim autoreferencijalnim iskazima $\mathrm{i} / \mathrm{ili}$ poetičkim očitovanjima u najvećem broju slučajeva posezali za znatno općenitijim terminološkim oznakama, dakle onima koje su (tada) pristajale i mnogim drugim žanrovskim opcijama, iako najčešće ni njih nisu bile u stanju zamjetnije konkretizirati. Je li i u kojoj mjeri takva praksa baroknih pisaca i (nekih) teoretičara zaista rezultirala sveopćom žanrovskom konfuzijom, iz današnje je perspektive poprilično teško utvrditi, no iako nam se - sagledan iz vizure modernih genoloških shvaćanja - barokni generički sustav „skrojen“ od definicijski i terminološki nedovoljno razlučenih žanrova može doimati pomalo kaotičnim, ne zaboravimo da sedamnaestostoljetni autori žanrovima nisu pristupali kao kompaktnim kategorijama, već kao „tek“ skupovima karakterističnih obilježja što su ih evocirali s obzirom na posebnu svrhu koju su danim ostvarenjem željeli postići u nekome specifičnom kontekstu ili situaciji. Budući da su ih u njihovu radu presudno usmjeravali stanoviti (mahom izvanknjiževni) ciljevi, jasno je da je svaki od njih morao itekako dobro znati o čemu mu i kako valja pisati ne bi li njegov tekst makar dobio priliku ispuniti zamišljenu svrhu, što će reći da je baš svakome baroknom autoru bilo i više nego jasno koja su generička obilježja najprimjerenija za postizanje konkretnih ciljeva te da je za njima i posezao bez obzira na to pod kojim ih je žanrovskim nazivom, a vjerojatno i iz kojega poetičkog opisa poznavao. Da je u književnosti 17. st. tomu nedvojbeno i bilo tako potvrditi nam ponajbolje može već spomenuta (,tipična“) onodobna sklonost žanrovskim hibridima i uopće kojekakvim generičkim združivanjima, koja i jest pretpostavljala svjesno, dakle promišljeno i proračunato kombiniranje obilježja iz repertoara točno određenih žanrova u cilju stvaranja novih generičkih varijanata, kojima se željelo odgovoriti na - ponajprije - izvanknjiževne zahtjeve što su ih pred autore i književna im djela postavljale stubokom izmijenjene okolnosti njihova doba.

Bez obzira na to je li raznoliko terminološko označavanje (a možda i poetičko shvaćanje) jednih te istih žanrova u 17. stoljeću za svoju posljedicu uistinu imalo možebitne generičke nejasnoće ili se radi o tek pogrešnoj književnopovijesnoj prosudbi izrasloj iz oslanjanja na moderne koncepcije (književnoga) žanra, ono što se sa sigurnošću može ustvrditi jest to da nepostojanje (poetički) propisanih, a onda i općeprihvaćenih (uvriježenih) naziva za pojedinačne žanrove nipošto nije bilo svojstveno samo i isključivo hrvatskom književnom baroku. Riječ je, naprotiv, o „problemu“ zamijećenom i u mnogim drugim sedamnaestostoljetnim europskim književnostima, pa dok su tako - primjerice - francuski književni teoretičari 16. i 17. st. ustrajno rabili ne samo neprecizne, već i poprilično zastarjele 
nazive za niz baroknih žanrova, ${ }^{346} \mathrm{u}$ malobrojnim njemačkim poetičkim raspravama iz istoga razdoblja jedna te ista generička odrednica vrlo je često pokrivala izrazito velik broj (katkad i nezanemarivo različitih) žanrovskih varijanata. ${ }^{347}$ Posvemašnjem izostanku poetičkih tekstova usprkos, barokna naša književnost ne samo što nije ostala uskraćena za identična terminološka „lutanja“, već u njoj - kako se može naslutiti (i) iz pojedinih natuknica čuvenoga Vitezovićeva latinsko-hrvatskog rječnika Lexicon Latino-Illyricum - nisu (još) postojali ni adekvatni termini za samu kategoriju (književnoga) žanra, odnosno vrste. ${ }^{348}$

$\mathrm{Za}$ očigledno nepostojanje primjerenoga termina za entitet što ga danas nazivamo književnim žanrom u hrvatskoj književnosti 17. st. najveću krivicu snose ipak sami autori, od kojih nijedan - iz ovoga ili onog razloga - nije držao svrsishodnim onodobne poetičke zahtjeve formulirati u obliku (čitaj: žanru) samostalnoga književnoteorijskog traktata $\mathrm{u}$ kojemu bi se, između ostalog, p(r)opisivalo i poželjno genološko nazivlje. Da to ipak ne znači i kako ti isti autori nisu bili u stanju razlikovati pojedine žanrovske varijante koje su u (nekim) drugim jezicima nosile daleko preciznije nazive uvidjet ćemo prelistamo li - iznova Ritterov latinsko-hrvatski rječnik, u kojemu nam pri prvom čitanju zacijelo neće promaknuti već dobro nam znano inzistiranje na oznakama „pisam“ (,pisan“), pa i „popivka“, kojima se ondje prevodi čitav niz latinskih termina, od kojih se mnogi odnose i na konkretne lirskopjesničke žanrove (cantio, carmen, poema, exagematicum poema, psalmus, oda, ode, paean itd.). Tražeći, međutim, najprikladnije prijevode za generičke pojmove čije istoznačnice u našem jeziku nisu (još) dotad postojale, Vitezović termine ,pisma“ i ,popivka“ u najvećem broju slučajeva, kako se čini, ipak ne rabi kao sinonime, čime kao da želi dati do znanja da je riječ o pojmovima koji podrazumijevaju - po nekom kriteriju - nezanemarivo

\footnotetext{
${ }^{346} \mathrm{U}$ sedamnaestostoljetnoj francuskoj teorijskoj literaturi književni žanr drame tako je, primjerice, nerijetko označavan kao „pjesma“, dok su, pak, žanrovima tragedije i komedije onodobni teoretičari redovito nadijevali zajednički naziv „komedija“, i to usprkos činjenici što su mnogi od njih izrazite napore istovremeno ulagali (i) u pojašnjavanje krucijalnih razlika između različitih (pod)vrsta „,komedije“.

${ }^{347}$ U tome je prednjačila odrednica „pjesma“ (Gedicht, odnosno Geticht), pod koju su njemački književni teoretičari baroknoga razdoblja svodili veliku većinu pjesničkih ostvarenja u stihu, i to u rasponu od onih koja bi se generički mogla kategorizirati kao lirske i epske pjesme te pastorale, pa sve do dramskih tekstova i djela ostvarenih u različitim žanrovima didaktične književnosti. Što se općenite odrednice „pjesma“ tiče, valja imati na umu da su je kao oznaku za veliku većinu žanrova lirskog i epskog pjesništva u to vrijeme koristili kako teoretičari, tako i literati diljem Europe, a „lirskom pjesmom“, „epskom pjesmom“ itd. tek će se u sljedećem osamnaestom - stoljeću sve češće početi označavati žanrovi koji su dotad bili poznati pretežno kao „pjesme“ ili „pjesništvo“. Usp. o tome npr. u: Kravar i Maroević 2010: 516.

${ }^{348}$ Prevodeći tako latinsku riječ „genus“ (vrsta), čije je značenje izvorno uključivalo i književnu vrstu, Vitezović se domišlja svega triju hrvatskih istoznačnica - „pleme“, „,koljeno“ i „,rod“ - očito pritom ne misleći na književne (žanrovske), već obiteljske srodnike, a književnoga žanra (vrste) neće se dosjetiti ni pri prijevodu pojma „forma“, za koji nalazi čak četiri istoznačnice - „način“, „spodoba“, „uprava“ i „tvor“. Znatno kasnije skovan termin ,žanr“, dakako, Vitezović nije mogao poznavati, no riječju „,vrsta“ (,vrst“) u svojem je Lexiconu ipak preveo nekolicinu latinskih pojmova - „,lassis“, „,conditio“, „series“ te „,species“ - za koje je ipak prilično teško utvrditi je li njihovo značenje uopće obuhvaćalo i kategoriju književne vrste kao takve (usp. Ritter Vitezović 2010). Bit će da su se pobrojani pojmovi - svojoj značenjskoj općenitosti usprkos - izvorno ponajviše odnosili na pojedine društvene razrede i obiteljske srodnike (usp. prijevode u: Divković 2006).
} 
različita žanrovska rješenja. U tom je smislu „satyra“ tako, primjerice, za njega „obodiva pisma“, ali je - s druge strane - „paean“ preveden kao „popivka na hvalu Božju“; a dok se „hymnus“ nadaje kao „pisma na pohvalu učinjena“ i „pisma pohvalna“, dotle je „elegia“ ništa drugo no ,žalostna popivka“, a „epinicium“ i „,canticum“ zapravo „popivka zvrh predobitja“, odnosno „ljubljena popivka“. Iako u prijevodu većine ovih žanrovskih termina ostaje po tom pitanju poprilično dosljedan, i Ritteru će se na nekoliko mjesta omaknuti i sinonimska uporaba navedenih dviju hrvatskih istoznačnica, pa će tako pojmove „bucolica“ i „,carmen bucolicum“ prevesti frazama „govedarska popivka“, „pastirska pisma“, ali i „pastirska djačkina“, ${ }^{349}$ dok će žanr ,genethliacon“ (rođendanska oda) u njegovu tumačenju postati „pisma aliti popivka na porođenje čije spravljena“.

Lexicon Latino-Illyricum definitivno je moguće izdvojiti kao možda i najuvjerljiviju potvrdu činjenice da su sedamnaestostoljetni naši literati bili ne samo vični razlikovati konkretne književne žanrove u praksi, nego i da je - bez obzira na to što su ih se u svojim autoreferencijalnim očitovanjima i samim književnim djelima najčešće klonili - velika većina njih vrlo vjerojatno poznavala (i) precizn(ij)e domaće termine za pojedine onodobne žanrove, koji se nipošto nisu svodili samo na one „pisma“ („pisan“), „popivka“ i „djačkina“. Pored „popivke“ i „pisme“, u Lexiconu ćemo tako zateći i (lirskopjesnički) žanr naziva „pisnica“, odnosno „pojčica“, kojima Vitezović prevodi čak četiri latinska pojma („cantiuncula“, „,cantilena“, „poetria“ i ,poetris“), dok za generičku frazu „carmen heroicum“ iznalazi poprilično zanimljivu i iz povijesti nam domaće (pisane i usmene) književnosti nimalo nepoznatu istoznačnicu „davorkinja“. S obzirom na to da će latinsku frazu „carmen heroicum canere“ (izvoditi, tj. pjevati junačku pjesmu) prevesti srodnim glagolima „bugariti“ i „davoriti“, posve je jasno da u žanru prozvanom „carmen heroicum“ vidi on ništa drugo no pjevanu, dakle usmenu (usmenoknjiževnu, folklornu) narativnu pjesmu o junačkim (očito ratnim) događajima, i to - kako su pokazala dosadašnja književnopovijesna istraživanja tzv. „davorija“ - najvjerojatnije bugaršćicu. ${ }^{350}$

\footnotetext{
${ }^{349}$ Riječ „djačenje“ - zajedno s riječima „petje“ i „pivanje“ - Vitezović navodi kao hrvatsku istoznačnicu latinskoga pojma „cantus“ (pjevanje, glazba, melodija, pjesma), iz čega slijedi da bi fraza „pastirska djačkina“ podrazumijevala upravo pastirsku pjesmu koja se pjeva uz glazbenu pratnju.

${ }_{350}$ Da bi žanr što su ga pojedini naši pjesnici izrijekom nazivali „davorijom“ trebao podrazumijevati upravo bugaršćicu u više je već navrata poprilično uspješno dospio dokazati Josip Kekez, koji je identičan motiv pjevanja „davorija“ na gozbi što ju je sigetski kapetan Nikola Šubić Zrinski upriličio u povodu pobjede nad Turcima locirao u povijesnim epovima Barne Karnarutića (Vazetje Sigeta grada) te Petra Zrinskog (Obsida sigecka). Da su se, pojašnjava Kekez, „bugaršćice nazvale i davorijama, pretpostavljamo prema Jurju Križaniću (17. stoljeće), koji pjesmu čiji početni stihovi glase: »Kliknite mi silna cara, mila bratjo, a družino, / Načni more davoriju, ili ja zapeti«naziva davorijom i što je bugaršćica u etimološkoj i semantičkoj svezi s glagolom bugariti, što bi značilo otužno pjevati, a to isto ili približno isto sadržava i oblik davoriti“ (Kekez 2000: 23, kurziv autorov). O ovome detaljnije i u: Kekez 1992: 55.
} 
Ako se, prema tome, pojam „davorkinja“ trebao odnositi na isključivo žanr usmenoknjiževne provenijencije, isto se ne može reći i za termine što ih Vitezović navodi uz latinske nazive različitih lirskopjesničkih žanrova, iako je pretežno riječ o izvorno antičkim generičkim rješenjima (himna, oda, satira, epinikij itd.) čvrsto vezanima uz sferu pisane književnosti. I više nego svjestan toga njihova antičkog porijekla, Ritter, međutim, nipošto nije mogao zanemariti tradicionalno usmjerenje svakog od njih usmenoj, odnosno pjevanoj prezentaciji (najčešće uz glazbenu pratnju), slijedom kojeg i za neke „pisme“ (dodatno) navodi da je riječ o „popivkama“ i/ili „djačkinama“, dok kao zaseban žanr (pjevanih) lirskih pjesama izdvaja još i „pojku“. Ipak, dok je latinski pojam „cantio“ za njega i „pisma“ i „pisan“ i „pojka“ i „popivka“ i „djačka“, onaj „poema“ samo je „pisma“, odnosno „pisan“, čime kao da želi implicirati kako je taj pjevni moment u ovima potonjim bitno ipak slabije izražen, pa i manje važan u odnosu na naki drugi. Pretpostavimo li da je u ,popivke“ naš autor ubrajao mahom kraće, pjevnije i uopće „lirskije“ pjesničke žanrove (premda u tu kategoriju kao što smo vidjeli - uključuje i epinikij, odnosno naracijom obično prožetu ,popivku zvrh predobitja“), u tom su slučaju „pisme“ mogle obuhvaćati jedino one lirskopjesničke žanrovske varijante koje su podrazumijevale opsegom nešto dulje - iako ne i epski ,zamašne“ - stihovane sastavke s izrazitijim ,udjelom“ naracije (pjesnička satira, pastorala, poema i sl.), što bi uvelike bilo na tragu maločas spomenute prakse baroknih naših pisaca, koji su terminom „pisma“ pretežno označavali relativno obimnija, tematski i formalno zaokruženija te katkad i zamjetnije narativizirana djela u stihu, a onim „popivka“ većinom kraće pjesničke tekstove, nerijetko zaista i namijenjene pjevanju. Vitezović se, međutim, nazive „pisma“ i „popivka“ - kao što smo vidjeli - nije ustručavao ni miješati, pa ni koristiti naizmjence (uvrštavajući u „pisme“ ponekad i ,popivke“ i obrnuto), a k tome su još u njegovu Lexiconu svoje mjesto našli i pojedini generički pojmovi koji i više nego bjelodano sugeriraju da odrednica „pisme“ u njegovim očima najvjerojatnije nije predstavljala kategoriju koja je obuhvaćala isključivo narativna ostvarenja u stihu, a pogotovo ne ona čiji je opseg znatnije nadmašivao tekstove žanrovski definirane kao ,popivke“.

Među potonjim žanrovskim pojmovima daleko bi najveću pozornost trebala plijeniti od ranije nam dobro već poznata riječ „rišma“, koju naš autor - osim kao prijevode termina „rhythmus“ i ,versus“ - donosi kao hrvatsku istoznačnicu latinskih riječi „carmen“ (pjesma) te „epos“ (ep, epska pjesma). ${ }^{351}$ Činjenica da spomenutim hrvatskim terminom - kojega je, podsjetimo, još 1684. uvrstio u podnaslov prvoga izdanja Odiljenja sigetskog - prevodi, između ostalog, i latinski naziv za pjesmu pritom je znatno manje važna od one da istu riječ

\footnotetext{
${ }^{351}$ Usp. Ritter Vitezović 2009 i 2010.
} 
navodi on kao ne samo najtočniji, već ujedno i jedini domaći ekvivalent latinske oznake za žanr epa, čime povlači vrlo jasnu terminološku, a onda i značenjsku granicu spram generičkih varijanata obilježenih pojmovima kao što su „pisma“, „pisan“, „popivka“, ,,pojka“, „djačka“ i „davorkinja“, odnosno njihovim istoznačnicama na latinskom jeziku. Drugim riječima, bez obzira na to što ga rabi i kao prijevod mnogo općenitijih termina poput „,carmen“, kojima bi možda podjednako pristajali i pojedini domaći lirskopjesnički generički nazivi (,pisma“, „pisan“), pojmom ,rišma“ kao (tada) jedinim prijevodnim terminološkim rješenjem za žanr latinskoga naziva „epos“ Vitezović jasno daje do znanja da njegovo mjesto nije uz spomenute pojmove za različite žanrove (pisane) lirske poezije, pa čak ni uz one koji se možebitno odnose na nešto dulje stihovane tekstove u kojima bitnu ulogu igraju pripovjedne „silnice“. A da, jednako tako, njegovo mjesto nije ni uz bok nazivima za usmenoknjiževne (epsko)pjesničke žanrove poput - primjerice - „davorkinje“, Ritter sugerira i brojnim izvedenicama pojma „rišma“, kao i njegovim uvrštavanjem u fraze kojima prevodi latinske versifikacijske termine (,,metrum“, „,versificare“, ,,versificus“ itd.), ${ }^{352}$ iz kojih postaje očito da se može on odnositi samo i jedino na onaj pjesnički žanr koji nastaje kao produkt stihotvoračke aktivnosti usmjeravane strogim (propisanim) versifikacijskim pravilima, a ne folklornoga čina kojim ravnaju nepisani običaji i koji se događa u trenutku ostajući najčešće nezabilježen. Ako, ukratko, usmena književnost ima svoju „carmen heroicum“, onda bi „epos“ ili „rišma“ bila zapravo ništa drugo nego neka vrsta njezine pisanoknjiževne inačice.

Vitezovićev nam Lexicon Latino-Illyricum u tom smislu nudi možda i najzorniju sliku (podugo negiranoga) žanrovskog terminološkog obilja naše barokne književnosti, za koju se, međutim, ni nakon svih dosad pobrojanih generičkih pojmova još uvijek ne može konstatirati da je upotpunjena. Naprotiv, trudeći se iznaći hrvatske istoznačnice za što je moguće veći broj latinskih žanrovskih oznaka, Ritter u svome djelu donosi svojevrstan mali popis (nekih od) i u nas tada aktualnih književnih žanrova - točnije, domaćih njihovih naziva - obavivši na taj način i posao za koji su u njegovo vrijeme obično bili (ili su makar trebali biti) zaduženi pisci (književno)poetičkih traktata. S obzirom na to da u sedamnaestostoljetnoj našoj književnosti poetičarima nema ni traga, upravo nam Vitezovićevo leksikografsko ostvarenje najbolje može otkriti koja su to doista žanrovska rješenja onovremeni hrvatski autori (pre)poznavali, pa i na koja su u svome radu toliko ozbiljno računali da su držali važnim osmisliti im (ili makar „samo“ očuvati) i adekvatne hrvatske nazive. Pored maločas nabrojanih, provizorni je

\footnotetext{
${ }^{352} \mathrm{~S}$ obzirom na to da riječ „rišma“ vuče svoje porijeklo od grčke riječi „rysmós“, koja znači upravo „stih“ i/ili „ritam“, u tom nas smislu nimalo ne smije čuditi to što Vitezović u Lexiconu riječ „metrum“ prevodi kao „del rišme“, „hemistichion“ kao „pol rišme“, „versificare“ kao „rišmiti“ i „rišme spravljati“, a „,versificusa“ kao „rišmena“. Potonjom riječju - važno je dodati - prevodi on ujedno i latinski termin „,epicus“, čime ujedno osnažuje njezino utvrđeno epskopjesničko značenje. Za detaljnije usp. Ritter Vitezović 2010.
} 
generički popis u rječniku našega autora obuhvaćao tako i žanrove poput „pisma“ (,epistola, litera, litarae, literatura itd.“), „,nagrobnice“ (,epitaphium“), „plača“ („lamentum“), „pričice“, „Zmišljenice“ ili „prikladnice“ („fabula“), „pripovisti“ (,apologus, evangelium, historia“), „zapletka“ (,allegoria“) i „pririča“, odnosno poslovice (,adagium, apophtegma, gnoma, sententio, sententia, paroemia, proverbium“), a od izvanknjiževnih žanrova koji su u barokno doba (i u nas) uživali posebno veliku popularnost navode se ondje i ,annuales“, odnosno anali (,godišćna pisma“ ili „godišćnik“) te „chronica“ili kronika („spomen vikov“).

Što se, međutim, samih književnoteorijskih, odnosno poetičkih spisa iz Ritterova doba tiče, ono što bismo svakako morali imati na umu kanimo li ih motriti iz genološke perspektive jest činjenica kako se razmatranja problematike književnih žanrova svi oni redom ipak nisu laćali u jednakoj mjeri, a u nemalom broju njih žanrovska pitanja jedva da su uopće i dotaknuta. Gotovo sasvim odustavši od (za dotadašnje poetičke traktate) uvriježenoga p(r)opisivanja konkretnih pravila za oblikovanje i funkcioniranje zasebnih generičkih rješenja, pisci najutjecajnijih će se sedamnaestostoljetnih poetika - španjolski teoretičar Baltasar Gracián te Talijani Matteo Peregrini (Pellegrini), Pietro Sforza Pallavicino i Emanuele Tesauro - u svojim raspravama ${ }^{353}$ tako u potpunosti fokusirati na stilsku dimenziju barokne književnosti u cijelosti, propagirajući uporabu onih (,modernih“") rješenja i postupaka pomoću kojih je moguće sastaviti uspjelo literarno ostvarenje, a to će reći tekst u kojemu su - bez obzira na žanrovski okvir - intenzivirane stilske posebnosti u stanju nametnuti se ispred sadržajnih i kompozicijskih njegovih osobitosti. Antiklasična poetika što su je zastupali ovi teoretičari zasnivala se, ukratko, na ideji o pjesničkom geniju koji posjeduje umijeće domišljatoga i oštroumnog izražavanja, pri čemu takav ,ingeniozan“ literarni stil - koji se najočitije manifestirao kroz nizanje dovitljivih metafora ili tzv. concetta - nije ujedno bio i generički „,vezan“, odnosno shvaćan kao prepoznatljiva karakteristika točno određenoga žanra ili većeg broja njih. Naprotiv, u spomenutim - kako ih se u sekundarnoj literaturi često proziva - „končetističkim traktatima“6354 inzistiranje na značenjem bremenitim dosjetkama baziranima na zbližavanju naoko oprečnih fenomena (concordia discors i discordia concors) zagovaralo se kao neizbježno svojstvo čitave „moderne“ književnosti, što će reći kao nadžanrovska stilska strategija kojom je svaki pjesnik uvjerljivo potvrđivao svoj kreativni talent ili genij. Oštro se odupirući renesansnim poetičkim i uopće estetskim postulatima, ovi su barokni poetičari naglasak s (vjerne) imitacije stvarnosti tako zapravo prebacili na njezino

\footnotetext{
353 Riječ je o, konkretno, Graciánovu tekstu Agudeza y arte de ingenio iz 1648. i traktatima Delle acutezze (1639.) Mattea Peregrinija, Del bene (1644.) i Dello stile e del dialogo (1646.) Pietra Sforze Pallavicina te Il canocchiale aristotelico (1654.) Emanuela Tesaura, koji i slovi kao najvažnije djelo barokne poetike uopće.

${ }^{354}$ Usp. npr. Fališevac 1995: 149.
} 
što vještije kreativno preoblikovanje, širom otvorivši „vrata“ književnosti (dotad nezamislivomu) stilskom - mahom figuralnom - (pre)obilju, a sve s ciljem stvaranja neobičnih, nerijetko kontradiktornih i paradoksalnih, ali neizbježno spektakularnih stilskih kombinacija uključenih u grandiozne literarne strukture, koje u recipijentu moraju izazvati čuđenje (tzv. meravigliju) i strahopoštovanje, i to neovisno od toga u kojoj ih generičkoj varijanti on u danome slučaju zatječe. ${ }^{355}$

O eventualnoj pojavi sličnoga izostavljanja generičkih (pr)opisa u domaćim (samostalnim) poetičkim raspravama izlišno je, dakako, govoriti budući da pokušaji njihova sastavljanja u 17. st. u nas nisu zabilježeni, što ipak ne znači da (makar neki) barokni naši autori moderne književnoteorijske zamisli nisu poznavali, a još manje to da ih barem $u$ pojedinim svojim sastavcima nisu i praktično iskušavali, a pokatkad i uzgredno razmatrali. Dapače, izvrsna upućenost u najsuvremenije poetičke norme ponajbolje se očitovala u djelima južnohrvatskih (ponajvećma dubrovačkih) sedamnaestostoljetnih pisaca, koji u njima donose možda i najuspjelije domaće primjere baroku svojstvena stilski opterećenog, odnosno „ingenioznoga“ načina pisanja. Premda je književnih tekstova koji svoju baroknost potvrđuju ponajprije prepoznatljivim stilskim rješenjima u 17. stoljeću na našem sjeveru bilo daleko manje, ${ }^{356}$ baroknim je dubrovačko-dalmatinskim ostvarenjima veći dio sjevernohrvatske literarne produkcije najsličniji ipak po nekim sadržajnim i uopće idejnim momentima, ali naročito (i) po tome što su se i kontinentalni naši sedamnaestostoljetni autori $u$ paratekstualnim odsječcima svojih djela rado upuštali u (kratka i usputna) književnopoetička razmatranja. Činjenica da se nijedan od baroknih hrvatskih pisaca - podjednako sjevernih ni južnih - nije (još) bio odvažio poetičke zahtjeve svoga vremena iznijeti u formi makar kraćega samostalnog traktata neke od njih, naime, nije (s)priječila u tome da o pojedinim aspektima vladajuće poetike - odnosno njezine domaće, ponešto modificirane varijante progovore u posvetama i predgovorima vlastitih ostvarenja, što su povjesnici hrvatske književnosti uočili tek relativno nedavno. ${ }^{357} \mathrm{~Pa}$ iako se iz tih nabačenih poetičkih očitovanja

\footnotetext{
355 Opširnije o baroknim poetičkim ishodištima u: Warnke 1972: 1-20, Segel 1974: 101-129, Kravar 1993: 7477, Posavac 1994: 507-510, Fališevac 2007b: 201-205, Cherci i sur. 2008: 312-313 i Johnson 2012: 121-126.

${ }^{356} \mathrm{Da}$ su, usprkos tome, i neki sjevernohrvatski barokni pisci bili i više nego dobro upućeni u postulate barokne poetike ponajbolje nam može dokazati predgovor što ga svome mađarskom zborniku Adriai tengernek Syrenaia (1651.) pridodaje Nikola Zrinski, a u kojemu se - kako primijetiše neki proučavatelji - očituje nesumnjiv utjecaj pojedinih sedamnaestostoljetnih poetičkih rasprava, i to ponajvećma onih talijanskih autora (poglavito $\mathrm{S}$. Speronija i D. Bartolija). Detaljnije o ovome pitanju u: Bene 2012: 548-550.

357 Naime, tek prije nešto više od deset godina ozbiljnijom se analizom paratekstualnih dionica pojedinih ostvarenja iz starije hrvatske književnosti u rasponu od posvete Marulićeve Judite do predgovora Kačićevu Razgovoru ugodnom naroda slovinskog u svojoj knjizi Skrivena teorija pozabavio Pavao Pavličić. Od paratekstova baroknih ostvarenja, konkretno, analizirao je on ondje njih čak četiri - i to posvete Gundulićevih Pjesni pokornih kralja Davida, Adrijanskoga mora Sirene Petra Zrinskoga, Magdalenićeva Zvončaca te Đurđevićev predgovor Uzdasima Mandalijene pokornice. Usp. Pavličić 2006.
} 
prilično jednostavno može utvrditi kako su barokni naši pisci uopće definirali svrhu svojega posla, odnosno koje su to konkretno literarne funkcije držali najbitnijima, žanrovskim definicijama i distinkcijama nema u njima gotovo ni traga, što ih čini i više nego bliskima maločas pobrojanim najutjecajnijim poetičkim iskazima njihova vremena te ujedno upućuje na zaključak da su (i) domaći sedamnaestostoljetni autori (neke) poetički presudne literarne faktore shvaćali kao nadžanrovske ili - preciznije rečeno - svežanrovske. Takva shvaćanja, međutim, kao da ni najmanje nisu utjecala na širinu žanrovskoga sustava ne samo hrvatskog, već ni europskoga književnog baroka, koji se iznimnom šarolikošću može podičiti i usprkos ovome (čestom) književnoteorijskom prešućivanju generičke problematike, tim više što je upravo odustajanje od strogih, poetički propisanih žanrovskih normi otvorilo nesagledive mogućnosti za manipuliranje žanrovskim obilježjima, što i nije moglo rezultirati ničime drugim no pojavom izuzetno velikoga broja novih, mahom hibridnih generičkih varijanata.

Ako, dakle, o sastavu baroknoga žanrovskog sustava malošto možemo otkriti čitajući „končetističke traktate“ španjolskih i talijanskih poetičara, a gotovo ništa zavirujući u paratekstualne odsječke djela onovremenih naših pisaca, možda bismo u obzir trebali uzeti i (književno)teorijske spise autora iz onih europskih sredina u kojima se književni barok nije svodio (samo) na stilska pretjerivanja i pomamu za strukturalnom grandioznošću, nego je ponajprije pretpostavljao udovoljavanje specifičnim sadržajnim zahtjevima u cilju ispunjavanja stanovitih - pretežno izvanknjiževnih - zadaća. Upravo takvu „,varijantu“ baroka susrećemo u njemačkoj sedamnaestostoljetnoj književnosti, koja je jedno od svojih poetičkih ishodišta iznašla i u djelu slavnoga pjesnika Martina Opitza iz 1624., naslovljenom Knjiga njemačke poetike (Buch von der Deutschen Poeterey), kojeg germanisti redovito izdvajaju kao prvi književnopoetički priručnik napisan na njemačkom jeziku. Oslanjajući se ponajviše na humanističke književne temelje i Scaligerovu poetičku raspravu Poetices libri septem (1561.), Opitz u svome tekstu predlaže korjenitu reformu njemačke poetike zasnovanu na asimilaciji žanrova iz suvremenoga neolatinskog pjesništva u književnost na narodnom jeziku, odnosno na potpunome generičkom stapanju dvaju jezično razjedinjenih polova njemačke sedamnaestostoljetne književnosti. Pritom on ne zaboravlja precizirati koja bi to sve (neo)latinska generička rješenja moralo „upiti“ stvaralaštvo na narodnom jeziku, pri čemu je posebno važno primijetiti kako su žanrovi što ih ondje navodi - a među kojima se posebno ističu junačka epska pjesma, tragedija, komedija, satira, epigram, ekloga, elegija, sonet, himna, oda, pjesma s figurom jeke (echo), panegirik itd. - razlučeni ponajprije prema svojim 
karakterističnim sadržajnim i/ili formalnim značajkama, dok o eventualnim stilskim njihovim specifičnostima gotovo da i nema riječi. ${ }^{358}$

Nepuna četiri desetljeća nakon Opitza genoloških će se razmatranja u čuvenoj svojoj studiji o njemačkom jeziku i književnosti Ausführliche Arbeit Von der Teutschen HaubtSprache (1663.) latiti i njemački pjesnik, lingvist i književni teoretičar Justus Georg Schottel, koji žanrove također razlikuje isključivo prema formalnim (metričkim) ili sadržajnim kriterijima. Schottelov je popis žanrova gotovo identičan onome Opitzovu (zatječemo tako u njemu komediju, tragediju, tragikomediju, epsku pjesmu, odu, elegiju, sonet, echo-pjesmu, anagram, epigram, zagonetku itd.), što i ne čudi znamo li da i on ponajviše uvažava generičke varijante neolatinske književnosti, no ono po čemu ipak čini iskorak u odnosu na pisca prve njemačke poetike jest činjenica da (budućim) autorima ostavlja na volju hoće li postojeće žanrove rabiti u ,čistom“ obliku ili ih, pak, varirati i miješati, odnosno kreirati neke posve nove, dotad neviđene generičke hibride. ${ }^{359} \mathrm{~S}$ obzirom na to da se - poradi uvažavanja većinom neolatinskih žanrovskih rješenja - ni u Schottelovu ni u Opitzovu genološkom fokusu nije našao nemali broj baroknih žanrova za kojima su posezali (i) njemački tadašnji pisci, posve bi, dakako, neopravdano bilo konstatirati kako nam navedena dva teksta mogu podastrijeti do u detalj točnu sliku žanrovskoga sustava njemačke, a kamoli europske sedamnaestostoljetne književnosti. Štoviše, ne samo što su Opitz i Schottel (svjesno ili nesvjesno) izbjegavali uvažiti čak i (mnoge) najsuvremenije generičke varijante, već u svojoj prezentaciji odabranih žanrova nisu iskazali ni dotad uobičajenu sistematičnost, pa dok tako neke od njih razlučuju isključivo prema stanovitim formalnim kriterijima, one druge raščlanjuju mahom prema onim sadržajnim, ne libeći se k tome još i neke od njih uključiti istovremeno u obje (pod)skupine.

(Književno)teorijski radovi dvojice utjecajnih njemačkih pjesnika i poetičara nameću se, usprkos svemu, kao ponajbolja potvrda teze da je jasno izražena svijest o konkretnim žanrovima i u 17. stoljeću ne samo postojala, već i da je pokatkad u izdvojenim poetičkim iskazima bila ona ipak i ponešto eksplicitnije formulirana. Bez obzira, međutim, na to što nas ova spoznaja navodi na pomisao kako je u barokno doba stoga morao postojati neki „opći“, sveeuropski sustav književnih žanrova u čiji je sastav poprilično lako proniknuti, suvremeni barokolozi (s pravom) sve češće upozoravaju na to da je o nadnacionalnome generičkom sistemu barokne književnosti posve iluzorno govoriti, i to ponajviše iz razloga što su tadašnje nacionalne književnosti diljem Europe bile na različitim stupnjevima razvoja, što je

\footnotetext{
${ }^{358}$ Podrobnije u: Hess 2007: 395-396 i 412-417.

${ }^{359}$ Usp. Isto: 418-419.
} 
neizbježno vodilo kako do razlika u repertoarima obilježja mnogih naoko istih žanrova i njihovih funkcija, tako i do krupni(ji)h nepodudarnosti u sastavima zasebnih (nacionalnih) žanrovskih sustava. Pa čak i kada su pisci iz različitih europskih sredina evocirali jednaka generička rješenja koristeći ih na relativno podudarne načine i imajući na umu otprilike iste svrhe, ti su i takvi žanrovi tada redovito postajali dijelom bitno različitih žanrovskih sistema sedamnaestostoljetnih nacionalnih književnosti, egzistirajući ondje uz bok žanrovskim varijantama koje u sustavima nekih drugih tadašnjih literatura nisu možda ni imale svoje mjesto, odnosno onima koje su u pojedinim drugim sredinama uključivale neka nezanemarivo različita obilježja i - u skladu s time - uživale dijametralno suprotan tretman.

I (provizorni) žanrovski bi sustav hrvatske barokne književnosti u tom smislu najopravdanije bilo motriti kao svojevrstan specifikum ili - preciznije rečeno - jedinstvenu sedamnaestostoljetnu kombinaciju generičkih varijanata različita porijekla kojih su pojava i uporaba presudno bile određene potrebama i zahtjevima stanovite književne i izvanknjiževne situacije, odnosno podjednako specifičnim unutarknjiževnim i izvanknjiževnim (kontekstualnim) okolnostima. Da te okolnosti ipak nisu bile posve različite od onih koje su zaslužne za formiranje generičkih sistema u drugim onovremenim europskim nacionalnim književnostima, razabrat ćemo iz samoga njegova sastava, koji se - u suštini - ne razlikuje odveć od onih ostalih baroknih literatura, ${ }^{360}$ i to nipošto zahvaljujući tek prisustvu novih, prepoznatljivo baroknih generičkih rješenja. Naprotiv, kao što je to bio slučaj i drugdje, i hrvatski je književni barok, pojednostavljeno govoreći, bitno obilježio pomak od prvotne uporabe isključivo naslijeđenih - iako repertoarom i funkcijama znatno modificiranih renesansnih (pa i srednjovjekovnih) generičkih rješenja do kasnijih sve učestalijih žanrovskih poigravanja i ustoličenja novih žanrovskih varijanata, čije prisustvo nepobitno upućuje (i) na promjenu književnih i izvanknjiževnih uvjeta, odnosno na pojavu nove osjećajnosti, novih ciljeva koji su se počeli postavljati pred literarna ostvarenja, a onda i nove publike, čiji je interes valjalo privući modernim sadržajnim, formalnim i stilskim postupcima. Upravo na tom supostojanju „starih“, no nezanemarivo dorađenih i prilagođenih žanrova baštinjenih iz ranijih književnopovijesnih razdoblja (povijesni ep, ljubavna i nabožna lirska pjesma itd.), onih „novih“, većinom preuzetih iz susjednih onodobnih književnosti (melodrama, religiozna i komična poema i sl.), ali i - kao što ćemo vidjeti na primjeru Vitezovićeva Odiljenja sigetskog - usmenoknjiževnih, pučkoknjiževnih i poluknjiževnih žanrova zasniva se

360 Diljem Europe su, konkretno, u 17. stoljeću ponajviše dominirali žanrovi poput nabožnoga pjesništva, parafraza psalama, religiozne poeme, refleksivne ili meditativne lirske pjesme, ljubavne lirike, prigodne (lirske) pjesme, propovijedi i uopće nabožne proze, povijesne i religiozne epske pjesme, drame, melodrame itd., od kojih je većina našla svoje mjesto i u generičkom sustavu hrvatskoga književnog baroka. O najčešćim žanrovima europske barokne književnosti, odnosno njezinih nacionalnih ,izvedenica“ detaljno npr. u: Segel 1974: 66-101. 
najtočnija slika (provizornoga) generičkog sustava hrvatske barokne književnosti, koji - kao takav - ponajbolje i otkriva pravo „lice“ baroka kao razdoblja u povijesti naše književnosti.

Međutim, baš kao što smo za (zamišljeni) žanrovski sistem europskoga književnog baroka maločas bili prisiljeni konstatirati kako je „razbijen“ u samostalne sustave žanrova pojedinih nacionalnih sedamnaestostoljetnih književnosti, tako i pretpostavljeni generički sustav hrvatske barokne književnosti unaprijed moramo okarakterizirati kao nejedinstven, i to s razloga što jedinstven nije bio ni književni naš barok uopće. Polazeći, naime, od spoznaje kako se u našoj regionaliziranoj ranonovovjekovnoj književnosti barokne silnice nisu dospjele manifestirati ujednačeno, suvremeni barokolozi u posljednjih nekoliko desetljeća sve glasnije ukazuju na heterogenost domaćega književnog baroka, odnosno njegovu raščlanjenost na nekoliko - relativno samostalnih - literarnih krugova, međusobno različitih ne samo po vremenskom trenutku nastupanja baroka, njegovu ukupnom trajanju, intenzitetu i dijalektalnoj osnovi na kojoj se ostvario, već naročito po drugačijoj funkciji i statusu što ga je književnost u svakome od njih posjedovala i u skladu s kojima je baroku na „korištenje“ nudila vidno različite kombinacije generičkih rješenja, točnije čitave samostalne žanrovske (pod)sustave. ${ }^{361}$ Konkretno, zbog političke rascjepkanosti države koju danas poimamo kao (jedinstvenu) Hrvatsku, u vrijeme ,ranoga novovjekovlja književnost na prostoru između Drave i Jadrana nije nastajala u jedinstvenu nacionalno-kulturnom okviru, kakav se

${ }^{361} \mathrm{O}$ regionalno razdvojenim krugovima ili varijantama hrvatske barokne književnosti do danas je najopsežnije i najuvjerljivije pisao Zoran Kravar, koji tu temu načinje još polovicom osamdesetih godina prošloga stoljeća (usp. pretisak rada u: Kravar 1993: 39-69), a potom joj se periodički vraća, ponešto korigirajući i nadopunjujući prethodna svoja zapažanja (usp. npr. Kravar 1991 i naročito 2010: 110-115). Valja, međutim, znati da je „dvojstvu“ hrvatskoga književnog baroka već 1968. pisao u nas i Đuro Novalić, koji pritom razlučuje sjevernohrvatski „agrarni“ barok - presudno obilježen afirmativnim odnosom spram pripadnika nižih slojeva i pokušajima književnog približavanja takvoj publici - od južnohrvatskoga (dubrovačkog) „urbanog“ baroka, koji je - prema njegovu mišljenju - počivao na klasnim antagonizmima i u kojemu se jak prijezir vlastele spram pučana i seljaka najjasnije iskazao u čestim literarnim parodiranjima pripadnika tih nižih društvenih slojeva (podrobnije u: Novalić 1968: 712-730). Uočivši nejednaku društvenu, a onda i književno-kulturnu razvijenost sedamnaestostoljetne Hrvatske, o baroknim je (točnije, ranonovovjekovnim) literarnim krugovima - svega nekoliko godina nakon Novalića - pisao i Franjo Švelec, koji u svome književnopovijesnom pregledu dubrovačku književnost razdvaja od književnoga stvaralaštva hvarskog, splitskog i zadarskog kruga, a potom cjelokupni taj kompleks razgraničava od književne produkcije „kajkavaca u sjevernoj Hrvatskoj“, dok slavonski barok ne spominje ni jednom jedinom riječju (usp. Švelec 1974: 175-292). Ipak, treba primijetiti da se Švelec književnih krugova dotiče tek usput, odnosno bez ikakve namjere da hrvatski književni barok doista i razmotri kao regionaliziranu pojavu, kao što će to - primjerice - u svome već spomenutom prikazu Das Barock in der kroatischen Literatur učiniti Zoran Kravar (usp. Kravar 1991), a poslije njega i Davor Dukić, koji piše o „književnom regionalizmu“ ne samo naše barokne, već ranonovovjekovne književnosti u cijelosti, ne zaboravljajući pritom napomenuti kako su u svakoj od pobrojanih regija pisci baratali i drugačijim generičkim varijantama (usp. Dukić 2003: 487-499). Da je stariju hrvatsku - pa onda, dakako, i baroknu - književnost nužno shvaćati kao nejedinstvenu, odnosno kao svojevrsan zbroj regionalnih književnosti, s pravom je upozorila i Joanna Rapacka, koja - oslanjajući se ponajvećma na Kravarove opservacije - razlikuje sveukupno pet ranonovovjekovnih literarnih regija: dubrovačko-dalmatinsku, sjevernohrvatsku, ozaljsku, bosansku i slavonsku. Te su regije ili književnih krugovi, napominje Rapacka, bili „međusobno različiti po književnom jeziku, društvenim uvjetima funkcioniranja književnosti te su se nalazili u dosegu različitih kultura: sredozemne, srednjoeuropske i istočnjačke“, uz to ih je razdvajala još i činjenica da je i ,samosvijest na različitim područjima bila poprilično neprecizna i različita“" (Rapacka 2005: 360). Detaljnije o ovome u: Isto: 359-373. 
uspostavio u 19. st., nego u međusobno odvojenim, regionalnim kulturama u čijoj se samosvijesti osjećaj lokalne pripadnosti kombinirao s činiteljima nadregionalnoga ili nadetničkoga identiteta (»slovinstvo«, »ilirstvo«, »hrvatstvo«)“ (Kravar 2011: 111). Te su regionalne kulture, precizira Kravar, pripadale „različitim zonama međunarodnih utjecaja, njegovale su vlastite, premda slične, jezične standarde, a književnost je u svakoj od njih uživala manje ili više različit društveni status“ (Isto: 111), što je za posljedicu imalo činjenicu da se barokne (ponajviše stilske i žanrovske) inovacije nisu u njima mogle očitovati podjednako, ali ni zadobiti podudaran, a kamoli posve identičan smisao. Razapetost onodobne Hrvatske između triju snažnih imperijalnih sila (Habsburške Monarhije, Mletačke Republike i Otomanskoga carstva), na gepolitičkom raskrižju kojih se tada nalazila, dovela je - između ostalog - i do gravitiranja pojedinih njezinih regija (zemalja) različitim sedamnaestostoljetnim kulturama, pa dok su tako južnohrvatski pisci barokna obilježja većinom upijali iz talijanske književnosti te ih u svojim djelima rabili kao hotimičan literarni eksperiment, do sjevernih su naših autora, koji ih - u želji da privuku i zadrže zanimanje čitatelja - koriste isključivo kao svojevrsnu retoričku nadopunu u tekstovima sazdanima mahom od značajki predrenesansnih žanrova, one dopirale pretežno iz njemačke i mađarske književnosti. Osim što su, dakle, regionalna fragmentiranost tadašnje Hrvatske i okrenutost njezinih zemalja različitim inozemnim političko-kulturnim sredinama kočile jedinstven kulturni razvoj i uzrokovale regionalizaciju baroka, one su ujedno najveći krivci i za to što o (zamišljenome) žanrovskom sustavu naše književnosti 17. st. ne možemo i ne smijemo govoriti kao o kompaktnoj pojavi.

Temeljitom, ipak, genološkom analizom književnih ostvarenja nastalih u okrilju svake od sveukupno četiriju sedamnaestostoljetnih hrvatskih političkih i kulturnih regija moguće je rekonstruirati i četiri relativno različita samostalna žanrovska (mikro)sistema, kojih je zbroj, uvjetno rečeno, „tvorio“ provizoran „opći“ sustav žanrova hrvatske barokne književnosti, s kojim je računao tek malokoji onodobni naš pisac. Bez obzira na to što se taj zamišljeni „sveobuhvatni““ generički sustav hrvatskoga baroka u barokološkim istraživanjima podugo uzimao kao samorazumljiva i neupitna činjenica te pritom ustrajno definirao iz perspektive isključivo južnohrvatske onodobne književnosti i u njoj prisutnih žanrovskih opcija, još bi jednom valjalo izričito naglasiti kako su društveno-političke i kulturne razlike između hrvatskih regija u ranonovovjekovlju bile tolike da su naprosto onemogućavale formiranje jedinstvene, odnosno zajedničke barokne književne kulture, zasnovane, između ostalog, i na identičnom shvaćanju književnosti kao (samostalne) djelatnosti, a onda i na jednakoj ili vrlo podudarnoj kombinaciji „dostupnih“ generičkih varijanata, posve usklađenoj sa zahtjevima književne i izvanknjiževne situacije. I dok je - u generičkom pogledu - barok na našem jugu 
tako istodobno nasljedovao i dubinski modificirao renesansne žanrove i njihov hijerarhijski poredak, u sjevernohrvatskoj se varijanti temeljio on na većinom predrenesansnim, srednjovjekovnim generičkim rješenjima, pri čemu ni oni - ponešto načitaniji i društveno mobilniji - autori upućeni u žanrovske posebnosti drugih književnih regija nisu iskazivali ni najmanju želju da u njima zatečene žanrove ciljano pokušaju ,„presaditi“ i u svoju (književnu) sredinu. Naprotiv, većini je njih bilo, kako se čini, poprilično jasno da time neće postići eventualno literarno „ujedinjenje“ (pojedinih) razjedinjenih hrvatskih regija, tim više što su ih u takvim možebitnim žanrovskim „manipulacijama“ priječile (bez)brojne unutar- i izvanknjiževne okolnosti, odnosno poglavito činjenica da bi žanrovi za kojima su namjeravali posegnuti odveć odudarali od novoga generičkog, pa time i situacijskog konteksta. Znamo li, k tome, da su uz bok ovim „osvješteni(ji)m“ piscima u svakome krugu djelovali još i oni literarno slabije upućeni, koji su - fokusirani na isključivo svoj književni (regionalni) „mikrokozmos“ i susjedne, inozemne književnosti iz kojih su crpili poticaje - o žanrovskim varijantama drugih sredina jedva znali ponešto, a gdjekad i doslovno ništa, neće biti nimalo neobično to što su se u hrvatskoj književnosti kroz čitavo razdoblje baroka održale četiri samostalne književne regije ili kruga, u ,dosluhu“ s kojima su djelovali čak i naši autori u dva inozemna barokna kruga, i to onome franjevačkom u turskoj Bosni te hrvatskom u mletačkoj Boki Kotorskoj. ${ }^{362}$ Baš svaki od tih četiriju domaćih baroknih književnih krugova dubrovačko-dalmatinski, kajkavski ili sjeverozapadni, slavonski (koji oživljava nakon oslobođenja Slavonije od turske vlasti potkraj 17. st.) te tzv. ozaljski književni krug ili krug velikaških obitelji Zrinski i Frankopan ${ }^{363}$ - odlikovao se, kao što ćemo vidjeti, nemalim generičkim posebnostima, odnosno sebi svojstvenim zbirom žanrovskih rješenja, kojima je ujedno i bitno obogaćivao iznimno šaroliku generičku sliku ili - jedino u teoriji zamisliv žanrovski sustav hrvatske barokne književnosti.

Što se književno i uopće kulturno najrazvijenije naše sedamnaestostoljetne regije one dubrovačko-dalmatinske ${ }^{364}$ - tiče, nije suvišno istaknuti da se radi o jedinomu našem

\footnotetext{
362 O spomenutim inozemnim baroknim krugovima više u: Dukić 2003: 492-493 i Rapacka 2005: 362-363.

363 Navedenu raščlambu književnih krugova uspostavio je Zoran Kravar. Podrobnije u: Kravar 1993: 39-69 i 2010: 110-115. Usp. i Kravar 1991.

${ }^{364}$ U nekima od najrecentnijih prikaza hrvatskoga književnog baroka - kao što je to, primjerice, slučaj s onim Davora Dukića - Dubrovnik i (mletačka) Dalmacija motre se kao dvije zasebne književne regije, i to s razloga što dalmatinska barokna književnost, kako se ondje ističe, vidno zaostaje za onom dubrovačkom, koja je u stopu slijedila aktualna zapadnoeuropska poetička strujanja i isticala se svojom izrazitom artificijelnošću, žanrovskim bogatstvom te sviješću o posebnom društvenom statusu lijepe književnosti (usp. Dukić 2003: 488-490). S obzirom na to da u književnosti dalmatinskoga baroka nastaju pretežno religiozna djela, dubrovačkome baroknom stvaralaštvu stilski bi i žanrovski, u tom smislu, u stanju bio „parirati“ tek opus korčulanskoga pjesnika Petra Kanavelića, a pojedini književni povjesnici navedenu primjedbu potkrepljuju još i činjenicom da su jezične i političke okolnosti ovaj zamišljeni književni krug razdvajale na onaj štokavski nezavisne Dubrovačke Republike te onaj čakavski mletačkih dalmatinskih gradova (usp. Rapacka 2005: 362).
} 
ranonovovjekovnom krugu koji je dosegao razinu moderne književne kulture, i to ponajviše zahvaljujući činjenici što je shvaćanje književnosti kao samostalne umjetničke djelatnosti prevladalo u njemu znatno prije nastupanja baroka. Upravo zahvaljujući takvu statusu što ga je književnost ondje uživala, ni priklanjanje baroknoj literarnoj „modi“ u ostvarenjima naših južnih pisaca i nije se moglo očitovati nikako drugačije nego otvorenim inzistiranjem na slobodi forme i naročito stila, što je - baš kao i u njihovih talijanskih književnih uzora podrazumijevalo nadređivanje stilske dimenzije opterećene figuralnim pretjerivanjima $\mathrm{i}$ končetističkim dosjetkama ostalim razinama teksta. S obzirom na to da je sadržaj njihovih ostvarenja beziznimno morao biti usklađen s temeljnim idejama protureformacije te da im nije ostavljao mnogo prostora za iskazivanje vlastite originalnosti, tj. poetički propisane „,ingenioznosti““, dubrovačko-dalmatinski su barokisti najveći dio svoga kreativnog fokusa bili prisiljeni usmjeriti upravo na stilski nivo teksta, shvaćajući ga kao dominantni „sadržaj“ svojih djela, odnosno kao neoboriv dokaz estetske uspjelosti književnoga teksta kao takvog.

Unatoč očitom uvažavanju najsuvremenijih poetičkih zahtjeva, inzistiranju na „pravovjernim“, kršćanskim motivima prožetim sadržajima te kreativnom promicanju tipično baroknih ideoloških zamisli (navlastito onih katoličke obnove, „baroknoga slavizma“ itd.), stvaralaštvo dubrovačko-dalmatinskoga književnog kruga u generičkom se pogledu - na prvi pogled - doima još uvijek prilično srodnim onome prethodne, renesansne epohe, tim više što obuhvaća čak i tekstove u kojima dominiraju obilježja stanovitih žanrova antičke provenijencije, koji su u ranonovovjekovnu književnost dospjeli isključivo zahvaljujući posredovanju talijanske i hrvatske renesanse (idila, ekloga, pastorala i sl.). Motrimo li ga, međutim, kao (zamišljenu) cjelinu, žanrovski sustav južnohrvatske barokne književnosti vidno ipak odudara od onoga renesansnog, i to ne samo poradi znatnog ,priljeva“ novih, mahom hibridnih žanrovskih varijanata, već naročito činjenice da su redom sva generička rješenja baštinjena iz prethodnog razdoblja bila podvrgnuta temeljitim modifikacijama u cilju njihova usklađivanja $\mathrm{s}$ aktualnim literarnim i izvanliterarnim imperativima i potrebama. Barokne su silnice, ukratko, prožele apsolutno sve žanrove sedamnaestostoljetne dubrovačkodalmatinske književnosti - u rasponu od lirske pjesme petrarkističke tematike, religiozne i liturgijske lirske pjesme, komične i religiozne poeme, povijesno-viteške epske pjesme i kraćega epa (epilija), pa sve do tragikomedije, melodrame, komičke drame (tzv. „smješnice“), maskerate, crkvenoga prikazanja i dr. ${ }^{365}$ - što je uvelike moguće držati posljedicom ugledanja naših pisaca u žanrovski šarolike opuse onodobnih talijanskih (Tasso, Marino, Chiabrera,

\footnotetext{
365 O konkretnim žanrovima južnohrvatske barokne književnosti detaljnije u: Kolumbić 1991: 39-51, Kravar
} 1993: 43 i 2010: 112-113. 
Tansillo, Pretti i dr.) te pojedinih inozemnih novolatinskih pjesnika (primjerice, poljskoga isusovca Macieja Kazimierza Sarbiewskog).

Težnja za modernizacijom tradicionalnih žanrovskih varijanata u južnom je odsječku našega baroka rezultirala iznimno zanimljivim kombinacijama $\mathrm{u}$ repertoarima njihovih karakterističnih značajki, pa će tako, primjerice, žanr barokne lirske pjesme - što se ponajbolje uočava u lirskopjesničkim zbirkama i ciklusima Ivana Mršića, Ivana Bunića Vučića, Petra Kanavelića i Ignjata Đurđevića - obilježiti prihvaćanje predbaroknih generičkih „predložaka“ (ljubavne pjesme, parafraza psalama, prepjeva crkvene lirike, ekloga itd.) i uopće snažno (sadržajno) nadovezivanje na starije lirske tradicije (ljubavnu petrarkističku poeziju i klasično latinsko pjesništvo), ali i njihovo „oplemenjivanje“ prepoznatljivo baroknim pretjeranim stilom (najčešće zasnovanim na ulančavanju figura) te inzistiranjem na svjetovnoj namjeni, odnosno odvojenosti od crkvenoga obreda čak i religioznih lirskopjesničkih sastavaka. Nasuprot renesansnoj lirskoj pjesmi, koja je primarno bila upućena visokoobrazovanim čitateljima, dakle eruditima, barokna je lirika - zahvaljujući svojoj izrazitoj didaktičnoj namjeni (poučnosti) - iskazivala otvorenost vrlo širokom krugu čitatelja, ${ }^{366}$ po čemu nipošto nije predstavljala izdvojen slučaj u sedamnaestostoljetnome južnohrvatskom sustavu književnih žanrova. Naprotiv, među čitateljima različitih profila svoju je publiku tražio i još uvijek najuvaženiji žanr u tadašnjoj generičkoj hijerarhiji - onaj, dakako, (poučne) epske pjesme - u kojemu do polaganoga gubljenja važnosti postupaka baštinjenih iz tradicije biblijsko-vergilijanskoga epa dolazi usprkos snažnom (pretežno sadržajnom) oslanjanju sedamnaestostoljetnih pjesnika na poetike humanističke i renesansne epike. To postupno pucanje spona kojima se barokni ep u svojim počecima povezivao s epskopjesničkom tradicijom ponajbolje se očitovalo u sve izrazitijem punjenju njegova okvira „neepskim partijama, genetski povezanima s tradicijom duhovnoga plača, religiozne lirike ili crkvenoga govorništva“, ali i u činjenici da su se povijesni događaji sve rjeđe opjevavali u formi jednostavnih kronikalnih epova, a sve češće u „vrstovno mješovitim kraćim spjevovima, u kojima se naracija miješa s laudacijskom dikcijom, a koji uključuju tematske skokove, generička prikapčanja, a kadšto i neobičan izbor pripovjedačke perspektive“ (Kravar 2010: 112). ${ }^{367}$ Otvaranje epskopjesničkih okvira (većinom sadržajnim) karakteristikama

\footnotetext{
${ }^{366}$ Usp. Kravar 2003a: 513-515. O žanru barokne lirske pjesme, posebno u usporedbi s onim renesansne lirike, vrlo detaljno i u: Pavličić 1979b: 10-13 i 69-104.

${ }^{367}$ Ponajvećma po uzoru na Tassov Oslobođeni Jeruzalem, naročito su se u velikim dubrovačko-dalmatinskim povijesnim epovima u to vrijeme povijesni sadržaji miješali s romantičnim, kvazipovijesnim (pseudopovijesnim) i transcedentalnim ili eshatološkim (,nebeskim“ i ,paklenim“) epizodama, što je neizbježno vodilo do njihova tematsko-motivskoga zasićenja. Uz to, velike su barokne epove na jugu karakterizirale i skokovita kompozicija te asimetrična i otvorena struktura, što je bilo u oštroj opreci spram renesansnoga zagovaranja simetrije (pravilnosti), a uopće je u svim tadašnjim epskopjesničkim žanrovima bila tada jasno izražena težnja kataloškoj
} 
drugih književnih - pa i ne samo književnih - žanrova za svoju je posljedicu imalo nagli rast broja „epskih“ generičkih oblika, slijedom čega u dubrovačko-dalmatinskoj književnosti 17. stoljeća, pored naslijeđenih žanrova poput povijesnoga i biblijsko-religioznog epa, zatječemo još i one poput epilija, prigodne epske pjesme o suvremenim povijesno-političkim temama (npr. Trublja slovinska Vladislava Menčetića), enciklopedijskoga epa (Kavanjinova Povijest vanđelska) te romantične priče u stihu (primjerice, Skvadrovićev Mačuš i Čavalica). ${ }^{368}$

Ništa manje raznolik na našem jugu u to doba nije bio ni izbor novoosmišljenih, „autohtono“ baroknih generičkih rješenja, nastalih miješanjem ili reinterpretacijom pojedinih tradicionalnih (antičko-renesansnih) žanrova, odnosno stapanjem obilježja iz repertoara čistih generičkih suprotnosti ili - riječima Nikice Kolumbića - „raznorodnih, većinom oprečnih kompleksa, bilo duhovnih i idejnih, bilo formalnih i strukturalnih“ (Kolumbić 1991: 47). Među intrigantnim hibridima što su ih iznjedrila takva generička poigravanja barokista posebnu su popularnost u dubrovačko-dalmatinskom baroku uživali žanrovi melodrame i poeme, koja se ondje pojavljuje u svojoj komičnoj i religioznoj varijanti (tzv. „,barokni plač“‘). Razlozi njihova iniciranja bili su pritom mahom izvanknjiževne prirode, pa dok se melodrama tako uvodi kao svojevrsan pandan klasičnoj tragediji i s ciljem da se publici ponudi sprega pisanoga i pjevanoga, odnosno književnoga teksta i glazbe, ${ }^{369}$ poema proizlazi iz potrebe za literarnom obradom poučnih sadržaja koji nisu poimani kao dovoljno važni ni opsežni da bi bili opjevani u formi epa, i to na način blizak izričaju lirske pjesme. Da su, međutim, obje inačice barokne poeme tadašnji pisci i čitatelji razumijevali kao jedinstven žanr razabiremo iz tematsko-motivskih, strukturnih i formalnih njihovih posebnosti, pa osim što i jedna i druga rabe potpuno isti tip strofe te redovito uspostavljaju jasne poveznice na petrarkističku književnu tradiciju, ujedno se i komične poeme nerijetko otvoreno parodijski osvrću na svoje religiozne generičke ,,srodnice“. 370

Ako se najzaslužnijom za raznovrsnost (provizornoga) žanrovskog sistema dubrovačko-dalmatinskoga baroknog književnog kruga ispostavlja upravo odlučnost njegovih autora u provođenju najsuvremenijih poetičkih postulata čak i u okvirima baštinjenih žanrova, odnosno otvorenost u kreiranju i/ili naprosto prihvaćanju inovativnih - pretežno hibridnih generičkih rješenja, onda bi i najveću „odgovornost“ za žanrovsko bogatstvo kojim se može

organizaciji sadržaja, koja je proizlazila iz tipično sedamnaestostoljetne enciklopedijske vizije stvarnosti. Detaljnije o „svjetovima“ baroknih povijesnih epova na primjeru Gundulićeva Osmana u: Kravar 1993: 104-125. 368 O konkretnim epskopjesničkim generičkim varijanatama zastupljenima u južnohrvatskome književnom baroku podrobnije u: Fališevac 1997: 91-126 i 2003: 501-511.

${ }^{369}$ Iz toga će razloga upravo iz melodrame nešto kasnije proizići i književno-glazbeno-scenski žanr opere.

${ }^{370} \mathrm{O}$ žanrovima barokne melodrame i poeme znatno detaljnije u: Pavličić 1979b: 16-23; o religioznoj poemi naročito u: Isto: 105-128 i Kolumbić 1991: 39-51. 
podičiti (i) generički sustav ozaljskoga ili zrinsko-frankopanskoga književno-jezičnog (kulturnog) kruga $^{371}$ trebala snositi ponajprije naklonjenost tamošnjih pisaca raznim predbaroknim žanrovskim varijantama, ali i njihova odvažnost u povremenim posezanjima $\mathrm{i}$ za onima daleko modernijim, iako počesto protkanim značajkama usmenoknjiževnih žanrova, a gdjekad i zamjetnije generički „dorađenim“ kako bi udovoljili potrebama konteksta iz kojega je izniklo i žanrovski šaroliko pučkoknjiževno stvaralaštvo. Naime, relativno malobrojni pripadnici ovoga po mnogočemu specifičnog sedamnaestostoljetnoga književnog i kulturnog kruga, ${ }^{372}$ nastalog na vrlo uskome području smještenom na samoj granici sjeverne (kontinentalne) i južne (primorske) onodobne Hrvatske, bili su ne samo na različite načine povezani s njegovim sjedištem - dvorom obitelji Zrinski u Ozlju - i centralnim njegovim figurama (ponajprije Petrom i suprugom mu Katarinom Zrinski), već su se ujedno i međusobno nezanemarivo razlikovali po književnom iskustvu i uopće shvaćanju književne djelatnosti i njezine svrhe, po literarnim uzorima na koje su se oslanjali, po publici kojoj su se obraćali, po samim varijantama trodijalektalnoga hrvatskog jezika kojim su se (pretežno) u svome radu služili, a onda i po žanrovskim obilježjima koja su uključivali u vlastita ostvarenja. S obzirom na to da - pod utjecajem spomenutih razlika - „Ozljani“ svome stvaralaštvu nisu mogli pristupati posve jednako, već tek donekle podjednako, ni najmanje nas ne bi trebala iznenađivati izuzetna širina generičkoga sustava njihove književne „regije“, u kojemu su uz bok svjetovnim žanrovima egzistirali ne samo oni religijski, već i pučkoknjiževni, pa i izvanknjiževni, za koje - međutim - nipošto ne bi bilo ispravno ustvrditi da su bili u potpunosti „očišćeni““ od pojedinih literarnih karakteristika.

\footnotetext{
371 O ozaljskome krugu vrlo detaljno u: Vončina 1968: 195-205, 1973: 203-237, 1977: 191-204, 1988: 187-195; Kravar 1991: 205-243 i 1993: 53-57; Posavac 1994: 530-540; Moguš 2009: 91-99; Bratulić 2011: 262-271; Jembrih 2011: 109-124; Pajur 2014: 55-68. Inače, prijepori oko konkretnoga naziva ovoga sedamnaestostoljetnog književno-kulturnog kružoka još ni izbliza nisu (raz)riješeni, pa je tako Zlatko Posavac već prije nekoliko desetljeća predložio da se naziv „ozaljski krug“ zamijeni onim „ozaljsko-čakovečki krug“, i to - kako pojašnjava - „ne samo zato što je brat Petrov, Nikola Zrinski, bio koliko inicijator političkih toliko baš upravo i kulturoloških umjetničkih i teorijskih (autorskih) akcija osamostaljenja, sa sjedištem u Čakovcu, nego zato što Petar nastanjuje Čakovec u idejnom i materijalnom smislu, zajedno s bibliotekom i ostalim bogatim umjetničkim inventarom“ (Posavac 1994: 533, bilješka 41). Alojz Jembrih, pak, relativno je nedavno konstatirao kako tome krugu daleko bolje pristaje naziv ,zrinsko-frankopanski književno-jezični krug“ (usp. Jembrih 2011: 115 i 2015: 597, bilješka 208), a s njime se ubrzo složio i Franjo Pajur, koji spomenuti krug u svojoj studiji također proziva „,zrinsko-frankopanskim jezično-književnim krugom“ (Pajur 2014: 68). Za razliku od njih, Zoran Kravar će - želeći jače istaknuti središnju njegovu figuru - taj barokni odsječak naše književnosti nazvati naprosto - „književnim krugom oko Petra Zrinskoga“ (Kravar 1991: 205), no za tu se varijantu njegova naziva u kasnijoj književnopovijesnoj literaturi neće odlučiti gotovo nijedan naš proučavatelj.

$372 \mathrm{O}$ konkretnim pripadnicima ozaljskoga ili zrinsko-frankopanskoga književnog kruga naši se književni povjesnici spore još i danas, no većina je njih ipak suglasna s tim da je - kao ,jedna jezično, ali i poetički posve osebujna književna pojava“ (Dukić 2003: 491) - ovaj krug iniciran ponajprije zahvaljujući Nikoli Zrinskom i njegovu djelu Adriai tengernek Syenaia te da su ga održali većinom pisci usko vezani uz magnatsko sjedište obitelji Zrinski u Ozlju (Petar i Ana Katarina Zrinski te Fran Krsto Frankopan), iako se njima počesto pribrajaju još i Juraj Rattkay te Ivan Belostenec.
} 
Ispunjavanju pretežno religioznih zadaća u ozaljskome su krugu bili tako namijenjeni (većinom „standardni““) žanrovi barokne molitve, kojih čitav niz - mahom u prozi - nalazimo u prevedenomu njemačkom molitveniku Putni tovaruš (1661.) Katarine Zrinski, te propovijedi ili propovjedne proze, čiji su vrlo uspjeli primjerci sadržani u zbirci Deset propovijedi o euharistiji (1672.) pavlina Ivana Belostenca. I dok sferu nabožnih žanrova samo rubno dotiče nedovršen satirički prozni tekst Trumbita sudnjega dneva Frana Krste Frankopana, zamišljen kao duhovita varijacija omiljene srednjovjekovne teme posljednjih čovjekovih stvari, dotle se u „ladicu“ izvanknjiževnih žanrova nastalih u okvirima (is)toga kruga bez ikakva „ostatka“ mogu uvrstiti čuveni dvosveščani Belostenčev (rukopisni) latinsko-hrvatski i hrvatsko-latinski rječnik Gazophylacium, a osim njega još i naglašeno literarizirani povijesni tekstovi Jurja Rattkaya Kriposti Ferdinanda II. (1640.) ${ }^{373}$ te Memoria regum et banorum regnorum Dalmatiae, Croatiae et Slavoniae (1652.). Da se pojedinim „Ozljanima“ nije bilo mrsko upustiti čak ni u ispisivanje pučkoknjiževnih generičkih rješenja poput knjige gatalica - jednog od možda i najraširenijih ranonovovjekovnih pučkih žanrova svjedoče nam i prevedeni rukopisni „poučno-zabavni zbornik“ (Bogišić 2007: 222) Sibila Petra Zrinskog, ${ }^{374}$ ali i fragmentarno sačuvan Lado horvatski (hervatski) iliti Sibila, kojega je sastavio te u zagrebačkoj Zemaljskoj tiskari - kojom je tada (još uvijek) upravljao - između 1702. i 1706. vlastoručno tiskao Pavao Ritter Vitezović. ${ }^{375} \mathrm{Za}$ razliku od Petrove Sibile, namijenjene isključivo uporabi na dvoru Zrinskih, Vitezovićev Lado potencijalne čitatelje nije tražio samo i isključivo među aristokratskom publikom, no s obzirom na to da nije moguće decidirano ustvrditi da Ritter pri sastavljanju svoje knjige gatalica nije znao baš ništa o onoj Petrovoj, na ovome je mjestu ipak valja navesti uz bok ostalim ostvarenjima autora ozaljskoga kruga. Krajnje je, međutim, upitno može li se to isto učiniti i s većinom drugih njegovih pučkoknjiževnih sastavaka - kalendarima, kronikom itd. - budući da eventualnoga žanrovskog uzora za njih među „Ozljanima“ naprosto nije mogao pronaći. ${ }^{376}$

\footnotetext{
373 Riječ je zapravo o prijevodu latinskog djela belgijskoga isusovačkog pisca Wilhelma Lamormainija Ferdinand II., Romanorum Imperatoris, Virtutes, objelodanjena svega dvije godine ranije (1638.). Detaljnije o Rattkayevu prijevodu u: Georgijević 1969: 115-118.

${ }^{374}$ Kako naglašava Rafo Bogišić, Petar je Sibilu najvjerojatnije preveo iz mađarskoga predloška, i to - kako se čini - Fortune iz 1594., koja je bila knjiga ,„̌tiva razbibrige, šala i savjeta u predviđanju budućnosti“ (Bogišić 2007: 219). S obzirom na to da je knjiga gatalica - kao žanr izvorno srednjovjekovne provenijencije - izrastao iz iznimne sklonosti onodobnoga čovjeka gatanjima, astrologiji i raznim drugim praznovjerjima, upravo je u 16. i 17. stoljeću diljem Europe on uživao izrazitu popularnost, slijedom čega je i Petar moguće poticaje za njegovo sastavljanje - osim u mađarskoj - mogao pronaći još i u njemačkoj te poljskoj ranonovovjekovnoj književnosti. ${ }^{375}$ Usp. Klaić 1914: 198-200.

${ }^{376}$ Iako Ritter za nj nije mogao znati, izuzetak bi predstavljala tek njegova zbirka stihovanih poslovica Priričnik aliti razliko mudrosti cvitje, koja je u ozaljskom krugu svoga prethodnika imala u rukopisnom Frankopanovu ciklusu (folklornih) poslovica Šentencije vsakojaške.
} 
Među znatno brojnijim svjetovnim književnim žanrovima zastupljenima u opusima pisaca ozaljskoga kruga kao izuzetno se zanimljiv i vrijedan raritet izdvaja komedija, čije tekstualne značajke nosi dramski fragment što ga nalazimo u pisanoj ostavštini Frana Krste Frankopana. Iako je riječ o ,tek“ nedovršenu pokušaju prijevoda, prvi čin Molièreove komedije George Dandin - kojega Frankopan prevodi pod naslovom Jarne bogati istovremeno se nameće kao ne samo čvrst dokaz autorove erudicije, istančana literarnog ukusa i neupitnoga prevoditeljskog umijeća, već ujedno i kao hvalevrijedan dodatak žanrovskomu sustavu zrinsko-frankopanskoga kruga, u kojemu će se žanru drame po nekim svojim karakteristikama približiti još samo pojedini dijaloški pjesnički Frankopanovi sastavci te dijaloške dionice Vitezovićeva Odiljenja sigetskog. Za razliku od dramskoga žanra, onaj epskopjesnički u ozaljskoj je kulturi bio predstavljen i više nego primjernim ostvarenjem, za što se pobrinuo sam Petar Zrinski, koji u zborniku epskih i lirskih pjesama Adrijanskoga mora Sirena (1660.) donosi bitno dorađeni prepjev mađarskoga povijesnog epa Szigeti veszedelem (1651.) brata Nikole u petnaest pjevanja naslovljen Obsida sigecka. I baš kao što se u epovima obojice braće susreću baroknom pjesništvu svojstvena sadržajna obilježja (preplitanje povijesnih, kvazipovijesnih, eshatoloških i romantičnih epizoda po uzoru na Tassa te pojedini motivi iz djela Giambattiste Marina) sa značajkama predbaroknoga - očito renesansnoga - književnog stila (stilska umjerenost umjesto baroknih figuralnih pretjerivanja), tako se i na nivou čitavih njihovih zbornika ciklusi lirskih pjesama „sudaraju“ sa samim epskim tekstom, koji u obje knjige zauzima „povlaštenu“ - središnju - poziciju.

Premda su u baroknoj književnosti lirski ciklusi podrazumijevali sadržajnu, stilsku, a onda i žanrovsku heterogenost, ${ }^{377}$ u slučaju epsko-lirskih zbornika braće Zrinski ne samo što „okolni“ lirskopjesnički sastavci generički vidno odskaču u odnosu na centralni epski tekst, već se oni ujedno po svojim žanrovskim obilježjima i međusobno umnogome razlikuju. Generička raznolikost lirskopjesničkih odsječaka Adrijanskoga mora Sirene tako se ujedno nameće i kao očit pokazatelj bogatoga literarnog iskustva pojedinih „Ozljana“, njihova i više nego dobrog poznavanja različitih, baroku osobito dragih žanrovskih varijanata lirske poezije, te suverena vladanja normama tih žanrova, odnosno njima svojstvenim generičkim repertoarima. Izuzetnu umješnost u sastavljanju različitih (baroknih) lirskih žanrova Nikola i Petar Zrinski tako potvrđuju u uvodnim i zaključnim dionicama svojih zbornika, u kojima nižu formalno različito realizirane pjesme religiozne i svjetovne - pretežno ljubavne i ratne tematike, obilježene generičkim karakteristikama idile, elegije, epigrama, epitafa, nabožne

\footnotetext{
${ }^{377}$ Odnosi se to ponajprije na barokne lirske zbirke južnohrvatskih autora, ali i - kao što ćemo vidjeti - na one mnogih sjevernih, naročito pjesnika iz ozaljskoga književno-jezičnog kruga. Detaljnije o strukturi, odnosno sadržajnoj i žanrovskoj šarolikosti naših baroknih lirskopjesničkih ciklusa u Kravar 2003a: 513-520.
} 
pjesme, pjesme s figurom jeke itd., ${ }^{378}$ no ništa manju stihotvoračku vještinu, odnosno okretnost u posezanju za različitim žanrovskim varijantama (pred)baroknoga lirskog pjesništva osim njih će u svojoj rukopisnoj lirskopjesničkoj zbirci Gartlic za čas kratiti iskazati i Petrov šurjak Fran Krsto Frankopan.

Neovisno od toga koliki broj pjesama u Gartlicu otpada na prepjeve ili prerade tekstova iz talijanske zbirke Diporti (Zabave, 1656.) njegova uzora - austrijskoga vojvode Leopolda Wilhelma Crescentea, Frankopanova knjiga poezije izdvaja se kao još jedan uvjerljiv dokaz raznolikih generičkih preferencija (lirskih) pjesnika ozaljskoga baroknog kulturnog kruga, ${ }^{379}$ koje su - pored nabrojanih žanrova - uključivale još i petrarkističke ljubavne pjesme, humorne i erotske lirske pjesme srednjovjekovne provenijencije, ${ }^{380}$ moralistička lirska razmatranja, kancone, ratne lirske govore (npr. Pozvanje na vojsku), dijaloške pjesme te deseteračku liriku s izrazitim folklornim obilježjima (okupljenu u ciklusu Dijačke junačke). ${ }^{381} \mathrm{U}$ žanrovskom je pogledu samo donekle na tragu bratovih (Frankopan) ${ }^{382}$ i suprugovih (P. Zrinski) pjesničkih ostvarenja bila i poezija što ju je u svoju tek nedavno (2014.) objelodanjenu rukopisnu pjesmaricu upisivala Ana Katarina Zrinski, no njezini su lirski tekstovi pored generičkih osobina molitve, ljubavne pjesme, elegije, tužaljke, povijesne pjesme itd. redovito uključivali još i povelik broj značajki folklornih i pučkoknjiževnih lirskih

\footnotetext{
${ }^{378}$ Usp. Zrinski 1957. Analizirajući lirskopjesničke dionice Petrova zbornika, ali i Sirenu kao homogen tekst, svakako bi se - u nedostatku prvoga, mletačkog izdanja iz 1660. - valjalo držati njegova Akademijina (cjelovitog) reizdanja, što ga je 1957. priredio Tomo Matić. Naime, iz njegova nedavnog novog, pola stoljeća mlađeg reizdanja, koje je - u povodu proslavljanja 450. obljetnice Sigetske bitke - priredio Josip Bratulić (usp. Zrinski 2016), iz posve nepoznatoga su razloga izostavljene tri lirske pjesme koje prethode središnjoj epskopjesničkoj dionici, dok se od onih dvanaest koje za Obsidom sigeckom slijede ispušta njih čak pet, slijedom čega samoj Obsidi bivaju ondje pridružene tek pjesme Epigrammata, pet epitafa te zaključno Ispivanje. Tome je krnjem novom izdanju pritom još nadjenut i prilično dvojben naslov (Adrijanskoga mora Sirena \& Obsida sigecka), a samomu se priređivaču - uz to - nigdje unutar njega očito nije činilo bitnim napomenuti da je riječ „tek“ o odabiru iz Petrove knjige, a kamoli iznijeti razloge zbog kojih Sirena pred suvremene čitatelje dolazi upravo u takvome obliku.

${ }^{379}$ Kako napominje Zoran Kravar, „motivske različitosti koje se zapažaju u sloju Frankopanove lirike obilježene Crescenteovim utjecajem ne nadilaze uobičajenu tematsko-vrstovnu raznolikost prosječnih lirskih zbirki 17. stoljeća“ (Kravar 2003a: 516), pri čemu valja primijetiti kako se u Gartlicu samo rijetko rabe barokna stilska rješenja, pa su tako zapravo najčešća ona što ih je Frankopan baštinio iz petrarkističke tradicije i folklornoknjiževnoga pjesničkog stvaralaštva.

${ }^{380} \mathrm{O}$ brojnim značajkama srednjovjekovnih žanrova u Gartlicu podrobnije u: Kravar 1993: 95-98.

${ }^{381} \mathrm{Ne}$ treba, dakako, zaboraviti ni Frankopanovu izrazitu sklonost drugim usmenoknjiževnim žanrovima poput poslovice i zagonetke. O žanrovskom sastavu njegova opusa detaljnije npr. u: Potočnjak 2015: 119-134.

${ }^{382}$ Najrecentnija su, doduše, istraživanja pokazala kako su paralele između Katarininih i pjesničkih ostvarenja Frana Krste Frankopana možda i najslabije uočljive upravo na ,gornjoj“, generičkoj razini, iako one postoje ne samo na onoj sadržajnoj, već i na formalnoj, pa i stilskoj. Dapače, zbog vrlo snažnih tematsko-motivskih sličnosti, forsiranja muškoga lirskog subjekta, obilja leksičko-frazeoloških i stilskih podudarnosti te pojedinih vrlo bliskih strofičko-metričkih rješenja neki su se proučavatelji odvažili pretpostaviti kako je stanovit broj pjesama u Katarininoj rukopisnoj zbirci zapravo proizišao iz Frankopanova pera, dočim se drugima znatno vjerojatnijom učinila mogućnost da su - uzme li se u obzir činjenica kako je Katarina bila prilično starija od brata Frana - kreativni utjecaji zapravo dolazili s njezine strane, što i potvrđuju mnogi gotovo neizmijenjeni ili tek malo varirani stihovi, a gdjekad čak i čitave strofe koje je Frankopan preuzeo od Katarine. Detaljnije o ovim pitanjima u: Dukić i Lukec 2017: 286-292.
} 
pjesama, što ih - kako su primijetili njihovi (za sada) malobrojni proučavatelji - čini motivski vrlo bliskima anonimnoj pučkoj lirici iz onodobnih kajkavskih pjesmarica. ${ }^{383}$

U nas izdvojena, no u europskim okvirima prilično česta i vrlo moderna pojava bili su rukopisni izbori iz znatno opsežnijih žanrova - mahom (povijesnih) epskih pjesama - koji su funkcionirali ili kao svojevrsne najave budućih cjelovitih tiskanih izdanja ili, pak, kao male kompilacije najintrigantnijih i/ili literarno najuspjelijih dionica iz već objelodanjena teksta, namijenjene ponajprije ženskoj publici koju nisu zanimali (ili za koju se pretpostavljalo da je neće zanimati) nadugačko opjevani povijesni događaji nužno izmiješani s mnogobrojnim ideološki nabijenim dionicama. Kao (zasad jedini) domaći, „ozaljski“ odjek te ranonovovjekovne literarne „mode“384 nameće se rukopisni sveščić što ga je sredinom šezdesetih godina prošloga stoljeća među građom pohranjenom u arhivu obitelji Drašković čuvanom, dakako, u zagrebačkome Državnom arhivu - pronašao naš barokolog Đuro Novalić, koji tomu vrijednom otkriću posvećuje i kraću studiju, u kojoj iznosi niz inovativnih te za naše istraživanje poprilično intrigantnih i korisnih zapažanja o stvaralaštvu ozaljskoga književnog kruga. Radi(lo) se, konkretno, o pronalasku djelomičnoga prijepisa Adrijanskoga mora Sirene Petra Zrinskoga, u koji su uvrštene sve lirske pjesme iz njezina venecijanskog izdanja (1660.) izuzev nabožnoga Vzdihanja $k$ Otkupitelju na križu raspetome te zaključne pjesme Ispivanje, dok se od čitava teksta epa Obsida sigecka donosi u njoj tek njegov peti „del“ ili pjevanje, i to upravo ono u kojemu su posve izostali opisi kršćansko-muslimanskih okršaja i uopće ,jaki“ epsko-pripovjedni momenti, odnosno koje se u cijelosti sastoji od tek (ratnih) govora sigetskoga kapetana suborcima, njegova oproštaja sa sinom, njegova pismovnog obraćanja kralju te opisa priprema Sigećana za daljnju obranu grada. Prema Novalićevu je sudu taj parcijalni prijepis - točnije, vrlo selektivan izbor iz Sirene -

${ }^{383}$ Usp. o tome u: Bratulić 2014: 277-319. Štoviše, Katarina u svoju zbirku uvrštava čak i Popivku od razboja Čingičevoga (usp. Zrinski 2014: 79-88), u kojoj se u 31 dvanaesteračkomu katrenu - dakle, u onoj istoj formi u kojoj će i njezin suprug Petar ispjevati Obsidu sigecku - opisuje pobjeda nad Osmanlijama pod vodstvom AliPaše Čengića što su je u listopadu 1663. Petar Zrinski i Fran Krsto Frankopan izborili kod Jurjevih stijena u Lici, a koja gotovo u potpunosti počiva na usmenoknjiževnim i pučkoknjiževnim sadržajnim, pa i stilskim rješenjima. O spomenutoj pjesmi više u: Bogišić 2007: 215-216.

${ }^{384}$ Spomenutim je rukopisnim izborima, međutim, moguće pribrojiti i prijepise cjelovitih književnih ostvarenja, kojih je i u nas - naročito u južnom odsječku ranonovovjekovne nam književnosti - kružio nezanemariv broj, i to ne samo u funkciji najavitelja kasnijih tiskanih izdanja. Naime, to je - kako pojašnjava Đuro Novalić - „bio svojevrsni oblik raspačavanja književnih proizvoda, kojem se pribjegavalo ne toliko zbog nedostatka sredstava za štampanje ili nedostatka štamparije (čime se obično tumači neobično mali broj tiskanih djela u čitavoj našoj starijoj književnosti), već zbog toga što je po mišljenju ljudi 17. st. pisati i štampati svoja djela dolikovalo samo profesionalnim literatima, koji su se nadali nekom utršku od svoje literarne djelatnosti, a ne otmjenim aristokratima, koji su pisali ne radi dobiti već da nečim ispune svoj gospodski »otium«. Takvo gledanje na svoju i tuđu literarnu djelatnost ne karakterizira samo naše sjeverno-hrvatske feudalce i dalmatinsko-dubrovačke patricije, iz čijih se redova regrutirala većina naših svjetovnih pisaca, već i čitavu Evropu 16. i 17. st., uključivši i književno živu i aktivnu Englesku. Objavljivala su se štampom većinom djela koja su imala nabožni ili patriotsko-politički karakter poput Sirene, ukoliko su im autori bili ljudi koji nisu bili materijalno zainteresirani za utržak od prodanih knjiga“" (Novalić 1967a: 215-216). 
najvjerojatnije nastao po nalogu samoga Petra Zrinskog, i to svakako prije njegova smaknuća 1671., a moguće i neposredno uoči objelodanjivanja djela 1660., pri čemu bi sam odabir tekstova iz opsežnoga zbornika jasno upućivao na to da je bio on namijenjen ponajprije nekoj konkretnoj čitateljici ili većem broju njih iz Petru vrlo bliske plemićke obitelji Drašković. ${ }^{385}$

Zamišljeni generički sustav ozaljskoga književnog kruga uvelike su obogatila i druga sedamnaestostoljetna rukopisna ostvarenja poput proznoga vernakularnog zbornika što je svojedobno pronađen ${ }^{386} \mathrm{u}$ fondu čakovečke knjižnice Petrova brata Nikole Zrinskoga, koji je - po mišljenju mnogih naših književnih povjesnika - i inicirao književnu djelatnost u toj srednjohrvatskoj regiji. U spomenutomu su, naime, zborniku, što ga je dvadesetih godina 17. st. - vjerojatno na zahtjev samoga Nikole - sastavio zapisivač Ivan Derečkaj, svoje mjesto našla tri prozna teksta srednjovjekovna podrijetla, i to prijevod romana o padu Troje (Rumanac trojski), roman o životu Aleksandra Velikog (Aleksandrida) te izvorno orijentalna Pripovijest o premudrom Akiru, svi redom ispisani tronarječnom varijantom hrvatskoga jezika, dakle hibridnim kajkavsko-čakavsko-štokavsko jezičnim tipom na kojemu su svoja ostvarenja pisali te međusobno komunicirali i sami „Ozljani“. Tzv. Derečkajev zbornik iz toga se razloga istovremeno nameće kao svojevrsna literarna riznica - u našem baroku izrazito rijetkih - proznih žanrova (roman, pripovijest), kao uvjerljivo svjedočanstvo preživljavanja i izrazite važnosti srednjovjekovne kulture i književnosti (točnije, predrenesansnih žanrovskih rješenja) i u barokno doba, ali i kao čvrst dokaz postojanja literarnih veza između južne i sjeverne hrvatske književnosti, bitno osnaženih upravo u 17. stoljeću. Zbornik je, kako su pretpostavili pojedini povjesničari hrvatske književnosti, ${ }^{387}$ uz to mogao izvršiti i stanovit većinom tematsko-motivski - utjecaj na pojedine barokne ,zrinijade“, poglavito na one braće Zrinski, ali možda (makar posredno) i na samo Vitezovićevo Odiljenje, što će i naše istraživanje na sljedećim stranicama pokušati donekle potvrditi ili opovrgnuti.

Mjestimična prisutnost značajki srednjovjekovnih književnih, pa i ne samo književnih žanrova u zrinsko-frankopanskome bi se baroknom kulturnom krugu zacijelo mogla doimati pomalo minornom u usporedbi s proširenošću predrenesansnih generičkih obilježja u literarnom stvaralaštvu naše najsjevernije - kajkavske - kulturne regije, u kojoj uvjeti za razvoj renesansne, a onda ni postrenesansne književnosti nisu uopće ni bili stvoreni. Kajkavski se književni krug, koji je uključivao produkciju autora iz Banske Hrvatske ili Kraljevine Hrvatske - dakle, književnost prostora u kojemu se kulturna djelatnost odvijala

\footnotetext{
${ }^{385}$ Detaljnije u: Isto: 212-221.

386 O njegovu pronalasku u svojoj je Povijesti hrvatske književnosti do narodnog preporoda još polovinom prošloga stoljeća izvijestio Mihovil Kombol (usp. Kombol 1961: 210).

${ }^{387}$ Usp. Hercigonja 1975: 381-384.
} 
ponajprije u okrilju dvaju gradskih epicentara: Varaždina i Zagreba ${ }^{388}$ - tako zasnivao na nastavljanju ondje još uvijek izuzetno aktivnih srednjovjekovnih tradicija, očuvanih zahvaljujući neprekidnom snažnom utjecaju Crkve na književnost, te tijesnoj isprepletenosti s vjerskim životom, koji i jest diktirao uporabu ,prikladnih“ žanrovskih obrazaca sasvim usklađenih s kršćanskim svjetonazorom te prilagođenih konkretnim religioznim potrebama. Nastajući u takvome okružju, barokna se kajkavska (pisana) književnost - još od prošloga stoljeća, kada ju je i začeo Antun Vramec - kontinuirano obraćala pretežno slabije obrazovanoj, gdjekad i jedva pismenoj, te uopće literarno nezahtjevnoj publici, trudeći se „privesti“ je kršćanskim idejama, odnosno uputiti u pravovjerni svjetonazor Katoličke crkve, a sve unutar dobro joj poznatih, izrazito tradicionalnih žanrovskih okvira počesto obogaćenih još i (većinom sadržajnim) generičkim značajkama pučke i usmene književnosti. Premda naoko posve nesumjerljivo s književnošću dubrovačko-dalmatinske i ozaljske kulturne regije, za kajkavsko se sedamnaestostoljetno stvaralaštvo - kao takvo - ipak ne može reći da predstavlja apsolutni otklon od baroknih literarnih ,principa“, poglavito ako znamo da je književnost 17. st. - kako je već poodavno dokazano ${ }^{389}$ - iskazivala očitu sklonost spram srednjovjekovnih ideja i literarnih sadržaja, a sve u nakani da revitaliziranjem tradicije izmami pozornost čak i dotad posve zanemarivanih krugova potencijalnih čitatelja.

Ukratko, (pisano)književna ostvarenja koja su u 17. stoljeću nastajala na našem sjeverozapadu sadržajno su i ideološki bila usuglašena s kršćanskim svjetonazorom te generički posredovana srednjovjekovnim „oblicima“, što se - na koncu - najočitije odrazilo i na (zamišljen) žanrovski sustav kajkavskoga književnog kruga, najvećim dijelom sazdanoga upravo od onih žanrova pragmatične namjene koji su predstavljali ogranak „,institucionaliziranih komunikacijskih procesa kojima Crkva komunicira s vjerništvom (katekizam, propovijed, nabožno-moralna literatura) ili se obraća Bogu (crkvena pjesma, molitvenik)“ (Kravar 2010: 114). Generički sistem ove je literarne regije, dakle, obuhvaćao mahom žanrove koji su ispunjavali praktične vjerske funkcije, odnosno bili namijenjeni crkvenom obredu, molitvi ili moralnoj pouci (katehetski tekstovi, vjerski zbornici, stihovane

\footnotetext{
${ }^{388}$ Usp. Rapacka 2005: 363.

389 Snažno i ustrajno nadovezivanje baroka na predrenesansnu, srednjovjekovnu tradiciju višestruko je već potvrđeno u studijama mnogih barokologa (usp. npr. Angyal 1961: 19-79 i 1964: 97-118; Curtius 1998 itd.), slijedom čega ni izrazit srednjovjekovni moment prisutan (i) u kajkavskoj baroknoj književnosti nipošto ne bi trebalo isticati isključivo kao potvrdu njezine posvemašnje zaostalosti. Riječima Zorana Kravara, „miješanje tekovina srednjovjekovne književnosti s postignućima postrenesansnoga vremena, posebno u liku stapanja književnih vrsta srednjovjekovnoga podrijetla s baroknom retorikom, formula je na kojoj se zasniva veliki dio ranonovovjekovne književnosti srednje Europe“, a „ista formula vrijedi, uostalom, i za neka područja starije hrvatske književnosti (za krug oko Petra Zrinskoga, za staru kajkavsku književnost)“ (Kravar 1993: 154-155), ali i za slavonski barok, u kojemu je naročito dominirala pojava Antuna Kanižlića i njegova stvaralaštva (o tome posebno u: Kravar 1991).
} 
narativne alegorije i sl.), ali ne i svjetovne žanrove s možebitnim izrazitijim baroknim obilježjima jer - na kraju krajeva - u tadašnjoj kajkavskoj kulturi nisu još ni bili uspostavljeni „književno-komunikacijski kanali preko kojih bi se građanin obraćao građaninu ili plemić plemiću“ (Kravar 1993: 59). Iz toga su razloga za religioznim, tj. pragmatičkim žanrovima posezali ne samo onodobni pisci iz crkvenih krugova, već i svjetovnjaci poput Matijaša Magdalenića, čiji je zbornik Zvončac (1670.) ustvari kompilacija prepjeva popularnih mađarskih nabožnih pjesama i poema Mátyása Nyékija Vörösa i Jánosa Szentmártonija Bodóa na temu četiriju posljednjih čovjekovih stvari, te Gabrijela Jurjevića, čija je pjesnička zbirka Listi heroov iz 1675. ništa drugo nego prijevod cjelokupne latinske knjige poslanica Heroum epistulae njemačkoga isusovca Jakoba Bidermanna, u kojoj se - među ostalim kršćanskim sadržajima - također pjeva (i) o posljednjim stvarima.

Posvemašnje priklanjanje kajkavskih - crkvenih i svjetovnih - sedamnaestostoljetnih pisaca repertoarima religioznih, vjersko-utilitarnih žanrova pretežno srednjovjekovne provenijencije neće, međutim, ujedno značiti i da su redom sva njihova ostvarenja bila u potpunosti lišena čak i prepoznatljivo baroknoga - ponajprije stilskog - tekstualnog „inventara“. Naprotiv, da su najmoderniji poetički postulati (najčešće nesvjesno) prihvaćani čak i u najnerazvijenijemu našem baroknom književnom krugu posvjedočiti nam mogu brojne figurama (pre)opterećene dionice, primjerice, Habdelićevih, Belostenčevih i Zagrepčevih propovijedi, pjesama iz Magdalenićeva Zvončaca, kao i onih iz korpusa religioznoga pjesništva okupljenog u onodobnim anonimnim pjesmaricama i zbirkama crkvene poezije, $u$ koje je barokni stil „presađen“ najvjerojatnije zahvaljujući ugledanju u mađarsko, njemačko i novolatinsko sedamnaestostoljetno pjesništvo. ${ }^{390} \mathrm{Ne}$ samo u rukopisne (Pavlinski zbornik) i tiskane (Cithara octochorda, 1701.) anonimne zbirke crkvenih lirskih pjesama, već i u nepotpisane rukopisne pjesmarice, koje su uz pretežno nabožne pjesničke uratke pokatkad sadržavale i poneki svjetovni (Prekomurska, Bedekovićeva, Fodroczyjeva, Ščrbačićeva ili Drnjanska pjesmarica), uvrštavana su možda i stilski najbaroknija kajkavska literarna ostvarenja, što je i razumljivo s obzirom na to da su njihovi tvorci redom pripadali krugu vrlo dobro obrazovanih pojedinaca, a u pojedinim slučajevima čak i onom aristokracije. ${ }^{391}$

\footnotetext{
${ }^{390}$ Više o tome u: Kravar 1993: 57-62 i 2010: 114. Osobito je velik broj liturgijskih pjesama te nabožnih proznih tekstova s izrazitim baroknim stilskim značajkama ispisan u austrijsko-njemačkoj književnosti 17. stoljeća, a znamo li se da su se sjeverni naši autori kontinuirano oslanjali na različite - naročito njemačke srednjoeuropske uzore, $\mathrm{u}$ tom nam smislu ni prisutnost naglašene figuralnosti u njihovim djelima predrenesansne generičke provenijencije nipošto neće djelovati kao krupnije iznenađenje. $\mathrm{O}$ srednjovjekovnim i srednjoeuropskim obilježjima hrvatske kajkavske književnosti 17. stoljeća detaljno u: Kravar 1991: 245-298.

${ }^{391}$ Konkretno, žanr anonimnih pjesmarica ili - s obzirom na premreženost nekih od njih čak i epskopjesničkim tekstovima - kajkavskih pjesničkih zbornika obuhvaćao je tako većinom rukopisne (samo iznimno i tiskane) kompilacije ponajprije nabožnih pjesama sastavljane u rasponu od 16. do 18. st., koje su kroz dulje -
} 
Provizorni sustav žanrova kajkavske sedamnaestostoljetne književnosti zaokruživali su - doduše, pretežno nekajkavski - tekstovi s dramskim generičkim obilježjima, proizišli iz kontinuirane kazališne djelatnosti koju su u (naj)većim sjevernohrvatskim gradovima inicirali i održavali pripadnici reda Isusovaca. Riječ je, dakako, o žanru baroknih isusovačkih drama, što su ih - kao nužnu komponentu svoga školovanja - javno izvodili polaznici jezuitskih škola, i to kako onih u Zagrebu (gdje su uprizorivane mahom na Markovu i Kaptolskom trgu), tako i onih u Varaždinu, ali i Požegi, obično četiri, ali pokatkad i više puta godišnje, najčešće oko blagdana Tijelova. Pisali su se ti dramski tekstovi i izvodili većinom na latinskom jeziku, a samo zgodimice sastavljani su i oni na hrvatskom, pa čak i na „mješovitom“ jeziku (u kojima se latinski preplitao s hrvatskim), pri čemu se - u sadržajnom pogledu - ponajprije radilo o biblijskim, mitološkim, alegorijskim, prigodnim i povijesnim dramama, među kojima su ipak prednjačile one inspirirane sadržajima iz Biblije (većinom Starozavjetnim motivima) te one koje su tematizirale događaje i junake iz antičke (starogrčke i starorimske) i hrvatske povijesti (naročito Nikolu i Jurja Zrinskoga, Ivana Draškovića, Tomu Erdödyja itd.). Njihovi su nam autori, nažalost, ostali nepoznati, no i usprkos tomu se s prilično velikom sigurnošću može pretpostaviti kako je najveći broj njih ipak proizišao iz pera inozemnih pisaca, a za samo gdjekoju „odgovorni“ su domaći autori, i to najvjerojatnije sami zagrebački Isusovci. ${ }^{392}$

višedesetljetno, a katkad čak i višestoljetno - vremensko razdoblje, kružeći od ruke do ruke među (visoko)obrazovanim pojedincima (građanima, plemićima, pučkim pjesnicima), neprekidno mijenjale svoje vlasnike, od kojih bi svaki ili gotovo svaki u njih anonimno dopisao izvorne i/ili prevedene stihovane sastavke. Fluktuirale su one, drugim riječima, kako u urbanim sredinama, tako i u plemićkim dvorcima, kurijama, pa čak i u župnim dvorovima, a s obzirom na to da u ranonovovjekovno doba nabožnoj poeziji na našem sjeveru - osim u usmenoknjiževnoj sferi, iz koje su i mnogi pjesmarički tekstovi crpili prepoznatljive značajke - nije konkurirala ona svjetovna, privremeni su njihovi vlasnici i (su)autori mahom u njih upisivali pjesme nabožne tematike, nerijetko stilski posve usklađene s baroknopoetičkim imperativima. U nekima su se, ipak, od njih - vjerojatno više slučajem nego ciljano - zatekli čak i „punokrvno“ svjetovni pjesnički tekstovi, što je rezultiralo i obogaćivanjem njihove pretežno jednolične žanrovske „slike“, koju su - pored (očekivano) dominantne religiozne lirike - tako sačinjavale i ljubavne lirske pjesme, povijesno-političko epsko pjesništvo, satiričke pjesme, pa čak i (izvorno usmene) napitnice, a sve redom protkane izrazitim folklornoknjiževnim značajkama (formulaičnim izrazima, prepoznatljivim motivima, narativnošću, tipom stiha, karakterističnim figurama, pjevnošću itd.). Osim ove paralelne zastupljenosti svjetovnog i religioznog pjesništva u nekima od njih, kao i supostavljanja lirskopjesničkih i (daleko malobrojnijih) epskopjesničkih sastavaka, dojam heterogenosti kajkavskih pjesmarica pritom je dodatno osnaživala još i činjenica da su mnoge u njih uvrštene pjesme bile tek prijepisi iz drugih sličnih kompilacija, kao i ona da znatan dio religiozne lirike otpada na prepjeve iz latinskih predložaka. Dodamo li tomu i da su u mnogima od njih uz bok pjesmama namijenjenim isključivo čitanju egzistirale $\mathrm{i}$ one (prvotno) namijenjene pjevanju ili recitiranju uz glazbenu pratnju, jasno je da se sjevernohrvatske pjesmarice $\mathrm{s}$ punim pravom mogu označiti kao vrlo šarolike zbirke generički različitih pjesničkih - najvećim dijelom pučkoknjiževnih - tekstova nejednakoga porijekla, starosti i uopće stupnja originalnosti, čija se heterogenost ponajviše očituje na formalnom i stilskom, a rjeđe (i) sadržajnom planu. Podrobno o ranonovovjekovnim kajkavskim pjesmaricama u: Šojat 1977a: 181-192, Bogišić 1993: 77-91 i Frndić 1993: 92-105. Dodajmo da je upisivanje pučkih, a ponekad i izvorno usmenoknjiževnih pjesama u rukopisne pjesničke kompilacije koje su cirkulirale u aristokratskim krugovima zapravo praksa koja je u ranome novovjekovlju zabilježena i u mnogim drugim europskim kulturama. Usp. o tome u: Burke 1991: 24-25

392 Detaljno o baroknim isusovačkim dramama u: Vanino 1969: 261-288, Batušić 1978: 144-147 i Bartolić 1985: 89-94. Isusovačke su se tragedije, uzgred budi rečeno, pisale (doduše, najččšce prevodile) i u dubrovačkodalmatinskoj književnosti 17. stoljeća, a od njih su nam poznate Krisp Cezar Mihe Gradića, Suevija Junija 
Najveće zasluge za „uspostavu“ baroka u književnosti posljednje i daleko najzaostalije - slavonske - ranonovovjekovne kulturne regije također pripadaju pojedincima iz isusovačkoga Crkvenog reda. Nakon njezina definitivnog oslobođenja od Osmanlija koncem 17. stoljeća, do vrlo sporoga će buđenja (pisano)književnog stvaralaštva u Slavoniji doći tek u narednom - „prosvjetiteljskom“ - stoljeću, što nipošto neće značiti da je taj kulturni krug svoju priliku za „prikapčanje“ na barok odavna već prespavao. Naprotiv, zahvaljujući ponajprije pojavi požeškoga Isusovca Antuna Kanižlića, slavonska će kultura i duboko u 18 . stoljeću dobiti priliku osjetiti „dašak“ barokne literarne mode, na koju će se poslije njega stići nadovezati jedva još dvojica njegovih djelomičnih nastavljača - Antun Ivanošić te Joso Krmpotić - i to samo u ponekim svojim ostvarenjima. Pišući prepoznatljivom ikavskom štokavštinom, Antun je Kanižlić u svome opusu tako iskušao obje u nas iskristalizirane varijante književnoga baroka - onu svjetovnu ili barem pretežno svjetovnu (u religioznoj poemi Sveta Rožalija) te onu praktično-vjersku ili crkvenu (u nizu liturgijskih žanrova stihovanim molitvama, crkvenoj lirici i nabožnoj prozi) - i to u vrijeme kada diljem Slavonije već nastaju prva ostvarenja s prosvjetiteljskim tendencijama, ali i s (formalnom i sadržajnom) podlogom u folklornome i pučkoknjiževnom stvaralaštvu. Da je Kanižlićeva Rožalija s tom tradicijom imala malo toga zajedničkog, sugeriraju nam i više nego očite tematske, formalne $^{393}$ i kompozicijske značajke baštinjene iz repertoara (dubrovačko-dalmatinske) barokne religiozne poeme, kao i pojedini sadržajni momenti preuzeti najvjerojatnije iz lirike njemačkih baroknih pjesnika (Spee, Brockes), dok pretežno stilski otklon od prosvjetiteljskih ostvarenja Kanižlić ostvaruje u nabožnim lirskim pjesmama umetnutima u prozne tekstove liturgijske namjene što ih donosi u svojim molitvenicima, u kojima - pored tipično baroknih motiva prolaznosti i mističkoga sjedinjenja s Bogom - susrećemo mjestimice i vrlo razigranu figuraciju koja neodoljivo podsjeća na onu iz Đurđevićevih Uzdaha Mandalijene pokornice te - nešto manje - Saltijera slovinskog. Bez obzira na počesto zavirivanje u njegov opus, barok u ostvarenjima Antuna Ivanošića i Jose Krmpotića ipak nije (više) dospio ostaviti toliko dubok trag, slijedom čega bismo za stanovite ideološke (baroknoslavističke), formalne i retoričke naznake uvažavanja barokne poetike u pojedinim njihovim prigodnicama i epskim

Palmotića, Leon filozof Ivana Gučetića, Sveta Venefrida Bartola Kašića te Justina mučenica Vladislava Menčetića. Međutim, za razliku od kajkavske onodobne sredine, ,isusovačka obrazovno-pedagoška djelatnost u dubrovačkoj kulturi nije bila institucionalno prihvaćena“" (Rafolt 2016: 390), što znači da se isusovačke tragedije ondje nisu izvodile u sklopu isusovačkih kolegija. Opširnije o ovom - tek nedavno detaljnije istraženom pitanju u: Isto: 377-392.

${ }^{393}$ Rabi on ondje metričko rješenje dubrovačkoga porijekla, i to dvostruko rimovani dvanaesterac južnoga tipa, dok, pak, u njegovoj liturgijskoj lirici zatječemo čak i - južnohrvatskom baroku svojstvenu - osmeračku sestinu. 
pjesmama $^{394}$ mogli konstatirati kako ,imamo posla prije s uspomenama na barok nego s barokom samim“ (Kravar 1993: 160). ${ }^{395}$

Usprkos nepobitnoj činjenici kako su izrazito snažne i, s literarnog gledišta, neobično plodonosne veze s našim najrazvijenijim - dubrovačko-dalmatinskim - baroknim književnim krugom njegovali i onodobni franjevački pisci u osmanlijskoj Bosni (Divković, Posilović, Margitić, Lastrić i dr.), kao i hrvatski autori što su djelovali na području mletačke Boke Kotorske (Bolica, Nenadić, Zmajević, Zanović itd.), ${ }^{396}$ ove bi susjedne (izvanhrvatske) barokne književne sredine, a onda i možebitne podudarnosti njihovih provizornih generičkih sustava s onima četiriju domaćih sedamnaestostoljetnih (pa i, dijelom, osamnaestostoljetnih) literarnih i uopće kulturnih krugova - zbog činjenice da izlaze izvan njegovih okvira - u ovome istraživanju ipak valjalo ostaviti po strani. Slijedom toga, naš bi istraživački fokus pao na isključivo žanrovske opcije s kojima se „svehrvatski“ pisac poput Pavla Rittera Vitezovića prije 1684. mogao susresti iščitavajući književna ili pretežno književna ostvarenja iz četiriju (točnije - zbog priličnoga kašnjenja slavonskog baroka - triju) tadašnjih hrvatskih političkih i kulturnih regija, čiji su se netom rekonstruirani generički sistemi po svojim sastavima $u$ velikoj mjeri poklapali (i) s onima većih i utjecajnijih europskih nacionalnih književnosti, iz kojih su kontinuirano primali konkretne književne (pa onda i žanrovske) impulse. Ipak, kako s pravom često ističu naši barokolozi, „u ukupnosti svojih regionalnih varijanata hrvatski književni barok (...) istodobno je i kontinuirana i diskontinuirana pojava“ (Kravar 2010: 114), pa iako su barokne značajke - najočitije u obliku prepoznatljivih figuralnih pretjerivanja prožele makar pokoje djelo u svakome od četiriju literarnih krugova, u različitim su se sredinama one ipak bitno drugačije manifestirale, a uz to su još i imale nejednak status, obnašale različite funkcije, ulazile u žanrovske okvire nejednake književnopovijesne starosti te su uopće poprilično različito bile percipirane. Ipak, bez obzira na to što su ta barokna obilježja u južnoj našoj književnosti u 17. stoljeću označavala oštru granicu među različitim generacijama autora, u onoj sjevernoj funkcionirala kao ornament tekstova napučenih osobinama predrenesansnih žanrovskih rješenja, a u onoj se, pak, slavonskoj pojavila većinom slučajno, u ne tako malom su broju slučajeva ona postajala dijelom istih ili gotovo istih književnih, pa i ne samo književnih žanrova, nametnuvši se tako kao svojevrsni putokazi za prepoznavanje dosad često previđanih paralela između generičkih sustava naših regionalno razdijeljenih baroknih kulturnih krugova.

\footnotetext{
394 Primjerice, u Ivanošićevoj alegorijskoj prigodnici Opisivanje sličnorično groba Jozipa Čolnića te Krmpotićevu povijesnom epu ili epskoj kronici Katarine II. $i$ Jose II. put u Krim.

395 Znatno detaljnije o slavonskoj inačici književnoga baroka u: Kravar 1993: 63-66 i naročito 126-160.

${ }^{396}$ O ovim inozemnih baroknim krugovima hrvatskih autora u: Dukić 2003: 492-493 i Rapacka 2005: 362-363.
} 
Ta ne odveć brojna ni inovativna, no ipak nipošto zanemariva žanrovska rješenja što su našla svoje mjesto u generičkim sustavima svih četiriju hrvatskih baroknih kultura (nabožna lirska pjesma, molitva, poslanica, prigodnica itd.) mogla bi se stoga izdvojiti kao jedna od nepobitnih potvrda kontinuiteta i cjelovitosti regionaliziranoga hrvatskog književnog baroka, iako je pritom gotovo nemoguće sa sigurnošću (u)tvrditi jesu li se i kojih to konkretno žanrova pojedini pisci laćali samo zato što su ih uočili u djelima autora iz drugih sedamnaestostoljetnih domaćih sredina. Ipak, među četirima našim baroknim literarnim krugovima kroz čitavo je 17., pa i velik dio 18. stoljeća (obostrana) komunikacija ipak postojala, što ponajbolje dokazuju kako intenzivne veze između dubrovačke i dalmatinske barokne književnosti (potvrđene ugledanjima mnogih dalmatinskih pisaca u one dubrovačke), tako i one između dubrovačko-dalmatinskoga i ozaljskog (povijesnih epova braće Zrinski ne bi bilo bez obilna oslanjanja na Karnarutićevo Vazetje Sigeta grada, kao ni Menčetićeve Trublje slovinske bez Petrove Sirene) te slavonskog i dubrovačko-dalmatinskog kruga (Kanižlićevo osamnaestostoljetno nastavljanje tradicije dubrovačkih religioznih poema). Osim što je, k tome, i jak utjecaj na slavonski barok izvršila kajkavska književnost 17. stoljeća, ${ }^{397}$ i književno je i uopće kulturno djelovanje samoga Petra Zrinskog u velikoj mjeri bilo obilježeno čvrstim prijateljskim i kulturnim vezama što ih je održavao s pojedincima iz Boke Kotorske, Dubrovnika te drugih južnohrvatskih sredina, ${ }^{398}$ a ne zaboravimo i da su njemu i bratu mu Nikoli, ali i slavnim njihovim precima mnogi pisci iz primorskih krajeva između ostalih, i sam Barne Karnarutić svoje Vazetje - s neprikrivenim oduševljenjem i zahvalnošću posvećivali svoja netom napisana književna djela. ${ }^{399}$ Govoreći, dakle, o heterogenosti, odnosno regionalnosti hrvatskoga književnog baroka, ni u jednome trenutku s uma ne bismo smjeli smetnuti da pretpostavljene granice između tadašnjih književnih krugova

\footnotetext{
${ }^{397}$ Antun Kanižlić i Antun Ivanošić školovali su se, naime, upravo u kajkavskom Zagrebu, u kojemu će ovaj potonji kasnije i tiskati svoje pjesme, dok će Kanižlić najprije ondje, a potom i u Varaždinu, nastaviti raditi kao učitelj. Obojicu se - iako mnogo više, dakako, Kanižlića - susret s kajkavskom religioznom književnošću očigledno vrlo snažno dojmio, zbog čega će i njihova ostvarenja - naročito Kanižlićeve liturgijske lirske pjesme, alegorijsko pjesništvo i moralno-didaktična proza - pokazivati izrazitu stilsku (retoričku) i generičku bliskost sjevernohrvatskome baroknom stvaralaštvu. Detaljnije o paralelama između kajkavskoga i slavonskog književnog kruga u: Kravar 1993: 126-160.

${ }^{398}$ Naime, kako otkriva Rafo Bogišić, Petar je iznimno često putovao u Boku Kotorsku, održavao diplomatske, prijateljske i kulturne veze s Dubrovnikom, a uz to je još i vrlo snažno bio povezan s trogirskim povjesničarom Ivanom Lučićem, „čije veze s hrvatskim kulturnim djelatnicima i književnicima hrvatskog sjevera i juga jasno svjedoče o jedinstvenoj duhovnoj organskoj povezanosti raznih hrvatskih krajeva“" (Bogišić 2007: 207-208).

399 Karnarutić je, konkretno, prvo izdanje Vazetja Sigeta grada posvetio Petrovu i Nikolinu djedu Jurju Zrinskome - sinu slavnoga sigetskog kapetana Nikole Šubića - a potom je isto učinio i Dominko Zlatarić sa svojom prevedenom Elektrom 1597. Potonjem je - s petogodišnjim zakašnjenjem - latinskim pismom datiranim na 26. kolovoza 1602. Juraj Zrinski osobno zahvalio na posveti zamolivši ga pritom i da mu, ukoliko je u međuvremenu sastavio kakve nove pjesničke uratke, iste što prije pošalje. Tri će, pak, desetljeća nakon Zlatarića Zrinskima, i to upravo Petru i bratu mu Nikoli, koji su tada još bili djeca (Nikoli je, naime, bilo tada osam, a Petru sedam godina), svoje nabožno-didaktičko djelo Četiri poslidnja človika (1628.) posvetiti i istarski pisac Franjo Glavinić. Opširnije u: Bogišić 2007: 208-211.
} 
nisu bile toliko nepropusne da (poneki) pisci - bez obzira na to kojemu od njih pripadali - ne bi bili u mogućnosti stupiti u kontakt s autorima iz drugih sredina $\mathrm{i}$ upoznati se s njihovom stvaralačkom produkcijom, pa čak i - poput samoga Vitezovića - pokušati prijeći granice „Svoje“ kulture u potrazi za što je moguće većim brojem potencijalnih čitatelja. ${ }^{400}$

Nepremostivim regionalno-kulturnim razlikama usprkos, stanovite podudarnosti u zamišljenim žanrovskim sustavima četiriju baroknih književnih krugova, ali i netom utvrđeno postojanje vrlo žive međuregionalne kulturne komunikacije lako bi nas mogli navesti na to da pokušamo zamisliti opći, svevažeći generički sistem hrvatske barokne književnosti kao logičnu i stvarnu, dakle književnopovijesnu pojavu koju su sačinjavale apsolutno sve do sada locirane, regionalne žanrovske opcije. Bez obzira na to što bi rezultat takvoga pokušaja, kao što je maločas upozoreno, bio ništa drugo no tek puki teorijski konstrukt - jer, na kraju krajeva, ni pojedinačni žanrovi nisu u svakome krugu gradili čvrst generički sustav s kojim su računali baš svi tamošnji autori i čitatelji - važno je znati da su neki sedamnaestostoljetni pisci - poput, primjerice, samoga Vitezovića - itekako dobro bili upoznati s punom raznovrsnošću u nas dostupnih, regionalnih žanrovskih varijanata, što im je i omogućilo da po volji evociraju obilježja mnogih od njih ne bi li na taj način sastavili tekstove kojima će moći doprijeti do čitatelja iz različitih sredina. Pored (ne tako brojnih) literata koji su, ispisujući takva ostvarenja, zapravo vršili prijenos konkretnih žanrova iz jednog u drugi krug, zamišljene generičke sisteme svih četiriju hrvatskih baroknih kultura ujedno je zbližavala $\mathrm{i}$ zastupljenost (ne uvijek identičnih) žanrova iz generičkih paleta stanovitih književnih i ne samo književnih sfera, i to kako onih (novo)latinske, usmene i pučke književnosti, tako i onih iz domene didaktično-pedagoškoga te već spomenutoga crkvenog stvaralaštva.

Posebno su tako važno mjesto u ,teorijskom“ žanrovskom sustavu hrvatske barokne književnosti imali i različiti žanrovi (novo)latinske, odnosno književnosti realizirane latinskim jezikom, kojoj su cijelošću ili velikim dijelom svojih stvaralačkih opusa pripadali i mnogi onodobni naši autori. Svoju izrazitu sedamnaestostoljetnu proširenost (novo)latinska bi književnost (i) u nas mogla zahvaliti poglavito isusovačkom utjecaju, odnosno činjenici da je upravo početkom stoljeća prihvaćen nastavni program Ratio et institutio studiorum Societas Iesu, temeljem kojega su Jezuiti diljem tadašnje Hrvatske otvarali srednje škole i više studije, u kojima se latinski prometnuo ne samo u ključni nastavni predmet, već ujedno i u osnovni nastavni jezik uopće. ${ }^{401} \mathrm{~S}$ obzirom na to da je isusovački školski program pretpostavljao

\footnotetext{
$400 \mathrm{O}$ (propusnoj) granici između naše sjeverne i južne ranonovovjekovne književnosti te konstantnim i raznolikim nastojanjima naših autora (između ostalih, i onima Pavla Rittera Vitezovića) da je prijeđu detaljnije u: Pavličić 2007: 7-19.

${ }^{401}$ Podrobnije o programu Ratio et institutio studiorum, objavljenome 1599., u: Macan 2016: 429-440.
} 
izvrsno poznavanje antičke - pretežno latinske, a onda i grčke - književnosti, čije su literarne obrasce i sami učenici morali slijediti pri sastavljanju svojih školskih književnih pokušaja, neće biti nimalo neobično to što se ,i u hrvatskome latinističkom seicentu mnogi (...) popularni književni oblici najlakše mogu razumjeti kao reminiscencije iz isusovačkih đačkih klupa: primjerice, brojne parafraze iz profanih ili sakralnih tekstova nadahnute su školskom praksom u kojoj se razumijevanje izvornoga teksta provjeravalo tako što ga je učenik morao prepričati na latinskome“", a ,istoga su podrijetla i raznoliki oblici prigodnoga pjesništva (...) ili njihovi prozni parnjaci, koji su nastajali u povodu različitih važnih datuma školska godine, crkvenih ili svjetovnih svečanosti“ (Novaković 2003: 553). Upravo zahvaljujući svome školovanju u (zagrebačkoj) isusovačkoj gimnaziji, u sklopu kojega je postulate antičke poetike usvojio teorijski i praktično, i Pavao Ritter Vitezović dospio se potvrditi kao jedan od onih naših pisaca u čijim se - poglavito latinskim - djelima zapaža ,,versifikacijska okretnost dobrog đaka latinske škole“ (Kombol 1961: 281), odnosno vrlo uspješno - a uglavnom posve intuitivno - vladanje formalnim, stilskim, sadržajnim i uopće žanrovskim mehanizmima starorimske i starogrčke književnosti.

Unatoč posebnom statusu, pa i - moglo bi se reći - dignitetu što ga je u nas još i u barokno doba uživala (novo)latinska književnost, ne treba zaboraviti da je upravo u 17 . stoljeću latinski jezik „u knjižnoj porabi ustuknuo pred hrvatskim, iako je nastavio služiti kao pouzdana komunikacijska spojnica između dijalektalno, geografski i politički razdvojenih hrvatskih krajeva“ (Isto: 553). Hrvatska književnost, međutim, po tom pitanju nipošto nije predstavljala izuzetak, jer i u većini drugih (zapadno)europskih književnosti baš u razdoblju baroka latinski „,gubi status jezika nepobjedivih estetskih i izražajnih kvaliteta“, i to ponajprije stoga što su se „narodni jezici u međuvremenu (...) formirali kao jezici fleksibilnijih izražajnih mogućnosti i kao književni mediji otvoreniji novim poetikama“" (Stepanić 2010: 68). Usprkos postupnom opadanju njezine važnosti, (novo)latinska se književnost - svjetovna i nabožna (još) i kroz čitavo 17. stoljeće nastavila ostvarivati u doista širokom rasponu žanrovskih varijanata, koji je obuhvaćao epsku pjesmu, heksametarsku carmen (religioznu i svjetovnu), heksametarsku prigodnicu, tužaljku, poslanicu, ljubavnu i religioznu elegiju, svjetovnu i nabožnu lirsku pjesmu, eklogu, idilu, fasti (pjesnički kalendar), epitalamij, metamorfozu, anagram i emblem, dok su od formalnih eksperimenata naše onodobne latiniste ponajviše, između ostalih, privlačili rebus, kronogram, abecedna pjesma te jeka ili tzv. versus echoici. ${ }^{402}$ Iako je - po pitanju čistoće žanrova - novolatinska barokna književnost bila znatno

${ }^{402}$ Opširnije u: Stepanić 2005. Dodajmo i da se - pored ovih književnih, pjesničkih žanrova - u 17. stoljeću na latinskom u nas obilato pisala i historiografska proza (s naglašenim domoljubnim momentom), govornička proza te filološke rasprave. 
konzervativnija od one vernakularne, iziskujući ,poslušno“ pridržavanje antičkih pravila koja su za svaki žanr ponaosob propisivala prikladnu temu, tip stiha te stilsku razinu, pojava pobrojanih formalnih eksperimenata u čitavom nizu žanrova, izrazitih figuralnih pretjerivanja (gomilanja jakih i inovativnih metafora, paradoksa, antiteza, etimoloških figura itd.), ali i prvih pokušaja hibridizacije pojedinih generičkih rješenja (kakvima je, između ostalih, bio sklon i sam Vitezović) nepogrešivo je - kako se čini - trebala upućivati na „kontaminiranost““ naše književne latinštine baroknom poetikom, koja i jest autore ohrabrivala na zaobilaženje mnogih žanrovskih normi, a katkada i na potpuno nadilaženje utvrđenih generičkih barijera. ${ }^{403}$

$\mathrm{S}$ jednim od (naoko) tipično baroknih hibridnih žanrovskih rješenja susrest ćemo se i u slučaju didaktičko-pedagoških literariziranih ostvarenja na latinskom jeziku namijenjenih ponajprije podučavanju u sklopu isusovačkih škola, čijem su objelodanjivanju redovito prethodila odobrenja poprilično neumoljivih crkvenih cenzora. Možda i ponajbolji (a ujedno i, do danas, najproučeniji) naš predstavnik toga poluknjiževnog latinskog žanra danje je svjetlo ugledao u okrilju kajkavske barokne kulture - 1705. u Zagrebu - pod naslovom Ideae magnanimitatis Illyricae et Pannonicae (Ideje ilirske i panonske velikodušnosti), a riječ je o zborniku, odnosno svojevrsnome moralističkom priručniku sjevernohrvatskoga pjesnika Ivana Franje Čikulina, u kojem se u nizu heksametarskih epilija, poslanica i nadgrobnica opjevavaju herojske vrline raznih hrvatskih (,,ilirskih“) i ugarskih (,panonskih“) vojskovođa iz bliže ili dalje povijesti, redom izginulih u protuturskim okršajima. Čikulinovo je, ukratko, djelo - a tako je bilo i u ostalim moralističkim tekstovima iz ovoga žanrovskog ,razreda“ - obrađivalo patriotsku tematiku kojom se, podsjećanjem na junaštva prethodnih generacija, pokušavalo osigurati nacionalno pamćenje te tako izgraditi nacionalni identitet, a ujedno i živopisnim literarnim evociranjem „ključnih“ figura i događaja iz domaće povijesti ponuditi najuvjerljiviji moralni obrazac mladim polaznicima isusovačkih škola. ${ }^{404}$

Kada bi se, kojim slučajem, iz zamišljenoga općeg generičkog sustava hrvatskoga književnog baroka izuzeli ne samo potonji didaktičko-moralistički, nego i svi (pre)ostali žanrovi onodobne (novo)latinske književnosti, velik bi dio njih - doduše, u ponešto modificiranom obliku - u njemu ipak zadržao svoje mjesto, no odsad kao isključivo dio generičke palete vernakularne, odnosno književnosti na narodnom jeziku. Popriličan, naime, broj žanrovskih varijanata u kojima su se tijekom 17. stoljeća - pa i kasnije - u nas realizirala djela na hrvatskom jeziku otpadao je zapravo na tek puke preoblike žanrova (novo)latinske dakle, originalno antičke - književnosti, pri čemu se samo dijelom radilo o rješenjima

\footnotetext{
${ }^{403}$ O „,barokizaciji“ novolatinske književnosti detaljno u: Stepanić 2005: 120-197.

${ }^{404}$ Detaljnije o navedenome Čikulinovu djelu i žanru baroknih didaktično-pedagoških priručnika u: Blažević 2007: 249-264.
} 
baštinjenima iz renesansnoga generičkog sustava, u kojemu su važnu ulogu igrali upravo žanrovi „skrojeni“ prema izvorno antičkim generičkim modelima. U barokno je doba, vrijedi pripomenuti, zabilježen i dijametralno suprotan proces - točnije, pojava prodora pojedinih žanrova (ili konkretnih obilježja iz njihovih repertoara) narodne književnosti u generički sistem one (novo)latinske ${ }^{405}$ - koji pokazuje da su žanrovske razmjene između dviju literarnih sfera bile tada obostrane, ${ }^{406}$ no u onovremenoj književnosti - kako u nas, tako i diljem Europe - daleko su veći značaj imali upravo „vernakularizirani“ (novo)latinski žanrovi poput epitafa, prigodnice, poslanice, elegije, anagrama itd. Taj je njihov značaj, konkretno, proizlazio ne samo iz maločas spomenute činjenice da je upravo u 17. stoljeću došlo do nagloga porasta ugleda književnoga stvaralaštva na narodnom jeziku, već ujedno i iz činjenice da je redom bila riječ o žanrovskim rješenjima u sastavljanju kojih su se - kako naši, tako i mnogi inozemni - pisci još u svojoj mladosti izvještili ponajprije zahvaljujući nebrojenim školskim literarnim vježbama. Uvidjevši na primjeru renesansne književnosti da većina njih izvrsno funkcionira i u okrilju vernakularnoga literarnog stvaralaštva, barokni su autori, potaknuti tim iskustvom i stečenim znanjima, te autohtono antičke žanrove - ponešto ih ipak ,prekrojivši“ kako bi pristajali novome okružju - naprosto prenijeli u sferu književnosti na narodnom jeziku, pri čemu je mnogima od njih bitno pomoglo i to što su u identičnim žanrovskim „kalupima“ - baš poput Vitezovića - paralelno sastavljali i pojedina svoja djela na latinskom jeziku. Budući da je (novo)latinska književnost na taj način zapravo poslužila kao temelj na kojemu se - u nas i u većini drugih europskih kultura - uvelike razvilo i vernakularno barokno stvaralaštvo, posve je jasno da vrlo bogatu paletu njezinih žanrova nipošto ne smijemo mimoići želimo li proniknuti (i) u porijeklo mnogih tada omiljenih generičkih rješenja literature na hrvatskom jeziku, odnosno namjeravamo li pretpostavljeni opći generički sustav hrvatskoga baroka spoznati u punome njegovu (teorijskom) opsegu.

Ako je, dakle, kao neizostavan dio provizornoga žanrovskog sistema barokne nam književnosti nužno prihvatiti generičke varijante novolatinskoga stvaralaštva, onda bi isto valjalo učiniti i s vrlo šarolikom „lepezom“ žanrova usmene ili folklorne književnosti, čija su mnoga obilježja prodrla u gotovo sve pisanoknjiževne (vernakularne) žanrove iz svih četiriju

\footnotetext{
405 O navedenoj pojavi opširnije u: Stepanić 2005.

406 Osim toga, baš kao što su pojedini sedamnaestostoljetni novolatinski tekstovi upili brojna stilska obilježja barokne vernakularne književnosti (usp. Stepanić 2010: 60-75), tako su i mnoga djela na narodnom - hrvatskom - jeziku nasljedovala neke stilske, točnije figuralne (retoričke) postupke - tj. ukrase - antičke provenijencije. Izvrstan primjer potonje pojave zatječemo i u Odiljenju sigetskom, u kojemu Vitezović čitav treći „dil““ - pjesmu Putnik $i$ jeka - gradi na figuri jeke, odnosno formalnome eksperimentu koji se sastoji od toga da se na kraju svakoga drugog stiha ponavlja završni dvoslog prethodnoga stihovnog retka. Riječ je, dakako, o vrlo uspješnome Ritterovu pokušaju da u pjesmi ispjevanoj narodnim jezikom ostvari one iste efekte kakve su postizali i latinski tzv. versus echoici (usp. Novaković 2003: 560), u sastavljanju kojih se i sam u nekoliko ranijih navrata okušao.
} 
onodobnih naših književno-kulturnih krugova. S obzirom na to da je riječ o generičkim rješenjima iz literarne sfere čiji produkti ne podliježu poetičkim mijenama kao oni pisane književnosti, posve je jasno da ne možemo govoriti o „baroknim“ usmenoknjiževnim žanrovima, a kamoli o „baroknome“ generičkom (pod)sustavu folklorne književnosti kojega su - možebitno - oni sačinjavali, no to nas ipak ne sprječava u tome da pokušamo rekonstruirati svojevrsni „sklop“ ili kombinaciju usmenoknjiževnih žanrova koji su bili u opticaju u razdoblju u kojemu su u sferi pisane književnosti dominirale barokne silnice.

$\mathrm{Na}$ (pogubnu) sveprisutnost folklornoknjiževnih tvorevina - kojoj je najviše pogodovala izuzetno skromna opismenjenost sedamnaestostoljetnoga hrvatskog društva otvoreno će tako u predgovorima vlastitih djela upozoravati pojedini barokni pisci poput Gabrijela Jurjevića $^{407}$ i napose Nikole Krajačevića Sartoriusa, koji se u paratekstualnim odsječcima svojih nabožnih zbornika Molitvene knjižice (1640.) i Sveti evangeliomi (1651.) oštro okomljuje na „pogane“ folklorne (lirske) popijevke što ih narod običava pjevati u različitim prigodama inzistirajući da se na njihove melodije odsad izvode ondje donesene pobožne pjesme, koje su mnogo prikladnije kao pratitelji najrazličitijih svakodnevnih aktivnosti. ${ }^{408}$ Izuzev tih, u narodu očito silno popularnih - mahom ljubavnih - lirskih pjesama s ,nekršćanskim“ motivima, područje usmene je književnosti (i) u 17. stoljeću uključivalo čitav niz različitih žanrovskih varijanata o kojima više nego uvjerljive dokaze možemo naći zavirimo li - između ostalih - i u opus Pavla Rittera Vitezovića, koji s punim pravom slovi za jednoga od najranijih folklorista u povijesti naše književnosti. Već u svome maločas spomenutom prvome tiskom objelodanjenom tekstu - povijesnoj raspravi Apographum ex Joanne Lucio (1681.) - Ritter tako doslovno citira prva četiri stiha usmene epske pjesme o banu Ivanu Karloviću, navodeći pritom kako se o njemu „najčešće pjeva u domovinskim pjesmama i popijevkama u kolu“ (Bošković-Stulli 1978: 208), odnosno u lirskim i epskim „narodnim“ pjesmama, dok se - pak - na drugome mjestu osvrće na tradiciju pjevanja (djevojačkih) lirskih popijevki u povodu svetkovine Ivanja, iz kojih - iznova - kao primjer

${ }^{407}$ Svjestan njihove iznimne raširenosti i omiljenosti, Gabrijel će Jurjević u predgovoru već spomenute zbirke heroida Listi heroov (1675.) tako navesti naslove nekolicine izvorno usmenoknjiževnih pjesama na čije bi se napjeve lako mogli izvoditi i tekstovi što ih donosi u nastavku svoje knjige (usp. Šojat 1977b: 305). Pritom on baš kao ni njegov prethodnik Krajačević - ne čini (u europskim okvirima) ništa neočekivano budući da su, primjerice, u nabožnim lirskim zbirkama identično „postupali i mnogi njemački pjesnici 17. stoljeća, dajući uz svoje pjesme ili originalne napjeve ili upućujući na napjeve poznatih pjesama“" (Georgijević 1969: 123).

${ }^{408}$ Krajačević, konkretno, u Opomenku svoje knjige Sveti evangeliomi tako napominje da su pjesme okupljene u njoj zapravo „postavljene vu to ime, da se popevaju ne leprav vu cirkvah, po svetkeh, pod mešami ali na procesjah od cirkve do cirkve putujuči, nego i po delatnikeh, vu vsake fele mestah, rekši: na polje koseči, orjuči, ženjuči etc., na goricah kopajuči, koleči etc., mesto navadneh negdašnjeh stareh poganskeh i sramotneh popevkih, kotere priprosti ljudi, poimene ženskoga spola, gustokrat popevaju plešuči, tancajuči, delajuči doma, vune na polje, na goricah, sramotno se šaleči te druge ljudi, keh nazoči ne, ogovarajuči, i to takove grehe za šalu jemljuči te za ništar držeči“ (cit. prema: Šojat 1977a: 330). Podrobnije o Krajačevićevim (neuspješnim) pokušajima da svojim nabožnim pjesmama izgura „pogane“ narodne popijevke i u: Georgijević 1969: 71-75. 
donosi dva stiha. ${ }^{409}$ Pored alegorijskoga tumačenja poznate folklorne romance o Marinoj izgubljenoj kruni, ${ }^{410}$ koja najvjerojatnije i potječe upravo iz 17. stoljeća, u Vitezovićevoj pisanoj ostavštini naići ćemo čak i na zapis fragmenta (vjerojatno autohtone) bugaršćice pod naslovom Sužanjstvo Krbave, koji se - podsjetimo - nalazi među mnogobrojnim tiskanim i rukopisnim njegovim ostvarenjima kompiliranima u zbornik Otia metrica, a stanovit broj izvorno folklornoknjiževnih - iako prerađenih - sastavaka našao je svoje mjesto i u njegovoj pučkoj zbirci osmerački ispjevanih poslovica Priričnik aliti razliko mudrosti cvitje iz 1703.

Ni kao zapisivač bugaršćica, a još manje kao zapisivač i stilizator usmenoknjiževnih poslovica Ritter u svome dobu, međutim, nije predstavljao izuzetak, pa dok tako već Juraj Križanić u svojoj sveslavenskoj gramatici kao primjere za pojedine jezične pojave podastire stihove iz nekih (onovremenih) bugaršćica, ${ }^{411}$ njegov zacijelo najveći (hrvatski) literarni uzor i neposredni prethodnik - Petar Zrinski - bilježi cjelovit tekst bugaršćice, i to glavninom kajkavske Popevke o Svilojeviću, koju prožimaju i izraziti štokavski te kajkavski jezični tragovi. ${ }^{412}$ Što se, pak, žanra folklornoknjiževne poslovice tiče, njegovi su autohtoni primjerci svojedobno privukli i pozornost Frana Krste Frankopana, koji će svoju rukopisnu zbirku izreka Sentencije vsakojaške premrežiti i određenim brojem (većinom stiliziranih) „narodnih“ poslovica, a za usmenoknjiževnom će građom potom on iznova posegnuti i pri sastavljanju također rukopisnoga - ciklusa zagonetaka Zganke za vrime kratiti, u koji uvrštava i niz ostvarenja s izrazitim folklornim značajkama (prepoznatljivim motivima, frazama, stilskim i formalnim - tj. metričkim - rješenjima itd.) što jasno ukazuju na to da je riječ, ako ne već o autohtonim, onda makar o sastavcima nastalima snažnim ugledanjem na one usmene. Pored opusa pobrojanih, za folklorno stvaralaštvo posebno senzibiliziranih naših baroknih literata, kao pravo vrelo najpouzdanijih informacija o generičkim oblicima u kojima se ostvarivala sedamnaestostoljetna usmena književnost svakako nam može poslužiti i ćirilićni Erlangenski rukopis, odnosno anonimni zbornik folklornoga pjesništva skupljenog na širem južnoslavenskom području (na potezu od hrvatskih zemalja, preko Bosne i Srbije, pa sve do Makedonije), čiji nastanak proučavatelji obično datiraju u vrijeme oko 1720. godine.

U taj je, naime, žanrovski poprilično šarolik pjesnički ciklus - pronađen tek 1913. u njemačkom Erlangenu - neki neidentificirani njemački činovnik početkom 18. stoljeća iz, kako se čini, raznih izvora prepisao sveukupno 217 većinom deseteračkih pjesama usmenoknjiževne provenijencije, koje su u svome „narodnom“ okružju očito cirkulirale još

\footnotetext{
${ }^{409}$ Riječ je o stihovima „Lipi Jive rože trga; / aj Lade, Lade, lipo Lade!““. Usp. Grgec 1944: 119.

${ }^{410}$ Detaljnije u: Bošković-Stulli 1978: 209-210.

${ }^{411}$ Usp. Kekez 2000: 49.

${ }^{412}$ O Petrovu zapisu Popevke o Svilojeviću podrobno u: Novalić 1967b: 66, Čubelić 1988: 91 i Botica 2013: 236.
} 
krajem 17. stoljeća, a različiti signali odaju i da mnoge od njih potječu iz znatno ranijih povijesnih razdoblja. ${ }^{413}$ Izuzetno veliku vremensku, prostornu, jezičnu (tekstovi ispjevani mješovitim narječjem) i tematsko-motivsku raznolikost pjesama Erlangenskoga rukopisa upotpunjuje pritom i njihova generička heterogenost, pa se uz bok epskopjesničkim folklornim tekstovima sa žanrovskim odlikama balade i romance ondje tako nalaze i mitske pjesme, ljubavne i erotske lirske pjesme, pjesme o svakodnevnim događajima itd., pri čemu se za najmanje trećinu njih s prilično velikom pouzdanošću može konstatirati da su upravo domaćega, hrvatskog porijekla. ${ }^{414}$

Prihvatimo li činjenicu da je, kao što to sve češće napominju povjesnici hrvatske (usmene) književnosti, (i) folklorna književnost - u smislu preferiranih generičkih varijanata - bila u nas uvelike regionalno distingvirana, vrlo slično zapažanje vrijedit će tada i za našu pučkoknjiževnu sedamnaestostoljetnu produkciju, za čiju su žanrovsku raznovrsnost u najvećoj mjeri bili zaslužni upravo pisci iz regija kontinentalne Hrvatske. Iako su svoja pučka ostvarenja zacijelo sastavljali (još uvijek) bez jasne svijesti o tome da je riječ o stvaralaštvu posebne literarne sfere, smještene na samoj granici između pisane i usmene književnosti, potonji su autori - ponajprije zahvaljujući ugledanju na slično inozemno štivo - zamišljeni generički sustav domaćega književnog baroka ipak dospjeli obogatiti i nizom žanrovskih varijanata ponajprije usklađenih s potrebama upravo one (sve brojnije) publike, koja je većinom stekavši tek najosnovniju naobrazbu - od književnih djela očekivala ponajprije zabavu i praktičnu korist. Među najranije bi pučke tekstove u našoj (baroknoj) književnosti stoga valjalo ubrojiti već niz anonimnih pjesama iz netom spomenutih - pretežno rukopisnih kajkavskih pjesmarica, u kojima su prepoznatljivo pučkoknjiževnim čimbenicima (folklorna motivika i forma, senzacionalizam, moralistički momenti itd.) bile prožete kako pojedine nabožne lirske pjesme, tako i - daleko malobrojniji - epskopjesnički sastavci u kojima se, između ostalog, opjevavao i neslavan kraj zrinsko-frankopanske urote. ${ }^{415}$ Čitatelje bez većega (pisano)književnog iskustva u ozaljskoj, kajkavskoj i slavonskoj baroknoj kulturnoj sredini tražili su i pisci religioznih ostvarenja - molitvenika, zbirki propovjedne proze te nabožnih zbornika - premreženih različitim obilježjima što ih danas prepoznajemo kao pučka, no količinom ovih potonjih uvjerljivo su ipak prednjačila pojedina vernakularna djela proizišla iz Vitezovićeva pera i ostvarena u žanrovima u rasponu od pučke kronike, zbirke versificiranih poslovica i knjige gatalica, pa sve do kraće pučke prigodne pjesame te - naročito - pučkih

${ }^{413}$ O Rukopisu detaljnije npr. u: Bošković-Stulli 1978: 221.

414 Ponajprije se to odnosi na ljubavne lirske te poglavito epske pjesme s uskočkom tematikom, odnosno s likovima Senjana, hajduka itd. Detaljnije u: Botica 2013: 121.

$415 \mathrm{O}$ sedamnaestostoljetnim pučkoknjiževnim pjesmama posvećenima protuhabsburškoj uroti detaljnije u: Matić 1962: 229-261 i Zečević 1972: 41-54. 
kalendara, s redovitim objavljivanjem kojih, zahvaljujući višegodišnjem upravljanju zagrebačkom Zemaljskom tiskarom, on i započinje u posljednjim godinama 17. stoljeća. Upravo s pojavom Pavla Rittera Vitezovića i njegova stvaralaštva na hrvatskom jeziku pučka će književnost u nas i doživjeti nagli procvat, namećući se kao nezaobilazna komponenta sedamnaestostoljetne književnosti, odnosno kao fenomen čije su specifična žanrovska rješenja - iako ciljanoj publici same razlike među njima vjerojatno i nisu bile toliko bitne - imala važno mjesto u provizornome općem generičkom sustavu hrvatskoga književnog baroka.

Zamišljajući tako - s poveće (književno)povijesne distance - (teorijski) sistem žanrova književnosti našega seicenta kao provizornu ukupnost apsolutno svih generičkih varijanata što su - bez obzira na sferu iz koje su proistekle - funkcionirale u specifičnoj situaciji, odnosno (kao takve) egzistirale isključivo u okrilju konkretne - hrvatske - nacionalne kulture u konkretnu vremenskom - sedamnaestostoljetnom - trenutku, možda suviše olako prelazimo preko činjenice da u stvaralačkoj praksi tadašnjih (naših) autora ne samo distinkciji između pisanoknjiževnih i usmenoknjiževnih, već ni onoj između književnih i rubno književnih, pa čak i izvanknjiževnih žanrova nije pridavan onakav značaj kakav im se, primjerice, pridaje u suvremeno doba. Usprkos tomu što je - zahvaljujući osamostaljenju znanosti - u baroku ipak uspostavljeno jasno (teorijsko) razlikovanje književna od neknjiževna teksta, koje se temeljilo na kriterijima vrlo sličnima onim po kojima se literarni sastavci od neliterarnih razlikuju i danas, ${ }^{416}$ niz primjera iz tadašnje naše književnosti pokazuje da su - u praksi - pojedini književni žanrovi i dalje služili ispunjavanju vrlo snažnih izvanknjiževnih (najčešće političkoideoloških) zadaća te bili shvaćani kao tek puke njihove literarizacije, ${ }^{417}$ dok su se - pak - u mnoge one neliterarne nerijetko uvodili stanoviti književni postupci (primjerice, naglašena figurativnost, pjesnička slikovitost itd.), a gdjekad - kao što je to slučaj i s nekim Ritterovim historiografskim radovima - i čitavi fragmenti odabranih literarnih ostvarenja ne bi li poslužili kao (povijesni) argumenti ondje izrečenim zaključcima. U stvaralačkom prelaženju fiktivne granice koja dijeli književnost od neknjiževnosti sami barokni pisci, dakle, (još uvijek) nisu vidjeli ništa sporno, znajući da će razumijevanje njihova teksta ionako najpresudnije odrediti samo okružje u kojemu će se zateći, ${ }^{418}$ odnosno da će - bez obzira na neknjiževnu svrhu ili dodane mu literarne značajke - pridruživanje krugu književnih ili neknjiževnih ostvarenja ujedno usmjeriti i njegovo daljnje poimanje. Ipak, budući da se - poradi manjka opipljivijih dokaza - nipošto ne može s punom sigurnošću tvrditi da je čak i teorijsko razlučivanje

\footnotetext{
416 Usp. Pavličić 1979a: 147, bilješka 10.

${ }^{417}$ Primarno političkoj su svrsi tako, primjerice, služile i obje Sirene - mađarska i hrvatska - braće Zrinski, a naročito njihove epskopjesničke dionice. Usp. o tome u: Blažević i Coha 2008.

${ }^{418}$ Detaljnije o ovom pitanju u: Pavličić 1979b: 38-40.
} 
izvanknjiževnih od književnih žanrova u hrvatskom baroku bilo ekvivalentno ovomu našem današnjem, a kamoli to da su ih i pisci i njihovi čitatelji razlikovali na jednak način, dakle prema istim kriterijima, i naredno (provizorno) razdvajanje četiriju generičkih „krugova“, iz kojih su obilježja iz pojedinačnih žanrovskih repertoara protkala tekst Vitezovićeve „zrinijade“, stoga treba shvatiti kao tek neizbježan teorijski dodatak analizi u njoj zastupljenih povijesnih žanrova, a nipošto kao možebitno uvažavanje stvarnih distinkcija koje su bile na snazi u prostoru i vremenu u kojemu je naš autor ispjevao svoje Odiljenje sigetsko.

\section{2. PISANOKNJIŽEVNE ŽANROVSKE SASTAVNICE ODILJENJA SIGETSKOG}

Genološka analiza koja Odiljenju sigetskom Pavla Rittera Vitezovića odluči pristupiti kao - očigledno - autorskomu književnoumjetničkom ostvarenju posve bi „logično“ i očekivano svoj rad na raspetljavanju zamršene mu žanrovske fakture morala, dakako, započeti upravo potragom za u nj uključenim značajkama konkretnih pisanoknjiževnih povijesnih žanrova. Cilj te potrage, drugim riječima, nipošto ne bi smjele biti (među dosadašnjim proučavateljima naročito obljubljene) „tipične“, odnosno svevremenske tekstualne posebnosti nadpovijesnih - prepoznatljivo staigerovskih - teorijskih konstrukata poput „epskog“, „lirskog“ i „dramskog“, već - upravo suprotno - obilježja stvarnih, povijesnih žanrovskih rješenja, i to mahom onih koja su imala važno mjesto u zamišljenome generičkom sustavu hrvatske, ali i europske barokne književnosti. Govoreći u terminima Bahtinove genološke teorije, pritom bi se većinom radilo o sekundarnim govornim žanrovima, dakle onima koji su proizišli iz složene, (pisano)književne komunikacije te su - kao takvi - i sami sazdani od stanovitog broja onih primarnih, s kakvima ćemo, pak, većinom imati posla kada se upustimo u pretresanje usmenoknjiževnih i poluknjiževnih generičkih slojeva Odiljenja. Inzistiranje na isključivo povijesnim - dakle, baroknim - žanrovskim rješenjima neće, dakako, u našoj književnoj znanosti predstavljati naročitu novinu budući da o specifičnostima (pisano)književnih žanrova hrvatskoga baroka domaći barokolozi sustavno pišu još od sedamdesetih godina prošloga stoljeća, ${ }^{419}$ no baš kao što ni njihova tumačenja nisu dospjela $u$ potpunosti umaknuti povremenim neizostavnim teorijskim sudovima, tako to neće biti $u$ stanju ni ova naša analiza, ponajprije stoga što je - zbog iznimne vremenske distance, ali i posvemašnjega izostanka preciznijih književnopovijesnih argumenata - u potpunosti vjernu i preciznu povijesnu sliku spomenutih žanrova naprosto nemoguće rekonstruirati.

\footnotetext{
${ }^{419}$ Svijest o povijesnoj određenosti, dakle specifičnosti žanrova hrvatskoga književnog baroka najviše se pritom provlači u književnopovijesnim studijama Pavla Pavličića (usp. npr. Pavličić 1979b), Zorana Kravara (usp. Kravar 1993) i Dunje Fališevac (usp. Fališevac 1997 i 2007).
} 
Što se obilježja pisanoknjiževnih žanrova koja prožimaju Odiljenje sigetsko tiče, ono na što bi odmah na početku valjalo skrenuti pozornost jest spoznaja da nemali broj njih zapravo potječe iz repertoara onih (latinskih) generičkih rješenja (i njihovih vernakularnih izvedenica) u pisanju kojih se Vitezović imao prilike izvještiti još za svoga školovanja u isusovačkoj gimnaziji, čiji je nastavni program - podsjetimo - i propisivao česte književne vježbe, odnosno praksu sastavljanja „standardnih“ Žanrova (novo)latinske književnosti. U tom smislu nimalo pretjeranima ne bi trebalo držati konstatacije pojedinih naših književnih povjesnika o tome kako Ritter u svojoj „zrinijadi“ demonstrira retoričko umijeće izbrušeno još u ranoj mladosti, pa dok tako, primjerice, već Branko Vodnik u svome pregledu povijesti hrvatske književnosti zaključuje kako je on, „kao isusovački gojenac, stekao (...) okretnost u versifikaciji i velik više retorički nego samonikli pjesnički pribor“ (Vodnik 1913: 299), dotle Slobodan Prosperov Novak ustvrđuje kako je Odiljenje ništa drugo no uvjerljiv literarni dokaz da je naš autor sjajno „poznavao latinsku retoriku“ (Prosperov Novak 1999: 699). Uostalom, već rana Vitezovićeva pjesnička ostvarenja na latinskom, u kojima se „naslućuje (...) produžetak u školi stečenih navika“ (Vončina 1976a: 339), ${ }^{420}$ pokazuju „,natprosječnu verzifikacijsku kompetenciju i upućenost u žanrovsku tradiciju“ (Kravar i Novaković 2000: 766), što će reći da je stvaralaštvo na hrvatskom jeziku uvelike on shvaćao (i) kao ništa drugo no svojevrsni generički nastavak svojih latinskih literarnih pokušaja. Na kraju krajeva, (novo)latinska i vernakularna (pisana) književnost u 17. stoljeću - kao što smo maločas utvrdili - u žanrovskom su pogledu bile čvrsto isprepletene, čemu bi razlog ponajprije trebalo tražiti upravo u ondašnjemu obrazovnom sustavu, čiji su obavezan dio bile vježbe pisanja književnih tekstova po obrascima izvorno antičkih književnih žanrova, a onda i u samome baroknom žanrovskom sistemu, kojeg je velik dio - ponovimo - otpadao na generička rješenja antičkoga porijekla naslijeđena iz renesanse.

Ako se, u tom smislu, obilato Vitezovićevo posezanje za obilježjima iz repertoara stanovitih pisanoknjiževnih žanrova antičke provenijencije nipošto ne može proglasiti nebaroknim ili baroku nimalo svojstvenim, onda ni za Odiljenje sigetsko u cijelosti, kao što se to povremeno dosad već činilo, ne bi bilo ispravno konstatirati da je $-\mathrm{u}$ generičkom pogledu - riječ o uvelike anakronom ostvarenju. Naprotiv, kao što će se u nastavku pokazati, svoju je „zrinijadu“ Ritter obilato napučio mahom značajkama onih pisanoknjiževnih žanrova čiju su uporabu ne samo otvoreno zagovarali pojedini sedamnaestostoljetni poetički tekstovi, nego i koji su uživali najveću popularnost među onodobnim piscima diljem Europe, ali i u nekima od

\footnotetext{
${ }^{420}$ Jak utjecaj isusovačke škole u tim latinskim Ritterovim pjesmama najjasnije odaju prepoznatljivi retorički postupci. Podrobnije u: Stepanić 2016: 335.
} 
kojih su svoja djela realizirali i autori iz četiriju naših tadašnjih kulturnih regija. Ukratko, da je Odiljenje po svojim pisanoknjiževnim žanrovskim značajkama - pa i ne samo po njima - u svoje vrijeme najvjerojatnije kotiralo kao itekako moderno ostvarenje ponajbolje sugerira njegova - dosad nikad još sustavno provedena - analiza, koja će potvrditi da ova neobična Ritterova „zrinijada“ itekako zaslužuje ponijeti dosad joj često osporavan epitet „barokne“.

\section{2. 1. Odiljenje - barokni povijesni ep?}

U dosadašnjim „ritterološkim“ studijama posvećenima generičkim osobitostima Odiljenja sigetskog uvjerljivo je najviše tinte potrošeno na utvrđivanje prisutnosti ili odsutnosti („tipično“) „epskih“ karakteristika unutar njegovih tekstualnih granica. Rezultati tih su analiza pritom redovito ukazivali na dva međusobno različita žanrovska identiteta Vitezovićeve „zrinijade“, pa dok se proučavatelji koji su u njemu locirali „dovoljan“ broj „epskih“ značajki najčešće nisu ustručavali proglasiti ga epskom pjesmom, ${ }^{421}$ oni drugi fokusirani na daleko mnogobrojnije njegove osobine koje ga udaljuju od pola „epskog“ i približavaju polu „lirskog“ - (u)tvrdili su kako Odiljenju znatno više pristaje oznaka zbirke lirskih pjesama no ona (junačkoga) epa. ${ }^{422} \mathrm{Ni}$ jedna ni druga skupina „ritterologa“ nije, međutim, vidjela ništa sporno u tome što u svojim razmatranjima polazi od posve identičnih genoloških predodžbi, odnosno što - umjesto na podlozi povijesnoga razumijevanja žanrova (baroknoga) junačkog epa i (barokne) lirske pjesme - iznesena zapažanja temelji na pojednostavljenim apstraktnim, odnosno teorijskim predodžbama o svevremenskim i svevažećim „epskim“ i „lirskim“ generičkim obilježjima. Vodeći se idejama suvremene (književne) genologije, koja žanrovima pristupa kao iz povijesti izraslim i uopće situacijski, odnosno „kronotopski“ (vremenski i mjesno) obilježenim kategorijama, naše istraživanje za svoj cilj - dakako - neće imati nastavljanje takve „ritterološke“ prakse, već će - upravo suprotno - pokušati otvoriti posve nove smjerove u generičkim interpretacijama Vitezovićeva ostvarenja, bazirane na njegovu shvaćanju kao povijesnom umjetničkom konstruktu satkanom od čitava niza značajki povijesnih (pisano)književnih žanrova. Neke je od njih bez imalo dvojbe uistinu moguće definirati kao „epske“ ili „epskopjesničke“, no da bismo takvo što uopće mogli učiniti, najprije nam valja utvrditi što je to - u optici Vitezovićeva doba, tj. u okvirima tadašnje (domaće) književne kulture - „epsko“ konkretno i podrazumijevalo,

\footnotetext{
${ }^{421}$ Dosad su Odiljenju sigetskom kao epskoj pjesmi u svojim radovima - između ostalih - pristupali i Pavao Pavličić (usp. Pavličić 1979b: 9-29), Franjo Švelec (usp. Švelec 1990: 179-188) te Dunja Fališevac (usp. Fališevac 1997: 161-175), koja lirske njegove momente tumači kao izravnu posljedicu Tassova utjecaja, čime ujedno i sugerira kako bi ga valjalo motriti upravo kao barokni ep „skrojen“ prema Tassovu epskom modelu. ${ }^{422}$ Usp. naročito Kolumbić 2005: 327-353 i Pavličić 2007: 253-284.
} 
odnosno zaviriti kako u pojedine sedamnaestostoljetne poetičke tekstove te paratekstualne autoreferencijalne iskaze prožete - između ostalog - i poetičko-genološkim razmatranjima, tako i u same barokne „epske“ (točnije, epskopjesničke) sastavke, i to kako one domaće, tako i one (znatno, dakako, utjecajnije) strane.

Premda se u poetičkim spisima iz baroknoga razdoblja konkretnim književnim žanrovima i repertoarima njihovih obilježja, kao što smo vidjeli, pažnja posvećivala tek zgodimice, onodobni su pisci - ponajprije zahvaljujući pretežnom oslanjanju na tradicionalne, mahom antičke generičke (pr)opise - itekako dobro znali za kojim im značajkama valja posezati ne bi li oblikovali djela koja će žanrovski odgovarati potrebama svake pojedinačne situacije. Među sedamnaestostoljetnim poetičkim tekstovima, ipak, bilo je i onih u kojima se podosta prostora posvećivalo upravo razmatranju ili - bolje rečeno - utvrđivanju tih tradicionalnih žanrovskih normi, a jedan od njih bio je i latinski poetičko-retorički priručnik Poeticarum Institutionum libri tres (O pjesničkom obrazovanju) nizozemskoga profesora povijesti i retorike Gerharda Johannesa Vossiusa iz 1647., koji je u svoje vrijeme diljem Europe uživao neobično veliku popularnost. U njemu ćemo - između ostalog - pronaći i (iz današnje vizure) prilično općenitu i bitno pojednostavljenu definiciju epa, shodno kojoj je on „pjesma sastavljena u heksametrima, koja biranim jezikom opisuje slavna djela slavnih osoba“, pri čemu se - u njezinu sastavljanju - od epskog pjesnika ,zahtijevaju četiri stvari: pjesma u heksametrima, fabula ili pripovijest, povijesna podloga ili spomen na drevne događaje, i primjeren, to jest uzvišen izričaj“ (Blažević 2007: 252, bilješka 10).

Ukoliko su navedenim generičkim zahtjevima morali udovoljavati ponajprije barokni pisci latinskih (junačkih) epskih pjesama, onda bi - posve logično - eventualne razrade žanrovskih normi što su ih uvažavali vernakularni epski pjesnici valjalo potražiti među poetičkim očitovanjima sastavljenima na narodnim jezicima, pa tako i onom hrvatskom. S obzirom na već utvrđen posvemašnji nedostatak sedamnaestostoljetnih poetičkih tekstova u nas, za mogućim poetičkim, a onda i genološkim iskazima bit ćemo prisiljeni tragati drugdje, i to mahom u paratekstualnim dionicama rijetkih tiskom objelodanjenih baroknih epskopjesničkih ostvarenja na hrvatskom jeziku poput Opside sigecke Petra Zrinskoga, uvrštene u (Vitezoviću posebno drag) zbornik lirskih i epskih pjesama Adrijanskoga mora Sirena. Ispisujući posvetu ,plemenito i dobro rojenim, svake hvale i časti dostojnim, virnim i vridnim junakom, vse hrvacke i primorske krajine hrabrenim vitezovom“ (Zrinski 1957: 19), Petar neće propustiti ukratko se osvrnuti i na razloge objavljivanja svoga djela, a poglavito na zadaće koje bi trebao ispuniti njezin središnji i najvažniji - epskopjesnički - odsječak, posvećen junačkim činima sigetskoga kapetana i njegova pretka Nikole Šubića. Svjestan da bi 
mu zbog manjkavosti estetske (stilsko-formalne) dimenzije njegova epa pokoji čitatelj mogao uputiti vrlo ozbiljne i nimalo neopravdane primjedbe, Petar tako naglašava da estetskoj kvaliteti djela ovakve vrste ionako ne bi trebalo pridavati suviše veliku važnost budući da su daleko bitnije same izvanknjiževne svrhe koje se njime žele postići, i to čuvanje sjećanja na presudne događaje i aktere iz domaće povijesti kako bi oni (po)služili kao moralni uzor te u recipijenata pobudili prijeko potrebne patriotske osjećaje. Shvatimo li, drugim riječima, ove autoreferencijalne izjave Petra Zrinskog - kao što su to već i učinili pojedini recentniji naši barokolozi ${ }^{423}$ - kao svojevrstan sažetak sedamnaestostoljetne poetike žanra (vernakularne) epske pjesme kakvoj su se priklanjali, prije svega, autori ozaljskoga književno-jezičnog kruga, tada će postati očito da su epici čija su djela izvršila najpresudniji utjecaj i na Pavla Rittera Vitezovića kao najvažniji generički aspekt epa shvaćali njegovu angažiranost, odnosno sposobnost da djeluje u zbilji, a ne stanovite unutartekstualne njegove specifičnosti.

Sagledano kroz prizmu navedenih dviju baroknih definicija žanra povijesne ili junačke epske pjesme, i Odiljenje sigetsko po svojoj bi se povijesnoj tematici, eksplicitno naznačenoj komemorativnoj funkciji, pa i (najvjerojatnijoj) angažiranosti vrlo lako moglo dovesti u vezu s punokrvnim epskopjesničkim sedamnaestostoljetnim ostvarenjima, tim više što je svoga primarnog (sadržajnog i idejnog) literarnog uzora pronašlo ono upravo u epu Petra Zrinskog. Kako je, međutim, iz ovih relativno šturih poetičkih opisa moguće izvući tek pokoju konkretnu tekstualnu značajku svojstvenu baroknim epovima, o stvarnom broju prepoznatljivo „epskih“ karakteristika uključenih u Vitezovićevu „zrinijadu“ opravdanije ćemo moći suditi tek nakon što generički repertoar (hrvatske) barokne epske pjesme rekonstruiramo na temelju uvida u neke od ponajboljih onodobnih domaćih primjeraka samoga žanra. Osnovnim obilježjima baroknoga povijesnog epa pritom nipošto ne bismo smjeli prići kao svevremenskim ili teorijskim - dakle, ,epskim“ - značajkama jer, iako je uvelike on počivao i na narativnosti, i na iscrpnosti, i na epizodičnosti, i na mnogobrojnosti likova, ${ }^{424}$ tim (,bazičnim“) karakteristikama sedamnaestostoljetni epici ne samo što nisu pridavali onaj isti značaj kao i njihovi prethodnici i nasljednici, već ih nisu ni nadograđivali „pobočnim“ epskopjesničkim tekstualnim osobinama identičnim onima što ih nalazimo u (domaćim) epovima 16. i 18. stoljeća. Specifičnosti žanrovskoga repertoara baroknoga povijesnog ili junačkog epa iz toga je razloga najprimjerenije razmatrati na podlozi generičkih posebnosti renesansne epske pjesme budući da su se upravo od njih one što više i težile udaljiti, kao što to, uostalom, pokazuje već i primjer „,protobarokne“ Vile Slovinke (1614.)

\footnotetext{
${ }^{423}$ Usp. Pavličić 2006: 177-194 i 2007: 199-202.

${ }^{424}$ O ovim i drugim temeljnim ,epskim“ značajkama detaljno npr. u: Pavličić 1998: 415-417.
} 
Jurja Barakovića, u kojoj - iako je formalno riječ o epskoj pjesmi - ne samo što jedinstvenoj i konzistentnoj priči svojstvenoj renesansnim epovima nema ni traga, već se $\mathrm{k}$ tome $\mathrm{i}$ uvriježene sadržajne značajke ranonoovjekovne epike (primjerice, baroknoslavistička ideologija) u njoj miješaju s onima karakterističnima za srednjovjekovne epove (kakav je, na primjer, i motiv neprekidnoga preplitanja vizija, sna i jave). ${ }^{425}$

Unatoč nezanemarivim razlikama u generičkim repertoarima našega - a i europskog baroknog povijesnog epa, na umu bi, prije svega, svakako trebalo imati da je i u 17. stoljeću žanr epske pjesme - kako je već ranije bilo rečeno - još uvijek kotirao kao uvjerljivo najvažnije žanrovsko rješenje, čije je mjesto na vrhu onodobne generičke hijerarhije i dalje bilo čvrsto i neupitno. Pritom se, u skladu s imperativima tada dominantne literarne poetike, od baroknoga epa daleko više no od njegova prethodnika očekivalo da djeluje u zbilji, odnosno da bude angažiran, i to ponajvećma oko zastupanja stanovitih religijskih, moralnih i napose političkih ideja, čija je važnost njegove (dotad daleko najbitnije) literarne kvalitete najčešće potiskivala u drugi plan. Nasuprot renesansnoj „epici“, u kojoj je on bio silno važna komponenta, u baroku povijesni ep tako ne samo što nije posjedovao jedino njemu svojstven i primjeren „epski“ stil, nego se ni čitava stilska njegova dimenzija nije tada shvaćala kao dominantna, što će reći da nije imala gotovo nikakva utjecaja na kompoziciju teksta, fabularni tijek i uopće razvoj teme, ${ }^{426}$ koja je - pak - striktno podrazumijevala stvarne povijesne događaje izvučene iz bliže ili dalje prošlosti, i to mahom pojedine epizode iz višedesetljetnoga kršćansko-muslimanskog rata.

Fokusiramo li se, uostalom, na same tekstualne posebnosti našega baroknog povijesnog epa, primijetit ćemo da su one - kao što je to, na kraju krajeva, bio slučaj i sa žanrovskim repertoarima epske pjesme u drugim sedamnaestostoljetnim europskim sredinama - najviše dugovale ugledanju domaćih epika u Oslobođeni Jeruzalem Torquata Tassa, ${ }^{427}$ koji je u to vrijeme nosio status paradigmatskoga epskopjesničkog ostvarenja. Zahvaljujući tom nasljedovanju tassovskoga epskog „modela“, i većina naših epova ispjevanih tijekom 17. stoljeća počivat će ne samo na inovativnim kompozicijskim postupcima te prepoznatljivo baroknom stilu obilježenom figuralnim pretjerivanjima, nego i na ideologiji proizišloj iz tadašnjih protureformacijskih nastojanja, ali i uopće specifičnim sadržajnim momentima $u$ kojima se odražavaju posve nove, tipično barokne svjetonazorske silnice. U domaćim baroknim epskopjesničkim ostvarenjima, redovito prožetim vrlo izrazitim kršćanskim i (barokno)slavističkim idejama, preplitale su se tako - tipično „tassovski“ - povijesne s

\footnotetext{
${ }^{425}$ Usp. Fališevac 2003: 502.

${ }^{426}$ Podrobnije o stilu hrvatskoga baroknog (povijesnog) epa u: Fališevac 1997: 127-137.

${ }^{427} \mathrm{O}$ utjecaju Tassova epa na žanr naše barokne povijesne epske pjesme posebno u: Fališevac 1997: 161-175.
} 
fikcionalnim (viteško-romantičkim i kvazipovijesnim) epizodama, podastirale brojne $-\mathrm{u}$ renesansnoj epici sustavno zanemarivane - informacije o privatnim svjetovima (točnije, karakternim i emocionalnim osobinama) epskih junaka, a samoj povijesnoj stvarnosti pristupano je kao kompleksnom fenomenu u sagledavanju kojega je kršćanskom etičkom shvaćanju napokon počelo ozbiljno konkurirati ono sekularno, u okvirima kojega se povijesni svijet razumijeva(o) kao politički svijet presudno određen autonomnim djelovanjem čovjeka kao političkoga bića, a ne nebesko-božanskim utjecajima i principima. ${ }^{428}$

Iznimnu kompleksnost pokazivale su u baroku i čitave kompozicije (naših) epskih pjesama, čemu razlog treba tražiti u njihovu prožimanju obilježjima nemalog broja književnih i ne samo književnih - žanrova, pa čak i cjelovitim primjercima pojedinih „manjih“ (,neepskih“) generičkih rješenja. Osim već spomenutih viteško-romantičkih dionica, u tadašnjim povijesnim epovima nerijetko će se tako zateći i ,putopisni i dnevnički segmenti, biografski ekskursi, romaneskna građa, razni religiozni žanrovi kao što su molitva i propovijed, a česti su i refleksivni dijelovi u kojima se raspravlja o vlasti i politici“ (Fališevac 2003: 505), ${ }^{429} \mathrm{i}$ to nejednakoga - najčešće antičko-humanističkog i renesansnog, a gdjekad i srednjovjekovnog - podrijetla, no njima će se ondje povremeno ,pridružiti“ čak i cjeloviti ili fragmentarni autohtoni ili fingirani usmenoknjiževni i pučkoknjiževni žanrovi, ponajvećma lirske pjesme, poslovice, blagoslovi itd. ${ }^{430}$ Iako otvoren generičkim rješenjima izuzetno širokoga raspona i porijekla, barokni je ep daleko rjeđe upijao čitave primjerke konkretnih žanrova nego izdvojena njima svojstvena obilježja, pa je najčešće on tako posezao ne samo za nekim generički „karakterističnim“ stilskim figurama (poput, primjerice, metafore svojstvene petrarkističkim lirskim pjesmama), nego i za stanovitim motivima obrađivanima u za njih „specijaliziranim“ žanrovima. Potonje bi motive pritom on redovito evocirao upravo na onim mjestima u tekstu u kojima se dotiče sadržaja karakterističnih za „njihove“ žanrove, a kao rezultat njegovih pokušaja reinterpretacije upravo onih tema i pitanja koji su bili (ili još uvijek jesu) predmet obrade ovih ili onih žanrovskih varijanata proizišli su i posve nova - „epska“ slika vjere (kojom se dotad bavila isključivo nabožna lirska pjesma, religiozna poema itd.) te „epska“ predodžba ljubavi (koja je opjevavana pretežno u amoroznoj petrarkističkoj lirici). ${ }^{431}$ Jedini, dakako, razlog radi kojega je sedamnaestostoljetni ep uopće zahvaćao u teme i motive

\footnotetext{
428 Uvažavanje sekularnoga shvaćanja povijesti jedan je od, dakako, najočitijih signala svjetonazorske modernosti baroknoga povijesnog epa.

${ }^{429}$ Tako će, primjerice, u Kanavelićevu epu Sveti Ivan biskup trogirski i kralj Koloman svoje mjesto naći i mnogobrojna obilježja ljubavne i religiozno-refleksivne lirike, a uz njih čak i ona religioznoga žanra propovijedi. ${ }^{430}$ Između ostalog, i u Gundulićevu Osmanu, pored elemenata različitih pisanoknjiževnih žanrova, nalazimo tako i fingirane folklorne pjesme, dvorske pučke pjesme te obilježja mnogih drugih usmenoknjiževnih i pučkoknjiževnih žanrova. Usp. o tome u: Fališevac 2007b: 229-243.

${ }^{431}$ O ovome detaljnije u: Pavličić 1979b: 13-16.
} 
svojstvene drugim generičkim repertoarima bila je njegova težnja za prikazivanjem (povijesnoga) svijeta u njegovu totalitetu, odnosno u punoj njegovoj kompleksnosti, što nikako nije bilo izvedivo bez posezanja za značajkama onih žanrova „zaduženih“ za literarnu obradu pojedinačnih - a međusobno različitih - aspekata života. ${ }^{432}$

Pristupanje stvarnosti kao izrazito složenu fenomenu za svoju je posljedicu u hrvatskome baroknom povijesnom epu - podjednako kao i u Tassovu slučaju - imalo (još) i niz sadržajnih specifičnosti koje su iskristalizirale kao možda i najbaroknije značajke unutar njegova žanrovskog repertoara. Posve suprotno renesansnomu epu, prepoznatljiv su njegov dio tako postale česte digresije (s brojnim analepsama i prolepsama) te praznine u radnji koje čitatelj sam mora popuniti, a uz to je iznošenje priče u njemu bilo povjereno ideološki vrlo pristranom pripovjedaču, koji je nerijetko dolazio iz redova protagonista te pritom redovito angažirano komentirao radnju, i koji je - kao takav - bio posve neusporediv s „objektivnim“, distanciranim kršćanskim naratorom svojstvenim šesnaestostoljetnoj biblijskoj epskoj pjesmi. Zbog nemogućnosti da prati neprekidna prostorno-vremenska premještanja $u$ tekstu, pripovjedač se u baroknome epu često bio prisiljen udvojiti, pri čemu bi njegovu poziciju u takvim slučajevima obično preuzimao jedan od (središnjih) likova, no do njihova preklapanja pritom ipak nije dolazilo budući da su događaji o kojima su pripovijedali - a koji su pripadali različitim (prostorno-temporalnim) dimenzijama - donošeni na različitim mjestima u tekstu. Takvo „raspoređivanje“ zbivanja u onodobnim povijesnim epovima proizlazilo je iz naglašeno subjektivnoga doživljaja vremena - sasvim oprečnog onome renesansnom, koji je bio podložan pravocrtnoj kronologiji - uslijed kojega je ponajmanje bilo važno jesu li se ona dogodila prije ili poslije ,sadašnjega“ trenutka, što je onda vodilo i do sastavljanja vrlo kompleksnih fabula, pokatkad oblikovanih po načelu montaže.

Iz potonjega se razloga u sedamnaestostoljetnoj (junačkoj) epskoj pjesmi ni hijerarhija među dijelovima teksta nije više uspostavljala shodno mjestu što su ga konkretne dionice zauzimale u strukturi djela, nego isključivo prema sadržajnom kriteriju, a budući da glavna radnja i popratne epizode u njemu nisu stajale u hijerarhijskom odnosu, već su supostojale kao ravnopravne, jasno je zašto u baroknome epu zatječemo (dotad) neuobičajeno velik broj epizoda, često i vrlo opsežne digresije te povremena napuštanja centralne linije pripovijedanja. U njemu, ukratko, ,ideja djela kao cjeline nije sugerirana njegovom strukturnom zaokruženošću, nego sadržajnom cjelovitošću opisanoga događaja, činjenicom da je on ispripovijedan do svojega logičnog kraja“ (Pavličić 1979b: 15), što je onda i uzrok

\footnotetext{
${ }^{432}$ Drugim riječima, barokni ep - kako napominje Dunja Fališevac - „,svojim generičkim osobinama teži uvijek sveobuhvatnoj, cjelovitoj, harmoničnoj slici svijeta“" (Fališevac 1997: 92).
} 
varijacijama u duljini i broju pjevanja te pojedinačnih njegovih epizoda, a uopće se pritom ni vrijednost baroknoga epa kao cjeline i ,njegova ideološka prihvatljivost ne određuju (...) čvrstinom njegove organizacije, niti njegovom unutrašnjom logikom, nego osobinama svakoga od njegovih dijelova“, odnosno „činjenicom da su sve sadržajne komponente zadovoljene i da je ispunjen onaj krug motiva koji norma iziskuje“ (Isto: 16). Iako je razbijenu, točnije necjelovitu literarnu strukturu naša barokna epska pjesma lako mogla naslijediti i iz srednjovjekovne književnosti, ${ }^{433}$ bit će da je ona u najvećoj mjeri ipak posljedica snažnoga nadovezivanja na Tassov epski model, pored kojega su na naše epike presudno utjecali kako „,̌isto“ književni fenomeni poput sve izrazitije raširenosti romanesknih fabula, tako i oni izvanknjiževni, među kojima naročito sedamnaestostoljetni svjetonazor zaokupljen čovjekom kao pojedincem, ${ }^{434}$ odnosno pitanjem ,nestanka simetrična položaja čovjeka u svijetu nakon propasti geocentričkoga sistema (Isto: 216). ${ }^{435}$

Imaju li se na umu ova netom pobrojana karakteristična obilježja baroknoga povijesnog epa, odnosno najprepoznatljivije komponente njegova žanrovskog repertoara, posve bi razumljivo u prvi mah bilo pomisliti kako je i Odiljenje sigetsko - usprkos višestruko utvrđenu izostanku ključnih „epskih“ ili „temeljnih“ epskopjesničkih čimbenika poput kategorije (objektivnoga) pripovjedača, pravocrtne epske naracije i ,tipičnih“ epskih likova ${ }^{436}$ - uz određene ograde generički ipak moguće podvesti pod sedamnaestostoljetnu junačku epsku pjesmu, ne suviše različitu od onih njezinih primjeraka u kojima su „epske“, povijesne teme na sebe vezale i stanovite sadržajne momente te formalne postupke svojstvene različitim „neepskim“ žanrovima. Štoviše, neuobičajeno velik broj kazivača ili (lirskih) subjekata što ih zatječemo u Vitezovićevoj ,zrinijadi“ možda bi se, slijedom takvih razmišljanja, mogao protumačiti kao baroknom epu ništa manje svojstveno umnožavanje ideološki pristranih, angažiranih (i u ,priču“ izravno upletenih) pripovjedača, proizišlo iz - u tadašnjim epovima također uobičajenih - (pre)čestih prostorno-vremenskih skokova, zahvaljujući kojemu se i pojavila opravdana potreba za uključivanjem nemaloga broja generičkih obilježja (barokne) lirske pjesme, a uz njih čak i onih pojedinih dramskih žanrova. U tom bi se smislu izuzetna žanrovska heterogenost, poprilično razvedena kompozicija i uopće kompleksniji „pripovjedački“ postupci lako mogli razumjeti ne samo kao jasni tekstualni signali pripadnosti

\footnotetext{
${ }^{433} \mathrm{Na}$ takav bi nas zaključak možda mogla navesti činjenica da će naročito „labave i otvorene kompozicijske cjeline karakterizirati narativna djela u stihu u svim onim sredinama gdje se renesansne epske poetike nisu strogo i čvrsto nametnule književnoj sredini““ (Fališevac 1997: 93), što će reći u ozaljskoj te poglavito u kajkavskoj i slavonskoj kulturi, ali djelomice čak i u onoj dalmatinskoj.

${ }^{434}$ Usp. Fališevac 2003: 504.

435 Znatno opširnije o konkretnim obilježjima našega baroknog (povijesnog) epa u: Fališevac 1997: 91-126, 2003: 501-511, 2007: 229-243 i 2010b: 485-486; Pavličić 1979b: 13-16 i 203-236.

436 Detaljnije npr. u: Dukić 2002: 68-69 i Pavličić 2007: 255-257.
} 
Odiljenja žanru hrvatskoga baroknog povijesnog epa, nego i - kao što su to već pretpostavili pojedini naši barokolozi ${ }^{437}$ - kao očiti dokazi nasljedovanja Tassa i njegova epskog modela, što bi pretpostavljenu mu epskopjesničkom identitetu možda i ponajviše govorilo u prilog.

Iako se za argumente koji, kako se čini, podupiru ovakvo generičko poimanje Odiljenja sigetskog nipošto ne bi moglo kazati da su u potpunosti neutemeljeni, to ipak neće značiti da njegovu žanrovsku šarolikost valja shvaćati isključivo kao jedan od indikatora bliskosti žanru sedamnaestostoljetne (junačke) epske pjesme. Naprotiv, premda je odabirom „epske“ teme te sadržajnim i formalnim nadovezivanjem na - dotad mahom epskopjesničku tradiciju „zrinijada“ (a naročito na Opsidu sigecku Petra Zrinskog) Vitezović dio svoje publike uistinu želio navesti na pomisao kako se i u njegovu slučaju radi o „tek“ epu, pažljivijem (i literarno iskusnijem) čitatelju jamačno nije mogla promaći činjenica kako su ta „epska“ svojstva Odiljenja zapravo „koncentrirana“ na tek nekoliko mjesta unutar teksta, odnosno da su raspršena i fragmentarizirana te da, kao takva, ne tvore možebitan „epskopjesnički“ okvir u koji se - u skladu s poetikom baroknoga epa - uvode pojedina obilježja iz repertoara „neepskih“ žanrova ili njihovi primjerci u cijelosti. Ukoliko bismo tako kao jednu od karakterističnih značajki sedamnaestostoljetne epske pjesme izdvojili vrlo kompleksnu naraciju u kojoj uz se uz bok centralnoj radnji „odvija“ i niz manjih, paralelnih epizoda, očit izostanak epizodične razvedenosti u Odiljenju sigetskom u tom bi se smislu mogao objasniti ničime drugim no činjenicom da u njemu - kao što su već utvrdili pojedini „ritterolozi“ - priča „ne samo da se ne pripovijeda izravno, nego nije ni implicitno prisutna u tekstu“ (Pavličić 2007: 256). Doduše, umjesto cjelovite povijesne priče o opsadi i turskom zauzeću Sigeta - kakvu bi recipijent i očekivao od jednoga junačkog epa - Vitezović na pojedinim mjestima u svojoj ,zrinijadi“ donosi tek njezine razbacane fragmente, $\mathrm{i}$ to gotovo $\mathrm{u}$ stopu slijedeći fabularne pojedinosti iz literarnog prikaza sigetske katastrofe što ga je u svome epskopjesničkom ostvarenju samo nekoliko desetljeća ranije ispisao Petar Zrinski.

Da bi navedene narativne djeliće i dionice - kojima su premrežena sva četiri dijela teksta - čitatelj uopće bio u stanju povezati u kompaktnu (,epsku“) priču o kršćanskomuslimanskom okršaju pod sigetskim zidinama, kronologiju pada Sigeta ${ }^{438}$ nužno je morao otprije poznavati iz bilo kojega ,vanjskog“ - književnog ili neknjiževnog - izvora, a najbolje upravo iz Petrove Obside sigecke, na čije se epizode i likove i odnose mnoga mjesta iz Vitezovićeve ,zrinijade“. Premda je stanovit broj motiva i junaka - od kojih su neki navedeni samo poimence, a uz druge se ističu i pojedina njihova junaštva - doista dugovao svoje

${ }^{437}$ O „Tassovim“ značajkama Odiljenja više u: Fališevac 1997: 161-175.

${ }^{438}$ Kronološki tijek bitke pod Sigetom i njezine dalekosežne posljedice najpreglednije su prikazani u: Mijatović 2010: 13-106. Usp. i nešto recentniji i sažetiji pregled tijeka sigetske katastrofe u: Bratulić 2016a: 9-14. 
porijeklo upravo Petrovu epu, ne bismo se ipak mogli u potpunosti složiti s tvrdnjama onih književnih povjesnika koji upozoravaju kako razumijevanja Odiljenja sigetskog nema bez njegova čitanja na podlozi Obside. ${ }^{439}$ Naprotiv, čak i pored možebitno im nerazumljivih i nepoznatih motiva i likova baštinjenih iz Petrove „zrinijade“, sam kronološki tijek bitke pod Sigetom onodobni su čitatelji mogli rekonstruirati makar na temelju usmenih lirskih i epskih pjesama o sigetskoj katastrofi, koje su u njihovo vrijeme (još uvijek) kružile među nepismenim i ne samo nepismenim pukom i u sadržaje kojih su se - kako je poodavno već utvrđeno - pri sastavljanju svojega mađarskog, odnosno hrvatskog epa ugledala i sama braća Zrinski. ${ }^{440}$ Uostalom, živa uspomena na junaštva (glavninom) hrvatskih branitelja Sigeta predvođenih Nikolom Šubićem Zrinskim iz kolektivnoga pamćenja još uvijek nije bila iščezla, pa i usprkos nemilim događajima u Bečkome Novom Mjestu, za kojima je uslijedila žestoka stigmatizacija nekad moćne porodice Zrinski, o kojoj - između ostalog - svjedoče i neke „,narodne“ pjesme što najvjerojatnije potječu upravo iz toga doba. Nije, jednako tako, nemoguće ni da su pojedini recipijenti informacije o turskom zauzeću Sigeta još i tada imali prilike upiti zahvaljujući letcima koji su vijesti o ishodu bitke diljem Europe - pa i u nas započeli širiti odmah poslije njezina svršetka u ranu jesen 1566., no iako je bila riječ o sredstvu izvještavanja koje se, obično nakon konkretnih važni(ji) događaja (poput primjerice - Mohačke bitke, pogubljenja Zrinskog i Frankopana i sl.), pokatkad pojavljivalo i na našim prostorima, većinom je njihov izostanak $\mathrm{u}$ hrvatskoj kulturi kompenzirala vrlo bogata folklornoknjiževna produkcija (mahom epske i lirske pjesme o danim zbivanjima), a uz njih i sve češće naglašeno folklorizirane pučkoknjiževne obrade tih istih događaja. ${ }^{441}$

Odlučivši se opjevati „tradicionalno“ epskopjesnički, čitateljima i više nego dobro znan povijesni događaj, a k tome se još i mnoštvom intertekstualnih (sadržajnih, formalnih, pa i - kako ćemo vidjeti - žanrovskih) poveznica ,priključiti“ na „,zrinijadu“ neposrednoga prethodnika, Ritter kao da je Odiljenju doista želio priskrbiti (i) epskopjesnički identitet, itekako dobro znajući da je žanr povijesnoga epa u njegovo vrijeme ne samo dozvoljavao, već i otvoreno preferirao mnoge od onih tekstualnih postupaka za kojima je i sam obilato ondje posezao. Ostavimo li (zasad) po strani njegovu najvjerojatniju angažiranost oko propagiranja očiglednih religijskih (protureformacijskih) i političkih (baroknoslavističkih) ideja te uopće postavljanja ideoloških temelja za buduće svehrvatsko ujedinjenje, o kojima će nešto kasnije biti više riječi, neće tako biti pretjerano ustvrditi da Odiljenje sigetsko uključuje niz značajki vrlo bliskih ili čak posve identičnih onima za koje smo maločas utvrdili da su bile dio

\footnotetext{
${ }^{439}$ Usp. Pavličić 2007: 273-277.

${ }^{440}$ O tome u: Novalić 1967b: 22-46.

${ }^{441}$ Podrobno o tome u: Zečević 1978: 436.
} 
generičkoga repertoara sedamnaestostoljetne junačke epske pjesme. Epski „sumnjivima“ u tom bi se smislu mogle označiti kako tematika, tekstualne pojedinosti preuzete od „epskopjesničkoga“ uzora i protkanost obilježjima različitih „neepskih“ žanrova, tako i govornici (,,pripovjedači“) koji pripadaju samome prikazanom svijetu i k tome još otvoreno progovaraju o svojim emocionalnim stanjima, uključivanje romantičnih i mitoloških motiva u pretežno povijesni sadržaj, slika stvarnosti kao složenoga fenomena kojeg ne usmjeravaju (isključivo) nebeske odluke te već spomenuta neprekidna temporalno-spacijalna pomicanja koja - uvjetno rečeno - rezultiraju kadšto i osjetnijim prazninama u „radnji“. Što se, pak, same „radnje“, odnosno „priče“ razbijene u fragmente što ih Vitezović razbacuje duž svoga teksta tiče, njoj - promatramo li je iz perspektive kronološkoga tijeka bitke pod Sigetom - u načelu ne nedostaje niti jedan važniji moment, a ni činjenica da o različitim njezinim etapama iz različitih gledišta pripovijedaju posve različiti govornici - kako će pokazati nešto podrobnija analiza - pritom možda ne bi trebala unaprijed isključiti mogućnost da svi oni zajedno ili makar stanovit broj njih pripada(ju) jednom te istom „tipu“ naratora.

Pođemo li, dakle, od već primijećene sklonosti baroknoga povijesnog epa za vrlo česta iskakanja iz pravocrtnoga kronološkog tijeka radnje, i za Odiljenje sigetsko moći ćemo utvrditi da je - možda i na tragu pojedinih sedamnaestostoljetnih epskopjesničkih ostvarenja njegova vremenska dimenzija oblikovana izrazito skokovito, što se razabire već iz načina raspoređivanja govornika i njihovih iskaza, u koje su i utkani signali o konkretnim trenucima kazivanja. Primjerice, prvi se tako „dil“ Ritterove „zrinijade“ otvara pismom personificirana Sigeta upućenu ,gospojama hrabrenim i hrvatskim vilama“ (Siget hrvatskim gospojam; I: 1477), u kojemu se majkama i suprugama u tom času već poraženih i mrtvih sigetskih branitelja pruža utjeha, da bi se fokus zatim iznenada vratio u vrijeme same opsade, i to na razgovor kapetana Zrinskog i sina mu Jurja (pjesme Ban sinu i Sin banu; I: 478-568 i 569603), koji odlučno odbija očev prijedlog za spasonosnim bijegom iz Sigeta stegnutog u turski obruč. Snažnoj temporalnoj fluidnosti, koja obilježava i naredne dionice Odiljenja usprkos, pojedinim se proučavateljima učinilo da bi - promatra li ga se na višoj kompozicijskoj razini - u vremenu ,priče“ “ipak bilo moguće uočiti postojanje stanovite kronološke pravocrtnosti, pa dok se tako prvi i veći dio druge dionice teksta odnose na posljednje dane i sate bitke okončane porazom Sigećana, pjesma Gospodična Sofija i oral (II: 735-906) tematizira vrijeme neposredno nakon turskog trijumfa, dok su pjesme u posljednjim dvama „dilovima“ vremenski pozicionirane u razdoblje koje je već zamjetnije udaljeno od konca rata za Siget. ${ }^{442}$

${ }^{442}$ Usp. Dukić 2002: 68. 
Premda bi ovo izuzetno zanimljivo, no ne i sasvim precizno čitanje ${ }^{443}$ Odiljenja dalo naslutiti kako na opjevavanje samog vremena opsade tako otpada - kvantitativno - gotovo polovina čitava teksta, toj vremenskoj perspektivi pripada zapravo svega devet pjesama prvoga i drugoga „dila“, 444 odnosno točno 498 od sveukupno 2313 stihova, što bi bilo tek nešto više od petine teksta, dočim preostali njegov dio zapremaju iskazi iz (od svršetka opsade manje ili više udaljenih) kasnijih vremenskih razdoblja. To, na kraju krajeva, i jest posve u skladu s osnovnim sadržajnim usmjerenjem djela ka opjevavanju višestrukih oproštaja, koji znatno šire implikacije i dobivaju tek nakon turskoga zauzeća utvrde (jer zbog njega tuguju čitave kršćanske obitelji, domovina, cjelokupno Kraljevstvo, pa i Crkva, vile te putnici koje će u kasnijim mjesecima ili čak godinama put nanijeti u neposrednu blizinu Sigeta), a ne neposredno pred posljednji okršaj, kada je ,pravo“ na nj imala „tek“ ona šačica branitelja (i, dakako, Siget kao branjenik), koji se jedni od drugih rastaju netom prije no što će položiti živote za „kralja, veru i orsag“. Odatle i - moglo bi se naslutiti - toliko izražena kvantitativna razlika u ukupnoj količini stihova koji otpadaju na „odiljanja“ manjine ratnika spram onih koji dolaze u iskazima govornika iz redova znatno mnogobrojnije skupine ožalošćenih.

Pod pretpostavkom da u Odiljenju sigetskom vrlo vjerojatno imamo posla s tekstom koji je pojedinim svojim obilježjima želio sugerirati, između ostalog, i (djelomičnu) generičku bliskost žanru barokne povijesne epske pjesme, neće biti izlišno te njegove možebitne „epske“ crte razmotriti iz očišta teorije pripovijedanja, čiji se alati ionako najčešće i rabe pri tumačenju pojedinih primjeraka ovoga (narativnog) žanra. Ukoliko bi se, shodno naratološkoj aparaturi što ju je u svojoj čuvenoj studiji Pripovjedni diskurs još sedamdesetih godina prošloga stoljeća ustanovio Gérard Genette, ${ }^{445}$ i Vitezovićevo poigravanje s vremenskim nivoima tako pokušalo sagledati u kontekstu strategija koje narušavaju pretpostavljenu kronološku

\footnotetext{
${ }^{443}$ Dukić, naime, očigledno previđa uvodnu pjesmu koja zaprema najveći dio (477 od sveukupno 603 stiha) prve dionice Odiljenja, a u kojoj nipošto nije riječ o vremenu opsade, već trenutku neposredno nakon trijumfalnog ulaska Turaka u grad (dakle, perspektivi odmah poslije bitke). Prava granica vremena opsade i okršaja od vremena poslije njega u drugome bi, pak, dijelu trebala biti pomaknuta znatno unatrag, u pjesmu Siget kralju (II: 440-466), u kojoj Siget pismom izvještava kralja o završetku bitke uslijed koje je njegova kruna izgubila vlast nad utvrdom, zbog čega se više ni ne mora truditi slati mu eventualnu pomoć (,Za pomoć slat više skrbiti se nemoj. / Turci grad dobiše i drže kako svoj“; II: 464-465). Povrh toga, kao problematično se mjesto u nizu pjesama s početka drugoga „dila“ ispostavlja i poslanica Kralj banu (koncipirana kao „odgođeni“ odgovor na prethodno banovo pismo koje do Beča nikada nije ni stiglo), u kojoj je već riječ o vremenu poslije pogibije kapetana Zrinskog (,Da ti pomoć priti ne činih u ti kraj / za moć te kripiti, zgovorena imaj, / jer prvo glas (to znaj) da mi došal nije / nego slišah vapaj: Siget grad turski je! - / i da tebe prije, bane, smrt nemila / ter tvoje delije s tobom umorila“; II: 78-83), a identičan se zaključak nameće i pri susretu s pjesmom Orsag banu, gdje personificirana domovina već preminulome banu otkriva kako je dobro upoznata s njegovim junaštvima i smrću (,„cusmo tve veliko borenje i rane / i smrti ke brane vratit ti se k svojim“; II: 119-120).

${ }^{444}$ Ban sinu i Sin banu iz prvoga dijela (I: 478-603) te Ban kralju, Ban orsagu, Ban Sigetu, Siget banu, Ban junakom, Junaci banu i Siget banu i vojnikom u drugome dijelu (II: 1-57, 93-117, 147-439).

${ }^{445}$ Riječ je, dakako, o knjizi Discours du récit (1972.), na koju se ovdje referiramo prema engleskom prijevodu Jane E. Levin (usp. Genette 1980).
} 
pravocrtnost fabule ili u okvirima tzv. „vremena priče“, ${ }^{446}$ u tom bi slučaju - s obzirom na njegove uokvirujuće dijelove (uvodnu pjesmu Siget hrvatskim gospojam, odnosno zaključni ciklus nadgrobnica iz četvrtoga „dila“) - bila zapravo riječ o analeptički orijentiranom tekstu koji „sadašnju“ situaciju (potrebu oproštaja od branitelja poginulih pod Sigetom) napučuje motivski srodnim „momentima“ iz razdoblja neposredno prije zauzeća utvrde, i to evociranjem međusobnih oproštaja Sigećana, koji se nameću kao pojašnjenje i svojevrstan uzor ,aktualnim“ rastancima. Kraćim analeptičkim iskliznućima u period opsade ispresijecani su i tekstovi koji - vremenski - pripadaju ,postopsadnom“ vremenu, pa se tako pojedinosti iz kršćansko-muslimanskoga okršaja prisjeća već Siget u uvodnom pismu ,gospojama“, a potom i vila u pjesmi Vila Hrvatkinja nad Sigetom (II: 614-734), orao u tekstu Gospodična Sofija i oral, vila Jeka u dijalogu s putnikom u trećemu dijelu (III: 1-376), kao i pojedini pokojnici u epitafima završnoga „dila“, koji događaje iz vlastitih života evociraju ne bi li putnike podsjetili na prolaznost i neizbježnost smrti. U cilju jačeg naglašavanja analeptičke usmjerenosti djela, u maločas pobrojanim dionicama koje pripadaju vremenu neposredno prije pada grada dominira, uz to, i glagolski prezent, kojim se fingira izvorna istrgnutost spomenutih - pisanih i usmenih - obraćanja iz prošlosti, što kao da žele ponuditi svojevrstan obrazac dostojanstvenoga rastanka od Sigeta i Sigećana svima onima koji iza njih ostaju.

Već i letimična bi analiza temporalnih dimenzija Odiljenja i više nego uvjerljivo trebala dati do znanja kako dosadašnji odrješiti sudovi o Vitezoviću kao autoru koji u svojoj literarnoj obradi opsade Sigeta - točnije, njezinih posljednjih trenutaka i neposrednih reperkusija - u potpunosti zaobilazi pripovjedne strategije karakteristične (i) za baroknu epsku pjesmu naprosto ne stoje, odnosno da očigledno nisu doneseni na temelju njegova promatranja pod naratološkim ,povećalom“, pod kojim ova ,zbirka lirskih pjesama objedinjenih temom sigetske bitke“ (Pavličić 2007: 277) nepogrešivo otkriva i svoje „epsko“ lice. Zamislimo li (dakako, samo uvjetno) Odiljenje kao kompaktan narativ s jedinstvenom, cjelovitom i sveprožimajućom pričom, tada bi se ono - govoreći u naratološkim terminima što ih je inaugurirao Genette pišući o odnosima koji reguliraju pripovjedni „tempo“ - moglo okarakterizirati kao tekst u cijelosti istkan od sceničnih ${ }^{447}$ iskaza (dakle, svjedočanstava aktera koji su - na bilo koji način - sudjelovali u okršaju pod Sigetom, odnosno koji su bili ili jesu zahvaćeni njegovim posljedicama), koji se na drugoj - smisaonoj - razini povremeno premeće

\footnotetext{
${ }^{446} \mathrm{O}$ „,vremenu priče“ (ispričanih događaja) kao suprotnosti „vremenu naracije“ (pripovjednom vremenu) opširnije u: Genette 1980: 33-35.

447 „Scena“ - prema Genetteu - podrazumijeva odsječke narativnoga teksta u kojima se, u punoj njegovoj doslovnosti i bez najmanjih intervencija pripovjedača, donosi upravni govor likova. Usp. Isto: 109-112.
} 
u „sažetak“, 448 i to ispresijecan brojnim „elipsama“4449 što proizlaze iz nejednakih kutova gledanja na samu bitku, točnije iz potrebe neprekidnoga premještanja fokusa na različite njezine etape i sudionike. „Scena“, koja obuhvaća pisanu i usmenu komunikaciju među akterima, u njemu je pritom - osim mjestimičnim (kronološki organiziranim) „sažetkovnim“ odsječcima premreženima „elipsama“ ili prazninama u „priči“ - nadopunjena i povremenim „pauzama“, koje se - umjesto uobičajenih više ili manje rastegnutih opisa - većinom ondje svode na relativno kratke komentatorske i refleksivno-poučne osvrte. ${ }^{450}$ Bez obzira, ipak, na utvrđenu dominaciju modusa „scene“ protkane ostalim čimbenicima narativnoga ritma, čini se kako posvemašnja pobrkanost vremenskih razina proizišla iz razbijanja središnjega događajnog tijeka i prebacivanja sadržajnog fokusa na posljednje dane opsade i razdoblje koje je za njima uslijedilo zapravo želi sugerirati pretežno eliptični karakter Odiljenja sigetskog, u čijoj se razmrvljenoj kompoziciji ionako zrcali sadržajno preskakanje najbitnijih segmenata priče o turskom zauzeću Sigeta. Time se, međutim, nipošto ne pokušavaju negirati ona maločas uočena uzgredna i sporadična referiranja na tijek bitke, pa i u cijelosti narativno realizirani odsječci Odiljenja koji funkcioniraju kao svojevrstan rezervoar - stvarnih i literarnih - podataka o sigetskoj katastrofi, među kojima se upravo uvodna pjesma (poslanica $^{451}$ ) Sigeta, u kojoj se „gospojam i vilam“ podnosi izvještaj o zbivanjima što su rezultirala smrću njihovih najbližih, izdvaja kao segment teksta u kojemu se tema sigetskoga poraza - iako slijedi pojedinosti iz ranijih obrada - pripovjedno možda i ponajbolje uobličuje.

Pjesma Siget hrvatskim gospojam, konkretno, nije tek (scenična) dionica Vitezovićeve „zrinijade“ koja u jednome svom segmentu (od sveukupno 477 stihova na koliko se prostire) razvija relativno koherentnu naraciju o osvajanju sigetske utvrde i smrti njezinih branitelja, već i odsječak Odiljenja u kojemu je moguće locirati sva četiri osnovna pripovjedna odnosa o kojima je netom bilo riječi: od govornikovim iskazom ustanovljene „scene“, preko „sažetka“, u kojemu se evociraju pojedinosti iz kršćansko-muslimanskog sukoba ispresijecane nizom „elipsa“ ili praznina što će ih (donekle) popuniti iduće pjesme, pa sve do „pauze“ koja se kristalizira u lamentacijama Sigeta nad vlastitim usudom i pokušajima da se ucviljene

\footnotetext{
${ }^{448}$ Genetteov termin „Sažetak“ odnosi se na one dionice pripovjednoga teksta u kojima se sažimaju podaci o djelovanju konkretnih aktera u prostorno-vremenskom kontinuitetu. „Sažetak“ bi, ukratko, bio priča u punom smislu riječi. Detaljnije u: Isto: 95-99.

449 „Elipsa“, konkretno, uključuje preskakanja pojedinih događajnih momenata ili zbivanja u cijelosti, i to s ciljem ubrzavanja „sažetka“. Usp. Isto: 106-109.

${ }^{450}$ Modus „pauze“ - kao četvrtoga Genettova čimbenika narativnog ritma - najčešće obuhvaća opisne dijelove teksta, ali podjednako se on odnosi i na segmente u kojima pripovjedač otvoreno stupa u priču s nakanom zauzimanja jasnoga (kritičkog, komentatorskog) stava prema ispričanome. Podrobno u: Isto: 99 i dalje.

${ }^{451} \mathrm{Da}$ je, naime, riječ o pismu, a ne ,tek“ govor(e)nom prenošenju vijesti o padu grada, eksplicira se u 245. i 246. stihu pjesme, gdje kazivač izražava žaljenje što ,gospojama i vilama“ nije mogao odaslati povoljniji izvještaj („Glase od njih bolje rad bih bil pisati, / al zla srića volje dobre ne hti dati“).
} 
„gospoje“ utješe poukama o hirovitoj sreći i neizbježnosti smrti. Najveću, dakako, pozornost u njoj plijeni spomenuta narativna dionica, koja se ujedno nameće kao možda i jedini „punokrvni“ (sižejno-fabularni) segment teksta, unutar kojega se u pravocrtnomu slijedu donose pojedinosti o tijeku opsade ne bi li se adresatkinje informiralo o pogibiji njihovih najmilijih, ali uz to i ispisao (idejni) okvir kako za žalopojku Sigeta, tako i za sve kasnije pjesme koje će se na nj referirati i postupno ga nadograđivati rasvjetljujući sigetski poraz iz drugačijih kutova. Riječ je o odsječku „pisma“ što ga zagrađuju 89. i 244. stih, odnosno koji je uokviren dionicama posvećenima naglašeno emotivnom, refleksivnom pretresanju gubitka i potrebom oproštaja od onih koji se neće vratiti svojim obiteljima, a u kojemu - rame uz rame - supostoje (povijesno provjerljivi) detalji iz opsade što ih je u svome kronikalnom prikazu prvi donio Ferenc Črnko (a potom u svoje „zrinijade“ preuzeli Barne Karnarutić i braća Zrinski) te čisto fiktivni motivi koje Vitezović posuđuje iz Obside sigecke Petra Zrinskoga. Upravo stoga u ovoj se epskoj „sličici“ od 150-ak stihova, pored podsjećanja na dolazak Turaka, njihovo raspoređivanje oko grada, prve kršćansko-muslimanske sukobe, uzaludno iščekivanje kraljeve pomoći, odvažno izjahavanje branitelja predvođenih Zrinskim na konačni okršaj te njihovu pogibiju i tursko zauzeće Sigeta, i nalaze motivi poput kobnoga putovanja dvojice „silnih vojvoda“ s vijestima u Beč (I: 127-136), kao i vrlo dojmljivo intertekstualno evociranje epizode s osujećenim letom goluba pismonoše na kraljev dvor (I: 163-174).

Odsječci uvodnoga izvještaja personificirana Sigeta koji uokviruju njezin pripovjedni segment (I: 1-88 i 245-477), premda također „kontaminirani“ mjestimičnim narativnim tragovima, lišeni su (kronološki, sižejno) strukturirane priče (dakle, „sažetka“ u punom smislu riječi) i teže stvaranju suosjećajno-utješne atmosfere kroz izmjenu lamentacijskih segmenata i poučno-refleksivnih dionica protkanih sentencioznim (poslovičnim) konstruktima (od kojih posebno valja izdvojiti one o neizbježnosti smrti, ${ }^{452}$ o kojima će doskora biti više riječi), a sve u cilju ublažavanja neizrecive boli koju su zabrinutim majkama i suprugama izazvale vijesti o smrti njihovih sinova i muževa. I dok prva lamentacijsko-refleksivna dionica evociranjem radosnoga dolaska Hrvata u Siget (,kot u svate“; I: 29) te otkrivanjem konačnoga ishoda bitke („Svi ti mrtvi leže vitezi hrabreni“; I: 69) - u naratološkom pogledu - priprema tlo za nadolazeći pripovjedni dio, u onoj drugoj, pak, dolazi do sadržajne konkretizacije utjecaja povijesnoga epa Petra Zrinskog, na kojeg su u narativnome odsječku i više nego jasno aludirala podsjećanja na dvije epizode preuzete iz Opside sigecke. Ta se sadržajna konkretizacija pritom ne svodi samo na motiv uvođenja duša izginulih branitelja u raj („,Bog

\footnotetext{
452 Poslovice ili sentencije o neizbježnosti smrti u pjesmi Siget hrvatskim gospojam javljaju se u čak nekoliko navrata (I: 265-272, 277-278, 301-304, 381-384, 407-408).
} 
ih čini priti da u raju stoje“; I: 315), koji priziva prepoznatljiv detalj iz epova obojice braće Zrinski (u kojima - podsjetimo - radnju i pokreće Božja kazna, nakon čijeg ispunjenja dolazi do uznesenja žrtvovanih kršćana na nebo), već se pojavljuje i u obliku kataloga likova (I: 365378), u kojemu su pobrojani neki od najvažnijih aktera iz Petrova spjeva (Deliman, Demirhan, Rustan, Amirašen, Embrulah, Deli Vid), ali i evocirane pojedine situacije (tj. epizode) iz Opside - poput dvoboja Deli Vida i Demirhana te Rustanovo ubojstvo pod Sigetom što ga je skrivio Deliman - u kojima su osobno neki od njih sudjelovali. ${ }^{453} \mathrm{Na}$ taj način Vitezović već od prve pjesme Odiljenja prilično jasno daje do znanja kako od čitatelja očekuje, prije svega, dobro poznavanje samih povijesnih činjenica, odnosno kronologije pada Sigeta, ali uz nju i fabula prethodnih ,zrinijada“ - a naročito one Petrove - u kojima je ta „sirova“ faktografija bila već literarno obrađivana i dorađivana, ${ }^{454}$ čime je i stvorena nužna podloga za opjevavanje dotad neopjevanih bolnih rastanaka što ih je uzrokovao ovaj silno važan povijesni događaj.

Intertekstualno prikapčanje na Petrov povijesni ep nastavit će se i u idućim dvjema pjesmama prvoga „dila - Ban sinu (I: 478-568) i Sin banu (I: 569-603) - zamišljenima kao dijalog (obraćanje i odgovor) oca i sina, u kojima se razrađuje također dobro znana, izrazito emotivna epizoda iz petoga pjevanja Obside, gdje ban Zrinski bezuspješno pokušava nagovoriti sina Jurja da napusti opkoljeni Siget. Pritom je i više nego evidentan poprilično dubok temporalni rez u odnosu na prethodnu lamentaciju personificirana Sigeta - zbog kojega se navedene pjesme doimaju kao svojevrsna analepsa, odnosno retrospektivno „povlačenje“ $u$ trenutak u kojemu su akteri što ih je Siget maločas proglasio mrtvima još uvijek živi, ali iščekuju skoru smrt, koja ih i tjera na međusobno „odiljanje“ - koji, kako će se uskoro pokazati, zapravo označava korjenitu izmjenu vremenske perspektive s obzirom na to da dirljivi razgovor oca i sina stoji na početku čitavog ,vala“ rastanaka (koji se protežu do duboko u drugi „dil“) kršćanskih sudionika bitke, poduzetih neposredno uoči njihove pogibije. Sadržaj ovih dviju pjesama također je protkan impliciranim fabularnim momentima, većinom vezanima uz motiv sve intenzivnijih neprijateljskih napada na grad (,Jurju dite moje, vidiš, da kot mravi / od svih stran nastoje turski na nas lavi“; I: 478-479) te anticipaciju skoroga poraza kršćanskih branitelja (,odkud neg teškoće moremo se nadat, / jer naše slaboće sila će obladat“, I: 489-490), zahvaljujući kojima i jest poprilično lako odrediti sam trenutak u

\footnotetext{
${ }^{453}$ Navedeno mjesto, konkretno, glasi: „Kako grad na boje obseđen ležaše, / od ke strane moje carov šator staše; / odkud grad rvaše s bručenimi lavi, / kako se držaše Embrulah gizdavi; / kadi konak stavi vojvoda Deliman / i u mnogoj slavi Amirašen iman; / gdi se Selim sultan - carov sin držaše / i carov zet Rustan zpod Hama ležaše; / kud ziti znaše s Hrvati slavni ban, / gdi poboj činjaše Del' Vid i Demirhan; / kuliko koji dan Turak pogubiše, / ki bi Turčin vridan, kuliko svih biše, / kako dosvršiše te sigetske rate, - / svak povidat htiše, gdi se k vam povrate“ (I: 365-378).

${ }^{454} \mathrm{O}$ rečenim (pred)znanjima što ih je ciljani čitatelj Odiljenja - kako se čini - najvjerojatnije morao posjedovati detaljnije u: Pavličić 2007: 270-284.
} 
kronologiji opsade kojemu pripadaju i koji se ujedno nameće i kao vremenska „kulisa“ sljedećih nekoliko pjesama, redom smještenih u drugi „dil“ teksta.

Najveći dio druge dionice Odiljenja u sadržajnomu se, ali i u pogledu samoga modusa obraćanja snažno nadovezuje na prvi „dil““, što će reći da je u njemu i više nego očit kontinuitet kako u opjevavanju posljednjih dana opsade ( $\mathrm{u}$ prvih deset pjesama), tako i u samomu načinu na koji govornici upućuju svoje iskaze, replike i/ili odgovore (usmenim ili pisanim, tj. pismovnim putem). Ipak, za razliku od triju pjesama prvoga dijela, čija se narativna obilježenost potvrđuje kroz kratko rekonstruiranje kronologije opsade u obliku svjedočanstva o prošlom svršenom vremenu, odnosno uvođenjem (,sada“) već izginulih njezinih sudionika i evociranjem nekih momenata iz kršćansko-muslimanskog sukoba unutar njihova dijaloga, u drugom ,dilu“ teksta najpouzdanijim indikatorom narativnosti ispostavlja se protok vremena što ga implicira slijed banovih iskaza (upućenih kralju, potom „orsagu“, pa Sigetu i - naposljetku - suborcima) kojeg odjednom prekida obraćanje Sigeta braniteljima (Siget banu i vojnikom; II: 361-439) u trenucima njihova poraza, za kojim slijedi i njegov pisani izvještaj o turskom zauzeću grada kralju i rimskoj Crkvi te tužaljka Siget zvrhu samoga sebe (II: 517-613), a zatim - u posljednje dvije pjesme ove dionice - i konačno ušutkivanje Sigeta koji se više „ne klanja krstu“ te - na koncu - zamjetnije vremensko i mjesno udaljavanje od ,pozornice“ što su je netom zaposjeli turski osvajači. (Provizoran) pripovjedni karakter drugoga dijela iz toga razloga ne dovode u pitanje ni iznimna prorijeđenost konkretnih narativnih (fabularnih) signala, a ni odsustvo ,sažetka“ kakvim se diči uvodna pjesma Siget hrvatskim gospojam, tim više što upravo (redo)slijed pjesama, a uz njega i pojedine događajno-temporalne aluzije utkane u pretežno refleksivne sadržaje, dostojno zamjenjuju „sažetak“ kao takav, odnosno nadomještaju objektivan prikaz bitke i pojedinačnih sudbina dramom u unutarnjim (psihičko-emotivnim) proživljavanjima neposrednih sudionika te onih kojih će se njihov poraz od Osmanlija izravno itekako ticati. ${ }^{455}$

Granicu između prvoga i drugoga dijela Odiljenja sigetskog valjalo bi, osim toga, motriti i u optici još jednoga vremenskog reza, koji će - u odnosu na trenutak u kronologiji opsade što ga pretpostavlja dijalog sigetskoga kapetana i njegova sina - sadržajni fokus prebaciti u nešto raniju temporalno-događajnu točku. Pretpostavi li se, naime, da je u prvoj pjesmi (poslanici) drugoga dijela - Ban kralju (II: 1-57) - riječ upravo o onom pismu što ga je, po očevu nalogu, Juraj Zrinski trebao osobno dostaviti na kraljev dvor (a koje će, slijedi li se fabularni tijek iz Petrova epa, kasnije podjednako neuspješno biti poslano po vojvodama

\footnotetext{
${ }^{455} \mathrm{U}$ potonje se - sadržajno, ali ne i vremenski - računaju i pjesme Kralj banu (II: 58-92) te Orsag banu (II: 118-146), kojih se kazivači javljaju iz trenut(a)ka poslije banove smrti i konačnoga turskog zauzeća Sigeta.
} 
Radivoju i Juraniću te golubu pismonoši), tada bi i trenutak njegova sastavljanja - koji se i želi simulirati prilaganjem pisma - očito padao u vrijeme neposredno prije razgovora oca $\mathrm{i}$ sina, tijekom kojega je ono već moralo biti napisano i spremno za „slanje“. Preskoči li se kraljev odgovor već poginulomu banu u poslanici Kralj banu (II: 58-92), očito je da tek od pjesme Ban orsagu (II: 93-117) - izuzev još jednoga „skoka“ u vrijeme nakon osmanlijske pobjede u pjesmi Orsag banu (II: 118-146) - doista kreće linearni slijed „zbivanja“ impliciran nizanjem bolnih rastanaka s kojima se i Siget nezaustavljivo približava času svoga pada. Naročito se pritom interesantnim ispostavlja oproštaj Zrinskoga i Sigeta u pjesmama Ban Sigetu (II: 147-189) i Siget banu (II: 190-278) budući da motiv inzistiranja Sigeta na tome da ga Zrinski bez borbe preda Turcima („Daj me jur sad 'z mira, jur sam na niš spravljen“, II: 234) uspostavlja jasne smisaone veze s identičnim motivom što ga zatječemo i u uvodnome pismu „gospojam i vilam“ („Prošćenje mi dahu umrit za me hteći, / da na to pristahu, plakah govoreći, / nek se pogodeći s Turci v sili ovoj / mene njim pusteći sahrane život svoj“, I: 186190), koji je - dakako - ništa drugo no očita aluzija na epizodu iz Obside sigecke, u kojoj car Sulejman preko poslanika nudi Zrinskome darove u zamjenu za mirnu predaju grada.

Ratni govor bana Zrinskog suborcima (Ban junakom; II: 269-347) te njihova prisega što je izriču u pjesmi Junaci banu (II: 348-360) - jamačno također ispjevani po uzoru na Obsidu, a kao sadržajni refleks ranijih obrada sigetske katastrofe (Črnka, Karnarutića, a možda i pojedinih usmeno- i pučkoknjiževnih) - posljednji su iskazi iz ustiju sigetskih branitelja prije završnoga okršaja, kojeg će do kršćanskoga poraza („Veće se ne vide Hrvati hrabreni, / smrt turskom naslide silom pokriveni“; II: 431-432) ispratiti sam Siget u pjesmi Siget banu i vojnikom (II: 361-439), ne zaboravljajući pritom ni „zrinskijevski“ zaziv Boga i zbora anđela, zaduženih za prenošenje Sigećana na nebo. ${ }^{456}$ Uslijedit će, potom, vremenska perspektiva neposredno nakon pada grada (sati, moguće i dani?), kojoj pripada ciklus izvještaja što ih Siget piše i odašilje različitim adresatima - kralju, ${ }^{457}$ rimskoj $\mathrm{Crkvi}^{458}$ te „Ugrinima perjenima“ u pjesmi Siget zvrhu samoga sebe (II: 517-613) - obavještavajući ih kako se grad više ne nalazi u rukama „krune svete“ te kako se sustavno u njemu zatiru tragovi kršćanske vjere, a ujedno i upućujući žestoku kritiku Ugarima koji nisu pritekli u pomoć hrvatskoj „,braći“ u nevolji, što bi im se doskora moglo višestruko osvetiti (,,nadaj se s vrimeni težu skrb neg ovu: / ki ti j' pred bedeni, dojde t' oganj krovu“; II: 605-606). Prijelaz u novu smisaonu (u kojoj riječ uzimaju transcedentalna bića i personificirane životinje), pa i donekle

\footnotetext{
${ }^{456}$ Ovako se u Odiljenju varira taj motiv iz Petrove Obside: „Bože obilati, u komu sva stoje, / molim, htij poslati k njim anjele tvoje, / koji mi na svoje njih primeju ruke, / odnesu v pokoje 'z ove trudne muke“ (II: 425-428).

${ }^{457}$ Riječ je o pjesmi Siget kralju (II: 440-466).

${ }^{458}$ U tekstu Siget rimskoj Crikvi (II: 486-516).
} 
temporalnu dimenziju, tek neznatno udaljeniju od vremena pisanja i odašiljanja spomenutih završnih izvještaja Sigeta, označit će pjesma Vila Hrvatkinja nad Sigetom (II: 614-734) koncipirana kao odgovor na uvodnu poslanicu Siget hrvatskim gospojam („Al mi zvrhu toga zlo sad Siget piše, / da smrt od turskoga meča svi podniše“; II: 658-659) - koja zaokružuje ciklus pjesama usko vezanih uz propast Sigeta (tj. vremenski smještenih na sam kraj opsade i razdoblje neposredno nakon nje), a već sljedeći tekst - dijaloška pjesma Gospodična Sofija i oral (II: 735-906) - podrazumijeva mjesno (ali ne i osjetnije vremensko ${ }^{459}$ ) udaljavanje, na koje upućuje motiv prenošenja vijesti o porazu kršćana pod Sigetom zabrinutoj zaručnici jednog od branitelja, do koje glasine o turskom trijumfu još uvijek nisu mogle doprijeti.

Nezanemariv narativni značaj potonjih pjesama, koje zaključuju drugi „dil““ Odiljenja, krije se u njihovoj premreženosti fabularno važnim podacima kojima se dopunjuju raniji pripovjedni segmenti teksta, odnosno koji uvelike pojašnjavaju pojedine tek ovlaš dotaknute fabularne momente, a mjestimice uvode i neke sasvim nove, mahom - dakako - preuzete iz Petrove Obside. U pjesmi Vila Hrvatkinja nad Sigetom tako će, primjerice, biti ponovljen (i proširen) katalog „,zrinskijevskih“ likova što ih je čitatelj već imao prilike „upoznati“ u uvodnom pismu Sigeta (u njemu će se, pored Delimana, Demirhana i Rustana, sada naći još i Kurt, Mehmet, te Sulejman ${ }^{460}$ ), a ondje će se - po prvi put u tekstu - (po)javiti i motiv Hajkune i njezine odvažnosti (,Odtud ze jakosti i Hajkune tvoja / i učini dosti srid turskoga boja“; II: 694-695), koji se zatim dodatno još pojašnjava u trećemu (III: 119-134) i četvrtom, nadgrobničkom dijelu Odiljenja, gdje se kroz zajedničke epitafe Julijane (Hajkune) i Deli$\mathrm{Vida}^{461}$ aludira na ranije iznijetu epizodu s Hajkuninim izbavljenjem supruga iz turskoga tabora preuzetu iz Obside. Narativni, pak, fragmenti svjedočanstva o tijeku sigetske bitke, što će ih zabrinutoj Sofiji u pjesmi Gospodična Sofija i oral prenijeti personificirani orao, prilično su podudarni onima iz izvještaja Sigeta, ali i onima što ih zatječemo u pismima i govorima drugih sudionika opsade (podsjeća se tako ondje na opsadu što ju je predvodio Sulejman, potom na palež Sigeta te pogibiju kapetana Zrinskog i ostalih kršćanskih branitelja, među kojima je bio i Sofijin zaručnik Gašpar Alapićc ${ }^{462}$ ), dočim će se nasljedovanje Petrova epa u njoj očitovati putem uključivanja ,podsjetnika“ na već spomenutu epizodu o neuspjelomu turskom pokušaju mirnoga preuzimanja grada (,Obstre bana moga u Sigetu gradu: / grada

\footnotetext{
${ }^{459} \mathrm{Na}$ što upućuje činjenica da je riječ o orlu koji se još uvijek nije dospio oprati od (svježe) ljudske krvi („Vidit te bolčicom, kako mašeš krili / zaštrapan krvčicom, ku ste nigdi pili““; II: 743-744).

${ }^{460}$ Rečeni katalog glasi: „Pred očmi imale jesmo Sulimana, / vazdar se bojale šege Delimana, / moći Demirhana, privare Mehmeta, / naredbe Rustana i Kurtova sveta, / kih imena eta sama ljude straše“ (II: 620-624).

${ }^{461}$ Radi se, zapravo, o čak dvije nadgrobnice: Istoga Deli-Vida i Julijane drugarice (IV: 154-158) i Deli-Vid i Julijana (IV: 159-167).

${ }^{462}$ Uzgred budi rečeno, (,povijesni“) Gašpar Alapić imao je sreću naći se među onih petero Sigećana koji su preživjeli opsadu i nekoliko mjeseci potom bili otkupljeni iz turskoga zarobljeništva (usp. Ratković 1971: 29).
} 
prosi toga da mu naši dadu, / al vole za svoga kralja da svi padu, / nego pod turskoga cara grad podadu“; II: 799-802) te uvođenja motiva „vražjih čarnosti“, pomoću kojih su Osmanlije vršile pritisak na branitelje („Car napri na boje sve svoje jakosti, / meč, oganj takoje, i vražje čarnosti““; II: 803-804), a koji je očita intertekstualna poveznica na epizodu o čarobnjaku Alderanu iz Obside sigecke, na koju će se Ritter nadovezati i u idućim dvama „dilovima“. 463

Prve dvije dionice Odiljenja sigetskog - povrh spomenute uokvirenosti uvodnim pismovnim izvještajem Sigeta zabrinutim ,gospojama i vilama“ te emotivnim (usmenim) odgovorom na nj potresene vile Hrvatkinje i jadikovkom neutješne Sofije - tako možda i najsnažnije sadržajno zaokružuje upravo temporalna perspektiva kojoj pripadaju u njima okupljene pjesme, a koja - ponovimo - obuhvaća raspon od posljednjih nekoliko dana opsade do, otprilike, jednako dugoga vremenskog razdoblja nakon osvajanja grada i zahvaljujući kojoj bismo ih (uvjetno) mogli motriti kao svojevrsnu zatvorenu narativnu cjelinu. Time se, međutim, nipošto ne želi sugerirati možebitna krupn(ij)a idejno-temporalno-narativna distanca među prvim dvama i ostalim dijelovima Vitezovićeve ,zrinijade“, tim više što će se i u trećemu te četvrtom „dilu“ nastaviti opjevavanje bolnih rastanaka iniciranih sigetskom katastrofom, i to pripadnih vremenskoj dimenziji koja je, doduše, osjetnije udaljena od trenutka pada Sigeta, no koja bi se mogla odrediti kao razdoblje koje se proteže do (okvirno) godinu dana nakon svršetka opsade. Osim što je ondje također riječ o iskazima likova koji se nalaze u neposrednoj fizičkoj blizini sada već turskoga Sigeta, valja primijetiti da ni narativni „,interesi“ nisu stali s posljednjim stihovima drugoga „dila“, no u trećem i četvrtom dijelu dolazi ipak do bitne izmjene pojavnih modusa i uloge ,pripovjednih činjenica“, kao i kazivača što ih - nastavljajući sceničnu prezentaciju iz ranijih dionica - uključuju u svoje iskaze.

Ukoliko su, konkretno, prvi i drugi dio Odiljenja sigetskog - u sklopu svoje pretežne sadržajne refleksivnosti i lamentativnosti - podastirali neke osnovne ili primarne narativne momente utkane u pismovne, dijaloške te monološke iskaze neposrednih sudionika ili svjedoka pada Sigeta, u trećemu i četvrtom „dilu“ većinom će biti zastupljene „tek“ kraće narativne dopune, odnosno proširenja primarnih pripovjednih elemenata iz ranijih dionica, $\mathrm{i}$ to donesena iz „druge ruke“, točnije kroz iskaze govornika koji nisu bili izravno upleteni u sam kršćansko-muslimanski okršaj ili koji se - pak - naprosto javljaju iz „druge dimenzije“. U pjesmi Putnik i Jeka - koja zauzima čitavu treću dionicu teksta (III: 1-378) - ostvaruje se tako dijalog putnika, koji se sasvim slučajno zatekao u neposrednoj blizini turskoga Sigeta, te vile Jeke kao mitološkoga bića koje spremno odgovara na putnikova pitanja o sigetskoj katastrofi i

${ }^{463} \mathrm{Na}$ epizodu o Alderanu, koji je u Obsidi prizvao paklene sile ne bi li Turcima pomogle u osvajanju Sigeta, u Odiljenju se dodatno podsjeća i u trećemu (III: 49-52) te četvrtom djelu, i to u nadgrobnici Alderana, vojvode harapskoga (gdje se izrijekom spominju „duhi nemili, / koje dozval biše, / da se za grad trudiše“; IV: 257-259). 
njezinim reperkusijama. S obzirom na to da je riječ o neobično dobro informiranu putniku koji - tražeći od sugovornice da potvrdi točnost informacija što ih posjeduje - postavlja ciljana pitanja o tijeku opsade i osvajanja grada, Jeka u ovome slučaju zapravo i ne dolazi kao nositelj nepoznatih svjedočanstava kojima će značajnije obogatiti putnikovo (pred)znanje, tim više što i njezinu eventualnu involviranost u zbivanja pod Sigetom isključuje već i nešto raniji iskaz vile Hrvatkinje iz pretposljednje pjesme drugoga dijela, u kojemu se jasno navodi da vile ni na koji način nisu participirale u borbi, pa čak ni kao izravne svjedokinje. ${ }^{464}$ Neovisno od takva „odnosa snaga“ među govornicima u ovoj dijaloškoj pjesmi sazdanoj na baroku omiljenoj figuri jeke, riječ je o segmentu Odiljenja koji unosi vrlo bitne pripovjedne „,impulse“ u tekst, odnosno koji uključuje ne samo podsjetnike na (ranije nespomenute) povijesno provjerljive činjenice o opsadi Sigeta poput one o Sulejmanovoj smrti koja ga je spriječila da dočeka pobjedu svoje vojske (III: 79-82) ili one kako je u posljednjem proboju ban Zrinski skončao pogođen puščanim zrnom u lice (III: 165-170), nego i prepoznatljive motive iz literarizacija sigetskoga pada, koji iznova jasno aludiraju na Petrov ep te njegove pobočne, retardirajuće epizode. Pritom je posebno zanimljivo uočiti kako su redom sve narativne komponente baštinjene iz Obside - a isto će vrijediti i za veliku većinu osvrta na sudbine pojedinih junaka uključene u stihove njihovih nadgrobnica u četvrtome „dilu“ zapravo u tijesnoj vezi s katalozima ,zrinskijevskih“ likova uvrštenih u neke pjesme prvoga i drugoga „dila“ (Siget hrvatskim gospojam, Vila Hrvatkinja nad Sigetom), i to zahvaljujući činjenici što svojim fabularnim signalima pojašnjavaju njihovu konkretnu ulogu u bitci te tako opravdavaju i tu raniju nužnost njihova uvođenja (i) u ovu ,zrinijadu““.

Dijalog putnika i Jeke čitatelja će, između ostalog, tako podsjetiti i na ranije već navedene (,zrinskijevske“) motive turskoga slamanja otpora kršćanskih branitelja „čarima“ (III: 49-52) te otvorenoga Božjeg pristajanja uz napadnute Sigećane (III: 61-62), a uz to će još i prethodna dva uvođenja lika Delimana opravdati njegovom nevjerojatnom neustrašivošću u okršajima s kršćanima (III: 109-116), pojavu Hajkune argumentirati pričom o njezinu spašavanju ,ljutoga i jaka kot medvida“ Deli Vida iz turskoga tabora (III: 117-134), dočim će Embrulahovo mjesto u tekstu učvrstiti evociranjem njegove smrti koja je ucvilila vjernu mu „ljubu“ (III: 213-222). Iako identičnim (literarnim) dopunama obiluju i epitafi zaključne, četvrte dionice Odiljenja sigetskog, njihovi pripovjedno dopunjujući motivi neće se odnositi isključivo na likove i situacije donesene u prvim dvama dijelovima, već nerijetko i na one što ih je uvela pjesma Putnik i Jeka, u kojoj njihov značaj u priči o padu Sigeta - onoj, dakako,

\footnotetext{
${ }^{464}$ Odatle i Hrvatkinjin gnjev na Siget, koji je u pismima ublažavao prave razmjere okršaja odbijajući zatražiti pomoć od ratovanju neočekivano vičnih vila (,Zač ne hti prositi i nas k toj teškoći, / da bi te braniti i mi mogle doći? / I u nas su moći k obrambi zgojene, / da b' mogle pomoći, ako smo prem žene“; II: 686-689).
} 
što ju je u svome epu ispričao Petar Zrinski - nije bio preciziran. U tim formalno vrlo raznolikim pjesničkim iskazima donesenima iz - naizmjenično - perspektive prvoga i trećega lica tako će se kontrastirati snaga osvajačke turske vojske neustrašivosti bana Zrinskog i njegove brojčano daleko skromnije čete (Mikule kneza od Zrinja, bana; IV: 63-103), prizivati epizode iz Obside u kojima su opjevana Delimanova junaštva u Sigetu te njegova ljubav prema Kumili (Delimana, sina velikog Hama, poglavnika tatarskoga; IV: 106-121), ali i u nizu pjesama podsjećati na priču o Julijani (Hajkuni) i Deli Vidu, koji se posebno istaknuo porazivši u dvoboju Demirhana - tursku „strahotu jakosti“ (Deli-Vida Žarkovića; Istoga DeliVida i Julijane drugarice; Deli-Vid i Julijana; Demirhana, drugoga vojvode harapskoga; IV: 138-179). Uz nadgrobnicu Amirašenu, u kojoj se evocira još jedan vrlo važan motiv iz Obside - onaj divana ili turskoga vijeća vezira, kojim je upravo Amirašen i koordinirao (Amirašena, velikoga vojvode harapskoga; IV: 126-137), za ranije dionice Odiljenja od posebnoga će pripovjednog značaja biti i već spomenuti epitaf čarobnjaku Alderanu, koji i jest zazvao paklene „čari“ na Siget (IV: 253-262), potom onaj Embrulahu, u kojemu njegovu smrt oplakuje zaručnica (Embrulaha lipoga u kojoj Arpijanine zaručnica plače; IV: 263-308), Rustanu, poginulomu od Delimanove ruke (Rustana vezira; IV: 225-234), te Gašparu Alapiću (IV: 207-214), koji predstavlja izravnu sadržajnu poveznicu na pjesmu Gospodična Sofija i oral s kraja drugoga „dila“, ali i - naročito - dva (uzastopna) epitafa posvećena pobratimima Radivoju i Juraniću, u kojima se razrađuje ranije tek usputno spomenuta epizoda s osujećenim pokušajem iskradanja dvojice „silnih vojvoda“ iz opkoljenoga Sigeta u nakani da kralju dostave vijesti o opsadi (Radivoja i Juranića vojvod; Samoga Juranića vojvode; IV: 352-384).

Razmotre li se, ukratko, pripovjedni „isječci“ trećega i četvrtog dijela Vitezovićeve „zrinijade“ na podlozi osnovnih narativnih momenata prvih dvaju njezinih „dilova“, ispostavit će se da pojedini naši književni povjesnici poput Milivoja Šrepela, koji je još početkom prošloga stoljeća četvrti dio Odiljenja proglasio svojevrsnim dodatkom (,appendixom“), u kojemu Ritter „nadopunjava historiju samoga boja, koju je prije samo sumarno i u refleksijama prikazao“ (Šrepel 1902: 109), te Davora Dukića, koji zbog težnje skiciranju sudbina poginulih junaka u ciklusu nadgrobnica vidi izuzetan informacijski potencijal, ${ }^{465} \mathrm{u}$ svojim zaključcima nipošto nisu bili na pogrešnom tragu. Dapače, u nešto široj analizi, u kojoj bi se ova sadržajno dopunjujuća funkcija četvrtoga dijela razmatrala zajedno s netom uočenim motivskim produbljivanjima ranijih (primarnih) pripovjednih segmenata kakva premrežuju (i) treći „dil“, možda ne bi bilo neopravdano govoriti čak ni o (eventualnim) naznakama (karakteristično renesansne) epskopjesničke simetričnosti - kakvu je, ugledajući se ponajviše

\footnotetext{
${ }^{465}$ Detaljnije u: Dukić 2002: 68.
} 
na Marulićeva epska ostvarenja, u svome Vazetju Sigeta grada postigao i Barne Karnarutić na koju bi lako mogle upućivati utvrđene distinkcije u vremenskim dimenzijama, iskaznim instancama, pa i idejnim usmjerenjima što postoje među prvim i drugim dvama dionicama teksta. Konkretno, pored uočenoga osjetnijeg temporalnog udaljavanja od trenutka pada Sigeta te prepuštanja riječi poodavno već poginulim sudionicima bitke ili govornicima koji u njoj nisu osobno participirali, u trećem i četvrtom „dilu“ uspostavlja se i znatno kompaktniji prostorno-vremenski okvir no što je to bilo slučaj u događajno i vremenski razbarušenijim prvim dvama odsječcima teksta, gdje su čak i pretpostavljenu kronologičnost drugoga „dila“ uvelike remetila pisma (najvjerojatnije) napisana i odaslana nakon smrti bana Zrinskog, a uvrštena među poslanice koje datiraju iz vremena same opsade.

Kao ključna figura obiju posljednjih dionica Odiljenja sigetskog nameće se, k tome, ona poprilično dobro informirana putnika-slučajnika, koji pristiže u neposrednu blizinu Sigeta u trenutku kada su od bitke ostala još samo sjećanja, a od u njoj izginulih tek stihovi na nadgrobnim pločama (odatle i motiv ,grobovja“ u prvome stihu pjesme Putnik i Jeka), te zapodijeva razgovor s Jekom po završetku kojega nastavlja s putovanjem (,Dakle, na drugi kraj šetuvat je nogom, / a ti draga, ostaj, vilo, sbogom! Sbogom“; III: 375-376). Da se i u zaključnom „dilu“ podrazumijeva upravo taj isti - ali i svaki sljedeći, podjednako fizički i simbolički (,životni“) - putnik što prolazi ili će proći cestom pored sigetskoga groblja, ukazuju nam česti nadgrobnički imperativi „putniku“ ili „onome koji šetuje“ da (za)stane i časkom posveti (zasluženu) pozornost poginulu junaku što ondje počiva. S obzirom na to da je očigledno riječ o višemjesečnom odmaku od trenutka svršetka bitke, u trećem se dijelu pod navedenim motivom „grobovja“ jamačno impliciraju i sami natpisi (stihovi) na nadgrobnim pločama, pokraj kojih će putnika u nastavku voditi njegov put, slijedom čega bi onda i niz epitafa u četvrtom „dilu“ također pretpostavljao figuru putnika kao svojevrsnoga vodiča koji njihove sadržaje prenosi a vista - dakle, onim redoslijedom kojim ih i sam recipira prolazeći pored njih - što neizbježno unosi dodatni narativni element u posljednju dionicu teksta, vrlo sličan onomu iz drugoga dijela, u kojemu je slijed pisama, dijaloga i monologa sudionika bitke čitatelja vodio kroz posljednje dane opsade završene turskim zauzećem utvrde. Time Vitezović postiže očito sadržajno zaokruživanje posljednjih dviju - ujedno i kronološki prezentiranih - dionica svoje ,zrinijade“, u cijelosti posvećenih vremenu putnikova boravka u blizini (turskoga) Sigeta (od njegova dolaska i razgovora s Jekom do odlaska putem što vodi između grobova poginulih ratnika), i to slijedeći vrlo sličan (narativni) „recept“ po kojemu je - tematizirajući u njima zapravo isti (iako ispremiješan) vremenski odsječak kroz niz govorno srodnih iskaza protkanih osnovnim pripovjednim momentima - sadržajno zbližio prvi i drugi 
„dil“", koji se - kao takvi - ispostavljaju kao svojevrsna semantička (ali ne ujedno i kvantitativna) protuteža drugoj polovini teksta.

Ukratko, locirani pripovjedni (,epski“) slojevi, odnosno fragmenti Odiljenja sigetskog jasno nam ukazuju kako na dosad sustavno previđan narativni ,potencijal“ njegovih naoko isključivo poučno-refleksivnih (ili - kazano rječnikom dosadašnjih proučavatelja - „lirskih“) dionica, tako i na nepobitnu deriviranost velike većine tih fabularnih momenata (likova i situacija) iz epskopjesničke obrade sigetske katastrofe Petra Zrinskoga. I više nego očite sadržajne intertekstualne poveznice kojima se Vitezovićeva „zrinijada“ prikapča na Obsidu sigecku ( pa i - kao što sugeriraju pojedini formalni i uopće žanrovski signali - Adrijanskoga mora Sirenu u cijelosti) definitivno su najuvjerljivija potvrda poprilične ovisnosti Odiljenja od nekoliko desetljeća starije literarizacije istoga povijesnog događaja, iako se nakon svega dosad utvrđenog teško ipak oteti dojmu kako neobično visok stupanj intertekstualnoga suodnošenja ne podrazumijeva ujedno i, kao što je to svojedobno konstatirao Pavao Pavličić, potpunu značenjsku sekundarnost Ritterova ostvarenja u odnosu na ono Petrovo. ${ }^{466}$ Naime, bez obzira na činjenicu što recipiranje Odiljenja na podlozi Obside zaista bitno olakšava razumijevanje i povezivanje razbacanih narativnih fragmenata, već i maločas utvrđeni Vitezovićevi napori da u različitim dionicama svojega djela ipak donekle osvijetli ulogu svih spomenutih likova u samome kršćansko-muslimanskom okršaju - kojeg je tijek, podsjetimo, ugrubo ocrtao u uvodnoj poslanici Sigeta „hrvatskim gospojam“ - rezultirali su uspostavljanjem fabularnih obrisa priče što ju je u svome povijesnom epu, slijedeći bratov mađarski original, iznio i Petar Zrinski. Upravo zahvaljujući toj bi sadržajnoj značajki i čitatelju koji, možebitno, priču o junačkoj pogibiji bana Zrinskog pod sigetskim zidinama ne poznaje iz Obside sigecke - a pod uvjetom da je pomno (od korica do korica) iščitao Vitezovićevu ,zrinijadu“ i da raspolaže informacijama o kronologiji bitke i njezinim sudionicima iz nekoga drugog (povijesnog i/ili literanog) izvora - trebala biti razumljiva velika većina ondje spomenutih situacija i njihovih aktera, tim više što - podsjetnicima na „Zrinskijevske“ epizode u kojima su sudjelovali usprkos - njihov tekstualni značaj u Odiljenju ionako ponajviše proizlazi iz uvjerljivosti bolnih „odiljanja“ na koja ih je prisilio nepovoljan ishod bitke za Siget. Podrobnija naratološka analiza, štoviše, uvjerljivo bi pokazala kako su posložena gotovo posve identičnim kronološkim redoslijedom - u Odiljenje sigetsko zapravo uvrštena više-manje sva važnija sižejna sižejna čvorišta iz Opside te kako čak i u tome novom

\footnotetext{
466 Pavao Pavličić, naime, napominje kako status „sekundarnoga književnog teksta“ u pogledu Vitezovićeva Odiljenja zapravo podrazumijeva njegovu komentatorsko-lirsku nakanu kojom nadopunjuje sižejni tijek Petrove Obside sigecke, radi čega izvan odnosa prema epu svoga neposrednog prethodnika, zaključuje, ,ne može biti ni ispravne recepcije teksta ni njegova adekvatnog vrednovanja“" (Pavličić 2007: 276).
} 
okviru ona grade posve razumljivu i smislenu priču, no za nju u okvirima ovoga istraživanja nedostaje prostora, ali i potrebe.

Usprkos činjenici da smo maločas središnjom figurom trećega i četvrtog dijela Odiljenja proglasili slučajnog putnika koji se - mjesecima nakon što je bitka okončana zatekao u blizini osvojena Sigeta, takav zaključak neće se moći protegnuti i na prva dva dijela teksta, u kojima se kao centralni akter, subjekt ili protagonist naprosto - kako se čini - ne izdvaja niti jedan konkretni govornik. U tom smislu problem glavnoga junaka kao instance pripovjednoga teksta posredstvom koje se ostvaruje (ili bi se moglo ostvariti) čvršće (semantičko i strukturalno) sabijanje prezentiranih sadržaja u okvirima Odiljenja naprosto nije moguće riješiti potragom za konkretnim likom ili kazivačem, kojega bi njegova kvantitativna izdvojenost, a onda i (možebitna) sižejna važnost nepobitno potvrdile kao protagonista. Umjesto oko konkretnoga centralnog lika, narativne silnice Ritterove „zrinijade“ i uopće svi njezini sadržajni čimbenici okupljaju se oko figure ,junaka“ kao nadpersonalne (tipske) kategorije kojoj bi - podjednako - mogli pripadati svi kazivači i uvedeni „likovi“ i koja i proizlazi iz tematskoga opredjeljenja teksta za „odiljenje“ (rastanak) kao nužnu postaju ne samo na (životnom) putovanju Sigećana i turskih napadača, već i - u ponešto široj interpretaciji - na onomu svakoga ,životnog putnika“, na što, uostalom, u svojim obraćanjima slučajnim prolaznicima u nadgrobnicama četvrtoga dijela podsjećaju i poginuli vojnici sahranjeni na sigetskom groblju. Iako spomenuti lik putnika najveću važnost, ponovimo, stječe tek u posljednjim dvjema njegovima dionicama, Odiljenje sigetsko zapravo je u cijelosti - kako su pojedina recentnija tumačenja pokušala dokazati ${ }^{467}$ - premreženo (provodnim) motivima putnika i putovanja zaustavljenih upravo na prostoru Sigeta, koji na taj način postaje ne samo ratnim stajalištem, već ujedno i onim memorijalnim (kao mjesto sjećanja na bitku) te transcedentalnim (kao svojevrsno skretalište iz „ovozemaljske“ u „onozemaljsku“ ili posmrtnu dimenziju). Motiv putnika stoga se čvrsto vezuje uz apsolutno sve govornike ili aktere Odiljenja (pa i pripadnike obiju vojski, koje su poduzele vojna putovanja ne bi li dospjele do Sigeta s nakanom da ga obrane ili osvoje) i tako promeće u obuhvatnu tipsku kategoriju prisutnu u svim prostornim i vremenskim dimenzijama prikazanoga svijeta, kreirajući usput i simboličko značenje ove djelomično i „epske“ barokne „zrinijade“.

Vitezovićevo Odiljenje sigetsko, kao što smo ustanovili, žanru baroknoga povijesnog epa najočitije se približava nekim svojim sadržajnim posebnostima, i to ponajprije odabirom (tada) „tipično“ epskopjesničke teme, koja bi se - ponešto općenito - mogla definirati kao „čin nasilnog prijelaza u »tuđi« prostor“ (Dukić 2002: 16), a potom i konstantnim posezanjem 
za prepoznatljivo „epskim“ motivsko-fabularnim momentima kojima su svoje „zrinijade“ obilno napučili Nikola i Petar Zrinski (motiv dvoboja, paralelni ljubavni zapleti, motiv čarobnjaka i njegovih „čari“, vrlo izrazite transcedentalne sadržajne silnice itd.). Iako već samo evociranje tih baroknom epu svojstvenih motiva, epizoda i aktera Ritterovu ostvarenju pridaje nepogrešivo „epske“ crte, pojedinim se proučavateljima posve opravdano učinilo kako je „epsku legitimaciju Odiljenju mogla (...) pružiti već sama tema odnosno vezanost uz jedno epsko djelo“ (Isto: 69), a u prilog njegovoj „epičnosti““ trebalo bi, uz to, ići i inzistiranje na dvostruko rimovanu dvanaestercu ${ }^{468}$ kao stihu koji se - u bilo kojoj od dvije svoje temeljne inačice - nametnuo kao vjerni formalni pratitelj ne samo dotadašnje tradicije domaćih „Zrinijada“, već i epskopjesničkoga stvaralaštva u rasponu od Marka Marulića do Petra Zrinskog. U sadržajnom, formalnom i uopće žanrovskom pogledu Vitezović bi, u tom slučaju, u svome djelu vršio - za žanr epske pjesme uobičajenu - selekciju iz tradicije, ${ }^{469}$ možda i u nakani da, kao što je to bio slučaj i s Karnarutićevim Vazetjem Sigeta grada, ustrajanjem na određenim već prokušanim idejno-oblikovnim postupcima opravda potrebu uvođenja svježih, tj. suvremenijih - odnosno, ,šrepelovski“ rečeno, ,,manirističkih““470 - tekstualnih rješenja.

Unatoč činjenici da za mogući epskopjesnički identitet Odiljenja sigetskog nimalo nevažno ne bi smjelo biti ni to što što su se i mnogi naši osamnaestostoljetni autori pri sastavljanju svojih ,epskih“ ostvarenja - očito poimajući ga kao svoga izravnog žanrovskog prethodnika - u velikoj mjeri nadovezivali upravo na njegove formalne i sadržajne značajke, ${ }^{471}$ valja znati da određen broj dosad pobrojanih karakteristika ipak ne može kotirati kao dovoljno pouzdan jamac njegove pretpostavljene „epičnosti“, i to ponajprije stoga što su u sedamnaestostoljetnoj književnosti postupno one već gubile svoju epskopjesničku „ekskluzivnost“. Prije svega, krajnje bi tako upitno bilo već i samu temu turske opsade i zauzeća Sigeta - govoreći iz perspektive onodobne naše književnosti - proglasiti jednom od tema svojstvenih isključivo žanru povijesne epske pjesme (osim ukoliko to činimo uzimajući u obzir cjelokupnu dotadašnju tradiciju ,zrinijada“), naročito prisjetimo li se da je jedna od temeljnih osobitosti našega književnog baroka bila upravo „seljenje“ tema i motiva iz žanra u žanr, odnosno odustajanje od strogih renesansnih normi koje su za svaki pojedinačni žanr propisivale vrlo konkretan (tj. poželjan) raspon sadržaja. ${ }^{472}$ Štoviše, može se stoga i

\footnotetext{
${ }^{468}$ Riječ je, kako je u svojoj analizi zamijetio Davor Dukić, o stihu koji u Odiljenju sigetskom (pod)nosi daleko najveći „,pripovjedni teret“. O najvjerojatnijoj funkcionalnoj specijaliziranosti stihova u Ritterovoj „zrinijadi“ detaljnije u: Dukić 2002: 69.

${ }^{469}$ O ovoj značajki (teorijskoga) žanra epske pjesme u: Pavličić 1998: 425.

${ }^{470}$ Usp. Šrepel 1902: 110.

${ }^{471}$ Podrobnije o ovim Vitezovićevim „epskim“ nasljednicima, koji bi također uvelike mogli osnažiti percepciju Odiljenja (i) kao epske pjesme, u: Dukić 2002: 69.

${ }^{472} \mathrm{O}$ tome npr. u: Pavličić 1995: 12-16.
} 
pretpostaviti da je ohrabren upravo sviješću o baroknom olabavljivanju generičkih granica, a naročito činjenicom kako su pojedini detalji sigetske katastrofe u njegovo vrijeme u već više navrata postali temom različitih „,neepskih“ žanrova (primjerice, epitafa u Petrovoj Sireni, anonimnih isusovačkih drama, usmenoknjiževnih lirskih pjesama itd.), Vitezović i posegnuo za (tradicionalno) „epskim“ sadržajima u formi (točnije, formama) koja jedva da i ima išta zajedničkog s onom epske pjesme. Pritom kao epskopjesnički formalni signal u Odiljenju posve olako ne bi trebalo proglašavati čak ni dvostruko rimovani dvanaesterac, čije obje varijante (sjeverna i južna) dominiraju u ovome metrički šaroliku tekstu, ponajviše - dakako stoga što ga je u 17. stoljeću s mjesta uvriježenoga epskopjesničkog stiha u dijelu naše književnosti (onoj dubrovačko-dalmatinskoga kruga) prilično naglo istisnuo osmerac.

Kako bilo, ono što bi se - na temelju svega dosad utvrđenog - s kakvom-takvom sigurnošću moglo konstatirati jest to da na pitanje postavljeno u naslovu ovoga poglavlja jednoznačan, a ujedno i posve precizan odgovor (u ovom trenutku) naprosto nije moguće ponuditi. Odiljenje sigetsko, naime, ukazuje nam se kao ostvarenje koje u isti mah posjeduje i ne posjeduje značajke posuđene iz repertoara baroknoga povijesnog epa, odnosno u kojemu obilježja koja bi se (uvjetno) mogla shvatiti kao „epska“ istovremeno upućuju i ne upućuju na možebitni epskopjesnički njegov identitet. Pritom je i više nego bjelodano da je Vitezović ciljano „skrojio“ upravo takvo ostvarenje koje će - naravno, iz određene vizure - neodoljivo podsjećati na žanr povijesnoga epa, no i koje će podjednako - motreno, dakako, iz drugoga očišta - razotkrivati (i) svoje „neepsko“ ili ne samo epsko lice. Računajući na čitatelje koji će $\mathrm{mu}$, iz ovih ili onih razloga, pristupati upravo kao baroknome povijesnom epu, Odiljenje on premrežuje nizom karakteristika koje su u njihovim očima lako mogle potvrditi ta unaprijed stvorena generička očekivanja, no ujedno i tim „epskim“ mu crtama supostavlja obilježja iz repertoara različitih književnih i ne samo književnih žanrova, nimalo ne ugrožavajući iluziju da je riječ o žanrovski (tada nimalo neobičnom) hibridnu povijesnom epu, ne bi li na taj način privukao i recipijente koji su od tekstova ovakva tipa i književnosti općenito gajili posve drugačija očekivanja. O obilježjima potonjih „,neepskih“ žanrova, koja brojnošću i važnošću u Odiljenju višestruko nadmašuju ona „epska“, u nastavku nam stoga i predstoji reći riječ-dvije.

\section{2. 2. Poslanice (heroide) i konzolacija}

Ako je mahom dosad bilo riječi o onim (tekstualnim) karakteristikama Odiljenja sigetskog što su ih pojedini prethodni proučavatelji ustrajno „staigerovski“ kvalificirali kao „epske“, onda će se u nastavku - govoreći rječnikom njima očito bliskije tradicionalne 
genologije - puna pozornost posvetiti pretežno „lirskim“ značajkama Vitezovićeve „zrinijade“, odnosno - držimo li se postulata suvremene teorije žanra - u nj utkanim obilježjima iz repertoara konkretnih žanrova barokne, pa i ne samo barokne lirske pjesme. Pokušavajući raspetljati klupko njegova zamršenog generičkog identiteta, spomenuti su već „ritterolozi“ u svojim analizama - pored „epskih“ - redovito upozoravali i na „lirske“ silnice Odiljenja sigetskog, slažući se pritom u prosudbi da bi kao nepobitno „najlirskiju“ njegovu osobinu valjalo izdvojiti upravo opjevavanje emocija likova ili govornika (subjekata) u ispovjednom obliku, koje se, kako tvrde, nipošto ne može podvesti pod odrednicu „epskoga“. ${ }^{473} \mathrm{U}$ prilog „liričnosti“ Vitezovićeva ostvarenja govorila bi, prema njihovu mišljenju, većina njegovih tekstualnih komponenata, počevši s naslovom, koji aludira na „tipično lirski“ doživljaj, preko dijaloško-monološke forme, u kojoj se potiskuje naracija, pa sve do sadržajne razine, na kojoj je sve podređeno prikazbi suosjećajnih odnosa među likovima, i jezika teksta, koji je u potpunosti usklađen s njegovom tematskom okrenutošću raspoloženjima aktera, a naročito njihovoj tuzi i bolu uzrokovanoj nasilnim rastankom od Sigeta i jednih od drugih. ${ }^{474}$ Nimalo ,epskim“ (is)tim se proučavateljima učinilo i sadržajno ustrajanje na ideologemima prolaznosti svega zemaljskog, a nauštrb (,epskih“) ideologema junaštva i borbe za ,više ideale“, ${ }^{475}$ kao i vrlo naglašen motiv kršćanskoga suosjećanja s protivnikom te uopće viteškoga odnosa spram turskih osvajača, zahvaljujući kojemu se Odiljenje potvrđuje kao književni tekst u kojemu je ostvaren „,najtolerantniji odnos prema Turcima u starijoj hrvatskoj književnosti“ (Dukić 2002: 69). U svojim razgraničavanjima „epskih“ od „lirskih“ značajki Vitezovićeva djela potonji ,ritterolozi“, međutim, ne samo što su olako prelazili preko već navedene činjenice iznimne otvorenosti baroknog epa značajkama iz generičkih repertoara različitih „lirskih“ žanrova, pa čak i uključivanju čitavih primjeraka lirske pjesme unutar vlastitih tekstualnih granica, već ni iznesene zaključke najčešće nisu držali neophodnim kontekstualizirati, odnosno locirane lirske momente omjeriti o repertoare žanrova barokne lirske pjesme ne bi li potvrdili njihovu „baroknost“", a s time i pretpostavku o možebitnu autorovu kreativnom oslanjanju na konkretne barokne „lirske“ tekstove.

Pristupimo li lirskoj pjesmi kao svojevrsnomu obuhvatnom žanru ili nadžanru, zapazit ćemo da se u sedamnaestostoljetnoj hrvatskoj književnosti - dakle, u sva četiri njezina kruga ili regionalne varijante - pojavljivala ona u poprilično široku rasponu svojih generičkih izvedenica, od kojih su prepoznatljiva obilježja mnogih našla svoje mjesto i u Odiljenju

\footnotetext{
${ }^{473}$ Usp. Dukić 2002: 68, Kolumbić 2005: 327-353, Pavličić 2007: 253-284.

${ }^{474}$ Detaljnije u: Kolumbić 2005: 327-353 i Pavličić 2007: 253-284.

475 O ovome posebno u: Dukić 2002: 68-69. Valja, međutim, imati na umu da u Odiljenju nipošto nisu zanemareni ni ideologemi borbe za ,uzvišenije ciljeve“, pa tako na više mjesta zatječemo upravo motive časnoga ratovanja i žrtvovanja za Boga, kralja i domovinu. Više o ovim ideološki nabijenim motivima nešto kasnije.
} 
sigetskom. U književnopovijesnim prikazima pjesničke produkcije našega baroka na prvome se mjestu obično navodi žanr ljubavne lirske pjesme (u kojemu važnu ulogu nastavljaju igrati posebnosti petrarkističke amorozne lirike), iako rasprostranjenošću i ukupnom količinom pojedinačnih primjeraka svoj mnogo veći tadašnji značaj potvrđuje žanr religiozne ili nabožne pjesme, koji se paralelno realizirao kako u svojoj (čisto) literarnoj (odvojen od prakse vjerskih obreda), tako i u liturgijskoj inačici (služeći, dakle, obredno-liturgijskim zadaćama). Pored parafraza psalama, stihovanih molitava i drugih nabožnih lirskopjesničkih žanrova, pisale su se u to vrijeme i pjesme „na narodnu“ ili (pučka) lirika s izrazitim folklornoknjiževnim karakteristikama, potom pjesme u povodu smrti istaknutih pojedinaca i/ili prijatelja, dijaloške pjesme, pjesničke poslanice, lirskopjesnički prepjevi u različitim žanrovskim „kalupima“, ali i pjesme na latinskom ili (nešto rjeđe) hrvatskom jeziku ispjevane prema generičkim obrascima antičke provenijencije (heroide, idile, epigrami, epitafi, elegije itd.). Ostavimo li (zasad) po strani i generički vrlo raznolik korpus usmenoknjiževnoga lirskog pjesništva, onodobnim pjesnicima nesumnjivo intrigantnog i kreativno poticajnog, možemo konstatirati da je svaki od netom pobrojanih, pa i mnogih još nespomenutih (pisanoknjiževnih) baroknih lirskih žanrova uključivao niz sebi svojstvenih, karakterističnih - sadržajnih i formalnih posebnosti, mnogima od kojih je svoju ,zrinijadu“ obilno prošarao i Pavao Ritter Vitezović.

Analizirajući u prethodnom poglavlju narativne (,epske“, epskopjesničke) odlike svih četiriju „dilova“ Odiljenja sigetskog dotaknuli smo se, između ostalih, i pojedinih pjesama prvih dviju njegovih dionica čiji tekstualni signali prilično jasno upućuju na to da je riječ o svojevrsnim pismima u stihu ili poslanicama. Osim formalne zaokruženosti (svojstvene, uostalom, svim pjesmama Odiljenja) i relativno kraćeg opsega, koji već sami po sebi navode na pomisao da se radi o primjercima žanra ili žanrova bliskijih baroknoj lirskoj negoli epskoj pjesmi, niz sadržajnih značajki poput naslova, u kojima se ekspliciraju pošiljatelj i primatelj „pisma“ (Siget hrvatskim gospojam, Kralj banu, Ban orsagu itd.), potom redovitih motivskih pozivanja na sam čin pisanja pisma, ${ }^{476}$ uopće dijaloškoga tipa iskaza koji pretpostavlja odgovor adresata te njihovih pisanih replika, koje se u većini slučajeva i prilažu uz pošiljateljeve poslanice (tako, primjerice, za poslanicom Ban kralju slijedi ona Kralj banu, za poslanicom Ban orsagu ona Orsag banu itd.), bjelodano sugerira kako ove pjesme - u

\footnotetext{
476 Tako već u uvodnoj poslanici „hrvatskim gospojam“ Siget izražava žaljenje što zabrinutim majkama i suprugama branitelja ne može javiti povoljnije vijesti („Glase od njih bolje rad bih bil pisati“; I: 245), ban Zrinski u nešto kasnijem pismu kralju ističe kako ga sve izgledniji poraz kršćanske vojske „,̌ini jur krvjom pisati“ (II: 3), u pismu domovini (,orsagu“) ispričava se, pak, što je prisiljen dojaviti joj vrlo nepovoljne novosti o skorom padu Sigeta (,Stvar ne pišem bolju u hipu ovomu“; II: 105), dok neutješni Siget svoju poslanicu kralju započinje napomenom kako je riječ o posljednjim vijestima što mu ih je u mogućnosti napisati (,,oš sad, kruno sveta, prilika j' pisati, / stvari od Sigeta na znanje ti dati“; II: 440-441).
} 
generičkom pogledu - pripadaju istom ili vrlo sličnom lirskom „tipu“, odnosno kako bi zahvaljujući prisustvu pobrojanih karakteristika - njihov žanrovski identitet neminovno morao biti srodan onomu sedamnaestostoljetnih lirskih tekstova što ih identificiramo kao (barokne) stihovane poslanice. Prepoznatljivim obilježjima (baroknih) poslanica, konkretno, bremenito je sveukupno osam pjesama Odiljenja, od kojih je jedna - ali od svih ujedno i najdulja (Siget hrvatskim gospojam; I: 1-477) - smještena u prvi, a preostalih sedam - Ban kralju (II: 1-57), Kralj banu (II: 58-92), Ban orsagu (II: 93-117), Orsag banu (II: 118-146), Siget kralju (II: 440-466), Kralj Sigetu (II: 467-485) i Siget rimskoj Crikvi (II: 486-516) - u drugi njegov „dil““, što će reći da od sveukupno 2313 stihova teksta na pjesme s epistolarnim crtama otpada njih točno 699 ili gotovo trećina. U tom nas smislu ne bi smjelo čuditi to što se u dosadašnjim književnopovijesnim prikazima od svih žanrova čijim je obilježjima Odiljenje protkano daleko najčešće isticalo upravo poslanice, pa tako već koncem pretprošloga stoljeća Đuro Šurmin u Povjesti književnosti hrvatske i srpske pojašnjava kako je drugi „dil“ Vitezovićeva ostvarenja „sastavljen od 15 pjesama, koje su kao poslanice u duhu lirskom, u kom ima i tona elegičnoga“" (Šurmin 1898: 135), a poslije njega u svojim pregledima povijesti domaće književnosti na zastupljenost stihovanih „pisama“ ili „poslanica“ u njemu će upozoriti i, redom, Branko Vodnik, David Bogdanović, Mihovil Kombol te Krešimir Georgijević. ${ }^{477}$

Obilno posezanje (i) za značajkama poslanice, kao uvjerljivo najzastupljenijega lirskopjesničkog žanra unutar okvira Odiljenja sigetskog, Vitezović na neki način nagoviješta - kako smo ranije zapazili - već u latinskoj posvetnoj pjesmi prvoga izdanja upućenoj Adamu Zrinskom, u kojoj posredstvom motiva „camoene“ ili pjesme (pjesničke poslanice) izravno aludira na Horacija i njegovu utjecajnu zbirku Epistole, u kojoj se identičan motiv pojavljuje već u početnim stihovima prve epistule (adresirane na Mecenata), i to kao vjerojatna oznaka upravo za pjesnički žanr kojemu pripada ta i sve ostale pjesme zbirke. Prešutno se referirajući na rečeni Horacijev epistolarni ciklus Ritter, naime, kao da želi sugerirati - ili, bolje rečeno, stvoriti iluziju - kako i u svome stvaralačkom radu na narodnom jeziku ,polazi od klasičnog shvaćanja pjesništva u duhu Horacija (...), dakle klasično-antiknog kao i humanističkorenesansnog shvaćanja, uvjetno rečeno »herojske« poezije“ (Posavac 1994: 868), ${ }^{478}$ a onda i čitatelju (ponajprije, dakako, onomu vičnom latinskom jeziku, pa ujedno i literarno iskusnijem) skrenuti pozornost na važnost što će ju obilježja žanra kojega je inaugurirao upravo rimski pjesnik imati u tekstu koji slijedi. Ne bi, štoviše, bilo nimalo nevjerojatno ni to da Vitezović spomenutom aluzijom Adamu i dijelu (učenije) publike pokušava predložiti

\footnotetext{
${ }^{477}$ Usp. Vodnik 1913: 299, Bogdanović 1932: 452, Kombol 1961: 280 i Georgijević 1969: 132-134.

${ }^{478}$ Detaljno o vjerojatnim Vitezovićevim estetičkim nazorima i uvjerenjima u Posavac 1994: 866-870.
} 
svojevrsni ključ za generičko razumijevanje svojega ostvarenja, izdvajajući stihovanu poslanicu kao njegov centralni ili „krovni“ žanr, koji bi u tom smislu trebao predstavljati koliko-toliko čvrst žanrovski okvir ove sadržajno i formalno razbijene „zrinijade“. Na kraju krajeva, upravo u pjesmama što smo ih netom definirali kao poslanice i jest doneseno daleko najviše informacija o tijeku i ishodu kršćansko-muslimanskoga okršaja, glavninom utkanih u narativno realiziranu dionicu uvodnoga pisma Sigeta, a k tome je još i riječ o tekstovima u kojima „osobno“ progovaraju dva neposredna (i ujedno najvažnija) kršćanska aktera sigetske bitke - personificirani Siget i ban Zrinski - obraćajući se adresatima koji u nju nisu izravno bili upleteni, ali koji itekako jesu ili će doskora biti pogođeni njezinim izrazito nepovoljnim ishodom (obitelji branitelja, Hrvatsko Kraljevstvo, bečki dvor, Katolička crkva).

Iako bi se - govoreći iz perspektive ranijih, „staigerovskih“ pretpostavki o žanrovskom identitetu Odiljenja - lako moglo zaključiti da je obilježjima stihovane poslanice Vitezović bio toliko sklon znajući da se radi o pjesničkom žanru „lirsko-epskoga karaktera“ (Brezak-Stamać 2012: 403), koji je - kao takav - savršeno trebao odgovarati izrazitoj „epskolirskoj“ usmjerenosti teksta u cijelosti, mnogo je vjerojatnije da razlog te njegove generičke sklonosti leži zapravo u činjenici omiljenosti toga lirskopjesničkog žanrovskog rješenja u gotovo svim onodobnim europskim književnim kulturama. Ne samo što su, konkretno, pisma u stihovima u 17. stoljeću kotirala kao posve „uobičajen oblik u suvremenoj njemačkoj, talijanskoj i latinskoj književnosti“ (Georgijević 1969: 121), već je i njihovo mjesto u žanrovskom sustavu hrvatskoga književnog baroka bilo - prisjetimo se - također čvrsto i neupitno, čemu je velikim dijelom svojega stvaralačkog opusa umnogome pridonio i sam Vitezović. U sastavljanju žanra pjesničke poslanice poprilično se on, naime, izvještio već u godinama uoči pisanja svojega hrvatskog prvijenca, ${ }^{479}$ a s različitim više ili manje utjecajnim domaćim i inozemnim adresatima (prijateljima, potencijalnim pokroviteljima, učiteljima, barunima, samim kraljem ${ }^{480}$ itd.) s područja čitave Habsburške Monarhije i šire nastavit će se on ustrajno dopisivati sve do smrti, o čemu nam i svjedoči nevjerojatan korpus od nekoliko stotina sačuvanih (glavninom latinskih) poslanica pronađenih među njegovom pisanom ostavštinom. To što, međutim, (i) Vitezovićev primjer jasno ukazuje na to da je i u 17.

\footnotetext{
${ }^{479}$ Samo iz dviju Vitezovićevih mladenačkih godina - 1676. i 1677., u kojima je najvjerojatnije već i započeo njegov rad na prvim inačicama teksta što će ga kasnije uobličiti u Odiljenje sigetsko - datira sveukupno 35 (sačuvanih) latinskih pjesničkih poslanica, redom uvrštenih u epistolarnu zbirku Equitis Pauli Ritter epistolarum metricarum liber primus (i liber secundus). Inače, upravo se informacije što ih je naš autor podastirao u svojim stihovanim, ali i proznim pismima mogu držati jedinim (koliko-toliko) pouzdanim izvorima za njegov životopis, na što je još prije više od stoljeća u - do danas - jedinoj monografiji o Vitezovićevu liku i djelu upozorio Vjekoslav Klaić (usp. Klaić 1914). Znatno detaljnije o sadržaju, formi i ostalim osobitostima Vitezovićevih latinskih pjesničkih poslanica u: Moretti 2014 i Moretti i Stepanić 2019: 9-116.

${ }^{480}$ Među Ritterovim stihovanim pismima našlo se tako čak i jedno - doduše prozno - upućeno tadašnjoj engleskoj kraljici Ann Stuart. Usp. Kosić 2013: 122.
} 
stoljeću - kao što je to, uostalom, bio slučaj već i u prethodna dva - pjesnička poslanica ubrajana među (književne) žanrove specijalizirane za komunikaciju među literatima, odnosno među pjesnicima i (stvarnim ili potencijalnim) pokroviteljima, drugim moćnicima ili naprosto tek bliskim prijateljima, ujedno bi valjalo shvatiti kao poziv na preispitivanje dosadašnjih preliminarnih određenja pojedinih pjesama Odiljenja sigetskog kao epistola.

S obzirom na to da bi već na prvi pogled trebalo biti jasno kako stihovana pisma što ih izmjenjuju pojedini govornici u Vitezovićevoj „zrinijadi“ sadržajno teško mogu biti usporediva s epistolama koje su - izravno se u njima referirajući na stvarnu, aktualnu zbilju u barokno doba (ali i mnogo ranije) sastavljali sami pisci u želji da uspostave komunikaciju s drugim njima važnim pojedincima, očito je da njihov generički uzor nije posve ispravno tražiti u žanru kojemu ,pripadaju“ i pjesnički tekstovi što ih je naš autor odašiljao utjecajnim i manje utjecajnim prijateljima i znancima ne bi li im javio važnije novosti iz svakodnevice ili pokušao od njih izmoliti kakvu uslugu. Da to ujedno ne znači i kako spomenuti odsječci Odiljenja ne stoje baš ni u kakvoj generičkoj vezi s epistolom, uvidjet ćemo sagledamo li ovaj izvorno antički žanr iz književnopovijesne vizure, točnije prisjetimo li se da se kroz svoju višestoljetnu povijest pojavljivao on ne samo u proznoj i stihovanoj varijanti, nego i da je epistola u stihu već u antici podrazumijevala zapravo dva po mnogočemu različita - iako formalno vrlo bliska - (pod)žanra, i to pjesničku poslanicu s jedne, te fiktivnu poslanicu ili heroidu s druge strane. ${ }^{481} \mathrm{Za}$ razliku od pjesničke poslanice, koja je nužno pretpostavljala stvarnu (izvanknjiževnu) pisanu komunikaciju autora (pošiljatelja) i konkretnoga, realno postojećeg adresata (primatelja) i stoga sadržajno bila usredotočena na opjevavanje zbiljskih događaja, svjetonazosko-filozofskih dilema, književnopoetičkih pitanja itd., fiktivna poslanica ili heroida je - kako joj i ime sugerira - bila u potpunosti knjiška, fikcionalna „tvorevina“, odnosno epistolarni žanr, čija pretpostavljena komunikacijska podloga i sadržajne preferencije nisu izlazile onkraj književnih (fikcionalnih) granica. Imamo li potonju distinkciju na umu, ni stihovana fikcionalna pisma što ih zatječemo u Odiljenju, koja - nepobitnoj povijesnosti pojedinih njihovih pošiljatelja usprkos (ban Zrinski, habsburški kralj) - izmjenjuju upravo „papirnati“ (većinom personificirani) sugovornici potaknuti fikcionalnim povodom, nikako ne bismo smjeli izjednačavati s pjesničkim poslanicama, a vjerojatno ih ni prozivati „poslanicama“, ponajprije stoga što ta generička oznaka (naročito u našoj književnosti) nužno upućuje na neku vezu s izvanknjiževnim iskustvom, koje u ovome slučaju izostaje.

\footnotetext{
${ }^{481} \mathrm{O}$ žanru stihovanih epistola i njegovu razvoju od antike do renesanse pregledno u: Fališevac 2007a: 78-82, Brezak-Stamać 2012: 403-438 i 2016: 32-68. Uzgred budi rečeno, obje autorice u svojim tekstovima u široku luku zaobilaze žanr heroida, a ne spominju čak ni njegovo „rađanje“ u Ovidijevoj zbirci Epistulae heroidum.
} 
Niz, dakle, sadržajnih njihovih posebnosti, ali i sam kontekst u koji su uvrštena, prilično nam jasno sugeriraju da bi generički predložak versificiranih pisama iz Odiljenja prije valjalo tražiti u Ovidijevoj epistolarnoj zbirci Epistulae heroidum (Heroide legendarnih junakinja $)^{482}$ nego u Horacijevu poslaničkom opusu, pa i usprkos činjenici da epistola u stihu kao samostalni (lirsko)pjesnički žanr svoje postojanje duguje upravo njegovim epistolarnim pokušajima. $^{483}$ Ovidijeva, međutim, ideja da sastavi zbirku od sveukupno 21 fiktivne poslanice što ih ostavljene i prevarene mitološke junakinje iz Homerovih epova, grčkih tragedija (Fedra, Medeja) i Vergilijeva pjesništva (Didona) pišu svojim nevjernim muževima i ljubavnicima - uz iznimku triju heroida koje predstavljaju odgovore trojice prozvanih muških likova - u tadašnjoj poslaničkoj produkciji ispostavila se kao apsolutni novitet, iznjedrivši i posve novi epistolarni žanr, umnogome različit od stvarnošću presudno određene („horacijevske“) pjesničke poslanice. ${ }^{484}$ Bez obzira na činjenicu što će Horacijev poslanički opus kroz čitavo ranonovovjekovlje ostati važnim i nezaobilaznim dijelom lektire, a time i izravnim (generičkim) uzorom mnogim tadašnjim pjesnicima, iznimna popularnost što su je istodobno uživale Ovidijeve Heroide urodit će i pozamašnim brojem njihovih izravnih imitacija, pri čemu će poseban interes za sastavljanjem heroida iskazivati upravo sedamnaestostoljetni autori diljem Europe. ${ }^{485}$ Ta već primijećena „popularnost heroida $u$ baroknom pjesništvu, i to podjednako na latinskom kao i na narodnim jezicima“" (Novaković 2010: 53), ponajviše se manifestirala u naglom porastu broja zbirki fiktivnih poslanica ili epistolara - poglavito onih religijske tematike, ispjevanih pretežno latinštinom - od kojih su brojne zacijelo dospjele i u Vitezovićeve ruke, potaknuvši ga ne samo da se u žanru heroida okuša i u svome hrvatskom prvijencu, već i da prepoznatljivim elementima iz Ovidijeva pjesništva protka velik dio svojih književnih, pa i ne samo književnih ostvarenja. ${ }^{486}$

Barokna obljubljenost heroide zapravo je ništa drugo no tek produžetak popularnosti što ju je ovaj pjesnički žanr počeo uživati još u 16. stoljeću, kada i dolazi do njegove

\footnotetext{
482 Ovidijeva zbirka u nas je prevedena 1849. pod naslovom Pub. Ovidia Nazona Heroidah, i to zaslugom dubrovačkih prevoditelja, braće Josipa i Jakova Betondića. Usp. Ovidije 1849.

${ }^{483}$ Horacijeve pjesničke poslanice, podsjetimo, većinom su pretpostavljale dopisivanje stvarnih individua $\mathrm{i}-\mathrm{u}$ sadržajnom pogledu - svodile su se na razgovore u dokolici ili učene poetološke (književnoteorijske) rasprave. Za razliku od heroida okupljenih u knjizi Epistulae heroidum, Ovidije za žanrom bliskim onome što ga je inaugurirao i prakticirao Horacije poseže u svojoj ništa manje znamenitoj epistolarnoj zbirci Epistulae ex Ponto (Poslanice iz Ponta), u kojoj u stihovanim pismima adresiranima na stvarne osobe opisuje svoje nesretne doživljaje iz vremena izgnanstva.

${ }^{484} \mathrm{O}$ Ovidijevu utemeljenju posve novoga epistolarnoga žanra - kojega autorica izrijekom ne proziva heroidom - detaljnije u: Brezak-Stamać 2012: 411-415 i 2016: 41-46.

485 Heroide su, naime, kotirale kao izuzetno ,popularno štivo diljem Mediterana tijekom gotovo čitavoga razdoblja na koje se odnosi sintagma »starija hrvatska književnost«““ (Škopljanac 2015: 44), zbog čega nas ni najmanje ne treba čuditi snaga njihova utjecaja i na naše ranonovovjekovne pjesnike.

${ }^{486}$ Dapače, prepoznatljive značajke ovidijevskih heroida Zrinka je Blažević nedavno locirala i u Vitezovićevoj kronici u stihovima (tj. epu) Dva stoljeća uplakane Hrvatske (usp. Blažević 2019: 16-17).
} 
svojevrsne revitalizacije i strelovitoga širenja, i to ponajprije zahvaljujući njemačkoj novolatinskoj književnosti, u okriju koje ga 1514. svojom zbirkom Heroidum Christianarum Epistulae (Pisma kršćanskih junakinja) „oživljuje“ pjesnik Eoban Koch (ili latinskim imenom Helius Eobanus Hessus). Evociravši ga u posve novim književnim i uopće društvenokulturnim uvjetima ili situaciji, Koch je ubrzo shvatio da ovaj žanr antičke provenijencije mora podvrgnuti temeljitoj kristijanizaciji, slijedom čega će Ovidijeve poganske junakinje, princeze, kraljice i druge mitske aktere u 24 heroide svoje zbirke i zamijeniti kršćanskim sveticama i svecima (u njoj tako pisma izmjenjuju Marija Magdalena i Krist, Marija i Josip itd.), koji - umjesto o ljubavnim nedaćama - raspravljaju o ključnim teološkim, odnosno biblijskim pitanjima (primjerice, o Kristovu bezgrešnom začeću, njegovoj muci, raspeću i sl.). Ono što u Kochovoj knjizi pritom posebno upada u oči jest činjenica da se kao pošiljatelji nekih od heroida pojavljuju nežive, (još) nerođene ili transcedentalne figure poput Isusa, koji se nekoliko mjeseci prije vlastita rođenja pismom (sic!) javlja Mariji, i anđela Emanuela, s kojim će Marija također razmijeniti nekolicinu pisama, a ovomu vrijedi dodati i da će - očito naslanjajući se na potonju praksu - nekoliko godina nakon objelodanjivanja svoje zbirke Koch ispjevati i heroidu u kojoj će poziciju subjekta ili pošiljatelja zauzeti personificirana Katolička crkva koja se obraća Lutheru.

Točno šest desetljeća nakon Kocha svoju će po mnogočemu prijelomnu knjigu heroida Sacrarum Heroidum libri tres (Tri knjige svetih heroida, 1574.) objaviti i nizozemski pjesnik Andreas Alenus, donijevši u njoj 77 fiktivnih poslanica biblijskih, povijesnih, mitskih (poganskih) i alegorijskih likova (od Eve, koja se pismom obraća Kajinu, do personificirane duše što piše tijelu) posloženih kronološkim redoslijedom. Riječ je, naime, o zbirci koja predstavlja prijelaznu točku između šesnaestostoljetnih humanističkih i sedamnaestostoljetnih isusovačkih heroida, najavljujući tako najproduktivnije - barokno - razdoblje ovoga žanra, no ono u čemu se krije njezina daleko najveća posebnost jest činjenica da se radi o prvom ciklusu heroida koji sažima cjelokupnu dotadašnju tradiciju žanra, progovarajući podjednako o biblijsko-teološkim, (tada) suvremenim religijskim, ali i konkretnim povijesnim temama, kojima će naročito biti skloni autori seicenta. ${ }^{487}$ Od izravnih referenci na suvremena povijesna zbivanja neće, doduše, zazirati ni pojedini raniji šesnaestostoljetni pisci poput - primjerice čuvenoga njemačkog pjesnika Georga Sabinusa, u čijem opusu - između ostalih - nalazimo i heroidu u kojoj se personificirana Njemačka izravno obraća caru i koja kao da je svojevrsna

\footnotetext{
${ }^{487}$ O Alenusovoj zbirci detaljnije u: Eickmeyer 2014: 419-427. Uzgred budi rečeno, kao i u Kochovu ciklusu heroida, i u onomu Alenusovu svoje je mjesto našao niz heroida što ih pišu i odašilju neživi pošiljatelji, odnosno personificirane institucije poput - primjerice - Crkve.
} 
preteča onih reformacijskih „politiziranih“ fiktivnih poslanica, u kojima će se Njemačka javljati kršćanima ne bi li ih podsjetila na golemu važnost borbe protiv turskih osvajača. ${ }^{488}$

No, tek u okrilju sedamnaestostoljetnoga isusovačkog literarnog stvaralaštva žanr heroide počet će redovito uzimati u obzir cjelokupnu biblijsku, stvarnu te legendarnu povijest i tradiciju prosvjećivanja, ${ }^{489}$ što vidimo i na primjeru epistolarnog opusa njemačkoga jezuitskog pjesnika i dramatičara Jakoba Bidermanna, koji sastavlja dvije zbirke fiktivnih poslanica ili heroida na latinskom - Heroum Epistulae (Poslanice junaka, 1630.) i Heroidum Epistulae (Poslanice junakinja, 1638.) - u kojima, u Ovidijevoj maniri, heksametarska pisma o nabožnim temama razmjenjuju pretežno kršćanske junakinje i junaci. Za razliku od velike većine svojih generičkih prethodnika, Bidermannove heroide - kao što to i najavljuju naslovi njihovih ciklusa - kao (zamišljene) pošiljatelje više neće imati isključivo (pa čak ni pretežno) ženske govornike, a to definitivno ustoličenje muškoga subjekta kao prvoga pošiljatelja (a ne, kao što je to dotad bio slučaj, najčešće tek primatelja kojemu se samo zgodimice daje mogućnost pisanoga repliciranja na pošiljateljičinu poruku) ujedno će nagovijestiti i posve novu, baroknu etapu u razvoju ovoga lirskopjesničkog žanra, odnosno nametnuti se kao prepoznatljivo sedamnaestostoljetno obilježje u njegovu generičkom repertoaru. Zahvaljujući nevjerojatnoj popularnosti Bidermannovih zbirki diljem onodobne Europe, ${ }^{490}$ ovaj nagli zaokret od dotadašnje - ovidijevsko-humanističke - tradicije žanra ubrzo je prihvaćen kao neizostavna značajka barokne fiktivne poslanice, a s njezinim možda i najuspjelijim primjercima imali su se prilike susresti čak i domaći čitatelji nevični latinskom jeziku, i to zaslugom varaždinskoga pisca Gabrijela Jurjevića, koji Poslanice junaka prevodi na hrvatski te zbirku - po običaju svoga vremena - pod vlastitim imenom i s posvetom Adamu Zrinskom objelodanjuje 1675. u Beču pod naslovom Listi heroov, to je velikeh na glasu ljudih.

Umjesto ,autorskih“ primjeraka „omiljelog oblika toga doba“ (Kombol 1961: 271), Jurjević je, dakle, domaćoj publici odlučio ponuditi prijevod jedne od tada najpopularnijih lirskopjesničkih zbirki, u kojoj heroide ili fiktivne poslanice jedni drugima upućuju znameniti (no do toga trenutka već stoljećima mrtvi) pojedinci iz crkvene ili svjetovne povijesti (sveci, kraljevi, generali, trgovci itd.), biblijski junaci te mitološka bića, raspravljajući u njima o nekim veoma važnim religijskim pitanjima i usput nudeći korisne moralne pouke.

\footnotetext{
${ }^{488}$ Podrobnije u: Palotás 2014: 66.

${ }^{489}$ O tome u: Kühlmann 2007: 286.

$490 \mathrm{~S}$ obzirom na to da su obje Bidermannove zbirke u 17. st. doživjele nekoliko izdanja te da su - $\mathrm{k}$ tome nerijetko bile rabljene i kao vjerski priručnici (usp. Kühlmann 2007: 286 i Eickmeyer 2014: 428), krajnje je nejasno na temelju kojih možebitnih podataka o njegovoj (ne)popularnosti Slobodan Prosperov Novak u svome pregledu povijesti hrvatske književnosti ustvrđuje kako je djelo ovoga njemačkog isusovca bilo ,zaboravljeno čim je napisano“" (Prosperov Novak 1999: 511).
} 
Bidermannov heksametar Jurjević ondje zamjenjuje (jednostruko rimovanim) dvanaestercem organiziranim u distihe, a heroide razvrstava u tri zasebna ciklusa, od kojih su u prvom okupljene pjesme koje opjevavaju četiri posljednje čovjekove stvari (smrt, sud, raj i pakao), u drugom tekstovi koji se dotiču raznoraznih (ovo)zemaljskih nevolja i vrlina (primjerice, vrline postojanosti i izdržljivosti, prevrtljive čovjekove sreće, prolaznosti svega materijalnog i dr.), dok su poslanice trećega dijela posvećene ništa manje bitnim religioznim temama, i to većinom sveopćoj prolaznosti i propadljivosti, potom pitanju ispovijedanja kršćanske vjere itd. Bez obzira na ovu izrazitu religijsku obilježenost svih heroida Jurjevićeve (čitaj: Bidermannove) zbirke, vrijedi zapaziti kako je u njoj ipak i više nego primjetan onaj maločas uočen pomak s (apsolutno) religijske na sekularnu povijest, odnosno sve izrazitije i sve češće oslanjanje na konkretne povijesne događaje, koje se očituje u neprekidnoj potrebi da se nabožni motivi povežu s historijskim činjenicama i prikažu kao od njih izravno ovisni.

Pohrvaćujući latinsku lirskopjesničku zbirku inozemnoga autora, sazdanu od primjeraka žanra koji u hrvatskoj književnosti do toga trenutka - osim posredstvom gdjekojeg (prošlostoljetnoga) prijevoda i prerade - gotovo da i nije imao nikakvu tradiciju, Gabrijel Jurjević zapravo vrši posao uvođenja ili udomaćivanja (barokne) fiktivne poslanice, pripravljajući tako put i svim (potencijalnim) kasnijim njezinim sastavljačima, među kojima, dakako, i samom Pavlu Ritteru Vitezoviću. Pokazavši svojim primjerom kako žanr heroide bez i najmanjih zapreka može funkcionirati ostvaren i na narodnom jeziku, Jurjević ne samo što fiktivnu poslanicu dospijeva udomaćiti otrgnutu iz zagrljaja (inozemne) novolatinske književnosti, već ujedno za nju - kao takvu - iznalazi i vrlo specifičnu publiku, na koju se i poziva u predgovoru svoje knjige i na koju će, pišući epistolarne dionice svoje „zrinijade“, jamačno zatim računati i Vitezović, svjestan da upravo ona posjeduje iskustvo recepcije generički identičnih tekstova na vernakularu. S obzirom na to da je od objavljivanja Listi heroov do prvoga izdanja Odiljenja prošlo manje od deset godina, očigledno je da je Ritter vjerovao kako će na heroide iz njegova ostvarenja također pozitivno reagirati identičan poprilično širok - krug čitatelja, odnosno kako će te odsječke teksta generički vrlo lako identificirati „gospoda, junaki i ostali obojega spola poglaviti ljudi“ (Šojat 1977b: 305), kojima se svojom prevedenom zbirkom prije njega obraćao i Gabrijel Jurjević.

Da će (i) žanrom heroida lakoćom privući pažnju vrlo raznolike publike Vitezović se mogao uvjeriti i na primjeru inozemnih pjesnika, prije svih silno popularna Bidermanna, čija su se ostvarenja - zajedno s nabožnim djelima mnogih drugih njemačkih jezuitskih autora (primjerice, Baldea, Bissela, Radera, Avanciniusa i dr.), u kojima je mahom obrađivana tema 
četiriju posljednjih stvari - čitala u sklopu naših isusovačkih kolegija. ${ }^{491}$ Osim toga, ako ne već tijekom njegova školovanja, onda vrlo vjerojatno kasnije Vitezoviću su u ruke mogle dospjeti i makar neke od mnogobrojnih stranih baroknih zbirki fiktivnih poslanica, nastalih na valu nasljedovanja utjecajnih Bidermannovih epistolarnih ciklusa, ${ }^{492}$ među kojima se - pukim slučajem - možda zatekla i pokoja iz Nizozemske, gdje u 17. st. dolazi do neočekivano nagloga procvata žanra heroide, $\mathrm{i}$ to ponajprije zahvaljujući isusovačkim pjesnicima Balduinusu Cabillaviusu (Boudewijn Cabeliau) i Johannesu Vincartiusu (Jean Vincart), a uz njih i znatno poznatijem svjetovnjaku Casparu Barlaeusu (Kaspar van Baerle). Njihove epistolarne zbirke posebno su značajne poradi forsiranja tzv. dvostrukih ili parnih heroida (pošiljateljevih pisama za kojima slijede odgovori primatelja) - koje, podsjetimo, nalazimo već u Ovidija, potom u pojedinih humanističkih pjesnika i, dakako, u Odiljenju sigetskom ${ }^{493}$ a uz to se one izdvajaju i po znatno većoj zastupljenosti povijesnih, pa čak i slavljeničkoprigodnih sadržaja u odnosu na biblijske i hagiografske teme, što će biti slučaj i u kasnijim zbirkama vernakularnih fiktivnih poslanica iz pera svjetovnih pjesnika poput, primjerice, Hoffmannswaldauove Heldenbriefe.

U svoj epistolarni ciklus Heldenbriefe (Junačke heroide, 1663.) čuveni je njemački barokni pjesnik Christian Hoffmann von Hoffmannswaldau - ugledajući se ponajviše na Ovidijeve Heroide - tako uključio sveukupno četrnaest pari fiktivnih poslanica ispjevanih u aleksandrincima, koje za svoje pošiljatelje i primatelje imaju najpoznatije ljubavne parove iz njemačke povijesti, odreda - dakako - aristokratskoga porijekla. ${ }^{494}$ To što je tematskomotivski fokus u ovoj zbirci pao na isključivo stvarne, povijesne aktere i njihove doživljaje predstavlja itekako krupan sadržajni iskorak u odnosu na dotadašnju (glavninom isusovačku) tradiciju ovoga žanra, na koji su Hoffmannswaldaua - kako se čini - najvjerojatnije potaknuli pojedini inozemni epistolarni modeli. Posebno je važnu ulogu u njegovu formiranju generičke predodžbe o heroidi - pored Ovidija - pritom zacijelo odigrala engleska epistolarna tradicija, i to kako njezin novolatinski odvjetak, kojega je svojom zbirkom Epistolae Heroides (1592.)

\footnotetext{
${ }^{491}$ Usp. Georgijević 1969: 65.

492 Podrobnije o Bidermannovim zbirkama heroida i njihovu značaju u: Eickmeyer 2014: 428-430. Inače, Jurjevićev prijevod Bidermannovih Poslanica junaka nije morao biti jedini domaći poticaj Vitezoviću da u Odiljenju posegne - među ostalim - i za obilježjima (barokne) heroide. Naime, ako je vjerojati pojedinim kasnijim napisima o toj knjizi, čini se da se u (danas izgubljenoj) latinskoj pjesničkoj zbirci Hortus poeticus (1683.) zagrebačkoga isusovca Ivana Despotovića Mlađeg nalazila i vrlo uspjela heroida Eurydice ad Orpheum, koja će kasnije dočekati i svoj prijevod na njemački jezik. Znamo li da se s Despotovićem Mlađim, ali i Despotovićem Starijim Vitezović vrlo intenzivno dopisivao, nema sumnje da se nedugo nakon njezina objelodanjivanja i jedan primjerak ove zbirke našao u Vitezovićevim rukama, što bi onda značilo i da je svojim sadržajnim - ili, bolje rečeno, žanrovskim - osobitostima vrlo lako mogao utjecati na njega i pri sastavljanju Odiljenja sigetskog. Detaljnije o Despotovićevoj latinskoj knjizi pjesama u: Stepanić 2005: 100-103.

${ }^{493}$ Od sveukupno osam tekstova Odiljenja što smo ih identificirali kao heroide, parnih ili dvostrukih je njih čak šest (Ban kralju, Kralj banu, Ban orsagu, Orsag banu, Siget kralju i Kralj Sigetu).

${ }^{494}$ Opširnije u: Hess 2007: 434.
} 
predstavljao Mark Alexander Boyd, tako i onaj vernakularni, iz kojega mu je - s obzirom na svoje sadržajne karakteristike - posebno bliska mogla biti zbirka heroida England's Heroicall Epistles (1597.) Michaela Draytona, u kojoj se (dakako, u izravnoj imitaciji Ovidija) donose ljubavne poslanice različitih znamenitih pojedinaca iz engleske povijesti, među kojima prednjače one kraljeva. ${ }^{495}$

Svega tri godine prije Hoffmannswaldaua svoj je - motivski također vrlo specifičan ciklus fiktivnih poslanica pod naslovom Urania Victrix (Pobjedonosna Uranija, 1660.) objelodanio i njemački jezuitski pjesnik Jakob Balde, postavivši u njegovo središte lik Uranije kao alegorije čovjekove duše, koju u njezinu kontemplativnom predanju Kristu i Bogu ometa pet ljudskih osjetila snubeći je zavodljivim stihovanim pismima, no koja i njima usprkos ostaje postojana te ih $\mathrm{s}$ gnušanjem sve redom odbija. Pored daleko najdominantnijih kršćanskih, Balde svoje heroide obilno premrežuje i (svjetovnim) motivima iz suvremene znanosti i umjetnosti, no pritom ipak u široku luku zaobilazi konkretne povijesne činjenice s obzirom na to da Uraniju prikazuje kao uporište kršćanske postojanosti koja ne poznaje granice prostora i vremena. Zamislivši pošiljatelje i primatelje svojih epistolarnih pjesama kao „čistokrvne“ alegorijske figure, Balde zapravo sastavlja ciklus u kojemu će pojedini književni povjesnici prepoznati kulminaciju alegoričnosti heroida, ${ }^{496}$ što - motreći ovaj žanr u njegovoj baroknoj ,inkarnaciji“ - ionako ne bi trebalo izdvajati kao njegovu dotad neviđenu posebnost budući da izrazit(ij)i alegorijski momenti stalnom značajkom sedamnaestostoljetne heroide postaju još od Bidermannovih zbirki, u kojima su poziciju pošiljatelja i primatelja s vremena na vrijeme također preuzimali alegorijski likovi. ${ }^{497} \mathrm{Za}$ sadržajnim osobitostima Baldeovih heroida u narednim će se godinama povesti i pojedini protestanstski pisci biblijskih fiktivnih poslanica poput Johanna Anselma von Ziglera und Kliphausena i Christiana Daniela Omeisa, dok će, pak, Hoffmannswaldauovoj „poetici“ (svjetovne) heroide daleko skloniji biti njegovi izravni imitatori - Daniel Casper von Lohenstein, Johann von Besier, Christoph Kiene i dr. u svojim fikcionalnim stihovanim pismima povijesnih osoba i biblijskih junaka.

Osim iz njemačke, engleske i nizozemske sedamnaestostoljetne književnosti, Pavao Ritter Vitezović uvjerljive je dokaze popularnosti žanra barokne heroide lako mogao dobiti i iz daleko bližega, talijanskog književnog baroka, u kojemu su u njegovo vrijeme posebno omiljene bile zbirke „herojskih epistola“ Antonia Brunija (Epistole Eroiche, 1627.) te Lorenza

\footnotetext{
${ }^{495}$ Usp. Eickmeyer 2014: 441-442. Za podrobnije informacije o spomenutoj Hoffmannswaldauovoj zbirci, ali i o žanru barokne heroide vidi izvrsnu studiju Veronique Helmridge-Marsillian (usp. Helmridge-Marsillian 1991). ${ }^{496}$ Usp. Isto: 440-441.

${ }^{497}$ Detaljnije u: Isto: 430-432.
} 
Crassa (Epistole Eroiche, 1655.). ${ }^{498}$ Izuzev njihovih, lako se on - možda i za svoga putovanja Italijom - mogao domoći i nekih drugih modernih fiktivnih epistolara talijanskih autora poput, primjerice, zbirke Lettere (Pisma, 1653.) čuvenoga mletačkog baroknog romanopisca i pjesnika Giovannija Francesca Loredana, objavljene pod pseudonimom Henrico Giblet, u kojoj se nižu heroide što ih jedne drugima upućuju neki od najznačajnijih i najuvaženijih pojedinaca (duždevi, kapetani, pjesnici, odvjetnici itd.) iz novije mletačke povijesti (15.-17. st.). S obzirom na to da su pošiljatelji ovih fiktivnih poslanica - razvrstanih u čitav niz zasebnih, tematski definiranih ciklusa (pisma preporuke, obećanja, čestitke, pohvalnice, izrazi sućuti, satirična pisma, pjesnička pisma, povijesna pisma, pozivnice, ljubavna pisma itd.), za kojima slijedi i ciklus adresatovih odgovora na neka od njih - mahom pokojnici koji u više slučajeva pokušavaju uspostaviti kontakt sa živim primateljima, sadržajna analogija s (pojedinim) epistolarnim odsječcima Vitezovićeva Odiljenja mogla bi se nametnuti već i sama po sebi. Štoviše, višestruke i vrlo očito generičke - pretežno sadržajne - poveznice Ritterove heroide nipošto ne uspostavljaju samo s pjesmama iz Loredanova epistolara, već gotovo s cjelokupnom ovdje ukratko predstavljenom tradicijom žanra barokne fiktivne poslanice, iz koje će već u sljedećem stoljeću izrasti mnogobrojni prozni epistolarni žanrovi kao svojevrsna potvrda njezina protoromanesknog ,potencijala“. 499

$\mathrm{Na}$ heroide iz netom pobrojanih sedamnaestostoljetnih epistolarnih zbirki po mnogobrojnim će svojim generičkim obilježjima neodoljivo tako podsjećati već i pjesma koja otvara Odiljenje sigetsko - Siget hrvatskim gospojam - a koju su pojedini povjesničari hrvatske književnosti, ozbiljno dvojeći oko njezina žanrovskog identiteta, definirali kao „neku elegičnu tugovanku grada Sigeta“ (Georgijević 1969: 132). I dok je o možebitnim elegijskim njegovim značajkama poprilično upitno govoriti, a karakteristikama „tugovanke“ ili tužaljke (lamenta) barem su podjednako - kao što ćemo doskora vidjeti - bremeniti i neki drugi tekstovi Vitezovićeve ,zrinijade“, uvodno pismo personificirana Sigeta zabrinutim majkama, zaručnicama i udovicama sigetskih branitelja po pojedinim svojim osobinama ponešto ipak odudara i od kasnijih generički mu srodnih tekstova Odiljenja. Osim činjenicom da je riječ o

\footnotetext{
${ }^{498}$ O tome više u: Helmridge-Marsillian 1991: 61.

499 Prema Claudiu Guillénu, zahvaljujući svojim je značajkama karakterističnima za kasniji žanr romana povišenoj individualnosti, autobiografičnosti, usmjerenosti na svakodnevne životne okolnosti i sl. ranonovovjekovna (humanističko-renesansna, a potom i barokna) poslanica i bila u stanju obnašati neke prepoznatljivo protoromaneskne funkcije (usp. Guillén 2005: 164-165). Iako se ovaj zaključak pretežno odnosi na (,stvarnosno orijentirane“) pjesničke poslanice, vrijedi primijetiti kako se ranonovovjekovna heroida u potpunosti bazirala na individualnom doživljaju stanovitih fiktivnih - većinom ljubavnih - ,zbivanja“, što ju i jest približavalo žanru romana, odnosno što joj je i omogućilo da u svome daljnjem - osamnaestostoljetnom razvoju posluži kao svojevrsna generička podloga epistolarnom i sentimentalnom romanu. O potonjem pitanju iscrpnije u: Eickmeyer 2014: 441-442. Opširnije o prepoznatljivim značajkama ranonovovjekovnih (pjesničkih) poslanica u: Guillén 2005: 160-165, Fališevac 2007a: 77-106, Brezak- Stamać 2012: 403-438 i naročito 2016.
} 
uvjerljivo najduljoj fiktivnoj poslanici u knjizi (obaseže ona - ponovimo - sveukupno 477 stihova), koje gotovo trećina otpada na maločas analiziran narativni („epski“) podsjetnik na tijek i ishod turskoga zauzeća sigetske utvrde, od susjednih heroida Siget hrvatskim gospojam razlikuje se i prilično upadljivim sadržajnim inzistiranjem na utješnom tonu, odnosno suosjećajnim pojašnjenjima razloga izginuća hrvatskih branitelja pod sigetskim zidinama te ukazivanjem na „više ciljeve“ njihove žrtve koja se, zbog hirovitosti sreće i sveprisutnosti smrti, naprosto nije mogla izbjeći. Zahvaljujući tim opetovanim pokušajima da navođenjem što uvjerljivijih, a onda i što utješnijih opravdanja sigetske tragedije personificirani pošiljatelj umanji bol koju će adresatkinjama izazvati nepovoljne i posve neočekivane novosti iz Sigeta, uvodna pjesma teksta - osim (glavninom) na heroidu i (djelomično) lamentaciju - svojim će tekstualnim specifičnostima ujedno neodoljivo podsjećati i na žanr antičke provenijencije koji u Vitezovićevo vrijeme uglavnom nije egzistirao izvan okvira novolatinske književnosti i čije su sadržajne preferencije i uopće način njihove obrade u potpunosti proizlazili iz njegove osnovne zadaće ublažavanja ljudske patnje prouzročene stanovitim vanjskim razlogom ili razlozima. Riječ je o, konkretno, žanru latinskoga naziva consolatio ili konzolacija, ${ }^{500}$ koji se - nastavši na presjecištu retorike i filozofije - u svojim retoričkim antičkim začecima isprva pojavljivao isključivo $u$ formi utješnoga govora izricanoga u povodu nečije smrti (najčešće u sklopu samih pogreba ili prilikom javnoga izražavanja sućuti i žaljenja), da bi postupno zatim prešao u književnost, sve češće se pojavljujući u stihovanim i proznim ostvarenjima. ${ }^{501}$

Budući da se i književna konzolacija - nalik svojoj „čisto“ retoričkoj prethodnici redovito svodi(la) na izricanje utjehe potaknute konkretnom nevoljom čiji je uzrok izvanjske, a ne unutarnje (mentalne ni tjelesne) prirode, ${ }^{502}$ nju - u sadržajnom pogledu - karakterizira upravo izravno obraćanje adresatu suočenu s teškim i nenadoknadivim gubitkom (najčešće sa smrću bliske osobe, progonstvom ili drugom jednako ozbiljnom životnom nedaćom), izražavanje sućuti te podastiranje utješnih argumenata u svrhu ublažavanja osjećaja patnje. Među potonjim (racionalnim) argumentima ili utješnim spoznajama, koje se u konzolaciji isprepliću s osobnim iskazima suosjećanja, pritom obično prednjače - kao i u Ritterovu slučaju - one o svemoći i nestalnosti sudbine i sreće, o privremenosti čovjekova

\footnotetext{
${ }^{500}$ Pohrvaćenim nazivom „konzolacija“ žanr consolatio u svojoj je studiji prvi u nas prozvao Neven Jovanović. Usp. Jovanović 1998.

${ }^{501}$ Za kratak pregled povijesti žanra consolatio, koji je - pojavivši se najprije u obliku utješnoga govora (kao jedna od podvrsta epideiktičkoga govora) - posebno u formi dijaloga bio proširen u grčkoj (Pseudo-Platon, Pseudo-Plutarh) i rimskoj antici (Ciceron, Seneka) te latinskom srednjovjekovlju (većinom zahvaljujući posredovanju kršćanskih autora, ponajprije Ambrozija, Jeronima i Paulina iz Nole), a otad sve češce i u utješnome pjesništvu, većinom sastavljanom u povodu nečije smrti, usp. Curtius 1998: 91-93, Jovanović 1998 i 2002: 413-442, Agrell 2015: 11-35.

${ }^{502}$ Detaljnije u: Agrell 2015: 16.
} 
ovozemaljskog bivanja, o vremenu koje će postupno zaliječiti rane, o životu čija je kvaliteta proporcionalna kvaliteti, a ne kvantiteti proživljenog, o pozitivnoj „ostavštini“ što su je pokojnici ostavili iza sebe itd., koje se najčešće i potkrepljuju mnogobrojnim općepoznatim primjerima. Zahvaljujući njezinim retoričkim korijenima, pobrojane utješne spoznaje u konzolaciji u pravilu bivaju protkane nizom prepoznatljivih stalnih motiva ili toposa poput dobro nam znanoga toposa memento mori, potom toposa neizbježnosti smrti ili druge nevolje, toposa prerane smrti, toposa smrti koja izjednačuje starca i mladića itd., ${ }^{503}$ kojih je - posve razumljivo - nemali broj našao svoje mjesto i u uvodnoj dionici Odiljenja sigetskog kao, istodobno, dokaz Ritterove nesumnjive upućenosti u žanrovski repertoar ovoga mahom novolatinskog žanra, ali i retoričke okretnosti proizišle iz mukotrpnih vježbi kojima je obilovalo njegovo školovanje u zagrebačkoj isusovačkoj gimnaziji. ${ }^{504}$

Razmotrimo li ga, međutim, nešto pažljivije, uvidjet ćemo da consolatio - kao takav nije zapravo ništa drugo nego kombinacija određenih sadržajnih čimbenika prizvanih u cilju izvršavanja specifične književne i/ili izvanknjiževne svrhe (pružanja utjehe adresatu), a bez jasno definirana - i, dakako, povijesno varijabilnog - tematskog, formalnog, stilskog ili, jednom riječju, generičkog okvira, slijedom čega nas ne bi trebalo iznenađivati to što u posljednjih nekoliko desetljeća povjesničari književnosti sve češće izražavaju sumnju u mogućnost njegova definiranja žanrom u punom smislu riječi. Shvativši, naime, da su tijekom njezina višestoljetnog povijesnog trajanja konzolaciju upijali generički kojekako ostvareni književni i ne samo književni tekstovi, navedenim proučavateljima daleko se opravdanijim učinilo govoriti o konzolatornim sadržajima no o (literarnom) žanru konzolacije, koja bi se u tom smislu trebala ispostaviti mnogo bliskijom, primjerice, alegoriji kao figuralno-sadržajnoj pojavi koja provocira sasvim određeni tip čitanja ili tumačenja generički raznoliko obilježenih tekstova u koje biva uvrštena. Na konzolaciju, drugim riječima, ne upućuje ništa više od tek nekoliko suosjećajnih, utješnih konstatacija protkanih prepoznatljivim retoričkim toposima, koje se - pojavi li se sadržajna potreba za njima - mogu uključiti u doslovno bilo koji književni, poluknjiževni, pa i neknjiževni žanr, iako se kroz svoju povijest u nekima od njih uistinu pojavljivao osjetno češće nego u nekim drugim. Iako, konkretno, vrlo bogatoj i

\footnotetext{
${ }^{503}$ O pobrojanim i mnogim drugim konzolacijskim toposima više u: Curtius 1998: 91-93 i Agrell 2015: 21.

${ }^{504}$ Tako je, primjerice, (konzolacijski) topos memento mori - kojim je Odiljenje premreženo od korica do korica - u pjesmi Siget hrvatskim gospojam isprepleten s toposom neizbježnosti smrti, utkanim u poučne dionice „nadograđene“ nizom poslovičnih potvrda (npr. I: 264-278, 301-314, 341-342, 381-388 itd.), dok topos prerane smrti zatječemo većinom u stihovima u kojima se podsjeća na neočekivanost rastanka sada već izginulih sigetskih branitelja s njihovim najmilijima (I: 290, 361-364, 409-410). Potonji je topos, uz to, pri samom kraju pjesme dodatno naglašen i vrlo uspjelom metaforom opće krhkosti života („Mnogič cvit uvene, prvo neg dozrije, / i litnje sunčene svitlosti tma krije“; I: 463-464), koja se odnosi upravo na suviše rano izgubljene živote kršćanskih branitelja Sigeta.
} 
dugotrajnoj tradiciji konzolacijske književnosti tako pripadaju čak i retorički priručnici, filozofski dijalozi i traktati, nadgrobni govori, biografije, hagiografije i propovijedi, uvjerljivo najdublji je trag consolatio ostavio u nadgrobnim natpisima, epicedijima, elegijama i utješnim (stihovanim i proznim) pismima, zbog čega onda i ne čudi Ritterova odluka da upravo u poduljem epistolarnom odsječku svoje ,zrinijade“ posegne za njemu svojstvenim motivskim momentima. Ipak, u gotovo bilo kojem žanru u koji se „ulijeva“ konzolacija je lakoćom mogla prijeći u puku etičku, fillozofsku ili teološku pouku, u izvještaj o smrti ili životopis, a $\mathrm{k}$ tome još treba imati na umu i da su konzolatorne nakane lako mogli iskazivati i tekstovi bez eksplicitnih tješiteljskih sadržaja poput, primjerice, nekih nabožnih ostvarenja, ali i da je consolatio zbog njegovih motivskih specifičnosti u praksi vrlo teško razlučiti od žanra lamenta ili tužaljke, što je - uostalom - poprilično bjelodano i iz samoga Odiljenja. ${ }^{505}$

No, usprkos činjenici što se poradi njene i više nego očite „,bezobličnosti“ u prvi mah zaista čini da konzolacija ne ispunjava nužne generičke „preduvjete“, čak i (pojedini) književni povjesnici koji su propitivali njezin žanrovski status tog je statusa u potpunosti ipak nisu željeli lišiti, i to ponajprije stoga što su, tvrde, ,temeljna“ (sadržajna) obilježja iz njezina „repertoara“ (zadaća pružanja utjehe, uvriježeni toposi i druge stalne retoričke procedure) od antike do konca ranoga novog vijeka glavninom ostala nepromijenjena. ${ }^{506}$ Consolatio se, uostalom, još od antičkih retoričkih početaka zasnivao na (otprilike) sličnoj kompoziciji, i to neovisno od toga u kojem se trenutno žanru zatekao, a u toj kompoziciji konstanta nisu bili samo izrazi suosjećanja $\mathrm{s}$ ožalošćenim adresatom, već i usporedbe njegove nevolje $\mathrm{s}$ nevoljama slavnih pojedinaca iz društvene povijesti ili mitologije, ali i utješni - toposima bremeniti - argumenti, za kojima bi na koncu redovito slijedili izrazi podrške, odnosno savjeti da se prisjeti lijepih trenutaka i da na njima bude zahvalan, ali i da ne dopusti da ga posve shrva tuga jer još uvijek ima za koga i zbog čega živjeti. Ponajbolji primjer opisane kompozicije nudi nam upravo pjesma Siget hrvatskim gospojam, u kojoj personificirani Siget već u prvoj dionici teksta otvoreno daje do znanja kako s ucviljenim „vilama i gospojama“ dijeli neizmjernu tugu zbog pogibije hrvatskih branitelja, a potom do konca pjesme - $\mathrm{s}$ izuzetkom, dakako, središnjega narativnog dijela (I: 89-244) - niže utješne argumente prepune topičkih momenata, ne zaboravljajući ni svoj težak usud prispodobiti drugim jednako nesretnim povijesnim događajima („Druga sam ja Troja i Muhačko polje“; I: 244), ali ni adresatkinjama savjetovati da se odveć ne predaju tuzi jer njihovi najmiliji smrtni ishod ionako nisu mogli izbjeći („Nemojte tužiti za njih više reda / nit lišca ružiti, gdi se mita ne da,

505 Podrobnije o žanrovskim ili nežanrovskim temeljima konzolacije u: Jovanović 1998: 86-89 i 2002: 414, Agrell 2015: 13-15.

${ }^{506}$ Usp. Jovanović 1998: 86-89. 
/ k smrti, ka sve žeda, k njoj svaka stvar živa, / kašnje ali vreda, li jednuč dospiva“; I: 339342), dok, pak, djecu poginulih ohrabruje da ne tuguju, već da svojim majkama i domovini služe baš kao što su to činili i njihovi očevi („Ditco plemenita, prosim, ne tužite, / vam srića još svita, neg majkam služite / tere se učite otac vaših slide / i vi se kažite domovini zide“; I: 431-434). Na kraju krajeva, baš kao što je u dotadašnjim (latinskim) konzolacijama bilo uobičajeno ne samo oprimjeriti navedene utješne spoznaje egzemplima ili slučajevima identičnih nevolja iz svjetovne ili religijske povijesti, nego i - nerijetko - citatima iz djela književnih i filozofskih autoriteta koji potvrđuju iznesena razmišljanja, ${ }^{507}$ tako i Vitezović u uvodnoj pjesmi kršćanski poraz pod Sigetom prispodobljuje padu Troje i nekoliko desetljeća starijem osmanlijskom trijumfu na Mohačkom polju, ali ujedno i svoje utješne argumente potkrepljuje nizom (dijelom i ,narodnih“) poslovica te prepoznatljivo neostoicističkih shvaćanja što ih je - pokazat će se nešto kasnije - najvjerojatnije upio čitajući neka od tada vrlo popularnih ostvarenja zastupnika filozofije neostoicizma.

Kao što je već nagoviješteno, Ritter se - kao isusovački đak - s nekima od najuspjelijih, ali i najstarijih primjeraka konzolacije nedvojbeno morao susresti još za svoga školovanja, što bi onda značilo da je prvu predodžbu o ovome žanru jamačno stekao čitajući antičke njegove autore. Osim što je (i) u antici consolatio u najvećem broju slučajeva bio adresiran na članove pokojnikove najbliže obitelji ne bi li im pomogao nositi se s tugom zbog neizmjernoga gubitka, odnosno pružiti im utjehu utemeljenu na racionalnim argumentima, već tada ga je bilo moguće zateći u uistinu širokom rasponu (književnih) žanrova, no iako su u to vrijeme napisana brojna prozna i stihovana književna djela obilježena konzolacijskim momentima (primjerice, neke Ovidijeve i Propercijeve elegije, Stacijeve prigodnice i dr.), najvažnijim i najutjecajnijim antičkim primjer(k)om konzolacije ostao je ipak Boetijev filozofski tekst Utjeha filozofije (Consolatio philosophiae). Daljnji prodori konzolacije u različite književne i ne samo književne žanrove bit će zabilježeni u razdoblju humanizma i renesanse, kada consolatio - najčešće se pojavljujući unutar generičkih okvira govora, filozofskih dijaloga, proznih epistola, stihovanih poslanica i brojnih drugih lirskopjesničkih žanrova - u europskoj književnosti zapravo i doživljava svoj (žanrovski) vrhunac. O iznimnoj šesnaestostoljetnoj njegovoj važnosti možda i najuvjerljivije svjedoči pojava (poetičkih) propisa ili naputaka za sastavljanje „dobrih“ (književnih) konzolacija, kojima se u svojem utjecajnom poetičkom priručniku Poetices libri septem (1561.) tada pozabavio i sam Julije Cezar Scaliger. S obzirom na to da je u ono vrijeme prevladalo mišljenje kako na žaljenje u najvećoj mjeri utječu uznemirujuće strasti, odnosno nerealne patnikove prosudbe o vanjskim

\footnotetext{
${ }^{507}$ O citatnosti kao jednoj od prepoznatljivih značajki „žanra“ konzolacije u: Jovanović 1998.
} 
okolnostima uslijed kojih se našao, i Scaliger, ali i drugi teoretičari i praktičari ovoga žanra vjerovali su kako bi se konzolacije najviše morale usredotočiti na ispravljanje tih i takvih loših prosudbi, i to podastiranjem prikladnih filozofskih argumenata koji ožalošćenomu mogu pomoći da svoje nevolje počne sagledavati iz daleko racionalnijega, „trezvenijeg“ očišta.

Makar poneki onodobni primjerak konzolacije koji je ispunjavao ove poetičke preduvjete Vitezović je najvjerojatnije za svoga školovanja (a i kasnije) također imao prilike pročitati, a nipošto ne bi trebalo posve isključiti ni mogućnost da je - u godinama uoči rada na Odiljenju - u njegove ruke (u možda nekom od svojih prijepisa) dospjelo i jedno od najuspjelijih domaćih konzolacijskih ostvarenja iz toga perioda, koje potpisuje naš čuveni humanistički pisac Nikola Modruški. Riječ je o, konkretno, retoričkom priručniku De consolatione $(O$ utjesi) što ga je Modruški sastavio polovinom 15. stoljeća (vjerojatno oko 1465./1466.), zamislivši ga kao svojevrsnu proznu zbirku verbalnih utjeha, točnije retoričkih „lijekova“ za ublažavanje tjeskoba prouzročenih najrazličitijim mogućim životnim nedaćama. I dok se u njemu tako obrađuju teorija i metode tješenja, odnosno nude upute za tješenje, definiraju vrijeme i načini pružanja utjehe te zatim potanko objašnjava svaki od navedenih načina, ${ }^{508}$ u nešto više od pola stoljeća „mlađoj“ dijaloškoj religiozno-didaktičkoj lirskoj pjesmi Utiha nesriće Marka Marulića znatan broj tih se teorijskih naputaka u književnom obliku vrlo uspješno dospijeva provesti u djelo. Doduše, Marulić se zapravo - kako je relativno nedavno utvrđeno ${ }^{509}$ - pri pisanju svoje pjesme otvoreno oslanjao na PseudoSenekin moralno-filozofski konzolacijski dijalog De remediis fortuitorum, koji je u njegovo vrijeme uživao ništa manju popularnost od one što ga je pratila još tijekom čitava srednjeg vijeka. U Utihi nesreće se tako, posve u stilu (do)tadašnjih - pa i kasnijih - konzolacijskih tekstova, nabrajaju raznorazne nesreće ili „tuženja“ te zatim za svaki od njih podastiru prikladni utješni argumenti ili lijekovi za ljudske patnje, a sve to u tekstu koji konzolacijska obilježja nosi isključivo u svojoj sadržajnoj dimenziji, dok čitatelje - baš kao i u slučaju Vitezovićeve heroide Siget hrvatskim gospojam - idejna i formalna njegova obilježja navode na neku sasvim drugačiju njegovu generičku identifikaciju (u ovom slučaju kao renesansne dijaloške lirske pjesme, i to - preciznije - nabožno-didaktičke).

Ako ne već iz Marulićeva ili konzolacijskih ostvarenja drugih šesnaestostoljetnih domaćih ili stranih pisaca, Vitezović se u dvostruke, pa čak i višestruke žanrovske identitete tekstova „,nadograđenih“ obilježjima ,žanra“ consolatio lako mogao uvjeriti čitajući generički srodna ostvarenja kojih nije manjkalo ni u njegovo doba. Naprotiv, ništa manja

\footnotetext{
${ }^{508}$ Vrlo detaljno o ovom konzolacijskom tekstu Nikole Modruškog u: Jovanović 1998.

${ }^{509}$ Usp. Jovanović 2002: 413-442.
} 
sedamnaestostoljetna omiljenost konzolacije mogla bi se razumjeti kao izravna posljedica izrazite barokne zaokupljenosti temama propadanja, razaranja, sveopćeg uništenja, kraja svijeta i umiranja, kojima su - bez obzira na osobna religijska uvjerenja - bili makar u nekoj mjeri skloni gotovo svi tadašnji literati, posvećujući im svoje generički raznoliko obilježene tekstove čiji su sadržaji gdjekad uključivali i motive tješenja. Osim što će tako konzolacijske momente sadržavati i mnogobrojni onodobni retorički i filozofski tekstovi, pa čak i liturgijski priručnici kršćanskih crkava, „punokrvnim“ konzolacijama moguće je proglasiti i niz sedamnaestostoljetnih literarnih ostvarenja, poglavito onih lirskopjesničkih poput - primjerice - pojedinih tekstova iz lirskog opusa Françoisa de Malherbea ili, pak, dirljive pjesme o očevoj smrti francuskoga baroknog pjesnika Théophilea de Viaua, koja se u književnopovijesnim pregledima već poodavno i ,vodi“ upravo kao consolatio. ${ }^{510} \mathrm{U}$ korpusu barokne književnosti moguće je, štoviše, zateći i nemali broj stihovanih epistola s prepoznatljivim konzolacijskim sadržajnim značajkama, a znamo li, k tome, da se još od antike do renesanse consolatio uvjerljivo najčešće i pojavljivao u žanru (proznoga) pisma ili poslanice u stihu, tada nam se ni Vitezovićeva odluka da jednu od heroida u svome Odiljenju obilato premreži konzolacijskim karakteristikama nipošto ne bi trebala učiniti neobičnom, a kamoli - iz književnopovijesne perspektive - novom i neočekivanom.

Štoviše, usredotočimo li se iznova na (sekundarni) žanr (barokne) stihovane poslanice, čijim karakterističnim obilježjima je (ne samo) pjesma Siget hrvatskim gospojam protkana od prvoga do posljednjeg stiha, ono s čime ćemo u vezi s njom svakako morati računati jest upravo njezina izrazita sklonost upijanju tekstualnih osobitosti neobično velikoga broja (primarnih i sekundarnih) književnih, ali i samo rubno književnih žanrova, a gdjekad čak i uključivanju cjelovitih njihovih primjeraka u svoje tekstualno tkivo. Naime, već od antičkih svojih začetaka oba su žanra epistole u stihu najčešće tako bila „proširivana“ stanovitim generičkim značajkama ili čitavim primjer(c)ima lirske pohvalnice (panegirika), nekrologa, elegije, satire, alegorije, ljubavno-erotske pjesme, filozofske lirske pjesme, polemičke rasprave itd., ${ }^{511}$ dok - s druge strane - brojni stihovi iz Ovidijevih Heroida neodoljivo podsjećaju na sentencije ili poslovice, zahvaljujući čemu su i u pojedinim kasnijim kompilacijama poslovica nerijetko nalazili svoje mjesto. ${ }^{512}$ Ništa drugačije od, primjerice, biblijskih novozavjetnih epistola, prožetih nemalim brojem obilježja drugih (književnih) žanrova (poglavito teološke rasprave, pouke, himne itd.) ili njihovih cjelovitih realizacija, ${ }^{513} \mathrm{i}$

\footnotetext{
${ }^{510}$ Usp. Warnke 1972: 212-213.

${ }^{511}$ Usp. npr. Fališevac 2007a: 81-82.

512 Podrobnije u: Curtius 1998: 68.

513 Više o tome u: Slavić 2016: 102.
} 
većina Ritterovih latinskih pjesničkih poslanica - kako su to uvjerljivo potvrdila novija istraživanja ${ }^{514}$ - „sklopljena“ je tako od značajki crpljenih iz različitih generičkih repertoara, a isti će zaključak vrijediti i za osam heroida uključenih u Odiljenje sigetsko, u kojima (tipično za žanr barokne fiktivne poslanice), pored konzolacijskih osobitosti i epskopjesničkih „tragova“, zatječemo još i niz poslovica, pouka, kletvi, blagoslova itd.

Osim otvorenosti karakteristikama raznoraznih literarnih i ne samo literarnih žanrova, fiktivne su s pjesničkim poslanicama dijelile i neke druge tekstualne crte poput formulaičnosti, odnosno stanovite topičke određenosti ili zadanosti, koju je - uostalom moguće uočiti i u heroidama prvoga i drugoga „dila“ Odiljenja. Baš kao što se, konkretno, u pjesničkim poslanicama redovito „na početku i na kraju lista javljaju (...) konvencionalne formule, uvodna i zaključna“ (Fališevac 2007a: 79), tako i u velikoj većini onih fiktivnih zatječemo vrlo slične „uokvirujuće“ topose uvoda i završetka - najčešće u obliku oslovljavanja i pozdravljanja adresata, pojašnjavanja razloga sastavljanja pisma, upućivanja adresatu dobrih želja ili molbi za odgovorom i sl. - uz koje nije rijetkost susresti čak ni pojedine druge topose iz bogate palete epistolarne topike poput, primjerice, toposa afektirane skromnosti, toposa pohvale, toposa žaljenja za prošlim vremenima itd. ${ }^{515}$ Činjenicu da je, pored onih maločas utvrđenih konzolacijskih, i određen broj uvriježenih epistolarnih toposa također našao svoje mjesto u heroidama Vitezovićeve „zrinijade“ valjalo bi stoga tumačiti ne samo kao neoboriv dokaz autorove upućenosti u poetiku (barokne) fiktivne poslanice, već i kao jasan pokazatelj njegove nakane da epistolarne dionice svojega ostvarenja realizira kao (sadržajno, formalno i uopće žanrovski) jasno zaokružene, u sebe zatvorene lirske tekstove koji - svaki ponaosob - pretpostavljaju precizno navedenog subjekta (pošiljatelja), adresata (primatelja) i ,predmet“ ili temu njihova dopisivanja, a sve to u vremenskoj perspektivi posljednjih dana opsade Sigeta i vrlo kratkome razdoblju neposredno nakon njegova pada. Tu zaokruženost upravo i valja izdvojiti kao ključni razlog zbog kojega pjesme-heroide, usprkos svojoj „kontaminiranosti“ posebnostima inih žanrova, definitivno spadaju - pored nadgrobnica četvrtoga „,dila“ - u generički najjasnije profilirane segmente Odiljenja, u kojima pisanim putem u trenucima kada Siget polagano prelazi u turske ruke neposredni sudionici bitke o svojoj nevolji izvještavaju adresate koje će ta nevolja i više nego ozbiljno zabrinuti.

Vitezovićevo uvažavanje poslaničke topike čak i u fiktivnim epistolama žanrovski mu razbarušene „zrinijade“ možda bi zapravo najopravdanije bilo motriti kao svojevrsnu kreativnu „posljedicu“ kontinuirane zaokupljenosti sastavljanjem - pretežno latinskih -

${ }^{514}$ Usp. Moretti 2014 i Moretti i Stepanić 2019: 9-116.

515 Detaljnije o epistolarnoj topici kao temeljnoj generičkoj značajki pjesničke poslanice u: Moretti 2014: 157 168 i Brezak-Stamać 2016: 85-163. 
pjesničkih poslanica adresiranih na onodobne uglednike i prijatelje, čije su (barokne) generičke norme i propisivale obilatu uporabu toposa i uopće oslanjanje na tradicionalne oblikovne sheme. ${ }^{516}$ Premda poetika (baroknih) fiktivnih poslanica nije pretpostavljala strogost u oblikovanju ekvivalentnu onoj pjesničkih poslanica, u gotovo svim heroidama Odiljenja sigetskog naići ćemo na prepoznatljive epistolarne topose i druge stalne motive, koji su se kroz povijest ovoga žanra - sve od Ovidija do sedamnaestostoljetnih njegovih evokacija - iskristalizirali kao njegova trajna i poželjna tekstualna svojstva. Riječ je o, konkretno, ne samo uvodnom toposu oslovljavanja adresata („Gospoje hrabrene i hrvatske vile“, I: 1; „Kralju, kruno sveta, svita gospodine“, II: 1; „Verni moj hrabreni kneže, dragi bane“, II: 58; „Gospodo i knezi hrvatske države“, II: 93; „Rimska crikvo sveta, čista viro krsta“, II: 486 itd.) i njemu vrlo bliskom toposu pohvale (,slavna vilo“, I: 254 i 299; „,viteže venčeni, šćite moje strane“, II: 2; „naš viteški bane“, II: 118; „preslavni kralju moj“, II: 460), već i dobro poznatom toposu referiranja na sam epistolarni medij (,evo od Sigeta najkašnje novine“, II: 2; „Još sad, kruno sveta, prilika j' pisati“, II: 440; „Tvoj list na veliko prijeh žalošćenje“, II: 467), potom toposu iskazivanja lojalnosti i vjernosti adresatu (primjerice, u heroidi Ban kralju: „Pisma uzrok drugi ni mi, gospodine, / neg vernosti dugi pisat ti me čine“; II: 7-8), toposu otvorenog žaljenja za prošlim vremenima (npr. ,Jur je dovršeno vrime sriće moje“; II: 502), ali i zaključnom toposu upućivanja dobrih - u ovome slučaju posmrtnih - želja („molimo ti dvora rajskoga svitline / i pomoć odzgora zvrh tvoje družine“, II: 142-143; „V misli ću imati vitezov trpljenje, / kojim Bog htij dati nebesko življenje“; II: 484-485). U fiktivnim poslanicama Odiljenja, osim toga, svoje je mjesto našao i Vitezoviću osobito drag epistolarni topos oplakivanja vlastite gorke sudbine (utkan pretežno u lamentacijske dionice uvodne heroide Siget hrvatskim gospojam, ali i u neke poslanice iz drugoga „dila“, npr. „Vas u tugi stojim iz ove prilike, / plačem zbranim mojim nesriće tulike“, II: 122-123; „došla je zla vrsta tužnih rokov mojih, / da ginem od prsta zmed prstenov tvojih“, II: 488-489 itd.), koji je - posredstvom motiva lamentiranja nad osobnom nesrećom (točnije, realiziran pomoću obilježja žanra tužaljke ili lamenta, o čemu će uskoro biti više riječi) - u žanru heroide bio prisutan još od Ovidija, u čijim su Heroidama zbog svojih ljubavnih nevolja tužile mitske

\footnotetext{
${ }^{516}$ Kako je utvrdila Violeta Moretti proučavajući korpus njegovih pjesničkih poslanica na (pretežno) latinskom jeziku, uobičajena Ritterova epistolarna shema sastojala se od naslova, referiranja na sam poslanički medij ( $\mathrm{tj}$. raniju korespondenciju), eksplicitno navedena imena (i epiteta) primatelja, iskaza prijateljstva i privrženosti, navođenja razloga sastavljanja poslanice (konkretne molbe popraćene opisom događaja iz kojih je ona proistekla i neizbježnih lamentacija nad teškom vlastitom situacijom) te zaključnoga iskazivanja odanosti, upućivanja dobrih želja te svojega (a gdjekad i tuđeg) pozdrava primatelju. Ono što se u Vitezovićevim poslanicama pritom nameće kao njihova vrlo očita specifičnost jest redovito inzistiranje na (nerijetko i vrlo opsežnim) jadikovkama nad nepovoljnim okolnostima u kojima se primatelj zatekao, ali i na mnoštvu pohvalnih izraza u čast adresata, očito s ciljem da ga se odobrovolji, odnosno potakne na pružanje konkretne pomoći unesrećenome adresatu (dakle, samomu Pavlu Ritteru). Opširnije o epistolarnoj shemi Vitezovićevih poslanica u: Moretti 2014: 156.
} 
junakinje povrijeđene bezosjećajnošću voljenih muškaraca, pa sve do baroknih svojih realizacija poput, primjerice, Bidermannovih Poslanica junaka, u kojima mnoge pjesmepisma do svojih primatelja stižu natopljene pošiljateljevim gorkim suzama.

Svoju nakanu sastavljanja heroida po očigledno suvremenim - sedamnaestostoljetnim - uzorima Pavao Ritter Vitezović nepogrešivo odaje i mnogim drugim posebnostima epistolarnih segmenata Odiljenja sigetskog. Konkretno, ukoliko bi uvodna heroida njegove „zrinijade“ trebala tako predstavljati (,neformalni“ i stoga daleko emotivniji) pisani izvještaj o sigetskoj katastrofi upućen najbliskijim članovima obitelji izginulih kršćanskih branitelja, onda se za one okupljene u drugome „dilu“ može reći da funkcioniraju kao („službene“ te stoga i jezgrovitije te vidno manje emotivne) obavijesti o padu Sigeta namijenjene istaknutim „javnim osobama“ (kralj), institucijama (katolička Crkva) i čitavu hrvatskom društvu kao personificiranom entitetu (orsag). S obzirom na to da $-\mathrm{s}$ izuzetkom Crkve, koja jedina Sigetu ne uzvraća pismo - iz njihovih netom priloženih odgovora čitatelj dobiva priliku vidjeti kako su kršćanski poraz osobno doživjeli oni u koje se ban Zrinski zaklinjao i uime kojih se do posljednjega daha odvažno odupirao osmanlijskim napadačima - kralj, hrvatska domovina i (neizravno) Bog - i više je nego očito da je generički predložak za ove svoje (većinom) parne heroide Vitezović našao upravo u onim svjetovnim epistolarima objelodanjivanima diljem sedamnaestostoljetne Europe, u kojima su se kao pošiljatelji i primatelji fiktivnih poslanica sve češće pojavljivale neke od najznačajnijih osoba iz (novije) povijesti, a među njima gdjekad čak i - kao što smo vidjeli - personificirani entiteti poput Crkve ili kraljevstva. Dapače, kao jedan od najočitijih signala Vitezovićeva nasljedovanja generičkog repertoara barokne heroide upravo bi se i moglo izdvojiti potonje inzistiranje na već poodavno mrtvim ili personificiranim neživim (iako neosporno povijesno postojećim) objektima, stvarima i institucijama u ulozi pošiljatelja i/ili primatelja fiktivnih poslanica, tim više što i u nizu drugih književnih i poluknjiževnih sedamnaestostoljetnih žanrova ni najmanje neobična nije bila pojava također „uskrslih“ ili personificiranih govornika. I baš kao što su se u baroknim heroidama dopisivale davno umrle istaknute povijesne ličnosti, u baroknim tužaljkama lamentirali pojedinačni gradovi ili čak čitave države, a iz baroknih epitafa ili nadgrobnica progovarali znameniti pokojnici ili tek bezimene „obične“ životinje, tako su i u baroknim heraldičkim lirskim pjesmama riječ uzimale „oživljene“ pokrajine ili zemlje ne bi li - kao što je to, uostalom, slučaj i u Ritterovu (svojedobno vrlo popularnu) grbovniku Stemmatographia $(1701 .)^{517}$ - osobno opisale svoje grbove, odnosno pjesnički razjasnile njihovu simboliku.

\footnotetext{
517 Podrobnije o Stemmatographiji u: Klaić 1914: 152-155, Ljubović 2002: 1190-1196, Blažević 2002 i 2016: 158, Kolanović 2012: 146-147.
} 
Jedan od najpresudnijih poticaja pri odabiru žanra barokne heroide Vitezoviću je zasigurno morao doći od njegova najvećeg (sedamnaestostoljetnog) literarnog uzora - Petra Zrinskog, koji u svojoj Adrijanskoga mora Sireni - slijedeći mađarski bratov predložak - na čak nekoliko mjesta (ne samo unutar Obside sigecke) donosi epistolarno realizirane dionice ili čitave pjesme. Bliskost žanru fiktivne poslanice u Sireni tako, prije svega, iskazuje već jedna od dviju ljubavnih lirskih pjesama što prethode Obsidi, i to ona naslovljena Pisam II., u kojoj se spoznaje tužba zvirara, u kojoj se - u 36 četverostruko rimovanih jedanaesteračkih katrena - beznadno zaljubljeni lovac (,zvirar“) obraća voljenoj vili Violi poručujući joj kako je povrijeđen njezinom hladnoćom i bezosjećajnošću - odlučio napokon raskrstiti s njom. Premda ovoj „poslanici“ nedostaje uobičajeno naslovno ekspliciranje pošiljatelja i primatelja, ali i uvodni te još niz drugih epistolarnih toposa što smo ih detektirali i u Vitezovićevim heroidama, činjenica da subjekt (pošiljatelj) u njoj o svojoj odluci izvještava odsutnu adresatkinju (primateljicu) koja s njime očigledno odbija uspostaviti govornu komunikaciju („Kot najtanja zgiba magla pred vitrom / i kot tinja pred padućim javorom, / kot mraz puzi pred toplotom sunčenom, / tako mi si ti šetuća pred manom“; 11. strofa), kao i činjenica da je već u prethodnoj pjesmi - Pisam I., u kojoj se spočita velika okornost Viole - subjekt istu adresatkinju preklinjao da posveti pažnju (ljubavnim) pismima što joj ih neprekidno šalje (,,i glej okom milim ma pisma ponizna“; 26. strofa), daju nam za pravo pomisliti kako se (i) u ovome slučaju radi upravo o pjesmi zamišljenoj kao fiktivna epistola u stihu. Uostalom, da Pisam II. obilježjima svojstvenima (baroknoj) heroidi nipošto ne oskudijeva u potpunosti sugerirat će nam ne samo zaključni pozdrav („Bog s tobom!“), vrlo blizak topičkim izrazima kojima su se poslanice obično privodile kraju, te naznake toposa žaljenja za minulim (predljubavnim) vremenima („Svaku radost, koju do sad prijimah, / velu žalost prema tebi proštimah, / zbog liposti tvoje vsagda prebivah / v turobnosti, v koj nigdar ne počivah“; 31 . strofa), nego i - ponajviše - lamentacijski ton koji je prožima od prvoga do posljednjeg stiha, a koji bi se lako mogao protumačiti kao posljedica uključivanja jednog od najprepoznatljivijih epistolarnih toposa, i to onoga tuženja nad gorkim vlastitim usudom.

U skladu s već primijećenom otvorenošću baroknoga povijesnog epa značajkama raznoraznih (književnih) žanrova, ni Petar Zrinski - na bratovu tragu - svoju Obsidu sigecku nije propustio napučiti generički kojekako ostvarenim dionicama, među kojima se svojom prepoznatljivošću - ali ne i naročitom brojnošću - izdvajaju upravo one epistolarne. Prvo takvo „umetnuto“ pismo zatječemo u petom „delu“ ili pjevanju Obside (V: 83-89518), u kojem

\footnotetext{
${ }^{518}$ Za razliku od Odiljenja, u citiranju kojeg se arapskim znamenkama označavaju stihovi unutar konkretnoga „dila“, u slučaju Petrove Obside sigecke arapske znamenke upućivat će na strofe unutar danoga pjevanja.
} 
ban Zrinski - uvjerivši se da su njegovi suborci spremni braniti utvrdu do smrti - piše ,,jedan list (...) kralju ugarskomu“ ne bi li ga obavijestio o pripremama za obranu, a ujedno se, za slučaj (vrlo izgledne) svoje smrti u okršaju s Turcima, od njega i zauvijek oprostio („Prošćenje ću vzeti od tebe na vike, / jer te već videti ne bu mi prilike“). Na sljedeća dva pisma - ovaj put iz pera turskih likova - čitatelj će pričekati tek dvanaesto pjevanje, u kojem jedan od najodvažnijih osmanlijskih ratnika Deliman svojom vrlo kratkom porukom (XII: 40) odgovara na ljubavno pismo voljene mu Kumile (XII: 35-38), a već u narednom pjevanju četvrtu i ujedno posljednju poslanicu u epu sastavljaju Sigećani pritisnuti turskim napadima (XIII: 89-96), čije nade da će pismo po golubu pismonoši dospjeti u ruke kralja ubrzo gasi turski sokol, koji presreće goluba natjeravši ga da sleti ravno pred Sulejmanov šator.

Osim pojedinačnih motivskih i topičkih paralela, pa čak i očitih podudarnosti u nekim stihovima, ${ }^{519}$ sličnosti između fiktivnih poslanica iz Petrove Sirene i onih iz Odiljenja sigetskog definitivno su najuočljivije na idejnoj ili tematskoj razini s obzirom na to da je većina epistolarnih odsječaka u oba teksta inicirana sadržajnom nužnošću pošiljateljeva (trajnog) rastanka s odsutnim primateljem, i to bez obzira na to radi li se o „tek“ razdvajanju zaljubljenika (kao što je to slučaj s pjesmom Pisam II.) ili o oproštaju neustrašivih branitelja kršćanske utvrde od njihova kralja (kao u pismima bana Zrinskog i Sigećana). Ugledajući se u četvrt stoljeća stariju ,zrinijadu“ svoga neposrednog prethodnika, Vitezović nije mogao ne primijetiti tu primjerenost teme (ratnoga) rastanka žanru heroide, naročito $\mathrm{u}$ kontekstu narativnoga ili epskopjesničkog teksta posvećenog opjevavanju opsade i pada Sigeta, u kojemu se upravo poslanice nameću kao temeljni medij opraštanja aktera zauvijek razdvojenih nepovoljnim ishodom kršćansko-muslimanskog okršaja. Ta uspješna literarna „simbioza“ epske pjesme i fiktivne poslanice svakako mu se morala učiniti bitnom upravo zbog nakane da i sam ispjeva ,zrinijadu“, ali takvu koja će se tematski pretežno fokusirati na mnogostruke rastanke što su uslijedili odmah po završetku sigetske katastrofe, no i koja istodobno ipak neće posve zanemariti narativne ili epskopjesničke momente, odnosno u kojoj ti ,epski“ momenti neće biti u tolikoj mjeri prigušeni da makar stanovit broj čitatelja ona ne bi bila u stanju podsjetiti na ,punokrvni“ barokni povijesni ep. Dapače, i Ritter heroide dovodi u tijesnu vezu s narativnim segmentima svoga ostvarenja, no za razliku od Petra, koji je fiktivne poslanice uklapao u pripovjednu cjelinu i njima postizao kratak (,lirski““) predah u priči, on upravo heroide puni narativnim dionicama i/ili kraćim narativnim dopunama i podsjetnicima,

519 Tako, primjerice, stih „Za pomoć nam ada već nemoj misliti“ (XIII: 94) iz Petrove poslanice Sigećana kralju u Vitezovićevoj heroidi Ban kralju glasi „Za pomoć slat više nemoj se skrbiti“ (II: 27), dok stih „Ne mrem pisat bolja zmožnu kralju momu“ (V: 85) iz pisma što ga u Obsidi Zrinski upućuje kralju susrećemo - neznatno izmijenjena - i u Vitezovićevoj poslanici Ban orsagu, gdje glasi „Stvar ne pišem bolju u hipu ovomu“ (II: 105). 
nimalo pritom ne ugrožavajući njihovo temeljno sadržajno usmjerenje opjevavanju trajnih poslijeratnih rastanaka. Uvidjevši da heroide uključene u pripovjedni tekst svojim sadržajnim fokusiranjem na „odiljanja“ ujedno predstavljaju i najemotivnije segmente epa, Vitezović upravo „narativiziranom“ fiktivnom poslanicom odlučuje - štoviše - i otvoriti svoju „Zrinijadu“, dajući tako već od samoga njezina početka do znanja kako će se u njoj ponajviše usredotočiti na osobni doživljaj neposrednih i posrednih sudionika opsade, odnosno kako ga interesira ponajprije individualni pogled na događanja pod Sigetom u kasno ljeto 1566., koji je bitno bio obilježen potrebom neodgodivih i silno bolnih međusobnih rastanaka.

Ukratko, zahvaljujući utvrđenoj brojnosti, generičkoj prepoznatljivosti i primjerenosti središnjoj temi čitava teksta, dionice Odiljenja sigetskog u kojima dominiraju obilježja (barokne) fiktivne poslanice ili heroide vidno odskaču kao možda i najvažniji njegovi segmenti, iz kojih o emocijama što ih je pobudio kršćanski poraz u Sigetu ne doznajemo neposredno samo od najvažnijih sudionika bitke, već i izravno od onih koje je - iako u bitku nisu bili osobno upleteni - taj poraz zbog dalekosežnih svojih posljedica itekako zabrinuo i ožalostio. Neprekidno, međutim, dosad ustrajući na žanrovskom obilježavanju navedenih dionica (baroknim) heroidama ili fiktivnim poslanicama propustili smo (raz)riješiti jednu nimalo nebitnu dvojbu terminološko-definicijske prirode, koja proizlazi iz ponešto različitih genoloških pristupa žanru ili žanrovima fiktivne epistole u stihu, točnije iz nejednakog razmatranja kako njegovih antičkih početaka, tako i - između ostalog - njegovih baroknih realizacija. Prisjetimo li se, naime, kako je žanr heroida već u Ovidija podrazumijevao fiktivna pisma mitoloških junakinja upućena nevjernim ljubavnicima, a u epistolarima 16. i 17. stoljeća također većinom obuhvaćao ljubavne poslanice značajnih povijesnih i mitoloških likova, odnosno - u slučaju isusovačkih heroida - religiozna pisma znamenitih kršćanskih figura, lako bismo mogli posumnjati u opravdanost označavanja epistolarnih odsječaka Odiljenja - pošiljatelji kojih zapravo iznose vlastito viđenje jednoga ratnog, povijesnog događaja, a ne ljubavnog odnosa ni stanovitih kršćanskih dilema - heroidama u punom smislu riječi. S obzirom na to da se u sedamnaestostoljetnoj književnosti za opjevavanje (i) aktualnih povijesno-političkih događaja u epistolarnom obliku „specijalizirao“ lirskopjesnički žanr kojega pojedini književni povjesnici nazivaju (isključivo) „fiktivnom poslanicom“, ta bi činjenica onda trebala dati do znanja da je ne samo pogrešno terminološki i definicijski izjednačavati žanr „,heroide“ sa žanrom „fiktivne poslanice“, nego i da - slijedom rečenog Vitezovićevim pjesmama-poslanicama nipošto nije mjesto $\mathrm{u}$ istome generičkom odjeljku $\mathrm{s}$ heroidama zaokupljenima pretežno nabožnim i amoroznim temama. 
Ipak, potonji proučavatelji skloni razlučivanju „fiktivne poslanice“ i „heroide“ ne samo što sustavno previđaju činjenicu da u antičkoj književnosti, u okrilju koje je i nastala epistolarna književnost u stihu, kao antipod žanru pjesničke poslanice (sadržajno usredotočenom na opjevavanje stvarnih doživljaja ili razmatranje filozofsko-poetičkih tema) nisu evocirana dva različita, već isključivo jedan epistolarni žanr posvećen fiktivnim sadržajima (heroida), nego i olako prelaze preko toga da - uslijed bezbrojnih transformacija kojima je bio podvrgnut u razdoblju od antike do baroka - žanr heroide nije mogao zadržati nepromijenjen repertoar obilježja sve do 17. stoljeća, a onda ni nastaviti u potpunosti zanemarivati one sadržaje (kršćansko-nabožne teme, društveno-politička zbivanja itd.) koji su u Ovidijevoj praksi ostali daleko izvan njegovih granica. Ne samo što, drugim riječima, odrješito generičko razdvajanje barokne „fiktivne poslanice“ sklone povijesnim sadržajima od „heroide“, koja od tih istih sadržaja - navodno - zazire, nigdje dosad nije argumentirano konkretnim i dovoljno uvjerljivim književnopovijesnim činjenicama, već se ni ono samo po sebi - kao teorijska intervencija u povijesni generički materijal - ne doima naročito opravdanim, posebice znamo li da je žanr heroide već od samih svojih začetaka makar neizravno uzimao u obzir i povijesnu stvarnost, odnosno da su još u Ovidija ljubavne nedaće mitskih pošiljateljica heroida često bile potaknute vrlo „stvarnosnim“ (iako u suštini mitskim) ratnim zbivanjima, koja su i onemogućavala povratak „,nevjernih“ primatelja usamljenim i ucviljenim ljubavnicama. U tom smislu, ni naše identificiranje poslaničkih dionica Odiljenja sigetskog heroidama ili fiktivnim poslanicama (jer riječ je ni o čemu drugome nego terminima za jedan te isti epistolarni žanr) ni $\mathrm{u}$ kojem slučaju ne bi trebalo naprečac proglasiti pogrešnim, tim više što su sazdane one od niza „temeljnih“ obilježja koja su u generičkom repertoaru heroide ostala konstanta još od antičkih njezinih začetaka, i to počevši od uloge pošiljatelja u kojoj se mogu naći govornici oba spola, preko njihova upućivanja nužno odsutnom primatelju, pa sve do naglašavanja trenutka u kojemu nastaje pismo i izražavanja žaljenja za nečime što se dogodilo ili radi nečega što se tek mora dogoditi. ${ }^{520}$ Osim toga, Vitezovićeve su poslanice - tipično za (barokne) heroide - u potpunosti fiktivne, napisane od strane znamenitih ličnosti iz svjetovne, mitske $\mathrm{i} / \mathrm{ili}$ crkvene povijesti, među njihovim primateljima i pošiljateljima ima čak i alegorijskih figura, odnosno personificiranih objekata i institucija (Siget, Crkva, hrvatska domovina), mnoge od njih dolaze u paru s primateljevim odgovorima, njihovi su sadržaji primjetno uzvišeniji (herojskiji od onih „običnih“ pjesničkih poslanica) i - kao takvi - doprinose snažnoj idealizaciji subjekta i adresata, u velikom broju njih otvoreno se evocira sam čin sastavljanja pisma, a uz to se još u njima inzistira i na

\footnotetext{
${ }^{520}$ O pobrojanim obilježjima heroide usp. Škopljanac 2015: 44.
} 
„lirskoj“ evokaciji prošlosti i sadašnjosti, dok se (u najvećem broju njih) narativne silnice istodobno pokušavaju svesti na minimum..$^{521}$

Zavirimo li, na kraju krajeva, u cjelokupan korpus europske barokne epistolarne književnosti, vrlo ćemo se lako uvjeriti u to da autori 17. stoljeća nisu zapravo poznavali nijednu drugu generičku opciju izuzev pjesničkih poslanica, kojih su se laćali kada su o doživljajima iz svoga života ili o nekim filozofskim opservacijama što su ih se netom dosjetili željeli izvijestiti konkretnoga stvarnog adresata, te fiktivnih poslanica ili heroida, koje su ispisivali uime nekih glasovitih osoba iz svjetovne ili crkvene povijesti ili, pak, mitskih junakinja ili junaka ne bi li demonstrirali svoju literarnu umješnost, odnosno vještinu u sastavljanju jednog od najomiljenijih baroknih književnih žanrova. Bjelodano je, drugim riječima, da se u pogledu dostupnih generičkih rješenja stihovane epistolarne književnosti što su ih na raspolaganju imali sedamnaestostoljetni pisci i nije mnogo promijenilo u odnosu na antičko razdoblje, u kojemu su dva (formalno, a posebice sadržajno) različita žanra poslanica u stihu u svojim epistolarnim korpusima inicirali Horacije (,stvarne“, pjesničke poslanice), odnosno Ovidije (fiktivne poslanice ili heroide), udarivši tako žanrovske temelje na koje će se oslanjati još i Vitezović te njegovi pjesnički suvremenici. Ako, slijedom toga, Ritter u tekstu poput Odiljenja nije mogao donijeti primjerke pjesničkih poslanica, onda mu nije preostalo ništa drugo no pojedine njegove segmente protkati značajkama fiktivnih epistola ili heroida, koje je dobro poznavao zahvaljujući zacijelo i višestrukom iščitavanju Ovidijevih epistolarnih ostvarenja, dok je - pak - barokno „lice“ heroide očito upoznao posredstvom epistolarnih zbirki pojedinih inozemnih sedamnaestostoljetnih autora, a gotovo sigurno i Listi heroov Gabrijela Jurjevića. Ključnu ulogu u njegovoj odluci da pojedine segmente svoje „zrinijade“ opskrbi značajkama fiktivne poslanice nedvojbeno je odigrala upravo omiljena mu Adrijanskoga mora Sirena Petra Zrinskog, čijem ćemo izuzetno snažnom utjecaju očigledno morati zahvaliti i na osobitostima niza drugih književnih i ne samo književnih žanrova kojih smo prisustvo u Odiljenju već utvrdili ili ćemo u nastavku ovoga istraživanja to tek učiniti.

\section{2. 3. Tužaljke (lamenti)}

Pobrajajući maločas različite epistolarne i konzolacijske tekstualne značajke heroide Siget hrvatskim gospojam (I: 1-477), nismo mogli ne dotaknuti se i njezinih lamentacijskih dionica, učestalost kojih smo tom prilikom protumačili kao posljedicu uključivanja čuvenoga poslaničkog toposa primateljeva jadanja zbog životnih nevolja, ali i posezanja za stanovitim

\footnotetext{
${ }^{521}$ Detaljnije o generičkom repertoaru barokne heroide u: Helmridge-Marsillian 1991: 61-124.
} 
karakteristikama žanra consolatio, kojega također prožima vrlo naglašen tužbalački ton. Kako se, međutim, lamentacijski segmenti Odiljenja sigetskog ne svode samo na tih nekoliko odsječaka poduljega uvodnog Sigetova pisma „gospojama hrabrenim i hrvatskim vilama“, već im je moguće pribrojiti i još neke sadržajno bliske pjesme lišene konzolacijskih i epistolarnih crta, očito je da tužbalačka obilježja Vitezovićeve ,zrinijade“ nipošto ne bismo trebali suviše usko shvaćati kao tek jedan od očitih signala uvažavanja generičkih repertoara heroide i/ili književne utjehe. Naprotiv, lamentiranje personificirana Sigeta nad teškom situacijom u koju ga je doveo poraz šačice njegovih kršćanskih branitelja u rečenim nam pjesmama i više nego jasno sugerira da bismo generički im predložak ponajprije morali tražiti u lirskopjesničkom žanru predbaroknoga porijekla, čiji se sadržaj redovito svodio na tugaljive monologe „oživljenih“ gradova ili drugih objekata zahvaćenih nekom nevoljom širih razmjera (najčešće upravo ratnim okolnostima). Riječ je, konkretno, o žanru koji je u povijesti književnosti ostao zabilježen pod nazivima lamento ili lamentatio, ${ }^{522}$ a iako njegovih primjeraka - u kojima su status lirskoga subjekta stjecale ucviljene personificirane zemlje, gradovi ili institucije - nije nedostajalo (još) ni u 17. stoljeću (osobito u talijanskoj, njemačkoj i poljskoj književnosti), ${ }^{523}$ treba znati da je zenit svoje popularnosti dosegao on $u$ srednjem vijeku, $i$ to ponajprije zahvaljujući onodobnom utjecaju Biblije, u kojoj su među nizom različitih književnih žanrova i tužaljke - kako nam je dobro poznato - našle svoje mjesto. Kao i u drugim sedamnaestostoljetnim europskim književnostima, tako su i u onoj našoj lamenti ili tužaljke bili većinom evocirani samo u posebnim, ne tako čestim prilikama, za koje je najsnažniji poticaj obično dolazio iz izvanknjiževne sfere, kao što je to - uostalom - u velikoj mjeri bio slučaj i s Vitezovićevim Odiljenjem sigetskim.

Da je upravo Odiljenje jedno od rijetkih domaćih baroknih ostvarenja u kojima se kriju primjerci žanra tužaljke prvi je u svome pregledu dopreporodne hrvatske književnosti upozorio još Mihovil Kombol, koji lamentima proglašava sve one dionice teksta u kojima riječ uzimaju „simbolična lica“, a zatim ih - ustvrdivši kako se taj „oblik kod Vitezovića i kasnije ponavlja do jednoličnosti“ (Kombol 1961: 280) - uspoređuje s drugim, žanrovski im bliskim autorovim stihovanim djelima, u kojima se kao govornici također pojavljuju različita „simbolična lica“, 524 i to vile Hrvatkinja i Dalmacija u hrvatskim pohvalnicama uvrštenima u Valvasorovo djelo Slava vojvodine Kranjske (1689.), odnosno personificirana Hrvatska u latinskim njegovim rukopisnim elegijama Lamentatio Segniae (1681.) i Ad comitem

\footnotetext{
${ }^{522}$ Oba naziva za ovaj lirskopjesnički žanr donio je u svojoj studiji Zoran Kravar (usp. Kravar 1991: 198).

${ }^{523}$ Usp. Blažević 2019: 17-19.

${ }^{524}$ Opširnije u: Kombol 1961: 280.
} 
Marsilium caesareum legatum (1700.) $)^{525}$ te kronici u stihovima Plorantis Croatiae saecula duo (1703.), koju identificira kao dugu lamentaciju ožalošćene Hrvatske. ${ }^{526}$ Napomenuvši kako se u pobrojanim ostvarenjima Vitezović zapravo laća žanra srednjovjekovne provenijencije, ${ }^{527}$ koji je ,već odavno postojao u talijanskoj i našoj književnosti“ (Kombol 1961: 280), Kombol kao neposredne generičke prethodnike tih tekstova izdvaja dvije renesansne lirske pjesme - Marulićevo Tuženje grada Hjerozolima te Vetranovićevu Tužbu

${ }^{525}$ U Lamentatio Segniae - koju je Vjekoslav Klaić žanrovski identificirao kao elegiju povijesnoga sadržaja (usp. Klaić 1914: 43), a Alojz Jembrih kao „elegijsku pjesmu“ (Jembrih 2015: 502, bilješka 39) - „varoš Senj tuži svoju nevolju ugarskomu palatinu, hrvatskomu banu i staležima saborskim u Šoprunu, te traži od njih pomoć“" (Klaić 1914: 43). Personificirani Senj se pritom - tipično za jednu tužaljku - s nostalgijom prisjeća svoje nekadašnje slave i blagostanja te to prošlo ,idilično“ stanje konfrontira teškim suvremenim okolnostima koje su nastupile nakon što su raseljeni senjski uskoci (1681.), a novoizabrani kapetani (među kojima naročito prednjači štajerski grof Ivan Josip Herberstein, koji je kapetanovao od 1669. do 1689. i za to vrijeme ustrajno kršio slobode i reputaciju Senja, zanemarivao siročad i ratne udovice te nemilosrdno slamao svaki izraz lokalnoga nezadovoljstva) otpočeli tlačiti Senjane i osporavati tradicionalna njihova prava i privilegije što su im ih dodijelili hrvatsko-ugarski kraljevi (usp. Putanec i dr. 1952: 13 i Simpson 1991: 69), no osim upozoravanja na loše postupke kapetana, u kojima zbog svega vidi veće neprijatelje čak i od Turske i Venecije, Senj se adresatima otvoreno žali i na nepravedno pripajanje područja što su ih Senjani vlastitim naporima nakon dugotrajnoga i krvavog ratovanja napokon oslobodili od Turaka Vojnoj krajini. Inače, ovaj „povijesno-politički obojeni pjesnički ostvaraj“ (Jembrih 2015: 502, bilješka 39) mogao bi se označiti kao svojevrsna prigodna lamentacija budući da je nastao u vrijeme kada je Vitezović zastupao rodni Senj na saboru u Šopronu, i to sa svrhom da potakne kralja na donošenje pozitivnih odluka u vezi zahtjeva Senjana da se njihova prava (točnije, prava Senja kao slobodnoga kraljevskog grada) i povlastice napokon zaštite od samovolje kapetana. Iz sličnih izvanknjiževnih razloga nastala je i nepuna dva desetljeća „mlađa“ elegija-lament Ad comitem Marsilium caesareum legatum, koju Ritter sastavlja razočaran otvorenim habsburškim popuštanjem Turcima prilikom određivanja hrvatskih granica spram turskih teritorija nakon Mira u Srijemskim Karlovcima (1699.), zbog kojega su Hrvati bili prisiljeni mnoge teško osvojene gradove iznova vratiti u osmanlijske ruke. Ta pjesma - u kojoj personificirana Hrvatska tuži zbog mirnoga prepuštanja osvojenih teritorija neprijatelju i pritom ističe kako to čini zbog lojalnosti Kralju i vjere u Boga te nadajući se da će u vrlo izglednom budućem ratu Turci napokon biti sasvim potučeni i prisiljeni vratiti joj zauzete gradove (usp. Klaić 1914: 138-141) - adresirana je na talijanskoga grofa Luigija Ferdinanda Marsiglija, kojega je kralj Leopold I. nakon sklopljenoga habsburško-turskoga Mira u Srijemskim Karlovcima potkraj siječnja 1699. izabrao kao svoga povjerenika u postupku određivanja hrvatskih granica prema Turskoj (turskoj Bosni) i Veneciji (tj. mletačkoj Dalmaciji), a kojemu je u tomu poslu osobno pomagao sam Vitezović, kojega su hrvatski staleži odabrali kao svoga povjerenika (podrobnije u: Isto: 127-145). Uzgred budi rečeno, naznake lamenta, točnije pojedini postupci svojstveni tomu žanru mogli bi se iščitati i iz opsežne latinske pohvalnice (točnije, pohvalničkoga ciklusa) što ju je Vitezović ispjevao također potaknut konkretnim društveno-političkim aktualnim zbivanjima, i to u čast kralja Leopolda, a povodom njegova zaključenja šopronskoga sabora koncem prosinca 1681. Naime, u tom ciklusu pohvalnica pojedinačnim se pjesmama Leopoldu na uspješnom zaključenju sabora u vlastito ime oduševljeno zahvaljuju personificirana Hrvatska, Slavonija, Dalmacija i Ugarska, zaklinjući mu se pritom na nepokolebljivu vjernost i odanost, obećavajući mu daljnje ustrajno odupiranje turskom neprijatelju, no istovremeno i iskazujući silno žaljenje što nisu u mogućnosti pokloniti mu se budući da su veliki dijelovi njihovih teritorija pod neprijateljskom upravom. Riječ je, inače, o pohvalnici kojom je svojedobno naš autor polučio izniman literarni uspjeh, odnosno koja se tiskala i raspačavala diljem Monarhije, no kojom ipak nije dospio steći titulu „ovjenčana pjesnika“ (poeta laureatus), za koju je priželjkivao da će mu je Leopold dodijeliti i uvrstiti ga među svoje dvorske pjesnike sa stalnom godišnjom plaćom (usp. o toj pohvalnici i njezinu uspjehu u: Klaić 1914: 43-44 i Marković 1987: 76). Ono što je u toj pjesmi pritom posebno zanimljivo jest činjenica da je premrežena pojedinim sadržajnim momentima što će ih Ritter samo koju godinu kasnije uključiti i u svoju hrvatsku „zrinijadu“, a među njima posebno se ističu alegorije gotovo identične onima koje su našle svoje mjesto i u Odiljenju sigetskom.

${ }^{526}$ Kombolovu popisu možemo dodati još i dvije latinske tužaljke što ih je Ritter ispjevao 1711. u povodu iznenadne smrti habsburškoga kralja Josipa I. - Ungaria pullata, u kojoj za preminulim kraljem plače personificirana Ugarska, te Austria pullata, u kojoj kralja oplakuje neutješna Austrija (detaljnije o ovim pjesmama u: Klaić 1914: 268-269). Što se, pak, Dvaju stoljeća uplakane Hrvatske tiče, da je doista riječ o tekstu koji je apsorbirao mnoge značajke (političke) lamentacije ili tužaljke nedavno je u svojoj studiji uvjerljivo potvrdila i Zrinka Blažević (usp. Blažević 2019: 17-19).

${ }_{527}$ Usp. Kombol 1961: 89 i 115. Kombol, inače, ovome žanru nadijeva talijansko ime - lamenti. 
grada Budima - u kojima kao ojađeni lirski subjekti nastupaju također „simbolična lica“, odnosno porobljeni i/ili porušeni personificirani gradovi koji oplakuju svoje „sadašnje“ katastrofalno stanje. Po pitanju porijekla lamentacije s Kombolom će se nekoliko desetljeća kasnije složiti Zoran Kravar, koji ističe kako tužbalice gradova predstavljaju zapravo jedan od najkarakterističnijih žanrova predrenesansnoga (srednjovjekovnog) alegorijskog pjesništva, precizirajući ujedno i da bi jadikovkama generički vrlo bliskima lamentatiju u Odiljenju valjalo označiti većinu replika što ih izgovara „oživljeni“ Siget (Siget hrvatskim gospojam, Siget banu, Siget zvrhu samoga sebe), a uz njih još i pjesmu Orsag banu, ${ }^{528}$ koju smo maločas izdvojili kao primjerak heroide. Za razliku od Kravara, Dušan Karpatský o Odiljenju piše kao o „skladbi (...), sastavljenoj od niza »lamentacija« sudionika i svjedoka sigetske bitke“ (Karpatský 2008: 627), implicirajući da je riječ o svojevrsnoj kompilaciji tužaljki sadržajno izraslih iz sigetske bitke, dok Dunja Fališevac - odredivši lament kao žanr religioznopolitičkoga pjesništva naročito proširen u talijanskoj srednjovjekovnoj književnosti ${ }^{529}$ konstatira da je Vitezovićeva „zrinijada“ napisana kako u (epskopjesničkom) slijedu Karnarutićeva Vazetja i Obside sigecke Petra Zrinskog, tako uvelike „i u tradiciji renesansnih lamenata“"(Fališevac 2013: 12).

Renesansni (domaći) lamenti, međutim, gotovo sigurno nisu bili - ako su uopće i bili jedini Vitezovićev generički predložak pri pisanju tužbalačkih dionica njegove „zrinijade“, ponajprije stoga što se s vrlo dojmljivim primjercima tužaljke morao on susresti i iščitavajući samu Bibliju, po uzoru na koju možda i poseže za značajkama ovoga (biblijskog) žanra, vjerujući da će se (i) uz pomoć njih lakše približiti što je moguće širem krugu publike. Na kraju krajeva, i šesnaestostoljetne lamentacije snažno su se nadovezivale upravo na svoje biblijske žanrovske prethodnice, pa će tako - primjerice - ondje prisutne govorne procedure (molba, apel, opomena, zaklinjanje $\mathrm{i}$ dr.) te specifični lirski subjekt (personificirani Jeruzalem) maločas spomenuto Marulićevo Tuženje grada Hjerozolima prokazivati kao mješavinu generičkih osobina psalmenih tužaljki i starozavjetnih Proročkih knjiga, i to osobito one Baruhove - u sklopu koje se nalazi i lament Plač i nada Jeruzalema (Baruh, 4-5) - te Jeremijine, u koju je također uklopljena i jedna tužbalica - O nevoljama rata (Jeremija, 15). Kako primjećuje D. Fališevac, Marulićeva je lamentacija - baš poput onih iz Proročkih knjiga - „sastavljena od raznih elemenata: pouka, prijetnji, prijekora“, služi se elementima „propovijedi, sudskog govora, žalobnica, pučkih tužaljki““, u njoj se „razabire uvjerenje da govornik iskazuje riječ Božju“ (Fališevac 2007b: 88), a uz to još i uključuje motive koji se

\footnotetext{
${ }^{528}$ Opširnije u: Kravar 1993: 153-154.

${ }^{529}$ O tome u: Fališevac 2007b: 88-89.
} 
referiraju na društveno-političku zbilju, odnosno izravno aludira na (političku) suvremenost. Prizivajući, ukratko, prepoznatljiva obilježja pojedinih starozavjetnih tužbalica, Marulić očito računa na to da će njegova pjesma čitatelja podsjetiti na značenja što su ih nosile i Proročke knjige te tako potvrditi svoj status ,angažiranog, biblijskom tradicijom posvećena teksta, koji poziva kršćansku Europu na sveti rat protiv Turaka“ (Isto: 88-89), odnosno da će na taj način - drugim riječima - njegov poziv na rat steći nasušno mu potrebno moralno opravdanje.

Iako nije riječ o žanru koji je u povijesti hrvatske književnosti zastupljen naročito velikim brojem primjeraka, u sastavljanju lamenata s vremena na vrijeme okuša(va)li su se ipak mnogi naši ranonovovjekovni pisci, pa će se tako nakon evokacija u opusima spomenutih renesansnih autora (Marulić, Vetranović) iznova on pojaviti već u sljedećem stoljeću, kada ga - potaknuti razornim posljedicama dubrovačkog potresa - u pojedinim svojim pjesničkim ostvarenjima najprije „oživljuju“ Nikolica Bunić (Grad Dubrovnik vlastelom u trešnji) i Petar Kanavelić (Dubrovnik u trešnji), a potom - možda slijedeći (i) njihov primjer - u nizu svojih vernakularnih i latinskih djela i sam naš Pavao Ritter Vitezović. Šesnaesto- i sedamnaestostoljetne revitalizacije žanra lamentacije uvjerljivo nam, tvrdi Zoran Kravar, potvrđuju da su stari naši pisci bili itekako dobri poznavatelji medijevalnoga alegorijskog pjesništva, odnosno da su ih specifične društveno-političke okolnosti podsjetile na to da je u povijesti književnosti postojalo generičko rješenje koje je gradovima, zemljama i drugim personificiranim objektima omogućavalo da preuzmu riječ te da se - kao takvi - nametnu kao ljudski subjekti, ${ }^{530}$ što bi se svakako moralo odnositi i na (određene) osamnaestostoljetne nam autore, među kojima je posebnu umješnost u sastavljanju tužaljki u svojoj religioznoj poemi Sveta Rožalija iskazao (slavonski „,barokist“") Antun Kanižlić. Riječ je, konkretno, o lirskoj pjesmi Plač Sicilije uklopljenoj u treći dio teksta, u kojoj personificirana Sicilija oplakuje svoje stanovništvo pomrlo zbog epidemije kuge i u kojoj prepoznajemo stanovit broj tematsko-motivskih paralela s Vitezovićevim (hrvatskim) lamentima, no premda bi te podudarnosti lako mogle navesti na pomisao kako je Kanižlića na posezanje za značajkama tužbalice navelo iskustvo čitanja Odiljenja sigetskog, daleko je ispravnije pretpostaviti da je Plač zapravo ništa drugo no posljedica odličnog poznavanja srednjovjekovnoga (alegorijskog) pjesništva, čijim je obilježjima ionako ispresijecan njegov književni opus u cijelosti.

Bez obzira na dosad višestruko isticanu činjenicu iznimne raširenosti žanra jadikovke personificiranih objekata u srednjovjekovnoj književnosti, ali i onu njegove zastupljenosti već i unutar korica same Biblije, ono što se o lamentatiju redovito (ne uvijek nehotice) propušta napomenuti jest ne samo to da je njegovo (književno)povijesno porijeklo zapravo daleko 
starije od onoga koje se za nj najčešće navodi (točnije, da ono seže poprilično onkraj srednjovjekovnih, pa i antičkih granica), nego i to da (ni) njegov generički repertoar za čitava mu povijesnog trajanja nije ostao „konzerviran“, odnosno da se - prije svega - u ulozi lirskoga subjekta u njemu isprva nije (još) pojavljivao (isključivo) „oživljeni“ grad koji neutješno oplakuje svoju trenutnu nevolju. Konkretno, najraniji primjer(c)i žanra lamentacije - koji je tada još podrazumijevao pjesmu što opjevava neki određeni gubitak te neizbježno uključuje i svoju performativnu „nadgradnju“ (ritualizirane geste ili simboličke činidbe poput udaranja u prsa i sl.) - potječu još iz trećeg tisućljeća pr. n. e., kada nastaje ciklus tzv. pet mezopotamijskih tužaljki za gradovima (Urom, Sumerom i Urom, Nippurom, Eridom te Urukom), u kojima nad razorenim objektima jadikuju boginje - gradske zaštitnice. Očite stilske i tematske podudarnosti ukazuju na to da su mezopotamijske tužbalice izvršile neposredan utjecaj i na biblijske lamente, a u njihovu su slijedu ispjevane i lamentacije što ih nalazimo uklopljene u mnoge kasnije epskopjesničke tekstove (primjerice, tužaljka za Hektorom u 24. pjevanju Homerove Ilijade, potom lamenti u Odiseji, Epu o Gilgamešu, Beowulfu, Pjesmi o Rolandu itd.), ali i tragedije, elegije, pa čak i u neka religijska ostvarenja. Vrlo su često već u antičkoj književnosti tužaljke tako postajale dijelom tragedija (primjerice, Eshilovih Perzijanaca) i pastorala, dok ih u srednjem vijeku - osim u talijanskoj književnosti, gdje se lamentacija uistinu prometnula u zasebni žanr nazivan lamento - nalazimo osobito u provansalskome, trubadurskom pjesništvu (u kojemu se posebno ističu tužaljke u povodu smrti istaknutih osoba - najčešće zaštitnika samih trubadura - pune pohvala pokojnikovim vrlinama i zaslugama) te, dakako, u sklopu brojnih epova što su nastajali diljem onodobne Europe. Lamentatio u formi stilizirane jadikovke nad palim vojnicima nastavlja potom ulaziti i u (neke) renesansne povijesne epske pjesme, u baroku dramska tužaljka postaje integralni dio opere, a uz to će se i kroz čitavo ovo razdoblje od kasne antike do baroka kontinuirano sastavljati i „samostalne“ lamentacije, u kojima lirski subjekti najčešće oplakuju osvojene i devastirane gradove, ali i netom preminule istaknute povijesne osobe (ponajčešće kraljeve), vlastito progonstvo ili druge - često i ljubavne - nevolje, a u istu žanrovsku „ladicu“ proučavatelji povremeno uvrštavaju čak i religijske tužbalice, u kojima ucviljena Marija tuži nad mrtvim Kristom. Iako bi se zbog potonje otvorenosti lamentacije čak i temi jadikovanja nad smrću konkretnoga pojedinca vrlo lako moglo posumnjati i na njezinu generičku bliskost folklornoknjiževnom žanru naricaljke, o kojoj će ovdje doskora biti više riječi, valja imati na umu da se radi ne samo o generičkim rješenjima nejednakoga porijekla, nego ujedno i o žanrovima koji ne pretpostavljaju identičnu razinu bliskosti subjekta s oplakivanom osobom, ali ni (društvenu) važnost pokojnika kojemu se stihovi posvećuju. Konkretno, dok se posmrtni 
lament obično sastavljao u povodu smrti društveno istaknutoga pojedinca, čiji odlazak ujedno predstavlja i nenadoknadiv gubitak za čitav kolektiv, slijedom čega se i od toga osjećajno ništa manje intenzivna teksta očekivalo da potiče što snažniju (kolektivnu) identifikaciju s pokojnikom, ${ }^{531}$ naricaljka se svodila na tek pogrebnu pjesmu u kojoj su na posebno emotivan način i uz obilnu uporabu prepoznatljivih formula tugu zbog smrti voljenoga pokojnika - čiji je eventualni društveni značaj ovdje bio sekundaran - iskazivali sami članovi njegove uže ili šire obitelji i bliski mu prijatelji, nerijetko prateći svoje naricanje i ritualiziranim gestama.

Budući da u okvirima hrvatske književnosti lamento kao samostalni (sekundarni) žanr egzistira tek od ranonovovjekovlja, jasno je da predodžbu o generičkim specifičnostima njegove domaće inačice možemo temeljiti isključivo na onih nekoliko (redom dubrovačkodalmatinskih) tekstova napisanih u nepuna dva stoljeća prije Vitezovićeva Odiljenja. Kao ključne (sadržajne) značajke hrvatskoga ranonovovjekovnog lamenta u tom bi se smislu iskristalizirali kako (porušeni) gradovi koji vape za obnovom u ulozi lirskoga subjekta (Jeruzalem u Marulića, Budim u Vetranovića, Dubrovnik u Bunića i Kanavelića) te snažno naslanjanje na tradiciju biblijskih tužaljki u cilju prizivanja njihova značenja (poglavito $u$ Marulića), tako i težnja prizivanju čitava kolektiva (puka, naroda) kao adresata pjesme, podsjećanje na mnogo sretniju prošlost unesrećena grada uz projiciranje slike željene (znatno povoljnije i pravednije) budućnosti, poimanje trenutne nevolje kao (Božje) kazne zbog počinjenih grijeha (posebno u Bunića i Kanavelića), uspoređivanje tragedije grada s padom Troje ili kojih drugih podjednako stradalih gradova (primjerice, u Kanavelićevoj pjesmi rušenje Dubrovnika prispodobljuje se propasti Troje) i, dakako, neizbježna (simbolička ili stvarna) vezanost s aktualnom društveno-političkom zbiljom. Također, jedna od ključnih osobitosti naših (ali i ne samo naših) šesnaesto-, a posebno sedamnaestostoljetnih lamentacija svakako bi bila i sklonost upijanju značajki čitava niza književnih i poluknjiževnih žanrova (samo u Marulićevo Tuženje grada Hjerozolima utkane su tako pouke, prijetnje, elementi propovijedi, pučkih tužaljki, naricaljki itd.), ali i oslanjanje na stanovit broj ustaljenih govornih procedura (katalog nevolja, apel, molbu, preklinjanje, upozorenje ili opomenu i s1.), ${ }^{532}$ od kojih neke zatječemo i u tužbalačkim dionicama Odiljenja sigetskog.

Pođemo li od netom pobrojanih karakteristika ranonovovjekovnih naših lamenata, $\mathrm{s}$ popriličnom ćemo lakoćom moći utvrditi da je nezanemariv broj njih koncentriran na čak nekoliko mjesta unutar Vitezovićeva Odiljenja, i to - prije svega - u dvije kraće dionice uvodne heroide Siget hrvatskim gospojam (I: 35-50 i 141-152), a zatim i unutar pjesme Siget

\footnotetext{
${ }^{531}$ Detaljnije u: Cavitch 2012b: 781-782.

532 O pobrojanim i drugim obilježjima lamenta podrobnije u: Kravar 1991: 198-199 i Fališevac 2007b: 88-90.
} 
zvrhu samoga sebe (II: 517-613), koja bi se (okvirno) i mogla generički odrediti kao lamentacija, iako se kao njezin „najtužbalačkiji“ segment izdvaja „tek“ dio od 525. do 536. stiha. S obzirom na to da su sve pjesme Odiljenja zamišljene kao (,izvještajni“) iskazi govornika ili lirskoga subjekta konkretnom (pojedinačnom ili kolektivnom) adresatu te da su - bez obzira na opću tugaljivost sadržaja - većinom one lišene prepoznatljivih lamentacijskih tekstualnih specifičnosti, krajnje bi promašeno bilo tvrditi - kao što su to već više ili manje eksplicitno učinili i Mihovil Kombol ${ }^{533}$ te Dušan Karpatský ${ }^{534}$ - da se Ritterova „zrinijada“ u cijelosti može identificirati upravo kao zbirka lamenata, ${ }^{535}$ tim više što motiv jadikovanja zbog pogibije najmilijih u nekim drugim njezinim pjesmama upućuje na srodan, no ipak bitno različit (usmenoknjiževni) žanr naricaljke. Štoviše, dok tužbalački odsječci u pjesmi Siget hrvatskim gospojam funkcioniraju tek kao svojevrsni dodatak epistolarnom izvještaju, uvršten ponajprije u cilju ekspliciranja pošiljateljeve boli izazvane neočekivanim porazom kršćanskih branitelja i izazivanja sućuti u adresatkinja, u kojih će vijesti o izginuću sinova i supruga pobuditi jednake i jednako intenzivne emocije, dotle u ,lamentaciji“ Siget zvrhu samoga sebe tužbalačko uzdisanje nad teškim stanjem u kojemu se zatekao nakon pada u ruke Osmanlija samo na momente dospijeva podsjetiti na primjere ,punokrvnih“ (samostalnih) lamenata porušenih i/ili porobljenih gradova, iako će se i ova pjesma iz Sigetova samosažalijevajućeg monologa (,zvrhu samoga sebe“) na koncu prometnuti u ozbiljno upozorenje „Ugrinima perjenima“ koji su Sigećanima u nevolji odbili priteći u pomoć i koji će radi toga doskora i sami osjetiti snagu turske sile.

Ukoliko nas i odabir razorenoga grada kao lamentirajućega subjekta, i prizivanje žanra s kojim su se recipijenti morali susresti makar posredstvom Biblije, i više ili manje eksplicitno adresiranje kolektiva (,gospoja hrabrenih i hrvatskih vila“, odnosno „Ugrina perjenih“), i objašnjavanje vlastite nevolje Božjom kaznom zbog grješnih navika i uopće moralnoga izopačenja suvremenih kršćana (navlastito u pjesmi Siget zvrhu samoga sebe), ${ }^{536}$ i otvoreno prispodobljivanje pada Sigeta osvajanju Troje i kršćanskom porazu na Mohačkom polju („Druga sam ja Troja i Muhačko polje“; I: 244), ali i jasno impliciranje aktualne društvenopolitičke situacije (potrebe trajnoga oslobađanja Sigeta od vlasti bitno oslabljenih Turaka, a zatim i njegova obnavljanja kao memorijalnoga lokaliteta) u ovim tužbalačkim odsječcima Odiljenja sigetskog uistinu neodoljivo podsjeća na naše šesnaesto- i sedamnaestostoljetne primjer(k)e žanra lamentatija, tada je očekivano upitati se o možebitnom njihovu izravnom

\footnotetext{
${ }^{533}$ Usp. Kombol 1961: 280.

${ }^{534}$ Usp. Karpatský 2008: 627.

${ }^{535} \mathrm{Na}$ ovu je pogrešnu praksu pojedinih povjesničara književnosti upozorio već i Zoran Kravar (usp. Kravar 1991: 238).

${ }^{536}$ Naročito usp. II: 549-602.
} 
utjecaju na Vitezovića, odnosno pretpostaviti da je naš autor imao prilike pročitati makar ponešto iz dotadašnje hrvatske - ne naročito bogate - tradicije tužbalačkog lirskog pjesništva. Otklonimo li kao znatno manje vjerojatnu mogućnost da je na odluku da u svoju ,zrinijadu“ uključi i značajke lamenta utjecala njegova recepcija inozemnih srednjovjekovnih tužaljki, ${ }^{537}$ a najvjerojatnije i onih (rukopisnih) Marka Marulića i Mavra Vetranovića, u tom nam slučaju ne preostaje ništa drugo nego usredotočiti se na eventualne tragove Ritterova kreativnog nasljedovanja dvaju naših baroknih lamentacijskih ostvarenja, i to maločas spomenutih pjesama u povodu dubrovačkoga potresa iz pera Nikolice Bunića i Petra Kanavelića, objelodanjenih u jesen 1667. u knjižici naslovljenoj Grad Dubrovnik vlastelom u trešnju. ${ }^{538}$

Iako nam uočene tekstualne paralele između lamentacijskih odsječaka Odiljenja i ranonovovjekovnih domaćih tužbalica sugeriraju da je Vitezović na umu morao imati (i) naše barokne (vernakularne) lamente, nužno je znati da po svojim sadržajnim karakteristikama Bunićevo i Kanavelićevo ostvarenje ipak nisu bili posve podudarni, što se možda i ponajbolje uviđa na primjeru njihovih kazivača ili lirskog subjekta. Naime, činjenica da je u obje pjesme riječ o gradu kao predmetu lamentacije, koji je - kao i obično u ranonovovjekovnim tužaljkama - sravnjen sa zemljom i vapi za obnovom, ove autore nije (s)priječila u nakani da figuru govornika realiziraju ponešto različito, pa dok se tako u Bunićevu tekstu u ulozi kazivača našao sam „oživljeni“ Dubrovnik, u Kanavelića tu će ulogu preuzeti vila ili književna muza (točnije, personifikacija hrvatskoga jezika i dubrovačke književnosti), predstavljena kao „slovinskoga jezika kraljica“, koja utjelovljuje Dubrovnik i u njegovo ime jadikuje nad nevoljom koja je zadesila grad i njegove stanovnike. Zahvaljujući motivu uplakane, bolom shrvane muze, koja se - izgledom zapuštena, no još uvijek s krunom na glavi - usred noći ukazuje prestravljenu pjesniku (Kanaveliću) ne bi li ga upozorila na teško stanje u potresom pogođenu Dubrovniku, pjesma Dubrovnik u trešnji priključuje se nizu sadržajno bliskih lirskopjesničkih ostvarenja, kojemu pripada i znamenita, punih pola stoljeća „starija“ lamentacija talijanskoga baroknog pjesnika Fulvija Testija Pianto d' Italia („Plač Italije“), u kojoj personificirana Italija u liku napaćene starice ulazi u san pjesnika kako bi mu se potužila na svoje sustavno propadanje. ${ }^{539}$ Ono, međutim, što - osim formalnih paralela - Kanavelićevu

\footnotetext{
${ }^{537}$ Kako u svome pregledu povijesti hrvatske barokne književnosti pripominje Zoran Kravar, prisutnost lamenta u Odiljenju sigetskom nipošto se ne bi trebala tumačiti kao dokaz Ritterova (izravnog) posezanja u žanrovski sustav srednjovjekovne književnosti, već prije kao jedan od brojnih signala „zaostalosti“ ili evolucijske tromosti sjevernohrvatske barokne književnosti (usp. Kravar 1991: 199).

${ }^{538}$ Riječ je o zbirci pjesama posvećenih katastrofalnome potresu koji je svega nekoliko mjeseci ranije gotovo u potpunosti razorio Dubrovnik. Svjetlo dana ugledala je ona početkom jeseni 1667. u Anconi, a u njoj se - pored Bunićeva i Kanavelićeva lamenta - našla još i pjesma na istu temu iz pera Bara Bettere. Vrlo detaljno o trima pjesmama iz spomenute knjižice u: Stojan 2015: 115-128.

${ }_{539}$ Opširnije o spomenutoj tužbalici u: Cherci i sur. 2008: 309.
} 
pjesmu ipak nerazdruživo povezuje s Bunićevim Gradom Dubrovnikom vlastelom u trešnji jest ne samo očigledna identičnost odabrane teme, već i potpuno jednaka kontekstualna podloga, odnosno stvaralački impuls koji je došao iz posve iste suvremene situacije, i to konkretno - zbivanja neposredno nakon katastrofalnoga potresa, uslijed kojih se pjesnicima učinilo kako je ulogu (,stvarnoga“) palog junaka, ali i poticatelja vlastite obnove preuzeo sam Dubrovnik, a ne njegovi stanovnici, kojima je uslijed sveopćega razaranja temeljna preokupacija bila spašavanje golog života. I baš kao što je i u Odiljenju jedino Siget - kao „posljednji“ preživjeli kršćanski „sudionik“ opsade - u svojim epistolarnim izvještajima i monolozima mogao dobiti priliku lamentirati nad svojom propašću, tako se i Buniću i Kanaveliću među bezbrojnim smrtima i drugim individualnim patnjama što ih je prouzročio veliki dubrovački potres učinilo da je nad vlastitom sudbinom jedini ostao zabrinut sam Dubrovnik, odnosno da se u tom trenutku isključivo personificirani grad može nametnuti kao lirski subjekt istinski ožalošćen zbog nepovoljne situacije u kojoj se odjednom zatekao. ${ }^{540}$

Ukratko, nipošto ne bi trebalo odbaciti mogućnost da je upravo Kanavelićevo i Bunićevo tužbalačko opjevavanje aktualnih dubrovačkih nevolja bitno utjecalo na Ritterovu odluku da u Odiljenje sigetsko uključi i prepoznatljive značajke iz repertoara (baroknoga) lamenta, premda njegova ranija, a naročito kasnija praksa ispisivanja generički identičnih ostvarenja na latinskom jeziku upućuje na to da je „poetiku“ lamentatija usvojio recepcijom pjesničkih ostvarenja ispisanih na latinštini, pa i vjerojatnim uvježbavanjem sastavljanja toga žanra još u isusovačkim gimnazijskim klupama. Bez obzira na to što - izuzev maločas utvrđenih sadržajnih podudarnosti - ne raspolažemo dovoljno opipljivim dokazima o njegovu eventualnom čitateljskom susretu s pjesmama iz knjižice Grad Dubrovnik vlastelom u trešnju, već nas sama činjenica da - nalik Kanaveliću i Buniću - generičkim obilježjima tužbalice premrežuje tekstove na narodnom jeziku sklopljene od elemenata različitih književnih i poluknjiževnih žanrova (heroida, pouka, poslovica, epska pjesma, propovijed, blagoslov, naricaljka itd.) navodi na pomisao da je podstrek za ispisivanje takve „,inačice“ vernakularnoga lamenta morao on dobiti ponajprije iz žanrovski „dvojbenijih“ baroknih tužaljki na hrvatskom jeziku, iako su karakteristikama raznih žanrova u nas redovito bile obogaćivane već i šesnaestostoljetne lamentacije (napose Marulićevo Tuženje). Uostalom, kao dotadašnjem čitatelju i piscu tužaljki isključivo na latinskom jeziku Vitezoviću su upravo vernakularne lamentacijske pjesme dvojice dubrovačkih baroknih pjesnika uvjerljivo mogle dokazati da žanr lamentatio izvrsno funkcionira i ,presađen“ u hrvatski jezik, odnosno da i u okrilju hrvatske književnosti i na hrvatskom jeziku može rezultirati dojmljivim, a ujedno i

540 Opširnije o tužaljkama Nikolice Bunića i Petra Kanavelića u: Kravar 1991: 198-199 i Stojan 2015: 115-128. 
stilski i formalno modernim tekstovima na već uobičajenu temu jadikovanja nad posvemašnjom destrukcijom grada. Tužbalice Bunića i Kanavelića Ritteru su, k tome, poslužile i kao nužna (sedamnaestostoljetna) generička „podloga“ za njegove vernakularne lamente, dakle kao ostvarenja posredstvom kojih je žanr tužaljke na narodnom jeziku stekao svoje mjesto u generičkom sustavu hrvatskoga književnog baroka, a iako se ni u nas - baš kao ni u drugim onodobnim nacionalnim književnostima - lamentatio nije dospio nametnuti kao jedan od odveć raširenih žanrova, već sama činjenica da je - ponajprije zahvaljujući svojoj egzistenciji unutar korica Biblije - imao čvrsto uporište u tradiciji za pojedine tadašnje pisce bila je očito dovoljan razlog da neke svoje pjesme realiziraju kao tužaljke vjerujući kako će ih njihovi recipijenti, čitajući ih (većinom) na biblijskoj podlozi, ispravno generički razumjeti.

S obzirom na to da je lamentacija jedan od rijetkih književnih žanrova čija obilježja u Odiljenju sigetskom nisu evocirana zahvaljujući ugledanju (i) na Adrijanskoga mora Sirenu Petra Zrinskog, a vrlo vjerojatno - usprkos pojedinim prilično indikativnim sadržajnim podudarnostima $^{541}$ - ni imajući na umu onih tek nekoliko renesansnih domaćih tužbalačkih ostvarenja, skromnom nizu Vitezovićevih domaćih prethodnika i možebitnih uzora u sastavljanju lamenata moguće je pribrojiti i još eventualno sedamnaestostoljetnoga omiškog svećenika i pjesnika Mateja Jelića Dražojevića, koji 1666. ispisuje odulju latinsku elegiju Cretae regni querelae, u kojoj se narativne dionice izmjenjuju s lamentacijama grada Krete koja, našavši se u rukama Osmanlija, oplakuje vlastitu nesreću i poziva svoga potencijalnog spasitelja - mletačkoga kapetana Dominika Moceniga - da je izbavi iz turskoga sužanjstva. ${ }^{542}$ Kao pjesma ispjevana u jeku Kandijskoga rata (1645.-1669.), Cretae regni querelae za svoj je primarni izvanknjiževni cilj imala mobilizacijsko djelovanje u svrhu oslobađanja Krete od osmanlijske vlasti, a shodno toj kontekstualnoj zadaći i vrlo izrazitim tužbalačkim značajkama ispostavila se ona - kako i sam naslov upućuje - kao ogledni primjerak tzv. querela, odnosno lirskopjesničkog žanra protuturske književnosti, koji je od 16. stoljeća bio proširen većinom u književnostima onih europskih zemalja zahvaćenih turskim osvajanjima. Osobito je querela bio čest u mađarskoj šesnaesto- i sedamnaestostoljetnoj književnosti, ${ }^{543}$

\footnotetext{
541 Osim motiva jadikujućega personificiranog grada kojega su zauzeli pripadnici „poganske“ vojske, Vitezovićeve lamentacijske dionice s lamentima Marka Marulića i Mavra Vetranovića dijele još i motiv upozorenja crkvenim poglavarima (papi u Tuženju grada Hjerozolima) ili svjetovnim vladarima (habsburškom kralju u Tuženju grada Budima) da okupe vojne snage i što prije se odupru neprijatelju koji se sprema na nove osvajačke pohode, dok u Vetranovićevu Tuženju - slično kao i u Odiljenju - zatječemo još i motiv kršćanske nevjere i nehaja kao razloga pada grada, ali i motiv ucviljenih ugarskih djevojaka i supruga koje oplakuju smrt svojih najmilijih poginulih pri obrani Budima.

${ }^{542}$ O ovoj Dražojevićevoj pjesmi detaljno u: Stepanić 2005: 81 i 134-135.

543 Žanr querela u mađarskoj je književnosti inaugurirao upravo hrvatski humanistički povjesničar i pjesnik Mihovil Vrančić (Michael Verancius), koji oko 1528. sastavlja dvije odulje latinske elegije naslovljene Querela Hungariae de Austria te Alia querela Hungariae contra Austriam. U objema pjesmama personificirana će
} 
gdje je nerijetko shvaćan i kao ,puki“ topos, pri čemu se redovito radilo o žanru sadržajno zasnovanomu na motivu tugovanja personificiranih zemalja i gradova razorenih uslijed osmanlijskih osvajanja te motivu ,zlatnih“ vremena konfrontiranih suvremenomu jadnom stanju ožalošćena subjekta, što će reći generičkom rješenju osmišljenom kao svojevrsna inačica lamentacije, koje se temelji na baroku omiljenom toposu žalovanja, ali je ujedno i idejno usklađeno s aktualnom društvenopovijesnom situacijom presudno obilježenom neprestanim turskim ratnim prijetnjama. ${ }^{544}$

Pokušaj kreativnog uvažavanja čak i karakteristika iz generičkoga repertoara Vitezoviću dobro znanog žanra querela - možda i u slijedu samoga Dražojevićeva ostvarenja - u Odiljenju se ne očituje u naglašeno protuturskom tonu dionica protkanih lamentacijskim segmentima, nego ponajprije putem uključivanja motiva nostalgičnog podsjećanja na nekadašnja „,slavna“ vremena iz perspektive nepovoljnoga „sadašnjeg“ trenutka (,Nut kako tvrdine moje omehčaše / i na što visine me slave opaše“; II: 539-540), ali i očitom aludiranju na suvremene (izvanknjiževne) povijesne okolnosti i potrebu definitivnoga oslobađanja i obnavljanja Sigeta kao mjesta sjećanja na važnu epizodu iz hrvatske povijesti. Takvo prikapčanje Odiljenja čak i na tradiciju ovoga ranonovovjekovnog žanra Vitezoviću se moralo činiti svrsishodnim ne samo iz razloga što je riječ o „,podžanru“ ili varijanti tužbalice prisutnoj - posredstvom malobrojnih ostvarenja tadašnjih pjesnika - i u generičkom sustavu hrvatskoga baroka te stoga nimalo nepoznatoj većini (pretežno učenije) suvremene domaće publike, nego i zato što se radilo o žanrovskom rješenju izravno proizišlom iz, kako tvrde pojedini književni povjesnici, nasljedovanja i dorađivanja žanra antičke heroide, koji se u svojim začecima ionako svodio na svojevrsnu tužbalicu fiktivne junakinje ili junaka realizirane u stihovanoj epistolarnoj formi. ${ }^{545}$ Poprilična generička srodnost heroide i querela našem je pjesniku očito

Ugarska - pojavivši se u obličju zapuštene žene - oplakivati svoju tešku sadašnju situaciju, u koju su je doveli mnogobrojni vanjski, ali i unutarnji ratovi (poglavito međusobni sukobi ugarskoga plemstva), te pritom preklinjati za pomoć kršćanske zemlje, i to poglavito Austriju, od koje očekuje da će joj (napokon) pomoći u vojnom i materijalnom smislu. Prozivajući Austriju koja joj je dosad sustavno odbijala priteći u pomoć, Ugarska naglašava kako se kontinuirano sama, bez ičije pomoći, u dugim i iscrpljujućim ratovima suprotstavljala osmanlijskoj vojsci te pretrpjela nenadoknadive gubitke nad kojima sada jadikuje, a zatim to nepovoljno sadašnje stanje konfrontira svojoj ,zlatnoj“ prošlosti (nekadašnjoj ugarskoj slavi i veličini) i zaključuje kako bi tu prijašnju moć i slavu mogao povratiti isključivo složan ratni odgovor njezine „djece“ moćnome vanjskom (turskom) neprijatelju. Opširnije u: Palotás 2014: 55-83.

${ }^{544}$ Informativno o žanru querela u: Blažević 2003: 202, bilješka 9.

545 Generičku vezu između querela i (antičke) heroide relativno su nedavno zapazili proučavatelji Vrančićevih latinskih elegija-querela, koji drže kako je krucijalni dokaz Vrančićeva nesumnjivog nasljedovanja Ovidijeva epistolarnog žanra činjenica da su obje njegove pjesme zapravo fiktivne poslanice u kojima se Ugarska preuzevši obličje ožalošćena ženskog lika - obraća Austriji ne bi li je podsjetila na svoju devastaciju i silne ratne gubitke za koje je ponajviše upravo ona odgovorna. Oslanjanje na Heroide razvidno je, nadalje, i iz mnogih drugih tekstualnih specifičnosti Vrančićevih elegija, počevši s izravnim adresiranjem primatelja (Austrije) u prvim stihovima pjesme, potom otvorenoga zazivanja bogova, inzistiranja na motivu ostavljene i zapuštene, a ujedno plodne i resursima bogate zemlje, detaljnoga nizanja svih ratnih gubitaka, tuženja poradi moralne štete 
bila važna zbog nakane da lamentacijske segmente - za koje je vjerovao da će makar neke recipijente podsjetiti na primjerke latinističkog querela - „ugradi“ ili u pjesme s personificiranim lirskim subjektom prožete jasnim žanrovskim signalima fiktivne poslanice (Siget hrvatskim gospojam), ili, pak, u naizgled monološke pjesme u kojima jadikovka personificirana kazivača nad gorkim vlastitim usudom odjednom prelazi u obraćanje odsutnom adresatu ekvivalentno onomu iz ranijih heroida, kao što je to slučaj u pjesmilamentaciji Siget zvrhu samoga sebe. Upravo nagli prijelaz iz monološkoga tuženja nad stanjem u koje je subjekta doveo trijumf Turaka - poslanih kršćanima u obliku Božje kazne za nagomilane grijehe - na (epistolarno?) obraćanje ugarskim „bratima“ koji Hrvatima nisu htjeli pomoći u obrani Sigeta („Poglej tuge moje, Ugrine perjeni, / ali bolje tvoje nesriće u meni“; II: 603-604) možda je pojedine „ritterologe“ i naveo na zaključak kako se u Sigetu zvrhu samoga sebe „očituje utjecaj Gundulićevih Suza“ (Pavličić 1979b: 28, bilješka 13), odnosno kako taj dio Odiljenja pokazuje bliskost žanru barokne religiozne poeme, i to ponajprije stoga što - pored prisutnosti prepoznatljivih sadržajnih momenata usmenoknjiževne naricaljke uključivanje poslaničkoga tipa iskaza neizbježno upućuje na žanr heroide, koje je niz tekstualnih osobitosti postao i dijelom generičkoga repertoara sedamnaestostoljetnih naših (podjednako religioznih i komičnih) poema. ${ }^{546} \mathrm{U}$ svakom slučaju, tužbalački bi se segmenti Odiljenja - neovisno od toga je li „stvarni“ izvor njihovih karakteristika bio generički repertoar (baroknog) lamentatija, onaj (baroknog) querela ili, pak, njih oba - definitivno mogli izdvojiti kao žanrovski iznimno interesantna mjesta Vitezovićeve „zrinijade“, pa i usprkos činjenici da količinska njihova zastupljenost u tekstu ni izbliza ne može parirati onoj drugih (lirskopjesničkih) žanrova, između ostalih i žanra (baroknog) epitafa ili nadgrobnice.

\section{2. 4. Nadgrobnice (epitafi)}

S potonjim detektiranjem lamentacijskih odsječaka Odiljenja sigetskog naša se potraga za obilježjima žanrova (barokne) lirske pjesme utkanima u tekstove neobične ,zrinijade“ Pavla Rittera Vitezovića nipošto još ne može sasvim privesti kraju. Naprotiv, ukoliko su nas u dosadašnjem istraživanju tragovi žanrova barokne heroide, konzolacije, lamentacije i querela

koju su pošiljateljici prouzročili ratovi, ali i predstavljanja Ugarske kao uporišta kršćanstva i braniteljice čitavoga kršćanskog svijeta. Svi pobrojani sadržajni momenti pojavljivat će se, napominju proučavatelji, i u kasnijim evokacijama toposa ili žanra querela Hungariae - dakle, u njegovim realizacijama u mađarskoj književnosti 16. i 17. stoljeća - pri čemu je posebno zanimljivo primijetiti kako će, iako za njima u tolikoj mjeri nije posezao pri sastavljanju vernakularnoga Odiljenja, niz ovih obilježja u svoju latinsku stihovanu kroniku Dva stoljeća ucviljene Hrvatske „ugraditi“ i naš Pavao Ritter Vitezović. Podrobnije o značajkama žanra ili toposa querela Hungariae u: Palotás 2014: 55-83.

${ }^{546}$ Opsežnije o tome u: Škopljanac 2015: 34-45. 
vodili isključivo do pojedinih pjesama situiranih u nekom od prvih dvaju „dilova“ Odiljenja, tada će nas naš zadatak da uđemo u trag (lirsko)pjesničkim njegovim dionicama što su u nekim barokološkim studijama bile već proglašene „epigramskim nadgrobnim natpisima“ (Kravar 1991: 239) odvesti, pak, na sam kraj teksta, odnosno u njegov „dil četrti“, u kojemu su okupljene jedine pjesme ove „zrinijade“ izrijekom obilježene vrlo preciznom generičkom odrednicom što ju im je dodijelio sam autor. Iza relativno jednostavnog i nimalo arhaičnoga (pod)naslova posljednje dionice Odiljenja sigetskog - „nadgrobnice“ - uslijedit će tako sveukupno 38 epitafa ili nadgrobnih pjesama različite duljine i realiziranih raznolikim metričkim rješenjima, gdjekad „kontaminiranih“ i značajkama drugih pisanoknjiževnih, pa i usmenoknjiževnih žanrova, ali redom posvećenih najvažnijim kršćanskim i muslimanskim izginulim sudionicima bitke za Siget, počevši od sultana Sulejmana (četiri epitafa) i bana Zrinskog (dva epitafa), pa sve do grada Sigeta, s čijim se dvjema nadgrobnicama Odiljenje i zaključuje. „Rezerviravši“ tako čitav jedan njegov dio za primjerke jednoga te istog lirskopjesničkog žanra Vitezović je, doduše, učinio svojevrsni presedan u okvirima svoje generički izrazito šarolike „zrinijade“, no ne i u kontekstu hrvatske, pa i europske barokne književnosti, u kojoj su - preferiranju žanrovske mješovitosti i unutar (lirsko)pjesničkih kompilacija - još uvijek ispisivani lirski ciklusi, pa i čitave zbirke sklopljene od žanrovski identičnih ili vrlo bliskih tekstova.

Lirske pjesme u povodu smrti pisaca, zaštitnika, bliskih prijatelja, znanaca, članova obitelji ili društveno značajnih pojedinaca na hrvatskom i ne samo na hrvatskom jeziku u sedamnaestostoljetnoj našoj - mahom dubrovačko-dalmatinskoj - književnosti nisu predstavljale generički raritet, pri čemu valja znati da je barokna produkcija takvih ostvarenja bila ništa drugo nego nastavak tradicije sastavljanja „nadgrobnica“ uspostavljene još u prethodnom stoljeću. Ispisujući, drugim riječima, pjesme u čast uvaženih pokojnika, Horacije Mažibradić, Ivan Gundulić, Ivan Bunić Vučić, Junije Palmotić i drugi naši barokisti većinom su slijedili ,poetiku“ ovoga lirskopjesničkog žanra utvrđenu još u tekstovima renesansnih im prethodnika, koja je pretpostavljala većinom prigodnički intonirana djela u stihu proizvoljne duljine, u kojima se ponajprije ističu vrline i društveni značaj pokojnika, a tek potom podastiru i eventualni izrazi osobne ožalošćenosti njegovom smrću. Domaći barokni pjesnici svojim su se nadgrobničkim stvaralaštvom tako gotovo u potpunosti generički nadovezivali na onu - daleko češću - prigodničku varijantu renesansnoga nadgrobničkog pjesništva, iako su u našoj šesnaestostoljetnoj književnosti zabilježeni i slučajevi sastavljanja epitafa, točnije kraćih posmrtnih pjesama koje formom i sadržajem simuliraju natpise sa nadgrobnih spomenika, postajući tako dijelom tradicije žanra koji svoje porijeklo vuče još iz antičkoga doba. Te vrlo 
rijetke šesnaestostoljetne primjer(k)e epitafskoga pjesništva naći ćemo, primjerice, u opusima Mavra Vetranovića (Nadgrobnica Nikoli Dimitroviću, Nadgrobnica gornjega rečenoga Marina), Nikole Nalješkovića (Nadgrobnica plemenitoga i vele vridnoga gospodina Nikše Andretića) i Dominka Zlatarića (Nadgrobje gospodina Miha Monalda i Nadgrobje istoga, ispjevano povodom prerane smrti sina mu Šimuna), u okrilju kojih se najčešće one pojavljuju u paru s prigodnicama u čast smrti istih pojedinaca, dakle kao „tek“ njihov epitafski dodatak.

„Nadgrobnice“ okupljene u četvrtom dijelu Odiljenja sigetskog u generičkom smislu u potpunosti pripadaju upravo ovoj - $\mathrm{u}$ našem ranonovovjekovlju znatno rjeđe zastupljenoj epitafskoj varijanti posmrtne ili nadgrobničke lirike, formirajući tako ciklus „samostalnih“ lirskih nadgrobnih natpisa kakvu ćemo u šesnaesto- i sedamnaestostoljetnoj (južno)hrvatskoj književnosti teško naći pravoga pandana. Vitezović je, ipak, uzora za svoj nadgrobnički ciklus itekako mogao pronaći unutar granica onodobne nam književnosti, i to nigdje drugdje nego u obljubljenoj mu Adrijanskoga mora Sireni Petra Zrinskog, u kojoj se među nekolicinom lirskih pjesama što slijede nakon Obside sigecke zatekla i rukovet od svega pet vrlo kratkih epitafa posvećenih kršćanskim junacima - Atili, Nikoli Šubiću Zrinskom, Deli Vidu Žarkoviću, vojvodama Radivoju i Juraniću te Petru Farkašiću ${ }^{547}$ - koji su živote izgubili uslijed junačke i bespoštedne borbe protiv daleko moćnijega osmanlijskog neprijatelja. Pored Sirene, koja mu je nesumnjivo dala ključni poticaj za sastavljanje ciklusa nadgrobnih natpisa, jak impuls za kreativno evociranje ovoga žanra Vitezoviću je jamačno stigao i iz inozemne barokne književnosti, u kojoj se nadgrobnica nametnula kao jedno od najomiljenijih lirskopjesničkih generičkih rješenja, o čemu najbolje svjedoči izuzetno velik broj tada ispisanih i objelodanjenih latinskih i - znatno češćih - vernakularnih epitafskih zbirki. Među potonjima svakako vrijedi izdvojiti (i) nadgrobnički ciklus Nagrobky i treny (Nadgrobnice $i$ tužbalice) posvećen kršćanskim junacima poginulima u borbama protiv Turaka i Tatara, kojega je u svoju rukopisnu zbirku Muza domowa (Muza doma) - napisanu između 1676. i 1683. - uvrstio glasoviti poljski barokni pjesnik Zbigniew Morsztyn. Po prisutnosti prepoznatljivo baroknih makabrističkih obilježja i dramatičnosti, motivu glorificiranja smrti na bojnom polju kao najuzvišenijega herojskog čina, predodžbi o kršćanskim junaštvima usklađenoj s tradicijom tzv. humanitas heroica (humanoga, čovječnog junaštva) te naglašeno baroknom - končetistički „pojačanom“ - stilu ${ }^{548}$ Morsztynovi se epitafi nameću kao idejno, sadržajno i stilski vrlo bliski pojedinim Vitezovićevim, pa donekle i onima Petra (ali i Nikole)

\footnotetext{
${ }^{547}$ Usp. Zrinski 1957: 292-293.

${ }^{548}$ Detaljnije o konkretnim sadržajnim i stilskim posebnostima Morsztynovih epitafa u: Angyal 1961: 185-186.
} 
Zrinskog, i to usprkos činjenici da je eventualne međusobne kreativne utjecaje ove četvorice pjesnika sa sigurnošću moguće u potpunosti isključiti.

Izuzev ciklusa „ozbiljnih“ nadgrobnih natpisa, prožetih naglašeno patetičnim iskazima poštovanja i divljenja spram palih kršćanskih sudionika protuturskih ratova, pjesnici 17. stoljeća nerijetko su se upuštali i u sastavljanje zbirki sadržajno „slobodnijih“ epitafa, u kojima su na bitno manje konvencionalan i izvještačen način opjevavali smrti važnih i manje važnih povijesnih osoba, pa i ne isključivo osoba. U susjednoj, talijanskoj književnosti maločas spomenuti će mletački pjesnik Giovanni Francesco Loredano 1645. u koautorstvu s Pietrom Michieleom tako objaviti nadgrobničku zbirku Il Cimiterio, Epitafi Giocosi, koja već svojom naslovnom sintagmom - ,razigrani epitafi“ - najavljuje dijametralno suprotan pristup smrti od onog za koji će se u narednim desetljećima u svome epitafskom stvaralaštvu opredijeliti Zbigniew Morsztyn, ${ }^{549}$ braća Zrinski ili Pavao Ritter Vitezović. Loredano i Michiele, ukratko, ne odveć patetičnim nadgrobnicama posvećenima različitim povijesnim ličnostima u rasponu od pjesnika i fillozofa do duždeva i vojskovođa u svojoj zbirci supostavljaju epitafe u čast mitskih junaka (primjerice, Narcisu, Didoni, Kupidu, Prijapu itd.), potom bezimenih pokojnika upamćenih po nekoj njihovoj karakternoj osobini, „dijagnozi“, porijeklu ili „profesiji“ (rasipniku, prostitutki, glupanu, lopovu, ciganki, gubavcu, izdajniku, šarlatanu, vojniku, političaru, astrologu, komičaru, alkemičaru, liječniku, ljubavniku, grbavcu, luđaku i dr.), ali i - domaćih ili divljih - životinja (Bukefalu, zecu, leptiru, pauku, psu, mački, mazgi, pijetlu, lavu, kravi, biku i dr.), personificiranih pojava (primjerice, epitaf $D^{\prime}$ Echo posvećen je preminuloj Jeki) te alegorija (Pravdi), dok je nekolicina nadgrobnica realizirana u formi zagonetke koja u rješenju krije pokojnikovo ime. Želeći, drugim riječima, u potpunosti demistificirati smrt prikazujući je kao sveprisutnu pojavu kojoj podliježu čak i oni „besmrtni“, ovaj talijanski pjesnički dvojac svojim „razigranim epitafima“ gradi fiktivno groblje na kojemu - jedni pored drugih - počivaju znani i neznani, (nekad) živi i „oživljeni“, ljudi i životinje, heroji i nitkovi, pravednici i prijestupnici, baš kao što i u dva i pol desetljeća „starijoj“ šestojezičnoj zbirci „nestašnih epitafa“ Epitaphia Ioco-Seria, Latina, Gallica, Italica, Hispanica, Lusitanica, Belgica (1623.) flamanskoga baroknog pjesnika Pierrea Françoisa Sweertsa (Franciscusa Sweertiusa) nadgrobne ploče s natpisima bivaju podignute kako za zaslužne pojedince iz povijesti (kardinale, vojskovođe, pjesnike i dr.), tako i za potpuno anonimne pokojnike, mitske junake, pa i životinje.

\footnotetext{
549 Doduše, valja znati da ni Morsztyn u jednoj svojoj stvaralačkoj fazi nije odolio pisanju „,razigranih“ nadgrobnica u čast uginulih životinja.
} 
Zamisao o smrti kao izjednačujućoj sili vodila je i čuvenoga njemačkog baroknog pjesnika Christiana Hoffmanna von Hoffmannswaldaua pri sastavljanju nadgrobničke zbirke Poetische Grab-Schrifften (Pjesnički epitafi, 1643.), u kojoj kratke nadgrobne natpise paralelno dobivaju važne osobe iz svjetovne i biblijske povijesti (primjerice, Seneka, Neron, Diogen, Lot, sveti Petar, Marija Magdalena i dr.), „obični“ pojedinci kojima povijest nije ni zapamtila ime (,jedna djevojka“, ,jedan ljubavnik“ itd.) te domaće životinje poput psa i papagaja. Upućujući te nevelike pjesničke tekstove pokojnicima različite vrste, statusa i porijekla, Hoffmannswaldau - poput svojih generičkih prethodnika i nasljednika - smrti odbija pristupati kao pojavi koja samo odabrane individue posvećuje i izdiže iznad ostalih, pa umjesto patetičnoga glorificiranja gotovo nadljudskih vrlina i nedostižnih zasluga izdvojenih pojedinaca, o umrlima počesto piše čak i s jakom ironijom te aludirajući na njihovu posmrtnu nemoć i jednakost, uslijed koje su - bez obzira na to o kojem se i kakvom biću radilo - sve njihove ovozemaljske razlike jednom za svagda poništene. Da ta svijest o sveprisutnosti i svemoći smrti, odnosno propadljivosti svega ovozemaljskog baroknoga čovjeka nije samo plašila, već i - na ironično-satiričan način - radovala, i više nam nego uvjerljivo dokazuju potonje zbirke „razigranih“ ili „nestašnih“ epitafa, u kojima se na zamišljenim grobljima susreću pojedinci i bića koje je - iz ovih ili onih razloga - život fizički i/ili duhovno dijelio, pa i grubo suprotstavljao, baš kao što je to bio slučaj i s kršćanskim i muslimanskim vojnicima poginulima u bitci za Siget, nad čijim se naizmjenično nanizanim grobnim humcima na sigetskom polju izdižu nadgrobni spomenici s natpisima donesenima u četvrtom „dilu“ Odiljenja sigetskog. Na takav vidno „demokratski““ pristup žrtvama sigetske katastrofe Vitezović se teško mogao odlučiti čitajući „ekskluzivno“ kršćanski ciklus nadgrobnica u Petrovoj Sireni, pa nam ne preostaje ništa drugo nego pretpostaviti da su ga na nadgrobničko izjednačavanje ,pravovjernika“ i ,pogana“ navele upravo neke od brojnih stranih baroknih zbirki „razigranih“ epitafa, u kojima uvriježeno ozbiljan i „uzvišen“ epitafski kult umrlih razvodnjuju ne samo nadgrobnička (izrazito parodijska) „oplakivanja“ uginulih životinja, već i smjenjivanje epitafa anonimnih pokojnika s onima važnih mitskih i povijesnih ličnosti, koji su - pak - pritom nerijetko još i protkani vrlo snažnim satiričkim i parodijskim momentima, gdjekad i onima s otvoreno političkim podtekstom.

U Vitezovićevoj odluci da čitav jedan dio svoje „zrinijade“ ispjeva kao skup nadgrobnih natpisa u čast najistaknutijih kršćanskih branitelja i muslimanskih osvajača Sigeta nezanemarivu je ulogu morala odigrati i - možda naizgled nevažna - činjenica kako je sama praksa uklesavanja stihova ili kratkih poruka na nadgrobne spomenike u njegovo vrijeme bila još uvijek poprilično živa. Štoviše, da je recipijente Odiljenja upravo na tu praksu želio on i 
otvoreno podsjetiti ukazuju nam mnoge usmenoknjiževne crte kojima su protkani (i) njegovi epitafi, a kojima kao da je bila svrha evocirati stvarne nadgrobne natpise, kadšto i izvorno folklornoknjiževnoga porijekla ili - u najvećem broju slučajeva - makar obilato napučene prepoznatljivim motivima i drugim značajkama usmenoga pjesništva. ${ }^{550}$ Pritom je naš autor ponajprije na umu jamačno imao onaj - slabije obrazovan, pa onda i književno neiskusniji dio publike, koji je tek ovlaš ili možda nimalo bio upoznat sa stanjem na onodobnoj europskoj književnoj sceni i koji u žanru epitafa nije bio u stanju prepoznati jedno od tada najraširenijih lirskopjesničkih generičkih rješenja, a kamoli u njemu detektirati (i) prisutnost obilježja svojstvenih repertoaru barokne nadgrobnice. Uostalom, za usmenoknjiževnim momentima - o kojima će uskoro biti više riječi - Vitezović je u svojim nadgrobnicama najvjerojatnije posegnuo i ponukan svojim osobnim ,sigetskim“ iskustvom, točnije činjenicom da je u drugoj polovini 1683., sudjelujući u kratkotrajnom (privremenom) oslobađanju Sigeta u sklopu hrvatske pukovnije grofa Ricciardija, imao prilike posjetiti vojničko groblje situirano istočno od Sigeta, ${ }^{551}$ koje je na njega očigledno moralo ostaviti i više nego snažan utisak. Imajući u vidu upravo to sigetsko groblje očigledno on i osmišljava ciklus epitafa kao literarnu aluziju na taj stvarni „lokalitet“, trudeći se pritom napučiti ih određenim brojem dovoljno prepoznatljivih usmenoknjiževnih značajki ne bi li nalikovali natpisima s nadgrobnih ploča sigetskih pokojnika, koji su zacijelo također bili bremeniti karakterističnim folklornim osobitostima - motivima, simbolizacijom, autohtonim poslovičnim izričajima itd. - poradi kojih žanr epitafa folkloristi sve češće i klasificiraju među „rubne usmenoknjiževne oblike““ ${ }^{552}$ Ipak, s obzirom na višestruko već istaknutu sedamnaestostoljetnu pisanoknjiževnu omiljenost žanra nadgrobnice, kao i činjenicu da su za njim svega nekoliko desetljeća prije Vitezovića u svojim jezično različitim Sirenama posegnula braća Zrinski, epitafe iz Odiljenja nužno je motriti kao generičko rješenje evocirano isključivo posredstvom pisane - ili, bolje rečeno, pismom fiksirane - književnosti, tim više što je riječ o žanru čiji pojedini primjerci zabilježeni na našim prostorima potječu još iz antičkih i ranokršćanskih vremena.

Da je naš autor itekako dobro poznavao i uvažavao tu antičko-ranokršćansku „poetiku“ žanra „stvarnog“ epitafa ili nadgrobnog natpisa sugerirat će nam čitav niz sadržajnih značajki koje prožimaju pjesme nadgrobničke dionice Odiljenja, a koje neodoljivo

\footnotetext{
${ }^{550}$ Već na natpisima na srednjovjekovnim nadgrobnim spomenicima ili stećcima proučavatelji su locirali čitav niz izvorno usmenoknjiževnih obilježja, kojima su - u ništa manjoj mjeri - bremeniti i ranonovovjekovni (stvarni) epitafi. Baš iz toga razloga pojedini su folkloristi skloni tvrditi kako bi natpis na stećku, odnosno nadgrobnom spomeniku valjalo motriti kao ,pisanoknjiževni tekst koji je oblikovan usmenoknjiževnim podacima“" (Kekez 1992: 17).

${ }^{551} \mathrm{O}$ vojničkom groblju u okolici Sigeta usp. Mijatović 2010: 55.

552 Podrobnije o tome npr. u: Botica 2013: 509-510.
} 
nalikuju karakteristikama što su ih nosili epitafski natpisi sastavljani još u starorimsko doba. Ti su natpisi na nadgrobnim spomenicima - kojih se nemali broj, pretežno razasutih duž prostora južne Hrvatske, dospio očuvati sve do danas ${ }^{553}$ - bili djelo anonimnih profesionalnih pjesnika koji su ih pisali po narudžbi, realizirajući ih u heksametrima te uz obilnu uporabu šabloniziranih sadržajnih i formalnih shema (točnije, uvriježenih epitafskih formula i klišeja), ne zazirući čak ni od uključivanja fraza ili čitavih stihova posuđenih iz pjesničkih ostvarenja „stožernih“ antičkih autora (napose Vergilija, Ovidija, Marcijala i dr.). S obzirom na to da je ustrajanje na njihovoj šabloniziranosti rezultiralo izuzetno visokim stupnjem podudarnosti, a kadšto i gotovo potpunom identičnošću pojedinih epitafskih natpisa iz toga doba, predodžbu o generičkom repertoaru antičke i ranosrednjovjekovne nadgrobnice lakoćom možemo stvoriti iščitavanjem jedva nekolicine njezinih očuvanih primjeraka, iz čega će nam već na prvi pogled postati jasno u kolikoj se zaista mjeri Ritter pri sastavljanju svojih epitafa oslanjao na ove predbarokne generičke predloške. Iako su, doduše, ranokršćanski epitafi u sadržajnom pogledu izrasli iz baroknom čovjeku stranog poimanja smrti kao nagrade i groba kao „počivališta“ u kojemu je pokojnik - u iščekivanju vlastita uskrsnuća - prisiljen boraviti samo privremeno, dokazani barokist Vitezović nije se ipak libio kreativno „poslužiti“ čitavim nizom onih sadržajnih (formulaičnih) elemenata (motivom pokojnikova obraćanja putnikuprolazniku, navođenjem razloga njegove smrti i dokaza o kreposnom životu, uključivanjem iskaza ožalošćenih članova obitelji ili drugih mu bliskih osoba, motivom protestiranja zbog prerane smrti i njezinim shvaćanjem kao nepravde i dr.), koji su antičkim nadgrobnicama pridavali vrlo snažnu dijalošku crtu. I baš kao što su $u$ tekstovima $\mathrm{s}$ antičkih i ranosrednjovjekovnih nadgrobnih spomenika „putnici“ / „stranci“ / „došljaci“ / „oni koji prolaze“ itd. ${ }^{554}$ pozivani da časkom zastanu i pažljivo iščitaju kratke stihove s informacijama o pokojniku, njegovim vrlinama i dostignućima, razlozima njegove prerane pogibije, ucviljenim najbližima koje je ostavio iza sebe i poukama o nužnosti uživanja u životu prije no što ga smrt zauvijek prekine, ${ }^{555}$ tako se i mnoge nadgrobnice četvrtoga ,dila“ Odiljenja sigetskog otvaraju ili zatvaraju pokojnikovim dozivanjem ili pozdravljanjem onog „koji mimo šetuje“ i kojemu su i upućeni podsjetnik o njegovoj junačkoj pogibiji pod sigetskim zidinama

\footnotetext{
${ }^{553}$ Riječ je o onim istim epitafima što ih je u svojoj antologiji Carmina epigraphica okupio Duje RendićMiočević (usp. Rendić-Miočević 1987).

${ }^{554} \mathrm{U}$ početnim stihovima tih ranokršćanskih epitafa obično se „životne putnike“ pozivalo da posvete pažnju pokojniku koji ondje počiva šabloniziranim frazama i formulacijama poput „Ej stranče, zastani čas i grobni mi pogledaj humak“; „Putniče, (...) ma tko da jesi“; „Tko bio ti što gledaš, došljače, grobni nam humak, / zastani molim te sad“; „Ti što uz pepeo moj prolaziš i grob mi gledaš“; „Tebi, što žuriš““; „Putniče, (...) pročitaj ovo“; „Ovamo pogledaj, čovječe“i i sl. Usp. Rendić-Miočević 1987 i Botica 2016.

${ }^{555}$ Detaljnije o ovoj i drugim osobitostima antičkih, pa i kasnijih „stvarnih“ nadgrobnih natpisa u: RendićMiočević 1987: 11-22, Botica 2016: 207-231 i Budišćak 2016a: 273.
} 
te pouka o prolaznosti, nestalnosti sreće i sveprisutnosti smrti, pred kojom je svakome - pa i njemu - suđeno kad-tad pokleknuti.

Iako su u potpunosti „čedo“ baroknih ideja i svjetonazora, potonje pouke o čovjekovoj smrtnosti i uopće privremenosti svega ovozemaljskog mogu se ujedno promatrati i kao odjek čuvenoga ranokršćanskog toposa memento mori ili neizbježnosti smrti, na kojem su se bazirala i poučna podsjećanja na sveprisutnost smrti što su ih sadržavali (,stvarni“) nadgrobni natpisi iz antičkoga i (rano)srednjovjekovnog perioda. ${ }^{556}$ Riječ je, štoviše, o toposu koji je višestruko prerastao granice srednjovjekovnoga epitafskog stvaralaštva te nastavio egzistirati ne samo uključen u nadgrobne natpise iz kasnijih razdoblja, ${ }^{557}$ nego i u sklopu umjetničke književnosti, i to naročito zahvaljujući činjenici što je većina izvorno epitafskih toposa $\mathrm{i}$ šabloniziranih formulacija ubrzo prešla kako u inozemnu, tako i u hrvatsku pisanu književnost, egzistirajući u njoj već „od srednjovjekovlja, i Marulića, do suvremenih uporaba i u literaturi i u najširim slojevima hrvatskog pučanstva“" (Botica 2016: 222). Prepoznatljivi toposi i drugi sadržajni momenti baštinjeni još iz antičke nadgrobničke tradicije nipošto se pritom ne bi mogli izdvojiti kao jedini signali Vitezovićeva oslanjanja (i) na stvarnu, do krajnosti klišeiziranu praksu sastavljanja natpisa za nadgrobne spomenike, poglavito zato što sumnju na ugledanje u „fizičke“ epitafe pobuđuje već i pojava višestrukih nadgrobnica upućenih jednome te istom pokojniku. Iako se ispisivanje četiriju epitafa u čast Sulejmana, a potom po dva u čast bana Zrinskog, Deli-Vida Žarkovića, Andrijina Radovana, Juranića te grada Sigeta može pravdati (povijesnom, literarnom) važnošću pokojnika kojima su posvećeni, a naročito presudnom ulogom koju su odigrali u samoj sigetskoj bitci, bit će da se na umnožavanje nadgrobnica istaknutih sudionika kršćansko-muslimanskoga sukoba Ritter odlučio znajući da je riječ o uobičajenoj izvanknjiževnoj praksi, odnosno da se posebno značajnim pojedincima na njihovim nadgrobnim spomenicima gdjekad upisivalo i više od jednog epitafa. ${ }^{558}$ Drugim riječima, računajući na to da praksa višestrukih epitafa ni njegovim potencijalnim recipijentima ne predstavlja nepoznanicu, Vitezović i u svojoj ,zrinijadi“ nekolicini važni(ji)h pokojnika odlučuje posvetiti više od „tek“ jedne nadgrobnice, uvjeren da će i na taj način te posebno značajne i hrabrošću istaknute žrtve sigetske katastrofe dodatno glorificirati i još više ,,podignuti“ u očima svoje vrlo raznolike publike.

\footnotetext{
556 Zahvaljujući tim poučnim podsjećanjima na čovjekovu smrtnost i uopće propadljivost svih fizičkih stvari, epitafi su se - kako navodi Stipe Botica - nametali kao „poticajan memento cijeloj zajednici“ (Botica 2016: 210). 557 Naročito se to odnosi na renesansne nadgrobne natpise, koji su se sadržajno pretežno fokusirali na glorificiranje pokojnikovih postignuća. Detaljnije o toposu memento mori i njegovim epitafskim manifestacijama posebno u: Curtius 1998: 91-93.

${ }^{558}$ Kao jedan od ponajboljih primjera ove prakse mogli bismo izdvojiti grob opatice Većenige u zadarskom samostanu Svete Marije, kojoj su u spomen ispjevana također četiri epitafa kao očit znak njezina silnog značaja i ugleda kojega je - za života - uživala u samostanu, a zacijelo i mnogo šire. Usp. Botica 2016: 219-220.
} 
Paralelno s ovim - većinom višestrukim - epitafima u čast pripadnika obiju sukobljenih strana koji su se u sigetskoj bitci istaknuli podjednako svojim hijerarhijskim značajem te - još više - učinjenim junačkim podvizima, Ritter u četvrtom dijelu Odiljenja donosi i niz mahom kraćih nadgrobnica namijenjenih „manjim“ vojskovođama ili običnim vojnicima (primjerice, Rahmatu Goliji, Jurju Ćakoviću, Iliji Golemu, Mikuli Sekuliću i dr.), čije sudioništvo u bitci nije ostalo upamćeno po nekim posebno vrijednim herojskim pothvatima, no kojih su se odvažnost i časna pogibija pod zidinama Sigeta nametnuli kao dovoljno valjani razlozi za (neveliko) epitafsko proslavljanje junačkog im ,lika i djela“. I u toj ideji sastavljanja nadgrobnih natpisa čak i za pojedine „pobočne“ aktere kršćanskomuslimanskoga okršaja također bi trebalo vidjeti svojevrsni odjek antičke epitafske prakse, $u$ sklopu koje nadgrobnice nisu shvaćane kao privilegija „samo određenih, gornjih društvenih slojeva provincije, jer taj način izražavanja počasti umrlima nalazimo i među oslobođenicima, pa čak i među robovima, kako u međusobnim odnosima roditelj - dijete ili suprug - supruga, tako i između patrona i oslobođenika ili gospodara i roba, čime je, na poseban način, izražena čvrsta povezanost unutar jedne rimske familije, kojoj su pripadali i njezini robovi“ (RendićMiočević 1987: 16-17). Bit će, štoviše, da je - uvelike imajući na umu upravo to antičko i ranosrednjovjekovno epitafsko stvaralaštvo - Vitezović zaključni „dil“ svoje zrinijade i zamislio kao ciklus epitafa uklesanih na nadgrobne spomenike razasute zajedničkim grobljem nadomak već turskoga Sigeta, na kojemu - jedni pored drugih - počivaju posmrtni ostaci poginulih kršćanskih branitelja i muslimanskih osvajača.

U činjenici da je u Vitezovićevim nadgrobnicama, kako zamjećuje Davor Dukić, „nivelirajuća snaga smrti, kao u nekom srednjovjekovnom danse macabre, izjednačila (...) kršćane i muslimane, pobjednike i poražene, cara i podanike, vojskovođe i vojnike“ (Dukić 2004b: 156) nipošto, dakle, ne bi bilo neopravdano prepoznati utjecaj te antičke „demokratičnosti“ žanra (,stvarnoga“) nadgrobnog natpisa, pri čemu valja znati kako je epitafsko izjednačavanje pogibije zakletih neprijatelja i protivnika - ne odveć različito od supostavljanja smrti uvaženih i posve anonimnih pojedinaca, životinja te alegorijskih i personificiranih bića i pojava u mnogim sedamnaestostoljetnim epitafskim zbirkama $-\mathrm{u}$ najvećoj mjeri zapravo posljedica bitno ublažene slike Turaka, na kojoj Odiljenje sigetsko u cijelosti počiva. ${ }^{559}$ Bez obzira, konkretno, na „protutursku tendencioznost“ (Kravar i Novaković 2000: 767), očigledno naslijeđenu iz ranijih „zrinijada“, sva četiri dijela Odiljenja dosljedno se klone jakih negativnih kvalifikacija osmanlijskoga protivnika, u čemu uvelike kroče putovima što ih je dva i pol desetljeća ranije počeo krčiti već Petar Zrinski, u čijoj se

${ }^{559}$ O slici Turaka u Odiljenju znatno opširnije u: Dukić 2004b: 155-158 i Budišćak 2013b: 343-362. 
Obsidi sigeckoj - usprkos povremenim izrazito negativnim obilježavanjima Turaka kao vjekovnoga kršćanskog neprijatelja - o pojedinim turskim junacima ipak piše s dotad gotovo nezamislivim eksplicitnim poštovanjem. ${ }^{560} \mathrm{I}$ baš kao što u Petrovoj ,zrinijadi“ Turci ne samo što ne bivaju sustavno sotonizirani, već im se nerijetko otvoreno priznaje vojna moć, izražava respekt spram pojedinih uglednih pripadnika njihove vojske te opisuju romantični događaji u koje neki od njih bivaju upleteni, ${ }^{561}$ tako se i Odiljenju sigetskom oni prikazuju kao protivnici koji - nalik kršćanima - (većinom) ratuju neustrašivo, časno i vodeći se „višim idealima“ (religijskim pobudama te vjernošću i odanošću caru i domovini), slijedom čega svojom junačkom smrću na bojišnici i zaslužuju počivalište tik uz ono kršćanskih suparnika na zemlji, odnosno - ,ppoganstvu“ usprkos - vječni život „,V rajskoj diki“ kao i njihovi neprijatelji. ${ }^{562}$

Fizičkom miješanju i idejno-motivskom zbližavanju epitafa kršćanskim i muslimanskim vojnicima i vojskovođama usprkos, Ritter je, kako se čini, ipak želio zadržati makar minimalno razlikovanje nadgrobnih natpisa posvećenih „našim“ i onih „njihovim“ žrtvama, što se ponajbolje razabire iz prvih dvaju izdanja Odiljenja, u kojima poginuli pripadnici suprotstavljenih tabora dobivaju nadgrobnice djelomično ili u cijelosti otisnute različitim tipovima slova. Za razliku od izdanja iz Linza i Beča, u kojima je - pored završne nadgrobnice Sigeta (Druga istoga grada, u kojemu rat govori; IV: 423-428) ${ }^{563}$ - od sveukupno 16 epitafa posvećenih osmanlijskim pokojnicima kurzivom u cijelosti bilo tiskano njih 13, dok su u preostalim trima - i to prvim trima Sulejmanovim epitafima - u kurzivu otisnuti tek njihovi naslovi, u zagrebačkom izdanju iz 1695. Vitezović će kurzivom tiskati svega dvije nadgrobnice, i to četvrtu Sulejmanu (Četrta istoga; IV: 55-61) te drugu Sigeta, obje ispjevane u heksametru. Drugim riječima, nasuprot prvim dvama izdanjima, u sklopu kojih je odabirom kurziva sve nadgrobnice pripadnika muslimanske vojske makar tipografski pokušao istaknuti i razdvojiti od onih poginulim Hrvatima, u onom trećem kurzivom je on želio istaknuti i iz epitafskoga „okruženja“ jače izdvojiti isključivo jedine dvije nadgrobnice ciklusa ispjevane stihom antičke provenijencije. Osim dvaju formalno specifičnih,

\footnotetext{
${ }^{560}$ Usp. Pavličić 2008a: 3.

${ }^{561}$ Budući da su u Obsidi sigeckoj Turci tako prikazani tek „,kao ljudi i s vrlinama i s manama, kojima ravnaju ljubav, zavist i mržnja“ (Dukić 2004b: 135), može se zaključiti kako se između pokudnih (no ne i apsolutno diskvalificirajućih) i pohvalnih iskaza o likovima s turske strane ostvaruje ondje jasno uočljiva ravnoteža (usp. o tome u: Dukić 2004b: 131-136). U tom bi se smislu i Vitezovićevo otupljivanje prezentacijske oštrice kada je turski neprijatelj u pitanju definitivno moglo i moralo shvatiti (i) kao posljedica snažnoga nadovezivanja upravo na „zrinijadu“ neposrednoga mu prethodnika. O potonjem pitanju podrobnije u: Budišćak 2013b: 346-347.

${ }^{562}$ Iako se u nadgrobnicama muslimanskih junaka njihov ulazak u nebo izboren na bojnom polju eksplicira znatno rjeđe, motiv uznesenja u raj gdjekad će se ipak pojaviti i u njima, kao što je to slučaj i u epitafu Murtuzana paše i Ahmeta, sina njegovoga (IV: 200-206), koji završava stihovima: „Tila med vojniki / počivaju ovdi, imena u viki, / duše v rajskoj diki“" (IV: 204-206).

${ }^{563}$ Razlog zbog kojega se i druga nadgrobnica Sigetu tipografski izjednačuje s epitafima u čast osmanlijskih junaka trebao bi ležati u činjenici da je nakon dovršetka opsade sigetska utvrda i „formalno“ prešla u turske ruke, što „mrtvi“ Siget u tom slučaju čini upravo muslimanskim, a ne (više) kršćanskim pokojnikom.
} 
heksametarskih pjesničkih ostvarenja, Vitezović kurzivom ujedno izdvaja i dva (kraća) epitafa sastavljena u čast dvojice možda i ključnih sudionika sigetske katastrofe - neustrašivoga osmanlijskoga osvajača, odnosno „oživljena“ objekta njegova posljednjeg osvajačkog pohoda - te na taj način dodatno ističe snagu smrti, koja je na sigetskom vojnom groblju prebrisala $i$ najmanje distinkcije među kršćanima i muslimanima i tako učinila izlišnom i potrebu bilo kakvoga, pa i tipografskog razlikovanja njihovih epitafa. ${ }^{564}$

Oslanjanje na dugu tradiciju sastavljanja stihovanih nadgrobnih natpisa u slučaju Vitezovićeva Odiljenja sigetskog možda nam i ponajbolje odaje žanrovska slojevitost velikog broja tekstova njegova četvrtog njegova „dila“, točnije činjenica da su mnogi od ondje uvrštenih epitafa generički zapravo hibridna ostvarenja protkana prepoznatljivim obilježjima iz repertoara različitih pisanoknjiževnih i usmenoknjiževnih žanrova. Na uključivanje značajki (barokne) povijesne epske pjesme, pohvalnice, dijaloške pjesme, naricaljke, poslovice, hvale i drugih žanrova $\mathrm{u}$ tekstove $\mathrm{s}$ prevladavajućim epitafskim generičkim svojstvima Ritter se vrlo vjerojatno odvažio potaknut (i) dobro mu poznatim primjercima antičkih $\mathrm{i} /$ ili znatno mlađih natpisa $\mathrm{s}$ nadgrobnih spomenika, u čijoj fakturi su gotovo neizbježni bili elementi najmanje jednog, a često i (mnogo) više od jednog primarnog ili sekundarnog žanra. Naime, osim kraćih (,stvarnih“) nadgrobnica, koje su se svodile na jednu zgusnutu misao realiziranu u obliku citata, poslovice, epigrama ili aforizma, oni nešto dulji epitafi s našega područja - u kojima se obično podastiru pojedinosti iz pokojnikova života vrlo su često upijali stil naricaljke, bili „nadograđivani“ kletvama i/ili biblijskim aforizmima te uključivali niz karakteristika pisanoknjiževnih lirskopjesničkih žanrova, pa i onih pučkoknjiževnih poput senzacionalnih formulacija, preuveličavanja itd. ${ }^{565}$ Budući da posezanje za karakteristikama različitih literarnih žanrova nije bilo ništa neobično ni u tradiciji pisanoknjiževnih ili umjetničkih - a naročito upravo sedamnaestostoljetnih - epitafa, može se konstatirati da je riječ o protežnoj ili temeljnoj posebnosti žanra nadgrobnice, koje je pri sastavljanju svoga nadgrobničkog ciklusa itekako bio svjestan i naš autor. Dapače, obilježivši četvrti dio Odiljenja i više nego preciznom generičkom oznakom - „nadgrobnice“ - unaprijed je on znao da neće biti u stanju - točnije, da se od njega neće ni očekivati da bude u stanju - ispjevati ciklus žanrovski „,̌istih“ epitafa, što mu je davalo odriješene ruke da i u završnom „dilu“ nastavi - u generičkom pogledu - činiti isto što je činio i pri sastavljanju pjesama prethodnih triju dionica, odnosno da ustraje u svojoj praksi pisanja (pretežno) žanrovski dvojbenih pjesničkih sastavaka satkanih od različitih pisanoknjiževnih,

\footnotetext{
${ }^{564}$ Usp. Budišćak 2016b: 87, bilješka 15.

565 Spomenute kraće nadgrobnice Stipe Botica u svojoj studiji proziva aforističkim (paremiološkim ili gnomskim) epitafima, dok one dulje označava kao literarizirane epitafe. Usp. Botica 2016: 223-231.
} 
usmenoknjiževnih, pučkoknjiževnih, poluknjiževnih i inih generičkih karakteristika. To, drugim riječima, pokazuje da Ritteru čak ni u dijelu teksta u kojem okuplja žanrovski naoko identične pjesme nije stalo do toga da postigne apsolutnu generičku čistoću, već - upravo suprotno - da i u zaključnom odsječku svoje ,zrinijade“ nastavi nizati hibridna ostvarenja, slijedom čega i odabire upravo onaj (sekundarni) žanr čija mu ,poetika“ i dopušta da - kao dosljedni barokist - tu mogućnost njegova generičkog „kontaminiranja“ iskuša do krajnosti. Baš iz toga razloga u kontekstu četvrtoga „dila“ nimalo neobičnom ne bi trebalo označiti ni pojavu dijaloški oblikovanih nadgrobnica (Druga istoga cara, gdi putniku car odgovara; IV: 21-36), potom nadgrobnica „obogaćenih“ pohvalničkim odsječkom (Mikule kneza od Zrinja, bana; IV: 62-103), ali ni poduljih nadgrobnica u kojima ženski lirski subjekt oplakuje poginuloga zaručnika puneći epitafski diskurs prepoznatljivim crtama usmenoknjiževne naricaljke (Embrulaha lipoga u kojoj Arpijanine zaručnica plače; IV: 263-308).

Ako je otvorenost karakteristikama iz repertoara drugih žanrova jedna od osnovnih specifičnosti epitafa zbog kojih je ovaj lirskopjesnički žanr i našao popriličan broj svojih praktikanata među sedamnaestostoljetnim autorima, onda bi se ciljano posezanje za različitim tipovima stihova pri sastavljanju pojedinačnih nadgrobnica ili čitavih epitafskih ciklusa moglo izdvojiti kao jedan od postupaka svojstvenih većinom baroknoj epitafskoj produkciji. Doduše, iako su se, pored onih - uvjerljivo najbrojnijih - ispjevanih u heksametru ili elegijskom distihu, već u antici i ranom srednjovjekovlju i na našim prostorima povremeno pojavljivali i nadgrobni natpisi realizirani u drugim metrima, pa čak i polimetrični epitafi, ${ }^{566}$ sustavno prepuštanje „verzifikatorskom žongliranju“ (Kolumbić 2005: 346) kakvom svjedočimo u četvrtom dijelu Vitezovićeve ,zrinijade“, ali i u pojedinim onodobnim epitafskim ciklusima stranih autora poput maločas spomenute šestojezične zbirke „razigranih epitafa“ Pierrea Françoisa Sweertsa iz 1623., zabilježeno je isključivo u baroknoj književnosti, gdje je njegova najvjerojatnija svrha trebala biti privlačenje i zadržavanje pažnje različitih tipova čitatelja. Metrička šarolikost Odiljenja sigetskog pritom nipošto nije bila inicirana „samo“ tim izvanknjiževnim ciljevima, odnosno s mišlju na potencijalne recipijente teksta, nego njezin uzrok definitivno valja tražiti i u pojedinim unutartekstualnim, pretežno sadržajnim čimbenicima poput pozicije kazivača ili lirskog subjekta, na kojoj će se u završnom „dilu“ izmjenjivati većinom pokojnici ne samo različitoga porijekla, već i nejednakoga društvenog i vojnog značaja te uloge koju su odigrali u obrani ili zauzeću Sigeta.

Konkretno, (poduljih) pet od sveukupno osam nadgrobnica posvećenih sultanu Sulejmanu, banu Zrinskom i personificiranu Sigetu ispjevano je tako u vrlo tradicionalnom i

\footnotetext{
${ }^{566}$ Usp. Rendić-Miočević 1987: 22.
} 
„knjiškom“ dvostruko rimovanom dvanaestercu južnoga tipa, koji bi - kao takav - ujedno trebao aludirati i na njihov povijesni značaj, povijesnu (dakle, „knjišku“, pa i literarnu) upamćenost te duhovne i materijalne vrijednosti koje su oni utjelovljivali ili predstavljali, što u slučaju Sulejmana i Sigeta dodatno biva potvrđeno još i dvjema kraćim nadgrobnicama u njihovu čast $\mathrm{u}$ (pseudo)heksametru, kojim se - s obzirom na njegovo vrlo staro porijeko očito željela naglasiti starost kršćanstva i islama kao religija, čiji su se „predstavnici“ i sukobili pod sigetskim zidinama, odupirući se ili asistirajući predvodniku osvajačke sile staroga i moćnog Osmanskog Carstva u zauzimanju jedne od strateški najvažnijih utvrda ništa manje moćne Habsburške Monarhije. ${ }^{567}$ I dok bi tradicionalni i „dugi“ heksametar u epitafima Sigeta i Sulejmana istodobno mogao upućivati i na svojevrsnu dugotrajnost i ,,arhaičnost“ turskoga i sigetskog tematskog kompleksa u povijesti hrvatske književnosti, dotle bi kraći stihovi većinom usmenoknjiževne provenijencije u kojima su ispjevane mnoge nadgrobnice posvećene „manjim“ vojskovođama te povijesnim ili fiktivnim običnim vojnicima (Amirašenu, Embrulahu, Kairbegu, Deli-Vidu, Andriji Gusiću itd.) trebali implicirati ne samo njihovo - gdjekad i narodno (pučko) - podrijetlo i nešto skromniju ulogu koju su imali u nemilim sigetskim događanjima, nego i znatno slabiju (a često i gotovo nikakvu ili, pak, samo usmenoknjiževnu) prethodnu literarnu obrađenost njihova „lika i djela“. Na tu prethodnu literarizaciju junaštava i žrtve koju su podnijeli pod sigetskim zidinama možda bi trebao ukazivati dvostruko rimovani dvanaesterac u kojem su realizirani također i epitafi u čast nekih od njih (primjerice, Delimanu, Demirhanu, Gašparu Alapiću, Radivoju i Juraniću, Stipanu Oršiću i dr.), pri čemu se kratkoćom tih dvanaesteračkih pjesama istodobno pokušava dati do znanja kako je riječ o pokojnicima koji se po svojoj važnosti i ulozi u sigetskoj bitci teško mogu mjeriti sa Sulejmanom, banom Zrinskim ili, pak, samim Sigetom. Metričkim varijacijama, kojima se u epitafskoj dionici Odiljenja, dakle, teži podcrtati nejednaka važnost, porijeklo te izvanknjiževni i književni status poginulih sudionika opsade Sigeta, u isti se mah pokušava i formalno dinamizirati zaključni ciklus epitafa u cijelosti, odnosno - kako je to svojedobno ispravno pretpostavio Milivoj Šrepel - izbjeći monotoniju ${ }^{568}$ te čitatelju učiniti intrigantnijom i ,privlačnijom“ ovu generički naizgled najujednačeniju dionicu teksta.

S očitom nakanom da razbije monotoniju nadgrobničkog segmenta svoje ,zrinijade“ Vitezović je pri njegovu sastavljanju odlučio uposliti i još jednu tipično baroknu - od svih, štoviše, možda i najbarokniju - strategiju, obogativši tako nekolicinu svojih žanrovski i

\footnotetext{
${ }^{567}$ Heksametar u drugoj - ujedno i posljednjoj - nadgrobnici Sigeta (Druga istoga grada, u kojemu rat govori; IV: 423-428) vrlo bi lako mogao proizlaziti i iz činjenice da se u ulozi kazivača koji govori o „smrti“ Sigeta ondje pojavljuje personificirani rat, čiji bi opći značaj, „starost“ i svemoć u tom smislu trebao implicirati i taj tradicionalni te literarno autoritativni i sveprisutni stih „,iz davnina“.

${ }^{568}$ Usp. Šrepel 1902: 105.
} 
metrički šarolikih ostvarenja $\mathrm{k}$ tome još i figuralno pojačanim stilom. Da su (inozemni) pjesnici 17. stoljeća prepoznatljivo barokna stilska svojstva nerijetko bili skloni isticati čak i u epitafskoj dionici svojih pjesničkih opusa ponajbolje se možemo uvjeriti - između ostalih - i na primjeru maločas spomenutoga Zbigniewa Morsztyna, čijem (pre)naglašenom končetizmu nadgrobnica u čast poginulih poljskih vojskovođa ${ }^{569}$ pojedini Ritterovi nadgrobni natpisi nisu ipak ni „do koljena“. Za razliku od žanrovski već i naoko raznolikijih prvih triju dijelova Odiljenja, u čijim pjesmama su čak i najmanju prijetnju eventualne monotonije otklanjali brojni generički „umetci“, neprekidne promjene kazivača, prostorni i vremenski skokovi te povremene formalne dosjetke (figura jeke, kronogrami, četverostruke rime itd.), u žanrovski ujednačenom ciklusu nadgrobnica nužno usredotočenom na vrlo uzak tematsko-motivski krug interes čitatelja različita profila mogao se - osim prizivanjem obilježja drugih žanrova izmamiti jedino ,intervencijama“ na formalnoj i stilskoj razini. Pored maločas zamijećenih metričkih varijacija, Vitezović se zaključni segment Odiljenja stoga odlučuje oplemeniti i mjestimičnim natruhama jakoga baroknog stila, pri čemu - kako su već zamijetili pojedini „ritterolozi“670 - u pojačavanju figuracije ipak ne odlazi predaleko, koncentrirajući ta stilski „svježija“ i inovativnija rješenja na svega nekoliko mjesta unutar ciklusa. Trudeći se zadovoljiti ukus i potrebe učenijih čitatelja, dobro upoznatih s poetički propisanom stilskom baroknom ingenioznošću, ali i one slabije obrazovane i književno neiskusnije publike, koja je također pokazivala izrazitu sklonost baroknim (stilskim) ornamentima, ${ }^{571}$ Ritter će tako stilski daleko najuspjelije domišljate formulacije uključiti u četvrtu - heksametarsku - Sulejmanovu nadgrobnicu, u kojoj se konstatira kao „mrtav dobi car, zadobit što ne mogaše živućc“ (IV: 61), te epitaf Andrijina Radovana, gdje se navodi kako je pokojnik ,prijel (...) dvisto ran kot oči tulike“ (IV: 186), odnosno kako „dvi stotin ran prije kot usta tulike“ (IV: 188), što bi definitivno bile usporedbe sasvim na tragu tipično barokne stilske oštroumnosti.

Premda u formalnom, stilskom i uopće generičkom pogledu ponešto on odskače od ostatka teksta, četvrti „dil“ Odiljenja sigetskog uspostavlja ipak vrlo čvrste sadržajne poveznice s preostalim trima dijelovima, i to ne samo posredstvom jednih te istih aktera koji se javljaju iz „druge dimenzije“ ne bi li slučajnog prolaznika (iznova) podsjetili na svoje sudioništvo u zbivanjima o kojima je bila riječ i ranije, već i stoga što zbog iznošenja posve novih pojedinosti o nekim pokojnicima funkcionira on - šrepelovski rečeno - kao svojevrsni „appendix“ koji uvelike „potpunjava pregjašnju sliku napomenom pojedinih kršćanskih i turskih junaka i njihovih osobitih djela“ (Šrepel 1902: 106). Da ni Šrepel, ni Alojz Jembrih -

\footnotetext{
${ }^{569}$ Usp. Angyal 1961: 185-186.

${ }^{570}$ Usp. Kravar 1991: 240.

${ }^{571}$ O tome posebno u: Kravar 1993: 161-191.
} 
koji će više od stotinu godina kasnije također zaključiti kako su epitafi posljednjega „dila“ ništa drugo nego „dopuna povijesnih zbivanja koje je Vitezović refleksivno-lirski uspio oslikati u prethodna tri dijela“ (Jembrih 2008: 54) - u svojim zapažanjima nipošto nisu bili u krivu, nešto nam je ranije već potvrdila analiza pripovjednih momenata utkanih u ovaj nadgrobnički ciklus, koji se - podsjetimo - svojim fabularnim signalima izravno nadovezuju na narativne segmente prethodnih triju „dilova“ namećući se kao njihova nužna dopuna ili pojašnjenje. Tijesna sadržajna isprepletenost svih četiriju „dilova“ očituje se i u samom kvantitativnom aspektu pjesama epitafskoga ciklusa, točnije u maločas već zamijećenoj činjenici da su količina $\mathrm{i}$ duljina nadgrobnica ispjevanih $\mathrm{u}$ čast pojedinih junaka zapravo $\mathrm{u}$ izravnoj vezi s njihovom povijesnom važnošću i ulogom koju su odigrali u bitci, a koja je barem kada su u pitanju oni najistaknutiji sudionici sigetske katastrofe - glavninom bila pojašnjena upravo u ranijim dionicama teksta.

Sastavljanje ciklusa od gotovo četrdeset formalno neujednačenih epitafskih pjesama sadržajno „privezanih“ na tematsko-motivsku „nit“ prethodnih triju dijelova njegove „Zrinijade“Vitezoviću - u generičkom pogledu - zasigurno nije predstavljalo veći napor, tim više što se radilo o jednom od najraširenijih baroknih lirskopjesničkih žanrova u pisanju kojega se u više dotadašnjih navrata jamačno već bio okušao. Iako se ti njegovi (vjerojatni) mladenački epitafski pokušaji iz vremena prije objelodanjivanja Odiljenja do danas nisu sačuvali, o Ritterovoj neupitnoj okretnosti u pisanju (latinskih) nadgrobnica svjedočio bi pored Odiljenja - i detalj iz pjesničke poslanice olomučkomu biskupu Karlu LiechtensteinCastelcornu, u kojoj - pišući o svojoj prvoj i diljem Europe neobično popularnoj zbirci anagrama Opera anagrammaton laurus auxiliatoribus Ungariae iz 1687. - otkriva kako je ona zamišljena kao prvi dio mnogo opsežnijega ciklusa od sveukupno pet knjiga posvećenih proslavljanju habsburških država, kraljevstava, vojvoda, vojskovođa, pa čak i dvorskih ministara kralja Leopolda, pri čemu bi posljednji - peti - njegov svezak trebao biti upravo zbirka epitafa $\mathrm{u}$ čast habsburških junaka poginulih u protuturskim okršajima. ${ }^{572} \mathrm{~S}$ obzirom na to da mu ni do toga trenutka, a ni kasnije nije pošlo za rukom pronaći pokrovitelja zainteresiranog za financiranje takva opsežnog izdavačkog pothvata, petosveščana pohvalnica habsburškim „velikanima“ ostala je - zajedno s planiranom zbirkom epitafa - tek puki Vitezovićev san, što našega autora ipak nije zaustavilo u sastavljanju i objavljivanju latinskih nadgrobnica. Naprotiv, povremeno se on epitafe nije libio uključiti čak ni u stihovane dionice nekih od svojih mnogobrojnih anagrama, pa su tako - primjerice - u njegovoj zbirci Fata et vota iz 1699. među više od 900 anagrama svoje mjesto našli i oni u kojima se proslavljaju 
znameniti umrli ili poginuli pojedinci, a u koje su utkani još i cjeloviti nadgrobni natpisi što nerijetko sadržavaju i kronogram s godinom pokojnikove smrti. ${ }^{573} \mathrm{Za}$ žanrom epitafa Ritter će, štoviše, posegnuti i u pojedinim svojim historiografskim ostvarenjima, pa tako nadgrobni natpis posvećen posljednjemu bosanskom kralju Stjepanu Tomaševiću ubacuje on u povijesni prikaz propasti Bosanskoga Kraljevstva Bossna captiva (Zasužnjena Bosna) iz 1712., ${ }^{574}$ što je samo jedna u nizu manifestacija njegove sklonosti ukrštavanju različitih žanrova, odnosno punjenju relativno sužena tekstualnog prostora pojedinačnim njihovim obilježjima ili cjelovitim primjercima, kakvoj - uostalom - svjedočimo i u Odiljenju sigetskom.

\section{2. 5. Dijaloške pjesme}

U ciklusu epitafa što ih je Pavao Ritter Vitezović nimalo slučajno situirao u zaključnu dionicu svoje ,zrinijade“ poradi neobične nam je forme za oko maločas zapela jedna od četiriju nadgrobnica ispjevanih u čast „glavi svitu svemu“. Riječ je, dakako, o drugoj nadgrobnici turskom sultanu Sulejmanu - Druga istoga cara, gdi putniku car odgovara (IV: 21-36) - koja se od epitafa što je okružuju naočigled izdvaja svojim vrlo specifičnim dijaloškim oblikom, točnije činjenicom da je realizirana kao tekst u kojemu se smjenjuju posebno označena pitanja slučajnog i nedovoljno informiranog putnika (,P“) i carevi odgovori („C“), od kojih svaki zaprema isključivo po jedan stih ove ne odveć opsežne pjesme. Druga istoga cara u tom bi se pogledu mogla izdvojiti kao svojevrsna kulminacija opće dijaloške usmjerenosti čitavoga nadgrobničkog ciklusa Odiljenja, koja je - kako smo netom utvrdili - zapravo izravna posljedica Ritterova nadovezivanja na vrlo staru ,poetiku“ žanra (,stvarnoga“) nadgrobnog natpisa, ali i u velikoj mjeri nastavak izrazite dijalogičnosti koja prožima tekst od prve do posljednje njegove pjesme. Dijaloška intencija - o kojoj će naknadno biti i znatno više riječi - u Odiljenju sigetskom nipošto se ne očituje samo u nadgrobničkim pokušajima privlačenja putnikove pažnje, već i u odašiljanju i razmjeni poslanica ili heroida u prvim dvama „dilovima“, ratničkom govoru bana Zrinskog (Ban junakom; II: 269-347) i prisegi kršćanskih branitelja kao odgovoru na nj (Junaci banu; II: 348-360), lamentaciji Sigeta (Siget zvrhu samoga sebe; II: 517-613) i naricaljki vile Hrvatkinje (Vila Hrvatkinja nad Sigetom; II: 614-734), u kojima se adresiraju uzroci njihova jada, a ponajviše u dijalozima bana Zrinskog (Ban sinu; I: 478-568) i sina mu Jurja (Sin banu;

\footnotetext{
573 Jedan od takvih anagrama u spomenutoj je zbirci i onaj posvećen biskupu Stjepanu Dojčiću, koji sadrži i epitaf s uključenim kronogramom, čije rješenje (o)daje datum biskupove smrti (usp. Luetić i Tvrtković 2016: 330). Detaljnije o ovom pitanju i u: Stepanić 2016: 335-336.

${ }^{574}$ Usp. Klaić 1914: 281-282.
} 
I: 569-603) iz prvog te Zrinskog (Ban Sigetu; II: 147-189) i Sigeta (Siget banu; II: 190-268) iz drugoga „dila“, koje po „stupnju“ dijalogičnosti nadmašuju samo dijaloška pjesma Gospodična Sofija i oral (II: 735-906) te pjesma s figurom jeke Putnik i Jeka (III: 1-376), što se proteže duž čitava trećeg dijela teksta.

Za razliku, međutim, od potonjih dviju pjesama, dijalog bana $\mathrm{i}$ sina te onaj bana $\mathrm{i}$ Sigeta formalno nisu ostvareni kao tekstovi u kojima se izmjenjuju pitanja i odgovori ili pojedinačne replike, već se radi o „tek“ parnim pjesmama, od kojih jedna predstavlja izjavu, a druga repliku i koje je u tom smislu moguće označiti kao lirski dvogovor ili razgovor. I dok se dijalog Ban Sigetu i Siget banu sadržajno svodi na neobično emotivan oproštaj sigetskog kapetana i personificirana grada, dotle se pjesme Ban sinu i Sin banu stapaju u dirljiv obiteljski razgovor Zrinskoga i sina mu Jurja, koji svoje motivsko porijeklo vuče glavninom iz ranijih „zrinijada“, poglavito iz Petrove Obside sigecke, u kojoj biva on razrađen $\mathrm{u}$ narativno najrazvodnjenijem petom pjevanju epa. Odlučivši se, ukratko, među ostalim rastancima u svojoj „zrinijadi“ obraditi i one Zrinskog i Sigeta te Zrinskog i sina, Vitezović njihovu komunikaciju - ponajprije zahvaljujući fizičkoj blizini sugovornika - generički nije mogao ostvariti drugačije nego posredstvom lirskoga dvogovora, zacijelo pritom imajući na umu da praksa pisanja parnih pjesama - „sastavljenih“ od pjesme-izjave i pjesme-replike nije bila strana ni pojedinim našim baroknim autorima, iako su u njihovu slučaju te i takve uparene pjesme redovito tematizirale pisani ili usmeni razgovor dvoje zaljubljenika. ${ }^{575} \mathrm{Naš}$ autor je, međutim, s pravom pretpostavio da bi žanru (baroknoga) lirskog dvogovora morala pristajati i tema oproštaja požrtvovnoga branitelja i opkoljenoga personificiranog branjenika, tim više što njihov odnos također počiva na vrlo snažnim osjećajima (domoljublja, bogoljublja i odanosti vrhovnom vladaru), kao i - još više - rastanak bana Zrinskog i sina Jurja, čija uzajamna ljubav i poštivanje proizlaze iz samih obiteljskih spona kojima su njih dvojica gotovo neraskidivo povezani. Forma dotad mahom korištena za opjevavanje muškoženskih ljubavnih dilema tako se ispostavila i više nego prikladnom i za tematiziranje emotivna vojskovođina opraštanja od „oživljena“ branjenog grada i člana vlastite mu obitelji, što će reći da ove parne pjesme u potpunosti dospijevaju generički funkcionirati kao (,punokrvni“) lirski razgovori, a ne kao dijaloške pjesme, kojima - izuzev stihovne „uobličenosti““ - ne nalikuju ni po kojemu svom drugom formalnom svojstvu.

\footnotetext{
${ }^{575}$ Iako je u njegovu slučaju zapravo riječ o izmjeni pisama (poslanica), parne pjesme - naslovljene Knjiga i Odgovor, u kojima odsutni ljubavnik voljenoj ženi priznaje svoja ljubavna osjećanja, a ona ga u odgovoru potom doziva k sebi - tako zatječemo i u pjesničkom opusu Ivana Bunića Vučića, dok će u svoju zbirku Gartlic za čas kratiti Fran Krsto Frankopan uvrstiti čak dva para takvih lirskih razgovora: pjesme Babajko od divojke ljubav prosi i Divojka rad ljubavi špota babajka, u kojima mlada djevojka odbija starčevu ljubavnu molbu, te Je al ne i Odgovor na je al ne, u kojima Fili izbjegava dati nedvosmislen odgovor na zaljubljenikove ljubavne dvojbe.
} 
Da je, s druge strane, u pjesmama Gospodična Sofija i oral te Putnik i Jeka posrijedi doista dijalog između dvoje (komunikacijski posve ravnopravnih) sugovornika dade se naslutiti već iz njihovih naslova, u kojima se - za razliku od onih što naslovljuju spomenute parne pjesme - oba navedena subjekta ili govornika u komunikacijskom smislu sasvim izjednačuju, odnosno veznikom „i“ povezuju kao sugovorničke instance teksta (gospodična Sofija I oral; putnik I Jeka), a ne kao sudionici komunikacije sa suprotnih strana komunikacijskoga lanca, od kojih jedan svoj iskaz (pjesmu) adresira na onoga drugog (primjerice, ban sinu, Siget banu itd.). Ti su sugovornici pritom najvećim dijelom zaokupljeni tijekom opsade Sigeta i pothvatima (pojedinih) sudionika bitke, pa dok se tako u pjesmi Gospodična Sofija i oral - koja formom podsjeća na onu druge nadgrobnice Sulejmanu zapravo „konkretiziraju neki detalji kao neposredne posljedice tragedije“, dotle „sličnu funkciju ima i dijalog između putnika i Jeke, kojim se na poseban lirski način rekapituliraju neke pojedinosti iz boja“ (Kolumbić 2005: 339). U sadržajnom se pogledu, dakle, iz ovih dviju pjesama doznaju neki (narativno bitni) novi detalji o događajima i akterima o kojima se već pisalo u prvom i većem dijelu drugoga „dila“, dok u generičkom pogledu u Vitezovićevu žanrovski šaroliku ,zrinijadu“ one unose niz - pretežno formalnih - obilježja iz repertoara dijaloške pjesme - još jednog od lirskopjesničkih žanrova za kojega je u sustavu barokne književnosti kako diljem Europe, tako i u nas bilo osigurano posebno mjesto.

Baci li se samo letimičan pogled na ova dva ponešto opsežnija ${ }^{576}$ dijaloški izvedena pjesnička teksta, postat će bjelodano da se - iako formom različiti - uvelike oni približavaju žanrovima dramske književnosti, odnosno da Odiljenje sigetsko, u generičkom smislu, obogaćuju vrlo izrazitom primjesom - staigerovski rečeno - „dramskoga“. S obzirom na to da se radi o lirskim pjesmama u kojima kazivači (,likovi“) izmjenjuju replike bez posredovanja „krovnog“ ili nadređenoga lirskog subjekta (koji bi u tom slučaju funkcionirao kao svojevrsni „lirski pripovjedač“) - dakle, pjesničkim tekstovima u cijelosti sazdanima od replika dvojice ravnopravnih govornika - nesumnjivo je da u njihovu slučaju ,imamo posla“ s primjercima lirskopjesničkoga žanra što ga je u jednoj od svojih studija Tomislav Bogdan prozvao „lirikom dijaloga“, pripominjući kako su pjesme koje pripadaju tomu generičkom „razredu“ zapravo ,intergenerička (...) pojava, one sjedinjuju dramske elemente, poput djaloške strukturiranosti, s tipičnim lirskim svojstvima“" (Bogdan 2012: 28), od kojih bi se kao najizrazitija, točnije lirici najsvojstvenija mogla - dakako - izdvojiti upravo kratkoća. Njihova dijaloška struktura, nastavlja Bogdan, pritom nikada ne uključuje za dramske žanrove

\footnotetext{
${ }^{576}$ Gospodična Sofija i oral, konkretno, proteže se na sveukupno 172 stiha, dok Putnik i Jeka - koja zauzima čitav treći „dil“ Odiljenja - broji točno 376 stihova.
} 
neizostavan aspekt izvođačkoga, što pokazuje da one nisu bile namijenjene izvedbi, na što uostalom - upućuju i renesansni kanconijeri, u kojima su dijaloške pjesme redovito bile smještane među lirske pjesme te tako jasno unaprijed određivane kao lirskopjesnička, a ne dramska ostvarenja. ${ }^{577} \mathrm{U}$ ranonovovjekovnom, ali i još starijemu lirskom pjesništvu dijalog se mahom upošljavao u svrhu izražavanja nejednakih, pokatkad i vidno oprečnih raspoloženja i osjećaja, a budući da su se - k tome - njime počesto isticala i oštra suprotstavljanja $u$ stajalištima i pogledima, dijaloška je lirika još od svojih začetaka dopuštala znatno veći raspon perspektiva, ideja i emocija od one monološke, nerijetko rezultirajući i „pravim“ dramskim sukobom, na kakvom su počivale već i mnoge srednjovjekovne dijaloške pjesme, iz čijih su alegorijskih pregovaranja o religioznim pitanjima (primjerice, prepirke duše i tijela) proizišli i kasniji lirski dijalozi ljubavnika nabijeni izuzetno snažnim emocijama.

I u nas žanr dijaloške lirske pjesme, dakako, vuče svoje porijeklo upravo iz srednjovjekovne književnosti, iz koje nam se dospjela sačuvati tek nekolicina pjesama s dvama lirskim subjektima što izmjenjuju replike (tj. pitanja i odgovore) na temu Kristova rođenja ili muke i uskrsnuća, a koje su ne samo protkane izrazitim narativnim i usmenoknjiževnim ${ }^{578}$ momentima, već jasno upućuju i na svoj scenski aspekt, odnosno aludiraju na to da je uz njih bila vezana i vizualno-scenska, predstavljačka komponenta. ${ }^{579} \mathrm{Te}$ se dijaloške laude - među kojima naročito vrijedi izdvojiti Prigovaranje blažene dive Marije $i$ križa Isusovoga, Isusova mučila te Govorenje Judino škalam na obišenje hodeći - u našem srednjovjekovlju, zahvaljujući djelovanju flagelantskih bratovština, pojavljuju u 13. i 14 . stoljeću pod izravnim utjecajem talijanskoga pjesništva, a zatim se vrlo brzo - već u narednom stoljeću - postupno transformiraju u religioznu dramu, odnosno pretapaju u žanr crkvenoga prikazanja. U razdoblju kasnoga srednjeg vijeka, naime, dijaloške pjesme ili laude polagano su poprimale sve izrazitiju scensku vizuru, a to dramsko strukturiranje najjasnije je došlo do izražaja u Marijinim plačevima ili tužbalicama nad raspetim Isusom, koje predstavljaju posljednji korak prije prelaska na potpunu dramatizaciju Kristove muke. ${ }^{580}$ Dakako, sam žanr dijaloške (lirske) pjesme kao takav iznova je oživljen u književnosti ranoga novog vijeka, a vrijedi spomenuti i da će srednjovjekovna lirska dijaloška forma pitanja i

\footnotetext{
577 Detaljnije u: Bogdan 2012: 28.

${ }^{578}$ Usp. Bošković-Stulli 1978: 75-78.

579 Osim izravnog navođenja pojedinih scenskih rekvizita u nekima od tih dijaloških pjesama ili lauda, na predstavljačku njihovu komponentu upućuju i neki konkretni sačuvani rekviziti koji su nesumnjivo korišteni u njihovim (vjerojatnim) izvedbama (usp. Hercigonja 1975: 422-424).

${ }^{580}$ Podrobnije u: Hercigonja 1975: 422-424 i Batušić 1978: 6-17.
} 
odgovora kasnije biti evocirana i u okvirima pučke književnosti, kao što to pokazuje i primjer čuvenoga Grabovčeva zbornika Cvit razgovora naroda i jezika iliričkoga aliti rvackoga. ${ }^{581}$

U korpusu (europske) srednjovjekovne književnosti u žanru dijaloške pjesme - osim lirskih prepirki duše s tijelom - realizirane su i mnogobrojne romance, balade, alegorije (primjerice, Roman o ruži), kao i glasoviti Villonovi dijalozi srca i tijela, a generičko širenje toga dijaloškog pjesničkog oblika nastavit će se i u renesansi, kada će posebnu popularnost steći žanr filozofskoga dijaloga u stihu. Tijekom 16. i 17. stoljeća diljem Europe sustavno će se ispisivati i „obične“ dijaloške lirske pjesme, od kojih kao najuspjelije svakako valja istaknuti one engleske pjesnikinje Margaret Cavendish, potom Shakespeareove pjesme u formi pitanja i odgovora, kao i znamenitu dijalošku pjesmu engleskoga metafizičkog pjesnika Andrewa Marvella Dijalog između duše i tijela. Gdjekoja dijaloška lirska pjesma zateći će se i u gotovo svakome ljubavnom kanconijeru naših šesnaestostoljetnih pjesnika, a liriku dijaloga kakvu, primjerice, nalazimo u Ranjininu zborniku te pjesničkom opusu Horacija Mažibradića u stopu će pratiti i barokne dijaloške pjesme, koje dobar dio onodobnih pjesnika - kako se čini - ipak nije pisao izravno se nastavljajući na (isključivo) renesansne domaće prethodnike.

$\mathrm{Na}$ sedamnaestostoljetnu sveprisutnost dijaloške lirske pjesme dobar se dio barokologa, dakako, nije mogao oglušiti, pa će tako i Frank Warnke - označivši je kao „dramsku liriku“ - u svojoj studiji napomenuti kako uvjerljivo najveći broj njezinih onodobnih primjeraka otpada na religiozne pjesme, u kojima zaokupljenost božanskim nije bila izražena pomoću ,jednostavne pobožne fraze niti kroz formalno opominjanje, već kroz odigravanje napete dramske situacije, sukoba u kojem sudionici mogu biti Bog i duša, duša i neka personificirana apstrakcija, suprotstavljeni aspekti duše ili neki drugi likovi projicirani iz unutrašnjega iskustva“ (Warnke 1972: 93-94). Sastavljanja nabožnih, ali i tematski posve drugačijih - pretežno ljubavnih - dijaloških pjesama povremeno su se laćali mnogi barokni autori, od kojih posebno valja izdvojiti one iz geografski nam bliskih književnih kultura poput austrijskoga nadvojvode i pjesnika Leopolda Wilhelma Crescentea, koji primjerke „lirike dijaloga“ uvrštava u svoju pjesničku zbirku Diporti (Uživanja) iz 1656., te nekih onodobnih furlanskih talijanskih pjesnika, među kojima se tematsko-motivskom, stilskom i žanrovskom raznolikošću ponajviše isticala lirika Ermesa di Colloreda. Crescente i Colloredo, uzgred budi rečeno, bili su članovi bečkih talijanskih akademija, odnosno učenih društava - mahom osnivanih u drugoj polovini 17. stoljeća - koja su okupljala pjesnike i uopće intelektualce vrlo različitoga spektra u cilju poticanja rasprava o važnim filozofskim i literarnim temama. Znamo li da su u radu tih akademija - pored (osobito) vojskovođa i teologa - sudjelovali

${ }^{581}$ O tome usp. Zečević 1978: 414. 
pjesnici-plemići iz austrijske i susjednih nacionalnih književnosti (između ostalih, čak i one hrvatske), neće nam biti teško zaključiti da je dijaloška lirika posebno bila cijenjena i njegovana upravo u tadašnjim aristokratskim krugovima, unutar kojih je - kao jedan od Žanrova dvorskog pjesništva - shvaćana kao estetsko zadovoljstvo i intelektualna zabava.

Imamo li to na umu, ni najmanje nas ne bi smjela iznenaditi pojava dijaloških pjesama i u kanconijeru Gartlic za čas kratiti Frana Krste Frankopana, također člana jedne od mnogobrojnih bečkih akademija te dokazanog štovatelja pjesničkih opusa Leopolda Wilhelma Crescentea i Ermesa di Colloreda. ${ }^{582}$ Za neke od sveukupno osam Frankopanovih dijaloških pjesničkih tekstova - u kojima replike izmjenjuju većinom mitološki junaci ${ }^{583}$ - relativno je nedavno utvrđeno da su ne samo ispjevani pod snažnim tematsko-motivskim utjecajem dijaloških pjesama iz Crescenteova i/ili Colloredova opusa, već i da se među njima nalaze čak i vrlo slobodni prepjevi nekih njihovih lirskih ostvarenja, ${ }^{584}$ što ukazuje na očiglednu povezanost Frankopanove odluke da posegne za žanrom dijaloške pjesme s njegovim aktivnim angažmanom $u$ jednoj od tadašnjih akademija, a onda i s iskustvom recipiranja generički bliskih ostvarenja, posebno obljubljenih upravo među članovima tih „akademskih“ krugova. Znatno je teže, s druge strane, možebitne iste utjecaje dokazati u lirici Frankopanove sestre Ane Katarine Zrinski, okupljenoj u generički vrlo raznolikoj rukopisnoj pjesmarici, u kojoj su se našle i jedna „svjetovna“ (pjesma 38. - Skoro mi to žarkost sunčena bijaše) te jedna religiozna dijaloška pjesma - Popivka vu kojoj se stvoritelj s dušom razgovara. Iako, za razliku prve pjesme, u potonjem slučaju nije riječ o Katarininu, već o pjesničkom tekstu što ga je u pjesmaricu 1698. dopisao jedan od njezinih kasnijih vlasnika Franjo Delišimunović, ${ }^{585}$ i samu je Popivku ipak moguće izdvojiti kao jedan u nizu uvjerljivih dokaza barokne omiljenosti lirskopjesničkoga žanra dijaloške pjesme, koja je u razdoblju kojemu je svojim „likom i djelom“ pripadao i Pavao Ritter Vitezović podjednako bila otvorena i za religiozne i za svjetovne sadržaje.

U sjevernohrvatskom baroku još je jedan slučaj dijaloške obrade religioznih sadržaja zabilježen i u anonimnoj kajkavskoj pjesmi Nočno viđenje svetoga Bernarda - često

\footnotetext{
582 Konkretnim tragovima ugledanja na liriku Leopolda Wilhelma Crescentea i pojedinih furlanskih sedamnaestostoljetnih pjesnika u Frankopanovu Gartlicu nedavno se u svojoj izvrsnoj studiji pozabavila Saša Potočnjak. Detaljnije u: Potočnjak 2015: 119-134.

${ }^{583}$ U nizu Frankopanovih mitoloških dijaloških pjesama - Spogajnanje prošastnoga vrimena, Aurora i Klituš, Jantea i Ožirio i dr. - izuzetak je Razgovor med mužem i ženom, u kojoj replike izmjenjuju bračni partneri.

${ }^{584} \mathrm{Za}$ dijalošku pjesmu Razgovor med mužem $i$ ženom tako je, primjerice, utvrđeno da je nastala pod vrlo izrazitim utjecajem nekih Colloredovih dijaloških sastavaka na temu muško-ženskih odnosa, dok je pjesma Spogajnanje prošastnoga vrimena prepoznata kao slobodni prepjev Crescenteove dijaloške kanconete Fileno Clori. O ovome podrobnije u: Potočnjak 2015: 123-130.

585 Opširnije o pjesmarici Katarine Zrinski i njezinim kasnijim vlasnicima u: Bratulić 2014: 277-319, Dukić i Lukec 2017: 273-294.
} 
pripisivanoj Matijašu Magdaleniću - koja „oživljuje“ omiljeni srednjovjekovni motiv prepirke duše s tijelom, opjevan u nizu predrenesansnih pjesničkih ostvarenja. Ovaj - kako ga opisuje Slobodan Prosperov Novak - „dramatizirani memento mori“ (Prosperov Novak 1999: 508) nije samo jedna od mnogih literarnih potvrda evolucijske zaostalosti sjevernohrvatske ranonovovjekovne književnosti, već ujedno i uvjerljiv dokaz iznimne barokne raširenosti dijaloške lirike s jakom „dramskom“ crtom, koja naročito u svojoj nabožnoj varijanti čitatelja nipošto nije tražila isključivo među učenijom, većinom aristokratskom publikom. Dapače, čini se da su pažnju različitih tipova čitatelja željele privući i ne tako brojne „sekularne“ dijaloške pjesme južnohrvatskih sedamnaestostoljetnih autora, naročito dijaloške pastorale Ivana Bunića Vučića iz zbirke Plandovanja te one iz ciklusa Pjesni razlike Ignjata Đurđevića, u kojima zaljubljeni pastiri izmjenjuju svoje misli o ljubavi s vilama u pastoralnom ambijentu.

Upravo u skladu s već primijećenom učestalošću teme ljubavi u (baroknoj) „lirici dijaloga“, amoroznim će motivima u dvjema dijaloškim pjesmama u Odiljenju sigetskom i Pavao Ritter Vitezović (neočekivano) prepustiti prilično mnogo prostora. Osim što će se tako najveći dio pjesme Gospodična Sofija i oral svesti na Sofijino neutješno oplakivanje pogibije voljenoga zaručnika Gašpara Alapića pod sigetskim zidinama, lirski subjekti u Putniku i Jeki svoj će „izvještaj“ o propasti Sigeta povremeno prekidati ne bi li se upustili u usputna razmatranja o ljubavi i njezinoj pogubnosti, ali i zajednički ispripovijedili dobro poznatu mitološku priču o Narcisovoj (Lužnjevoj) beznadnoj zaljubljenosti u vilu Jeku. Premda se Milivoju Šrepelu zbog obilne premreženosti ljubavnim motivima učinilo da Putnik $i$ Jeka u jednom trenutku ,prelazi u ton idile“, zaključiti kako je Ritter ,,po ukusu svoga vremena i u samu epsku gragju umio utisnuti idilu“ (Šrepel 1902: 115) bilo bi ipak suviše ishitreno, ponajprije stoga što - u generičkom pogledu - niti jedna dionica Odiljenja ne uključuje karakteristična obilježja iz repertoara (barokne) idile. Naime, kao žanr antičke provenijencije, koji je u ranonovovjekovlju podrazumijevao većinom pastirsku poeziju, idila se svodila na (mahom kraća) stihovana djela u kojima se glorificira idiličan život pastira i seljaka $\mathrm{u}$ prirodnom ambijentu (locus amoenus) te opisuju njihovi ljubavni i prijateljski odnosi, a sve to najčešće u kontrastu spram nepovoljne aktualne društveno-političke stvarnosti. Bez obzira na to što bi amorozni „umetci“ u trećem „dilu“ po svojoj zaokupljenosti pitanjem ljubavi i evociranju priče o Narcisovoj zaljubljenosti na momente doista mogli podsjetiti na neke primjerke idile, već sama činjenica da tema ljubavi u sedamnaestostoljetnoj književnosti nije bila vezana uz isključivo žanr idile, kao i prilično očit izostanak tipično ,idiličnih“ likova (seljaci, pastiri), ambijenata i uopće ideje proslavljanja harmonije između čovjeka i prirode, i više su nego uvjerljiva potvrda deficita ključnih značajki ovoga žanra u Odiljenju sigetskom. 
S druge strane, zbog izrazito tugaljive atmosfere, odnosno motiva oplakivanja zaručnikove smrti, pojedini se književni povjesnici pjesmu Gospodična Sofija i oral nisu libili identificirati kao „dijalogiziranu elegiju“ (Georgijević 1969: 133), imajući pritom na umu generičko shvaćanje elegije kojem je u doba baroka još uvijek ozbiljno konkuriralo ono izvorno, antičko. ${ }^{586}$ Iako se, naime, već od 16. stoljeća elegiji počelo pristupati (i) kao žalosnoj pjesmi bez jasno propisane forme (tj. bez nekoga karakterističnog metričkog kalupa u kojemu nužno mora biti realizirana), znatan broj sedamnaestostoljetnih praktikanata ovoga žanra još uvijek se pridržavao klasične definicije elegije kao lirske pjesme ispjevane isključivo elegijskim distihom, no ujedno otvorene različitim - povijesnim, mitološkim, filozofsko-religijskim, ljubavnim itd. - temama. Tomu je ponajprije bilo tako zbog same onodobne prakse pisanja elegija, koja se većinom odvijala na latinskom jeziku i paralelno s kojom se tek vrlo mali broj autora upuštao u sastavljanje tugaljivih pjesama na vernakularu koje su bile u stanju isprovocirati ,ispravnu“ generičku predodžbu i kojima - slijedom toga žanrovski identitet elegije ni danas ne treba dovoditi u pitanje. Osim što, konkretno, nepostojanje drugih žanrovski podudarnih primjeraka „dijalogizirane elegije“ na hrvatskom jeziku iz (is)toga ili njemu bliskog vremenskog razdoblja već samo po sebi baca sjenu sumnje na Georgijevićevo generičko određenje Gospodične Sofije i orla!, tu i takvu žanrovsku predodžbu ove pjesme najsnažnije će ipak potkopati pažljiv uvid u njezinu tekstualnu „fakturu“, iz kojeg postaje i više nego očito da Vitezović pri sastavljanju ove pjesme žanr elegije najvjerojatnije nije imao ni u primisli.

Iza naoko „elegijske“ atmosfere koju razvija ovaj lirski dijalog gospođice Sofije i personificirana orla ne stoji, naime, niti jedno iole karakterističnije obilježje žanra (barokne) elegije, već je njegova usredotočenost na motiv ženina oplakivanja smrti ljubljena zaručnika i zapomaganja nad vlastitom nesretnom sudbinom u potpunosti „tek“ produkt uvažavanja generičkih posebnosti usmenoknjiževne naricaljke, kojima ćemo se detaljnije pozabaviti u nastavku našega istraživanja. Toliko izrazito inzistiranje na značajkama jednoga folklornoknjiževnog žanra upravo u lirskoj pjesmi izvedenoj u dijaloškom obliku nije - kako se čini - bilo slučajno, nego je proizišlo iz Vitezovićeve želje da se približi i publici zadojenoj na usmenoj književnosti, u okvirima koje su vrlo česte bile upravo (lirske) pjesme zasnovane na dijalogu. Ritter je, drugim riječima, vjerovao da će njegova „lirika dijaloga“ premrežena prepoznatljivim folklornoknjiževnim elementima lakoćom privući (i zadržati) pažnju (i) recipijenata koji su prvi dodir s književnošću ostvarili upravo posredstvom „narodnoga“

\footnotetext{
${ }^{586}$ Na kraju krajeva, sam će Vitezović u svome rječniku Lexicon Latino-Illyricum generičku odrednicu „elegia“ prevesti kao „žalosna pjesma“ (usp. Ritter Vitezović 2010).
} 
stvaralaštva, u sklopu kojega su - između ostalog - imali prilike susresti i kraće lirske pjesme realizirane na vrlo sličan način kao i Gospodična Sofija i oral, no s tom razlikom što u njima između replika dvoje govornika („likova“) redovito posreduje „okvirni“ lirski subjekt. Osim „dijalogiziranih“ lirskih pjesama - u kojima se izmjena replika odvija preko subjektaposrednika - na (posredovanom) dijalogu temeljili su se i pojedini primjerci drugih folklornih književnih žanrova poput bugaršćice, od kojih je jedna od naših najpoznatijih - Majka Margarita iz Barakovićeve Vile Slovinke - izvedena upravo kao posredno donesen razgovor između majke Margarite i vile. S obzirom na tu ne tako rijetku dijalogičnost lirskih i ne samo lirskih usmenih pjesama, Vitezović je s punim pravom mogao očekivati da će i njegove dijaloške pjesme - ali i Odiljenje u cijelosti - prihvatiti i čitatelji s nešto slabijim književnim iskustvom, odnosno oni koji su umjesto praćenja aktualnih zbivanja na domaćoj i naročito inozemnoj (pisano)književnoj „sceni“ još uvijek radije osluškivali pjesme „narodnih“ pjevača.

I dok se tek malokoji dosadašnji povjesničar hrvatske književnosti pjesmi Gospodična Sofija $i$ oral odvažio ,priznati“ generički identitet dijaloške pjesme, ${ }^{587}$ posvemašnje ustručavanje od identičnoga žanrovskog etiketiranja teksta Putnik i Jeka ne bi ipak bilo posve opravdano proglasiti posljedicom manjka stručne hrabrosti, ponajprije stoga što se u okvire „lirike dijaloga“ uistinu on može svesti samo djelomično i samo iz teorijske genološke perspektive. Iako je, konkretno, dijaloška uobličenost pjesme Putnik i Jeka već na prvi pogled i više nego bjelodana, generička odrednica „dijaloška pjesma“ ima vrlo malo veze s njezinim stvarnim, (književno)povijesnim žanrovskim identitetom, koji u najvećoj mjeri proizlazi iz činjenice da je riječ o lirskom tekstu baziranom na figuri jeke i u tom pogledu generički srodnom mnogim sedamnaestostoljetnim pjesničkim ostvarenjima na latinskom jeziku što su pripadala žanru tada znanom kao tzv. versus echoici ${ }^{588}$ odnosno eho-pjesma ili pjesma-jeka. Takvo jasno žanrovsko podudaranje pojedinih vernakularnih i latinskih tekstova u baroknoj književnosti nipošto nije predstavljalo rijedak, a kamoli izdvojen slučaj, pa baš kao što su u mnoga onodobna hrvatska djela ugrađivani različiti (generički prepoznatljivi) stilski i retorički postupci porijeklom iz latinske književnosti, tako je i obogaćivanje pjesme Putnik $i$ Jeka formalnom dosjetkom zasnovanom na ponavljanju završnog dvosloga svakoga prvog stiha na kraju svakoga drugog ništa drugo nego jedan od nekolicine onodobnih pokušaja da se u lirskom tekstu na vernakularu postignu učinci identični onima iz latinskih versus echoici. ${ }^{589}$

\footnotetext{
${ }^{587}$ Kao „dijalošku pjesmu“ (dialogischen Gedicht) Gospodičnu Sofiju i orla! izrijekom je dosad označio tek Zoran Kravar (usp. Kravar 1991: 239).

588 Usp. Stepanić 2005: 209-214 i Moretti 2014: 55.

${ }^{589}$ Detaljnije o tome u: Novaković 2003: 560 i Stepanić 2005: 211.
} 
U pisanju lirskopjesničkoga žanra kojemu bi, dakle, pripadao i tekst Putnik i Jeka - u kojemu se na kraju svakoga parnog stiha ponavljaju završna dva sloga pitanja što ga je u prethodnom (neparnom) stihu postavio putnik ne bi li se simulirao odgovor vile Jeke - ni Pavao Ritter Vitezović, zahvaljujući ranijim svojim literarnim pokušajima na latinskom, nipošto nije bio apsolutni početnik. Naprotiv, kao svojevrsnu latinističku generičku „predigru“ njegove pjesme-jeke iz trećega „dila“ Odiljenja moguće je izdvojiti čak dva primjerka versus echoici što ih je ispjevao u godinama neposredno uoči objelodanjivanja hrvatske „zrinijade“, a koja se čuvaju u već dobro nam poznatu zborniku rukopisnih i tiskanih Ritterovih mladenačkih ostvarenja Otia metrica manuscripta et impressa. Tako, ponajprije, iz razdoblja između 1682. i 1684. datira segment Vitezovićeve (rukopisne) nedovršene heksametarske pjesme De morte (O smrti), u kojoj „svaki sljedeći stih započinje zadnjim dvama slogovima posljednje riječi prethodnog stiha“ (Stepanić 2016: 344), pri čemu bi - osim u identičnom formalnom rješenju - njezine paralele s Putnikom i Jekom valjalo tražiti i na sadržajnom planu, odnosno u činjenici da je figuru jeke nekoliko godina prije objavljivanja Odiljenja naš autor već bio iskušao u tematski bliskoj pjesmi koja opjevava neizbježnost i sveprisutnost smrti. ${ }^{590}$ Osim nje, Vitezović će 1682. sastaviti i tiskom izdati i latinsku prigodnu lirsku pjesmu u čast habsburškoga prijestolonasljednika - princa Josipa - pod naslovom Sacer chorus, također „obogaćenu“ figurom jeke, koja, međutim, ondje nije smještena samo na kraju, već i u sredini stiha, pa dvosložnica koja se pojavljuje na kraju svakoga njezina stihovnog retka nije ništa drugo nego jeka riječi koja u tom istom retku dolazi prije cezure, što će reći da se rimuju sredina i kraj stiha tvoreći tako leoninsku rimu. ${ }^{591}$

$\mathrm{Na}$ poprilično brz prelazak s prakse pisanja latinskih versus echoici na ništa manje uspješno sastavljanje eho-pjesama na hrvatskom jeziku Vitezovića je nedvojbeno morala potaknuti (i) spoznaja kako je u ranonovovjekovnom europskom, pa i hrvatskom pjesništvu ovaj lirskopjesnički žanr već poodavno izašao izvan uskih okvira (neo)latinske književne produkcije. Štoviše, upravo će zahvaljujući sedamnaestostoljetnim pjesnicima i doći do nagloga bujanja zamišljenog korpusa vernakularnih eho-pjesama, koje su se u barokno doba često tako sastavljale ne samo u engleskoj, ${ }^{592}$ njemačkoj, talijanskoj i francuskoj književnosti, nego i u većini onodobnih slavenskih nacionalnih literatura, ${ }^{593}$ pa onda - između ostalih - i u onoj hrvatskoj. Iako su suvremeni književni povjesnici - polazeći vjerojatno od njezine

\footnotetext{
${ }^{590} \mathrm{Na}$ ovu intrigantnu temu pjesme De morte posebno se osvrnula i Gorana Stepanić (usp. Stepanić 2005: 211).

${ }^{591}$ O ovoj Ritterovoj versus echoici podrobnije u: Stepanić 2005: 212-213.

592 Kao posebno dojmljiv primjer versus echoici valjalo bi izdvojiti pjesmu Heaven (Nebo) engleskoga metafizičkog pjesnika Georgea Herberta.

${ }^{593}$ Niz eho-pjesama na vernakularu ispjevao je tako - između ostalih - i čuveni bjeloruski barokni pjesnik Simeon Polocki. O tome posebno u: Angyal 1961: 51-54.
} 
antičke predodžbe - versus echoici ili jeku najskloniji shvaćati kao „tek“ motiv, retorički rekvizit ${ }^{594}$ formalni eksperiment ${ }^{595}$ ili ,golu“ figuru koja se zgodimice pojavljivala već u latinskih klasika, uvid u nekolicinu baroknih poetičkih tekstova jasno će nam dati do znanja kako je pjesmi s „motivom“ jeke u 17. stoljeću ipak bilo osigurano mjesto uz bok drugim tada preferiranim žanrovima lirskoga pjesništva. Nabrajajući, konkretno, sedamnaestostoljetne žanrove novolatinske književnosti za koje je bio uvjeren da ih je moguće „primijeniti“ i u stvaralaštvu na narodnom (njemačkom) jeziku, Martin Opitz u svojoj već spomenutoj Knjizi njemačke poetike tako navodi i žanr ,echo“ ${ }^{596}$ odnosno pjesme-jeke ili versus echoici, ničime ga pritom ne izdvajajući u odnosu na ostala pobrojana generička rješenja - epsku pjesmu, eklogu, satiru, tragediju, lirsku pjesmu i dr. Četrdesetak godina kasnije u svojoj (također već spomenutoj) monumentalnoj studiji o njemačkom jeziku i književnosti Ausführliche Arbeit Von der Teutschen HaubtSprache isto će zatim postupiti i Justus Georg Schottel, uvrštavajući u niz baroku svojstvenih žanrova - elegiji, epskoj pjesmi, sonetu, epigramu, zagonetki itd. također i „echo“, dakle iznova eho-pjesmu, ${ }^{597}$ čime uvjerljivo potvrđuje da je - u očima poetičara, a onda nedvojbeno i u onima samih onodobnih literarnih ,praktičara“ - versus echoici kotirao kao „punokrvni“ književni žanr, odnosno kao nešto daleko više od pukoga formalnog eksperimenta, motiva i figure, kakvim ga se teži(lo) prikazati u novije vrijeme.

Zasigurno najpresudniju ulogu u Vitezovićevoj odluci da se u Odiljenju sigetskom okuša u sastavljanju versus echoici na vernakularu morala je odigrati upravo činjenica kako su prije njega to učinili brojni njegovi literarni prethodnici i izravni mu uzori, među kojima je ipak bio i znatan broj onih koji su se umjesto pisanja eho-pjesama zadovoljavali tek uvrštavanjem motiva ${ }^{598}$ ili figure jeke u drugačije generički realizirana (mahom opsežnija) svoja stihovana ostvarenja. Među potonjima ipak nije bio i Ritterov daleko najveći literarni (pa onda i žanrovski) uzor Petar Zrinski, ${ }^{599}$ koji - u slijedu bratova mađarskog predloška - u Adrijanskoga mora Sireni završnom ciklusu lirskih pjesama priključuje i jedan tipičan (temom ljubavni) versus echoici, zasnovan na ponavljanju posljednjih dvaju slogova svih

\footnotetext{
594 Usp. Šundalić 2005: 34-61, Šundalić i Mateljak Popić 2018: 21-63.

595 Usp. Stepanić 2005: 209-214.

596 Opširnije u: Hess 2007: 395-396 i 412-417.

${ }^{597}$ Usp. Hess 2007: 418-419.

${ }^{598}$ Motiv jeke (Eha) bio je osobito čest u pjesničkim ostvarenjima autora ozaljskoga baroknog književnog kruga, pa ga tako - primjerice - nalazimo u nizu pjesama okupljenih u rukopisnoj pjesmarici Ane Katarine Zrinski, kao i u Frankopanovu Gartlicu (posebno u pjesmi Eha odgovor).

${ }^{599}$ Doduše, na jednome mjestu i u samoj Obsidi sigeckoj - u 21. strofi njezina 15. pjevanja - zatječemo ipak i motiv Eha (jeke), koji „odgovara iz vrha rajskoga: / Svet svet svet, odzgora višnji Bog od Boga, / puna su cesara nebo, zemlja toga“ (XV: 21). Riječ je, konkretno, o motivu nebeske jeke, odnosno nebeskom odjeku molitava i pjesama u Božju čast i slavu, koje se neprekidno uzdižu sa zemlje.
} 
četiriju stihova prvih sedam katrena pjesme, ${ }^{600}$ koji se po svojoj (ne)uspjelosti, doduše, teško može mjeriti s Putnikom i Jekom. Govoreći s „„čisto“ generičkoga aspekta, neće stoga biti nimalo slučajno što Mihovila Kombola „Vitezovićev razgovor između putnika i jeke podsjeća na sličan oblik u »Adrijanskoga mora Sireni«, uostalom do dosade raširen u ono doba“ (Kombol 1961: 280), tim više što je - kao i za niz drugih žanrova o kojima je ovdje već bilo ili će tek biti riječi - naš autor ključni podstrek i za uključivanje eho-pjesme u svoju „zrinijadu“ očito dobio iz one Petra Zrinskog. S obzirom na to da se radilo o žanru u našoj književnosti raširenom „osobito u doba sečentizma“ (Matić 1968: 105), nipošto se - dakako ne može i ne smije otpisati ni možebitni generički utjecaj makar nekih tekstova iz bogatoga domaćeg korpusa baroknih eho-pjesama na Ritterova Putnika i Jeku, no ono što je ipak sa sigurnošću po tom pitanju moguće konstatirati jest to da niti jedno od tih ostvarenja našega autora nije moglo usmjeriti u pravcu vernakularnoga versus echoici kao što je to mogla upravo Petrova Sirena. Da je naš autor, međutim, osim Petrova slučaja, itekako dobro znao i za neke druge domaće sedamnaestostoljetne pokušaje „udomaćivanja“ ovoga žanra - počevši od onih u ljubavnoj lirici Bobaljevića i Bunića Vučića, preko onih u Gundulićevoj Prozerpini ugrabljenoj od Plutona, Palmotićevoj Atalanti i Gazarovićevu Muratu gusaru, pa sve do ehopjesama u Frankopanovu Gartlicu za čas kratiti ${ }^{601}$ i dionicama Skvadrovićeva Mačuša $i$ Čavalice - svakako ne bi trebalo biti sporno, kao ni to da je pjesmom-jekom iz svoga Odiljenja vrlo vjerojatno potaknuo i neke kasnije (osamnaestostoljetne) autore da se i sami okušaju u sastavljanju ovoga barokistima posebno dragog žanrovskog rješenja. ${ }^{602}$

Analizirajući nekolicinu ovih naših ranonovovjekovnih eho-pjesama, odnosno književnih ostvarenja s uklopljenim versus echoici ili dionicama prožetima figurom (motivom) jeke, Zlata Šundalić utvrdila je kako se u najvećem broju tekstova jeka zapravo pojavljuje u kontekstu vrlo ozbiljnih - svjetovnih ili nabožnih - sadržaja, obično povezanima s motivom smrti, pri čemu je njezina pojava redovito motivirana neznanjem, odnosno jeka kao takva - najčešće se nameće kao dobro upućen „lik“ koji odgovara na pitanja drugoga, slabije upućena lika, koji bi želio steći njezino znanje. Jeka se - nastavlja Šundalić - u

\footnotetext{
${ }^{600}$ Iako je u izdanju iz 1660. navedena pjesma tiskana bez naslova, Tomo Matić - priređivač Akademijina izdanja iz 1957. - nadjenut će joj ipak jednostavan naslov Eho. Usp. ovu pjesmu u: Zrinski 1957: 285-287.

${ }^{601}$ Naročito vrijedi obratiti pažnju na Frankopanovu pjesmu Eha sričan glas, u kojoj se na kraju svakoga stiha ponavljaju završna dva sloga (pret)posljednje riječi ne bi li se stvorio dojam jeke (usp. Frankopan 1999: 186).

${ }^{602}$ Pritom se ponajprije misli na Antuna Kanižlića, koji za obilježjima versus echoici (personificirana Echo) poseže u svojoj Svetoj Rožaliji, ali i na druge osamnaestostoljetne (epske i lirske) pjesnike (Jerolima Kavanjina, Matiju Petra Katančića, Vida Došena), iako se figura jeke naročito intrigantnom učinila i nekolicini onodobnih dramatičara poput Antuna Gleđevića (u Porođenju Gospodinovu) i Ivana Antuna Nenadića, koji je evocira u svome crkvenom prikazanju Prikazanje muke Jezusove, u kojemu napušta srednjovjekovnu tradiciju žanra te priziva mnogobrojne barokne elemente. Podrobnije o pojavi jeke (versus echoici) u hrvatskoj književnosti u: Matić 1968: 105, Prosperov Novak 1999: 703, Šundalić 2005: 40, Šundalić i Mateljak Popić 2018: 21-63.
} 
formalnom pogledu pritom realizira kao zrcalna struktura uglavnom bazirana na homofonskim ponavljanjima, odnosno proizlazi iz potpunih homofonskih ponavljanja, uslijed kojih se glasovi jedne riječi ponavljaju kao dio druge riječi ne bi li se stvorio dojam jeke koja podastire kratke i vrlo precizne odgovore na (znatno opširnija) pitanja što ih je postavio „živi“ sugovornik. Premda - po njezinu mišljenju - ovom opisu odgovara velika većina (domaćih) eho-pjesama i tekstova obogaćenih motivom jeke, Šundalić ipak upozorava i na ostvarenja koja od njega u određenoj mjeri ipak odudaraju poput, primjerice, drame Murat gusar Marina Gazarovića, u kojoj jeka - aktivirana u svrhu komične karakterizacije glavnoga junaka, a ne (kao obično) u kontekstu ozbiljnih tema poput smrti - uvelike propituje žanrovske konvencije versus echoici, ${ }^{603}$ slično kao i - u određenoj mjeri - pjesma Eho Petra (i Nikole) Zrinskog, u kojoj beznadno zaljubljeni lirski subjekt od Eha traži pomoć u rješavanju vlastitih ljubavnih nedoumica. Vitezovićeva pjesma Putnik i Jeka u tom bi smislu bila negdje na pola puta između „konvencionalne“ eho-pjesme i one sadržajno „neozbiljnije“, poglavito stoga što se njezini lirski subjekti svoj niz pitanja i odgovora o tijeku bitke pod Sigetom i njezinim (za kršćane) nepovoljnim posljedicama s vremena na vrijeme neće ustručavati prekinuti kako bi raspredali o pogubnosti ljubavi ili se zajednički prisjetili mitološke priče o zaljubljenosti Narcisa ${ }^{604} \mathrm{u}$ čemu valja vidjeti ništa drugo nego izravnu posljedicu generičkoga nadovezivanja na Petrovo djelo i njegovu ljubavnu versus echoici.

Vitezović je, kako se čini, uključivanjem dijaloških pjesama - točnije, dijaloške i eho pjesme - u tekstualno tkivo svoga Odiljenja sigetskog na neki način pokušao dodatno istaknuti svojevrsnu svakodnevnost ili „običnost“ čak i velikoga povijesnog događaja poput zauzeća Sigeta, odnosno sigetsku katastrofu uvjerljivije prikazati kao događaj koji je imao neposredne i dalekosežne posljedice ne samo u političkom smislu, već i na svakodnevicu kao takvu, a poglavito na živote „malih“ ljudi, pa čak i onih koji o njemu jedva da su i načuli išta. Usprkos činjenici što i u jednoj i u drugoj pjesmi ljudski lirski subjekti zapodijevaju razgovor s personificiranim životinjama ili pojavama, već sam njihov dijaloški oblik recipijenta neodoljivo podsjeća na ,živu“ komunikaciju zasnovanu na izmjeni replika, a taj formalni detalj ne samo što ih približava (izvanknjiževnoj) svakodnevici kao takvoj, već ih ujedno potvrđuje i kao „tipično“ barokna ostvarenja, tim više što - podsjetimo - „našu sedamnaestostoljetnu lirsku pjesmu (...) karakterizira uočljiva blizina živom, glasnom govoru, govornim radnjama kakve su zamislive i u izvanestetičkoj komunikaciji“ (Kravar 1993: 80),

\footnotetext{
${ }^{603}$ Detaljnije o žanrovskim konvencijama versus echoici i Gazarovićevu Muratu u: Šundalić 2005: 34-61.

${ }^{604}$ Nimalo, naime, neće čuditi pojava Ovidijeve mitske priče o mladiću Narcisu i nimfi Eho u okvirima jedne versus echoici, tim više što je riječ o motivu koji je u okvirima naše ranonovovjekovne književnosti najčešće i obrađivan upravo u eho-pjesmama (primjerice, u Mavra Vetranovića, Jerolima Kavanjina, Matije Petra Katančića i dr.). Usp. o tome u: Šundalić i Mateljak Popić 2018: 23-26.
} 
odnosno u komunikaciji kakva se ostvarivala i u svim krugovima i sferama društvenog života u onodobnoj Hrvatskoj, pa i šire. Našu baroknu liriku (osobito njezin dubrovačko-dalmatinski „odvjetak“), kao i veliku većinu pjesama okupljenih u četirima „dilovima“ Odiljenja, ponajviše će tako karakterizirati izrazita dijalogičnost, odnosno obraćanje adresatu (ili sugovorniku) u cilju uspostavljanja komunikacije i izražavanja vlastitih osjećaja, zbog čega ne čudi što su - u želji da naglase tu dijalošku intenciju - domaći barokisti, osim za dijaloškim i (nešto rjeđe) parnim pjesmama ili lirskim dvogovorima - najčešće posezali za izjavnim lirskim pjesmama, odnosno pjesmama u formi obraćanja. Uzore u sastavljanju takvih pjesničkih ostvarenja domaći pjesnici pritom nisu trebali tražiti samo u brojnim inozemnim tadašnjim autorima, naročito znamo li da su izjavne pjesme ili pjesme-replike bile ne tako rijetka pojava već u ranopetrarkističkom stvaralaštvu, u koje su, pak, dospjele još iz srednjovjekovne svjetovne (dakle, trubadurske) lirike, potvrdivši se tako kao neočekivano stara lirskopjesnička forma. Iako, drugim riječima, ovaj tip lirske pjesme nipošto nije bio barokna inovacija, sama njegova sedamnaestostoljetna raširenost nepobitno potvrđuje da su se onodobni pjesnici - svjesno ili nesvjesno - u velikoj mjeri naslanjali na starije lirske tradicije, ${ }^{605}$ što je - uostalom - primjetno i u samom Odiljenju sigetskom, u kojem najveći dio generičkoga „materijala“ pripada (lirskim) žanrovima izvorno predbarokne provenijencije.

\section{2. 6. Lirske pohvalnice (panegirici)}

Još jedan u nizu predbaroknih lirskopjesničkih žanrova čijim obilježjima Pavao Ritter Vitezović pojačava generičku šarolikost svoje neobične ,zrinijade“ bila bi lirska pohvalnica ili panegirik - žanr originalno antičkoga porijekla, koji je upravo u razdoblju u kojem će i Odiljenje ugledati danje svjetlo uživao izuzetno veliku popularnost. Kao žanrovski slojevito pjesničko ostvarenje u kojemu se proslavlja iznimno važan i uzoran događaj iz dotadašnje hrvatske povijesti te glorificira herojska uloga što ju je u njemu odigrao jedan od najznačajnijih i najopjevanijih hrvatskih zapovjednika svih vremena, Odiljenje sigetsko samo se po sebi nameće kao izrazito ,plodno tlo“ za uključivanje značajki iz generičkoga repertoara (barokne) pohvalnice. Upravo njih i prepoznajemo u dionicama teksta u kojima se s posebno naglašenom emocionalnošću i patetičnom uzvišenošću - uz neizbježnu „podršku“ nekolicine uvriježenih panegiričkih retoričkih toposa - pristupa pohvalnom isticanju ratnih junaštava i uopće vrlina kršćanskih branitelja Sigeta na čelu s Nikolom Šubićem Zrinskim, odnosno (na momente vidno pretjeranom) glorificiranju njihovih silnih zasluga u obrani hrvatske 
domovine, kraljevstva, pa i kršćanstva u cijelosti, zahvaljujući kojima su i stekli mjesto na nebu te neprolaznu ovozemaljsku slavu. Zanemarimo li tragove usmenoknjiževne pohvalnice ili „počasnice“, čijoj ćemo prisutnosti u njima doskora posvetiti više pozornosti, za spomenute bi se segmente Odiljenja već na prvi pogled moglo zaključiti kako su glavninom skrojeni po obrascu (pisanoknjiževnih) lirskih pohvalnica ili panegirika, odnosno u baroku posebno obljubljenoga žanra prigodnog pjesništva, koji se diljem sedamnaestostoljetne Europe - pa tako i u Ritterovu slučaju - mahom sastavljao na latinskom jeziku.

Te strukturom vrlo konvencionalne, ali tematski prilično raznolike prigodne lirske pjesme, u kojima su se na izrazito emocionalan, no počesto i neukusno patetičan način opjevavali nesvakodnevni, najčešće institucionalni događaji iz života određene zajednice ili nekoga pojedinca (npr. stihovane čestitke, rođendanske pjesme, pjesme u povodu vjenčanja itd.), obično su izrijekom bile namjenjivane konkretnomu naslovljeniku, kojega su - povodom stanovitoga događaja - silnim pretjerivanjima i preuveličavanjima trebale zadiviti u cilju stjecanja ili održavanja njegove naklonosti. ${ }^{606}$ Latinske prigodnice, koje su se - u različitim generičkim varijanatama - prometnule u jedan od daleko najeksploatiranijih lirskopjesničkih žanrova u književnosti 17. stoljeća, svoju tadašnju popularnost ponajvećma duguju činjenici što su tijekom čitava ranonovovjekovlja izravno bile upletene u književno-poetsku i izvanknjiževnu (znanstvenu) komunikaciju, ali i što su - odnoseći se na neke posebne trenutke u životima (ponajprije) društveno značajnih pojedinaca - služile kao „spremište“ kulturnoga pamćenja, osnaživale kategorije vrijednosti i značenja te potvrđivale društvenu predodžbu o onome što je primjereno i prikladno, poglavito s moralnoga gledišta. S obzirom na to da su prigodne pjesme većinu ovih funkcija ispunjavale kako u svojoj ,privatnoj“ varijanti, tako i u sklopu ,javnih“, panegiričkih glorifikacija prijelomnih društvenih zbivanja, s punim se pravom može pretpostaviti da nam prigodnice štošta mogu otkriti ne samo o razdoblju baroka, nego i o europskom ranonovovjekovlju u cijelosti. ${ }^{607}$

Iako se pohvalnički odsječci Odiljenja čine prilično dalekima aktualnoj panegiričkoj (baroknoj) lirici, u kojoj se biranim riječima - dakle, uvriježenim retoričkim ,alatima“ proslavljalo konkretne suvremenike, objekte ili institucije radi nekih njihovih aktualnih dostignuća ili naprosto zbog njihove osobite (trenutne) društvene važnosti, utjecajnosti i moći, Vitezović osnovni generički uzor za svoje panegiričke segmente nije mogao pronaći drugdje nego u neobično bogatom korpusu sedamnaestostoljetnoga (latinskog) pohvalničkog pjesništva većinom posvećenog tadašnjim političkim moćnicima i uopće društvenim

\footnotetext{
${ }^{606}$ Usp. Avsenik Nabergoj 2011: 421.

${ }^{607}$ Detaljnije o ovim funkcijama i značaju ranonovovjekovnih prigodnica u: Kühlmann 2007: 287.
} 
uglednicima i dostojanstvenicima. Taj nagli procvat panegiričkoga pjesništva i drugih (po izvantekstualnoj važnosti) njemu srodnih žanrova - anagrama, epigrama te povijesnopolitičkih i publicističkih spisa - u Habsburškoj Monarhiji u 17. stoljeću moguće je objasniti isključivo specifičnim društvenopovijesnim okolnostima, odnosno činjenicom da upravo tada dolazi do strelovite porasti moći kralja i sve dubljega ukorjenjivanja apsolutizma. Svojevrsna barokna moda ispisivanja lirskih pohvalnica, odnosno prigodnih lirskih pjesama, u potpunosti je, naime, povezana s tadašnjim procesima apsolutističke centralizacije, na što najuvjerljivije ukazuje upravo činjenica da je daleko najveći broj takvih sedamnaestostoljetnih sastavaka bio posvećen samom habsburškom kralju i/ili drugim njemu bliskim uglednicima. ${ }^{608} \mathrm{Ti}$ lirski panegirici, kojima se željelo uvećati kraljevu pozitivnu reputaciju i osnažiti dojam njegove moći i ugleda, mogli bi se stoga promatrati kao neka vrsta „reklame“ kraljevskoga dvora, čija je svrha bila podsjećanje recipijenata na činjenicu da je kraljeva moć apsolutna i bezgranična te da mu se stoga valja u potpunosti pokoriti, tim više što je on od Boga dan vladar koji kraljuje u interesu cjelokupne Monarhije. Pohvalne pjesme ili panegirici - u mnogima od kojih se kralja uzdizalo čak i do razine besmrtnoga polubožanstva - u barokno su doba, u društveno-političkom smislu, upravo iz toga razloga i imali toliko značajnu ulogu, sudjelujući u oblikovanju stavova i ,javnoga mnijenja“, odnosno u izravnom propagiranju poželjnoga gledanja na vladajuću dinastiju i uopće Monarhiju te prihvatljivoga svjetonazora i prikladnih moralnih vrlina. ${ }^{609}$ Specifične izvanknjiževne okolnosti (ili „situacija“), drugim riječima, tako su neposredno utjecale na baroknu popularnost ovoga literarnog žanra, koji se - govoreći rječnikom suvremene genologije - svojim sadržajnim osobitostima nameće kao jedno od žanrovskih rješenja koje na tu istu „situaciju“ podastire uvjerljivo najprikladniji „odgovor“.

Sastavljanje upravo takvih, aktualnih pjesničkih prigodnica i prigodničkih ciklusa na latinskom jeziku, ispjevanih $\mathrm{u}$ čast različitih onodobnih svjetovnih $i$ crkvenih dostojanstvenika, različitih političkih moćnika, vojnih uglednika, ali i samoga kralja Leopolda i nekih njemu najbližih suradnika, Vitezoviću je - kako se čini - predstavljalo svojevrsnu kreativnu opsesiju, koje se nije dospio „riješiti“ doslovno ni na „samrtnoj postelji“. Razlog ustrajnog ispisivanja prigodnih pjesničkih ostvarenja, međutim, krio se u njegovoj želji da se približi centrima onodobne habsburške političke moći, da stekne naklonost ključnih figura tadašnjega političkog života, odnosno da se - predstavljajući se kao vrstan historiograf i pjesnik od zanata - nametne kao osoba koja bi tim istim moćnicima mogla biti od konkretne koristi te da ujedno na taj način riješi i „goruće“ pitanje svoje vječno ugrožene životne

\footnotetext{
${ }^{608}$ Podrobnije u: Blažević 1997: 16.

${ }^{609}$ Usp. o tome u u: Stepanić 2005: 162.
} 
egzistencije. Sustavno prateći domaću i inozemnu (neo)latinsku prigodničku produkciju kao čitatelj, ali i kontinuirano joj doprinoseći vlastitim autorskim panegiričkim pjesničkim tekstovima, Ritter na žanrovska obilježja prigodnice očigledno nije mogao zaboraviti ni pišući svoju generički „,zapetljanu“ hrvatsku „zrinijadu“, gdje ga je na njihovu evokaciju zacijelo potaknula nakana da neustrašivoga sigetskog kapetana - kojega je i sam držao i više nego dostojnim svake slave i časti - obdari zasluženim, uobičajeno pretjeranim pohvalama junaštava i ratničkih mu vrlina. Nije on pritom vidio ništa sporno ne samo u pohrvaćivanju pretežno (neo)latinskoga baroknog lirskopjesničkog žanra, u čemu u našoj onodobnoj književnosti ionako nije bio usamljen, već ni u njegovu uklapanju u znatno veću literarnu cjelinu, jamačno svjestan činjenice da su lirskopjesničke pohvalne dionice još od srednjega vijeka povremeno postajale dijelom opsežnijih stihovanih ostvarenja, u sklopu kojih su svojim stilski prenaglašenim pohvalama pridonosile učvršćivanju kulta konkretnoga „hvaljenika“ (sveca, božanstva, vladara ili kojega drugog istaknutog pojedinca), potenciranju njegova i značaja njegovih djela te održavanju svijesti o potrebi njihova upamćivanja i slavljenja.

Nema dvojbe da su iste zadaće bile stavljene i pred panegiričke odsječke Odiljenja sigetskog, u kojima se, međutim, ne glorificiraju samo junaštva sigetskih junaka predvođenih banom Nikolom Šubićem Zrinskim, već i vrline, slavno porijeklo te ratničke i ne samo ratničke zasluge pokrovitelja i zaštitnika prvih dvaju izdanja Ritterova djela. Usprkos činjenici da se radi o pobočnim, paratekstualnim sastavnicama Vitezovićeve „zrinijade“, latinska posvetna pjesma Adamu Zrinskom iz prvog te ona Matiji Ignaciju Radanoviću iz (fiktivnoga) „drugog“ izdanja svakako zaslužuju da im se - kao integralnim i nipošto manje vrijednim komponentama tiskanih izdanja - posveti puna analitička pozornost, odnosno da se i njih razmotri iz genološke perspektive ne bi li se utvrdile eventualne žanrovske podudarnosti teksta i parateksta. Upravo jedna od nekolicine generičkih paralela između posvetnih pjesama izdanja iz 1684. i 1685. te samoga teksta Odiljenja sigetskog bile bi značajke iz repertoara pohvalne ili panegiričke pjesme, kojima je naročito bremenit nešto duži tekst heksametarske posvetnice opatu Radanoviću iz bečkoga izdanja „zrinijade“, u kojemu se hvale adresatove vrline, višestruko dokazano domoljublje, vojničke sposobnosti te iznimne crkvene zasluge, ${ }^{610}$ a sve ne bi li se - između ostalog - pretjeranim naglašavanjem i hiperboliziranjem posvetnikova značaja i društvenog ugleda ujedno podigla i „cijena“ (reputacija) samoga djela, kojemu je takav uglednik pristao biti mecenom i izravnim zaštitnikom. U nešto manjoj mjeri prepoznatljivim tragovima ovoga - za posvetne pjesme nimalo neuobičajenoga panegiričkog diskursa protkana je i pjesnička posveta prvoga izdanja Adamu Zrinskom, u 
kojoj se proslavlja „tek“ Adamovo slavno porijeklo i podsjeća na herojsku pogibiju čuvenog mu pretka, sigetskog zapovjednika, dok je njegov društveni značaj signaliziran brojnim titulama i dužnostima što ih obnaša, koje se nabrajaju u podnaslovu pjesme. ${ }^{611}$ Premda na pretjeranim glorificiranjima posvetnika i panegiričkoj poeziji svojstvenim toposima počiva i (hrvatska) posveta trećega izdanja Odiljenja Ivanu Andriji Makaru, glavninom fokusirana na njegove ratničke uspjehe, ona ipak izlazi izvan našega fokusa budući da je riječ o proznoj prosveti čiji panegirički momenti najvjerojatnije potječu iz tradicije pohvalnoga govora.

Što se, pak, samoga teksta Ritterove ,zrinijade“ tiče, značajke pohvalne pjesme naći ćemo u njemu glavninom koncentrirane na dva mjesta, i to - ponajprije - u pjesmi Siget banu i vojnikom iz drugoga „dila“ (II: 361-439), gdje netom osvojeni personificirani Siget hvali junačke podvige čete svojih (redom izginulih) hrvatskih branitelja pod zapovjedništvom Nikole Šubića Zrinskog, te u središnjem dijelu (IV: 68-85) već spomenute odulje nadgrobnice Mikule kneza od Zrinja, bana (IV: 62-103), u kojem se slave banove mnogobrojne ratne zasluge, a naročito uspjesi u raznim borbama protiv Osmanlija u kojima je za života sudjelovao. Fokusirajući se na višim idealima motivirana herojstva Zrinskog i njegovih suboraca, ove pjesme - točnije, njihove panegiričke dionice - izrazito emotivno proslavljaju silnu žrtvu što su je podnijeli „Hrvati hrabreni“ (II: 431) trudeći se obraniti Siget od daleko moćnija neprijatelja, pri čemu ne zaziru ni od mjestimičnih pohvalnički tipičnih preuveličavanja poput, primjerice, predstavljanja Zrinskog kao ,jedno čudo svita“ (IV: 66), kojega se „straši Turčin kako groma“ (IV: 94) i koji samo u bitci za Siget „sto tisuć s carom na smrt dade“ (IV: 86). Prepleteni s ovim pohvalnicama svojstvenim pretjeranim veličanjima hvaljenika, u obje dionice Odiljenja egzistiraju i neki prepoznatljivo panegirički retorički toposi poput toposa neizrecivosti i toposa nadmašivanja, ${ }^{612}$ koji su se u onodobnim i ne samo onodobnim (latinskim) primjercima retorički vrlo konvencionalnoga i šabloniziranoga žanra pohvalne lirske pjesme nametnuli kao u potpunosti neizbježna komponenta. I dok je topos neizrecivosti - posredstvom motiva nemogućnosti iznalaženja adekvatnih, njihovu značaju dostojnih riječi, kojima bi se adresate (hvaljenike) uzvisilo na primjeren način (,ne morem vam dosti vikom zahvaliti““, II: 392; „Nis' moguć hvaliti toj ljubavi dosti“, II: 399), odnosno motiva sveopćega ili kolektivnog divljenja adresatu i njegovim postignućima (,Viteški moj bane, koga slavno dilo / na sve svita strane jur se j' raztočilo“; II: 361-362) - pritom znatno uočljiviji u pjesmi Siget banu i vojnikom, dotle naznake toposa nadmašivanja - koji se obično svodio na uspoređivanje hvaljenika s drugim, njegovom „liku i djelu“ bliskim proslavljenim

\footnotetext{
${ }^{611}$ Usp. Ritter Vitezović 1684.

${ }^{612} \mathrm{O}$ panegiričkoj lirici i njoj svojstvenom topičkom „rekvizitariju“ podrobnije u: Curtius 1998: 170-183.
} 
povijesnim ličnostima, čije su vrline i herojske dosege uvjerljivo zasjenili njegovi silni uspjesi - zamjetno više prostora dobivaju u epitafu Mikule kneza od Zrinja, bana, pri početku kojega se lirski subjekt neće ustručavati Zrinskoga proglasiti jednim od najvećih - ako ne i najvećim - vojskovođa svih vremena. ${ }^{613}$

Neupitnu vještinu i okretnost u pisanju pohvalnih pjesama, koju je u Odiljenju sigetskom demonstrirao i na vernakularu, Pavao Ritter Vitezović stekao je - nije teško zaključiti - već za školovanja u isusovačkoj gimnaziji, nastavni program koje je, između ostalog, propisivao i vježbe sastavljanja književnih žanrova antičke provenijencije, među kojima je - dakako - bio i onaj panegiričke lirike. Osim uspješnoga praktičnog usvajanja generičkoga repertoara pohvalnice i niza drugih žanrova prigodnoga pjesništva, zahvaljujući kojemu će kasnije biti u stanju prigodnice „sipati“ gotovo kao „,iz rukava“, Vitezović se u gimnaziji imao prilike upoznati $\mathrm{i}$ s bogatom tradicijom toga njemu neobično dragog lirskopjesničkog žanra, koji je svoj korijen imao još u starogrčkim pohvalnim govorima, javno izricanima na različitim svečanostima i skupovima. Sama panegirička lirska poezija, međutim, pisati se počela tek u starome Rimu, gdje neke od najranijih njezinih primjeraka $u$ svojoj zbirci prigodnoga pjesništva Silvae (̌̌ume) donosi Stacije, a potom žanr pohvalnice ponajviše i posredstvom Biblije, u kojoj je niz njezinih primjeraka također našao svoje mjesto - ,život“ nastavlja u srednjem vijeku, gdje će naročito biti cijenjen na feudalnim dvorovima, ${ }^{614}$ iako će za njime nerijetko posezati i nabožni pjesnici, proslavljajući u svojim lirskim panegiricima glasovite crkvene oce, mučenike i svece. Vrhunac popularnosti pohvalne pjesme pada upravo u 17. stoljeće, kada, pored ostalih, u sklopu velikih europskih kraljevskih dvorova (poglavito onoga francuskog i habsburškog) djeluju i tzv. ovjenčnani pjesnici (poeta laureatus), pretežno „specijalizirani““ za pisanje panegiričkih i njima srodnih prigodnih lirskih pjesama u čast kraljevstva, kralja, kraljeve obitelji i drugih dvorskih velikodostojnika.

Zbog maločas pojašnjenih razloga barokne obljubljenosti žanra prigodne, poglavito pohvalne lirske pjesme, možda bi daleko jednostavnije bilo pobrojati one sedamnaestostoljetne europske pjesnike koji u svojoj stvaralačkoj ostavštini nemaju niti jedan primjerak (latinskoga i/ili vernakularnog) lirskoga panegirika no one koji su se u njegovu sastavljanju okušali najmanje jednom. Iz toga razloga spomenimo „tek“ da je uvjerljivo najveći prilog obimnome korpusu europskoga panegiričkog baroknog pjesništva od svih slavenskih književnih kultura dala ona poljska, u sklopu koje se bogatim pohvalničkim

\footnotetext{
${ }^{613}$ Spomenuto mjesto iz nadgrobnice bana Zrinskog glasi: „Ni bilo do sih dob (što je svit okružil) / vridnijih, ki bi grob veće suz zaslužil / nego ov, v kom počiva jedno čudo svita, / slika vire živa, cvit ratnoga cvita, / knez Mikula Zrinski, vitez Runa zlata, / slavni ban slovinski, Dalmat i Hrvata“"(IV: 64-69).

${ }^{614}$ Naime, popriličan dio korpusa trubadurskoga pjesništva u tom se smislu generički može okarakterizirati upravo kao prigodnička, panegirička lirika.
} 
opusima mogu podičiti gotovo svi najvažniji tadašnji pjesnici (S. Twardowski, Z. Morsztyn, W. Potocki i dr.), a k tome dodajmo još i da je učestalost žanra pjesničke prigodnice u njemačkoj književnosti u 17. st. bila tolika da su ga poetičari - ponajprije Martin Opitz, koji će to učiniti u svojoj Knjizi njemačke poetike - okrstili posebnim generičkim nazivom, i to „šume“ (Wälder), izravno pritom nasljedujući Kvintilijana, koji je tim terminom (silvae) sustavno obilježavao ovaj lirskopjesnički žanr. ${ }^{615}$ Nepostojanje specifičnoga i sveprihvaćenog žanrovskog naziva za prigodnu (panegiričku) lirsku pjesmu u hrvatskoj baroknoj kulturi nipošto, međutim, automatski ne upućuje i na možebitni izostanak interesa naših sedamnaestostoljetnih pjesnika za ovo generičko rješenje, koji su u njegovu uvažavanju, pa i vernakulariziranju definitivno krenuli stopama inozemnih svojih pjesničkih suvremenika.

Ostavimo li po strani korpus domaćih latinskih baroknih prigodnica, kojemu je mnoštvom svojih ostvarenja značajno pridonio i sam Vitezović, panegiričke i druge onodobne prigodne lirske pjesme ispjevane na hrvatskom jeziku bit ćemo prisiljeni tražiti pretežno među književnim ostvarenjima južnohrvatskih autora 17. stoljeća, koji se - kao visokoobrazovani i literarno sjajno potkovani pojedinci - na udomaćivanje ovoga žanra većinom (neo)latinske književnosti najvjerojatnije odlučuju potaknuti stranom pohvalničkom lektirom. Žanru vernakularne barokne pohvalnice pripadala bi tako ponajprije poznata Gundulićeva lirska pjesma u čast toskanskoga kneza Ferdinanda II. Visini privedroj Ferdinanda II., velikog kneza od Toskane, potom omanji ciklus od čak tri lirska panegirika Petra Kanavelića posvećena poljskome kralju Janu Sobjeskom povodom oslobođenja Beča od turske opsade 1683., 616 zatim kraća pjesnička pohvala Ivana Bunića Vučića upućena Gundulićevoj melodrami Arijadna (otisnuta 1633. u Anconi zajedno s Gundulićevim tekstom) te - naposljetku čuvena odulja pohvalnica Vladislava Menčetića Trublja slovinska iz 1665., ispjevana u čast Petra Zrinskog i njegove Adrijanskoga mora Sirene. Premda i više nego očita sadržajna aktualnost pobrojanih pjesama navodi na pomisao kako - osim jezične podloge i poneke vrlo vjerojatne motivsko-retoričke paralele - panegirički segmenti Odiljenja sigetskog nemaju s njima mnogo dodirnih točaka, nužno je ipak uočiti kako baroknim pohvalnicama svojstvenu aktualnost, odnosno posvećenost znamenitim (živućim) suvremenicima i/ili njihovim značajnim djelima Ritter donekle ipak pokušava ispoštovati - točnije, fingirati - i u svojim fiktivnim panegiricima, u kojima pohvale u čast Nikole Šubića Zrinskog bivaju izrečene u trenucima kada ovaj zajedno sa svojim suborcima pogiba od turske ruke (Siget banu $i$ vojnikom) ili se, s druge strane, odnose na slavnog pokojnika čiji „duh v nebu pribiva“ (IV:

\footnotetext{
615 Opširnije o ovom pitanju u: Matvejević 1986: 602-603 i Avsenik Nabergoj 2011: 421.

${ }^{616}$ Jan Sobjeski je, uzgred budi rečeno, Kanaveliću na ovom pohvalničkom ciklusu osobno zahvalio pismom.
} 
100) i koji se - iako fizički neprisutan u ovozemaljskoj, materijalnoj dimenziji - stoga i dalje može „računati““ kao živi adresat (Mikule kneza od Zrinja, bana).

Kako bilo, pohvalna lirska pjesma u Vitezovićevo je vrijeme kotirala kao jedan od najpopularnijih i najraširenijih žanrova prigodnoga pjesništva, realiziran paralelno $u$ (neo)latinskoj i vernakularnoj svojoj varijanti, ali i u onoj „samostojećoj“ (samostalnoj) i „pridruženoj“ (uključena u drugi, obuhvatniji i složeniji sekundarni žanr), no redovito kao iznimno šablonizirano i topički „učvršćeno“ generičko rješenje, čija su specifična obilježja katkad ulazila i u okvire drugih lirskopjesničkih žanrova (primjerice, himne, ode, soneta itd.) obogaćujući ih tzv. pohvalničkim tonom. U baroknoj književnosti pohvalničke značajke u nemalom su broju slučajeva postajale dijelom generički (tada) najsloženijih, epskopjesničkih ostvarenja, egzistirajući u njima ili u obliku više-manje cjelovitih panegiričkih tekstualnih umetaka, ili kao niz vrlo kratkih, rastrganih pohvalničkih fragmenata razasutih tekstom, kakvih nekolicinu zatječemo i u Obsidi sigeckoj Petra Zrinskog. Te panegiričke krhotine što se protežu na svega nekoliko stihova, najčešće ne prelazeći granice jedne strofe, zbog svoje su kratkoće ujedno i vrlo bliske usmenoknjiževnom retoričkom žanru (obliku) hvale, no s obzirom, ipak, na njihovu jasno izraženu težnju preuveličavanja adresatova značaja i zasluga $^{617}$ očito je da su glavninom one skrojene upravo po uzoru na pohvalnu lirsku pjesmu. Jamačno uvidjevši (i) iz omiljenog mu Petrova primjera kako pohvalnički segmenti vrlo uspješno mogu funkcionirati uklopljeni u veću literarnu (čitaj: žanrovsku) cjelinu tematski posvećenu sigetskoj katastrofi, Pavao Ritter Vitezović i sam se odvažio uključiti obilježja panegiričke lirske pjesme u svoju (žanrovski daleko složeniju) ,zrinijadu“, baš kao što je, na kraju krajeva slijedeći ponajvećma Adrijanskoga mora Sirenu pri sastavljanju svojega Odiljenja i posegnuo za značajkama nemalog broja u njoj zastupljenih pisanoknjiževnih i ne samo pisanoknjiževnih žanrova, među kojima ipak nije zatekao i onaj (barokne) alegorije.

\section{2. 7. Alegorija}

U svojoj ovdje već spomenutoj utjecajnoj genološkoj studiji Anatomija kritike iz 1957. Northrop Frye dotaknuo se - između ostalog - i alegorije, proglasivši je tzv. tematskim

617 Pohvalnicama svojstveno pretjerivanje u hvaljenikovu proslavljanju zamjećujemo tako, primjerice, na početku obraćanja Nikole Šubića Zrinskog kapetanima u 4. pjevanju Obside („Vitezi kršćanski, kruno človičanska, / glavari vitežki, obrambo hrvacka, / virom mučeniki, rad hiže, ostanka / proliste človečki krvcu prez prestanka“; IV: 35), potom u dvjema strofama 12. pjevanja, u kojima Terhat-beg svoje obraćanje Delimanu otvara vidno pretjeranim apostrofiranjima adresata (,Diko otca tvoga, viteže nesmerni, / kolina turskoga junače operni, / roda gosposkoga nasledniče verni, / glasa uzmožnoga gospodine željni! // Kud god sunce šeta, zrače pohvaljeni, / vire Mahometa bor i cvit zeleni (...); XII: 64-65), kao i u jednoj od posljednjih strofa 15. pjevanja i epa u cijelosti uopće, u kojoj se netom poginuli Nikola Šubić Zrinski hvali kao „stup, šćit, ban hrvacki, grada sigeckoga / glavar i strah turski, prvi vika svoga“ (XV: 115). 
modusom, odnosno dijelom „tematske književnosti“, koja iskazuje u potpunosti idejni interes. Za razliku od tematske književnosti, glavninom fokusirane na smisao djela, fikcionalna je književnost, pojašnjava se u nastavku, u cijelosti usredotočena na fabulu teksta - točnije, na djelovanje junaka - pa dok je tematski odnos tako moguće prepoznati mahom u lirskom pjesništvu i eseju, dotle se onaj fikcionalni najizrazitije očituje u romanu i drami. Bez obzira, ipak, na ovu naoko (pre)strogu podjelu, Frye napominje kako je „čisto“ tematski ili „čisto“ fikcionalni literarni tekst ništa drugo nego puka zabluda budući da apsolutno svako književno ostvarenje istodobno uključuje i fikcionalni i tematski aspekt, no pritom nešto veći naglasak stavlja ili na jedan ili na onaj drugi. ${ }^{618}$ Shvaćanje alegorije za kakvo se u svojoj knjizi zalaže Frye ispostavlja se - kao takvo - zapravo tek jednim u nizu oprečnih, iako ne u svemu isključujućih sudova što su o ovom žanru / modusu / figuri / procesu tumačenja itd. kontinuirano izricani od antike do našega doba, neprekidno ukazujući na heterogenu narav ili - bolje rečeno - pojavnost alegorije, koja onemogućuje njezino podvođenje pod isključivo jednu, a kamoli jedinstvenu definiciju.

Alegorija je za svoga neobično dugog književnopovijesnog trajanja većinom razumijevana na tri bitno različita načina, od kojih se onaj prvi - generički - nipošto ne bi mogao izdvojiti kao najstariji, ali još manje kao najčešći ili možebitno najprecizniji. Žanrovski se, naime, o alegoriji može govoriti isključivo ako određeno književno ostvarenje u cijelosti počiva na sekundarnom značenju, odnosno ako je njegov sadržaj tek svojevrsna krinka ili okvir unutar kojega se krije „,pravo“ (primarno) značenje ili smisao toga teksta. S druge, pak, strane, alegorija se u ,obliku“ tropa ili figure misli pojavljuje kada je svedena na stilsko figuralno rješenje koje daje formu apstraktnim konceptima i procesima, što će reći u slučajevima kada se govorom o nekim konkretnim i bliskim stvarima teže predočiti stanovita ideja ili kakva - filozofska, religijska, moralna ili emocionalna - kategorija. Naposljetku, kao „alegoreza“ ili proces tumačenja alegorija se nadaje ukoliko se neki književni, u suštini nealegorijski tekst čita i tumači kao alegorija nečega drugog, odnosno kada mu se pokušava „,učitati“ sekundarno ili alegorijsko značenje koje izvorno u njega nije bilo upisano. ${ }^{619}$

Nas će, dakako, u kontekstu ovoga istraživanja ponajviše zanimati prvo - žanrovsko poimanje alegorije, točnije onaj vid alegorije kojemu pripadaju literarna ostvarenja u kojima se prikazani svijet ispostavlja tek simbolom (alegorijom) nečega posve drugog. Alegorija kao književni žanr u teorijskoj bi se, ali i povijesnoj optici najjednostavnije mogla definirati kao generičko rješenje koje obuhvaća ona ostvarenja u kojima je sam tekst sekundaran u odnosu

\footnotetext{
${ }^{618}$ Detaljnije naročito o tematskim modusima, odnosno tematskoj književnosti u: Frye 2000: 66-82.

${ }^{619}$ Znatno podrobnije o trima navedenim shvaćanjima alegorije u: Zlatar 2010: 13-14, Bagić 2012: 16-21, Teskey 2012: 37-40 i Pšihistal 2014: 95-117.
} 
na vlastito tumačenje, odnosno književna djela sa dvoznačnim sadržajem, unutar kojih „doslovni“ tekst podrazumijeva „figuralno“ kao stvarno značenje i iz toga razloga od recipijenta iziskuje primjerenu alegorijsku interpretaciju posredstvom koje jedino i može steći svoj (pot)puni, dakle izvorni smisao. Riječ je, ukratko, o takvim literarnim tekstovima koji prezentiraju donekle necjelovitu i gusto simboličnu (simbolima nabijenu) priču, čiji elementi snažno upućuju na neko značenje izvan onoga doslovnog, i to obično posredstvom nekih čitatelju dobro poznatih „tragova“ ili konkretnih alegorijskih toposa, indicija i signala. U ulozi alegorijskih signala, čija je zadaća čitatelja usmjeriti ka skrivenom stvarnom značenju teksta, pritom se - osim stanovitih tradicionalnih simbola - najčešće pojavljuju znakovita topografija, personificirane apstrakcije (na primjer, alegorijski prikazi kršćanskih vrlina ili poroka) te simbolične arhitektonske strukture poput, primjerice, „kuće ponosa“. Pojednostavljeno rečeno, osnovna se zadaća tih signala, dakle, svodi na uspostavljanje općega konteksta značenja (povijenog, političkog, religijskog, moralnog itd.) unutar kojega bi valjalo provesti tumačenje, pri čemu se od čitatelja očekuje „samo“ da taj kontekst popuni detaljima i tako „izgradi“ značenje djela u cijelosti. Iako bi alegorija - kao takva - lako mogla isprovocirati usporedbu sa žanrom umjetničke bajke, niz proučavatelja s pravom je već upozorio kako nipošto između njih - u generičkom smislu - ne bi trebalo povlačiti ozbiljnije paralele jer, dok bajka puni smisao i moralnu svrhu zadobiva - zahvaljujući pouci ili poanti tek na svome kraju, dotle alegoriju preneseno značenje prožima doslovno od korica do korica, odnosno iziskuje alegorijsko tumačenje teksta u cijelosti, a ne tek njegove eventualne pouke.

Pristupajući alegoriji kao pretpostavljenomu ,punokrvnom“ književnom žanru, ${ }^{620}$ posve je očekivano, pa i nužno - kao što je to i dosad bio slučaj - upustiti se i u razmatranje ostalih (sadržajnih i formalnih) značajki iz njezina žanrovskog repertoara, navlastito onih iz sedamnaestostoljetne, barokne joj ,inkarnacije“. U tematsko-motivskom smislu, moguće je tako konstatirati da je kroz svoju povijest - a uvelike i u 17. stoljeću - žanr alegorije ponajviše bio sklon tematiziranju putovanja (alegorija putovanja) i bitke (alegorija bitke), iako se realizirao također i u mnogim tekstovima filozofskoga sadržaja, pri čemu se kao jedno od trajni(ji)h njegovih sadržajnih obilježja - bez obzira na konkretnu mu tematsku orijentaciju ispostavlja premreženost različitim toposima poput opisa mističnih stanja i snoviđenja, motiva traženja pravoga puta ili duhovne potrage, motiva psihološkoga putovanja, toposa odnosa duše i tijela, ljudskog i božanskog, unutarnjeg i vanjskog svijeta itd. Što se, pak, njezina možebitnog karakterističnog formalnog okvira tiče, situacija se ispostavlja znatno složenijom

${ }^{620}$ O alegoriji kao književnom žanru usp. Zlatar 2010: 13, Bagić 2012: 17-19, Pšihistal 2014: 109-112 i Grmača 2015: 63-78. 
budući da je znatno prije 17. stoljeća alegorija već pokazala nevjerojatnu „sposobnost upletanja u vrlo raznolike generičke oblike - od vizija i utopija, viteških, dvorskih i pikarskih romana, enciklopedijskih suma i političkih satira, pa do peregrinacija i moraliteta, ljubavnih poema i pastorala“ (Grmača 2015: 73). Poradi potonje uklopivosti u zaista širok raspon generičkih rješenja, koju je ponajviše olakšavala fluidnost njezina žanrovskog repertoara, a naročito odsustvo njoj svojstvenoga formalnog obrasca, i više je nego jasno da se alegorija po svome statusu teško može izjednačiti s većinom žanrova unutar čijih je granica egzistirala, što onda i njezino često potencirano generičko razumijevanje ozbiljno dovodi pod znak pitanja.

Naime, unatoč tomu što je još u svojim počecima - počevši od Prudencijeva alegorijskog epa Psychomachia (Borba za dušu) iz 4./5. st. - kotirala kao isključivo narativni, epskopjesnički žanr, u kojemu su ulogu junaka preuzimale personificirane apstrakcije (primjerice, „oživljene“ vrline i poroci), alegorija je s vremenom nadrasla te svoje prvotne formalne okvire, počevši sve češće ulaziti u generički kojekako obilježene književne, pa i ne samo književne tekstove. To je ubrzo dovelo do situacije u kojoj se nije više mogla izdvojiti „nijedna književna vrsta koja ne bi mogla postati alegorijom“ (Pšihistal 2014: 112), odnosno koju alegorija ne bi bila u stanju ,alegorizirati“, pa je krug alegorijskih djela tako počeo uključivati i ostvarenja realizirana u žanrovima maksime, krilatice, aforizma, zagonetke, poslovice, basne, parabole, drame, pastirske igre, lirske pjesme, romana, satire, epske pjesme, ali i u različitim srednjovjekovnim (naročito prikazanjima, moralitetima, peregrinacijskim epovima, prenjama), pa čak i u neknjiževnim žanrovima poput didaktičkih ili filozofskih epova, filozofskih i političkih traktata itd. Kroz povijest književnosti od srednjega vijeka do danas uvjerljivo se tako pokazalo da ,ne postoji nijedna književna vrsta koja ne bi mogla preuzeti alegorijske diskurzivne strategije, kao što nema niti književnoga djela ili (...) bilo kojega teksta koji ne bi mogao biti čitan kao alegorija“ (Isto: 114), zbog čega i recentni proučavatelji sve češće ističu kako se razlikovne značajke alegorije nipošto ne mogu izdvojiti poput onih drugih književnih žanrova jer je u njezinu slučaju riječ „tek“ o konkretnim

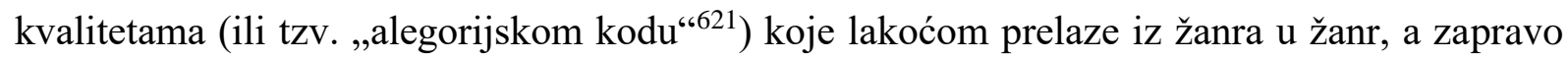
se radi ni o čemu drugom nego o alegorijskom tipu čitanja ,alegoriziranih“ sadržaja u nekome određenom tekstu. Izuzev specifičnoga tipa tumačenja, pojedinih karakterističnih toposa i nekolicine preferiranih tema, nikakva druga prepoznatljivija razlikovna obilježja koja bi trebao uključivati ,žanrovski repertoar“ alegorije iz toga se razloga ne mogu izlučiti ni obilježiti kao njoj svojstvene tekstualne značajke, od kojih je stanovit broj - između ostalih na koncu našao svoje mjesto i unutar korica Vitezovićeva Odiljenja sigetskog.

${ }^{621}$ Usp. Bagić 2012: 16. 
Imamo li na umu ovu generičku neuobličenost ,žanra“ alegorije, čiji ,alegorijski kod“ posjeduje nevjerojatnu sposobnost prilagođavanja najrazličitijim mogućim žanrovskim okvirima, jasno je da bismo ,generički“ pristup alegoriji morali temeljiti ne (više) na netočnoj predodžbi o njoj kao o jednom od ,punokrvnih“ povijesnih žanrova s povijesno promjenjivim repertoarom karakterističnih joj obilježja, već upravo na njezinu shvaćanju kao jednog od nadpovijesnih generičkih čimbenika, koji se aktivira tek kada se - u obliku dodatne (većinom sadržajne) nijanse - uključi u neki od stvarnih žanrova. Alegoriji kao takvoj, drugim riječima, valjalo bi - slijedom Fryea - stoga priznati „tek“" status (tematskoga) modusa, odnosno neke izvanžanrovske sadržajne ili idejne komponente koja može ući u različite žanrove s nakanom da ih „oboji“ alegorijskom crtom, točnije da se poveže s njihovim - pretežno sadržajnim, ali i formalnim i stilskim - obilježjima ne bi li isprovocirala alegorijsko tumačenje djela $\mathrm{u}$ cijelosti. Rezultat takvoga generičkog „djelovanja“ alegorije je snažna modifikacija, odnosno alegorizacija danoga primjerka žanra, koji svojim alegorijskim signalima čitatelja navodi na alegorijsku recepciju i koji iz toga razloga u književnopovijesnoj literaturi nerijetko i biva identificiran kao „alegorijska lirska pjesma“, „alegorijski ep“, „alegorijski roman“, „alegorijska drama“" itd. S obzirom i na činjenicu da se ni u jednome poetičkom priručniku iz 17. stoljeća alegorija nije izdvajala kao zaseban književni žanr, čini se da bismo i u našem istraživanju što prije morali odustati od utvrđivanja prisutnosti značajki iz repertoara žanra barokne alegorije u Odiljenju sigetskom te se - umjesto toga - fokusirati na razmatranje alegorijske obilježenosti ili alegoriziranosti generički drugačije realiziranoga segmenta Ritterove „zrinijade“. To, dakako, ne podrazumijeva i automatsko isključivanje alegorije iz niza ovdje navedenih pisanoknjiževnih žanrova čije smo karakteristike uočili ili ćemo tek uočiti u ovom neobičnom Vitezovićevu stihovanom ostvarenju, no definitivno pretpostavlja nešto drugačiji genološko-analitički pristup njegovoj dionici u kojoj je alegorija ostavila i više nego dubok sadržajni trag.

Alegorizirani odsječak Odiljenja sigetskog, zbog čijega je generičkog tumačenja bilo neophodno ispisati ovaj podulji uvod, zapravo se svodi na ne naročito opsežan alegorijski „umetak“ situiran u već analiziranoj dijaloškoj pjesmi Gospodična Sofija i oral (II: 735-906), kojom se zaključuje drugi „dil““ teksta. Riječ je o dijelu pjesme što obaseže svega 24 stiha raspoređena u šest dvanaesteračkih katrena (II: 763-786), koji je označen kao replika ili odgovor personificirana orla na prethodno Sofijino pitanje u vezi njegova porijekla, odnosno mjesta s kojega dolazi i na kojemu je sve do nedavno služio gospodara s kojim se naglo bio 
prisiljen „razdružiti““ ${ }^{622}$ Iako već sam po sebi ostavlja dojam značenjski slojevita teksta, taj se odgovor orla odmah u nastavku - u Sofijinu dodatnom pitanju, kojim traži pojašnjenje orlovih „riči““ punih „skrovnosti“ (II: 787) - i izrijekom označava kao dionica čije doslovno značenje ne otkriva njen stvarni smisao budući da je riječ o „skrovitom“ ili nedoslovnom (dakle, alegorijskom) iskazu što iziskuje semantičko „dešifriranje“. Na Sofijino pitanje odakle leti, orao je, naime, odgovorio prilično ,prozirnom“ alegorijskom pričicom, otkrivši joj da je niz godina služio grifa - dakle, grifona ili orlolava, odnosno mitskoga krilatog lava s orlovom glavom - s kojim je počesto zalazio u Zorine šume (lugove) kako bi lovio vukove. Zori su, međutim, ti njihovi ,pohodi“ ubrzo dozlogrdili, pa je okupila silnu vojsku različitih zvijeri vukova, medvjeda, pasa i lavova - pomoću koje je na koncu i dospjela zaskočiti grifa i grifiće u njihovu gnijezdu te ih - unatoč junačkom otporu koji su pružili - sve redom pogubiti.

Orao će u nastavku dijaloga, ipak, uvažiti Sofijinu molbu za dodatnim pojašnjenjem ove „skrovite“ pričice, ispripovijedivši joj u 20 stihova naredne replike (II: 791-810) nesretne događaje koji su prethodili njihovu susretu. Objašnjavajući prethodno izrečenu alegoriju, orao tako otkriva da je godinama u Sigetu služio bana Zrinskog, neustrašivoga borca protiv turskih osvajača, kojega je - želeći jednom za svagda zaustaviti njegove uspješne protuturske akcije car Sulejman zajedno s golemom osmanlijskom vojskom iznenada napao i zatočio u sigetskoj utvrdi. Ni ne pomišljajući pristati na predloženu mirnu predaju grada, kapetan Zrinski je sa svojim suborcima dugo odolijevao svakojakim turskim napadima, na koncu ipak časno poginuvši, odlučan u nakani da do posljednje kapi krvi brani Siget od mrskih mu neprijatelja. Premda je čak i skromno upućenu čitatelju već iz alegorijskoga odsječka moglo i moralo biti jasno na koju se to povijesnu epizodu i na koje povijesne figure odnose ondje opisane akcije i navedeni akteri, orlovo pojašnjenje funkcionira kao i definitivna potvrda kako u ovoj dionici Odiljenja zatječemo povijesnu alegoriju, u kojoj se lik grifa pojavljuje kao alegorija kršćanske mudrosti, hrabrosti, vojne odvažnosti, pa i drskosti, kome su suprotstavljene zvijeri kao alegorija krvožednih turskih neprijatelja, predvođenih Zorom kao očitom alegorijom moćnoga cara Sulejmana, koji je za svoj pohod na Beč - što je vodio preko Sigeta - pod istom zastavom dospio okupiti silan broj turskih vojnika i vojskovođa vrlo raznolika porijekla.

Dijaloška pjesma Gospodična Sofija $i$ oral Ritteru se morala učiniti definitivno najsretnijim i najprimjerenijim mjestom u Odiljenju za uključivanje rečenoga alegorijskog dodatka, navlastito zbog činjenice što poziciju jednog od sugovornika u njoj preuzima upravo personificirani orao. Pojava personificirane životinje u ulozi lirskoga subjekta komunikacijski

\footnotetext{
${ }^{622}$ Sofijino pitanje, konkretno, glasi: „Odkud lićeš sada, gdi si do sad služil, / s kim si se najzada, moj orle, razdružil? / Cić koga li jada tako se raztužil? / Povij, to bih rada da bi mi poslužil““(II: 755-758).
} 
ravnopravnoga drugome, ljudskom govorniku u ovome je lirskom dijalogu na neki način tako učinila „logičnom“ i prisutnost „skrovite“, odnosno zagonetne, (čovjeku-sugovorniku) nedovoljno razumljive alegorijske priče, $\mathrm{k}$ tome još i sa životinjskim te mitskim animalnim akterima, situirane upravo u repliku unesrećenoga orla. $\mathrm{Na}$ isti se način „logičnim“ ispostavlja, u tom smislu, i smještanje mitološke pričice o fatalnoj Narcisovoj zaljubljenosti upravo u eho-pjesmu Putnik $i$ Jeka, u kojoj vila Jeka - kao mitološko biće - s pozicije sugovornika posredstvom svoga kratkog mitološkog narativnog podsjetnika putniku pokušava pomoći u razrješavanju njegovih brojnih ljubavnih nedoumica. I potonje povezivanje mitske priče s mitskim govornikom, kao i uvrštavanje povijesne alegorije s animalnim „likovima“ u iskaz personificirane životinje bjelodan su dokaz Vitezovićeva do u tančine promišljenog literarnog postupka, koji se u najvećoj mjeri bazira na imperativu uključivanja „pravih“ žanrova na ,prava“ mjesta u tekstu, odnosno aktiviranja prepoznatljivih njihovih obilježja na za njih najprimjerenijim ili naprosto ,najlogičnijim“ tekstualnim pozicijama.

Oplemenjujući modusom alegorije jedan segment svoje posebno dirljive dijaloške pjesme Gospodična Sofija i oral, Vitezović se nedvojbeno oslanjao na generičku predodžbu što ju je stekao posredstvom ostvarenja brojnih domaćih i inozemnih „praktikanata“ alegorijskoga stvaralaštva, i to kako onih iz predbaroknih razdoblja, tako i onih koje je alegorija intrigirala u njegovu stoljeću. U slijedu navlastito srednjovjekovne, pa i (donekle) renesansne popularnosti, koja je u europskoj književnosti iznjedrila neka od do danas najreprezentativnijih alegorijskih djela (primjerice, Roman o ruži Guillaumea de Lorrisa i Jeana de Meuna, Danteovu Božanstvenu komediju, Vilinsku kraljicu Edmunda Spensera itd.), iznimno povoljnu reputaciju među piscima i čitateljima alegorija je uživala i u Ritterovo doba, zbog čega se neki proučavatelji ne libe čak ustvrditi kako je, ,nakon srednjovjekovlja, barok (...) drugo veliko književno razdoblje koje pokazuje pojačani interes za alegoriju i alegorijske postupke“ (Zlatar 2010: 13-14). Na alegorijskim prekoračivanjima doslovnoga značenja počivala su tako mnoga onodobna inozemna ostvarenja, od kojih posebno vrijedi izdvojiti drame njemačkih protestantskih dramatičara (Martina Opitza, Andreasa Gryphiusa i Daniela Lohensteina), ali i neke od tada najutjecajnijih epskopjesničkih tekstova poput Miltonova Izgubljenog raja (1667.), pa i Tassova Oslobođenog Jeruzalema, u kojima mnogi književni povjesnici također nalaze prepoznatljive alegorijske momente.

Kada je, pak, riječ o domaćoj nam književnosti toga vremena, nakon učestalog pojavljivanja alegorije u čitavom nizu žanrova u renesansno doba (primjerice, u Marulićevoj Juditi i Davidijadi, Vetranovićevu Piligrinu, Zoranićevim Planinama, pojedinim Držićevim i Vetranovićevim dramskim tekstovima itd.) i ,prijelaznu“ manirističkom razdoblju (navlastito 
u Barakovićevoj Vili Slovinki), barok će u nas iskazivati posebnu sklonost alegorizaciji ponajprije lirskih pjesama ${ }^{623}$ te religioznih poema, ali i epskih pjesama (osobito Osman), pastoralnih drama (pri čemu se ponajprije misli na Gundulićevu Dubravku, u kojoj se lik Dubravke obično tumači kao alegorija dubrovačke slobode), ${ }^{624}$ pa čak i propovjedne proze, u sedamnaestostoljetnom korpusu koje je možda i najdublji trag alegorija ostavila $u$ Habdelićevoj zbirci propovijedi Prvi oca našega Adama greh. ${ }^{625}$ Vitezovićevo Odiljenje u tom se pogledu nadaje kao jedna od potvrda sveopće barokne obljubljenosti i generičke sveprisutnosti alegorije, pri čemu treba znati kako njegov uočeni alegorijski odsječak ne egzistira samo uklopljen u baroku također vrlo drag žanr dijaloške lirske pjesme, koji je - k tomu - utkan još i u (tipično baroknu) generički hibridnu literarnu cjelinu, već i kao dio teksta u kojemu alegorijsko tumačenje nipošto ne provocira isključivo jedan njegov izdvojeni segment. Naprotiv, da replika personificirana orla u pjesmi Gospodična Sofija i oral ipak ne predstavlja usamljeni slučaj alegorije u Ritterovoj „zrinijadi“ sugeriraju nam pojedini govornici ili lirski subjekti, čije nejasno porijeklo i status otvaraju mogućnost njihova tumačenja kao alegorijskih likova, koji svojom pojavom upućuju na nešto drugo, odnosno koji - kao takvi - podrazumijevaju ili alegorijski impliciraju neki točno određen krug ili tip (realno postojećih, izvanknjiževnih) osoba. I dok bi ožalošćena i ogorčena vila Hrvatkinja, koja dobiva riječ u pretposljednjoj pjesmi drugoga „dila“ (II: 614-734), u ponešto slobodnijoj interpretaciji tako mogla biti shvaćena kao svojevrsna alegorija svih neutješnih majki, sestara, supruga i zaručnica, koje je nepovoljan ishod bitke za Siget zauvijek razdvojio od voljenih muških članova obitelji, dotle bi putnika (ili Putnika) što u trećem dijelu o sigetskoj katastrofi raspreda s Jekom (III: 1-376) definitivno valjalo pojmiti kao alegoriju svakoga čovjeka (homo viator) na životnomu putu, koji će ga kad-tad nanijeti i na neki povijesno značajan, možda i memorijalni lokalitet kao što je to (ili kao što bi to trebao biti) i sam Siget. ${ }^{626}$ Dapače, uvjeren u to da bi - nakon izvjesnog oslobođenja od turske vlasti - Siget morao postati jednom od (naj)važnijih postaja na životnom putovanju svakoga homo viatora, Vitezović Odiljenjem sigetskim na neki način i pledira za njegovu obnovu te vraćanje u kolektivnu svijest, i to tek nešto više od desetljeća nakon što su urotničke aktivnosti Zrinskih i njihov neslavan kraj u hrvatskome narodu ozbiljno poljuljali vjeru u tu nekad moćnu magnatsku obitelj, a onda i u njezina najslavnijeg, a možda i povijesno najznačajnijeg izdanka.

\footnotetext{
${ }^{623}$ Popriličan broj alegorijskih lirskih pjesama u 17. stoljeću u nas je, između ostalih, ispjevao Ivan Bunić Vučić.

${ }^{624}$ Usp. Zlatar 2010: 14.

${ }^{625}$ Opširnije o alegoričnosti Habdelićevih propovijedi u: Bartolić 1985.

${ }^{626} \mathrm{O}$ figuri putnika kao mogućoj alegoriji homo viatora detaljnije u: Budišćak 2016a: 263-278.
} 
Računajući, između ostalog, i s njihovim izvantekstualnim potencijalom, odnosno mogućnošću da djeluju u zbilji, Pavao Ritter Vitezović alegorijom će - kao tipični barokist obogatiti i niz drugih svojih hrvatskih, ali i latinskih književnih i ne samo književnih ostvarenja. Tako će se, primjerice, u rukopisnoj lirskoj minijaturi Hroma pravica zabilježenoj u dobro nam znanom njegovu zborniku Otia metrica manuscripta et impressa pravda pojaviti u alegorijskom obličju šeprtljave djevojke koja lomi nogu, dok će, pak, u latinskom grbovniku Stemmatographia sami vizualni prikazi grbova funkcionirati kao alegorije zemalja i pokrajina koje su njima predstavljene i koje potom u pridodanim heraldičkim pjesmama u vlastito ime opisuju te „svoje“ grbove, posebno ističući kako se u heraldičkim simbolima zrcali i sama njihova povijest. Iako u njihovu slučaju nije riječ o „pravim“ alegorijama, već o tekstovima koji se sadržajno zasnivaju na evokaciji alegorijske personifikacije kao jednog od ključnih mehanizama alegorijskoga postupka, ${ }^{627}$ alegoriji bi i više nego bliska bila i ona Vitezovićeva latinska i vernakularna pjesnička ostvarenja - lirske pjesme Lamentatio Segniae, Hrvatkinja i Dalmacija, kronika u stihu Plorantis Croatiae saecula duo i dr. - u kojima personificirani gradovi, regije ili čitave zemlje nastupaju kao lirski subjekti ili pripovjedači osvrćući se pritom na svoju (zlatnu) povijest i (većinom nepovoljno) sadašnje stanje. $U$ usporedbi, međutim, $s$ pobrojanim alegorijskim i „polualegorijskim“ sastavcima, umetnuta alegorija što je nalazimo u zaključnoj pjesmi drugoga dijela Odiljenja sigetskog bez i najmanje se dvojbe nameće kao daleko najuspjelije, pa i „najtipičnije“ Vitezovićevo alegorijsko ostvarenje, odnosno kao alegorijska lirska pjesma kojom se naš autor dospio pozicionirati uz bok ponajboljim baroknim i predbaroknim praktikantima ovoga ,žanra“ ili - preciznije rečeno - ovoga modificiranog (alegoriziranog) generičkog rješenja.

\section{2. 8. Dramska obilježja (Odiljenje kao barokna varijanta postajne drame?)}

Ako se vrhuncima barokne pisane književnosti svojom alegoričnošću Odiljenje sigetsko približava „samo“ djelomično, odnosno tek jednim - prilično kratkim - tekstualnim segmentom, onda im se nedavno već primijećenom dijalogičnošću ili dijaloškim usmjerenjem $\mathrm{u}$ isti mah ono ipak dospijeva približiti u svojoj cijelosti. Da se, naime, Vitezovićeva „zrinijada“ uvelike zasniva upravo na dijaloškoj intenciji, odnosno da posjeduje vrlo izrazite crte - rečeno rječnikom tradicionaln(ij)e genologije - „dramskog“, imali smo prilike uvjeriti se već maločas, razmatrajući ponajprije one njezine segmente što smo ih generički obilježili

${ }^{627} \mathrm{O}$ personifikaciji, na kojoj se najvećim dijelom i temelji alegorijski postupak, opširnije u: Grmača 2015: 63. 
kao dijalošku pjesmu, dijalošku nadgrobnicu, eho-pjesmu te parne pjesme ili lirski razgovor. S obzirom na (prividnu) monologičnost (pre)ostalih njezinih dionica - koje ne počivaju na izmjeni „govornih“ replika dvaju ravnopravnih subjekata - pojedini su književni povjesnici u u svojim studijama i prikazima isticali kako je ona koncipirana, tj. strukturirana kao „niz monologa i dijaloga“ (Švelec 1974: 259), prešutno time ukazujući na njezinu dramatičnost ili dramsku realiziranost, na koju će, pak, znatno eksplicitnije upozoravati kasniji „ritterolozi““.

U nekima od najrecentnijih književnopovijesnih pristupa Odiljenju otvoreno će se tako naglašavati kako se poglavito u prva tri njegova „dila“ - u kojima se redaju fiktivni monolozi i dijalozi različitih govornika - očituje jasna nakana približavanja dramskim žanrovima, ${ }^{628}$ a s vremena na vrijeme neće se, također, zaboraviti pripomenuti ni to da dijaloški strukturirane njegove dionice tekstu u cijelosti daju ,izniman dramski naboj“ (Blažević 2012: 435). Polazeći od već zamijećenoga nedostatka instance (epskoga) pripovjedača te činjenice da u njoj sami protagonisti sigetske katastrofe (navlastito u prvim dvama te u četvrtom „dilu“) govore u vlastito ime, pojedini su proučavatelji konstatirali kako u „zrinijadi“ našega autora „autorskog glasa zapravo nema, pa da zato čitatelj ne sluša priču, nego gleda dramu“ (Pavličić 2007: 255), dok su - s druge strane - u njezinu tumačenju neki književni povjesnici otišli toliko daleko da se nisu libili dovesti je u vezu čak ni s pojedinim domaćim ,punokrvnim“ dramskim baroknim ostvarenjima. Tako je za Slobodana Prosperova Novaka „lirski intonirano Odiljenje sigetsko u najvećem (...) dijelu nalik na prizore Junija Palmotića“, i to ponajprije zato što u njemu - kao i u, primjerice, Palmotićevim Gostima grada Dubrovnika scenom „defiliraju povijesni značajevi, a da njihovi dolasci i odlasci uopće nisu određeni ni unutarnjom ni vanjskom motivacijom“ (Prosperov Novak 1999: 700).

Jedan od najsnažnijih poticaja za razmatranje dramatičnosti Odiljenja pobrojanim je „ritterolozima“ nesumnjivo dala i spoznaja kako su se prepoznatljivo „dramske“ silnice i uopće teatralnost kao takva u baroku nametnule kao gotovo neizbježan dodatak većine literarnih ostvarenja, pa čak i onih koja s dramskim žanrovima na prvi pogled nisu imala previše dodirnih točaka. Ne zaboravimo, naime, da je - izuzev teatarske spektakularnosti, koja se bila u stanju očitovati na svim tekstualnim razinama ${ }^{629}$ - u sedamnaestostoljetnoj (ne samo dramskoj) književnosti također vrlo čest bio i izvorno antički topos svijeta kao pozornice (theatrum mundi), ${ }^{630}$ a uz to je i upravo u barokno doba došlo do naglog procvata dramskih žanrova, ali i širenja njihove tada ionako bogate palete novim (književno-glazbenoizvedbenim) generičkim rješenjima ili kazališnim spektaklima poput opere i igre pod

\footnotetext{
${ }^{628}$ Usp. Blažević 2011: 252.

${ }^{629}$ Detaljnije u: Angyal 1961: 19-79.

${ }^{630}$ Usp. Warnke 1972: 66-89.
} 
maskama. Naglašenom dijalogičnošću, višestrukim govornicima, upošljavanjem obilježja dijaloških lirskopjesničkih žanrova, ispisivanjem lirskih razgovora i ostalim signalima njezina teatralnog usmjerenja Vitezović tako samo dodatno potvrđuje baroknost svoje „zrinijade“, realizirane kao žanrovski izrazito šaroliko stihovano ostvarenje, u čijoj su generičkoj „drami“ važnu ulogu (od)igrala i karakteristična obilježja dramskih žanrova. Suočeni sa zamršenošću njegove jednoznačne žanrovske klasifikacije, pojedini su povjesničari književnosti upravo u tim sveprožimajućim „dramskim“ značajkama Odiljenja vidjeli mogući izlaz iz „začaranoga kruga“" manjkavih mu dosadašnjih generičkih identifikacija, dodjeljujući mu novoskovane teorijske - odrednice, koje su otvoreno trebale ukazivati na tu njegovu hibridnu, ali pretežito dramsku narav. Tako će i Nikica Kolumbić, usprkos činjenici da ga je ranije u više navrata okrstio kao „spjev“, Odiljenje sigetsko proglasiti jedinim (domaćim) predstavnikom tzv. „lirske drame“, odnosno inovativnoga baroknog žanra u kojemu se sljubljuju dvije (u suštini) oprečne strukture - „lirska“ i „dramska“ - i za čiju je pojavu zaslužan upravo Vitezović, koji se na taj način ukazuje „kao barokni žanrovski inovator, bez ograda i obzira koje bi mu nametala nekakva poetika ili škola“ (Kolumbić 1991: 49).

Da Odiljenje, međutim, uključuje i neke generički znatno konkretnije „dramske“ karakteristike od tek drami svojstvene ,strukture“, u svome je pregledu hrvatske barokne književnosti sugerirao Zoran Kravar, koji - pretpostavivši da je Vitezović pri njegovu sastavljanju najvjerojatnije bio pod utjecajem stanovite teatralne predodžbe - zaključuje da bi se, reducirano na isključivo upravni govor, ono lako moglo ispostaviti kao vrlo pogodno za pozornicu, odnosno za teatarsku izvedbu, i to u obliku (srednjovjekovne) alegorijske stationendrame ili postajne drame. ${ }^{631}$ Kravar, drugim riječima, u Ritterovoj „zrinijadi“ primjećuje potencijalnu generičku bliskost onom tipu drame, koji se oblikovao u izravnoj opoziciji spram Aristotelova modela zatvorenoga dramskog teksta s linearnom kompozicijom podijeljenom na činove te s nužno kronološki prezentiranim događajnim tijekom, s kojim - na kraju krajeva - Odiljenje zbog svoje bjelodane nekronologičnosti i kompozicijske nelinearnosti naprosto i nije moglo ostvariti nikakve dublje žanrovske poveznice. Postajna je drama, ukratko, otvorena dramska forma, lišena pravocrtnoga nizanja događaja, u kojoj su pojedinačne scene vrlo labavo povezane, pri čemu je svaka od njih koncentrirana oko jednoga dramskog lika, što na koncu rezultira njezinom izrazitom višeperspektivnošću. Riječ je, dakle, o žanru drame koji počiva na nizanju u sebe zatvorenih, opsegom i važnošću nejednakih i samo ovlaš povezanih prizora ili postaja, koje se drže na okupu isključivo zahvaljujući središnjem liku, iz čijega subjektivnog očišta svi događaji u tekstu i bivaju doneseni. Budući 
da zbog potonjega razloga u stationendrami ne postoji imperativ povezivanja prizora ili postaja u njihovu „logičnom“ ili pravocrtnom slijedu, u njoj se odustaje ne samo od kronologičnosti zbivanja, već i od tradicionalne konstelacije dramskih likova, ali i uobičajenih dijaloga, sadržajno se u potpunosti usredotočujući na subjektivni doživljaj svijeta glavnoga junaka, u okvirima kojega zapravo svi prikazani događaji i svi prisutni likovi postaju ništa drugo no tek njegova puka projekcija. ${ }^{632}$ Subjektiviziranost sadržaja postajne drame nerijetko ide toliko daleko da svi ostali likovi odjednom počinju nastupati iz protagonistove perspektive, dok - istodobno - dolazi do dijalogizacije njegova unutarnjeg monologa, odnosno rascjepljivanja na nekoliko glasova, uslijed čega taj monolog postaje dijalogom koji u svojoj suštini to zapravo i nije. Sve u svemu, očito je da se ovaj dramski žanr - koji potječe od srednjovjekovne religijske drame (drame raspeća) i koji će se, nakon oživljavanja potkraj 19. stoljeća, prometnuti u jedan od omiljenih žanrova ekspresionističkih dramatičara $-u$ sadržajnom pogledu ne fokusira (nalik tradicionalnoj drami) na tijek događaja, već na same likove i njihov subjektivni doživljaj stvarnosti, u čemu je uistinu moguće nazrijeti vrlo očite paralele i s Odiljenjem sigetskim Pavla Rittera Vitezovića.

Prihvati li se - dakako, uz neophodne ograde - ovakva generička percepcija kao jedan od legitimnih (iako ne i nužno ispravnih) pristupa Ritterovu žanrovski slojevitom ostvarenju, neriješenim će se u tom slučaju ispostaviti pitanje središnje figure, odnosno glavnoga lika ili protagonista teksta, čije bi subjektivno iskustvo pada Sigeta trebalo dominirati svim „dilovima“ teksta funkcionirajući ujedno i kao njihovo „vezivno tkivo“. Iako među likovima, točnije govornicima Odiljenja sigetskog ne postoji - na prvi pogled - niti jedan čiji su iskazi zastupljeni u svakoj od četiriju njegovih dionica, moguće je ipak zapaziti kako iza svih ili makar velike većine u njima okupljenih pjesama stoje kazivači koji pripadaju jedinstvenoj nadpersonalnoj figuri ili kategoriji, i to - konkretno - onoj putnika. Na putovanje u Siget bili su tako „osuđeni“ hrvatski branitelji na čelu s banom Zrinskim, potom osmanlijski napadači koji su prevalili dug put ne bi li ga osvojili i produžili prema Beču, zabrinuta vila Hrvatkinja što osobno dolazi u Siget provjeriti istinitost glasina o kršćanskom porazu, nesretni orao koji nakon dovršetka sigetske bitke traži mirno mjesto na kojem će provesti posljednje svoje dane,

\footnotetext{
${ }^{632}$ Pobočni se likovi u stationendrami, kako pojašnjava Peter Szondi, pojavljuju isključivo u susretu s glavnim likom, odnosno u njegovoj perspektivi te se isključivo kao takvi oni i odnose spram njega. Sama radnja iz toga razloga nije zasnovana na međuljudskim odnosima, već se u njoj pokušava oblikovati, tj. prikazati put glavnoga junaka, zbog čega se scene (činovi i prizori) - čije jedinstvo slijeda osigurava jedinstveni protagonist - nameću kao „tek“ isječci razvoja koji nadilazi same dramske granice. Te pojedinačne scene stoga ne proizlaze - kao u „tradicionalnoj“ drami - jedna iz druge, što će reći da ne stoje u uzročnom odnosu (nisu, dakle, organski povezane), već se „pojavljuju kao izolirani kamenčići nanizani na konac subjekta u pokretu“ (Szondi 2001: 41), a k tome su još i statične i besperspektivne te posredstvom njih radnja drame ni izbliza nije zahvaćena u svojoj cijelosti. Detaljnije o ,poetici“ postajne drame, odnosno postajnoj tehnici u: Szondi 2001: 41-49.
} 
pokojnici koji se u posljednjem „dilu“ iz druge „dimenzije“, u koju su otputovali uz pomoć anđela, javljaju živima ne bi li ih podsjetili na sveprisutnost i svemoć smrti kojoj su i sami bili prisiljeni podleći, a - naposljetku - i sam putnik-slučajnik, kojega je put nanio u neposrednu blizinu sada već turske sigetske utvrde. Shvatimo li „likove“ ili lirske subjekte Odiljenja na ovaj način, postat će i više nego očito da je upravo figura ili kategorija putnika ona koju nalazimo zastupljenu u jednakoj mjeri u svim četirima „dilovima“, što će onda reći i da bi jedino za nju trebala biti rezervirana pozicija ,protagonista“ ili središnjega lika (govornika), o čijem je osobnom doživljaju opsade i riječ u svim naoko nepovezanim dionicama teksta i koje upravo zahvaljujući njoj i stječu tu nužnu provodnu, odnosno zajedničku sadržajnu „,nit““633

Možebitne generičke veze Odiljenja sigetskog i izvorno medijevalnih dramskih žanrova nipošto se, kako se čini, ne svode isključivo na one što ih Vitezovićeva „zrinijada“ ostvaruje s postajnom dramom, tim više što je brojne značajke iz njezina generičkog repertoara - zastupljene, uostalom, i u samom Odiljenju - sa stationendramom dijelilo i srednjovjekovno crkveno prikazanje. Kao dramski je žanr prikazanje, naime, po karakterističnim tekstualnim svojstvima uvelike usporedivo upravo s postajnom dramom, ponajprije stoga što se i u njoj ,jednakovrijedne epizode nižu jedna do druge, ne uvjetujući se međusobno nekim motivacijskim sustavom“, slijedom čega „svijet predstavljen i prikazan u srednjovjekovnoj drami djeluje na taj način kao panorama, $\mathrm{u}$ kojoj istodobno i istovrijedno $-\mathrm{u}$ dramskom smislu - postoji i zemaljsko i nebesko i pakleno“ (Fališevac 2007b: 69). Pored toga što je (i) u njima redovito tematiziran neki publici otprije dobro poznat (i pretpostavljeno istinit) događaj te činjenice da su njihovu „,radnju“ nosili pasivni tipski likovi podložni sudbinskim hirovima (među kojima nije postojala „prava“ hijerarhija), sama struktura prikazanja počivala je na redanju paralelnih epizoda, odnosno jednakovrijednih fabularnih tokova lišenih značajnijih uzročno-posljedičnih veza, što je za svoju posljedicu imalo izostajanje dramske napetosti koja bi proizlazila iz kronološki vođene radnje bazirane na zapletu i raspletu te oštro profiliranim likovima. Štoviše, među likovima u prikazanju nije postojala uzajamnost (međusobno razumijevanje), pa onda ni pretpostavka za razvijanje konflikta, već su njihovi iskazi - od kojih je svaki donosio jedan djelić priče - bili upućivani izravno publici, pri čemu je i „radnja“ - kao takva - bez ikakve motivacije prelazila od jednoga lika na drugi i selila se usput s jednoga mjesta na drugo. Zahvaljujući svojoj labavoj strukturi crkveno se prikazanje ispostavilo kao žanr naročito otvoren za upijanje dodatnih (sporednih) epizoda i likova, ali i cjelovitih primjeraka manjih žanrova ili žanrovski raznoliko realiziranih umetaka, pa osim što u njemu često svjedočimo miješanju uzvišenih prizora $\mathrm{i}$

${ }^{633}$ Usp. o figuri putnika kao mogućem ,glavnom junaku“ Odiljenja sigetskog u: Budišćak 2016a: 268-269. 
epizoda iz svakodnevice te uključivanju transcedentalnih bića (npr. anđela) i personificiranih apstrakcija (poput, primjerice, personificiranih sedam kršćanskih vrlina), unutar njegovih tekstualnih granica gotovo u pravilu nalazimo i generički kojekako ostvarene dionice, koje je moguće identificirati kao kraće dramske tekstove, narativno-dijaloške lirske pjesme, moralnodidaktičke pouke, religiozne lirskopjesničke žanrove (pjesme o Kristovoj muci, molitve, himne) itd. Crkveno prikazanje, drugim riječima, ne samo što je poticalo preplitanje različitih književnih žanrova, koje je pritom podvrgavalo višemu organizacijskom načelu, nego je i samo - kao žanr - nastalo upravo kombiniranjem značajki iz repertoara nekolicine (,jednostavnijih“) generičkih rješenja, odnosno njihovim prefunkcioniranjem i stapanjem, ${ }^{634}$ po čemu se ispostavlja kao izrazito blisko žanrovski hibridnoj fakturi Odiljenja, kojem identitet (baroknoga) prikazanja ipak - složit ćemo se - ne pristaje u potpunosti.

Bez obzira na poveći broj postajnoj drami i crkvenom prikazanju vrlo bliskih, pa čak i gotovo identičnih tekstualnih osobina, Ritterova „zrinijada“ teško bi se, dakako, bez ostatka generički mogla okarakterizirati kao „punokrvan“ dramski tekst, i to samo dijelom (i) zbog činjenice što su ti njezini eventualni dramski žanrovski uzori bili rečenoga predbaroknog, odnosno medijevalnog porijekla. Doduše, treba znati da primjercima crkvenog prikazanja nakon njegove silne popularnosti u srednjem vijeku, koja se zatim prelila i u renesansno doba - nije oskudijevala ni književnost 17. stoljeća, no barokna se praksa sastavljanja ovoga žanra gotovo u potpunosti bazirala na uvažavanju prvotnoga, srednjovjekovnog njegova modela, za razliku od - primjerice - one šesnaestostoljetne, u sklopu koje je došlo do privremenoga osuvremenjivanja žanrovskog mu repertoara. ${ }^{635}$ Također, Vitezovićevo kreativno oslanjanje na stanovite primjerke crkvenoga prikazanja ili postajne drame nije moguće potkrijepiti konkretnim dokazima, ali niti argumentirano opovrgnuti, slijedom čega nam ne preostaje ništa drugo nego tek osloniti se na pretpostavku kako se - kao literarno iznimno dobro potkovan autor i sjajan poznavatelj domaće književne tradicije - jamačno on imao prilike susresti i s nekolicinom predbaroknih primjera ovih dramskih žanrova, a vrlo vjerojatno i s pokojim sedamnaestostoljetnim domaćim crkvenim prikazanjem. Ukoliko je tomu doista i bilo tako, nije nemoguće da su ga (i) ta žanrovski šarolika dramska ostvarenja potaknula na pisanje njegove hibridne ,zrinijade“, protkane njima vrlo bliskim tekstualnim postupcima, čija se svrha - između ostalog - možda sastojala i u tome da makar ponekog čitatelja navedu na pomisao da je riječ o dramskom ostvarenju pogodnom čak i za scensko uprizorenje.

\footnotetext{
${ }^{634}$ Podrobnije o žanru (srednjovjekovnoga) crkvenog prikazanja u: Fališevac 2007b: 63-75.

${ }^{635}$ O tome u: Kolumbić 1991: 42.
} 
Utvrđenu dijalogičnost i uopće dramski „naboj“ Odiljenja sigetskog naš je autor, međutim, lako mogao postići i bez izravnoga ugledanja u konkretne dramske tekstove barokne i/ili predbarokne provenijencije, tim više što su se upravo dijalozi ili dijaloške dionice nametnuli kao više-manje neizostavan tekstualni čimbenik mnogih (baroknih) žanrova, poglavito (povijesne) epske pjesme, ali vrlo često i lirske pjesme, koja je i u 17. stoljeću - naročito kada se njome željelo opjevati konflikt nepomirljivih suprotnosti ${ }^{636}$ počesto realizirana u otprije nam dobro znanom dijaloškom obliku. Osim što svoje djelo napučuje pojedinim prepoznatljivo epskopjesničkim postupcima i obilježjima dijaloške lirike, ali i u nj uvrštava čak i nekolicinu u svoje vrijeme ništa manje popularnih parnih lirskih pjesama ili lirskih razgovora (dvogovora), on će ujedno i jednu čitavu njegovu dionicu generički realizirati kao eho-pjesmu ili versus echoici, ispisavši tako jedan od brojnih domaćih primjeraka u ranonovovjekovlju vrlo proširenoga književnog žanra, koji je u renesansi - kada je i započelo razdoblje njegove izuzetne omiljenosti - svojom prisutnošću nerijetko učvršćivao žanrovske konvencije pastoralne drame ili pastorale. ${ }^{637}$ Dijaloškodramske crte Odiljenja, na kraju krajeva, nipošto ne bi bilo neopravdano dovesti ni u vezu s Ritterovim školovanjem u zagrebačkoj isusovačkoj gimnaziji, ${ }^{638}$ u sklopu kojega je jedna od nastavnih njegovih obaveza bila i sudjelovanje u javnim đačkim predstavama, u kojima su uprizorivani (većinom latinski) dramski tekstovi različite - iako mahom religiozne - tematike.

Znamo li, naime, da su mnoga od maločas pobrojanih obilježja postajne drame $\mathrm{i}$ crkvenoga prikazanja - na koja neodoljivo podsjećaju i pojedine tekstualne posebnosti Odiljenja - bila ujedno zastupljena i u (nesačuvanim) sedamnaestostoljetnim isusovačkim dramama što su ih izvodili polaznici jezuitskih škola, i Vitezovićevo će nam se možebitno posezanje za njima ili njima izuzetno sličnim „dramskim“ značajkama u tom smislu učiniti ciljanim, odnosno tijesno povezanim s njegovom isprva recipijentskom, a onda i izvođačkom percepcijom tih dramskih tekstova sastavljanih ponajprije za jezuitske obrazovne potrebe. Konkretno, iako se takvoj pretpostavci mogu suprotstaviti brojni i nimalo neopravdani prigovori, potonje nas zapažanje vrlo lako navodi na pomisao kako je rečenim „dramskim“ momentima Ritter napučio svoju ,zrinijadu“ računajući na izvedbu njezina teksta u cijelosti ili makar navedenih joj dijaloških dionica, i to - kako se čini - svjestan da bi upravo njezino uprizorenje bitno pridonijelo širenju i ,uvježbavanju“ jedinstvenoga, tronarječnog hrvatskog jezika, baš kao što je, uostalom, i većina (do)tadašnjih isusovačkih predstava učenicima-

\footnotetext{
${ }^{636}$ Usp. Warnke 1972: 70.

637 Tako će, primjerice, 1589. mađarski pjesnik Bálint Balassi objelodaniti preradu pastorale Amarilli talijanskoga pjesnika Cristofora Castelletija pod naslovom Szép Magyar Komédia (Lijepa mađarska komedija), u kojoj bitnu ulogu igraju upravo versus echoici.

${ }^{638} \mathrm{O}$ tom razdoblju Vitezovićeva života podrobno u: Klaić 1914: 9-38.
} 
glumcima bila od iznimne pomoći pri uvježbavanju dobroga govora i izgovora latinskog jezika. ${ }^{639}$ Bit će da se, osim toga, Vitezović ozbiljno nadao da će njegovu literarnu glorifikaciju žrtve sigetskih branitelja polaznici isusovačkih kolegija, ako ne već postaviti na pozornicu, onda makar čitati kao svojevrsnu obaveznu lektiru, slijedom čega je i držao nužnim opremiti je toliko „napadnim“ izrazima domoljublja, odanosti kralju i „pravoj“ vjeri te uopće propagiranjima kršćanskih vrijednosti i „pravovjernoga“ svjetonazora, kakvima su bili bremeniti i mnogi didaktički tekstovi namijenjeni učenicima jezuitskih gimnazija. S obzirom na to da su upravo onodobni isusovački kolegiji (u Zagrebu i Varaždinu) imali zadaću da „odgojem mladih generacija u katoličkome duhu i dušobrižničkim djelovanjem u gradovima i selima učvršćuju nacionalno jedinstvo, potiskuju protestantizam i doista osposobljuju visoki i sve više srednji stalež za ustrajnu obranu domovine i vjere“ (Hoško i Korade 2003: 195), njihovi su pitomci neke od ključnih vjerskih i „svjetovnih“ lekcija usvajali i čitanjem latinskih priručnika za odgoj mladeži, odnosno moralističko-didaktičkih (književnih) djela za školsku uporabu poput - primjerice - zbornika Ideae magnanimitatis Illyricae et Pannonicae (Ideje ilirske $i$ panonske velikodušnosti, 1705.) Ivana Franje Čikulina, u kojemu se propagiraju herojske vrline najistaknutijih kršćanskih junaka iz ,ilirske“ i ,panonske“ prošlosti. ${ }^{640}$

Premda je Pavao Ritter Vitezović najvjerojatnije gajio nadu da bi i njegovo Odiljenje kao literarni primjer poželjnoga domoljublja, junaštva, lojalnosti i odanosti kršćanskim vrijednostima i uopće „,višim idealima“ - moglo ući u krug potonjih lektirom „propisanih“ poučnih ostvarenja i tako osigurati (i) čitatelje u jezuitskim školama, ta je njegova nada ipak počivala na vrlo krhkim temeljima budući da su isusovački didaktički tekstovi redom bili utilitarna, poluknjiževna djela ispisana, u pravilu, latinskim jezikom. Neznatno veću šansu za ulazak u isusovačke gimnazije njegova je ,zrinijada“ stoga imala u obliku svojevrsnoga dramskog predloška za scensko uprizorenje, tim više što je jezuitsko kazalište pokazivalo bitno veću otvorenost tematski, pa i žanrovski raznolikijim dramskim ostvarenjima, navlastito ako su ona, k tome, bila još i na latinštini. Imperativ latinskoga jezika, kako se čini, u pogledu ovih dramskih sastavaka ipak nije bio toliko neumoljiv kao što je to bilo u slučaju didaktičkih priručnika, iako su do domaćih isusovačkih pozornica zaista rijetko dospijevale nelatinske drame, među kojima su - pored, dakako, nabožnih - najbrojnije bile one povijesne tematike. I baš kao što su, primjerice, u njemačkim i romanskim isusovačkim kazalištima u barokno doba često izvođeni tekstovi u kojima se tematizira borba između ,pogana“ i kršćana te proslavlja

\footnotetext{
${ }^{639}$ Usp. Bartolić 1985: 89-92.

${ }^{640}$ O spomenutom Čikulinovu djelu posebno u: Blažević 2007: 249-264.
} 
teško izborena, ali zaslužena pobjeda ovih potonjih, ${ }^{641}$ tako su i na našim jezuitskim pozornicama prostora dobivale ne samo nabožne i mitološke, već i drame s motivima iz starogrčke, ali i - znatno više - hrvatske povijesti, i to navlastito one koje su progovarale o nekim posebno značajnim pojedincima iz domaće nam prošlosti, u krugu kojih je posebno omiljen i najglasnije slavljen (još uvijek) bio upravo Nikola Šubić Zrinski. ${ }^{642}$ Uz njih, polaznici domaćih isusovačkih kolegija počesto su uprizorivali i alegorijske igre, u kojima su se kao likovi pojavljivale alegorije ili personifikacije, i to najčešće stanovitih kršćanskih ideja i motiva (primjerice, personifikacije vrlina i grijeha, naslade i kazne, ljubavi i boli, duše i tijela itd.), potom gradova, zemalja, pokrajina, dvorova, imanja te samih institucija, ${ }^{643}$ ali nije u njima bila rijetkost susresti ni personificirane zvijezde, vile, pa čak i - u skladu s baroknim duhom - personificirane grbove plemićkih obitelji. ${ }^{644}$ To će, drugim riječima, reći kako ni potencijalnoj publici dramatiziranoga Odiljenja sigetskog zacijelo ni najmanje ne bi bilo neobično na pozornici ugledati lik personificirane utvrde, orsaga, vile ili čak orla, iako bi kako se čini - u slučaju svoga uprizorenja ono najvjerojatnije bilo svedeno ne na „punu“ dramsku igru, već na tek ,puku“ deklamaciju, što će reći na kazališni oblik, koji je u 17. stoljeću također poiman kao „punopravni“, integralni dio isusovačkoga teatra.

Da Vitezovićeve vjerojatne ideje o scenskoj izvedbi nedramskog, odnosno samo u naznakama dramskog teksta nipošto nisu bile sasvim promašene potvrdit će nam - doduše, znatno kasniji - primjer njegova hagiografskog spisa Vita et martyrium B. Vladimiri, Cratiae regis (Život $i$ mučeništvo hrvatskog kralja blaženog Vladimira, 1705.), iz čijih će motiva izrasti latinska legenda o sv. Vladimiru Princeps pro populo victima sive D(ivus) Vladimirus, Podgoriae rex et martyr (Vladar žrtva za narod ili Sv. Vladimir, kralj podgorski i mučenik), koju su 1732. izveli polaznici zagrebačke jezuitske gimnazije. ${ }^{645}$ Iako se ne radi o potvrdi uprizorenja konkretnoga Ritterova (u ovom slučaju hagiografskog) teksta, potonji slučaj i više nego bjelodano ukazuje na postojanje dramski ,potentnih“ mjesta, kojih je nezanemariv broj moguće locirati i u samome Odiljenju sigetskom, pri čemu nipošto ne treba upasti u zamku njihova proglašavanja ,punokrvnim“ dramskim obilježjima, baštinjenima iz žanrovski ovako

\footnotetext{
${ }^{641}$ Usp. Angyal 1961: 223-227.

${ }^{642}$ Opširnije u: Georgijević 1969: 64-65, Vanino 1969: 261-288 i Batušić 1978: 144-147. Pouzdano se tako zna da su sigetska junaštva Nikole Šubića Zrinskog tematizirana u isusovačkoj latinskoj drami prikazanoj na kraju školske godine 1749. (usp. Vanino 1969: 270), no ispravno je pretpostaviti da je ista tema svoju dramsku obradu, a onda i uprizorenje na isusovačkim pozornicama doživjela i znatno prije te godine, jamačno već i u Vitezovićevo vrijeme, a vrlo vjerojatno i mnogo ranije.

${ }^{643}$ Tako su, primjerice, 1653. - povodom prenošenja moći sv. Viktora mučenika - ispred crkve sv. Katarine kratku dramsku igru odigrala četiri genija, i to ,geniji Hrvatske, grada Zagreba, kolegija Družbe Isusove i gimnazije“"(Vanino 1969: 275).

${ }^{644}$ Detaljnije u: Vanino 1969: 261-288. Za preciznije informacije o dramama izvedenima na onodobnim isusovačkim pozornicama usp. Ljubić i Petranović 2012: 11-82.

${ }^{645}$ Usp. Vanino 1969: 266.
} 
ili onako ostvarenih konkretnih dramskih tekstova, ponajprije zato što iza njih ne stoji nužna izvedbena intencija, odnosno zato što tu intenciju u samom tekstu nije moguće sa sigurnošću utvrditi. Budući da su se i u 17. stoljeću dramski žanrovi u odnosu spram drugih generičkih rješenja najjasnije izdvajali svojom eksplicitnom izvedbenom, tj. scenskom namjenom, Vitezovićevu ,zrinijadu“ - oplemenjenu (baroknoj) drami podudarnim svojstvima i rješenjima - nikako nije ispravno, a ponajmanje opravdano žanrovski označiti kao dramu, pa onda ni kao bilo koji ranije već spomenut ili nespomenut dramski žanr. Odiljenje sigetsko Pavla Rittera Vitezovića, ukratko, ništa je drugo no „tek“ pjesničko ostvarenje obilježeno izrazitom dijalogičnošću, u kojem se na gotovo svim tekstualnim razinama očituje većini baroknih tekstova svojstvena teatralnost, dok konkretne njegove osobine koje bi pojedini recipijenti mogli prepoznati kao nepobitno „dramske“ zapravo ne potječu iz repertoara pojedinih dramskih žanrova, već je riječ o generički fluidno izvedenim rješenjima čije porijeklo u potpunosti ovisi kutu gledanja i očekivanjima s kojima recipijent prilazi tekstu, previđajući pritom da se radi o djelu koje je u stanju poprimati identitet različitih pisanoknjiževnih, pa i ne samo pisanoknjiževnih žanrova i u čijoj fakturi zatječemo i niz obilježja onih poluknjiževnih, izvanknjiževnih, pučkoknjiževnih, ali i usmenoknjiževnih, kojima nam na stranicama što slijede napokon i valja posvetiti punu istraživačku pozornost.

\section{3. USMENOKNJIŽEVNI ŽANROVI}

Razmatrajući pisanu i usmenu književnost kao dvije literarne sfere, književni su povjesničari u prošlim desetljećima u više navrata potvrdili ${ }^{646}$ kako se svaka od njih oslanja na sebi svojstvenu poetiku, čija se različitost u usporedbi s onom drugom najsnažnije očituje upravo u domeni samih književnih žanrova. Specifičnim tretmanom usmene književnosti, odnosno njezinim razgraničavanjem $\mathrm{i}$ isticanjem $\mathrm{u}$ odnosu spram pisanoknjiževnih ili „umjetničkih“ sastavaka ili dijelova teksta, naši su „stari“ pisci jasno pokazivali da im ta „poetička“ specifičnost folklorne književnosti nipošto nije strana, što bi značilo da su i sami već tada uvidjeli kako je izostanak svijesti o mijenama literature kroz vrijeme u njoj rezultirao postojanim žanrovskim konvencijama (formulama, funkcijama itd.), ${ }^{647}$ neusporedivima s privremenim generičkim normama pisanoknjiževnih žanrova, u potpunosti ovisnima od

\footnotetext{
${ }^{646}$ Naročito usp. Pavličić 1983: 129-155.

${ }^{647}$ Imajući to umu, pojedini će proučavatelji - možda ne posve bezrazložno - upozoriti kako se u kontekstu razgovora o samoj usmenoj književnosti sam termin ,žanr“" ne bi trebao shvaćati na isti način na koji se to čini kada je riječ o pisanoj književnosti, tim više što su usmenoknjiževni ,žanrovi“ zapravo ništa drugo no svojevrsne uvriježene kombinacije osnovnih konvencija ili generičkih elemenata (formula, shema, tema i motiva, tipova junaka, stilskih figura itd.), koje se pri svakoj novoj izvedbi opet iznova sklapaju u novu literarnu cjelinu (usp. Burke 1991: 76-95).
} 
poetike svakoga književnoumjetničkog razdoblja. Perzistentnost tih žanrovskih normi (dakle, očita težnja da se žanrovi održe i, kao takvi, nasljeduju) u usmenoj se književnosti nameće kao jedan od ključnih alata pomoću kojega sama djela - koja ne kruže u pisanom obliku jer uopće nisu grafički fiksirana, nego se iznova re-kreiraju posredstvom svake nove izvedbe dospijevaju preživjeti u svijesti zajednice, konzervirajući se kao skup „vječno“ važećih konvencija svojstvenih svakom pojedinačnom žanru. Budući da folklornoknjiževni žanrovi uvijek teže jednakomu cilju, „logično“ je i da se služe uvijek jednakim sredstvima, vodeći se pritom idejom „kako je jednoj formi najprimjerenija jedna tema, jedan tip stila, stiha ili strukture“ (Pavličić 1983: 149), iz čega bi - na kraju krajeva - slijedilo kako je posve promašeno pristupati im kao pisanoknjiževnim povijesnim (primjerice, renesansnim, baroknim itd.) žanrovima zanemarujući pritom činjenicu da se njihov „repertoar“ nije mijenjao zajedno s poetikama pojedinih književnih razloga te da vrijeme nastanka i/ili bilježenja u tom smislu nema mnogo veze s konkretnim im generičkim osobitostima.

Za razliku od pisanoknjiževnoga podvođenja manjih žanrova (formi) pod veće generičke kategorije, odnosno jasno razvijene svijesti o vertikalnoj klasifikaciji, u „narodnoj“ književnosti žanrovi egzistiraju kao zasebni, horizontalno odijeljeni entiteti, što će reći posve ravnopravno i ne računajući jedni na druge, zbog čega gotovo nikada i ne dolazi do njihova (svjesnog) miješanja (kao što je to često slučaj u pisanoj književnosti), ali ni do „migriranja“ konkretnih obilježja u „repertoare“ drugih žanrova. Ta njihova ravnopravnost i individualnost, osim što dodatno osnažuje postojanost generičkih im normi, ujedno se ispostavlja i kao jamstvo trajanja samih folklornoknjiževnih ostvarenja s obzirom na to da onemogućavanjem njihova miješanja ujedno sprječava pojavu nerazumijevanja tih žanrova, zbog kojega bi i sam čin usmenoga prenošenja djela kao takav postao nemoguć. Zahvaljujući tom svojstvu folklornoknjiževnih žanrova, „narodna“ ostvarenja čiji zapisi datiraju iz davnijih vremena posve legitimno možemo uspoređivati sa znatno „mlađim“ zapisima, točnije pristupiti rekonstruiranju njihovih generičkih konvencija na podlozi novije zabilježenih primjeraka istoga žanra, jer su kroz vremenski period što ih dijeli te konvencije ionako ostale gotovo u potpunosti netaknute. Štoviše, da se „stari“ usmenoknjiževni žanrovi bez i najmanjih prepreka mogu prepoznati u optici onih ,novih“ potvrdit će se upravo u ovomu poglavlju, gdje ćemo sud o žanrovima folklorne književnosti zastupljenima unutar granica Odiljenja sigetskog donijeti upravo oslanjajući se na njihove opise zasnovane na analizi znatno modernijih zapisa žanrovski identično realiziranoga folklornoknjiževnog blaga.

Usprkos neprekidnom inzistiranju na ,žanrovskim konvencijama (normama)“, generičkom „repertoaru“ te „karakterističnim“ značajkama pojedinih usmenoknjiževnih 
žanrova, nužno je znati da se ne radi zapravo ni o čemu drugome no o teorijski (naknadno) skrojenim konstruktima, koji u folklornoj literarnoj praksi - kao takvi - nemaju gotovo nikakva značaja, ponajprije zato što se ni sami stvaratelji, a još manje „konzumenti“ tih usmenih ostvarenja pri samom činu njihove izvedbe nimalo ,ne obaziru na teorijske postavke za pojedine rodove i vrste“ (Botica 2013: 45). Premda i jedni i drugi - na temelju ranijega recipijentskog iskustva - intuitivno itekako dobro znaju koji je žanr najprikladniji u kojoj situaciji te kakve konkretno sadržaje i formu svaki od njih pretpostavlja (u stanju su, dakle, povezati određenu temu s ,njezinim“ žanrom, ali i u praksi razlikovati „pjesmu“ od priče“, „predstavu“ od „poslovice“ i sl.), teorijski (poetički) formuliranim znanjem o tim žanrovima oni ipak ne raspolažu, ${ }^{648}$ što je vidljivo i u izostanku eksplicitnih žanrovskih imenovanja ili određenja njihovih djela, iako se u njima povremeno ipak mogu zateći motivi pjevanja „popijevki“, „napojnica“, „bugaršćica“, „začinki“, „davorija“ itd. Razlučivanje žanrova „narodne“ književnosti prema „karakterističnim“ značajkama iz njihova „repertoara“ ili svevažećim im generičkim normama ili konvencijama u tom bi pogledu, dakle, bilo ništa drugo no puka teorijska intervencija, odnosno svojevrsno „domišljanje“ ili organiziranje usmenoknjiževne tradicije, u kojoj se žanrovska podloga za svako ostvarenje - zajedno s pripadajućom joj kombinacijom „specifičnih“ obilježja - odabire spontano, dakle bez pretpostavljenoga teorijsko-poetičkog ,predumišljaja“ i u potpunosti u skladu s konkretnim okolnostima (kontekstom ili situacijom) te samom svrhom dane izvedbe ili teksta.

S obzirom na - ponajviše - ovu provizornost generičkih razgraničenja, koja se u samoj folklornoknjiževnoj praksi ne pojavljuju u (književno)teorijski osviještenu obliku, znatan će broj folklorista glasno zagovarati potpuno odvojen pristup usmenoj i pisanoj književnosti, napominjući kako je riječ o dvjema zasebnim literarnim sferama s posve različitim generičkim sustavima i uopće različitom koncepcijom i strukturom žanra, odnosno književnim ,arealima“ u kojima se umjetnička poruka recipira na bitno drugačije načine, iako se obje temelje na ljudskoj jezičnoj aktivnosti, koja ih usprkos svim distinkcijama dubinski povezuje. ${ }^{649}$ Kako su folkloristička istraživanja već poodavno utvrdila, žanrovi folklorne od onih pisane književnosti ne razlikuju se samo po svome usmenom načinu postojanja, nego ujedno i po specifičnim situacijama ili okolnostima svoje izvedbe te po neobično čvrstoj vezanosti uz konkretne izvanknjiževne funkcije; oni su, drugim riječima, presudno obilježeni svojom (,izvanknjiževnom“) uporabom te se - kao takvi - u isti mah nameću i kao književne

\footnotetext{
${ }^{648}$ Detaljnije o ovom pitanju u: Botica 2013: 45-46.

${ }^{649}$ Usp. o tome u: Lozica 1990: 111.
} 
kategorije i kao pojave životne svakodnevice. ${ }^{650}$ Premda je, međutim, maločas uočena poetička nepromjenjivost „narodne“ književnosti rezultirala time da folklorni žanrovi - za razliku od onih pisanoknjiževnih - počivaju na (zamišljenim) trajnim generičkim normama, apsolutna ovisnost njihove egzistencije od izvedbe koja se odvija unutar nekoga određenog konteksta ostavila je ipak otvorenom mogućnost variranja njihovih „karakterističnih“ osobina, koje se od jedne do druge izvedbene evokacije - kako su neke maločas spomenute recentnije analize uvjerljivo potvrdile - ponešto doista mijenjaju, no nikada (ili zaista rijetko) u tolikoj mjeri da bi to dovelo do ispuštanja stanovitih „temeljnih“ žanrovskih obilježja (poput, primjerice, formulaičnih izraza u epskoj pjesmi), bez kojih ni sama izvedba žanra primjerenog danim okolnostima naprosto ne bi bila moguća.

Dubinskim razlikama što stoje između generičkih rješenja ovih dviju literarnih sfera usprkos, zanimljivo je primijetiti kako relativno „svježa“ genološka spoznaja da (pisanoknjiževne) žanrove na svim razinama presudno obilježava upravo njihova usklađenost s konkretnim književnim i/ili izvanknjiževnim kontekstom ili situacijom, uslijed koje im valja izvršiti stanovite zadaće, nije tako daleko od netom utvrđene kontekstom inicirane izvedbene egzistencije folklornoknjiževnih žanrova, u potpunosti podređene ispunjavanju određenih funkcija u stvarnosti. Pritom, međutim, ne treba smetnuti s uma da je upravo potonja specifična društvena svrha, što su je u okvirima danoga društvenog konteksta ostvarivali pojedinačni folklorni žanrovi, bila ona koja je određivala provizornu generičku hijerarhiju usmene književnosti, dok se - s druge strane - hijerarhijski poredak žanrova u sferi pisane literature temeljio na poetici svakoga zasebnog književnoumjetničkog razdoblja, koja je književnost obično razumijevala kao zasebnu djelatnost obilježenu zasebnim (društvenim i estetskim) vrijednostima zajedničkima za sve žanrove, a ne različitima od žanra do žanra, kao što je to bio slučaj s usmenom književnošću, gdje je žanrove definiralo okružje iz kojega su iznikli, točnije stanovita društvena funkcija što su je u njemu imali. ${ }^{651}$ Zahvaljujući utvrđenoj neizbježnoj kontekstualnoj orijentiranosti žanrova obiju literarnih sfera, nimalo neće biti neobično to što se suvremeni (književnopovijesni i folkloristički) pristupi usmenoknjiževnim žanrovima ne razlikuju odviše od recentnih genoloških razmatranja pisanoknjiževnih žanrova, ${ }^{652}$ odnosno što se teorijske predodžbe formulirane u okrilju književne genologije sve češće i sa sve većim uspjehom - kao što smo vidjeli nešto ranije - primjenjuju i u folklorističkim proučavanjima generičkih rješenja „narodne“ književnosti. Usprkos njezinoj

\footnotetext{
${ }^{650}$ Opširnije naročito u: Bošković-Stulli 1978: 22.

${ }^{651}$ Detaljnije o posebnostima usmenoknjiževnih žanrova npr. u: Bošković-Stulli 1978: 21-28, Kekez 1998: 133152 i Botica 2013: 44-52.

652 O tome osobito u: Honko 1989: 13-28.
} 
već konstatiranoj nedorečenosti, i pri razmatranju usmenoknjiževnoga bi se žanrovskog „materijala“ uključenog u Vitezovićevo Odiljenje sigetsko bez većega ustručavanja stoga moglo posegnuti i za teorijom govornih žanrova Mihaila Bahtina, navlastito za njezinim pretpostavkama o kontekstualnoj (socijalnoj) definiranosti svakoga govornog žanra, kao i za čuvenom joj distinkcijom između primarnih i sekundarnih žanrova, na kojoj se - unatoč popriličnoj praktičnoj uporabljivosti tih koncepata i u slučaju folklornoknjiževnih žanrova ${ }^{653}$ - u narednoj analizi ipak neće (kao ni dosad) suviše inzistirati.

Ono čega ćemo se - imajući u vidu specifičnu prirodu ili „poetiku“ usmene književnosti - u idućoj etapi naše analize svakako morati kloniti jest dosadašnje temporalno smještanje pojedinih žanrovskih varijanata u okvire (domaće) barokne - ili uopće ranonovovjekovne - književnosti, a onda i utvrđivanje njihova „karakteristično baroknog“ generičkog repertoara, iz kojeg je za pojedinim značajkama u Odiljenju posezao i naš autor. Kao što je maločas konstatirano, zbog činjenice da u folklornoj književnosti nije izražena dinamika smjene stilova i stilskih formacija kao u onoj pisanoj, ${ }^{654}$ usmenoknjiževni se žanrovi nadaju kao relativno stabilne i postojane strukture, koje se kroz vrijeme ne mijenjaju onom brzinom, a kamoli onim istim ritmom kojim to čine pisanoknjiževna generička rješenja, što ujedno ne znači - na što sve glasnije upozoravaju folkloristi - da je njihova pretežno formulaična, konvencionalna „faktura“6655 u potpunosti lišena utjecaja mnogih izvanknjiževnih (situacijskih) činitelja te da iz toga razloga ne pokazuje ni najmanju podložnost (povijesno nešto dugotrajnijoj, no ipak konstantnoj) promjeni. Osim toga, do danas nam se nije dospio sačuvati ni nešto ozbiljniji broj domaćih zapisa usmenoknjiževnih žanrova iz razdoblja iz kojega potječe i Odiljenje sigetsko, što će reći da ne raspolažemo dovoljno bogatim ni razgranatim literarnim korpusom na temelju kojega bismo mogli stvoriti koliko-toliko preciznu predodžbu o pretpostavljenoj „baroknoj“ usmenoj književnosti, a onda ni o eventualnu njezinu generičkom sustavu, sazdanom od žanrova možebitno opremljenih „tipično baroknom“ kombinacijom ili repertoarom generičkih značajki. Malobrojni sedamnaestostoljetni zapisi (vjerojatno autohtonih) primjeraka „narodne“ književnosti što ih nalazimo uklopljene u pojedina pisanoknjiževna ostvarenja, odnosno uvrštene u onodobne

\footnotetext{
${ }^{653} \mathrm{O}$ opravdanosti razlučivanja primarnih od sekundarnih govornih žanrova na „području“ usmene književnosti usp. npr. Lozica 1990: 117.

${ }^{654}$ Usp. Pavličić 1983: 129-155.

${ }^{655}$ Folklornoknjiževni su žanrovi, podsjetimo, glavninom sazdani od niza „općih“, više ili manje stalnih sadržajnih i formalnih obilježja, odnosno od sebi svojstvenoga sustava izrazito stabilnih i vremenski otpornih formula ili formulativnih obilježja, koje se u „povijesti“ usmene književnosti neprekidno perpetuiraju i ovladavanje kojima je „narodnim“ stvarateljima bitno olakšavalo posao njihova izvedbenog re-kreiranja na „licu mjesta" pred zainteresiranom publikom. Podrobnije o formulaičnosti žanrova usmene književnosti u: BoškovićStulli 1978: 29-40.
} 
kajkavske pjesmarice te već spomenuti zbornik južnoslavenskoga „narodnog“ pjesništva Erlangenski rukopis, ne iskazuju pritom - usporede li se s folklornim ostvarenjima zabilježenima tijekom prethodnoga, odnosno narednog stoljeća - nikakvu specifičnu „baroknost“ po pitanju svojih obilježja, što je ujedno moguće izdvojiti kao jednu od mnogih potvrda ranije iznesene pretpostavke o razvojnoj tromosti usmene književnosti, u kojoj do promjena dolazi vrlo rijetko te nezavisno od relativno čestih smjena dominantnih poetika pojedinih epoha i pravaca u pisanoj književnosti. Ima li se to na umu, s pravom bi se - iako ne bez nužne doze opreza zbog malobrojnosti sačuvanih primjeraka - moglo govoriti „tek“ o nešto većoj zastupljenosti konkretnih folklornoknjiževnih žanrova (navlastito poslovice, bugaršćice te epske i lirske pjesme) u provizornome generičkom sustavu barokne usmene književnosti, a time i u žanrovskom sustavu hrvatskoga književnog baroka u cijelosti, kao čiji se važan i neizostavan dio - trudili smo se pokazati nešto ranije - oni također nameću.

Prije no što prionemo na posao lociranja izdvojenih obilježja ili čitavih u nj „usađenih“ primjeraka pojedinih usmenoknjiževnih žanrova, neće biti izlišno još jednom naglasiti kako će se - poradi rečenoga deficita sačuvane izvorne građe iz toga vremena predodžba o danim žanrovima i repertoaru njima svojstvenih obilježja u ovom dijelu generičke analize Vitezovićeva Odiljenja većinom zasnivati na suvremenim definicijama tih istih žanrova proizišlima iz razmatranja njihovih znatno novijih zapisa. ${ }^{656}$ Nemajući drugog izbora, naše istraživanje po toj i takvoj praksi u domaćoj književnoj znanosti nipošto neće predstavljati (krupniji) izuzetak budući da i većina ostalih povjesničara hrvatske književnosti i folklorista - suočena s činjenicom kako se usmenoknjiževni ,produkti“ kontinuirano bilježe tek u posljednja dva stoljeća - o ,starijoj“ folklornoj književnosti i njezinim osobitostima redovito iznosi sudove tek na osnovi vlastitih pretpostavki i „,mjestimičnih tragova usmene u pisanoj književnosti i podataka u povijesnim vrelima“, što na koncu rezultira upravo time da „svaka pretpostavka o starijem stanju biva previše ovisna o slici stvorenoj na osnovi mlađih zapisa“ (Dukić 2004a: 13-14). Kada je u pitanju razdoblje u kojemu je naš autor živio i djelovao, o tadašnjoj usmenoj književnosti na temelju spomenutih očuvanih zapisa također možemo steći tek poprilično mutan dojam, što će reći ne samo da posredstvom njih nismo u stanju spoznati puno njezino sedamnaestostoljetno generičko bogatstvo, nego i to da sačuvani primjerci predstavljaju odveć skroman uzorak za utvrđivanje njezine možebitne sedamnaestostoljetne posebnosti, a kamoli za „dešifriranje“ eventualne poetike, odnosno rekonstruiranje generičkoga repertoara svakoga pojedinačnog žanra u kojemu su oni

${ }^{656}$ Letimičnih osvrta na usmenoknjiževna ostvarenja bilo je - kako navode pojedini proučavatelji - i znatno prije, no pritom treba znati kako ,u proteklim stoljećima svjedočanstva i zanimanja za usmeno pjesništvo obično nisu bila žanrovski razdvojena“" (Dukić 2004a: 14). 
realizirani. O stvarnom bogatstvu i prirodi usmenoknjiževnih žanrova što su bili u opticaju u Ritterovo doba ne preostaje nam stoga ništa drugo nego tek nagađati, polazeći pritom od njihovih znatno suvremenijih opisa te čvrsto vjerujući u maločas im konstatiranu postojanost, pa i usprkos činjenici da je baš svaka njihova izvedbena realizacija trenutna i jednokratna, što će onda reći i nužno (pa makar neznatno) drugačija od onih ranijih i onih narednih.

S obzirom na to da apsolutno svaki pristup usmenoj književnosti i njezinim žanrovima - dakle, ne samo onaj folklornoknjiževnoj produkciji „starijih“ razdoblja - polazi od razmatranja kvantitativno više ili manje ograničenoga korpusa očuvanih zapisa, neizbježno je da se najvećim on dijelom svodi zapravo na (teorijska) nagađanja i domišljanja, odnosno da njegovo tumačenje izvorne građe počiva pretežno na proučavateljevim pretpostavkama donesenima na temelju vrlo suženih uvida. Iz toga bi se razloga i sami usmenoknjiževni žanrovi kao takvi nužno morali motriti ne kao povijesne kategorije ili - todorovljevski rečeno - povijesni žanrovi, već upravo kao teorijske kategorije ili žanrovi, tim više što je predodžba (suvremenih) recipijenata o njima - kao što je već više puta istaknuto - oblikovana isključivo na temelju njihovih općih (dakle, teorijskih) definicija što su ih iznijeli kasniji književni povjesnici i folkloristi, a ne posredstvom možebitnih poetičkih im opisa za koje bi bili zaslužni sami njihovi tvorci i koji bi vrijedili samo za jedan period u povijesti usmene književnosti, baš kao što je to slučaj s generičkim poetikama u sferi pisane književnosti. Budući da su takve „aktualne“ poetičke refleksije o usmenoknjiževnim žanrovima iz pera „narodnih“ pjevača puka iluzija jer, osim što je riječ o stvaralaštvu mahom nepismenih pojedinaca, ujedno se - ponovimo - radi o literarnoj domeni koja ne počiva na smjenjivanju razdoblja i njima pripadajućih poetika, samo povijesno shvaćanje žanrova folklorne književnosti uopće se kao takvo ispostavlja izlišnim, slijedom čega bi - umjesto o povijesnim folklornoknjiževnim generičkim rješenjima iz ovoga ili onoga razdoblja - daleko preciznije bilo govoriti o kreativnoj sklonosti pojedinih literata iz nekoga (književno)povijesnog trenutka određenim „,narodnim“ žanrovima, odnosno njima svojstvenim karakteristikama, kao što će se to - uostalom - pokušati sustavno činiti i na ovome mjestu.

Što se, konkretno, Ritterove i više nego očite fasciniranosti (pojedinim) žanrovima usmene književnosti tiče, valja naglasiti kako se ona izvrsno uklapala u znatno širu, baroknu sklonost folklornoknjiževnim ostvarenjima koja je vukla svoj korijen još iz renesansnoga doba, od kada je i moguće pratiti porast interesa naših pisaca za literarnim stvaralaštvom bespismenih društvenih slojeva te njegovim uključivanjem u vlastite, autorske književne tekstove. Za razliku, međutim, od renesansnoga tretmana folklorne književnosti, koji je 
podrazumijevao jasno isticanje usmenoknjiževnih „,dodataka“ $u$ pisanim djelima, ${ }^{657} \mathrm{u}$ sedamnaestostoljetnoj će se domaćoj književnosti većinom težiti njihovu organskom stapanju s pisanoknjiževnim „okružjem“, pa onda i dokidanju eksplicitnih tekstualnih signala „narodnoga“ im porijekla, ${ }^{658}$ a tu će težnju u 18. stoljeću smijeniti njihovo ponovno sve češće izdvajanje, na kakvo se - između ostalih - odlučio i Matija Petar Katančić, koji u hrvatskom dijelu svoje lirske zbirke Jesenski plodovi (1791.) tako donosi i ciklus Popivke narodne. Ovaj ranonovovjekovni kontinuitet preplitanja pisanoga $\mathrm{s}$ usmenim literarnim stvaralaštvom ponajbolje se može pratiti upravo na primjeru niza autorskih ,zrinijada“, koje su - kako je poodavno već zamijećeno - redovito bile „oblikovane značajnim udjelom usmene književnosti““ (Kekez 1987: 115), pri čemu treba znati da se na prizivanju obilježja folklornoknjiževnih žanrova nipošto nisu temeljile samo ,zrinijade“ na potezu od one Ferenca Črnka do Vitezovićeva Odiljenja, već i pjesme o sigetskoj katastrofi u Kačićevu Razgovoru ugodnom naroda slovinskoga, ali i većina devetnaestostoljetnih ostvarenja na istu temu.

Za našu će se analizu, dakako, najintrigantnijima ispostaviti tragovi folklorne književnosti prisutni u ,zrinijadama“ što su prethodile Odiljenju sigetskom, a koje su jamačno (i) tom svojom izrazitom usmenoknjiževnom crtom odreda Ritteru dale jedan od ključnih poticaja za implementiranje mnogih generički prepoznatljivih značajki „narodnih“ ostvarenja i u tekst njegove vizije kršćanskoga poraza pod Sigetom. Na posezanje za karakteristikama folklornih književnih žanrova našega je autora tako mogao ponukati već jedan od mnogobrojnih tada dostupnih prijepisa Črnkova ljetopisa Podsjedanje i osvojenje Sigeta, u kojemu su suvremeni proučavatelji prepoznali ne samo „usmenopripovijedni način izražavanja“ (Hranjec 2016: 24) i ritmičko kazivanje koje priziva folklornu deseteračku i osmeračku strukturu, nego i niz formulaičnih izraza, naznake narodnih vjerovanja, mnoštvo metafora i hiperbola, česta ponavljanja, težnju (usmeno)epskoj objektivnosti, početak in medias res, kao i usmenoj književnosti vrlo drag motiv navođenja nadnevaka prema praznicima u Crkvenoj godini (primjerice, ,na Malu Mašu“) ${ }^{659}$ Pored Črnkova Podsjedanja, jedno od literarnih polazišta i Barni Karnarutiću u sastavljanju njegova Vazetja Sigeta gradautvrđeno je - također je bila „narodna“ epska pjesma, iz koje će baštiniti pojedina metrička

\footnotetext{
${ }^{657}$ Već u Ranjininu će se tako Zborniku rukovet „narodnih“ pjesama izuzeti u poseban ciklus pod naslovom Pisme na narodnu, u Hektorovićevu Ribanju i ribarskom prigovaranju umetnute će se autohtone bugaršćice i zagonetke u tekstu specijalno naznačiti i - kao takve - vidno izdvojiti, dok će Juraj Baraković u svojoj renesansno-manirističko-predbaroknoj Vili Slovinki izvornu bugaršćicu o majci Margariti što ju u osmome dijelu izriče poklisar (pod)naslovom istaknuti upravo kao Bugaršćicu.

${ }^{658}$ Izuzetak je Frankopanov pjesnički opus, u kojemu će nekolicina žanrovski različitih pjesama stiliziranih po usmenoknjiževnome „obrascu“ biti okupljena u izdvojenomu ciklusu naslovljenom Dijačke junačke (usp. Frankopan 1999: 257-269).

${ }^{659}$ Detaljnije o usmenoknjiževnim osobitostima Črnkove kronike u: Ratković 1971: 27-34, Kekez 1987: 122124, Zvonar 2008: 24-30 i Hranjec 2016: 24.
} 
rješenja, prepoznatljivu sintagmatiku, „karakteristične“ stilske figure (epitet, poredbu, metaforu), epske formule, težnju za uključivanjem poslovica, ali i motiv pjevanja „bugarkinja“ (bugaršćica), što ga ondje donosi pri kraju drugoga pjevanja. ${ }^{660}$ Ako ne već iz Črnkova i/ili Karnarutićeva ostvarenja, Vitezović je bitan podstrek za kreativno uvažavanje usmene književnosti svakako dobio iz Obside sigecke Petra Zrinskog, za čije je pretežno sadržajne posudbe iz folklornoga epskog i bugaršćičkog pjesništva - uključena narodna vjerovanja i praznovjerja, niz likova izvorno usmenoknjiževne provenijencije (Radivoj, Delivid, Malkoč-beg, Idriz, Kajtaz) te konkretne motive (navlastito motiv Sulejmanova poziva Zrinskom da preda Siget mirnim putem, potom motiv pokrštene Turkinje koja spašava supruga iz turskog zarobljeništva, motiv dvoboja istaknutoga kršćanskog i muslimanskog junaka, motiv Sulejmanove tuge za poginulim Ali Kurtom, „karnarutićevski“ motiv pjevanja bugaršćica itd.) - najzaslužniji ipak Nikolin mađarski epski predložak, u kojem su one sve redom također našle svoje mjesto. ${ }^{661}$

Uz neupitnu zadojenost pobrojanih autora (i) na produktima usmenoga stvaralaštva, jedan od najvažnijih razloga njihova obilnog evociranja prepoznatljive usmene motivike, formalnih i stilskih obilježja nesumnjivo će ležati i u činjenici što je, neposredno nakon okončanja opsade, kršćansko-muslimanska bitka pod Szigetvárom diljem cijele Hrvatske snažno „odjeknula u narodu i potaknula oblikovanje novoga kruga usmenoknjiževnih tekstova ili neke likove dotadašnjih pjesama supstituirala likom bana Zrinovića“ (Kekez 1987: 115). Osluškujući folklornoknjiževne obrade herojske pogibije bana Zrinskog u okršaju s turskim osvajačima, pisci „zrinijada“ i taj su segment verbalne umjetnosti očigledno shvaćali i prihvaćali kao neku vrstu uzorne tradicije (pa i - pored rukopisa Črnkove kronike ili možda nekog od njezinih objelodanjenih prijevoda - kao legitimni izvor povijesnih podataka) osjećajući potrebu da ga nasljeduju u određenim njegovim elementima - ponajviše onim sadržajnim (likovi, motivi, fabularne komponente), ali i stilskim (figuracija, formulaični izrazi). Bogatstvo sadržajnih poticaja kojima je autohtona folklorna - epska i lirska - pjesma mogla oplemeniti ove pisane obrade sigetske katastrofe proizlazi, prije svega, iz variranja različitih momenata samoga okršaja, njegovih odjeka, ali i pojedinosti iz života središnjih aktera koje su mu prethodile (primjerice, ženidbe bana Zrinskog, njegova tamnovanja, dvoboja u kojima je sudjelovao i sl.), a o kojima - dakako - povijesna vrela nisu pisala budući da se mahom radilo o pukim literariziranim ,domišljajima“ narodnih pjesnika.

\footnotetext{
${ }^{660}$ Usp. Hranjec 2016: 24-27. O tome ponešto i u: Novalić 1967b: 15-16 i Kekez 1987: 124-126.

${ }^{661} \mathrm{O}$ ovim sadržajnim elementima što ih Nikola i - posredno - Petar Zrinski crpe iz „narodnoga“ pjesništva vrlo detaljno u: Novalić 1967b: 22-46.
} 
Usprkos činjenici kako nam iz toga razdoblja nije ostao sačuvan ni jedan zapis usmene pjesme o padu Sigeta izuzev anonimne Pjesme o Sigetu u četiri pjevanja iz Prekomurske pjesmarice, koju Franjo Fancev datira u 1593. godinu, ${ }^{662}$ kasniji - glavninom devetnaestostoljetni - zapisi tekstova sigetske tematike mogli bi se držati dalekim odjecima, možda čak i varijantama pjesama što su ih usmeni pjevači izvodili na prostoru između Drave i Jadranskoga mora u 16. i 17. stoljeću. Josip Kekez kao (drugi) najraniji zapis iz „ciklusa“ o Sigetu tako navodi pjesmu Mujo Ljubović pod Sigetom zabilježenu u Erlangenskome rukopisu s početka 18. stoljeća, kojoj će se u 19. stoljeću pridružiti Opsada Sigeta 1566. iz zbirke Luke Ilića Oriovčanina, a uz nju i bokokotorska bugaršćica Ban Mikloš Zrinski u Sigetu gradu, što ju je 1878. u svojoj zbirci donio Baltazar Bogišić (a koja je zapisana u Kotoru početkom 18. st., iako je prilično očito da je nastala početkom 17. st.), te Boj na Sigetu iz Hörmannova zbornika Narodne pjesme Muhamedovaca u Bosni i Hercegovini (1888.). ${ }^{663}$ Dvadeset godina prije Kekeza Đuro je Novalić upozorio i na deseteračku pjesmu na temu (povijesno potvrđena) dvoboja bana Zrinskog s Malkoč-begom Kako Nikola ban Zrinski silni vitez osveti Radivoja slugu svoga pogubljena od Malkoča bega i kako Malkoč na zapovijed carevu poginu (zabilježenu u Dubrovačkome rukopisu s kraja 18. st.) te na još nekoliko epsko-lirskih pjesama zapisanih u 19. stoljeću (Ban Zrinjanin i kćer caričina, Tamnovanje bana Zrinjanina, Ban Zrinjanin i Begzada djevojka, Razbolje se care Sulejmane), kojih bi se pojedini motivski aspekti lako mogli prepoznati u ,zrinijadama“ braće Zrinski. ${ }^{664}$ Naravno, kao što je krajnje dvojbeno govoriti o konkretnim utjecajima znatno kasnije zapisanih primjeraka usmenog pjesništva na (pisano)književna iz razdoblja renesanse i baroka, tako ne bi trebalo posve isključiti ni mogućnost da su upravo pojedini fabularni momenti pisanih „zrinijada“ $\mathrm{u}$ višestoljetnom procesu preplitanja usmene s pisanom te pisane s usmenom književnošću dospjeli na prostor „narodnoga“" stvaralaštva postavši tako literarnom sastavnicom koja će kasnije odrješito biti prepoznata kao ,,autohtona“ svojina usmenoknjiževnoga oblikovanja.

Kako bilo, višestruke potvrde kreativnoga nadovezivanja na folklornu književnost u svim pisanim „zrinijadama“ od Črnka (Karnarutića) do Vitezovića nipošto nisu samo dokaz odličnoga poznavanja „narodnog“ stvaralaštva i prihvaćanja njegovih značajki kao (jednako)vrijedne komponente pisanoknjiževnoga teksta kojom je moguće privući i pažnju

\footnotetext{
${ }^{662}$ O spomenutoj Fancevljevoj dataciji Prekomurske pjesmarice u: Šojat 1977: 19-20. Sumnju u (autohtono) usmeno podrijetlo Pjesme o Sigetu još je 1967. izrazio Đuro Novalić ustvrdivši kako njezina versifikacijska obilježja (stih aleksandrinac) i podjela u četiri pjevanja bjelodano govore u prilog činjenici kako nipošto ne može biti riječi o zapisu s ustiju narodnoga pjevača (usp. Novalić 1967b: 23). O usmenim, ponajviše bugaršćičkim specifičnostima Pjesme detaljnije u: Kekez 1987: 129-131.

${ }^{663}$ Usp. Kekez 1987: 116-122.

${ }^{664}$ Podrobnije u: Novalić 1967b: 22-46. O usmenoknjiževnom pjesništvu iz ovoga tematskog „kruga“ podrobno i u: Mijatović 2010: 135-138 i Hranjec 2011: 96-99.
} 
slabije obrazovanih recipijenata, nego ujedno i jasan indikator da su i prije 1684. kolala tematski srodna usmenoknjiževna ostvarenja, čije su prepoznatljive (poglavito sadržajne) posebnosti Ritter i njegovi prethodnici evocirali, između ostalog, i s ciljem uspostavljanja snažnih poveznica i na taj - čitateljima dobro poznat - segment književnosti. Posvemašnji nedostatak zapisa potonjih usmenih ,zrinijada“ iz 16. i 17. stoljeća stoga ne može zamagliti činjenicu da je upravo u tom razdoblju folklornoknjiževna produkcija na temu kršćanskomuslimanskog okršaja pod Sigetom bila osobito živa, pa i generički izuzetno raznolika (epske pjesme, lirske pjesme, bugaršćice itd.), čega su podjednako bili svjesni onodobni čitatelji i pisci, među kojima se našao i Pavao Ritter Vitezović. Lativši se pisanja tematski srodnog sastavka, Vitezović je - nalik svojim neposrednim prethodnicima - bio prisiljen računati s dvostrukom (pisanoknjiževnom i usmenoknjiževnom) tradicijom opjevavanja turskoga zauzeća Sigeta, odnosno paralelno uvažavati ne samo ranijim „zrinijadama“ posredovane folklorne momente (primjerice, neke autohtono usmenoknjiževne likove iz Petrove Obside sigecke), nego (u znatno većoj mjeri) i one izvorne, pa onda i „aktualne“, kojima svoj tekst premrežuje od korica do korica, čvrsto uvjeren da će ih - zahvaljujući prethodnomu čitateljskom iskustvu - lakoćom prepoznati i generički identificirati recipijenti različita profila, a navlastito oni što ih je u svijet književnosti uvelo upravo „narodno“ stvaralaštvo.

Folklornoknjiževnim značajkama napučeno Odiljenje sigetsko, međutim, ispostavlja se - kao takvo - tek jednim u nizu generički raznolikih tekstova iz Ritterova pera, u kojima naš autor opetovano potvrđuje svoje nevjerojatno zanimanje za literarno stvaralaštvo bespismenoga puka. Da je usmenu književnost već u svojoj mladosti naš autor percipirao ne samo kao posebnu i vrijednu pažnje, nego ujedno i kao društvenopovijesno, pa i nacionalno važnu pojavu, potvrdit će nam već prvo njegovo tiskom objelodanjeno djelo - latinska povijesna rasprava o porijeklu obitelji Gušić Apographum ex Joanne Lucio iz 1681., u kojoj na jednome mjestu vlastito svjedočanstvo o pjevanju (usmenih) pjesama u čast hrvatskoga bana Ivana Karlovića potkrjepljuje citiranjem (točnije, bilježenjem) uvodne dionice jednog od tih deseteračkih pjesničkih ostvarenja. ${ }^{665}$ Motreći ih kao vjerodostojne povijesne dokaze o banu Karloviću i njegovim ratnim i ne samo ratnim podvizima, Vitezović u nastavku pripominje kako se o njemu „najčešće pjeva u domovinskim pjesmama i popijevkama u kolu“ (Bošković-Stulli 1978: 208), čime nesumnjivo aludira na usmene lirske i epske pjesme u kojima se Karlović promeće u glavnog ili jednoga od glavnih junaka, ali i na „lirsko-epske“ bugaršćice, u kojima je njegovim djelima bilo ipak posvećeno daleko najviše prostora. $\mathrm{S}$

\footnotetext{
${ }^{665}$ Spomenuti fragment glasi: „Kuliko je u Lici gradova, / Sedamdeset i sedam gradova; / Ni divojke ni neviste mlade / Koju ni Karlović ljubio“ (cit. prema: Klaić 1914: 36).
} 
obzirom na to da će se na Karlovićeve ljubavne dogodovštine, na koje se i referira fragment citirane „narodne“ pjesme, Ritter zakratko osvrnuti - kao što ćemo vidjeti - i u trećem „dilu“ Odiljenja sigetskog ${ }^{666}$ ne bi bilo neopravdano pretpostaviti kako je obilje usmenoknjiževnih momenata što ih zatječemo u njegovoj „zrinijadi“ ništa drugo nego produkt njegova dotadašnjeg intenzivnog osluškivanja folklornoga pjesništva ponajprije u cilju prikupljanja „povijesnih podataka“ za historiografske spise, zahvaljujući kojemu je dobro ovladao karakterističnim folklornoknjiževnim postupcima i mehanizmima što će ih potom s(p)retno iskoristiti i pri sastavljanju svoga vernakularnog prvijanca.

Naravno, Vitezovićevo recipiranje usmenoga stvaralaštva nipošto nije bilo inicirano ovim kasnijim, mladenačkim mu profesionalnim interesima budući da prvi njegovi kontakti s folklornom književnošću jamačno datiraju još iz djetinjstva, u kojemu se nedvojbeno krije i korijen njegovih kasnijih specifičnih promišljanja omiljele mu „narodne“ poezije. O važnosti koju je još za mladih dana, a onda i kasnije Ritter pridavao usmenoknjiževnoj produkciji ponajbolje govori činjenica da je „u narodnim pjesmama vidio povijesne izvore“, pa je tako i „finu i izrazito lirsku romancu o Marinoj izgubljenoj kruni, koja je proširena sve do danas, tumačio kao alegorijsku sliku o propasti stare hrvatske dinastije Trpimirovića“ (BoškovićStulli 1978: 209-210), dok se, pak, na drugome mjestu - u latinskoj povijesnoj raspravi Natales Divo Ladislavo Rege Slavoniae Apostolo Restituti (1704.) - „dokaze“ o hrvatskom porijeklu mađarskoga kralja sv. Ladislava nije ustručavao izvoditi također iz usmenog pjesništva, kojega ondje iznova i citira. Pišući, naime, o narodnim običajima vezanima uz svetkovinu Ivanja, Vitezović u potonjoj raspravi posebno izdvaja „pjesme, koje po cieloj Slavoniji i donjoj Hrvatskoj (kuda se širi svakako najprostranija zagrebačka biskupija) za ljetne suncostaje običava pjevati pučki zbor djevojaka uz ples oko kresova“" (Grgec 1944: 119) i u kojima se redovito zaziva „lijepi Lado“, baš kao što je to slučaj i u jednoj od tih pjesama što ju otvara distih „Lipi Jive rože trga / aj Lade, Lade, lipo Lade“, 667 a sve ne bi li podsjetio na činjenicu kako je upravo „sv. Ladislav ukinuo slavljenje »praznovjernoga Lade«, koji (...) je starim Hrvatima značio isto, »što je Grcima i Latinima značio Pean«, te da je mjesto toga uveo kršćanski obred »na uspomenu sv. Ivana Krstitelja«" (Isto: 119). ${ }^{668}$

Svega dvije godine prije objelodanjivanja Odiljenja svjetlo je dana ugledala i Ritterova latinska prigodna pjesma ispjevana u čast grofa Petra Ricciardija i njegove netom

\footnotetext{
${ }^{666}$ O Ivanu Karloviću kao jednom od usmenoknjiževnih junaka prisutnih u Odiljenju usp. i u: Šrepel 1902: 115. ${ }^{667}$ Cit. prema: Grgec 1944: 119.

668 Opširnije u: Grgec 1944: 119-120. Vrlo slična svjedočanstva o narodnim običajima u našem je baroku moguće zateći i u djelima Gundulića, Kavanjina, Kanavelića i mnogih drugih (glavninom južnohrvatskih) pisaca, u čemu domaći barokisti zapravo umnogome slijede renesansne prethodnike (navlastito Marulića, Držića, Zoranića i dr.), od kojih se mnogi u svojim ostvarenjima također nisu libili evocirati pučke svetkovine.
} 
stečene plemićke titule te čina zapovjednika jedne hrvatske pukovnije pod i više nego indikativnim naslovom Novus Skenderbeg (1682.). U toj zamašnoj pohvalnici naš će autor, ukratko, Ricciardija otvoreno proglasiti novim Skenderbegom - odnosno dostojnim nasljednikom glasovitoga albanskog kneza Jurja Kastriotića Skenderbega, koji se istaknuo u brojnim okršajima protiv Turaka te tako zaslužio svoje mjesto uz bok drugim znamenitim junacima usmene pjesme što su se proslavili u protuturskim akcijama poput Kraljevića Marka, Ive Karlovića ili Nikole Šubića Zrinskog - izrazivši čvrsto uvjerenje kako će, nalik svome prethodniku ,po oružju“, Osmanlije jednom za svagda protjerati iz Like i povratiti je u sastav Hrvatske. ${ }^{669}$ Tragove usmenoknjiževnih legendi i predaja Vitezović je ugrađivao i u mnoga svoja kasnija latinska (glavninom povijesna) ostvarenja, pa osim što će za elementima folklorne književnosti obilato tako posezati u povijesnom prikazu propasti Kraljevstva Bosne Bossna captiva (Zasužnjena Bosna, 1712.), ujedno će i na motivima iz porijeklom „,narodnih“ priča zasnovati svoj hagiografski spis Vita et martyrium B. Vladimiri, Cratiae regis (Život $i$ mučeništvo hrvatskog kralja blaženog Vladimira, 1705.), u kojemu razrađuje čuvenu legendu o dukljanskomu kralju sv. Vladimiru - čije hrvatsko porijeklo ondje nastoji dokazati - i supruzi mu Kosari, znanu još iz Ljetopisa popa Dukljanina iz 12. st. ${ }^{670}$ Identičnu sklonost pohrvaćivanju inozemnih vladara Ritter je, podsjetimo, iskazao već u spomenutoj godinu dana „starijoj“ povijesnoj raspravi Natales Divo Ladislavo..., ${ }^{671}$ u kojoj - uvelike se također oslanjajući na izvorno folklornoknjiževne sadržaje - pokušava osporiti porijeklo kralja sv. Ladislava iz loze mađarskih Arpadovića ne bi li ga prikazao kao potomka hrvatske kraljevske obitelji rođenog upravo na našem tlu, i to najvjerojatnije u Pokuplju. ${ }^{672}$ Usmenoknjiževni momenti, osim toga, ispostavit će se i kao važna sastavnica Vitezovićevih (latinskih) genealogija, pa tako u rodoslovlju plemićke obitelji Vojnović - kojeg je, zajedno s genealogijama porodica Makar i Molli, otisnuo kao prilog primjerku svoje čuvene latinske spomenice Oživljena Hrvatska namijenjenom utjecajnomu bolonjskom grofu Marsigliju -

\footnotetext{
${ }^{669}$ Podrobnije o ovoj Ritterovoj prigodnici u: Klaić 1914: 49.

${ }^{670} \mathrm{O}$ usmenoknjiževnim slojevima same legende o Vladimiru, ali i Ljetopisa popa Dukljanina - u kojemu je najranije ona zapisana - u cijelosti detaljnije u: Bošković-Stulli 1978: 70-74.

${ }^{671}$ Detaljnije o ovoj Vitezovićevoj strategiji pohrvaćivanja stranih svetaca i kraljeva kao jednom od „učvršćivača“ njegove čuvene pankroatističke koncepcije u: Blažević 2008b: 316-317 i 2016: 160-161.

${ }^{672}$ Usp. Klaić 1914: 191. Uzgred budi rečeno, možda bi i u ovome Ritterovu „posvajanju“ ili pohrvaćivanju inozemnih vladara također trebalo prepoznati svojevrstan odjek postupka svojstvenog upravo folklornoj književnosti, koja - ne poznajući nacionalne granice kada je riječ o znamenitim povijesnim ličnostima nerijetko posuđuje junake porijeklom iz stranih, većinom susjednih kultura, zahvaljujući čemu su i dijelom hrvatske usmene epike, između ostalih, tako postali i „stranci“ Marko Kraljević i Skenderbeg. Prisvajanjem mađarskoga i dukljanskoga kralja Vitezović kao da je želio evocirati upravo taj postupak folklorne književnosti, u sklopu koje konkretna nacionalna pripadnost danih junaka nije imala nikakvu važnost sve dok se radilo o figurama koje su utjelovljivale poželjne vrline (hrabrost, srčanost, lojalnost itd.), a k tome se još i u sklopu svoga vojnog djelovanja s uspjehom suprotstavljale istomu moćnom (osmanlijskom) neprijatelju kao i pripadnici „domaćega“" naroda.
} 
zatječemo napomenu kako su podaci za nj crpljeni, između ostalog, i iz „,starih domovinskih pjesama koje Iliri uzimaju u obzir pri pisanju povijesti“ (Blažević 1999: 190) ili, drugim riječima, upravo iz „narodnoga“ epskog pjesništva.

S izuzetkom Odiljenja sigetskog, na ništa manje očitu folklornoknjiževnu podlogu Vitezovićevih vernakularnih ostvarenja naši su proučavatelji upozoravali znatno rjeđe no što je to bio slučaj s njegovim latinskim tekstovima, pa je tako tek Branko Krmpotić svojedobno zamjetio kako u prigodnoj mu pjesmi Senjčica ,pričanje suvremenoga događaja teče dosta glatko u senjskoj govornoj čakavštini prema maniri iznošenja sličnih junačkih događaja naših narodnih rapsoda“ (Krmpotić 1970: 625). Dodamo li tomu i da je riječ o osmeračkom pjesničkom tekstu protkanom poslovicama ${ }^{673}$ - kao, dakako, jednim od prepoznatljivo folklornih žanrova - time ni izbliza nećemo reći sve o usmenoknjiževnim obilježjima Ritterovih hrvatskih djela, koja sumnju na neizbježan kontakt s „narodnom“ književnošću pobuđuju već svojom vrlo očitom pučkoknjiževnom orijentacijom. Ne odnosi se to, dakako, samo na njegove pučke kalendare bremenite sadržajima kakvima obiluju i mnogi produkti folklorne književnosti te zbirku stihovanih poslovica Priričnik aliti razliko mudrosti cvitje, među kojima se zatekao i znatan broj onih autohtono „narodnih“, već i na djelomično mu očuvanu knjigu gatalica Lado horvatski iliti Sibila, koja usmenu književnost priziva već svojim intrigantnim naslovom, ali i čuvenu Kroniku aliti spomen vsega svieta vikov, koje bi nešto pažljivija (folkloristička) analiza također potvrdila uključenost nemalog broja obilježja svojstvenih upravo usmenomu literarnom stvaralaštvu.

Korpusu ovih pučkoknjiževnih Vitezovićevih ostvarenja dijelom bi pripadalo i samo Odiljenje, koje je, zahvaljujući uvjerljivo najvećoj koncentraciji - generički izrazito raznolikih - usmenoknjiževnih karakteristika, pa i uključenih cjelovitih primjeraka pojedinih „,narodnih“ Žanrova, s vremena na vrijeme ipak dospjelo isprovocirati (doduše, najčešće samo uzgredna) folkloristička čitanja. Ta povremena ukazivanja na usmenoknjiževne sastavnice Ritterove „zrinijade“ započela su već u pretprošlom stoljeću, i to zaslugom Đure Šurmina, koji u svojoj Povjesti književnosti hrvatske i srpske iz 1898. dijalošku pjesmu Gospodična Sofija i oral izdvaja kao dionicu kojom se Odiljenje najviše približava „narodnom“ pjesništvu, neodoljivo podsjećajući na čuvenu epsku pjesmu Kosovka djevojka, zasnovanu na gotovo

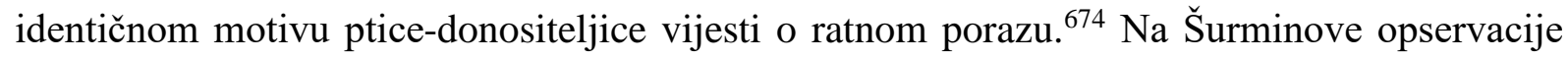
nadovezat će se potom čitav niz kasnijih povjesničara hrvatske književnosti na čelu s

\footnotetext{
${ }^{673}$ I na tu je činjenicu pozornost prvi skrenuo upravo Krmpotić (usp. Krmpotić 1970: 625-630).

${ }^{674}$ Opširnije u: Šurmin 1898: 135.
} 
Brankom Vodnikom, ${ }^{675}$ kojega će središnji motiv Gospodične Sofije i orla! također podsjetiti na Kosovku djevojku, ,gdje mjesto krvlju poštrapana orla ranjeni junak Orlović Pavle priča djevojci o kosovskoj pogibiji, javljajući joj smrt zaručnika“ (Vodnik 1913: 298), dok će Tomo Matić posegnuti i za nešto širom usporedbom, prispodobljujući Vitezovićev tekst još i „narodnim“ pjesmama u kojima Kraljević Marko razgovara sa sokolom, ali i poznatoj pjesmi o majci Jugovića, koja za sinovljevu smrt doznaje po odsječenoj njegovoj ruci što su joj je s ratišta donijeli gavrani. ${ }^{676}$ Nalik Matiću, koji je Gospodičnu Sofiju i orla! doveo u vezu s folklornoepskim pjesmama u kojima o pogibiji istaknutih junaka izvješćuju ptice, Josip će Kekez u Ritterovu tekstu prepoznati motiv tragičnoga doznavanja ratnog ishoda svojstven mnogim našim fragmentarno ili cjelovito zabilježenim bugaršćicama (između ostalih, i bugaršćici Popevka od Svilojevića, što ju je polovinom 17. st. zapisao Petar Zrinski), ${ }^{677}$ dok će za Davora Dukića biti ondje riječ ni o čemu drugome no o dobro poznatom općemu usmenoknjiževnom toposu ,ptice-glasnika koja donosi tužne vijesti s bojnog polja, najčešće nekoj ženi iz tabora poraženih (supruzi, vjerenici, sestri poginulog junaka)“ (Dukić 2004a: 23). Kao jedan od najrecentnijih proučavatelja folklornoknjiževnih osobina Odiljenja sigetskog Dukić će, međutim, u nastavku iznijeti poprilično iznenađujuć i posve netočan zaključak kako je „,u jednom od najartificijelnijih tekstova stare hrvatske književnosti to (...),

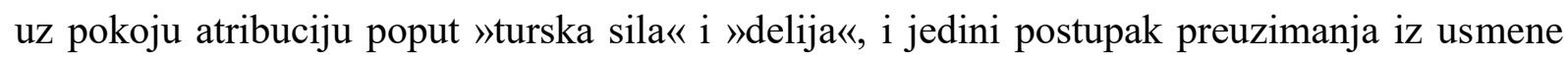
tradicije“ (Dukić 2004a: 23), zanemarujući pritom nemali broj u njemu prisutnih žanrovski jasno profiliranih usmenoknjiževnih posebnosti, na neke od kojih su desetljećima ranije upozoravali mnogi naši književni povjesnici i folkloristi.

Pored ove poodavno već uočene prisutnosti karakteristično folklornoga motiva ili toposa ptice-glasnika, u nešto „svježijoj“ sekundarnoj literaturi pokatkad se tako upućuje i na zastupljenost drugih porijeklom usmenoknjiževnih sadržajnih elemenata u Odiljenju sigetskom poput figure vile te motiva pjevanja pjesama u čast konkretnih (,narodnih“) junaka, ${ }^{678}$ kojima svakako valja pridodati i maločas spomenut motiv Karlovićevih ljubavnih pothvata što ga nalazimo u trećem „dilu“ (III: 239-240), ali i omanji katalog tipično

${ }^{675}$ Usp. Vodnik 1913: 298, Bogdanović 1932: 453, Grgec 1944: 120, Kombol 1961: 280, Švelec 1974: 259, Bošković-Stulli 1978: 210.

${ }^{676}$ O tome više u: Matić 1968: 104-105.

${ }^{677}$ Usp. Kekez 1987: 128.

${ }^{678}$ U nadgrobnici Ivana Novakovića (IV: 314-321) lirski subjekt - sam pokojnik - tako ističe da je on, kao jedan iz „plemena“ ili porodice Debeljaka, zbog svojih sigetskih (ali i drugih) ratnih junaštava već „po krajinah spivan za dobra junaka“" (IV: 316), čime bi se - po mišljenju Josipa Kekeza - zapravo trebalo aludirati na bugaršćice o Novaku Debeljaku, koje su u Vitezovićevo vrijeme kružile i na prostoru sjeverozapadne Hrvatske (usp. Kekez 1987: 128-129). Ne zaboravimo, jednako tako, i da će upravo „narodne“ (glavninom epske) pjesme što se pjevaju u čast Nikole Šubića Zrinskog implicirati zaključni stih heroide Orsag banu (II: 118-146), u kojemu personificirana domovina sigetskome kapetanu potvrđuje kako je zbog svojih junaštava zaslužio mjesto u kolektivnoj memoriji, odnosno u epskom folklornom pjesništvu (,pisme ti se čine na sve svite strane“; II: 146). 
usmenoepskih likova uključen u latinsku posvetnu pjesmu Adamu Zrinskom prvoga izdanja. ${ }^{679}$ Da se, međutim, usmenoknjiževni momenti u Vitezovićevoj „,zrinijadi“ ne svode samo na pobrojane sadržajne detalje potvrdilo je nekoliko osvrta na njezina formalna i stilska svojstva, u sklopu kojih je - ponajprije - utvrđeno kako je riječ o tekstu prošaranom prepoznatljivo usmenoknjiževnim frazama poput „moj bore“, kojom se ondje na jednome mjestu apostrofira samoga bana Zrinskog, ${ }^{680}$ te „ljuta rana“, „tužna ljuba“, „cvit rumeni“, „suze roniti“ i dr., što ih je kao preuzete iz „narodnoga“ pjesništva svojedobno označio Milan Moguš. ${ }^{681}$ Nekolicina folklornoknjiževnih pojmova i fraza (,tužna vila“, „,sokolova draga“ i dr.) zapet će za oko i Stjepanu Hranjecu, koji kao porijeklom „narodne“ izdvaja - također - i neke motive (motiv vile Hrvatkinje i motiv obraćanja Sigetu kao neživom objektu) te brojne u tekst uključene poslovice, ${ }^{682}$ dok Josip Kekez osim formulaičnih izraza (primjerice, ,i Bogu samomu ugodilo“) i karakteristično usmenoknjiževnih fraza (,sokolovi dragi“, „moj Sigete mili“, „moj cvit“, „tužna vila“ itd.), u Odiljenju zamjećuje i prisutnost folklornih motiva (vila) i žanrova (poslovica), bugaršćičkih sadržajnih i formalnih elemenata, ali i „narodnoj“ književnosti svojstvene sintagmatike i stilskih figura (poredba, metafora) te prepoznatljivo folklornoknjiževnih metričkih rješenja. Zbog činjenice da, precizira Kekez, svaki drugi dvanaesterački stihovni redak pjesme Putnik i Jeka završava dvosložnicom koja predstavlja odjek, odnosno „odgovor“ Jeke putniku, deset slogova što ih zauzima putnikovo pitanje neodoljivo podsjeća na usmenoepski deseterac, dok je - s druge strane - u nadgrobničkom segmentu Odiljenja na nekoliko mjesta moguće naići na pokušaje uključivanja „,narodnim“ bugaršćicama svojstvenoga dugog stiha. ${ }^{683}$

Govoreći o formalnoj, metričkoj razini Vitezovićeva djela, iz perspektive njegovih folklornoknjiževnih značajki nimalo se nebitnom neće ispostaviti ni već utvrđena dominacija dvostruko rimovanoga dvanaesterca, navlastito znamo li da je riječ o stihu kojeg - kako je svojedobno pokazao Ivan Slamnig - cezura raspolovljuje na (rimovane) šesterce, odnosno na jedno od najčeščih stihovnih rješenja u sferi našega usmenoknjiževnog stvaralaštva. ${ }^{684}$ Kao takav, Ritterov bi dvostruko rimovani dvanaesterac - u obje svoje ondje upotrijebljene

\footnotetext{
${ }^{679}$ Vitezović, naime, u rečenoj stihovanoj posveti Nikolu Šubića Zrinskog uvrštava u krug najvećih ,junaka ilirske zemlje“, i to zajedno s Novakom Debeljakom, Skenderbegom, Kraljevićem te Kobilićem, odnosno redom sa „stožernim“ junacima usmenoga epskog pjesništva. Usp. tekst latinske posvete i njezin hrvatski prijevod Vladimira Vratovića u: Zrinski, Frankopan i Ritter Vitezović 1976: 357-360.

${ }^{680} \mathrm{Na}$ usmenoknjiževno porijeklo ove fraze još je 1902. upozorio Milivoj Šrepel, napomenuvši kako je riječ o izrazu kojega je moguće zateći već u Karnarutićevu Vazetju, ali i u Adrijanskoga mora Sireni Petra Zrinskog (usp. Šrepel 1902: 111).

${ }^{681}$ Usp. Moguš 1986: 150.

${ }^{682}$ Podrobnije u: Hranjec 2016: 28-29.

${ }^{683}$ Usp. Kekez 1987: 126-129.

${ }^{684}$ Znatno detaljnije o ovom pitanju u: Slamnig 1981: 60-67.
} 
varijante $-\mathrm{u}$ isti mah predstavljao čvrstu poveznicu Odiljenja s prethodnom (glavninom dvanaesterački realiziranom) tradicijom pisanoknjiževnih ,zrinijada“, ali i ništa manje snažnu formalnu konekciju na „narodno“ pjesništvo, ispostavljajući se kao svojevrsni podsjetnik čitateljima na metar s kojim su se dotad imali prilike susresti isključivo osluškujući poeziju bespismenih pjevača, između ostalog, dakako, i onu posvećenu junaštvima sigetskih branitelja predvođenih banom Zrinskim. S tim raznolikim porijeklom Vitezovićeva dvostruko rimovanog dvanaesterca računao je dosad tek malokoji proučavatelj, pa će tako Stjepan Hranjec - napomenuvši kako naš autor njime izravno nasljeduje, između ostalih, i Marulića tek nedavno ustvrditi kako se on paralelno uklapa i u „usmenoknjiževnu metriku“ (Hranjec 2016: 28), dakle onu istu kojoj bi pripadao i „sedmerac, u tonu narodnoga stiha“ (Kolumbić 2005: 344) što ga Nikica Kolumbić locira u završnom, nadgrobničkom ciklusu Odiljenja. Imamo li na umu ovo formalno uvažavanje obilježja folklornoknjiževne provenijencije, ali i mnoga iz „narodne“ poezije crpljena sadržajna, pa i stilska rješenja što su ih detektirali netom spomenuti književni povjesnici i folkloristi, teško ćemo moći ne složiti se s Ivom Bancem, koji je svojedobno ustvrdio kako je u Odiljenju sigetskom Vitezovićevo „pozivanje na narodnu književnost ostalo jedinstvenim u sedamnaestom stoljeću“ (Banac 1996: 18), navlastito iz razloga što se radi o književnom ostvarenju s - kao što ćemo vidjeti - generički nevjerojatno širokim rasponom uključenih „karakterističnih“ usmenoknjiževnih značajki, skladno isprepletenih s onima iz repertoara različitih pisanih žanrova, ali i onima deriviranima iz repertoara pučkoknjiževnih, poluknjiževnih, pa i izvanknjiževnih žanrova.

\section{3. 1. Žanrovski rekviziti usmene epske pjesme}

Nalik prethodnom razmatranju obilježja žanrova pisane (barokne) književnosti, i potragu za generički prepoznatljivim izvorno usmenoknjiževnim karakteristikama Odiljenja sigetskog valja nam otvoriti detektiranjem konkretnih značajki što ih je Pavao Ritter Vitezović vrlo vjerojatno posudio (i) iz ,palete“ konvencionalnih sadržajnih, formalnih i stilskih sastavnica žanr(ov)a epske pjesme. Budući da se Ritterovo kreativno oslanjanje na točno određene (po mogućnosti zapisane i sačuvane) primjerke folklornoga epskog pjesništva ni na koji način ne može sa sigurnošću utvrditi ni potvrditi, jasno je da nam ne preostaje ništa drugo no već na samomu početku odustati od možebitnoga inzistiranja na razlikovanju pojedinačnih (pod)žanrova usmene epske pjesme, a onda i njima svojstvenih osobitosti, za kojima je crpeći ih iz ovoga ili onog „narodnog“ ostvarenja - on u svome tekstu možda ili sigurno posezao. Znajući da se folklornoknjiževno epsko pjesništvo u nas pojavljivalo u čitavu 
rasponu manje ili više različitih generičkih varijanata - konkretno, u obliku junačke epske pjesme, hajdučke i uskočke epske pjesme, pjesme-bajke, balade, romance, religiozne epske pjesme te fantastične epske pjesme ${ }^{685}$ - bit ćemo stoga prisiljeni zaustaviti se tek na pretpostavci kako je pri sastavljanju Odiljenja Vitezović najvjerojatnije na umu imao ponajprije generički „repertoar“ junačke usmenoepske pjesme, koji je imao prilike usvojiti možda i posredstvom (u njegovo vrijeme vrlo brojnih) folklornih epskopjesničkih ostvarenja na temu sigetske katastrofe. Dodamo li toj pretpostavci i da je - zahvaljujući svome senjskom podrijetlu - jamačno još u djetinjstvu u više navrata slušao i izvorne epske „narodne“ pjesme uskočke tematike, ali i da njegovo maločas spomenuto političko tumačenje usmene pjesme Marina kruna ukazuje na činjenicu da je posjedovao i iskustvo recipiranja folklornoepskih romanci, postat će i više nego očito kako obilježja Odiljenja sigetskog što ćemo ih na narednim stranicama označiti kao ekvivalentna onima usmene epske pjesme zapravo vuku porijeklo iz više različitih njezinih (pod)žanrova, odnosno da Vitezovićevo ugledanje na značajke folklornog epa - kako se čini - nije bilo striktno generički usmjereno.

Žanrovski rekvizitarij ili norme „narodne“ epske pjesme Ritteru su se u ovom slučaju mogle učiniti literarno ,primamljivima“ naročito i zbog činjenice da je već desetljećima, pa i dulje kao jedna od najomiljenijih njezinih tema kotirao upravo kršćansko-muslimanski okršaj pod Sigetom i junačka smrt bana Zrinskog i njegovih suboraca. Pritom su, kako u jednoj od svojih studija navodi Josip Bratulić, mnoge od tih junačkih epskih pjesama na temu pada Sigeta isprva zapravo „sastavljali i izvodili, tj. pjevali »dijačili«, dijaci, pisari, te su se takve pjesme zvale jačke (»dijačke«), a kasnije su ih pjevali narodni pjevači, obično slijepci“ (Bratulić 2016b: III). Konkretno, „dijacima“ su - pojasnit će na drugom mjestu Bratulić ustvari nazivani pisari u kancelarijama obitelji Zrinski i mnogih drugih onodobnih velikaških porodica, dužnost kojih su najčešće obnašali ,pismeni vojnici koji su znali pisati, ali i sastavljati dopise, naredbe, i prepisivati pjesme“ i koji su „najčešće pratili svoga gospodara u ratne pohode“, dok bi „za vrijeme kratkotrajnih zatišja oni (...) svome gospodaru i njegovim suborcima pjevali pjesme »dijačke junačke«“" (Bratulić 2016a: 51). „Dijaci“ ili pisari su, drugim riječima, zgodimice sastavljali (epske) pjesme - mahom na temu važnih (ratnih) događaja te o istaknutim vojskovođama iz domaće povijesti - koje bi potom čitali i/ili pjevali svojim gospodarima i kojih se do danas dospio sačuvati doslovno zanemariv broj, među

\footnotetext{
${ }^{685}$ Usp. Dukić 2004a: 52-56. O klasifikaciji usmene epske pjesme te konkretnim značajkama svakoga od pobrojanih njezinih žanrova znatno detaljnije i u: Čubelić 1988: 129-143 i Botica 2013: 256-378.
} 
kojima svakako vrijedi spomenuti odulju (anonimnu) Pjesmu o Sigetu, zapisanu oko 1593. u Prekomurskoj ili Martjanskoj pjesmarici. ${ }^{686}$

Ostavimo li po strani činjenicu da su na sustavnije bilježenje i izvorno usmenih epskih pjesama o turskom zauzeću Sigeta - koje odreda pobuđuju dojam znatno starijih ostvarenja ${ }^{687}$ - tek u 18. i naročito 19. stoljeću prionuli tadašnji zapisivači usmenoknjiževnoga blaga, sigetsku ćemo bitku u statusu jedne od najeksploatiranijih folklornoepskih tema zapravo zateći već u 16. stoljeću, kada na njezinu iznimnu raširenost u paratekstualnim dionicama svojih djela eksplicitno ukazuju pojedini naši onodobni pisci. Ispisujući posvetu Vazetja Sigeta grada „prisvitlomu i uzvišenomu gospodinu Jurju Zrinskomu“, i Barne će Karnarutić tako otvoreno ustvrditi da se uspomena na slavna djela Jurjeva oca u njegovo vrijeme ponajviše prenosi usmenim (usmenoknjiževnim) putem, odnosno „bez svakoga pisan'ja“ (Zoranić, Karnarutić i Budinić 2002: 225), ${ }^{688}$ što zatim dodatno podcrtava i samim tekstom svoje ,zrinijade“, opskrbljenim popriličnim brojem značajki svojstvenih upravo žanru „,narodnog“ pjesništva počesto zaokupljena opjevavanjem sigetske katastrofe. Da tema herojske pogibije sigetskih branitelja u žanru folklorne epske pjesme ni u 17. stoljeću nije (iz)gubila na popularnosti može nam, pak, (posredno) posvjedočiti uvid u barokne ,zrinijade“, navlastito u one braće Zrinski, napučene „tipično“ usmenoepskim momentima poput karakterističnih likova, junačkih motiva, dramatsko-naturalističkih opisa borbi (ili tzv. „dinarskoga nasilja“) i njihovih posljedica te uopće ideje herojskog suprotstavljanja turskome neprijatelju, ${ }^{689}$ kojima se željelo uspostaviti očitu poveznicu (i) na tu bogatu i još uvijek itekako živu i plodonosnu tradiciju usmenoknjiževnoga opjevavanja teme pada Sigeta.

Ukratko, kao dio znatno širega folklornog epskopjesničkog tematskoga kompleksa, koji je obuhvaćao različite (pretežno ratne) momente iz višestoljetne (15.-18. st.) burne povijesti hrvatsko-turskih odnosa, epizoda herojske kršćanske obrane i osmanlijskoga zauzeća Sigeta izdvojila se kao vrlo popularna tema odmah po svršetku sigetske bitke, iniciravši mnoga „narodna“ epska ostvarenja što su desetljećima i stoljećima potom u raznim svojim

\footnotetext{
${ }^{686}$ Iako je riječ o anonimnoj autorskoj epskoj pjesmi, folkloristi su u Pjesmi o Sigetu dospjeli locirati ne samo fraze koje jasno upućuju na slušanje, već i niz stihova podudarnih onima iz drugih usmenih pjesama, ali i tipično folklornoknjiževne sintagme, mnoštvo stalnih epiteta i inih tragova „narodnoga“ pjesništva (usp. Zvonar 2008: 36-37).

${ }^{687}$ Usp. o tome: Hranjec 2011: 96-99.

${ }^{688}$ Na ovaj je detalj iz Karnarutićeve posvete svojedobno prvi pažnju skrenuo Vončina (usp. Vončina 1976b: 11), a na nj se nedavno osvrnuo - u čak dva navrata - i Josip Bratulić (usp. Bratulić 2016a: 19 i 2016b: V).

${ }^{689}$ Pobrojane usmenoepske značajke u nizu sedamnaestostoljetnih pisanoknjiževnih ostvarenja sa slavenskoga prostora zapazio je Andreas Angyal, pripomenuvši kako su onodobni pisci obilato za njima posezali ne samo potaknuti općom sklonošću barokne književnosti spram folklornoga stvaralaštva, već naročito (i) zato što su mnogi junaci njihovih djela, koji su se zajedno s plemićima junački suprotstavili „poganima“, bili zapravo porijekom iz naroda. O „narodnome baroknom heroizmu“ i drugim folklornim epskopjesničkim obilježjima zastupljenima u velikoj većini sedamnaestostoljetnih ostvarenja iz gotovo svih onodobnih slavenskih književnosti podrobnije u: Angyal 1961: 228-264.
} 
inačicama nastavila kružiti na hrvatskom tlu, ali i šire. ${ }^{690}$ Usmene (epske) pjesme o sigetskom porazu cirkulirale su, naime, kako na prostoru današnje Hrvatske, tako i na onom susjednih zemalja, zahvaljujući čemu u korpusu sačuvanih njihovih zapisa možemo susresti ne samo hrvatske, već i muslimanske sastavke te pjesme zabilježene među Srbima, ${ }^{691}$ ali ne i one s prostora Mađarske, u čijoj usmenoj književnosti herojska pogibija sigetskoga kapetana i njegovih suboraca nije - kako se čini - ostavila gotovo nikakvoga traga. ${ }^{692}$ Upravo posredstvom tih se literarizacija opsade Sigeta ban Nikola Šubić Zrinski - kojega se u njima počesto naziva banom Zrinjaninom - u našoj i (pojedinim) susjednim kulturama ubrzo dospio prometnuti u arhetipskoga junaka folklorne epike, našavši se tako „u društvu najomiljenijih i najpopularnijih likova narodne epske pjesme: Kraljevića Marka, vojvode Janka, Skenderbega, Ive Karlovića“" (Bratulić 2016b: IV). Taj arhetipski status lika bana Zrinskog najuvjerljivije će - zbog posvemašnjeg nedostatka sačuvanih zapisa iz Vitezovićeva vremena - posvjedočiti maločas spomenute folklorne epske pjesme zabilježene tijekom 18. i 19. st., čije pretpostavljeno starije porijeklo sugerira da je ranije inačice barem nekih od njih morao poznavati i naš autor, ${ }^{693}$ baš kao što je vrlo vjerojatno imao prilike čuti i/ili pročitati i jednu od (onodobnih) varijanata Pjesme o Sigetu, koja se samo uvjetno može prihvatiti (i) kao autohtono usmenoknjiževno ostvarenje. Na uvažavanje njihovih specifičnih obilježja u svojoj generički šarolikoj „zrinijadi“, koja se - kako smo nešto ranije utvrdili - u očima pojedinih čitatelja pokušavala žanrovski iskristalizirati (i) kao primjerak (baroknoga) povijesnog epa, Rittera su jamačno ohrabrili prethodni naši epici, ponajprije - dakako - braća Zrinski, čije se „epske“ vizije propasti Sigeta premrežene nemalim brojem prepoznatljivih folklornoepskih značajki nameću kao tek jedna u nizu domaćih epskopjesničkih ostvarenja s izrazitim udjelom elemenata preuzetih iz usmene epske pjesme. ${ }^{694}$

\footnotetext{
${ }^{690}$ Opširnije o tome u: Kekez 1987: 116-122, Mijatović 2010: 135-138, Botica 2013: 244-256 i 275-277.

${ }^{691}$ Usp. Novalić 1967b: 1.

${ }^{692}$ Ovaj svakako intrigantan podatak iznio je svojedobno također Đuro Novalić (usp. Novalić 1967b: 22).

${ }^{693}$ Izuzev bugaršćice Ban Mikloš Zrinjski u Sigetu gradu, zapisane u Kotoru početkom 18. st., no gotovo sigurno „nastale“ još početkom 17. st., u navedenom je razdoblju zabilježen - podsjetimo - čitav niz „narodnih“ epskih ostvarenja, od kojih vrijedi izdvojiti pjesme Opsada Sigeta 1566., Ban Zrinjanin i Begzada djevojka, Smrt cara Sulejmana pod Sigetom, Kad su Turci pod Sigetom bili, Kako Nikola ban Zrinski silni vitez osveti Radivoja slugu svoga pogubljena od Malkoča bega i kako Malkoč na zapovijed carevu poginu, Tamnovanje bana Zrinjanina, Zrinski i Sulejman, Boj na Sigetu itd. (usp. Novalić 1967b: 22-46, Mijatović 2010: 135-138 i Hranjec 2011: 9699). S obzirom na to da mnoge karakteristike pobrojanih pjesama upućuju na zaključak kako je riječ o ostvarenjima znatno - možda i nekoliko stoljeća - starijima od trenutka njihova bilježenja, nema sumnje da su neka od njih u narodu kružila već i tijekom 17. st., kada se obilježjima iz njihovih onodobnih varijanata - kako je dokazano - pri sastavljanju svoga epa Szigeti veszedelem obilno služio i Nikola Zrinski (usp. Novalić 1967b: 2246), a u Odiljenju sigetskom vrlo vjerojatno i sam Vitezović, o čijem itekako dobrom poznavanju tadašnjih folklornih epskih pjesama na temu sigetske katastrofe suvremeni folkloristi više ni najmanje ne dvoje. O tome usp. npr. Botica 2013: 277.

${ }^{694} \mathrm{U}$ red spomenutih djela pripadaju tako i Marulićeva Judita, Karnarutićevo Vazetje Sigeta grada, Barakovićeva Vila Slovinka, Gundulićev Osman itd. O tome opširnije u: Botica 2013: 264-267.
} 
Zahvaljujući kontinuiranoj prisutnosti teme opsade Sigeta i na „području“ usmene književnosti, a onda i neupitnom iskustvu recipiranja tih folklornih „zrinijada“ što ga je posjedovala velika većina njegovih čitatelja, Odiljenje sigetsko svojim je izrazitim silnicama naslijeđenima iz „narodne“ (epske) pjesme prilično lako moglo navesti publiku da mu pristupa upravo iz folklornoknjiževne vizure, odnosno da pojedine njegove (pretežno sadržajne) elemente i postupke interpretira kao da su sastavnice „pravoga“ usmenoepskog konteksta. Konkretno, recipijenti snažno zadojeni na usmenoj književnosti u Sigetu kao mjestu „radnje“ Odiljenja - pa i unatoč dobro im znanoj činjenici da je riječ o povijesnom, stvarnom lokalitetu - stoga su najvjerojatnije prepoznavali „samo“ još jedno „tipsko mjesto“, na kojemu se odvijala jedna u nizu žestokih bitaka između pravovjernih kršćana i ,poganih“ muslimanskih napadača, a k tome su zasigurno i ondje opjevane kršćanske njezine sudionike - bez obzira na njihovo stvarno, tj. u tekstu jasno naznačeno „hrvatsko“ podrijetlo percipirali također kao tipske, odnosno kao tipove određenih karaktera vođenih poželjnim (pozitivnim) vrlinama (hrabrošću, lojalnošću, domoljubljem itd.). Računajući - između ostalog - upravo s takvim pristupom velikog dijela ciljane publike, Vitezović se i upustio u sastavljanje svoje folklornim značajkama bremenite, no ujedno i sadržajno fragmentarne „zrinijade“, znajući da to što u njoj nije ispripovijedio cjelovitu, kronološki realiziranu priču o sigetskoj bitci ni najmanje neće otežati njezino (ispravno) razumijevanje, već će, naprotiv, čitatelje potaknuti na evokaciju pojedinosti o padu Sigeta iz kolektivnoga pamćenja, utkanoga (i) u „narodna“ epskopjesnička ostvarenja na ovu temu, s kojima su se dotad u nemali broj navrata imali prilike susresti. Da bi potonje recipijente dodatno potaknuo na evokaciju tih usmenom književnošću posredovanih činjenica, Ritter ne samo što će svoj tekst napučiti likovima i uz njih vezanim situacijama (epizodama) preuzetima iz ,zrinijada“ braće Zrinski, a onda i iz ranijih folklornoknjiževnih obrada sigetske katastrofe, na koje su se - podsjetimo - i Nikola i Petar snažno oslanjali, ${ }^{695}$ već u njemu - usprkos činjenici da sami po sebi ondje ne posjeduju veći sadržajni (,fabularni“) značaj - neće zaobići ni nekolicinu „tipičnih“ usmenoepskih motiva, također zastupljenih i u djelima neposrednih prethodnika (motiv dvoboja, motiv pobratimstva, motiv čarobnjaka itd.). ${ }^{696}$ Pored svega toga, na dva će mjesta $u$ tekstu ubaciti on još i indikativne likove znatiželjnika (Sofija, putnik), koji pojedinosti o tijeku i ishodu bitke pod Sigetom naknadno doznaju od personificiranih bića (orao, vila Jeka), i to ne samo ne bi li se nadovezao na u usmenoj književnosti ne tako rijetku pojavu „oživljenih“ govornika, već ponajprije kako bi motivom prenošenja informacija o sigetskoj katastrofi od

\footnotetext{
695 Više o tome u: Novalić 1967b: 22-46.

${ }^{696} \mathrm{O}$ navedenim i inim prepoznatljivim obilježjima usmene epske pjesme posebno u: Botica 2013: 243-384.
} 
strane fiktivnih, čisto „literarnih“ likova velik dio svojih čitatelja podsjetio i na njih same, koji su (temeljno) znanje o herojskoj obrani i padu Sigeta dobili upravo posredstvom ,narodnih“ (pretežno epskopjesničkih) književnih ostvarenja. Izrazita usmenoknjiževna orijentacija Odiljenja sigetskog u tom se smislu u isti mah ispostavlja i kao sredstvo, ali i kao cilj, proizlazeći u nezanemarivoj mjeri upravo iz u nj uključenih značajki autohtone folklorne epske pjesme, koje u njemu ne nalazimo u „tek“" skromnome broju.

Pođemo li, konkretno, od same tematske usmjerenosti Vitezovićeve „zrinijade“ jednoj od ključnih epizoda u višestoljetnoj povijesti kršćansko-muslimanskih (hrvatsko-turskih) ratnih okršaja, već na prvi pogled neće biti dvojbe da je riječ o karakteristično „epskoj“ problematici izvedenoj iz zbivanja koje je označilo prijelomni trenutak u životu „ciljane“ zajednice. $^{697}$ Kolektivna se svijest o povijesnoj važnosti dugog odolijevanja sigetskih branitelja napadima osmanlijskih osvajača ponajbolje manifestirala u već utvrđenoj ovećoj količini usmenoknjiževnih i pisanih (epskopjesničkih) varijacija na temu opsade Sigeta koje su prethodile Odiljenju te na nj izvršile presudan utjecaj, pri čemu je ojačavanju njegovih „epskih“ silnica uvjerljivo najviše pridonijelo uspostavljanje intertekstualnih spona s Petrovom Adrijanskoga mora Sirenom, navlastito s njezinim epskopjesničkim segmentom Obsida sigecka, zbog kojih se u dijelu recentnije sekundarne literature ono i uvriježilo motriti u ulozi „epsko-lirskog, vrlo artificijelnog priloga starijemu baroknom epu“ (Dukić 2002: 68). To Vitezovićevo kreativno crpljenje elemenata iz Petrova ostvarenja pri utvrđivanju usmenoknjiževnih - poglavito „epskih“ - komponenata njegove „zrinijade“ ukazuje se kao izrazito bitan detalj, i to - dakako - zbog poodavno već dokazanoga izvorno usmenoepskog podrijetla čitavog niza fabularnih momenata u Obsidi sigeckoj, zahvaljujući kojemu i naš autor u sklopu intertekstualnog prikapčanja na prethodnikov ep ujedno (posredno) stupa $\mathrm{u}$ kontakt i s „narodnim“ (epskim) pjesništvom, čime i „epski“ legitimitet za svoje Odiljenje stječe ne samo izravnim oslanjanjem na pisanu, nego i neizravnim na (u pisanoj sadržanu) folklornu epskopjesničku tradiciju.

Prizivanje karakteristika usmene epske pjesme u Odiljenju sigetskom započinje već $\mathrm{s}$ paratekstualnom njegovom dionicom, pri čemu se ponajprije ovdje misli na ranije zamijećen detalj iz latinske posvetne pjesme prvoga njegova izdanja (Linz, 1684.), ispjevane u čast kapetana Adama Zrinskog - posljednjega muškog potomka obitelji Zrinski. Naime, posvećujući svoj sastavak jednom od izravnih nasljednika po junaštvima nenadmašnoga sigetskog zapovjednika, Pavao Ritter Vitezović „Hektora sigetske snage“ izjednačava s

${ }^{697}$ O ključnomu „epskom“ obilježju pretresanja (povijesnih) tema važnih za cjelokupnu zajedinicu u: Pavličić 1998: 413-415. 
nekolicinom dobro poznatih, (arhe)tipskih junaka „narodne“ epike - Novakom Debeljakom, Skenderbegom, Kraljevićem Markom i Kobilićem ${ }^{698}$ - napominjući pritom kako je odreda riječ o herojima koji „hrabrim djelima zaslužiše ime i vječnu diku“ (Zrinski, Frankopan i Ritter Vitezović 1976: 359). Ako već ovim paratekstualnim priključivanjem Zrinskog nizu velikih aktera folklornoga epskog pjesništva Ritter aludira na neprikosnoven usmenoepski status sigetskoga kapetana, nema sumnje da isto pokušava učiniti i u samome tekstu Odiljenja, gdje ban Nikola na više mjesta biva prozvan imenima etimološki vrlo bliskim onima iz sfere „narodne“ književnosti („Mikula Zrini“, „Mikula Zrinski“, „Mikula od Zrinja“), a neće biti slučajno ni to što se u djelu u kojemu se glorificiraju njegovi i herojski podvizi malobrojnih njime predvođenih kršćanskih („hrvatskih“) branitelja Sigeta iznenada pojavljuje još jedan folklornoepski lik - Ivo Karlović, čijih se ljubavnih nevolja opjevanih u nizu folklornih pjesama prisjećaju Putnik i vila Jeka u trećem „dilu“ (III: 239-240). ${ }^{699}$

Očigledan poticaj uvođenju lika nesretno zaljubljena bana Karlovića u segment Odiljenja u kojemu - udaljivši se nakratko od evociranja pojedinosti o tijeku opsade Sigeta putnik i vila Jeka raspredaju o manifestacijama ljubavi bila je učestala pojava usmenih pjesama (i) o Karlovićevim ljubavnim dogodovštinama, na podlozi kojih su (onodobni) recipijenti i bili u stanju razumjeti ovu kratku, no dobro im znanu literarnu aluziju. Štoviše, da se tadašnja raširenost „narodnih“ pjesama s Karlovićem kao protagonistom nipošto ne može držati tek nepotvrđenom pretpostavkom pokazat će nam upravo sam Vitezović, koji u ranije spomenutom, od Odiljenja svega tri godine starijemu latinskom povijesnom spisu o plemićkoj obitelji Gušić Apographum ex Joanne Lucio (1681.) iznosi podatak kako se diljem Hrvatske pjevaju folklorne lirske i epske pjesme posvećene Karlovićevim ljubavnim pothvatima, među kojima je i ona što je otvaraju (deseterački) stihovi: „Kuliko je u Lici gradova, / sedamdeset i sedam gradova, / ni divojke ni neviste mlade / koju nije Karlović 1jubio““ ${ }^{700}$ Drugim riječima, nije dvojbeno kako u Odiljenju sigetskom Vitezović polazi od usmenoknjiževnoga konteksta i na taj isti kontekst ozbiljno računa, čvrsto vjerujući kako će upravo on čitateljima pomoći pri „dešifriranju“ motiva „ranjena“ Karlovića, ali ujedno i pri podsjećanju na konkretna „hrabra djela“" te uopće stvarni značaj folklornih junaka u krug kojih u posvetnoj pjesmi prvoga izdanja uključuje i samoga Nikolu Šubića Zrinskog. Ovakva pisanoknjiževna „eksploatacija“ likova i motivskih aluzija folklornoknjiževnoga, odnosno pretežno usmenoepskog porijekla -

\footnotetext{
${ }^{698}$ Spomenuta dionica posvetne pjesme - u prepjevu Vladimira Vratovića - glasi: „Tu vise snažni štitovi NOVAKA DEBELJAKA i buzdovan koji bi i Herkulova ruka jedva nosila. / Tu SKENDERBEG nosi različite bojne znakove i znakove KRALJEVIĆ, znakove KOBILIĆ drži. / (...) / A među njima sjajno oružje drži srčani ZRINSKI, onaj Hektor sigetske snage“" (Zrinski, Frankopan i Ritter Vitezović 1976: 359).

${ }^{699}$ Rečeno mjesto glasi: „Zmed čuda ditića, kojim je granila, / ni li Karlovića hranila? Ranila“.

700 Cit. prema: Bošković-Stulli 1978: 208.
} 
uzgred budi rečeno - u okvirima hrvatskoga književnog baroka nije predstavljala izdvojen, a kamoli neuobičajen (epskopjesnički) postupak, pa tako vrijedi spomenuti da se, između ostalih, na nj u svome Osmanu odlučio i Ivan Gundulić, koji premrežuje treće i osmo njegovo pjevanje motivima bugarenja o Kobiliću, Mihajlu Svilojeviću, Kraljeviću Marku, vojvodi Janku, despotu Đurđu i dr. ${ }^{701}$ Kao i u slučaju (nekih) njegovih „epskih“ prethodnika i nasljednika, i Vitezovićevo literarno apsorbiranje konkretnih folklornoepskih aktera te epizoda u kojima su u ranijim ostvarenjima oni sudjelovali trebalo bi stoga motriti kao „tek“ jedno u nizu rješenja posredstvom kojih naš autor pokušava učvrstiti „,epsku“ okosnicu svoje „zrinijade“, odnosno približiti je generičkom ,polu“ povijesnog epa, pa i usprkos tomu što se ostalim njezinim žanrovskim slojevima od toga ,pola“ istovremeno nastoji i što više udaljiti.

Osim izravnim posuđivanjem pojedinih folklornoknjiževnih junaka iz izvornoga usmenoepskog „okružja“, Ritter je zastupljenost epskopjesničkih čimbenika u fakturi Odiljenja sigetskog bitno povećao i preuzimanjem dijela likova iz Petrove Obside (odnosno posredno - Nikolina epa Szigeti veszedelem) dokazano skrojenih po uzoru na neke aktere što (također) potječu iz „,narodne“ epske poezije. Naime, kako je svojedobno uvjerljivo utvrdio Đuro Novalić, kao likovi s jakim zaleđem u usmenomu (epskom) pjesništvu u Petrovu (Nikolinu) epu izdvajaju se oni Radivoja, Hajkune, Deli Vida, Ali Kurta i Idriza, ${ }^{702}$ koje sve redom susrećemo i u Vitezovićevoj ,zrinijadi“, i to upletene u one iste situacije iz kojih su „,iznikli“ i u Obsidi sigeckoj. Budući da su i potonje situacije ili epizode, ističe u nastavku Novalić, zapravo ništa drugo no također Petrove (Nikoline) sadržajne posudbe iz ,narodnih“ epskih pjesama (posebice epizoda s dvobojem Demirhana i Deli Vida, potom ona u kojoj pokrštena Turkinja Hajkuna izbavlja supruga iz osmanlijskoga zarobljeništva itd.), to ce značiti da - presađujući ih (većinom u obliku motivskih evokacija) iz prethodnikove u vlastitu „Zrinijadu“ - i sam Vitezović posredničkim kanalom tako zapravo dospijeva ostvariti dvostruko sadržajno nadovezivanje na autohtonu usmenoepsku tradiciju. Iako, dakako, ne bismo smjeli sasvim isključiti ni mogućnost Ritterova neposrednog „kontakta“ s varijantama makar nekih od onih folklornoepskih pjesama čiji su elementi umnogome obogatili i sižeje epova braće Zrinski, nedostatak dovoljno opipljivih dokaza tjera nas ipak da tu (ni najmanje nevjerojatnu) mogućnost zasad ostavimo tek na razini nepotvrđene pretpostavke.

Kako bilo, dionicom Odiljenja s uvjerljivo najvećom koncentracijom folklornoepskih čimbenika književni su povjesnici i folkloristi - podsjetimo - desetljećima proglašavali dijalošku pjesmu Gospodična Sofija i oral (II: 735-906), u kojoj vijesti o pogibiji njezina

\footnotetext{
${ }^{701}$ Podrobnije o tome u: Bošković-Stulli 1978: 207-208.

${ }^{702}$ Usp. Novalić 1967: 22-46.
} 
zaručnika pod sigetskim zidinama zabrinutoj Sofiji donosi personificirani orao. S obzirom na to da motiv ptice-glasnika, koja zaručnicu, suprugu ili kojega drugog člana najbliže obitelji izvještava o pokojnikovu tragičnom kraju na bojnom polju, spada u krug najeksploatiranijih usmenoepskih toposa, neki od rečenih proučavatelja nisu se libili upustiti ni u (većinom uzgredna) kompariranja Vitezovićeve pjesme sa sadržajno bliskim „narodnim“ pjesničkim ostvarenjima, i to najčešće s - kako smo vidjeli - glasovitom Kosovkom djevojkom, u kojoj „mjesto krvlju poštrapana orla ranjeni junak Orlović Pavle priča djevojci o kosovskoj pogibiji, javljajući joj smrt zaručnika“ (Vodnik 1913: 298). U vezi s potonjom je usporedbom, međutim, neizbježno primijetiti kako se, izuzev motiva kobnih vijesti o sudbini čak trojice potencijalnih djevojčinih zaručnika, zapravo tek malokoji zapravo fabularni moment Kosovke djevojke izdvaja kao posve usporediv sa sadržajem Gospodične Sofije i orla!, tim više što se protagonistica čuvene usmene pjesme - za razliku od Sofije - ne prepušta pasivnom iščekivanju ,vojvoda“ ni eventualnih vijesti o njihovom usudu, već tijekom aktivne potrage za njima na koncu i sama dospijeva na poprište tek okončane bitke - Kosovo polje. Imajući to na umu, čini se kako bi se stoga ponešto s(p)retnijima i opravdanijima mogle ispostaviti usporedbe što ih je - fokusirajući se isključivo na zapise folklornih epskih pjesama iz istoga, kosovskog ciklusa - svojedobno učinio Tomo Matić, prispodobivši lirski razgovor Sofije i orla usmenoepskim dijalozima teško ranjenoga Kraljevića Marka i sokola te majke Jugovića i dvaju gavrana, koji joj dojavljuju smrt svih devetorice njezinih sinova u bitci na Kosovu. ${ }^{703}$

Možebitan utjecaj usmenih epskih pjesama iz - porijeklom nedvojbeno vrlo staroga kosovskog ciklusa na sadržajne posebnosti Vitezovićeve Gospodične Sofije i orla! iznimno se, međutim, teško može dokazati, i to prije svega zbog „kroničnog“ nedostatka očuvanih zapisa iz nešto dublje prošlosti, poradi kojega bi se i utvrđivanje mogućih kreativnih posudbi neizbježno svelo na tek nizanje pretpostavki izrečenih na temelju pojedinačih komparacija Ritterove pjesme s primjercima bitno kasnije zabilježenih „kosovskih“ epskih pjesama. Da to, dakako, ni najmanje ne dovodi u pitanje nepobitnu činjenicu kako su ključni poticaji za Gospodičnu Sofiju i orla! pristigli iz sfere usmene (epske) književnosti uvjerljivo nam između ostalog - potvrđuje i u njemu prisutan lik kneza Alapije (točnije, povijesnoga Gašpara Alapića), čiju smrt ondje i oplakuje neutješna Sofija i kojega upravo taj (čisto literarni) motiv njegove pogibije ${ }^{704}$ i „lansira“ među tipično usmenoknjiževne (folklornoepske) junake. Naime, iako u ovome odsječku Odiljenja sigetskog Vitezović opjevava njegovu smrt u okršaju s turskim napadačima, povijesni Gašpar Alapić - kako je dobro poznato - ipak nije

\footnotetext{
${ }^{703} \mathrm{O}$ tome opširnije u: Matić 1968: 104-105.

${ }^{704}$ Gašpar Alapić, štoviše, u četvrtome dijelu Odiljenja dobiva čak i vlastitu (kraću) nadgrobnicu - Kneza Gašpara Alapića (IV: 208-215).
} 
skončao pod zidinama opkoljenoga Sigeta, što će reći da na djelu ovdje imamo literarno „falsificiranje“ činjeničnih (povijesnih) podataka, u kojemu bi - zamijetio je svojedobno već Branko Vodnik ${ }^{705}$ - valjalo prepoznati manifestaciju ničega drugog no tipično usmenoknjiževnoga prilično slobodnog odnosa spram povijesti i povijesnih činjenica. U okvirima „narodne“ epske pjesme - na koju se pri sastavljanju Gospodične Sofije i orla! i drugih segmenata svoje ,zrinijade“ uvelike nadovezivao naš autor - bilo je tako, drugim riječima, posve uobičajeno junaka poput Gašpara Alapića „lišiti života“ uslijed kršćanskomuslimanskoga okršaja iz kojega je u stvarnosti izašao živ, i to naročito ako bi - kao i u slučaju Odiljenja - opjevavanje (povijesno potvrđenoga) preživljavanja njegov lik lišila neophodne ,aure“ junaka-mučenika, odnosno heroja koji je za obranu „viših ideala“ (domovina, kršćanska vjera) odvažno žrtvovao i vlastiti život ne bi li se naposljetku prometnuo u (arhe)tipsko utjelovljenje ratničke snage, hrabrosti i odanosti.

„Presađena“, također, iz sfere usmenoga (najčešće epskopjesničkog) književnog stvaralaštva svakako bi bila i težnja pridavanju antropomorfnih obilježja ne-ljudskim živim bićima, objektima i pojavama, zahvaljujući kojoj u Odiljenju Sofija i dospijeva uspostaviti komunikaciju s orlom, ban i kralj sa Sigetom, a putnik-namjernik s vilom Jekom, koja mu i otkriva neke (njemu nepoznate) pojedinosti iz sigetske bitke. S obzirom na to da dodjeljivanje sposobnosti govora drugim živim bićima i neživim ,akterima“ u folklornoj književnosti ujedno implicitno priziva mitsko (pra)stanje, ,kad su svi sudjelovali u komunikaciji - i ljudi i stvari, i predmeti i pojave, i životinje i biljke“ (Botica 2013: 306), posve opravdanom, pa i „logičnom“ u kontekstu Vitezovićeve ,zrinijade“ ispostavila bi se i rečena pojava vila - kao uvjerljivo najbitnijeg motiva ,cijele hrvatske mitske i mitologijske izgradnje“ (Isto: 171) - u ulozi govornica i adresatkinja iskaza drugih „likova“. Ukratko, Ritterovo sustavno posezanje za idejnim i oblikovnim strategijama usmenoga (epskog) pjesništva rezultiralo je tako između ostalog - i apsorbiranjem u njemu suptilno prisutnoga mitskog sloja, koji u Odiljenju sigetskom i jest raščistio prostor za uključivanje „blagoglagoljivih“ životinja, objekata i vila, čiji se doživljaj ovoga velikog povijesnog događaja i njegovih reperkusija odjednom također ispostavio ne manje važnim i zanimljivim. Doduše, iako pojedini proučavatelji nimalo ne dvoje u to da pojava vila u Ritterovoj „zrinijadi“ najviše ipak duguje oslanjanju na folklornu književnost, ${ }^{706}$ ni u jednom trenutku s uma ne bismo smjeli smetnuti kako je ništa manje bitan

\footnotetext{
${ }^{705}$ Vodnik u svome književnopovijesnom pregledu tako ističe: „Gašpar Alapija bio je doista za vrijeme opsade u Sigetu, ali nije pao u boju, pače oslobodio se iz turskoga sužanjstva te je poslije bio hrvatskim banovcem, što je sve Vitezović kao historik svakako znao, i upravo je to znak, da je Vitezović i motiv i ovo lice uzeo iz narodne pjesme, koja se ovako odmiče od povijesti“ (Vodnik 1913: 298, bilješka 1).

${ }^{706} \mathrm{Da}$ je motiv, odnosno figuru vile Vitezović baštinio isključivo iz usmene književnosti u jednoj od svojih studija odrješito će ustvrditi Josip Kekez (usp. Kekez 1987: 126).
} 
poticaj našem autoru za prizivanje figure vile gotovo sigurno došao i iz pisane, $i$ to ponajprije dubrovačko-dalmatinske renesansne književnosti - na pojedine literarne strategije koje se Odiljenje ionako uvelike nadovezuje - u kojoj je lik i motiv vile (najčešće kao brižne čuvarice kolektivnoga duhovnog nasljeđa) kotirao kao jedan od definitivno najčešćih i najvažnijih.

Vitezovićeve vile, na čijem se izravnom (verbalnom) sudjelovanju sadržajno temelje dvije podulje dionice Odiljenja sigetskog - pjesma Vila Hrvatkinja nad Sigetom (II: 614-734) te već spomenut poetski dijalog Putnik i Jeka (III: 1-376) - pozicijom koja im je dodijeljena, ali i vlastitim iskazima i činidbama jasno ipak odaju daleko veću bliskost usmenoknjiževnim (folklornoepskim) no pisanoknjiževnim svojim renesansnim parnjacima. Konkretno, u „svijetu“ Ritterova teksta vile ne samo što poprimaju prepoznatljiv mitsko-bajkoviti izgled (u pjesmi Siget banu $i$ vojnikom Siget tako ističe da njihovu pojavu obilježavaju „krila i ruha svitline“; II: 386), nego - k tome - i na više mjesta izriču svoju spremnost da se osobno uključe u nemila ratna zbivanja u Sigetu, kao što će to učiniti i Hrvatkinja, koja - gnjevno se obraćajući Sigetu - naglašava kako bi njome predvođena „družina“ vila na njegov poziv bez mnogo razmišljanja bila priskočila u pomoć hrvatskim braniteljima budući da su i same junačkoga porijekla te itekako vične ratovanju (,I u nas su moći k obrambi zgojene, / da b' mogle pomoći, ako smo prem žene. / I mi smo rođene od junakov vile, / o boju zgojene, srčene bi bile“; II: 688-691), a uz to bi ih i silno motivirala činjenica kako će se protiv neprijatelja boriti rame uz rame s vlastitim sinovima [,,(..) tužna ja mati razcviljena vila, / ka sam v tvojoj rati tu ranu dobila, / da prez moga mila navik sam ostala, / i što sam rodila, mrtvo ne kopala“; II: 700-703], pa i po cijenu vlastite smrti, koja bi se u takvim okolnostima ispostavila u potpunosti svrhovitom i slatkom (,da bi s dragim pala svaka svojim bila, / nasladnost imala barem v smrti vila“; II: 680-681). Takva koncepcija vila u Vitezovića najvećim dijelom proizlazi upravo iz karakteristično usmenoknjiževnog ustrajanja na njihovoj antropomorfizaciji, odnosno na čestom isticanju izvorno ljudskog im porijekla, koje im i omogućuje uspostavljanje komunikacije s ljudskim rodom te u njih pobuđuje zanimanje za čovjekove brige i nedaće, ${ }^{707}$ ali i iz kojega ujedno vuče svoj korijen njihova katkad vrlo snažna težnja za dijeljenjem sudbine s ljudskim „rođacima“ i potreba da im se - navlastito uslijed krupnijih društvenopovijesnih previranja - neprekidno bude na usluzi. ${ }^{708}$

Potonja vilinsko-ljudska rodbinska povezanost, u Odiljenju učvršćena još i motivom majčinstva nad mnogim u Sigetu izginulim ratnicima, Vitezovićevim vilama nije dopustila -

\footnotetext{
${ }^{707}$ Usp. o ovome u: Botica 2013: 171.

${ }^{708}$ Vilinskim „uslugama“ u usmenoj se epici tako vrlo često koriste neki od „stožernih“ folklornih aktera poput primjerice - Kraljevića Marka, kojega čitav niz „narodnih“ pjesama prikazuje upravo u pratnji zaštitnica vila. Podrobnije o vilama kao zaštitnicama velikih epskih junaka u: Botica 2013: 307-309.
} 
za jedan dio (glavninom starijih) usmenih pjesama te većinu pisanoknjiževnih ostvarenja karakteristično - posvemašnje distanciranje od zbivanja među „smrtnicima“, odnosno zatvaranje u ,vilinski svijet“ vođen korjenito drugačijim načelima u odnosu na onaj ljudski te ujedno od njega i (fizički) čvrsto odvojen. ${ }^{709}$ Ipak, po završetku hrvatsko-turskog okršaja u kojemu - poradi dezinformacija što ih je u ranijim pismima s bojišta odašiljao Siget - nisu dobile priliku participirati, vile će se okrenuti čuvanju uspomena (Jeka), pjevanju pjesama o junačkoj pogibiji bana Zrinskog („,Ka im je gospoja zelen venac zvila / i pisam od boja njim spravila? Vila; III: 363-364), odnosno kontinuiranom oplakivanju pojedinih, posebno im omiljelih junaka poput vojvode Juranića, kojega zbog naročite ljepote svojedobno „kruto ljubihu vile“ (IV: 370). Drugim riječima, aktivnosti vila u razdoblju što je uslijedilo nakon pada utvrde u ruke Osmanlija i smirivanja uskomešanih emocija, po kojima je uvjerljivo prednjačila Hrvatkinja, približit će se nešto starijem folklornom poimanju njihove egzistencije i naročito pisanoknjiževnoj im (renesansnoj) koncepciji, što će reći literarnoj predodžbi o njihovu samozatajnom suživotu s ljudskim društvom te ključnoj im ulozi u čuvanju važnih, mahom duhovnih čimbenika čovjekova postojanja. Sve u svemu, samo inkorporiranje motiva vile u Odiljenje sigetsko ispostavlja se kao jedan od zacijelo najuočljivijih indikatora mitskoga zaleđa (usmeno)epskog sloja Odiljenja, dok njezino uključivanje u podug popis govornika, kojim je Vitezović postigao dodatno razbijanje komunikacije na više kazivača i adresata, nepogrešivo upućuje na - kako primjećuje Kekez - ,poetsko-transmisijski postupak“, uslijed kojega se „mitski osmišljava tragična zbilja odnosno faktički povijesni podatak, kako to već biva u lirskim narodnim pjesmama“ (Kekez 1987: 128). Takvo sadržajno rješenje, posve istovjetno onome iz folklornoga pjesništva, Vitezoviću zapravo daleko „više odgovara i stoga što je od sigetskoga zbivanja prošlo već stotinu godina“ (Isto: 128), zahvaljujući čemu se kao nasušna više ne nameće potreba za koherentnim epskim, čvrstim sižejnim okvirima i jedinstvenom pripovjedačkom perspektivom sapetim opjevavanjem kronologije pada Sigeta i junaštva njegovih (hrvatskih) branitelja.

Govoreći o folklornim epskopjesničkim čimbenicima Vitezovićeve „zrinijade“, jasno je kako će se (i) njihov tekstualni (pa i, velikim dijelom, izvantekstualni) značaj iskristalizirati tek na podlozi činjenice da se kao presudno (žanrovsko) obilježje podjednako usmene i pisane epske pjesme ispostavlja upravo ,iznošenje, opisivanje neke radnje, događaja“ (Čubelić 1988: 84). Doduše, premda bi vjeru u njegove pripovjedne silnice lako mogli poljuljati dosadašnji sudovi o Odiljenju kao tekstu koji „,nema uopće narativnoga karaktera“ (Matić 1968: 104) jer su u njemu „naracija i radnja isključeni kao umjetničke komponente“ (Kolumbić 2005: 336),

${ }^{709} \mathrm{O}$ ovakvom modusu egzistencije vila u usmenim pjesmama detaljnije u: Botica 2013: 305-306. 
odnosno o tome kako priča u Ritterovu djelu „ne samo da se ne pripovijeda izravno, nego nije ni implicitno prisutna u tekstu“ (Pavličić 2007: 256), očit izostanak pripovjedačkog motrišta nadomješten iskazima različitih govornika nije istodobno značio i dokinuće bilo kakvih narativnih čvorišta, pa je tako, naprotiv, u svakom od četiriju „dilova“ moguće locirati - kako smo ranije pokazali i dokazali - kraće segmente, a kadšto i nešto duže dionice, u kojima upravo radnja ili tek neki njezin djelić opterećen narativnim značenjem postaje dominantnom komponentom, pri čemu se glavninom radi o posuđenim fabularnim momentima i likovima iz Obside sigecke Petra Zrinskog. Ti narativni i narativizirani (,epski“‘) fragmenti pritom se ne donose kronološko-logičnim redoslijedom, razlog čemu treba tražiti u njihovu rasipanju kroz monologe i dijaloge mnogobrojnih aktera sigetske katastrofe koji ne pripadaju ni istoj vremenskoj, a često ni prostornoj dimenziji, iako četiri dijela Odiljenja na višoj razini ipak pokazuju određen stupanj temporalnog kontinuiteta (pravocrtnosti). ${ }^{710}$ Dok bi tako, ukratko, pjesme prvih dvaju dijelova „zrinijade“ vremenski obuhvaćale sam završetak kršćanskomuslimanske bitke pod Sigetom i razdoblje neposredno nakon turskog trijumfa, treći (dijalog putnika i Jeke) te poglavito četvrti, epitafski dio Odiljenja pripadali bi znatno udaljenijim temporalnim perspektivama, kada je Siget već najvjerojatnije dulji niz mjeseci u rukama osvajača, a u čast poginulih već isklesane i podignute nadgrobne ploče u polju uokolo utvrde.

Vremenski „procijep“ između konca drugog i početka trećeg „dila“ postaje, na kraju krajeva, i ključnim razlogom zbog kojega velika većina pripovjednih segmenata posljednjih dviju dionica Odiljenja neće unijeti gotovo nikakve fabularne novitete u ,priču“ o padu Sigeta, čije su obrise iscrtali narativni odsječci prvoga i drugoga dijela. Podsjetimo, informacije što ih čitatelj u njima zatječe nadaju se kao tek svojevrsna nadopuna ili vezivno tkivo ranijim „krhotinama priče“, koje nakon takvih pojašnjenja dobivaju pun(ij)i smisao i mogu se - no isključivo na podlozi Petrove Obside - povezati u nešto širu cjelinu. Tako, primjerice, uvodni Sigetov pisani izvještaj adresiran na „gospoje hrabrene i hrvatske vile“ uključuje i spomenuti odulji, gotovo ,punokrvan“ epsko-narativni odsječak (I: 89-244), u kojemu se evociraju svi važniji trenuci opsade, počevši od dolaska Turaka i njihova strateškog raspoređivanja oko utvrde, preko prvih okršaja i uzaludnog iščekivanja kraljeve pomoći, pa sve do konačnog izjahavanja Sigećana predvođenih banom Zrinskim na posljednji okršaj, njihove junačke smrti te konačnoga osmanlijskog zauzeća grada. Posebno će mjesto $u$ Sigetovoj poslanici pritom zauzimati dvije (iz Petrova djela preuzete) epizode vezane uz osujećene pokušaje dojavljivanja vijesti o opsadi na kraljev dvor - pogibijom prekinuto

\footnotetext{
${ }^{710} \mathrm{Na}$ ovu je činjenicu - podsjetimo - pozornost skrenuo Davor Dukić zamijetivši kako Odiljenje, „ako se promatra vrijeme priče na globalnom kompozicijskom planu, onda ono zadovoljava načelo pravocrtnog kronološkog hoda“" (Dukić 2002: 68).
} 
putovanje dvojice (neimenovanih) vojvoda u Beč (I: 127-136) te također neuspješan let goluba pismonoše u istome smjeru (I: 163-174) - od kojih se onoj drugoj Vitezović kasnije više neće vraćati, no zato će - svjestan da je nedovoljno narativno preciziran proboj „dva silna vojvode“ iziskivao razjašnjenje - prvoj dodatan prostor posvetiti u zaključnom „dilu“, gdje su vojvodama ispjevane čak dvije nadgrobnice - Radivoja i Juranića vojvod (IV: 353-365) i Samoga Juranića vojvode (IV: 366-385). Za fabularnu podlogu Odiljenja od posebne će važnosti biti prva nadgrobnica, u kojoj (do toga trenutka) anonimnim „vojvodama“ napokon bivaju „razotkrivena“ imena, ali ujedno i precizirani detalji njihova bezuspješnog putovanja u Beč, koje je - otkriva Siget - završilo pogibijom nakon što su ih turski neprijatelji razotkrili u ubijanju pozaspalih im suboraca usred njihova tabora. Epitaf Radivoja i Juranića vojvod, konkretno, ovu ranije ovlaš prezentiranu epizodu oplemenjuje čak trima novim informacijama o smrti Radivoja i Juranića, i to - ponajprije - činjenicom kako je njihov bijeg otkriven tek nakon što su nabasali na tatarsku stražu, zatim onom kako su obojica ubijeni vjerno braneći sudruga od neprijatelja (,drug za druga, pade“; IV: 361) te, naposljetku, detaljem da je Radivoj u žaru borbe dospio odsjeći glavu i samome turskom veziru. Pored maločas uočenog motiva Juranićeve iznimne obljubljenosti među vilama, druga će nadgrobnica donijeti tek ponovljen motiv ,zasluge“ Tatara za Juranićevu smrt (,Vilam žalost veliku / Tatari učiniše, / bana i Siget udriše / u ovomu vojniku“; IV: 374-377), slijedom čega u prikazbi i konkretizaciji spomenute epizode o vojvodama ona i ne dospijeva steći veću narativnu težinu.

Identičnim epsko-fabularnim nitima Odiljenje je sigetsko - kako je i ranije već uočeno - protkano gotovo u cijelosti, pri čemu posebno treba pripomenuti kako će se narativni fragmenti povezani s nekim točno određenim motivom gdjekad pojaviti i na više mjesta unutar teksta. Izvrstan nam primjer u tom pogledu nudi motiv smrti Nikole Šubića Zrinskog, koji se u uvodnom „,pismu“ Sigeta najprije utapa u prizoru kolektivne pogibije „hrvatskoga zbora“, potom se u motivski nepromijenjenu kontekstu pojavljuje i u nekolicini pjesama drugoga dijela (Siget banu i vojnikom, Siget kralju, Vila Hrvatkinja nad Sigetom, Gospodična Sofija i oral) te čak i u podužoj nadgrobnici Mikule kneza od Zrinja, bana (IV: 62-103), da bi tek u pjesmi Putnik i Jeka trećega ,dila“ doživio (narativno) proširenje podatkom o izravnom pogotku puščanim zrnom u lice kao razlogom banove smrti (,Gdi ga pogodi on, da opade nice, / zrnom al oštrinom sulice? U lice“; III: 167-168). Neobično je zanimljivo pratiti i pripovjedni „put“ pojedinih (iz Petrove „zrinijade“ preuzetih) aktera kroz „dilove“ Odiljenja, pa dok se tako - između ostalih - turski junak Deliman u pjesmi Siget hrvatskim gospojam pojavljuje „tek“ kao pripadnik osmanlijske vojske što je dospjela pod zidine Sigeta (,kadi konak stavi vojvoda Deliman“; I: 369), a svega nekoliko se stihova kasnije - posve nevezana 
za Delimanov lik - spominje smrt careva zeta Rustana (I: 372), dotle kazivačica pjesme Vila Hrvatkinja nad Sigetom izražava ozbiljnu bojazan zbog Delimanove lukavosti ili „šege“ (II: 621), a u trećem „dilu“ evocira se i njegova hrabrost, ali i samovoljnost zbog koje je sam car bio prisiljen sazvati vijeće (III: 109-116). Konačno, prethodni narativni „,nagovještaji“ svoju će dopunu ili razjašnjenje dočekati tek u epitafu Delimana, sina velikoga Hama, poglavnika tatarskoga (IV: 106-121), gdje će pokojnikovu hrabrost i lukavost potvrditi činjenica da je jednom prilikom silom provalio u još neosvojen Siget i u njemu pobio brojne kršćanske branitelje, a njegovu svojeglavost ubojstvo careva zeta Rustana radi Kumiline ljubavi, pri čemu se ondje neće još zaboraviti naglasiti ni to kako je Deliman skončao od ruke samoga bana Zrinskog, dok je voljenoj mu Kumili presudilo slučajno ispijanje otrova. Nalik navedenim primjerima, i vrlo velik broj ostalih će tek „okrznutih“ motiva (poput, primjerice, onog Hajkunine odvažnosti, Deli Vidova i Demirhanova dvoboja, Alderanovih „vražjih čarnosti“ itd.) ili ugrubo skiciranih epizoda iz prvih dviju dionica Odiljenja upravo narativne komponente što ih sadržava nadgrobnički ciklus i - u nešto skromnijoj mjeri - dijalog putnika i Jeke upotpuniti ključnim dopunskim informacijama, zahvaljujući kojima i jest moguće sazdati kakvu-takvu fabularnu konstrukciju, u koju su glavninom uklopljene i izvorno folklorne epskopjesničke značajke Ritterove „,zrinijade“.

Intertekstualno preuzimanje konkretnih likova, epizoda i situacija iz Obside sigecke Petra Zrinskog našem autoru, naime, nije samo omogućilo uspostavljanje (olabavljena) narativno-epskog zaleđa Odiljenja te potvrđivanje njegova (i) epskopjesničkog generičkog usmjerenja, nego i posredno stupanje u kontakt s čitavim nizom „epskih“ žanrovskih značajki usmenoknjiževne provenijencije, kojima učvršćuje ionako izrazito snažnu folklornu podlogu svoga ostvarenja. Naime, znamo li da bi nemali broj sižejnih komponenata Petrova epa u rasponu od figure pokrštene Turkinje (Hajkuna) i motiva dvoboja istaknutijih junaka (Deli Vid i Demirhan) do motiva prerušavanja, odsjecanja glava poginulih neprijatelja te motiva širenja vijesti o bitci ${ }^{711}$ svoje porijeklo morao vući iz usmenoga pjesništva, to bi značilo i da Ritter njihovim kreativnim preuzimanjem svoj tekst obogaćuje vrlo šarolikom paletom posredovanih, no zato nimalo razvodnjenih karakteristika „narodne“ epske poezije. Za razliku, ipak, od Petra, koji se u Obsidi s vremena na vrijeme nije ustručavao prilično pogrdnim atribucijama okvalificirati pripadnike suparničkoga, muslimanskog tabora, ${ }^{712}$ Vitezović svoju jasnu nakanu otupljivanja diskvalifikacijske oštrice dokazuje ne samo ustrajnim zaobilaženjem negativni(ji)h atribucija Turaka (među kojima se uvjerljivo

\footnotetext{
${ }^{711}$ Detaljnije o tome u: Novalić 1967: 22-46 i Botica 2013: 261-378.

${ }^{712}$ Znatno oštriji, gotovo mrzilački stav prema Turcima jedna je od ključnih razlika između Petrove hrvatske adaptacije Szigeti veszedelema i mađarskog originala Nikole Zrinskoga (detaljnije u: Novalić 1967: 84-126).
} 
„najtežom“ stoga ispostavlja ona „pogana“), nego i ublažavanjem polarizacije dviju sukobljenih strana, koje će do izražaja najviše doći u četvrtoj, epitafskoj dionici Odiljenja, u cijelosti baziranoj na ideji zajedničkoga sigetskog groblja, na kojem - jedni uz druge sahranjeni leže kršćanski i muslimanski ratnici i zapovjednici. Štoviše, bit će da je upravo tim odustajanjem od odveć napadnih diskvalifikacija turskoga neprijatelja Ritter svoje djelo želio još više približiti autohtonoj folklornoj epskoj pjesmi, koja se, u pravilu, kloni(la) uspostavljanja čvrstih dihotomijskih oznaka nastojeći „opjevati događaj bez teških, uvredljivih kvalifikacija“ (Botica 2013: 265), a uz to ga je još i - također imajući na umu „narodnu“ poeziju, u kojoj se junaštvo i viteštvo poimaju kao najviše (uzorne) vrijednosti što iziskuju dolično proslavljanje, a ne okaljano verbalnim omalovažavanjem neprijatelja ${ }^{713}$ napučio „napadnim“ idealizacijama herojstva, zahvaljujući kojima će u njegovu svijetu ne samo kršćanski branitelji, već i turski osvajači Sigeta s podjednakim žarom na bojišnici ginuti za vjeru, za domovinu i za kralja ili cara.

Razmatrajući karakteristično usmenoepske elemente zastupljene u Vitezovićevoj „zrinijadi“, svakako bismo pozornost morali obratiti i na ranije već analiziran motiv, točnije žanr (doslovno prenesena) pisma, koji je - usprkos činjenici da mu u Petrovoj Obsidi nije bilo prepušteno ni približno toliko prostora - u Odiljenju sigetskom izrastao u jednog od „nosivih stupova“ teksta u cijelosti, i to ponajprije zahvaljujući prvim dvama „dilovima“, u kojima izuzetno velik broj iskaza otpada upravo na epistolarnu komunikaciju među različitim akterima ili govornicima (Sigeta i vila, bana i Sigeta, kralja i bana, Sigeta i kralja itd.). Ti epistolarni odsječci Ritterova teksta, premda - kao što smo vidjeli - u potpunosti „,skrojeni“ po modelu pisanoknjiževnoga žanra (barokne) fiktivne poslanice ili heroide, $u$ isti se mah nameću kao uvelike srodni identičnim motivsko-generičkim sastavnicama folklorne epske pjesme, u kojoj nerijetko kolaju (u cijelosti također „citirana“) pisma s novostima s bojišnice, ali i u kojoj motivi poput pisanja, odašiljanja i primanja pisma te brzoga sastavljanja kratkog odgovora na nj uopće spadaju u krug gotovo neizbježnih motiva. Iako, drugim riječima, pozamašnu količinu fiktivnih poslanica u Odiljenju bez trunke dvojbe valja tumačiti kao posljedicu maločas utvrđene barokne popularnosti pisanoknjiževnih epistolarnih žanrova, nipošto se zbog toga ne ni smjela previdjeti (a kamoli negirati) ni njihova očita bliskost „narodnom“ epskom pjesništvu, ali ni pojedini njihovi sadržajni momenti što sugeriraju da je Vitezović pri njihovu sastavljanju na umu imao i recipijente koji će im (generički) pristupati većinom na podlozi svoga ranijeg iskustva s folklornoepskim ostvarenjima. Tu se, ponajprije, misli na Ritterovo evociranje izvorno usmenoknjiževnoga naziva za pismo - „knjiga“ (II:

${ }^{713} \mathrm{O}$ ovome obilježju usmene epike u: Botica 2013: 265-266. 
633) - što ga zatječemo u naricaljki Vila Hrvatkinja nad Sigetom, ali i na samo otvaranje mogućnosti za epistolarno općenje personificiranim (Siget, „orsag“, rimska Crkva) i mitskim (vila) likovima ili govornicima, koje - iako je riječ o postupku svojstvenom žanru heroide neodoljivo podsjeća na čestu folklornoknjiževnu pojavu „oživljenih“, personificiranih kazivača te stoga $\mathrm{s}$ pravom navodi na pomisao kako je naš autor, želeći ispisati tekst prilagođen različitim tipovima čitatelja, svoju ,zrinijadu“ napučio višeznačnim tekstualnim rješenjima koja je svaki pojedinačni recipijent bio pozvan interpretirati u skladu sa svojim predznanjem, čitateljskim iskustvom i sebi svojstvenim očekivanjima, a pritom od teksta ipak dobiti jednaku poruku kao i onaj koji mu je pristupao iz neke bitno drugačije perspektive.

Inzistirajući na epistolarnom modusu prenošenja osobnih dojmova pojedinih ,junaka“, Vitezović je - štoviše - dospio postići ne samo iznimno visok stupanj intimnosti (zbog impliciranja „privatnosti“ korespondencije), već i posve nov - „unutarnji““ - pogled u publici i više nego dobro poznatu povijesnu priču o osmanlijskom zauzeću Sigeta i herojskoj pogibiji bana Zrinskog i njegovih suboraca, zbog čega ni to plasiranje individualnih „svjedočanstava“ o posljednjim danima obrane grada i vremenu neposredno nakon njegova pada ne bi bilo neopravdano donekle poistovijetiti (i) s usmenoepskom sklonošću domišljanja, odnosno „krivotvorenja“, pa i iskrivljavanja konkretnih povijesnih činjenica, tim više što među njima kada je sigetska bitka u pitanju - nije moguće pronaći nikakav podatak o eventualnom oproštajnom pismu što ga je Zrinski pisao hrvatskoj domovini („orsagu“), a kamoli o onima što su ih razmjenjivali Siget i kralj te hrvatske vile i Siget. Takvo fikcionalno ,interveniranje“ u povijesno provjerljivu kronologiju sigetske katastrofe u tom bi smislu valjalo izdvojiti kao možda i najizrazitiju potvrdu Vitezovićeva kreativnog oslanjanja i na ,poetiku“ usmene epske pjesme, koja se velikim dijelom zasnivala upravo na iskrivljavanju faktografske zbilje, ${ }^{714}$ uslijed kojega se, između ostalih, posve „,vjerojatnom“ i uvjerljivom mogla ispostaviti i „činjenica“ poput one kako je bana Zrinskog - kao što to pjevaju brojne usmene pjesme svega nekoliko godina prije pogibije pod Sigetom iz turske tamnice spasila njegova pokrštena supruga. Govoreći o Ritteru naročito dragom motivu razmjenjivanja pisama, odnosno o samim epistolarnim segmentima Odiljenja, nimalo nam nevažna neće biti ni maločas uočena njihova usklađenost $\mathrm{s}$ temeljnom nakanom dijaloškoga oblikovanja građe (s obzirom na to da odaslano pismo ujedno pretpostavlja i odgovor na nj), navlastito znamo li da upravo dijaloško moduliranje scena i čini jednu od kompozicijskih okosnica usmenih epskih pjesama. ${ }^{715}$ Naime, u (iz)govorenim i/ili pismom posredovanim dijalozima što premrežuju usmenoepska

${ }^{714} \mathrm{O}$ (usmeno)epskoj samo djelomičnoj oslonjenosti na stvarne povijesne događaje i autentične podatke te njezinu kreativnom domišljanju događaja iz prošlosti detaljnije u: Botica 2013: 261-378.

${ }^{715}$ Usp. Kekez 1998: 181-183. 
ostvarenja krije se nezaobilazna dramska crta „,narodnoga“ pjesništva, ${ }^{716}$ koju i Vitezović osim posredstvom poslaničkih dionica - u Odiljenju razvija i kroz uspostavljanje verbalne komunikacije između bana Zrinskog i sina mu Jurja (I: 478-603), potom Sigeta i Zrinskog (II: 147-268) te bana i njegovih suboraca (II: 269-360), ali i one između konkretnih ili manje konkretnih ljudskih aktera i antropomorfiziranih životinja ili personificiranih prirodnih pojava (mitskih bića), kao što je to slučaj u pjesmama Gospodična Sofija i oral te Putnik i Jeka. Nalik pismima-poslanicama, u pogledu kojih smo konstatirali nešto vrlo slično, i samo obdarivanje stvari i drugih živih bića i pojava sposobnošću govora stoga bi lako moglo upućivati (i) na kreativno oslanjanje na folklornu epsku poeziju, dok bi dramatičnost, koja se pojavljuje kao nužna posljedica toga postupka, otkrivala ne samo Vitezovićevu svjesnu namjeru sastavljanja žanrovski izrazito slojevitoga ostvarenja primjerena različitim krugovima čitatelja, već i naglašavanja uvjerljivosti opjevanih sadržaja, koji baš pomoću dramskih dijaloških crta dobivaju na neposrednosti, svježini, pa i zanimljivosti.

Pismovni i (iz)govoreni dijalozi u Odiljenju sigetskom, povrh toga, u gotovo podjednakoj su mjeri bremeniti i drugim prepoznatljivo folklornoepskim značajkama poput formulaičnih fraza i motiva, ${ }^{717}$ koje je definitivno moguće izdvojiti kao možda i najvažniji (a dosad i svakako najproučavaniji) oblikovni čimbenik usmene epske pjesme. Prilično očitim formulativnim posudbama iz „narodnoga“ pjesništva pripadalo bi tako - prije svega Sigetovo zazivanje Božje naknade ucviljenim majkama i udovicama za žrtvu koju su podnijeli hrvatski branitelji („Bog vam stokrat plati ove prijaznosti“; I: 19), zatim izricanje zahvalnosti frazom koja neodoljivo podsjeća na karakterističnu formulu završetka usmenoepskih pjesama (,budi Bogu hvala“; I: 331), ali i motiv Bogu ugodnoga djela (,i Bogu samomu ugodilo“; III: 182), kakvo je i herojska smrt Zrinskoga pod Sigetom. Svojedobno je - prije više od stoljeća - Milivoj Šrepel ${ }^{718}$ u Odiljenju detektirao i poznatu usmenoknjiževnu frazu „,moj bore“ (II: 248), kojom Siget u pjesmi Siget banu apostrofira Zrinskog, a kojoj bi valjalo pribrojiti i nešto kasnije dvostruko prozivanje šume „lugom“ (II: 767), odnosno šuma „lugima“ (III: 342), što vuče svoje porijeklo iz mitsko-obrednih pjesama duboke starosti, najvjerojatnije ispjevanih još u pretkršćansko vrijeme, dakle u doba praslavenske duhovnosti. ${ }^{719}$ Vezu s formulativnim izričajima folklornoepske pjesme uspostavljaju i epitafska podcrtavanja (čudesne) veličine i

\footnotetext{
${ }^{716}$ Podrobnije o dramskoj komponenti usmene epske poezije u: Čubelić 1988: 159.

${ }^{717}$ Pitanjem formulativnosti usmene književnosti i uopće formulaičnih mehanizama posebno se pozabavila Maja Bošković-Stulli u: Bošković-Stulli 1978: 29-40.

${ }^{718}$ Usp. Šrepel 1902: 111.

${ }^{719}$ Starost fraze ,(zeleni) lug“ i njezino sakralno mitsko-alegorijsko značenje istražuje Radoslav Katičić u svojoj studiji o svetim (usmenim) pjesmama našega pretkršćanskog razdoblja nazvanoj upravo - Zeleni lug (Zagreb Mošćenička Draga, 2010.).
} 
snage cara Sulejmana (,čudo veliko“, IV: 46) i bana Zrinskog (,,jedno čudo svita“, IV: 66), ali i prepoznatljivo usmenoknjiževna slika „pijenja krvi“ protivnika $^{720}$ te poprilično živopisan motiv trava pocrnjelih od krvi poginulih ratnika („Trave počrnihu od krvi velike“; III: 45).

Pokoji formulaični izraz moguće je locirati i u nadgrobničkom ciklusu četvrtoga „dila“ Odiljenja, pri čemu posebnu pozornost valja obratiti na one epitafe što ih „uokviruju“ ranije već primijećene prepoznatljivo epitafske formule ili toposi početka i završetka, odnosno one u kojima se - u pravilu - uvodnim stihovima obično poziva (simboličkog) putnika na zastajkivanje u svrhu primanja poruke s nadgrobnoga natpisa („Postoj, ki šetuješ mimo rake ove, / neka ništo čuješ, na č te mrtvac zove“, IV: 1-2; „Stoj ter štij razlogom, tumači ter plači“, IV: 62; „Postoj, putniče, i čtij“, IV: 154), dočim ga se onim zaključnim otpravlja na daljnji put (,naklonivši glavu moreš sbogom iti““, IV: 20; ,,sada moreš s tvojim putem iti“, IV: 54), no tek nakon što je preminulome udijelio zaslužen pokoj (,,A ti, / da im zaman spomenik nije, / reci, prvo nego odideš: / Počivajte v miru“, IV: 164-167; „Koji mimo ideš, ah, reci veziru, / prvo neg odideš: Počivaj u miru“, IV: 346-347). Na tragu formulaičnih fraza (točnije, formulaične njihove uporabe) bila bi i pojedina gotovo doslovna ponavljanja segmenata stihova u pjesmi Gospodična Sofija i oral, koju otvara karakteristično folklornoknjiževni „zaziv“ ptice („Orle moj, orle moj“; II: 735) i u kojoj zatječemo ne samo primjere opetovane uporabe nekih sintagmi [,Pusti me (...) / litat v strane (...)“ (II: 739-740) i ,nego me litati pusti v strane“ (II: 749)], već i čitavih stihova s minimalnim izmjenama [,,lipe jesu snage za dragim umriti““ (II: 882) i „lahko je sasvima za dragim umriti“ (II: 894)], koji kao da ciljano preslikavaju modus funkcioniranja izvorno ,narodnih“ formula.

Pobrojanim (većinom) izvorno usmenoknjiževnim formulaičnim elementima Odiljenja sigetskog nužno je pribrojiti i prilično široku paletu u njemu zastupljenih stalnih epiteta primjerice, „družba mila“, „krv rumena“, „,sokolovi dragi“, „tužna vila“, „verna ljubav“, „,srce hrabreno“, „mila mati“, „sinki mili“, „črna zemljica“, „,zidine bile“, „ruke bile“, „,crikva sveta“, „ljute rane“, „zelen venac“ itd. - koja nije mogla proizići ni iz čega drugog no Vitezovićeva dugogodišnjeg iskustva slušanja autohtonih usmenoepskih ostvarenja, baš kao ni nekolicina po njihovu obrascu skrojenih ,autorskih“ epitetskih konstrukata - „turska sila“, „srića kleta“, „gospoje hrabrene“, „slavni ban“ i dr. - koji, iako nisu originalno „,narodnog“ porijekla, zbog činjenice da se u identičnom obliku evociraju na više mjesta duž teksta također stječu status (autorskih) ,stalnih atributa“ te - kao takvi - zavrjeđuju poziciju tik uz

\footnotetext{
${ }^{720}$ Formulativan motiv pijenja protivnikove krvi pojavljuje se na nekoliko mjesta u tekstu, kako u vezi s kršćanskim braniteljima Sigeta („,svak' je želil piti one turske krvi“, I: 77; „Drugače stvoriti ne hti srce vruće, / za tursku krv piti od mlada kipuće“, II: 72-73), tako i muslimanskim napadačima („Samo je vesel bil, na želju pogansku / kad je do volje pil krvčicu kršćansku“; IV: 112-113).
} 
autohtone epitetske formule. Štoviše, nizu formulaičnih strategija deriviranih iz „narodne“ epske poezije, kojima je svoju „zrinijadu“ napučio naš autor, pripadala bi i druga prepoznatljivo usmenoknjiževna (folklornoepska) stilska (figuralna) rješenja u rasponu od „jakih“ i učestalih hiperbola i specifično „narodnih“ metafora, pa sve do (ondje nešto prorijeđenijih) metonimija i poredaba s tipično folklornim prizvukom. Među njima, svojom će količinskom zastupljenošću - izuzmemo li (stalne) epitete - u Odiljenju prednjačiti vrlo uspjele (epskopjesničke) hiperbole, koje u nekoliko navrata dojmljivim preuveličavanjima dospijevaju sustići efektivnost autohtono folklornoknjiževnih svojih parnjaka, što se - između ostalih - ponajbolje uviđa iz primjera uvodnoga Sigetova izvještaja, u kojemu se zastrašujuća moć turskih napadača prikazuje kao potencijalna prijetnja „i za zemlju i za nebo“ („Tulike zvrviše na ov mal grad sile, / da svit rvat htiše, svit bi prevratile“, I: 91-92; „Čudo se j' činilo turačkoga jada: / od pušak grmilo, kot da nebo pada“, I: 95-96), kao i pjesme Orsag banu, u kojoj se u prikazbi Sulejmanove snage hiperbolički pretjeruje ne bi li se time paralelno istaknula i odvažnost bana Zrinskog koji se toj i takvoj moći i sili odlučno suprotstavlja (,gdi si biti boje s onim se podstupil, / ki vas svit skoro je pod svoj strah sakupil, / ki j' na zemlju stupil kod robče bojeću, / da ni sablju ztupil ni Leksander veću“; II: 134-137). Također, u nešto kasnijoj je poslanici Siget kralju hiperbolički „napuhan“ broj pogubljenih turskih napadača, iz čijih „,(...) kosti bi čisto tulik grad zgradili“ (II: 454), još kasnije će, pak, Hrvatkinja u Vili Hrvatkinji nad Sigetom hiperbolički konstatirati kako je prolivena krv palih sigetskih branitelja dospjela ispuniti čak i riječna korita („,mojih krvjom rike da ste protočile“; II: 637), dok se u nadgrobnici Mikule kneza od Zrinja, bana putnika-prolaznika „informira“ kako je Zrinski, sudjelujući u bitci što je prethodila njegovoj smrti, dospio smaknuti ni manje ni više nego stotinu tisuća Turaka (,Neg pokle sto tisuć s carom na smrt dade, / i on za viru vruć ban viteški pade“; IV: 86-87).

Za hiperbolama u Odiljenju sigetskom po svojoj uspjelosti neće zaostajati ni količinom nešto skromniji primjeri metafore kao „temeljne figure (...) usmenog pjesništva“ (Botica 2013: 225), pa tako već u uvodnoj pjesmi Siget pogibiju „kršćanskoga sinka“ od ruke turskih osvajača prezentira kroz sliku zmijskoga ujeda (,zmija ga j' ujila kod mojega stanka“; I: 470), u pjesmi Ban sinu opsada grada metaforički biva izjednačena s ugroženošću maloga ptičjeg jata (,sila k malom jatu vrvi ah velika“; I: 497), dok personificirani „orsag“ junački Zrinskijev otpor Osmanlijama obilježava prizorom „oskvrnuća mjeseca“ kao simbola muslimanske vjere („Misec si oskrvnil i zvrnul takoje, / da j' kruto pobrunil od svitlosti svoje“; II: 132-133). Izrazit usmenoknjiževni prizvuk će, pored (folklornoepske) metafore, u Vitezovićevu tekstu imati i nekolicina ,indikativnih“ metonimija poput one u kojoj se „silna“ osmanlijska vojska 
semantički sažima na tek „koban predmet“ (kao što je to slučaj sa Sigetovim obznanjivanjem „gospojama i vilama“ kako su njihovi najmiliji svi redom „,pobijeni od meča turskoga“; I: 71), odnosno one u kojoj ta ista turska osvajačka sila semantički biva „svedena“ na svog vrhovnog zapovjednika [i to u pjesmi Siget banu, gdje Siget stihom „Zdavna me pustiti mogoste pod cara“ (II: 202) Zrinskoga podsjeća na odbijenu mogućnost svoje mirne predaje Turcima]. Da bi bliski izvorno usmenoknjiževnoj (epskopjesničkoj) figuraciji trebali biti čak i pojedini primjeri poredaba u Odiljenju poodavno je pretpostavio već i Milivoj Šrepel, koji folklornu podlogu prepoznaje u epitafskome prispodobljivanju snage i odvažnosti Mikule Sekulića onima zmaja (,Sekulić Mikula, zmaj ognjeni v ratu“; IV: 403), ${ }^{721}$ a čini se da bi na istome, folklornoepskom tragu moralo biti i nešto ranije uspoređivanje Delimanove svojeglavosti s onom lava („On se ne da vladat, samovoljan kot lav“; III: 115), kao i Deli Vidove snage s jakošću samoga medvjeda („Ovdi gorski medvid, zmeđu jakih jedan“; IV: 138).

Uplitanje karakterističnih obilježja usmene epske pjesme uočljivo je, povrh toga, čak i na formalnoj (metričkoj) razini Odiljenja sigetskog, i to ne samo četiriju „dilova“ njegova teksta, već i u paratekstualnoj dionici prvoga mu izdanja, u kojoj versifikacijski dijalog s folklornim pjesništvom Ritter zapodijeva kroz predgovor $K$ čtavcu, kojemu - podsjetimo pridružuje četverokatrensku lirsku pjesmu ispjevanu u (,,narodnom“) osmercu (4+4), što će reći onom istom stihu kojemu će se potom vratiti tek u posljednjem dijelu svoje ,zrinijade“ 722 Ako je vjerovati tumačenju Josipa Kekeza, ${ }^{723}$ kao pokušaj formalnog nadovezivanja Odiljenja na folklornu epiku trebalo bi označiti i figuru jeke iz pjesme Putnik i Jeka, zbog prisutnosti koje se zaključna dvosložnica što predstavlja Jekin odgovor izdvaja od ostatka (dvotruko rimovanoga) dvanaesteračkog stihovanog retka, koji - pak - sadržava putnikovo pitanje. Naime, „očišćen“ od ovih dvosložnih replika Jeke, svaki će drugi stih spomenute pjesme zaključuje Kekez - tako zapravo prizivati formu usmenoepskog deseterca 4+6, tim više što nezanemariv broj tih parnih stihovnih redaka uistinu otvara mogućnost „,pomicanja“ cezure za dva sloga unatrag (dakle, na kraj onoga četvrtog), suptilno na taj način provocirajući osluškivanje (i) njihova deseteračkog ritma (primjerice, ,Jeda li to | zamet Sigetov je? [Ov je] “; III: 2). Konačno, u sklopu svojega iznimnog metričkog obilja i završni će epitafski ciklus - pored netom spomenutih simetričnih osmeraca - donijeti čitav niz usmenom pjesništvu bliskih stihova, ${ }^{724} \mathrm{i}$ to u rasponu od šesterca (Druga istoga bana, IV: 104-105) i sedmerca ,u tonu narodnoga stiha“ (Kolumbić 2005b: 344), kakvim su ispjevane nadgrobnice Kairbega,

\footnotetext{
${ }^{721}$ Detaljnije u: Šrepel 1902: 116.

${ }^{722}$ U simetričnom (folklornom) osmercu bit će, konkretno, ispjevane dvije nadgrobnice toga zaključnog ciklusa, i to Amirašena, velikoga vojvode harapskoga (IV: 126-137) te Andrija Gusića glavara (IV: 386-399).

${ }^{723}$ Usp. Kekez 1987: 126.

${ }^{724}$ O najčešćim stihovima hrvatskoga usmenog pjesništva podrobno npr. u: Čubelić 1988: 49-68.
} 
vezira mamalučkoga (IV: 323-348) i Samoga Juranića vojvode (IV: 366-385), pa sve do (pseudo)heksametra u pjesmama Četrta istoga (IV: 55-61) i Druga istoga grada, u kojemu rat govori (IV: 424-429), kojega bi - hrabro će ustvrditi Kekez - zapravo valjalo percipirati kao Vitezovićev pokušaj imitiranja (ili naprosto baštinjenja) dugoga stiha bugaršćice. ${ }^{725}$

\section{3. 2. Naricaljke}

Poput prepoznatljivih sadržajnih, formalnih, pa i stilskih značajki usmene epske pjesme, koje su se - kao što smo vidjeli - prometnule u gotovo neizostavan dodatak naših ranonovovjekovnih pisanoknjiževnih epova i ne samo epova, i pojedina karakteristična obilježja folklornoga lirskog pjesništva od ranoga su 16. stoljeća redovito pronalazila put do generički kojekako realiziranih literarnih ostvarenja onovremenih hrvatskih pisaca. Počevši s Ranjininim Zbornikom (1507.), u kojemu ciklus Pisama na narodnu okuplja lirskopjesničke tekstove bremenite specifično usmenoknjiževnom motivikom, formulaičnim izričajima te stilskim i metričkim rješenjima, za konvencionalnim elementima žanrova „narodne“ lirske pjesme, a pokatkad i cjelovitim zapisima izvedenih varijanata pojedinih njezinih primjeraka kontinuirano će otad posezati ne samo naši lirici, već i autori žanrovski bitno drugačijih ostvarenja poput Mavra Vetranovića, Marina Držića i Hanibala Lucića, koji su folklornu liriku i njezine osobitosti imali na umu pri sastavljanju dramskih svojih djela. Nekolicina pjesama što po sadržajnim i stilskim osobitostima snažno podsjeća na autohtonu usmenu lirsku poeziju svoje će mjesto, osim toga, naći i u Planinama Petra Zoranića, dok će - zajedno s (izvornim) primjercima raznih drugih folklornoknjiževnih žanrova (bugaršćice, počasnice, poslovice i zagonetke) - u svoje Ribanje i ribarsko prigovaranje jednu „,narodnu“ lirsku pjesmu - I kliče devojka, pokliče devojka ${ }^{726}$ - također uvrstiti i Petar Hektorović. Izuzev folklornoj lirici svojstvenih motiva što ih na nekoliko mjesta u Osmanu evocira i Ivan Gundulić, uvelike prožeti usmenolirskim momentima ispostavit će se i pjesnički opusi Antuna Sasina, Barne Karnarutića, Sabe Bobaljevića, Dinka Ranjine te Ignjata Đurđevića (koji u sklopu svoga ciklusa $Z a$ gutke donosi tri deseteračke pjesme), dok će niz lirskih tekstova stiliziranih po obrascu „,narodne“ lirske poezije u ciklus Dijačke junačke svoje rukopisne zbirke Gartlic za čas kratiti uvrstiti i Fran Krsto Frankopan. ${ }^{727}$ Uopće, snažno kreativno naslanjanje (i) na usmenu liriku razabire se u ostvarenjima baš svih pripadnika ozaljskoga

\footnotetext{
725 Opširnije o ovome u: 1987: 129.

${ }^{726}$ Usp. o tome Kekez 1992: 44-46 i Dukić 2004a: 18.

727 Riječ je o, konkretno, sveukupno sedam pjesama ispjevanih epskim desetercem 4+6, napučenih prepoznatljivim motivima i frazeologijom usmene lirske pjesme.
} 
književno-jezičnog kruga, ${ }^{728}$ a nešto slično vrijedit će i za brojne sjevernohrvatske autore 17. stoljeća, navlastito za Jurja Habdelića - čiji religiozni tekstovi također uvelike počivaju (i) na asimiliranju značajki folklornoga lirskog pjesništva - te Stjepana Krajačevića i Jurja Muliha, koji su se u sastavljanju svoje nabožne lirike - usprkos činjenici da su obojica otvoreno osporavali narodnu praksu pjevanja nepoćudnih lirskih pjesama te pritom zagovarali njihovo nadomještanje religioznim pjesništvom, odnosno njegovo smještanje u melodijske „okvire“ te tematski „raskalašene“ usmene lirike - obilno nadovezivali na karakteristično „narodne“ motive i neka folklornolirska stilska rješenja. ${ }^{729}$

Poneka od tih usmenoknjiževnih lirskih pjesama, čije su pojedinačne karakteristike ili - nešto rjeđe - čitave izvedbene varijante netom pobrojani autori uvrštavali u svoja žanrovski raznolika djela, gotovo je sigurno - u sadržajnom pogledu - pripadala sigetskomu tematskom kompleksu, iz kojega je proistekao ne samo poveći broj maločas razmatranih epskopjesničkih „narodnih“ ostvarenja, već i nimalo zanemariv niz onih lirskopjesničkih. S tematskomotivskoga se gledišta pritom, dakako, radi(lo) o znatno manje obuhvatnim, pa i disperziranim sastavcima budući da je sadržajni fokus u njima redovito padao na samo jedan aspekt ili detalj kršćansko-muslimanskoga okršaja pod zidinama Sigeta ili njegovih reperkusija poput - primjerice - Sulejmanove smrti ili pozitivnoga ozračja među sigetskim braniteljima neposredno uoči konačnoga okršaja s Osmanlijama, a ne smije se zaboraviti ni da je među njima bilo čak i podrugljivih, satiričnih lirskih pjesama, sadržajno većinom uperenih protiv turskih napadača. ${ }^{730}$ Usprkos činjenici da nam tu pretpostavku ne mogu potvrditi konkretni sačuvani njihovi zapisi, krugu tih generički nejednako ostvarenih usmenih lirskih pjesama vrlo su vjerojatno - budući da je svaka individualna pogibija u sigetskoj bitci ujedno predstavljala i nenadoknadiv osobni, odnosno obiteljski gubitak - pripadale i naricaljke, što su ih povodom smrti voljenih bližnjih neposredno nakon svršetka opsade zacijelo izvodili članovi njihovih obitelji, baš kao što je to jamačno bio slučaj još i u Vitezovićevo vrijeme, navlastito nakon završetka za brojne žrtve odgovornih onodobnih pojedinačnih hrvatskoturskih sukoba. Iako kao nimalo nevjerojatnu ne treba otpisati ni mogućnost da je u rukama imao (do danas nesačuvan) zapis makar jedne od tih - više od stotinu godina „starih“ naricaljki ispjevanih u čast nekog od sigetskih pokojnika, Pavla Rittera Vitezovića na ispravnu su pomisao o njihovu već tadašnjem cirkuliranju gotovo sigurno navele ponajprije „suvremene“ izvedbene evokacije ovoga usmenolirskog žanra, odnosno zacijelo naricaljke što

\footnotetext{
${ }^{728}$ Detaljnije u: Kekez 1992: 65-69.

${ }^{729}$ Znatno opširnije o uključivanju elemenata usmenoga (lirskog) pjesništva u pisanoknjiževna djela renesanse $\mathrm{i}$ baroka u: Bošković-Stulli 1978: 152-217.

${ }^{730}$ Podrobnije u: Kekez 1987: 120-122.
} 
su ih u njegovo vrijeme pjevali ožalošćeni pojedinci iz uže ili šire obitelji poginulih hrvatskih vojnika i po uzoru na koje će i oblikovati one segmente Odiljenja sigetskog čija (sadržajna) bliskost s folklornom naricaljkom i više nego jasno dolazi do izražaja.

Uočivši kako je - podsjetimo - cjepkanje komunikacije na veći broj govornika i adresata u Vitezovićevoj „zrinijadi“ zapravo ništa drugo no posljedica ,poetskotransmisijskoga postupka“ pod utjecajem kojega se „mitski osmišljava tragična zbilja odnosno faktični povijesni podatak, kako to već nerijetko biva u lirskim narodnim pjesmama“" (Kekez 1987: 128), Josip Kekez prvi će - tek koncem osamdesetih godina prošloga stoljeća - tako utvrditi da se u nekim dionicama Odiljenja - prije svega u dijaloškoj pjesmi Gospodična Sofija $i$ oral te u dijelu pjesme Vila Hrvatkinja nad Sigetom (naročito u II: 650-657) funkcionalno primjenjuje usmena lirika, i to, konkretno, čakavska ljubavna pjesma, Marijini plačevi, ali i „tužbalica““.731 Nakon njegova prilično kasnog ,pionirskog“ detektiranja prisutnosti elemenata (folklorne) „tužbalice“, odnosno naricaljke ${ }^{732}$ u Odiljenju sigetskom nastupit će pomalo iznenađujuć dugogodišnji muk po pitanju njegovih značajki potencijalno baštinjenih iz usmenoknjiževnoga žanra naricaljke, kojega će tek nedavno - i to više slučajno nego sa stvarnom nakanom da segmente teksta što će ih proglasiti naricaljkama generički povežu s primjercima istoimenoga žanra - napokon prekinuti suvremeni ,ritterolozi““. Osvrnuvši se, konkretno, na Odiljenje i njegovu ne baš uobičajenu strukturu, Andreja Sršen i Davor Piskač u svojoj će recentnoj „ritterološkoj“ studiji tako konstatirati da je riječ o tekstu u kojemu se Vitezović najprije usredotočuje na samu sigetsku bitku, a potom ,na kraju, u formi naricaljke, nakon završetka bitke, interpretira bitku koristeći sudbinu glavnih junaka kao metonimiju za iznošenje povijesnih događanja koja su uslijedila“ (Sršen i Piskač 2016: 221). S obzirom na to da u nastavku studije Sršen i Piskač nisu osjetili potrebu dodatno pojasniti i precizirati svoje zapažanje, iz navedene je rečenice teško sa sigurnošću reći kojem to doista odsječku Ritterove „zrinijade“ oni pristupaju kao naricaljki, no bit će da naglašavanjem njezine pozicije „na kraju“ teksta, gdje je riječ isključivo o reperkusijama bitke, hoće sugerirati da se uistinu radi o zaključnomu, nadgrobničkom dijelu Odiljenja. Ako bi tomu doista bilo tako, tada je očito da su autori previdjeli ne samo (teško previdivu) činjenicu da je riječ o „dilu“ zamišljenom kao ciklus od nekoliko desetaka (samostalnih) epitafa - dakle, nipošto realiziranom u formi cjelovite pjesme, koja bi po svojim obilježjima odavala bliskost

\footnotetext{
${ }^{731}$ Usp. o tome u: Isto: 128-129.

732 Iako su ga raniji folkloristi bili skloniji obilježavati terminom „tužbalica“ ili „tužaljka“ (usp. npr. Čubelić 1988: 25 i Kekez 1992: 21-22), kao znatno s(p)retniji i uopće precizniji nameće se za nj upravo naziv „naricaljka“, tim više što se na taj način i na terminološkoj razini ovaj folklornoliterarni žanr snažnije razgraničava od maločas razmatranoga pisanoknjiževnog žanra lamenta ili lamentacije, kojemu hrvatski termin „tužaljka“" - na kraju krajeva - daleko bolje pristaje.
} 
usmenoknjiževnoj naricaljki - nego i da su generičke norme naricaljke što ih u toj dionici nalazimo uistinu svedene na minimum, odnosno da - konkretno - njihovu prisutnost možemo utvrditi u tek jednoj jedinoj ondje prisutnoj nadgrobnici.

Želimo li se stoga upustiti u (do danas neučinjenu) ozbiljn(ij)u analitičku potragu za obilježjima svojstvenima usmenoknjiževnoj naricaljki u Odiljenju sigetskom, svakako ćemo morati unaprijed biti svjesni toga da su ona koncentrirana u svega nekoliko intenzivni(ji)m emocijama nabijenih (i duljinom nejednakih) segmenata Vitezovićeve „zrinijade“, koji upravo zahvaljujući toj njihovoj involviranosti i dospijevaju postići „ton“ što će čitatelja koji posjeduje makar i skromno iskustvo recipiranja generički srodnih usmenoknjiževnih ostvarenja nepogrešivo podsjetiti na onaj autohtono folklornih naricaljki. Doduše, tog bi i takvog čitatelja na neke osobitosti ili generičke konvencije naricaljke lako mogao podsjetiti i dobro nam već poznat kraći odsječak uvodnoga Sigetova pisma „gospojama“ i „vilama“ točnije, dio pjesme što započinje 35., a završava 50. stihom - u kojemu personificirani grad tugaljivo uzdiše nad nesklonom mu sudbinom zbog koje su životom platili i njegovi hrvatski branitelji i u čijem tuženju do posebnoga izražaja dolaze „,indikativni“ motivi fizičkog iskazivanja boli (,s plačem prilivati potoke i mlake, / trudit čvrste šake bijuć prsi ove“; I: 4041) te spremnosti na žrtvovanje vlastita života ne bi li se spasio onaj voljenih pokojnika (,Ah, da me ni htila prvo u prah dati / nego je činila vas cvit za me stati!“; I: 47-48). Osim što bi navedeni sadržajni momenti našeg čitatelja mogli navesti na pomisao kako - baš kao i u izvornim naricaljkama - u osnovi Sigetova oplakivanja izginulih ,ljubljenih Hrvata“ zapravo stoji ,postupak kojim se žalopojka ostvaruje tako da u središte žalosti dospijeva osoba koja nariče/žali“ (Botica 2013: 126), slična bi mu razmišljanja lako mogao izmamiti i naredni, stotinjak stihova udaljeniji segment iste pjesme (I: 141-152), u kojemu Siget sve veći broj pobijenih kršćana izvrće u vlastitu ožalošćenost i nesreću kojoj na svijetu nema premca („Deh, na svitu što je veće nesrićnije, / je li srce koje pod nebom tužnije? / More li ružnije ranit srića koja, / nego mene bije i rani me moja?“; I: 141-144). Štoviše, naricaljki svojstveno ekspliciranje boli potaknute iskustvom smrti najmilijih isti bi čitatelj mogao prepoznati i u Sigetovim iskazima iz drugoga „dila“ Odiljenja, gdje će on tako najprije - svjedočeći trenutku pogibije Zrinskoga i njegovih suboraca - u pjesmi Siget banu i vojnikom (II: 361-439) u „stilu“ naricaljke gorko zapomagati nad vlastitom nevoljom, koja ga je učinila bespomoćnim promatračem smrti „,svih njegovih“ („Mogu li se dati veće tuge koje, / neg su v ovoj rati tuge moje, / gdi gledam sve svoje nejednuč zgibati, / s blagom krv takoje dragu prolivati! / (...) / „Jaoh, jaoh meni, ke gledam žuhkine! / I srce uveni, kad sve dobro gine“; II: 421-424 i 433434), dok će, pak, u lamentaciji Siget zvrhu samoga sebe (II: 517-613) oplakivati svoju 
nasilnu otrgnutost od kršćanske vjere (,Ajmeh viro prava, ajmeh Krsta ime, / na č time odzava nesmiljeno vrime! / Odiljen sasvime od tvoje ljubavi / turačkoga brime robstva Siget bavi“; II: 525-528), evocirajući pritom naricaljki svojstvene „motivske rekvizite“ (odnosno fizičke manifestacije žalosti) poput oblačenja crnine i nezaustavljivih slapova suza („Suze prolivati vrime je dospilo / ter se odivati u crno odilo“; II: 533-534).

Iako su navedenim dionicama Ritterove ,zrinijade“ zaista zajedničke naricaljki naoko identične sadržajne značajke, niti za jednu se od njih ipak neće moći utvrditi generička bliskost tome folklornoknjiževnom žanru, i to ponajprije stoga što su njihovi žanrovski izvori - kako je i ranije već utvrđeno - u mnogo većoj mjeri pisanoknjiževnoga porijekla. Naime, sama uloga ožalošćena govornika ili (lirskog) subjekta - svim ,indikativnim“ im sadržajnim karakteristikama usprkos - u njihovu je slučaju prepuštena upravo personificiranom objektu, koji smrt „ljubljenih“ kršćanskih (čitaj: hrvatskih) branitelja - kojoj implicitno pristupa kao iznimnome kolektivnom gubitku ${ }^{733}$ - koristi tek kao poticaj za emotivno prenaglašene lamentacije nad vlastitom propašću, odnosno silno teškim usudom koji ga je snašao upravo nakon herojske pogibije njegovih branitelja. Ako bi to, drugim riječima, značilo da $\mathrm{u}$ pobrojanim žalobnim odsječcima očito imamo posla $\mathrm{s}$ generičkim tragovima ranije razmatranoga pisanoknjiževnog žanra lamenta ili tužaljke - koji s naricaljkom uistinu dijeli nekolicinu sadržajnih svojstava - tada nam ne preostaje ništa drugo nego našu potragu za segmentima Odiljenja premreženima obilježjima naricaljke proširiti i na pjesme preostalih njegovih „dilova“. Doduše, prva od dviju pjesama protkanih prepoznatljivim značajkama iz „generičkoga repertoara“ naricaljke smjestila se već na samome kraju drugoga dijela, a riječ je - dakako - o Gospodični Sofiji i orlu!, u kojoj nakon dovršetka dijaloga s personificiranom pticom (II: 735-834) Sofija pristupa opširnom oplakivanju pogibije Gašpara Alapića (II: 835906), ${ }^{734}$ koje će uključivati gotovo sve temeljne (motivske) čimbenike „narodne“ naricaljke, počevši od izravnog obraćanja voljenu pokojniku („Gašpare moj mili, dušo srca moga“; II: 843), preko narikačine želje da mu se pridruži u smrti (,Dojdi, smrt nemila, sada mila meni, / i 'z ovoga tila tužnu dušu zreni“; II: 895-896), sve do tjelesnih očitovanja njezine boli (,,pukni srce moje“, „usahni moj jezik“, ,zkrivi se, moj vrate“ i sl.). Identična obilježja zateći ćemo potom samo još u nadgrobnici Embrulaha lipoga u kojoj Arpijanine zaručnica plače (IV: 263-308), koju je - shodno idejnoj njezinoj usmjerenosti i općemu „tonu“ - moguće označiti kao svojevrstan „turski pandan“ Sofijina oplakivanja Alapića, tim više što se i Arpijanino

\footnotetext{
${ }^{733}$ Očituje se to u činjenici da se izginuli hrvatski branitelji u pjesmama što sadrže ove lamentacijske segmente sustavno apostrofiraju kao „(hrvatski) cvit“ (I: 36, 48), „vitezi hrabreni“ (I: 69), „vitezi čestiti“ (II: 369), „cviće (...) junačke lipote“ (II: 547) itd.

${ }^{734}$ Spomenut segment teksta već je Josip Kekez - podsjetimo - označio naricaljkom skrojenom prema modelu iz usmene književnosti (usp. Kekez 1987: 128-129).
} 
naricanje nad zaručnikovom smrću pod Sigetom na koncu također promeće u opjevavanje osobne nevolje praćene ,standardnim“ fizičkim manifestacijama (,,(..) da mi sad divojki udovi / oslabljuju i gineju udovi. / Za tobom ja žuhko cvilim i plačem, / vetre s zdišci, vode ponavljam s plačem“; IV: 293-296) te zazivanje vlastite smrti (,Za te ljuba rada hoću umriti“; IV: 299) zbog činjenice da je pogibija odvažnoga Embrulaha („Bil si ljuto, Embrulahe moj, boje, / ter s Hrvati, ki se boja ne boje“; IV: 283-284) posve obesmislila i njezin život. U jednakoj mjeri kao i Sofijina naricaljka, i potonje će epitafsko tuženje nad Embrulahovom smrću sugerirati kako je dionice teksta što nose naricaljsko-oproštajni usmenoknjiževni prizvuk ponajprije uvjetovala opća tematska usmjerenost (poslije)ratnim rastancima, među kojima se kao možda i najvažniji ispostavljaju definitivni, odnosno posmrtni oproštaji ožalošćenih od članova obitelji palih za „više ideale“. Budući da se radi o gotovo praiskonskoj navici i običaju oplakivanja voljenih pokojnika, Ritter prizivanjem generičkih posebnosti usmenoknjiževnoga žanra naricaljke stoga kao da želi podsjetiti na duboku antropološku ukorijenjenost toga običaja (podjednako,,živog“ u vrijeme pada Sigeta i u vrijeme u kojem je nastajalo Odiljenje) te njegovu sveprisutnost, na koju bi - uostalom - i trebale aludirati naricaljke neutješnih zaručnica s obiju pod Sigetom sukobljenih strana.

Poput običaja tuženja nad smrću najmilijih, i samo posezanje za motivom folklorne naricaljke i/ili njezinim prepoznatljivim značajkama u pisanoknjiževnim ostvarenjima i prije Odiljenja sigetskog imalo je u nas već poprilično dugu povijest, makar jednog dijela koje je zasigurno bio svjestan i Pavao Ritter Vitezović. Konkretno, osim što će - kao što su to već utvrdili pojedini naši folkloristi ${ }^{735}$ - na autohtone usmene naricaljke podsjećati mnogi srednjovjekovni tekstovi poput Marijinih plačeva i nekih dijaloških pjesama, u drugima poput srednjovjekovne legende o sv. Aleksiju - naricaljke i uopće praksa naricanja pojavit će se „tek“ kao motiv, baš kao što će to biti slučaj i u čuvenom latinskom djelu $O$ smještaju Ilirije i gradu Šibeniku (1487.) šibenskoga humanističkog pisca Jurja Šižgorića, u kojemu između ostalog - biva riječi i o folklornim običajima i ,narodnim“ pjesmama pjevanima u Šibeniku i njegovoj okolici. ${ }^{736}$ I dok će se na pojavu izvođenja folklornih naricaljki ili naricanja u 16. st. na našem sjeveru u znamenitoj Postili osvrnuti i Antun Vramec, ${ }^{737}$ dotle će istodobno na hrvatskom jugu karakterističnim značajkama naricaljke svoja djela puniti Mavro

\footnotetext{
${ }^{735}$ Detaljnije u: Kekez 1992: 21-22.

736 Šižgorić u svome tekstu - pored naricaljki - nabraja čitav niz tada očito vrlo čestih žanrova usmene lirske pjesme, počevši od ljubavnih i svatovskih pjesama, preko pjesama što se pjevaju uz rad, pa sve do pjesama u kolu i pastirskih pjesama. Uzgred budi rečeno, naricaljke su u Šižgorićevo vrijeme - usprkos izričitim zabranama Crkve - bile izuzetno raširene, a na grobljima su ih izvodili ne samo članovi pokojnikove obitelji, već i ,profesionalne“ narikače. Detaljnije o tome u: Botica 2013: 110.

${ }^{737}$ Usp. Kekez 1992: 65.
} 
Vetranović (naricanje Sare nad Izakom u Posvetilištu Abramovu), Barne Karnarutić (naricaljka Tižbe nad mrtvim Piramom u istoimenom mu epu) te Juraj Baraković (naricaljke u Vili Slovinki), koji se u tim njihovim „naricaljskim“ segmentima uvelike fokusiraju (i) na pokojnikove vrline te herojska mu djela. ${ }^{738} \mathrm{Uz}$ Odiljenje, u hrvatskom baroku ponajbolje ćemo primjere pisanoknjiževnog uvažavanja žanra „narodne“ naricaljke pronaći u Osmanu Ivana Gundulića, i to u dionici u kojoj vrlo dirljivu naricaljku izriče Sunčanica, ${ }^{739}$ potom u pojedinim lirskim pjesmama što u Adrijanskoga mora Sireni Petra Zrinskog okružuju središnji ep Obsida sigecka, ${ }^{740}$ a bit će i da su štošta iz naricaljki baštinili i onodobni pisci religioznih poema ili plačeva ${ }^{741}$ (Gundulić, Bunić Vučić, Đurđević), u čijim tekstovima zatječemo niz „sumnjivih“ motivskih momenata poput motiva jadikovanja, proklinjanja dijelova tijela te fizičkog iskazivanja ožalošćenosti i očaja udaranjem u prsa, čupanjem kose itd. Iako o možebitnom utjecaju naricaljke na formiranje žanrovskoga repertoara religiozne barokne poeme u našoj književnopovijesnoj literaturi dosad nije bilo riječi, ${ }^{742}$ taj se utjecaj sam po sebi nadaje kao i više nego vjerojatan, upravo kao i onaj autohtone usmenoknjiževne naricaljke na pojedine ranije pobrojane segmente Vitezovićeva Odiljenja sigetskog. S obzirom na neosporne podudarnosti u žanrovskim „repertoarima“ naricaljke i barokne religiozne poeme, navedene dionice Odiljenja - naročito Gospodična Sofija i oral - iskazivat će ujedno i nezanemarivu motivsku bliskost sedamnaestostoljetnim (pa i kasnijim) našim plačevima (naročito u motivima proklinjanja dijelova tijela i fizičkim manifestacijama očaja zbog zaručnikove smrti), no može li se ta bliskost ujedno nametnuti i kao dovoljno opravdan argument pretpostavci o Vitezovićevu generičkom nadovezivanju na (neke) religiozne poeme - za postojanje kojih je definitivno morao znati - pitanje je koje se u okvirima ovoga istraživanja ipak ne čini nužnim otvarati.

\footnotetext{
${ }^{738}$ Podrobnije o evociranju naricaljke u hrvatskoj (pisanoj) književnosti u: Bošković-Stulli 1978: 152-155.

${ }^{739}$ Usp. Botica 2013: 118.

${ }^{740}$ Iako je samo u jednom (manjem) dijelu ovih Petrovih pjesama riječ o uzdisanju nad smrću voljene osobe, pojedinim motivima karakterističnima za „narodnu“ naricaljku bit će premrežene čak i one pjesme u kojima se opjevava tuga subjekta zbog neuzvraćenih ljubavnih osjećaja, odnosno kako Pisam I., u kojoj se spočita velika okornost Viole te Pisam II., u kojoj se spoznaje tužba zvirara, koje obje prethode tekstu Obside, tako i pjesme Plač Arijane, Žalost Orfeuša za Euridice te uz nju vezana Orfeuš k Plutonu za Euridice, koje će u Petrovu zborniku uslijediti za Obsidom sigeckom. Te „naricaljske“ značajke (motivi nepresušnih rijeka suza i plivanja u suzama, priželjkivanja vlastite smrti, fizičkih manifestacija boli poput čupanja kose i grebanja lica, izravnog obraćanja konkretnom - iako nužno odsutnom - uzročniku nevolje itd.) bit će, dakle, uočljive već i u prvim trima jadikovkama nesretno zaljubljena „zvirara“ (lovca), ali do posebnoga će izražaja one ipak doći u Orfejevim oplakivanjima prerano preminule Euridike, u kojima neutješni subjekt ne samo što prolijeva potoke suza i zaziva vlastitu smrt, već i poziva druga živa bića, prirodne pojave te nežive prirodne objekte da mu se pridruže u žalovanju za zauvijek izgubljenom ljubavnicom.

${ }^{741}$ Pregledno o baroknim religioznim poemama i njihovim „tipičnim“ obilježjima u: Pavličić 1979b: 105-128.

${ }^{742}$ Neke od najrecentnijih studija dokazale su - podsjetimo - tek utjecaj žanra heroide na baroknu našu (religioznu) poemu, i to ponajprije u pogledu njezine sižejne izgradnje. Usp. o tome u: Škopljanac 2015: 34-45.
} 


\section{3. 3. Molitve}

Uvažavanje karakterističnih značajki usmenolirskih žanrova u Odiljenju sigetskom ne svodi se, međutim, samo na posudbu onih svojstvenih folklornoj naricaljki, koje u pojedinim segmentima teksta svojom brojnošću i prepoznatljivošću uvelike natkriljuju sve ostale. Naprotiv, pri sastavljanju ove (generički) neobične „zrinijade“ Pavlu Ritteru Vitezoviću posebno su se interesantnima i njezinoj tematskoj orijentaciji primjerenima učinila - između ostalih - čak i specifična obilježja (versificirane) molitve, odnosno žanra primarno usmenoknjiževne provenijencije, koji je u barokno doba (pa i stoljećima ranije) paralelno egzistirao i u svojoj pisanoknjiževnoj varijanti. S obzirom na to da su mnoge od tih pisanih, autorskih molitava redovito ulazile u usmenoknjiževni opticaj, u kojemu se ime njihova tvorca, dakako, istoga časa zaboravljalo, te je njihove folklorizirane inačice gdjekad vrlo teško razlikovati od autohtono „,narodnih“ molitvi, slijedom čega se neće odveć pogriješiti ubroji li se i njih među ,punokrvno“ folklornoknjiževna molitvena ostvarenja. Doduše, zbog činjenice da je riječ ne samo o žanrovskom rješenju koje je u vrlo velikom broju slučajeva pretpostavljalo religijsku namjenu (dakle, najčešće sastavljanom ponajprije za liturgijske potrebe), nego i o literarnom žanru uz kojeg je nerijetko bila vezana i glazbena „,nadgradnja“, molitva se ujedno nadaje i kao poluknjiževni, točnije rubno književni žanr, iako je kroz svoju generičku povijest istodobno ona pripadala sferi (usmene i pisane) književnosti, crkvenoga (liturgijskog) stvaralaštva te glazbene umjetnosti. Za njezin književni status kao dodatna se „otegotna okolnost“, osim toga, ispostavlja i činjenica da je ,znanost o književnosti već dugo ostavlja po strani posve prepuštajući njezino izučavanje teologiji i muzikologiji“ (Boban 2008: 367), zbog čega i ne čudi to što su se njezinim razmatranjem dosad uvjerljivo najčešće bavili bibličari, koji su je generički pritom obično određivali kao „tek“ podvrstu psalma.

Ukratko, (domaći) književni povjesnici i teoretici molitvi su - kao (i) književnom žanru - do danas posvetili doslovno zanemarivu pažnju, što je i rezultiralo sveopćim manjkom njezinih genoloških istraživanja, odnosno - s druge strane - apsolutnom prevlašću teoloških pristupa, koji forsiraju poimanje molitve kao tek jednog od nabožno-liturgijskih „oblika“. Ipak, u malobrojnim usputnim (književnoteorijskim) osvrtima na žanr molitve, redom objelodanjenima u posljednjih desetak godina, proučavatelji su razlučili dva osnovna njezina tipa ili žanra, i to ,pragmatičnu“ molitvu - koja potječe iz utilitarne (nabožne) književnosti i namijenjena je za pojedinačnu ili kolektivnu obrednu uporabu - te iz nje izvedenu ,poetičnu“ molitvu ili molitvenu liriku, koja je „u startu“ zamišljena kao lirska pjesma, dakle kao književno ostvarenje namijenjeno čitanju, a ne uporabi u sklopu crkvenoga 
obreda. Usprkos ovoj naoko prilično oštroj razdiobi, proučavatelji će pritom istaći i kako između ovih dvaju tipova (ili žanrova) molitve nipošto ne bi trebalo povući odveć čvrstu i nepropusnu granicu budući da brojne dodirne točke između „poetične“ i „pragmatične“ molitve u samoj praksi najčešće rezultiraju primjercima koji bi se mogli okarakterizirati kao tipične ,miješane“ forme, što je vidljivo čak i u teološkim ostvarenjima, u kojima molitva vrlo rijetko biva realizirana u svome „,̌istokrvnom“ pragmatičnom obliku. ${ }^{743}$ Imamo li, međutim, na umu da je u Vitezovićevo doba molitva kao takva - podjednako u svojoj usmenoknjiževnoj i pisanoknjiževnoj inačici - glavninom egzistirala kao pragmatični, odnosno obredni žanr, koji je u folklornu književnost vrlo često prelazio iz crkveno-liturgijskoga „okružja“, ni najvjerojatniji generički poticaj za molitvi bliske dionice Odiljenja sigetskog nećemo moći tražiti u možebitnim ,čisto“ poetičnim molitvama iz toga vremena, nastalima bez i najmanjih praktičnih (čitaj: obrednih) nakana. Izuzev pisanih i folkloriziranih liturgijskih molitava, bit će stoga da su Ritteru kao glavni uzor pri oblikovanju molitvenih odsječaka njegove „zrinijade“ poslužili oni formalno nešto manje stroži „narodni“" molitveni izričaji, spontano izricani u konkretnim životnim prilikama te formulirani na temelju uvriježenih molbenih fraza i formula usvojenih posredstvom pragmatičnih (liturgijskih) molitava. S obzirom na to da segmenti Odiljenja premreženi obilježjima molitve najviše upravo i nalikuju tim spontanim folklornim (usmenoknjiževnim) iskazima molitvenih zahtjeva izrečenima u svakodnevnim prilikama, a ne formalno strogo ukalupljenim molitvama što potječu iz nekoga molitvenika, katekizma, same Biblije ili kojega drugog pisanog izvora, tim se njihovim molitvenim obilježjima na ovome mjestu i pristupa kao (očito) deriviranima iz autohtonih usmenoknjiževnih molitava.

Neovisno, međutim, od netom utvrđene razlike između dvaju njezinih tipova ili (pod)žanrova, molitvu bismo - kao specifično generičko rješenje - mogli definirati kao (stihovani, ali i prozni) žanr, koji podrazumijeva uspostavljanje kontakta s konkretnim transcedentalnim bićem, transcedentalnom dimenzijom ili instancom koja se drži predmetom kulta (Bog, bogovi, sveci itd.) u svrhu traženja konkretne povlastice, koristi, zaštite, milosti, pokore itd. Podjednako književne i liturgijske molitve - kojima je u generičkom pogledu doista vrlo blizak žanr (biblijskoga) psalma - u tom smislu po svome sadržajnom fokusu pokazuju popriličnu raznolikost, koja je malobrojne dosadašnje proučavatelje ponukala na dodatna razlučivanja molitvene „građe“, i to kako prema „čisto“ motivskim kriterijima (marijanska molitva, jutarnja molitva, večernja molitva, angelus itd.), tako i prema onim tematsko-formalnim, u sklopu kojih se iskristaliziralo nekoliko zasebnih podtipova molitve.

\footnotetext{
${ }^{743}$ Detaljnije o podudarnostima i razlikama između „pragmatičnog“ i „poetičnog“ tipa molitve u: Avsenik Nabergoj 2011: 358.
} 
Shodno tumačenju Irene Avsenik Nabergoj - koja ne zaboravlja pripomenuti kako se ti podtipovi u praksi nerijetko isprepliću - molitva bi se tako pojavljivala u obliku: 1 . preklinjanja (molitve) za zaštitu, pribježište, sigurnost, za oprost od grijeha (u trenucima pokajanja); 2. molbe za pomoć i oslonac, 3. jadikovke koja se najčešće pretvara u optuživanje; 4. osnovnog izražavanja (za)hvale $\mathrm{i}$ iskazivanja poštovanja; te 5. ispovijednog potvrđivanja ljubavi sprem Boga i prihvaćanja njegove volje, ${ }^{744}$ dok se u optici drugih proučavatelja ovo tematsko raščlanjivanje pojavnih varijanata ili podtipova molitve ponešto pojednostavljuje, pa će tako Vjekoslav Boban izdvojiti „samo“ tri takva podtipa, i to molitvu iskanja, molitvu zahvaljivanja te - na koncu - molitvu slavljenja. ${ }^{745}$

Ono što se - usprkos svim mogućim (teorijskim) razlikovanjima njezinih podtipova nikako ne bi smjelo smetnuti s uma jest činjenica da i (usmenoknjiževna) molitva, nalik maločas analiziranoj naricaljki, vuče svoje porijeklo još od prastarih obreda, iz čega onda slijedi kako bi i sam motiv (spontanoga) molitvenog zazivanja transcedentalnih figura kakvih nekoliko zatječemo i u Odiljenju sigetskom - u neku ruku valjalo čitati (i) kao pokušaj neizravnog upućivanja na same izvore čovjekove duhovnosti. Premda je, konkretno, taj i takav čin izravnog adresiranja, odnosno uspostavljanja kontakta s Bogom ili božanskim silama u molitvenim značajkama bremenitom fragmentu pjesme Orsag banu (II: 118-146) izostao, molitva za Zrinskoga ondje će se pojaviti u obliku prepoznatljivog motiva s konkretnim molbenim zahtjevom (,Mi, tebe i tvoga žalujući zbora / od briga murskoga ća do sinja mora, / molimo ti dvora rajskoga svitline / i pomoć odzgora zvrh tvoje družine“; II: 140143), dok će spontani, trenutnim izrazito nepovoljnim okolnostima potaknut „punokrvni“ molitveni zaziv Boga svoje mjesto naći u (pohvalnoj) pjesmi Siget banu i vojnikom (II: 361439), u kojoj se personificirani Siget oprašta od neustrašivih svojih hrvatskih branitelja. Naime, u trenucima u kojima pod njegovim zidinama život gube ljubljeni mu Hrvati predvođeni kapetanom Zrinskim, očajni Siget Bogu upućuje molitvu u kojoj od njega traži da pošalje zbor anđela, koji će dušama časno poginulih pomoći pronaći put u „nebesku državu“ (II: 405), čije su „državljanstvo“ svojom neizmjernom ratničkom žrtvom bez ikakve dvojbe zaslužili (,,Bože obilati, u komu sva stoje, / molim, htij poslati k njim anjele tvoje, / koji mi na svoje njih primeju ruke, / odnesu v pokoje 'z ove trudne muke“; II: 425-428).

U citiranim, iznimno kratkim molitvenim odsječcima Vitezovićeve „zrinijade“ moguće je - kao što vidimo - tek nazrijeti obrise „punokrvnih“ liturgijskih i/ili književnih molitava, sazdanih od uvriježenih strukturno-sadržajnih elemenata ili prepoznatljivih ,stalnih“

\footnotetext{
${ }^{744}$ Usp. Avsenik Nabergoj 2011: 357-358.

745 Opširnije u: Boban 2008: 376.
} 
dijelova (poklon, slavljenje, moljenje, zahvaljivanje), kojima se u konkretnim primjercima (doduše, mahom onima novijega datuma) obično pridružuju i motivski drugačije realizirani segmenti, ponajviše oni u kojima se ispovijeda vjera, priznaju grijesi, izriče kajanje, a katkada i iznosi kritika upućena moljeniku. Drugim riječima, gotovo sve molitve najčešće se tako otvaraju moliteljevim oslovljavanjem moljenika, njegovim himničnim slavljenjem i glorificiranjem te poklonom, kojim se učvršćuje hijerarhijski odnos između molitelja i moljenika, a iako se u toj uvodnoj dionici teksta molitelj pokatkad otvoreno buni zbog svoje podređenosti, sam molitveni odnos zadržava jednosmjernost, što će reći da između moljenika i molitelja ne dolazi do uspostavljanja dijaloga, pa onda ni do moljenikova uzvraćanja molitelju odgovorom ili povratnom obaviješću. Nakon ekspliciranja povoda moljenju, odnosno izricanja konkretne prošnje ili želje, molitelj moljeniku u nastavku obično zahvaljuje na samoj prilici moljenja, iznova ga glorificira, izriče mu zahvalnost te time molitvu privodi kraju, osim ukoliko se prethodno nije odvažio svoj molitveni iskaz proširiti nekim od „pobočnih“, dodatnih motiva, koji premrežuju mnoge primjerke pisanih i folklornih molitava. ${ }^{746}$ Kao što je vidljivo, molitvene dionice Odiljenja sigetskog uključuju tek pokoju od pobrojanih strukturnih komponenata ,prave“ molitve, i to - konkretno - oslovljavanje i glorificiranje moljenika (,Bože obilati, u komu sva stoje“) samo u prvom te izricanje molbe (,molimo ti dvora rajskoga svitline / i pomoć odzgora zvrh tvoje družine“; „molim, htij poslati k njim anjele tvoje“) u oba slučaja, iz čega - dakako - proizlazi da ih nipošto nije moguće podvesti pod cjelovite, u tekst inkorporirane primjerke (,narodnih“) molitava, već da im valja pristupati isključivo kao prepoznatljivim obilježjima molitve realiziranim fragmentima, koji generički ponajprije žele evocirati maločas spomenute kratke usmene molitve ili molbe spontano izricane u svakodnevnim životnim prigodama.

Iz netom pobrojanih temeljnih sadržajno-strukturnih sastavnica domaćih folklorno- i pisanoknjiževnih (,poetičnih“ i ,pragmatičnih“) molitava postat će i više nego očito kako ne samo naša liturgijska molitvena tradicija, nego i ,svekolika hrvatska pjesnička molitva ima neprijeporno biblijsko utjecište“" (Boban 2008: 372), na koje se mnogi hrvatski autori - poput, primjerice, Marulića u čuvenoj Molitvi suprotiva Turkom - nisu libili ni izrijekom poz(i)vati. Svjesno i/ili nesvjesno oslanjanje na biblijske njegove primjerke moglo bi se stoga izdvojiti kao konstanta u višestoljetnoj domaćoj tradiciji žanra molitve, koji je - kao i u većini drugih onodobnih nacionalnih književnosti - posebnu (pisanoknjiževnu) popularnost stekao u 16 . i 17. stoljeću, kada diljem Europe iz tiska počinju izlaziti molitvenici, i to najčešće naslovljeni

${ }^{746}$ Znatno opširnije o ovim uvriježenim strukturno-sadržajnim dionicama molitve u: Boban 2008: 367-377. 
kao „hortulusi“, odnosno vrtići. Osobito velik broj objelodanjenih „hortulusa“ $u$ hrvatskoj ${ }^{747}$ i uopće europskoj sedamnaestostoljetnoj književnosti nije moguće protumačiti nikako drugačije no snažnim utjecajem Tridentskoga koncila (1545. - 1563.), „na kojem je, slobodno možemo reći, molitva postala nezaobilaznim dijelom liturgije“ (Isto: 369), nametnuvši se tako i kao jedno od najpoželjnijih generičkih rješenja nabožnoga versificiranog i ne samo versificiranog stvaralaštva. Dapače, možda i najvažniji naš molitvenik iz 17. stoljeća - Putni tovaruš (1661.) Katarine Zrinski - sadrži isključivo prozne molitve, pored njega su u prozi realizirani također i mnogi molitveni tekstovi što ih nalazimo u zborniku Molitvene knjižice Nikole Krajačevića iz 1640., dok će, s druge strane, jednu od najdojmljivijih baroknih versificiranih molitava pored onih što ih je Petar Zrinski utkao u svoju Obsidu sigecku - u nas ispjevati upravo Pavao Ritter Vitezović, i to u sklopu svoje latinske kronike u stihovima Dva stoljeća ucviljene Hrvatske, koju zaključuje molitvom za spas Hrvatske. ${ }^{748}$ To će, drugim riječima, značiti kako Odiljenje sigetsko ne predstavlja jedino ostvarenje u Vitezovićevu opusu u kojem je moguće utvrditi posezanje za prepoznatljivim obilježjima molitve, pri čemu posebno treba imati na umu da je - kako se čini - i na oba Ritterova kreativna evociranja žanra molitve, ali i na samu njegovu (ranonovovjekovnu) folklornoknjiževnu raširenost daleko najviše ipak utjecala pojava molitvenih dionica u obljubljenom mu Petrovu epskopjesničkom ostvarenju, a zatim i prisutnost molitve u liturgijskim okvirima, odnosno njezina iznimna obredna važnost, iako se ni u jednome trenutku ne smije zaboraviti kako je - u generičkom smislu - pisanoknjiževna molitva štošta ipak baštinila upravo od one autohtnono usmenoknjiževne. ${ }^{749}$

\section{3. 4. Usmenoknjiževne pohvalnice (,počasnice“) i hvale}

Usprkos nešto ranijem sagledavanju pohvalničkih momenata u Odiljenju sigetskom kao očitih ,posuđenica“ iz repertoara pisanoknjiževnoga žanra (barokne) lirske pohvalnice ili panegirika, dio tih pohvalnih čimbenika Vitezovićeve ,zrinijade“ svoj bi izvor imao (i) u (izvorno obrednim) usmenoknjiževnim lirskim pjesmama što su se - pretežno u sklopu nekih proslava, gozbi, svetkovina itd. - pjevale u čast određenih istaknutih pojedinaca. Te „narodne“ pohvalnice ili - kako ih njihovi zapisivači često nazivaju - „počasnice“ svojim sadržajem - poput autorskih lirskih panegirika - najčešće veličaju konkretne zasluge i pozitivne vrline hvaljene osobe, blagoslivljaju njezino zdravlje, slave ljubav i njezinu ljepotu te izriču želje u pogledu njezina općeg blagostanja, no gdjekad se - doduše u tek iznimnim

\footnotetext{
747 O osobitostima naših sedamnaestostoljetnih molitvenika vrlo detaljno u: Tvorić 2013.

${ }^{748}$ Usp. Ritter Vitezović 2019: 200-201. Detaljnije o ovom molitvenom odsječku u: Jurišić 1995: 212.

${ }^{749}$ Podrobnije o ovome u: Boban 2008: 373.
} 
slučajevima - ne ustručavaju ni izravno joj se narugati, odnosno otvoreno se podsmjehnuti nekim njezinim manama, pa i pojedinim ranijim neprikladnim joj postupcima. Premda bi zbog te njihove suštinske sličnosti u ostvarenju poput Odiljenja bilo vrlo teško razlučiti dionice napučene obilježjima lirskog panegirika od onih u kojima prevladavaju značajke folklorne „počasnice“, već i letimičan će nam uvid tekst pokazati kako za takvom njihovom analitičkom raščlambom neće ni biti potrebe budući da karakteristike usmenoknjiževne i pisanoknjiževne (lirske) pohvalnice u njima zapravo dolaze u potpunosti pomiješane.

Konkretno, potenciranje „viteške“, odnosno pogibije koja dolazi kao posljedica junačkog otpora neprijatelju uime vjere, domovine i kralja (cara) naprosto je već samo po sebi moralo širom otvoriti „,vrata“ Odiljenja - kao ostvarenja koje je težilo privući pažnju različitih tipova čitatelja - čak i prepoznatljivim značajkama pohvalničke usmene lirske pjesme, koje će i više nego uočljivo premrežiti one njegove dijelove usredotočene na proslavljanje individualnih ratnih zasluga. Desetak stihova (II: 130-139) pjesme-poslanice Orsag banu posvećeno je tako (hiperboličkom) isticanju vojničke hrabrosti Nikole Šubića Zrinskog, koji je sa svojim suborcima odbijao uzmaknuti i pred daleko nadmoćnijom Sulejmanovom vojskom, ${ }^{750}$ dok je dionica naslovljena Siget banu $i$ vojnikom gotovo u cijelosti protkana pohvalničkim glorifikacijama srčanosti i nepokolebljivosti Zrinskog i hrvatskih trupa koje su stale u obranu Sigeta (primjerice: „I vi s banom takoj vitezi čestiti, / ki dojdoste na boj za Siget braniti, / ne hteć se skratiti na tulike trude, / mučno izmoriti te hrabrene ude“; II: 369372). Poveći broj pohvalničkih (među njima i ,počasničkih“) silnica koncentriran je u posljednjemu, nadgrobničkom dijelu Vitezovićeve „zrinijade“, razlog čemu - dakako - valja tražiti u epitafskoj ideji slavljenja pokojnikovih životnih (u ovome slučaju pretežno ratničkih) dosega, pri čemu će se žanrovskim okvirima pohvalničke (usmenoknjiževne) lirike svojim opjevavanjem Sulejmanove odvažnosti i moći ondje najviše približiti pjesma Treta istoga (IV: 37-54), dočim će u nadgrobnici Mikule kneza od Zrinja, bana (IV: 62-103) temom postati banovske zasluge Zrinskog, poglavito predanost u obrani Sigeta i herojska njegova pogibija.

Kada se, međutim, usmenoj lirskoj pohvalnici pristupa kao izdvojenomu žanru, osobito je bitno da se to čini s povećom opreznošću, i to ponajprije stoga što njezina generička obilježja vrlo lako mogu navesti na miješanje s retoričkim folklornoknjiževnim oblikom hvale, oko kojega sama kompozicija pohvalnice - kao što, uostalom, pokazuju i pohvalnički segmenti Odiljenja - nerijetko i biva sazdana. Ipak, budući da se retorička hvala mahom

\footnotetext{
${ }^{750}$ Spomenuti segment glasi: „Jakoga vojnika hrabrosti si izpunil, / od vika do vika slavom si se krunil. / Misec si oskvrnil i zvrnul takoje, / da j' kruto pobrunil od svitlosti svoje, / gdi si biti boje s onim se podstupil, / ki vas svit skoro je pod svoj strah sakupil, / ki j' na zemlju stupil kot robče bojeću, / da ni sablju ztupil ni Leksander veću. / Na tvojemu pleću podnesal si mnoga, / Herkula nevmreću čast vika ovoga“ (II: 130-139).
} 
realizira u duljinom znatno reduciranijim tekstovima u kojima se (,tek") nabrajaju pozitivne karakteristike glorificirane osobe, ${ }^{751}$ dok se u detektiranim pohvalničkim odsječcima Vitezovićeve „zrinijade“ većinom radi o opsežnijim segmentima posvećenima proslavljanju ratnih podviga izdvojenih aktera ili čitava vojnog kolektiva, jasno je da spomenute dionice Odiljenja u svojoj cijelosti nipošto ne mogu biti identificirane kao ,punokrvn(ij)i“ primjerci hvale kao takve. Pritom, s druge strane, neće biti nimalo sporno kako se velika većina tih pohvalničkih odsječaka doista zasniva na stanovitim retoričkim mehanizmima „narodne“ hvale, što je posebno uočljivo u nekim retorički umješnije izvedenim dionicama Vitezovićeva teksta, koje neće pokazivati nakanu prerastanja u opsežnije, lirske pohvalničke segmente. Tako je, primjerice, tipična jezgrovita hvala s folklornim prizvukom situirana na samom početku pjesme Siget banu i vojnikom (,Viteški moj bane, koga slavno dilo / na sve svita strane jur se j' raztočilo“; II: 361-362), dočim je vrlo sličnu težnju sažetom i retorički efikasnom isticanju pojedinčevih zasluga i/ili vrlina moguće susresti i u uvodnim stihovima nadgrobnice Rustana vezira („Razumom umićan i rukom stanovit, / u tanaču srićan, u dilu hrabrovit“; IV: 225-226) te onima Mikule Sekulića, obogaćenima i prepoznatljivom folklornoknjiževnom poredbom (,Sekulić Mikula, zmaj ognjeni v ratu, / koga j' zemlja čula hrabrost obilatu“; IV: 403-404).

Inače, sama hvala kao usmenoretorički oblik ili žanr - navode folkloristi - svoje porijeklo najvjerojatnije vuče još iz srednjega vijeka, dok ih je u zapisima - nerijetko (i) u sklopu samih pisanoknjiževnih ostvarenja - nešto češće moguće zateći upravo od 17. stoljeća. ${ }^{752}$ Što se, pak, usmenolirske pohvalnice ili „počasnice“ tiče, kao daleko najpoznatiji primjer njezina uključivanja u tekst pisane književnosti izdvaja se, dakako, Hektorovićevo Ribanje i ribarsko prigovaranje, ${ }^{753}$ no folklorna pohvalnica posredstvom prepoznatljivih će svojih obilježja ili „tek“ u obliku motiva biti prisutna i u književnim ostvarenjima Marina Držića, Antuna Sasina, Petra Zoranića, Barne Karnarutića, Junije Palmotića te Jakete Palmotića Dionorića. ${ }^{754}$ Pribrojimo li tom nizu i Petrovu Adrijanskoga mora Sirenu, čija epskopjesnička sastavnica - Opsida sigecka - također sadrži nekolicinu pohvalnici bliskih dionica, ${ }^{755}$ postat će i više nego jasno da je makar za neke od navedenih ranijih pisanoknjiževnih evokacija ,počasnice“ Vitezović naprosto morao znati, pa i da se (u najvećoj

\footnotetext{
${ }^{751} \mathrm{O}$ hvali kao usmenoknjiževnome retoričkom obliku npr. u: Botica 2013: 485.

${ }^{752}$ Usp. o tome u: Botica 2013: 485.

${ }^{753}$ Usp. Bošković-Stulli 1978: 185.

${ }^{754}$ Detaljnije u: Isto: 193-194.

${ }^{755}$ Konkretno, radi se o nekoliko pojedinačnih ili uzastopnih strofa Opside, u kojima dominira „počasnicama“ i hvalama svojstven pohvalni ton, odnosno u kojima se jezgrovito glorificiraju većinom ratni dosezi, a uz njih i porijeklo te društveni status hvaljenika (posebno IV: 35; VIII: 28; IX: 95, 100-103, 111; XII: 64-65; XV: 115).
} 
mjeri) upravo po uzoru na njih i sam odvažio na posezanje za njezinim značajkama, baš kao što je na tragu mnogih ranonovovjekovnih domaćih autora koji su u svojim ostvarenjima činili isto vrlo vjerojatno svoje Odiljenje sigetsko odlučio napučiti i karakteristikama svojstvenima drugim folklornim lirskopjesničkim žanrovima. Konkretno, u njegovoj ćemo tako „zrinijadi“ - između ostalih - „nabasati“ i na motive neobično bliske onima karakterističnima za usmenoknjiževnu ljubavnu i svadbenu lirsku pjesmu, što će reći dvaju zacijelo najučestalijih folklornolirskih žanrova, za čijim su karakteristikama rado posezali i mnogi šesnaesto- i sedamnaestostoljeni naši pisci, počevši s pjesnicima Ranjinina Zbornika, preko Petra Zoranića i Hanibala Lucića, pa sve do Sabe Bobaljevića, Frana Krste Frankopana i dr. Daleki odjek euforičnosti narodnoga svadbenog pjesništva Vitezović će tako postići izuzetno zanimljivim usporedbama ratnih akcija sa svatovima, od kojih se prva donosi već u uvodnoj poslanici Sigeta, gdje se radostan dolazak hrvatskih branitelja u Siget prispodobljuje polasku na svečanost vjenčanja (,kot u svate veselo hodiše“; I: 29), dočim u onoj drugoj - smještenoj u pjesmi Junaci banu (II: 348-360) - sigetski branitelji užitak u duelu s neprijateljem poistovjećuju s onim svadbenoga dana (,Ziti na poboje i u njih opasti / srce gotovo je kot na pirne slasti“; II: 358-359). Prizivanje, pak, usmene ljubavne lirske poezije na djelu je u pjesmi Putnik $i$ Jeka, i to u središnjem njezinu segmentu (III: 223-302), u kojem putnik-namjernik načinje i temu zaljubljenosti koju oprimjeruje „,fatalnim“ slučajem (recipijentima usmene književnosti dobro znanih) ljubavnih razočaranja Ive Karlovića (III: 239-240), a zatim i pričicom o tragičnim ishodom prekinutoj ljubavi Narcisa („Lužnja“) i Jeke (III: 253-276).

Nije, naposljetku, na odmet primijetiti ni to da je brojne prethodnike, a onda i možebitne uzore i poticaje naš autor imao i u pogledu evociranja motiva pjevanja ,narodnih“ - ponajprije epskih, ali i lirskih, vrlo vjerojatno i pohvalničkih - pjesama u čast junaštava bana Zrinskog i ostalih sigetskih branitelja, ${ }^{756}$ o kojemu je u kontekstu Odiljenja dosad već bilo i o kojemu će doskora iznova biti znatno više riječi. Na izvedbu usmenoknjiževnih pjesama u svojim su se djelima s vremena na vrijeme osvrtali već i renesansni naši autori, pa dok će tako Marulić u Juditu uvrstiti „tek“ motiv folklorne (lirske) pjesme i plesa, dotle će Petar Zoranić u Planinama, odnosno Juraj Baraković u svojoj Vili Slovinki donijeti vrlo živopisne motive pjevanja ,narodnih“ (lirskih i ne samo lirskih) pjesama uz glazbenu, točnije guslarsku pratnju. Pored (literariziranih) svjedočanstava o izvođenju pojedinih usmenopjesničkih žanrova, u 17. stoljeću pojavit će se i otvorene kritike duboko ukorijenjenoga i sveprisutnoga ,poganskog“ običaja pjevanja „nepoćudnih“ svjetovnih lirskih pjesama, u kontekstu kojih će se obično iznositi i prijedlozi za supstituiranje njihovih tekstova

${ }^{756}$ Riječ je, podsjetimo, o motivskim evokacijama smještenima u: II: 146, II: 415, ali i III: 364. 
onima daleko pobožnijima, dakle usklađenima s kršćanskim duhom. Ne računajući Jurja Habdelića, koji u svojoj zbirci propovijedi Prvi oca našega Adama greh „samo“ žestoko napada (neke prilično lascivne) ljubavne folklorne pjesme te ističe njihovu pogubnost, ${ }^{757}$ takve će zahtjeve za nadomještanjem tekstova „nemoralnih“ usmenih (lirskih) pjesama onima pobožnim ili makar prožetim kršćanskim idejama iznijeti Nikola Krajačević (u predgovorima Molitvenih knjižica i Svetih evangelioma), Gabrijel Jurjević (u predgovoru Listima heroov), ${ }^{758}$ ali i biskup Petar Petretić, koji pjevanje crkvenih pjesama na melodije onih folklornih zagovara u svome Lekcionaru iz $1651 .^{759}$ Ritterov pristup usmenome lirskom pjesništvu kako se to ponajbolje očituje iz njegovih neprekidnih posezanja za karakterističnim mu obilježjima duž čitava Odiljenja - stoga bi se mogao i morao izdvojiti kao korjenito drugačiji u odnosu spram onoga što ga je njegovala većina njegovih literarnih suvremenika, naročito onih čije je književno djelovanje tijesno bilo vezano uz crkvene, odnosno liturgijske potrebe.

\section{3. 5. Bugaršćička obilježja}

Identificiravši značajke Vitezovićeva Odiljenja sigetskog derivirane iz različitih žanrova „narodne“ epske i lirske pjesme, neće nam - prije no što posvetimo pozornost u nj utkanim primjercima kratkih retoričkih i jednostavnih usmenoknjiževnih žanrova - preostati ništa drugo nego razmotriti još i one njegove ništa malobrojnije tekstualne osobitosti što potječu iz graničnoga, međužanrovskog folklornopjesničkog područja, odnosno karakteristike svojstvene podjednako „epskom“ i ,lirskom“ tipično usmenoknjiževnom žanru bugarštice ili bugaršćice. Želimo li podastrijeti što sažetiju, a ujedno i što precizniju definiciju za ovaj ,jedinstveni hrvatski usmeni oblik“ (Kekez 2000: 6), mogli bismo kazati da su - riječima Stipe Botice - bugaršćice zapravo „otužne pjesme, zasnovane na kakvom događaju ili na nekoj važnosti za psihički život ljudi, sa znatnom infiltracijom lirizma i baladičnog ugođaja“ (Botica 2013: 228), kojih najraniji zapisi datiraju još iz 14. stoljeća, iako se kao dio pisanoknjiževnih ostvarenja pojavljuju one tek od 16. stoljeća. Radi se, ukratko, o usmenoknjiževnome pjesničkom žanru dugoga stiha (što najčešće varira od trinaesterca do čak osamnaesterca i pritom uključuje brojna ponavljanja te - redovito - refren ili pripjev), ${ }^{760}$ koji najčešće opjevava junakova unutarnja, duševna stanja potaknuta nekim konkretnim povijesnim (mahom ratnim) događajem, i to na način koji se ne bi sasvim mogao označiti ni

\footnotetext{
${ }^{757}$ Usp. spomenuti tekst iz Habdelićeve zbirke propovijedi u: Bratulić 1996: 46.

758 Podrobnije o tome u: Bošković-Stulli 1978: 217-220 i Bartolić 1985: 289-294.

${ }^{759}$ Usp. Čubelić 1988: 89.

${ }^{760}$ Usp. Kekez 2000: 14-20.
} 
kao svojstven epskoj pjesmi, ali ni kao u potpunosti tipičan za lirsku pjesmu. ${ }^{761}$ Naime, iako se njezin sadržaj nameće kao izuzetno srodan onome folklornoknjiževne balade, bugaršćica je - u pravilu - narativno realiziran tekst, u kojemu glavnu riječ vode izvorno usmenoepski likovi, i to usprkos činjenici što ne posjeduje ni epsku objektivnost, a još manje opširnost te što u njoj redovito dospijeva prevladati usmenoj epskoj pjesmi stran melankolični ugođaj.

Bugaršćica je - kao takva - kroz čitav ranonovovjekovni period kontinuirano privlačila pažnju naših literata, zbog čega ne čudi što će se pojedina njoj svojstvena motivska i stilsko-formalna obilježja naći već u čuvenoj pjesmi Odiljam se iz Ranjinina Zbornika, a ubrzo nakon toga i u nekim lirskim tekstovima iz pjesničkoga opusa Mavra Vetranovića. Dvije cjelovite bugaršćice - Marko Kraljević i brat mu Andrijaš te Kada mi se Radosave vojevoda odiljaše - uključit će potom u svoje Ribanje i ribarsko prigovaranje i ovdje već višestruko spomenuti Petar Hektorović, a isto će s bugaršćicom Majka Margarita nepunih pola stoljeća kasnije u Vili Slovinki učiniti i Juraj Baraković, koji osim njezina izvornog zapisa ondje podsjeća i na sam čin „bugarenja“, ali i evocira jednog od najpoznatijih bugaršćičkih junaka - Jurja Smiderskoga, odnosno Đurđa Brankovića, čime i definitivno potvrđuje da je na njegovo djelo izuzetno velik utjecaj izvršilo usmenoknjiževno pjesničko stvaralaštvo. ${ }^{762}$ Da temu protuturskoga rata „na bugaršćički način“, odnosno „, i bez opisa krvavoga boja a ističući nostalgičnu stranu samoga događaja“ (Kekez 1992: 49), u svojim Razbojima od Turaka obrađuje i Antun Sasin svojedobno je primijetio Josip Kekez, čijem zapažanju valja dodati i kako je u šesnaesto- i sedamnaestostoljetnoj našoj književnosti iznimno učestao bio i motiv pjevanja bugaršćice, kojega nalazimo već u Karnarutićevu Vazetju Sigeta grada, a zatim i u Gundulićevu Osmanu, gdje se bugari o junacima Svilojeviću, Kobiliću, Janku, kralju Matijašu, hercegu Stjepanu, despotu Đurđu i dr., te osmeračkim pjesmama Gosti grada Dubrovnika i Glas Junija Palmotića, u kojima također biva spomenut čitav niz bugaršćičkih, a ujedno i usmenoepskih junaka. ${ }^{763} \mathrm{I}$ dok će „bugaršćice“ i „,bugarkinje“ u pojedinim svojim versificiranim ostvarenjima evocirati čak i Martin Benetović i Ignjat Đurđević, dotle će Juraj Križanić u čuvenoj sveslavenskoj

\footnotetext{
761 Premda presijecanje ,tipično“ lirskopjesničkih čimbenika i (povijesne) naracije otvara dvije različite mogućnosti klasifikacija bugaršćica - u usmenoknjiževne epske ili lirske pjesme - u nov(ij)im žanrovskopovijesnim prikazima hrvatske usmene književnosti (Kekez 1998; Botica 2013) bugaršćice su pripojene „,narodnoj“ lirici, i to ponajviše zato što ih pripjev, stihičko-ritmička obilježja, melankoličnost opjevanih sadržaja, pa i lirizmom protkana fabula u znatno većoj mjeri približavaju ,lirskome“, nego „epskom“ polu (usp. Kekez 1998: 179-180; Botica 2013: 124). Podrobnije o sadržajnim i formalno-stilskim specifičnostima bugaršćice u: Čubelić 1988: 61-63; Kekez 1992: 51-61, 1998: 179-180 i 2000: 5-63; Botica 2013: $228-242$.

${ }^{762}$ Detaljnije u: Bošković-Stulli 1978: 202-205.

${ }^{763}$ Usp. Bošković-Stulli 1978: 202-208.
} 
gramatici, pak, kao primjer jedne jezične pojave navesti dva izvorno bugaršćička stiha, ${ }^{764} \mathrm{a}$ dubrovački kapetan Nikola Ohmućević na marginama svojega prijepisa Gundulićeva Osmana polovinom 17. st. zabilježiti dvije cjelovite autohtone bugaršćice, i to Smrt despota Vuka te Smrt kralja Vladislava. ${ }^{765}$ Također, vrijedan će prilog nevelikom korpusu zapisa izvornih „narodnih“ bugaršćica dati i Petar Zrinski, koji - pored nekolicine (do danas, nažalost, nesačuvanih) usmenih (lirskih) pjesama - pedesetih ili šezdesetih godina 17. st. bilježi pretežno kajkavsku bugaršćicu prožetu štokavskim i čakavskim elementima ${ }^{766}$ naslovljenu Popevka o Svilojeviću, ${ }^{767}$ a uz to još i u svoju Obsidu sigecku - vrlo vjerojatno potaknut (i) istim detaljem iz ranijih ,zrinijada“ - uvodi motiv bugarenja. Naime, kao i u Vazetju Sigeta grada, i u njegovu će tako epu ban Zrinski nakon trijumfa u jednom manjem okršaju s Turcima upriličiti veličanstvenu pobjedničku gozbu, na kojoj se „davori zibrani hrvacki djačihu“ (IV: 43), odnosno u sklopu koje su se pjevale i „davorije“ ili - kako pokazuje Kekez - bugaršćice, ${ }^{768}$ pri čemu valja zamijetiti kako se taj fabularni moment nameće kao posve usklađen s (književno)povijesno i folkloristički potvrđenom činjenicom kako su se bugaršćice izvodile i rado slušale u raznim prilikama povodom kojih se okupljalo veće mnoštvo ljudi. ${ }^{769}$

I Pavao Ritter Vitezović bio je svjestan te sveprisutnosti i omiljenosti „narodnoga“ žanra bugaršćice, pa osim što su ga na kreativno uvažavanje njezinih specifičnosti potaknuli prije svega - motivi bugarenja u Petrovoj (pa onda i Nikolinoj),,zrinijadi“, gotovo je sigurno da je njegova generička fasciniranost „davorijom“ u Odiljenju sigetskom štošta dugovala i drugim ostvarenjima na temu pada Sigeta, također uvelike premreženima prepoznatljivim bugaršćičkim obilježjima. Da se oslanjanje na značajke iz „generičkog repertoara“ bugaršćice ili makar motivsko njezino evociranje u dotadašnjoj tradiciji „zrinijada“ iskristaliziralo kao gotovo neizostavan čimbenik naš je autor mogao uvidjeti kako iz pisanoknjiževnih i usmenoknjiževnih primjera, tako čak i iz pučkoknjiževnih sastavaka, kakav je i već spomenuta anonimna Pjesma o Sigetu zabilježena u Prekomurskoj pjesmarici s kraja 16. stoljeća. U njoj je, naime, Josip Kekez tako svojedobno utvrdio prisutnost bugaršćicama karakterističnoga leksika, ritma, sintagmatike i niza drugih posebnosti, ${ }^{770}$ zamijetivši pritom kako je ta njezina svojstva čine neobično podudarnom također nam već dobro znanoj bugaršćici Ban Mikloš Zrinjski u Sigetu gradu, koje je jedna varijanta zapisana početkom 18.

\footnotetext{
764 Opširnije u: Kekez 2000: 49.

765 O Ohmućevićevim zapisima bugaršćica podrobnije u: Botica 2013: 238-242.

766 Usp. Botica 2013: 236.

${ }^{767}$ Više o Popevki o Svilojeviću u: Novalić 1967b: 66 i Čubelić 1988: 91.

${ }^{768} \mathrm{Da}$ je ovdje zapravo riječ o motivu pjevanju bugaršćica Kekez procjenjuje ,po tomu što je nekim starijim piscima davorija isto što i bugaršćica“" (Kekez 1992: 55).

${ }^{769}$ Usp. o tome u: Kekez 2000: 21.

${ }^{770}$ Usp. Kekez 1987: 129-130 i 1992: 56.
} 
stoljeća u Boki Kotorskoj ${ }^{771}$ i koju je moguće izdvojiti kao neoboriv argument pretpostavci kako je tema sigetske katastrofe našla svoje mjesto čak i u ovome folklornoknjiževnom pjesničkom žanru. Osim toga, Pjesma o Sigetu je - zajedno sa zapisima bugaršćica Petra Zrinskog, Jurja Križanića te Petra Znike, koji je zabilježio (kajkaviziranu) bugaršćicu o pobjedi hrvatske nad turskom vojskom kod Siska 1593. - ujedno i jedan od najuvjerljivijih dokaza prisutnosti bugaršćica čak i na sjevernohrvatskom, kajkavskom prostoru, a ne - kako se podugo mislilo - isključivo duž istočne obale Jadrana, u Primorju i zaleđu Dalmacije, ${ }^{772}$ tim više što su i neki kajkavski jezični momenti locirani čak i u zapisima bugaršćica s kranjega juga, dočim je i u mnogim kajkavskim književnim ranonovovjekovnim tekstovima moguće prepoznati „tipična“ bugaršćička obilježja. ${ }^{773}$

Je li Ritter svoju generičku predodžbu o bugaršćici razvio i na temelju nekih njezinih primjeraka čiju je izvedbu imao prilike čuti i na kajkavskom (poglavito zagrebačkom) jezičnom području, sa sigurnošću je - dakako - nemoguće utvrditi, no zato neće biti ni najmanje dvojbe da je - kao „tipični“ barokni čovjek - itekako bio svjestan činjenice da su mnogi njegovi domaći literarni suvremenici skloni „prepjevavati, prerađivati i slijediti formu i sadržaj bugaršćice“, i to ponajprije iz razloga što se ,za uglađen odnos među likovima bugaršćica (...) u baroku pokazala najprimjerenijom“ (Kekez 2000: 41). Poput tih književnih svojih suvremenika, i naš je autor gajio neskrivenu naklonost spram „narodnih“ bugaršćica, o čemu nam možda i ponajbolje svjedoči ranije već spomenut vlastoručni njegov zapis fragmenta bugaršćice o hrvatskom porazu na Krbavskom polju - „o kojoj se vrlo malo znade i koja je sva u kolokvijalnomu, pučkomu dakle govorenomu stilu“ (Kekez 1992: 54) - što ga u pisanoj mu ostavštini nalazimo pod naslovom Sužanjstvo Krbave, a koji je nastao svega dvije godine prije objelodanjivanja prvoga izdanja Odiljenja sigetskog. ${ }^{774}$ Potonji fragment, drugim riječima, uvjerljiva je potvrda ne samo Vitezovićeva posjedovanja iskustva recipiranja toga folklornoknjiževnog žanra i očitog shvaćanja njegove neosporne (literarne i ne samo literarne) vrijednosti - koja ga je i potaknula na sam čin (pa makar i parcijalnog) zapisivanja - već i jasan dokaz njegova preferiranja bugaršćice i ovladavanja generičkim joj „,repertoarom“, i to ni dvije godine uoči izlaska iz tiska usmenoknjiževnim posebnostima napučena vernakularnog mu prvijenca. Bilježenje odsječka Sužanjstva Krbave i posezanje za bugaršćičkim karakteristikama u Odiljenju sigetskom u vezu je do sada pokušao dovesti tek malokoji naš

\footnotetext{
${ }^{771}$ Detaljnije u: Kekez 2000: 53-54.

772 Podrobnije o dokazima postojanja kajkavskih bugaršćica u: Kekez 2000: 48-55.

${ }^{773}$ Znatno opširnije o bugaršćici kao usmenoknjiževnom žanru i njezinim konkretnim ,tipičnim“ obilježjima u: Kekez 1992: 51-61, 1998: 179-180 i 2000: 5-63; Botica 2013: 228-242.

${ }^{774}$ Usp. tekst rečene bugaršćice u: Šurmin 1902: 537-538 i Kekez 2000: 114-115 (gdje je donesen pod nešto drugačijim naslovom - Ban Derenčin boja bije).
} 
proučavatelj, pa će tako tek „neizbježni“ Josip Kekez konstatirati kako Vitezović „ne samo da je zabilježio onu lijepu, čak i za njegovo doba drevnu bugaršćicu, već je u svojoj sigetskoj epopeji iz 1684., uz usmenu poeziju inače, podosta koristio i bugaršćicu, versifikacijski i sintagmatski“ (Kekez 1992: 55), što je zapažanje koje u drugim njegovim studijama nalazimo ne samo ponovljeno, već i ponešto prošireno i precizirano.

Upozoravajući na prožetost Odiljenja prepoznatljivim bugaršćičkim značajkama, u jednomu će svom tekstu Kekez tako istaknuti da je „osobito poglavlje Gospodična Sofija $i$ oral te Nadgrobnice iz epopeje Odiljenje sigetsko (Linz, 1684.) Vitezović oblikovao primjenom bugaršćice“ (Kekez 2000: 40), no tek će u drugim studijama doista i precizirati kako je eksploataciju tih generičkih karakteristika ondje moguće utvrditi kako na motivskoj i sintagmatskoj, tako i na leksičkoj i versifikacijskoj razini. ${ }^{775}$ Ukratko, Ritterovo neosporno nadovezivanje na tradiciju bugaršćica - pojašnjava Kekez - u tim ,poglavljima“ ponajprije odaju pojedine „,napadno“ usmenoknjiževne fraze (,sokolovi dragi““, „moj cvit“, „tužna vila“, „moj Sigete mili“ i sl.), zatim prepoznatljivi motivi (poglavito motiv tragičnoga djevojčina doznavanja vijesti o zaručnikovoj smrti na bojnomu polju) te nadasve prisutnost „autohtonih“ usmenopjesničkih junaka poput Debeljaka, čijim su herojskim pothvatima posvećene pjesme o kojima je riječ u nadgrobnici Ivana Novakovića (IV: 314-321) ${ }^{776}$ i koje bi - mišljenja je Kekez - nedvojbeno morale aludirati na (u Vitezovićevo vrijeme vrlo česte) bugaršćice o Novaku Debeljaku. Usprkos činjenici da su stih nadgrobnice Četrta istoga (IV: 55-61) te one Druga istoga grada, u kojemu rat govori (IV: 424-429) povjesnici književnosti poodavno već identificirali kao (pseudo)heksametarski, ${ }^{777}$ Kekez se, također, neće libiti u ovim pjesmama iščitati „versifikacijski prilog bugaršćice“ (Kekez 1987: 129), koja je, podsjetimo, obično bila realizirana izrazito dugim stihovima, gdjekad i onima što su brojili i po osamnaest slogova. ${ }^{778}$

Većim dijelom ispravnim zapažanjima Josipa Kekeza valjalo bi dodati i još pokoji ovdje uočen dokaz Vitezovićeva baštinjenja karakteristično bugaršćičkih osobitosti poput maločas utvrđenoga prizivanja elemenata folklorne naricaljke, na preuzimanju i ponavljanju čijih „naricaljskih“ stilema je uvelike i počivala liričnost iznimno velikog broja autohtonih bugaršćica. ${ }^{779}$ Ranije primjećeno ,ugrađivanje“ segmenata bremenitih značajkama „narodne“ naricaljke upravo u pjesmu Gospodična Sofija i oral i pojedine epitafe četvrtoga „dila“ stoga možda ne bi trebalo razmatrati u potpunosti odvojeno od u njima prisutnih (drugih)

\footnotetext{
${ }^{775}$ Usp. Kekez 1987: 126-129 i Kekez 1992: 55.

776 Ključno mjesto navedene nadgrobnice glasi: „Novaković Ivan, plemen Debeljaka, / po krajinah spivan za dobra junaka“" (IV: 316-317).

${ }^{777}$ Usp. Šrepel 1902: 116, Petravić 1939: 16-18, Slamnig 1981: 52-53 i Kravar 1986: 129-144.

778 Za detaljnije usp. Kekez 1987: 126-129.

${ }^{779} \mathrm{O}$ ovom obilježju bugaršćica posebno u: Botica 2013: 126.
} 
bugaršćičkih specifičnosti, tim više što je identično upijanje naricaljki svojstvenih elemenata naš autor imao prilike susresti ne samo u onodobnim zapisima mnogih bugaršćica, već i u sklopu aktualne bugaršćičke prakse tijekom druge polovine 17. stoljeća. Dapače, čitajući i osluškujući autohtono usmenoknjiževne bugaršćice Vitezović je mogao i morao zapaziti i da se kao jedan od vrlo čestih bugaršćičkih motiva nameće upravo onaj rastanka ili „odiljenja“, koji - između ostalog - tako zatječemo i u karakteristikama bugaršćice napučenoj pjesmi Odiljam se iz Zbornika Nikše Ranjine, potom bugaršćici Kada mi se Radosave vojevoda odiljaše zabilježenoj u Hektorovićevu Ribanju, ali i u drugim primjercima bugaršćica što su ih zapisali različiti naši ranonovovjekovni autori (poglavito u Majci Margariti, koju u Vili Slovinki donosi Baraković). Iako je, međutim, emocijama nabijen (većinom prisilni) rastanak likova - nerijetko potaknut nepovoljnim ishodom nekoga društveno važnog (obično ratnog) događaja - uistinu kotirao kao jedan od nimalo rijetkih motiva naših bugaršćica, zastupljenost identičnog motiva i u Odiljenju sigetskom nipošto se, dakako, ne može izdvojiti kao dovoljno pouzdan dokaz Ritterova motivskog nadovezivanja na žanr bugaršćice, pa i usprkos tomu što je naš autor na njemu inzistirao, između ostalog, vrlo vjerojatno i sa sviješću da će recipijente literarno formirane na usmenoj književnosti zacijelo on podsjetiti i na (neke) bugaršćice.

Štoviše, dodatnu poveznicu s usmenim, pa onda i bugaršćičkim pjesništvom Vitezović će u svojoj ,zrinijadi“ graditi i posredstvom drugih (ništa manje indikativnih) motiva, među kojima će se - osim netom zamijećenog aludiranja na onodobne bugaršćice izvođene u čast Novaka Debeljaka - posebno istaknuti ranije već detektiran motiv pjevanja (,narodnih“ ponajprije epskih, ali i lirskih, pa i „mješovitih“) pjesama o padu Sigeta, koje bi „u narodu“ trebale funkcionirati kao neka vrsta literarizirane uspomene na neustrašiv otpor kršćanskih branitelja predvođenih kapetanom Zrinskim osmanlijskim osvajačima i časnu njihovu pogibiju pod sigetskim zidinama. Heroidu Orsag banu (II: 118-146) privest će tako kraju obećanje pošiljatelja - personificirane domovine - banu Zrinskom da će njegova sigetska junaštva zasvagda ostati upamćena, i to ponajprije zahvaljujući (folklornim) pjesmama, koje se u vrijeme sastavljanja same poslanice već pjevaju diljem čitava „orsaga“, pa i šire („Trud tvoj, gospodine naš hrvatski bane, / navik mnoge cine v spomenu ostane, / pisme ti se čine na sve svita strane“; II: 144-146), a vrlo sličnim formulacijama operirat će potom i pohvalnica Siget banu i vojnikom (II: 361-439), u kojoj „oživljeni“ Siget najprije konstatira strelovito širenje vijesti o netom podnijetoj žrtvi bana Zrinskog (,Viteški moj bane, koga slavno dilo / na sve svita strane jur se j' raztočilo“; II: 361-362), da bi zatim - pedesetak stihova kasnije istaknuo i kako su junaštva njegovih hrvatskih branitelja već postala dijelom (usmeno)književnih obrada, koje su pritom dospjele nadići čak i jezične (a onda vjerojatno i 
geografske) barijere (,Svakoga jezika pisam zaslužiste“; II: 415). Vidljivo je, ukratko, da oba primjera sadržajno ponajviše združuje upravo (povijesno potvrđen) detalj rapidnog širenja novosti o turskom zauzeću Sigeta, koje su sa sobom donijele i potrebu da se taj važan povijesni događaj što prije (usmeno)književno uobliči ne bi li se time osiguralo i njegovo konzerviranje $\mathrm{u}$ formi literariziranoga pamćenja, pri čemu nema dvojbe kako navedeni motiv njegova proslavljanja u pjesmama „svakoga jezika“ što se pjevaju „na svim svita stranama“ želi referirati upravo na nebrojena „,narodna“ epska, lirska i bugaršćička pjesnička ostvarenja izvođena netom nakon pogibije Zrinskog i njegovih suboraca duž čitava onodobnog hrvatskog i ne samo hrvatskog prostora, koja su - prenoseći se kroz mnoge kasnije varijante sve do onih izvedaba što ih je u svoje vrijeme Ritter i sam imao prilike čuti - i u bespismenom dijelu hrvatskoga društva figuru bana Zrinskog i njegove ratne zasluge predano štitile od zaborava. Zbog toga, na kraju krajeva, i ne čudi tolika sadržajna važnost uspomene i uopće upamćivanja žrtve kršćanskih branitelja Sigeta, odnosno izuzetno velika zastupljenost motiva sjećanja u Odiljenju sigetskom, ${ }^{780}$ kojom kao da je Vitezović želio konotirati i svrhu usmenih (ponajprije epskih) pjesama te, dakako, bugaršćica - od čijih elemenata je uvelike i skrojio svoju „zrinijadu“ - a koja se u svojoj suštini svodila upravo na memorijalnu funkciju, točnije na upamćivanje društveno prijelomnih povijesnih događaja i njihovih ključnih sudionika.

Ukoliko bismo - s obzirom na sve u njemu dosad uočene bugaršćičke momente Odiljenje sigetsko željeli usporediti s malobrojnim konkretnim primjercima bugaršćice zapisanima prije 1684., uvjerljivo najveću sličnost pojedine bi njegove dionice - poglavito dijaloške pjesme Gospodična Sofija i oral te Putnik i Jeka, pa i neke nadgrobnice (ponajviše Embrulaha lipoga u kojoj Arpijanine zaručnica plače; IV: 263-308) - iskazivale već spomenutoj iznimno dirljivoj bugaršćici Majka Margarita, cjelovit zapis koje je u osmomu pjevanju svoje Vile Slovinke točno sedam desetljeća ranije donio Juraj Baraković. Mnoge značajke što ih nalazimo u ovim njegovim segmentima gotovo bi tako mogle navesti na pomisao o izravnom nadovezivanju na Majku Margaritu, posebice stoga što se i oni zasnivaju na dijalogičnosti te pritom uključuju likove (govornike) ekvivalentne onima Barakovićeve bugaršćice, u kojoj razgovaraju neutješna majka Margarita (kao ljudsko biće) i vila planinkinja (kao mitološko biće), koja - poput personificirana orla u Odiljenju - majci donosi nepovoljne vijesti o njihovim najmilijima. Dapače, u Majci Margariti zatječemo čak i dobro nam poznat motiv ptice - doduše, u ovome slučaju gavrana - poškropljene ljudskom krvlju, s kojom Margarita uzaludno pokušava uspostaviti kontakt ne bi li doznala gdje su joj brat Petar i sin Ivan (gavran, naime, odbija odgovoriti na njezina pitanja, no njegova zakrvavljenost i

${ }_{780}$ O spomenutoj sadržajnoj važnosti sjećanja u Odiljenju podrobnije u: Budišćak 2016a: 263-278. 
usprkos tome joj djeluje zloslutno), a kao uopće središnji motiv pjesme u cijelosti nameće se onaj - također dobro nam znan - zabrinute žene, koja je zauvijek ostala bez voljenih joj muških članova obitelji, no s tom razlikom što njezin brat i sin nisu poginuli ni završili u turskom zarobljeništvu, već su pronašli djevojke zbog kojih joj se više ne namjeravaju vratiti. Uz to, u Barakovićevoj bugaršćici - kao što to obično i jest slučaj u bugaršćicama - vrlo bitnu ulogu igraju elementi svojstveni „narodnoj“ naricaljki, slijedom čega će i u njoj tako ožalošćena Margarita - nalik neutješnim zaručnicama u Vitezovićevim pjesmama Gospodična Sofija i oral i Embrulaha lipoga u kojoj Arpijanine zaručnica plače - gorko tužiti, cviliti i zapomagati zbog svojih zauvijek joj izgubljenih najmilijih, čime je postignuta opća atmosfera ljudskoga gubitka i jadikovanja kakva prevladava i u „naricaljskim“ značajkama bremenitim odsječcima Odiljenja sigetskog.

Mogu li se detektirane paralele između rečenih dionica Vitezovićeve ,zrinijade“ i Barakovićeva zapisa bugaršćice prihvatiti kao dovoljno uvjerljiv dokaz pretpostavci da je naš autor imao prilike osobno čuti izvedbu jedne od inačica Majke Margarite i/ili da je pri pisanju Odiljenja bio pod posebnim dojmom one njezine varijante zabilježene u Vili Slovinki, čini se iznimno nezahvalnim prejudicirati, iako ne bi trebalo dvojiti u to da je - kako će se pokušati potvrditi i nešto kasnije - možda već i nekoliko godina prije početka rada na svome tekstu u rukama svakako imao to žanrovski ništa manje neobično djelo zadarskoga pisca. Osim što se, dakle, prilično vjerojatnom čini mogućnost da je svoju generičku predodžbu o bugaršćici i njezinu ,žanrovskom repertoaru“ Vitezović temeljio na iskustvu čitanja Barakovićeva zapisa Majke Margarite, bit će i da ne treba sumnjati u to da se na posezanje za njezinim značajkama odvažio (i) iz razloga što je, zbog naglašene svoje „melankolično-baladične ugođajnosti, upravo (...) bugaršćica Vitezoviću bila prikladna za oblikovanje spjeva“ (Kekez 1987: 129), a k tome je još i dodatno učvršćivala veze što ih je Odiljenje svojim ionako brojnim posebnostima „narodnih“ žanrova ostvarivalo s usmenom književnošću, dospijevajući tako privući pažnju i onih čitatelja koji su prva književna iskustva stekli upravo slušajući „narodna“" stihovana ostvarenja. Povrh bugaršćičkih, u zaokupljanju pozornosti tih i takvih recipijenata zadojenih na ,produktima“ folklorne književnosti sudjelovala su u Odiljenju vidjeli smo - i mnogobrojna prepoznatljiva obilježja lirskopjesničkih i epskopjesničkih usmenih literarnih žanrova, ali također i u nj utkani cjeloviti primjerci kratkih jednostavnih i retoričkih „narodnih“ žanrova, o kojima bi u nastavku također valjalo reći bar poneku riječ. 


\section{3. 6. Blagoslovi i kletve}

Paralelno s konkretnim „tipičnim“ sadržajnim, formalnim i - donekle - stilskim značajkama folklornih epskopjesničkih, lirskopjesničkih, pa i „epsko-lirskih“ pjesničkih žanrova te mjestimičnim motivskim evokacijama „narodnoga“ pjevanja, Pavao Ritter Vitezović svoje Odiljenje sigetsko prožima i stanovitim brojem cjelovitih retoričkih (blagoslov, kletva) i jednostavnih (poslovica, zagonetka) oblika usmene književnosti, pomoću kojih dospijeva intenzivirati pojedine iskaze, odnosno pojačati njihovu emocionalnu napregnutost ili, pak, naprosto u njima poentirati određena „ključna“ zapažanja i razmatranja. Konkretno, kada je tako riječ o (usmenoknjiževnom) obliku ili žanru blagoslova, njegovim će „tipičnim“ preporučivanjem Božjoj zaštiti subjekt odati osobnu emotivnu vezanost uz adresata iskaza, točnije zabrinutost za njegovu daljnju sudbinu, baš kao što to u pjesmi Siget hrvatskim gospojam (I: 1-477) čini i Siget, koji pred kraj svojega dugog pisma skrbno blagoslivlja poginule branitelje i njihove ožalošćene obitelji („,Božja milost sveta njim večni poda raj, / a vas do diteta u zdravju obdržaj / i blagoslov vam daj sveti, sreću i mir, / koji s vami ostaj i sigdor i sigdir“; I: 443-446). Doduše, valja uočiti kako je upošljavanje blagoslova u potonjem slučaju uvelike uvjetovano i ,praktičnim“ razlozima budući da se radi o završnoj dionici pisma „gospojama i vilama“, u okrilju koje se zazivanje Božje milosti ponajprije nameće kao neka vrsta „formulaične poante“ epistolarnoga iskaza, kojim se ondje ujedno pokušava i donekle ublažiti adresatima izuzetno mučne vijesti pristigle s bojnoga polja.

Za razliku od blagoslova, jake emocije iz kojih proizlaze kletveni izričaji ne posjeduju ni trunku dobronamjerne usmjerenosti spram adresata, premda i u podlozi klevetanja kao takvog ustvari stoje odjeci arhaične (mitske) uvjerenosti u magijsku moć izrečenog. ${ }^{781}$ Upravo iz toga razloga kletve će u Odiljenju biti situirane na emotivno posebno naglašenim mjestima, i to mahom onima koja se odnose na vremensku perspektivu neposredno nakon dovršetka opsade Sigeta, kada je preostala tek potreba rastanka, zbrajanja ratne štete i traženja kriv(a)ca za izgubljenu bitku. Prvo takvo mjesto bila bi žalopojka Siget zvrhu samoga sebe (II: 517613), u kojoj se najveća odgovornost za turski trijumf prebacuje na „braću“ Ugare, koja nisu ni pomišljala na slanje pomoći hrvatskim braniteljima, zbog čega u završnoj dionici pjesme Siget nelojalnoga „Ugrina perjenog“ ozbiljno upozorava kako mu se uskoro valja nadati

\footnotetext{
${ }^{781}$ U starijim prikazima hrvatske usmene književnosti kletve su redovito bile kategorizirane kao podvrsta poslovica u grupu „poslovične zakletve i kletve“ (primjerice u: Čubelić 1988: 335 i Kekez 1998: 171-174). Najsvježije povijesne studije (Botica 2013: 486-487), međutim, kletve priključuju „niši“ govorničkih usmenoknjiževnih oblika opravdavajući takav postupak činjenicom kako je u njima najvažniji epideiktički retorički stil, odnosno ukrašeno umijeće govorenja kojim se teži postići određene učinke (oklevetati adresata), zbog čega se kletve i u ovome istraživanju motre odvojeno od poslovičnih izričaja.
} 
novim napadima Osmanlija (,nadaj se s vrimeni težu skrb neg ovu“; II: 605), poentirajući to svoje upozorenje u prepoznatljivo kletvenom tonu: „znat ćete i svoju sriću u tužnosti“ (II: 612). Mnogo uvjerljivije, retorički vidno zaoštrenije kletve izreći će Hrvatkinja u pjesmi Vila Hrvatkinja nad Sigetom (II: 614-734), u kojoj otvoreno proklinje Siget zbog sustavnog umanjivanja stvarnih razmjera ratne katastrofe i odbijanja traženja pomoći u ranijim njegovim pismima s ratišta. Naime, prispjevši na bojišnicu po samom završetku bitke, Hrvatkinju će tako neizrecivo šokirati prizor obezglavljenih hrvatskih branitelja, pod dojmom kojega zaziva rušenje i preostalih zidina Sigeta (,da bi se razpale te zidine tvoje, / ke su još ostale, na žalosti moje“; II: 712-712), da bi svega nekoliko stihova poslije, prateći riječi prepoznatljivim (magijsko-obrednim) pokretima („Vila ruke lama, bije se nemila“; II: 724), izgovorila i gotovo uzoran primjer kletve uperene ne samo protiv Sigeta, već i čitava njegovog „potomstva“ (,Ah, vazdar te bila rat i zlo zgođenje, / za sužnje vodila tvoje porođenje; / vazdar pomorenje tužil i rezike, / da nisi prošćenje vzel prez moje dike. / Ne bilo prilike gorega zameta / niti veće prike nigdar od Sigeta! / Vazdar bil za kmeta, vazdar plakal sebe / i tvoga diteta dite nakon tebe / za ovoga leta mojih rož pogrebe“; II: 726-734). Mitološko porijeklo vila u Vitezovićevu je tako slučaju - vidimo - otvorilo i prostor za retorička očitovanja mitskoga porijekla kakvo je i sama kletva, pa i usprkos činjenici kako motiv proklinjućih vila ulazi među zacijelo najveće motivske raritete „,narodne“ poezije, što bi onda dalo nagovijestiti da se maločas zamijećeno upućivanje na ljudsko njihovo porijeklo (pa odatle i naslijeđene im ljudske osobine) našem autoru moralo učiniti dovoljno jakim argumentom za prepuštanje mogućnosti kletvenoga prizivanja negativnog ishoda čak i daleko „najpozitivnijim“ akterima domaćega folklornog literarnog stvaralaštva.

Doduše, kada je riječ o žanrovima blagoslova i kletve - koji su posebno važno mjesto imali već (i) u Bibliji, ${ }^{782}$ odakle je čitav niz njihovih primjeraka kasnije prešao u usmenoknjiževni opticaj, pa i u mnoga pisanoknjiževna ostvarenja - ne bi bilo posve ispravno tvrditi kako je jedini podstrek za njihovo uključivanje u Odiljenje sigetsko Vitezoviću pristigao tek iz sfere folklorne književnosti. Naprotiv, da se kletve i blagoslovi sjajno mogu uklopiti u pisanoknjiževne tekstove posvećene opjevavanju junaštava sigetskih branitelja Ritteru su demonstirale već i ,zrinijade“ braće Zrinski, a navlastito, dakako, ona Petrova, u kojoj - što je iznimno znakovito - vrlo dojmljiva kletva uperena protiv turskih „pogana“ koji su zapodjenuli krvavu bitku za Siget također biva stavljena u usta jedne vile, odnosno zore koja - preuzevši obličje vile - prispjeva pod sigetske zidine te tamo, zaprepaštena golemim brojem tijela izginulih vojnika što ondje leže, proklinje rata željne ,pogane nevirne“ (,Ne daj,

782 Vrlo pregledno o blagoslovima i kletvama u Bibliji u: Slavić 2016: 97-99. 
Bože, ne daj moć, pogani jer su, / Ugrom je skončat daj, tvoji dragi ki su“; VIII: 11). Tek što je izrekla potonju kletvu, vila-zora već u sljedećoj će strofi bitno ublažiti retoriku te uputiti ništa manje dojmljiv blagoslov banu Zrinskom, koji je neustrašivo stao u obranu Sigeta i čitave domovine (,Blagoslovljen, bane, koji si je ranil, / Turke od vse strane da s' verno obšanil, / i tak domovine prose, da b' jih branil, / za glas i krajine da b' žitak ne shranil“; VIII: 12), a sličnim će blagoslovima i drugdje u Obsidi sigeckoj različiti govornici blagoslovljati ne samo bana Zrinskog (IX: 48), već i druge istaknute kršćanske sudionike bitke za Siget (IX: 96, 100, 122; XIII: 96), pa čak i samoga habsburškog kralja, kao što će to pri kraju svoga pisma-poslanice učiniti upravo kapetan Zrinski (V: 89). Ima li se na umu to Nikolino i Petrovo pisanoknjiževno ,aktiviranje“ ovih „narodnih“ retoričkih žanrova, ni Vitezovićevo njihovo uvrštavanje u tekst Odiljenja sigetskog stoga nipošto neće biti neutemeljeno proglasiti kako očitim signalom uvažavanja autohtonih žanrovskih rješenja usmene književnosti, tako i još jednim u nizu prilično uvjerljivih dokaza generičkog nadovezivanja njegove „,zrinijade“ uz onu neposrednoga mu prethodnika, pa onda i mađarskog njezina predloška.

\section{3. 7. Poslovice $^{783}$}

Ukoliko bi se zastupljenost cjelovitih primjeraka retoričkih usmenoknjiževnih žanrova blagoslova i kletve u Odiljenju sigetskom s punim pravom mogla protumačiti (i) kao posljedica Vitezovićeva generičkog prikapčanja na žanrovski ništa manje slojevitiju Obsidu sigecku, pa i Adrijanskoga mora Sirenu Petra Zrinskog u cijelosti, isti bi zaključak u tom slučaju vrijedio i za jednostavni (,narodni“) žanr poslovice, koje neočekivano velik broj primjeraka zatječemo - kao što ćemo vidjeti - najprije u ,zrinijadi“ starijega pisca, a zatim i u onoj njegova prvog i jedinog literarnog (idejnog i generičkog) nastavljača. Odlučimo li se tim poslovičnim izričajima razasutima duž tekstove obojice autora doista pristupati kao primjercima jedinstvenoga (usmeno)književnog žanra, u tom ćemo slučaju nužno morati imati na umu da je riječ o jednom od (u nas, ali i u inozemstvu) relativno dobro proučenih generičkih rješenja, kojega su dosadašnja razmatranja nerijetko urodila bitno različitim njegovim definicijama i određenjima, odnosno nepostojanjem - do daljnjega - genološkog dogovora oko toga koji bi „oblici“, (pod)žanrovi ili tipovi trebali potpadati pod etiketu poslovice, a kojima - pak - pod (is)tom etiketom uopće nije mjesto. Primjerice, već će André Jolles u svojoj glasovitoj studiji Jednostavni oblici tako izdvojiti izreku kao „književni oblik koji zaključuje stanovito iskustvo, a da ono time ne prestaje biti pojedinošću u svijetu

\footnotetext{
${ }^{783}$ Ovo je poglavlje, u nešto proširenom obliku, prvi put objavljeno u: Budišćak 2019: 143-155.
} 
izdvojenog“ (Jolles 2000: 145), te ga potom oštro - ne samo terminološki, već i značenjski razlučiti od poslovice, ističući kako poslovicu (zajedno s krilaticom, sentencijom, apoftegmom, moralnom izrekom i poslovičnom uzrečicom) valja motriti kao „stvarni jednostavni oblik“, dakle onaj koji je posebno usmjeren ili ostvaren, dočim izreka predstavlja temeljni jednostavni oblik, točnije oblik u kojemu su se jezične geste „smjestile tako da se u svakom trenutku mogu osobito usmjeriti i postati zbiljski važnima“ (Isto: 46). ${ }^{784}$

Unatoč njezinoj (počesto zanemarivanoj) višetisućljetnoj ukorijenjenosti u oba vida jezičnoga stvaralaštva, znanstveni interes za žanr poslovice dosad su iskazivali pretežno stručnjaci za folklornu književnost, što je, dakako, rezultiralo sveopćim prihvaćanjem poslovice kao isključivo usmenoknjiževnoga kratkog, odnosno ,,jednostavnog ${ }^{6785}$ ili - u novije vrijeme - ,minimalističkog،786 oblika, koji u vrlo sažetoj formi (obično svedenoj na tek jednu rečenicu) donosi univerzalno primjenjivo poučno zapažanje o konkretnoj životnoj pojavi proizišlo iz pojedinčeva životnog iskustva i usklađeno sa svjetonazorom čitave zajednice. Ta se definicija, međutim, bez trunke oklijevanja može protegnuti i na pisanoknjiževne poslovice, također presudno obilježene istinitošću, kratkoćom i iskustvenim polazištem, a pridoda li se tim osnovnim značajkama žanra poslovice još i izrazit „poantni karakter“ (Čubelić 1988: 317), postat će posve razumljiv razlog zbog kojega su - bez obzira na svoje porijeklo - u gotovo svim književnim razdobljima poslovice često uključivane u veće (pisane) forme. Štoviše, zahvaljujući izuzetnoj postojanosti njezine strukture i spomenutoj univerzalnosti značenja, poslovica se u povijesti svjetske književnosti i ističe kao jedan od tek nekoliko žanrova dugoga trajanja, a činjenica da je - promijenjenim društvenopovijesnim i književnim okolnostima usprkos - potreba za poslovičnim koncentracijama životnoga iskustva jaka još i dan danas objašnjava zašto je i poslovicu „staru“ nekoliko stoljeća većina suvremenih čitatelja u stanju žanrovski prepoznati „,na prvi pogled““.

Sastavljajući svoje preglede žanrova usmene književnosti, (domaći) folkloristi u „pretinac“ jednostavnih (kraćih) oblika (ili „mikrostruktura“) ${ }^{787}$ zajedno s poslovicom obično svrstavaju i usmenu zagonetku, ${ }^{788}$ no kada je riječ o eventualnim podvrstama same poslovice, odnosno „paremiološkim tipovima“ (Kekez 1984: 68), njihovi se zaključci pokazuju kao

\footnotetext{
${ }^{784}$ Detaljnije u: Jolles 2000: 140-158. O poslovicama - kao jednome od (književno)minimalističkih žanrova detaljnije i u: Užarević 2012: 203-212.

785 Poslovicu (izreku) kao jednostavni, tj. „pretknjiževni“ oblik prvi je definirao upravo André Jolles, prema kojemu bi jednostavne oblike - među kojima, dakako, i poslovicu - valjalo oštro razlikovati od književnih žanrova što nastaju u kasnijoj, pisanoj književnosti, i to ponajprije stoga jer je riječ o ,prvobitnim“ načinima izražavanja koji su „složenim“ oblicima (žanrovima) poslužili tek kao podloga. Usp. Jolles 2000.

${ }^{786}$ U „,male (sitne) govorne žanrove“ poslovicu je u svojoj knjizi uvrstio Josip Užarević (usp. Užarević 2012).

${ }^{787}$ Podrobnije u: Dragić 2006: 524.

${ }^{788}$ Usp. Čubelić 1988: 296-365, Kekez 1998: 167-176, Dragić 2006: 524-539 i Botica 2013: 488-505.
} 
znatno manje podudarni. Premda su tako, kao što su i pokazala najrecentnija istraživanja, ${ }^{789}$ po većini svojih obilježja bliži govorničkim (retoričkim) usmenoknjiževnim oblicima ili žanrovima, blagoslov i kletva u prijašnjim su studijama o usmenoj književnosti ${ }^{790}$ redovito pridruživani ostalim podvrstama poslovice, odnosno izdvajani kao zasebne paremiološke skupine. Još veću pomutnju izaziva, štoviše, već i samo inzistiranje proučavatelja na razlučivanju paremioloških podvrsta i/ili poslovici srodnih oblika, pri čemu se kao zacijelo najdvojbenija i najšarolikije definirana kategorija ispostavlja ona tzv. paremiologizama. Paremiologizmima tako, primjerice, Josip Kekez drži frazeologizme, metafore i poredbe, koje zatim razlikuje od drugoga paremiološkog ,gradiva“ (,potpunih“ poslovica, izreka, dijaloških poslovica, poslovica-anegdota, kletvi i blagoslova), ${ }^{791}$ dočim Tvrtko Čubelić jednom od (pod)vrsta poslovice proglašava i ,poslovice-frazeologizme“, pod kojima podrazumijeva poslovične izreke, poredbe, zaklinjanja i kletve. ${ }^{792}$ Pavao Mikić i Vjekoslav Suzanić u svojoj se antologiji zadovoljavaju tek razlikovanjem (,,prave“) poslovice od srodnih joj oblika (krilatice, sentencije, aforizma, maksime, slogana, epigrama, proširene poslovice, poslovične izreke, poslovične usporedbe i protuposlovice), ${ }^{793}$ no zato će Stipe Botica - ne navodeći (druge) moguće tipove poslovice - iznova uvesti kategoriju paremiologizama, i to kao zajednički naziv za „sve oblike koji nisu prave poslovice već izričaji koji imaju nepotpunu strukturu poslovice ili su to poslovične sintagme i fraze u kojima se nazire dio poslovičnog izričaja ili dio stiliziranja na način poslovice“ (Botica 2013: 491). Pritom će u paremiologizme, premda ih je nešto ranije klasificirao u usmenoknjiževne govorničke oblike, Botica uključiti i već spomenute kletve i blagoslove (s obzirom na to da se, pojašnjava, „dio paremiološkoga blaga nazire u njihovoj strukturi“; isto: 491), dok će im s ,područja“ pisane književnosti pribrojiti još i krilatice, aforizme, sentencije, poslovične fraze, apoftegme i biblijski mašal. ${ }^{794}$

Očito je, dakle, da su domaći folkloristi još uvijek poprilično daleko od postizanja konsenzusa o tome bi li se i koje konkretno tipove ili srodne oblike moglo uključiti u žanr poslovice, kako bi te podvrste trebalo nazivati, što bi sve morala obuhvaćati kategorija paremiologizama te koje bi joj - shodno tomu - određenje najbolje pristajalo. Nije pritom upitno da je, prihvatimo li ih kao takve, zaista „teško povući čvrstu granicu između poslovice i njoj srodnih oblika jer ti srodni oblici mogu s vremenom postati poslovice“ (Mikić i Suzanić

\footnotetext{
${ }^{789}$ Usp. Dragić 2006: 503-523 i Botica 2013: 475-488.

${ }^{790}$ Navlastito u: Čubelić 1988: 325-340, Kekez 1984: 66-70 i 1998: 171-174.

${ }^{791}$ Usp. Kekez 1984: 69-70.

792 Opširnije u: Čubelić 1988: 334-335.

${ }^{793}$ Usp. Mikić i Suzanić 1994: 7-11.

${ }^{794}$ Usp. Botica 2013: 491.
} 
1994: 11), kao ni to da bi te oblike - maksimu, sentenciju, krilaticu, izreku i dr. - stoga možda i najopravdanije (ili makar najmanje pogrešno) bilo motriti kao svojevrsne varijante poslovice. Štoviše, čini se da su tragu takva zaključka i pojedini strani proučavatelji, koji u srodnim oblicima prepoznaju karakteristično poslovični tip izražavanja ${ }^{795}$ te stoga predlažu da se, s obzirom na to da se (formom) od poslovica bitnije ne razlikuju, svi redom oni priključe „širem“ žanru poslovice, odnosno shvate kao „,različiti nazivi načelno iste vrste u varijacijama“" (Solar 2011: 376). Žanrovski se naziv „poslovica“, drugim riječima, očito ispostavlja kao dovoljno elastičan da bi se mogao proširiti i na navedene srodne forme, a k tome i dalje obuhvaćati različite tipove poslovičnih izričaja (dijaloške poslovice, posloviceanegdote, frazeologizme itd.), i to neovisno od njihova usmeno- ili pisanoknjiževnog podrijetla. Žanr poslovice stoga bi mogao i morao podrazumijevati svaki onaj (jednostavni) oblik, formu ili (pod)žanr baziran na poslovičnom tipu izražavanja, koji nosi poslovici blisku strukturu i postiže poslovici srodne učinke, ${ }^{796}$ i to bez obzira na to iz koje sfere dolazi, je li ostvaren u stihu ili prozi, kolika je njegova starost te kojoj konkretno podvrsti pripada. U tom smislu, svim bi (eventualnim) podvrstama poslovice i/ili srodnim oblicima možda ponajbolje tako pristajao upravo zajednički naziv „,paremiologizmi“, kojim bi se s(p)retno naglasila njihova različitost u odnosu na ,pravu“ poslovicu, a ujedno i istaknula pripadnost tih oblika žanru poslovice u širem smislu riječi.

Bez obzira na to kako i što konkretno odredili poslovicom, nepobitna je književnopovijesna činjenica da će u našoj i većini drugih europskih kultura njezin žanr na važnosti naročito dobiti od razdoblja humanizma, točnije „tek“ od posljednjih desetljeća 15. stoljeća. Iako je skupljanje poslovica i njihovo uvrštavanje u pisanoknjiževna ostvarenja ${ }^{797} \mathrm{u}$ nas započelo već u srednjem vijeku, prva naznaka toga rapidnog ranonovovjekovnog porasta zanimanja za ovaj žanr bit će opis „,narodne“ prakse kruženja autohtonih folklornih poslovica što ga u svome već spomenutom djelu O smještaju Ilirije i gradu Šibeniku (1487.) donosi šibenski humanist Juraj Šižgorić, nakon kojega će u narednim stoljećima domaća zaokupljenost poslovicom u stopu pratiti onu što su je iskazivali strani onodobni literati i zapisivači. Svojevrstan vrhunac iskazivanja sveopćeg interesa za poslovicu u Europi zbit će tijekom 16. i 17. stoljeća, kada se uzrečice počinju prikupljati i objavljivati u zasebnim zbirkama, ali i u znatnijoj količini uvrštavati u generički različito realizirana pisanoknjiževna djela, a da su se toj europskoj „modi“ ubrzo priklonili i naši ranonovovjekovni autori

\footnotetext{
795 Detaljno u: Hoffman 2012: 1122-1123.

${ }^{796}$ Podrobnije o konkretnim strukturnim i drugim obilježjima žanra (usmenoknjiževne) poslovice u: Kekez 1984, Čubelić 1988: 303-343, Mikić i Suzanić 1994: 7-37, Užarević 2012: 203-212 i Botica 2013: 488-500.

${ }^{797}$ Nemali broj poslovica tako - primjerice - nalazimo i u srednjovjekovnom djelu Cvet vsake mudrosti nastalom između 14. i 15. stoljeća. Više o ovome u: Kekez 1992.
} 
ponajbolje nam svjedoči prva hrvatska rukopisna zbirka poslovica Proričja slovinska iz 1697., koju je sredinom 17. stoljeća najvjerojatnije započeo sastavljati Dubrovčanin Đuro Matijašević, a potom je konačno redigirao njegov nećak Ivan Marija Matijašević. 798

Trag kreativnog uvrštavanja (glavninom usmenoknjiževnih) poslovica u tekstove naše pisane književnosti moguće je, pak, pratiti još od pjesama Džore Držića i Šiška Menčetića, preko opusa Marina Držića, Zoranića, Hektorovića i Barakovića, pa sve do ostvarenja Gundulića, Palmotića, Đurđevića, Kavanjina i Frankopana, koji, između ostalog, sastavlja i zbirku poslovica Šentencije vsakojaške. ${ }^{799}$ Iako je do potonje rukopisne zbirke pohranjene u autorovoj pisanoj ostavštini što se čuva(la) u Beču Ritter vrlo teško mogao doći, svojim sakupljanjem i stiliziranjem poslovica ili ,priričja“ (a zatim i njihovim uvrštavanjem u gotovo sve svoje vernakularne sastavke) nametnuo se on kao izravni nastavljač Frankopanova rada, pri čemu se kao naročito zanimljiva i indikativna koincidencija ispostavlja činjenica da je u nekim njegovim hrvatskim tekstovima (ponajprije Priričniku) - kako su to izvrsno zamijetili pojedini književni povjesnici - moguće susresti nemali broj poslovica neodoljivo sličnih onima što ih je u Sentencije vsakojaške nekoliko desetljeća ranije uvrstio i sam Frankopan. Taj detalj, dakako, nipošto se pritom ne može iskoristiti kao dovoljno pouzdan dokaz Vitezovićeva možebitnog čitanja Frankopanove zbirke, već - upravo suprotno - isključivo kao pokazatelj da su obojica autora - svaki, dakako, za sebe - očito imali prilike u svakodnevnome govornom općenju čuti (i upamtiti) posve identične „,narodne“ poslovice, ${ }^{800}$ od kojih će neke potom ući i među one „sentencije“ što su - zajedno sa „zgankama“ ili zagonetkama - tijekom 17. stoljeća bile zapisivane u svrhu iznalaženja sinonima za pojedine riječi koje je Ivan Belostenec namjeravao uvrstiti u svoj čuveni Gazophylacium. ${ }^{801}$

Razmatrajući ovu šesnaesto- i sedamnaestostoljetnu domaću „pomamu“ za žanrom (većinom usmenoknjiževne) poslovice, nikako nećemo moći ni smjeti previdjeti i poprilično veliku zastupljenost „sentencija“ i u (pisano)književnim tekstovima iz ovdje posebno nam bitnoga ciklusa „zrinijada“, u sklopu kojega kao da se poslovična nadgradnja pojedinih važnijih sadržajnih momenata nametnula jednom od nezaobilaznih, gotovo konvencionalnih sadržajno-generičkih strategija. Izuzmu li se, dakako, usmeno- i pučkoknjiževne obrade turskoga zauzeća Sigeta, kao i kronikalni prikaz Podsjedanje i osvojenje Sigeta (1568.) Ferenca Črnka, na povelik broj poslovičnih izričaja svojedobno su tako upozorili i neki

\footnotetext{
${ }^{798}$ Rukopis u kojem se danas nalaze Proričja slovinska poznatiji je kao tzv. Dubrovački rukopis (usp. Kekez 1984: 17-18).

${ }^{799} \mathrm{O}$ tome podrobnije u: Kekez 1984: 25-49.

${ }^{800}$ Naročito o ovom pitanju u: Vončina 1976a: 345.

${ }^{801}$ Detaljnije u: Vončina 1976a: 344-345.
} 
stručni čitatelji povijesnoga epa Vazetje Sigeta grada (1584.) Barne Karnarutića, ${ }^{802}$ no oku književnih povjesnika također nije promaknula ni ništa manja količina poslovica „ugrađenih“ u epskopjesničku, ali i ne samo epskopjesničku komponentu Adrijanskoga mora Sirene Petra Zrinskoga. Naime, u Obsidi sigeckoj - kako je još prije nekoliko desetljeća zamijetio Đuro Novalić - teško je naći makar jedno pjevanje u potpunosti lišeno refleksivnih dionica, $u$ kojima ne samo što se raspreda o nestalnosti sreće i ljudskoj smrtnosti te zagovara važnost junačkoga i časnog umiranja, nego i u okrilju kojih se obično i pojavljuju nerijetko i vrlo dojmljive „sentencije“, egzistirajući ondje (i) kao odjek „opće književne mode onoga vremena" (Novalić 1967b: 86). Pored više desetaka poslovica porazbacanih samim tekstom Petrova epa, u Sireni se - štoviše - krije i još nekolicina onih uvrštenih na druga mjesta unutar zbornika, i to ne samo u jednu od lirskih pjesama što okružuju centralni epskopjesnički segment, ${ }^{803}$ već i u paratekstualni (posvetni) odsječak teksta u cijelosti, u kojem zatječemo dobro poznatu latinsku poslovicu o slasti koju pričinja umiranje za vlastitu domovinu („Dulce pro patria mori“). Da bi - naposljetku - i mnoštvo poslovica što ih u svoje Odiljenje sigetsko uvrštava Pavao Ritter Vitezović također trebalo tumačiti „kao ukus toga vremena koje je bilo bremenito baroknim recidivima“ (Kolumbić 2005: 346) u više je navrata ustvrdio Nikica Kolumbić, ${ }^{804}$ koji uz to primjećuje i kako „sentencije“ u njegovu tekstu „dolaze uglavnom kao logičan slijed razmišljanja pojedinih lica o svojoj sudbini““ (Isto: 346-347), no zato ipak previđa da su - u sadržajnom pogledu - mnoge od njih zapravo posve na tragu onih Petrovih, u kojima se većinom također glorificiraju moralne vrline ili „krepost“, ističe važnost umiranja za „više ideale“ te upozorava na neizbježnost smrti i hirovitost sreće. 805

Kao ni u većine sedamnaestostoljetnih (domaćih) pisaca, ni Vitezovićeva sklonost spram poslovica - međutim - nije bila privremena, uz rad na jednom književnom tekstu vezana pojava, koju je velikim dijelom potaknulo ugledanje na drugo poslovicama bremenito i tematski srodno pisanoknjiževno ostvarenje. Naprotiv, kontinuiranu njegovu fasciniranost ovim izvorno usmenoknjiževnim žanrom daleko će nam najbolje potvrditi već spomenuta zbirka osmerački ispjevanih ,priričja“ Priričnik aliti razliko mudrosti cvitje (1703.), ${ }^{806} \mathrm{u}$ koju

\footnotetext{
${ }^{802}$ Usp. Kekez 1987: 124-126.

${ }^{803}$ Riječ je o lirskoj ljubavnoj jadikovki Pisam II., u kojoj se spoznaje tužba zvirara, u 27. strofi koje susrećemo gotovo ratarsku poslovicu što glasi: „Tim je bolja zemlja, čim je črnija“.

${ }^{804}$ Opširnije u: Kolumbić 1971: 89, 2005: 324 i 346-347.

805 Pored ranije citirane latinske poslovice o slasti umiranja za domovinu, nekim poslovičnim iskazima iz Odiljenja po svojoj tematsko-motivskoj orijentaciji poprilično će nalikovati mnoge poslovice iz Obside sigecke poput one „Človika rasutku veseli se srića“ (IV: 3), zatim „Nijedno ni vrime kasno na kaštigu“ (V: 1) i ,Slavno umriti najlipše j' spećenje (V: 4), ali i „Uzeti človiku nigdor smrt ne more“ (V: 110), „Pot, trud i nevolja žitka svitovnoga / kripostnoga pelja do dobra stalnoga“ (VI: 1), „Vsaki človik kripost u napridak meće“ (VI: 23) itd. ${ }^{806}$ Naslov potječe od riječi „priričje“, odnosno „,prirječje“, koja je zapravo doslovni (staro)hrvatski prijevod latinske riječi „,proverbium“ (poslovica). „Priričnik“ bi - dakle - značio „zbirka poslovica“ (usp. Kekez 1984: 8).
} 
je naš autor uvrstio redom sve poslovice (njih, konkretno, tristotinjak) što ih je od 1697. do 1703. - pod istim naslovom - objavljivao kao prilog svojim pučkim kalendarima i među kojima se nalazio samo određen broj uzrečica izvorno folklornoknjiževnoga podrijetla. ${ }^{807} \mathrm{Da}$ je, štoviše, Ritterova „zagrijanost“ za poslovice datirala ne samo iz vremena prije sastavljanja potonjih pučkih kalendara i Priričnika - koji je, uzgred budi rečeno, „prva kod nas tiskana zbirka poslovica“ (Bratulić 1994: 84) - nego i iz razdoblja uoči samoga početka rada na Odiljenju sigetskom, još sedamdesetih godina 17. stoljeća na vlastite se oči (i uši) - između ostalih - imao prilike uvjeriti i njegov suvremenik i veliki prijatelj Janez Vajkard Valvasor. Taj kranjski barun i polihistor, u čijem je dvorcu u Bogenšperku mladi Vitezović boravio tijekom 1676. i 1677. godine, ${ }^{808} \mathrm{u}$ autobiografskim se dionicama svojega zamašnog djela Slava vojvodine Kranjske (1689.) tako prisjetio, uz ostalo, i Ritterove nevjerojatne vještine u smišljanju originalnih kratkih poslovica (sentencija), koje je u gotovo svakoj prilici bio spreman ,izvući“ gotovo kao iz rukava, ${ }^{809}$ možda i zahvaljujući tomu što je još od malih nogu - osim za izvorne „narodne“ poslovice - živo bio zainteresiran i za autorske poslovice, koje je imao prilike iščitati u djelima mnogih onodobnih i ne samo onodobnih pisaca. Kao nepobitan dokaz ovoga potonjeg zanimanja (i) za pisanoknjiževne poslovice ostao je iza Vitezovića priručni rukopisni zbornik naslovljen Varia extracta et notitiae (danas pohranjen u fondu NSK), u kojega je - očito sluteći da bi mu one mogle kad-tad zatrebati - niz godina vlastoručno prepisivao mudre izreke i poslovice što ih je zatekao u svojoj lektiri, točnije u pjesničkim i filozofskim ostvarenjima raznih antičkih (podjednako starogrčkih i starorimskih) autora - Epikteta, Auzonija, Juvenala i dr. - te nekih šesnaesto- i sedamnaestostoljetnih njemačkih (pretežno isusovačkih) pisaca. ${ }^{810}$

Svjesni utvrđenoga Vitezovićeva kontinuiranog čitateljskog i kreativnog napajanja $\mathrm{s}$ dvaju izvora poslovica - usmenoknjiževnog i pisanoknjiževnog - posve je jasno da poslovične izričaje što ih nalazimo u pojedinim njegovim ostvarenjima nipošto nećemo smjeti naprečac proglasiti isključivo „narodnima“, već ćemo svakako morati računati i s njihovim makar djelomičnim, a katkada i posvemašnjim pisanoknjiževnim, odnosno autorskim porijeklom. Izuzme li se kronikalni prikaz hrvatske i svjetske povijesti Kronika aliti spomen vsega svieta vikov (1696.), u kojemu su izreke sasvim izostale, rečeno će se - osim na one okupljene u Priričniku - odnositi i na poslovice što ih je moguće zateći u drugim Ritterovim

\footnotetext{
${ }^{807}$ Detaljnije o poslovicama u Priričniku i uopće učestaloj sedamnaestostoljetnoj pisanoknjiževnoj evokaciji poslovica kao jednom od karakteristično neostoicističkih rješenja u: Simpson 1991: 52-53, Hrgić 2015: 46-53.

${ }^{808}$ Detaljnije o Vitezovićevu boravku u Bogenšperku u: Klaić 1914: 9-38.

${ }^{809}$ Usp. Kovač 1973: 118-119. Doduše, spomenuti podatak - zbog već konstatirane djelomične fikcionalnosti autoričina (polu)biografskog teksta teksta - nužno je uzeti s nemalom dozom opreza.

${ }^{810}$ O ovom rukopisnom zborniku opširnije u: Putanec i dr. 1952: 32 i Kosić 2013: 36-37.
} 
hrvatskim književnim djelima, i to kako na one iz tek fragmentarno mu sačuvane knjige gatalica Lado horvatski iliti Sibila, tako i na one što ih je uključio u osmeračku prigodnu pjesmu Senjčica objelodanjenu $1704 .{ }^{811} \mathrm{I}$ dok su „sentencije“ što su ih recentni proučavatelji locirali čak i u njegovoj latinskoj kronici u stihovima Dva stoljeća ucviljene Hrvatske u potpunosti pisanoknjiževne provenijencije, ${ }^{812}$ udio autorskih poslovica u Odiljenju sigetskom ispostavlja se, s druge strane, ipak zamjetno manjim, što - dakako - ne znači da one izvorno folklornoknjiževne u njemu odnose apsolutnu prevlast. Naprotiv, iako je riječ o jedinom Vitezovićevu (literarnom) tekstu (s izuzetkom, dakako, Priričnika) u kojemu se - u usporedbi s ostalim u njemu prisutnim usmenoknjiževnim, pa i pisanoknjiževnim žanrovima - svojom brojnošću, odnosno gotovo ravnomjernom zastupljenošću u svim četirima dijelovima teksta ističu upravo poslovice i paremiologizmi, a ujedno i o možda jedinom ostvarenju našega autora s tolikim udjelom onih „narodne“ provenijencije, poslovice koje bi se mogle označiti kao usmenoknjiževne u njemu ipak ne čine premoćnu većinu, pa i usprkos činjenici što pretežno folkloristička pažnja koja je do danas posvećivana (svim) poslovičnim izričajima utkanima u ovu Vitezovićevu ,zrinijadu“ kao da želi sugerirati nešto posve drugo. ${ }^{813}$ Ukoliko spomenuta brojnost poslovica u Odiljenju sigetskom od proučavatelja iziskuje da ovome žanru posveti nešto veću analitičku pozornost, onda ga njihova raznolikost suočava s nužnošću da za potrebe te iste genološke analize to - po podrijetlu i značenju - šaroliko mnoštvo poslovičnih iskaza zbog preglednosti na neki način svede na zajednički nazivnik, odnosno da $\mathrm{u}$ njihovu razmatranju primjeni zajedničke kriterije. S obzirom na to da su se žanrom poslovice - pristupajući mu kao jednom od jednostavnih usmenoknjiževnih oblika - daleko najviše bavili i bave upravo stručnjaci za folklornu književnost, razlikovanje poslovica u Odiljenju valjalo bi provesti prema „tipično“ folklorističkim kriterijima, koji podrazumijevaju njihovo značenjsko razvrstavanje u nekoliko unaprijed zadanih tzv. ,semantičkih polja““ ${ }^{814} \mathrm{i}$

\footnotetext{
${ }^{811} \mathrm{Na}$ poslovice, odnosno „kratke sentence s didaktičnom namjenom“ u Senjčici prvi je pozornost skrenuo još Branko Krmpotić (usp. Krmpotić 1970: 625-630), a puna će tri desetljeća nakon njega o poslovicama kojima se u Senjčici komentiraju opjevana zbivanja pisati i Davor Dukić (usp. Dukić 2002: 72).

${ }^{812}$ Već je Zrinka Blažević u nekoliko navrata (usp. Blažević 2003: 203 i 2005: 39) skrenula pozornost na činjenicu kako se u Dva stoljeća ucviljene Hrvatske „manje tematske cjeline unutar pjevanja zaključuju (...) kraćim sentencijama neostoicističke filozofske inspiracije“ (Isto: 203), dok je Pavao Knezović relativno nedavno također utvrdio kako su sentencijama većinom premrežene poučne dionice ove Vitezovićeve stihovane kronike (usp. Knezović 2016: 236).

${ }^{813}$ Iako većinom uzgredno, o poslovicama u Odiljenju u nekoliko su se ranijih navrata laćali pisati gotovo isključivo stručnjaci za našu usmenu književnost (usp. Kekez 1987: 126-129, Mikić i Suzanić 1994: 154, Kolumbić 2005: 345-348 i Hranjec 2016: 28-29).

${ }^{814}$ Usmene (ruske) poslovice u više je od 150 značenjskih polja razvrstao još čuveni devetnaestostoljetni ruski leksikograf i etnolog Vladimir Pal' (usp. Užarević 2012: 204), a u nas se za takav način klasificiranja (,narodnih“) poslovica najodlučnije opredijelio Josip Kekez. Kekez tako poslovice dijeli u više skupina prema unaprijed određenim „semantičkim poljima“ (povijesno, filozofsko, etnološko, sociološko, religijsko, psihološko, antropološko, politološko, profesijsko i dr.) te pritom napominje i kako bi se svako od njih dodatno
} 
to neovisno od njihova stvarnog ili pretpostavljenog (pisano- ili usmenoknjiževnog) porijekla. Dapače, uspješna primjenjivost takve folklorističke klasifikacije i na korpus poslovica pisanoknjiževne provenijencije ujedno može poslužiti i kao dodatni, vrlo uvjerljiv argument za ranije predloženo ujednačavanje definicije poslovice kao žanra s dvostrukim podrijetlom.

Konkretno, Vitezovićeva namjera da Odiljenje sigetsko protka poslovicama doslovno „od korica do korica“ očituje se već u paratekstualnim njegovim segmentima, obilato ispresijecanima poslovičnim izričajima, kojih sveukupno tri - iznimno bliska autohtonim „narodnim“ poslovicama - obogaćuju već predgovor $K$ čtavcu prvoga njegova izdanja, pri čemu je prvi od njih (u formi distiha u dvostruko rimovanom dvanaestercu) uključen u proznu dionicu, dok su preostala dva dio nenaslovljene osmeračke pjesme, kojom se predgovor zaključuje. Promotre li se te uzrečice u značenjskome (smisaonom) kontekstu, pokazat će se kako dvanaesteračka poslovica „Človik najdičnije svoju halju nosi, / a što doma nije, to se vani prosi“ i osmeračka „dobrim jezik zal ne udi“ potvrđuju svoju pripadnost sociološkome, a druga osmeračka ,pod nebom ne znam gdo je / ki svim more ugoditi“ - poradi ukazivanja na urođeno karakterno čovjekovo obilježje - psihološkome semantičkom polju.

Poslovice, nadalje, nisu izostavljene ni iz predgovora Prijaznivi štavče! drugog izdanja Odiljenja (Beč, 1685.), a s obzirom na to da je i ovaj (para)tekst koncipiran prema modelu identičnom onome predgovora prethodnom izdanju (prozni segment koji završava pridruženom lirskom pjesmom), izreke je ponovno moguće locirati kako unutar prozne dionice (distih u dvostruko rimovanom dvanaestercu), tako i sklopu lirske pjesme Učinitelj knjigam (tri primjera), pa dok tako poslovica uključena u prozni dio predgovora („Čim ki veće ima, već želi imati, / A ki ništar nima, otkud će što dati?“) teži ukazati na općepoznatu čovjekovu sklonost prekomjernom stjecanju (psihološko semantičko polje), one utkane u dvanaesteračku pjesmu najbliže su sociološkom (,,Dosta j' da te hvale ljudi od razbora, / a pameti male ne boj se prikora“ $\mathrm{i}$, , dobru se ne vznesi, nit se $\mathrm{v}$ zlu ražali“), odnosno filozofskom polju (,Nima se prevzeti komu srića dvori, / kad srića odleti, nisko se obori“). Za razliku od predgovora prvom i drugom izdanju, u oduljoj proznoj posveti nedavno otkrivena trećeg Vitezovićeva izdanja Odiljenja (Zagreb, 1695.) mjesta se nije našlo ni za jednu jedinu poslovicu, što je - po svemu sudeći - izravna posljedica činjenice da je ono bilo namijenjeno posve drugačijem krugu čitatelja, i to isključivo onima iz najviših društvenih slojeva, a ne više (i) skromnije obrazovanoj publici, kao što je to bio slučaj s prijašnjim izdanjima. ${ }^{815}$

\footnotetext{
još moglo razdijeliti na podskupine ili „reme“ (filozofsko značenjsko polje tako bi, primjerice, uključivalo reme „,sudbina“, „,smrt“, „vrijeme“, „život“, „,̌ovjek““itd.). Opširnije u: Kekez 1984: 57-70.

${ }^{815} \mathrm{O}$ vjerojatnoj ciljanoj publici triju Vitezovićevih izdanja Odiljenja sigetskog opširnije u: Budišćak $2016 \mathrm{~b}$.
} 
Što se, pak, - u sva tri izdanja gotovo nepromijenjenog - samoga teksta „zrinijade“ tiče, već prvi se njegov „dil“ izdvaja brojnošću izuzetno upečatljivih poslovica i poslovičnih nizova o sveprisutnoj razarajućoj snazi smrti („Ni človik ni dite smrti vteć ne more, / da ga prem sve šćite vode, ognji, gore. / Smrti se pokore poglavniki svita, / svakim ona more, s nijednim ne pita“, I: 265-268; „Pod nje vlasti dika i jakost opada, / od vika do vika smrt na svitu vlada“, I: 277-278; „Koje godar tilo na 'vom svitu hodi, / il knjasto il cilo, smrt na svoj cilj vodi. / Zna človik, gdi rodi njega mila mati, / al gdi ga smrt zgodi, to ne more znati“, I: 301-304; „Mladosti nit roda ljuta smrt ne gleda“, I: 383; „Svakomu umriti jednuč suđeno je, / nigdor ne m're biti prost od smrti svoje“, I: 407-408; „Smrti se sakriti ni moći človiku, / a svakom dobiti smrćom ni moć diku“, I: 599-600). Istomu - filozofskom - semantičkom polju pripadaju i pobrojanim primjerima srodne poslovice o hirovitosti sreće (,Srića ima ćudi i dvisto i tristo, / sad udi, sad prudi, minja misto“, III: 99-100; „Tako srića svita nestanovita je: / što dugo obita, to dugo ne daje“, IV: 51-52), dok spoznaju o destruktivnoj prirodi podjednako nepostojane sreće i vječno vrebajuće smrti donose poslovice o prolaznosti, mahom situirane u posljednjemu (nadgrobničkom) dijelu Odiljenja („,Tako svita stvari (kot tekuće vode), / časti i timari i krune prohode“, IV: 13-14; „Ni veruvat diki svita, da prem sije“, IV: 28; „Suprot smrti ni lik, srića vik ne služi“, IV: 30; „Roka nigdor svoga previdit ne more, / srića ni stanovita, / sve stvari ovoga svita se pokore / smrti, ka sve hita“, IV: 219-222).

Poslovice u Odiljenju nerijetko se dotiču i važnosti junačkoga umiranja za „,više ideale“, što će reći da u podjednakoj mjeri ulaze i u religijsko i u filozofsko semantičko polje (,za Boga umriti i za dom slavno je“, I: 316; „, krvjom vitez diku kupi, / iz zemlje na nebo stupi“, IV: 397-398), dočim bi isključivo antropološkom polju pripadala poslovica kojom sin Juraj ocu Nikoli Šubiću Zrinskom u pjesmi Ban sinu pokušava ukazati na važnost dobroga glasa (,pozitivne reputacije“) proizišlog iz hrabrih (ratničkih) djela („Da ima sve stvari i svega zadosti, / ki za glas ne mari, vik žive v tamnosti“; I: 581-582). Poslovice poput „što suđeno je, ono mora biti“ (I: 338), „Život uživati Bog človiku poda, / al do kih dob, znati to mu Bog ne doda“ (I: 381-382) i ,telo zemlja biva, a Bog dušu primi“ (II: 110) - kojih se velik broj inačica može pronaći i među do danas zabilježenim autohtonim narodnim mudrostima „tipični“ su, pak, izdanci religijskoga polja, dok bi istodobno na razmeđu religijskoga i filozofskoga značenjskog polja valjalo smjestiti uzrečice poput „Navike živiti ovdi se ne može, / zemlja mora biti 'z kosti, 'z mesa, 'z kože“ (I: 492-493) te „umrit je človiku“ (II: 343).

Pored navedenih sadržajnih ishodišta (smrt, sreća, prolaznost, rat), nešto skromnija će količina poslovica i paremiologizama u Odiljenju prizivati i sasvim drugačiji krug životnih tema poput (ne)sloge, opreznosti, ljubavi, tuge i bogatstva, pa će tako filozofsko semantičko 
polje obuhvaćati poslovice o nepovoljnim životnim okolnostima (,ni jelvi izrasti srid ognja ni moći“, II: 154; „tilo truda sito izlahka umira“, II: 187), dok sociološkome (možda donekle i antropološkom) polju pripadaju poslovični izričaji o pogubnosti nesloge (,Ruše se, ne stoje gradi prez složnosti“, II: 613; „Zla ta naša sloga od naravi stare / razpušća orsaga nam kotare“, III: 197-198). Iz psihološkoga značenjskog polja valja izdvojiti dvije poslovice o emotivno-mentalnoj (ne)uravnoteženosti i (ženskoj) tuzi što ih izgovara ucviljena Sofija naručući nad poginulim Alapićem u pjesmi Gospodična Sofija i oral (,glavi prez srca ni, a srcu prez glave“, II: 866; „ni žalosti sila veća neg u ženi““, II: 898), potom poslovicu o ozbiljnosti ljubavi („,Kot pri ognju dima, gdi su drva huda, / posla ljubav ima i kot ruda“; III: 293-294) te iznimno zanimljivo poslovično ismijavanje bogataške sebičnosti („Al ki su bogati, gospoda takoje, / sami uživati sve nastoje“; III: 103-104), koje je u potpunosti na tragu poslovice o pretjeranom gomilanju (materijalnih) dobara iz predgovora Prijaznivi štavče!.

Osobitu pozornost svakako zaslužuju dva i više nego zanimljiva poslovična izričaja uklopljena u treći „dil“ Odiljenja, koji zapravo predstavljaju tipične primjere tzv. ,poslovica s izvedbenim sponama“ ${ }^{816}$ a riječ je o - konkretno - onim poslovicama kojima su pridodani očiti izvedbeni signali, odnosno u kojima jedan dio „teksta“ izrijekom upućuje na govorno (folklorno) porijeklo ili frekventnost u svakodnevnoj razgovornoj uporabi. Ispitujući vilu Jeku o detaljima turskog zauzeća Sigeta, putnik u pjesmi Putnik i Jeka hotimice tako umeće (odvajajući ih zagradama) jasne aluzije na usmenoknjiževno podrijetlo najprije u poslovicu „Ludo je prositi (veli se rič zdavno), / što ni moć dobiti.“ (III: 21-22), a potom i u onu „Čim već blagoviti človik (kot se veli), / tim veće želiti može li? O, želi!“ (III: 89-90). Promotre li se, međutim, iz perspektive semantičkih polja, pokazat će one ipak dva različita lica, pa dok bi prva od njih podjednako mogla biti uvrštena i u sociološko, i u antropološko polje, druga je najbliža psihološkom polju, a k tome se - s obzirom na svoju ,pitalačku“ formu - može klasificirati i u podvrstu tzv. dijaloških ili poslovica-pitalica. ${ }^{817}$

Utvrđena (mnogo)brojnost poslovica u Odiljenju sigetskom nije, kako se čini, mogla biti slučajna, pa iščitaju li se pažljivije dijelovi teksta protkani poslovicama, sam će se od sebe nametnuti zaključak da za poslovičnim izričajima različita podrijetla Vitezović najčešće poseže želeći što efektivnije poentirati iznesene misli i zapažanja, a sve u cilju približavanja „recepcijskoj logici“ i onog dijela publike s ponešto skromnijom (književnom) naobrazbom. Da je tomu zaista trebalo biti tako najlakše je razabrati upravo iz onih segmenata teksta u kojima kazivanja pojedinačnih govornika prelaze u razmatranja o varljivosti sreće, prolaznosti

\footnotetext{
${ }^{816}$ Frazom „poslovice s izvedbenim sponama“ ovaj tip poslovica u svojoj je antologiji Poslovice, zagonetke $i$ govornički oblici (Zagreb, 1996.) relativno nedavno okrstio Josip Kekez.

${ }^{817}$ Detaljnije o poslovicama-pitalicama u: Kekez 1984: 68.
} 
svega zemaljskog ili važnosti herojskog umiranja za „više ideale“ (Bog - domovina - kralj), koje naš autor - ne bi li ih smisaono zaokružio i uopće snažnije naglasio - dosljedno „ovjerava“ značenjem srodnim iskustvenim tvrdnjama. Pa kada tako, primjerice, moralistička razmišljanja o časnoj pogibiji na bojišnici prožima nizom poslovica na temu prolaznosti i neizbježnosti smrti, Ritter zapravo koristi prokušanu strategiju pomoću koje će „visoku“ (elitnu) književnost i njezine ideje lakše ,približiti puku, ne bi li njezin utjecaj bio veći“ (Pavličić 2007: 283). Na kraju krajeva, s identičnom nakanom i na gotovo isti način na koji ih rabi i u sva četiri „dila“ poslovice on uvrštava i u predgovore prvih dvaju izdanja, u kojima također pojedina ključna mjesta (i to, konkretno, zapažanja o pogubnoj raširenosti tuđica u hrvatskom jeziku, odnosno o gramzivosti domaćih bogataša) teži značenjski potvrditi u (stihovanoj) zgusnutoj poučnoj formi ne bi li njihove zaključke učinio pristupačnima kako učenoj, tako i jedva pismenoj publici. I baš kao što se - u svome izvornom okružju poslovice „prema potrebi i situaciji ubacuju u (raz)govorni proces ili kontekst“ (Užarević 2012: 208), tako i Vitezović poslovice i paremiologizme donosi upravo na mjestima čiji je sadržaj nužno dodatno istaknuti kako bi i čitatelji različitoga profila bili u stanju razumjeti njegovu važnost, a onda ga i - transformiranoga u kratku poslovičnu poantu - mogli lakše upamtiti, pa i, po potrebi, primijeniti. 818

Sveprisutnost poslovičnih izričaja u Odiljenju, ipak, samo je djelomice uvjetovana brojnošću refleksivnih dionica budući da uvjerljivo najveći broj poslovica u tekstu ima svoje idejno ishodište u problemima prolaznosti i nestalnosti, koji i jesu u neposrednoj vezi s temeljnim njegovim tematskim usmjerenjem opjevavanju višestrukih rastanaka. S obzirom na to da gotovo opsesivno isticanje varljivosti sreće, trošivosti materijalnih (ovozemaljskih) dobara i općenito pesimistički pogled na čovjekov usud pripadaju među ključna barokna sadržajna uporišta, koja su se nerijetko pojačavala i sentencijskim poentiranjima, jasno je zašto Vitezovićevo ustrajanje na poslovicama o neizbježnosti smrti i kolebljivoj sreći treba ujedno motriti i kao „ukus toga vremena koje je bilo bremenito baroknim recidivima“ (Kolumbić 2005: 346). Neće, k tome, biti slučajno ni to što je - kao što smo maločas uočili mnogim poslovicama (sentencijama) proizišlima iz identičnih tematskih krugova svoju Obsidu sigecku - neposrednu prethodnicu i važan intertekstualni oslonac Odiljenja - protkao i Petar Zrinski, ${ }^{819}$ što bi također najopravdanije bilo držati odzrcaljenjem ,duha vremena“ s

\footnotetext{
${ }^{818}$ Ujedno to objašnjava i već uočenu činjenicu da - među svim hrvatskim Ritterovim tekstovima - poslovice u potpunosti izostaju tek u njegovoj Kronici iz 1696. S obzirom na to da je riječ o kronikalnom pregledu hrvatske i svjetske povijesti, u njemu se - za razliku od drugih njegovih djela na hrvatskom - ne iznose pojedina specifična razmatranja koja bi bilo potrebno poentirati poslovicama, pa se i njihov izostanak stoga čini posve opravdanim.

${ }^{819}$ Slično kao i u Vitezovićevoj „zrinijadi“, i u onoj Petra Zrinskog poslovice su daleko najzastupljenije upravo u refleksivnim dijelovima, situiranima pretežno na samim počecima pjevanja, gdje se donose neka opća
} 
kojim se s(p)retno ispreplelo bogato iskustvo recipiranja usmenoknjiževnih tvorevina. Pridoda li se toj baroknoj „modi“ - uvelike nasljeđenoj iz renesansne književnosti - još i činjenica kako (usmene) poslovice, u pravilu, ponajbolje prianjaju upravo uz „lirski“ diskurs (kao svojevrsna „didaktičko-moralizatorska“ nadgradnja opjevanih sadržaja), ${ }^{820}$ posve će se razumljivim ispostaviti i Vitezovićevo često posezanje za poslovičnim koncentracijama (narodne) mudrosti (i) duž izrazito lirizirane njegove ,zrinijade“.

Iako bi maločas konstatirano Ritterovo kreativno eksploatiranje žanra poslovice ponajprije u svrhu poentiranja refleksivno-poučnih dionica Odiljenja te time i olakšavanja razumijevanja njihovih ideja slabije obrazovanim i literarno neiskusnijim čitateljima predstavljalo strategiju u književnoj povijesti dobro poznatu još od (literariziranih) antičkih filozofskih dijaloga, čiji su autori - znajući da se njima obraćaju i neobrazovanijim društvenim slojevima - svoja moralistička razmatranja redovito punili poslovicama i poslovičnim izričajima preuzetima iz pjesničkih djela svojih suvremenika, ${ }^{821}$ sam čin literarnog evociranja poslovica u 17. stoljeću nipošto nije mogao ostati usmjeren samo i jedino na recipijente koji su prvi dojam o književnosti izgradili dugogodišnjim osluškivanjem isključivo izvedbi folklornoknjiževnih ostvarenja. Naprotiv, znamo li da su - kako navodi Olga Maruševski - u brojnim domaćim sedamnaestostoljetnim dvorcima i plemićkim kućama (kurijama) zidovi bili ukrašeni tzv. tezesima, odnosno dekorativno uokvirenim svjetovnim i nabožnim poslovicama, ${ }^{822}$ ali i da su vlasnici mnogih od njih u svoje (danas većinom izgubljene) priručne rukopisne zbornike sustavno bilježili „,narodne“ i/ili prepisivali pisanoknjiževne uzrečice, postat će i više nego jasno da su na pojavu poslovica u književnim tekstovima - pa tako i u Odiljenju sigetskom - naprosto morali pozitivno reagirati čak i najučeniji čitatelji, odnosno čak i publika što je dolazila iz aristokratskih i uopće plemićkih krugova. Imajući na umu tu sveopću baroknu popularnost i sveprisutnost žanra poslovice, ni zastupljenost „sentencija“ u Vitezovićevoj ,zrinijadi“ ne bismo smjeli motriti isključivo kao jedan u nizu generičkih „mamaca“ kojima se pokušavala privući i zadržati pozornost gdjekad čak i jedva opismenjenih recipijenata, tim više što je žanr poslovice u vrijeme u kojemu je

razmatranja vezana uz fabulu konkretnoga „dela“. Također, najveća je koncetracija poslovica primjetna i duž čitavoga petog pjevanja Obside, vjerojatno zahvaljujući činjenici da je riječ o - pripovjedno - najstatičnijem odsječku epa, u kojemu se opisuju tek pripreme sigetskih branitelja za okršaj s Turcima te donosi posljednji razgovor bana Zrinskog sa sinom Jurjem.

${ }^{820}$ Podrobnije o tome u: Botica 2013: 489.

${ }^{821}$ Dubravka Brezak Stamać u nekoliko će svojih studija tako podsjetiti na to da je žanr filozofskog dijaloga koji se prakticirao u Aristotelovoj peripatetičkoj školi u Likeju - zbog svoje usmjerenosti (i) na niže, znatno neobrazovanije slojeve društva, bio otvoren uključivanju citata poslovičnih uzrečica deriviranih iz djela različitih onodobnih pjesnika, uz pomoć kojih su se ondje pretresane ideje na vrlo jezgrovit način pokušavale približiti čak i shvaćanjima tih gdjekad i sasvim neukih recipijenata. Opširnije u: Brezak-Stamać 2012: 404-405 i 2016: 33. ${ }^{822}$ Usp. Maruševski 1993: 62. 
Odiljenje sigetsko nastajalo i konačno ugledalo danje svjetlo kotirao kao jedno od rijetkih generičkih rješenja za kojim su u različitim životnim situacijama gotovo svakodnevno posezali kako vrhunski obrazovani velikaši, tako i (još uvijek) posve neopismenjeni puk.

Činjenica kako su ne samo u nas, već i diljem sedamnaestostoljetne Europe mnoga svoja književna djela, ali i zasebne (rukopisne i tiskane) zbirke poslovicama obilno punili autori koji su u netom spomenutim svakodnevnim životnim situacijama evocirali pretežno mudre izreke „narodne“ provenijencije lako bi nas - kako je upozoreno već i nešto ranije mogla navesti na izricanje ne sasvim točnih sudova o njihovu stvarnom podrijetlu. Naime, da se u rečenim slučajevima najčešće radilo samo o djelomičnoj - a gdjekad čak ni takvoj zastupljenosti autohtonih ili ponešto prerađenih izvornih folklornoknjiževnih poslovica možda nam i ponajbolje može ilustrirati upravo stvaralački opus Pavla Rittera Vitezovića, u kojemu se kao svojevrsna „kruna“ autorova kontinuiranog uvažavanja ovoga (jednostavnog) žanra izdvaja već višekratno spomenuta zbirka osmerački ispjevanih poslovica Priričnik aliti razliko mudrosti cvitje. Podsjetimo, iako zamišljena kao pučkoknjiževno štivo, odnosno namijenjena ponajprije skromno obrazovanim čitateljima literarno „othranjenima“ na usmenoj književnosti, u Ritterovoj se zbirci - potvrdile su to već dobro nam znane najrecentnije analize - mjesta našlo samo za dio (stiliziranih) poslovica izvorno usmenoknjiževne provenijencije, dočim mnogo veći broj njih ondje otpada na poslovične izričaje što ih je naš autor posudio iz različite - svjetovne i vjerske - lektire, pa i one kojih se samostalno domislio.

Ukoliko bi, konkretno, usmenoknjiževne korijene trebalo tražiti isključivo u onim primjer(c)ima poslovica koje se dotiču omiljenih „folklornih“ tema - vremena, obitelji, prijateljstva, odnosa života i smrti, bogatstva i siromaštva, sloge i nesloge, ludosti i mudrosti i dr., dotle se za većinu preostalih poslovica okupljenih u Priričniku, tvrde proučavatelji, ${ }^{823}$ izvori prilično lako mogu pronaći u djelima tadašnjih filozofskih autoriteta te Bibliji i drugim teološkim spisima. Svojom se zastupljenošću ondje pritom posebno ističu poslovice sadržajno oslonjene na postulate neostoicističke filozofije, koju je u svojim djelima razradio ranije spomenuti šesnaestostoljetni belgijski filolog Justus Lipsius i koja se ubrzo nametnula kao ideološko ishodište europskoga baroka u cijelosti, ${ }^{824}$ pri čemu je mahom riječ o onim primjerima u kojima se glorificiraju moralne vrline (,kripost“), kritizira ljudska opsjednutost novcem, progovara o odnosu zakona prema malom čovjeku ili ističe važnost domoljublja, naročito u ratnim okolnostima. Priričnik, k tome, donosi i nemali broj biblijskih poslovica, redom fokusiranih na moralističko pretresanje teme odnosa čovjeka i Boga, koje - zajedno s

\footnotetext{
${ }^{823}$ Usp. Hrgić 2015.

${ }^{824}$ Vrlo detaljno o neostoicističkoj baroknoj filozofiji - o kojoj će u nastavku ovoga rada biti i znatno više riječi - u: Oestreich 2008: 13-131 i Simpson 1991: 45-49.
} 
onima neostoicističkog podrijetla - najjasnije daju do znanja da je primarna svrha zbirke bila naglašeno edukativna, što će reći da se njome naš autor očigledno namjeravao približiti glavninom skromnije (gdjekad i jedva) obrazovanoj publici ne bi li joj prenio neka moderna znanja $\mathrm{i}$ ideje, $\mathrm{i}$ to pomiješana $\mathrm{s}$ tradicionalnim vrijednostima, odnosno uklopljena $\mathrm{u}$ prepoznatljivo usmenoknjiževne formalne okvire. Ti okviri, međutim, nisu podrazumijevali samo odabir poslovice kao jednoga od omiljenih i gotovo sveprisutnih (izvorno) folklornih žanrova, već i opredjeljenje za stih osmerac, koji je izrastao upravo iz usmene književnosti i koji je - kao takav - mogao jamčiti Vitezoviću da će makar neke od izreka iz Priričnika prijeći u usmenoknjiževni „optjecaj“ i tako nastaviti svoju egzistenciju. ${ }^{825}$

A da elitna kultura vrlo lako može prodrijeti u onu pučku Ritter je, kako se čini, shvatio već i nekoliko desetljeća prije objavljivanja svoje zbirke „priričja“. Naime, osim što će Priričnik postati prvom u nas tiskanom knjigom (usmenih) poslovica, ${ }^{826}$ a kasnije se prometnuti i u „najčešće upotrebljivanu knjigu hrvatskoga poslovičnog blaga“ (Botica 2013: 497), njegova se književnopovijesna, a naročito „ritterološka“ važnost krije i u činjenici da je u njemu moguće zateći i određen broj „priričja“ koja bi se mogla shvatiti kao svojevrsne varijante poslovica uvrštenih u Odiljenje. Premda je poslovica s takvom tematskom orijentacijom u Priričniku svega tek nekoliko, vrijedi zabilježiti one koje progovaraju o ljepoti junačkog umiranja za domovinu (,Kako lipo jest živiti, / za dom dično jest umriti“; Zrinski, Frankopan i Ritter Vitezović 1976: 478), nestalnosti sreće i inih zemaljskih stvari („Srića i stvar vsaka svita / nijedna ni stanovita“; isto: 484), ali i neizbježnosti smrti (,Ludo se je bojat smrti / s kom se vsaki rođen prti“; isto: 482; „Svit se vrti, svit obraća: / v samoj smrti vsih je plaća“, isto: 484;) te potrebi održavanja dobre, po mogućnosti na časnim i hrabrim djelima izgrađene reputacije („Ako ti prem vse izgine, / pošten glas te nek ne mine“; isto: 478). Malobrojnosti usprkos, potonji se primjeri nameću kao i više nego uvjerljiv dokaz da je računajući (u prva dva izdanja) na vrlo široku, no pretežno pučku publiku - Vitezović već svoju ,zrinijadu“ premrežio, između ostalih, i značenjski gotovo identičnim mudrim izrekama utemeljenima na tada modernim idejama i spoznajama, što će reći (i) onim poslovicama koje definitivno nije mogao pronaći na području (onodobne) usmene književnosti.

Imamo li sve ovo na umu, nimalo nas ne bi trebalo iznenaditi ni to što je većinu poslovica iz Priričnika moguće razvrstati upravo u ona semantička polja kojima su najbliže i gotovo sve poslovice što ih sadrži i Odiljenje sigetsko, što će reći u filozofsko, sociološko,

\footnotetext{
${ }^{825}$ O ovome podrobno u: Hrgić 2015: 42-72.

${ }^{826}$ Usp. Bošković-Stulli 1978: 183-184.
} 
psihološko te religijsko polje. ${ }^{827} \mathrm{~S}$ druge, pak, strane, usprkos činjenici da je - kao i kada je riječ o onima iz Priričnika - „točan izvor Vitezovićevih izreka nemoguće precizirati““ (Hrgić 2015: 47), također se samo za dio poslovičnih izričaja uključenih i u Odiljenje sa sigurnošću može tvrditi da su usmenoknjiževnoga porijekla, što bi se ponajprije odnosilo na poslovice izrasle iz već pobrojanih općeživotnih, ,narodnoj“ književnosti naročito bliskih tema (ljubav, sloga, sudbina, ludost i mudrost, bogatstvo i siromaštvo itd.), a gotovo nimalo ili samo djelomično na one koje proizlaze iz tipično baroknih motiva hirovite sreće, propadljivosti materijalnih dobara, junačkog umiranja na bojnom polju i sl. Budući da je redom riječ o pitanjima koja su pretresali diljem Europe tada iznimno popularni tekstovi Justusa Lipsiusa, posve je jasno da bi potraga za njihovim podrijetlom ponajprije trebala krenuti upravo od radova toga čuvenog neostoicističkog filozofa, dočim bi - pak - poslovice s izraženom moralnom poukom i naročito one koje se dotiču odnosa čovjeka i Boga svoj izvor očigledno trebale imati u Bibliji, ${ }^{828}$ a možda i u nekim drugim teološkim spisima koje je - kao nekadašnji isusovački đak - naš autor u svojoj mladosti jamačno čitao. ${ }^{829}$ Pridoda li se spomenutima još i poneka Vitezovićeva „autorska“ mudra izreka, postat će bjelodano da poslovice u Odiljenju sigetskom definitivno nisu u cijelosti rezultat autorova sustavnog zapisivanja i prerađivanja autohtonoga usmenoknjiževnog poslovičnog blaga, iako je upravo izravni susret s tim blagom očito ponajviše utjecao na njegovu i više nego izrazitu sklonost (folklorno)književnom žanru poslovice.

\section{3. 8. Zagonetke}

U slijedu nekolicine naših šesnaestostoljetnih autora poput Marina Držića, koji u pojedine svoje komedije uključuje primjerke „,narodnih“ rugalica i zagonetki, potom Petra Zoranića, u čijim Planinama zatječemo nekoliko folklornih „ganki“, te Petra Hektorovića, koji niz izvorno usmenoknjiževnih žanrova što ih uklapa u Ribanje i ribarsko prigovaranje

\footnotetext{
${ }^{827}$ Usp. Hrgić 2015: 47.

${ }^{828}$ Pavao Mikić i Vjekoslav Suzanić u svojoj antologiji Biblijske poslovice u Hrvata izdvajaju tako četiri biblijske poslovice iz Odiljenja. Tri bi se od njih („Bogu se v ruke dat, jer nam je umriti“, I: 491; „Navike živiti ovdi se ne može, / zemlja mora biti 'z kosti, 'z mesa, 'z kože“, I: 492-493 i „,Smrti se sakriti ni moći človiku, / a svakom dobiti smrćom ni moć diku“, I: 599-600) pritom moglo povezati s biblijskom poslovicom „Tko se rodi, onaj će i umrijeti“ (Mudr 7, 6), a onu „telo zemlja biva, a Bog dušu primi“ (II: 110) autori su, pak, prepoznali kao odjek čuvene biblijske poslovice „Prah si, u prah ćeš se vratiti“(Post 3, 19). Usp. Mikić i Suzanić 1994: 154. ${ }^{829}$ Doduše, kao što su to potvrdila i istraživanja naših folklorista, dio biblijskih poslovica ubrzo je apsorbirala i usmena književnost, gdje su one nastavile cirkulirati sve do naših dana (usp. Mikić i Suzanić 1994, Botica 1995: 123-135 i 2011: 100-108), a iznimno velik broj njih zastupljen je i u Lipsiusovim neostoicističkim tekstovima (o kršćanskoj podlozi Lipsiusova učenja u: Oestreich 2008: 13-56). Na kraju krajeva, osim što mnoge poslovice prihvaćene u većini zapadnoeuropskih naroda potječu iz djela antičkih (grčkih i rimskih) pisaca, znatan je njihov broj porijeklom upravo iz Biblije (usp. Mikić i Suzanić 1994: 19-21 i Užarević 2012: 204), što svakako treba imati na umu pri svakoj više ili manje oštroj razdiobi poslovica na ,izvorno usmene“ i ,biblijske“.
} 
također upotpunjuje zagonetkama, ${ }^{830}$ i Pavao Ritter Vitezović svoje Odiljenje sigetsko neće propustiti „opskrbiti“ čak ni cjelovitim primjercima izvorno folklornoknjiževnih ili makar po folklornoknjiževnom obrascu skrojenih, odnosno stiliziranih zagonetki. Neovisno, međutim, od toga u kolikoj je mjeri u njegovu slučaju doista riječ o autohtonim „,narodnim“ zagonetkama, u evociranju ovoga jednostavnog ili „minimalističkog“ žanra u okvirima sedamnaestostoljetne književnosti Vitezović nipošto nije bio usamljen, i to ponajprije zahvaljujući činjenici što je jedan od „ozaljskih“ njegovih neposrednih prethodnika - Fran Krsto Frankopan - svega nekoliko desetljeća ranije sastavio (njemu, doduše, nepoznat) rukopisni ciklus zagonetki pod naslovom Zganke za vrime kratiti, u cijelosti premrežen prepoznatljivim usmenoknjiževnim značajkama u rasponu od „tipičnih“ motiva, fraza i stilskih rješenja, sve do formalnih, odnosno metričkih paralela. I baš kao što je zbog prilično visoke koncentracije karakteristično folklornoknjiževnih obilježja u Frankopanovu (pa i, kao što ćemo vidjeti, Ritterovu) slučaju prilično teško razabrati radi li se o izvornim ili, pak, po uzoru na one „narodne“ pomno stiliziranim primjercima zagonetki, tako je - zbog istoga razloga - većinom moguće samo spekulirati i o ,pravom“ porijeklu zagonetki što su ih kroz čitavo 17. stoljeće i u većini drugih europskih književnosti - poglavito, između ostalih, u onoj poljskoj - u svoja djela uvrštavali mnogi strani pisci, među kojima je bilo kako onih sklonijih sastavljanju autorskih zagonetki s izuzetno visokim udjelom usmenoknjiževnih posebnosti, tako i onih otvorenijih bilježenju izvorno „narodnih“, nerijetko poprilično ipak „dotjeranih“.

Neovisno od nemogućnosti utvrđivanja stvarnoga porijekla velike većine njezinih primjeraka razasutih domaćim i inozemnim (sedamnaestostoljetnim) ostvarenjima, ,zganka“ ili zagonetka redovito se poima kao (izvorno usmenoknjiževni) jednostavni oblik ili žanr, koji - poput poslovice - paralelno egzistira u kako u usmenoj, tako i pisanoj književnosti, u kojoj je neke od najstarijih njezinih primjeraka moguće iznaći već u antičkoj književnosti te naročito u Bibliji. Prema Andréu Jollesu - koji će je prvi, još tridesetih godina prošloga stoljeća, ubrojiti među ,jednostavne oblike“ - zagonetka je oblik koji se „ostvaruje pitanjem i odgovorom“ (Jolles 2000: 118), pri čemu se, za razliku od srodnoga jednostavnog oblika mita, u njoj ne pretpostavlja stjecanje znanja iz pitanja i odgovora, već znanje kao takvo unaprijed postoji u trenutku kada pitač postavlja pitanje. Iz toga se razloga kao temeljni cilj zagonetke kao takve nameće upravo proces rješavanja, a ne rješenje, jer pitač samo želi provjeriti je li njegov sugovornik (pitanik) u stanju ponuditi ispravan odgovor na postavljeno

\footnotetext{
${ }^{830} \mathrm{O}$ prisutnosti ,narodnih“ zagonetki u pobrojanim ostvarenjima spomenutih šesnaestostoljetnih naših pisaca detaljnije u: Bošković-Stulli 1978: 184-190 i Botica 2013: 502-505.
} 
pitanje, odnosno je li uopće dorastao „izazovu“ pitanja. ${ }^{831}$ Drugim riječima, struktura zagonetke - kako je iz ovoga vidljivo - ispostavlja se kao u cijelosti dijaloška, iz čega slijedi da se ta njezina dijalogičnost u Odiljenju sigetskom s(p)retno uklapa u sveopću dijalošku orijentaciju teksta, koja u najvećoj mjeri proizlazi kako iz pojedinih u nj utkanih generičkih rješenja (dijaloška pjesma, lirski razgovor, naznake dramskih žanrova itd.), tako i specifičnih u njemu prisutnih dijaloških postupaka (figura jeke, neprestana adresiranja iskaza i sl.).

Konkretno, ukoliko je (usmenoknjiževnim) poslovicama Vitezović u Odiljenju postigao zgusnuto, poentno isticanje ključnih sadržajnih silnica teksta, i to utemeljeno u općem („narodnom“) iskustvu, prisutnošću zagonetki i zagonetačkih elemenata obilježeni pojedini će se segmenti teksta izdvojiti zahvaljujući izrazitoj ludičkoj komponenti proizišloj iz evociranja oblikovnih strategija folklornoga zagonetaštva. Pažnju recipijenata pritom neće ondje plijeniti isključivo binarno strukturirane (,punokrvne“) zagonetke, ${ }^{832}$ već i mjestimični primjeri „učahurenih“ zagonetljaja izvedenih u formi metaforizirano-aluzivnih sličica s prizvukom zagonetke koje mame na odgonetanje, iako nisu prezentirane u obliku pitanja, a i „odgonetljaj“ je već poznat iz širega konteksta. Konkretno, na zagonetačko provociranje odgovora na aluzijama zakriven sadržaj (pitanje) tako će neodoljivo podsjećati stihovi iz dionice uvodne Sigetove pjesme posvećene opjevavanju pogubna djelovanja smrti u kojima se njezina svemoć oslikava stiliziranim prizorom koji kao da priziva traženje rješenja (odgonetljaja) vrlo uspjele konotacije (,Njoj kralji i cari pod oblast dohode / i sve žive stvari, zrak, zemlja i vode“; I: 387-388). Nema dvojbe da bi - izdvojen iz (kon)teksta u kojemu je i sadržan odgovor na nj - ovaj distih lako mogao nastaviti egzistirati kao samostalna (usmena) zagonetka utemeljena na vrlo jasnoj aluziji koja vodi do isključivo jednog (ne odveć teško naslutivog) rješenja, što i jest temelj uspješno sročena zagonetljaja.

Gotovo posve jednak slučaj krije i pjesma Ban sinu (I: 478-568), gdje se - iznova zagonetački vrlo slikovito i stilizirano - sveprisutnost i neizbježnost smrti oslikava na izrazito aluzivan, dakle način strukturiranja tipičnog zagonetljaja (,u nje mriže svakomu je pasti, / zgrabi ga sred hiže i najveće vlasti“; I: 508-509), kojemu nedostaje tek pitalačka usmjerenost i odsustvo odgonetljaja što ga nudi kontekst pjesme. Istrgnuti iz Odiljenja, i ovi bi stihovi posve uspješno mogli zagonetački funkcionirati, pri čemu bi se u tom slučaju oba distiha ispostavila primjerima ,,potpunih, pravih zagonetaka““ ${ }^{833}$ u kojima je odgonetljaj zamaknut iza cjelovitih, metaforiziranih prizora što na nj aludiraju tek svojom slikovitošću.

\footnotetext{
${ }^{831}$ Podrobnije u: Jolles 2000: 118-139.

${ }^{832} \mathrm{O}$ osnovnoj binarnoj strukturi usmenoknjiževne zagonetke u: Čubelić 1988: 345-347; Kekez 1998: 174-176; Botica 2013: 500-503.

${ }^{833}$ Opširnije o podvrsti potpunih zagonetaka u: Čubelić 1988: 357-358.
} 
Prepoznatljivu binarnu fakturu usmene zagonetke Vitezović će, međutim, prizvati tek uslijed dijaloga putnika i Jeke u trećem „dilu“ Odiljenja. Razgovarajući o turskom osvajanju Sigeta i mogućim budućim kršćanskim akcijama protiv Osmanlija, putnik na jednome mjestu vili upućuje vrlo metaforizirana, gotovo alegorična pitanja (pitalice) koja bi djelomice trebalo iščitati i na povijesno-političkoj podlozi (intenzivno kopnjenje turske moći poslije poraza pod Bečom 1683., na kojeg pitanja moguće i impliciraju), no u kojima se prepoznaje tipična struktura i elementi zagonetke (,Još bih tvoje viće na to pitat moral: / ki j' ptić pod se ptiće sve primoral? Oral. / Ka zvir vrhu drugih od najvećih je slav, / il v gorah il v lugih je kod jelav? Je lav. / Što vodi (kada je dobro) dobre sriće, / v tamnoj skrbi daje puku sviće? Viće; III: 339-344). Za razliku od ranije navedenih slučajeva, ove „zagonetke-pitalice“ ${ }^{\text {(834 }}$ s jakim usmenoknjiževnim prizvukom ni na sadržajnoj razini Odiljenja ne pokušavaju prikriti svoju žanrovsku određenost i funkciju, o čemu i svjedoči nastavak putnikova obraćanja u kojem Jeki priznaje zaigranost („Ne broj me med lude, da se prem zigrujem“; III: 345), koja i jest upravo zagonetačke naravi - bazirana, dakle, na poigravanju riječima i slikama. Upravo s potonjim lociranim primjer(c)ima ,prave“ zagonetke i naša se potraga za usmenoknjiževnim žanrovskim obilježjima razasutima duž svih četiriju „dilova“ Vitezovićeve „zrinijade“ napokon primakla kraju, što istodobno ipak ne znači i da je kucnuo čas da se o generičkim svojstvima Odiljenja sigetskog, odnosno njegovu (najvjerojatnijem) žanrovskom identitetu na stranicama koje slijede već iznesu konačni zaključci.

\section{4. POLUKNJIŽEVNI I IZVANKNJIŽEVNI ŽANROVI}

Kada bi se iz zamišljenoga korpusa ranonovovjekovne hrvatske, pa i europske književnosti željelo izlučiti ostvarenja u cijelosti realizirana spregom obilježja iz repertoara isključivo ovih i/ili onih pisanoknjiževnih i usmenoknjiževnih žanrova, jasno bi se pokazalo da je riječ o gotovo zanemarivom broju literarnih tekstova, i to mahom onima skromnoga opsega, koji je u potpunosti otklanjao ili bitno smanjivao mogućnost uključivanja karakteristika poluknjiževnih, pa i u potpunosti izvanknjiževnih žanrova. Znamo li (i) da se od vrlo velikog broja onodobnih književnih djela očekivalo da ispunjavaju i stanovite izvanliterarne, dakle izvanestetske (ideološko-političke, religijske, propagandne, mobilizacijske itd.) funkcije, to njihovo ,nadograđivanje“ značajkama svojstvenima rubno književnim i/ili neknjiževnim žanrovima na prvi se pogled ne bi trebalo doimati nimalo neobičnim, tim više što se i pisci neknjiževnih - filozofskih, historiografskih, lingvističkih

\footnotetext{
${ }^{834}$ O zagonetkama-pitalicama u: Čubelić 1988: 353-354.
} 
znanstvenih i dr. - tekstova iz istoga razdoblja ni najmanje nisu ustručavali posezati za izdvojenim specifičnim obilježjima, a gdjekad i cjelovitim primjercima književnih žanrova, navlastito kada su u tim svojim raspravama trebali dokazati kakvu pretpostavku ili, pak, podastrijeti kakav zgodno odabran primjer za netom iznijeta zapažanja. Ni Odiljenje sigetsko u tom se smislu - baš kao ni velika većina (pre)ostalih (hrvatskih i latinskih) tekstova Pavla Rittera Vitezovića - ne ispostavlja kao (ranonovovjekovni) izuzetak, što će reći da se nemali broj u njemu zastupljenih karakteristika deriviranih iz „repertoara“ poluknjiževnih i izvanknjiževnih žanrova nipošto ne bi smio proglasiti neočekivanim, a kamoli specifičnim u kontekstu hrvatske i ne samo hrvatske književnosti 17. stoljeća.

Govoreći, doduše, o značajkama žanrova potonjih dvaju generičkih „,razreda“, već na samom će nam se početku kao neizbježno nametnuti pitanje kriterija po kojima su u baroknom razdoblju u praksi razlikovana „književna“ od „neknjiževnih“ žanrovskih rješenja, odnosno (možebitnih) konkretnih distinkcija u njihovoj predodžbi, pa onda i generičkim očekivanjima s kojima su tim žanrovima pristupali ponajprije njihovi pisci, a zatim i publika na koju su oni - konačno - i bili adresirani. Usprkos činjenici da poimanje žanrova u Vitezovićevo vrijeme još uvijek nije u tolikoj mjeri počivalo na prepoznavanju pretežno njima svojstvenih, razlikujućih karakteristika - kao što će to biti slučaj od romantizma nadalje ipak se već u baroku, zahvaljujući maločas konstatiranom osamostaljenju znanosti, uspostavilo relativno jasno razlikovanje književnih od neknjiževnih tekstova, koje se temeljilo na kriterijima vrlo sličnima onim po kojima se neknjiževni od književnih pisanih sastavaka u praksi razlikuju i dan danas. ${ }^{835} \mathrm{U}$ tom smislu, premda - u teorijskom pogledu - distinkcije među njima još uvijek nisu bile toliko jasno i čvrsto postavljene, već u 17. su stoljeću žanrove književnoga i one neknjiževnoga izražavanja na dva bitno različita načina razumijevali i s različitim im očekivanjima pristupali podjednako njihovi praktikanti i njihovi recipijenti, iz čega bi slijedilo da ni ovdje provedeno izdvajanje poluknjiževnih i neknjiževnih generičkih rješenja (za potrebe naredne analize) u zasebnu kategoriju nipošto nije (samo) posljedica priklanjanja suvremenoj genološkoj perspektivi, nego da itekako odgovara žanrovskim shvaćanjima što su bila „na snazi“ u razdoblju u kojemu je Odiljenje i ugledalo svjetlo dana.

S druge strane, kao što je netom i konstatirano, poluknjiževne i izvanknjiževne žanrove što ih je Ritter držao svrsishodnim uključiti u svoju ,zrinijadu“ - pa i ne samo njih književna su djela već i mnogo prije i poslije baroka u velikoj mjeri gotovo redovito ,apsorbirala“, pri čemu su neki od njih - poput posvete i predgovora - ubrzo toliko srasli s literarnim tekstovima da je njihovo objelodanjivanje bez tih nužnih poluknjiževnih 
„produžetaka“ postalo gotovo sasvim nezamislivo. Premda - dakle - ti i drugi žanrovi, o čijim će obilježjima zastupljenima u Odiljenju sigetskom u nastavku biti riječi, jednim dijelom ili gotovo u cijelosti potječu iz drugih kulturnih i društvenih „domena“, zahvaljujući (već i ranonovovjekovnoj) učestalosti svoga pojavljivanja u generički kojekako obilježenim književnim ostvarenjima bez ikakve dvojbe zaslužuju da ih se (makar samo uvjetno) sagledava (i) kao gotovo integralni dio književnosti, tim više što su ih, kako se čini, upravo na taj način shvaćali i prihvaćali i žanrovskim mješavinama skloni barokni pisci.

$\mathrm{Pa}$, ipak, unatoč tomu što ćemo u okvirima našega istraživanja distinkciju između njih zadržati ponajprije zbog preglednosti, nužno je da ni u jednome trenutku ne smetnemo s uma kako se rečeni poluknjiževni i izvanknjiževni žanrovi - odnosno u njima prisutna karakteristična im obilježja - u konkretnim književnim djelima zapravo ponašaju na isti način kao i primarni govorni žanrovi asimilirani od strane onoga sekundarnog, što će reći da između - primjerice - primarnog žanra svakodnevnog razgovora u romanu i izvanknjiževnog žanra ratnoga govora u epskoj pjesmi u pogledu njihova statusa i načina funkcioniranja u okrilju „krovnoga“ (sekundarnog) žanra zapravo i ne postoji neka krupnija razlika. I izvanknjiževne žanrove uključene u literarna ostvarenja iz toga bi razloga trebalo motriti u potpunosti bahtinovski, točnije po njihovoj ih ulozi u književnom žanru izjednačiti s onom što su je u sekundarnim žanrovima vršili primarni govorni žanrovi, no ne zaboravljajući pritom da se tek malokoji od neknjiževnih žanrova uopće može proglasiti primarnim žanrom, tim više što je u njihovu slučaju pretežno riječ o kompleksn(ij)im generičkim rješenjima sposobnima da u sebe „usisaju“ druge primarne i ne samo primarne žanrove, što će - na kraju krajeva - ponajbolje pokazati primjer žanra predgovora u samom Odiljenju, kojeg je dio postala i kraća lirska pjesma, i sama pritom „nadograđena“ žanrom (folklorne) poslovice. Sve u svemu, u slučaju Ritterove generički slojevite „zrinijade“ u „pretinac“ s rubno književnim i neknjiževnim žanrovima nužno je uvrstiti ne samo žanrove što ih zatječemo u paratekstualnoj njezinoj dionici, već i u samome tekstu prisutna ona generička rješenja - uopće prilično učestala u sedamnaestostoljetnim (poglavito epskopjesničkim) literarnim ostvarenjima - za koja je već na prvi pogled moguće ustanoviti da svoje porijeklo vuku iz drugih sfera, i to ne samo one religijsko-liturgijske, već i vojne, pedagoške, enigmatske, pa i nekih drugih.

\section{4. 1. Posvete i predgovori}

Među uvjerljivo najintrigantnije i za ispravno njegovo tumačenje te (književnopovijesno i generičko) situiranje najvažnije dionice Odiljenja sigetskog bez ikakve 
je dvojbe moguće ubrojiti posvete i predgovore svih triju za Vitezovićeva života objelodanjenih njegovih izdanja, kojih međusobne razlike u daleko najvećoj mjeri i proizlaze upravo iz tih u cijelosti izmijenjenih popratnih tekstualnih segmenata. Konkretno, riječ je kako smo to već višestruko dosad istaknuli - o tipičnim „okvirnim“ ili paratekstualnim komponentama književnoga teksta, koje je u čuvenoj svojoj studiji Seuils iz 1987. kao dio „parateksta“ prvi definirao Gérard Genette, pojasnivši tom prilikom kako bi paratekst zapravo podrazumijevao sve one - književnopovijesno ne manje promjenjive - nužne tekstualne komponente, koje okružuju središnji književni tekst (naslovnica, naslov, podnaslovi, ime i prezime autora, predgovor, posveta, sadržaj, bilješke, uvod, epilog itd.) proširujući njegova značenja te olakšavajući i bitno usmjerujući i njegovu recepciju, ali - iznad svega - uopće omogućujući tekstu da postane knjiga te da, kao takva, naposljetku i stigne pred čitatelje. ${ }^{836}$ Da $\mathrm{i}$ te paratekstualne komponente (većine) književnih ostvarenja posjeduju nezanemariv unutartekstualni značaj te da iz toga razloga moraju biti uzimane u obzir prilikom svakoga iole ozbiljnijeg tumačenja konkretnih djela dat će nam do znanja sam Genette, koji posebno naglašava kako je svaki paratekstualni odsječak nužno razmatrati kao integralni dio samoga književnog teksta, i to ne samo zbog čisto „fizičke“ činjenice kako su tekst i paratekst otisnuti i uvezani unutar istih korica, već ponajprije radi toga što paratekst obično uključuje neke bitne informacije o „svojemu“ tekstu, čime onda uvelike usmjerava i proces njegova razumijevanja.

Možda i najuvjerljivija potvrda potonjih Genetteovih zapažanja stiže upravo iz korpusa „stare“ (dopreporodne) hrvatske književnosti, u kojoj je - kako su to uspješno utvrdile recentne književnopovijesne analize - moguće susresti čitav niz literarnih ostvarenja opremljenih posvetama i predgovorima u kojima njihovi autori poprilično eksplicitno progovaraju o svojim poetičkim uvjerenjima. ${ }^{837}$ Ti paratekstualni segmenti mnogih naših ranonovovjekovnih književnih tekstova - koji su obuhvaćali prozne ili stihovane posvete i/ili predgovore na hrvatskom, odnosno latinskom jeziku - svojim su autorima, drugim riječima, samo djelomično služili (i) za iskazivanje zahvalnosti i poštovanja pokroviteljima tiskanih njihovih izdanja ili, pak, bliskim znancima od kojih su očekivali da će svojim ugledom i utjecajem njih i njihova djela zaštiti od eventualnih sveopćih bespoštednih kritika. Naprotiv, čini se da su u predgovorima i napose posvetama - kao (u njihovo vrijeme) neizostavnim konvencionalnim „dodacima“ tekstu - pojedini domaći literati vidjeli prikladan tekstualni

\footnotetext{
${ }^{836}$ Podrobnije o paratekstu u: Genette 1997: 1-15.

${ }^{837}$ Nizom svojih studija okupljenih u knjizi Skrivena teorija Pavao Pavličić uvjerljivo je tako pokazao i dokazao da se nemali broj šesnaesto-, sedamnaesto-, pa i osamnaestostoljetnih hrvatskih literata - iako sami nisu njegovali običaj pisanja poetičkih traktata - u predgovorima i posvetama svojih ostvarenja ipak nije libio iznijeti „skrivenu teoriju“, odnosno eksplicirati poetička polazišta koja su ih vodila u njihovu radu na konkretnom ostvarenju, pa i literarnom djelovanju uopće. Opširnije u: Pavličić 2006.
} 
okvir za eksplicitno definiranje svrhe (funkcije) svoga ostvarenja, određivanje ciljane njegove publike, podastiranje pokojeg signala njegova žanrovskog identiteta, pojašnjavanje konkretnih u tekstu evociranih postupaka, ali i jasno otkrivanje književnih - pa onda i generičkih - svojih (glavninom inozemnih) uzora. Osim što su rečeni, pretežno barokni naši autori na taj način dospijevali generički bitno modificirati poluknjiževne žanrove predgovora i navlastito posvete (uobičajeno u cijelosti usredotočene na izricanje zahvalnosti uvaženom meceni i/ili prijatelju zaštitniku), mnogi od njih odlazili su čak i korak dalje, upuštajući se čak i u žanrovsko „onečišćavanje“ tih paratekstualnih segmenata drugim minimalističkim žanrovima (počesto poslovicama, za kojima u posveti Adrijanskoga mora Sirene poseže i Petar Zrinski), kraćim „lirskim“ umecima (poput posvete zbirci Pjesni pokorne kralja Davida, u kojoj Ivan Gundulić citira distih iz Vergilijeve Eneide ne bi li jače istaknuo pojedina u njemu iznesena zapažanja), a gdjekad i cjelovitim lirskim pjesmama sadržajno povezanima s temom čitava teksta (kao što je to - primjerice - slučaj i s predgovorom Katarine Zrinski njezinu molitveniku Putni tovaruš, koji biva dopunjen religioznom osmeračkom pjesmom). Ništa manje izrazitu sklonost žanrovskom „obogaćivanju“ posvete i predgovora kao najvažnijih komponenata paratekstualne dionice književnoga teksta demonstrirat će u Odiljenju i sam Vitezović, koji u njegovu paratekstu tu generičku šarolikost kao da se svojski trudi intenzivirati do krajnosti.

U njih utkana konkretna pojedinačna obilježja te cjeloviti primjerci manjih (književnih) žanrova jedan su od osnovnih razloga zbog kojih u sklopu ovoga genološkog istraživanja zastajemo (čak) i na posveti i predgovoru kao neporecivo najvažnijim sastavnicama parateksta ${ }^{838}$ generički osebujne ,zrinijade“ Pavla Rittera Vitezovića. Govoreći o paratekstualnoj dionici Odiljenja sigetskog, nije zgorega još jednom podsjetiti kako se u ovome slučaju radi zapravo o tri posve različite inačice parateksta, od kojih je svaka dolazila unutar okvira jednog od triju za Vitezovićeva života objavljenih - tekstualno gotovo posve nepromijenjenih - njegovih izdanja, što će - dakle - reći onih koja su danje svjetlo ugledala 1684., 1685., odnosno 1695. godine. Inače, što se upravo njihovih (gotovo) neizmjenjenih dionica sa samim tekstom ,zrinijade“ tiče, ni najmanje nas ne bi smjela iznenađivati odsutnost želje u našega autora da nešto krupnijim ,zahvatima“ u centralni dio svoga ostvarenja sam tekst u drugom i trećem izdanju na neki način „uskladi“ s korjenito izmijenjenim paratekstom, i to ponajprije stoga što se može pretpostaviti da je - osmislivši ga kao djelo koje ,podilazi“ ukusima i očekivanjima različitih tipova čitatelja - s pravom mogao očekivati da će publiku pouzdano naći i nakon što ga paratekstualno usmjeri samo na najučenije recipijente, dakle one

\footnotetext{
838 O predgovoru i posveti kao komponentama parateksta te njihovim (pod)tipovima, formalnim značajkama, funkcijama i drugim karakteristikama znatno detaljnije u: Genette 1997: 117-143 i 161-293.
} 
iz najviših društvenih slojeva, baš kao što je to učinio s posljednjim njegovim - zagrebačkim - izdanjem. Doduše, s obzirom na to da je - kako je ranije već uočeno - arak s „osvježenim“ paratekstualnim elementima u (fiktivnom) „drugom“ izdanju dao uvezati s arcima s otisnutim tekstom ,zrinijade“ istrgnutima iz neprodanih primjeraka prošlogodišnjega (prvog) izdanja, za spomenute ,intervencije“ u tekst u bečkom izdanju naprosto nije (još) ni imao mogućnosti, dočim se u trećem izdanju odvažio na tek nekoliko uistinu neznatnih, „kozmetičkih“ preinaka, koje - na kraju krajeva - nisu imale nikakvoga utjecaja ne samo na sadržaj „zrinijade“ u cijelosti, već ni na onaj pojedinih joj „dilova“, pa ni pjesama u okrilju kojih su učinjene.

Shodno tomu, želimo li utvrditi po kojim se to konkretno unutartekstualnim specifičnostima svako od tri izdanja Odiljenja razlikuje od preostalih dvaju, bit će potrebno gotovo sasvim nam se fokusirati upravo na paratekstualne njihove segmente, u kojima jedino i jest moguće locirati „opipljive“ tekstualne distinkcije među njima. I dok se tako - izuzmemo li (i) tri različito koncipirane njihove naslovnice - u prvome izdanju Vitezovićeve ,zrinijade“ (Linz, 1684.) paratekstualna dionica sastoji od stihovane latinske posvete Adamu Zrinskom te proznog predgovora $K$ čtavcu, u koji je uklopljena i lirska pjesma (u četiri osmeračka katrena) upućena čitateljima, dotle (fiktivno) „drugo“, bečko njegovo izdanje (1685.) u paratekstu donosi stihovanu latinsku posvetu Matiji Ignaciju Radanoviću koja završava anagramom te hrvatski prozni predgovor Prijaznivi štavče! s uključenom lirskom pjesmom (protegnutom na 15 dvostruko rimovanih dvanaesteraca), u kojoj se lirski subjekt obraća Sigetu. Za razliku od paratekstualnih odsječaka ovih prvih dvaju ,inozemnih“ njegovih izdanja, u kojima su stihovane posvete i prozni predgovori k tome još premreženi i stanovitim brojem (ne samo „,narodnih“) poslovica, u poslovicama „deficitarnom“ paratekstu prvoga domaćeg zagrebačkog - Ritterova izdanja Odiljenja (1695.) za vrlo siromašno naslovnicom uslijedit će „tek“ odulja prozna posveta pokrovitelju Ivanu Andriji Makaru na hrvatskom, u kojoj se nabrajaju ratne zasluge ovoga čuvenog pukovnika te mu se upućuju molbe za zaštitu djela.

Laćajući se razmatranja poluknjiževnih žanrova posvete i predgovora u Odiljenju sigetskom, na umu ćemo posebno morati imati činjenicu kako je riječ o paratekstualnim komponentama u kojima njihovi autori - kao što su to genolozi u već više navrata dosad ustanovili $^{839}$ - vrlo često donose eksplicitna žanrovska (samo)određenja, odnosno prilično jasne i nedvosmislene generičke identifikacije vlastitih ostvarenja ili makar vrlo očite signale svojega poimanja žanrovskog identiteta vlastita djela. Naročito bi se to odnosilo na žanr predgovora, čija svrha i jest (ili bi trebala biti) upravo podastiranje autorova tumačenja teksta ili barem iznošenje njegove izjave o namjeri (točnije, pojašnjavanje načina na koji on vidi

${ }^{839}$ Usp. Fowler 1982: 88-105 i Genette 1997. 
tekst, otkrivanje ciljeva s kojima ga je sastavljao itd.), pa stoga ne čudi što je kroz povijest književnosti uvjerljivo najveći broj autorskih žanrovskih (samo)određenja mjesto našao baš u predgovorima, ${ }^{840}$ upravo kao što se i u onima Vitezovićevim - utvrdili smo to nešto ranije zatekla nekolicina onih u prvom i drugom izdanju Odiljenja. Generičkih odrednica u pojedinim djelima ne manjka čak ni u posvetama, primarna svrha kojih ipak nije bila iznošenje piščevih autoreferencijalnih očitovanja o vlastitu tekstu, već - upravo suprotno „uspostavljanje ili učvršćivanje odnosa između autora, s jedne, i pripadnika društvene, crkvene ili političke elite, s druge strane“ (Stipčević 2005: 142).

I dok „obogaćivanje“ paratekstualnog dijela knjige predgovorom u ranonovovjekovnoj književnosti nije predstavljalo neizbježan čin, uvrštavanje posvete napučene hvalospjevima u čast velikodušnoga mecene ili uglednoga (potencijalnog) zaštitnika držalo se u to vrijeme naprosto samorazumljivim i neizostavnim, tim više što je - nametnuvši se kao opća moda onoga razdoblja - pridruživanje posvete književnome tekstu ujedno predstavljalo i vrlo učinkovitu strategiju pomoću koje se pisac u očima publike lišavao neugodne ,aure“ oholosti ili svojevrsne avangardnosti. Dapače, potonja „moda“ sastavljanja dojmljivih posveta prepunih vidno pretjeranih glorifikacija pokroviteljeve učenosti, plemenitosti i velikodušnosti naročito je bila izražena upravo u 17. stoljeću, pa „kao što je barokna likovna umjetnost, arhitektura i poezija bila kićena i puna nepotrebnih pojedinosti, tako su i naslovne stranice i posvete bile prenatrpane nizom efemernih informacija“ (Isto: 145), odnosno napadnih veličanja uvaženih (i dobrostojećih) individua od kojih su autori i njihova ostvarenja imala izravnu materijalnu i ne samo materijalnu korist. S obzirom na to da se radi(lo) o razdoblju u kojemu većina (profesionalnih) autora ne samo što nije bila dovoljno imućna, već ni dovoljno ugledna, a ni dovoljno cijenjena, nije im preostajalo ništa drugo no skrušeno preklinjati daleko moćnije i društveno utjecajnije pojedince za financijsku pomoć, odnosno za zaštitu konkretnoga književnog ostvarenja (najčešće od opasnih protivnika, ali i neumoljive crkvene cenzure), a pokatkad i za ,pomoć u poticanju ljudi da se ta knjiga širi i čita“ (Isto: 145). S druge - pak - strane, kada su se pisanja književnih sastavaka laćali pojedinci iz aristokratskih krugova, koji su bili u stanju sami financirati njihovo tiskanje u cijelosti, ta su svoja ostvarenja oni najčešće posvećivali bliskim prijateljima iz istih društvenih krugova ili drugim utjecajnim osobama, a sve ne bi li - podsjećajući čitatelje na to koliko su njihovi prijatelji značajni i koliko ih cijene - $\mathrm{u}$,javnosti“ osnažili dojam o svome silnom društvenom ugledu. Kao adresati posveta, štoviše, u nekim su se slučajevima pojavljivali čak i autorima $u$ potpunosti nepoznati pojedinci, a da ta i takva praksa posvećivanja literarnih ostvarenja

\footnotetext{
${ }^{840}$ O tome detaljnije u: Genette 1997: 224-229.
} 
uglednicima koje pisci nisu osobno poznavali te ih stoga nisu ni mogli pitati za dopuštenje da to uopće (u)čine (ni) u baroknoj nam književnosti nije bila nimalo neuobičajena posvjedočiti nam mogu mnogi njezini primjeri, među kojima i onaj iz „drugoga“ izdanja Odiljenja. ${ }^{841}$

Bacimo li makar letimičan pogled na paratekstualne segmente Ritterove „zrinijade“, za oko će nam zacijelo najprije zapeti identično koncipirani prozno-stihovni predgovori „čtavcu“, odnosno „štavcu“ smješteni u prvim dvama njezinim izdanjima. Radi se, štoviše, ne samo o paratekstualnim komponentama uzastopnih izdanja koje po svojoj strukturi neodoljivo nalikuju „tek“ jedna drugoj, nego i o (para)tekstovima strukturno podudarnima nemalom broju predgovora i posveta što su ih ispisali i (tiskanim) tekstovima svojih djela priložili i mnogi drugi sedamnaestostoljetni naši autori. S obzirom na to da je redom riječ o piscima koji su spomenuta ostvarenja obogaćena strukturno identičnim paratekstualnim dodacima dogotovili i objelodanili nekoliko godina ili čak desetljeća prije no što će to u svome Odiljenju sigetskom učiniti i Pavao Ritter Vitezović, nipošto ne bi bilo ishitreno pomisliti da je predložak za prozne svoje predgovore $\mathrm{s}$ utkanom poslovicom ispjevanom $\mathrm{u}$ dvanaesteračkom distihu te pridruženom kraćom lirskom pjesmom naš autor pronašao $u$ barem nekima od tih prethodno tiskanih ili makar za tisak priređenih djela. Među njima, ionako se kao ne samo neprijeporan, nego ujedno i daleko najveći uzor Vitezoviću u sastavljanju njegove ,zrinijade“ nametnula Adrijanskoga mora Sirena, koju Petar Zrinski otvara proznom posvetom „vse hrvacke i primorske krajine hrabrenim vitezovom“ (Zrinski 1957: 19), u koju je inkorporirao poslovicu, ali i zaključni lirskopjesnički fragment, odnosno latinski elegijski distih, koji ondje funkcionira kao svojevrsna „lirska“ poanta onoga o čemu je u većem dijelu posvete i bilo riječi.

Ispisujući predgovore za prva dva izdanja svoga hrvatskog prvijenca Vitezović je na umu definitivno mogao imati i predgovor čitateljima što ga je u vrlo bogati paratekstualni odsječak molitvenika Putni tovaruš (1661.) uvrstila Katarina Zrinski, pridruživši mu još i religioznu osmeračku lirsku pjesmu - također adresiranu na publiku - naslovljenu Vsakomu

\footnotetext{
${ }^{841} \mathrm{Ne}$ samo što, naime, ni danas nisu u potpunosti jasni razlozi Vitezovićeva posvećivanja (fiktivnoga) bečkog izdanja Odiljenja Matiji Ignaciju Radanoviću, nego je i poprilično vjerojatno to da ovoga opata i vrhovnog kapetana u Szalaváru naš autor (fizički) uopće nije ni poznavao. Vrlo sličan onodobni slučaj posvećivanja književnoga teksta nepoznatom ugledniku nalazimo i u Ignjata Đurđevića, koji svoju poemu Uzdasi Mandalijene pokornice posvećuje nadbiskupu Vicku Zmajeviću, kojega osobno naprosto nikako nije mogao poznavati. Uzgred budi rečeno, sama praksa izravnog obraćanja nekoj uglednoj i moćnoj osobi s molbom za zaštitu, pomoć ili prijateljsko razumijevanje što je zatječemo u paratekstualnim segmentima mnogih naših literarnih tekstova nastalima od 16. stoljeća nadalje mogla bi se i morala shvatiti (i) kao derivat humanističkog shvaćanja da „kulturni i obrazovani ljudi mogu komunicirati, da se mogu razumjeti, da govore istim jezikom i da pripadaju istom svijetu duha“ (Fališevac 2007b: 195). Ipak, iako je sam taj čin posvećivanja vlastitoga književnog djela uglednom pojedincu u svojoj srži, dakle, predstavljao nesumnjivi odjek humanističkih razmišljanja, niz „tipično“ baroknih značajki što ih je uključivala velika većina tih sedamnaestostoljetnih posveta jasno ipak sugerira da se radi o itekako baroknim, odnosno baroknim postupcima obilježenim paratekstualnim segmentima. Detaljnije o posvetama u našoj ranonovovjekovnoj književnosti u: Stipčević 2005: 141-154.
} 
onomu, ki štal bude ove knjižice. Ako se, povrh toga, Ritter tom prilikom prisjetio i proznoga „opomenka“ u zbirci propovijedi Zrcalo marijansko (1662.), u kojega je Juraj Habdelić - u funkciji svojevrsne poante ili potvrde netom iznesenih sadržaja - također umetnuo lirskopjesnički isječak na latinskom izvorniku i u hrvatskom prepjevu, evocirati ipak nije mogao niti jedan od čak dva prozno-stihovana predgovora što ih je na početak svoje zbirke lirskih pjesama Gartlic za čas kratiti pozicionirao Fran Krsto Frankopan, čija su djela podsjetimo - odmah nakon njegova smaknuća potonula u višestoljetni arhivski mrak zaborava. Inače, osim „samo“ generički mješovito realiziranim predgovorima, većina pobrojanih je izdanja na našega autora lako mogla utjecati i svojim paratekstualnim segmentom u cijelosti, potičući ga da kombinaciju (latinske) posvete pokrovitelju i/ili zaštitniku te predgovora potencijalnim čitateljima u paratekst Odiljenja uvrsti (i) sa sviješću o tome kako su uspješnu njihovu koegzistenciju u okvirima svojih izdanja dotad već dospjeli između ostalih - postići i Juraj Habdelić, koji se vernakularnim proznim predgovorima nadovezuje na latinske posvete u zbirkama Zrcalo marijansko (1662.) i Prvi oca našega Adama greh (1674.), potom Katarina Zrinski, čijem predgovoru Putnom tovarušu prethode čak dvije posvete - Bogu i Djevici Mariji - na hrvatskom jeziku, pa i Ignjat Đurđević, koji u paratekstualnom odsječku čuvenih svojih Uzdaha Mandalijene pokornice uz bok hrvatskoj proznoj posveti uvrštava predgovor Štiocu namijenjen publici ovoga svog nabožnog teksta.

Ukoliko bismo se posvetama i/ili predgovorima situiranima u paratekstualne dionice književnih ostvarenja pobrojanih sedamnaestostoljetnih naših literata napokon odvažili pristupiti kao primjercima (specifičnom baroknom situacijom i idejama uvelike određenih) poluknjiževnih žanrova skrojenih od samo njima svojstvenog i kontekstu prilagođenog repertoara karakterističnih obilježja, njihova će nas prilično ujednačena „izvedba“ brzo uvjeriti kako imamo posla s visoko konvencionaliziranim generičkim rješenjima kojih prakticiranje pretpostavlja prethodno ovladavanje spletom „temeljnih“ im značajki, koji je u ovoj sedamnaestostoljetnoj njihovoj ,inkarnaciji“ bio proširen ili „moderniziran“ i nekolicinom prepoznatljivo „baroknih“ crta. Konkretno, pođemo li u našem razmatranju od žanra (proznog) predgovora, uočit ćemo da su - za razliku od (pre)često latinštinom realiziranih posveta upućenih mahom visokoobrazovanim, pa onda i literarno iskusnijim mecenama i zaštitnicima - u književnosti našega baroka predgovori većinom bili sastavljani na narodnom, dakle hrvatskom jeziku, i to ponajprije stoga što je njihova svrha bila uspostavljanje piščeve komunikacije s vrlo širokim krugovima potencijalnih (nejednako obrazovanih, pa onda i nejednako literarno potkovanih) čitatelja s nakanom da ih se izvijesti o konkretnim pojedinostima vezanima uz dano književno ostvarenje. Taj i takav žanr proznoga 
vernakularnog prijevoda - a to će uvelike vrijediti i za onaj (pretežno) latinske prozne posvete - u okvirima sedamnaestostoljetne se književnosti pritom obično ostvarivao $\mathrm{u}$, kao što je već primijećeno, generički naglašeno hibridnim tekstovima ,nadograđenima“ primjercima (,narodnih“ i ne samo izvorno „,narodnih“) poslovica te (većinom) kraćim lirskim umetcima, čija se svrha svodila na jače isticanje, odnosno potkrjepljivanje pojedinih zapažanja iznijetih u prethodnim (proznim) dionicama danoga paratekstualnog segmenta. ${ }^{842}$ Štoviše, u pojedinim doduše, znatno rjeđim - slučajevima predgovore će baroknih ostvarenja, umjesto lirskoga umetka od tek nekoliko stihova, kraju privesti nešto dulja lirska pjesma, u kojoj se također dodatno razrađuju neke misli predstavljene u proznom odsječku, kao što to biva i s već spomenutom osmeračkom pjesmom Vsakomu onomu, ku štal bude ove knjižice, koju Ana Katarina Zrinski uključuje u paratekst svojega Putnog tovaruša ne bi li opširnije progovorila o nekim kršćanskim idejama kojih se u prethodnomu predgovoru dospjela tek ovlaš dotaknuti.

Što se, pak, samoga sadržajnog aspekta tih paratekstualnih dodataka baroknih ostvarenja tiče, u oči će nam - prije svega - upasti nakana velikog broja onodobnih naših pisaca da upravo u njima izrijekom definiraju ciljanu, odnosno primarnu publiku svojih djela. Pored Petra Zrinskog, koji će se paratekstom i tekstom Sirene tako eksplicitno obraćati „plemenito i dobro rojenim, svake hvale i časti dostojnim, virnim i vridnim junakom, vse hrvacke i primorske krajine hrabrenim vitezovom“ (Zrinski 1957: 19), (is)tom će paratekstualnom adresiranju u predgovoru Putnoga tovaruša pribjeći i supruga mu Katarina, namijenivši svoj molitvenik „,vsega hervatckoga i slovinskoga orsaga gospodi i poglavitim ljudem obojega spola, vsake verste i fele“ (Zrinski 2006: 7), dočim Gabrijel Jurjević u predgovoru svoje (prijevodne) zbirke heroida Listi heroov precizira da bi ,idealnu“ publiku njegove knjige trebali sačinjavati ,gospoda, junaki i ostali obojega spola poglaviti ljudi“ (Šojat 1977b: 305). Predgovore (a gdjekad i posvete) svojih ostvarenja mnogi će hrvatski pisci 17. stoljeća iskoristiti i da bi recipijente upoznali s osnovnom njihovom svrhom, odnosno razlozima zbog kojih su ona uopće morala ugledati svjetlo dana, pa dok tako primjerice - Petar Zrinski u posveti Sirene navodi čak tri namjene svoga teksta (propagiranje hrabrosti i vojnih uspjeha hrvatskih vitezova, ukazivanje na egzemplarni značaj žrtve što su je hrvatski junaci podnijeli za Siget, proslavljanje potomaka sigetskih branitelja), dotle Katarina

\footnotetext{
${ }^{842}$ Tako bi, primjerice, distih „V šišaku Marčenom učiniše gnijezdo golubi, / da se zna, načinom kim Venus Marča ljubi““ (Zrinski 1957: 20), kojim Petar Zrinski privodi kraju posvetu svoje Adrijanskoga mora Sirene, trebao potvrditi u ranijem dijelu teksta izrečen sud o tome kako ,ništar tako ne veseli junaka kako ljuba, konj i oružje“ (Isto: 20), dočim se (prepjevana) osmeračka sestina „S fundamenta ispeljana / Hiža ova i zidana, / Ako komu ne po volje, / Nego mu se hoče bolje, / Naj nam ovu tak ostavi, / Svoju sebe naj popravi“ (Šojat 1977b: 5960), što ju je Juraj Habdelić uključio u predgovor („opemenek“) svojega Zrcala marijanskog, izravno nadovezuje na (u posvetama uobičajene) savjete zahtjevnom čitatelju da se - u slučaju da mu ovdje napisano nije bude po volji - sam lati pera i „knjižice (...) nove bolše spravi““ (Isto: 60).
} 
u predgovoru Putnoga tovaruša, Habdelić u „opomenku“ Zrcala marijanskog te Juraj Rattkay u ,pregovoru k štavcu“ Kriposti Ferdinanda II. redom otkrivaju kako su se na objelodanjivanje svojih djela odvažili zbog malobrojnosti dotad tiskom objavljenih sličnih ostvarenja na hrvatskom jeziku, dočim Matijaš Magdalenić u (hrvatskoj) posveti Zvončaca i Gabrijel Jurjević u predgovoru Listi heroov otvoreno priznaju kako su ih na objavljivanje njihovih djela ponajviše potaknuli snažni religijsko-moralni, točnije didaktični razlozi.

Čvrsto uvjereni $\mathrm{u}$ korisnost svojih sastavaka, pa onda $\mathrm{i}$ njihovu (vjerojatnu) obljubljenost među publikom, brojni će domaći sedamnaestostoljetni pisci čitateljima u predgovorima ukratko nagovijestiti i što ih - u sadržajnom smislu - očekuje na stranicama koje slijede, računajući pritom i s možebitnim kritikama koje bi im s njihove strane mogle biti upućene, odnosno iskazujući jasnu svijest o tome kako će se nužno naći i oni kojima se njihovo ostvarenje ipak neće svidjeti. U njegovu obranu oni će pritom najčešće naglašavati kako su ih pri njegovu sastavljanju vodile isključivo „plemenite namjere“ te da - iako su u sam proces pisanja uložili nemali trud, a k tome još i građu za nj crpili iz različitih stranih tekstova - ono naprosto nije moglo ispasti besprijekorno ponajprije zbog toga što sami nisu dovoljno učeni da bi ga takvim bili u stanju učiniti. Da su ti isti pisci priželjkivali steći publiku ne samo u svome neposrednom životnom okruženju, odnosno isključivo unutar provizornih granica jedne od onodobnih kulturnih regija ponajbolje će nam potvrditi činjenica kako u gotovo svim domaćim baroknim predgovorima (i ponekoj posveti) zatječemo još i skrušene isprike zbog (možebitne) jezične nerazumljivosti, točnije poradi uporabe mješovitog ili „nečistoga“ jezika, koju najčešće biva opravdana autorovim porijeklom upravo iz onih hrvatskih krajeva u kojima se svakodnevna komunikacija i odvija na takvoj višenarječnoj inačici narodnoga jezika. I dok je te i takve isprike moguće locirati - između ostalog - i u Šimunićevu predgovoru Feniksa pokore, Magdalenićevoj posveti Zvončaca te predgovoru Zrcala marijanskog, u kojemu Juraj Habdelić odrješito pripominje kako je „činil štampati onak, kak onde govore, gde sam pisal“ (Šojat 1977b: 60), u ništa manjem broju paratekstualnih komponenata baroknih naših sastavaka svoje će mjesto naći (još) i autorove isprike zbog niza drugih formalnih pogrešaka - metričkih, pravopisnih, tiskarskih i dr. - za koje su, osim samih autora, vrlo veliku odgovornost snosili (i) inozemni njihovi tiskari, kojima je hrvatski jezik predstavljao gotovo apsolutnu nepoznanicu.

Tolika količina identičnih sadržajnih, formalnih i - uopće - generičkih značajki što su ih dijelili predgovori i gdjekoja posveta domaćih sedamnaestostoljetnih vernakularnih ostvarenja jasno nam sugerira kako su se pri njihovu sastavljanju autori oslanjali na jednu te istu - baroknu - ,poetiku“ ovoga poluknjiževnog, odnosno paratekstualnog žanra, što će reći 
upravo na onu „poetiku“ koja je dubok trag ostavila i u paratekstu naročito prvih dvaju izdanja Odiljenja sigetskog. Poput predgovora uključenih u izdanja većine onodobnih književnih, pa i ne samo književnih djela na hrvatskom jeziku, i oni što ih Vitezović pridružuje svojoj ,zrinijadi“ tako ne samo što su - vidljivo je već na prvi pogled - realizirani kao generički kompleksni vernakularni sastavci prošireni stihovanim (poslovičnim) umetcima i cjelovitim kraćim lirskim pjesmama, nego ujedno egzistiraju i kao paratekstualni odsječci u kojima se kratko osvrće na sam sadržaj (sastav) djela (u predgovoru fiktivnoga „drugog“ izdanja Ritter tako iznova ističe kako je Odiljenje ostalo „krnje“ s obzirom na to da „ne budući jošće ona tri dila po misli mojoj dovršena“; Ritter Vitezović 1685), ali i u kojima se poprilično jasno definira sama (izvanknjiževna) svrha teksta u cijelosti [,da slavni hrvatski jezik naš u tuliko pozabljenje ne dohodi““ (Ritter Vitezović 1684), odnosno „pisma mojega sprave ne na drugo nego jezika hrvatskoga uzdržanje i naroda ime upravljam“ (Ritter Vitezović 1685)], anticipiraju mogući prigovori pojedinih čitatelja (,Znam, dragi prijatelju, da kod mnogih dilo ovo prijetno, a kod mnogih pogovoreno bude“; Ritter Vitezović 1684), ${ }^{843}$ pa čak i - „tipično“ za jedan barokni predgovor - skreće pozornost na moguće poteškoće u jezičnom razumijevanju teksta (,kada u knjižicah ovih riči morebit nikoje čtal budeš koje nisi lahko čul, ne reci: ni hrvatska, ali slovinska rič“; Isto).

Iako se, s druge strane, u predgovorima naslovljenima $K$ čtavcu, odnosno Prijaznivi štavče! naš autor neće upustiti - nalik mnogim svojim prethodnicima - u eksplicitna definiranja ciljane publike svoje ,zrinijade“, i više nego indikativnom u tom će se pogledu ispostaviti ne samo činjenica da u oba teksta izravno on adresira (nepreciziranoga), „čtavca“, odnosno „štavca“ kao pripadnika vrlo neodređene, pa onda i iznimno široke i raznolike potencijalne publike, nego i ona da u predgovoru prvoga izdanja on silno teži uspostavljanju prisnoga odnosa s ,„čtavcem“, kojega ondje u nekoliko navrata apostrofira kao „dragoga prijatelja“, dakle kao nekoga dobro mu znanog ili makar po društvenom statusu ravnog, u ophođenju s kojim ne mora rabiti uvriježena oslovljavanja ni druge konvencionalne izraze poštovanja, odnosno kao nekoga tko ne pripada uskom krugu društvenih uglednika iz redova aristokracije, kojima je neprimjereno obraćati se sličnim familijarnim tonom. Dodamo li tomu

\footnotetext{
${ }^{843}$ Vjerojatne prigovore dijela svojih čitatelja Vitezović je, osim toga, pokušao preduhitriti i pridruženom osmeračkom lirskom pjesmom, u sva četiri katrena koje se i usredotočuje na pitanje raznolikosti ljudskih ukusa i činjenicu da „pod nebom ne znam gdo je / ki svim more ugoditi“ (Ritter Vitezović 1684). Računajući s vrlo vjerojatnim pokudama što će ih njegovu djelu uputiti pokoji nezadovoljniji i kritici skloniji recipijent, naš autor se - u „tipično“ baroknome duhu - unaprijed ispričava zbog možebitnih propusta navodeći kako su oni „tek“ posljedica činjenice „da stvoritelj ni dal znati / sve jednomu Bog človiku“ (Isto), da bi zatim u nastavku istaknuo kako ga „zli jezici“ neće pokolebati sve dok postoje oni kojima je Odiljenje ipak po volji. Svoju lirsku minijaturu Ritter će privesti kraju posve uobičajeno i očekivano, i to savjetujući svakomu negativno nastrojenom kritičaru da - u slučaju da mu se ona ne sviđa - njegovu „zrinijadu“ naprosto „ostavi / ter učini sebi bolju“ (Isto).
} 
i činjenicu kako u oba predgovora - baš kao što će to ustrajno činiti i duž čitava teksta svoje „zrinijade“ - hotimice sljubljuje jezične elemente iz svih triju hrvatskih narječja ne bi li postigao „univerzalno“, odnosno sveopće (,svehrvatsko“) razumijevanje Odiljenja, postat će i više nego očito da se - premda je ondje izrijekom ne definira - Ritter svojim predgovorima obraća neobično šarolikoj publici, točnije recipijentima iz različitih društvenih slojeva i različitih čitateljskih profila s prostora čitave (današnje) Hrvatske.

Usmjerimo li sada pažnju na one komponente paratekstualnih dijelova svih triju Vitezovićevih izdanja Odiljenja sigetskog koje bi se po svojim prepoznatljivim obilježjima mogle identificirati kao posvete, ni najmanje nas ne bi smjela iznenaditi njihova frapantna sličnost generički identičnim - pretežno latinskim, ali i vernakularnim - tekstovima što ih je velika većina naših sedamnaestostoljetnih autora donosila u sklopu parateksta tiskom objelodanjenih izdanja svojih (književnih) ostvarenja. Riječ je, podsjetimo, o poluknjiževnom žanru u stihu (posvetna pjesma) ili prozi, u kojemu su pisci obznanjivali posvetnike ili posvetnika svojega tiskanog književnog (pa i ne samo književnog) djela, izražavajući mu najdublju zahvalnost i odanost, a pokatkad i upućujući molbu za (dodatnom) zaštitom toga njemu posvećena djela, a sve to u daleko konvencionaliziranijem tekstualnom okviru od onoga što ga je pretpostavljao predgovor, najčešće napučenom nizom toposa (primjerice, onima pohvale, afektirane skromnosti, neizrecivosti, iskazivanja vjernosti i odanosti itd.) te uobičajeno pretjeranih glorifikacija adresata (mecene, zaštitnika ili naprosto utjecajnoga bliskog prijatelja) i njegova društvenog ugleda te nebrojenih zasluga. Svjesni te konvencionaliziranosti i šabloniziranosti žanra posvete, kao posve shvatljivu morali bismo označiti činjenicu kako - bez obzira na to što se u prva dva izdanja radi o latinštinom ispjevanim stihovanim tekstovima, a u onome trećem o opsežnomu proznom sastavku na hrvatskom jeziku - u sve tri posvete Odiljenja ne samo što se pojavljuju pojedine identične formulacije, nego ujedno imamo posla i s gotovo identično koncipiranim tekstovima $u$ cijelosti posvećenima naočigled prenaglašenom proslavljanju uglednih domaćih pojedinaca koji su pristali financijski potpomognuti objelodanjivanje njegove osebujne ,zrinijade“.

Već latinskom posvetnom pjesmom prvoga izdanja Odiljenja sigetskog Vitezović će tako oduševljeno veličati Adama Zrinskog kao „baštinika imena i djedovske vrline“ (Zrinski, Frankopan i Ritter Vitezović 1976: 360), odnosno kao izravnoga potomka „Hektora sigetske snage“ (Isto: 359), koji je svojom srčanošću i herojskim djelima zaslužio mjesto uz bok drugim junacima „ilirske zemlje“ - Novaku Debeljaku, Skenderbegu, Kraljeviću Marku, Kobiliću i dr. S glorificiranjem adresatove vojne vještine i brojnih ratničkih zasluga Vitezović će potom nastaviti i u godinu dana „mlađoj“ (versificiranoj) posveti fiktivnoga „drugog“ 
izdanja Odiljenja, ovoga puta adresiranoj na Matiju Ignacija Radanovića, koji se u njegovim očima nametnuo kao idealni posvetnik „novoga“ izdanja Odiljenja (i) poradi niza pozitivnih vrlina što ih utjelovljuje, a koje se - ističe - ponajbolje očituju u njegovu kontinuiranom djelovanju na čast „narodu, Bogu i kralju“. Na iste će se momente naš autor usredotočiti i u oduljoj proznoj posveti na hrvatskom jeziku trećega izdanja svoje ,zrinijade“, koja se gotovo u cijelosti svodi na potanko nabrajanje brojnih ratničkih podviga Ivana Andrije Makara - po svome značaju gotovo posve jednakih i jednakovrijednih onima Nikole Šubića Zrinskog, Skenderbega i „ostalih glasovitih nigdašnjih vitezov“ (Ritter Vitezović 1695) - zbog kojih se ovaj glasoviti hrvatski kapetan (po Ritterovu sudu) prometnuo u daleko najprimjerenijega posvetnika - a prije toga, vrlo vjerojatno, i velikodušnog pokrovitelja - (n)ovoga izdanja njegova vernakularnog prvijenca.

Kao što će oba hrvatska predgovora izdanja Odiljenja iz 1684. i 1685. Vitezović zaključiti kraćim lirskim pjesmama u kojima (iznova) progovara o pozitivnoj i negativnoj recepciji svoje „zrinijade“ i zanimanju za Siget uopće, tako će i posvetnoj pjesmi bečkoga njezina izdanja pridružiti vrlo uspjeli primjerak anagrama, u kojemu se upušta u dodatno proslavljanje (potencijalnog) zaštitnika i mecene Matije Ignacija Radanovića. Bit će da sastavljanje toga pohvalničkog anagrama za paratekst fiktivnoga „drugog“ izdanja Ritteru nije predstavljalo ni najmanji napor, tim više što je - kao „tipični“ pisac baroknoga doba, koje je izuzetno visoko cijenilo ovaj enigmatsko-pjesnički žanr - do toga trenutka iza sebe već imao višegodišnju praksu kontinuiranoga ispisivanja latinskih anagrama, koje će u narednim godinama skupiti te ih objelodaniti u sklopu nekoliko samostalnih anagramskih zbirki. Konkretno, pristupajući anagramu kao jednom od (poluknjiževnih) žanrovskih rješenja koje je imalo istaknuto mjesto u okvirima baroknoga generičkog sustava, nipošto s uma nećemo smjeti smetnuti činjenicu kako je u 17. stoljeću on zapravo shvaćan kao svojevrsna pjesnička figura bazirana na zagonetačkim kombinacijama, čiju su strukturu redovito sačinjavale tri komponente, i to zadani pojam ili ,program“ (programma), zatim ,,anagram“ (anagramma) ili premetaljka (u kojoj se ime, naziv ili pojam iz programa pojavljuje u premetnutu obliku) te „stihovano objašnjenje“ ili exegesis - najčešće realizirano u žanru epigrama - u kojemu se donosi konačno (raz)rješenje zagonetke, odnosno podastire versificirano tumačenje novoskovanoga pojma (anagrama). Potonje tumačenje novonastaloga pojma $u$ toj se zaključnoj stihovanoj dionici anagrama vršilo na način da su se u nju uvrštavale redom sve riječi iz anagramske fraze, pa dok su tako - kao što je vidljivo i na primjeru anagrama $u$ Radanovićevu čast - u ,programima“ najprije predstavljana imena i prezimena proslavljanih (redovito društveno istaknutih) pojedinaca, odnosno nazivi konkretnih gradova, pokrajina, 
zemalja, naroda ili posve apstraktnih pojmova, a u ,anagramima“ nizane dosjetke skrojene od ispremiješanih slova imena navedenoga autoriteta, lokaliteta itd., dotle su se u exegesisu podastirala (većinom) epigramska pojašnjenja tih istih dosjetaka, a sve s ciljem da se živoga ili oživljenoga (personificiranoga) adresata što primjerenije uzveliča. ${ }^{844}$

Kao autor čiji se cjelokupan stvaralački opus nadaje kao najuvjerljiviji dokaz silnoga truda što ga je sustavno ulagao ne bi li se u što je moguće većoj mjeri približio centrima onodobne političke moći, Pavao Ritter Vitezović još od mladenačkih je dana ciljano forsirao sastavljanje anagrama znajući da ta „enigmatska vrsta, odnosno postupak“ (Stepanić 2016: 336) baroknu svoju popularnost najviše duguje činjenici što je izravno bio povezan $s$ društvenopovijesnim mijenama koje su se zbile kao posljedica uspostave apsolutizma i strelovita porasta moći kralja. Podsjetimo, s obzirom na to da su kulturni obrasci u stopu pratili sedamnaestostoljetne procese apsolutističke centralizacije i integracije, unutar granica Habsburške su se Monarhije (pa i drugdje diljem Europe) kao „dominantni književni oblici“ u barokno doba - uz bok tada toliko prominentnoj političkoj publicistici ${ }^{845}$ - nametnuli „prigodni epigrami, anagrami i historijski spisi, najčešće posvećeni vladaru, ali i drugim uglednicima“" (Blažević 1997: 16), zbog čega nas ni najmanje ne treba iznenađivati Ritterovo kontinuirano ustrajanje $\mathrm{u}$ ispisivanju i objelodanjivanju tekstova sazdanih upravo od značajki iz repertoara navedenih žanrova, uz pomoć kojih je priželjkivao uspostaviti blizak odnos s vladarom i drugim uglednicima iz onodobnoga političkog života u zemlji i inozemstvu. Ukratko - riječima Zrinke Blažević - ,služeći se omiljenim baroknim žanrovima panegirikom, epistolom i anagramom, Vitezović nastoji zadobiti naklonost najpoznatijih osoba u bečkom političkom i kulturnom životu i ujedno se kao pjesnik afirmirati u carskoj prijestolnici, koja je predstavljala meku za umjetnike i intelektualce iz svih krajeva Carstva“ (Blažević 2002: 170 i 2016: 152). Naravno, to što je - ponesen njihovim izvanliterarnim značajem - naš autor za gotovo čitava svog života lakoćom ,izbacivao“ anagrame te ih potom okupljene $\mathrm{u}$ više zbirki tiskom izdavao ${ }^{846} \mathrm{u}$ isti bi mah valjalo držati i jednom od brojnih „posljedica“ njegova višegodišnjeg školovanja u isusovačkoj gimnaziji, čijim su programom, među ostalim, bile propisane i česte i mukotrpne vježbe u sastavljanju anagrama na latinskom

\footnotetext{
${ }^{844}$ Daleko podrobnije o komponentama žanra (baroknog) anagrama i drugim njegovim tekstualnim značajkama u: Bratulić 1997: 14, bilješka 2; Stepanić 2005: 186-193 i 2016: 335-336; Luetić i Tvrtković 2016: 317-332.

${ }^{845}$ Usp. o tome u: Blažević 2002: 40.

846 Od Ritterovih brojnih zbirki anagrama svakako valja izdvojiti onu Opera anagrammaton laurus auxiliatoribus Ungariae (1687.), potom Anagramaton sive laurus auxiliatoribus Ungariae liber secundus (1689.) i Anagrammaton liber tertius (1696.), ali i Fata et vota sive opera anagrammaton (1698.) i dr.
} 
jeziku, ${ }^{847}$ zahvaljujući kojima i jest bio u stanju stvoriti anagramski opus kojim se prometnuo u našega daleko najplodnijeg i najprofesionalnijeg pisca anagrama u čitavu 17. stoljeću. ${ }^{848}$

Kako bilo, kada bismo, na koncu, svaki od triju posve različitih paratekstualnih odsječaka triju izdanja Odiljenja sigetskog (s izuzetkom, dakako, njihovih naslovnica) poželjeli sagledati kao cjeline te ih - kao takve - usporediti s istim takvim paratekstualnim cjelinama drugih naših (ranije već spomenutih) baroknih vernakularnih ostvarenja, kao točku u kojoj se ti Vitezovićevi (para)tekstovi najviše približavaju onima inih sedamnaestostoljetnih literata bili bismo ipak prisiljeni izdvojiti prozne vernakularne predgovore s uklopljenim lirskim pjesmama što ih sadrže izdanja iz Linza te Beča, koji - nalik onima iz mnogih drugih izdanja iz toga vremena - zbog svoje adresiranosti na poprilično širok krug „čtavaca“, odnosno „štavaca“ sugeriraju da su ta prva dva izdanja (za razliku od onoga trećeg, „rezerviranog“ za znatno probraniju skupinu recipijenata) bila namijenjena publici što je pripadala različitim društvenim slojevima i živjela u različitim dijelovima (današnje) Hrvatske i kojoj je iz toga razloga u posebnom tekstu bilo potrebno pojasniti razloge nastanka djela te joj skrenuti pažnju na neke njegove pojedinosti i nejednake čitateljske reakcije koje će zahvaljujući tome što računa na različite tipove recipijenata - ono najvjerojatnije izmamiti. Ekvivalentno brojnim drugim tadašnjim piscima, i Vitezović će tako u predgovoru $K$ čtavcu premijernoga izdanja svoje ,zrinijade“ - pomirivši se s činjenicom da se ona jamačno neće svidjeti apsolutno svim čitateljima - istaknuti kako ju je napisao još prije punih pet godina, $\mathrm{i}$ to s nakanom da hrvatski jezik sačuva od zaborava koji mu prijeti zbog sve veće asimilacije tuđica što se ukorjenjuju u njemu kvareći mu izvornu ljepotu, pa stoga adresate upozorava da će u njoj naići na niz najvjerojatnije im nepoznatih (no isključivo „čistokrvno“ hrvatskih) riječi, ali i na nova pravopisna pravila kojih se sam dosjetio i koja će podrobnije razjasniti u jezikoslovnoj raspravi koju još nije dogotovio. Prije no što ga dovrši obećanjem kako će se potruditi da i tri još nenapisana dijela Odiljenja u što skorije vrijeme ugledaju svjetlo dana, Vitezović u predgovor ubacuje osmeračku lirsku pjesmu, u kojoj nanovo izriče svijest o tome kako među svojom publikom neće steći samo poklonike, nego i kritičare, kojima tom prilikom unaprijed poručuje da se, umjesto upućivanja zlonamjernih kritika, sami late pera te, ukoliko već misle da su u stanju napisati bolje djelo, vlastitim sastavkom pokušaju nadmašiti njegov.

Pred kritički nastrojeniji dio svoje publike Ritter takav izazov ipak neće staviti i u predgovoru Prijaznivi štavče! nepunih godinu dana „mlađega“ bečkog izdanja, no zato će tu paratekstualnu dionicu gotovo u cijelosti iskoristiti ne bi li pred čitatelje podastro što

\footnotetext{
${ }^{847}$ Usp. Stepanić 2005: 118.

${ }^{848}$ O anagramskom dijelu Vitezovićeva (pre)bogatoga stvaralačkog opusa naročito u: Peleh 1973: 397-402, Luetić i Tvrtković 2016: 317-332 i Stepanić 2016: 335-336.
} 
uvjerljivije razloge zbog kojih svoj tekst iznova tiskom objavljuje „krnj“, odnosno lišen triju obećanih zaostalih dijelova, od kojih još uvijek nije dospio napisati ni jedan jedini stih. Jadajući se kako mu u međuvremenu nije pošlo za rukom pronaći pokrovitelja voljnog novčano potpomoći njegov rad na ovome djelu, naš autor čitateljima tako priznaje da sam ne raspolaže financijskim sredstvima dovoljnima da bi mogao „kupiti mir“ i posvetiti se isključivo dovršavanju Odiljenja, pripominjući usput i kako ga posvemašnja financijska oskudica trenutno priječi i u tome da tiskom objavi i niz drugih svojih potpuno dovršenih tekstova, zbog čega recipijente moli da se - za sada - zadovolje čitanjem ovoga koje je im je upravo došlo u ruke i na čijim stranicama će zacijelo svaki od njih pronaći makar štogod vrijedno. Pomalo na tragu lirske pjesme iz predgovora prethodnoga izdanja, i ona dvanaesteračka - kojom naš autor zaključuje predgovor ovoga bečkog (naslovljena Učinitelj knjigam) pjeva o kuditeljima i hvaliteljima, no u njezinu se slučaju ni u jednome trenutku prestroge kritičare neće pozivati na izazov budući da se lirski subjekt u njoj izravno obraća (personificiranu) Sigetu ne bi li ga podsjetio na to da se - iako je oduvijek bilo i uvijek će biti onih koji ga vole i onih spremnih da mu upute prijekore - jedinim vrijednim na koncu ispostavlja samo mišljenje razboritih ljudi, zbog čega ga na koncu i potiče da progovori o nemilim događajima pod njegovim zidinama u ljeto 1566.

Nije, konačno, nevažno primijetiti ni to kako je - karakteristično za paratekstualne sastavnice većine drugih domaćih sedamnaestostoljetnih književnih ostvarenja - i duž svih triju paratekstova navedenih izdanja Odiljenja moguće locirati prepoznatljive literarne klišeje, odnosno topose izvorno antičko-srednjovjekovne provenijencije. I dok je o pojedinim toposima „ugrađenima“ u sam tekst Ritterove „zrinijade“ ponešto već rečeno na prethodnim stranicama, što se onih prisutnih u paratekstu tiče, među njima najviše će se isticati topos afektirane skromnosti (u koji bi se, između ostalog, mogle ubrojiti i Vitezovićeve izjave iz posveta drugoga i trećega izdanja o tome kako se na objavljivanje novih izdanja odvažio isključivo poradi molbi prijatelja), potom topos ravnodušnosti spram svih onih kojima se djelo možda neće svidjeti i koji će ga se zbog toga usuditi kritizirati („Il me hvali lud il kudi, / sve jednako skoro hajem: / dobrim jezikom zal ne udi, / komu uzrok tu ne daje“; Ritter Vitezović 1684), a uz njih i nekolicina panegiričkih ili pohvalničkih toposa kojima su bremenite posvete svih triju izdanja (tako se, primjerice, u posveti onoga trećeg pukovnika Makara ustrajno apostrofira kao „presvitloga viteza“, „hrabrenoga gospodina“, ,presvitloga gospodina“ itd.), ${ }^{849}$ kojima svakako treba dodati i prisutnost čuvenoga (srednjovjekovnog) toposa „iznosim nešto što još nikada nije rečeno“ (Curtius 1998: 97) na naslovnici prvoga 
izdanja, i to - konkretno - u podnaslovu, u kojemu se precizira kako je Odiljenje „tuliko različitom, kuliko nečujenom dosle hrvatske rišme lipotom spravljeno“ (Ritter Vitezović 1684). ${ }^{850}$ Upošljavanje toposa predrenesansnoga porijekla u posvetama i predgovorima triju izdanja Odiljenja sigetskog u tom se smislu može izdvojiti kao jedan od mnogobrojnih pouzdanih indikatora Vitezovićeva snažnog ugledanja ne samo u tekstualne, već podjednako i u paratekstualne komponente pojedinih domaćih tiskom objavljenih sedamnaestostoljetnih ostvarenja, koji nam definitivno potvrđuje kako bismo u tim paratekstualnim njihovim sastavnicama bez ikakve dvojbe mogli i morali gledati barokne generičke realizacije tih poluknjiževnih žanrova. Bit će da su ta paratekstualna očitovanja uvrštena kao dodatak svim tiskanim izdanjima baroknih naših ostvarenja Rittera posebno privlačila (i) zbog njihove generički hibridne prirode, odnosno činjenice da je redom bila riječ o sastavcima skrojenima od obilježja različitih žanrova i uvrštenih primjeraka pojedinačnih cjelovitih žanrova (kao što je to - primjerice - slučaj i s posvetom naročito mu drage Adrijanskoga mora Sirene, u koju Petar Zrinski uključuje poslovice, blagoslove, hvale, zakletve, pouke i lirskopjesničke umetke), potičući ga da se i sam okuša u sastavljanju upravo tih i takvih poluknjiževnih tekstova, tim više što su se oni posebno dobro mogli uklopiti u izdanje koje je sadržavalo onakav tip žanrovski šarolikoga literarnog ostvarenja kakvim je naš autor zamislio i realizirao i svoje Odiljenje sigetsko u cijelosti.

\section{4. 2. Ratni govor i zakletva (prisega)}

U trećem pjevanju svoga povijesnog epa Vazetje Sigeta grada Barne će Karnarutić slijedeći (i) u tom fabularnom detalju u potpunosti kronikalni prikaz sigetske bitke iz pera Ferenca Črnka ${ }^{851}$ - donijeti podulju dionicu označenu kao upravni iskaz bana Nikole Šubića Zrinskog, koja - u sadržajnom pogledu - zapravo predstavlja dojmljivi motivacijski govor sigetskoga kapetana njegovim suborcima uoči očekivanoga dolaska turskih napadača i početka opsade grada. Za spomenutim odsječkom, koji broji punih 66 stihova (605. - 670.), uslijedit će bitno kraći odjeljak od svega 13 stihova (677. - 689.), u kojemu riječ preuzima maločas adresirani kolektiv sigetskih branitelja te Zrinskome pozitivno odgovara na njegove zahtjeve, prisežući mu na apsolutnu poslušnost i odanost, da bi već u sljedećem (ujedno i posljednjem) pjevanju, spremajući se na posljednji okršaj s Osmanlijama u gotovo sasvim razorenom Sigetu, ban Zrinski preživjeloj šačici tih istih branitelja još jednom pokušao podići

\footnotetext{
850 Opširnije o toposima srednjovjekovne književnosti, koje su kontinuirano rabili i mnogobrojni ranonovovjekovni pisci, u: Curtius 1998: 90-118.

${ }^{851}$ Usp. sadržajno i generički istovjetne dionice u Črnkovoj kronici u: Črnko 1971: 8-11 i 20-21.
} 
moral nadahnutim ratnim govorom, protegnutim na sveukupno 43 stiha (927. - 969.), u kojem ih podsjeća na smisao njihove žrtve i traži od njih da hrabro daju svoje živote braneći sigetsku utvrdu kao da brane kršćanstvo u cijelosti. Slijedom Karnarutića, a onda i - dakako - Ferenca Črnka, za identičnim će fabularnim momentima, odnosno generički jednako realiziranim dionicama u svojoj neusporedivo opsežnijoj Obsidi sigeckoj na nekoliko mjesta posegnuti i Petar Zrinski, koji ratnički govor kapetana Nikole Šubića Zrinskog suborcima uključuje u treće (III: 47-53), potom naročito u peto (V: 13-43), u bitno kraćem opsegu i u sedmo (VII: 57-58) te, naposljetku, u petnaesto pjevanje (XV: 2-8), pri čemu je nemoguće ne primijetiti kako od navedena četiri ratna banova govora sigetski branitelji prisegom kapetanu odgovaraju samo po završetku najduljeg, dakle onoga situiranog u petom pjevanju, i to iznenađujuće kratkom zakletvom protegnutom na svega dvije strofe (V: 49-50). ${ }^{852}$ Potonja zakletva ili prisega, što je još zanimljivije, k tome ni ne biva izgovorena kao kolektivno zaklinjanje zapovjedniku na odanost i poslušnost, već je zamišljena kao individualni izraz prisezanja nadređenom kojega bi pojedinačno trebao izgovoriti svaki od „vojvoda“ i „vitezova“, odnosno višerangiranih vojnika, što je u tekstu „riješeno“ na način da jedan njezin primjerak ili "prototip“ najprije u cijelosti izriče kapetan Farkašić, a zatim se u nastavku - u sljedećih nekoliko desetaka strofa - kataloški nabrajaju istaknut(ij)e „vojvode“ koje su za njim učinile isto (Ivan Novaković, Gašpar Alapić, Andrijan Radovan, Stipan Golemi i dr.).

Da se motiv banova ratnog govora te prisege kršćanskih branitelja Sigeta ponajviše zahvaljujući pobrojanim (redom pripovjednim) ostvarenjima nametnuo kao neizostavan sadržajno-generički moment (ne samo pisanoknjiževnih, autorskih), ,zrinijada“6853 bjelodano će Odiljenjem sigetskim potvrditi upravo Pavao Ritter Vitezović, koji - usprkos prilično očitom nedostatku ambicije da sastavi ,punokrvni“ povijesni ep po uzoru na neposredne prethodnike (koji ga, podsjetimo, ipak nije spriječio u tome da svoj tekst napuči mnogim uvriježeno epskopjesničkim značajkama) - također u nj neće propustiti „ugraditi“ dionice, odnosno čitave pjesme koje bismo žanrovski mogli identificirati kao primjerke izvorno izvanknjiževnih žanrova ratnoga govora te zakletve ili prisege. Prisutnost „govora“ u Ritterovoj su „zrinijadi“ još u prvoj polovini prošloga stoljeća u književnopovijesnim svojim priručnicima utvrdili Branko Vodnik i David Bogdanović, ${ }^{854}$ da bi svega nekoliko desetljeća

\footnotetext{
${ }^{852}$ Ova kratka - no generički gotovo paradigmatska - prisega u cijelosti glasi: „Usliši, o Bože, sad prisegu ovu, / i ti, grof viteže, nagni glavu tvoju, / da krajina može zet mi žitak v boju, / jer me ljubav veže zlit za nju krv moju. // Ako te ostavim živ, moj gospodine, / al virnost zatajim potribnoj krajine, / trisnulo me, prosim, z nebeske visine, / mrtva poždru, molim, paklenske dubine!“( V: 49-50).

${ }^{853}$ Štoviše, ratnički govor Nikole Šubića Zrinskog tako zatječemo čak i u anonimnoj (pučkoknjiževnoj) Pjesmi o Sigetu zabilježenoj u Prekomurskoj pjesmarici vjerojatno koncem 16. stoljeća.

${ }^{854}$ Usp. Vodnik 1913: 299 i Bogdanović 1932: 452.
} 
kasnije ponešto precizniji povjesnici poput Mihovila Kombola i Krešimira Georgijevića ${ }^{855}$ otvoreno upozorili kako se „i u Odiljenju (kao i u Obsidi) nalazi (...) banov oproštajni govor junacima“ (Kombol 1961: 280), misleći - makar u Kombolovu slučaju - upravo na pjesmu Ban junakom situiranu u drugi njegov „dil“. Ukoliko bi se pjesma Ban junakom (II: 269-347) doista mogla generički označiti kao primjerak ratnoga govora, tada bi njoj susjedni, znatno kraći pjesnički tekst naslovljen Junaci banu (II: 348-360) valjalo obilježiti kao „tipičan“ primjerak ratničke prisege ili zakletve, i to imajući u vidu kako u Odiljenju sigetskom ponovno imamo posla s „karnarutićevskim“ njezinim (pod)tipom, u kojemu se na poziciji govornika pojavljuje kolektiv sigetskih branitelja, a ne pojedinačni „vitezovi“, kao što to biva u petom pjevanju Obside.

Neovisno, međutim, od činjenice kako ih počesto nalazimo uklopljene u veća literarna ostvarenja, ratni govor i prisega praktični su, odnosno izvanknjiževni govorni žanrovi koji izvorno potječu iz vojne (militarističke) sfere, u kojoj služe ispunjavanju vrlo opipljivih ciljeva, i to ne samo podizanju morala pripadnika jedne vojske neposredno prije odlučujućega ratnog okršaja (ratni govor), već i ojačavanju zajedništva među istim tim pripadnicima vojnog kolektiva uoči nadolazeće bitke (prisega). Ratnomu govoru, ukratko, osnovni je cilj osnažiti motivaciju pripadnika vojne postrojbe za sudjelovanje $\mathrm{u}$ konkretnoj ratnoj akciji, i to ukazivanjem na njihovo višestruko potvrđeno ratno umijeće, evociranjem ranijih im vojnih uspjeha te podsjećanjem na „višu svrhu“ ratnog pothvata koji se spremaju izvesti, pri čemu se ne radi samo o žanru u kojemu subjekt - zapovjednik vojske - iskazuje otvorenu vjeru u sposobnosti svoje momčadi, nego i o svojevrsnom dijaloško-apelativnom tipu iskaza, kojim se od te iste momčadi pokušava isprovocirati adekvatna reakcija, tj. izravan odgovor. Taj odgovor, dakako, redovito dolazi u vidu prisege, posredstvom koje se vojnici individualno ili - znatno češće - kao dio vojnoga kolektiva zapovjedniku zaklinju na odanost te mu obećaju hrabru borbu protiv neprijatelja u skladu s utvrđenim idealima zbog kojih je čitava akcija i poduzeta (u slučaju Odiljenja ti su ideali vjernost Bogu, kralju i domovini), iz čega bi slijedilo da je zakletvu nužno shvatiti ponajprije kao potvrdu da je postrojba ispravno razumjela i prihvatila zapovjednikove poruke i naređenja, da je spremna na okršaj te da će biti posve odana zapovjedniku, točnije onomu što on u materijalnu i nematerijalnu pogledu predstavlja.

Kapetanov ratni govor, za kojim (najčešće) slijedi srčana zakletva vojnoga kolektiva, spadali bi u krug možda i najstarijih fabularnih sastavnica svojstvenih pisanoknjiževnim

${ }^{855}$ Usp. Georgijević 1969: 132-134. Valja, međutim, imati na umu kako Georgijević „oproštajnim govorima“ u Odiljenju proglašava čak i poslanice što ih Zrinski piše i odašilje kraju i hrvatskom „orsagu“, što će reći da to generičko rješenje shvaća znatno šire od svoga prethodnika, odnosno da „oproštajni govor“ za njega nipošto ne označava isključivo ratni govor zapovjednika suborcima izrečen u trenucima neposredno uoči konačnog okršaja. 
povijesnim epovima, što će reći onima koje nalazimo već u - primjerice - Vergilijevoj Eneidi, ali i onima koji će - stoljećima kasnije - podjednako važno mjesto imati i u za baroknu epskopjesničku produkciju uzornim ostvarenjima poput Tassova Oslobođena Jeruzalema, u kojem ga susrećemo u 20. njegovu pjevanju. Ta kontinuirana zastupljenost ovih originalno izvanknjiževnih, vojničkih govornih žanrova u fakturi junačkih epskih pjesama mogla bi se, dakako, protumačiti ponajprije sadržajnim imperativima, točnije namjerom epika da prizivanjem obilježja karakterističnih za žanrove iznikle iz onoga „područja“ ili aspekta svakodnevice o kojemu je i u samome tekstu riječ pokušaju osnažiti utisak povijesnosti opjevanih događaja, odnosno jače naglasiti njihovu stvarnu (izvanknjiževnu) podlogu, a samim time i istaknuti prijelomni značaj što su ga oni imali tijekom višestoljetnoga povijesnog hoda konkretne zajednice koja je njima bila pogođena. I baš kao što su ti epski pjesnici računali s time da će čitatelji njihovih epova u dionicama napučenima generičkim značajkama ratnoga govora i prisege lakoćom prepoznati ona ista žanrovska rješenja redovito evocirana u ratnim okolnostima, točnije u ,ulozi“ neizbježnih pratitelja svih ratnih akcija, s identičnim je generičkim ,predznanjem“ svoje publike također računao i sam Vitezović, svjestan i da će - $\mathrm{k}$ tome - velik dio te iste publike prisutnost zakletve i ratnoga govora ujedno shvatiti i kao indikator „epskosti“ njegove ,zrinijade“, pa i usprkos činjenici da je u njegovu slučaju riječ o žanrovskim sastavnicama koje ne dolaze u „uobičajenome“ epskopjesničkom formalno-sadržajnom okviru, već u generički šarolikom i jednoznačno teško odredivu tekstu. Ipak, kao jedni u nizu - bahtinovski rečeno - primarnih govornih žanrova (po svome statusu i funkciji istovjetnih - primjerice - pozdravima, oslovljavanjima, dijalozima itd.), ratni govor i prisega i u Odiljenju su neizbježno postali „tek“ generičkom komponentom obuhvatnijega, sekundarnog govornog žanra, i to usprkos činjenici što ih u ovome konkretnom slučaju nije u sebe apsorbirao tekst kojega je moguće identificirati (samo) kao povijesnu epsku pjesmu ili točnije rečeno - tekst čiji su (i) epskopjesnički žanrovski identitet dosad prepoznali tek pojedini njegovi recipijenti. Vitezovićeva generički zamršena i iznimno slojevita „zrinijada“ po pitanju upijanja tekstualnih karakteristika zakletve i ratnoga govora u okvirima naše sedamnaestostoljetne književnosti ipak neće predstavljati izuzetak, što će ujedno reći i da (pisano)književno prizivanje ovih dvaju vojnih primarnih žanrova nipošto ne bi trebalo držati svojstvenim samo i isključivo žanru (baroknoga) junačkog epa.

Naprotiv, da (mahom) žanr zapovjednikova motivacijskog govora ili zasebna njemu svojstvena obilježja tijekom našega 17. stoljeća s vremena na vrijeme neće postajati svojinom jedino epskopjesničkih tekstova ponajbolje se - osim iz Vitezovićeva Odiljenja - možemo uvjeriti i na primjeru poetske zbirke Gartlic za čas kratiti Frana Krste Frankopana, koji u nju, 
između ostalih, uvrštava i pjesmu pod prilično indikativnim naslovom Pozvanje na vojsku. Radi se, konkretno, o slobodnom prepjevu pjesme Invito alla guerra što ju je u Frankopanu posebno dragu lirskopjesničku zbirku Diporti svojedobno uključio austrijski pjesnik Leopold Wilhelm Crescente i koja će u hrvatskoj svojoj inačici biti „obogaćena“ čak i prepoznatljivim motivima (pučkih i usmenih) vojnih pjesama (primjerice, motivima „vere kerščanske“ i „turskoga miseca“) što su ih u to vrijeme pjevali mnogi domaći sudionici protuturskih ratova. ${ }^{856}$ Sadržaj Pozvanja na vojsku svodi se, ukratko, na pozive što ih lirski subjekt (očigledno zapovjednik jedne vojne jedinice) upućuje ponešto inertnim svojim vojnicima potičući ih da se priključe ratnim akcijama, odnosno da se što prije trgnu iz letargije te pronađu u sebi hrabrost za nove ratne podvige jer je - posebno se ističe - samo dobar glas što se stječe junačkim djelima, a naročito uslijed herojske smrti na bojišnici jedini zaista vrijedan i neprolazan. Osim što subjekt kao posebno važan detalj svakoga ratnog pothvata ističe Božju pomoć, koju u svakome trenutku valja iskreno zazivati, ključem pobjede on ipak ističe zajedništvo, i to gotovo bratsku povezanost među vojnicima i odanost kapetanu, ali i zapovjednikovu odanost njemu podređenim suborcima, pa pored neprekidnoga isticanja jedinstva i zajedništva (forsiranjem zamjenice „mi“), ujedno on vojnicima obećaje kako u samoj bitci neće ustuknuti, već će se uz njih nastaviti boriti sve do posljednjega trenutka.

Frankopanov slobodni prepjev Crescenteova lirskog poziva u rat nameće se, dakle, kao izvrstan primjer sedamnaestostoljetne uklopivosti žanra ratnoga govora u generički raznoliko realizirana pisanoknjiževna ostvarenja, a ne samo ona s dominantnim obilježjima barokne povijesne epske pjesme. Uz to što je, dakle, Pozvanje na vojsku moguće izdvojiti kao bjelodan dokaz da su prepoznatljive karakteristike ratnoga govora u ranonovovjekovnoj književnosti s podjednakim uspjehom asimilirane čak i u žanrove lirske pjesme, ujedno ovaj pjesnički tekst može poslužiti i kao pokazatelj izrazite konvencionaliziranosti toga izvanknjiževnog žanra, koji je otprilike jednakim rasponom posve identičnih značajki oplemenjivao kako pojedine dionice epskopjesničkih ostvarenja stranih i domaćih epika, tako i lirske pjesme nalik onima Crescentea i Frankopana, ali i generički „mutna“ djela kakvo je i Odiljenje sigetsko Pavla Rittera Vitezovića. U tom smislu, ni najmanje nas ne bi trebalo čuditi to što po pojedinim formalnim i naročito sadržajnim svojim posebnostima Frankopanova „budničarska“ pjesma neodoljivo nalikuje ratnim govorima iz epa Petra Zrinskog i Vitezovićeve ,zrinijade“, odnosno što u svome tekstu ,tipično“ srednje duljine (protegnutom

${ }^{856}$ Podrobnije o tome u: Potočnjak 2015: 125. 
na sveukupno 35 stihova) $)^{857}$ riječ prepušta vojnom zapovjedniku, koji se - svjestan ratne opasnosti i nužnosti suprotstavljanja neprijatelju - moral svoje postrojbe trudi podignuti podsjećanjem na dosadašnje zajedničke ratne uspjehe, učinjene viteške pothvate te slavan glas kojega su tim svojim podvizima uspjeli steći. Iako se ni u Frankopana, ni u drugih autora pritom ne propušta upozoriti na iznimnu moć i silinu protivnika, jednako se tako ne zaboravlja iskazati ni bezgranična vjera u ratne sposobnosti pripadnika postrojbe, a naročito istaknuti zajedništvo („mi ćemo se pobiti...“) kao možda i najveća snaga ovoga vojnog kolektiva uz dakako - pravovjerje, koje ih dodatno osnažuje i tjera da se suprotstave „poganim“ protivnicima sklonima svakojakim prevarama i podlim radnjama, a sve to imajući na umu junaštva predaka, za koja se očekuje da će ih u svojim ratnim pothvatima slijediti kao uzor. Naglasivši im kako je časno na bojnom polju poginuti boreći se za „više ideale“ (kršćansku vjeru, domovinu, kraljevstvo, narod, obitelj id.) te kako je samo takva smrt jamstvo vječne slave, zapovjednik suborcima obećaje da će se boriti uz njih do samoga kraja te ih sve zajedno još jednom hrabri, potičući ih da budu odvažni i bez okolišanja se suprotstave „poganskom“ neprijatelju, tražeći od njih na koncu da mu prisegnu na vjernost. Pored nabrojanih sadržajnih naglasaka, kao gotovo neizostavan se moment ovih ratnih govora nameću još i izraziti religiozni motivi, i to u vidu percipiranja ratnog sukoba kao isključivo Božje volje (neprijatelj je - prema tom mišljenju - poslan od samoga Boga ne bi li kršćansku vojsku stavio u iskušenje, odnosno testirao njezinu vjeru, hrabrost i domoljublje) te naglašavanja važnosti apsolutnog pouzdavanja u Boga, njegovu moć i volju, ponajprije stoga što je on na njihovoj strani i uvijek će - bez obzira na konačni ishod bitke - samo na njoj i biti.

Ako bi se Ritterova pjesma Ban junakom u tom smislu mogla izdvojiti kao gotovo ogledni primjerak versificiranoga ratnog govora, skrojen od svih netom pobrojanih njemu svojstvenih (sadržajnih) elemenata, tada bi isto - govoreći, dakako, u kontekstu žanra prisege ili zakletve - valjalo učiniti i s višestruko kraćom pjesmom Junaci banu, koja se nameće kao generički znatno „,̌išće“ poetsko ostvarenje u kojemu se pripadnici čete sigetskih branitelja zajednički zaklinju na vjernost i odanost svome zapovjedniku (,Naše ti vernosti pod zapovid stoje“; II: 356) te izražavaju apsolutnu spremnost da se predvođeni njime upuste u posljednji okršaj s mrskim neprijateljem (Ziti na poboje i u njih opasti / srce gotovo je kot na pirne slasti“; II: 357-358). S obzirom na to da se subjekt(i) u prisegi tijekom samoga čina zaklinjanja na vjernost redovito pozivaju na uzvišeniju svrhu ratovanja, odnosno prisežu imajući u vidu više ideale koji se - s ljudskoga i moralnog aspekta - drže posve neupitnima,

${ }^{857}$ Kao zajednička formalna odlika ratnih govora mogla bi se izdvojiti njihova relativno podudarna (srednja) duljina, koja ne prelazi 120-ak stihova, koliko ih broji najdulji govor sigetskoga kapetana u petom pjevanju Petrove Adrijanskoga mora Sirene. 
nimalo nas u pjesmi Junaci banu ne bi trebala iznenaditi neizravna evociranja ideje o pogibiji na bojnome polju kao ulaznici u vječni nebeski život (,,venci nam se goje posrid rajske vlasti“; II: 360), razrađene kako u prethodnom ratnom govoru bana Zrinskog, tako i na više drugih mjesta duž teksta. Fokusirajući se, međutim, na prisegu kao autohtono izvanknjiževni govorni žanr - za prepoznatljivim obilježjima kojega se, u „kompletu“ s onima ratnoga govora, nije ustručavao posegnuti ni naš autor - neće biti zgorega pripomenuti kako se u isti mah radi i o žanrovskom rješenju učestalo prisutnom i u sferi usmene književnosti, pa i usprkos činjenici što ta spoznaja u kontekstu ove naše analize ne bi trebala imati posebno velik značaj. Naime, sadržajna naslonjenost pjesme Junaci banu na prethodni ratni govor Ban junakom, a uz to i činjenica da na njezinu suženom tekstualnom prostoru ne zatječemo niti jedan tematsko-motivski, formalni ni stilski element karakterističan za zapise autohtonih folklornoknjiževnih tvorevina, sami nas od sebe navode na to da kao vjerojatan generički uzor ove lirske prisege pokušamo zamisliti isključivo izvanknjiževna ostvarenja ili makar pisanoknjiževnim djelima posredovana neka od tih i takvih ostvarenja, osobito prisjetimo li se da se - osim na vlastito vojno iskustvo - pri sastavljanju ove dionice Vitezović mogao i morao glavninom ugledati upravo na one primjerke prisega što su ih u svoje „zrinijade“ sustavno inkorporirali neposredni mu literarni prethodnici.

\section{4. 3. Pouke}

Imajući u vidu ponajprije kontekst koji ju je iznjedrio, ali i već višestruko prepoznatu suvremenost Vitezovićeva stvaralačkog postupka, ni najmanjim kuriozitetom nipošto ne bismo trebali proglašavati činjenicu kako je u njegovoj „zrinijadi“ iznimno dubok trag ostavila i većini baroknih literarnih ostvarenja svojstvena sklonost didaktičnosti, odnosno podastiranju poučnih, usputnih filozofsko-refleksivnih zapažanja. Ritterovo je povođenje za tom sklonošću u Odiljenju sigetskom pritom najuočljivije upravo u onim - opsegom ne odveć dugim - dionicama teksta posvećenima pretresanju tipično baroknih pitanja prolaznosti, neizbježnosti smrti, prevrtljivosti sreće i njima sličnim, generički redovito „nadograđenima“ još i (ulančanim) primjercima motivski srodnih poslovica, kojih se svrha svodila upravo na poučavanje ili - bolje rečeno - podsjećanje recipijenata na ideje utkane u ideološkosvjetonazorske temelje neprekidnim društvenopovijesnim previranjima obilježena razdoblja što ga nazivamo baroknim u njegovoj cijelosti. Potonji ,poučni segmenti“, odnosno neveliki razmatralačko-refleksivni odsječci Ritterove ,zrinijade“, glavninom koncentrirani u 1. i 3. njezinu „dilu“, zbog te bi se svoje jasno izražene didaktičke funkcije generički mogli i morali 
okarakterizirati kao prilično uspjeli primjerci pouke, odnosno poluknjiževnoga žanra što vuče svoje porijeklo još iz Biblije i koji je tijekom svoga (književno)povijesnog trajanja ponajviše bio raširen u filozofskome stvaralaštvu te naročito u nabožno-didaktičnoj književnosti (gdje je pretežno egzistirao u obliku vjerske pouke), redovito ondje - s obzirom na to da je nastojao progovarati o svakodnevnim, općim pojavama na poučan način - izvršavajući jasnu praktičnu svrhu. Pouka kao žanr, drugim riječima, (do)nosi neke općeživotne smjernice, odnosno poučava ne bi li izmamila odgovarajuću praktičnu reakciju čitatelja ili slušatelja u konkretnim životnim situacijama, što je - kako se čini - trebao biti i cilj pojedinih dionica iz prvoga (ratni izvještaj Sigeta) i trećeg (dijalog putnika i Jeke) „dila“ Odiljenja, za koje je s punim pravom moguće konstatirati da sadržajno funkcioniraju kao pouke budući da u njima neke „vječne“ životne istine otkriva Siget ucviljenim majkama i udovicama sigetskih branitelja, a Jeka neobično znatiželjnomu putniku slučajniku. Ove dionice pritom ne samo što na ,punokrvne“ primjerke pouka jasno podsjećaju svojom formalnom dimenzijom, točnije relativnom (za pouke posve uobičajenom) kratkoćom, već takav svoj generički identitet dodatno osnažuju i samim unutartekstualnim statusom, odnosno činjenicom da navedeni govornici $\mathrm{u}$ „svijetu djela“" upravo za njima ciljano i posežu u nakani da adresata upute u stanovita životna „pravila“, trudeći se k tome da im razumijevanje tih korisnih pouka olakšaju i nizom dodanih poslovica kao svojevrsnih mudrih, a ujedno jezgrovitih i pučkom „umu“ shvatljivih potvrda.

Žanrovski posve identično realiziranih segmenata - redom, doduše, uklopljenih u iskaze pripovjedača, a ne one konkretnih likova - neće manjkati ni u mnogim našim sedamnaestostoljetnim povijesnim epovima, počevši - primjerice - s onima Ivana Gundulića i Petra Kanavelića, pa sve do Obside sigecke Petra Zrinskoga, po uzoru na čije će poučne epske odsječke Pavao Ritter Vitezović u najvećoj mjeri najvjerojatnije i ispjevati pouke kojima su ispresijecana rečena dva „dila“ njegova hrvatskog prvijenca. Naime, osim što je i u Petrovu slučaju tako riječ o didaktičnim dionicama protegnutima na najviše četiri strofe, ${ }^{858}$ u kojima se raspreda o pitanjima nestalnosti i prolaznosti, sreće i nesreće, neizbježnosti sudbine i Božjoj pravednosti, časnoga umiranja na bojnome polju, pogubnim posljedicama nepromišljenosti i impulzivnosti, hrabrosti i drugim pozitivnim vrlinama itd., ujedno se radi i o segmentima teksta bremenitima poslovicama ili sentencijama, kojima se - kao i u Ritterovu slučaju - potkrjepljuju, odnosno „učvršćuju“ netom prezentirane pouke, vjerojatno i u cilju njihova što lakšeg upamćivanja. Inače, mjestimičnim poslovicama bili su već protkani i vrlo

\footnotetext{
${ }^{858}$ Poučni odsječci u Opsidi sigeckoj isključivo su situirani na počecima pojedinih pjevanja, pri čemu se kao najopsežnije izdvajaju pouke što ih zatječemo u prvim strofama četvrtog (IV: 1-4), petog (V: 1-4) i desetog pjevanja (X: 1-4), dočim su one u uvodima šestog (VI: 1-2) i jedanaestog pjevanja (XI: 1-2) upola kraće. Didaktični segmenti kojima se otvaraju treće (III: 1) i trinaesto pjevanje (XIII: 1) zapremaju - pak - tek jednu jedinu strofu.
} 
dojmljivi poučni dijelovi u Gundulićevu Osmanu, u kojima su pripovjedača ponajviše zaokupljali problemi prolaznosti moći i ljepote, pogubnosti mladenačke taštine i nepromišljenosti, varljivosti istine i laži i dr., a ne treba zaboraviti ni da su poslovice s vremena na vrijeme ulazile čak i u didaktične odsječke žanrovski drugačije realiziranih naših baroknih ostvarenja, među kojima će uvjerljivo prednjačiti ona sjevernohrvatskih onodobnih pisaca. Poslovicama „nadograđene“ tipično barokne pouke o prolaznosti svih zemaljskih stvari, pogubnoj taštini, neizbježnosti smrti, a onda i posljednjega suda - između ostalih - u svome će Zvončacu tako donijeti Matijaš Magdalenić, no daleko zanimljivijom ispostavit će se činjenica kako od uključivanja pouka nisu zazirali čak ni anonimni sastavljači lirskih i epskih pjesama zabilježenih u sedamnaestostoljetnim kajkavskim rukopisnim pjesmaricama. Govoreći o inkorporiranju poučnih segmenata u druge (,neepske“) onodobne književne žanrove, vrijedi podsjetiti i kako je - polazeći od ranijega književnopovijesnog zapažanja kako se u baroknome plaču ,značajne partije teksta oblikuju po uzoru na pojedine govorne procedure kršćanskoga obreda: po uzoru na propovijed, molitvu ili ispovijed“" (Kravar 1993: 183) - Julijana Matanović na primjeru Uzdaha Mandalijene pokornice Ignjata Đurđevića svojedobno utvrdila da, pored elemenata iz brojnih vjersko-didaktičkih, odnosno liturgijskih žanrova (molitva, traktat, ispovijed, propovijed, pasija itd.), važnu ulogu (i) u fakturi barokne religiozne poeme doista igra žanr vjerske pouke. ${ }^{859}$ Pritom bi činjenica kako u Đurđevićevim Uzdasima duljinom skromnu pouku redovito nalazimo uključenu u opsežnije segmente teksta u kojima dominiraju značajke drugih, kompleksnijih liturgijskih žanrova (ponajvećma ispovijedi) upućivala na uobičajen način egzistiranja pouke u okrilju onodobnih „,neepskih“ žanrova, u kojima su ti didaktični odsječci obično priključivani „većim“ žanrovima, odnosno evocirani unutar dionica napučenih karakteristikama drugih generičkih rješenja, kao što je to uostalom - vidljivo i iz primjera Vitezovićeva Odiljenja.

Imajući ovo na umu, neće nam preostati ništa drugo no predodžbu o repertoaru karakterističnih obilježja (barokne) pouke pokušati stvoriti na temelju „seciranja“ upravo onih njezinih primjeraka sadržanih u generički kojekako ostvarenim sedamnaestostoljetnim književnim i ne samo književnim tekstovima, odnosno utkanih u pojedine njihove dionice $s$ visokom koncentracijom značajki ovoga ili onog žanrovskog rješenja. Ono što ćemo pritom zamijetiti kao njihovu možda i najprepoznatljiviju - a maločas već spomenutu - osobinu jest relativna formalna kratkoća (riječ je o didaktičkim odsječcima duljine od - najčešće - tek nekoliko stihova, iako u pojedinim slučajevima oni bivaju „rastegnuti“ i na nekoliko strofa), koja je u oštroj opreci spram sadržajne im ozbiljnosti, odnosno filozofičnosti što se

\footnotetext{
${ }^{859}$ Detaljnije u: Matanović 1992: 71-97.
} 
manifestira kroz težnju razmatranja konkretnih „ključnih“ životnih istina. Poučne konstatacije koje iz takva razmatranja proizlaze usto su čvrsto ideološki utemeljene i proistječu iz kršćanskoga svjetonazora ili drugih baroku bliskih (pretežno neostoicističkih) filozofskih ideja, a njihova se svrha svodi na to da čitatelju pruže sažetu moralističku, a ujedno i praktično primjenjivu općeživotnu uputu ili smjernicu ne bi li posredstvom nje usmjerile i njegova buduća razmišljanja i akcije. Želeći ispuniti svoju unaprijed određenu svrhu, pouka razvija vrlo intenzivne slike kojima pokušava što upečatljivije djelovati na publiku, a pritom nerijetko pribjegava čak i personificiranju motiva koji je predmet „lekcije“, kao što je to primjerice - učinjeno i u nešto duljoj vjerskoj pouci o ljepoti iz drugoga plača Gundulićevih Suza sina razmetnoga, u kojoj sin - izravno joj se obraćajući - ljepotu predstavlja kao nestalnu i pogubnu pojavu koja snosi odgovornost za mnoge nepovoljne pojave u rasponu od čestih razvrgnuća brakova do nagle propasti čitavih gradova.

$\mathrm{Na}$ strategiju personificiranja objekta pouke Vitezović će se osloniti pri sastavljanju gotovo svih didaktičnih odsječaka u svome Odiljenju sigetskom, pa će tako u uvodnoj heroidi Siget hrvatskim gospojam u poučnoj dionici o nestalnosti sreće (I: 51-64) personifikaciju u nemilosrdnu pojavu ,zaslužnu“ za propast Sigeta doživjeti upravo sreća, u pouci o neizbježnosti smrti (I: 381-388) u sveprisutnu silu kojoj je nemoguće umaknuti bit će personificirana smrt, dočim će se u poučnom segmentu posvećenom hirovitoj sreći i svemoćnoj smrti (I: 419-424) zajedno pojaviti smrt i sreća, i to personificirane u neizbježne pojave od kojih se čovjeku nemoguće sakriti, a kamoli spasiti. Za vrlo kratkom poukom o neizbježnosti smrti uključenom u iskaz sigetskoga kapetana u pjesmi Ban sinu, u kojoj je smrt predstavljena kao svojevrstan lovac u čije „,...) mriže svakomu je pasti, / zgrabi ga srid hiže i najveće vlasti““ (I: 508-509), nastupit će kratki predah od poučnih dionica, kojega će prekinuti slijed od čak četiri pouke uklopljene u pjesmu s figurom jeke Putnik $i$ Jeka trećega „dila“. U prvoj od njih, koja predstavlja kraći didaktički osvrt na nestalnost sreće (III: 99-106), personifikaciju će ponovno iskusiti sreća, još jednom prikazana kao prevrtljiva pojava u koju je teško (zapravo, posve nemoguće) proniknuti, dočim u dvjema nešto kasnijim, znatno duljim poukama o pogubnosti ljubavi (III: 229-250 i 277-300) predmetom personifikacije postaje ljubav, zamišljena kao hirovita sila kojoj ne polazi za rukom smiriti se na jednom mjestu, zbog čega (pre)često postaje uzročnikom raznih ljudskih nevolja. Od četiriju poučnih segmenata Putnika $i$ Jeke personifikacijom će ostati neokrznuta tek (kritički izrazito nastrojena) pouka o suvremenim ženama i njihovoj nedovoljnoj posvećenosti muževima (III: 135-150), u kojoj bi - iz posve razumljivih, već golim okom vidljivih sadržajnih razloga personifikacija sama po sebi ionako predstavljala suvišan dodatak. 
Motreći pobrojane didaktičke odsječke Vitezovićeve „zrinijade“ kao primjerke (barokne) pouke, popriličnom bismo lakoćom trebali uočiti kako - pored utvrđene težnje „oživljavanju“ predmeta o kojemu se iznose poučni sudovi - posjeduju oni redom sve one značajke što smo ih maločas izlučili kao karakteristične za sedamnaestostoljetnu (literarno posredovanu) pouku. Uz to što je, konkretno, riječ o kraćim dionicama, čija se poučnost (pa onda i praktična uporabljivost) postiže ukazivanjem na „vječno“ važeće životne istine te izvođenjem korisnih općeživotnih smjernica, ujedno se radi i o dijelovima u kojima se upečatljivost iznesenih uputa dodatno pokušava osnažiti ne samo personificiranim pojavama, već i dojmljivim, čitateljima istovremeno zaprepašćujućim i privlačnim motivima poput primjerice - onoga vječno vrebajuće i svemoćne smrti, čije se „djelovanje“ na čovjeka u pouci utkanoj u uvodni izvještaj Sigeta neizravno prispodobljuje odnosu između nemilosrdnoga lovca i u stupicu stjerane lovine (,Na koga se gane, predobi človika, / i komu da rane, ni mu ranam lika. / Pod nje vlasti dika i jakost opada, / od vika do vika smrt na svitu vlada“; I: 275278). Nemoguće je, osim toga, previdjeti i kako Ritter u didaktičnom „okviru“ svojih poučnih dionica zapravo prezentira ideološki jasno profilirana shvaćanja, odnosno mahom ideje što su ih glavninom pretresala u baroku izuzetno obljubljena neostoicistička filozofska razmatranja, no uz bok njima - jednako tako - ne propušta uključiti ni neke temeljne, prepoznatljivo kršćanske zamisli koje su se posebno važnima ispostavljale upravo u to nemirno protureformacijsko doba. Na kraju krajeva, svoje poučne segmente bremenite tim korisnim i „aktualnom“ ideologijom prožetim općeživotnim uputama Vitezović - nalik drugim baroknim autorima - inkorporira u dijelove teksta koje je zbog visoke koncentracije značajki iz generičkih repertoara pojedinih književnih žanrova moguće relativno precizno (ali i nejednako) generički odrediti, pri su čemu pouke donesene u prvome „dilu“ tako utkane u žanr (barokne) fiktivne poslanice ili heroide, pritom još i dodatno „,nadograđene“ vrlo izrazitim karakteristikama (književne) konzolacije, ${ }^{860}$ dok su one što smo ih locirali u trećem „dilu“ postale integralnim dijelom pjesme koju smo ranije identificirali kao primjerak žanra (barokne) eho-pjesme ili versus echoici.

Pretpostavimo li da je ključni poticaj i primarni uzor za ove pouke naš autor doista iznašao u didaktičnim dijelovima Obside sigecke svoga neposrednog prethodnika, nimalo ishitrenima ne bi nam se trebali činiti sudovi poput onoga Pavla Pavličića, koji - motreći Vitezovićevo ostvarenje iz perspektive Petrove „zrinijade“ - ustvrđuje kako „Odiljenje nije

\footnotetext{
${ }^{860}$ Dapače, u uvodnoj heroidi Siget hrvatskim gospojam te se didaktične dionice vrlo s(p)retno isprepliću upravo sa segmentima obogaćenima većom koncentracijom konzolacijskih generičkih obilježja, u sklopu kojih se i nameću kao utješni, a ujedno i poučni (racionalni) argumenti što ih personificirani Siget upućuje neutješnim članicama obitelji poginulih sigetskih branitelja ne bi li (i) posredstvom njih pokušao makar donekle ublažiti neizrecivu bol koju im je uzrokovao gubitak najmilijih.
} 
samo lirski komentar, nego također i skup filozofskih pouka što iz starijega spjeva slijede“ (Pavličić 2007: 278). Usprkos prilično očitoj činjenici da je Zrinski pouke u svome tekstu ne samo tretirao na bitno drugačiji način, nego i da im je pridavao znatno manju važnost no što će to kasnije činiti Pavao Ritter Vitezović, ${ }^{861}$ već i golim je okom moguće zapaziti kako između poučnih dionica Obside i Odiljenja (po)stoji čitav niz dodirnih točaka, među kojima bi posebnu pozornost definitivno trebalo obratiti na poslovične (sentencijske) potvrde, koje oba autora u gotovo podjednakoj mjeri rabe ne bi li jače istaknuli pojedina didaktična zapažanja. S obzirom na to da se i u Rittera i u Petra Zrinskog didaktički odsječci sadržajno zasnivaju na ukazivanju na neku pojedinačnu situaciju ili konkretan primjer, odnosno na izvlačenju pouke iz danoga primjera ili razotkrivanju „trajne“ općeživotne istine koja je u njemu sadržana, svrha njihova nadopunjavanja poslovicama u djelima njih obojice svodila se zapravo na poentiranje poučnih zaključaka, njihovo ovjeravanje, a ujedno i na jezgrovito preformuliranje same pouke, njezino pojednostavljivanje, $\mathrm{i}$ to ponajprije $\mathrm{u}$ cilju približavanja recepcijskoj logici slabije obrazovanih čitatelja zadojenih na usmenoj književosti, u kojoj je „rezervoar“ životnih mudrosti praktično primjenjivih u svakoj prilici predstavljao upravo žanr poslovice. Bilo kako bilo, Ritterovo inkorporiranje primjeraka (barokne) pouke u tekst generički šarolikoga mu hrvatskog prvijenca moglo bi se i moralo okarakterizirati kao jedan od daleko najupadljivijih baroknih postupaka, naročito znamo li da je sveopća pomama sedamnaestostoljetnih (domaćih i navlastito inozemnih) pisaca za tim usputnim - i najčešce neobično jezgrovitim - filozofskim i nabožnim didaktičkim osvrtima u najvećoj mjeri bila inicirana jasno formuliranim imperativima same barokne poetike.

\section{4. 4. Kronogrami}

Naslovno sugeriranje da se naša analiza u nastavku neće propustiti pozabaviti čak ni primjercima kronograma što ih Pavao Ritter Vitezović također donosi na stranicama Odiljenja sigetskog za početak bi - razumljivo - samo od sebe iziskivalo nekoliko prijeko potrebnih genoloških pojašnjenja. Konkretno, s obzirom na povijesni pristup žanrovskom materijalu, za koji smo se još u uvodu rada bili odlučno opredijelili, ovaj nas pokušaj da se kronogram razmotri u kontekstu drugih (poluknjiževnih i izvanknjiževnih) žanrova nipošto ne bi trebao ostavljati u nedoumici, posebice imamo li na umu kako je u baroknoj optici kronogram - kao

\footnotetext{
${ }^{861}$ Naime, kako uočava Pavličić, „sam se Zrinski (...) u takve pouke upuštao vrlo rijetko i odmjereno; učinio bi to obično na početku svakoga pjevanja, a i to više iz strukturalnih razloga nego radi sadržaja samih tih razmatranja. Ono što je on tek dotakao, Vitezović u svojim pjesmama razrađuje; njemu kao da i jest najviše stalo da pokaže koje sve pouke slijede iz Sirene“" (Pavličić 2007: 278).
} 
izvorno retoričko-pjesnička figura srednjovjekovne provenijencije - najvjerojatnije tretiran ne samo kao puki formalni eksperiment ili postupak, ${ }^{862}$ već i generički, odnosno kao svojevrsna slovno-brojčana zagonetka koja je od recipijenta tražila da se upusti u njezino odgonetavanje. Da je tomu jamačno moralo biti tako naslućujemo ponajvećma iz činjenice kako su barokni (i ne samo barokni) pisci kronogramima najčešće težili prožeti konkretan (obično kraći) tekst pretežno lirsku pjesmu ili stihovanu posvetu - u njegovoj cijelosti, kao što je to, uostalom, u više navrata učinio i sam naš autor, u čijem su opusu kronogrami daleko najrašireniji u paratekstualnim, točnije posvetnim dionicama literarnih, historiografskih i inih mu ostvarenja.

Tražimo li najprecizniju definiciju ove figure, formalnog eksperimenta i/ili ,žanra“, mogli bismo - krajnje pojednostavljeno - kazati kako je kronogram ništa drugo no jedna (pod)vrsta kriptograma, u kojemu je pojedinim slovima (I, V, X, L, C, D, M) - nužno ispisanima ili otisnutima verzalom kako bi sam kronogram uopće mogao biti prepoznat kao takav - pridana konkretna brojčana vrijednost, odnosno koja je nužno otčitati kao rimske brojeve, kojih konačan zbroj najčešće daje godinu nastanka teksta ili njegova pojavljivanja u tiskanu obliku. ${ }^{863}$ Prvotno shvaćen isključivo kao pjesničko-retorička figura, kronogram je od svojih začetaka ponajviše bio usredotočen na ispunjavanje zabavljačkih funkcija, trudeći se brojčano-slovnim zagonetljajima privući čitateljevu pozornost i zabaviti ga, što i jest bio temeljni razlog zbog kojega su za njim - u želji da publici demonstriraju svoju maštovitost, dovitljivost i uopće meraviljoznost - toliko često i posezali sedamnaestostoljetni literati, među kojima, dakako, i sam Pavao Vitezović. Pored Odiljenja sigetskog, u kojemu donosi kronograme u čijim rješenjima se krije godina u kojoj se zbila bitka za Siget, možda i najuspjeliji, a svakako najupečatljiviji primjerak kronograma Ritter će prezentirati u posveti čuvene svoje latinske spomenice Oživljena Hrvatska - adresirane na habsburškoga kralja Leopolda i njegova sina, prijestolonasljednika Josipa - rješenje kojeg čitatelju otkriva upravo godinu pisanja, sastavljanja posvete, a onda i tiskanja toga njegova historiografskog teksta.

S izuzetkom Odiljenja sigetskog, Vitezović je kronograme - kao jedno od izrazito mu omiljelih formalnih (,žanrovskih“) rješenja - redovito podastirao isključivo u okvirima svojih latinskih ostvarenja, pa će ih tako već u godinama uoči objelodanjivanja prvijenca na hrvatskom jeziku uključiti najprije u enigmatsko djelo Nova equestris imago (1682.), potom (para)tekstove panegiričkih pjesama Sacer chorus seu applausus metricus a Phoebo et Musis celebratus (1682.) i Corona lauro-palmaris (1682.), ali i u one pohvalne pjesme Novus Jason

\footnotetext{
${ }^{862}$ O kronogramu kao formalnom eksperimentu detaljnije u: Stepanić 2005: 202-203 i 2016: 336-337.

${ }^{863}$ Odnosno, u nešto s(p)retnijoj definiciji Gorane Stepanić, kronogram je natpis „u kojem se zbrajaju vrijednosti onih slova koja u rimskom sustavu zapisivanja brojaka imaju brojčanu vrijednost“, pri čemu ,zbroj njihovih vrijednosti daje obično godinu nastanka ili izdanja djela“" (Stepanić 2016: 336).
} 
Hungariae (1682.) te maločas spomenute prigodnice Novus Skenderbeg (1682.), ${ }^{864} \mathrm{koju}-\mathrm{ne}$ mareći za činjenicu da je ispjevana latinštinom - napučuje i nekolicinom karakteristično usmenoknjiževnih elemenata za kojima će kasnije posegnuti i u generički daleko kompleksnijoj vernakularnoj ,zrinijadi“. Pobrojani književni i poluknjiževni tekstovi, međutim, ne predstavljaju jedine latinske sastavke $u$ kojima je Ritter $u$ godinama prije objavljivanja Odiljenja brusio vještinu sastavljanja ove enigmatske figure ili žanra budući da je kronogramima također držao nužnim obogaćivati čak i (latinske) poslanice što ih je u razdoblju između 1682. i 1684. ustrajno odašiljao različitim adresatima u zemlji i inozemstvu, pri čemu se u njihovu slučaju mahom radilo o kronogramima situiranima u naslovima, koji su otkrivali godinu sastavljanja tih stihovanih pisama. ${ }^{865}$ I baš kao što će kronogrami ostati gotovo stalnim dodatkom njegovih pjesničkih poslanica i u godinama, pa i desetljećima nakon što Odiljenje ugleda danje svjetlo, njima također neće oskudijevati ni niz kasnijih Vitezovićevih literarnih i ne samo literarnih ostvarenja, u pretežno paratekstualnim dionicama kojih će kronogrami pritom nerijetko biti kombinirani s drugim pjesničkim i kombinatoričkim postupcima poput - primjerice - rimovanih heksametara. ${ }^{866} \mathrm{U}$ tom smislu, Odiljenje će $\mathrm{u}$ Ritterovu stvaralačkom opusu zaista nastaviti „stršati“ kao jedini njegov sastavak na hrvatskom jeziku u kojemu zatječemo primjerke kronograma, što bi - samo od sebe navodilo na zaključak kako je predstavljanjem toga formalnog rješenja vrlo šarolikoj (i velikim dijelom skromnije obrazovanoj) domaćoj publici kojoj je ovo njegovo djelo i bilo namijenjeno naš autor zapravo želio skrenuti pozornost velikoga njezinog dijela i na ovaj postupak ili žanr porijeklom iz pisane (,visoke“) novolatinske književnosti ne bi li je na taj način poučio i nečem novom, odnosno proširio njezine možda i odveć skučene ,generičke horizonte“. Pritom je on itekako dobro naslutio da će kronogram izazvati poprilično zanimanje navlastito i među tek jedva opismenjenim, pučkim recipijentima Odiljenja, koji su ipak posjedovali toliko znanja da su bili u stanju prepoznati i ispravno otčitati verzalom otisnuta slova što su predstavljala rimske znamenke, a onda i osnovnom računskom operacijom njihova zbrajanja odgonetnuti godinu u kojoj se dogodila opsada Sigeta, što je nesumnjivo trebalo (a - kako se može pretpostaviti - najvjerojatnije i jest) dodatno osnažiti i njihov interes za tekst ove ,zrinijade“ $u$ cijelosti.

\footnotetext{
864 Sačuvani primjerci ovih mladenačkih latinskih tekstova - podsjetimo - čuvaju se u već spomenutome zborniku Ritterovih rukopisa, tiskanih djela i pisama Otia metrica manuscripta et impressa. Usp. o tome u: Kosić 2013: 23-29 i 274-285.

${ }^{865}$ Usp. o kronogramima u Vitezovićevoj latinskoj epistolografici u: Moretti 2014: 74-75.

${ }^{866}$ Detaljnije o pojavi uključivanja ulančanih kronograma u rimovane heksametre u Ritterovu pjesništvu na latinskom jeziku u: Stepanić 2016: 337.
} 
Kao „tipično“ dijete svoga doba, Vitezović je od mladenačkih dana iskazivao kontinuiranu fascinaciju enigmatikom, igrama riječi, skrivenim značenjima itd., jednom od očitih „posljedica“ koje se ispostavlja i njegova odluka da Odiljenje obogati primjercima kronograma, kojima se po činjenici da je riječ o baroknim autorima posebno dragom formalnom rješenju također baziranom na verbalnoj dosjetci izrazito srodnom ispostavlja i figura jeke što prožima čitav njegov treći „dil““. Znajući da je, „poput pravog pripadnika baroknog intelektualnog kruga sklonog, među ostalim, i okultnom i mističnom, Vitezović (...) tijekom cijelog života sastavljao oblike kao što su zagonetke, kronogrami, anagrami, rebusi i horoskopi““ (Luetić i Tvrtković 2016: 318), prisutnost formalnih postupaka poput figure jeke i naročito kronograma u njegovoj ,zrinijadi“ trebali bismo držati gotovo samorazumljivom, pa i očekivanom, tim više što se kronogram po svome enigmatskom načinu funkcioniranja nameće kao (generički) vrlo blizak samoj zagonetki, primjer(k)e koje smo - skrojene po uzoru na autohtone usmenoknjiževne zagonetke - također locirali na tekstualnom ,,prostoru“ Odiljenja. Tako bi - drugim riječima - zagonetke, kronograme, pa i anagram u čast opata Radanovića, ${ }^{867}$ što ga priključuje paratekstualnoj dionici njegova drugog, bečkog izdanja, valjalo motriti kao neoborive dokaze Ritterova enigmatskog umijeća, koje je do punoga izražaja došlo već u ovome njegovu vernakularnom mladenačkom književnom ostvarenju. ${ }^{868}$

Poželimo li se napokon usredotočiti na konkretne primjerke kronograma uvrštene ili realizirane u tekstu Odiljenja sigetskog, neće biti zgorega najprije podsjetiti na to kako je na zastupljenost ove figure ili ,žanra“ u Vitezovićevu tekstu još prije više od stotinu godina prvi upozorio Milivoj Šrepel, ${ }^{869}$ poslije kojega se istim pitanjem tek nekoliko desetljeća kasnije iznova pozabavio Nikica Kolumbić, koji će - za razliku od svoga prethodnika, kojemu je pošlo za rukom locirati tek primjerak kronograma uvršten u lamentaciju Siget zvrhu samoga sebe - ondje dospjeti uočiti još i kronogram utkan u drugu nadgrobnicu banu Nikoli Šubiću Zrinskom. ${ }^{870}$ Polazeći od zapažanja spomenute dvojice naših književnih povjesnika, na vlastite ćemo se oči moći uvjeriti kako je Ritter u svoju ,zrinijadu“ kronograme doista uvrstio „tek“ na dva navedena mjesta, pri čemu se u prvome slučaju, odnosno tužbalici Siget zvrhu samoga sebe (II: 517-613), radi o kronogramu ostvarenom u jednom jedinom, i to trinaestom

\footnotetext{
${ }^{867}$ U kronogramima uključenima u Odiljenje, naime, očituje se onaj isti snažni „ludički impuls“ (Kravar i Novaković 2000: 766) što ga je Vitezović ponajviše iskazivao u svojim anagramima koje je neumorno sastavljao za čitavoga svog života. Dapače, osim što je „žanrove“ kronograma i anagrama unutar istih tekstualnih okvira donio upravo u drugom izdanju Odiljenja, u latinskom dijelu svoga stvaralaštva nije se on ustručavao ni anagrame povremeno „nadograđivati“ kronogramima, pa je tako - primjerice - u njegovoj zbirci Fata et vota (1699.) moguće susresti i anagrame u koje su inkorporirani kronogrami što (najčešće) donose godinu smrti osobe u čast koje je dana anagramska pjesma i ispjevana. O tome opširnije u: Luetić i Tvrtković 2016: 330.

${ }^{868}$ Podrobno o Ritterovoj sklonosti zagonetaštvu, odnosno njegovu enigmatskom radu u: Peleh 1973: 397-402.

${ }^{869}$ Usp. Šrepel 1902: 112.

${ }^{870}$ Detaljnije u: Kolumbić 2005: 342.
} 
stihu pjesme ili 529. stihu drugoga „dila“ (,ah, na što Me spraVI oVo Letto hVDo“), dočim je u epitafu posvećenom sigetskom kapetanu Druga istoga bana (IV: 104-105) riječ o kronogramu koji se proteže duž čitave ove šesteračke dvostihovne minijature (,oVDI Ie zasIpan / MIkVLa ZrInskI ban“). Ono što je, međutim, zajedničko i jednome i drugome kronogramu jest ne samo činjenica da ih povezuje već odgonetnuto brojčano rješenje - 1566, kao aluzija na godinu u kojoj je Siget pao u turske ruke - nego i to da su oba uklopljena u lirske pjesme koje, u sadržajnom pogledu, predstavljaju svojevrsne „završne riječi“ svojih kazivača ili uopće posljednje pojavljivanje pojedinih likova na „pozornici“ ovoga teksta, pa dok tako Siget, nakon što ispjeva svoju dirljivu tužaljku, sve do kraja teksta više neće uzimati riječ, dotle ni o Nikoli Šubiću Zrinskom poslije njegove (druge) nadgrobnice ili epitafskog natpisa također $\mathrm{u}$ tekstu neće više biti ni usputnoga spomena.

Prizivajući na rečenim mjestima Odiljenja, ,žanr“" kronograma, Vitezović je i bez trunke sumnje znao da će ga velika većina njegovih čitatelja vrlo lako prepoznati kao enigmatsko rješenje, a onda i ispravno protumačiti, odnosno razriješiti, $i$ to ponajprije zahvaljujući onodobnoj gotovo kolektivnoj zadivljenosti zagonetaštvom i uopće skrivenim značenjima, koja i jest mnoge od njih ,automatski“ (u)činila osjetljivima na pojavu raznoraznih enigmatskih oblika ili postupaka. Naime, u 17. stoljeću - navlastito u kontinentalnoj Hrvatskoj - „mnogi su se zanimali za enigmatiku, za simbologiju, za zoroaster, za heraldiku, za istraživanje znakova, anagrama, kriptograma, uopće za emblematiku“ (Prosperov Novak 1999: 695), pa je tako - primjerice - samo Ritteru dobro znan međimurski autor Ivan Despotović Stariji u drugoj polovici stoljeća „dao tiskati desetak knjiga koje su prošarane mnogim kriptogramima, anagramima i simbolima“" (Isto: 695). Barok je, k tome, u nas i diljem Europe ujedno i razdoblje u kojemu su simbologiju kršćanstva posebno njegovali isusovci, odnosno u kojemu su gotovo opsesivno sastavljali spise s mnogim alegorijskim prizorima, hijeroglifima i nepoznatim jezicima, iz čega bi onda i definitivno slijedilo kako je sveopće traganje za skrivenim značenjima predstavljalo svojevrsni duh onoga vremena, na koji se naš autor nije mogao ni želio oglušiti, tim više što je s njime ozbiljno računao pri sastavljanju svoje ,zrinijade“. Inače, što se kronograma tiče, njih su - izuzev Vitezovića i Despotovića - u svoja latinska djela redovito uključivali i mnogi drugi naši onodobni autori poput Vicka Zmajevića i Kajetana Vičića, ${ }^{871}$ a ne zaboravimo da su kronogramima bremenita i ostvarenja nemalog broja inozemnih sedamnaestostoljetnih pjesnika poput Friedricha von

\footnotetext{
${ }^{871}$ Usp. o tome u: Stepanić 2005: 202.
} 
Logaua, kojima je ovaj njemački barokni pjesnik - poput Rittera, koji to čini upravo u Odiljenju - obilato punio svoje pjesme posvećene pretežno ratnim temama. ${ }^{872}$

Kronogrami što ih je Pavao Ritter Vitezović uvrstio u svoju „zrinijadu“ poradi „,indikativnoga“ bi brojčanog rješenja ujedno figurirali i kao postupak gotovo istovjetan onomu na kojemu počiva i epskopjesnička dionica mađarskoga zbornika Adriai tengernek Syrenaia Nikole Zrinskoga, ispjevana pod naslovom Obsidio Sygethiana ili Szigeti veszedelem. Nikolin se ep, naime, proteže na točno 1566 strofa, koje i više nego očito aludiraju na godinu u kojoj se zbio kršćansko-muslimanski okršaj za Siget, ${ }^{873}$ ujedno tako stvarajući i efekt usporediv s onime Vitezovićevih kronograma, tim više što je također riječ o tekstualnome formalnom postupku koji se zapravo svodi na brojčanu zagonetku, odnosno prilično ,prozirnu“ brojčanu aluziju. Budući da nije moguće sa sigurnošću utvrditi je li naš autor doista imao prilike upoznati se s Nikolinim mađarskim ,epskim“ ostvarenjem, ${ }^{874}$ koje u Petrovu hrvatskom prijevodu zbog mnogobrojnih kraćenja, dodavanja i preinačivanja ${ }^{875}$ ipak nije dospjelo zadržati tu svoju prvotnu (brojčano indikativnu) duljinu, o eventualnom utjecaju (i) ove formalne dosjetke iz mađarske ,zrinijade“ na Ritterove kronograme dopušteno je zasad tek nagađati, i to s nužnom sviješću kako impuls za uvrštavanje te enigmatske figure ili „Žanra“ našem autoru zacijelo nije stigao isključivo iz opusa jednoga literarnog suvremenika.

\section{5. ELEMENTI PUČKOKNJIŽEVNIH ŽANROVA U ODILJENJU SIGETSKOM}

U dosadašnjim, pretežno recentnijim interpretacijama Odiljenja sigetskog Pavla Rittera Vitezovića zgodimice se načinjalo i pitanje njegove pučkoknjiževne recepcijske orijentiranosti, na koju bi - kako su pojedini povjesnici predmnijevali - ponajviše trebala upućivati (i) nemala količina u njemu zastupljenih usmenoknjiževnih (generičkih) značajki. ${ }^{876}$ Pritom se najčešće polazilo od pretpostavke kako svoj književni prvijenac na hrvatskom jeziku Vitezović ispisuje „misleći na široke slojeve čitalaca, tj. namjenjuje ga ljudima i visokoga i skromnoga obrazovanja, onima koji znaju čitati i onima koji znaju samo slušati, samo neka su zadojeni žarkim domoljubljem“ (Bratulić 1997: 16), što bi onda i trebao biti razlog zbog kojega paralelno u njemu poseže za idejnim i oblikovnim strategijama

\footnotetext{
${ }^{872}$ Podrobno o tome u: Hess 2007: 419-420.

873 O tom detalju usp. Bene 2012: 548-550.

${ }^{874}$ Pojedini proučavatelji, doduše, u tu mogućnost ni najmanje ne dvoje. Usp. Bene, Hausner i Ladić 2012: 8.

875 Prema Novalićevim zapažanjima, Petar je u svoj prijevod mađarskoga izvornika dodao sveukupno 137 vlastitih strofa, 41 Nikolinu strofu je ispustio, njih 21 proširio na dvije ili više strofa, dočim je u 15 strofa proveo značajnije preinake pojedinih stihova, odnosno njihova sadržaja. Podrobnije u: Novalić 1967b: 124.

${ }^{876} \mathrm{Na}$ možebitnu pučkoknjiževnu usmjerenost Odiljenja prvi se osvrnuo već Milivoj Šrepel (usp. Šrepel 1902: 103-117), da bi se kasnije u njezino preispitivanje upustili Josip Bratulić (usp. Bratulić 1990: 187-190), Nikica Kolumbić (usp. Kolumbić 2005a: 322-325) te navlastito Pavao Pavličić (usp. Pavličić 2007: 253-284).
} 
pisanoknjiževnoga (,visokog“, ,elitnog“) te folklorno- i pučkoknjiževnoga stvaralaštva. Kako se ta pretpostavka o šarolikoj publici kojoj je Odiljenje najvjerojatnije bilo namijenjeno pritom još potkrepljivala i kasnijom Vitezovićevom zauzetošću sastavljanjem (i tiskanjem) štiva na hrvatskom jeziku pretežno prilagođenog potrebama skromno obrazovana „puka“ (Kronika, Priričnik, Sibila, kalendari), odnosno također realiziranoga prepoznatljivo pučkoknjiževnom „,metodom“ stapanja odlika pisane s obilježjima folklorne književnosti, ${ }^{877}$ navedena tumačenja dospjela su iznjedriti prilično uvjerljiva zapažanja koja su bacila neko sasvim novo svjetlo na Ritterovu ,zrinijadu“ u cijelosti i koja iz toga razloga ni na ovome mjestu nipošto neće smjeti biti zaobiđena, tim više što ujedno upućuju (i) na to kako je naš autor pri njezinu sastavljanju na umu imao i konkretne žanrove, točnije konkretna obilježja pojedinih žanrova karakterističnih za sferu pučke književnosti.

Da sumnja na postojanje pučkoknjiževnih elemenata u Odiljenju, a time i na njegovu prilagođenost recepcijskoj logici bazično obrazovanih i literarno neiskusnijih čitatelja nipošto nije bila bez podloge $u$ vidu specifičnih društvenopovijesnih okolnosti onoga vremena ponajbolje će nam potvrditi povijesna činjenica kako upravo u 17. stoljeću dolazi do oživljavanja tiskarske proizvodnje u Hrvatskoj, što je rezultiralo ne samo time da su se knjige mnogih domaćih autora napokon mogle tiskati (i) na hrvatskome tlu, nego i time da se knjiga i u nas počela prilagođavati specifičnim domaćim potrebama. To, drugim riječima, znači da upravo od razdoblja baroka i na našim prostorima „knjižna kultura postaje svojina sve širih društvenih slojeva“, odnosno da sadržaji knjiga počinju u sve većoj mjeri zrcaliti „zanimanje i učenih ljudi i onih koji su u školama naučili samo osnovnu pismenost za svjetovnu (znanstvenu, povijesnu, literarnu, praktičnu) knjigu“ (Stipčević 2003: 285), što će reći da se pored (pretežno latinskih) izdanja namijenjenih visokoobrazovanoj društvenoj eliti - od 17. stoljeća redovito u nas tiskaju i pučkoknjiževna ostvarenja poput pučkih kalendara, sastavljanjem i objelodanjivanjem kojih je tada bio zaokupljen baš Pavao Ritter Vitezović. Dapače, u tom sedamnaestostoljetnom usponu pučke književnosti u nas veliku je, ako ne i ključnu ulogu odigrao upravo naš autor, koji se pisanju i tiskanju štiva namijenjenog pučkim čitateljima posvetio netom nakon što je - odlukom Hrvatskog sabora iz studenoga (is)te godine - koncem 1694. preuzeo dužnost upravitelja zagrebačke Zemaljske tiskare, ${ }^{878}$ koju će obnašati sljedećih dvanaest godina, doprinijevši svojim angažmanom tomu da Zagreb stekne i na neko vrijeme održi status našega najvažnijeg baroknog tiskarskog središta.

\footnotetext{
877 Pučka književnost, prema Maji Bošković-Stulli, upravo i jest „područje koje povezuje usmenu i pisanu umjetničku književnost"“ (Bošković-Stulli 1983: 63).

${ }^{878}$ Usp. npr. Klaić 1914: 93-126 i Janković 2016: 97-120. Doduše, neka istraživanja pokazuju kako je Ritter u zagrebačkoj tiskari knjige povremeno tiskao počevši već od 1690. godine. Detaljnije o tom pitanju u: Marković 1987: 78-82, Dobronić 1994: 119-120 i 1995: 173, Stipčević 1995: 187-188, Budišćak 2016b: 94-97.
} 
Počevši s trećim - ujedno i jedinim ne-pučkim - izdanjem Odiljenja sigetskog iz 1695., Vitezović će u godinama što su uslijedile u Zemaljskoj tiskari tako otisnuti niz vlastitih i ne samo vlastitih pučkoknjiževnih ostvarenja u rasponu od kalendara i molitvenika, pa sve do zbirki propovijedi i poslovica, od kojih se mnoga - u nedostatku financijskih sredstava neće ustručavati ni osobno prodavati pučkim čitateljima nudeći ih na sajmovima i proštenjima. Ritteru je, osim toga, naročito bilo stalo do toga da njegovi autorski pučkoknjiževni tekstovi - u kojima je prezentirao zamisli što ih je prethodno razradio u nizu svojih (pravno)povijesnih latinskih spisa - pronađu put do slabije obrazovane publike, i to ponajprije stoga što je njima nakanio „osigurati pedagošku formaciju i političku mobilizaciju širih slojeva“" (Blažević 2012: 435), iako je itekako dobro znao da će ti isti tekstovi doći i u ruke visokoobrazovane publike iz aristokratskih društvenih krugova, koja se ni najmanje nije libila zaviri(va)ti i u djela primarno namijenjena pučkim recipijentima. ${ }^{879}$ Sve u svemu, svojim višestrukim angažmanom oko pisanja, tiskanja, ali i raspačavanja pučkoknjiževnih tvorevina naš se autor priključio podugačkom nizu onih domaćih i inozemnih intelektualaca koji su - počevši od 17. stoljeća - sastavljali djela prilagođena čitateljima vrlo različita profila, a sve s namjerom da jedva pismene pojedince, ali i ženske pripadnice aristokratskih krugova (koje su u to vrijeme bile na bitno nižem stupnju učenosti od svojih muževa, braće i očeva) prosvjećuju, obrazuju i uopće uključe u kulturni život, što našega autora ujedno bjelodano potvrđuje i kao najavitelja sljedećega, prosvjetiteljskog stoljeća. ${ }^{880}$

Kako primjećujemo, izrazitiju autorsku zaokupljenost pučkom književnošću Pavao Vitezović demonstrirat će tek u godinama nakon što je Odiljenje već bilo objelodanjeno, pri čemu će jednim od prvih ostvarenja s kojima je započeo stjecati (i) status pučkoga autora proučavatelji obično označavati (do danas, nažalost, nesačuvanu) deseteračku ,novinsku pjesmu“ (Zečević 1978: 442) Novljančica iz 1689., koja predstavlja svojevrsni stihovani izvještaj o pobjedi hrvatske vojske nad turskom kod Novoga na Uni ispjevan neposredno po završetku bitke. ${ }^{881} \mathrm{U}$ okvirima identičnoga će se žanra Ritter kao „pisac pučke retorike“ (Prosperov Novak 1999: 705) iznova predstaviti punih petnaest godina kasnije, i to s pjesmom Senjčica (1704.), ${ }^{882}$ u kojoj u 144 osmerca raspoređena u 24 seste rime sa shemom rimovanja „ababcc“ opisuje (također vrlo „svjež“) junački podvig Senjana, koji su - načuvši da se

\footnotetext{
${ }^{879} \mathrm{O}$ zanimanju što su ga (ne samo u nas) pučkoknjiževni tekstovi izazivali i među publikom iz viših društvenih slojeva podrobnije u: Burke 1991: 23-47.

${ }^{880}$ O Ritteru kao jednom od začetnika prosvjetiteljskih ideja opširnije u: Fališevac 2013: 12.

${ }^{881}$ Detaljnije o ovoj pučkoj Vitezovićevoj pjesmi u: Zečević 1978: 442, 489 i Dukić 2002: 70-71.

${ }^{882}$ I dok je Slobodan Prosperov Novak shvaća „nekom vrstom pjesničkoga letka“ (Prosperov Novak 1999: 705), Zrinka Blažević u njoj vidi „kratku pohvalnicu“ (Blažević 2012: 435), iako bi se - mnogo preciznije - Senjčica, nalik zagubljenoj Novljančici, trebala zapravo poimati svojevrsnom pučkom prigodnicom.
} 
Francuzi, koji su u Italiji ratovali protiv habsburške vojske u sklopu Rata za španjolsku baštinu, spremaju napasti i zauzeti Senj - kod otoka Šolte, ploveći na maloj galiji, dospjeli zarobiti dva francuska teretna broda. Osim što se - zahvaljujući već i činjenici da u njima „prevladava retorika nad lirizmom“ - oba teksta nameću kao primjer(c)i „karakteristične pučke pjesme u kojoj retorika nije odijeljena, otcijepljena od pjevanja“ (Isto: 489), ujedno su ovi „pučki (...) spjevovi“ (Isto: 705) - „tipično“ za pučku literaturu - napučeni i brojnim usmenoknjiževnim značajkama, zbog poveće prisutnosti kojih će, kako je svojedobno pretpostavio Josip Vončina, ${ }^{883}$ Ritter Senjčicu izrijekom i podnasloviti kao „dijačku“ ${ }^{884}$

U desetljeće i pol, koliko će proteći od (vjerojatnoga) objavljivanja Novljančice do tiskanja Senjčice, Pavao Ritter Vitezović kao „ozbijan“ će se pučki pisac potvrditi ponajprije ustrajnim sastavljanjem i tiskanjem tzv. ,proštenjarske književnosti“ (Bošković-Stulli 1983: 63), odnosno pučkih kalendara, ${ }^{885} \mathrm{u}$ kojima su se redovito izmjenjivale zabavne s poučnim stihovanim dionicama, pri čemu su potonje obično nudile konkretne savjete praktične naravi za svaki dan u mjesecu te podastirale literarizirane vijesti o pojedinim zbivanjima, informacije o svecima, pa čak i o planetarnim konstelacijama, ${ }^{886}$ a vrijedi zabilježiti i kako su na stranicama kalendara svoje mjesto našle i brojne (izvorno „narodne“ i ne samo narodne) poslovice, pa čak i pripovijetke s nezanemarivim udjelom folklornoknjiževnih posebnosti. ${ }^{887}$ Osim u kalendarima, Ritter će nevjerojatnu umješnost i okretnost u sastavljanju pučkoknjiževnih sastavaka u spomenutomu razdoblju iskazati i u onodobnim pučkim recipijentima posebno dragoj zbirci poslovica popabirčenih iz ranijih kalendara Priričnik aliti razliko mudrosti cvitje iz 1703., ali i u svega nekoliko godina „starijoj“ Kronici aliti spomenu vsega svieta vikov (1696.), u kojoj svjetsku i hrvatsku povijest - premreženu i ,podacima“ iz folklornih legendi i predaja - prilagođava razumijevanju širih masa namjenjujući je ponajprije slabije učenim čitateljima. Dakako, ne smijemo zaboraviti ni usmenoknjiževnim momentima bremenitu njegovu (samo djelomično sačuvanu) knjigu gatalica Lado horvatski iliti Sibila, koju je - kako se čini - također vlastoručno tiskao u zagrebačkoj tiskari, i to parcijalno, odnosno u nekoliko navrata između 1702. i 1706.

Iako, dakle, ne potječe iz navedene Vitezovićeve stvaralačke faze, obilježene intenzivnom zaokupljenošću ispisivanjem i objelodanjivanjem ,punokrvnih“ pučkoknjiževnih

\footnotetext{
${ }^{883}$ Usp. Vončina 1976a: 346.

${ }^{884}$ Puni naslov Senjčice, konkretno, glasi: Senjčica aliti djačka od senjskoga na moru junaštva, učinjenoga $v$ misecu sičnju leta tekućega 1704. spravljena. Podrobnije o ovoj Vitezovićevoj (pučkoj) pjesmi i u: Matić 1968: 106-108, Krmpotić 1970: 625-630, Zečević 1978: 489 i Dukić 2002: 71-72.

885 Od Vitezovićevih pučkih kalendara do danas su nam se u cijelosti dospjeli sačuvati „tek“ oni za 1698., 1699. i 1705. godinu, dočim onaj za 1692. posjedujemo očuvan tek fragmentarno. Usp. o tome u: Hrgić 2015: 17-65.

${ }^{886}$ O pučkim, među ostalim i Ritterovim kalendarima detaljno u: Zečević 1978: 489-496 i naročito Hrgić 2015.

${ }^{887}$ Opširnije o pripovijetkama uvrštenima u kalendare Pavla Rittera Vitezovića u: Čubelić 1988: 177.
} 
ostvarenja, Odiljenju sigetskom u već nekoliko je ranijih navrata - ponovimo - pristupano kao djelu koje posjeduje čak i golim okom razaznatljive pučkoknjiževne crte, kojima je u svoje vrijeme bilo kadro privući i zadržati pozornost i jedva opismenjenih čitatelja što su stekli tek najelementarniju (književnu) naobrazbu. Još početkom prošloga stoljeća u Vitezovićevu je stvaralaštvu Milivoj Šrepel tako zapazio „,prvu klicu demokratskoga smjera u književnosti““, pripominjući kako - usprkos činjenici da je većinom bio posvećen pjevanju na latinskom jeziku - „vas njegov hrvatski književni rad svjedoči, da je želio i samome puku podati duševne hrane“ (Šrepel 1902: 103-104). To će svoje zapažanje on zatim ilustrirati upravo primjerom Ritterova vernakularnog prvijenca, sastavljanja kojeg se - po njegovu mišljenju naš autor i latio uvidjevši „da je Sirena pisana samo za obrazovane ljude, a budući zanesen slavom sigetskoga junaka, u kojoj je vidio i slavu svega hrvatskoga naroda, odlučio je opjevati sigetski boj u popularnom obliku“ (Isto: 104). Podjednako indirektno Odiljenje će tek potkraj prošloga i početkom tekućega stoljeća - pučkoknjiževnim ostvarenjem proglasiti Nikica Kolumbić ${ }^{888}$ i Josip Bratulić, ${ }^{889}$ koji ni najmanje ne dvoji u to kako ga je Ritter ispjevao „misleći na široke slojeve čitatelja“ (Bratulić 1994: 9), baš kao ni Andreja Sršen i Davor Piskač, koji su - pak - uvjereni u to da ga u potpunosti on ,namjenjuje (...) ljudima skromnoga obrazovanja“" (Sršen i Piskač 2016: 221). Naposljetku, daleko najuvjerljivija potvrda snažne pučkoknjiževne obilježenosti (pa i djelomične pučke namjene) Vitezovićeve „Zrinijade“ prije nešto više od desetljeća došla je iz pera Pavla Pavličića, ${ }^{890}$ koji u svojoj studiji posvećenoj tekstualnim joj specifičnostima upozorava na konkretna njezina pučka obilježja eksplicitno pritom napominjući kako je riječ o tekstu koji bi se mogao i morao pojmiti kao svojevrsna „,najava pučke književnosti““(Pavličić 2007: 283).

Kada govorimo o u njemu prisutnim karakteristično pučkoknjiževnim značajkama, neće biti nepromišljeno ustvrdimo li kako na upućenost Odiljenja (i) na skromnije obrazovanu publiku vrlo izrazito sugerira već i sam formalna njegova dimenzija, točnije činjenica da se u „moru“ tadašnjih književnih i ne samo književnih ostvarenja na latinštini, namijenjenih isključivo visokoobrazovanim čitateljima iz najviših društvenih slojeva - radi o tekstu napisanom narodnim, hrvatskim jezikom, što će reći usredotočenom na isključivo domaće „tržište“, odnosno na domaće recipijente najrazličitijega mogućeg čitateljskog profila. Podsjetimo, redom svi maločas pobrojani Ritterovi pučkoknjiževni sastavci objelodanjeni za vrijeme njegova upravljanja Zemaljskom tiskarom realizirani su upravo hrvatskim jezikom, pri čemu će i u njihovu slučaju također biti riječi o onoj istoj tronarječnoj jezičnoj stopljenici

\footnotetext{
${ }^{888}$ Usp. Kolumbić 2005a: 322-325.

${ }^{889}$ Usp. Bratulić 1994: 10 i 1997: 16.

${ }^{890}$ Usp. Pavličić 2007: 279-284.
} 
ili interdijalektu kojim je ispjevan i vernakularni mu književni prvijenac, a evociranje kojega upućuje na jasnu nakanu približavanja što je moguće raznovrsnijoj publici iz svih onodobnih hrvatskih regija. ${ }^{891}$ Znamo li da je - počevši, dakako, s Odiljenjem - u svakom od tih pučkoknjiževnih ostvarenja na vernakularu naš autor eksplicitno ili implicitno zagovarao uporabu sinonimima (pre)bogatoga hrvatskog jezika očišćenog od izlišnih tuđica, postat će očito da je popularnost tekstova takva tipa zapravo koristio ne bi li svojoj raznolikoj publici ukazao na važnost korištenja (čistoga) narodnog jezika, odnosno da je pučkim sastavcima realiziranima trodijalektalnom mješavinom želio doprijeti do što je moguće većeg broja recipijenata ne bi li im predstavio svoj jezični hibrid te ih tako pokušao zainteresirati da se i sami okušaju u njegovoj uporabi, tim više što je bila riječ o jedinstvenom hrvatskom jeziku koji je bio u stanju izbrisati jezične razlike među regijama te se tako nametnuti kao okosnica za buduće ujedinjenje („čitave“) Hrvatske. Da bi postigao širenje svoga ujedinjujućeg jezičnog tipa, Vitezović je - dakako - morao ne samo ispisati djelo tom svima razumljivom, „svehrvatskom“ jezičnom inačicom, nego ga i sadržajno, stilski, formalno, pa i - uopće žanrovski realizirati tako da privuče pozornost kako visokoobrazovanih čitatelja s rafiniranim književnim ukusom, tako i - još više - onih neukijih i literarno daleko neiskusnijih, koji su u njegovo vrijeme bili u većini i zbog kojih njegovi hrvatski sastavci i jesu redom pučko štivo ili makar literarna ostvarenja s vrlo izrazitim udjelom pučkoknjiževnih elemenata.

Ovom jezičnom približavanju šarolikoj, no glavninom pučkoj publici u Odiljenju se pridružila i još jedna strategija uspostavljanja bliskosti s potencijalnim recipijentima, koja bi se također mogla i morala izdvojiti kao jedan od pouzdanih indikatora pučkoknjiževne njegove recepcijske orijentiranosti. Riječ je, konkretno, o ranije već zamijećenom inzistiranju našega autora na pohrvaćivanju vlastita njemačkog prezimena Ritter u Vitezović, kojemu svjedočimo na naslovnicama prvih dvaju izdanja Odiljenja, s tom razlikom što se na onoj prvoga izdanja hrvatskoj mu inačici prezimena (još uvijek) pridružuje i izvorna njemačka, dočim na naslovnom listu bečkoga izdanja originalno autorovo prezime izostaje, baš kao što će to biti slučaj i u posveti trećega, zagrebačkog izdanja, koje ipak nije bilo namijenjeno raznolikom, a ponajmanje pučkom čitateljstvu poput prethodnih. ${ }^{892}$ Predstavivši kroatiziranu varijantu prezimena u pretežno vernakularnoj pjesničkoj poslanici kapetanu Franji Ivanoviću iz svibnja 1682., Pavao Ritter će se kao „Vitezović“ - podsjetimo - otad ustrajno potpisivati na naslovnicama svih hrvatskih ostvarenja (izuzev kalendara), očito čineći to u uvjerenju da

\footnotetext{
${ }^{891} \mathrm{Na}$ taj pokušaj Vitezovićeva jezičnog približavanja čitateljima iz različitih dijelova Hrvatske - fokusirajući se posebice na „slučaj“ njegovih trodijalektalnih pučkih kalendara - u svojoj je studiji posebno upozorio i Danijel Hrgić (usp. Hrgić 2015: 17).

${ }^{892} \mathrm{O}$ tome detaljnije u: Budišćak 2016b.
} 
time ostvaruje bliskost sa svojom raznolikom „narodnom“ publikom, a napose s onim njezinim (daleko mnogobrojnijim) dijelom kojemu su pripadali pojedinci literarno stasali na usmenoj književnosti, pa i na ranijim više ili manje sličnim pučkoknjiževnim ostvarenjima svojih sunarodnjaka. Težnja kroatiziranju prezimena iskazana u paratekstu Odiljenja sigetskog u tom bi smislu možda i ponajbolje ukazivala na pučkoknjiževni status što ga je Vitezović pokušavao doseći s prvim dvama njegovim izdanjima, odnosno sugerirala na to da su izdanja iz Linza i Beča doista trebala dospjeti u ruke čitatelja iz različitih društvenih slojeva, ali ponajprije onih u čijim se očima pohrvaćenim prezimenom mogao stvoriti dojam „hrvatskosti“, dakle pripadnosti istome kulturnom i nacionalnom, pa i staleškom krugu, a time i steći aura nepogrešivo hrvatskoga pisca koji piše ponajprije za one (nerijetko i jedva pismene) pojedince što se služe isključivo ili većinom narodnim jezikom.

Dotaknuvši se naslovnica kao „najisturenijih“ paratekstualnih dionica prvih dvaju Vitezovićevih izdanja Odiljenja sigetskog, teško ćemo moći ne primijetiti njihovu nipošto slučajnu vizualnu atraktivnost, koje kao da se temeljna svrha zapravo svodi(la) na to da $\mathrm{u}$ recipijenta već pri prvom susretu s tekstom izazove sumnju (i) u njegovu pučkost, odnosno jasnu mu pučkoknjiževnu usmjerenost. Da ciljanog čitatelja, naime, zacijelo nisu tražila isključivo u uskom krugu učenije i literarno potkovanije publike izdanja Ritterove „,zrinijade“ iz 1684. i 1685. možda i najuočljivije tako daju do znanja svojim pomno osmišljenim naslovnim listovima, koji ponajviše plijene pažnju upravo atraktivnim grafičkim rješenjima što prate ondje podastrijete osnovne i pobočne informacije o autoru i samomu njegovu netom objelodanjenu ostvarenju. Osim što su, k tome, podaci o autoru, njegovu porijeklu i stečenim titulama, naslovu, samoj strukturi teksta, njegovim formalnim posebnostima, broju izdanja te - konačno - mjestu i godini tiskanja i samom tiskaru tako otisnuti nejednakim tipovima slova, različitim stilom (kurent, kurziv, verzal, spacionirano) i u nekoliko različitih veličina, na bolju su prijemljivost knjige i uopće što je moguće širu (vertikalnu i horizontalnu) njezinu recepciju pokušala utjecati i (s)likovna rješenja (vinjete, stilizirani florealni ornamenti, grafička ilustracija u bečkom izdanju), koja su tekstualno i grafički ionako bogate naslovnice izdizala na još višu razinu dopadljivosti. S druge strane, izuzev naslova djela tiskanog verzalom i pozicioniranog na samu njezinu sredinu, naslovnica trećega, zagrebačkog izdanja Vitezovićeve ,zrinijade“ neće prezentirati niti jednu od netom pobrojanih dodatnih naslovničkih informacija, pa čak ni otkrivati ime autora, ali ni podatke o tiskaru te vremenu i mjestu objelodanjivanja teksta, čime je - kako nedavno pretpostavismo ${ }^{893}$ - najvjerojatnije impicirala namijenjenost ovoga izdanja nekom posve drugačijem tipu publike, kojega nije 
bilo potrebno mamiti primamljivom naslovnicom napučenom nužnim i manje nužnim podacima, a i do kojega ovo izdanje očito nije imalo stići uobičajenim, tržišnim putem.

Informacijama bogate i vizualno primamljive naslovnice prvih dvaju izdanja Odiljenja uvod su u, podsjetimo, znatno složenije paratekstualne dionice, koje se u oba slučaja - pored naslovnoga lista - sastoje još i od latinskih posvetnih pjesama posvećenih pokroviteljima te proznih predgovora s uklopljenim lirskim pjesmama na vernakularu upućenih nedefiniranom „čtavcu“, odnosno „štavcu“ ${ }^{894}$ Potonja paratekstualna komponenta, adresirana na „čtavca“ kao metonimiju cjelokupne potencijalne publike ove neobične „zrinijade“, nameće se pritom kao neizbježna posljedica Ritterova pokušaja da se svojim ostvarenjem približi što je moguće šarolikijem čitateljstvu, kojemu nije zgorega pojasniti i razloge nastanka djela te skrenuti pozornost na neke njegove specifičnosti, čime automatski ona postaje i jednim od najpouzdanijih pokazatelja (i) pučkoknjiževne orijentacije djela u cijelosti. U prilog njegovu pučkoknjiževnom statusu, točnije pučkoknjiževnom statusu prvih dvaju njegovih izdanja, trebala bi, k tome, govoriti i činjenica kako je bečko izdanje svoga posvetnika, što će reći (vrlo vjerojatno) i pokrovitelja, pronašlo u jednom svećeniku - opatu Matiji Ignaciji Radanoviću - navlastito zna li se da su u 17. stoljeću svećenici pristajali biti pokroviteljima gotovo isključivo nabožnoga pučkog štiva (molitvenika, zbirki propovijedi i sl.), koje je redovito uključivalo vrlo snažnu didaktičku komponentu. Te didaktičke intencije, odnosno jasnu nakanu prosvjetiteljskoga djelovanja na šire mase, u njegovoj će Kronici i pojedinim njegovim pučkim kalendarima očigledno prepoznati kasniji Ritterovi pokrovitelji iz crkvenih redova (kanonik Ivan Znika, biskupi Stjepan Selišćević i Martin Brajković i dr.), što bi onda sugeriralo i da je tu istu pučku poučnost u Odiljenju vrlo vjerojatno uočio i sam Radanović, pristavši naposljetku financirati novo njegovo izdanje, točnije isključivo tiskanje arka $s$ „osvježenim“ paratekstualnim odsječkom priključenim tome fiktivnom „drugom“ izdanju.

Ipak, kao zacijelo najuvjerljivija potvrda pretpostavke kako u slučaju prvih dvaju njegovih izdanja imamo posla s tekstom koji je ciljao na glavninom pučku publiku ispostavit će se nedavni pronalazak trećega Vitezovićeva izdanja Odiljenja, u kojemu nema ni traga ne samo raskošnoj naslovnici, već ni vernakularnom predgovoru ,štavcu“ s pridodanom lirskom pjesmom, dočim je latinska posvetna pjesma iz prethodnih izdanja u (n)ovome doživjela preobrazbu u odulju proznu hrvatsku posvetu meceni, pukovniku Ivanu Andriji Makaru. Potpuni izostanak u prijašnjim dvama izdanjima neizbježnoga predgovora potencijalnim čitateljima pritom nam, uz već spomenutu skromno izvedenu naslovnicu, možda i ponajbolje

\footnotetext{
${ }^{894}$ Paratekstualni segment bečkoga izdanja Odiljenja sastoji se, doduše, još i od kazala, umetnutog između naslovnoga lista i posvete (usp. Ritter Vitezović 1685).
} 
ukazuje na to kako zagrebačko izdanje nije ni trebalo dospjeti u ruke publike iz različitih društvenih slojeva, nego da je - upravo suprotno - Ritter njime namjeravao udovoljiti isključivo „volji i željenju prijateljov (...), navlastito viteških i razumnih ljudi“ (Budišćak 2016b: 99), kako to - uostalom - i eksplicira u samoj posveti pukovniku Makaru. Iz navedene formulacije postat će tako i više nego bjelodano da se naš autor na objavljivanje trećeg izdanja svoje ,zrinijade“ odvažio s poprilično jasnom predodžbom o publici u čijim će rukama ono naposljetku i završiti, a među njom ovoga puta nisu bili (i) recipijenti skromnije naobrazbe, kojima bi se u specijalno sročenu predgovoru razjašnjavala svrha djela, a kamoli otkrivali razlozi njegove neobične strukture. ${ }^{895}$ Naprotiv, nju je ovoga puta sačinjavao iznimno uzak, probran krug učenijih i književno iskusnijih čitatelja (,viteških i razumnih ljudi“), a to onda znači ništa drugo nego da je - usprkos tomu što se prethodna izdanja trudio (paratekstualno) otvoriti recipijentima različitih profila - naš autor tu svoju tekstualno nepromijenjenu „,zrinijadu“ u zagrebačkom izdanju odjednom (paratekstualno) „prekrstio“ u elitnoknjiževno ostvarenje namijenjeno isključivo znanim mu literarnim sladokuscima iz redova aristokracije, što ne bi bio stanju učiniti da je prethodno nije opremio takvom kombinacijom (žanrovskih) značajki koja je baš svakom čitatelju neovisno od stupnja obrazovanja i ranije čitateljsko iskustvo omogućavala da u njoj nađe upravo ono što je ondje unaprijed i očekivao pronaći.

Paratekstualne varijacije kojima svjedočimo u trima Vitezovićevim izdanjima Odiljenja sigetskog u tom bi se, dakle, smislu ispostavljale kao izravna posljedica težnje podilaženju ciljanoj publici, odnosno posvemašnjega (tekstualnog) prilagođavanja njezinu ukusu i očekivanjima, itekako usporedivog s onim na kojemu se temelji(o) i „tipično“ pučkoknjiževni stvaralački postupak. Naime, kako to u posljednje vrijeme sve češće ističu ne tako brojni proučavatelji fenomena pučke književnosti, za samu „pučkost“ ili pučkoknjiževni status nekoga konkretnog literarnog sastavka kao daleko najpresudniji faktor pokazuje se upravo njegov odnos spram recipijenta, točnije specifičan način na koji recipijent pristupa tekstu privučen stanovitim njegovim ,indikativnim“ unutarnjim značajkama. To i jest razlog zbog kojega za ,poetiku“ pučke književnosti gotovo nikakva značaja neće imati originalnost danoga teksta, nego upravo činjenica da ga sam čitatelj percipira kao pučkoknjiževno ostvarenje, odnosno da su mu pozornost dospjele zaokupiti one njegove posebnosti (obilna prisutnost usmenoknjiževnih postupaka, težnja za sadržajnom zanimljivošću, izražena utilitarnost i sl.) kojima daje do znanja da je „skrojen“ upravo po mjeri svoga recipijenta, i to ni manje ni više nego ponajprije baš onog recipijenta koji dolazi iz redova „nepovlaštene“

${ }^{895}$ Pod "recipijentima skromnije naobrazbe" ovdje ponajprije mislimo na opismenjeni puk, potom "obične" građane, vojnike i časnike, ali i čitateljice iz viših društvenih slojeva, čiji je dosegnuti stupanj obrazovanja u Vitezovićevo vrijeme još uvijek bio daleko ispod onoga muških pripadnika njihovih obitelji. 
publike. Drugim riječima, pučkoknjiževni se sastavci kao takvi upravo i prepoznaju po svome apsolutnom prilagođavanju tom i takvom čitatelju, točnije težnji da udovolje njegovim (literarnim) potrebama i očekivanjima, koja se - na koncu - i ispostavlja kao razlog zbog kojega je većina njih primarno usredotočena na ispunjavanje stanovitih izvanknjiževnih funkcija (poučnost, utilitarnost itd.), dočim estetska funkcija u njima redovito ima sekundaran značaj te je i ona u potpunosti ,u službi“ ispunjavanja čitateljevih očekivanja. S obzirom na to da pučki recipijent u literarnom tekstu priželjkuje pronaći neka njemu korisna i praktično primjenjiva iskustva, razumljiva u kontekstu svakodnevice te prezentirana na zanimljiv način (dakle, spregu poučnih i zabavnih sadržaja), pučkoknjiževna ostvarenja tu mu se želju obično svojski trude ispuniti, usredotočujući se upravo na one sadržaje koji će svojom konkretnošću, primjenjivošću, a uz to i interesantnošću pouzdano zaokupiti njegovu pažnju. Ukratko, zbog činjenice da se recepcijski interes pučkoga čitatelja u cijelosti usmjerava na sadržajni aspekt teksta, ne mareći pritom za način na koji je taj sadržaj prezentiran (o čemu iskusniji čitatelji s druge strane - redovito vode računa), i u pučkoknjiževnim će se sastavcima kao daleko najkompleksnija ispostaviti upravo sadržajna razina, bremenita uzbudljivim, počesto senzacionalistički prikazanim te intenzivnim emocijama obojanim sadržajima, ${ }^{896}$ kakvih uvjerili smo se - ne manjka ni u pjesmama Odiljenja sigetskog.

S mišlju (i) na takvu - pučku - svoju potencijalnu publiku, Vitezović će Odiljenje ne samo napučiti silno emotivnim sadržajima protkanima usmenoknjiževnim motivima te pojedinim formalnim eksperimentima dodatno „zaduženima“ za održavanje njihove pozornosti, već će ga - njegovoj neupitnoj baroknosti usprkos - realizirati i kao stilski vidno olakšanije djelo, lišeno figuralnoga (pre)obilja, napadnih concetta te inih stilskih pretjerivanja kojima su mnogi njegovi suvremenici u svojim djelima željeli postići dojam maraviljoznosti. Štoviše, ako je suzdržavanjem od baroknim ostvarenjima svojstvene stilske bujnosti naš autor jasno dao do znanja kako se svojom ,zrinijadom“ obraća i slabije učenim čitateljima, dakle onima pretežno zadojenim na usmenoj književnosti, kojoj je svaka stilska ekstravagancija bila strana, onda je želju da se njome približi publici istoga tipa dodatno potvrdio i na formalnom, odnosno stihovnom planu. Da bi, konkretno, metričko preferiranje oba tipa dvostruko rimovanoga dvanaesterca te mjestimično upošljavanje osmerca također trebalo upućivati na Ritterovu nakanu da Odiljenju priskrbi i auru pučkoknjiževnoga štiva moguće je razabrati iz kasnijih njegovih posezanja za ovim stihovima u okvirima vernakularnih pučkih ostvarenja za osmercem u Priričniku, za dvostruko rimovanim dvanaestercem u Ladu horvatskom iliti

\footnotetext{
896 Znatno detaljnije o ciljanoj publici kao najvažnijem faktoru pučkoknjiževne komunikacije i drugim posebnostima pučke književnosti u: Tomašić 2015: 179-194.
} 
Sibili te za oba u pojedinim pjesmama uvrštenima u kalendare ${ }^{897}$ - iz kojih postaje i više nego jasno da je dvostruko rimovani dvanaesterac i osmerac ujedno on shvaćao i kao stihove prikladne i za pučku uporabu, a vrlo vjerojatno i kao „punokrvne“ pučke stihove s izvorom u usmenoknjiževnoj tradiciji. Ukoliko su njegova razmišljanja doista išla u tom smjeru, to bi značilo da ga na svoj ne tako rjedak folklornoknjiževni stihovni parnjak nipošto nije podsjećao isključivo osmerac, nego i da je snažnu vezu s ,narodnim“ pjesništvom jamačno morao prepoznati i u dvostruko rimovanu dvanaestercu, i to ponajprije zahvaljujući činjenici da je riječ o stihu koji se - kako je to svojedobno primijetio Ivan Slamnig ${ }^{898}$ - raspada na šesteračke članke što prizivaju jedan od najeksploatiranijih folklornoknjiževnih stihova i koji se na taj način definitivno potvrđuje kao i više nego prikladna metrička opcija (i) za pučkoknjiževna ostvarenja, u kojima je - kao takav - čitatelje bio u stanju podsjetiti na kratki stih s kojim su se dotad imali prilike susresti isključivo slušajući izvedbe „narodnih“ pjesama.

Metričko prizivanje usmenoknjiževnoga stvaralaštva, kakvom je u Odiljenju sigetskom pribjegao i Pavao Ritter Vitezović, u ,punokrvnomu“ pučkoknjiževnom štivu - prisjetimo se - $\mathrm{u}$ pravilu ne dolazi kao usamljena poveznica na autohtonu folklornu književnost. Naprotiv, svoj status literarnog fenomena ili pojave što egzistira na specifičnom književnom području „,između usmene, tradicionalne narodne i hrvatske umjetničke književnosti“ (Zečević 1978: 369) pučka literatura upravo i duguje apsorbiranim izvorno usmenoknjiževnim elementima i postupcima kojima redovito puni sve razine svojih pisanih (ali vrlo često i anonimnih) ostvarenja, posve uvjerena $\mathrm{u}$ to kako recipijentima neće biti teško proniknuti u njihovo stvarno porijeklo. Za karakteristično folklornoknjiževnim temama, motivima, formulama te stilskim i formalnim mehanizmima poput - primjerice - usmenoepskog deseterca ili klišeiziranih izraza pučka je književnost obilno i posezala imajući na umu upravo ciljane čitatelje, odnosno znajući da joj jedino prisutnost tih značajki može jamčiti uspjeh u pokušaju da se približi (nerijetko tek jedva opismenjenoj) publici, čije je književno iskustvo gotovo u

${ }^{897} \mathrm{U}$ dvostruko rimovanom dvanaestercu Marulićeva tipa ispjevao je tako Vitezović posvetnu pjesmu svoga kalendara za 1698. - Zoroast hervacki, aliti mesečnik $i$ dnevnik gospodski i gospodarski - u čast Marije Sidonije barunice Schaffman (inače, supruge pukovnika Ivana Andrije Makara, kome je - podsjetimo - nepune tri godine ranije posvetio zagrebačko izdanje Odiljenja), dočim kraći ciklus poslovica - Priričnik - u njemu, baš kao i u svim preostalim (do danas sačuvanim) kalendarima, realizira osmeračkim distisima. Dvostruko rimovanim dvanaestercem južnoga tipa Vitezović će potom napisati posvetnu pjesmu zagrebačkome biskupu Martinu Brajkoviću koja otvara kalendar Misečnik hervacki za 1705., a u distisima u osmercu u istom će kalendaru iznova donijeti ispjevan i niz poslovica pod dobro nam već znanim naslovom Priričnik. Inače, što se osmerca kojim je ispjevao svoje poslovice tiče, Danijel Hrgić ustvrdit će kako „korištenje lako pamtljive forme, koju je kasnije lako reproducirati zbog rime i jednostavne strukture, ukazuje na Vitezovićevu intenciju da se izreke dalje šire usmenom tradicijom. Naime, mada su kalendari bili namijenjeni široj publici, opravdano je pretpostaviti da si ga još uvijek nisu svi mogli priuštiti, a osim toga, nepismeni ljudi ne bi ni bili zainteresirani za kupnju. Pa ipak, ti bi ljudi u dodir s kalendarima dolazili na javnim mjestima (krčmama, trgovima itd.), gdje bi im se sadržaji mogli i prepričati“" (Hrgić 2015: 46).

${ }^{898}$ Usp. o tome u: Slamnig 1981: 60-67. 
cijelosti bilo „proizvod“ recipiranja autohtonih usmenoknjiževnih tvorevina. ${ }^{899}$ Poput drugih tadašnjih pisaca „specijaliziranih“ za sastavljanje tih i takvih pučkoknjiževnih sastavaka, koji su uvažavanjem obilježja „narodne“ provenijencije težili postići veću razumljivost i uopće primamljivost u njima obrađenih sadržaja, ni Vitezović svoju „zrinijadu“ nije propustio napučiti nizom ranije već detektiranih obilježja deriviranih iz „repertoara“ različitih usmenoknjiževnih žanrova, čime ju je možda i najsnažnije pogurnuo u ,zagrljaj“ pučke književnosti, u kojem ju je i pronašao najveći dio onodobne njezine publike - onaj, konkretno, zadojen upravo na produktima folklornoga književnog stvaralaštva.

Da je Ritter neumorno osluškivao potrebe i očekivanja te svoje buduće pretežno pučke publike ne bi li se domislio „dobitne formule“ kojom bi im u svome tekstu i udovoljio, u samom nam Odiljenju ponajbolje mogu potvrditi pojedine cjelovite njegove dionice - prožete, dakako, nezanemarivim brojem folklornoknjiževnih karakteristika - poput poduljega središnjeg odsječka (II: 549-602) lamentacije Siget zvrhu samoga sebe, u kojem lirski subjekt - u ,tipično“ pučkoknjiževnom duhu - na kritičko-moralizatorski način komentira pogubna suvremena ponašanja i navade zbog kojih su kršćani, naposljetku, i morali podnijeti kaznu u vidu opsade i pada sigetske utvrde. Prema riječima personificirana Sigeta, sveopće kršćansko odmetanje od vjere manifestirano na svim područjima života i na raznorazne načine ponajviše u nepoštivanju deset Božjih zapovijedi, ignoriranju misnih slavlja, otvorenom ruganju Crkvi, izbjegavanju molitvenih dužnosti te uživanju u nepravdi, oholosti, lakomosti, bludnosti, zavisti i inim grijesima - poslužilo je kao izravan otponac Božjoj kazni (,,pak Bog radi toga šalje biče svoje: / kugu, glad, krvnoga i prolića boje“; II: 601-602), realiziranoj u obliku poraza kršćana i konačnoga turskog zaposjedanja Sigeta. Usprkos prilično očitoj činjenici kako ovaj motiv sigetske katastrofe kao nebeske kazne Vitezović najvećim dijelom preuzima iz Obside sigecke Petra Zrinskog - u kojoj se, podsjetimo, bezbožnički postupci kršćana također navode kao uzrok Božjega gnjeva na Ugare i njihova kažnjavanja padom Sigeta - nužno je primijetiti kako se kritika protukršćanskoga načina življenja u Odiljenju proteže na gotovo čitav katolički svijet (,tuđ bog skoro sidi v svakoj državi“; II: 554), čime se naposljetku promeće u gotovo ogledan primjer pučkoliterarnog jadikovanja radi udaljavanja od tradicije i njezinih višestruko potvrđenih, pa stoga i ,jedinih ispravnih“ vrijednosti.

Podastiranje otvorenih kritika uperenih protiv pogubnih (suvremenih) navika i ponašanja, i to s pozicije branitelja tradicionalnih - što će reći „temeljnih“ kršćanskih vrijednosti, valjalo bi izdvojiti kao jedno od uvjerljivo najkarakterističnijih obilježja pučkoga književnog stvaralaštva uopće. Da je upravo za tim obilježjem u rečenom segmentu pjesme 
Siget zvrhu samoga sebe posegnuo i Pavao Ritter Vitezović uvjerljivo će posvjedočiti ne samo netom detektiran motiv uopćavanja krivice za Božju kaznu, nego i inzistiranje na prikazbi same kazne kao općenitoga ,pravila“ - a ne kao posljedice konkretnoga prijestupa - kojim se (tipično pučki) željelo ukazati na tradicionalnu i svevremensku općevažećost „transcedentalnih“ zakona. Poput onih prezentiranih u ,punokrvno“ pučkoknjiževnim sastavcima, i Vitezovićeva kritika modernoga bezbožništva stoga uključuje (doduše, nešto suptilnije izraženo) zagovaranje povratka utvrđenoga otklona ili devijacije u ,koncipirani red“ koji je vrijedio do njezine pojave, što će reći da se i u njoj - kao i u mnogim drugim pučkim tekstovima - kršćanski način življenja brani kao ustaljena, pa time i poželjna društvena vrijednost te stoga glasno pledira za mijenjanje nepovoljne stvarnosti upravo u njegovu smjeru. ${ }^{900}$ Ipak, za razliku od literarnih prethodnika - ponajprije Petra Zrinskog, ali i Barne Karnarutića, pa čak i Ferenca Črnka - koji su osmanlijsko zauzeće u svojim „zrinijadama“ također sagledavali kroz prizmu ideje o Božjoj osveti za počinjene kršćanske grijehe, ${ }^{901}$ Ritter u Odiljenju nudi pomalo neočekivan opći, bitno osuvremenjen (pučki) komentar na pojavu sve nemoralnijih sklonosti u kršćana, koje će u svakome slučaju i u bilo kojem vremenskom kontekstu isprovocirati Božji gnjev i kaznu ne dođe li do njihova ispravljanja.

Usprkos tomu što je njegova kritička oštrica uperena protiv bitno drugačijih nepovoljnih suvremenih pojava, prethodnoj dionici Odiljenja po koncentraciji prepoznatljivo pučkoknjiževnih sastavnica i više će se nego srodnim ispostaviti segment pjesme Putnik $i$ Jeka! iz trećega njegova „dila“ posvećen ukazivanju na loše navike i uopće nedolična ponašanja onodobnih udanih žena. Kroz usta putnika namjernika i vile Jeke naš će autor u svega šesnaest stihova navedene pjesme (III: 135-150) tako ponovno iznijeti tipično pučkoknjiževnu kritiku, no ovoga puta ticat će se ona manjkavih suvremenih bračnih odnosa između (loših) žena i njihovih muževa, uslijed kojih žene pokazuju sve izrazitiju sklonost koristoljublju, zakulisnim činidbama, pa čak i obmanjivanju vlastitih partnera, što na koncu rezultira međusobnim nepovjerenjem koje postaje otponcem za sve učestalije razmirice („,Kad joj muž zamira, kara ju al sviti, / malo ga tad smira ljubiti? Ubiti“; III: 145-146). Nalik prethodnom kritičkom odsječku, koji se bazirao na ideji o Božjoj kazni baštinjenoj iz dotadašnje tradicije ,zrinijada“, i kritika nepoćudnih ženskih ponašanja svoje je porijeklo također vukla iz književne tradicije (riječ je, na kraju krajeva, upravo o tipično baroknoj zamisli o grešnim ženama, usklađenoj s duhom katoličke obnove), u kojoj se do toga trenutka vrlo rijetko pojavljivala obogaćena pučko- i usmenoknjiževnim čimbenicima, odnosno

\footnotetext{
900 O navedenim obilježjima pučkoknjiževnih sastavaka detaljnije u: Zečević 1978: 401-415.

${ }^{901}$ Podrobnije o motivu ili koncepciji Božje kazne u prijašnjim „,zrinijadama“ u: Novalić 1967b: 18-22.
} 
tekstualno prilagođena ponajprije ukusu i očekivanjima recipijenata sa skromnim književnočitateljskim iskustvom. To bi, drugim riječima, značilo da u okvirima Vitezovićeva Odiljenja pučkoknjiževni status i funkcije stječu čak i literarnom tradicijom ili aktualnim poetičkim sustavom legitimirane komponente ,visoke“ književnosti koje manje učeni recipijent ne bi bio osposobljen promatrati ni na podlozi „kanona“, ni na onoj suvremenoga baroknog književnog ukusa, slijedom čega se može reći da je naš autor iz tradicije u svoje ostvarenje prenio upravo „ono što će učeni prepoznati kao njezin dio, a neukima neće smetati i još će im biti i inovativno i zanimljivo“ (Pavličić 2007: 282).

Osim detektiranih segmenata sa zamjetnijom koncentracijom pučkoknjiževnih karakteristika, u kojima je do posebnoga izražaja došla tipično pučka kritičko-moralizatorska intencija komentiranja neprikladnih suvremenih društvenih pojava i ponašanja, u Odiljenje su također uklopljeni i mnogi izdvojeni motivi prepoznatljivo pučkoknjiževne provenijencije. Ponajprije, kao sasvim lišen poveznica s pučkom literaturom - u sklopu koje se ističe kao jedno od najeksploatiranijih motivskih rješenja $a^{902}$ - tako se nipošto ne bi mogao označiti gotovo opsesivno variran (i baroknoj književnosti osobito drag) motiv prevrtljivosti sreće, koji ondje postaje dijelom višeslojnoga mehanizma krutoga binarnog opozicioniranja što ga Ritter provodi na relacijama sreća-nesreća, život-smrt, ovozemaljsko-onozemaljsko, sloganesloga, hrabrost-kukavičluk itd. Pored njega, na pučkoknjiževno bi svoje porijeklo upućivao i u Odiljenju - kako smo vidjeli - također iznimno važan motiv kazne (koji u pučkim tekstovima obično vrši ulogu ,alata“ kojim se postiže vraćanje društvenoga otklona u koncipirani red), koja će doskora zadesiti nelojalnoga „Ugrina perjenog“ jer je odbio poslati pomoć hrvatskim braniteljima Sigeta, ali i pojedini motivi stradanja kršćanskih branitelja što karakteristično pučki - aludiraju na arhetip Kristove muke ili pasije. ${ }^{903}$ Pučkoknjiževno impliciranje Isusove patnje najočitije će se tako očitovati u dvjema Radovanovim nadgrobnicama - Andrijina Radovana (IV: 180-193) i Druga istoga (IV: 194-199) - u kojima se naglašava kako je poginuli prije smrti ranjen ni manje ni više nego punih dvjesto puta (,Vitez od dvisto ran oslabljen on jaki“, IV: 194), čime se ujedno postiže i senzacionalistički dojam, koji se također nameće kao vjerni pratitelj pučkih literarnih ostvarenja. Naposljetku, ne treba zaboraviti ni ranije već primijećen motiv ispjevavanja (usmenih) pjesama o sigetskim junaštvima bana Zrinskog, koji kao da želi prizvati upravo pučki „strah od zaborava““ (Zečević 1978: 446) kao temeljni stvaralački impuls pučkoknjiževnih autora.

\footnotetext{
902 Usp. Zečević 1978: 440.
}

${ }^{903} \mathrm{O}$ tome u: isto: 538-539. 
Gotovo svi dosad pobrojani (para)tekstualni indikatori usmjerenosti (prvih dvaju izdanja) Odiljenja sigetskog recipijentima i iz pučkih krugova - uporaba tronarječne inačice hrvatskoga jezika, vizualno dopadljiva naslovnica, uvrštavanje predgovora čitateljima, posvemašnja stilska olakšanost, posezanje za različitim usmenoknjiževnim elementima, eksplicitno naznačena didaktičko-utilitarna intencija itd. - nisu zapravo ništa drugo no skup pretežno načelnih tekstualnih značajki zajedničkih vrlo velikom broju žanrova prisutnih u sferi pučke književnosti. Prihvatimo li ih doista kao takve, samo će nam se od sebe - kao posve logično i očekivano - nametnuti i pitanje o konkretnim dokazima za pretpostavljenu Vitezovićevu generičku percepciju pučkoknjiževnih ostvarenja, potičući nas da istražimo je li naš autor specifična obilježja iz ,repertoara“ pojedinih pučkih žanrova preuzimao ciljano i sa sviješću o njihovoj specifičnosti ili je - pak - iz generički raznolikoga korpusa pučkog štiva crpio upravo one (,tipično“ pučkoknjiževne) značajke čija egzistencija nije bila vezana uz isključivo okvire jednoga žanra, pa čak ni uz one njih „tek“ nekolicine. Da bismo to uopće bili u stanju učiniti, valja nam se prisjetiti kako je pučkoknjiževno stvaralaštvo u nas u 17. stoljeću - ubrojimo li u nj sve „ono što ima grafički (ili kako drugačije) fiksiran tekst, a predstavlja se kao informacija ili ima kakvu praktičnu svrhu“ (Pavličić 1987: 82) - pred čitatelje dospijevalo generički realizirano ili u „obliku“ molitvenika, katekizma, zbirke propovijedi i isusovačke drame, ili u formi pučkoga kalendara, anonimne rukopisne pjesmarice, zbirke poslovica, povijesno-kronikalnoga prikaza itd., ${ }^{904}$ čemu je svojom kontinuiranom autorsko-tiskarskom djelatnošću sam Vitezović dao izniman doprinos. Računajući s generičkim posebnostima svake od pobrojanih sedamnaestostoljetnih pučkih žanrovskih varijanata, posao traganja za prisutnošću nekih od njih na tekstualnom prostoru Odiljenja ispostavit će se ne samo lakšim, već i nimalo izlišnim, tim više što su - pokazat će se - pučkoknjiževne Ritterove ,aspiracije“ kada je Odiljenje u pitanju bile itekako žanrovski određene i odrađene.

Naime, da pojedina prepoznatljivo pučkoknjiževna obilježja te njihove kombinacije što ih nalazimo u Vitezovićevoj „zrinijadi“ prilično jasno ipak upućuju na svoje vrlo konkretno generičko podrijetlo možda je ponajbolje moguće uvjeriti se na primjeru maločas

\footnotetext{
904 Govoreći o žanrovima pučke književnosti, treba znati kako je njezin (teorijski) ,generički sustav“ daleko bogatiji i obuhvaća „razne pričice, anegdote ili pjesme u pučkim kalendarima u kojima se daju i upute iz agrotehnike i meteorologije, kao i štivo u svim sličnim publikacijama“, potom ,stihove na kuhinjskim krpama, nadgrobnim spomenicima i u čituljama, kao i stvaralaštvo pučkih pjesnika koji, najčešće u desetercu, opjevavaju boks-mečeve, pobjede nogometne reprezentacije, sudare vlakova i druge važne događaje“ (Pavličić 1987: 82). Ovoj ionako bogatoj i razvedenoj žanrovskoj slici pučke književnosti pridružit će se i niz povijesnih pučkih žanrova (srednjovjekovne legende, mirakuli, viteški romani, životi svetaca, isusovačke školske drame iz 17. i 18. stoljeća), potom kompilacije poput rukopisnih pjesmarica sklopljenih od epskih i lirskih pjesama nejednake tematike, ali i pučki romani, letci, almanasi, parodijski govori, dosjetke i šatrovački rječnici, pa čak i sanjarice, proročanstva i astrološke prognoze. Znatno podrobnije o generičkom rasponu pučke književnosti u: Zečević 1978: 357-638 i Bošković-Stulli 2011: 499-501.
} 
detektiranih dionica uključenih u pjesme Siget zvrhu samoga sebe i Putnik i Jeka!, u kojima se iznose kritičko-moralistički osvrti na pogubna (moderna) ponašanja. Ostavimo li, ukratko, po strani moguće generičke paralele molitvenih odsječaka Odiljenja (uvelike skrojenih po usmenoknjiževnim predlošcima) i pučkih anonimnih molitava okupljanih u brojnim onovremenim molitvenicima, kao i vjerojatne podudarnosti u nekim značajkama (glavninom onima posuđenim iz usmenoknjiževnoga pjesništva) što ih pojedine Ritterove pjesme dijele $\mathrm{s}$ pjesničkim tekstovima zabilježenima u anonimnim rukopisnim kajkavskim pjesmaricama iz 17. stoljeća, rečeni komentatorski dijelovi, u kojima govornici upućuju otvorene kritike (suvremenim) kršćanima što ustraju u prakticiranju bezbožničkih navika te udanim ženama nedovoljno posvećenima vršenju bračnih dužnosti, upravo bi se zahvaljujući svome bespoštednom šibanju pojedinih aktualnih društvenih pojava iz pozicije branitelja tradicionalnih kršćanskih vrijednosti mogli i morali izdvojiti kao generički najbliži pučkoknjiževnom (točnije, poluknjiževnom, odnosno književno-religijskom) žanru barokne propovijedi ili „prodečtva“. Pritom u samom činu „nadograđivanja“ žanrovski šarolikoga književnog teksta posvećenog važnom povijesnom događaju kritičko-moralistički nastrojenim dionicama oblikovanima po generičkom „obrascu“ propovijedi ne bi trebalo vidjeti ništa sporno, i to ne samo iz razloga što ih Ritter vješto i promišljeno pozicionira na sadržajno i generički daleko najprikladnija mjesta u tekstu, već i stoga što je riječ o jednom od (u nas i u većini drugih europskih kultura) najpopularnijih, najčešćih $i$ najvažnijih baroknih (polu)književnih žanrova, čija su se prepoznatljiva obilježja lakoćom uklapala i u žanrovski daleko „konzervativnija“ sedamnaestostoljetna ostvarenja od hibridnoga Odiljenja sigetskog.

$\mathrm{Na}$ silnu onodobnu popularnost ,prodečtava“ ni naš se autor pri sastavljanju svoje „zrinijade“ očito nije mogao tek tako oglušiti, tim više što su mu konvencije ovoga žanra morale biti i više nego dobro poznate, ne samo zahvaljujući redovitom slušanju (iz)govorenih propovijedi u crkveno-liturgijskom okružju, nego i iz niza pročitanih primjeraka ovoga žanra što su ih mnogi onodobni autori iz crkvenih krugova skupljali u svojim u to vrijeme iznimno rado čitanim kompilacijama. Među potonjim pripadnicima svećenstva, što su se iz religioznih potreba u 17. stoljeću rado laćali pera, bio je i sam rektor zagrebačke isusovačke gimnazije iz vremena Vitezovićeva školovanja - Juraj Habdelić - čije je obimne dvije zbirke propovijedi (Zrcalo marijansko iz 1662., odnosno Prvi oca našega Adama greh iz 1674.) naš autor u godinama uoči početka rada na Odiljenju gotovo sigurno imao u rukama, a vrlo vjerojatno dobio je - osim njih - priliku zaviriti i u makar još poneku sličnu kompilaciju, u sastavljanju kojih su se tih godina u nas okušali mnogi nenadmašni propovjednici, počevši s Ivanom Belostencem i Nikolom Krajačevićem, preko Jurja Muliha i Mihalja Šimunića, pa sve do 
Baltazara (Boltižara) Milovca, koji je u svoje vrijeme slovio kao jedan od najuspješnijih praktikanata ovoga žanra. Dojmljivošću svojih propovijedi i reakcijama što su ih one izazivale u nas se u 17. stoljeću ponajviše isticao upravo Habdelić, koji se nije ustručavao redovito se u njima upustiti gdjekad i u vrlo zamašna razmatranja iskvarenosti i bezbožnosti suvremenoga društva te otvorene, nerijetko i prilično žestoke kritike modernih pojava i ponašanja, u kojima su se lako mogli prepoznati čak i konkretni pripadnici aristokracije što su tada uživali izniman društveni ugled. Habdelić, ukratko, žanr barokne propovijedi ponajvećma rabi za kritičko seciranje stanja u suvremenome (sjeverno)hrvatskom društvu, nemilosrdno u njemu „šibajući“ ne samo nemoralna ponašanja i navike što su se ukorijenile u nižim društvenim slojevima, već naročito one prisutne među građanstvom, plemstvom, pa čak i svećenstvom, puneći pritom te svoje uvide humorno-satiričnim osvrtima te otvoreno pledirajući za pokoru i ispravljanje pobrojanih bezbožničkih „,aktivnosti“ kako ne bi i dalje izazivale sablazan i Božji gnjev. ${ }^{905}$

Bit će da su upravo ovakvom „habdelićevski“ jetkom tipu barokne propovijedi - u kojemu bespoštedna kritika pojedinih društvenih pojava izrasta u vrlo živopisnu sliku javnog i privatnog života onoga vremena, ali i u kojemu su, između ostalog, predmetom najoštrijih kritika nerijetko postajale i vlastitom vanjštinom te drugim materijalnim zadovoljstvima suviše „opsjednute“ suvremene žene - generički željeli biti bliski spomenuti kritičkomoralistički odsječci Odiljenja sigetskog, u kojima su se iznesene osude protukršćanskih ponašanja što su raspirila Božji bijes i dovela do sigetske katastrofe te vlastitim muževima nedovoljno posvećenih žena itekako aludirale i na najsuvremenije pojave koje su se doslovce zbivale „pred očima“ našega autora. Ne želeći propustiti priliku da se u svome tekstu namijenjenom različitim tipovima čitatelja iz svih hrvatskih regija ili zemalja ukratko osvrne i na te i takve moderne društvene ,,anomalije“ - dakako, računajući na jednaku osviještenost $\mathrm{i}$ interes većeg dijela ciljane publike - Pavao Ritter Vitezović nije imao drugog izbora no rečene komentatorske „umetke“ generički realizirati glavninom po uzoru na (proznu) baroknu propovijed, koja je - kao „tipično“ pučki (polu)književni žanr - iz kršćanske perspektive upozoravala na svaki (moralni) otklon od zamišljenoga ustaljenog reda, odnosno „vječno važećega“" poretka utemeljenog na kršćanskim mjerilima, potkrepljujući svoje kritike ideološki obojanim argumentima primjerenima širokim čitateljskim (ili „samo“ slušateljskim) masama, čiju je pozornost privlačila ne samo intrigantnošću sadržaja prezentiranih njima razumljivim jezikom, već počesto i stilsko-retoričkim „vratolomijama“, izvedenima po uzusima barokne poetike, kojima je željela postići publici iznimno primamljiv dojam maraviljoznosti. Težeći originalnosti kao višestruko potvrđenoj „univerzalnoj“ strategiji

${ }^{905}$ Usp. primjere Habdelićevih propovijedi u: Šojat 1977b: 41-132, Bartolić 1985 i Bratulić 1996: 38-47. 
buđenja interesa kod izrazito šarolike publike, pisci baroknih su propovijedi svoje sadržajno i formalno relativno pojednostavljene tekstove obilno, naime, punili kojekakvim kombinacijama retoričko-figuralnih ukrasa te raznim drugim stilskim efektima i senzacijama, a sve ne bi li ciljanoga recipijenta - bez obzira na stečeno obrazovanje i prethodno čitateljsko i/ili slušateljsko iskustvo - što efektivnije zapanjili, odnosno ne samo privukli, nego i održali njegovo zanimanje za samu propovijed i u njoj podastrijete korisne pouke i upozorenja. ${ }^{906}$

Pisce baroknih propovijedi Vitezović je pri sastavljanju komentatorskih dijelova Odiljenja u potpunosti slijedio svojom nakanom da ispiše intrigantnim kriticizmom prožete tekstualne segmente jezično prilagođene čak i skromno obrazovanim recipijentima, očito i više nego svjestan činjenice da je - još od sredine 16. stoljeća - upravo propovijed „,izgrađivala govorni i pisani hrvatski jezik (...) jer je najčešće i najneposrednije komunicirala s velikim brojem slušatelja i govornika, jednako u pučkoj propovijedi kao i u odjecima te propovijedi u pučkom govoru: na svečanostima, pučkim igrama i obrednim sastancima“ (Bratulić 2003: 549). Ako se, međutim, žanr baroknog „prodečtva“ tim svojim imperativom jezične pristupačnosti u potpunosti podudarao s njegovom zaokupljenošću osmišljavanjem i realiziranjem (tronarječne) vernakularne ,zrinijade“ jezično razumljive apsolutno svim čitateljima s prostora „cjelovite“ Hrvatske, (is)to se ne može reći i za sklonost propovijedi začudnim i uopće pretjeranim stilskim konstrukcijama, koja je teško išla pod ruku s Ritterovom stilskom suzdržanošću, od koje se u četiri „dila“ Odiljenja sigetskog odvažio odstupiti na svega tek nekoliko mjesta. Shvativši kako kritičko-moralistički odsječci njegova hrvatskog prvijenca u stilskom pogledu neće moći držati korak s baroknom propovijedi, koja je - uvažavajući ključne propise barokne poetike - stremila figuralnoj bujnosti, paradoksu, duhovitosti, jezičnim igrama i napose teatralnosti, a k tome još i obilno bila premreživana filozofskim dionicama te primjerima iz antičke - grčke i rimske - tradicije, ${ }^{907}$ naš je autor tu njihovu prilično uočljivu stilsku ,inferiornost“ pokušao donekle kompenzirati pridruživanjem pojedinih obilježja i cjelovitih primjeraka drugih (mahom enigmatskih) žanrova (kronogram, zagonetka itd.), intenziviranjem neostoicističke ideološke podloge te involviranjem motiva porijeklom iz antičke mitologije, a sve u cilju stvaranja makar kakvoga-takvog efekta začudnosti kao jamca privlačenja i zadržavanja čitateljeve pozornosti.

Ukratko, generičkog obrasca barokne propovijedi u komentatorskim se segmentima Odiljenja Vitezović ponajviše pridržavao u sadržajno-ideološkom pogledu, pribjegavajući

\footnotetext{
906 O posebnoj pučkoknjiževnoj sklonosti tematiziranju događaja koji su predstavljali moralni otklon od ustaljenih vrijednosti konkretne zajednice i njezinu otvorenom zagovaranju (sada narušenoga) prvobitnog poretka naročito u: Zečević 1978: 357-638. Podrobnije o žanru (barokne) propovijedi u: Bartolić 1985 i Bratulić 1996: 5-12.

${ }^{907}$ Usp. o tome u: Bratulić 2003: 533-549.
} 
kritici stanovitih nepoćudnih društvenih pojava iz perspektive branitelja ustaljenih kršćanskih vrijednosti, baš kao što su to u svojim intrigantnim ,prodečtvima“ neumorno činili i vrsni onodobni propovjednici poput Jurja Habdelića. Znamo li da su - između ostalog - upravo žene bile „vrlo česta meta Habdelićevih satiričnih napadaja“ (Bartolić 1985: 219), ali i da su u mnogim sedamnaestostoljetnim propovijednim ostvarenjima što su nastajala $u$ različitim slavenskim kulturama prezentirani ne samo savjeti o ponašanju muškarca i navlastito žene u idealnomu braku, nego nerijetko i otvoreno mizogine kritike suvremenih žena koje su, zbog pomanjkanja dostojanstva, u stanju pukom slatkorječivošću sasvim razoružati i zavesti muškarce, ${ }^{908}$ čini se da će se to Vitezovićevo sadržajno približavanje baroknim propovijedima ipak znatno jače očitovati u kritičkoj dionici uklopljenoj u pjesmu Putnik i Jeka!, u kojoj podsjetimo - kritici bivaju podvrgnuta nepoželjna ponašanja udanih žena. Habdelićevi i ne samo Habdelićevi propovijedni sastavci, povrh toga, na svojem nam primjeru vrlo jasno pokazuju kako se (ni) barokno ,prodečtvo“ nije bilo u stanju realizirati kao „čisti““ žanr, što znači da bi upravo činjenicu kako je redovito ono apsorbiralo čitav niz cjelovitih ili fragmentarnih žanrova te njihovih karakterističnih značajki - počevši od onih rasprave, traktata, pripovijesti i basne, preko anegdote, alegorije i lirske pjesme, pa sve do molitve, egzempla (,pelde“), poslovice i dr. ${ }^{909}$ - valjalo prihvatiti (i) kao temeljni razlog bjelodanoga Vitezovićeva odustajanja od toga da svoje propovijedi srodne dionice pokuša ostvariti kao „čiste“, tragovima drugih žanrova nekontaminirane segmente. Ako, u tom smislu, njegovo oslanjanje na konkretna (glavninom sadržajna) obilježja generičkoga hibrida poput barokne propovijedi - koja se, kao takva, sjajno uklapala u žanrovski ionako „zapetljano“ Odiljenje stoga nipošto ne bi trebalo držati iznenađujućim, ni najmanje nam čuđenje ne bi trebala izazivati ni njegova odluka da prepoznatljivo propovijednim elementima premreži baš dionice jednoga u cijelosti versificiranoga teksta, naročito znamo li da je riječ o žanru koji se usprkos tomu što pojava stihovanih ,prodečtava“ u našoj sedmnaestostoljetnoj književnosti nije zabilježena - u posebnim slučajevima ostvarivao i u vesificiranu obliku, kao što to možda i ponajbolje demonstrira opus glasovitoga bjeloruskog baroknog pjesnika Simeona Polockog, u kojemu su se zatekle čak i propovijedne lirske pjesme. ${ }^{910} \mathrm{Na}$ kraju krajeva, ,punokrvnoj“ propovijedi sadržajno izrazito bliskom segmentu - u kojemu se pripovjedač, nalik Vitezovićevu Sigetu, oštro okomljuje na suvremeno ustrajanje Ugara u kojekakvim grješnim, bezbožničkim ponašanjima u rasponu od nesloge i zatiranja vjere, pa sve do pohlepe,

\footnotetext{
${ }^{908}$ Detaljnije o posebnostima propovijedi različitih slavenskih baroknih autora u: Angyal 1961: 44-51. ${ }^{909} \mathrm{O}$ generičkoj hibridnosti barokne propovijedi na Habdelićevu primjeru opširnije u: Bartolić 1985.

${ }^{910}$ Pojedine lirske pjesme Simeona Polockog, ponajprije zahvaljujući stanovitim im sadržajnim posebnostima, stihovanim je propovijedima svojedobno proglasio Andreas Angyal (usp. Angyal 1961: 51-54).
} 
sklonosti krađi, bludu, „ljudomorstvu“, pijanstvu itd. (I: 1-5) - svoju Obsidu sigecku otvara i Petar Zrinski, davši time možda i najsnažniji podstrek izravnome literarnom nasljedniku da se u tek koje desetljeće „mlađem“ Odiljenju - uvjerivši se da propovijedne silnice itekako dobro mogu funkcionirati i u stihovanoj formi - i sam odvaži učiniti isto.

Kao što se rečena „kontaminiranost“ barokne propovijedi nizom drugih žanrova i/ili pojedinih njima svojstvenih značajki nametala kao jedna od strategija za privlačenje pozornosti raznolike - no ponajprije ipak slabije obrazovane - publike, a time i za potvrđivanje njezina pučkoknjiževnog statusa, tako je i generički „,nered“ kojem svjedočimo na tekstualnom prostoru Ritterove „zrinijade“ za svoj primarni cilj imao upravo provociranje zanimanja što je moguće većeg broja potencijalnih čitatelja, poglavito onih koji su još „do jučer" recipirali isključivo produkte folklornoknjiževnoga stvaralaštva. Naime, za razliku od prilično uskog kruga visokoobrazovane čitateljske „elite“, koja je - zahvaljujući stečenoj klasičnoj naobrazbi i formiranom, vrlo rafiniranom literarnom ukusu - preferirala „čiste“ ili makar „čišće“ književne žanrove, pažnju daleko mnogobrojnijih (i mahom samo bazično obrazovanih) recipijenata iz nižih društvenih slojeva - dakle, pučke publike - glavninom su zaokupljali zamršeni generički spletovi, odnosno žanrovski vrlo „nečista“ i slojevita, no istodobno i sadržajno intrigantna utilitarna književna ostvarenja. Drugim riječima, s obzirom na to da se pristup tih i takvih pučkih čitatelja književnom tekstu temeljio na (pr)ocjeni ne njegove estetske uspjelosti, već - upravo suprotno - stvarne praktične koristi koju su od njega trebali imati, ne začuđuje što na „čistoću“ njegove žanrovske dimenzije oni nisu obraćali naročito veliku pozornost, tim više što velika većina njih nije ni bila u stanju razlučiti u njemu prisutne značajke različitih književnih i ne samo književnih žanrova, a kamoli proniknuti u konkretan njihov žanrovski izvor. Upravo iz razloga što je pučkim recipijentima ponajmanje bilo važno je li dani tekst „primjereno“ žanrovski realiziran sve dok ih je zaokupljao svojom formalnom šarolikošću, sadržajnom uzbudljivošću i uopće korisnošću, u ranonovovjekovnoj su pučkoj književnosti brojnošću i dominirala višežanrovska ostvarenja zborničkoga tipa poput kalendara, almanaha, pjesmarice, molitvenika, katekizma itd., čime je ujedno nastavljana ranija (proto)pučkoknjiževna praksa sastavljanja štiva za širu publiku, i to mahom generičkih mješavina poput prozno-versificiranoga zbornika i antičkoga romana, za ispravnu recepciju kojih pronicanje u njihov stvarni žanrovski identitet nije bilo gotovo ni najmanje neophodno. ${ }^{911}$ Uzgred budi rečeno, zahvaljujući fascinaciji skromnije obrazovanih čitatelja žanrovski „nečistim“ sastavcima, točnije postupno sve većem otvaranju književnosti i publici

\footnotetext{
911 Podrobnije o pučkom čitatelju i konkretnim obilježjima pučke književnosti ili - riječima Divne Zečević „pučkoga književnog fenomena“ u: Zečević 1978: 357-638, Bošković-Stulli 1983: 5-114 i 2011: 499-501, Pavličić 1987: 74-83 i 2017b: 5-17, Tomašić 2015: 179-194, Budišćak 2015: 154-169.
} 
sa slabijim literarnim (pred)znanjem, koju, umjesto estetskih kvaliteta, u literarnome tekstu intrigiraju ponajprije uzbudljivi zapleti prezentirani u generički slojevitu okviru, sam roman kao jedan od uopće najhibridnijih, pa time i „najdemokratičnijih“ žanrova - neobičnom je svojom žilavošću dospio preživjeti brojne smjene književnih poetika prometnuvši se na koncu u najomiljenije i najeksploatiranije, odnosno dominatno suvremeno žanrovsko rješenje.

$\mathrm{Na}$ tragu nemalog broja domaćih i stranih pisaca ,punokrvnih“ pučkoknjiževnih tvorevina, Pavao Ritter Vitezović Odiljenju sigetskom pridaje - povrh svega rečenog - još i vrlo izrazitu zabavnu, ludičku crtu, na koju upućuje nekolicina u njemu zastupljenih izdvojenih formalnih postupaka i generički specifičnih tekstualnih karakteristika. Konkretno, formalno-sadržajni ludizam što ga naš autor - kako je maločas već nagoviješteno - pokušava postići eksploatacijom mehanizama usmenoknjiževnih zagonetki, uključivanjem kronograma i homonimskih rima, posezanjem za figurom jeke, ali i „napadnom“ metričkom šarolikošću te pojedinim sadržajnim rješenjima (dijalog Sofije i orla), u kontekstu Odiljenja trebao bi vršiti zadaću verbalnog zabavljanja slabije učenih čitatelja (a gdjekad i „,samo“ slušatelja), ${ }^{912}$ što na kraju krajeva - i jest temeljna funkcija pučkoliterarnoga štiva, pored, dakako, jasne praktične koristi. Sa zabavljačkom se svrhom, povrh toga, u Odiljenju prepliće i već zamijećena (pučka) utilitarno-didaktička komponenta, budući da je - osim čuvanja i prenošenja sjećanja na važan povijesni događaj te predstavljanja novoga (sve)hrvatskog jezika i stvaranja podloge za njegovo buduće širenje i prihvaćanje - ono recipijenta trebalo poučiti i o važnosti herojske (ratničke) žrtve za „više ciljeve“ kojom se stječe dobar glas na zemlji i mjesto u raju, što je posebno moralo biti važno i poticajno baš u godinama nakon poraza Turaka pod Bečom, kada su u pripremi bile protuturske akcije kojima će uskoro biti oslobođeni dijelovi okupiranih hrvatskih teritorija. Nije stoga nimalo neobično što će moralističke pouke o časnoj vojničkoj pogibiji Ritter ustrajno „nadograđivati (folklornim) poslovicama na temu prolaznosti i neizbježnosti smrti želeći - tipično pučki - „visoku“ književnost i njezine osnovne ideje ,približiti puku, ne bi li njezin utjecaj bio veći“ (Pavličić 2007: 283), što je ideja za koju se s punim pravom, doduše, može reći da proizlazi iz općega baroknog (protureformacijskog) usmjerenja na široke čitateljske slojeve, iako je u svojoj srži pučka i s(p)retno se - kao takva - u ovome slučaju upotpunjuje s djelom koje mnogobrojnim svojim svojstvima uvelike anticipira kasniji vrlo razgranat spektar pučkoknjiževnih oblika u rasponu od letaka, kalendara i molitvenika, preko sanjarica i horoskopa, sve do pučkih romana, deseteračkih pjesama o aktualnim događajima i deseteračkih kronikalnih prikaza.

\footnotetext{
912 O tome posebno i u: Pavličić 2007: 279-284.
} 
Govoreći (djelomično) o Odiljenju sigetskom, ali i drugim „pučkim“ sastavcima Vitezovićeva vremena kao svojevrsnoj predigri za nagli procvat pučke književnosti u narednim stoljećima, treba naglasiti da je - usprkos činjenici kako su mnogi književni povjesnici začetke pučkoga literarnog stvaralaštva u nas datirali u 18., a neki čak i u 19. stoljeće - pučki književni fenomen u okvirima hrvatske književnosti, kako se u nešto recentnijoj stručnoj literaturi sve glasnije tvrdi, kontinuirano bio prisutan već od samih njezinih početaka (točnije, još od pojave srednjovjekovnoga poučnog i vjerskog štiva za puk), dočim bi njegovu ,početnu točku“ kada je svjetska književnost u pitanju zapravo predstavljala sama Biblija, iako stvarne korijene on najvjerojatnije vuče još iz literarnoga stvaralaštva poganskih vremena. ${ }^{913}$ Doduše, iako pojedini proučavatelji takvim konstatacijama suprotstavljaju spoznaju da pučka književnost - kao (pisano) stvaralaštvo namijenjeno ponajprije vrlo brojnom čitateljstvu sa slabijom naobrazbom - nipošto nije mogla postojati prije pojave tiska ${ }^{914}$ (slijedom čega bi prvim pučkim štivom u nas trebalo proglasiti vjerske pučke knjige što su ih u 16. st. tiskali domaći reformatori), nekolicina stručnjaka za ova pitanja ne da se ipak pokolebati u uvjerenju kako „najveći dio srednjovjekovne proze pisane glagoljicom, na staroslavenskom, a zatim na starohrvatskom jeziku, po stilu i tematici pripada naivnoj pučkoj literaturi“ (Stipčević 2005: 171). Kada je, međutim, riječ o književnoj produkciji našega 17. stoljeća, s uma se nipošto ne bi smjelo smetnuti kako je (i) hrvatska barokna književnost - nalik svojim „srodnicama“ iz drugih onodobnih europskih kultura zbog vrlo izrazitih, ovdje već spomenutih izvanknjiževnih (pretežno društveno-ideoloških) ciljeva koje je morala ispuniti, bila prisiljena prilagoditi se očekivanjima recipijenata uistinu vrlo raznolikoga čitateljskog spektra ne bi li na svakoga od njih djelovala (ili makar pokušala djelovati) na jednak način, prenoseći mu neke ključne poruke, spoznaje i ideje.

Budući da su - kako je ovdje već višestruko istaknuto - u „sastav“ književne publike 17. stoljeća ulazili kako učeniji i literarno iskusniji čitatelji iz viših društvenih slojeva, tako i jedva opismenjeni pojedinci skromne (književne) naobrazbe, čija je predodžba o književnom stvaralaštvu bila stvorena pretežno kroz recepciju usmenoknjiževnih tvorevina, barokna se književnost - kako bi udovoljila očekivanjima i potrebama jednih i drugih - postupno raslojila na (isključivo) književnu produkciju za znalce (visokoobrazovane recipijente) te na onu za šire mase, odnosno za slabije obrazovanu publiku, koja je od literature iziskivala „samo“ zanimljivo prezentiranu praktično uporabljivu činjenicu. Bez obzira na to što su djela upućena pretežno potonjem tipu publike doista bila sastavljana (pa i, nešto kasnije, objelodanjivana) i

\footnotetext{
${ }^{913}$ Detaljnije u: Zečević 1978: 392.

${ }^{914}$ Usp. Bošković-Stulli 1983: 55.
} 
znatno prije 17. stoljeća, tek u baroku pučka se književnost nametnula kao neizostavan dio literarnoga života, osamostalivši se do te mjere da je napokon postalo moguće razlikovati je od „visoke“ ili „umjetničke“ književnosti, čemu je ponajviše doprinijelo upravo spomenuto oživljavanje tiskarske proizvodnje u Hrvatskoj, zahvaljujući kojemu se i otvorila mogućnost tiskanja knjiga za oba tipa publike. Što se komunikacije između dviju ovih baroknih književnih varijanata tiče, ona je itekako postojala, o čemu možda i ponajbolje svjedoči ustoličenje osmerca kao „službenoga“ stiha naše južne - dubrovačko-dalmatinske sedamnaestostoljetne (,umjetničke“) književnosti, odnosno upravo metričkoga rješenja usmeno-pučke provenijencije, s kojim je većina recipijenata bila i više nego dobro upoznata, slijedom čega je on i bio u stanju uspješno izvršiti funkciju pridobivanja širokih čitateljskih masa. Iako je, konkretno, najprije bio evociran kao forma onih djela koja su se primarno željela približiti slabije učenim čitateljima, naposljetku je on ipak prihvaćen čak i u okvirima umjetničke barokne književnosti, potvrdivši se kao stih prihvatljiv čak i publici koja je posjedujući bogato čitateljsko iskustvo - od književnosti imala krupna očekivanja, čime je ujedno s punim pravom stekao (i) status visokoliterariziranoga stihovnog rješenja. Uostalom, to paralelno služenje istim istim stihom neminovno je rezultiralo i olakšavanjem razmjene literarnih rješenja i postupaka „visoke“ ili umjetničke i pučke književnosti, a onda uopće i pojednostavljivanjem komunikacije između tih dviju baroknih literarnih opcija. ${ }^{915}$

Osim formalnih - metričkih - poveznica, rečene su dvije, naoko oštro razlučene sedamnaestostoljetne literarne varijante dodatno zbližavali i sami njihovi „konzumenti“, i to ponajprije visokoobrazovani aristokrati, koji su - pored njima namijenjene ,elitne“ literature - rado „gutali“ i autohtona folkornoknjiževna ostvarenja (točnije, prisustvovali njihovim izvedbama), ali i ,pravo“ pučkoknjiževno štivo u rasponu od molitvenika i zbirki propovijedi, pa sve do kalendara i knjiga gatalica, među stalnom publikom kojega su u 17. i 18. stoljeću bile i mnoge ženske pripadnice plemićkih porodica. Tu pojavu aristokratskoga uspostavljanja zanimanja (i) za pučkoknjiževnu produkciju moguće je - osim u nas - zapaziti i drugdje diljem ,predindustrijske“ Europe, i to ponajprije zahvaljujući činjenici što su - kako u svojoj studiji konstatira Peter Burke - pripadnici viših slojeva još i u barokno vrijeme njegovali poseban osjećaj za „narodnu“ kulturu, a time i za pučku književnost, i to glavninom zahvaljujući svojim vrlo čestim osobnim sudjelovanjima u kolektivnim proslavama narodnih običaja (primjerice, u pokladnim svečanostima), ali i činjenici da su još od malih nogu

\footnotetext{
915 Podrobnije o tome u: Pavličić 1995: 169-188. O pučkoj književnosti kao jednoj od najvažnijih komponenata naše ranonovovjekovne književne produkcije u: Stipčević 2005: 169-182.
} 
dolazili u kontakt s izvornim „,narodnim“ stvaralaštvom, ${ }^{916}$ primjerke kojega su kasnije svakodnevno okruženi kulturom jedva opismenjenih ili gotovo posve nepismenih društvenih slojeva - nerijetko i bilježili u pjesmarice ili druge njima slične kompilacije. To su, ukratko, bili osnovni razlozi zbog kojih pripadnici najviših društvenih slojeva pučku književnost isprva još nisu shvaćali kao toliko strogo odijeljenu od svoga kulturnog kruga, točnije zbog kojih je nisu povezivali (isključivo) s nižim društvenim slojevima, što je rezultiralo time da su njezine tvorevine tada (još) čitali kako siromašni, tako i bogati pojedinci; kako oni neobrazovani, tako i oni visokoobrazovani, ${ }^{917}$ kao što se to lijepo može razabrati baš iz primjera Vitezovićevih kalendara. Premda namijenjeni ponajprije čitateljima iz ruralnih područja, u rukama kojih su morali ispuniti neku svoju privremenu praktičnu svrhu, primjerci pojedinih Ritterovih kalendara dospjeli su se sačuvati sve do današnjega dana, što bjelodano upućuje na to da ih nikako nisu mogli posjedovati ,pravi“ pučki čitatelji, koji - nakon što bi godina došla svome kraju, a sam se kalendar stoga pokazao zastarjelim i beskorisnim - takvo štivo naprosto nisu držali svrsishodnim čuvati, već su ga ili bacali ili svezak ,upotrebljavali“ na raznorazne načine. U tom smislu, nije neopravdano pretpostaviti da su sačuvani primjerci kalendara našega autora bili vlasništvo učenijih čitatelja, koji su u njima ipak prepoznali i neku neprolaznu vrijednost, odnosno neki detalj vrijedan čuvanja, zbog kojega su ih naposljetku i pohranili u vlastitim kućnim bibliotekama, baš kao što su mnogi od tih istih aristokrata u svojim bibliotekama posjedovali i primjerke Vitezovićeve Kronike (1696.), koja usprkos činjenici da je primarno bila zamišljena kao djelo ,maleno i priprosto, te prilagodjeno shvatanju manje obrazovanih“ (Klaić 1914: 106), nije također promaknula ni pažnji tih daleko kvalitetnije obrazovanih i literarno iskusnijih recipijenata. ${ }^{918}$

Neovisno, ipak, od utvrđene ,polarizacije“ barokne književnosti na literarno stvaralaštvo za uži krug učenijih književnih sladokusaca te utilitarnu književnost namijenjenu široj publici na nižem stupnju obrazovanja, važno je primijetiti kako je - za razliku od pučke literature kakva se razvila od 18. stoljeća, koja egzistira kao tržišni proizvod što se pojavljuje u generički kojekako realiziranim publikacijama (poučno štivo, kalendari, sveščići i sl.) te je u cijelosti fokusirana na to da njezin čitatelj ili konzument od nje ponajprije ima neku konkretnu (opće)životnu korist, a ne (,,samo“) estetski užitak ${ }^{919}$ - pod onim što ovdje ustrajno nazivamo

\footnotetext{
916 Naime, izvorne usmenoknjiževne pjesme u tim su im godinama zacijelo izvodili ženski članovi obitelji, a vjerojatno i dadilje-seljanke, od koji su također mogli doći u dodir s izvornom usmenom i pučkom književnošću. ${ }^{917}$ Usp. Burke 1991: 23-47.

${ }^{918}$ Upozorio je na to svojedobno - pišući Ritterovu biografiju - i Vjekoslav Klaić (usp. Klaić 1914: 105-112).

${ }^{919} \mathrm{~S}$ obzirom na činjenicu kako će tijekom 18. st. otpočeti sve intenzivnije povlačenje pripadnika aristokratskoga društvenog sloja - točnije, pripadnika viših klasa uopće - iz pučke kulture, i pučka će književnost upravo otad postati sve raslojenija, sve razvedenija, ali i sve prilagođenija tržišnim zahtjevima, odnosno željama i potrebama ciljanoga kupca i ,potrošača“. Detaljnije o ovome u: Burke 1991: 26.
} 
baroknim pučkoknjiževnim stvaralaštvom zapravo ,još uvijek riječ o naporima umjetnika da svoja djela približe publici, pri čemu je i samo to približavanje dio umjetničkog koncepta“ (Pavličić 1995: 179), a ne - dakle - o „punokrvnoj“ književnoj sferi u kojoj različiti autori participiraju štivom sastavljenim s jasnom nakanom da se uključe u tu sferu, a kamoli sa sviješću o eventualnim konkretnim poetičkim zakonitostima što ih ta sfera podrazumijeva i kojima valja udovoljiti želi li se kreirati „pravo“ pučkoknjiževno ostvarenje namijenjeno ciljanom, pučkom čitateljstvu. ${ }^{920}$ Time se, dakako, nipošto ne pokušava sugerirati kako su postbarokna i „barokna“ pučka književnost možebitno predstavljale dva različita svijeta, pogotovo stoga što već u pučkoknjiževnim ostvarenjima Vitezovićeva vremena prepoznajemo one iste osobine koje će se kao neizbježne nametnuti (i) u pučkoliterarnoj produkciji od 18. stoljeća nadalje, počevši s već višestruko spomenutom orijentiranošću ponajprije na bazično obrazovane čitatelje bez značajnijega književnog iskustva, preko snažnog naglašavanja utilitarne nauštrb estetske dimenzije teksta (dakle, korisnosti i učinkovitosti u informiranju, prosvjećivanju, vjerskoj pouci i sl., navlastito i iz razloga što u svijesti pučkih čitatelja pojam estetskoga užitka kao društveno prihvaćene i autonomne vrijednosti nije ni postojao), pa sve do neobično slobodnoga kreativnog uvažavanja književne tradicije, iz koje se baštine samo oni postupci i tekstualna rješenja za koja je autor procijenio da će svojom zanimljivošću, privlačnošću i lakoćom prenošenja „ključne“ poruke ostaviti dubok utisak na recipijenta. ${ }^{921}$ $\mathrm{Pa}$, ipak, za razliku od velike većine kasnijih pučkoknjiževnih tvorevina, pučki tekstovi nastali tijekom 17. i u ranom 18. stoljeću mahom su bili opskrbljeni i poprilično jasnim poetičkim signalima, odnosno karakteristično baroknim stilskim, sadržajnim, idejnim, pa gdjekad i formalnim silnicama, a kada tome dodamo i činjenicu da njihovi autori većinom nisu težili (za pučku književnost tako učestaloj) anonimnosti, nećemo nimalo pogriješiti pridružimo li ih umjesto izdvajanja u zasebnu, provizornu kategoriju sedamnaestostoljetnih ,„pučkih tekstova“ - krugu „baroknih književnih djela“, tim više što za pojavu znatnog broja njih „odgovornost“ snose one isti literati koji su povremeno sastavljali i djela „visoke“ književnosti, iz koje su

\footnotetext{
${ }^{920}$ Iz toga je razloga tek u toj kasnijoj, znatno razvijenijoj varijanti pučke književnosti i moguće raspoznati svojevrsnu najavu (ili uopće prvu manifestaciju) popularne književnosti, koja će se nekoliko stoljeća kasnije - s pojavom masovne i trivijalne književnosti - i iskristalizirati kao „pravi“ kontrapunkt „elitnoj“ ili umjetničkoj književnosti. Podrobnije o pučkoj književnosti kao jednoj od izvedenica popularne književnosti u: Budišćak 2015: 154-169. Posve oprečno tumačenje pučke književnosti - dakle, kao fenomena neusporedivog s popularnom književnošću, koja ne samo što je evocirana znatno kasnije, nego i koja ujedno podrazumijeva tiskom fiksirane (dakle, nepromjenjive) tekstove namijenjene svim čitateljima, a ne samo puku - nedavno je ponudio Pavao Pavličić (usp. Pavličić 2017b: 5-17). Opširnije o konkretnim tekstualnim distinkcijama između (kasnije) pučke književnosti te trivijalne i masovne književnosti kao (pod)varijanata popularne književnosti u: Pavličić 1987: 74-83. O pojmu popularne književnosti vrlo pregledno (i) u: Peternai Andrić 2018: 152-170.

${ }^{921}$ Pritom se, uzgred budi rečeno, ne vodi ni najmanjega računa o starosti rečenih rješenja i postupaka, a kamoli o njihovoj usklađenosti unutar samoga teksta.
} 
bitno pojednostavljene sadržajne i stilske elemente naprosto presadili u štivo prilagođeno predznanjima, razumijevanju i očekivanjima skromnije obrazovanih recipijenata.

Unatoč činjenici kako su već sasvim na tragu „razvijene“ pučke književnosti usmjeravane isključivo tržišnim interesima bila i mnoga onodobna pučkoj publici namijenjena ostvarenja, pa tako i gotovo cjelokupno hrvatsko stvaralaštvo Pavla Rittera Vitezovića, čini se da korpus sedamnaestostoljetnoga štiva prošaranog prepoznatljivo pučkoliterarnim crtama ipak ne bi bilo posve ispravno proglasiti pučkom književnošću u punom smislu riječi, ponajprije zato što je on predstavljao ništa drugo no tek jedan njezin poseban tip ili varijantu, kojoj bi znatno bolje - evociramo li oznaku što ju je, preuzevši je iz domene likovne umjetnosti, za ovaj fenomen predložio Pavao Pavličić - pristajao naziv ,pučki barok“.922 „Pučkim barokom“, drugim riječima, tako bi se obilježavalo upravo ono o čemu se pokatkad piše kao o ,baroku namijenjenom publici koja ne zna za umjetničke mode i trendove, nego misli da je ono što gleda odnosno čita naprosto lijepa forma poučnoga ili vjerskog sadržaja, forma koja je u toj svojoj estetskoj dimenziji zapravo svevremenska i bez odnosa prema onome što joj je prethodilo“ (Pavličić 1995: 180), odnosno - pojednostavljeno rečeno upravo ono što prepoznajemo kao specifičnu sedamnaestostoljetnu inačicu pučke književnosti ili, preciznije, kao pučki „odvjetak“ ili „ogranak“ barokne književnosti. Ta ista ili otprilike ista pojava, kojoj je Pavličić nadjenuo oznaku ,pučki barok“, u drugih će recentnih barokologa biti okrštena ponešto drukčijim nazivom, pa tako u jednoj od svojih studija Zoran Kravar piše o tzv. „baroku kao potonulom kulturnom dobru“, u kojega ubraja i barokno pučko, ali i ne samo onodobno pučkoknjiževno stvaralaštvo. ${ }^{923}$ Definiravši, konkretno, ,barok kao potonulo kulturno dobro“ kao skup svih „dostignuća visoke umjetnosti koja se s vremenom spuštaju u niže slojeve kulturnoga života, bez obzira da li pritom, na najnižem stupnju svoga silaska, dosežu kulturu seoske zajednice“ (Kravar 1993: 166), Kravar će u taj skup uvrstiti svekolik korpus utilitarne - liturgijske, nabožne i didaktičke - književnosti 17. st., u koju se „spuštao“ ili „tonuo“ prepoznatljivo bujan barokni stil dotad prakticiran isključivo u elitnoknjiževnim ostvarenjima, točnije djela „subliterarnoga“ statusa pisana većinom za niže slojeve (poput molitvenika, crkvenih pjesama, propovijedne proze, nabožnog pjesništva itd.), ali i tekstove generički realizirane kao religiozne poeme, dvorske pohvalne pjesme, didaktička lirika i sl., koji nisu ciljali (isključivo) na skromnije obrazovane recipijente iz nižih slojeva. S obzirom na ovu zamjetno veću obuhvatnost Kravarova koncepta, i više je

\footnotetext{
922 Podrobnije u: Pavličić 1995: 178-179 i 2003: 92-97. O „pučkom baroku“ kao pojavi u baroknoj umjetnosti općenito, koja je - upošljavanju srodnih stilskih obilježja usprkos - stajala u izravnoj opreci spram aristokratskoga duha u: Maleković 1993: 26-30.

${ }^{923}$ Detaljnije o Kravarovu konceptu „baroka kao potonula kulturnog dobra“ u: Kravar 1993: 161-191.
} 
nego očito kako se „pučki barok“s njime može poistovijetiti samo djelomično, odnosno da je pojava što smo joj maločas nadjenuli naziv „,pučki barok“ egzistirala ustvari kao tek jedna od manifestacija „baroka kao potonuloga kulturnog dobra“, koji je - pored pučkih - obuhvaćao i ne-pučka ostvarenja, ali i tekstove što ih je publika recipirala kao pučke, iako prvotno nisu bili zamišljeni ni ostvareni kao pučko-popularno štivo. Dodamo li ovome još i spoznaju kako u čitav niz sedamnaestostoljetnih „pučkoknjiževnih“ sastavaka prepoznatljivo barokne stilske silnice nisu uopće ni bile prodrle, postat će i više nego bjelodano da je literarni „kompleks“ što bismo ga olako danas prozvali baroknom pučkom literaturom bio zapravo daleko heterogeniji i razvedeniji no što nam to naša predodžba o njemu možda sugerira, čime se samo potvrđuju netom iznesene sumnje u to da rečenom ,kompleksu“ - pa čak i uz stanovite veće ograde - uopće pristaje oznaka ,punokrvne“ pučke književnosti.

Da skepticizam po pitanju proglašavanja pojedinih sedamnaestostoljetnih ostvarenja pučkim štivom nipošto ne bi smio prerasti u odrješito negiranje (proto)pučkoknjiževnih momenata u hrvatskoj književnosti 17. stoljeća sugerirat će nam ovdje već nagoviještena činjenica kako je praksu ispisivanja tekstova za slabije obrazovane čitatelje moguće susresti već u okrilju našega srednjeg vijeka i humanizma, kojom se uvjerljivo pobija pretpostavka da je do prvih nagovještaja i proplamsaja pučke književnosti u nas došlo tek u razdoblju baroka. Tako će, primjerice, već u drugoj polovini 16. stoljeća trogirski pjesnik Petar Lucić sastaviti svoj čuveni zamašni zbornik Vartal, u kojem okuplja pretežno nabožne tekstove namijenjene široj publici, ponajprije malobrojnim opismenjenim čitateljicama iz crkvenih krugova (dakle, redovnicama), dajući na taj način ujedno i svoj prilog poprilično bogatoj predbaroknoj zborničkoj produkciji, koja će poslužiti i kao neposredan uzor kasnijim sastavljačima pučkih zbornika, a možda djelomično i kao jedan od mnogih generičkih uzora Pavlu Vitezoviću u njegovu radu na žanrovski zamršenu Odiljenju sigetskom. Dapače, upravo bi se pojava zbornika nalik Lucićevu - u kojima su se miješali stih i proza, koegzistirali raznorazni žanrovi kojekakvoga podrijetla te različiti sadržaji i formalna rješenja - mogla i morala označiti kao nepobitan dokaz uzimanja u obzir (i) potreba i očekivanja vrlo široke publike, a ne više isključivo čitatelja iz najviših društvenih slojeva, koji su, zahvaljujući izvrsnoj za života stečenoj (klasičnoj) književnoj naobrazbi, preferirali generički čista ili makar čišća ostvarenja. Ti i takvi (religiozni) pučki zbornici, kojih će popriličan broj svjetlo dana ugledati baš u baroku (točnije, neposredno nakon Tridentskog koncila), vrlo vjerojatno su - osim po obrascu prethodnih primjeraka ovoga žanra - uvelike bili sačinjeni i po modelu Biblije, također generički jednoznačno teško odrediva zbornika skrojenog od zasebnih knjiga ispresijecanih mnoštvom raznoraznih žanrova, na koju se - kako će se doskora pokušati dokazati - i sam 
Ritter u svome Odiljenju jamačno uvelike oslanjao. Pritom, dakako, treba imati na umu kako je ta uvriježena generička hibridnost pučke književnosti najvećim dijelom bila ne samo posljedica već primijećenoga gotovo posvemašnjeg nehaja za žanrovski aspekt teksta, nego i (također maločas detektirane) želje da taj tekst (i) svojom generičkom intrigantnošću, šarolikošću i uopće nemonotonošću pokuša privući, ali i zadržati pozornost što je moguće većeg broja (pismenih) čitatelja ne bi li na njih - na koncu - izvršio i stanovit utjecaj.

Kako bilo, na temelju svega dosad uočenog s punim se pravom može ustvrditi da se u Odiljenju sigetskom Pavao Ritter Vitezović - ne odustajući od strategije miješanja značajki brojnih literarnih i ne samo literarnih žanrova kako bi maksimalno proširio krug potencijalnih čitatelja - uvjerljivo potvrđuje kao jedan od naših najustrajnijih posrednika između „elitne“ ili umjetničke te „,narodne“ (usmene) književne kulture. ${ }^{924}$ Mameći recipijente posve različitoga čitateljskog profila u želji da im kroz svoju ,zrinijadu“ predstavi novi hrvatski jezik, osvježi sjećanje na jedan od najvažnijih događaja iz naše povijesti, ali i potakne na sudjelovanje u skorim protuturskim akcijama, Vitezović već u Odiljenju iskušava pristup na kojemu će kasnije inzistirati i u svojim pučkim kalendarima, u kojima stanovite političke ideje (vlastiti pankroatistički program, odnosno ideološku platformu što ju je prethodno razradio u brojnim latinskim spisima) i tada aktualne neostoicističke filozofske zamisli - drugim riječima, znanja koja su dotad pripadala isključivo „elitnoj“ kulturi - pokušava (na, dakako, bitno pojednostavljen način) prezentirati i pučkoj publici iz nižih društvenih slojeva ne bi li je (moralno) educirao i informirao, a time pridonio i moralnoj homogenizaciji čitavoga hrvatskog društva baziranoj na sprezi suvremenih znanja i tradicionalnih načela. ${ }^{925}$ Osim na predstavljanje pojedinih ,elitnih“ ideja i spoznaja (i) recipijentima na nižem stupnju obrazovanja, posrednička Vitezovićeva uloga u kontekstu Odiljenja u velikoj se mjeri svodila i na upoznavanje tih istih pučkih čitatelja i s pojedinim žanrovskim rješenjima svojstvenima isključivo pisanoj književnosti (heroida, konzolacija, lament, eho-pjesma, alegorija itd.), iako ona - pomiješana s cjelovitim primjercima ili izdvojenim generičkim obilježjima usmeno- i pučkoknjiževnih te poluknjiževnih i izvanknjiževnih žanrova - svojom prisutnošću nepogrešivo zapravo sugeriraju da je hrvatski prvijenac naš autor ciljano namijenio najrazličitijim tipovima čitatelja, kadrima da u tekstu prepoznaju makar neke njima bliske žanrove te se upravo preko njih ,povežu“ i s tekstom u cijelosti, a onda i s njegovim poukama i porukama namijenjenima u jednakoj mjeri apsolutno svim potencijalnim čitateljima.

\footnotetext{
${ }_{924}$ O ranonovovjekovnim posrednicima između ,učene“ i ,pučke“ kulture navlastito u: Burke 1991.

${ }^{925}$ Podrobnije o ovom pitanju u: Hrgić 2015: 66-72.
} 


\section{ODILJENJE SIGETSKO KAO SEKUNDARNI GOVORNI ŽANR}

Ako je u dosadašnjem dijelu istraživanja naša pažnja u potpunosti bila zaokupljena unutarnjom generičkom složenošću Odiljenja sigetskog, točnije iznenađujuće širokim rasponom u nj ugrađenih tekstualnih obilježja crpljenih s različitih žanrovskih ,izvora“, sada je kucnuo čas da na narednim stranicama Vitezovićevu „zrinijadu“ napokon sagledamo (i) kao zaokruženo ostvarenje, čiji bi se generički identitet - pretpostavljamo - nekako ipak morao moći jednoznačno definirati. Drugim riječima, uvažavajući dobro nam već znanu Bahtinovu predodžbu o književnim žanrovima kao kompleksnim (sekundarnim) govornim žanrovima sklopljenima od stanovitog broja jednostavnih ili primarnih govornih žanrova, detektiranim „karakterističnim“ generičkim obilježjima te u Odiljenje uvrštenim cjelovitim primjercima pojedinih žanrovskih rješenja u nastavku ćemo pristupati kao svojevrsnim „gradbenim jedinicama“ ili sastavnicama jednoga žanrovski izrazito hibridnog ostvarenja, koje bi - kako nas to povijest i teorija književnosti uče - i kao takvo nužno moralo posjedovati i neki sveobuhvatn(ij)i, „krovni“ generički identitet. Prethodno učinjeno popisivanje pisanoknjiževnih, folklornoknjiževnih, pučkoknjiževnih, rubno književnih i izvanknjiževnih žanrova, za „tipičnim“ značajkama kojih je pri njezinu sastavljanju konstantno posezao Pavao Ritter, u tom bi se smislu ispostavilo kao „tek“ predigra ili predradnja znatno kompleksnijega posla traganja za najprikladnijom (ili, možda bolje rečeno, najmanje neprikladnom) generičkom odrednicom ove po mnogočemu neobične „zrinijade“, koja - eventualnom pogrešnom dojmu što ga možda pobuđuje usprkos - nipošto nije egzistirala kao „tek“ splet nasumično razbacanih žanrova i njihovih prepoznatljivih karakteristika slučajno okupljenih unutar korica jedne knjige.

No, prije nego što se zaista i upustimo u potragu za (povijesnim) sekundarnim žanrom, za kojega bi se - po ovim ili onim pokazateljima - pouzdano ili makar donekle pouzdano trebalo utvrditi da mu je pripadalo ili da je u njemu participiralo i Odiljenje sigetsko, neće nam biti zgorega još se jednom prisjetiti suvremenoga genološkog shvaćanja (književnog) žanra kao entiteta presudno određenog kontekstualnim okvirom ili situacijom u okrilju koje se pojavljuje i u skladu s kojom potom i egzistira, i to kao neposredan odgovor na nju, točnije na njezine specifične zahtjeve i potrebe. Izrastao iz konkretnih, podjednako književnih i izvanknjiževnih okolnosti, (književni) žanr bi se - uvjereni su recentni teoretičari žanra nužno morao sagledavati kao izravna posljedica konteksta, što će reći kao kategorija nerazdruživo povezana kako sa samom društvenopovijesnom stvarnošću, tako i s očekivanjima i potrebama različitih instanci ili sudionika književne komunikacije, počevši od 
autora, preko tadašnje, ali i kasnije publike, pa sve do poetičara, izdavača, knjižara i dr. Budući da svaka individualna situacija ili situacijsko okružje podrazumijeva i posve novu „paletu“ (kombinaciju, sustav) žanrova koji odgovaraju njegovim potrebama, tj. stvaraju toj istoj situaciji primjerene načine razumijevanja teksta, žanrove ne bi trebalo poimati nikako drugačije nego kao posrednike između situacije i teksta, odnosno kao entitete koji ostvaruju specifična, trenutnim okolnostima određena značenja i za koje se iz toga razloga može kazati kako su u najvećoj mjeri definirani upravo svojom namjenom ili namjenama.

Dakle, kanimo li, imajući u vidu netom iznesene moderne genološke zamisli, Odiljenju sigetskom zaista prići kao generičkoj cjelini, odnosno makar pokušati dokučiti u okvire kojega bi se to (povijesnog) sekundarnog žanra mogla smjestiti njegova žanrovski zapetljana faktura, neće nam preostati ništa drugo no da ga - kao (pretpostavljeni) primjerak konkretnoga žanra u potpunosti usklađenog s potrebama konteksta književnosti hrvatskog baroka, ali i znatno širega (društvenopovijesnog) onodobnog okružja - razmotrimo upravo na podlozi raznolikih kontekstualnih okvira unutar kojih je u svoje vrijeme očito obnašao specifične, svakoj od tih situacija prilagođene funkcije. Osim konteksta hrvatske, ali i ne isključivo hrvatske barokne književnosti te s njim tijesno povezana ideološkog konteksta, to će podrazumijevati i uzimanje u obzir konteksta slijeda tematsko-motivski srodnih djela (,zrinijada“), potom konteksta Vitezovićeva opusa, ali i recepcijskoga, točnije konteksta sedamnaestostoljetne publike, a sve ne bi li se promatranjem Odiljenja iz njihove vizure posrednim putem pokušalo doći do što je moguće preciznijeg odgovora na pitanje o njegovu „stvarnom“ žanrovskom identitetu.

\section{1. ODILJENJE - BAROKNO DJELO (EUROPSKI I HRVATSKI KONTEKST)}

U mnoštvu različitih kontekstualnih dimenzija, dijelom kojih je - kako svojom pojavom na „književnoj sceni“, tako i apsorbiranjem njihovih utjecaja još u vrijeme svoga nastajanja - neizbježno postalo i Vitezovićevo Odiljenje sigetsko, istraživačko bi zanimanje najprije trebala privući upravo ona najšira, odnosno kontekst književne produkcije razdoblja koje se u domaćim i europskim okvirima redovito označava kao seicento ili (književni) barok. Kada se govori o Pavlu Ritteru Vitezoviću i izrazito mu šarolikom stvaralačkom opusu, pitanje njegove vremenske, a time i poetičko-ideološke obilježenosti obično se (naročito u posljednjih nekoliko desetljeća) nameće samo od sebe, pa među recentnim „ritterolozima“ tako više ne postoji ni najmanjega spora oko toga da je - u stvaralačkom smislu - našega autora najpresudnije oblikovalo upravo „barokno povijesno obzorje druge polovice 17. 
stoljeća“ (Blažević 2002: 39). Dapače, o „baroknosti“ njegova hrvatskog književnog prvijenca u stručnoj se literaturi povremeno piše već dulje od stotinu godina, pa je tako „ukus secentizma“ (Šrepel 1902: 110) još početkom prošloga stoljeća u „fakturi“ Odiljenja prepoznao i Milivoj Šrepel, proglasivši u njoj pritom „tipično“ baroknom ne samo strategiju razmrvljivanja „epske“ građe u pojedine „manje“ žanrove - govore, poslanice, epitafe - te uključivanje ,idile“ i ciklusa nadgrobnica kao svojevrsnih ,pjesničkih igrarija“, nego i pojavu personificiranoga Sigeta u ulozi jednog od govornika, potom učestala razmatranja o hirovitoj sreći, ali i mjestimična concetta (primjerice, „Mnogič cvit uvene, prvo neg dozrije, / i litnje sunčene svitlosti tma krije“; I: 463-464) kao potvrdu Vitezovićeva ovladavanja čak i baroku svojstvenim prenaglašenim stilom. ${ }^{926}$

Da je naš autor zaista sastavio književni tekst koji po mnogočemu podilazi šrepelovski kazano - „,sečentističkom ukusu“ iz svega što je dosad rečeno neće biti teško zaključiti, no ipak nije zgorega o tim njegovim baroku bliskim značajkama u nastavku kazati još riječ-dvije, naročito jer se radi o nepobitnim dokazima Ritterova pokušaja da svoju osebujnu „zrinijadu“ uklopi u poetički kontekst domaće, pa i ne samo domaće sedamnaestostoljetne književnosti. Ponajprije, prilično jasna težnja usklađivanja s tadašnjim (pisano)književnim preferencijama i uopće dominatnim književnim modelima razvidna je već na sadržajnom nivou, poglavito u izboru centralne teme teksta - višestrukih oproštaja potaknutih nepovoljnim ishodom ratnoga sukoba - koja uključuje ,punokrvnim“ baroknim ostvarenjima i više nego svojstven moment sadržajne aktualnosti. Opisivanje posljednjih trenutaka života Sigeta i njegovih branitelja, nizanje njihovih definitivnih rastanaka, podsjećanje na herojsku im pogibiju pod sigetskim bedemima te podastiranje završnih riječi i pouka što ih posredstvom nadgrobnica preživjelima upućuju iz onozemaljske dimenzije izuzetno je - u sadržajnom smislu - blisko baroknoj tradiciji opjevavanja posljednjih stvari, oproštaja i smrti, ali i baroku posebno dragom toposu memento mori, navlastito čestom u sedamnaestostoljetnoj religioznoj lirici, ${ }^{927}$ po uzoru na koju ga Ritter vjerojatno i uključuje u svoje žanrovski zamršeno djelo. S obzirom na ovu prilično bjelodanu suvremenost njegova sadržajnog aspekta, ni najmanje nas ne bi trebalo iznenađivati otkriće Milana Moguša, koji se - želeći razmotriti njezin čestotnik ili frekvencijar - svojedobno upustio u esktenzivnu čestotnu analizu Odiljenja, utvrdivši pritom kako, pored veznika „i““ te imenica „Siget“ i

\footnotetext{
${ }^{926}$ Detaljnije u: Šrepel 1902: 103-117.

${ }^{927}$ Posebno je zanimljivo kako se čak i u sedamnaestostoljetnoj religioznoj lirici i drugim onodobnim nabožnim djelima nerijetko pojavljuje i baroku osobito drag motiv konflikta ili sukoba, zbog čega i u mnogim takvim ostvarenjima svjedočimo - primjerice - prepirci, a gdjekad i otvorenom ratu između duše i tijela, potom čovjekovu sukobu sa samim sobom, razdoru između duhovnih težnji i privremenih, prolaznih (materijalnih) užitaka i sl. O tome usp. Segel 1974: 89.
} 
„grad“, među sveukupno 16220 riječi u Vitezovićevoj „zrinijadi“ po učestalosti svoga pojavljivanja prednjače upravo imenice „,smrt“ i „srića“ (koja obično podrazumijeva sudbinu ili kob), što - po njegovu mišljenju - nepogrešivo „upućuje na amblem naše barokne književnosti““ (Moguš 1986: 150), koji se upravo i svodio na u to doba odveć često rabljenu sintagmu ,smrt i sudbina“.928

Zadržimo li se još časkom na sadržajnoj razini Odiljenja sigetskog, povođenje za motivskim „rekvizitarijem“ svojstvenim baroknoj književnosti prepoznat ćemo i u gotovo opsesivnom isticanju herojskoga mučeništva i žrtve kao neposrednih dokaza „pravoga“ ratnog junaštva, odnosno u prizivanju prepoznatljivo barokne figure ratnika-mučenika koji se dobrovoljno (samo)žrtvuje u korist ,viših ideala“: Boga (kršćanske vjere), kralja i domovine. Motiv mučeništva, na koje taj i takav junak pristaje iz nepokolebljive odanosti „nebeskom“ i ovozemaljskom vrhovnom vladaru te vlastitoj domovini, ${ }^{929}$ pritom se - ,tipično“ sečentistički - prikazuje kao manifestacija jedne od najvećih vrlina po tada naročito utjecajnim neostoicističkim filozofskim shvaćanjima, iako razloge njegova evociranja nipošto ne treba tražiti samo u prihvaćanju baroknom dobu svojstvena svjetonazora i „ključnih“ onodobnih idejnih strujanja, nego i u otvorenom Vitezovićevu pristajanju uz barokni plemićki viteški etos, kojega su se pridržavali brojni domaći sudionici tadašnjih protuturskih ratova. ${ }^{930}$ Doduše, premda je ovo glorificiranje viteštva i herojsko-mučeničke smrti, kojim se željelo postići da junak-ratnik u što većoj mjeri nalikuje samome Kristu, ${ }^{931}$ (i) u okrilju hrvatske barokne književnosti kotiralo kao iznimno važan motiv, nužno je imati na umu da je riječ ne samo o motivu ili moralnom stavu koji se u našoj literaturi pojavio još u srednjovjekovlju te potom nastavio egzistirati kroz čitavo ranonovovjekovlje, ${ }^{932}$ nego ujedno i o pisanoknjiževnoj inačici autohtono usmenoknjiževne ideje ,čojstva i junaštva“ (humanitas heroica) - koja je podrazumijevala „,̌ovječno“ junaštvo, odnosno junački pristup borbi, svetost dane riječi te prijateljsku odanost i pobratimstvo - uz koju se obično vezivao i kršćanski ideal branitelja Krista (athleta Christi), tj. heroja-spasitelja kršćanstva, koji mučenički umire neustrašivo braneći kršćanstvo od žestokih napada ,pogana““.933 Kao jedan od prilično uvjerljivih dokaza

\footnotetext{
${ }_{928}$ Znatno opširnije o ovome u: Moguš 1986: 145-153.

${ }^{929}$ Maksimu „pro Rege, Deo et Patria“ - kao svojevrsnu zakletvu na trojnu (ratničku) lojalnost - moguće je zateći na mnogim mjestima duž Vitezovićeva opusa (nešto manje hrvatskoga njegova dijela, a znatno više onoga latinskog), pri čemu se, u ideološkom smislu, ona zapravo ukazuje kao ,izvedenica tipično baroknog plemićkog moralnog kodeksa“ (Blažević 2002: 165), kojemu se, u „teoriji“ i praksi, i naš autor tako u potpunosti priklonio. ${ }^{930}$ Usp. o tome u: Blažević 1999: 179-191, 2002: 164-174 i 2016: 150.

931 O motivskim paralelama između ratnika-mučenika i Isusa Krista detaljnije u: Warnke 1972: 187-204.

932 Usp. Posavac 1994: 536.

933 Radi se, preciznije rečeno, o motivima ili koncepcijama za kojima su, pišući svoja protuturska literarna ostvarenja, rado posezali barokni autori iz različitih slavenskih književnih kultura, većinom ih baštineći iz usmenoga epskog pjesništva posvećenog opjevavanju kršćansko-turskih ratova, odakle su - između ostalog -
} 
uvažavanja spomenutih izvorno (ili makar uvelike) folklornoknjiževnih predodžbi u Ritterovu je vernakularnom prvijencu tako moguće izdvojiti (i) motiv pomalo prijezirnoga odbacivanja tjelesnoga (materijalnog), odnosno sustavno sadržajno naglašavanje bezvrijednosti fizičke, ovozemaljske egzistencije u usporedbi s mjestom na nebu, koju će duhovno postojanim braniteljima Sigeta predvođenima banom Zrinskim osigurati nesebična žrtva za više ideale.

Iako će o (prepoznatljivo baroknoj) idejno-ideološkoj podlozi Odiljenja sigetskog znatno više riječi biti na stranicama koje slijede, zasad je nužno tek osvijestiti činjenicu da su, na sadržajnoj njegovoj razini, netom pobrojani „sečentistički“ tematsko-motivski elementi tijesno isprepleteni s baroku svojstvenim ideološkim silnicama različita porijekla, i to kako već spomenutim zamislima kršćanskoga pravovjerja i neostoicističkim filozofskim postulatima, tako i predodžbama tada osobito popularnoga baroknog slavizma, koje se u ovome slučaju ponajviše očituju u neprekidnom naglašavanju hrvatskosti branitelja Sigeta te uopće motivu „,̌istokrvno“ slavenskih čuvara kršćanstva u cijelosti. Baroknoslavističkim idejama - kao možda i najevidentnijom posljedicom „duha vremena“ te ujedno i najsnažnijom ideološkom poveznicom s „punokrvno“ baroknom književnom i ne samo književnom pisanom produkcijom - opus Pavla Vitezovića ispresijecan je gotovo u cijelosti, što će reći da ih $\mathrm{u}$ podjednakoj mjeri on formulira kako $\mathrm{u}$ pjesničkim radovima, tako $\mathrm{i} u$ nizu historiografskih i lingvističkih svojih ostvarenja, ${ }^{934}$ u kojima redovito - ,tipično“ slavistički miješa pridjeve „,slovinski“ (,slovenski“), „,dalmatinski“, „,ilirski“ i „,hrvatski“, a k tome još i obnovu slavenske (čitaj: hrvatske) države ili „Ilirika“ zamišlja pod isključivo hrvatskim imenom. ${ }^{935}$ Osim toga, da je naš autor bio trajno ,inficiran“ idejnim sklopom što ga danas

dospjeli i u mađarsku „zrinijadu“ Nikole Zrinskoga te hrvatski njezin prijevod i adaptaciju iz pera brata mu Petra, po uzoru na koje će neke od tih motiva i u svoje Odiljenje potom uključiti i Pavao Vitezović. Znatno detaljnije o koncepcijama humanitas heroica, athleta Christi i drugim motivima i idejama što su ih slavenski barokni pisci preuzimali iz (većinom) usmenoknjiževne sfere u: Angyal 1961: 228-263.

${ }_{934}$ Podrobnije u: Bogišić 1991: 28-30.

${ }^{935}$ Govoreći o prilično očitim tragovima baroknoslavističke ideologije unutar korica Odiljenja sigetskog, posebno će zanimljivo biti zaviriti u neke od latinskih pjesničkih poslanica u kojima je Ritter svoju tada još nedogotovljenu ,zrinijadu“ podjednako raznoliko predstavljao bliskim prijateljima i znancima. Kako su, naime, zapazili pojedini minuciozniji ,ritterolozi“, u tim stihovanim pismima Vitezović - apostrofiravši sebe kao „nobilis Croata“ (plemeniti Hrvat) - adresatima najavljuje kako će njegovo djelo biti napisano „slavo sermone“ (slavenskim govorom), točnije „dalmatica lingua“ (dalmatinskim jezikom), te pritom izražava uvjerenje da će ono - kao takvo - zasigurno steći mnogo poklonika među ,illyricis gentibus“, odnosno ilirskim narodom ili pukom. Iako su potonji podatak o ovoj prilično šarolikoj, no u isti mah i - iz perspektive ideja što ih je zagovarao barokni slavizam - nadasve indikativnoj Vitezovićevoj najavi buduće vernakularne „zrinijade“ u svojim studijama prezentirala čak dvojica naših književnih povjesnika - najprije Josip Vončina (usp. Vončina 1976a: 348), a poslije njega i Rafo Bogišić (usp. Bogišić 1991: 30) - niti jedan od njih taj podatak nije držao svrsishodnim potkrijepiti navođenjem konkretnoga izvora iz kojega je on crpljen. Ipak, kao što je svojedobno u njegovoj biografiji istaknuo Vjekoslav Klaić, naš je autor o svome budućem djelu koje bi trebalo biti rado čitano u hrvatskom (,,ilirskom“) narodu krajem 1678. pisao u (latinskoj) poslanici kranjskom plemiću Ivanu Krstitelju Locatelliju, dočim je dovršetak rada na slavenskim (tj. hrvatskim) „knjižicama“ (libelli) u godinu dana ,mlađoj“ epistoli obznanio Ivanu Despotoviću mlađem (usp. Klaić 1914: 32-35), što bi onda trebalo sugerirati i da je 
prepoznajemo pod nazivom „barokni slavizam“ možda i ponajviše naslućujemo (i) iz silnoga njegova truda što ga je ulagao u osmišljavanje i širenje zajedničkog jezika za svoje sunarodnjake s čitavoga prostora (,cjelovite“) Hrvatske, utemeljenoga na miješanju svih triju hrvatskih narječja, i to po uzoru na koncepciju trodijalektalnoga hrvatskog jezika što su je zagovarali pisci ozaljskoga (zrinsko-frankopanskog) književnojezičnog kruga, imajući pritom na umu ,živi““ naddijalekt kojim su komunicirali žitelji Ozlja i njegove šire okolice.

U neusporedivo manjoj mjeri nego za baroknoslavističkim idejnim polazištima ${ }^{936}$ Vitezović se povodio i za prepoznatljivo baroknim, poetički propisanim imperativom stilske domišljatosti, kojem je u Odiljenju pokušao udovoljiti na svega nekoliko mjesta u tekstu, i to - kako su „ritterolozi“ već utvrdili ${ }^{937}$ - pretežno u zaključnom, epitafskom njegovu dijelu, u kojem su po tom pitanju posebno interesantne nadgrobnica caru Sulejmanu Četrta istoga (IV: 55-61) te ona Andrijina Radovana (IV: 180-193), obje oplemenjene stilski „osvježenim“ (figuralnim) rješenjima. I dok je u latinskom dijelu njegova stvaralaštva - posebice u korpusu anagrama i prigodnih mu lirskih pjesama - i više nego primjetno ,vješto baratanje antičkim i novijim, na manirističkim postupcima usustavljenim retoričkim klišejima“, koje uvjerljivo svjedoči o tome da mu nipošto ,nisu bili strani temeljni zahtjevi barokne poetike: konstruktivizam, ingenioznost, končetoznost, pa i meraviljoznost“" (Fališevac 2013: 12), dotle se u hrvatskoj njegovoj polutci očituje poprilična suzdržanost u pogledu uvažavanja „sečentističkih“ stilskih inovacija, pa tako ni u samom Odiljenju figuralno bujan stil, evociran s ciljem potvrđivanja pjesnikove ingenioznosti i uopće izazivanja začudnosti, ne igra posebno zapaženu ulogu. Za razliku od, primjerice, južnohrvatskih sedamnaestostoljetnih pjesnika, koji oštroumnim i pomalo zaprepašćujućim figuralnim kombinacijama svoje pjesme premrežuju doslovce od prvoga do posljednjeg stiha, Vitezović u svojoj „zrinijadi“ svjesno odustaje od izraženije figuracije, razlog čemu bi uvelike mogao ležati (i) u činjenici da se ni u samoj Obsidi sigeckoj njegova uzora također ne teži „,demonstraciji ingenija, niti je cilj da se čitatelj iznenadi i zadivi ljepotom slika i prštavošću metaforike“ (Pavličić 2007: 196). Štoviše, teško je oteti se dojmu kako su upravo tu stilsku nepretencioznost, kojom se mogu podičiti redom sva šesnaesto- i sedamnaestostoljetna naša pjesnička ostvarenja posvećena sigetskoj katastrofi, autori na potezu od Karnarutića do Vitezovića shvaćali kao jedno od nužnih obilježja (,žanra“) ,zrinijade“, koje su ustrajno uvažavali čak i kada je vladajuća (literarna)

ostala ovdje navedena pozivanja na svoje „slavensko“, odnosno „dalmatinsko“ buduće ostvarenje on donio u nekom od brojnih stihovanih pisama na latinskom što ih je ispjevao u drugoj polovini sedamdesetih godina 17.st. ${ }^{936}$ Detaljnije o baroknom slavizmu kao (i) sedamnaestostoljetnom idejnom stremljenju, na koje nije ostao „imun“ ni sam naš autor, u: Bogišić 1991: 9-38, Golub 2003: 123-140, Kravar 2003b: 120-121 i Fališevac 2010a: 116. O ideološkim slojevima hrvatske barokne književnosti uopće posebno u: Dukić 2003: 496-498.

${ }^{937}$ Posebno usp. Kravar 1991: 240 i 2010: 113. 
poetika razdoblja od njih iziskivala stilski stubokom drugačiju, kompleksniju i pretjeraniju tekstualnu fakturu.

Iz dosadašnje nam je analize, povrh svega rečenog, moralo postati i više nego jasno kako je Vitezović Odiljenje realizirao ne samo kao sadržajno, ideološki, pa u tragovima čak i stilski barokno djelo, već i kao tekst koji svojom žanrovskom slojevitošću i zapetljanošću nedoljivo podsjeća na najuspjelije sečentističke generičke hibride, odnosno kao „zrinijadu“ u kojoj je propast Sigeta - riječima Dunje Fališevac - opjevana „ne u epskoj nego u žanrovski inovativnoj formi baroknih obilježja“ (Fališevac 2013: 12). Štoviše, detektirane različite generičke karakteristike od kojih je sazdan ujedno bi nam nepogrešivo trebale davati do znanja i kako se Ritter u njemu glavninom težio oslanjati na repertoare onih žanrova koji su u barokno doba, kolokvijalno rečeno, bili „na cijeni“, pa stoga neće biti (posve) pogrešne tvrdnje onih proučavatelja kojima se svojedobno učinilo kako su upravo „prema suvremenom ukusu sečentizma i marinizma u djelo (...) umetnuti monolozi i dijalozi; razgovori, u kojima jeka dolazi kao sugovornik; poslanice pa i epitafi onima, koji su poginuli u boju“ (Putanec i dr. 1952: 7). Drugim riječima, već golim okom razaznatljiva intencija sprezanja poprilično velikog broja pojedinačnih „karakterističnih“ generičkih značajki, pa i cjelovitih primjeraka pojedinih (,manjih“) žanrova, među kojima je - k tome - znatan broj otpadao upravo na one što su u baroku uživali posebnu popularnost, još je jedan u nizu prilično očitih dokaza Vitezovićeve nakane da napiše po mnogočemu aktualno, barokno ostvarenje, i to usprkos činjenici što se istovremeno u stilskom, ponešto i u sadržajnom, ali ponajviše u formalnom pogledu oslanjao on i na postupke i elemente predbarokne provenijencije.

Iza odrješitih konstatacija pojedinih „ritterologa“ kako je „u stilskopovijesnom smislu Odiljenje (...) obilježeno utjecajima dalmatinske renesansne književnosti“ (Kravar i Novaković 2000: 767) krit će se tako, između ostalog, i činjenica da je glavninom ono ispjevano dvostruko rimovanim dvanaestercem, što će reći ni manje ni više nego baš onim stihom kojim su na našem jugu svoja najvažnija pjesnička ostvarenja u cijelosti ili velikim dijelom formalno realizirali kanonski renesansni autori, počevši s Markom Marulićem i Petrom Hektorovićem, pa sve do Barne Karnarutića i već manirističko-(pred)baroknoga Jurja Barakovića. Iako je, međutim, (dvostruko rimovani) dvanaesterac zaista kotirao kao „stožerni“ stih dubrovačko-dalmatinske šesnaestostoljetne i ranosedamnaestostoljetne književnosti, da se u Vitezovićevim očima istodobno on prometnuo (i) u najpopularnije metričko rješenje onodobne sjevernohrvatske književnosti moguće je razabrati iz njegove odluke da jednu od dvije svoje pohvalne pjesme koje će svega nekoliko godina kasnije ispjevati u čast objelodanjivanja Valvasorova zamašnog djela Slava vojvodine Kranjske 
(1689.) - onu naslovljenu Hrvatkinja - ispiše upravo tim našim „tipično“ renesansnim stihom, formalno joj pritom suprotstavljajući pohvalnicu pod ništa manje indikativnim naslovom Dalmacija, realiziranu dominantnim stihovno-strofičkim oblikom južnohrvatske barokne književnosti - osmeračkom sestinom sa shemom rimovanja ,ababcc“ ili tzv. sestom rimom..$^{938}$ To i takvo njegovo shvaćanje (dvostruko rimovanog) dvanaesterca kao najvažnijega ili najistaknutijega stiha sedamnaestostoljetne sjevernohrvatske, točnije književnosti Kraljevstva Hrvatske imalo je, doduše, itekakvo pokriće u tadašnjem pjesničkom stvaralaštvu što je nastajalo na prostoru od Ozlja, preko Zagreba, pa sve do Varaždina i Čakovca, koje je glavninom doista i bilo ostvarivano kao dvanaesteračko, i to kako u svojoj izvornoj (autorskoj) inačici, tako i u onoj prijevodnoj, za koju su izvornici dolazili pretežno iz mađarske literature. ${ }^{939}$ Dapače, premda je pokoji sjevernohrvatski barokni pisac - pri čemu se, prije svih, misli na Petra Zrinskog, Frana Krstu Frankopana i navlastito Pavla Vitezovića - za (mahom jednostruko rimovanim) dvanaestercem najvjerojatnije i posegnuo imajući na umu i pjesničku produkciju naše dubrovačko-dalmatinske renesansne književnosti, većini se njih on kao najprikladniji metrički izbor nametao ponajprije stoga što je u književnosti njihove sredine desetljećima već bio raširen zahvaljujući prijevodima djela iz mađarske književnosti, iz koje jednostruko rimovani dvanaesterac (s cezurom iza šestoga sloga) kao metrički oblik i potječe i u kojoj je posebno bio raširen napose u epskom pjesništvu 16. i 17. stoljeća. ${ }^{940}$

U tom smislu, neće biti da je (pretežnim) formalnim opredjeljenjem za dvostruko rimovani dvanaesterac - i to podjednako obje njegove varijante (sjevernu i južnu) - Ritter u

\footnotetext{
${ }_{938}$ O navedenim Ritterovim pohvalnicama što ih je Valvasor uvrstio u svoje djelo podrobnije u: Klaić 1914: 7678 te Bogović i Pavić 2016: 243-261 (u tom članku, uzgred budi rečeno, obje se pohvalnice i donose kao prilog). ${ }^{939}$ Dvanaesterac - doduše, dvostruko rimovani te organiziran u katrene - kao itekako suvremenu je formalnu opciju kada je sjeverna hrvatska barokna književnost u pitanju Vitezović tako imao prilike susresti već u „zrinijadi“ svoga daleko najvećeg uzora - Petra Zrinskog - a u učestalost ispisivanja književnih djela realiziranih tim stihom na našem sjeveru gotovo sigurno se imao prilike uvjeriti i iz niza drugih tada objelodanjenih ostvarenja. Iako nije mogao znati za to da je otprilike trećinu pjesama u svojoj rukopisnoj lirskopjesničkoj zbirci Gartlic za čas kratiti Frankopan ispjevao upravo u (jednostruko rimovanim) dvanaestercima, da je mnoge pjesme iz svoje također rukopisne pjesmarice u dvanaestercu sastavila i Katarina Zrinski (između ostalih, i čuvenu epsku Popivku od razboja Čingićevoga, koja se proteže na sveukupno trideset dvanaesteračkih katrena), ali - vrlo vjerojatno - ni da je u dvanaesteračkim katrenima iz mađarskoga predloška naslovljenog Fortuna (1594.) šezdesetih godina 17. st. prevedena rukopisna knjiga gatalica obitelji Zrinski Sibila, ne treba sumnjati u to da je naš autor prije rada na Odiljenju u rukama imao mnoga dvanaesteračka ostvarenja naših sedamnaestostoljetnih (glavninom kajkavskih) autora, koja su baš tih godina ugledala danje svjetlo. Misli se tu, ponajprije, na već spomenuti Zvončac (1670.) Matijaša Magdalenića, u kojemu su prvi i treći dio ispjevani upravo u dvanaesteračkim katrenima s provodnom rimom isključivo na kraju stiha (pri čemu je, dakako, riječ o metričkom rješenju što ga Magdalenić u svoj prepjevani tekst preuzima iz mađarskih predložaka Bodóa i Vörösa), potom anonimni (no vjerojatno Magdalenićev) kajkavski prijevod religioznoga djela u - također jednostruko rimovanim dvanaesteračkim katrenima (iznova preuzetima iz mađarskoga originala, i to Vöröseva djela Dialogus iz 1623.), koji je od 1670. kružio u rukopisu pod naslovom Nočno viđenje svetoga Bernarda, ali i na prepjevanu zbirku fiktivnih poslanica ili heroida Listi heroov (1675.), u kojoj originalne heksametre iz zbirke Heroum Epistulae (1630.) njemačkoga isusovca Jakoba Bidermanna Gabrijel Jurjević prevodi jednostruko rimovanim dvanaesteračkim distisima.
}

${ }^{940}$ O ovome detaljnije u: Lőkös 2008: 95. 
Odiljenju želio isključivo evocirati pjesničku tradiciju južnohrvatskoga renesansnog pjesništva, navlastito znamo li da je četverostrukim dvanaestercem s rimom u polustihu Obsidu ispjevao i Petar Zrinski. Iako će Petrove dvanaesteračke katrene daleko najizravnije evocirati u dijaloškoj pjesmi Gospodična Sofija i oral! (II: 735-906), sačinjenoj od katrena s četverostruko rimovanim dvanaestercima koji također posjeduju još i četverostruku polustihovnu rimu, nije upitno da se forsiranjem dvostruko rimovanog dvanaesterca Vitezović svojom „zrinijadom“ u cijelosti želio približiti književnom, ali i ne samo književnom idolu, odnosno jasno naglasiti, pored (donekle) žanrovske, tematsko-motivske i stilske, ujedno i formalnu bliskost njegovu iznimno popularnom pjesničkom ostvarenju. Štoviše, ustrajući na dvostruko rimovanom dvanaestercu, pored kojega su druga ondje zastupljena metrička rješenja doslovno svedena na tek „mrvice“ teksta, Vitezović kao da je - s gledišta forme istovremeno želio nastaviti i čitavu dotadašnju tradiciju (pisanoknjiževnih), ,zrinijada“, točnije ispoštovati činjenicu da su i Barne Karnarutić i braća Zrinski svoje epove posvećene opsadi i padu Sigeta ispjevali posve identičnim tipom stiha s ubačenom središnjom rimom.

Oslanjajući se na prethodnike, ukratko, (i) naš autor kao da je u dvanaestercu - upravo metametrički - vidio najprikladniji stih za obradu teme sigetske katastrofe i njezinih posljedica, ispravno shvativši da je riječ o metričkom obliku čija će uporaba nepogrešivo sugerirati čitavu dotadašnju pisanoknjiževnu tradiciju literariziranja ovoga važnog povijesnog događaja, do toga trenutka sazdanu od isključivo ostvarenja izvedenih u epskopjesničkome žanrovskom „kalupu“. Osim što je, dakle, tim vlastitim literarnim prilogom „potvrdio“ dvanaesterac kao najprimjerenije stihovno rješenje za književna djela koja se svojim tematskim opredjeljenjem uklapaju u niz „zrinijada“, a k tome ga još i svojim metričkim odabirom - uz činjenicu da je ionako nastao kao „proizvod“ sjevernohrvatske književne kulture - (formalno) snažnije (pri)vezao uz pretežno dvanaesteraračku produkciju našega „kontinentalnog baroka“, Vitezović je ujedno inzistiranjem na objema varijantama dvostruko rimovanoga dvanaesterca Odiljenju dospio priskrbiti i znatno veći literarni dignitet od onog kojeg bi - kao ostvarenje zaokupljeno proslavljanjem važne epizode iz hrvatske povijesti ono imalo kao tekst ispjevan u tada „modernoj“ osmeračkoj stihovnoj formi. Taj dignitet, međutim, trebalo je ono steći isključivo u očima potencijalnih čitatelja iz tada literarno najrazvijenije, dubrovačko-dalmatinske kulturne sredine, u književnosti koje se - poslije njegova nadomještanja osmercem kao „ključnim“ stihom baroknoga razdoblja - dvostruko rimovani dvanaesterac prometnuo u posebno obilježeno metričko rješenje, čija je evokacija u 17. stoljeću nužno nosila ,prizvuk bilo arhaičnosti, bilo osobite podignutosti tona, važnosti i težine onoga što se njime izriče“ (Pavličić 1995: 19), što će reći da je svako njime realizirano 
djelo u to vrijeme neizbježno bilo unaprijed sagledavano kao posebno i stoga vrijedno da mu se posveti puna čitateljska pažnja. ${ }^{941}$

Ako je Pavao Ritter za dvostruko rimovanim dvanaestercem odlučio posegnuti računajući na to da će njegovo ciljano metričko nadovezivanje na cjelokupnu dotadašnju tradiciju „zrinijada“ te hotimično „oživljavanje“ (u južnohrvatskom baroku) već nadvladanoga i pomalo arhaičnog stiha s nakanom isticanja važnosti opjevanih sadržaja prepoznati učen(ij)a publika s našega sjevera i/ili juga, onda je nesumnjivo očekivao i da će slabije obrazovane čitatelje metrički okvir Odiljenja podsjetiti na tadašnje (pretežno) dvanaesteračko pučko-nabožno literarno stvaralaštvo sjevernohrvatskih autora, a vrlo vjerojatno i na izvorne usmenoknjiževne pjesme u šestercu, odnosno u onom istom metričkom obliku u kojem su bili ispjevani i polustihovi - kako je već utvrđeno - dvostruko rimovanog dvanaesterca. ${ }^{942}$ Vitezović je pritom (s pravom) bio i više nego uvjeren da potonjim recipijentima, usprkos tomu što je njihova predodžba dvanaesterca bila oblikovana na temelju spomenutih tadašnjih religioznih pjesničkih ostvarenja napisanih jednostruko rimovanim dvanaestercem, srednja (polustihovna) rima u dvanaesterački realiziranim dionicama Odiljenja neće (odviše) smetati, ne samo zato što će većinu njih natjerati na pomisao o šestercima, s kojima su se dotad već bili susreli posredstvom „narodnih“ pjesama, nego i stoga što će im - sama po sebi - gotovo sigurno biti zanimljiva kao još jedna u nizu brojnih

${ }^{941} \mathrm{Da}$ je Ritter itekako bio upućen u to da je u dubrovačko-dalmatinskoj „sečentističkoj“ književnosti došlo do nagle promjene na „mjestu“ dominantnoga metričkog rješenja, odnosno da njegovi južnohrvatski literarni suvremenici u svojim ostvarenjima znatno više preferiraju osmerac nego (renesansni, pa time i zastarjeli) dvostruko rimovani dvanaesterac u bilo kojoj od njegovih izvedenica, zacijelo je ponajbolje dao do znanja u maločas već spomenutoj pohvalnici Dalmacija, koju ciljano odlučuje stihovno realizirati upravo u osmercu. S druge strane, imajući na umu metričke preferencije onodobnih pisaca iz sjevernohrvatske kulturne sredine, pri sastavljanju svoje Hrvatkinje odlučio se on za formu dvostruko rimovanoga dvanaesterca, ujedno njime implicirajući i to kako kontinentalna naša književnost nije dobila priliku iskusiti „prolazak“ kroz renesansno razdoblje u kojemu bi se upravo dvanaesterac - kao na našem jugu - nametnuo kao „središnji“ metrički oblik kojega bi potom sedamnaestostoljetni (barokni) autori osjetili potrebu nadomjestiti osmercem, što bi onda sugerira - i trebao biti ključni razlog zbog kojega se dvanaesterac u svojoj jednostruko rimovanoj varijanti tek tada, duboko u 17. stoljeću, iskristalizirao kao najvažnija stihovna opcija na našem sjeveru. Bez obzira na identičnu tronarječnu osnovu na kojoj počivaju, Vitezović se ujedno u obje svoje pohvalnice - kako su to nedavno utvrdile Lidija Bogović i Jasmina Pavić - potrudio jasno naglasiti identitetske posebnosti dviju hrvatskih regija i različitosti njihovih tradicija, $i$ to ne samo odabirom različitih stihova, već $i$ ustrajanjem na različitim grafijama, pa dok tako u Hrvatkinji prilagođava kajkavsku grafiju za sjever, u Dalmaciji prezentira dalmatinsku grafiju za jug, dajući time do znanja kako se svakom od dviju pjesama zapravo želi obratiti publici iz regije koju njihovim naslovima i eksplicira (detaljnije o ovome u: Bogović i Pavić 2016: 243-261). Ipak, nipošto ne treba zanemariti rečenu činjenicu kako su obje pjesme ispjevane u suštini istom, naddijalektalnom inačicom hrvatskoga jezika (s jakom čakavskom osnovicom), koju je time - kao i u Odiljenju - očigledno želio predstaviti kao rješenje za zajednički, svehrvatski jezik kao medij koji bi - premošćujući nemale regionalne razlike - trebao povezati tada razjedinjene dijelove „čitave“ Hrvatske. Na kraju krajeva, osim prijedlogom zajedničkoga, mješovitog hrvatskog jezika, Pavao Ritter tu potrebu za što skorijim sjedinjenjem razjedinjenih hrvatskih regija u jednu (,oživljenu“) hrvatsku državu daleko jasnije izražava i sadržajno, i to na nekoliko mjesta u tekstu obiju pjesama, čime njihova idejna polazišta i literarne funkcije zapravo otkriva kao posve identične onima Odiljenja sigetskog.

${ }_{942}$ Detaljnije o mogućnosti cijepanja dvostruko rimovanoga dvanaesterca na šesteračke (polu)stihove koji neodoljivo podsjećaju na izvorno usmenoknjiževni metrički oblik u: Slamnig 1981: 60-67. 
formalnih dosjetaka prisutnih u tekstu. Sve u svemu, kao uradak nastao u vrijeme (ranije već utvrđenog) raslojavanja književnosti na produkciju za učeniju te na onu za tek bazično obrazovanu publiku, Odiljenje sigetsko svojom „metričkom infrastrukturom“ također odaje nakanu prilagođavanja ukusima, potrebama i očekivanjima ciljanih čitatelja, no ne u smislu opredjeljenja za dvanaesterac iz razloga da se njime - kao i osmercem u dubrovačkodalmatinskoj tadašnjoj književnosti - pokuša privući ponajprije pažnja (možda i tek jedva opismenjenih) književnih nevježa. Naprotiv, dok su forsiranjem osmerca južnohrvatski sedamnaestostoljetni literati svoje tekstove željeli učiniti primamljivima najprije skromnije obrazovanim recipijentima, ${ }^{943}$ Vitezović poseže za dvostruko rimovanim dvanaestercem ispravno procijenivši da je riječ o metričkom rješenju podjednako bliskom književnim sladokuscima i jedva obrazovanu ,puku“, odnosno stihu kojeg će učeni čitatelji lako prepoznati kao dio književne tradicije, dočim će one slabije obrazovane nepogrešivo podsjetiti na stihovne obrasce dobro im znane iz aktualnih pučkoknjiževnih ostvarenja, a navlastito iz autohtonoga folklornoknjiževnog pjesništva.

Inače, pored „zrinskijevskih“ dvanaesteračkih katrena, kojima je ispjevao završnu pjesmu drugoga njegova „dila“ (Gospodična Sofija i oral), Ritter će u Odiljenju, u završnom nadgrobničkom ciklusu, donijeti i dva epitafa ostvarena dvama u našem baroku najeksploatiranijim stihovno-strofičkim oblicima - osmeračkim katrenom te osmeračkom sestinom ili sestom rimom - i to onaj Amirašena, velikoga vojvode harapskoga (IV: 126-137), koji je sklopljen od dvije seste rime, te onaj Andrije Gusića glavara (IV: 385-398), u kojemu u pratnji dva osmeračka katrena dolazi (još) jedna osmeračka sestina. Za razliku od osmeračkog katrena, kojeg u njegovu opusu nalazimo isključivo u Odiljenju, za sestom rimom posegnut će on u još dva kasnija navrata, i to najprije u ovdje već mnogo puta spomenutoj pohvalnici Dalmacija iz Valvasorove Slave vojvodine Kranjske, a zatim i u prigodnoj pjesmi Senjčica iz 1704., opetovano potvrđujući u praksi svoju iznimnu vještinu u sastavljanju ovoga možda i najbaroknijeg metričko-strofičkog rješenja. Toj malobrojnosti njegovih pjesničkih tekstova realiziranih sestom rimom usprkos, bez i najmanje bi se dileme moglo ustvrditi kako je već samim uvažavanjem ovoga formalnog oblika Ritter možda i najeksplicitnije iskazao svoju privrženost baroknoj književnoj poetici, dajući (još jednom) do znanja da je ne samo itekako dobro ovladao izrazito raznolikom paletom baroku svojstvenih žanrovskih i strofičkometričkih rješenja, nego i da je posjedovao iskustvo čitanja djela naših južnih „,sečentista“, posredstvom kojih je jedino i mogao otkriti i usvojiti to „suvremeno“ formalno rješenje, na

$943 \mathrm{O}$ želji da se pisana književnost približi (i) literarno neiskusnijim recipijentima kao temeljnom razlogu odbacivanja „renesansnoga“ dvostruko rimovanog dvanaesterca i njegova supstituiranja ,pučkijim“ osmercem u našem južnom baroku podrobnije u: Pavličić 1995: 12. 
učestalost kojega u dubrovačko-dalmatinskoj književnosti 17. stoljeća zato najbjelodanije i upućuje indikativnim formalnim opredjeljenjem u svojoj Dalmaciji.

S aspekta formalnih posebnosti Odiljenja sigetskog, znatno suvremenijim, odnosno gotovo nimalo renesansnim njegovim obilježjem valjalo bi označiti i već zamijećenu metričku šarolikost, ponajviše izraženu u četvrtom „dilu“ teksta, u kojem se ona nameće kao isključivo produkt Vitezovićeve nakane da dinamizira, tj. učini formalno privlačnijim taj sadržajno i generički jednoličan ciklus stihovanih nadgrobnih natpisa. ${ }^{944}$ Kako je, naime, dobro poznato, $\mathrm{u}$ razdoblju renesanse pjesničkim su ostvarenjima poetički strogo bile zabranjivane bilo kakve, pa čak i mjestimične strofičke i metričke kombinacije, a kamoli dosljedno izvedene polimetrijske tekstualne „konstrukcije“, kojima će - pak - s druge strane posebno biti sklono barokno pjesništvo, ${ }^{945}$ čija su formalna poigravanja s različitim tipovima stihova i strofa unutar relativno suženih tekstualnih okvira ponajviše bila motivirana željom autora da se sadržajno, stilski i formalno zanimljivim, a onda i vizualno dopadljivim sastavcima približe (i) čitateljima sa znatno slabijom naobrazbom i zanemarivim literarnim iskustvom. Pojava metrički i uopće formalno razbarušenih pjesničkih tekstova u 17. stoljeću ispostavlja se, ukratko, kao izravna posljedica općega baroknog nastojanja da se pisanoj riječi „privedu“ čak i jedva opismenjeni, bazično obrazovani recipijenti koji su zbog književnoga neiskustva točnije, činjenice da je njihova predodžba književnosti bila oblikovana pretežno posredstvom usmenoga, a potom i pučkoga stvaralaštva - spram literature gajili posve drugačija očekivanja od visokoobrazovanih književnih znalaca iz viših društvenih slojeva, tražeći u njoj ponajprije zabavu i praktičnu korist.

S druge strane, kada je o formalnoj dimenziji Vitezovićeve „zrinijade“ riječ, u očima barokologa i ,ritterologa“ ustrajnih u njezinu poimanju ,punokrvnom“ epskom pjesmom kao baroknoj (redovito glomaznoj i sadržajno iscrpnoj) epici posve nepodudarna karakteristika gotovo bi se sigurno morala učiniti njezina poprilično reducirana duljina (sveukupno „tek“ 2313 stihova), znatno bliža onoj opsegom daleko skromnijih i uopće konciznijih renesansnih epova. Štoviše, želi li se Odiljenju generički prići kao povijesnoj epskoj pjesmi, mnogo renesansnijom doimala bi se čak i njegova četverodijelna struktura, koja kao da priziva onu istu četverodijelnost Karnarutićeva Vazetja Sigeta grada te se ujedno implicitno odupire baroknim epovima svojstvenoj zamašnosti i sadržajnoj sveobuhvatnosti kakvu su, između

\footnotetext{
944 Vođen istim naumom, Ritter je - podsjetimo - u prvim dvama izdanjima svoje „zrinijade“ većinu nadgrobnica posvećenih poginulim turskim napadačima (njih, konkretno, 13 od sveukupno 16) odlučio dodatno istaknuti i tipografski, točnije otisnuti ih kurzivom, a sve ne bi li ih snažnije razdvojio od epitafa ispjevanih u čast hrvatskih branitelja te time ujedno postigao i veću dinamičnost, odnosno vizualnu atraktivnost ovoga žanrovski možda i najhomogenijega odsječka Odiljenja.

${ }^{945}$ Posebno o tome u: Pavličić 1995: 7-29.
} 
ostalih, (i) u svojim epskopjesničkim obradama opsade i turskoga zauzeća Sigeta rastegnuvši ih na punih petnaest relativno poduljih pjevanja - lakoćom postigli Nikola i Petar Zrinski. Osim pojedinih za barokno (epsko) pjesništvo ,atipičnih“ svojstava njegove forme, spomenutim bi proučavateljima za oko zacijelo zapele i stanovite posebnosti sadržajnoga „punjenja“ Odiljenja sigetskog, porijeklo kojih bi, kako se čini, također valjalo tražiti u versificiranim književnim ostvarenjima predbaroknoga - renesansnog - razdoblja.

Konkretno, na pomisao da ih je Pavao Ritter Vitezović baštinio iz (južnohrvatske) renesansne književnosti navodili bi pojedini u Odiljenju zastupljeni motivi poput, primjerice, vila kao transcedentalnih (no dijelom i poluljudskih) ${ }^{946}$ bića, koja uspostavljaju kontakt kako s personificiranim kazivačima (Siget), tako i s ljudskim akterima ili subjektima poput putnika u pjesmi Putnik $i$ Jeka trećega „dila“. I dok bi se prisutnost vila jednako uvjerljivo mogla pravdati i snažnim nadovezivanjem na usmenoknjiževno (epskopjesničko) stvaralaštvo, u kojemu su lik i uopće motiv vile - primijećeno je već maločas - imali važno mjesto, kao isključivo (ili barem pretežno) pisanoknjiževne bi renesansne provenijencije valjalo označiti motiv ili predodžbu turske opsade Sigeta kao Božje kazne kršćanima za počinjena zlodjela i ustrajno prakticiranje bezbožničkih navika. Riječ je, podsjetimo, o ideji koju su u nas zastupali već pisci šesnaestostoljetnih (književnih i ne samo književnih) protuturskih tekstova i koju je kao uzrok turskoga pohoda na Siget istaknuo i Karnarutić u svome Vazetju, slijedeći - pak - u tom sadržajnom detalju Črnkov kronikalni prikaz sigetske katastrofe, ${ }^{947}$ u kojemu se izrijekom navodi kako je pad Sigeta ništa drugo no pravedna kazna Svevišnjega za grijehe čitave zemlje, a navlastito kršćanskih vojnika. S obzirom na činjenicu da će ta zamisao o kršćanskom porazu pod sigetskim zidinama kao nebeskoj kazni potom biti „implementirana“ i u ,zrinijade“ obojice braće Zrinski - dospjevši onamo, dakako, kao posljedica izrazitoga njihova ugledanja na Karnarutićev ep - ne bi bilo netočno pretpostaviti kako je ponajprije tim baroknim „kanalom“ - dakle, najvjerojatnije upravo posredstvom Petrove Obside - ona na koncu doprla i do Odiljenja sigetskog, postavši tako jednom od očitih poveznica Ritterova teksta s cjelokupnom dotadašnjom (pisanoknjiževnom) tradicijom protuturskoga stvaralaštva.

$\mathrm{Na}$ temelju svih dosad iznesenih opservacija o generičkim posebnostima Odiljenja sigetskog predbaroknim njegovim čimbenicima posve netočno ne bi bilo proglasiti čak ni u njemu zastupljena konkretna obilježja pojedinih žanrovskih rješenja koja su u generičkom

\footnotetext{
${ }^{946}$ U obilježjima naricaljke bremenitu obraćanju vile Hrvatkinje Sigetu u pjesmi Vila Hrvatkinja nad Sigetom (II: 614-734) na jednom se mjestu tako upozorava na to da je i „,rod“ vila zapravo junačkoga podrijetla (,I u nas su moći k obrambi zgojene, / da b' mogle pomoći, ako smo prem žene. / I mi smo rođene od junakov vile, / o boju zgojene, srčene bi bile; / što bi ne imile u prsih tvrdosti, / to bi posudile od svoje dragosti“; II: 688-693), što bi dalo sugerirati da i njihovim ,žilama“ zapravo teče krv ljudskih im očeva - neustrašivih ratnika.

${ }^{947}$ Usp. Novalić 1967b: 18.
} 
sustavu šesnaestostoljetne književnosti imala istaknuto mjesto, odnosno onih žanrova čija je renesansna ,inkarnacija“ predstavljala vrhunac u cjelokupnom njihovu književnopovijesnom trajanju. Pa, ipak, čak i kada poseže za konkretnim karakteristikama u renesansi izuzetno često eksploatiranih žanrova poput (fiktivne) poslanice, alegorije, konzolacije i dr., Ritter ih u tekstualne okvire svoje „zrinijade“ uklapa na prepoznatljivo barokni način, supostavljajući ih značajkama deriviranima iz repertoara pojedinih drugih žanrova te tako stvarajući žanrovski vrlo slojevito ostvarenje nepodudarno generički „čisti(ji)m“ sastavcima kakvima je većinom težila književnost 16. stoljeća. Dapače, iako vrlo spretno kombinira te posebnosti različitih žanrova na nivou svake pojedinačne pjesme, $u$ isti mah on razbijanjem „dilova“ u zasebne pjesmovne odsječke u kojima se kao dominantna ili okvirna nameću obilježja iz ne uvijek jednakih žanrovskih repertoara jasno daje do znanja da mu ni najmanje nije stalo do „kamufliranja“ generičkih „šavova“, nego - upravo suprotno - do ekspliciranja izrazite žanrovske heterogenosti i nekompaktnosti svoga ostvarenja, odnosno potenciranja činjenice da je svaki „dil““, pa i svaka njegova pjesmovna sastavnica bitno drugačije žanrovski skrojena, što djelu kao cjelini onemogućava postizanje možebitno očekivane generičke ujednačenosti. $\mathrm{U}$ tom smislu, premda su pojedini u renesansi omiljen(ij)i žanrovi posredstvom odabranih svojih obilježja i u Odiljenju doista stekli važno mjesto, generička njegova razina u cijelosti ipak zrcali „tipično“ barokne Vitezovićeve nakane, koje bi se mogle opisati kao pokušaj da se prizivanjem i ukrštavanjem što je moguće većeg broja raznovrsnih žanrovskih rješenja i/ili njima svojstvenih karakteristika stvori svojevrsni gesamtkunstwerk, odnosno (barokistima toliko drago) „sveukupno“ umjetničko (književno) djelo. 948

Nimalo zanemarive renesansne silnice utkane u barokni tekst, kakvime je s punim pravom moguće držati i Odiljenje sigetsko, nipošto pritom ne bi trebalo poimati kao signal možebitne piščeve „literarne nostalgije“, a ponajmanje kao posljedicu njegova nedovoljnog ovladavanja tada suvremenim, baroknim literarnim (sadržajnim, formalnim, pa i žanrovskim) preferencijama i strategijama. Naprotiv, kako je u književnopovijesnoj literaturi već poodavno utvrđeno, prisutnost izvorno renesansnih značajki u ,punokrvnom“ ili makar pretežno baroknom tekstu sama po sebi ne predstavlja „eksces“ budući da je riječ o posve uobičajenom nadovezivanju baroka na književnu prethodnicu, iz koje je on baštinio štošta u rasponu od petrarkističke tematike (tzv. barokni petrarkizam) ${ }^{949}$ do konkretnih žanrovskih rješenja. ${ }^{950} \mathrm{~S}$

\footnotetext{
948 O težnji stvaranju „ukupnoga umjetničkog djela“ ili gesamtkunstwerka kao prepoznatljivo baroknoj „pojavi“ detaljnije u: Angyal 1961: 104.

949 Opširnije o „baroknom petrarkizmu“, odnosno o brojnim petrarkističkim značajkama prisutnima u našoj baroknoj religioznoj poemi, melodrami i povijesnom epu u: Pavličić 1979b: 185-201.

${ }^{950}$ Osim ljubavne tematike petrarkističke provenijencije, barok - u tematsko-motivskom smislu - upravo iz renesanse crpi još i pastoralne sadržaje, potom viteške sadržaje izvorno srednjovjekovnoga podrijetla, ali i
} 
obzirom na to da se posezanje za pojedinim izvorno renesansnim literarnim značajkama tako potvrđuje kao učestao barokni postupak, ${ }^{951}$ ni prisutnost renesansnih motiva, ni iskušavanje nekih renesansnih formalnih rješenja, a onda ni evociranje stanovitih u renesansi važnih generičkih opcija ne treba automatski izdvajati kao očit pokazatelj Ritterova priklanjanja predbaroknoj poetici ili poetikama, tim više što uvjerljiva većina dosad već pobrojanih pokazatelja jasno govori u prilog (dominatno) baroknom ,identitetu“ njegova osebujnog hrvatskog prvijenca. Štoviše, prilično je vjerojatno i da je - odlučivši se sastaviti djelo temom srodno ranijim „zrinijadama“ - Vitezović prizivanje pojedinih (karakteristično) renesansnih obilježja percipirao kao nužnu, (nepisanoj) poetici „,zrinijada“ svojstvenu strategiju, koju je imao prilike uočiti kako u „tipično“ renesansnom Karnarutićevu Vazetju Sigeta grada (s kojim se najvjerojatnije upoznao zahvaljujući njegovu trećem - Fodroczyjevu - izdanju iz 1661.), ${ }^{952}$ tako i u omiljenoj mu Petrovoj Obsidi sigeckoj (a možda i u njezinu Nikolinu mađarskom predlošku), premreženoj mnogim elementima izravno preuzetima upravo iz epa šesnaestostoljetnoga literarnog prethodnika. ${ }^{953}$

Pretežno baroknu „narav“ Vitezovićeve „zrinijade“ najizrazitije, štoviše, potvrđuje i činjenica da ona - iako je generički samo uvjetno i samo djelomice shvatljiva kao epskopjesnički tekst - okuplja redom obilježja ni manje ni više nego baš onih žanrova što su ih obično apsorbirale (i) barokne epske pjesme (poglavito Petrova Obsida), odnosno karakteristično za (sedamnaestostoljetni) ep - društveno važan povijesni događaj motri iz vizure književnih i ne samo književnih žanrova (ratni govor, prisega) u izvanknjiževnoj praksi „specijaliziranih“ baš za obradu tih u njima opjevanih sadržaja. Drugim riječima, premda je Odiljenje sigetsko tematski posve fokusirano na opjevavanje bitne ratne epizode iz domaće povijesti, ono se ipak ne ostvaruje u očekivanim generičkim (epskopjesničkim) okvirima koji su u njegovo vrijeme bili ,rezervirani“ upravo za te i takve teme, nego priziva obilježja iz repertoara („manjih“) žanrova koji su redovito ulazili u fakturu baroknoga povijesnog epa, što će reći upravo onih generičkih rješenja koja danom historijskom događaju ne pristupaju „epski“ - dakle u njegovu totalitetu - već proizlaze iz pojedinih njegovih momenata te se

tradicionalne sadržaje kojima napučuje novoosmišljene žanrove religiozne i komične poeme, no pritom ih redovito obrađuje na formalno i stilski „osvježen“, prepoznatljivo barokni način. O ovom pitanju iscrpnije u: Kravar 1978: 223-241.

${ }^{951}$ Više o izrazitom baroknom nastavljanju mnogih renesansnih tradicija ili tzv. „baroknom humanizmu“ u: Angyal 1961: 80-139.

$952 \mathrm{O}$ spomenutom trećem izdanju Vazetja Sigeta grada, koje je - s posvetom banu Nikoli Zrinskom - uz potporu obitelji Zrinski 1661. priredio i objelodanio Petar Fodroczy (Fodroci), detaljnije u: Bratulić 2016a: 19 i naročito Jembrih 2017a: 35-62. Inače, zahvaljujući priređivačkom trudu Alojza Jembriha, pretisak Fodroczyjeva izdanja Vazetja (Šopron, 2016.) odnedavno je postao dostupan i suvremenim čitateljima.

${ }^{953}$ Znatno detaljnije o konkretnim - mahom sadržajnim i stilskim - paralelema između Karnarutićeva i epova braće Zrinski u: Novalić 1967b: 5-22 i Lőkös 2008: 131-176. 
sadržajno na njih u potpunosti usredotočuju. I dok tako, primjerice, heroida ili fiktivna poslanica žanrovski želi podsjetiti na epistolarnu formu u kojoj su komunicirali sudionici i suvremenici sigetske katastrofe, ratni govor i zakletva prizivaju iste govorne žanrove što su ih - pripremajući se za konačni okršaj - razmijenili branitelji Sigeta predvođeni Zrinskim, dočim na uobičajenu, formalno izrazito konvencionaliziranu praksu oplakivanja i odavanja počasti poginulim ratnicima upućuju ondje zastupljeni primjerci naricaljke i epitafa. Ako je literarnu predodžbu o značajnom povijesnom događaju i njegovim reperkusijama - koja teži „okrznuti“ sve njegove aspekte - barokni ep tako obično donosio u homogenu obliku, inzistirajući na kompaktnoj i (više ili manje) pravocrtnoj naraciji s upletenim paralelnim epizodama i k tome još napučenoj mnoštvom likova, u Odiljenju tom se istom događaju pristupa na prilično disperziran način, prepuštajući glavnu riječ samim sudionicima i svjedocima bitke za Siget, koji o njoj progovaraju u različitim situacijama i posredstvom kojekakvih generičkih rješenja, no ni $\mathrm{u}$ jednome trenutku ne ispuštajući iz vida moment (svoje)voljne žrtve sigetskih branitelja kao svojevrsni sadržajni epicentar teksta u cijelosti, neprekidnim referiranjem na kojeg svi ti njihovi iskazi zapravo postaju dijelom opće težnje Vitezovićeve „zrinijade“ da upravo „epski“ - zahvati u totalitet tematizirane povijesne epizode.

Usprkos činjenici da njegovu usvajanju baroknih literarnih preferencija, poetički propisanih strategija i tada poželjnih žanrovskih opcija - koje je uvjerljivo demonstrirao već u svome hrvatskom književnom prvijencu - podrobnija razjašnjenja nisu potrebna, poželimo li ipak proniknuti u korijene toga Vitezovićeva „sečentizma“, odnosno izvore tipično baroknoga mu literarnog senzibiliteta, morat ćemo znati ponešto i o „standardnom“ obrazovanju budućih intelektualaca u 17. stoljeću te onodobnim mogućnostima za proširivanje intelektualnih - pa time i književnih vidika - u kojima su posebno uživali upravo onodobni ljudi „od pera““. Naime, ovladavanje baroknim postupcima i vrlo kompleksnim generičkim sustavom sedamnaestostoljetne književnosti naš je autor mogao zahvaliti ponajprije upoznavanju s velikim dijelom korpusa tadašnje domaće i inozemne literarne produkcije, koje je i njemu baš kao i ostalim njegovim suvremenicima - bilo omogućeno ponajprije naglim porastom pokretljivosti kako samih ljudi, tako i njihovih ideja i idejnih dosega. Kako navodi Harold Segel, barokno (književno) iskustvo zapravo je kotiralo kao u potpunosti univerzalno, i to ne samo zbog činjenice što su tadašnji autori fizički bili izrazito mobilni, nego i stoga što im je ta mobilnost nudila mogućnost da stupe u kontakt s izvornim djelima literata iz drugih europskih sredina, iako su se s nekima od njih vrlo vjerojatno već imali prilike upoznati i posredstvom 
prijevoda, kojih je broj diljem tadašnje Europe nezaustavljivo bio rastao. ${ }^{954}$ Upoznavanje s ostvarenjima suvremenika iz drugih kultura brojne je „sečentiste“ - pa tako i našeg Vitezovića - potaknulo da preuzmu ulogu kulturnih posrednika, odnosno da u nacionalnu književnost kojoj su pripadali „presade“ pojedina moderna motivska, stilska, formalna i uopće generička rješenja što su ih zatekli u inozemnoj lektiri, čime su ujedno davali i uvjerljivo najveći doprinos utvrđenoj univerzalnosti baroknoga iskustva.

Kada se, međutim, govori o iznimnoj pokretljivosti sedamnaestostoljetnih pisaca, ono na što je posebno bitno ukazati jest činjenica da se na prvo veće putovanje svaki od njih imao prilike otisnuti još u vrijeme školovanja, koje je u ranomu novom vijeku podrazumijevalo kako formalnu (institucionalnu), tako i praktičnu naobrazbu, u sklopu koje se kao neizostavna komponenta nametalo upravo višegodišnje akademsko putovanje europskim, ali i ne samo europskim (neke od njih - poput, primjerice, Janeza Vajkarda Valvasora - ono je odnijelo sve do sjeverne Afrike) prijestolnicama, a sve u cilju učenja stranih jezika, upoznavanja kulturnih znamenitosti te stupanja $\mathrm{u}$ kontakt $\mathrm{s}$ inozemnom društvenom elitom. Polihistori poput Vitezovića i najboljeg mu prijatelja Valvasora u okviru svoga tzv. grand toura ${ }^{955}$ ili kavalierstoura $^{956}$ tako nisu samo dospjeli upoznati „najvažnije simboličke i materijalne resurse barokne europske kulture“ (Hrgić 2015: 12) i steći nužnu transkulturnu kompetenciju, već i iskustveno osvijetliti „fenomen kulturne razlike, što je u obojice vjerojatno povratno potaknulo pojačano zanimanje za vlastitu kulturu i njezinu promociju u skladu s aktualnim europskim kulturnim trendovima i reprezentacijskim modelima“" (Blažević 2014a: 283). Ponajprije, dakle, zahvaljujući tomu sedmogodišnjem akademskom putovanju - u sklopu kojega je (prije no što je dospio u Rim kao njegovo krajnje odredište) često boravio i u Kranjskoj, glavninom u Valvasorovu Bogenšperku, u kojemu je (između 1676. i 1678.) i upoznao mnoge istaknute onodobne europske intelektualce, stekao vrijedna praktična iskustva te usvojio moderne (barokne) kulturne forme, prakse i zamisli - Ritter se u najvećoj mjeri i dospio „osposobiti“ za buduću ulogu kulturnoga posrednika, koju će, kako se naslućuje već iz primjera samoga Odiljenja, vršiti kontinuirano, a k tome još i više nego uspješno. Naime, baš poput svoga kranjskog prijatelja, i naš je autor tijekom svojih konstantnih putovanja živo pratio (pretežno) inozemnu književnu produkciju, a zatim - u okvirima vlastitih ostvarenja ustrajno transponirao „u domaću kulturu filozofske, političke i ideološke koncepte te književno-umjetničke forme karakteristične za srednjoeuropski barok“ (Blažević 2012:

\footnotetext{
954 Detaljnije u: Segel 1974: 130-139.

${ }_{955}$ Usp. Budišćak 2016a: 269.

${ }^{956}$ O tome u: Blažević 2014a: 282.
} 
436), ${ }^{957}$ najčešće ih pritom prilagođavajući recepcijskoj logici skromnije obrazovane publike iz nižih slojeva, što („eksperimentalno“) čini već u Odiljenju, a kasnije naročito u svojim pučkim kalendarima, u kojima se svojski trudio popularizirati mnoge onodobne ideje i predodžbe prihvaćene u većini zapadnoeuropskih sredina. ${ }^{958}$ Ukratko, dokaze o Ritterovu suverenom poznavanju modernoga inozemnog književnog i ne samo književnog stvaralaštva - iz kojega je glavninom i baštinio obilježja mnogih u baroku posebno popularnih žanrova moguće je locirati duž njegova opusa, što jasno navodi na zaključak kako je barokne značajke u daleko većoj mjeri dospio on „apsolvirati“ zahvaljujući neprekidnomu znatiželjnom zavirivanju preko nego unutar hrvatskih kulturnih granica.

\section{2. ODILJENJE - „VITEZOVIĆEVSKO“ DJELO (KONTEKST AUTOROVA OPUSA)}

Zaokupljeni traženjem odgovora na pitanje o generičkom mu identitetu ili sekundarnom žanru u kojemu je realiziran, u nastavku ovoga kontekstualnog razmatranja Odiljenja suočit ćemo se s nužnošću njegova omjeravanja o znatno uže izvantekstualne okvire od onih književnoga razdoblja, i to najprije one (sve)ukupnoga pisanog stvaralaštva ili autorskog opusa Pavla Rittera Vitezovića. Već iz dosadašnjega nam je izlaganja, naime, moralo postati i više nego jasno kako je - (prividnoj) osebujnosti usprkos - Vitezovićev hrvatski prvijenac napučen idejnim silnicama, motivskim elementima, formalnim rješenjima, pa i stilskim postupcima što ih je moguće zateći i na mnogim drugim mjestima unutar njegova prebogatog i generički iznimno razvedenog stvaralačkog opusa. Kao ostvarenje sazdano od tih (većinom) žanrovski „karakterističnih“ obilježja, deriviranih iz više različitih generičkih repertoara, Odiljenje sigetsko tako se samo od sebe nameće i kao tekst uvelike svojstven upravo Ritterovu opusu, koji uključuje od istoga žanrovskog „materijala“ skrojen čitav niz prije ili (navlastito) nakon njega nastalih - književnih, ali i ne samo književnih djela.

Drugim riječima, gotovo niti jedan generički obilježen tekstualni čimbenik inkorporiran u „tkivo“ Ritterove „zrinijade“ ne može se i ne smije naprečac proglasiti „nevitezovićevskim“, odnosno olako otpisati kao žanrovsko obilježje za kojim ni prije ni nakon objelodanjivanja Odiljenja naš autor nije posegnuo u barem nekom od svojih ostvarenja. O tome koje je žanrove iz bogate palete onih ondje prisutnih on evocirao u drugim - ranijim ili kasnijim - vlastitim radovima redovito se isticalo u prethodnim poglavljima, slijedom čega nam, kako bismo izbjegli suvišna ponavljanja, na ovome mjestu ne preostaje

\footnotetext{
${ }^{957} \mathrm{O}$ transkulturnoj aktivnosti Pavla Rittera Vitezovića i Janeza Vajkarda Valvasora te brojnim intertekstualnim poveznicama između njihovih ostvarenja mnogo opširnije u: Blažević 2014a: 279-299.

${ }^{958}$ Detaljno o ovom pitanju u: Hrgić 2015.
} 
ništa drugo no (,tek“) konstatirati kako ga je na uključivanje znatnog broja njih možda i presudno potaknula ranija uspješna praksa njihova sastavljanja. Primjerice, kao bitan impuls za uvrštavanje pjesama s dominantnim karakteristikama fiktivne poslanice ili heroide Ritteru je nesumnjivo poslužilo (tada) već dugogodišnje iskustvo kontinuiranog ispisivanja i odašiljanja pjesničkih poslanica prijateljima, uglednicima i/ili potencijalnim pokroviteljima, a slično se može reći i za prigodne pjesme, posvetnice (posvetne pjesme), anagrame i kronograme, u pisanju kojih se u godinama uoči početka rada na svojoj ,zrinijadi“ također već bio poprilično izvještio.

Kao književno djelo koje zbog mnogih (generičkih) posebnosti s punim pravom zaslužuje nositi epitet „tipično vitezovićevskoga“, Odiljenje sigetsko ne samo što na svome tekstualnom prostoru spreže prepoznatljiva obilježja upravo onih (baroknih) žanrova u kojima je Ritter realizirao znatan broj vlastitih ostvarenja (pohvalnica, poslanica, epska pjesma itd.), već i inzistira na onom stihovnom rješenju (dvostruko rimovani dvanaesterac) kojim će on ispjevati podosta svojih hrvatskih pjesničkih sastavaka, a ujedno se i na sadržajnoj razini poziva redom na one ideje i idejne sklopove koji su našega autora već vodili ili će tek voditi u (daljnjem) njegovu književnom i uopće stvaralačkom djelovanju (neostoicizam, pankroatističke zamisli, baroknoslavističko nastojanje za pronalaskom jedinstvenoga hrvatskog jezika). Što se potonjih tiče, da se Vitezovićeva „zrinijada“ idejno zasniva na nekima od u njegovu opusu najeksploatiranijih ideoloških postulata, nagovijestit će nam pored već naslovnicom prvoga izdanja najavljenoga formalno-generičkog opredjeljenja za „nečujenu“ hrvatsku „rišmu“, odnosno trodijalektalno ispjevanu vernakularnu pjesmu snažno sadržajno nastojanje da se Siget predstavi kao (gotovo) hrvatska utvrda, u obranu koje su stali isključivo ili mahom hrvatski branitelji, dočim se uloga onih mađarskih (ugarskih) u njegovoj obrani cijano ne samo prešućuje, nego i izrijekom negira. Pridoda li se tome i uvodni motiv neutješnih isključivo „hrvatskih vila“, koje su zbog nemilih sigetskih događanja „mnogu skrb imile“ (I: 2), postat će i više nego jasno da je pri sastavljanju Odiljenja našem autoru glavom prolazio svojevrsan više ili manje razrađen zametak buduće ideje tota Croatia, odnosno predodžbe o „,jelovitoj“ Hrvatskoj rastegnutoj daleko izvan tadašnjih, odviše skučenih (vanjskih i unutarnjih) granica. ${ }^{959}$ Ponajvećma utemeljena na baroknoslavističkim zamislima o slavenskom (a time i hrvatskom) jedinstvu, koje su se najizrazitije ondje manifestirale u spomenutom ustrajanju na dijalektalnom hibridu kao rješenju problema svehrvatskoga jezika, ideja o Sigetu kao „čistomu“ hrvatskom gradu za kojega je prolivena krv hrvatskih očeva, sinova, braće i supruga u Odiljenju je motivski potencirana do krajnosti s

${ }^{959}$ Detaljnije o rečenoj Vitezovićevoj predodžbi i njezinim pojavnim varijantama posebno u: Blažević 2002. 
očiglednom svrhom da se čitateljima iz različitih društvenih slojeva jasno i glasno ukaže na važnost Sigeta kao posebno važnoga memorijalnog lokaliteta, dakle „mjesta sjećanja“,960 kojemu se u kolektivnom pamćenju Hrvata mora povratiti zaslužen status, odnosno nedavnim zrinsko-frankopanskim urotničkim aktivnostima bitno poljuljan dignitet, a sve s krajnjim ciljem da se time potaknu snage koje će sudjelovati u njegovu konačnom oslobođenju od turske vlasti, a naposljetku i prijeko mu potrebnoj fizičkoj (a time i simboličkoj) obnovi.

Utvrđujući konkretne idejno-ideološke silnice kojima je Pavao Ritter protkao svoj vernakularni prvijenac doslovno od prvoga do posljednjeg njegova stiha, ponešto upućenijem čitatelju zasigurno neće promaknuti (ni) mnogobrojni signali tekstualne prisutnosti jedne od najpopularnijih i najutjecajnijih sedamnaestostoljetnih filozofskih doktrina, i to - dakako one neostoicizma, čije idejne postulate tom prilikom on ne evocira ni prvi, a još manje zadnji put u svome opusu. Naprotiv, oslanjanje na neostoicistički idejni kompleks mogao bi se i morao izdvojiti kao jedna od najsnažnijih tekstualnih spona između Odiljenja sigetskog i ostatka njegova vrlo raznolikog stvaralaštva, velikim dijelom „napadno“ prožetoga prepoznatljivim tragovima ove u 17. st. sveprisutne filozofije, koja je zahvaljujući autorima što su živo pratili inozemnu pisanu (literarnu, filozofsku i političku) produkciju dospjela postati važan čimbenik i u okrilju naše barokne kulture.

Uz sadržajne momente proizišle iz uvažavanja idejnih zasada ranonovovjekovnoga neostoicizma, u Vitezovićevoj „zrinijadi“ mjesto su našle i ideje njegove neposredne prethodnice - filozofije stoicizma - koja potječe od učenja stoika iz vremena antike, kada je stoicizam, uostalom, i egzistirao kao jedna od najvećih filozofskih škola. Ta izvorna idejna gledišta starogrčkoga i starorimskoga stoicizma, naime, tijekom 16. i 17. stoljeća proći će kroz temeljitu reviziju, koja će naposljetku iznjedriti posve nov filozofski pravac - novi stoicizam ili „neostoicizam“ - baziran na sprezi klasične (stoicističke) i kršćanske filozofije te u tolikoj mjeri usklađen sa sedamnaestostoljetnim duhom da su njegove zamisli ubrzo nakon što su predstavljene strelovito prožele kulturu i uopće društvo mnogih onodobnih europskih sredina. Zahvaljujući ponajprije ugledanju brojnih tadašnjih intelektualaca na kulturu susjedne Ugarske, u kojoj je on uživao iznimnu popularnost, neostoicizmu svojstven idejni sklop udomaćit će se i u hrvatskoj sredini, gdje su u 17. stoljeću također rado bili čitani utjecajni tekstovi rodonačelnika ranonovovjekovnoga neostoicizma - šesnaestostoljetnoga belgijskog filozofa Justusa Lipsiusa ${ }^{961}$ - i to pretežno u krugovima visokoga plemstva i magnata, koji su

\footnotetext{
960 O Sigetu kao pretpostavljenom „mjestu sjećanja“ više u: Budišćak 2016a: 274-275.

${ }^{961}$ Justus Lipsius bio je, naime, belgijski filolog, humanist i profesor, koji je novu filozofsku doktrinu utemeljenu - najvećim dijelom - na idejnim načelima antičkoga stoicizma prezentirao u omanjoj knjižici, točnije latinskom filozofskom dijalogu punoga naslova De constantia libri duo qui alloquium praecipue continent in publicis
} 
- razmišljajući „tipično“ neostoicistički - i sami u svojim ostvarenjima otvoreno zagovarali vrlinu dosljednosti ili postojanosti (constantia) u javnim nevoljama te njihovo strpljivo i ponizno podnošenje umjesto pukoga nadanja u boljitak.

Kada govorimo o neostoicizmu kao duhovnom pokretu izraslom iz Lipsiusovih filozofskih opservacija, nećemo pogriješiti konstatiramo li da se u idejnom smislu on ponajvećma bazirao na predodžbi o svemiru kao strogo determiniranoj cjelini, koje je „poredak“ određen i uređen ni manje ni više nego blagotvornom providnošću samoga Boga. Drugim riječima, iako su - poput protureformacijskih katoličkih teologa - i neostoicisti vjerovali u autonomnu čovjekovu volju, za sve ovozemaljske nevolje držali su oni ipak „odgovornom“ upravo božansku providnost, koja određuje ne samo slijed događaja u svijetu, nego i svačije mjesto u svemiru, što i jest razlog zbog kojega joj nikako nije moguće umaći i zbog kojega bi - umjesto da se uzaludno to pokušava učiniti - najuputnije bilo sasvim joj se pokoriti te stoički otrpjeti nevolje što ih šalje. Zagovarajući apsolutno čovjekovo povjerenje u Boga, tj. u božanske postupke i odluke, neostoicisti su - kao što je to razvidno iz većine

malis, objelodanjenom 1584. godine. Kratko vrijeme nakon izlaska iz tiska, čitanost Lipsiusova dijaloga uspjela je nadmašiti sva očekivanja, zbog čega se uskoro on pojavio i u prijevodima na mnoge europske (narodne) jezike (francuski, engleski njemački, španjolski, talijanski, poljski, nizozemski i dr.), prometnuvši se u pravi međunarodni bestseler, koji je u razdoblju između 16. i 18. stoljeća doživio nevjerojatnih osamdesetak izdanja. Svojom popularnošću i sveprisutnošću De constantia je dospjela inspirirati i sam intelektualni „pokret“ neostoicizma u Europi, nametnuvši se tako i kao svojevrsna idejna podloga baroka (točnije, barokne kulture) u cijelosti, čije su se ideje pokazale i više nego prijemljivima u tome nemirnom razdoblju obilježenom mnogim ratnim sukobima i kojekakvim drugim nevoljama, kada je sama od sebe ojačala svijest o ništavnosti svega ovozemaljskog, apsolutnoj bezvrijednosti materijalnih dobara te o unutarnjim (duševnim) kvalitetama ili vrlinama kao jedinim neprolaznim čovjekovim vrijednostima. De constantia se, konkretno, zapravo svodi na dijalog ili raspravu posvećenu prirodi društvenih nevolja, koju vode sam Lipsius te njegov prijatelj Charles Langius (Charles de Langhe) i zaključci koje pokazuju jasnu nakanu usklađivanja ideja proizišlih iz okrilja stoicizma s kršćanskim svjetonazorom. Riječ je, konkretno, o svojevrsnoj pouci kršćanima o tome kako im oslanjanje na stoicistički etos postojanosti ili izdržljivosti (constantia) može pomoći da lakše istrpe raznorazna ovozemaljska zla i nedaće, navlastito razviju li svijest o tome - a to je uopće jedno od osnovnih neostoicističkih idejnih polazišta - kako nevoljama ni uz krajnje napore naprosto nije moguće pobjeći. Lipsius čitateljima zato savjetuje da steknu spomenutu vrlinu postojanosti, odnosno da izgrade nepokolebljivu snagu uma ne bi li ga na taj način spriječili u suviše emotivnom reagiranju na konkretne vanjske - sudbinski (pred)određene i stoga neizbježne - događaje, no pritom ističe kako je - pored postojanosti - nužno posjedovati još i vrlinu strpljivosti (patientia) kako bi uopće bilo moguće posve voljno i bez jadikovanja (samosažalijevanja) otrpjeti - dakle, stoički podnijeti - baš svaku od potencijalnih nepogoda što bi ih pojedincu mogao donijeti (ovo)zemaljski život. Bitno je pritom, naglašava se u nastavku, ni u jednome trenutku ne smetnuti s uma kako su apsolutno sve potencijalne nevolje - kako one javne i u to vrijeme posebno proširene poput ratova, kuge i kladi, tako i one privatne (bol, siromaštvo, smrt i dr.) - ništa drugo no izraz Božje volje, odnosno dio znatno većega Božjeg plana za čovjeka ili - drugim riječima - puki proizvod nužnosti (tj. posljedica nestalnosti fizičkoga svijeta, koji se mijenja prema zakonima uzročnosti i u kojemu je sve podložno stvaranju i razaranju) te da stoga nisu ni neobične ni bolne za pojedinca jer je njegova patnja ionako sudbinski zacrtana. U tom smislu, Lipsius zaključuje kako bi čovjek morao biti u stanju spremno i ravnodušno podnositi čak i najveće nevolje ne zaboravljajući kako su one u suštini zapravo manifestacija Božje volje i božanske pravde (jer one, kažnjavajući sve loše, ujedno ispravljaju pogreške i tako donose boljitak u pojedinčev život) te kako od njih nije izuzet baš nitko, slijedom čega jedini izbor koji svatko od nas ima kada ga sustignu jest isključivo način na koji će se s njima suočiti tugujući i očajavajući ili ih, pak, strpljivo i postojano, dakle stoički podnoseći. Vrlo podrobno o Justusu Lipsiusu i njegovoj filozofiji u: Oestreich 2008: 13-131 (o popularnosti dijaloga De constantia i pozitivnom čitateljskom odjeku što ga je izmamio diljem Europe navlastito na str. 57-131). 
„tipično“ baroknih književnih tekstova - neprekidno naglašavali kako je baš sve na ovome svijetu podložno vječnoj mijeni i smrti te kako su javne i privatne nevolje u tom smislu zapravo ništa drugo nego svojevrsni alati kojima se provodi u praksi taj ovozemaljski zakon propadanja i nestajanja. Zakon je to koji u potpunosti proizlazi iz Božje providnosti i kojemu su podvrgnuti podjednako priroda, ljudi te društveni i politički odnosi, točnije zbog kojega je baš svemu na ovome svijetu „suđeno“ roditi se, proći kroz razdoblje sazrijevanja i starenja te na koncu umrijeti, što mogu potvrditi čak i primjeri čitavih gradova, pa i carstava i nacija, koje se također rađaju (nastaju), rastu i stare, da bi naposljetku sasvim nestale s lica zemlje, kao što to - prisjetimo se - na jednome mjestu u svojoj poemi Suze sina razmetnoga vrlo slikovito ističe i Ivan Gundulić. ${ }^{962}$

Potonje je filozofske zamisli u svome stvaralačkom radu ne samo jednom uvažio i Pavao Ritter Vitezović, iz čijeg su opusa kao neostoicistički posebno „potentna“ mjesta proučavatelji dosad izdvajali više žanrovski kojekako realiziranih ostvarenja. Catherine Anne Simpson kao nadasve bremenit idejnim silnicama neostoicizma svojedobno je tako proglasila tekst Ritterova latinskog obrambenog govora iz 1710., kojim je na sudu pokušao pobiti teške optužbe na vlastiti račun, što su mu ih uputili pojedini domaći plemići i kaptolski dostojanstvenici, čvrsto uvjereni da je kao doušnik bečkoga dvora sustavno radio protiv hrvatskih interesa. ${ }^{963}$ Samo nekoliko godina prije Obrane danje svjetlo je ugledao i još jedan Vitezovićev (ovoga puta vernakularni) sastavak, u kojemu bi - prema mišljenju Simpson također trebalo prepoznati neostoicistički ideološki poticaj i utjecaj. Riječ je, dakako, o zbirci osmerački ispjevanih poslovica Priričnik aliti razliko mudrosti cvitje iz 1703., koja već samim svojim generičkim okvirom evocira brojnim poslovicama (sentencijama) premrežene filozofske spise Justusa Lipsiusa i njegovih nasljedovatelja, a u isti mah i predgovorom, u kojemu se ističe kako bi svrha knjige trebala biti da služi kao riznica moralno potičućih poslovica te kao potvrda stajališta da je upravo „vrlina ono što potječe od svakoga dobra“ (Simpson 1991: 52), razloge svoga objelodanjivanja pojašnjava i više nego „tipičnim“

\footnotetext{
${ }^{962}$ Misli se, dakako, na čuvene stihove iz drugoga plača (dijela) Suza, koji glase: „Gdi su istočna carstva stara, / gdi gospodstvo od Rimljana? / Svi pod plugom kijem svit hara / od bremena su uzorana; / jes tko njegda svijetom vlada, / a ne zna mu se ime sada! // Mru kraljevstva, mru gradovi / i njih plemstvo trava krije; / a er umrli život ovi, / čo'ek u srcu miran nije; / a svaki dan vidi očito / da nije ništor vjekovito“ (II: 229-240).

${ }_{963}$ Razlog takvim sumnjama ležao je u činjenici da je, zahvaljujući poveljama kralja Leopolda iz 1701., Vitezović dobio nesmetan pristup javnim i privatnim arhivima u svrhu skupljanja građe za utvrđivanje kraljevskih prava u Hrvatskoj, a - osim toga - domaći su mu velikaši silno bili zamjerili i to što je 1708. od kralja Josipa I. dobio dekret kojim mu je bilo odobreno preuzeti skrbništvo nad bolesnim Ivanom Jonatom Ivanovićem, a time i priznato pravo da naslijedi njegov posjed u Šćitarjevu. Potonji dekret, uostalom, bio je i razlogom zbog kojega je naš autor 1710. završio na sudu, a iako je povodom parnice napisao tu vrlo dojmljivu vlastitu obranu, sud će na koncu presuditi protiv njega te ga time prisiliti da se iseli iz Śćitarjeva. Podrobnije o parnici protiv Vitezovića u: Klaić 1914: 216-292 i 1915: 375-377. Usp. prijepis teksta Vitezovićeve obrane na izvornom latinskom jeziku u: Klaić 1915: 375-394.
} 
neostoicističkim argumentima. Činjenica da se u mnogim ondje okupljenim poslovicama $\mathrm{k}$ tome još i progovara o onim istim pitanjima koja su zaokupljala i (neo)stoiciste ujedno upućuje ne samo na to da njihovo porijeklo nipošto nije moglo biti ni biblijsko ni usmenoknjiževno, ${ }^{964}$ već i na to da su - zahvaljujući njima - prepoznatljivo neostoicističkim predodžbama ujedno bili premreženi i Vitezovićevi pučki kalendari, u sklopu kojih su te iste poslovice u prethodnih nekoliko godina (1697. - 1703.) prvi put i ugledale svjetlo dana. To će, drugim riječima, reći kako je prezentiranjem tih i takvih filozofskih poslovica najprije u kalendarima, a potom i u (podjednako pučkom) Priričniku - kao što je u recentnoj „ritterološkoj“ literaturi ispravno utvrđeno ${ }^{965}$ - naš autor zapravo želio temeljnim idejnim postulatima tada sveprisutne i silno utjecajne neostoicističke filozofije zaogrnutima $u$ „popularni“ oblik poučiti i slabije obrazovanu domaću publiku, za koju je ispravno pretpostavio da će prva posegnuti za vizualno i sadržajno primamljivim tekstovima takva tipa. Štoviše, maločas utvrđena prisutnost filozofskih (neostoicističkih) poslovica i na tekstualnom prostoru Odiljenja sigetskog jasno upućuje na to da je već u svojoj „zrinijadi“ Ritter iskušavao strategiju poslovičnoga formuliranja modernih ideoloških spoznaja i njihova prezentiranja $u$ široj publici intrigantnom ostvarenju, i to najvjerojatnije s ciljem da je - u generički i sadržajno ,pitkom“ obliku - upozna makar s ključnim idejnim ishodištima nove epohe.

I dok pretpostavka o možebitnoj didaktičnoj funkciji u njemu prisutnih neostoicističkih poslovica ostavlja ipak ponešto prostora sumnji, činjenicu da Odiljenje pripada među najranija Vitezovićeva djela u kojima se otvoreno inzistira na karakteristično baroknomu (čitaj: neostoicističkom) motivu apsolutne odanosti nebeskom (Bog) i zemaljskom (kralj) vladaru te domovini s punim se pravom može i mora označiti kao definitivno neprijepornu. Dapače, osim ovoga „tipično“ baroknoga plemićkog viteško-moralnog kodeksa, djelomice će već i Odiljenje, ali u daleko zamjetnijoj mjeri većinu kasnijih Ritterovih ostvarenja prožimati neostoicizmu svojstvene teme kao što su „providnošću uspostavljen poredak; moralno propadanje i otklon; zauzetost općim dobrom“ (Simpson 1991: 56) i dr., prisutnosti kojih - pored mnogih drugih čimbenika - opus našega autora ponajviše i duguje svoju izrazitu baroknost. Iako, dakle, bitno „razblažen“ u usporedbi s onim što se opredmetio u kasnijim Vitezovićevim sastavcima, neostoicizam Odiljenja ipak nije mogao promaknuti pažnji (doduše, ne tako brojnih) pronicljivijih ,ritterologa“, koji su relativno nedavno dospjeli utvrditi (i) da, „sukladno provodnome motivu »odiljenja«, odnosno rastanka, ideološku potku djela čini reformnokatolička eshatologija neostoicističke inspiracije, protkana elementima

964 O filozofskim - čitaj: neostoicističkim - izvorima mnogih Ritterovih poslovica uvrštenih u Priričnik detaljnije u: Simpson 1991: 52-53.

${ }_{965}$ Usp. Hrgić 2015: 42-65. 
ideologije baroknog heroizma, pri čemu se herojsko mučeništvo, neovisno o etničkoj i vjerskoj pripadnosti, hipostazira kao apsolutni moralni ideal“ (Blažević 2011: 253).

Usredotočimo li se, napokon, na konkretne sadržajne manifestacije neostoicističke idejne paradigme u Ritterovoj ,zrinijadi“, u oči će nam gotovo sigurno najprije upasti po neostoicističkim zamislima „skrojen“ lik bana Nikole Šubića Zrinskog, odnosno slavnoga sigetskog kapetana koji je - u pokušaju da obrani strateški važnu kršćansku utvrdu - zajedno sa svojom malobrojnom „hrvatskom“ četom mučenički poginuo odvažno se suprotstavljajući brojčano daleko superiornijoj vojsci turskih napadača. U kontekstu Odiljenja, konkretno, ban Zrinski je koncipiran kao akter - tj. govornik ili (lirski) subjekt - kojega odlikuje izuzetna vojna hrabrost, silna pobožnost te snažna volja za samožrtvovanjem svojstvena samo „istinskim“ mučenicima, ${ }^{966}$ dakle kvalitete kojima se dospijeva prometnuti u svojevrstan obrazac za sve buduće protuturske ratne pothvate, pri čemu se to inzistiranje na Zrinskom kao vojničkom, kršćanskom i moralnom uzoru posebno važnim nameće ponajprije zbog tada „aktualnoga“ Bečkog rata te mogućega definitivnog oslobođenja Sigeta - kao simbolički važnoga lokaliteta iz hrvatske prošlosti - iz dugogodišnjega turskog „,sužanjstva“.

Govoreći o Turcima kao (tada) još uvijek opasnom ratnom protivniku te osvajačkoj sili koja je tek nakon slamanja otpora žilavih kršćanskih branitelja na čelu sa Zrinskim uspjela zaposjesti Siget, izrazit neostoicistički utjecaj zapazit ćemo i u poimanju osmanlijske vojske kao „Božje kazne“ što ju valja ponizno i postojano otrpjeti, a zbog kojeg Vitezović hotimice i ne zaoštrava sliku turskih napadača, točnije odustaje od njihove pretjerane demonizacije, tim više što se ona - sama po sebi - ispostavlja posve neuskladivom s neostoicističkim inzistiranjem na pobožnom trpljenju ratnih nedaća. ${ }^{967}$ Kako je relativno nedavno zapazila i Catherine Anne Simpson, motiv turske najezde kao biča kojim Bog udara na iskvarene i uopće moralno posrnule kršćane ne bi li ih natjerao na skrušeno pokajanje zapravo je, kao takav, ništa drugo no izravan odjek ideja što ih je u svojim filozofskim spisima razradio Justus Lipsius, koji - razmišljajući o nevoljama s kojima su se u njegovo vrijeme suočavali žitelji Nizozemske - višestruko naglašava kako su baš sva teška razdoblja u povijesti neke nacije, društva ili pojedinca zapravo poslana od Boga, odnosno da su ništa drugo no dio poretka (Božje) providnosti namijenjenog isključivo osiguravanju dobrobiti čovječanstvu. Doduše, iako je riječ o motivu ili ideji koja se u korpusu (domaće) protuturske literature redovito pojavljivala počevši od humanizma, predodžba o turskim osvajanjima kao nebeskoj kazni u isti se mah tako nameće i kao vrlo suvremena, „tipično“ barokna zamisao, koja bi mogla i

\footnotetext{
966 Detaljnije u: Simpson 1991: 103-105.

${ }^{967} \mathrm{O}$ toj znatno ublaženijoj slici Turaka u Vitezovićevu Odiljenju posebno u: Budišćak 2013 b.
} 
morala sugerirati (i) Vitezovićevo usvajanje idejnih koncepata prezentiranih u neostoicističkom stvaralaštvu, premda je - kako pretpostavlja Simpson - njegovo posezanje za tim motivom vjerojatno bilo potaknuto i pojedinim tekstovima iz mađarske književnosti, $u$ kojoj se o Božjem kažnjavanju grješnih kršćana također pisalo još od humanizma, i to redovito u vezi s motivom pojave i prihvaćanja protestantizma kao otponca za Božju srdžbu.

Kada se, nadalje, u predgovoru Prijaznivi štavče! fiktivnoga „drugog“ izdanja Odiljenja iz 1685. naš autor (ponovno) dotakne njegove (navodne) nedovršenosti, kao najkrupniji njezin razlog on će navesti činjenicu kako mu ni u međuvremenu nije (još) pošlo za rukom naći pokrovitelja voljnog da ga financijski, ,podrži“ u njegovu radu na dogotovljavanju, a potom i objelodanjivanju teksta, za što drži krivim opće „stanje duha“ u Hrvatskoj, koje je dovelo do toga da „čim ki veće ima, već želi imati, / a ki ništar nima, otkud će što dati?“ (Ritter Vitezović 1685). Podastirući takav prigovor, Ritter zapravo evocira ni manje ni više nego neostoicizmu svojstven motiv zanemarenoga općeg dobra i/ili poljuljanih vrlina, koji je moguće locirati i drugdje unutar njegova stvaralaštva, a koji se obično pritom svodio na isticanje koristoljublja i inih sebičnih interesa kao glavnih razloga zapostavljanja javnoga dobra, odnosno na naglašavanje činjenice kako su mnogobrojni poroci istisnuli izvorne vrline te kako je nesebična posvećenost kršćanskim idealima odavno postala stvar prošlosti. Uopće, Vitezović u više svojih djela zagovara taj ideal brige za opće dobro ne zaboravljajući pripomenuti kako je među Hrvatima on sve deficitarniji, što, između ostalog, potvrđuje i primjerom odnosa svojih sunarodnjaka spram hrvatskoga jezika, kojega se dotaknuo (i) u predgovoru $K$ čtavcu prvoga izdanja Odiljenja sigetskog. Konstatirajući ondje kako je izvorni hrvatski jezik već u tolikoj mjeri pao u zaborav da ,skoro vikovični (na jedno rečenje) domoroci materinskim jezikom dobro općiti i svaku rič pravim nje imenom spovidati ne mogu“ (Ritter Vitezović 1684), naš autor - ozbiljno zabrinut za njegovu budućnost - kao najveću prijetnju izdvaja suvišno asimiliranje nebrojenih tuđica iz različitih jezika, koje, po njegovu mišljenju, proizlazi ni iz čega drugoga no nedovoljno dobrog poznavanja (trodijalektalnoga) bogatstva vlastita jezika. Svjestan da, drugim riječima, Hrvati nisu podlegli kulturnom imperijalizmu, već da strane utjecaje upijaju isključivo poradi vlastite taštine i ravnodušnosti, u njihovoj ,pomami“ za tuđicama on prepoznaje udomaćivanje pogubnih kozmopolitskih trendova, kojima se odlučuje otvoreno usprotiviti znajući da oni vode ka moralnom izopačavanju te da - kao takvi - donose rizik od mogućega (ponovnog) buđenja Božjega gnjeva. ${ }^{968}$

\footnotetext{
968 O ovome usp. Simpson 1991: 73-77. Inače, Tim plediranjem za povratak (čistomu) hrvatskom jeziku Ritter se, uzgred budi rečeno, (ne)izravno nadovezuje na brojne literarne prethodnike koji su se u svojim djelima
} 
Treba li, nakon svega dosad (iz)rečenog, posebno ukazivati i na neostoicističku utemeljenost prepoznatljivo baroknoga svjetonazora, za kojim se od prvoga do posljednjeg stiha svoje „zrinijade“ Pavao Vitezović ustrajno povodi, gotovo opsesivno inzistirajući na evociranjima čovjekove, ali i smrtnosti baš svih ovozemaljskih stvari? Bit će u tom smislu dovoljno tek prisjetiti se uvodne pjesme - heroide Siget hrvatskim gospojam (I: 1-477), u kojoj upravo spoznaja o neizbježnosti smrti kao sveprisutne i sverazarajuće sile biva potencirana do krajnosti, i to ne samo da bi u konkretnom tekstu poslužila kao utješna spoznaja ožalošćenim majkama, udovicama i zaručnicama poginulih branitelja, već i kako bi se njome ujedno inicirao i motiv apsolutne pomirenosti bana Zrinskog i njegovih suboraca sa skorom smrću, u kojemu se zrcali već dobro nam znana također neostoicistička ideja prepuštanja sudbini te strpljivoga i postojanog podnošenja čak i najtežih životnih iskušenja. Na kraju krajeva, i neprekidno isticanje smislenosti pogibije kršćanskih junaka pod zidinama Sigeta, odnosno veličine njihove žrtve što su je podnijeli poradi „viših ideala“ - odanosti kralju, vjere u Boga i ljubavi spram domovine - uočljivo je također neostoicističke provenijencije, iz čega proizlazi kako u baroku obljubljena ideologija neostoicizma sa sebi svojstvenim predodžbama o potrebi stoičkoga podnošenja čak i (Božjom voljom poslanih) nedaća koje će rezultirati smrtnim ishodom ustvari nije ispuštena ni u jednom jedinom „dilu“ ove neobične ,zrinijade“.

Promotre li se njegove formalno-generičke osobitosti, bit će teško oteti se dojmu kako Odiljenje sigetsko na neki način kao da teži iskazati čak i karakteristično neostoicističku, Vitezoviću nimalo stranu sklonost prezentiranju raznovrsnih činjenica u formi (baroknih) enciklopedijskih djela, odnosno da se svojom vrlo složenom kompozicijom i ciljanom generičkom šarolikošću želi potvrditi (i) kao svojevrsna tematski homogena „enciklopedija“ književnih i ne samo književnih žanrova koji su ili neposredno bili evocirani od samih sudionika ili makar suvremenika sigetske katastrofe (poslanica, ratni govor, prisega, blagoslov, molitva, epitaf i dr.) ili, pak, o njoj progovarali s duljim ili kraćim vremenskim odmakom (epska pjesma, panegirik, bugaršćica itd.), pri čemu bi njihovo supostojanje na zajedničkom tekstualnom prostoru - opet „tipično“ neostoicistički - u tom slučaju nedvojbeno trebala podržavati pretpostavljena „blagotvorna providnost““969 Formalno-generička slika

također kritički osvrtali na ravnodušnost Hrvata spram vlastita jezika, i to ne samo na izrazitu njihovu sklonost apsorbiranju pojedinih tuđica (koja je na koncu rezultirala onečišćavanjem hrvatskoga), nego i - još više - na njihovo ustrajanje u kreativnoj, pa i svakodnevnoj uporabi konkretnih stranih jezika, koja je - između ostalih zasmetala i Jurju Barakoviću u Vili Slovinki. Naime, na nepoštivanje vlastita jezika osvrnuo se tako Baraković, konkretno, u posvetnoj pjesmi An'jelu Justinijanoviću, u kojoj za Hrvate na jednome mjestu otvoreno kaže: „Sramni su možebit jazikom svojime / ter vole govorit svaki čas tujime“ (Baraković 2000: 55, stihovi 443-444). 969 Jamačno najuvjerljivijim dokazom Vitezovićeve izuzetne sklonosti (baroknom) enciklopedizmu moguće je proglasiti njegovo nedovršeno enciklopedijsko djelo $O$ žrtvenicima i ognjištima Ilira, koje je trebalo predstavljati 
Odiljenja, jednako tako, daje nam za pravo da posumnjamo čak i u Ritterovo možebitno snažno ugledanje na dijalošku formu omiljenih mu neostoicističkih filozofskih ostvarenja Justusa Lipsiusa, zahvaljujući kojemu su - kao što je ranije već primijećeno - mnoge dionice njegove ,zrinijade“ (vjerojatno) i poprimile dijaloški oblik, realizirajući se ne samo u žanru dijaloške pjesme i pjesme-jeke, nego i u formi usmeno (Ban sinu i Sin banu; Ban Sigetu i Siget banu) ili pisano ostvarena dijaloga, odnosno izmjene iskaza i replika (Ban kralju, Kralj banu, Siget kralju, Kralj Sigetu itd.), ali i uopće iskazujući snažnu dijalošku intenciju, koja do izražaja dolazi u doslovno svakoj pjesmovnoj dionici svakog od četiriju njezinih dijelova.

U razmatranju ove (potencijalno neostoicističke) „enciklopedijske“ generičke slojevitosti Odiljenja posebnu bi pozornost svakako trebalo posvetiti ranije već analiziranu žanru poslovice, među ondje uvrštenim primjercima koje zatječemo i manji broj onih čije tematsko-motivsko (semantičko) usmjerenje nepogrešivo upućuje na uvažavanje idejnih uporišta filozofije neostoicizma. Naime, posezanje za „tipično“ neostoicističkim poslovicama u kontekstu Ritterova stvaralačkog opusa - podsjetimo - ne predstavlja ni najmanji raritet, pa osim što ih je tako znatan broj, između ostalog, uključen i u zbirku Priričnik aliti razliko mudrosti cvitje, ujedno i među mudrim izrekama pridodanima (ranijim i kasnijim) pučkim njegovim kalendarima - kako je utvrdio Danijel Hrgić - također „postoji određen broj onih koje je Vitezović preuzeo iz Lipsiusovih djela“" (Hrgić 2015: 16). I dok je u Odiljenju neostoicistički „sumnjivima“ moguće označiti one poslovice koje se dotiču baroku posebno omiljenih motiva trošivosti, tj. privremenosti ovozemaljskih dobara, nestalnosti sreće i herojske pogibije na bojišnici kao najvrjednijoj čovjekovoj zasluzi, u Priričniku i Ritterovim kalendarima kao „lipsiusovske“ izdvajaju se ponajprije one uzrečice što progovaraju o vrlini ili „kriposti“, kritiziraju pohlepu, podmitljivost i uopće pristranost sudaca te ističu važnost domoljublja, a sve s ciljem kako bi se - evociranjem tada najaktualnijih i najutjecajnijih filozofskih (neostoicističkih) postulata - ta „elitna“ znanja prenijela i na skromnije obrazovanu publiku te time postigla njezina moralna edukacija. ${ }^{970}$

Ne bi se, jednako tako, olako smjelo prijeći ni preko činjenice kako su poslovične koncentracije općeživotnih spoznaja, kojima Vitezović poentira mnoge refleksivno-poučne segmente svoje ,zrinijade“, s gotovo istom svrhom kao i one u Odiljenju bile inkorporirane i u većinu Lipsiusovih filozofskih ostvarenja, koji ih - nalik brojnim drugim šesnaesto- i poglavito sedamnaestostoljenim piscima - većinom baštini iz djela raznih povjesničara,

spregu cjelokupnoga znanja i spoznaja o „Ilirima“, odnosno koje je bilo zamišljeno kao sveobuhvatan pregled hrvatske svjetovne i crkvene povijesti s pridodanim zemljopisnim prikazima i filološkim raspravama. Vitezović je, međutim, od čitava tog planiranog djela dospio realizirati tek njegov opći nacrt, koji se - srećom - do danas dospio i sačuvati. Podrobnije o tomu enciklopedijskom Ritterovu ,projektu“ naročito u: Simpson 1991: 98-101. ${ }^{970}$ Više o tome u: Hrgić 2015: 48-50. 
filozofa i pjesnika. Dapače, posve identično Lipsiusu, koji izlaganje u svojim tekstovima počesto prekida versificiranim (najčešće distihovnim) poslovičnim poentama ili „običnim“ literarnim citatima (ponajviše deriviranima iz pjesničkih ostvarenja antičkih autora u rasponu od Hesioda, Homera i Sofokla, pa sve do Seneke, Euripida i Vergilija) ne bi li njima jače naglasio iznesene opservacije, Vitezović poslovice $u$ distihu uključuje čak i u prozne predgovore prvih dvaju izdanja Odiljenja, efektivno njima podcrtavajući pojedine „ključne“ konstatacije, baš kao što to ustrajno čini i duž čitava teksta svoga vernakularnog prvijenca. ${ }^{971}$ Ipak, usprkos prilično vjerojatnom ugledanju na Lipsiusovu praksu učestalog upošljavanja mudrih izreka, naš je autor uzor za poslovična potkrepljivanja pojedinih naročito bitnih misli i zapažanja lako mogao pronaći i u posebno mu dragoj ,zrinijadi“ Petra Zrinskog, koji ne samo što izrekama i sentencijama „osnažuje“ refleksivne odsječke mnogih pjevanja Obside, nego i posvetu Sirene koncipira upravo onako kao što će biti koncipirani i predgovori Odiljenja, u kojima se značajnije opservacije također podcrtavaju vrlo uspjelim poslovičnim potvrdama.

Čak i kada bismo slučajno ili hotimice ostavili po strani potonju idejno-ideološku neostoicističku pozadinu njegove žanrovske šarolikosti, Odiljenje sigetsko kao karakteristično bi „,vitezovićevsko“ djelo i dalje potvrđivala činjenica da je riječ o generički izrazito „Zapetljanom“ i višeslojnom ostvarenju, skrojenom od obilježja neobično velikog broja književnih i ne samo književnih žanrova, koje je bilo u stanju isprovocirati gdjekad i posve oprečne generičke identifikacije. Kao jedan od nekolicine naših ,punokrvni(ji)h barokista“, Pavao Ritter Vitezović nije nam zapravo u nasljeđe ostavio gotovo nijedan žanrovski posve „čist“" tekst, pri čemu je posebno zanimljivo primijetiti kako njegova stvaralačka ostavština ne oskudijeva ni sastavcima poput Odiljenja, koji su - zahvaljujući svojoj „pojačanoj“ Žanrovskoj hibridnosti - različite čitatelje počesto navodili i na prilično nesumjerljive pokušaje generičkih kategorizacija. Pored njegove već i naoko žanrovski šarolike „zrinijade“, među ta generički raznoliko definirana Ritterova ostvarenja pripadao bi i daleko najpoznatiji mu (historiografski) tekst - Oživljena Hrvatska (1700.), koju su različiti „ritterolozi“, polazeći od podjednako (ne)uvjerljivih tekstualnih argumenata, dosad paralelno svrstavali među spomenice (memorandume), ali i među tzv. ,ilirsku literaturu“, što će reći u historiografske Žanrove koji su se u ranonovovjekovnom, navlastito sedamnaestostoljetnom stvaralačkom korpusu izdvajali svojom popriličnom učestalošću. ${ }^{972}$ Izostanak ,ritterološkog“ konsenzusa po pitanju njegova žanrovskog identiteta primjetan je i kada je riječ o stihovanomu kronikalnom

\footnotetext{
${ }^{971}$ Da je - podsjetimo - i sam Pavao Ritter Vitezović nerijetko pabirčio po literaturi u potrazi za poslovicama za koje je bio uvjeren da će mu zatrebati u njegovu kasnijem stvaralačkom radu najuvjerljivije nam dokazuje već spomenuti njegov priručni rukopisni zbornik Varia extracta et notitiae, u kojemu nalazimo čitav niz prepisanih izreka i uzrečica što ih je pronašao u lektiri antičkih i ranonovovjekovnih filozofa, pjesnika i isusovačkih pisaca. 972 Opširnije o ovom pitanju u: Blažević 2002: 100-113.
} 
Vitezovićevu djelu Dva stoljeća ucviljene Hrvatske, za kojega će recentni proučavatelji konstatirati kako se radi „o heksametarskom spjevu koji iz niza razloga (promjena iskaznog subjekta, nedostatak prave radnje, žanr kronike u njegovu temelju, oslanjanje na srednjovjekovne lamente) izmiče lakom žanrovskom definiranju“ (Stepanić 2010: 72).

Dapače, u novijim studijama posvećenima latinskom Vitezovićevu stvaralaštvu sve češće će se podastirati i više nego uvjerljivi dokazi o tome kako čak i taj segment njegova opusa - iako usklađen s bitno strožim postulatima antičke poetike - pokazuje pomalo iznenađujuću otvorenost žanrovskim ,poigravanjima“, odnosno „onečišćavanju“ tekstualnih faktura koje bi trebale pretpostavljati generičku jasnoću, tj. homogenost. Tako će, konkretno, čak i njegova latinska ostvarenja ispisana u žanrovima koji „tradicionalno“ nisu podnosili uplitanje političko-ideoloških sadržaja, pa čak ni izravnih aluzija na javni pjesnikov život (poput, primjerice, epistula i ljubavnih elegija) posve neočekivano demonstrirati izrazitu političku angažiranost, tijesno - dakako - povezanu s Ritterovom izravnom uključenošću u onodobni kulturni i javno-politički život u Kraljevini Hrvatskoj. ${ }^{973} \mathrm{~S}$ druge strane, iako će najveći dio ljubavne mu lirike ponajprije svojom duljinom i poentiranošću jasno prizivati žanr epigrama, motivskim i retoričkim značajkama odavat će ona istodobno (i) generičku bliskost elegiji te time silno otežavati postupak možebitnoga jednoznačnog definiranja, baš kao što će to biti slučaj i s onim njegovim anagramima, u kojima stihovano pojašnjenje novoskovanoga pojma (egzegeza), umjesto u uvriježenom žanru epigrama, biva ispjevano u onom epinikija, epitafa ili epitalamija. ${ }^{974}$ Osim toga, neobično velikom broju Ritterovih bi anagrama ponajbolje pristajala generička odrednica prigodnice budući da su redom oni posvećeni proslavljanju pojedinih domaćih i/ili inozemnih (političkih) uglednika, a gdjekad i konkretnih zemalja i gradova, što će reći da se radi o tekstovima u kojima se pred čitateljevim očima „sukobljuju“ obilježja žanra zasnovanog na kompleksnim jezičnim operacijama s onima žanra čija je estetska dimenzija u najvećem broju slučajeva sekundarna. ${ }^{975}$

Jednako tako, zahvaljujući nedavnim, iznimno ozbiljnim „ritterološkim“ analitičkim pretresanjima Vitezovićeve (gotovo u cijelosti latinske) epistolarne ostavštine, utvrđeno je, također, i to da se povelik broj njegovih pjesničkih poslanica može podičiti ne samo vrlo naglašenim sadržajnim (motivskim) bogatstvom, nego i generičkom višeslojnošću, proizišlom iz kombiniranja obilježja različitih žanrova, koja je rezultirala posvemašnjom nemogućnošću

\footnotetext{
${ }^{973}$ Primjerice, u jednu od svojih elegija naslovljenu Ad Herulam Slavam Vitezović tako uključuje sadržaje povezane s njegovim ilirskim političkim mitom, a isti će „postupak“ zatim u nekoliko navrata ponoviti i u pojedinim svojim pjesničkim poslanicama.

${ }^{974}$ O tome detaljnije u: Stepanić 2005: 190-191 i 2016: 335-336.

${ }^{975}$ Opširnije u: Stepanić 2005: 186-193.
} 
jednoznačnoga njihova generičkog određenja. ${ }^{976} \mathrm{Uz}$ to, u latinskim (epistolarnim i ne samo epistolarnim) pjesničkim ostvarenjima našega autora detektirani su i kojekakvi formalni eksperimenti - rebusi, kronogrami, rimovani kvantitativni stihovi (ponajviše dvostruko rimovani heksametar), abecedne pjesme, versus echoici itd. - čija je brojnost pojedine proučavatelje navela na to da Vitezovića okvalificiraju kao apsolutnoga prvaka i majstora formalnih igrarija među svim domaćim sedamnaestostoljetnim (novo)latinskim pjesnicima. 977 Dapače, o Ritterovoj iznimnoj vještini ,žongliranja“ različitim generičkim obilježjima i formalnim eksperimentima (i) na ,prostoru“ latinskoga pjesništva zacijelo ponajbolje svjedoči primjer njegove prigodnice sastavljene u čast princa Josipa Sacer chorus, otisnute u Beču 1682., ${ }^{978}$ koja uključuje „kompleksnu naslovnicu, stihovani predgovor, odnosno posvetu princu u elegijskim distisima, 20 heksametara - kronograma koji su rimovani po četiri u nizu, epigram u elegijskom distihu sa leoninskim stihovima - jekom, anagram čiji je zadani pojam svih sedam prinčevih imena, rebus, niz od 9 naizmjeničnih stihovanih kronograma i grupu od po 7 heksametara na kojima je izveden akrostih, mezostih i telostih, oveći epigram u distihu s figurom traductio, te dvostruko rimovanu heksametarsku pjesmu“ (Stepanić 2005: 214). Slučaj potonje prigodnice, ali i čitavog niza drugih njegovih latinskih sastavaka ujedno se nameće kao možda i ponajbolja potvrda Vitezovićeve kontinuirane otvorenosti različitim formalnim, nešto rjeđe i stilskim, a naročito žanrovskim inovacijama i kombinacijama, za kojima je - kao „tipični“ stvaratelj baroknoga doba, koje je svesrdno podržavalo te i takve literarne eksperimente i generička preklapanja - u obilnoj mjeri počeo posezati već u svojim radovima nastalima znatno prije Odiljenja. ${ }^{979}$

Sve u svemu, kao djelo koje pripada njegovoj ranoj - mladenačkoj - stvaralačkoj fazi, Odiljenje sigetsko svojim se osebujnim tekstualnim značajkama i žanrovskom mješovitošću potvrđuje kao tekst koji u isti mah spreže pojedina rješenja i postupke što ih je Pavao Ritter iskušao već u nekima od svojih prethodnih - vernakularnih i latinskih - ostvarenja, ali i najavljuje većinu oblikovnih strategija na kojima će se bazirati njegovi kasniji stvaralački „pothvati“. Za nj se, drugim riječima, s punim pravom može ustvrditi kako funkcionira kao svojevrsna summa čitavih Vitezovićevih kreativnih napora (ili, kazano u terminima romantičkih književnih teoretika, kao nekovrsni autorski gesamtkunstwerk), odnosno kao

\footnotetext{
976 Tako, primjerice, pojedine Vitezovićeve poslanice sadržajno funkcioniraju kao pozdravi, dočim se po svojim formalnim obilježjima ispostavljaju kao daleko bliže žanru epigrama. Detaljnije o tome u: Moretti 2014 i Moretti i Stepanić 2019: 9-116.

977 Usp. naročito Stepanić 2005: 199-214 i 2016: 333-348.

978 Jedan njezin primjerak čuva se uvezan u već višestruko spomenut Vitezovićev zbornik Otia metrica.

979 Znatno detaljnije o pojavi žanrovskih hibrida i formalnih eksperimenata u Vitezovićevu latinskom pjesničkom opusu u: Stepanić 2005 i 2016: 333-348.
} 
točka u kojoj se susreću i raznoliki njegovi stvaralački interesi (kako za književnost i povijest, tako i za jezik, politiku, enigmatiku itd.), i književne poetike što će ih je uvažavao i što će ih uvažavati u svome daljnjem radu (ponajprije barokna, ali i renesansna, antičko-neolatinska, srednjovjekovna te ona usmene i pučke književnosti), i - naposljetku - obilježja derivirana iz repertoara upravo onih književnih i ne samo književnih žanrova, u kojima će i realizirati značajan dio svoga autorskog opusa. Ukratko, Odiljenje - kao takvo - ostavlja dojam svojevrsnoga kreativnog (epi)centra Vitezovićeva opusa, u kojemu kao da se prelamaju baš svi njegovi - dotadašnji i budući - interesi i stvaralački afiniteti, odnosno susreću sva područja njegova profesionalnog bavljenja i značajke većine omiljenih mu žanrovskih rješenja, što će reći da ga - sagledanog na podlozi cjelokupne mu pisane ostavštine - valja motriti kao možda i ključno, središnje ostvarenje našeg autora, koje zaslužuje da mu se prizna čak i status svojevrsne „metonimije Vitezovićevih kreativnih napora“ (Budišćak 2013a: 37).

\section{3. ODILJENJE I ADRIJANSKOGA MORA SIRENA PETRA ZRINSKOG}

Kada bismo načas smetnuli s uma sve dosad detektirane tekstualne paralele između Odiljenja sigetskog i Opside sigecke, ali i čitave Adrijanskoga mora Sirene Petra Zrinskog, kao najuvjerljiviji, a ujedno i najraniji ,materijalni““ dokaz stvaralačkoga nadovezivanja Pavla Rittera Vitezovića na „zrinijadu“ neposrednoga prethodnika i najvećeg literarnog uzora nametnuo bi nam se ni manje ni više nego njegov tiskom objelodanjen prvijenac - latinski historiografski spis Apographum ex Joanne Lucio (1681.), posvećen dokazivanju plemićkoga porijekla obitelji Gušić. Naime, kao što je to još prije više od stotinu godina uočio njegov biograf Vjekoslav Klaić, Vitezović već u posveti izrijekom navodi konkretne izvore iz kojih je crpio podatke za ovu svoju raspravu, otkrivajući tako da se - osim na povijesna djela Ivana Lučića i Jurja Rattkaya te na ugarske kronike i folklorne predaje - u njezinu sastavljanju uvelike oslanjao čak i na (još uvijek) popularnu literarnu viziju osvajanja Sigeta donesenu u Adrijanskoga mora Sireni. ${ }^{980}$ Da njegovo (sadržajno) uvažavanje Petrova ostvarenja nipošto ondje nije bilo zanemarivo potvrdit će i čitave dionice teksta poput, primjerice, one u kojoj se dotiče junačkih podviga što ih je jedan od najistaknutijih članova spomenute porodice Andrija Gušić - učinio pod Sigetom u kasno ljeto 1566., a u sklopu koje čak - kao potkrjepa iznesenim zapažanjima - doslovno bivaju citirani i neki stihovi iz Obside sigecke. Iako, međutim, ovaj detalj neoborivo dokazuje da je najmanje tri godine prije no što će dogotoviti i tiskom objaviti Odiljenje Pavao Ritter već itekako dobro poznavao Petrovu ,zrinijadu“, čini

\footnotetext{
${ }^{980}$ Usp. Klaić 1914: 35-36.
} 
se da je do prvoga njegova „kontakta“ sa Sirenom došlo daleko ranije, odnosno najkasnije već 1677., od kada - vjerojatno - i datira prva (dovršena) verzija njegove rasprave, koja je do svoga objelodanjivanja godinama u rukopisu kolala od ruke do ruke. ${ }^{981}$ Sve to će, drugim riječima, značiti da motivske, formalne i žanrovske spone kojima je povezao svoj hrvatski prvijenac s djelom Petra Zrinskoga nisu ni prvi, a kamoli jedini dokazi Vitezovićeve mladenačke zadivljenosti Sirenom, tim više što se radilo o tih godina još uvijek izrazito popularnom literarnom ostvarenju posvećenom glasovitoj ratnoj epizodi iz domaće povijesti, čija nam tadašnja obljubljenost daje za pravo da se složimo s onim „ritterolozima“ koji su svojedobno iznijeli uvjerenje kako ju je naš autor „upoznao još za školovanja“ (Vončina 1976a: 341). ${ }^{982}$ Dapače, po Klaićevu se mišljenju mladi Vitezović i odvažio propjevati „u hrvatskom jeziku, potaknut jamačno »Adrianskoga mora Sirenom« od grofa Petra Zrinskoga, koja bijaše još god. 1660. u Mlecima izašla“" (Klaić 1914: 22).

Kako bilo, sudeći po tvrdnjama što ih književni naši historici ustrajno iznose u svojim pregledima povijesti hrvatske književnosti još od polovine prošloga stoljeća, o Vitezovićevu višestrukom kreativnom oslanjanju na najvažnije literarno ostvarenje Petra Zrinskog poglavito na epskopjesnički njegov segment - u domaćoj znanosti o književnosti već poodavno nema ni najmanjega spora. ${ }^{983} \mathrm{U}$ očima rečenih povjesnika, dakako, to se Ritterovo oslanjanje na slavnog prethodnika svodi isključivo na niz tekstualnih paralela primijećenih unutar korica Odiljenja sigetskog, na neke od kojih je već 1902. jasno upozorio i Milivoj Šrepel. ${ }^{984}$ Slijedeći njegove zaključke, snažnoj je intertekstualnoj vezi između Sirene i četvrt stoljeća mlađe Ritterove „zrinijade“ u posljednjih pedesetak godina manju ili veću pažnju posvetilo još nekoliko naših eksperata za književna pitanja u rasponu od Đure Novalića i Tome Matića, pa sve do Josipa Bratulića i Pavla Pavličića, ${ }^{985}$ dočim će se u najrecentnijim

\footnotetext{
${ }^{981}$ Opširnije o tome u: Isto: 36-37.

982 O tome koliko je dobro Pavao Vitezović poznavao prethodnikovu „zrinijadu“ možda će nam ponajbolje posvjedočiti činjenica kako je za jednoga svog boravka u Beču, pretresajući ondje (nakon sloma protuhabsburške urote) pohranjene zaplijenjene njegove rukopise i druge dragocjenosti, dospio on pronaći čak i Petrov rukopis prve verzije Obside sigecke, koja sadržava prijevod prvih sedam i dijela osmoga pjevanja. Iako Đuro Novalić koji ga i prvi navodi (usp. Novalić 1967a: 212) - ne precizira odakle je crpio taj podatak, spomenuta prva verzija Obside u posljednjim se desetljećima 17. st., zajedno s drugim Petrovim zaplijenjenim sastavcima, uistinu nalazila u Beču, pri čemu treba znati kako se radilo o prvom njegovu pokušaju prijevoda mađarskoga originala brata mu Nikole, kojega se najvjerojatnije latio neposredno nakon što je Adriai tengernek Syrenaia 1651. ugledala svjetlo dana, no i ubrzo ga - nezadovoljan s dotad prevedenih sedam i pol pjevanja - trajno napustio. Podrobnije o ovome Petrovu rukopisu u: Matić 1957: 8-10. O svojstvima mađarskoga izvornika Nikole Zrinskoga u usporedbi s onima Petrova prijevoda i adaptacije vrlo detaljno u: Angyal 1961: 231-246, Novalić 1967b, Prosperov Novak 1999: 438-458, Bene 2012: 548-550 i Bitskey 2012: 229-250.

983 Usp. po tom pitanju književnopovijesne preglede Mihovila Kombola (Kombol 1961: 280), Krešimira Georgijevića (Georgijević 1969: 134), Franje Šveleca (Švelec 1974: 258) te Slavka Ježića (Ježić 1993: 147-148). ${ }^{984}$ Detaljnije u: Šrepel 1902: 107-110.

985 Podrobnije u: Novalić 1967b: 129, Matić 1968: 104, Bratulić 1990: 183-190 i 2016a: 38 te Pavličić 2007: 253-284.
} 
analizama pojaviti čak i pretpostavka o Vitezovićevu stvaralačkom nasljedovanju podjednako Petrove hrvatske i Nikoline mađarske Sirene. ${ }^{986}$

Većina navedenih literarnih povjesnika i „ritterologa“ slaže se pritom u prosudbi kako su podudarnosti između dviju ,zrinijada“ najuočljivije na sadržajnoj (identični motivi, likovi i situacije), formalnoj (tj. jezičnoj), ali i generičkoj razini, odnosno kako su i u Vitezovićevu tekstu prostora dobili neki od onih istih žanrova za kojima je posegnuo već i Petar Zrinski. I dok je tako - primjerice - već Milivoj Šrepel svojedobno konstatirao da je Odiljenje ne samo ispisano „onom mješavinom jezika, koju nahodimo i u Sireni“ (Šrepel 1902: 104), nego i realizirano posredstvom pojedinih žanrova što ih nalazimo i u prethodnikovu tekstu, Josipu Bratuliću učinilo se da je Ritter svoju „zrinijadu“ podijelio na „dilove“ želeći je još čvršće povezati s Petrovim epom, u kojemu se pjevanja nazivaju upravo - „delovima““.987 Nemale intertekstualne poveznice dviju, u suštini, bitno različitih književnih vizija opsade i pada Sigeta najpreglednije će u svojoj interpretaciji Odiljenja sigetskog predstaviti Pavao Pavličić, koji polazi od pretpostavke kako Vitezoviću pri sastavljanju njegove „zrinijade“ nije ni bila namjera ispisati pravocrtno strukturiranu priču o tijeku kršćansko-muslimanskoga okršaja pod sigetskim zidinama budući da je bio uvjeren kako su potencijalni njegovi čitatelji s kronologijom zbivanja upoznati zahvaljujući drugom (pisano)književnom tekstu, i to ponajprije - dakako - baš Obsidi sigeckoj. ${ }^{988}$

Pouzdajući se u to predznanje svoje publike, Ritter se - precizira Pavličić - upušta u pisanje svoga fabularno razbijenog prikaza sigetske katastrofe, nizom signala pritom dajući do znanja kako je ključ za njegovo puno razumijevanje upravo Petrova „zrinijada“, odnosno kako bi ni manje ni više nego baš njezinim fabularnim momentima valjalo popuniti brojne praznine u događajno raspršenoj i uopće fragmentarnoj ,priči“ što ju donosi Odiljenje. Obsida sigecka, konkretno, u Vitezovićevu se tekstu tako priziva ponajprije prepoznatljivo „zrinskijevskim“ (fiktivnim) likovima, zatim konkretnim situacijama i identičnim epizodama, ali i podudarnim „običnim“ motivima, iz čega bi slijedilo da je trebao on funkcionirati kao svojevrsno proširenje, točnije kao komentar fabule prezentirane u prethodnikovu ostvarenju. Stoga ne čudi da se - računajući na čitateljevo poznavanje događajnoga tijeka iz Obside Ritter u svome djelu odlučuje odreći kronologije, po volji nizati likove (govornike), jedva

\footnotetext{
986 Usp. Bene, Hausner i Ladić 2012: 8.

${ }^{987}$ Usp. Bratulić 2016a: 38 i 2016b: VII. Nužno je, međutim, prisjetiti se kako Obsida sigecka ipak nije naš prvi ep u kojemu umjesto pjevanja nalazimo „delove“ budući da je već 1584. segmente svoje epske pjesme posvećene propasti Sigeta - kojih, uzgred budi rečeno, ima isti broj kao i Vitezović - „dilovima“ prozvao i Barne Karnarutić. Zanimljivo, Nikola Zrinski u svome je mađarskom epskopjesničkom predlošku dijelove teksta naslovio ni manje ni više nego pjevanjima (mađ. enek). Opširnije o ovom pitanju u: Novalić 1967b: 10.

${ }^{988}$ O tome detaljno u: Pavličić 2007: 253-284.
} 
ovlaš doticati pojedinih Petrovih epizoda te neprekidno mijenjati medije komunikacije (realistički, apostrofički, konvencionalni), ni u jednome trenutku ne iskazujući sumnju u to da će publika - na temelju priče koju je usvojila iz ranijih literarnih obrada - biti u stanju razbijenu fabulu povezati u kompaktnu cjelinu. Polazeći od ovih zapažanja, Pavličić zaključuje kako je upravo intertekstualni odnos spram Obside daleko najvažnija karakteristika Ritterove „zrinijade“ budući da - kako se čini - ,,izvan toga odnosa ne može biti ni ispravne recepcije teksta ni njegova adekvatnog vrednovanja“, tim više što u njoj on - u suštini ispisuje ništa drugo no svojevrstan komentar prethodnikova ostvarenja, odnosno „one motive o kojima Zrinski nije stigao mnogo kazati - zato što su ga vezivali zakoni epskog pripovijedanja - (...) u Odiljenju proširuje i razvija“ (Pavličić 2007: 276-277). ${ }^{989}$

Iz vizure Pavla Pavličića, dakle, Odiljenje sigetsko ukazuje se tako kao svojevrstan komentatorski literarni „produžetak“, čija „,neobična struktura (...) upućuje na njegov sekundarni karakter, odnosno na njegovu intertekstualnu vezu s već postojećim djelom: s Obsidom sigeckom P. Zrinskoga“" (Pavličić 2008b: 535). ${ }^{990}$ Pritom se, tvrdi on, najkrupnije posudbe iz ranije „,zrinijade“ mogu zapaziti na sadržajnoj razini Odiljenja, mahom u obliku pojedinih „naslijeđenih“ likova i motivsko-situacijskih podsjetnika na neke od dobro znanih epizoda iz Opside - poput one s neuspjelim banovim pokušajem organiziranja sinova bijega iz grada, potom one s propalim izaslanstvom vojvode Radivoja i pobratima mu Juranića ili, pak, one s osujećenim letom goluba pismonoše što je trebao prenijeti pismo kralju na bečki dvor ali ništa manje uočljive nisu ni one na formalnoj njegovoj razini, razvidne, primjerice, $u$ dijaloškoj pjesmi Gospodična Sofija i oral!, u kojoj zatječemo četverostruko rimovani dvanaesterački katren (na kraju polustiha i stiha), što ga je naš autor gotovo sigurno preuzeo upravo od prethodnika. ${ }^{991}$ Pavličić stoga zaključuje kako „Odiljenje nije primaran književni tekst, nego sekundaran“ budući da i više nego očito „ono svoju egzistenciju - svoje postojanje u svijesti publike - veže uz Obsidu odnosno Sirenu i svoju recepciju zamišlja u vezi s tim djelima“ (Pavličić 2007: 276), a vrlo sličan sud iznosi o njemu i Davor Dukić, za kojega je ono „nešto poput epsko-lirskog, vrlo artificijelnog epiloga starijemu baroknom epu“ (Dukić 2002: 68). Ponajprije zaslugom ovih tumačenja, Odiljenje sigetsko danas se uvriježilo poimati

\footnotetext{
${ }^{989}$ Iz toga će razloga Pavličić i pretpostaviti kako bi „za Odiljenje idealna recepcija bila ona kod koje bi se djelo tiskalo u istom svesku sa Sirenom, pa bi tako čitatelj najprije usvojio glavnu priču Obside, a onda bi se mogao posvetiti onim njezinim fabularnim momentima koji su ga najviše privukli i uzbudili, jer su u Odiljenju upravo oni dodatno osvijetljeni“ (Pavličić 2007: 277).

${ }^{990}$ Ustvrdivši kako Ritter u Odiljenju ne čini zapravo ništa drugo no fabulu Obside „samo komentira i razrađuje pojedine njezine uzbudljive točke“ (Pavličić 2008b: 535), Pavličić na jednome mjestu iznosi i izuzetno zanimljivo (no niti jednim konkretnim dokazom potvrđeno) uvjerenje o tome kako je naš autor najvjerojatnije „Svoje Odiljenje sigetsko od početka zamislio kao dio veće skupine djela posvećenih sigetskoj tematici, gdje bi se - na različite načine i različitim književnim vrstama - taj događaj osvijetlio s različitih strana“" (Isto: 536).

${ }^{991}$ Usp. Kravar 1991: 239.
} 
kao književno ostvarenje koje uspostavlja vrlo snažne i vrlo očigledne intertekstualne poveznice s Petrovom Adrijanskoga mora Sirenom, ali navlastito s njegovim epskim pjesmovnim odsječkom, na koji se ono nadovezuje istodobno „na formalnoj (leksik, versifikacija), tematskoj, motivskoj i ideološkoj razini““ (Blažević 2011: 252-253).

Pojednostavljeno rečeno, osim ,,indikativnim“ tematskim okvirom, Vitezovićevo Odiljenje priključak na tradiciju ili književni kontekst „zrinijada“ - kao pretežno epskopjesničkih obrada opsade i pada Sigeta - ostvaruje gotovo isključivo posredstvom brojnih tekstualnih obilježja izravno preuzetih iz Sirene Petra Zrinskoga, odnosno evociranih po uzoru na pojedina u njoj zastupljena specifična rješenja i strategije. Da se, konkretno, pri sastavljanju Odiljenja naš autor uvelike trudio kročiti stazama što ih je prijevodom i adaptacijom bratove mađarske ,zrinijade“ utabao Petar Zrinski, možda će i najjasnije - prije svega - dati do znanja pojedine njegove formalne posebnosti, poglavito opredjeljenje za naddijalektalnu inačicu hrvatskoga jezika, kojom je ono u cijelosti ispjevano. Riječ je, podsjetimo, o onom istom trodijalektalnom ili interdijalektalnom tipu hrvatskoga jezika, kojim su se u 17. stoljeću služili pisci ozaljskoga ili zrinsko-frankopanskoga književnojezičnog kruga, a među njima - dakako - i sam Petar, čiji interdijalekt u Sireni nešto više ipak naginje kajkavštini, baš kao što i onaj Vitezovićev u Odiljenju vidno preteže na „stranu“ čakavskoga idioma. Bez obzira na te sitne razlike u količinskoj zastupljenosti elemenata iz pojedinih dijalekata, za Vitezovića se može reći kako ga je na prihvaćanje koncepta mješovitoga hrvatskog jezika ponajprije potaknula mogućnost osjetnoga širenja kruga potencijalne publike, koju je pri prevođenju Nikoline „zrinijade“ na umu jamačno imao već i njegov prethodnik, iako je Sirenu primarno namijenio čitateljstvu s područja Vojne krajine na kojemu je upravo i dolazilo do miješanja elemenata iz svih triju hrvatskih narječja. ${ }^{992}$ Takvu recepcijsku orijentiranost svoga ostvarenja jasno je on nagovijestio i u proznoj posveti Sirene, u kojoj se izrijekom obraća „vse hrvacke i primorske krajine hrabrenim vitezovom“, sugerirajući kako bi primarni njegovi čitatelji trebali biti ni manje ni više nego upravo ti isti „hrvacke i primorske krajine branitelji i čuvari“, za koje ga i sastavio „,ne kako dijak, nego kako krajinski (...) tovariš“ (Zrinski 1957: 19). ${ }^{993}$

Kada govorimo o Adrijanskoga mora Sireni, nipošto ne bismo smjeli smetnuti s uma kako je interdijalekt u Petrovu slučaju predstavljao zapravo „tek“ produžetak stvarne jezične

\footnotetext{
992 Naime, kako pojašnjava Josip Vončina, prisutnost „sva tri narječja na relativno malom prostoru Vojne krajine učinila je da je to područje predstavljalo čitavo stanje našega jezika u malom. Onaj tko se obreo na tom krajiškom tlu, dolazio je u dodir s njegovim cjelokupnim stanovništvom i želio mu biti razumljiv - morao je poznavati sva tri narječja i njima se služiti. Zato se još mnogo prije Petra Zrinskoga formirao ondje saobraćajni jezik koji je sadržavao elemente svih triju dijalekata i kojem se trag sačuvao u listinama“ (Vončina 1968: 198). ${ }^{993}$ Usp. minucioznu analizu Petrove posvete Adrijanskoga mora Sirene u: Pavličić 2006: 177-194.
} 
prakse obitelji Zrinski, članovi koje su se i u privatnoj (obiteljskoj), ali velikim dijelom i u javnoj svojoj komunikaciji također služili identičnim tipom hrvatskoga jezika, ${ }^{994}$ što se može reći i za druge autore ozaljskoga kruga (osobito za Frana Krstu Frankopana), ${ }^{995}$ pa i - donekle - za samoga Vitezovića, koji je relativno blisku jezičnu varijantu imao prilike usvojiti u svojoj rodnoj, senjskoj sredini. $\mathrm{K}$ tomu, posezanje za ovom dijalektalno mješovitom jezičnom varijantom u književne svrhe ujedno je podrazumijevalo i pridruživanje Sirene nizu ostvarenja ispisanih istim ili vrlo sličnim jezičnim tipom, kojemu su - među ostalim - pripadali i Petru itekako dobro poznati nabožni tekstovi istarskoga pisca Franje Glavinića (Četiri poslidnja čovika, Cvit svetih) te ostvarenja Ivana Belostenca (Gazophylacium, zbirke propovijedi), s kojim je, štoviše, čak i prijateljevao. ${ }^{996}$ Uostalom, ne treba zaboraviti da su dijalektalnim mješavinama svoja ostvarenja realizirali i mnogi drugi Petrovi suvremenici, počevši od Jurja Habdelića, preko Jurja Rattkaya (koji elemente različitih narječja spreže u svome prevedenom životopisu Kriposti Ferdinanda II. iz 1640.), pa sve do Baltazara Milovca (u čijim molitvenicima Dvojdušni kinč i Dušni vrt dominantno kajkavsko narječje biva prožeto brojnim štokavskim elementima) i Matijaša Magdalenića, čiji je Zvončac samo jedan u nizu literarnih dokaza već poodavno primijećene činjenice kako se „pisci sjeverne Hrvatske u 17. stoljeću opredjeljuju (...) za stariji (čakavsko-kajkavsko-staroštokavski) morfološki tip kakav je, uostalom, vladao kao pretežan u starijoj hrvatskoj književnosti ne samo od renesanse nego i od mnogo dublje prošlosti, sve od prvih početaka pismenosti i književnosti“ (Isto: 230). Na kraju krajeva, s uma ne treba smetnuti ni činjenicu da su naši stručnjaci za jezična pitanja još prije nekoliko desetljeća ispravno zapazili kako se u okvirima hrvatske književnosti „od kraja 15. do početka 19. stoljeća po svoj prilici ne može naći pisac koji se bar u ponečemu nije iznevjerio svojemu zavičajnom govoru, odnosno narječju kojem taj govor pripada“ (Vončina 1988: 187), što ni slučaj ,zrinijade“ Petra Zrinskoga, a onda ni one Pavla Vitezovića ne čini nimalo jedinstvenim, a kamoli izdvojenim.

Usredotočimo li se, nadalje, na sadržajno-ideološku dimenziju „zrinijade“ Vitezovićeva najvećeg književnog uzora, pažljivijim njezinim čitanjem na podlozi specifične društveno-političke situacije druge polovine 17. st. uvjerit ćemo se kako u njezinu slučaju nije riječ o tek ,„pukom“ pjesničkom zborniku namijenjenom (isključivo) Petrovim „krajinskim“ sudruzima i suborcima, u kojemu je povlašteno mjesto imao povijesni ep o padu Sigeta, nego

\footnotetext{
994 Tim i takvim su jezičnim tipom, naime, Zrinski i njihovi suradnici pisali i darovnice, ugovore, zadužnice i druge isprave, ali i trgovali, pa čak i govorili na sudu. Detaljnije u: Vončina 1973: 203-237 i 1977: 196-200.

995 Usp. Pajur 2014: 66. O jeziku autora ozaljskoga (zrinsko-frankopanskoga) književnojezičnog kruga znatno detaljnije u: Vončina 1968: 195-205, 1973: 203-237, 1977: 191-204, 1988: 187-195; Moguš 2009: 91-99; Bratulić 2011: 262-271; Jembrih 2011: 109-117; Pajur 2014: 55-68.

${ }^{996}$ Opširnije u: Vončina 1968: 195-205.
} 
ujedno i o „punokrvnomu“ političkom programu, koji će poslužiti kao ideološki otponac skorim protuhabsburškim urotničkim aktivnostima braće Zrinski i njihovih domaćih i ugarskih pobornika i suučesnika. U takvom su, naime, svjetlu Adrijanskoga mora Sirenu relativno nedavno prve promotrile Zrinka Blažević i Suzana Coha, uvjerljivo pritom dokazavši kako se i ona, ali i mađarski njezin predložak što ga je ispjevao Nikola Zrinski, u isti mah nameću kao „nositelji“ identičnoga „poetskoga političko-mobilizacijskog programa“ (Blažević i Coha 2008: 93), koji je - rabeći ambivalencijom obilježene elemente tzv. „političkoga spektakla“9997 u svrhu legitimiranja (aktualne) pozicije i (povijesne) važnosti obitelji Zrinski - hrvatsku i mađarsku aristokraciju trebao potaknuti na pobunu protiv centralizirajuće politike kralja te ponovno uspostavljanje staleškoga poretka. ${ }^{998}$

U tom smislu, baš kao što se epski odsječak Petrove Sirene ideološki tako bazirao na odrednicama antihabsburškoga programa, kojeg je ondje valjalo prezentirati ponajprije domaćem plemstvu razočaranom politikom Dvora u Beču, tako se i za Nikolinu Obsidio Sygethianu (tj. Szigeti veszedelem) može kazati da je nudila ,program političkog djelovanja i uzor etičkog ponašanja za nastavak borbe protiv Turaka, u znaku imitacije Krista“ (Bene 2012: 549), ali u ovom slučaju upućen potencijalnim suučesnicima iz kruga ugarskih velikaša. Iako je, dakle, ,zrinijada“ Nikole Zrinskoga bila (ne samo jezično) prilagođena očekivanjima mađarske publike, a ona Petrova - koja nije „tek“ puki prijevod, već parafraza bratova mađarskog predloška - očekivanjima hrvatskih čitatelja, s poetičko-generičkoga aspekta riječ je o posve identičnim tekstovima koji se mogu identificirati kao ,žanrovski i poetički hibridi nastali fuzijom starougarske kronike u stihovima (Tinódi, Balassa, Töke, Szabadkay), vernakularne elitne i pučke epske tradicije (Karnarutić, Budina), te mediteranske barokne poezije i prethodne renesansne tradicije (Tasso, Marino, Zoranić, Marulić)“ (Blažević 2008c: 330-331). ${ }^{999}$ Razlog ove njihove izrazite generičke slojevitosti pritom ne treba tražiti ni u čemu drugome no u silnoj želji obojice autora da privuku što raznolikiju publiku, čime ona ujedno postaje i najpouzdanijim signalom propagandne svrhe oba djela, baš kao što, uostalom, i žanrovska preklapanja u Odiljenju sigetskom - na koja se Vitezović vrlo vjerojatno odlučio potaknut, između ostalog, (i) primjerom svoga literarnog uzora - upućuju na njegov (uvelike) pučko-didaktički, pa i donekle također propagandni karakter. Štoviše, uzme li se u obzir

\footnotetext{
${ }^{997}$ Autorice ovdje koriste pojam američkoga politologa Murraya Edelmana, koji je njime označio ambivalentnu medijski (jezično) posredovanu predstavu uslijed koje se - radi propagandističkih i/ili mobilizacijskih ciljeva oblikuje konkretan individualni ili društveni identitet. Podrobnije u: Blažević i Coha 2008: 91, bilješka 1.

998 Znatno opširnije o ,zrinijadama“ braće Zrinski kao političkim programima buduće urote u: Blažević i Coha 2008: 91-104.

${ }^{999}$ Podrobnije o (najvjerojatnijim) književnim i izvanknjiževnim uzorima, ponajprije onima Nikole Zrinskoga, i u: Bitskey 2012: 230-232.
} 
cjelokupan njezin tekst, Adrijanskoga mora Sirena tu će svoju generičku hibridnost svojstvenu onodobnim propagandnim i ne samo propagandnim literarnim ostvarenjima dodatno potvrditi i ciklusom lirskih pjesama što okružuju centralni ep o sigetskoj katastrofi, a čija se svrha u kontekstu samoga zbornika - baš kao što je to bio slučaj i s, primjerice, bukoličkom poezijom u habsburškoj apsolutističkoj pamfletistici, odnosno panegiričkoj produkciji - ponajviše svodila na svojevrsno književno prikrivanje, kadšto i vrlo suptilno travestiranje „ključnih“ ideoloških poruka. ${ }^{1000}$ Prema Zrinki Blažević i Suzani Cohi, to bi se ponajprije trebalo odnositi na „funkciju uvodnih pastirskih epigrama o Violi i »zviraru« koji služe kao kontrastivan uvod u Opsidu, odnosno antički stiliziranih elegija (Plač Arijadne i Žalost Orfeuša za Euridice) koji prethode herojskim epitafima“ (Blažević i Coha 2008: 99), prisustvu kojih valja zahvaliti što Sirena - kroz, dakako, supostavljanje neideoloških lirskih pjesama i snažnim ideološkim silnicama „nabijene“ središnje epske pjesme - uspijeva postići ambivalenciju svojstvenu upravo tekstovima koji funkcioniraju kao tzv. ,politički spektakli““.

Protuhabsburškim političkim programom protkana Adrijanskoga mora Sirena, točnije Obsida sigecka Petra Zrinskog po pitanju svoje ideologičnosti i s njom povezanih izvanknjiževnih funkcija što ih je trebala obnašati nipošto se ne ispostavlja kao usamljen primjer u okvirima domaće sedamnaestostoljetne epskopjesničke produkcije. Naprotiv, snažna ideološko-politička pozadina i težnja ispunjavanju konkretnih izvanknjiževnih ciljeva karakterizirale su i veliku većinu drugih naših baroknih epova, ${ }^{1001}$ počevši od - primjerice izraženom polonofilijom i referiranjima na onodobnu dubrovačku politiku napučena Gundulićeva Osmana, pa sve do baroknoslavističkim dionicama premrežene Povijesti vanđelske Jerolima Kavanjina. ${ }^{1002}$ Dapače, kada govorimo o (južno)hrvatskim baroknim epovima posebno omiljenoj ideologiji slavizma, inzistiranje naših „sečentističkih“ epika na njezinim idejama dovelo je do toga da su ,nakon Osmana, Trublje slovinske i nakon Kanavelića sveslavenske (...) teme predstavljale visoko konvencionalan sadržaj epike, a pritom su fungirale i kao signal roda“ (Kravar 1975: 13), što dovoljno govori o važnosti koju su ideološke silnice imale u kontekstu domaće „epike“ 17. stoljeća. Forsiranje ideološke „nadgradnje“ opjevanih sadržaja, međutim, ni u kojem se slučaju ne bi smjelo držati svojstvenim isključivo našemu baroknom epskopjesničkom stvaralaštvu budući da je već „od humanista i Marulića ep (...) imao (...) naglašene idejne i ideološke zadaće, te je opjevavao prvenstveno one teme koje su bile relevantne za život zajednice, za njihovu kolektivnu

\footnotetext{
${ }^{1000}$ Usp. o tome u: Blažević i Coha 2008: 99-100.

${ }^{1001}$ Posebno detaljno o tome npr. u: Fališevac 2003.

1002 Usp. Kravar 1975: 12-13.
} 
društvenu svijest“" (Fališevac 1997: 169), ${ }^{1003}$ a k tome je još i redovito obavljao neke bitne izvanknjiževne funkcije, ponajvećma one političko-povijesne te religiozno-poučne.

Izdvajanje snažnoga ideološko-političkog naboja i propagandnog karaktera Opside sigecke kao njezinih možda i „,najbaroknijih“ epskopjesničkih značajki ujedno nam otvara i mogućnost da u pravom svjetlu napokon promotrimo i ,zrinijadu“ Petrova izravnog nasljednika, u kojoj će tako već i sam izostanak izrazite političke izvanknjiževne funkcije ukazivati na odabir posve drugačijega generičkog okvira. Konkretno, Vitezovićeva zamisao da Odiljenje sigetsko - usprkos mnogim u nj utkanim prepoznatljivo epskopjesničkim karakteristikama - žanrovski ne realizira kao („,punokrvni“) barokni povijesni ep, već kao osebujni pjesnički hibrid nipošto nije bila potaknuta eventualnom njegovom generičkom nedoraslošću, odnosno možebitnom neupućenošću ili poluupućenošću u žanrovski repertoar povijesne barokne epske pjesme ${ }^{1004}$ nego - baš naprotiv - svjesnim i ciljanim zaziranjem od žanra u kojemu je Petar Zrinski ispjevao, točnije prepjevao i dopjevao svoju Opsidu. Tom Ritterovu hotimičnom distanciranju od povijesnog epa kao najeksploatiranijega generičkog rješenja u (još uvijek) ne tako bogatoj dotadašnjoj tradiciji ,zrinijada“ pritom je bez ikakve sumnje najviše „kumovalo“ naglašeno antihabsburško ideološko usmjerenje Petrove „epske“ vizije turske opsade i zauzeća Sigeta, koje je ponajprije zahvaljujući njoj i njezinu mađarskom Nikolinu predlošku u okvirima naše kontinentalne sedamnaestostoljetne književnosti junački ep kao žanr u očima tadašnje publike tako naprosto sam od sebe počeo pretpostavljati. S obzirom na to da se u vrijeme u kojemu naš autor piše i objavljuje Odiljenje protuhabsburške političke aspiracije - zahvaljujući ne tako davnom neslavnom slomu urote hrvatskih i mađarskih magnata - na našim prostorima više nisu očitovale na način kao prije 1671., ali i da ta i takva ideološka „nadgradnja“ naprosto nije odgovarala njegovu literarnom pristupu sigetskoj katastrofi, a ni izvanknjiževnim zadaćama koje je svojim ostvarenjem nakanio izvršiti, Pavao Ritter ovu je „tipično“ epskopjesničku temu odlučio obratiti na samo rubno „epski“ način, raspršujući je na čitavu lepezu književnih i ne samo književnih žanrova, koji nisu pretpostavljali ,aktiviranje“ sjevernohrvatskom baroknom povijesnom epu neizbježne ideološke, dakle protuhabsburške komponente. Drugim riječima, iako je zbog ,epskosti“ teme pada Sigeta Vitezović morao ostati literarno tijesno vezan uz Petrovu Sirenu, točnije Obsidu

\footnotetext{
1003 Naš barokni ep po svojoj ideologičnosti nije, međutim, samo nastavak epskopjesničke tradicije hrvatske, nego i svjetske književnosti, u kojoj je - kako je to u svojoj studiji uvjerljivo dokazao David Quint - povijesni ep već od Vergilija nadalje redovito funkcionirao kao naglašeno politički žanr s jasno definiranom ideološkom podlogom i ciljevima, odnosno najčešće s prilično „prozirnim“ političkim aluzijama (usp. Quint 1993: 3-18).

${ }^{1004} \mathrm{Ili}$, kako je relativno nedavno ustvrdio Pavao Pavličić, strukturna „neobičnost Odiljenja ne proizlazi otuda što bi Vitezović želio napisati konvencionalni ep pa to ne bi znao, nego otuda što on želi napisati nešto drugo, te to drugo i piše“" (Pavličić 2007: 254).
} 
sigecku - u kojoj je, na kraju krajeva, kronološki iznijeta priča o tijeku turske opsade i pada grada te njezinim sudionicima, koja će u njegovu tekstu (u takvu obliku) izostati - iz nje ipak nije bio primoran apsorbirati i ondje prezentiranu antihabsburšku ideologiju jer se, pojednostavljeno rečeno, nije ni latio pisanja generički identično ostvarenoga teksta, koji bi iziskivao evociranje upravo tih (ili njima srodnih) ideoloških tekstualnih uporišta.

Naprotiv, osim što je u Odiljenju tako izbjegao epskopjesnički žanr - no ne, dakako, i neka njemu svojstvena generička obilježja - ,inficiran“ (nepoželjnim) ideološkim silnicama, Pavao je Vitezović čitavim sadržajnim aspektom svoje „zrinijade“ ujedno težio ostaviti dojam maksimalne političke ,korektnosti“, odnosno usklađenosti s tada prevladavajućom politikom Kraljevstva Hrvatske, a time i čitave Habsburške Monarhije, i to kako zbog toga jer nije želio politički kompromitirati svoje djelo posvećeno istoj onoj temi kao i ideološki sporno ostvarenje njegova prethodnika i uzora, tako i stoga što nije htio kompromitirati svoju buduću karijeru, za koju je bio čvrsto uvjeren da će neposredno biti vezana upravo uz habsburški Dvor u Beču. ${ }^{1005} \mathrm{Ne}$ namjeravajući se politički (ideološki) suprotstavljati kralju Leopoldu i drugim vladajućim habsburškim strukturama, a ipak silno želeći opjevati junaštva sigetskih branitelja ne bi li - između ostalog - na taj način pomogao (o)čuvanju sjećanja na važnu epizodu iz hrvatske povijesti, povijesno važan lokalitet i herojski podvig nedvojbeno najslavnijega pripadnika (nedavnim urotničkim aktivnostima prilično osramoćene) obitelji Zrinski, Vitezović nije imao drugoga izbora no odustati od pisanja povijesne epske pjesme, odnosno epskopjesničke ,zrinijade“ - dakle žanra koji je nakon politikantski nastrojene Obside kotirao kao ideološki „onečišćen“ i zbog svoje političke nekorektnosti ne odveć poželjan u kontekstu tadašnje društvenopovijesne situacije - te se okrenuti drugim žanrovskim rješenjima koja su mogla podnijeti taj „izvorno“ epskopjesnički sadržajni

${ }^{1005}$ Kako je, naime, svojedobno pretpostavio Davor Dukić, „ovim je djelom (Odiljenjem sigetskim, op. V. B.) Vitezović nastojao sebe legitimirati kao književnika od zanata“, a sve s ciljem „da zadobije mjesto dvorskog pisca“ (Dukić 2002: 70), što će - dakako - reći da bi njegove šanse da u tome i uspije bitno umanjio „Zrinskijevski“ (epskopjesnički) tekst posvećen padu Sigeta s političko-ideološkom pozadinom uperenom protiv samoga kralja Leopolda. Premda je takve Ritterove nakane u svome prikazu povijesti hrvatske književnosti donekle nagovijestio već i Ivo Frangeš, koji tvrdi kako se u Odiljenju, ,jedva desetak godina poslije uništenja obitelji Zrinskih, ponovno preuzima sigetski mit, s potajnom željom da se literarnom lojalnošću prikrije Petrova politička nelojalnost“ (Frangeš 1987: 106), ovoj predodžbi o njegovu hrvatskom prvijencu kao možebitnom djelu kojim se naš autor želio potvrditi kao profesionalni pisac ne bi li stekao mjesto na bečkomu Dvoru nužno je ipak prigovoriti činjenicom kako je riječ o ostvarenju ispjevanom narodnim, dakle ne (latinskim) jezikom kojim bi u očima „dvorske“ publike zaista bio u stanju potvrditi svoju književnu (stihotvoračku) umješnost te tako „Zaraditi“ mjesto među „odabranim“, kralju omiljelim pjesnicima. Da je Ritter, međutim, uistinu pretendirao na mjesto dvorskoga pjesnika i više je nego dobro poznata činjenica iz njegove biografije, no svi njegovi književni sastavci kojima je želio zadiviti kralja i njegove suradnike te steći njihovu naklonost redom su bili ispisani na latinskom jeziku. Podsjetimo, prvo takvo djelo kojim je naš autor pokušao pokazati i dokazati svoju okretnost u sastavljanju stihova ne bi li dospio na Dvor bila je latinska pohvalnica što ju je ispjevao u povodu zaključivanja sabora u Šopronu koncem 1681. i u primjerak namijenjen kralju Leopoldu koje je priložio (na koncu ipak neuslišanu) molbu da ga imenuje za „ovjenčanoga pjesnika“ te uvrsti u krug svojih dvorskih pjesnika. $\mathrm{O}$ tome detaljnije u: Klaić 1914: 44. 
„materijal““. To jasno generičko distanciranje od baroknoga povijesnog epa o padu Sigeta Ritteru se očito moralo nametnuti kao daleko najvažniji problem pri sastavljanju Odiljenja, poglavito zato što mu se valjalo domisliti načina na koji će temu, likove, događaje, motive te neke formalne strategije izravno preuzete iz Obside sigecke ukomponirati u žanrovski posve drugačiji okvir „očišćen“ od suvišnoga ideološkog „balasta“, a da se konačan „produkt“ tim svojim prepoznatljivo epskopjesničkim značajkama u očima pojedinih čitatelja ipak uzmogne potvrditi i kao „punokrvno epsko“ ili makar kao (junačkom) epu žanrovski najbliskije djelo. Pritom je on bio i više nego svjestan činjenice da će taj svoj odrješiti literarni zaokret od političkih pretenzija kakve je moglo sugerirati njegovo opredjeljenje za žanr baroknoga povijesnog epa o padu Sigeta jednako uvjerljivo morati prezentirati ne samo sjevernohrvatskoj publici, dakle onoj što je dolazila s prostora Kraljevstva Hrvatske i Vojne krajine, nego i južnohrvatskom čitateljstvu, koje je - kako najbolje posvjedočuje primjer pohvalnice Trublja slovinska dubrovačkoga pjesnika Vladislava Menčetića ${ }^{1006}$ - također bilo dobro upoznato sa sadržajem Petrove Sirene, navlastito Obside sigecke, pa onda i upućeno u pojedinosti (,ozloglašenoga“) protuhabsburškog programa što ga je ona propagirala te tako ideološki presudno obilježila i žanr (sjevernohrvatske) epskopjesničke ,zrinijade“.

Ni trena, dakle, ne ispuštajući iz vida tadašnje kompleksne društvenopolitičke prilike, Vitezović Odiljenje sigetsko realizira kao tek u naznakama epskopjesnički tekst, skrojen od generički kojekako realiziranih dionica napučenih obilježjima čak i onih književnih i neknjiževnih žanrova, za kojima je u Obsidi sigeckoj, ali i cjelokupnoj Adrijanskoga mora Sireni bio posezao već i Petar Zrinski. Od mnoštva tih „Petrovih“ žanrova, međutim, Ritter pomno odabire samo one lišene ,spornoga“ ideološkog naboja, točnije one koji $u$ prethodnikovu ostvarenju nisu bili ,natopljeni“ otvoreno protuhabsburškim zamislima, a potom ih u toj svojoj viziji sigetske katastrofe sve zajedno obilato premrežuje nizom drugih, $\mathrm{u}$ (domaćem) baroku posebno učestalih i poželjnih ideoloških silnica, u potpunosti usklađenih s onodobnim dominantnim političkim usmjerenjem. Radi se, dakako, o ideologemima ili tekstualnim signalima prihvaćanja nekolicine tada naročito proširenih i utjecajnih ideološkosvjetonazorskih tendencija, počevši - naravno - od protureformacije, odnosno kršćanskog pravovjerja, koje je predstavljalo religijski temelj Habsburške Monarhije, preko baroknoga

\footnotetext{
1006 Vladislav Menčetić u svojoj je Trublji slovinskoj tako Petra Zrinskoga tako ne samo potvrdio kao legitimnoga baštinika imena i vrline slavnoga mu pretka (pradjeda), nego mu i otvoreno izrazio želju za uspjehom političko-mobilizacijskoga programa što ga je iznio u Adrijanskoga mora Sireni, na što - uostalom - i ukazuju njegovi stihovi: „Vidim bojne sred potjere, / Gdi stijeg carski po tleh pada, / Gdi se drugi s križem stere / Vrh bijeloga Carigrada. / Cesarovijem tu pod krilom / Ban će čestit stolovati, / Ban imenom, a kralj dilom / Podložni će puk vladati“ (cit. prema: Blažević i Coha 2008: 100). Detaljnije o Menčetićevoj pohvalničkoj afirmaciji Petrovih političkih aspiracija ekspliciranih u Sireni u: Isto: 100.
} 
slavizma kao ideologije koja se nametnula kao ideološka poveznica slavenskih zemalja obuhvaćenih habsburškim granicama, pa sve do neostoicističke idejne podloge kao osnovice sedamnaestostoljetne politike i uopće svjetonazora, inzistiranjem na kojoj Vitezović kao da je težio naglasiti odanost i lojalnost kralju, a time se i snažnije distancirati od Petra i njegovih urotničkih aspiracija kojima vrvi Obsida sigecka. Pritom treba imati na umu kako Odiljenje sigetsko nipošto ne strši kao jedino mjesto unutar Ritterova opusa u kojemu su pobrojani ideološki kompleksi odigrali važn(ij)u ulogu budući da je i za protureformacijskim, i za neostoicističkim, a navlastito za baroknoslavističkim idejnim ishodištima naš autor redovito posezao kako već u ostvarenjima nastalima uoči, tako i u onima što će ih napisati u godinama nakon objelodanjivanja svoga vernakularnog prvijenca.

Generički iznimno zamršena slika Odiljenja stoga bi vrlo lako mogla navesti na pomisao da je prizivanje raznoraznih žanrova oplemenjenih elementima tada utjecajnih ideologija bilo ništa drugo no Vitezovićeva strategija razbijanja ili, bolje rečeno, rastakanja (zamišljenoga) politiziranog epskopjesničkog žanrovskog okvira kojega je - sama od sebe nagovještavala „tipično“ epska tematsko-motivska orijentacija teksta. S obzirom na to da se poradi odabrane teme - pred Vitezovića na samom početku njegova rada na Odiljenju doista morao postavljati imperativ epskopjesničkoga generičkog oblikovanja teksta, takva pretpostavka možda se i ne bi trebala otpisati kao sasvim netočna, tim više što je svojim tematskim ishodištem te pojedinim motivskim, formalnim i drugim osobitostima njegova „,zrinijada“ snažno bila i ostala „prikopčana“ za ideološki „spornu“ Petrovu Obsidu, što bi sugeriralo da se prizivanjem mnogobrojnih (,apolitičnih“ i uopće ideološki ,ispravnih“) žanrova u kojima je težište stavljeno na emotivni, a ne narativni aspekt teme ona težila otrgnuti iz generički pogrešnoga i politički nekorektnog književnog „,zagrljaja“ ne bi li se istom približila drugim prilično bliskim onodobnim hibridnim žanrovskim srodnicima poput (pučkih) baroknih zbornika, izbora iz većih pjesničkih djela, pa čak i drugih ostvarenja zborničkoga tipa poput Biblije. Upravo Biblija je - kao jedan od žanrovski najhibridnijih tekstova u književnoj povijesti uopće - u 17. stoljeću, kako je dobro poznato, uživala status jednog od najvažnijih, ako ne i daleko najvažnijega, a svakako najutjecajnijega pisanog ostvarenja, iz čega bi slijedilo da je generičkim preklapanjima i pretapanjima što ih prakticira u Odiljenju, a koja su pojedine recipijente lako mogla podsjetiti na žanrovsku šarolikost biblijskih knjiga, Ritter pokušao ne samo postići odmak od žanra epskopjesničke „,zrinijade“ u cijelosti „,inficirane“ ideološko-političkim konotacijama, nego i osigurati kakav-takav predložak za njegovu recepciju, točnije za generičko mu identificiranje. 
Pa, ipak, usprkos silnim naporima da svoj hrvatski književni prvijenac do krajnosti žanrovski hibridizira $\mathrm{i}$ fragmentira te na taj način - ponajprije u očima učenije i literarno „potkovanije“ publike - istakne njegovu (prividnu) „,neepskost“, Pavlu Vitezoviću nije pošlo za rukom - jer mu, uostalom, to i nije bila namjera - u potpunosti raskrstiti s karakterističnim epskopjesničkim obilježjima, slijedom čega Odiljenje nije ostalo lišeno ni „tipično“ epskih junaka (kazivača), ni prepoznatljivo epskih motiva i situacija, ni naznaka epske naracije, a ni specifično epske formalne, točnije metričke podloge u vidu dvostruko rimovanoga dvanaesterca, čije obje varijante, podsjetimo, uvjerljivo dominiraju među mnoštvom u njemu zastupljenih stihovnih i stihovno-strofičkih oblika. I premda se u njihovu slučaju radi o elementima iz repertoara (barokne) epske pjesme redom preuzetima iz Obside sigecke, Ritter se intertekstualne spone između Petrove i svoje ,zrinijade“ paralelno nije ustručavao ojačati i evociranjem „neepskih“ generičkih rješenja, odnosno uključivanjem pojedinačnih obilježja ili cjelovitih primjeraka ni manje ni više nego nekih od „pobočnih“ (,manjih“) žanrova što ih je njegov neposredni prethodnik ili utkao u sam tekst središnjega epa o turskom zauzeću Sigeta (poslanica, ratni govor, zakletva i dr.) ili, pak, razasuo duž ciklusa lirskih pjesama koje okružuju Obsidu (versus echoici, epitaf ${ }^{1007}$ itd.), što su - donekle - bili zapazili već i pojedini raniji književni povjesnici, kojima se također učinilo kako neke pjesme donesene u Odiljenju „s tehničke strane (pjesma s jekom, nadgrobnice) podsjećaju na pjesme, koje su dodane epu u »Adrianskoga mora sireni«“ (Ježić 1993: 148). Zahvaljujući tomu višestrukom izravnom generičkom nadovezivanju na četvrt stoljeća stariju njegovu ,zrinijadu“, Petra se Zrinskog s punim pravom može izdvojiti kao Ritterova uvjerljivo najvećeg žanrovskog uzora, pri čemu treba biti svjestan kako je tijekom sastavljanja Odiljenja ugledanje našega autora u znatno većoj mjeri išlo u pravcu čitave njegove Sirene negoli „tek“ epskopjesničkoga joj odsječka, iz kojega - pored nekih „ubačenih“ žanrova i njima svojstvenih značajki - spomenute „epske“ karakteristike nipošto ne crpi s nakanom da i sam ispjeva (,punokrvni“) ep o sigetskoj katastrofi, a ponajmanje da to učini izravno se nadovezujući na politički u tolikoj mjeri kompromitiran tekst poput Obside sigecke, odnosno Adrijanskoga mora Sirene.

Generičko Vitezovićevo intertekstualno naslanjanje na Obsidu sigecku neće se, međutim, zasnivati i na posve identičnom načinu uporabe iz njega baštinjenih žanrovskih rješenja, pa dok tako u Petrovu djelu ti „,neepski“ žanrovi funkcioniraju ili kao dodatak središnjem epu ili, pak, kao dio njegova lirskopjesničkog „okvira“, dotle u Odiljenju oni

\footnotetext{
1007 Što se epitafa ili nadgrobnica tiče, bit će da ih je Petar (što će reći i brat mu Nikola u svome mađarskom predlošku) u Sirenu uključio iz gotovo istih razloga radi kojih će to kasnije učiniti i Vitezović, zbog čega se kako je to svojedobno zapazio Đuro Novalić - već i u njima tako prilično jasno očituje „,nastojanje da se sažeto opišu i naknadno obrade pojedini likovi iz epa“" (Novalić 1967b: 55).
} 
stječu posve ravnopravan status, promećući se u jednakovrijednu komponentu žanrovski heterogene strukture sadržajno posvećene osvjetljavanju bitke za Siget i njezinih posljedica iz različitih, krajnje subjektivnih kutova gledanja. S obzirom na to, moglo bi se reći kako u Ritterovoj „zrinijadi“ dolazi do svojevrsnoga izvrtanja žanrovske „hijerarhije“ što ju je uspostavio Petar Zrinski, zbog čega najveća važnost biva pridana upravo onim generičkim rješenjima koja su u Sireni posjedovala tek sekundarni značaj, odnosno služila kao puka „potpora“ centralnomu epskopjesničkom segmentu zbornika, dočim su obilježja koja je lako prepoznati kao „tipična“ za žanr (baroknoga) povijesnog epa u njoj pretežno koncentrirana na tek nekoliko mjesta u tekstu, gdje većinom funkcioniraju kao „nadopuna“ generički kojekako ostvarenih dionica, a ne kao možebitne sastavnice ,punokrvnoga“ epskopjesničkog sastavka. Pođemo li, dakle, od činjenice da - u žanrovskom, ali i ne samo žanrovskom pogledu - u njemu na važnosti tako dobiva ono što je u Petrovu slučaju uvelike (o)stajalo po strani, Odiljenje sigetsko nadat će nam se (i) kao očit produkt Vitezovićeve potrebe da „reagira“ na ostvarenje svoga prethodnika, odnosno da se pozabavi ni manje ni više nego baš onim sadržajnim aspektima i detaljima što ih je Petar u Obsidi ili u potpunosti preskočio, ili uvelike marginalizirao, ili, pak, jedva ovlaš dotaknuo, ${ }^{1008}$ a koji su - po njegovu sudu - itekako važni jer priču o herojskoj obrani i konačnom padu Sigeta obogaćuju nekim posve novim, dosad nepravedno zapostavljenim dimenzijama.

Obilato Vitezovićevo eksploatiranje upravo onih generičkih rješenja zastupljenih (i) u Adrijanskoga mora Sireni ponajvećma je, može se pretpostaviti, potaknula činjenica da se izuzev, dakako, ideološki ,inficiranoga“ povijesnog epa - glavninom radi o žanrovima posve lišenima političkih konotacija, odnosno upotrijebljenima na način da ne pojačavaju ionako dovoljno izrazit politički naboj zbornika u cijelosti, što će reći posve prikladnima za evociranje u okvirima teksta koji se ciljano želio potvrditi kao ideološki „,ispravno“, odnosno u potpunosti legitimističko ostvarenje. Uostalom, uloga većine tih „pobočnih“ žanrova unutar korica Petrove (pa onda i Nikoline), ,zrinijade“ ionako se, ponovimo, glavninom svodila ni na što drugo nego na prikrivanje ključnih ideološko-političkih poruka koncentriranih u Obsidi, odnosno na uspostavljanje prijeko potrebnoga neideologiziranog kontrasta centralnomu, antihabsburškim idejama premreženom epskopjesničkom odsječku, kao što je to i bilo uobičajeno u većini onodobnih propagandno-pamfletističkih tekstova, ${ }^{1009}$ „,razredu“ kojih bi svakako valjalo pridružiti i samu Sirenu. Ideološku ,ispravnost““ Odiljenja sigetskog Ritter će, štoviše, težiti istaknuti ne samo upošljavanjem ,primjerenih“ žanrova i njima svojstvenih

\footnotetext{
${ }^{1008}$ O takvoj sadržajno-žanrovskoj orijentaciji Odiljenja sigetskog detaljnije i u: Pavličić 2007: 277.

${ }^{1009}$ Usp. o tome u: Blažević 2008c: 332-333 i Blažević i Coha 2008: 99.
} 
obilježja te apsorbiranjem zamisli isključivo proisteklih iz tada prihvaćenih ideoloških tendencija, nego i eksplicitnim sadržajnim ,prohabsburškim“ signalima poput motiva kraljeve neobaviještenosti, zbog koje bečki Dvor i nije poslao pomoć malobrojnim kršćanskim braniteljima u opkoljenu Sigetu, potom motiva nagovještavanja budućih habsburških uspjeha u ratu s Turcima i definitivnoga oslobađanja Sigeta iz njihova sužanjstva, ${ }^{1010}$ ali i motiva prozivanja inertnih i vjerolomnih Ugara, koje se optužuje kao jedine odgovorne za bolan sigetski poraz. Prisutnost potonjega motiva pritom bi se - osim Vitezovićevom nakanom da krivnju za poraz svali s politički moćnoga krivca na „leđa“ čitavoga jednog, sve manje moćnog (vojnog) kolektiva - lako mogla objasniti onodobnom društveno-političkom situacijom, točnije u to vrijeme sve uočljivijim distanciranjem politike hrvatskih staleža od one ugarske, koja se još i u osamdesetim godinama 17. st. - dakle, puno desetljeće nakon neslavne propasti hrvatsko-ugarske magnatske urote - zasnivala na protuhabsburškim aspiracijama, točnije na otvorenom suprotstavljanju bečkomu Dvoru. ${ }^{1011}$ I više nego dobro upućen u suvremena politička strujanja u Kraljevstvu Hrvatske, dokazani legitimist Vitezović tako nije ni imao drugoga izbora nego ispjevati dvostruko „politički korektno“ djelo, u kojemu će do izražaja doći ta otvoreno prohabsburška politika hrvatskih staleža, koji su odrješitim odbacivanjem ugarskih političkih težnji bečkomu Dvoru željeli potvrditi svoju bezgraničnu lojalnost i time iznova steći njegovo povjerenje što su ga ozbiljno bile poljuljale ne tako davne urotničke aktivnosti Zrinskih i Frankopana.

Unatoč ovoj i više nego očitoj težnji Pavla Rittera da svojim Odiljenjem sigetskim ne uznemiruje opasne ideološko-političke (čitaj: protuhabsburške) „duhove prošlosti“, čini se da ipak ne bi trebalo kao posve neutemeljena odbaciti (n)i ona posebno brojna dosadašnja tumačenja, u kojima se sustavno pokušavalo iznaći poveznicu između njegova sadržaja i samog čina smaknuća Petra Zrinskog i Frana Krste Frankopana u Bečkome Novom Mjestu u proljeće 1671. ${ }^{1012}$ Naime, kontinuirano ukazivanje na potrebu upamćivanja junaštava svih

\footnotetext{
${ }^{1010}$ Misli se, dakako, na svojevrsno proročanstvo što ga u heroidi Kralj Sigetu (II: 467-485) izriče sam kralj, uvjeravajući ožalošćeni personificirani Siget kako će jednoga dana ponovno on dospjeti u ruke svojih prvotnih kršćanskih, dakle habsburških - gospodara (,Još će ki lav doći od moga kolina, / koji hoće zmoći i prognat Turčina, / a ti gospodina prvoga spoznati / i Božjega sina križ sveti štovati“; II: 479-482).

${ }^{1011}$ Mnogo opširnije o tome u: Blažević 2002: 67-82.

1012 Vitezovićev stav spram ovoga krvavog svršetka protuhabsburške urote hrvatskih i mađarskih magnata, koji se zbio nepunih desetljeće i pol prije objelodanjivanja njegova prvog izdanja, u Odiljenju sigetskom pokušali su iščitati mnogi dosadašnji književni povjesnici i ,,ritterolozi“, pa će tako već 1976. Josip Vončina - uvjeren da ju ispjevao on u želji da proslavi cjelokupnu obitelj Zrinski - primijetiti kako Ritter u svojoj „zrinijadi“ - i to „, prizvukom prijekora - ističe slavna djela Zrinskih u prošlosti te tako aludira na nepravednost sudbine koju su nedavno doživjeli“ (Vončina 1976a: 340), dočim Franjo Švelec ni trena neće posumnjati u to kako je Odiljenje „označavalo vrlo određen stav prema austrijskom dvoru i prema tuđinskoj vlasti uopće“ (Švelec 1990: 187), odnosno da se ono može čitati kao i više nego jasan znak autorove apsolutne „odanosti Zrinskima“ (Švelec 1974: 258). I Zoran Kravar najprije će Odiljenje izdvojiti kao prilično jasan dokaz činjenice da se Vitezović „nije slagao s konformističkim shvaćanjem urote koje je u kontinentalnoj Hrvatskoj imalo brojne zagovornike“ 
sigetskih branitelja, no poglavito herojske pogibije bana Nikole Šubića Zrinskog - kojoj bi se u čast neumorno trebale širiti pjesme „,na sve svita strane“ (II: 146), tim više što se ona ujedno nameće i kao najuvjerljivija potvrda vjekovnoga značaja obitelji Zrinski u hrvatskoj povijesti - a k tome još i eksplicitno posvećivanje prvoga izdanja Adamu Zrinskom kao „baštiniku imena i djedovske vrline“ (Zrinski, Frankopan i Ritter Vitezović 1976: 360) te posezanje za obilježjima pojedinih žanrova, ali i postupcima i stategijama kojima Petar u Sireni jasno upućuje na svoje literarne uzore i implicitno otkriva vlastita književnostvaralačka uvjerenja (poput, primjerice, odabira dvostruko rimovanoga dvanaesterca, koji odaje jak utjecaj južnohrvatske književnosti), itekako bi se mogli, a vrlo vjerojatno i trebali pojmiti (i) kao signali kojima Vitezović na krajnje suptilan način izriče vlastiti sud o strogoj kazni koja je zadesila urotnike, a onda i vrlo negativnoj reputaciji koja je od otkrića urote pratila čitavu obitelj Zrinski. Naš autor, štoviše, kao da je tim silnim glorificiranjima ponajprije sigetskoga kapetana, a onda i njegovih sedamnaestostoljetnih potomaka ujedno pokušavao ponuditi argumente za opovrgavanje loših glasina koje su bile usmjerene ne samo protiv sudionika urote, već i cjelokupne porodice Zrinski, a koje su u znatnoj mjeri bile „podgrijavane“ i u to vrijeme još uvijek vrlo čestim usmenim i pučkim anonimnim pjesmama o Zrinskom i Frankopanu, u kojima se urota prikazivala kao nepromišljen i neoprostiv (zlo)čin, a smaknuće urotnika kao i više nego zaslužena kazna. ${ }^{1013} \mathrm{~S}$ obzirom na to da se radilo o pjesmama koje su zbog svoje raširenosti i sveprisutnosti poprilično bile odgovorne za oblikovanje i održavanje (ne baš pozitivnoga) javnog mnijenja (i) o Zrinskima, nije nemoguće da je Vitezović Odiljenjem zapravo - između ostalog - težio ponuditi i jedan sasvim drugi, po njegovu mišljenju puno realniji pogled na Petrovim urotničkim ,pothvatima“ znatno okaljanu obitelj Zrinski, u kojemu podsjeća na silan značaj Zrinskih u hrvatskoj povijesti, ponajbolje

(Kravar 1991: 241), da bi potom - motreći ga zajedno s Darkom Novakovićem - utvrdio kako je taj njegov književni tekst „prikriveno polemičan i prema austrijskoj politici u Hrvatskoj: diveći se junaštvu Nikole Šubića Zrinskoga i vidljivo se oslanjajući na ep Petra Zrinskoga, Vitezović obnavlja uspomenu na kuću Zrinskih, stvarnu i simboličnu žrtvu carskoga apsolutizma“ (Kravar i Novaković 2000: 767). Što se, pak, Dunje Fališevac tiče, „po vremenu nastanka i intencijama Vitezovićev je spjev zapravo reakcija na suvremena politička previranja (zrinsko-frankopanska urota, pogubljenje Petra Zrinskog i F. K. Frankopana u Bečkom Novom Mjestu 1671. godine) i ima naglašeni politički kontekst“ (Fališevac 2003: 503), dok Dubravko Jelčić u svome prikazu povijesti hrvatske književnosti izriče uvjerenje kako je Odiljenjem Ritter „htio, ni petnaest godina nakon tragedije u Bečkom Novom Mjestu, makar i posredno, preko sigetskog junaka, obnoviti uspomenu i štovanje obitelji Zrinskih" (Jelčić 2004: 117), koje potom ponavlja i ponešto nadopunjuje u drugome svome tekstu, u kojemu će u ovoj specifičnoj i osebujnoj „zrinijadi“ razabrati ni manje ni više nego „nepokoreni pjesnički glas koji se odupire carskom nasilju protiv velikaške obitelji Zrinski, obnavljajući njenu povijesnu veličinu i sjaj“ (Jelčić 2002: 1174-1175).

${ }^{1013}$ Rečene su usmene i anonimne pučke pjesme u hrvatskim okvirima u 17. stoljeću imale posebnu važnost s obzirom na to da su funkcionirale kao svojevrsne dnevne novine, odnosno jer su se ispostavile kao domaći pandan pjesama-letaka ili novinskih pjesama, koje su cirkulirale diljem onodobne zapadne Europe, i to u formi stihovanih tekstova otisnutih na jednom listu papira te pritom popraćenih i (s)likovnim ilustracijama opjevanih sadržaja (detaljnije o potonjim novinskim pjesmama u: Zečević 1972: 41). O pučkim pjesmama na temu urote znatno opširnije u: Matić 1962: 229-261 i Zečević 1972: 41-54, 1978: 442. 
manifestiran upravo u „liku i djelu“ neustrašivoga Nikole Šubića Zrinskoga kao njezina najistaknutijega člana. Na taj će način, kako se čini, naš autor - premda mu namjera nije bila opravdavati njihov čin, a još manje ideologiju kojom je on bio iniciran - prešutno ipak stati na stranu urotnika, jasno pritom dajući do znanja kako se preko važne uloge što ju je loza Zrinskih imala u domaćoj povijesti nipošto ne bi trebalo ni smjelo suviše olako prelaziti, poglavito stoga što se radi(lo) ne samo o neposrednim sudionicima višestoljetne borbe protiv Turaka, nego ujedno i o velikašima koji su vlastitim sredstvima sustavno financirali mnoge protuturske akcije, a povrh toga i o pjesnicima koji su uspomene na neke od th akcija poprilično uspješno pretočili u više književnih ostvarenja.

Ukratko, iako mu - na što, uostalom, ukazuje i njegovo izbjegavanje žanra epskopjesničke „zrinijade“ - ni na kraj pameti nije bilo (eksplicitno) pristati uz sporne ideološko-političke težnje Nikole i Petra Zrinskog, Pavao Ritter Vitezović u Odiljenju sigetskom ipak će otvoreno i neumorno proslavljati zasluge njihove obitelji, jasno pritom sugerirajući kako čuvanje sjećanja na Siget ujedno neizbježno podrazumijeva i evociranje žrtve što ju je za njegovu obranu podnio ni manje ni više nego jedan Zrinski, a možebitno sudjelovanje u njegovu (ponovnom) oslobođenju i obnovi - na koje je velik dio svojih čitatelja, na kraju krajeva, i želio potaknuti - ništa drugo nego kročenje onim istim putovima što su ih kroz dosadašnja stoljeća svojom ustrajnom protuturskom zaokupljenošću bili utabali upravo pripadnici obitelji Zrinski. Kao osvjedočeni legitimist, odnosno autor koji će tijekom čitava svog stvaralačkog djelovanja - sustavno nastupajući s ideološke pozicije prohabsburškoga lojalista - zazirati čak i od najsuptilnijih pokušaja izravnoga suprotstavljanja instituciji kralja i uopće Monarhije kao takve, Pavao Ritter svoje će divljenje spram porodice koja je trajno zadužila hrvatsko društvo, hrvatsku (političku) povijest i hrvatsku kulturu u Odiljenju tako iskazati nizom tekstualnih (pretežno sadržajnih, ali i formalnih) signala, posve lišenih bilo kakvih ideološki neprimjerenih aluzija, ali ne i neobilježenih silnicama tada iznimno poželjne neostoicističke ideologije, zahvaljujući kojima mučenička smrt Nikole Šubića pod zidinama Sigeta prilično uvjerljivo biva prikazana kao žrtva za kralja, Boga i domovinu, kojoj se - (i) kao primjeru vrlinama vođenoga zapovjednika koji postojano i samoprijegorno podnosi Božju kaznu u obliku turske opsade - bez ikakve dileme mora odati nužna počast. Naravno, Ritter pritom ni najmanje ne dvoji u to da će publika njegova djela lakoćom prepoznati to ideološki „primjereno“ glorificiranje Nikole Šubića Zrinskog i uopće Zrinskih izvedeno u bitno drugačijem (čitaj: ideološki nekompromitiranomu) generičkom okviru od onog ranijih „zrinijada“ te da će njime dospjeti pripomoći „oslobađanju“ teme sigetskoga poraza od politički nekorektnoga ideološkog „balasta“ kojim su je opteretili Nikola 
i navlastito Petar, poglavito zato što je - prema njegovu mišljenju - napokon kucnuo čas da se Siget vrati u nacionalno pamćenje kao mjesto sjećanja na junački otpor hrvatskih boraca turskomu neprijatelju, ali i kao svojevrsni simbol svehrvatskoga jedinstva, a sve s krajnjim ciljem da se upravo on nametne kao bitan poticaj još žešćemu suprotstavljanju vojno ozbiljno poljuljanim Osmanlijama, čiji se pad nakon još uvijek vrlo „svježega“ poraza pod Bečom izuzetno snažno bio „osjećao u zraku“. Ipak, ako je tomu doista bilo tako, samo od sebe neizbježno će se nametnuti pitanje opravdanosti takvih Ritterovih očekivanja od potencijalnih recipijenata, na koje dovoljno precizan ili makar iole precizniji odgovor neće biti moguće podastrijeti ukoliko prethodno ne istražimo kako je naš autor uopće zamišljao svoju ciljanu publiku, odnosno tko su - na kraju krajeva - uopće bili oni kojima je jedno ili barem jedno od triju za njegova života objelodanjenih izdanja Odiljenja zaista i uspjelo doći u ruke?

\section{4. „С̆TAVCI“ I „ŠTAVCI“ ILI KOMU I ČEMU ODILJENJE?}

U razmatranju (vjerojatne) recipijentske usmjerenosti ove po mnogočemu najneobičnije ,zrinijade“ u povijesti hrvatske književnosti ni u jednome se trenutku ne bi smjelo smetnuti s uma kako pitanje njezine ciljane publike specifičnim i ujedno iznimno kompleksnim čini otprije nam dobro poznata činjenica kako se trima za života objelodanjenim joj izdanjima Pavao Ritter Vitezović zapravo nije obraćao istim krugovima čitatelja, točnije da je - ,jaussovski“ kazano - različitim njezinim izdanjima (implicitno i eksplicitno) provocirao i posve drugačije ,horizonte očekivanja“. ${ }^{1014}$ Iako je, drugim riječima, ispjevao tekst koji je zahvaljujući svojim raznolikim (generičkim) obilježjima, postupcima i strategijama već sam po sebi apsolutno bio u stanju zadovoljiti potrebe i očekivanja kako učenijih recipijenata, tako i onih sa znatno skromnijom (književnom) naobrazbom (čije se literarno iskustvo najvećim dijelom baziralo na recepciji usmenoknjiževnih ostvarenja, Biblije te pučkih nabožnih djela - molitvenika, zbirki propovijedi itd.), preinakama i doradama što će ih unijeti u naredna dva izdanja - i to poglavito onima prisutnima u zagrebačkomu, tj. trećem izdanju Odiljenja sigetskog - Ritter jasno daje do znanja da cilja na recipijente bitno drugačijega čitateljskog profila, odnosno da se, preciznije rečeno, ponajprije teži približiti publici koja na prvo i fiktivno „drugo“ njegovo izdanje najvjerojatnije nije ni obratila (dovoljnu) pažnju. Spomenute „preinake i dorade“ pritom će on izvršiti isključivo u paratekstualnim dionicama najprije drugoga (1685.), a potom i trećeg (1695.) izdanja Odiljenja, ostavljajući sam tekst „,zrinijade“ u oba slučaja gotovo u potpunosti netaknutim, pa 
time i svejednako bliskim senzibilitetu i potrebama različitih tipova publike. Daleko će najveće paratekstualne modifikacije, kako je i nešto ranije bilo utvrđeno, pretrpjeti ipak zagrebačko njegovo izdanje, u kojemu umjesto raskošne naslovnice bremenite podacima o samom izdanju te versificirane latinske posvete praćene vernakularnim proznim predgovorom sa stihovanim umetcima - dakle, komponenata uvriježenih u paratekstovima izdanja iz Linza i Beča - zatječemo „tek“ vizualno krajnje neatraktivnu naslovnicu s jednostavno otisnutim naslovom djela (koja očigledno nije imala zadaću ,snubljenja“ mogućih kupaca i čitatelja) te odulju proznu posvetu na hrvatskom jeziku adresiranu na pukovnika Ivana Andriju Makara.

Kao posebno zanimljiv i indikativan detalj u potonjoj posveti pritom se izdvaja Vitezovićevo „priznanje“ Makaru kako se u objelodanjivanje trećega izdanja Odiljenja upustio želeći udovoljiti „,volji i željenju prijateljov (...), navlastito viteških i razumnih ljudi“, ${ }^{1015}$ kojim prilično jasno i nedvosmisleno otkriva tip publike kojemu je namijenio to posljednje za života objavljeno izdanje svoga hrvatskog literarnog prvijenca. Dapače, da su njegovi ciljani čitatelji trebali biti upravo dobro mu znani „,viteški i razumni ljudi“, točnije prijatelji i znanci iz redova aristokracije, potvrđuje - pored odveć jednostavno izvedenoga naslovnog lista - i izostanak (prozno-stihovnoga) vernakularnog predgovora ,čtavcu“, odnosno „prijaznivu štavcu“, nalik onima iz paratekstualnih odsječaka prvog i fiktivnoga „drugog“ izdanja, kojih se svrha svodila na uspostavljanje kontakta s posve mu nepoznatim „konzumentima“ iz - po mogućnosti - svih, no primarno nižih slojeva društva, kojima je na taj način trebalo objasniti temeljnu nakanu teksta i rasvijetliti im neke njegove najbitnije pojedinosti. Na kraju krajeva, da je taj eksplicitno najavljeni zaokret k publici iz isključivo najviših slojeva društva presudno bio potaknut stanovitim izvanknjiževnim činiteljima, točnije da je proizlazio iz njegove uronjenosti u konkretne onodobne povijesne okolnosti, ukazat će nam biografski podatak kako je upravo u posljednjem desetljeću 17. st. Vitezović vrlo intenzivno prijateljevao s tadašnjom društveno-političkom „kremom“ Kraljevstva Hrvatske, i to ponajviše zahvaljujući vrtoglavom usponu svoje karijere u tom razdoblju, u kojemu je obnašao čitav niz istaknutih političkih dužnosti (podžupan Like i Krbave, izaslanik hrvatskih staleža, upravitelj Zemaljske tiskare), a uz to i bio neposredno upleten u rješavanje tada gorućih političkih pitanja Kraljevstva, o čemu - uostalom - i svjedoči poveći broj povijesnih spisa što ih je sastavio i objelodanio upravo tih godina. $U$ tom smislu, kada u posvetnom obraćanju Makaru apostrofira „,viteške i razumne ljude“, nema sumnje da ponajprije on misli na magnate, zagrebačke biskupe i druge crkvene velikodostojnike, potom na krajiške zapovjednike, plemstvo zaduženo za obavljanje saborskih funkcija, ali i ine utjecajne 
pojedince s kojima je u to vrijeme održavao prijateljske veze, što će reći da je upravo u tom krugu tadašnje društvene „elite“ on i traži idealne čitatelje za svoju „zrinijadu“, točnije za treće njezino tiskom objelodanjeno izdanje.

Dodamo li svemu rečenom još i činjenicu da se treće izdanje Odiljenja sigetskog do danas dospjelo sačuvati u tek jednomu jedinom primjerku - koja bi također trebala signalizirati da ga je Vitezović u zagrebačkoj tiskari ciljano otisnuo u vrlo skromnoj nakladi u cijelosti namijenjenoj raspačavanju među isključivo aristokratskom publikom - postat će i više nego jasno da 1695. ono više nije egzistiralo kao različitim tipovima čitatelja prilagođeno (pučko)književno ostvarenje namijenjeno i dostupno na „književnom tržištu“, već, upravo suprotno, kao tekst koji striktno mora dospjeti u ruke književnih sladokusaca, koji će mu pristupati kao ,punokrvnomu“ elitnoknjiževnom sastavku. S obzirom na to da ni u godinama koje su slijedile Pavao Ritter više nije osjećao potrebu svoju „zrinijadu“ otisnuti i s „pučkoknjiževnom“ paratekstualnom „opremom“ ne bi li iznova njome pokušao privući pozornost i znatno šire publike, može se reći da je sa zagrebačkim izdanjem ona - kao do toga trenutka pretežno pučkoknjiževno ostvarenje namijenjeno slobodnoj prodaji - odjednom prešla u "sferu“ elitnoknjiževnoga stvaralaštva, i to bez ikakvih krupnijih intervencija u samom njezinu tekstu. A to što je, ponovimo, punih deset godina poslije njegova zadnjeg „pučkog“ izdanja Vitezović bio u stanju Odiljenje takvom lakoćom naprosto „prebaciti““ iz domene pučkoknjiževne produkcije u onu elitne književnosti samo nepobitno upućuje na to da je ono posjedovalo i ,pučke“ i ,elitne“ unutartekstualne značajke, ${ }^{1016}$ odnosno da je bilo ispjevano tako da $\mathrm{u}$ isti mah privlači kako visokoobrazovanu i literarno izvrsno ,potkovanu“ publiku, tako i onu s bitno skromnijom naobrazbom, pa time čak i onu jedva opismenjenu.

Prihvatimo li, dakle, kao potpuno argumentiranu pretpostavku da je Odiljenje sigetsko (prvim dvama svojim izdanjima) ciljanoga čitatelja paralelno tražilo kako među visokoobrazovanim književnim sladokuscima, tako i među pojedincima koji su stekli tek bazičnu naobrazbu i čije se čitateljsko iskustvo ponajvećma temeljilo na recepciji usmenoknjiževnih i pučkoknjiževnih tvorevina, kao posve bi se logičan i očekivan idući korak u našem nastojanju da utvrdimo kakav je čitateljski odziv isprovocirala (ili makar mogla isprovocirati) njegova pojava ispostavilo što preciznije definiranje najvjerojatnijega sastava te i takve ,učene i neukije“ njegove publike, odnosno (barem približno) identificiranje konkretnih mu vrsta čitatelja, koji su dolazili iz svih društvenih slojeva i računajući s kojima je - ispravno anticipiravši njihove nejednake potrebe te bitno različita očekivanja s kojima će mu pristupati - Pavao Vitezović svoje djelo, između ostalog, i napučio maločas primijećenim 
mnoštvom pojedinih karakterističnih obilježja, a gdjekad čak i čitavih primjeraka određenih žanrova izrazito raznolikoga porijekla. S obzirom na to da znamo da je pri sastavljanju svoje „zrinijade“ Ritter u mnogim dosad već višestruko navedenim (tekstualnim) pojedinostima vjerno slijedio Adrijanskoga mora Sirenu Petra Zrinskog te da je pritom itekako bio svjestan njezine još uvijek prilično velike popularnosti, nekako se najlogičnijim čini pomisliti da je toliko ga čvrsto (pri)vezavši uz prethodnikovu viziju turskoga zauzeća Sigeta - priželjkivao da se Odiljenje nađe u rukama onih istih čitatelja koji su ranije već pažljivo iščitali i Petrovo ostvarenje, odnosno upravo onih (pa i ne samo onih) recipijenata kojima je Petar izrijekom i namijenio svoje djelo. ${ }^{1017}$

Iako je o obljubljenosti Sirene među sedamnaestostoljetnim čitateljstvom na prethodnim stranicama bilo već podosta riječi, da bismo utvrdili koje je to recipijente Petar prvotno imao na umu prilikom pisanja svoje ,zrinijade“ i njezina priređivanja za tisak, bit će nam dovoljno „tek“ zaviriti unutar njezinih korica, i to ponajprije u prilično joj intrigantnu paratekstualnu dionicu, u sklopu koje je - pored drugih komponenata - svoje mjesto našla i ranije već spomenuta prozna posveta, ,plemenito i dobro rojenim, svake hvale i časti dostojnim, virnim i vridnim junakom, vse hrvacke i primorske krajine hrabrenim vitezovom“ (Zrinski 1957: 19). Kao što je očito, riječ je o paratekstualnom dodatku u kojemu Zrinski i više nego eksplicitno otkriva do pozornosti kojega mu je kruga čitatelja daleko najviše stalo, odnosno iz čijega je sadržaja moguće saznati da je Sirena primarno bila namijenjena ni manje ni više nego njegovim suborcima, što će reći pripadnicima vojnoga staleža, među kojima, kako se čini, nipošto nisu bili samo i isključivo (visoko)obrazovani pojedinci iz aristokratskih krugova, već i profesionalni vojnici, koji su se po dosegnutomu stupnju obrazovanja teško mogli mjeriti s onim vojnika - plemića. ${ }^{1018}$ Ova i ovakva nas, i više nego jasna i nedvosmislena recipijentska usmjerenost Adrijanskoga mora Sirene pritom ni najmanje ne bi trebala iznenađivati, poglavito prisjetimo li se činjenice da su „stožerni“ autori ozaljskoga književnojezičnog kruga - kako braća Zrinski, tako i Fran Krsto Frankopan - i sami bili vojskovođe, što bi i morao biti ključni razlog poradi kojega ih je u njihovu književnom djelovanju pretežno vodila želja da udovolje (izuzetno heterogenim) čitateljskim potrebama i očekivanjima svojih suboraca, a to će reći pripadnika vojnoga staleža, koji su u tadašnjoj kontinentalnoj Hrvatskoj ujedno i predstavljali uvjerljivo najbrojniji tip publike.

\footnotetext{
${ }^{1017} \mathrm{Na}$ (is)tu je pomisao Odiljenje ne tako davno već bilo navelo i Pavla Pavličića (usp. Pavličić 2007: 280-281). 1018 O nejednako obrazovanim, pa onda i nejednako literarno „potkovanim“ pripadnicima vojnoga staleža, kojima Petar posvećuje svoju „zrinijadu“, podrobnije u: Pavličić 2006: 177-194. Opširnije o Petrovu definiranju ciljane publike u posveti Sirene i u: Pavličić 2007: 199-202. O posveti Petrove „zrinijade“ i nekim njezinim idejno-poetičkim naglascima također i u: Novalić 1967b: 60-71.
} 
Prema tome, spoznaja da je Pavao Ritter Vitezović pišući svoju „zrinijadu“ u mnogočemu polazio od one neposrednoga prethodnika stoga bi ,automatski“ morala upućivati i na to da je idealni njezin recipijent dolazio ili barem trebao dolaziti iz onoga istog čitateljskog kruga kao i publika Sirene, tj. da je naš autor zacijelo čvrsto bio uvjeren u to da će Odiljenje pozitivnoga odjeka imati ponajprije među čitateljima iz vojnoga staleža, odnosno među muškom publikom koju su sačinjavali kako učeniji i literarno iskusniji „konzumenti““, tako i oni zamjetno skromnije obrazovani te pretežno na usmenoj i pučkoj književnosti zadojeni pojedinci. Ukoliko je tomu doista bilo tako, to bi onda značilo da je Odiljenje do (najprije) hrvatskih vojnika i vojskovođa očito moralo doprijeti s ciljem da ih podsjeti na junački otpor i žrtvu što su je za obranu Sigeta podnijeli ban Zrinski i njegova daleko malobrojnija četa (hrvatskih) branitelja, a sve ne bi li im prezentiranjem kršćanskih (čitaj: hrvatskih) aktera sigetske bitke kao svojevrsnih obrazaca u ratničkom i moralnom smislu ponudilo uzor i poticaj za njihove daljnje protuturske akcije. Da je, štoviše, Ritterov vernakularni literarni prvijenac ne samo mogao, nego vrlo vjerojatno i morao (iz)vršiti takvu izvanknjiževnu svrhu ponajbolje nam sugerira sam trenutak njegova objavljivanja - nepunih godinu dana nakon teškoga poraza Turaka pod zidinama Beča te neposredno uoči najžešćih bitaka za oslobođenje okupiranih teritorija - kojega su pojedini „ritterolozi“ već izdvojili kao dokaz da je Odiljenje nepobitno posjedovalo i političko-mobilizacijsku važnost uoči rata, točnije da je ono funkcioniralo (i) kao „mobilizacijska platforma u okviru aktualnih protuosmanskih oslobodilačkih ratova“ (Blažević 2012: 435). ${ }^{1019}$

Uistinu, sagledamo li ga na podlozi specifične povijesno-političke situacije koja ga je iznjedrila, Odiljenje sigetsko definitivno će ostaviti dojam književnoga teksta koji je - takav kakav jest - mogao biti napisan i objelodanjen isključivo u danomu povijesnom trenutku, odnosno u prvoj godini tzv. Bečkoga rata (1683. - 1699.), kojega su, podsjetimo, izazvali Turci naprasno prekinuvši - svega godinu dana prije njegova isteka - dogovoreni dvadesetogodišnji Vašvarski mir s Habsburškom Monarhijom. Iako su te 1683. pokušale zauzeti Beč s izuzetno moćnom vojskom, Osmanlije su pod bečkim zidinama ipak doživjele katastrofalan poraz od kršćanskih branitelja predvođenih poljskim kraljem Janom Sobjeskim, a taj njihov poraz ujedno je (o)značio i početak protuofenzive, tj. dugogodišnjega kršćanskog oslobodilačkog rata, koji se velikim dijelom, dakako, vodio i na hrvatskom teritoriju, odnosno za hrvatski teritorij. (Ne)očekivane vijesti o kršćanskom trijumfu ubrzo su doprle i do ušiju žitelja s ovih prostora, pa je - kako navodi Marko Valentić - „,bečki poraz Osmanskog carstva

1019 Usp. o tome i u: Blažević 2011: 252-253. Doduše, još će 1902. Milivoj Šrepel konstatirati kako je Vitezović Odiljenje ispjevao u želji ,da slavnim primjerom Nikole Šubića Zrinjskoga osokoli svoj mili narod na junaštvo i ustrajnost u borbi za dobro domovine“"(Šrepel 1902: 104). 
dočekan (...) u okupiranim hrvatskim i ugarskim zemljama kao poziv na ustanak“ (Valentić 2002: 1169), dakle s iznimnom euforijom, koja je i rezultirala time da se „na izmaku zime i u proljeće 1684.“ na otpor turskim osvajačima vrlo ozbiljno i ustrajno pripremalo „i kršćansko stanovništvo između Drave i Save“ (Mažuran 1998: 248). Intenzivnim pripremama za protuofenzivu, dakako, neposredno je svjedočio i sam Vitezović, zacijelo pritom procijenivši kako je kucnuo pravi čas za objelodanjivanje „zrinijade“ koja će - „osvježavajući“ sjećanje na jednu od najslavnijih ratnih epizoda iz hrvatske povijesti - ponajprije čitateljima iz vojnih krugova dati prijeko potrebno ohrabrenje i moralnu potporu te ih tako dodatno motivirati na bespoštednu borbu za oslobođenje (pre)dugo okupiranih dijelova („čitave“) Hrvatske.

Odiljenjem sigetskim Ritter je, osim toga, svoju publiku otvoreno želio podsjetiti i na dugogodišnju, točnije višestoljetnu ulogu koju su Hrvati - dakle, hrvatski vojnici i vojni zapovjednici - imali u obrani cjelokupne Habsburške Monarhije od turskih najezdi, a možda čak i - kako je pretpostavio Nikica Kolumbić - (posredno) apelirati na kralja Leopolda, „koji je poveo rat protiv Osmanlija i koji bi poslije pobjede morao Hrvatima uzvratiti za zasluge, povratiti u krilo domovine zauzete krajeve“ (Kolumbić 2005: 350). Dapače, (slijepo) vjerujući da će, po (uspješnom) završetku protuofenzive, tomu doista i biti tako, Vitezović u samome tekstu - u pjesmi Kralj Sigetu (II: 467-485) - iznosi vlastito uvjerenje u pozitivan ishod netom pokrenutih protuturskih akcija, i to ni manje ni više nego ranije već spomenutim proročanskim stihovima o oslobođenju Sigeta iz muslimanskoga sužanjstva („Još će ki lav doći od moga kolina, / koji hoće zmoći i prognat Turčina“; II: 479-480), kojima je očigledno recipijente iz redova vojske želio navesti na to da povjeruju u uspjeh oslobodilačkoga rata te da s tom vjerom i krenu u odlučujući okršaj s Osmanlijama odvažno poput bana Zrinskog i njegovih suboraca, znajući da će područja što ih oslobode svakako biti vraćena u „krilo“ domovine, kojoj su, na kraju krajeva, i pripadala. U tom bi se smislu - imajući na umu pobrojane sadržajne naglaske i konkretne ,indikativne“ motive, prisutnost kojih je (najvećim dijelom) moguće opravdati primarnom njegovom recipijentskom usmjerenošću publici iz vojnoga staleža, odnosno (aktualnim i budućim) sudionicima protuturske odmazde - s pravom moglo ustvrditi kako je i Odiljenje u okvirima tadašnje društveno-političke situacije uslijed koje se pojavilo trebalo ispunjavati (i) konkretne političko-mobilizacijske ciljeve, na koje su uostalom - dosad već bili upozorili i pojedini, mahom recentniji njegovi tumači.

Svjestan da će „,pravim“ književnim sadržajima u ,pravome“ trenutku gotovo sigurno moći isprovocirati očekivanu reakciju ciljane publike, Pavao Vitezović mobilizacijski se potencijal svoga hrvatskog literarnog prvijenca dodatno odlučuje učvrstiti i ranije već uočenom primjerenom ideološkom nadgradnjom, i to na način da neprekidnim inzistiranjem 
na imitaciji Krista, točnije prepoznatljivo neostoicističkim glorificiranjem (kršćanskoga) mučeništva i uopće samoprijegornoga podnošenja nepovoljnih ratnih okolnosti $\mathrm{s}$ kulminacijom u vidu herojske pogibije Zrinskoga i sigetskih branitelja poradi „viših ideala“ (Boga, kralja i domovine), čitateljima ujedno nudi i obrazac etičkoga ponašanja, odnosno etički uzor za sve buduće borbe protiv Turaka u kojima će osobno sudjelovati. Osim toga, obraćajući se (primarno) istomu onom krugu čitatelja kao i Petar Zrinski Adrijanskoga mora Sirenom, Ritter njihovo zanimanje ujedno pokušava privući i održati i drugim otprije im dobro poznatim tekstualnim karakteristikama i strategijama, a sve ne bi li postigao da ga recipiraju na identičan način, odnosno da za njim posežu uslijed onih istih okolnosti koje su ih - kako se može pretpostaviti - poticale i da se late čitanja Petrova zbornika. Konkretno, ne Želeći da se njegova ,zrinijada“ u očima ciljanih čitatelja svede samo i isključivo na tekst $s$ mobilizacijskom funkcijom, vrijedan pažnje jedino u iščekivanju budućih ratnih akcija, Vitezović je odlučuje „opremiti“ kako raznovrsnim sadržajnim momentima, tako i različitim žanrovskim slojevima, stvorivši naposljetku generički rascjepkano ostvarenje čije su zasebne (lirske) pjesme okupljene u četirima njegovim „dilovima“ - poučio ga je tomu primjer Sirene - publici mogle i morale biti zanimljive ne samo uoči važnih bitaka, već i uslijed njih, dakle doslovno čak i na samoj bojišnici. Znajući da su među recipijentima iz vojnoga „miljea“ posebno obljubljene (lirske) pjesme u kojima se miješaju ratni, ljubavni i religiozni motivi ili, riječima Petra Zrinskog, ,da ništar tako ne veseli junaka kako ljuba, konj i oružje“ (Zrinski 1957: 20) - i naš će autor u Odiljenju tako okupiti upravo pjesničke tekstove u većini kojih dolazi do ukrštavanja motiva iz navedenih triju motivskih sklopova, što će za svoju „posljedicu“ imati svojevrsnu četverodijelnu pjesničku zbirku koja je - osim kao književno ostvarenje s jakim mobilizacijskim potencijalom - ujedno bila u stanju funkcionirati i kao „štivo za bojišnicu“, dakle kao djelo koje se svojim čitateljima podjednako interesantnim ispostavljalo kako neposredno uoči polaska u bitku, tako i za vrijeme sudjelovanja u njoj, odnosno u kraćim ili duljim trenucima predaha od ratnih aktivnosti, baš kao što je to, uostalom, bio slučaj i s Adrijanskoga mora Sirenom.

$\mathrm{Za}$ razliku, međutim, od Petrove Sirene, koja je - u svome prvotnom, integralnom obliku - i implicitno i eksplicitno bila namijenjena isključivo muškoj publici iz vojnoga staleža, Odiljenjem sigetskim Pavao Vitezović ne samo što nije imao u planu privući jedino recipijente iz redova vojske, nego nije njime računao ni samo na pažnju muškoga - dakle, kako visokoobrazovanoga, tako i neukijega i literarno neiskusnijeg - čitateljstva, na što ukazuje nemali broj podjednako tekstualnih i izvantekstualnih njegovih signala. Konkretno, usprkos činjenici da je doista težio isprovocirati ponajprije interes potencijalne muške publike 
iz vojnih krugova, već i letimičan će nam uvid u njegovu ,zrinijadu“ pobuditi sumnju u to da je pri takvu njezinom recipijentskom orijentiranju bio on do krajnosti isključiv te da je posljedično - i eventualan interes čitatelj(ic)a drugoga profila za nju stoga više bio plod pukoga slučaja no pojedinim njezinim značajkama jasno izražene nakane. Hotimično napuštanje (čvrstih) epskopjesničkih generičkih okvira, težnja žanrovskoj hibridizaciji od prvoga do posljednjeg njegova stiha, uključivanje nezanemarivog broja ženskih (su)govornika, odustajanje od pravocrtnoga narativnog nizanja događaja, sadržajno inzistiranje na emotivnom doživljaju bitke za Siget i njezinih posljedica, učestali refleksivni segmenti u mnogim pjesmama, utješni ton pojedinih dionica te inkorporiranje izdvojenih karakterističnih obilježja ili čak čitavih primjeraka pojedinih ,ženskih“ usmenoknjiževnih žanrova (naricaljka, ljubavna pjesma, molitva, donekle poslovica i kletva) karakteristike su Odiljenja koje bi nam tako prilično jasno trebale davati do znanja da je Ritteru snažno bilo stalo i do zanimanja (do)tada većinom zanemarivane ženske publike, dakle skromnije obrazovanih čitateljica, kojih u to vrijeme u nas nipošto nije bio zanemariv broj. Naprotiv, opismenjene, a to će reći i (makar bazično) obrazovane potencijalne recipijentice književnih i ne samo književnih tekstova u 17. stoljeću glavninom su dolazile iz najviših društvenih slojeva, no izuzev supruga i kćeri vlastelina, plemića i građana, u krug ženske publike tih su godina ulazile još i redovnice, među kojima je - zbog otvorenosti onodobnoga obrazovnog sustava ženskoj djeci iz isključivo viših društvenih slojeva ${ }^{1020}$ - još uvijek bio i povelik broj nepismenih ili tek polupismenih osoba. S obzirom na to da su se rečene žene - za razliku od svojih muževa, braće i očeva - hrvatskim jezikom služile ne samo u svakodnevnoj komunikaciji, nego i u korespondenciji, ${ }^{1021}$ većina njih je stoga gotovo isključivo posezala za onodobnim pučkim štivom na vernakularu, pa je tako i iznimno velik broj čitateljica kupovao i čitao upravo ona pučkoknjiževna ostvarenja što ih je i sam Vitezović sastavljao i/ili tiskom objelodanjivao u vrijeme upravljanja Zemaljskom tiskarom koncem 17. i početkom 18. st.

O postojanju svijesti o ženskoj publici kao nimalo nevažnom književnom čimbeniku, odnosno o već sedamnaestostoljetnom autorskom poznavanju i uvažavanju specifičnih čitateljskih potreba i očekivanja opismenjenih recipijentica iz (naj)viših slojeva društva posvjedočiti nam - izuzev tadašnjeg ,procvata“ pučke književnosti - svakako najzornije može nešto ranije već spomenuto rukopisno otkriće, do kojega je svojedobno bio došao naš „barokolog“ Đuro Novalić. Njemu je, podsjetimo, polovinom šezdesetih godina prošloga

1020 Naime, u isusovačkim će se školama tek od narednoga, dakle 18. stoljeća u obrazovni proces početi uključivati i ženska djeca iz nižih slojeva, što je i razlog zbog kojega su - kako napominje Aleksandar Stipčević - žene do tada (pa tako još i tijekom 17. stoljeća) bile prisiljene ,saznavati za sadržaj neke knjige na hrvatskom jeziku više kao slušateljice nego kao čitateljice“" (Stipčević 2005: 186).

${ }^{1021}$ Usp. Janković 2016: 106-107. 
stoljeća među pisanom ostavštinom obitelji Drašković pohranjenoj u zagrebačkome Državnom arhivu tako pošlo za rukom pronaći parcijalni rukopis Adrijanskoga mora Sirene, točnije rukopisni izbor iz „zrinijade“ Petra Zrinskog, kojega je - kako je pretpostavio neposredno uoči vlastitoga smaknuća u Bečkome Novom Mjestu 1671. najvjerojatnije dao sastaviti sam Petar, i to ni manje ni više nego za stanovitu čitateljicu ili možda nekolicinu njih iz bliske mu obitelji Drašković. Da je (novo)otkriveni rukopisni odabir bez gotovo ikakve sumnje bio namijenjen upravo ženskoj publici, Novalić je ustanovio već na temelju njegova pukog prelistavanja, otkrivši pritom da je riječ o nepotpunom prijepisu, koji - podsjetimo sadržava sve lirskopjesničke tekstove iz tiskanoga (mletačkog) izdanja Sirene iz 1660. izuzev religiozne pjesme Vzdihanje k Otkupitelju na križu raspetome te zaključnoga Ispivanja, dočim je iz cjelokupnoga teksta junačkog epa Obsida sigecka prepisivač izdvojio i u njega prenio samo peto pjevanje (,del peti“), u kojemu se nalazi daleko najmanje narativnih elemenata. ${ }^{1022}$

Osim kao (vjerojatna) potvrda književnih veza koje su održavali (pojedini) barokni pisci iz kontinentalnoga dijela Hrvatske, a ujedno i kao „posljedica“ podilaženja čitateljskom ukusu i uopće potrebama slabije obrazovane i literarno neiskusnije ženske publike, Novalićevo vrijedno, no dosad sustavno ignorirano otkriće rukopisnoga izbora iz Sirene istodobno se nameće i kao poziv na preispitivanje, pa i proširivanje kruga mogućih domaćih književnih uzora za kojima se Pavao Ritter povodio prilikom sastavljanja Odiljenja sigetskog. Imajući u vidu da se Petrovom ,zrinijadom“ ionako presudno obilježeno Odiljenje željelo približiti kako publici iz vojnoga staleža, tako i učenim aristokratkinjama - od kojih su neke, a

\footnotetext{
1022 Potonja prepisivačeva (očito ne svojevoljna) odluka da od čitave Obside u rukopis uvrsti baš peto njezino pjevanje ujedno je, kako se čini, ponajvećma i usmjerila Novalićeva razmišljanja o najvjerojatnijoj ciljanoj (ženskoj) publici ovoga odabira, $i$ to poglavito stoga što se radi upravo o onoj - jedinoj - dionici epa u kojoj se ne inzistira na opisivanju turskih napadača ni samih kršćansko-muslimanskih okršaja, već se radnja usporava i „smiruje“ ne bi li se prikazao tijek priprema Sigećana za skorašnji dolazak osmanlijske vojske, iznio nadahnuti ratni govor Nikole Šubića Zrinskog suborcima, opjevao banov dirljivi rastanak sa sinom te naposljetku donijelo njegovo posljednje, oproštajno pismo kralju. Pribrojivši toj „poetičnosti“ i uopće naglašenoj emotivnosti petoga „dila“ Obside još i prethodeće mu epitafe te lirske pjesme preuzete iz Sirene, sve odreda ljubavne tematike i napučene elementima deriviranima iz antičkoga pjesništva (mitske figure, amorozne situacije itd.), Đuro Novalić dolazi do nimalo neargumentirane pretpostavke da je „idealnoga“ čitatelja ovaj izbor iz Petrove „zrinijade“ trebao naći među obrazovanim pripadnicama aristokracije, koje ionako nisu bile odveć sklone epskopjesničkim literarizacijama protuturskih ratnih akcija. Pođe li se, drugim riječima, tako od činjenice da ovaj rukopisni izbor „sadrži ljubavnu marinističku liriku bez lascivnih frankopanskih elemenata, punu konvencionalnih »loci communas «" te da „epski odlomak daje upravo ono mjesto iz Obside, koje je najmanje krvavo, naturalističko, bojovno“, u tom je slučaju itekako valjano pretpostaviti „da je taj izbor namijenjen nekoj osobi koju je više zanimala ljubavna lirika, a manje ratne strahote: dakle ženskoj osobi, vjerojatno ne staroj, kada je jedini neepski prilog Sirene nabožno Vzdihanje ispušteno“ (Novalić 1967a: 218). Uzimajući u obzir da ga je dospio pronaći ni manje ni više nego u Arhivu Drašković, kao i činjenicu da su veze između obitelji Zrinski i Drašković u ranomu novom vijeku bile itekako čvrste i mnogostruke, Đuri Novaliću najlogičnijom se učinila mogućnost da je ovaj odabir iz Sirene prvotno bio namijenjen stanovitoj ženskoj osobi iz obitelji Drašković, što bi ujedno značilo i da ga je moguće motriti kao jedan od čvrstih dokaza postojanja nimalo zanemarivih književnih veza između naših kontinentalnih (sjevernohrvatskih) baroknih pjesnika, odnosno kao najvjerojatniju posljedicu prakse međusobnoga razmjenjivanja rukopisa (ne)dovršenih književnih tekstova što su je njegovali pripadnici njihova literarnog kruga. Znatno opširnije o ovome u: Novalić 1967a: 212-221.
} 
možda i ne samo neke, prethodno već imale priliku pročitati i neki od (jamačno višestrukih) prijepisa odabranih dionica iz politički krajnje nekorektne Sirene - neće biti sasvim netočno pretpostaviti kako je, između ostalog, (i) upravo zahvaljujući izboru iz Petrova ostvarenja glavninom namijenjenom opismenjenim recipijenticama Vitezović dospio steći predodžbu o čitateljskim preferencijama ženske publike. ${ }^{1023}$ Spoznavši tako da - za razliku od muškoga čitateljstva, (očekivano) najnaklonjenijega povijesno-političkim temama obrađenima u epskopjesničkom obliku - čitateljice daleko najveći interes iskazuju spram ljubavnih tema i uopće sadržaja prožetih intenzivnom emocionalnošću obrađenih u kvantitativno nepretencioznijim, no najčešće hibridnim generičkim okvirima, naš se autor u Odiljenju ciljano odlučio naglasiti upravo motive neutješnih udovica, majki, supruga i zaručnica izginulih sigetskih branitelja, ispravno pritom procijenivši kako će se žene-čitateljice i same najlakše moći identificirati s ucviljenim ženskim junakinjama (odnosno sugovornicama, kazivačicama ili makar adresatkinjama pojedinih pjesama), tim više što su mnoge od njih i same - živeći u vrijeme bespoštednih kršćansko-muslimanskih ratova, u kojima su svakodnevno pogibali (ili se makar izlagali ozbiljnoj opasnosti da će poginuti) njihovi očevi, sinovi, braća, zaručnici i muževi - imale priliku doživjeti identično iskustvo gubitka muških članova obitelji. Težnjom da pobudi ponajprije zanimanje čitateljica moglo bi se, također, objasniti i njegovo sadržajno inzistiranje na motivu „odiljenja“ ili (trajnoga) rastanka - dakle onoga istog motiva koji dominira i u petomu pjevanju Obside, jedinom iz nje uvrštenom u izbor iz Sirene - koji je posebno bio obljubljen među tadašnjom širom (pa onda i ženskom) publikom, ali i „rezerviranje“ čitavoga jednog dijela teksta za ciklus nadgrobnica posvećenih poginulima, odnosno pjesama realiziranih u žanru za kojim je u lirskopjesničkom segmentu svoje ,zrinijade“ posegnuo i njegov prethodnik, ispjevavši znatno kraći ciklus epitafa u čast pojedinih žrtava sigetske bitke, koji će kasnije u cijelosti biti prenesen i u odabir iz Sirene.

I baš kao što je Pavao Ritter Vitezović, s jedne strane, bio uvjeren da će i u njegovoj viziji turskoga zauzeća Sigeta žene-čitateljice, između ostalog, zaintrigirati i ciklus pjesama ispjevanih u žanru većini njih dobro znanom još iz djelomičnoga prijepisa Adrijanskoga mora Sirene - i ujedno jednom od najpopularnijih baroknih lirskopjesničkih žanrova uopće, u

\footnotetext{
${ }^{1023}$ Pored nimalo upitne činjenice da je predodžbu o literarnim afinitetima ženske publike Vitezović najvećim dijelom stekao zahvaljujući onodobnim domaćim ostvarenjima namijenjenima (i) potencijalnim obrazovanim recipijenticama - počevši od izbora iz Adrijanskoga mora Sirene, preko tiskanoga (glavninom nabožnog) pučkoknjiževnog štiva, pa sve do anonimnih rukopisnih pjesmarica - prilično je vjerojatno da se sa specifično ženskim čitateljskim ukusom i potrebama bio on upoznao već tijekom svoga višegodišnjeg kavalierstoura Europom, i to posredstvom tadašnje inozemne pučkoknjiževne produkcije poput, primjerice, njemačkih $\mathrm{i}$ latinskih pučkih kalendara, pozamašan broj kojih je imao prilike prelistati u Valvasorovoj biblioteci u Wagenspergu, koja je posjedovala više od stotinu primjeraka takvih publikacija (usp. o tome u: Jembrih 2015: 531 i Hrgić 2015: 27-37).
} 
kojemu su, podsjetimo, tada ispisivane čitave pjesničke zbirke - tako je, s druge strane, bio i više nego svjestan da bi možebitno realiziranje Odiljenja u (,nepoćudnomu“) sekundarnom žanru povijesne epske pjesme značilo ne samo generičko svrstavanje uz ideološki neprimjerenu ,zrinijadu“ proizišlu iz pera jednoga veleizdajnika, nego ujedno i jasno fokusiranje na isključivo potencijalne muške čitatelje, koji su u to vrijeme i sačinjavali jedinu publiku epskopjesničkih djela. Ne ispuštajući iz vida ni jedne ni druge recipijente, Vitezović odabire prepoznatljivo epsku temu te niz (mahom sadržajnih) značajki iz repertoara (baroknoga) junačkog epa, no potom ih implementira u žanrovski izrazito hibridan tekst, $\mathrm{u}$ kojemu prisustvo obilježja maločas već primijećenih ,ženskih“ usmenoknjiževnih žanrova (naricaljka, ljubavna pjesma, poslovica itd.), nezanemariv broj ženskih govornika (vila Hrvatkinja, Sofija, Jeka i dr.) te naglašena osjećajnost koja proizlazi iz sadržajnog fokusiranja na mnogostruke i trajne rastanke jasno ukazuju na to da je krug njegovih recipijenata trebao biti vrlo širok te da je neizbježno morao uključivati kako čitatelje iz (pretežno) vojnoga „miljea“, tako i opismenjene čitateljice, i to - po mogućnosti - iz svih hrvatskih regija.

Također, ostavi li se po strani nekolicina detektiranih narativnih odjeljaka, u kojima u najkraćim crtama podsjeća na tijek kršćansko-muslimanskog okršaja za Siget, moglo bi se reći da se Vitezović u najvećem dijelu svoga hrvatskog prvijenca zapravo usredotočuje na neutralne, odnosno ,ideološki prazne“ momente sigetske bitke, što će reći ni manje ni više nego baš na one detalje (ratni govor kapetana suborcima i njihova zakletva, emotivni obiteljski rastanci, pismovni izvještaji kralju o tijeku opsade grada, očajne reakcije neutješnih zaručnica i supruga poginulih branitelja, pouke pokojnika s nadgrobnih ploča itd.) koji su suviše općeniti i univerzalni da bi se mogli protumačiti iz ove ili one ideološko-političke perspektive, što bi bila tek još jedna od mnogih njegovih tekstualnih strategija kojima ovomu samo u naznakama „epskomu“ ostvarenju pokušava privesti žensko čitateljstvo, a uz to još i otkloniti opasnost od toga da se prihvaćanjem ,epski“ cjelovite i dosljedne naracije ujedno generički nadoveže na inkriminirane epove braće Zrinski te tako stvori već unaprijed politički sumnjivo djelo. Na kraju krajeva, upravo su se ti ideološki neutralni detalji bitke za Siget Ritteru i nametnuli kao daleko najprikladniji za opjevavanje u generički razbarušenom, no istodobno i tematski iznimno homogenu tekstualnom okviru, koji je - kao takav - u pojedinih, mahom muških čitatelja lako mogao isprovocirati dojam ,punokrvn(ij)e epskosti“ (poglavito iz perspektive generički ionako prilično hibridiziranih baroknih epova), pa i usprkos činjenici što je u njemu stavljen naglasak redom na one momente kojima Petar Zrinski u Sireni nije držao nužnim ili naprosto nije mogao prepustiti više prostora, odnosno što se Vitezović u njemu samo ovlaš dotiče slijeda događaja pod sigetskim zidinama u ljeto 1566., ispravno 
pretpostavivši kako je ciljanoj publici on ionako dobro znan iz ranijih „zrinijada“ (dakako, primarno one Petrove) te stoga nema potrebe na nj iznova podsjećati, a time ni inzistirati na kompaktnoj i pravocrtnoj priči prožetoj ideologijom svojstvenoj „epskim“ obradama. ${ }^{1024}$

Rezultat Vitezovićeva osebujnog književnostvaralačkog pristupa temi junačkog otpora šačice kršćanskih (hrvatskih) branitelja Sigeta neusporedivo moćnijem osmanskom okupatoru bio je, dakle, žanrovski hibridna četverodijelna ,zrinijada“ rascjepkana u formalno nejednake samostalne lirske pjesme posvećene reperkusijama sigetske katastrofe što ih - također hibridnim, tronarječnim tipom hrvatskoga jezika - izgovaraju različiti kazivači iz posve različitih vremenskih dimenzija, koja je - takva kakva jest - lakoćom privlačila zanimanje prilično široke publike, odnosno opismenjenih recipijentica i recipijenata iz različitih čitateljskih krugova, a k tome još i - kako se čini - iz svih dijelova (velikim dijelom još uvijek okupirane) Hrvatske. Dobar odaziv toga vrlo šarolikog ciljanog čitateljstva - koji je, dakako, pratio isključivo prva dva, slobodnom raspačavanju namijenjena njegova izdanja - bio je, uostalom, reakcija koju je Ritter ne samo otvoreno priželjkivao, nego i zbog koje je silan trud uložio u sastavljanje po mnogočemu slojevitoga književnog teksta u isti mah prilagođenog kako visokoobrazovanim pojedincima, tako i literarnim nevježama, odnosno kako nejednako učenoj muškoj publici iz vojnoga staleža, tako i aristokratkinjama od kojih je većina primila tek znatno skromniju naobrazbu, a sve to imajući na umu važne izvanknjiževne zadaće koje je njime nakanio izvršiti. O kojim se to, konkretno, svrhama Vitezovićeva hrvatskog prvijenca radilo djelomično će nam dati do znanja već predgovor $K$ čtavcu prvoga mu, Adamu Zrinskom posvećenoga izdanja, u kojemu se naš autor - podsjetimo - ne libi izrijekom naglasiti kako ga je na objelodanjivanje ove „zrinijade“ ponukala želja da „slavni hrvatski jezik naš u tuliko pozabljenje ne dohodi da skoro vikovični (na jedno rečenje) domoroci materinskim jezikom dobro općiti i svaku rič pravim nje imenom spovidati ne mogu“" (Ritter Vitezović 1684). Posve identičnu svrhu svojega ostvarenja neće on potom propustiti eksplicirati ni u nepunih godinu dana „mlađem“, dakle fiktivnome „drugom“ njegovu izdanju, u predgovoru kojega - ovoga puta naslovljenom Prijaznivi štavče! - jasno ističe kako pjesničke tekstove što ih je u njemu okupio (tj. ,pisma mojega sprave“) zapravo „,ne na drugo nego jezika hrvatskoga uzdržanje i naroda ime upravlja[m]“ (Ritter Vitezović 1685), dočim će, pak, u oduljoj proznoj hrvatskoj posveti pukovniku Ivanu Andriji Makaru, pridodanoj

\footnotetext{
${ }^{1024}$ Ustvrdio je to - ne tako davno - u jednom od svojih „ritteroloških“ radova i Josip Bratulić, koji, polazeći od pretpostavke da je Pavao Ritter svoje Odiljenje sigetsko namijenio upravo „ljudima visokoga i skromnoga obrazovanja, jednako onima koji znaju čitati kao i onima koji znaju samo slušati“, također napominje da je redom bila riječ o recipijentima koji su „znali kako su se odvijali posljednji dani u Sigetu, pa zato ta povijesna zbivanja Vitezović ne opisuje, nego u svojem spjevu daje pojedinačne i rastrgane slike o posljednjim danima obrane“ (Bratulić 1994: 9-10).
} 
njegovu trećem - zagrebačkom - izdanju iz 1695., pripomenuti kako „ove pravične imenitoga vojništva i slavnoga viteštva spomenke, da se ne dotrgnu“ (Ritter Vitezović 1695), ${ }^{1025}$ iznova objavljuje tiskom, udovoljavajući time ponajprije zahtjevima ,viteških i razumnih ljudi““.

Ukratko, na temelju izjava što ih donosi u spomenutim paratekstualnim dionicama svih triju svojih izdanja Odiljenja sigetskog lako se uviđa da su Vitezovićeve izvanknjiževne nakane s ovom ,zrinijadom“ tako zapravo bile dvojake, točnije da je - s jedne strane njezinim ispisivanjem na „,̌istom“ (trodijalektalnom) vernakularu želio apelirati na važnost korištenja (suvišnih tuđica lišenoga) hrvatskog jezika kao jedinoga načina njegova očuvanja, a time i očuvanja hrvatskoga naroda u cijelosti (čiji identitet, pa onda i postojanje, uvelike ovisi i o ,vitalnosti“ zajedničkoga narodnog jezika), dočim je - s druge strane - sadržajnim fokusiranjem na pojedine momente kršćansko-muslimanskoga rata za Siget čitateljima ujedno htio skrenuti pozornost (i) na nužnost čuvanja uspomene na jedan od najznačajnijih događaja iz hrvatske povijesti uopće, koji - po njegovu sudu - također predstavlja važan „kamenčić“ u „mozaiku“ identiteta. Drugim riječima, kontekstualne ili situacijske zadaće što ih Ritter dodjeljuje svome djelu na prvi se pogled tako čine nimalo bliskima političko-propagandnim ciljevima kakve je trebala ispunjavati Petrova Sirena, no baš kao što su i zagovaranje uporabe „čistoga“ hrvatskog jezika i osnaživanje sjećanja na možda i najherojskiju epizodu iz domaće povijesti u jednakoj mjeri - kao što ćemo vidjeti - proizlazili iz jasnoga ideološkog opredjeljenja, tako se i posredstvom njih ustvari težilo isprovocirati (re)akcije koje su nužno iziskivale znatno širi, dakle društveno-politički konsenzus, koji je - barem kada govorimo o ideji zajedničkoga, naddijalektalnog hrvatskog jezika kao rješenja za jezičnu razjedinjenost Hrvatske - naposljetku ipak u potpunosti izostao.

Već 1684. Pavao je Vitezović tako shvatio da očuvanje hrvatskoga jezika ovisi isključivo o njegovoj uporabi u ,čistom“ - tuđicama nekontaminiranu - obliku, odnosno ni manje ni više nego upravo u onoj varijanti u kojoj će mjesto tuđica zauzeti istoznačnice iz drugih hrvatskih narječja, tvoreći tako općerazumljiv svehrvatski naddijalekt kadar da se prometne u zajednički hrvatski jezik koji istovremeno uvažava i odražava punu idiomsku raznolikost naših regija. I više nego svjestan činjenice kako dijalektalna šarolikost hrvatskih krajeva - usprkos tomu što doprinosi bogatstvu domaćega jezičnog fonda - bitno otežava, a katkad čak i posve onemogućuje međusobno razumijevanje njihovih žitelja, pa ujedno time i uvelike sužuje mogućnosti širenja (ionako ne odveć brojnih) idiomski nejednako ostvarenih književnih ostvarenja, ${ }^{1026}$ Vitezović izlaz iz takve jezično zamršene situacije vidi upravo u

1025 Cit. prema: Budišćak 2016b: 100.

1026 Podrobnije o tom problemu naše ranonovovjekovne književnosti u: Stipčević 2003: 285-296. 
širenju i prihvaćanju tronarječne inačice vernakulara kao svehrvatskoga jezika ili medija kojim bi bilo moguće premostiti nemale (dijalektalne) regionalne razlike, odnosno napokon povezati hrvatski Sjever i Jug te tako stvoriti temelje za prilično izgledno buduće prostorno ujedinjenje ili obnavljanje (,oživljavanje“) Hrvatske, o kojemu je - zahvaljujući postupnom slabljenju moći Osmanlija i sve većim ratnim uspjesima udruženih kršćanskih snaga - već tih godina očito ozbiljno bio razmišljao. Pojednostavljeno rečeno, dobro znajući da je ,regionalna rascjepkanost tadašnje hrvatske književnosti uvjetovana povijesno, ali i jezično (afirmacijom više dijalekata u službi književnog jezika), on izlaz vidi u jezičnoj sintezi“" (Vončina 1976a: 351), pokušavajući tako već i posredstvom Odiljenja svoje sunarodnjake potaknuti na to da „govore istim jezikom bez obzira na dijalektalne razlike“ (Moguš 1986: 148), i to vodeći se mišlju da razlikama u narječjima - kako, uostalom, u predgovoru prvog izdanja otvoreno i naglašava - nipošto ne bi trebalo pristupati kao zaprekama u razumijevanju teksta, nego baš kao izvrsnoj prilici da se „nauče i izričaji udomaćeni u drugim sredinama“ (Isto: 148) te tako bitno proširi vlastiti leksički fond.

Želeći njime ponajprije predstaviti i potaknuti širenje tronarječnoga (sve)hrvatskog jezika kao odgovor na sve primjetnije zapostavljanje vernakulara te stoljetnu dijalektalnu razjedinjenost hrvatskih regija, Pavao Vitezović svoje će Odiljenje ciljano protkati nizom tekstualnih strategija i rješenja kojima pogađa ukus i ispunjava očekivanja recipijenata raznolikoga čitateljskog profila, počevši od mahom muške visokoobrazovane i na kanonskim literarnim djelima „stasale“ publike, pa sve do znatno skromije (gdjekad i samo bazično) obrazovanoga muškog, ali i ženskog čitateljstva, čija se lektira pretežno svodila na pučkoknjiževno nabožno štivo, anonimne rukopisne pjesmarice te rukopisne izbore iz većih (glavninom epskopjesničkih) ostvarenja. Što se daleko najbrojnije, dakle muške publike iz redova vojnoga staleža tiče, Vitezoviću je - kao i njegovu najvećem literarnom uzoru - ona bila na prvomu mjestu poradi važnih izvanknjiževnih razloga, no za razliku od Petra Zrinskog, koji joj se Sirenom obraćao ne bi li je upoznao s političkim programom protuhabsburške urote te među njom u konačnici stekao i istomišljenike, pa i buduće suučesnike u urotničkim aktivnostima, našem je autoru do privlačenja njezine pozornosti bilo stalo isključivo zbog jezično-obnoviteljskih ciljeva, točnije zato što je vjerovao da će prihvaćanje novoga hrvatskog jezika među (ponajprije) vojnicima iz svih krajeva Hrvatske dovesti kako do nadvladavanja (jezičnih) barijera među njima, pa onda i ojačavanja njihova osjećaja dužnosti služenja vlastitoj domovini, tako i do lakšega širenja toga istog svehrvatskog jezika na netom oslobođenim područjima. Potonje očekivanje Ritter je - očito poučen i vlastitim ratničko-vojničkim iskustvima - temeljio na dobro poznatoj spoznaji o tome kako 
pobjednička (osvajačka ili oslobodilačka) vojska na prisvojenom području uvijek iznova uspostavlja svoj identitet, kojega je važan dio i jezični aspekt, iz čega bi slijedilo da i oslobođenje stoljećima okupiranih hrvatskih teritorija, između ostalog, ujedno pretpostavlja i ponovno širenje (zajedničkoga) hrvatskoga jezika među žiteljima tih prostora, a taj je jezik po njegovu mišljenju - morao biti upravo trodijalektalna stopljenica, a ne tek jedna od triju njegovih idiomskih varijanata. Polazeći od uvjerenja da teritorijalna cjelovitost oslobođene ili - kako će je nazivati u svojim kasnijim povijesnim spisima - „čitave“ Hrvatske (tota Croatia) ne znači mnogo bez narodnoga, a time i jezičnog ujedinjenja, Vitezović implicitno daje do znanja kako bi i u područjima koja će uskoro biti oslobođena turske vlasti valjalo proširiti upravo svehrvatski ili naddijalektalni jezik jer je isključivo posredstvom jezičnoga zbližavanja (dakako, uz pretpostavku da mu prethode junački ratni podvizi po uzoru na one Nikole Šubića Zrinskog i sigetskih branitelja), a potom i održavanja sjećanja na slavne ratničke događaje iz hrvatske prošlosti naposljetku moguće postići „oživljavanje“ Hrvatske, o kojemu je - kako se čini - već u toj svojoj mladenačkoj stvaralačkoj fazi itekako on bio ozbiljno razmišljao.

Izuzev muške publike različitoga stupnja obrazovanja i nejednakoga književnog predznanja, Odiljenje sigetsko paralelno se obraćalo i ženskomu, nešto slabije obrazovanom čitateljstvu iz (pretežno) velikaških krugova, među kojim je - ne smije se zaboraviti - bilo i autorica, točnije prevoditeljica i prirediteljica nabožnih knjižica za širi puk. Pouzdajući se u to da će njegova „zrinijada“, između ostalih, naći put i do nekolicine supruga onodobnih aristokrata, koje su - poput Katarine Zrinski i Marije Magdalene Drašković ${ }^{1027}$ - iskazivale afinitete spram sastavljanja religioznoga, glavninom molitveničkog štiva za praktičnu (djelomice i liturgijsku) namjenu, Vitezović je, kako se čini, bio čvrsto uvjeren da će makar neka od njih (izuzev Katarine, koja je trodijalektom već realizirala svoj molitvenik) usvojiti svehrvatski jezik kojim je ispjevao Odiljenje te da će se potom tim istim jezikom možda i sama odvažiti napisati ili prevesti (još jedno) pučkoknjiževno nabožno ostvarenje i tako pridonijeti njegovu širenju osobito među neukijim čitateljstvom. Interes čitateljica iz najviših društvenih slojeva, koji je stoga lako mogao rezultirati prihvaćanjem novoga jezičnog rješenja, u tom je smislu značio da su se s naddijalektalnim tipom zajedničkoga jezika dospjele upoznati cjelokupne velikaške obitelji, što će reći da su se u njegovu poznavanju muževima, očevima i braći, koji su jednu od njegovih inačica mogli pročitati već u Petrovoj Sireni pridružile i supruge, kćeri i sestre možebitno lišene iskustva čitanja također tronarječnoga Katarinina Putnog tovaruša, što - uostalom - i jest bio jedan od ciljeva Pavla

${ }^{1027}$ Molitvenik Sobotni kinč Marije Magdalene Drašković, štoviše, 1696. Pavao će Vitezović osobno otisnuti u zagrebačkoj Zemaljskoj tiskari kojom je tada upravljao. Podrobnije o tom molitveniku u: Tvorić 2013: 81-82. 
Vitezovića, koji je priželjkivao da poglavito u aristokratskim domovima novim hrvatskim jezikom progovore kako muški (pripadnici vojnoga staleža), tako i ženski članovi obitelji.

Kao i njegovi literarni prethodnici, koji su „kontaminiranje“ dijalektalne osnovice svojih djela elementima iz drugih narječja vidjeli kao učinkovitu strategiju za proširivanje kruga potencijalnih čitatelja, i Pavao Ritter Vitezović tronarječnu se jezičnu mješavinu kao rješenje za budući jedinstveni hrvatski jezik (a onda i kao „mamac“ za publiku iz svih hrvatskih regija) odlučio zagovarati ponajprije ponesen zamislima tada iznimno raširene ideologije slavizma, utjecaj koje je u njegovu pisanom stvaralaštvu, podsjetimo, moguće pratiti gotovo od (kronološki) prvoga mu do posljednjeg - rukopisnog i tiskanog - ostvarenja. Naime, upravo je barokni slavizam našim sedamnaestostoljetnim piscima, između ostalog, osnaživao „nacionalnu i književnu svijest vjerom u veću publiku“ (Slamnig 1965: 168), s mišlju na koju su se mnogi od njih - pa tako i sam Ritter - angažirali oko standardizacije, odnosno traženja najprihvatljivijega rješenja za zajednički hrvatski jezik kao jedan od važnih temelja budućega svehrvatskog jedinstva. Kada je riječ o Vitezoviću, ne treba zaboraviti ni to da je on, pored predlaganja trodijalekta ozaljskoga književnojezičnog kruga kao hrvatskoga standarda, u predgovoru $K$ čtavcu prvoga izdanja Odiljenja sigetskog - također „tipično“ baroknoslavistički - udario i temelje buduće reforme (sve)hrvatskoga pravopisa (bazirane na načelu bilježenja jednoga glasa jednim znakom), i to potaknut ne samo jezičnom, već i pravopisnom razjedinjenošću hrvatskih regija, koja se počela očitovati kao sve krupniji problem uoči sve izvjesnijega „oživljavanja“ Hrvatske.

Nada u takav ishod Rittera je nagnala da se - kao jedan od naših najustrajnijih praktikanata slavističkih ideja - već prilikom rada na Odiljenju usredotoči kako na razrađivanje nove hrvatske grafije, tako i na propagiranje zajedničkoga hrvatskog jezika satkanog od riječi iz svih triju hrvatskih narječja i u potpunosti očišćenoga od već duboko ukorijenjenih tuđica, koje se u njegovoj varijanti nadomještaju brojnim domaćim sinonimima iz različitih narječja, a sve s ciljem da se čitatelju skrene pažnja na (u praksi prečesto zanemarivano) leksičko bogatstvo hrvatskoga jezika i njegovu ljepotu, ali i da ga se ujedno pouči kako dijalektalne razlike nisu i ne bi trebale biti smetnja pri recepciji (književnih) tekstova, već upravo poticaj za usvajanje riječi iz drugih narječja. I dok u Odiljenju tako na vlastitom primjeru recipijentima demonstrira učinkovitost strategije eliminiranja bespotrebnih tuđica lijepim domaćim riječima iz svih triju dijalekata, za niz drugih porijeklom stranih riječi i izraza ipak mu neće poći za rukom iznaći hrvatske ekvivalente, što ga nipošto neće spriječiti u tome da ih zamijeni podjednako lijepim hrvatskim istoznačnicama, i to ni manje ni više nego novokovanicama (novotvorenicama) kojih se sam za tu priliku domislio. U tom bi se 
smislu s punim pravom moglo ustvrditi kako je Pavao Ritter - usprkos činjenici da će svoj pankroatistički (u suštini, dakako, baroknoslavistički) politički program razraditi i „službeno“ predstaviti tek pri kraju posljednjega desetljeća 17. st. - već u prvoj polovini osamdesetih godina ozbiljno razmišljao o ujedinjenju ili „oživljavanju“ Hrvatske, koje mu se, poglavito nakon katastrofalnoga poraza Turaka pod bečkim zidinama 1683., iz dana u dan počelo činiti sve ostvarljivijim i uopće sve bližim. ${ }^{1028}$

Propagiranje novoga, trodijalektalnog jezika lišenog „nataloženih“ tuđica kao budućega hrvatskog jezičnog standarda, a usto i (naznaka) reformiranoga hrvatskog pravopisa, i to u tekstu u kojemu se eksplicitno glorificiraju herojski podvizi sigetskoga kapetana, ali pored njih implicitno i povijesne zasluge čitave obitelji Zrinski, nipošto - kao što je utvrđeno maločas - ne predstavlja jedinu izvanknjiževnu svrhu Ritterova hrvatskog prvijenca. Naprotiv, podjednako tekstualno i paratekstualno isticanje važnosti upamćivanja, odnosno prisjećanja junaštava malobrojnih sigetskih branitelja koji su se suprotstavili višestruko moćnijim osmanlijskim osvajačima jasno upućuje na to da su Vitezovićeve kontekstualne nakane po pitanju Odiljenja bile daleko „slojevitije“ te da su išle u smjeru kako zagovaranja zajedničkoga (sve)hrvatskog jezika i jedinstvene grafije, tako i osvježavanja uspomene na jedan od najupečatljivijih događaja u hrvatskoj povijesti i njegova centralnog aktera, a sve to u trenucima u kojima je loš glas što ga je nakon propasti protuhabsburške urote stekla čitava porodica Zrinski uvelike priječio objektivno sagledavanje stvarnoga značaja žrtve koju su Nikola Šubić i njegovi suborci podnijeli u želji da Osmanlijama otežaju naoko lako osvajanje strateški važne kršćanske utvrde. Vitezovićeva težnja da svojom „zrinijadom“ pridonese ne samo širenju jedinstvenoga hrvatskog jezika, nego i (ponovnom) buđenju - u njegovoj viziji pogrešnom ideologijom neopterećenih - sjećanja na sigetska junaštva kapetana Zrinskog, koja bi po svemu mogla i morala postati (i) uzorom suvremenih protuturskih akcija, očitovat će se tako već na nekoliko mjesta unutar samoga njezina teksta, u kojemu najeksplicitnije izražene motive sjećanja na opsadu Sigeta nose pjesme Siget hrvatskim gospojam (I: 1-477), Ban orsagu (II: 93-117), Orsag banu (II: 118-146), Ban Sigetu (II: 147-189) Siget banu i vojnikom (II: 361-439) te Putnik i Jeka (III: 1-376). ${ }^{1029}$

\footnotetext{
1028 Znatno detaljnije o Vitezovićevim jezikoslovnim naporima, a poglavito o njegovu radu na uređenju hrvatskoga pravopisa, odnosno o koncepciji njegove grafijske reforme utemeljene na zamisli o bilježenju svakoga fonema ili glasa isključivo jednim slovom ili (mono)grafemom npr. u: Moguš 1974: 73-79 i 2009: 99103, Putanec 1986: 349-356, Vajs i Meštrović 2009: V-LXIII.

${ }^{1029} \mathrm{Na}$ nužnost trajnoga upamćivanja neustrašivoga otpora sigetskih branitelja osvajačkoj turskoj vojsci u pobrojanim će tako pjesmama izrijekom upućivati motivi „spomena“ ili neprolazne (književno posredovane) uspomene na slavne sigetske trenutke, od kojih prvi zatječemo ni manje ni više nego već u uvodnoj heroidi Siget hrvatskim gospojam, koju njezin pošiljatelj - personificirani Siget - zaključuje obećanjem adresatkinjama kako nikada neće dopustiti da se sjećanje na „hrabreni rat“ olako zatre („Ni noći ni danka neću ja pustiti / od toga
} 
Pobrojanim tekstualnim isticanjima važnosti čuvanja uspomena na častan poraz brojčano osjetno inferiornije kršćanske čete pod zidinama Sigeta u Odiljenju će prethoditi i još izravnija paratekstualna Vitezovićeva plediranja za trajno održavanje sjećanja na ovaj neizmjerno važan trenutak iz hrvatske povijesti, upamćivanje kojega - po njegovu implicitnom sudu - ujedno znači i potvrđivanje i učvršćivanje hrvatskoga nacionalnog identiteta. S izuzetkom latinske posvetnice i hrvatskoga predgovora fiktivnoga „drugog“ izdanja, u kojemu takva očitovanja ne nalazimo, (i) memorijalne funkcije svoje „zrinijade“ Pavao će se Ritter eksplicitno tako dotaknuti već u latinskoj posvetnoj pjesmi Adamu Zrinskom prvoga njezina izdanja, u kojoj Nikolu Šubića Zrinskog - proglasivši ga „Hektorom sigetske snage“ - uspoređuje s nizom drugih junaka protuturskih ratova (Skenderbegom, Kraljevićem Markom, Novakom Debeljakom i Kobilićem), pripominjući kako je i on svojim junaštvima zaslužio vječnu slavu, odnosno trajno divljenje kasnijih pokoljenja, kojemu se, eto, ,prvinama svoga pjesničkog ploda“ $i$ on sam sada dostojno pridružuje. ${ }^{1030}$ Jedanaest godina kasnije, čuvanja uspomene na bitku za Siget kao jedne od osnovnih svrha svoga književnog prvijenca Vitezović će se dotaknuti i u zamašnoj proznoj posveti na vernakularu trećega njegova izdanja, u kojoj - podsjetimo - otvoreno ističe kako „ove pravične imenitoga vojništva i slavnoga viteštva spomenke“ iznova objelodanjuje, i to potaknut željom „da se ne dotrgnu“ (Ritter Vitezović 1695), odnosno da se ne zaborave, a na intenciju Odiljenja da potiče (pri)sjećanje na sigetske vitezove potom će se dodatno još pozvati i na samom kraju posvete pukovniku i sudioniku konačnoga oslobođenja Sigeta Ivanu Andriji Makaru. ${ }^{1031}$

\footnotetext{
rastanka spomen ne imiti. / I ki bude iti putnik mimo mene, / š njim ću govoriti od rati hrabrene“; I: 471-474). U heroidi, pak, upućenoj personificiranoj domovini ili „orsagu“ ban će Zrinski - neposredno uoči pogibije - od sunarodnjaka zatražiti da se sigetske bitke prisjećaju u svojim molitvama (,spomen 'z nas imajte u svetom moljenju“; II: 113), da bi već u sljedećoj pjesmi - zamišljenoj kao pisani odgovor „orsaga“ banu - ta ista personificirana domovina banu obećala kako njegovi ratni podvizi nikada neće iščeznuti iz sjećanja hrvatskoga naroda, i to ponajprije zahvaljujući pjesmama koje se njemu i njegovim suborcima u čast već sastavljaju na svim stranama svijeta (,Trud tvoj, gospodine naš hrvatski bane, / navik mnoge cine v spomenu ostane, / pisme ti se čine na sve svita strane“; II: 144-146). Gotovo identičnim riječima kojima je od svojih sunarodnjaka („orsaga“) tražio da ga ne zaborave Zrinski će mjesto u kolektivnome pamćenju pokušati izmoliti i u pjesmi Ban Sigetu, zahtijevajući ondje od personificirana Sigeta da održava uspomenu na njega i njegove suborce (,'z mene se spomeni i 'z moje družine“; II: 178), dok će - s druge strane - kazivači pjesama Siget banu i vojnikom (Siget) te Putnik i Jeka (Putnik) na trajni „spomen“ kojega su stekli sigetski branitelji na čelu s Nikolom Šubićem aludirati motivom pjesama što se u njihovu čast pjevaju na različitim jezicima (,Svakoga jezika pisam zaslužiste“; II: 415), odnosno koje je za njih - neposredno po završetku opsade - ispjevala sama „gospoja Vila“ (,Ka im je gospoja zelen venac zvila / i pisam od boja njim spravila? Vila“; III: 363-364). Detaljnije o motivu (pri)sjećanja u samom tekstu Vitezovićeva Odiljenja u: Budišćak 2016a: 274-276.

${ }^{1030}$ Usp. Ritter Vitezović 1684. Usp. i Vratovićev hrvatski prijevod navedene posvetnice u: Zrinski, Frankopan i Ritter Vitezović 1976: 359-360.

1031 Pripomenu o Odiljenju kao ostvarenju čiji je cilj iniciranje sjećanja na tursku opsadu i zauzeće Sigeta Vitezović će tako ponoviti i u zaključnom dijelu posvete, u kojemu Makara moli da njegovu „knjižicu“ uzme pod zaštitu da se ,po njoj svetih onih grada sigetskoga braniteljov vridan vojništva glas i viteštva spomen, kojega oni i s turskom obilno, i svojom do kaplje krvjom na zemlji materi, prosto i prez reda i onoj teškoj silnoga boja nepriliki za znamenovaše, nigdar ne dotrgne“ (Ritter Vitezović 1695; cit. prema: Budišćak 2016b: 102).
} 
Kako bilo, upravo u želji da se ratni događaji što su se zbili pod zidinama Sigeta u ljeto 1566. (sada napokon lišeni neprimjerenoga ideološkog „balasta“ kakvim ih je opteretio Petar Zrinski) jednom za svagda vrate u sjećanje (šire) publike kao možda i naslavnija epizoda iz domaće povijesti, koja predstavlja ne samo važan kamenčić u mozaiku hrvatskoga nacionalnog identiteta, nego i koja se - zahvaljujući ponajprije mučeničko-herojskoj figuri Nikole Šubića Zrinskog - može i treba nametnuti kao obrazac u moralno-etičkom i vojnom smislu za buduće protuturske akcije, Pavao Vitezović sastavlja žanrovski slojevitu „zrinijadu“ skrojenu od tekstualnih postupaka i značajki raznolike provenijencije, kojima je čini primamljivom izuzetno širokom rasponu recipijenata, počevši od visokoobrazovanih aristokrata, preko nešto slabije učene ženske publike iz istoga društvenog sloja, pa sve do opismenjenoga, no tek bazično obrazovanog „puka“, zadojenog na usmenoknjiževnomu stvaralaštvu i pučkom, mahom nabožnomu štivu. Štoviše, osjetivši da je kucnuo pravi trenutak da se - uslijed ubrzanoga slabljenja turske moći - „zbiju redovi“, odnosno da se njegovi sunarodnjaci angažiraju u oslobodilačkim akcijama i obnoviteljskim zadaćama na do još jučer okupiranim područjima, Ritter piše literarnu viziju sigetske katastrofe kojom u kolektivnu memoriju vraća - od nepoćudnih ideološko-političkih silnica „dekontaminirano“sjećanje na junački otpor Sigećana predvođenih banom Zrinskim, a sve ne bi li potencijalne čitatelje potaknuo kako na fizičku, tako i na duhovnu obnovu Sigeta kao (pre)važnoga i u tom smislu nezaobilaznoga „mjesta pamćenja“. ${ }^{1032}$ Naime, imaju li se u vidu izrijekom navedene izvanknjiževne funkcije koje mu je pridao, ali i - još više - sam kontekst ili društvenopovijesna situacija unutar koje ga je ispjevao i objelodanio, postat će prilično jasno da je već Odiljenje Vitezović zamislio kao tekst koji je trebao vršiti (i) obnoviteljskooživljavateljske zadaće, odnosno koji je trebao apelirati na ciljane čitatelje da, nakon povlačenja osmanlijskih okupatora, daju svoj (fizički i/ili duhovni) doprinos doslovnom dizanju Sigeta ,iz pepela“, svjesni pritom da je riječ o jednom od ključnih mjesta (kulturnoga) prisjećanja, koje ne samo što čuva uspomenu na slavan (i uzoran) događaj iz domaće povijesti, već se - kao takvo - ujedno ispostavlja i jednim od bitnih uporišta hrvatskoga nacionalnog identiteta uopće.

S takvom kontekstualnom svrhom na umu, naš je autor temu Sigeta najprije lišio ideološko-političkih „okova“ kojima ju je sputao njegov književni prethodnik, a potom je i istrgnuo iz čvrstoga epskopjesničkog ,zagrljaja“ u kojemu je dotad počivala, jasno nagovješćujući (i) tim novim - ili makar samo naizgled novim - generičkim okvirom kako njegov pristup ovome već višestruko književno obrađenom događaju teži biti iz temelja 
drugačiji, i to ponajprije u odnosu na onaj Petra Zrinskog. Neepski ili tek poluepski pristup temi sigetske katastrofe i njezinih reperkusija bio je - znao je to Vitezović - neizbježan ukoliko se Odiljenjem kanilo barem pokušati povratiti uvelike poljuljanu reputaciju obitelji Zrinski, i to upravo posredstvom glorificiranja žrtve što ju je, braneći strateški bitnu kršćansku utvrdu uime ,viših ideala“, podnio njezin daleko najistaknutiji predstavnik, čija su junaštva i herojska smrt pod bedemima Sigeta u konačnici i same čitatelje trebali motivirati da, slijedeći njegov primjer, i osobno sudjeluju u ratnim akcijama za oslobađanje Sigeta i njegovoj obnovi te mu na taj način povrate onaj povijesno-memorijalni značaj koji mu - kao utvrdi u obrani koje su Hrvati i dali najveći doprinos - bez ikakve dvojbe i pripada. Dapače, da bi još uočljivije podcrtao taj nemjerljivi značaj što ga (još uvijek okupiran i najvećim dijelom razoren) Siget ima za hrvatski nacionalni identitet, ${ }^{1033}$ Vitezović ne samo što u Odiljenju neprekidno ističe kako je njegovu obranu predvodila jedna od najvažnijih figura u hrvatskoj povijesti uopće, nego i - kako je nešto ranije već bilo primijećeno - inzistira na pohrvaćivanju redom svih sigetskih branitelja, odbijajući pritom makar jednom riječju spomenuti i ulogu mađarskih vojnika (određen broj kojih je, potvrđuju to povijesne činjenice, također dao nimalo nebitan obol obrani), a uz to i forsira apostrofiranja „hrvatskosti“ Sigećana od strane inih govornika, poglavito personificirana Sigeta, koji u svojim iskazima ne prestaje isticati kako su se za njega do posljednje kapi krvi borili nitko drugi nego upravo ,ljubljeni Hrvati“ (I: 18), „Hrvati hrabreni“ (II: 431), „hrvatske hrabrosti“ (II: 446), odnosno „,brati (...) i sini“ (I: 5) te „dragi ljubovnici“ (I: 392) onih istih „gospoja hrabrenih i hrvatskih vila“, epistolarnim obraćanjem kojima se Odiljenje i otvara.

Baš iz razloga što su ne samo najveće, nego i jedine zasluge u njegovoj - na koncu ipak neuspješnoj - obrani imali Hrvati (koji su jedini i bili dovoljno hrabri odazvati se Sigetovim pozivima upomoć), na potomke tih se istih junački izginulih Hrvata u Odiljenju sigetskom i apelira da još jednom ,,pomognu“ Sigetu, implicitno im pritom dajući do znanja kako je za to napokon došao stigao pravi čas, odnosno kako je baš sada - dakle, u trenucima objelodanjivanja teksta - najbolje vrijeme da se ostvari već spomenuto proročanstvo što ga $u$

\footnotetext{
1033 Da je upravo u (graničnim) utvrdama vidio izuzetan simbolički potencijal kada je hrvatski nacionalni identitet u pitanju - točnije, da ih je shvaćao kao simboličke nositelje nacionalnoga identiteta - Pavao Ritter Vitezović najočitije će demonstrirati u već višestruko spomenutoj kronici u stihu Dva stoljeća uplakane Hrvatske, u kojoj najveću sadržajnu važnost posvećuje ni manje ni više nego opisima domaćih graničnih utvrda, točnije njihova postupnog prelaženja u turske ruke. Ukratko, s obzirom na to da su utvrde - iz njegove perspektive - kotirale kao jedno od najbitnijih uporišta hrvatskoga identiteta, u tom je smislu i njihovo oslobađanje i obnova predstavljalo ništa drugo no obnovu jednoga važnog dijela nacionalnoga identiteta, i to ne samo zato što je u okružju mnogih od njih - kao što je to bio slučaj (i) sa Sigetom - doslovno pisana hrvatska povijest, nego i iz razloga što „u tradicionalnoj zapadnoj simbolici“, za kojom se naš autor uvelike i povodi, „grad redovito znači ponajprije zaštićenost i sigurnost, a potom civiliziranost, sofisticiranost i religioznost"“ (Blažević 2003: 204).
} 
heroidi Kralj Sigetu habsburški kralj Maksimilijan II. daje Sigetu, uvjeravajući ga kako će ne tako daleko u budućnosti kucnuti čas kada će „ki lav doći od moga kolina, / koji hoće zmoći i prognat Turčina“ (II: 479-480). Vjeru u pozitivan ishod toga ,proreknutog“ oslobodilačkog rata ciljanim je čitateljima Ritter, k tome, pokušao pobuditi i implicitnim podsjećanjem na „stvarno stanje“ osmanske sile nakon teškoga poraza što ju je doživjela 1683. pod Bečom, i to ni manje ni više nego osjetnim ublažavanjem slike Turaka u sva četiri dila svoje „Zrinijade“, ${ }^{1034}$ kojim je želio dati do znanja kako ovaj vjekovni hrvatski i uopće kršćanski neprijatelj iz dana u dan predstavlja sve slabiju prijetnju budući da je njegova (vojna) moć u postupnom opadanju, zbog čega mu i prijeti definitivni poraz te protjerivanje iz ovoga dijela Europe. Poticaj za vraćanje Sigeta u kršćanske ruke te njegovo „oživljavanje“ kao važnoga hrvatskog memorijalnog mjesta Pavao Ritter recipijentima svoga vernakularnog prvijenca pritom nudi u uvjerenju kako upravo Hrvati i imaju (ili bi trebali imati) daleko najveća „prava“ na utvrdu koja se formalno nalazi unutar granica Ugarske, no koja zapravo predstavlja jedno od ključnih mjesta (pri)sjećanja za hrvatski narod, i to kako zbog povijesne činjenice da su u pokušaju njezine obrane 1566. upravo hrvatski vojnici pod vodstvom hrvatskoga bana odigrali možda i ključnu ulogu te podnijeli najveću žrtvu, tako i zbog (nimalo sporne) spoznaje da upravo Hrvati - za razliku od literarno znatno manje ambicioznih Mađara - u svojoj (pisanoj, usmenoj i pučkoj) književnosti brižno čuvaju sjećanje na tu važnu protutursku ratnu epizodu, jednu od brojnih hrvatskih literarizacija koje se - eto - sada odvažio potpisati i on sam. Osvješćivanje toga nedovoljno prepoznatoga memorijalnog „potencijala“ Sigeta stoga bi se i moglo izdvojiti kao temeljni razlog poradi kojega naš autor u Odiljenju u tolikoj mjeri i inzistira na čuvanju sjećanja na zalaganje hrvatskih branitelja u sigetskoj bitci, a sve to s konačnim ciljem ne bi li (i) „svijetu“ pokazao i dokazao da Siget makar u duhovnom smislu - pripada upravo Hrvatskoj te da bi, u tom smislu, nitko drugi nego baš Hrvati trebali dati najveći doprinos njegovu „oživljavanju“, što će reći ponajprije obnavljanju sjećanja na njegovu važnost, a onda i oslobađanju i obnavljanju u fizičkom smislu, možda čak i s ciljem njegova pripajanja budućoj ,cjelovitoj“ Hrvatskoj (tota Croatia), uvjeti za postojanje koje će se steći nakon što se Turci i definitivno povuku s ovih prostora.

$\mathrm{Na}$ temelju svega dosad utvrđenog, neće biti ishitreno konstatirati kako se već Odiljenje sigetsko nameće kao baš ono Vitezovićevo ostvarenje u kojemu razabiremo prve obrise njegove - u kasnijim tekstovima potanko razrađene - ideje „,̌itave“ ili „oživljene“ 
Hrvatske, ${ }^{1035}$ na koju ovdje neodoljivo podsjeća upravo intencija da se Siget predstavi kao Hrvatima osobito važan, ako ne i posve hrvatski lokalitet, čija „hrvatskost“ proistječe ponajprije iz činjenice da čuva uspomenu na važnu epizodu iz višestoljetne povijesti hrvatskoturskih vojnih sukoba, odnosno da su u njegovu obranu svojedobno bili stali (isključivo) hrvatski branitelji, iskazavši onu istu odlučnost i neustrašivost s kojom su hrvatski vojskovođe kroz povijest ulazili u okršaje s Turcima, što i jest razlog radi kojega događaji pod Sigetom iz ljeta 1566. zaslužuju da budu upamćeni u hrvatskomu narodu te da se upravo Hrvati angažiraju na njegovu konačnom oslobođenju te materijalnom i duhovnom „dizanju iz pepela“. To „prisvajanje“ utvrde koja se - geografski gledano - već stoljećima nalazi(la) na ugarskomu tlu pritom bi nas neodoljivo moglo i moralo podsjetiti na dva desetljeća „mlađu“ Ritterovu praksu, uslijed koje će se - vođen utopijskim „oživljavateljskim“ (u suštini velikohrvatskim) nakanama - upustiti u dokazivanje (nepostojećega) hrvatskog porijekla stranih kraljeva i svetaca, i to mađarskoga kralja sv. Ladislava (u povijesnoj raspravi Natales Divo Ladislavo Rege Slavoniae Apostolo Restituti iz 1704.) te dukljanskoga kralja sv. Vladimira (u hagiografiji Vita et martyrium B. Vladimiri, Cratiae regis iz 1705.), a sve ne bi li (i) time dokazao da se Hrvatska proteže daleko onkraj granica unutar kojih je koncem 17. stoljeća bila (silom prilika) svedena. Na kraju krajeva, ozbiljno računajući sa skorim „oživljavanjem“ Hrvatske, Vitezović u Odiljenju predstavlja i tronarječni hibrid kao rješenje za zajednički hrvatski jezik, koji je po njegovu mišljenju bio jedan od neizostavnih čimbenika svehrvatskoga ujedinjenja i poradi kojega, da bi ga uzmogao što lakše proširiti, svoju „zrinijadu“ realizira kao djelo u kojemu se susreću obilježja gotovo svih (važnijih) žanrova zastupljenih u žanrovskim sustavima četiriju naših onodobnih književnih krugova te gotovo svi poznati stihovi ranonovovjekovne hrvatske književnosti, a sve s ciljem da bi povećao šanse da će doprijeti do publike s čitavoga prostora Hrvatske, i to posve neovisno od dosegnutoga stupnja naobrazbe te prethodnoga književnog iskustva, afiniteta i očekivanja.

Dapače, sama žanrovska višeslojnost pritom se i nameće kao daleko najbjelodaniji pokazatelj usmjerenosti Odiljenja sigetskog publici vrlo raznolikoga čitateljskog profila, što će reći recipijentima iz svih dijelova Hrvatske, i to bez obzira na njihov spol, stalež, a time i stupanj obrazovanja što su ga dosegnuli te ranija literarna iskustva koja posjeduju. Kao daleko najvažniji Vitezovićev putokaz pri sastavljanju takve, vrlo širokom čitateljstvu namijenjene „zrinijade“ ispostavila se - dakako - u svim onodobnim hrvatskim regijama također rado čitana Adrijanskoga mora Sirena, ponajviše zahvaljujući kojoj će naš autor i shvatiti da nije

1035 Da upravo u Odiljenju sigetskom Ritter donosi nacrt svoga budućeg nacionalno-političkog, pankroatističkog programa, nedavno su zamijetili i Andreja Sršen i Davor Piskač (usp. Sršen i Piskač 2016: 221-222). 
nemoguće ispjevati tekst koji svoje čitatelje nalazi i izvan granica kulturnoga kruga unutar kojega je nastao, ali i na koju će se (i) stoga u tolikoj mjeri - glavninom sadržajno, ali i formalno - u Odiljenju i nadovezivati, ozbiljno računajući na to da će publika Petrova ostvarenja lakoćom prepoznati iz njega preuzete elemente te tako i sama proniknuti $u$ „podtekst“ osebujnoga mu hrvatskog književnog prvijenca. Shodno tomu, definitivno bi se moglo ustvrditi kako Vitezović Odiljenjem sigetskim zapravo kroči onim istim putovima što ih je svega nekoliko desetljeća ranije svojom popularnom Sirenom bio prokrčio Petar Zrinski, koji ne samo što njezinom tronarječnošću (s osnovicom u čakavskom dijalektu) uvelike „pripravlja teren“ za kasnije otvorene pokušaje zagovaranja naddijalekta kao zajedničkoga hrvatskog jezika (kakav će u Odiljenju iznijeti i sam naš autor), nego ujedno i rabi mnoga od onih žanrovskih rješenja karakteristikama kojih će četvrt stoljeća kasnije Ritter obilato puniti pjesme svoje ,zrinijade“. Poput književnoga prethodnika i najvećeg uzora, i Vitezović će tako - u želji da Odiljenje učini primamljivim podjednako sjeverno- i južnohrvatskoj publici, odnosno visokoobrazovanim i znatno skromnije obrazovanim čitateljima - prizivati kako usmenoknjiževne (poslovica, bugaršćica, elementi „narodne“ lirske i epske pjesme itd.), tako i pisanoknjiževne žanrove, i to imajući u vidu nimalo zanemarive razlike između generičkih sustava tadašnjih književnih krugova ili kulturnih regija, odnosno trudeći se u tekst uklopiti značajke makar nekih iz palete najomiljenijih žanrova naših sedamnaestostoljetnih kako sjevernih (heroida, molitva, propovijedni elementi itd.), tako i južnih pisaca (epskopjesničke značajke, lament, konzolacija, alegorija, panegirik i dr.).

Pojednostavljeno rečeno, u svome pokušaju sastavljanja literarnog ostvarenja bliskog senzibilitetu, očekivanjima i potrebama recipijenata iz različitih čitateljskih krugova Vitezović se najvećim dijelom oslanjao na strategiju prizivanja pojedinačnih obilježja ili cjelovitih primjeraka žanrova vrlo šarolikoga porijekla, odnosno žanrovskih rješenja s makar nekima od kojih su se u usmenomu i/ili pisanom obliku dotad imali prilike susresti (gotovo) svi njegovi potencijalni čitatelji. Imajući u vidu izuzetno široku publiku - dakle, nejednako obrazovane pojedince iz različitih društvenih slojeva, čija su čitateljska iskustva bila samo djelomično podudarna - naš je autor Odiljenje tako napučio ne samo značajkama pisanoknjiževnih i rubno književnih žanrova, već i onih usmenoknjiževnih, pa čak i pučkoknjiževnih, posredstvom kojih je zbivanja pod Sigetom u ljeto 1566. i njihove reperkusije nakanio približiti, prije svega, slabije obrazovanim, no ipak opismenjenim recipijentima iz nižih slojeva onodobnoga društva. Naime, i posudbama iz „repertoara“ usmeno- i pučkoknjiževnih žanrova Ritter je - kako se čini - htio ublažiti (u ranijim ,zrinijadama“ vrlo uočljivu) tipično knjišku patetičnu ,istrgnutost“ opjevanoga događaja i njegovih aktera iz „življene stvarnosti““, 
točnije naglasiti „svakodnevnu“ ili privatnu dimenziju sigetske katastrofe, čvrsto vjerujući kako će se u očima šire publike ovo literarno podsjećanje na povijesni značaj pada Sigeta i ukazivanje na potrebu njegova obnavljanja kao mjesta pamćenja doimati daleko interesantnijim i uvjerljivijim pristupi li se sigetskoj katastrofi (i) kao događaju koji je imao i svoju „emotivnu“ pozadinu, odnosno iza kojega nije ostala samo razorena strateški važna (odsad turska) utvrda i dupkom puno groblje poginulih branitelja i osvajača, već i neutješne majke, sestre, udovice, zaručnice i djeca sigetskih žrtava, ali i transcedentalna bića poput „vila“, koje se također ne mogu pomiriti sa smrću ljubljenih hrvatskih branitelja.

Ustrajanje na prepoznatljivo folklornoknjiževnim žanrovima i motivima (navlastito onomu usmene epske pjesme kao održavateljice sjećanja), ali i eksploatiranje pojedinih „narodnoj“ književnosti svojstvenih formalno-metričkih rješenja u pogledu bi se Odiljenja osim toga - moglo i trebalo protumačiti i kao izravna tekstualna poveznica na kontekstualnu, društveno-kulturnu situaciju razdoblja unutar kojega je ono i nastalo, a u kojemu je usmenoknjiževno pjesništvo (još uvijek) egzistiralo kao doslovno sveprisutna pojava (daleko, štoviše, učestalija od pisanoknjiževnoga pjesničkog stvaralaštva), koja je ujedno vršila (i) funkciju čuvara te jednoga od temeljnih prijenosnika kolektivnoga sjećanja na ključne epizode iz nacionalne povijesti. S obzirom na to da je u tadašnjoj društvenoj strukturi uvjerljivo dominirao upravo seljački sloj, u okvirima kojega je broj posve nepismenih ili jedva polupismenih pojedinaca bio zapanjujuće visok, iznimna raširenost usmene književnosti posredstvom koje je najveći postotak sedamnaestostoljetnoga stanovništva i stjecao jedino književno iskustvo - pokazuje se kao i više nego samorazumljiva činjenica, slijedom koje se ni Vitezovićeva odluka da svoj vernakularni književni prvijenac obilato napuči značajkama folklornoknjiževnih žanrova nipošto ne čini slučajnom, a kamoli neočekivanom. Dapače, usmenoknjiževna je generička rješenja i pojedina njihova prepoznatljiva obilježja Ritter u svoju ,zrinijadu“ i uključivao ponajprije s namjerom da je približi i potencijalnoj publici iz najnižih, najslabije obrazovanih društvenih slojeva, čvrsto pritom - kako se čini - vjerujući da će lakoćom ona doprijeti čak i do recipijenata koji će je biti u stanju recipirati isključivo slušanjem, tim više što je danje svjetlo imala ona ugledati ni manje ni više nego u razdoblju u kojemu su mnoge od nepismenih osoba u kontakt s pisanom - ponajčešće pučkom, odnosno samo iznimno ,elitnom“ - književnom produkcijom i dolazile zahvaljujući pojedincima što su naglas čitali dijelove tih tiskom odjelodanjenih ili makar rukopisnih ostvarenja. ${ }^{1036} \mathrm{U}$ tom

1036 Konkretno, u društvima s izrazito niskim postotkom pismenih - kakvo je, dakako, bilo i ono ranonovovjekovno hrvatsko - neopismenjeni su pojedinci u doticaj s pisanom (tiskanom, rukopisnom) književnošću dolazili isključivo njezinom auditivnom recepcijom, odnosno „pukim“ slušanjem, što je podrazumijevalo slušanje kako naglas pročitanoga propovjednog, liturgijskog i drugoga nabožno-pučkog štiva u 
smislu, nipošto ne bi bilo neutemeljeno pretpostaviti da se - znajući za tu i takvu praksu „glasnoga“ čitanja - i sam Pavao Vitezović ponadao kako će i Odiljenje istim „kanalom“ biti prenošeno barem dijelu onodobne neopismenjene publike, a vjerojatno i da će pokoji njegov pjesmovni odsječak uslijed takve prakse možda čak biti i folkloriziran te potom nastaviti kružiti (i) usmenim putem, u čemu je onda i mogao ležati jedan od ključnih razloga zbog kojih je držao on nužnim opskrbiti ga tolikim brojem folklornoknjiževnih karakteristika, koje su ga u konačnici i trebale učiniti pristupačnijim onima čije se dotadašnje literarno iskustvo svodilo na isključivo slušanje „narodnih“ književnih ostvarenja, a sve ne bi li se i njih potaknulo na usvajanje i korištenje naddijalekta kao budućega hrvatskog jezičnog standarda te podsjetilo na dalekosežan značaj žrtve što su je podnijeli hrvatski branitelji braneći sigetsku utvrdu, koja iz toga razloga zaslužuje ponijeti status jednoga od najvažnijih hrvatskih memorijalnih lokaliteta uopće.

S druge strane, obiljem različitih pisanoknjiževnih žanrova i njima svojstvenih značajki odlučio je Ritter premrežiti Odiljenje sigetsko računajući, dakako, (i) na interes učenijih, a time i literarno znatno potkovanijih „,̌tavaca“ i „štavaca“, koji će ga - znao je prosuđivati po nekim korjenito drugačijim kriterijima od onih zadojenih na usmenomu stvaralaštvu, iako ne treba zaboraviti da je čak i među ovim potonjima bio nemali broj onih koji su - pretežno polazeći od iskustva čitanja Biblije, u sklopu koje su ih ranije već morali susresti - definitivno bili u stanju prepoznati, a onda i ispravno razumjeti velik dio tih, isključivo u pisanoj književnosti zastupljenih generičkih rješenja. Unatoč tomu što ih $\mathrm{u}$ književni svoj prvijenac uvrštava i sa željom da se u očima tih literarnih sladokusaca potvrdi kao izvrsni poznavatelj onodobne (pisano)književne produkcije i književnoga kanona uopće, dakle kao autor koji svoju umješnost u gradnji stihova i okretnost u baratanju raznolikim (suvremenim) žanrovskim „materijalom“ duguje ponajprije kvalitetnoj naobrazbi i iznimnoj načitanosti, taj žanrovski „splet“ - točnije, njihovim značajkama ispjevane dionice teksta ponajprije je potencijalne čitatelje iz redova aristokracije trebao potaknuti na one iste izvanknjiževne ,akcije“ koje su trebali (iz)vršiti i znatno skromnije obrazovani recipijenti Odiljenja, a to će reći - ponovimo - kako na uporabu svehrvatskoga (tronarječnog) jezika,

sklopu crkvenih (misnih) obreda, tako i „svjetovnih“ pisanoknjiževnih tekstova što su ih okupljenim pojedincima u pojedinim prigodama pokatkad glasno čitale njima bliske obrazovane osobe. Pritom se takva praksa najčešce pojavljivala u obiteljskim krugovima, u kojima su nepismenim pojedincima čitali njihovi obrazovani, dakle opismenjeni srodnici (većinom djeca školskoga uzrasta starijim članovima obitelji), i to mahom pučkoknjiževno (osobito nabožno) štivo i Bibliju, zahvaljujući čemu su i ti potpuno nepismeni pripadnici obitelji „slušajući više puta istu priču ili pjesmu mogli (...) mnogo toga naučiti naizust i dalje prenijeti drugima“" (Stipčević 2005: 350), baš kao što su to - uostalom - mogli i nakon višekratnoga slušanja mjesnoga župnika ili, pak, kojega drugog opismenjenog pojedinca. Znatno detaljnije o praksi čitanja naglas u našemu ranom novovjekovlju u: Stipčević 2005: 347-351. 
tako i na osvježavanje uspomene na junaštva sigetskih branitelja te, naposljetku, i na to da i sami pokušaju dati vlastiti doprinos fizičkoj i duhovnoj obnovi (iz turskoga sužanjstva „,izbavljena“) Sigeta kao podugo zanemarenoga hrvatskog mjesta sjećanja. U tom bi se smislu bez ikakve dvojbe moglo ustvrditi kako uočena generička obilježja i oblikovne strategije što ih eksploatira u svim četirima njezinim ,dilovima“ i više nego bjelodano upućuju na to da se Pavao Ritter svojom žanrovski hibridnom „zrinijadom“ težio približiti posve različitim tipovima (onodobnih) čitatelja, a sve $s$ nakanom da i jedne i druge pokuša potaknuti na ispunjavanje - u suštini - sasvim istih, silno važnih i nipošto zanemarivih izvanknjiževnih ciljeva, potrebu rješavanja kojih su inicirale sve povoljnije društvenopovijesne okolnosti.

Ipak, bez obzira na pojedine u Odiljenju zastupljene tekstualne postupke i strategije kojima je naš autor (visoko)obrazovanim čitateljima nakanio dokazati svoju književnu kompetenciju, ali ga u isti mah i onima neukijim učiniti bitno zanimljivijim i intrigatnijim (počevši od supostavljanja iznimno velikoga broja žanrova nejednake provenijencije, preko mjestimičnog nizanja homonimskih rima i uključivanja figure jeke, pa sve do uporabe dvostruko rimovanoga dvanaesterca, iskušavanja metričkih varijacija itd.), treba primijetiti kako je velik broj u njemu prisutnih generičkih značajki, ali i čitavih u nj uvrštenih primjeraka konkretnih žanrova zapravo bio u stanju vršiti posve različite zadaće ili funkcije, točnije da su - bez obzira na to što su svi zajedno bili „aktivirani“ u svrhu postizanja već spomenutih izvanknjiževnih ciljeva - lakoćom mogli „mijenjati“ svoje uloge, i to ovisno o recipijentovu književnom iskustvu, odnosno predznanjima i očekivanjima s kojima je i pristupao samomu tekstu. Tako je, primjerice, mnoštvo ondje prisutnih uvodnih toposa ili primarnih govornih žanrova oslovljavanja adresata, ${ }^{1037}$ toposa referiranja na epistolarni medij, ${ }^{1038}$ kao i zaključnih toposa ili govornih žanrova pohvale ili blagoslova (ili uopće pozitivnih želja) upućenih adresatu, ${ }^{1039}$ kojima se neke pjesmovne dionice privode kraju, u očima učeni(ji)h čitatelja ponajprije trebalo dočarati ili fingirati retorički okvir i uopće ,atmosferu“ (fiktivne) poslanice ili heroide, dočim je one tek bazično obrazovane, čije je literarno iskustvo gotovo u cijelosti proizlazilo iz recipiranja usmenoknjiževnih i pučkoknjiževnih tvorevina, moglo podsjetiti na formu umetnutih stihovanih pisama, s kakvima su se imali prilike upoznati slušajući

\footnotetext{
1037 „Gospoje hrabrene i hrvatske vile“ (I: 1), „Kralju, kruno sveta, svita gospodine“ (II: 1), „Gospodo i knezi hrvatske države“ (II: 93), „Rimska crikvo sveta, čista viro krsta (II: 486) i dr.

${ }^{1038}$ Poput, na primjer, „Još sad, kruno sveta, prilika j' pisati“ (II: 440) ili „Tvoj list na veliko prijeh žalošćenje“ (II: 467).

1039 Riječ je o završnim stihovima pojedinih pjesama poput „Bog nam se stati daj u raju svetom“ (II: 57), „Sbogom na svršenju života i rati: / Bog k ovom trpljenju nemoj vas pušćati, / daj nam se v življenju nebeskom zastati“ (II: 115-117), „Trud tvoj, gospodine naš hrvatski bane, / navik mnoge cine v spomenu ostane“ (II: $144-$ 145), ,, misli ću imati vitezov trpljenje, / kojim Bog htij dati nebesko življenje“ (II: 484-485) i sl.
} 
„narodne“ epske pjesme, unutar kojih su ih usmeni pjevači često bili „uvrštavali“، ${ }^{1040}$ Jednako tako, dok su utkane primjerke poslovica književni sladokusci nesumnjivo bili najprije generički povezivali $\mathrm{s} u$ to vrijeme silno popularnim pisanoknjiževnim (autorskim) žanrovskim varijantama poslovice - ponajprije aforizmima i maksimama - a tek potom i s (također im dobro znanim) „,narodnim“ mudrim uzrečicama, dotle literarnim nevježama nije preostajalo ništa drugo no motriti ih iz vizure upamćenih izvornih folklornih poslovica, a time i onih folkloriziranih biblijskih, velik dio kojih je vremenom ušao i u usmenoknjiževni „opticaj“, nastavivši tako cirkulirati (i) u neposrednoj životnoj stvarnosti. „Epski“, odnosno narativni dijelovi Odiljenja - u kojima se, ponovimo, evociraju neki važniji detalji iz kršćansko-muslimanske bitke pod sigetskim zidinama opjevani u prethodnikovoj „zrinijadi“ baš sve su potencijalne recipijente trebale podsjetiti na tijek događaja pod Sigetom u ljeto 1566., no za razliku od učenije publike, koja je informacije o tim zbivanjima prethodno bila usvojila glavninom zahvaljujući ranijim pisanoknjiževnim njihovim obradama (ponajprije Obsidi sigeckoj Petra, a moguće i Szigeti veszedelemu Nikole Zrinskog, ali i Karnarutićevu Vazetju, pa i - vrlo vjerojatno - nekom od brojnih prijepisa Črnkova Podsjedanja i osvojenja Sigeta), neukiji čitatelji svoju su predodžbu o junaštvima sigetskih branitelja temeljili na „narodnim“ epskopjesničkim, bugaršćičkim, pa i (ne tako čestim) lirskopjesničkim tematizacijama sigetske katastrofe, što će reći na fabulama i likovima što su ih upoznali u tim i takvim ostvarenjima, a dio kojih su najprije braća Zrinski, a slijedom njih i sam Vitezović, preuzeli i u svoje pisanoknjiževne vizije opsade i pada Sigeta.

Upućene je recipijente, nadalje, najveći broj žanrova okupljenih na stranicama Odiljenja sigetskog trebao navesti na to da se ,automatski“ prisjete upravo onih žanrovskih rješenja što ih je Petar (a prije njega već i Nikola) Zrinski donio u Adrijanskoga mora Sireni, a slijedom toga i da imaju na umu njihovu dugu tradiciju, odnosno iznimnu popularnost što ju je dobar dio njih uživao u većini europskih nacionalnih književnosti u 17. stoljeću, pa tako donekle - i u onoj sedamnaestostoljetnoj hrvatskoj. Nasuprot tomu, što se skromnije obrazovanih čitatelja tiče, za njihovo je razumijevanje Vitezovićeve „zrinijade“ sasvim dostatno bilo to da su - zahvaljujući gotovo redovitom susretanju s njezinim ,produktima“ dospjeli ovladati bogatom ,paletom“ žanrova folklorne književnosti, odnosno da su živo pratili usmenoknjiževnu praksu svoga vremena, uslijed koje su mnogi od žanrova što ih zatječemo u samomu tekstu - a odnosi se to i na usmenoknjiževne ,varijante“ nekih od njih, poput, primjerice, umetnutoga stihovanog pisma iz „narodnih“ epova kao potencijalne inačice

${ }^{1040} \mathrm{O}$ važnoj ulozi što su je imala pridodana stihovna pisma - kojima se „pojačavao“ utisak intimnosti - ali i sam motiv pisama - kao medija posredstvom kojega su se (i) u „epskom svijetu“ bile širile i priopćavale bitne vijesti - u sklopu folklornoknjiževnih epskih ostvarenja opširnije u Botica 2013: 344-345. 
pisanoknjiževne poslanice, potom same usmene epske pjesme kao varijante one „umjetničke“, stihovanoga nadgrobnog natpisa kao inačice pisanoknjiževnoga epitafa, folklorne dijaloške pjesme kao „dvojnice“ one pisanoknjiževne itd. - doista i bili u neprekidnomu „opticaju“. Kada je, pak, riječ o onim žanrovima što ih potonja publika većinom nije bila kadra prepoznati na podlozi prethodnoga iskustva recipiranja usmene književnosti - dakle, lamentu, pouci, consolatiu itd. - prilično je vjerojatno da je Vitezović ustvari čvrsto bio uvjeren u to kako će ih ti, generički im ponešto „dvojbeni“ odsječci teksta navesti na to da evociraju identične ili vrlo im podudarne žanrove što su ih imali prilike susresti unutar korica Biblije (ili posredstvom usmenoga prenošenja odabranih njezinih dijelova), kao što je - uostalom ispravno naslutio i da će na istome mjestu njihove eventualne predloške ili podudarna generička rješenja (usprkos tomu što su ih poznavali i iz nekih znatno suvremenijih književnih ostvarenja), potražiti i mnogi visokoobrazovani pojedinci, tim više što je bila riječ o vremenskom periodu u kojemu je Biblija (još uvijek) bila shvaćana kao univerzalna literarna tradicija. Konačno, što se tiče onih žanrova ili formalno-stilskih rješenja - versus echoici ili figura jeke, kronogram itd. - koje neiskusniji ,„čtavci“ dotad nisu imali prilike susresti ni u jednom od njima dostupnih i znanih izvora (dakle, niti u usmenoj i/ili pučkoj književnosti, niti u Bibliji), bit će da je Ritter svoju odluku da i njih uvrsti u Odiljenje sigetsko temeljio na (nimalo pogrešnoj) pretpostavci kako s njihovim razumijevanjem i prihvaćanjem slabije obrazovana publika ne samo što neće imati (krupnijih) problema, već će im sama po sebi ona biti silno primamljiva i intrigantna, ${ }^{1041}$ što što bi - pak - sugeriralo da se cilj njihova uključivanja u tekst nije zapravo svodio ni na što drugo nego na privlačenje i zadržavanje zanimanja širega (u jednakoj mjeri visokoobrazovanog i neukijeg) čitateljstva, tim više što se upravo pomoću njih u samomu tekstu težilo postići dodatne učinke, odnosno zabavno-ludičke efekte, koji su - bazirajući se na gotovo intermedijalnim strategijama - recipijente različitih tipova poticali na dodatne intelektualne napore.

Na kraju krajeva, svojim (pisano)književnim vernakularnim prvijencem, u kojemu se donosi pregršt prepoznatljivih obilježja različitih pučkoknjiževnih i usmenoknjiževnih žanrova i kojim se - slijedom toga - otvoreno računa i na zanimanje neiskusnijega čitateljstva, a ne samo na ono visokoobrazovane publike, u okvirima hrvatske književnosti 17. stoljeća Pavao Vitezović zapravo nije učinio ništa odveć „revolucionarno“ budući da se ionako radilo o razdoblju u kojemu „elitna“ i ,pučka“ (a uz nju i usmena) književnost još uvijek nisu bile toliko oštro odvojene. Konkretno, zahvaljujući svome prilično bogatom prethodnom iskustvu recipiranja usmenih (pa i nekih pučkih) literarnih tvorevina, i 
potencijalna publika iz (naj)viših društvenih slojeva - dakle, ponajprije ona iz redova vlastele - u spomenutomu razdoblju ne samo što je (još uvijek) posjedovala prijeko potreban senzibilitet za taj i takav „tip“ književnosti, nego joj je ujedno i nedostajao „smisao“ za čvrsto razlučivanje pisanoga stvaralaštva za elitu od (ne uvijek pismom fiksirane) književnosti namijenjene širem, mahom skromnije obrazovanu čitateljstvu, točnije za striktno povezivanje ove potonje $\mathrm{s}$ isključivo recipijentskim potrebama i očekivanjima jedva pismenoga ili posve nepismenog puka. $^{1042}$ Prepoznavši, drugim riječima, u pojedinim pisanoknjiževnim ostvarenjima prisutnost usmeno- i pučkoknjiževnih značajki, recipijenti iz aristokratskih krugova - dakle, sve odreda književni znalci - u to vrijeme najčešće nisu ni pomišljali na eventualno odustajanje od recepcije tih i takvih tekstova, a kamoli na njihovo odbacivanje $\mathrm{i}$ ignoriranje pod izlikom da je riječ o štivu koje nije na „njihovoj razini“, pri čemu ne treba zaboraviti kako je nezanemarivih distinkcija između usmene (pučke) i „elitne“ pisane književnosti upravo u vrijeme baroka obrazovanija publika gotovo danomice postajala sve svjesnija, i to ni manje ni više nego iz razloga što baš u 17. stoljeću dolazi do postupnoga kristaliziranja tih dvaju tipova književnosti.

Pa, ipak, usprkos takvom razvoju ,situacije“, još će i tijekom čitava baroka, ali i desetljećima nakon njegova „gašenja“, čitateljska „elita“ u nas kontinuirano nastaviti sudjelovati (i) u kulturnom životu „,narodnih“ masa, slijedom čega podugo još neće biti u stanju tu narodnu kulturu - a u sklopu nje i usmeno, pa i pučko književno stvaralaštvo naprosto odjednom početi shvaćati kao čvrsto odvojenu od kulture što je dominirala u njihovu društvenom krugu. U tom smislu, ni možebitno se „rezerviranje“ (usmenoknjiževnim obilježjima u potpunosti protkanoga) Odiljenja sigetskog samo i isključivo za krug recipijenata što su stekli tek bazičnu ili vrlo skromnu naobrazbu te posjeduju gotovo zanemarivo literarno iskustvo nipošto ne može dovoljno uvjerljivo opravdati, tim više ako se zna da je riječ o ostvarenju čije su razumijevanje, a time i ciljani krug publike, presudno bili usmjeravali kako kontekst uslijed kojega se ono pojavljivalo, tako i njegovi okvirni, paratekstualni dijelovi, čije mijene ujedno možda i ponajbolje ukazuju na prilagodljivost Ritterove ,zrinijade“ publici iz posve različitih čitateljskih krugova. Upravo nedavno otkriće njegova trećeg - zagrebačkog - izdanja iz 1695., koje je gotovo u potpunosti - kako se može zaključiti - bilo namijenjeno književnim sladokuscima iz najviših društvenih slojeva, u tom se pogledu nameće kao daleko najuvjerljivija potvrda pretpostavke da je Vitezovićev književni prvijenac na hrvatskom jeziku zapravo ostvarenje koje je - zahvaljujući činjenici što posjeduje obilježja baštinjena iz neobično velikoga raspona žanrova nejednakoga porijekla - 
bilo u stanju lakoćom izmamiti pozornost recipijenata iz posve različitih književnih krugova, odnosno koje je bez ikakve dvojbe rado bilo čitano na „oba fronta“ te, (i) slijedom toga, dospjelo paralelno postojati i kao pučkoknjiževno, i kao elitnoknjiževno ostvarenje podjednako omiljeno među različitim tipovima onodobnih čitatelja.

\section{5. BEZ UZORA I NASLJEDNIKA?}

Da se u Odiljenju sigetskom Pavla Rittera Vitezovića suočavamo s jednim od najspecifičnijih i najosebujnijih literarnih ostvarenja $u$ povijesti naše barokne $i$ ne samo barokne književnosti, u dosadašnjem je dijelu istraživanja bilo već istaknuto nebrojeno mnogo puta. Pored svih ranije iznijetih dokaza, spoznaju o specifičnosti Vitezovićeve „zrinijade“ možda se i ponajbolje može potkrijepiti njezinim sagledavanjem u kontekstu domaćega sedamnaestostoljetnog književnog stvaralaštva, odnosno njezinim omjeravanjem o korpus hrvatske književnosti baroknoga razdoblja, poglavito onaj njegov dio što su ga sačinjavali (makar samo naoko) generički joj podudarni tekstovi. Taj korak u kontekstualnoj analizi generičkih značajki Odiljenja nameće nam se, naime, ne samo kao poželjan, već upravo kao nasušno potreban i nezaobilazan, i to ponajprije stoga što je riječ o djelu koje je ispjevano ni manje ni više nego u (književnom) periodu u kojemu je (još uvijek) na snazi bilo načelo imitacije, pod utjecajem kojega se od svakoga književnog teksta očekivalo da bude „skrojen“ po stanovitomu neposrednom uzoru ili nekolicini njih, odnosno koje je iziskivalo da se baš svaki pisac u svome radu veže uz konkretna (uzorna) djela prethodnika koja će oponašati, tj. na koja će se - sadržajno, stilski, formalno, pa onda i žanrovski - u što većoj mjeri izravno nadovezivati. Kada se, konkretno, radi o našim književnim „sečentistima“, i više je nego dobro poznato kako su se odreda oni - osim na rijetke i ne tako utjecajne domaće prethodnike, pa i ponekog suvremenika - naslanjali na barokne i predbarokne inozemne autore, pri čemu se kod južnohrvatskih barokista redovito radilo o uzorima iz talijanske književnosti, dočim su oni sjevernohrvatski bili skloniji ugledanju u mađarske i njemačke pisce, a samo iznimno neki bi od njih - kao što je to bio slučaj i s braćom Zrinski - posegnuo i za uzorima iz drugih nacionalnih književnosti, ponajprije one talijanske.

Govoreći o Vitezovićevu hrvatskom književnom prvijencu, generička osebujnost Odiljenja već na prvi bi nas pogled, uspoređena sa žanrovskom „slikom“ (naj)većega dijela barokne produkcije, mogla navesti na pomisao kako punopravnoga žanrovskog uzora ili, bolje rečeno, možebitni generički predložak - izuzev (donekle) Adrijanskoga mora Sirene, pa i (u 
određenoj mjeri) rukopisnoga izbora iz Petrove ,zrinijade“ iz ostavštine Draškovićevih ${ }^{1043}-\mathrm{u}$ kontekstu domaćega sedamnaestostoljetnog književnog stvaralaštva nije ono uopće ni imalo. Što se, međutim, žanrovske ,pripadnosti“ Sirene i parcijalnoga njezina prijepisa iz Arhiva Drašković tiče, nipošto ne bi trebalo smetnuti s uma kako je u okvirima našega književnog „sečenta“ ipak postojao (količinski ne odviše razveden) niz generički im izrazito bliskih - ako ne i posve identičnih - ostvarenja, koje su pojedini naši barokolozi pokatkad obuhvaćali zbirnom žanrovskom oznakom ,djela zborničkoga tipa“ (Fališevac 2003: 505), ne zaboravljajući pritom navesti kako je redom riječ o tekstovima uvelike „skrojenima“ po izvorno srednjovjekovnim generičkim „obrascima“. Jedno od tih i takvih djela bila je i Kita cvitja razlikova (1642.) bračkoga pjesnika Ivana Ivaniševića, ${ }^{1044}$ realizirana kao kompilacija osmeračkih i dvanaesteračkih (lirsko- i epskopjesničkih) i proznih tekstova mahom religiozno-moralističke, pa i svjetovne tematike, razlučenih u devet dijelova ili tzv. „cvitova“, u kojima je - neovisno od poprilično naglašenih i nimalo malobrojnih u njima prisutnih obilježja medievalnih žanrova - moguće zamijetiti izrazito inzistiranje na baroknom ornatusu, kojim se Kita u cijelosti jasno (stilski) nadovezuje na barokne religiozne poeme. U generičkom pogledu Ivaniševićevo se djelo nameće kao „tipični“ zbornik sastavljen od tekstova ostvarenih u, otprilike, istim onim žanrovskim „kalupima“ kao i mnoge dionice Vitezovićeva Odiljenja, počevši od poslanica i nadgrobnica (epitafa), preko pohvalnica, dijaloških lirskih pjesama (konkretno, dijaloške Kristove muke, tj. razgovora duše s raspetim Isusom) te pjesama s figurom jeke ili versus echoici, pa sve do ljubavnih lirskih pjesama, alegorija i uopće tekstova prožetih i više nego izrazitim značajkama autohtono folklornoknjiževnih žanrova (poglavito onih molitve, naricaljke, poslovice i dr.), pri čemu treba uočiti kako se one od generički kojekako ispjevanih „dilova“ Odiljenja razlikuju ponajprije po gotovo posvemašnjem odsustvu tematsko-motivske konzistentnosti i kompaktnosti. ${ }^{1045}$ Što se, međutim, eventualnoga generičkog ugledanja našeg autora na Kitu cvitja razlikova tiče, čini se da o njemu nipošto ne bi bilo neopravdano razmišljati ili - bolje rečeno - spekulirati, i to ponajprije s razloga što je bila riječ o ostvarenju što ga je Ritter svakako bio iščitao prije 1700., kada će iz tiska izići njegova čuvena latinska spomenica

\footnotetext{
${ }^{1043}$ Detaljnije o navedenomu rukopisu u: Novalić 1967a: 212-221.

${ }^{1044}$ O sadržaju, generičkom „sastavu“ i drugim značajkama Ivaniševićeva zbornika, ali i o Slavi ženskoj, odnosno odgovoru šibenskoga pisca Jakova Armolušića na jednu dionicu Kite, i to mizogino „intoniran“ šesti njezin dio ili „,cvit“ (naslovljen upravo Od privare i zle naravi ženske), znatno više u: Fališevac 1995: 77-104. ${ }^{1045}$ Usp. Ivanišević 1642.
} 
Oživljena Hrvatska, u kojoj i jest donio jasnu potvrdu svoga zapanjujuće dobrog poznavanja Ivaniševićeva žanrovski kompleksnoga baroknog zbornika. ${ }^{1046}$

$\mathrm{Za}$ razliku od i više nego bjelodanih u njemu prisutnih signala poznavanja Ivaniševićeve Kite, u Vitezovićevu ćemo stvaralačkom opusu uzalud tragati kako za eksplicitnim, tako i za makar implicitnim potvrdama čitanja i kreativnoga uvažavanja još jednoga domaćeg sedamnaestostoljetnog zbornika, i to ni manje ni više nego onoga što ga je pod (pretpostavljenim) naslovom Zvončac 1670. u Grazu objelodanio turopoljski pjesnik Matijaš Magdalenić. Posvemašnjem odsustvu izravnih dokaza o recepciji Magdalenićeva ostvarenja usprkos, zbog specifične strukture i uopće izrazite žanrovske heterogenosti Odiljenje sigetsko nipošto ne bi bilo u potpunosti pogrešno dovesti u vezu (i) s također uvelike hibridnim Zvončacem, pa i bez obzira na činjenicu da je u slučaju potonjega riječ o u cijelosti moralističko-nabožnoj trodijelnoj kompilaciji versificiranih tekstova posvećenih opjevavanju različitih kršćanskih predodžbi i ideja, počevši od one o četirima posljednjim stvarima, kojima se bavi uvodna pjesma Premišljanja zvrhu četirih poslenjih človeka, preko spoznaje o neizbježnosti smrti obrađene u nabožnoj lirskoj pjesmi Plač smrtelnosti, pa sve do baroku osobito omiljene teme rastrošnoga sina, o kojoj je riječ u zaključnom tekstu religioznoj poemi Rasipnoga sina hištorija. ${ }^{1047}$ Ostavimo li po strani gotovo nepremostive sadržajne distinkcije između dvaju ostvarenja, osnažene još i činjenicom da je Zvončac zapravo ništa drugo no „tek“ kompilacija prepjevanih pjesničkih tekstova čiji izvornici potječu iz pera popularnih mađarskih pučkih pisaca, Vitezovićeva „zrinijada“ svojom bi četverodijelnošću i tematskom okrenutošću opjevavanju mnogostrukih konačnih rastanaka što ih je isprovocirao poraz sigetskih branitelja vrlo lako mogla podsjetiti na - također četverodijelno strukturirano - dvanaesteračko razmatranje o četirima posljednjim čovjekovim stvarima (smrti, sudu, paklu i blaženstvu), kojim Magdalenić i otvara svoje djelo i koje bi se

\footnotetext{
${ }^{1046}$ Naime, da se u sastavljanju svoje Croatie redivive Pavao Vitezović u određenoj mjeri itekako bio oslanjao i na Ivaniševićev nevelik pjesnički opus jasno nam potvrđuje ne samo činjenica kako u njoj na jednome mjestu izrijekom spominje Kitu cvitja razlikova (kao jedan od argumenata za neke iznesene opservacije i konstatacije), nego $i$ - još više - to što se ondje ni najmanje ne libi doslovno citirati pojedine njezine dionice. Iako se, doduše, radi o „tek“ citiranju pohvalne pjesme Bartolomea Ginammija, točnije sina mletačkoga tiskara Marca Ginammija, koji će 1642. i otisnuti prvo izdanje Kite „obogaćeno“ rečenom pohvalnicom, taj je citat - zajedno s navedenim spominjanjem Ivaniševićeva djela - bez ikakve dvojbe moguće izdvojiti kao možda i najuvjerljiviji dokaz činjenice da je naš autor svakako prije 1700. - točnije, u godinama koje su prethodile početku njegova rada na Oživljenoj Hrvatskoj - imao u rukama izdanje Kite cvitja razlikova. U tom se smislu nipošto ne bi moglo, a ni smjelo u potpunosti isključiti ni njegovo znatno ranije čitateljsko upoznavanje s Ivaniševićevim zbornikom, do kojega je lako moglo doći i već koje desetljeće ranije, možda baš i koncem sedamdesetih ili početkom osamdesetih godina, kada je Ritter - kako smo pretpostavili - i radio na ranijim verzijama svoje buduće „zrinijade“. Podrobnije o Vitezovićevu citatnom i kreativnom uvažavanju Ivaniševićeva djela posebno u: Klaić 1914: 143. Usp. i tablični prikaz u: Blažević 1997: 24.

1047 Vrlo pregledno o pojedinim specifičnostima Magdalenićeva djela usp. npr. Prosperov Novak 499-500 i osobito Pavličić 2006: 195-214.
} 
po toj i takvoj svojoj tematskoj zaokupljenosti itekako moglo usporediti i s konačnim oproštajima kao - u neku ruku - također ,posljednjim stvarima“, kojima su posvećena sva četiri „dila“ Odiljenja. S druge strane, što se eventualnoga Vitezovićeva (prešutnog) kreativnog naslanjanja na Magdalenićev zbornik u cijelosti tiče, s priličnom bi se sigurnošću moglo ustvrditi kako - njegovu vrlo vjerojatnom izvrsnom poznavanju usprkos - našem autoru „priključivanje“ na nj gotovo sigurno nije bilo ni na kraj pameti, i to ne samo iz razloga što je Zvončac fokusiran na isključivo nabožne teme, već i zato što mu - baš kao i Kiti cvitja razlikova - nedostaje (,,prave“) sadržajne kompaktnosti, i to bez obzira na činjenicu da sva tri njegova dijela povezuje provodna nit u obliku usmjerenosti nabožnim temama te uopće moralističko-poučne svrhe, kojoj u podjednakoj mjeri streme. ${ }^{1048}$

Govoreći o domaćim sedamnaestostoljetnim djelima, „zborničkoga tipa“ kao potencijalnim generičkim uzorima Odiljenja sigetskog, (i) na ovomu ćemo mjestu još jednom biti prisiljeni ustvrditi kako je - bez daljnjega - najuvjerljivijom potvrdom Vitezovićeva oslanjanja na tekstove iz toga (teorijski osmišljenoga) žanrovskog „razreda“ moguće označiti upravo karakteristike preuzete iz Adrijanskoga mora Sirene Petra Zrinskog, koju bi također valjalo kategorizirati upravo kao zbornik kojekako generički realiziranih pjesničkih sastavaka. Unatoč činjenici da su se povjesničari hrvatske književnosti - fokusirajući se na isključivo najdulju, epskopjesničku njezinu dionicu - podugo libili klasificirati je na taj način, Petrova „Zrinijada“ unatrag posljednjih se nekoliko desetljeća ipak sve češće motri upravo kao zbornik ili, pokatkad, kao (pjesnička) zbirka, ${ }^{1049}$ što - dakako - ne znači i da se slučajevi njezina svođenja na Obsidu kao najekstenzivniju joj, pa time i „najbitniju“ dionicu ne mogu susresti još i dan danas. Adrijanskoga mora Sirena, međutim, po svim svojim temeljnim osobitostima - poglavito po svojoj žanrovskoj i (u nešto manjoj mjeri) sadržajnoj i formalnoj heterogenosti te uopće kompiliranosti - u najvećoj se mjeri i nadaje kao „punokrvno“ djelo zborničkoga tipa, čija kompaktnost proizlazi ponajprije iz činjenice da su u nj uvršteni pjesnički tekstovi ne samo obujmljeni zajedničkim tekstualnim granicama, nego i „skupnim“ naslovom kao

\footnotetext{
1048 O toj i takvoj (izvanknjiževnoj) namjeni Zvončaca posebno u: Pavličić 2003: 75-97.

${ }^{1049}$ Kao „svojevrsni zbornik raznolike građe“ Sirenu je prvi u nas preciznije žanrovski odredio Slobodan Prosperov Novak (usp. Prosperov Novak 1999: 447), iako ju je još 1991. zbirkom (Sammlung) u svome izvrsnom pregledu povijesti hrvatske barokne književnosti odlučno proglasio Zoran Kravar (usp. Kravar 1991: 238). Dapače, može se primijetiti kako su upravo za potonju (teorijsku) generičku odrednicu proučavatelji Petrovih ostvarenja dosad i pokazali daleko najveći interes, pa će Sirenu tako još i dan danas „pjesničkom zbirkom“" gotovo redovito definirati Zrinka Blažević (usp. Blažević i Coha 2008: 92 i Blažević 2008c: 329), a za njezinim primjerom povest će se još i István Bitskey (Bitskey 2012: 240), ali i Sándor Bene, Gábor Hausner i Zoran Ladić, koji „knjigom poezije, odnosno „zbirkom poezije“ proglašavaju ne samo hrvatsku Sirenu, već i njezin Nikolin mađarski predložak (usp. Bene, Hausner i Tadić 2012: 7). Nužno je, međutim, prisjetiti se kako su povjesnici domaće (barokne) književnosti - kao što je utvrđeno i nešto ranije - ipak bili (a i još uvijek jesu) najskloniji kranje neutralnim određenjima Adrijanskoga mora Sirene, koju stoga najčešće kategoriziraju „tek“ kao „djelo“, uspješno time zaobilazeći bilo kakvu nužnost njezina iole ozbiljnijega generičkog preciziranja.
} 
signalom makar površne (fizičke) njihove povezanosti, zbog koje se nipošto ne doima uputnim, a kamoli (dovoljno) opravdanim izlučivati Obsidu kao „centralni“ joj, najdulji, pa time i sadržajno najvažniji dio, odnosno redom zanemarivati sve ostale njezine dionice, $u$ kojima su se smjestile žanrovski iznimno šarolike lirske pjesme (idile, epitafi, religiozne pjesme, epigrami, versus echoici itd.) koje ne samo što uokviruju epskopjesnički segment, nego se i - makar neke od njih - djelomice na nj i motivski nadovezuju. Shodno tumačenju Zorana Kravara, taj „uokvirujući“ lirskopjesnički odsječak Sirene sastoji se od, konkretno, šest oduljih idila (u kojima o neispunjenim ljubavnim željama pjevaju arkadijski pastiri), potom šest epigrama (od kojih su četiri realizirana kao nadgrobni natpisi ili epitafi), pjesme o Kristu (tj. religiozne pjesme Vzdihanje $k$ odkupitelju na križu raspetomu) te zaključne pjesme Ispivanje, pri čemu je redom riječ o pjesničkim tekstovima što proistječu iz žanrovskoga sustava ranonovovjekovne književnosti, odnosno koje se nameću kao generički iznimno suvremeni sastavci kojima braća Zrinski kao da se žele nadovezati na generički sustav dubrovačko-dalmatinske barokne književnosti. ${ }^{1050} \mathrm{U}$ tom bi smislu valjalo napokon prihvatiti činjenicu kako samo i isključivo skup tih (lirsko- i epsko-) pjesničkih komponenata čini (stvarnu) cjelinu Petrove generički, sadržajno i formalno hibridne ,zrinijade“, koja ujedno kao takva - i prilično jasno daje do znanja kako joj žanrovska odrednica (pjesničke) zbirke, kojom je sve više proučavatelja odjednom pokušava pobliže odrediti, zapravo pristaje samo djelomično, odnosno u znatno manjoj mjeri no ona zbornika, $i$ to ponajprije poradi toga što uključuje ona i formalno te sadržajno prilično razveden „epski“ sastavak o sigetskoj katastrofi, što je svojevrsni ,presedan“ među sedamnaestostoljetnim kanconijerima, u korpusu kojih je na takve narativne „umetke“ ne samo teško, već i sasvim nemoguće nabasati.

Neospornim strukturno-kompozicijskim i navlastito generičkim paralelama usprkos, tri bi se netom pobrojana primjerka „žanra“ (baroknoga) zbornika - Ivaniševićeva Kita, Magdalenićev Zvončac te osobito Petrova Sirena - zapravo samo do neke mjere mogli prihvatiti kao potencijalni žanrovski uzori, odnosno možebitni predlošci Vitezovićeve generički disperzirane ,zrinijade“, i to ponajprije iz razloga što se - za razliku od nje, koja je, u tematsko-motivskom pogledu, od prve do posljednje stranice dosljedno fokusirana na prikaz posljednjih trenutaka bitke za Siget i njezinih izravnih posljedica - u njihovu slučaju redom radi o sadržajno daleko heterogenijim kompilacijama žanrovski kojekako ostvarenih tekstova. Sudeći po toj izrazitoj tematskoj i motivskoj šarolikosti njima obuhvaćenih tekstualnih „jedinica“, navedeni zbornici bili bi ništa drugo no svojevrsni izravni „nasljednici“ srednjovjekovnih (npr. Lucićev Vartal), ali i nešto kasnijih anonimnih pučkih (stihovno- 
proznih) kompilacija, kojih je naglašena sadržajna i poglavito žanrovska heterogenost proizlazila iz činjenice da se radilo o sastavcima koji najčešće nisu posjedovali nikakvu, a kamoli makar iole čvrstu fabulu, što im je u konačnici i otvaralo mogućnost za nemotivirano „skakanje“ s teme na temu, a onda i za njihovu obradu u žanrovski vrlo raznolikim okvirima.

Nalik našim baroknim zbornicima iz navedenoga niza, i oni srednjovjekovni - za razliku od žanrovski daleko ujednačenijih antologija (florilegija) i pjesmarica - bili su, dakle, otvoreni za uvrštavanje sadržajno zaokruženih tekstova realiziranih u doista vrlo širokom rasponu žanrova, pri čemu se ne smije zaboraviti kako su već i prije 16. stoljeća njihovi sastavljači tekstove ciljano bili grupirali shodno tematskoj im orijentaciji i namjeni, što je naposljetku dovelo do razlučivanja (pretežno glagoljaških) zbornika duhovnoga štiva od kodeksa i (rukopisnih) zbornika neliturgijskih sadržaja, koji su se sve učestalije počeli pojavljivati u razdoblju između konca 14. i 16. stoljeća. U obje ove medijevalne zborničke varijante radilo se, međutim, o kompilacijama književnih, poluknjiževnih, a počesto čak i neknjiževnih ostvarenja raznolikih sadržaja i nejednake žanrovske pripadnosti, no s tom razlikom što su u onima liturgijskim bili zastupljeni mahom biblijsko-duhovni tekstovi za liturgijsko-obredne namjene (primjerice, liturgijske molitve, himne, isječci evanđelja, psaltir itd.), dočim su neliturgijski zbornici uključivali sadržajno i generički daleko raznolikija ostvarenja preuzeta iz mnogih izvora, odnosno predložaka, među kojima su najčešće bili religiozno-didaktički članci, tekstovi iz liturgike, moralizatorski osvrti, propovijedi, legende, mirakuli, apokrifi, crkveno pjesništvo, prikazanja, anegdote, svjetovne pripovijesti, pitanja i odgovori (o općim srednjovjekovnim znanjima iz biologije, zoologije i kozmologije) te drugi žanrovi koji su nudili informacije i znanja o različitim područjima života. Kako primjerci jednoga, tako i oni drugoga zborničkog tipa pritom su ponajprije bili namijenjeni duhovnicima - kojima su obično služili kao udžbenici kršćanskoga nauka te podsjetnici na neka osnovna teološka znanja - te svećenicima, kojima su bitno olakšavali propovjedničke aktivnosti među vjernicima, a ujedno im i osiguravali lektiru koja nije bila vezana uz njihove svakodnevne pastoralne potrebe. ${ }^{1051}$

\footnotetext{
${ }^{1051} \mathrm{U}$ tom bi se smislu te predrenesansne višežanrovske kompilacije - među kojima posebno vrijedi izdvojiti dobro poznati Petrisov, ali i Vinodolski te Kolunićev zbornik - istodobno nametale (i) kao daleko najuvjerljivija potvrda jasnoga pučkog usmjerenja hrvatske srednjovjekovne književnosti, tim više što su redom one proizišle ni iz čega drugog no snažne želje za uspostavljanjem što obuhvatnije komunikacije s vjernicima, što i jest razlog zbog kojega je većina njih u cijelosti bila realizirana hrvatskim, dakle narodnim jezikom, a k tome još i obilato napučena prepoznatljivim jezičnim i stilskim osobitostima usmene književnosti. Zahvaljujući upravo apsorbiranju karakterističnih značajki folklornoknjiževnoga stvaralaštva, velik dio tekstova iz spomenutih medijevalnih zbornika u konačnici je uistinu i našao put do ciljanih recipijenata iz (mahom) pučkih krugova, dospjevši ih pritom u tolikoj mjeri impresionirati da su mnoge od njih - djelomično ih ili u cijelosti upamtivši oni naprosto spontano prenijeli u usmenoknjiževno „okružje“, u kojemu će tako nastaviti egzistirati nemali broj (prvotno u zbornicima donesenih) mirakula, legendi, egzempla i apokrifnih tekstova. Iako se, s druge strane,
} 
Usprkos nimalo netočnim zapažanjima pojedinih naših književnih povjesnika, koji su svojedobno težili dokazati kako je jedini sedamnaestostoljetni generički „odjek“ tih srednjovjekovnih zbornika moguće prepoznati u rukopisnim kajkavskim pučkim pjesmaricama iz toga vremena, uvelike skrojenima po onim istim principima po kojima su bile sastavljane i predrenesansne kompilacije, ${ }^{1052}$ nipošto se ne bi smjelo smetnuti s uma kako se medijevalnim zbornicima žanrovski identična ostvarenja nisu prestajala pisati i prepisivati čak ni u razdoblju našega „sečenta“, i to ponajprije na području kontinentalne Hrvatske, što će reći u onomu istom kulturnom krugu kojemu je djelomice pripadao i Pavao Ritter Vitezović. Podsjetimo, u fondu knjižnice Nikole Zrinskog u Čakovcu svojedobno je otkriven tzv. Derečkajev zbornik, točnije latinična rukopisna kompilacija, u koju je turopoljski zapisivač Ivan Derečkaj - vrlo vjerojatno po nalogu samoga Nikole - u razdoblju između 1621. i 1622. tronarječnim, kajkavsko-čakavsko-štokavskim jezikom prepisao tri važna srednjovjekovna teksta, i to Roman o troji ili Rumanac trojski (tj. prvotno hrvatskoglagoljski prijevod - očito izvorno latinskoga - romana u Troji, u kojemu se naročito glorificira srednjovjekovni viteški moral i mentalitet), potom Aleksandridu (vjerojatno originalno glagoljski čakavski prijevod romana o životu Aleksandra Velikog, nastalog prema Pseudo-Kalistenovu grčkom romanu iz 3. st.) te Pripovijest o premudrom Akiru (tj. originalno orijentalnu pripovijest o doglavniku asirskoga kralja Senaheriba, najvjerojatnije nastalu na ruskom ili bugarskom području).

Kompilacija Ivana Derečkaja - sastavljena od srednjovjekovnih ostvarenja prvotno raširenih u našoj južnoj književnosti - tako se ujedno promeće i u jedan u nizu prilično uvjerljivih dokaza postojanja nezanemarivih književnih, pa i uopće kulturnih veza između sjeverne i južne Hrvatske u doba baroka, pri čemu su činjenicu da su se zahvaljujući njoj pojedini literarni sastavci sada napokon pojavili i na našem sjeveru neki proučavatelji pokušali objasniti društvenopolitičkim razlozima, odnosno situacijom obilježenom svakodnevnim ratnim prijetnjama što su stizale s turske strane. Naime, upravo te su i takve kontekstualne okolnosti, mišljenja je Eduard Hercigonja, upravo i mogle ,oživjeti i aktualizirati ovu srednjovjekovnu vitešku borbenu i moralizatorsku tematiku posvećenu ratu, feudalnom poimanju časti i odanosti vladaru“ (Hercigonja 1975: 384), iz čega - drži - samo od sebe proizlazi i to da su Roman o Troji i Aleksandrida neizbježno morali biti uključeni već

radilo o (ne)liturgijskim zbornicima uvjerljivo najsrodnijemu srednjovjekovnom žanrovskom rješenju, bitno slabije zanimanje publike izazivale su maločas već spomenute antologije ili tzv. florilegiji, u koje su se uvrštavali tekstovi ili segmenti tekstova popabirčenih iz različitih izvora i uopće proizišlih iz pera raznih autora, pri čemu su glavninom bili ondje zastupljeni primjerci biblijskih citata, molitava, pitanja i odgovora, fragmenata moralne teologije i sl., u što je moguće uvjeriti se već i letimičnim uvidom u jedan od naših najpoznatijih medijevalnih florilegija - Cvet vsake mudrosti - u kojemu su doneseni opisi vrlina, razne sentencije, moralizatorske refleksije, anegdote, pa čak i same priče.

1052 Podrobnije o žanru kajkavskih pučkih pjesmarica u: Šojat 1977a: 181-192 i Zečević 1978: 399-401. 
i u tematsko-motivsku i idejnu razinu kako kronike Ferenca Črnka, tako i (upravo zahvaljujući Derečkaju i njegovu zborniku) u onu ,zrinijada“ braće Zrinski, a time onda i u onu Vitezovićevu, tim više što su u Trojanidi opisane opsada i pad grada, dočim se u Aleksandridi tematiziraju napadi osvajača s istoka i Aleksandrova veličanstvena pobjeda nad njima, a uz to se i u oba dijela u podjednakoj mjeri zagovaraju srednjovjekovni viteški moral, čast, hrabrost, poštivanje protivnika i milosrđe spram pobijeđenih, a naročito su u njima učestale i razvedene moralizatorske refleksije. ${ }^{1053}$

O mogućnosti da je Pavao Ritter $u$ doticaj $s$ tematsko-motivskim i idejnim kompleksom prisutnim u pobrojanim sastavcima Derečkajeva zbornika došao i neposrednim uvidom u sam njegov rukopisni „izvornik“ (ili možda u neki od njegovih eventualnih, do danas nesačuvanih prijepisa) nipošto neće biti bespredmetno nagađati, naročito prisjetimo li se da su ne samo u Petrovoj Sireni, nego također i u Odiljenju sigetskom - kako na sadržajnomu, tako i na cjelokupnom žanrovskom planu - zastupljeni mnogi prepoznatljivo srednjovjekovni elementi, moguće preuzeti baš i iz Derečkajeve kompilacije ili možda (i) iz nekih drugih (nesačuvanih) rukopisnih baroknih zbornika „skrojenih“ po medijevalnim predlošcima. Želimo li se, međutim, upustiti i u dodatna nagađanja o mogućim njegovim zborničkim uzorima, mogli bismo također pretpostaviti i da je Vitezović - dakako, pod uvjetom da je doista imao prilike zaviriti u Derečkajev zbornik ili koju drugu sličnu rukopisnu kompilaciju iz 17. stoljeća - svoju ,zrinijadu“ žanrovski upravo i realizirao kao tekstualno raspršen (točnije, kompiliran) žanrovski hibrid ne bi li makar neke od potencijalnih čitatelja naveo na to da mu pristupe upravo kao svojevrsnoj (autorskoj) varijanti ,punokrvnoga“ rukopisnog zbornika, s primjercima kojega su se - vjerovao je - dotad već imali prilike u više navrata susresti. Dapače, u krajnjoj bi se liniji moglo pretpostaviti i da su se iz istih ili vrlo sličnih razloga u ispisivanje svojih zbornički ostvarenih ,zrinijada“ nekoliko desetljeća ranije upustila i sama braća Zrinski, kojima je itekako dobro bila poznata popularnost onodobnih višežanrovskih i sadržajno šarolikih rukopisnih zbornika ispisanih po uzorima porijeklom iz domaćega srednjovjekovlja, no pritom ni u jednome trenutku ne bi trebalo smetnuti s uma kako - zbog manjka opipljivijih argumenata - Derečkajev zbornik ni u slučaju obiju Sirena, a još manje u slučaju Odiljenja ne možemo proglasiti provjerenim, odnosno potvrđenim književnim uzorom, a još manje izravnim stvaralačkim predloškom.

Kada smo se maločas dotaknuli potencijalnoga Ritterova žanrovskog ugledanja i u pretežno nabožni zbornik Kita cvitja razlikova Bračanina Ivana Ivaniševića, implicitno smo

1053 O Derečkajevu zborniku i njegovu pretpostavljenom utjecaju na ranonovovjekovna pisanoknjiževna djela ponajviše u: Hercigonja 1975: 381-384. Pregledno o Zborniku više i u: Kombol 1961: 210 i Bratulić 2011: 264. 
time načeli i pitanje možebitnih drugih južnohrvatskih generičkih uzora Odiljenja sigetskog, a zajedno s njim i ono autorove upućenosti u stvaralačku produkciju toga odvjetka naše književnosti, o kojoj također valja kazati makar nekoliko riječi. Da, naime, nimalo ne bi trebalo sumnjati u poodavno već izrečenu konstataciju kako su Pavlu Vitezoviću predobro bila „poznata štampana djela hrvatskih pisaca od Dubrovnika na jugu do Varaždina na sjeveru“ (Klaić 1914: 107) potvrditi nam može već i sam uvid u njegov vernakularni literarni prvijenac, u kojemu na relativno uskome tekstualnom prostoru zatječemo iznimno šaroliku paletu obilježja deriviranih (i) iz onih žanrovskih rješenja kojima su u 17. stoljeću (a i već ranije) naročito bili skloni poglavito književnici dubrovačko-dalmatinskoga književnog i kulturnog kruga. O mogućim kanalima posredstvom kojih se on bio „dokopao“ pojedinih ostvarenja naših južnih ranonovovjekovnih autora u pomanjkanju bi se opipljivih ili makar iole opipljivih dokaza doslovce moglo do unedogled spekulirati, no najrazumnijim nekako se ipak čini pretpostaviti da je prvi kontakt s tekstovima onodobnih dubrovačko-dalmatinskih pisaca naš autor ostvario još za svojih mladenačkih putovanja, ako ne i već tijekom odrastanja u rodnomu Senju, u koji su jamačno dospijevala mnoga djela južni(ji)h hrvatskih literata. Jedan od tih i takvih južnohrvatskih tekstova, koji su tijekom 17. stoljeća nedvojbeno uživali nezanemarivu popularnost i među Senjanima, gotovo je sigurno bio i već višekratno spomenuta (pred)barokna Vila Slovinka Zadranina Jurja Barakovića, koju je kao sadržajno, formalno, stilski te uopće žanrovski poprilično hibridno štivo Ritter vrlo vjerojatno imao na umu i pri sastavljanju svoje osebujne ,zrinijade“.

Da je tomu doista i bilo tako posvjedočiti nam mogu kako pojedine motivske paralele između dvaju tekstova, tako i Vitezovićevo ustrajanje na stanovitim, mahom formalnim postupcima i rješenjima, kojima u svome „spjevu“ pribjegava i Juraj Baraković, osobito na funkcionalnoj specijaliziranosti, odnosno na metametričkoj uporabi različitih stihovnih i strofičkih rješenja, ${ }^{1054}$ koja u Odiljenju kao da priziva ono isto funkcionalno eksploatiranje „,̌ctarih vrsti petja“ - pismi skupnih, osmoredki, poluretki i zučnopojki - što ga susrećemo i unutar korica Vile Slovinke. ${ }^{1055} \mathrm{Ne}$ treba, povrh toga, zanemariti ni činjenicu da i Vitezović većinom poseže za dvostruko rimovanim dvanaestercem sjevernoga tipa, ali ni da se, uz to, još i u predgovorima „čtavcima“ i ,štavcima“ prvih dvaju izdanja ne ustručava izraziti svoju ozbiljnu zabrinutost poradi preobilne zastupljenosti tuđica u hrvatskom jeziku, čime kao da se

\footnotetext{
${ }^{1054} \mathrm{Na}$ tu je funkcionalnu specijaliziranost različitih tipova stihova u Odiljenju sigetskom prvi - podsjetimo upozorio još Davor Dukić, i to u: Dukić 2002: 69.

1055 Detaljnije o metametričkoj uporabi raznoraznih stihovnih i stihovno-strofičkih rješenja u Vili Slovinki u: Petrović 1968: 44-65 i 178-212.
} 
eksplicitno teži nadovezati (i) na samoga Barakovića, koji se - strepeći nad njegovom budućnošću - na čak dva mjesta u Vili dotiče nemara sunarodnjaka spram vlastita jezika. ${ }^{1056}$

Prisjetimo li se tako podatka da je Vila Slovinka tijekom 17. stoljeća doživjela sveukupno čak tri izdanja (izuzev onoga „premijernog“ iz 1614., na književnom će se „tržištu“ tada pojaviti još i izdanja iz 1626. te 1682.), koja nepogrešivo ukazuju na to kako je njezina tadašnja popularnost zaista bila poprilična, sama od sebe nametnut će se pomisao da je - u godinama ili makar mjesecima prije početka rada na finalnoj inačici svoje „zrinijade“ jedno od tih triju izdanja u svojim rukama morao imati i Pavao Ritter Vitezović. Ako je tomu doista bilo tako, tada se posve opravdanim čini pretpostaviti i da je iz toga nevjerojatno popularnog, no ujedno i izrazito raspršenoga i generički višeslojnog teksta crpio on i makar dio svoje inspiracije za Odiljenje sigetsko, tim više što je uvidio da se i u Vili očituje snažno nastojanje na žanrovskoj hibridizaciji odabranoga temeljnog generičkog okvira, koje se ponovimo - u baroknoj književnosti očitovalo ne samo u primjercima naoko „čistih“ žanrova poput epske pjesme, nego i u tada posebno učestalomu kompilacijskom (zbirčanozborničkom) štivu, što i jest rezultiralo time da je žanrovski ništa šarolikije od kakve (naoko) zaokružene i kompaktne epske pjesme ,izgledao (...) i tipičan rukopisni zbornik raznolike građe u hrvatskoj književnosti toga vremena“ (Petrović 1968: 210, bilješka 37). Uostalom, i više je nego uvjerljivu potvrdu ove pretpostavke o Ritterovu preuzimanju pojedinih elemenata (i) iz Barakovićeva „spjeva“ moguće iznaći ni manje ni više nego u samome tekstu Odiljenja, i to ponajprije na njegovu jezičnom nivou, na kojemu se, između ostalog, pojavljuje i poneka (čakavska) riječ koju je naš autor mogao preuzeti samo i isključivo iz teksta Vile Slovinke, ${ }^{1057}$ što vrijedi i za nekolicinu sadržajno vrlo intrigantnih motiva poput (identično koncipiranoga) lika vile, ali i motiva razgovora između vile (Jeke) i „smrtnika“ (putnika namjernika), koji zatječemo u pjesmi Putnik i Jeka trećega „dila“, a koji iznimno snažno podsjeća upravo na dionice Vile Slovinke u kojima komunikaciju zapodijevaju Pisnik i Vila. ${ }^{1058}$

\footnotetext{
${ }^{1056} \mathrm{Na}$ taj će se problem, konkretno, osvrnuti Baraković najprije u stihovanoj posveti An'jelu Justinijanoviću, u kojoj kritizira veću sklonost svojih sunarodnjaka stranim jezicima nego njihovu vlastitom, hrvatskom (usp. Baraković 2000: 54-55, stihovi 435-448), a potom i u „petju sedmom“, u kojemu Vila Pisniku izražava svoju ojađenost činjenicom da se Hrvati srame svoga narodnog jezika, odnosno da neprekidno daju prednost stranim jezicima i uopće iskazuju interes spram isključivo inozemnih književnih ostvarenja (usp. naročito VII: 923-938). ${ }_{1057}$ Prema Tomi Matiću, priređivaču jednoga od cjelovitih dvadesetostoljetnih (re)izdanja Odiljenja sigetskog (Zagreb, 1968.), riječi što ih je Vitezović prethodno mogao susresti jedino u tekstu Barakovićeve Vile Slovinke bile bi tako glagol „raztanil“ (rastao se; IV: 83) te imenica ,„̌krila“ [(nadgrobna) ploča; IV: 256], no i više je nego vjerojatno da bi se pažljivijim čitanjem mogla ondje naći i još pokoja. Usp. Matić 1968: 103-108 i tekst Odiljenja sigetskog s Matićevim bilješkama na str. 109-165.

1058 Inače, da je Vitezović za života itekako pomno - pa i, kako se čini, u više navrata - bio iščita(va)o Vilu Slovinku daleko će nam najuvjerljivije potvrditi dva njegova historiografska ostvarenja, i to najprije vernakularni kronikalni prikaz hrvatske i svjetske povijesti Kronika aliti spomen vsega svieta vikov iz 1696., a zatim i čuvena mu latinska spomenica Croatia rediviva (Oživljena Hrvatska), koja je svjetlo dana ugledala 1700. godine. Ekspicitan dokaz o dobrom poznavanju Barakovićeva „spjeva“ Ritter će tako iznijeti već u (proznoj) latinskoj
} 
Ovo i ovakvo, i više nego izgledno Vitezovićevo kreativno oslanjanje na jedno „punokrvno“ epskopjesničko ostvarenje, kakvim se teži predstaviti Vila Slovinka, ujedno kao neizbježnu nameće i potrebu razmatranja potencijalnih drugih njegovih generičkih uzora iz redova baroknih epskih pjesnika, čija su ostvarenja dijelila karakteristike tada dominantnoga epskopjesničkog modela, za koji je kao predložak - podsjetimo - poslužio glasoviti povijesni ep Torquata Tassa Oslobođeni Jeruzalem. Zastupljenost nezanemarivog broja tih značajki „tipičnih“ za sedamnaestostoljetnu (junačku) epsku pjesmu i u „fakturi“ Odiljenja - počevši od već zamijećenih ,tassovskih“ tematsko-idejnih ishodišta (opjevavanje sukoba kršćana i muslimanskih „nevjernika“ te njegovih reperkusija), preko onodobnoj „epici“ posebno dragoga ukrštavanja ratnih, nabožnih i ljubavnih motiva, pa sve do paralelnoga sadržajnog fokusiranja na „zbivanja“ koja se odvijaju u trima „epskim svjetovima“: realističkom, romantičkom i eshatološkom - moguće je, dakako, glavninom pripisati Ritterovu obilatom ugledanju u Adrijanskoga mora Sirenu Petra Zrinskog, središnji i „najvažniji“ dio koje čini upravo zamašni „tassovski“ ep Obsida sigecka. Budući da je sam Tasso epsku pjesmu zamišljao kao versificirano djelo u kojemu bi doslovce trebalo biti moguće čitati o svemu i svačemu, odnosno koje - iz toga razloga - neizbježno mora težiti popriličnoj žanrovskoj hibridnosti, jasno je da bi „tassovskim“ nasljeđem u Odiljenju svakako valjalo izdvojiti još i „napadnu“ lirizaciju teksta koji bjelodano obrađuje „epsku“ temu i posjeduje niz prepoznatljivo epskopjesničkih obilježja, a koja neodoljivo podsjeća upravo na Tassovo prožimanje „epskoga“ sastavka „tipično“ lirskopjesničkim posebnostima u rasponu od naglašene osjećajnosti i afektivnosti, pa sve do lirici svojstvene kontemplativnosti i patosa. ${ }^{1059}$ Ispisujući svoju (tematski neupitno „epsku“) ,zrinijadu“ (i) na podlozi žanrovski krajnje hibridnih ,sečentističkih“ epova, iz kojih i potječu njezina maločas detektirana „tipično“ epskopjesnička (glavninom sadržajna) obilježja, Pavao Vitezović kao da je u očima

posveti pučkim recipijentima primarno namijenjene Kronike petrovaradinskom opatu Ivanu Zniki, u kojoj izrijekom citira segment iz sedmoga pjevanja Vile (usp. o Vitezovićevu pozivanju na Barakovićevu Vilu u posveti Kronike u: Jembrih 2015: 526-527, 2016a: 38-39 i 2017b: 36), dajući time ujedno do znanja kako se taj specifičan ,spjev“ u njegovim rukama definitivno bio našao već i prije 1696. Nepune četiri godine kasnije, Ritter će ponovno posegnuti za Barakovićevim sastavkom, i to u sklopu (isključivo) društvenoj eliti namijenjene povijesne rasprave Oživljena Hrvatska, u kojoj svoju tezu kako bi Hrvatskom valjalo proglasiti čitav onaj prostor što su ga Rimljani svojedobno bili nazivali Ilirikom potkrepljuje, među ostalim, i nekolicinom izravnih navoda (citata) izvučenih upravo iz Vile Slovinke (o tome usp. Klaić 1914: 143), kojima prilično jasno aludira na (historiografsku) važnost što ju je u njegovim očima imalo to - ne samo žanrovski - specifično ostvarenje zadarskoga pjesnika. Štoviše, kako su to pokazale neke od recentnijih analiza Oživljene Hrvatske, po učestalosti referiranja na njezin tekst Vila Slovinka zauzima iznenađujuće visoko treće mjesto među ostvarenjima na koja se Vitezović pozivao pri sastavljanju ovoga svog historiografskog spisa (usp. tablični prikaz u: Blažević 1997: 24), pri čemu je najopravdanije pretpostaviti da su se i njegova recepcija, a onda i oba spomenuta ,čina“ citiranja teksta najvjerojatnije bili temeljili na posljednjemu, što će reći venecijanskom izdanju Barakovićeva djela, objelodanjenu 1682. godine.

${ }^{1059}$ Usp. o ovome u: Fališevac 1997: 161-175. 
čitatelja dobro upoznatih s tada suvremenom epskopjesničkom produkcijom želio stvoriti dojam kako se i u Odiljenju sigetskom zapravo radi o ostvarenju generički najbližem upravo baroknoj epskoj pjesmi, ${ }^{1060}$ dočim je - s druge strane - cjepkanjem teksta u zasebne, žanrovski raznolike, no tematski donekle ipak povezane pjesme recipijente sa slabijom naobrazbom i skromnijim književnim iskustvom pokušao navesti na to da mu pristupe kao „običnomu“ (baroknom) zborniku, odnosno kao žanrovski heterogenoj kompilaciji, s kakvima su se dotad već jamačno bili višestruko susretali zahvaljujući pučkim zborničkim ostvarenjima, anonimnim rukopisnim pjesmaricama, ali i - u krajnjoj liniji - samoj Bibliji, koja i nije ništa drugo no stihovno-prozni religiozni zbornik žanrovski kojekako realiziranih zasebnih tekstova. Realiziravši ga kao generički raznoliko odrediv tekst, koji je, kao takav, gotovo savršeno odražavao temeljne poetičke zasade književnoga baroka, naš je autor svoje (djelomično „epsko“) Odiljenje ujedno pozicionirao i uz bok mnogim drugim domaćim epskopjesničkim sastavcima iz toga vremena, što će reći nipošto samo onomu Petra Zrinskog, iz kojega je - kako je već utvrđeno - i posudio glavninu od u njemu prisutnih značajki „tipičnih“ za žanr (baroknoga) povijesnog epa. Njegov se hrvatski književni prvijenac, između ostalog, tako nameće i kao neobično blizak osobito nekolicini onih žanrovski krajnje hibridnih baroknih epskopjesničkih ostvarenja poput, primjerice, Povijesti vandjelske bogatoga a nesrećna Epuluna i ubogoga a čestita Lazara), koje je splitski pjesnik Jerolim Kavanjin u cijelosti dospio dogotoviti tek u prvom desetljeću 18. stoljeća. Naime, u tomu se svom - Odiljenju po mnogočemu podudarnom - tematski neuobičajeno raspršenom te prostorno i vremenski skokovitom i uopće diskontinuiranu (,epskom“) tekstu lišenom čvrste fabule $\mathrm{i}$ figure glavnoga junaka, Kavanjin ni najmanje nije ustručavao (formalni) epskopjesnički okvir obilato napučiti zasebnim značajkama, a mjestimice čak i cjelovitim primjercima žanrova u rasponu od lirske pjesme, preko nabožno-didaktičkoga pjesništva i religijske poeme, pa sve do različitih biblijskih generičkih rješenja, ${ }^{1061}$ pri čemu je s potpunom sigurnošću nemoguće ustanoviti u kolikoj mu je mjeri - i je li uopće - podstrek za takva generička poigravanja došao i od ,zrinijade“ Pavla Vitezovića, za čijim je opusom tijekom rada na svome ,epu“ dokazano on bio posezao. ${ }^{1062}$ Dakako, sličan je zaključak - koji

\footnotetext{
1060 Da je u tom naumu naš autor doista i uspio pokazuje već spomenuti primjer kasnijih, osamnaestostoljetnih čitatelja Odiljenja iz krugova pjesnika, koji su mu - očigledno ga pročitavši na podlozi Tassova i drugih sedamnaestostoljetnih, žanrovski „kaotičnih“ epskopjesničkih ostvarenja - redovito prilazili ni manje ni više nego upravo kao (povijesnoj) epskoj pjesmi.

${ }^{1061}$ Podrobnije o žanrovskim i drugim posebnostima Kavanjinova „epa“ u: Kravar 1975: 7-102.

1062 Povijest vanđelska ujedno se, naime, kristalizira i kao nepobitan dokaz Kavanjinova sjajnog poznavanja (dijela) pisanoga stvaralaštva Pavla Rittera Vitezovića, i to ni manje ni više nego stoga što je na jednome mjestu u njoj moguće zateći upravo izravnu parafrazu heraldičke pjesme posvećene grbu Hrvatske što ju je naš autor donio u svome čuvenom grbovniku Stemmatographia (usp. o tome u: Bratulić 1997: 33-34). Kavanjinovo
} 
bi upućivao na njegovo možebitno kreativno nadovezivanje na druga točno određena žanrovski „,zamršena“ barokna epskopjesnička ostvarenja poput Povijesti vanđelske - i u pogledu našega autora izrazito teško, ako ne i posve nemoguće izvesti, što će reći da nam ne preostaje ništa drugo no zadovoljiti se spoznajom kako su u barokno doba za mnogima od onih rješenja što ih je on utkao u Odiljenje počesto bili posezali i (drugi) naši epski pjesnici, i to s posve identičnom nakanom da stvore (generički) što modernija, a ujedno i potencijalnim čitateljima što intrigantnija djela.

Drugim riječima, usprkos činjenici da se pri sastavljanju svoje ,zrinijade“ nije mogao oslanjati ni na kakav žanrovski posve identično realiziran literarni predložak iz domaće, a još manje europske (barokne, ali i predbarokne) književnosti u cijelosti, Pavao je Ritter nesumnjivo polazio od generički izrazito kompleksnih epskopjesničkih tekstova svoga vremena, ali i, još više, onih - podjednako hibridnih - djela kompilacijskoga tipa, među kojima mu je daleko najvažniji stvaralački oslonac nudila Adrijanskoga mora Sirena neposrednoga prethodnika. Na ,žongliranje“ žanrovskim obilježjima raznolike provenijencije lako ga je mogao - a vrlo vjerojatno i jest - navesti već spomenuti rukopisni izbor iz Sirene, koji je svojedobno kružio među većinom ženskom (dvorskom) publikom, ${ }^{1063}$ dočim je govoreći iz perspektive isključivo južnohrvatskih baroknih tekstova - istovjetan poticaj mogao on dobiti i iz zborničkih djela poput Ivaniševićeve Kite cvitja razlikova, ali i (makar samo formalno epskopjesničke) Vile Slovinke Jurja Barakovića. Osim svih netom spomenutih, pa i možebitno neuočenih ili ne(pre)poznatih domaćih književnih uzora, žanrovski poticaj za Odiljenje Vitezoviću je gotovo sigurno stigao i iz same Biblije kao jednog od daleko najutjecajnijih ostvarenja zborničkoga tipa ne samo u 17. stoljeću, nego i tijekom čitava ranonovovjekovlja, na što bi ponajprije upućivale kako njegova kompilacijska struktura i neobično velika količinska zastupljenost „biblijskih“ žanrova (u rasponu od poslanice do poslovice), tako i već višestruko istaknuta činjenica kako se njime on silno želio približiti i tek bazično obrazovanim potencijalnim čitateljima, za koje je pouzdano znao da ih je najlakše zaintrigirati upravo tekstom napučenim folklornoknjiževnim obilježjima, koji, uz to, svojom zborničkom formom i žanrovskim „sastavom“ snažno podsjeća na više im i nego dobro poznatu, također generički krajnje šaroliku Bibliju.

Naime, pored toga što je (i) u periodu baroka (po)služila kao - ponajprije motivsko, idejno (ideološko) i žanrovsko - ishodište mnogih literarnih i ne samo literarnih djela, Biblija

oslanjanje na njegov latinski grbovnik u tom se smislu nameće i kao jedan od najuvjerljivijih potvrda raširenosti i prihvaćenosti Vitezovićeva stvaralaštva, a time i kao još jedan u nizu dokaza nimalo slabašne povezanosti sjevernohrvatske i južnohrvatske književnosti u ranomu novom vijeku.

1063 O tom rukopisnom izboru posebno u: Novalić 1967a: 212-221. 
je također - zajedno s autohtonim usmenoknjiževnim, ${ }^{1064}$ ali i pučkoknjiževnim ostvarenjima - određenim krugovima recipijenata osiguravala jedini kontakt s književnim stvaralaštvom, i to ni manje ni više nego onim (njihovim potrebama i očekivanjima najprimjerenijim) prožetim jakom didaktičko-utilitarnom komponentom. U tom smislu, ukoliko bi iznijete pretpostavke o možebitnomu Vitezovićevu žanrovskom nadovezivanju na neke od dosad pobrojanih zborničkih i epskopjesničkih sastavaka - izuzev, dakako, na obljubljenu mu Petrovu Sirenu i njoj pripadajući povijesni ep Obsida sigecka - definitivno još i bile podložne sumnji, prilično izglednomu njegovu kreativnom ugledanju u Bibliju znatno je teže pronaći iole suvisliji i ozbiljniji prigovor, posebice stoga što je svoje kompilacijski skrojeno Odiljenje premrežio mnoštvom žanrova koji su (i) u biblijskim okvirima imali istaknuto mjesto, a u sastavljanju kojih se jamačno izvještio još tijekom školovanja u zagrebačkoj jezuitskoj gimnaziji, kada je i njegov kontakt s Biblijom - u smislu njezina gotovo svakodnevnog, minucioznog proučavanja - bio i više nego intenzivan. Sastavljajući svoj zbornički vernakularni literarni prvijenac, dapače, nedvojbeno je on i računao s time da će velik dio potencijalne njegove publike neodoljivo on podsjetiti upravo na Bibliju, i to nipošto samo žanrovski, dakle činjenicom da se u njegovu kompilacijskom generičkom okviru sprežu tekstovi prožeti (i) obilježjima žanrova biblijske provenijencije, nego i idejno-motivski (baroku svojstvenim propagiranjem kršćanskoga pravovjerja, neprestanim nizanjem pouka o neizbježnosti smrti i potrebi kreposnoga življenja, glorificiranjem figure ratnika-mučenika koji pogiba za „više ideale“ itd.) te uopće tematski i sadržajno, odnosno tematskom izraslošću apsolutno svih u nj uvrštenih pjesama iz jednoga centralnog događaja, kojom nalikuje biblijskim tekstovima, odreda fokusiranima na problem odnosa Boga i ljudi. ${ }^{1065}$

\footnotetext{
${ }^{1064} \mathrm{Ne}$ zaboravimo, $\mathrm{k}$ tomu, i da su brojne izvorno biblijske teme, motivi, likovi, fabule, likovi, simboli, ali i niz stilskih, formalnih, pa i - u krajnjoj liniji - žanrovskih rješenja, iznimno bili rašireni i u samoj usmenoj književnosti, što se - po mišljenju Stipe Botice - može shvatiti kao i više nego uvjerljiv pokazatelj duboke ukorijenjenosti Biblije u hrvatskome narodu. Detaljnije o utjecaju Biblije na hrvatsku usmenu književnost u: Botica 1995 i 2011.

1065 Navedenim prilično očitim tekstualnim sličnostima usprkos, za Bibliju bi ipak suviše ishitreno bilo konstatirati da se radi o ,pravome“, neupitnom (generičkom) uzoru Odiljenja sigetskog, i to zbog čitava niza razloga koji se tiču kako njezina porijekla te (izvornoga i kasnijeg) društveno-kulturnoga statusa, tako i same njezine namjene, pa i unutartekstualnih distinkcija, počevši s mnogim nepomirljivim sadržajnim, strukturnokompozicijskim, stilskim i inim razlikama, koje jasno daju do znanja kako se radi o djelima iz dvaju posve različitih stvaralačkih i kulturnih registara. Pa, ipak, usprkos tomu što je tih distinkcija i sam bio i više nego svjestan, Pavao je Vitezović, kako se čini, čvrsto vjerovao u to da će skromnije obrazovana publika svoja žanrovska očekivanja od njegove „zrinijade“ - osim na podlozi dotadašnjih kontakata s drugim generički podudarnim, kompilacijskim sastavcima - temeljiti (i) na prethodnom iskustvu recipiranja nebrojenim mnoštvom žanrova napučene Biblije, koja je mogla i morala poslužiti kao ogledni primjer(ak) jedne varijante tekstova zborničkoga tipa, u kojoj su raznolika generička rješenja ,aktivirana“ ne bi li podastrijela što obuhvatniji i slojevitiji prikaz ideološki bliskoga skupa tema. Dapače, s pravom se Ritter nadao i da će ti isti čitatelji ne samo dospjeti uočiti vrlo sličnu (generičku) koncepciju na kojoj se zasnivaju oba ostvarenja, nego i da će mnoge žanrove za čijim je značajkama u Odiljenju i sam posegnuo prepoznati i razumjeti upravo na temelju ranijega susreta s istim ili vrlo sličnim generičkim rješenjima zastupljenima unutar korica Biblije, odnosno da će
} 
Kada, međutim, govorimo o žanrovskom obilju u Bibliji kao pretpostavljenom uzoru ili predlošku generičke višeslojnosti Odiljenja sigetskog, ni na tren s uma ne bismo smjeli smetnuti činjenicu kako u njezinu slučaju ipak nemamo posla s kompilacijskim ostvarenjem u potpunosti - dakle, strukturno i uopće konceptualno - istovjetnim baroknim i/ili predbaroknim zbornicima, u kojima se mnoštvo u njih uvrštenih tekstova najčešće nije svrstavalo ni razvrstavalo u zasebne manje (pod)cikluse. S druge strane, već pri prvom susretu s Biblijom biva jasno da je ona zapravo ništa drugo no kompilacija žanrovski (donekle) zaokruženih tekstova, odnosno (biblijskih) „knjiga“ vrlo raznolikoga generičkog sastava, koje se, po tradiciji, okupljaju u dvije veće cjeline ili zbornika - Stari i Novi Zavjet, što se nadaju kao žanrovski do krajnosti hibridizirane i sadržajno zaokružene, no u isti mah i tematski izrazito međuovisne dionice jedinstvene biblijske „naracije“. Promotrimo li je, međutim, kao kompaktno djelo, u kojemu se, izuzev tematsko-motivskih, može zateći i niz žanrovskih poveznica između dviju cjelina, spoznat ćemo da je riječ o možda i najkompiliranijemu ostvarenju u povijesti svjetske književnosti i kulture uopće, sazdanom od nepojmljivo velikoga raspona žanrova, koji se proteže od legendi, biografija, ljetopisa, rodoslovlja, kronika i predaja, preko poslanica, psalama, poema, himni, molitava, tužaljki i balada, pa sve do rasprava, zakonika, pouka, basana, kletava, blagoslova, jadikovki, poslovica itd. ${ }^{1066}$

im biti u stanju pristupiti s očekivanjem da se radi o žanrovima koji se - baš poput njihovih biblijskih „predložaka“ i $\mathrm{i} / \mathrm{ili}$,srodnika“ - također hvataju u koštac s nekim iznimno važnim temama te stoga posjeduju i poseban značaj, pa i unatoč tomu što su mnoge od njih u više navrata oni mogli susresti i u usmenoknjiževnom „opticaju“, svedene na „razinu“ posve svakodnevnih, životno-prigodnih žanrova lišenih neke osobito velike (nadtekstualne) važnosti. Biblija je, drugim riječima, Vitezoviću tako mogla i morala poslužiti isključivo kao strukturno-žanrovski, pa i - u određenoj mjeri - sadržajno-motivski (osobito u pogledu evociranja već spomenutoga motiva kršćanskoga ratnika-mučenika ili tzv. toposa athleta Christi, izravno proizišloga iz biblijskoga lika Krista-mučenika i otkupitelja) te idejni uzor ili - s(p)retnije rečeno - predložak, dočim njezina utilitarna funkcija, odnosno ideološka svrha te promidžbeno-propagandni i didaktički ciljevi nisu u njegovoj „Zrinijadi“ dospjeli ostaviti gotovo nikakva traga, premda se i u njezinu slučaju - u suštini - ne radi zapravo ni o čemu drugome no o djelu u cijelosti obilježenom kršćanskim svjetonazorom te uvelike sastavljenom i poradi stanovitih, nešto ranije već detektiranih propagandnih (širenje svehrvatskoga jezika), pa i - donekle mobilizacijskih (poticanje čitatelja da se uključe u akcije oslobađanja i obnove Sigeta kao važnoga hrvatskog mjesta pamćenja) izvantekstualnih ciljeva.

1066 Drago Šimundža u jednomu će tako svom eseju posvećenom žanrovskim osobitostima biblijskih knjiga i Biblije kao cjeline podastrijeti daleko pregledniji, ali i po rodovskim kategorijama grupiran popis nekih od najprepoznatljivijih žanrovskih rješenja što ih ona obuhvaća, a iz kojega postaje jasno da u njoj ne manjka ni „epskih“ žanrova (priče, biografije, legende, anegdote, pripovijesti, novele, ljetopisa, rodoslovlja, kronike, parabole, predaje, basne, bajke, prozne izreke i poslovice, putopisa, propovijedi, proroštva u prozi, meditacije itd.), ni onih „lirskih“ (psalma, kancone, himne, poeme, hvalospjeva, molitve, tužaljke, versificirane meditacije, proroštva u stihu, balade i dr.), a u konačnici čak ni „dramskih“, pa ni tzv. „diskurzivnih“ žanrova poput tužba i jadikovki, blagoslova, kletvi, prijepora, razgovora (dijaloga), sudbenih svjedočanstava, dramskih recitacija (poput, primjerice, Pjesme nad pjesmama), ali i segmenata protkanih „komičnim“, „tragičnim“ i „satiričnim“ značajkama (znatno detaljnije o ovome u: Šimundža 2010: 279-296). Za nijansu manje detaljan, no po sastavu gotovo identičan popis žanrovskih rješenja čijim su značajkama bremenite pojedine dionice biblijskih knjiga u svojoj je monumentalnoj studiji o Bibliji kao književnomu djelu donio i Dean Slavić, po čijem su sudu u Staromu i Novoти Zavjetu zastupljeni žanrovi u rasponu od sage, legende, romanse, kronike, pripovijetke, parabole, proroštva, genealogije, etiologije, pripovijesti o rođenju, pripovijesti o čudima, bogojavljenja i junačkih djela, pa sve do tužaljke, zahvalnice, blagoslova, prokletstva, proroštva, domoljubne poezije, zakonika, 
Ukoliko nam netom utvrđena nemogućnost pronalaženja konkretnih, generički dovoljno podudarnih uzora ili predložaka daje za pravo konstatirati kako vernakularni Ritterov literarni prvijenac stvarnoga uzora u žanrovskomu smislu - ni u okvirima naše (barokne) književnosti, pa ni šire - nije zapravo niti imao, s identičnim nedoumicama suočit će nas i pitanje možebitnih njegovih generičkih nastavljača i nasljednika, kojih u hrvatskoj književnosti nakon 1700. nije nedostajalo, no među kojima je ne samo teško, nego i posve nemoguće naći makar jednoga koji se u (pretpostavljenomu) sekundarnom žanru kojim je Odiljenje ispjevano i sam odvažio realizirati neko od svojih literarnih ostvarenja. Odiljenje sigetsko, naime, za razliku od velikoga je broja inih djela iz domaće književne prošlosti u 18. stoljeću tako uistinu ,imalo sreću da bude čitano, pa i djelomice nasljedovano“ (Dukić 2002: 70), no ne i da među svojim tadašnjim recipijentima - koji su i sami mahom bili literati, i to pretežno pisci epskopjesničkih tekstova ${ }^{1067}$ - nađe ,punopravnoga“, apsolutnog generičkog nastavljača, kadrog ili naprosto voljnog da, slijedeći njegov „obrazac“ i sam ispiše formalno i uopće žanrovski raspršeno djelo „učvršćeno“ zajedničkim sadržajno-idejnim „nazivnikom“. No, iako ta činjenica možda i najuvjerljivije govori u prilog njegovoj žanrovskoj osebujnosti, nipošto se ne smije zaboraviti kako su i tijekom 18. stoljeća na danje svjetlo nastavila izlaziti u većoj ili manjoj mjeri generički (relativno) bliska ostvarenja, obogaćena još i intrigantnim sadržajnim, formalnim i strukturnim rješenjima i postupcima, za kojima je prije njih u kontekstu naše književnosti bio posegnuo nitko drugi no sam Ritter, što i jest ključni razlog koji ta i takva djela čini i više nego nužnim uzimanja u obzir pri razmatranju eventualnih (pa makar i samo djelomičnih) osamnaestostoljetnih književnih nasljednika Odiljenja sigetskog.

Prvo iz slijeda rečenih će se djela pojaviti točno desetljeće (1705.) nakon izlaska iz tiska posljednjega Vitezovićeva izdanja Odiljenja, kada pred čitatelje dospijeva već spomenuta latinska knjiga grofa Ivana Franje Čikulina Ideje ilirske i panonske velikodušnosti (Ideae magnanimitatis Illyricae et Pannonicae), sastavljena od „dvadeset četiri povjestice, dvije žalopojke i četiri poslanice u kojima je opjevao primjere onih junaka koji su se proslavili u ratovima protiv Turaka“ (Prosperov Novak 1999: 721-722). Radi(lo) se, drugim riječima, o Ritterovoj hibridnoj „zrinijadi“ formalno, strukturno, pa i žanrovski ne toliko različitom kompilacijskom ostvarenju, u kojemu se kroz dvadesetak epilija i još nekoliko (fiktivnih) poslanica ili heroida te epitafa odaje počast požrtvovnim hrvatskim i mađarskim vojskovođama iz bliže ili dalje prošlosti, koji su se u dosadašnjim protuturskim akcijama itd., a razabrati je mjestimično u njima moguće čak i neka obilježja plautovske komedije. Daleko iscrpnije o žanrovskim komponentama Biblije u: Slavić 2016: 87-103. Usp. i opis „žanrovskoga sastava“ Biblije i u: Duda 2003: 1171-1173.

${ }^{1067}$ Usp. o tome npr. u: Dukić 2002. 
istakli do te mjere da bi ih s punim pravom valjalo držati nenadmašnim uzorima „,̌istokrvne“ hrabrosti, odanosti i domoljublja. S obzirom na njegovu temu i način na koji je ona obrađena, i više je nego očito da se ovaj latinski zbornik težio nametnuti kao moralno-didaktički priručnik, koji je - odobren od strane crkvene cenzure - $\mathrm{u}$ isusovačkim školama trebao služiti u memorijalno-edukativne svrhe, odnosno koji je pitomcima mogao pomoći u osnaživanju domoljubnih osjećaja, osvježavanju pamćenja na važne trenutke i aktere iz domaće povijesti, a u konačnici i osvješćivanju potrebe izgradnje nacionalnoga identiteta, temelj kojega je - po njegovu mišljenju - trebalo biti upravo sjećanje na slavnu prošlost i junačke pretke.

Osim potonjih, i više nam nego dobro poznatih zamisli, iz kojih je i proizlazila izvanknjiževna svrha Čikulinove kompilacije, na možebitno kreativno oslanjanje (i) na hrvatski Vitezovićev prvijenac upućivat će gotovo čitava njezina tekstualna „faktura“, počevši od odabrane joj forme generički heterogenoga zbornika napučenog žanrovskim obilježjima prisutnima i u Odiljenju (primjerice, onima heroida, epitafa, povijesne epske pjesme, ratnoga govora itd.), preko zajedničke tematske intencije ka proslavljanju junaka protuturskih ratova i njihovih egzemplarnih herojskih vrlina koja povezuje sve njezine dijelove, pa sve do motivskoga joj rekvizitarija, u kojemu su važnu ulogu igrali „vitezovićevski“ motivi poput onoga junaštvima sklonih ženskih govornica (u slučaju Ideja riječ je o suprugama kršćanskih vojskovođa, koje uzimaju riječ ne bi li skrenule pozornost na vlastite junačke pobude), zapovjednikova motivacijskog govora uoči ključne bitke, dvoboja istaknutih junaka, motiva odvažnoga zazivanja smrti itd., no ne smiju se zaboraviti ni u nju uključene mjestimične izravne aluzije na antičke epove (možda i u slijedu Rittera, koji u Odiljenju evocira epskopjesnički opis opsade i pada Troje, Čikulin u svome djelu tako donosi česte aluzije na Vergilijevu Eneidu), kao ni metričke inovacije situirane u epitafima (u kojima zatječemo i ne odveć uobičajene kombinacije segmenata ispjevanih heksametrom i onih u elegijskom distihu), koje i više nego snažno podsjećaju na polimetrično realiziran četvrti „dil““ Vitezovićeve ,zrinijade“. Čikulinov je, štoviše, zbornik i u strukturno-kompozicijskom pogledu gotovo u potpunosti usporediv s Ritterovim hrvatskim književnim prvijencem, pa i u njemu tako nakon poduljega pjesničkog uvoda napučenog mnogobrojnim epskopjesničkim značajkama (odnosno uvodne heroide protkane naracijom i drugim „epskim“ čimbenicima, ali i prepoznatljivim obilježjima consolatia) slijede ciklusi ratnih govora i heroida, da bi ga posve „vitezovićevski““ - zaključio ni manje ni više nego niz epitafa, koji tu sumnju u 
pretpostavljeno ugledanje u kompoziciju i strukturu žanrovski šarolikoga Odiljenja sigetskog čini još vjerojatnijom. ${ }^{1068}$

Kada govorimo o potencijalnim osamnaestostoljetnim žanrovskim „sljedbenicima“ Vitezovićeva Odiljenja sigetskog, nipošto neće biti (posve) neutemeljeno pretpostaviti kako se u svojstvu jednoga od njih našao i znameniti kasnobarokni isusovački pjesnik Antun Kanižlić, navlastito stoga što se radilo o autoru koji je - ponajprije zahvaljujući činjenici da se u Zagrebu najprije školovao, a potom i radio kao učitelj, te da je, povrh toga, još u mladosti razvio neobično snažnu čitateljsku sklonost spram južnohrvatskoga nabožnog pjesništva, osobito prema religioznim poemama dubrovačkih „sečentista“ - dospio steći izrazito dobar „pregled nad dostignućima decentriranoga kulturnog života između Drave i Jadrana“ (Kravar 1993: 138). I više nego sumnjivima u tom bi nam se smislu mogle i morale učiniti pojedine karakteristike njegove barokne religiozne poeme Sveta Rožalija (1780.), poglavito formalna joj podloga u obliku dvostruko rimovanoga dvanaesterca, za koju se opredijelio ponesen možda i primjerom samoga Rittera i njegova favoriziranja (is)toga stiha u sva četiri „dila“

1068 Svojim Idejama ilirske i panonske velikodušnosti Ivan Franjo Čikulin kao da je - ponovno ekvivalentno Vitezoviću - težio pokazati da barokni heroizam, koji se očitovao u tada izrazito učestalim i (od pisaca i publike) silno obljubljenim temama i motivima neustrašivog i samoprijegornog ratnoga žrtvovanja, može biti pogodan za obradu kako u njemu najprikladnijim žanrovima junačke epske pjesme i epilija, tako i u raznim lirskopjesničkim generičkim rješenjima poput heroide i epitafa, iz čega bi slijedilo da u pozadini ovoga latinskog zbornika - kako je svojedobno izvrsno poentirala Zrinka Blažević - zapravo stoji nastojanje da se herojsko promovira u svojevrsni „univerzalni model ljudske životne prakse“ (Blažević 2007: 254). Bit će, naime, da se ovom vrlo intrigantnom i efektivnom spregom „,lirskih“ $i$,epskih“ momenata ustvari težilo naglasiti isprepletenost junačkih podviga i emocija, odnosno pokazati kako „transpozicijom herojskoga iz epskoga u lirski modus dolazi i do kontaminacije herojske vrline afektima“" (Isto: 258-259), pri čemu treba uočiti kako i ondje - gotovo identično kao i u Odiljenju, gdje se epitafi donose kao svojevrsne završne potvrde memorijalne važnosti Sigeta, koja proizlazi iz žrtve što su je za njega podnijeli kršćanski (čitaj: hrvatski) branitelji - „nadgrobnice predstavljaju konačan akt diskurzivne memorijalizacije ilirskih i panonskih heroja koji im ujedno omogućuju metafizičku transpoziciju u arhetipske uzore velikodušnosti - ideae magnanimitatis (Isto: 259). I Čikulinu je, moglo bi se reći, očito itekako bilo stalo do toga da opjeva ne samo ,javni“, nego i „privatni“ aspekt protuturskih ratova zbog čega se i jest fokusirao kako na motive koji su pripadali vremenu samih bitaka, tako i na momente koji su uslijedili nakon smrti njihovih najistaknutijih sudionika - pri čemu je u njegovu djelu, nasuprot Odiljenju, posebnost $\mathrm{u}$ tome što je fokus ondje postavljen na junake različite (ne samo hrvatske, već i mađarske) nacionalnosti koji su sudjelovali u kršćansko-muslimanskim ratovima, dočim se Vitezović nepokolebljivo odlučuje usredotočiti na jednu konkretnu bitku i njezine (hrvatske) heroje, što bi onda značilo da su Ideje realizirane kao upravo onaj tip zbornika (ili djela „zborničkoga tipa“), u kojemu se u različitim žanrovima opjevavaju tematski i motivski donekle različiti sadržaji (u Odiljenju se, podsjetimo, radi o jednoj „središnjoj“ temi i iz nje izraslim otprilike srodnim motivima), odnosno da su - u konačnici - žanrovski one najbliskije varijanti pjesničke kompilacije kakvoj pripada i Petrova Sirena. Osim toga, govoreći o sadržajnim i oblikovnim podudarnostima Odiljenja sigetskog i Ideja ilirske i panonske velikodušnosti, nipošto ne bismo smjeli zaboraviti ne samo činjenicu da je prvo izdanje Čikulinova zbornika u svojoj zagrebačkoj Zemaljskoj tiskari 1705. vlastoručno otisnuo sam Vitezović, nego i to da je naš autor pristao to učiniti tek nakon što je knjizi pridodao svoju latinsku pohvalnu pjesmu (tj. prigodnicu), u kojoj je biranim riječima pohvalio književnu vještinu svoga suvremenika te nagovijestio velik uspjeh njegova zanimljivog i vrijednog ostvarenja. Tim se podatkom, dakako, nipošto ne želi sugerirati kako je Ritterova odluka da otisne Čikulinov zbornik bila motivirana spoznajom da se radi o generički bliskim tekstovima, što će reći da bi - želi li se sumnja o povezanosti dvaju djela doista i potvrditi - definitivno valjalo provesti i mnogo detaljniju usporedbu dvaju djela i naročito njihovih generičkih osobitosti ne bi li se utvrdile i potvrdile konkretne Čikulinove posudbe iz Odiljenja sigetskog, što je - dakako posao koji uvelike izlazi izvan okvira ovoga rada. Znatno detaljnije o posebnostima Čikulinovih Ideja u: Blažević 2007: 249-264. 
Odiljenja, kao što se - uostalom - (i) po uzoru na njegovo učestalo posezanje za generičkim značajkama fiktivne poslanice ili heroide možda i sam odvažio isti žanr „aktivirati“ i u svome tekstu, (sadržajno) zamišljenom upravo kao poslanica, odnosno „knjiga“ što je Rožalija šalje majci i ocu. Štoviše, pretpostavljeno itekako dobro poznavanje Odiljenja Kanižlića je, također, lako moglo navesti i na to da pokuša sastaviti pjesnički tekst koji će samo naoko (dakle, pretežno formalnim svojim aspektom) provocirati dojam djela „skrojenog“ po žanrovskom obrascu barokne religiozne poeme, a dubinski zapravo egzistirati kao „kuriozna i vrlo samosvojna mješavina književnih vrsta“ (Isto: 149), i to glavninom onih koje su dominirale u generičkom sustavu srednjovjekovne književnosti, kao što je to slučaj i s otprije nam dobro poznatim žanrom tužaljke ili lamentatia, prepoznatljivim značajkama kojega je potaknut možda i iznimno uspjelim tužbalačkim odsječcima Odiljenja - protkao pjesmu Plač Sicilije iz trećega dijela poeme.

Iako o pretpostavljenim Kanižlićevim posudbama iz Vitezovićeva hrvatskog prvijenca svakako valja govoriti s određenom dozom opreza, ništa manji oprez bit će nužan i pri razmatranju potencijalnih signala njegova (žanrovskog) nasljedovanja i u djelima drugih naših pjesnika iz 18. stoljeća, u kojemu je - kako se čini - Odiljenje sigetsko u pojedinim kulturnim krugovima uživalo status jednoga od najpopularnijih književnih djela iz ranijih razdoblja. Možda i najvećim brojem tih i takvih signala njegova uvažavanja moći će se tako podičiti pjesnički opus ranije već spomenutoga osamnaestostoljetnog senjskog pjesnika Mateše Antuna Kuhačevića, u čijim se „epskim“ prigodnicama može zateći čitav niz prepoznatljivo „vitezovićevskih“ karakteristika, počevši od personificiranih kazivača (vila, gradova, pokrajina) i figure putnika koji pokušava uspostaviti komunikaciju s potonjim „oživljenim“ govornicima, preko uključivanja nemalog broja kronograma i formalnoga forsiranja (jednostruko rimovanoga) dvanaesterca bliskog onomu iz pojedinih dionica Odiljenja, pa sve do naizmjeničnog nizanja dvanaesterački i osmerački ispjevanih dionica u nekim pjesmama, iza kojega stoji različita funkcionalna specijaliziranost tih metričkih rješenja. S obzirom na to da je Kuhačević jedini zajednički izvor pobrojanih postupaka u hrvatskoj književnosti mogao iznaći samo u „zrinijadi“ Pavla Vitezovića - koja mu je morala biti bliska kako vremenski, tako i zbog činjenice da joj je autor bio nitko drugi no njegov sugrađanin - oko pitanja njihova porijekla ne bi trebalo biti ni najmanjega spora ili prijepora, pa i usprkos činjenici što su se neki od njih povremeno pojavljivali $\mathrm{i} u$ onodobnim njemačkim prigodnicama $\mathrm{i}$ pohvalnicama posvećenima Sedmogodišnjemu ratu. ${ }^{1069}$

${ }^{1069}$ Usp. o tome u: Dukić 2002: 73-84. 
Da su pojedina, pretežno motivska rješenja iz Odiljenja prilično inspirativno bila djelovala i na osječkoga osamnaestostoljetnog pjesnika Antuna Ivanošića dosad su u već nekoliko navrata isticali povjesničari hrvatske pisane i ne samo pisane književnosti, svi odreda suglasni kako je koncentracija tih „,vitezovićevskih“ motiva daleko najveća u njegovoj kraćoj „epskoj“ deseteračkoj pjesmi Pisma od uzetja Turske Gradiške iliti Berbira grada, u kojoj se tematizira kršćansko (austrijsko) oslobađanje Gradiške od turske vlasti iz 1789. Polazeći od činjenice da u invokaciji ove pjesme personificirani orao dolijeće u Banju Luku s poprišta kršćansko-turske bitke te Fatimi, nećakinji osmanlijskoga zapovjednika Gradiške, obznanjuje pad grada, potonji su povjesnici redom iskazivali čvrsto uvjerenje kako je taj izvorno usmenoknjiževni - motiv ptice kao glasnice kobnih vijesti Ivanošić posudio upravo iz pjesme Gospodična Sofija i oral iz drugoga „dila“ Odiljenja sigetskog, ${ }^{1070}$ dočim je Zoran Kravar - usporedivši neobično podudarne početne stihove obiju pjesama - došao čak i do zaključka kako u invokaciji Pisme od uzetja Turske Gradiške susrećemo ni manje ni više nego jasnu parafrazu uvoda Gospodične Sofije $i$ orla. ${ }^{1071}$ Osim u Pismi, tragove vjerojatnoga motivskog, pa i, donekle, formalnog naslanjanja na Ritterovu „zrinijadu“ moguće je uočiti i drugdje duž Ivanošićeva ne odveć obimnog opusa, u kojemu bi generički šarolikom pretresanju jedne teme kakvome svjedočimo unutar korica Odiljenja u određenoj mjeri bila podudarna višedijelna „epska“ prigodnica Opivanje sličnorično grofa Jozipa Čolnića ispjevana u povodu smrti đakovačkoga biskupa Josipa Antuna Čolnića - iz 1786., u prvom dijelu koje se biskupov život glorificira kao primjer triju kršćanskih vrlina, u drugom donosi alegorija u kojoj Vičnost, Ufanje i Djevica Marija razgovaraju s umirućim biskupom, u trećem ispisuje nadgrobnica Čolniću, dočim u četvrtom - metrički najraznovrsnijemu - dijelu svjedočimo monologu mladića koji se oprašta od života. Pored četverodijelnosti, koja bi vrlo lako mogla aludirati i na četverodijelnu strukturu Odiljenja, ali i težnje da se odabrana tema opjeva i u okvirima žanrova za kojima je u svome hrvatskom književnom prvijencu posegnuo i sam Ritter (alegorija, epitaf, lirski monolog, epskopjesnički segmenti), na generičku srodnost dvaju tekstova mogla bi upućivati i činjenica da domaći književni povjesnici sve do danas nisu bili u stanju domisliti se žanrovske odrednice koja bi Opivanju pristajala u potpunosti, slijedom čega se još uvijek najčešće zadovoljavaju njegovim proglašavanjem prigodnicom, a tek s vremena na vrijeme u stručnoj se literaturi pojave i pokušaji njegova preciznijeg žanrovskog razmatranja poput onoga Zorana Kravara, koji u njemu uočava (i) značajke - tada

\footnotetext{
1070 O Ivanošićevoj Pismi od uzetja Turske Gradiške kao motivskoj „nasljednici“ Gospodične Sofije i orla detaljnije u: Bošković-Stulli 1978: 228 i Dukić 2002: 125-126.

${ }^{1071}$ Podrobnije u: Kravar 1993: 155, bilješka 37.
} 
osobito popularnoga - žanra alegorijske školske drame. ${ }^{1072}$ Dapače, možebitno se oslanjanje na Odiljenje razabire - također - i na formalnoj, odnosno metričkoj razini Ivanošićeva pjesničkog opusa, koja jasno otkriva dubrovačko-dalmatinske uzore (dvostruko rimovani dvanaesterac, osmerački katren), pri čemu su, kako s pravom ističe Kravar, ti stihovni utjecaji južnobaroknih pjesnika najvjerojatnije bili posredovani ne samo pjesničkim ostvarenjima pojedinih onodobnih literata, nego i Vitezovićevom „zrinijadom“, preko koje se Ivanošić mogao „upoznati s metričkim tekovinama južnohrvatske ranonovovjekovne poezije podjednako dobro kao i preko Kanižlićeve poezije“ (Kravar 1993: 155, bilješka 37).

Među proučavateljima zaokupljenima književnom produkcijom našega 18. stoljeća našao se i stanovit broj onih koji ni najmanje nisu sumnjali u snažan i višestruk utjecaj što ga je Odiljenje imalo čak i na stvaralaštvo kajkavskoga pjesnika, patera Grgura Kapucina ili Jurja Malevca, i to ponajprije na njegovu (jednostrukim) dvanaestercem realiziranu „epsku kroniku“ (Dukić 2003: 490) Nestrančno vezdašnjega tabora ispisivanje, koja je - izlazeći tri godine zaredom između 1789. i 1791. i pritom se sadržajno oslanjajući na najsvježije vijesti o ratnim zbivanjima što su ih redovito donosile bečke dvorske novine - opjevavala događaje iz tada aktualnoga austrijsko-rusko-turskoga rata. Da se, naime, Malevac pri sastavljanju svih triju njezinih nastavaka obilato nadovezivao na Odiljenje prvi je tako - još u drugoj polovini 19. stoljeća - upozorio ni manje ni više nego August Šenoa, odlučno tvrdeći kako je Ispisivanje bremenito motivskim rješenjima (motiv vila zaokupljenih ratnim zbivanjima te motiv razgovora slučajnoga putnika-namjernika i pokojnika, u Malevčevu slučaju poginuloga maršala Laudona), formalnim paralelama (dvanaesterac kao dominantni stih), ali i uopće pojedinim žanrovima (dijaloške pjesme, nadgrobnice u čast poginulih vojskovođa) nesumnjivo preuzetima iz Vitezovićeva vernakularnog književnog prvijenca. ${ }^{1073}$ Iako skeptičan po pitanju nekih Šenoinih uvjerenja o tekstualnim podudarnostima Ispisivanja i Odiljenja, i Vladoje će Dukat - naglasivši kako ni u formalno-stihovnom, ni u jezičnom pogledu, ali ni u samom načinu prikazivanja ova dva djela ipak nisu u tolikoj mjeri bliska kao što je to držao Šenoa - potvrditi kako bi signale Malevčeva nasljedovanja Vitezovića valjalo tražiti ne samo u njegovoj težnji da svoju narativnu „epsku kroniku“ napuči epitafima, dijaloškim nadgrobnicama, poslanicama, tužbalicama, dijalozima i govorima, nego i da u nju uključi motiv razgovora između putnika i poginuloga maršala Laudona na njegovu grobu te figuru vile kao neposredne svjedokinje bespoštednih ratnih okršaja, koji potvrđuju da „ne može biti nikakove sumnje o tome, da je Gregur, izrađujući svoje Nestrančno ispisavanje,

\footnotetext{
1072 Usp. o tome u: Kravar 1993: 155.

1073 Opširnije u: Šenoa 1879: 719-720 i 738-739.
} 
imao pred sobom Vitezovićevo Odiljenje Sigetsko i tamo amo zagledavao u nj“ (Dukat 1915: 179). ${ }^{1074} \mathrm{Na}$ tragu Šenoinih i Dukatovih opservacija u svojoj će znatno recentnijoj potrazi za književnim uzorima Malevčeva djela uvelike biti i Davor Dukić, koji također ne dvoji u postojanje kako motivskih (motiv vile), tako i formalnih (identično inzistiranje na parno rimovanomu, astrofičnom dvanaestercu, variranje različitih metričkih rješenja u nadgrobničkim ciklusima, funkcionalno specijalizirana uporaba pojedinih stihova) paralela između Ispisivanja i Odiljenja, ali ni onih generičkih, koje se svode na tek mjestimična posezanja za pojedinim žanrovima iz bogate generičke palete što ju je u svoju „zrinijadu“ uključio Pavao Ritter (poslanice, tužaljke, epitafi), a nipošto na pokušaj žanrovskoga usklađivanja teksta u cijelosti s „obrascem“ “ kojega je ondje ustanovio naš autor. ${ }^{1075}$

U tom smislu, slijedom svega bi se dosad iznesenog moglo ustvrditi kako ni u slučaju žanrovski slojevitih ostvarenja Jurja Malevca, baš kao ni u onomu generičkih hibrida što su ih sastavljali ostali dosad pobrojani osamnaestostoljetni „nastavljači“ zapravo nemamo posla s „punokrvnim“ žanrovskim nasljednicima Odiljenja, nego s „tek“ njegovim pažljivim čitateljima zaintrigiranima pojedinim u nj uključenim (mahom motivskim i formalnostihovnim) postupcima, preuzimajući koje su u svoje tekstove ,presadili“ i neke u njemu zastupljene žanrovske značajke, no bez ikakve nakane da ih žanrovski u potpunosti realiziraju onako kako je svoj književni prvijenac na hrvatskom jeziku svojedobno bio zamislio i ispjevao Pavao Vitezović. Ovu će nam konstataciju, štoviše, dodatno potvrditi još i opusi nekih drugih naših pjesnika 18. stoljeća, u kojima također zatječemo tekstove protkane prepoznatljivo „vitezovićevskim“ obilježjima, vrlo vjerojatno - kako je to u svojoj studiji o osamnaestostoljetnoj „epici“ ne tako davno bio pretpostavio i Davor Dukić - apsorbiranima neposredno iz Odiljenja sigetskog. Prema Dukiću, posezanje za nekim rješenjima i postupcima što su ostavili dubok trag (i) u Ritterovoj ,zrinijadi“ moguće je tako zapaziti i u nekim pjesničkim tekstovima okupljenima u Razgovoru ugodnom naroda slovinskoga Andrije Kačića Miošića, među kojima se posebno izdvaja zaključna pjesma zbirke, u kojoj ulogu govornika - nalik „oživljenu“ Sigetu u Odiljenju - preuzima personificirana Bosna. U nedovršenoj, pak, pjesničkoj zbirci Pripisanje Neretve i njezina početka $i$ naseljenja do sadašnjega vrimena franjevačkoga pjesnika Luke Vladimirovića zatekla se i jedna deseteračka pjesma u kojoj ogorčena personificirana Neretva za sve svoje proživljene nedaće izravno okrivljuje Osmanlije, dočim u „epskoj“ prigodnici Pisma od Ivana Salkovića Šimuna

1074 O Malevčevu Nestrančnom ispisivanju kao možebitnomu - između ostalog, djelomično i žanrovskom literarnom nasljedniku Vitezovićeve ,zrinijade“ podrobnije u: Dukat 1915: 179-190. Usp. o istoj problematici i: Fališevac 1995: 207-221.

1075 Detaljnije o osobitostima Nestrančnoga vezdašnjeg tabora ispisivanja i njegovim značajkama (najvjerojatnije) baštinjenima iz Odiljenja sigetskog u: Dukić 2002: 137-143. 
Štefanca ne samo što se u ulozi kazivača pojavljuje vila, nego i u njoj nalazimo čak i uklopljenu nadgrobnicu Mijata Salkovića s „vitezovićevskim“ motivom putnika-prolaznika kojemu se pokojnik izravno i obraća. ${ }^{1076}$

S obzirom na i više nego bjelodanu činjenicu kako se u pogledu svih dosad pobrojanih književnih ostvarenja (mogućih) Vitezovićevih žanrovskih „nasljednika“ odreda radi o epskopjesničkim, odnosno o tekstovima s pretežno „epskim“ karakteristikama, očito je da nećemo nimalo pogriješiti pretpostavimo li kako su osamnaestostoljetni literati (i) Odiljenje sigetsko generički pojmili kao „punokrvno“ ili makar glavninom epskopjesničko ostvarenje, za čijim se prepoznatljivim tekstualnim postupcima dobar dio njih i povodio u uvjerenju da će njihovim asimiliranjem ne samo učvrstiti „epsku“ generičku podlogu svojih (također uvelike hibridnih) sastavaka, nego ih i učiniti intrigantnijima različitim krugovima (sve pismenije) onodobne publike. Ukoliko je, međutim, u njihovim očima Odiljenje zaista predstavljalo jedan od „pravovaljanih“ domaćih epskopjesničkih uzora, odnosno kotiralo kao tekst opskrbljen „tipičnim“ ili makar dominantno „epskim“ obilježjima, tada bi ta spoznaja definitivno trebala biti uvažena kao jedan od dodatnih argumenata ranije iznesenoj tvrdnji kako je ustrajanjem na žanrovskoj slojevitosti svoje „zrinijade“ - u kojoj se količinskom zastupljenošću i tekstualnom važnošću doista ističu neka od obilježja crpljenih iz generičkoga repertoara baroknoga povijesnog epa - naš autor zapravo težio iznjedriti djelo koje na prvi pogled (ni strukturno, ni formalno, a ni sadržajno) ne ostavlja epskopjesnički „dojam“, no u kojemu „epski“ momenti ipak imaju itekako zapaženu ulogu, uspijevajući u pojedinih recipijenata izmamiti (ponajprije) epskopjesnička generička očekivanja.

$\mathrm{Pa}$, ipak, premda bi ta i takva (pretpostavljena) žanrovska predodžba što su je gajili onodobni čitatelji i „nastavljači“ zaista trebala biti posljedica Vitezovićeva pokušaja da svoj hrvatski književni prvijenac sastavi na takav način da izaziva podjednaku pozornost recipijenata iz različitih čitateljskih krugova, potičući ih da mu pristupe iz gotovo bilo koje (prikladne) žanrovske perspektive, odnosno s generičkim očekivanjima stvorenima na temelju nejednakih iskustava i predznanja s kojima raspolažu, čini se da je ona ujedno proizišla i kao rezultat činjenice da je u desetljećima što su dijelila Odiljenje i njihove pjesničke pokušaje došlo do postupne promjene književne situacije, uslijed koje se zbila i temeljita „revizija“ cjelokupnoga naslijeđenog žanrovskog sustava, a zajedno s njom i dubinsko pretresanje generičkog repertoara (povijesne) epske pjesme i drugih epskopjesničkih žanrova. Drugim riječima, zbog osamnaestostoljetnoga ustoličenja nove, bitno osuvremenjene poetike epa i

1076 O (vjerojatnomu) sadržajnom i generičkom oslanjanju navedenih osamnaestostoljetnih pjesnika na Odiljenje sigetsko podrobnije u: Dukić 2002: 95-100 i 172-173. 
srodnih mu žanrovskih „oblika“, i u detektiranom će crpljenju brojnih motivskih, formalnih, pa i generičkih značajki Odiljenja od strane navedenih epika definitivno trebati vidjeti i jasnu posljedicu „osvježenoga“ žanrovskog shvaćanja epske pjesme, koje je dovelo do toga da se čak i strukturno i uopće generički ,razlomljena“ ostvarenja s minimumom naracije shvaća i prihvaća kao „punokrvno“ epskopjesničke ili makar „epske“ tekstove. ${ }^{1077}$ Dapače, u slučaju Vitezovićeva hrvatskog književnog prvijenca taj je dojam „epskosti“ dodatno pojačavala i njegova tijesna (sadržajno-idejna, formalno-metrička i, također, žanrovska) vezanost uz Petrovu Sirenu, osobito uz njezin epskopjesnički segment, koje su njegovi „,nasljednici“ jamačno bili i više nego svjesni i koju su najvjerojatnije i vidjeli kao dodatni podstrek za „presađivanje“ mnogih primijećenih čimbenika iz Odiljenja u njihova pjesnička djela o većinom - tada aktualnim ratnim zbivanjima.

\section{6. ŽANR(OVI) ODILJENJA SIGETSKOG}

S obzirom na to da je o sekundarnomu žanru Ritterova hrvatskog književnog prvijenca najispravnije suditi kako na temelju njegovih unutarnjih (tekstualnih) generičkih karakteristika, tako i na podlozi netom razmotrenih kontekstualnih, situacijskih čimbenika žanrovskoga mu identiteta, u toj bi genološkoj prosudbi svakako valjalo poći od dobro nam već znanoga zapažanja modernih teoretičara žanra o tome kako je baš svaki pojedinačni književni - pa i ne samo književni - tekst istodobno sazdan i od značajki što ih dijeli s nekom većom skupinom tekstova (dakle, primjeraka ili pripadnika stanovitoga žanra), i od karakteristika kojima obogaćuje, točnije nepovratno mijenja taj repertoar obilježja zajedničkih danomu nizu djela, odnosno kojima modificira njihov (i, dakako, svoj) žanr. ${ }^{1078}$ Iako bi, međutim, ovakvo eksplicitno pozivanje na navedeno genološko polazište dalo nagovijestiti kako se (i) Odiljenju sigetskom pristupa s uvjerenjem da je riječ o ostvarenju kojemu je moguće precizno utvrditi njegov generički identitet ili pripadnost konkretnomu sekundarnom žanru, već iz prethodnoga je razmatranja raznolikih mu generičkih značajki trebalo postati i više nego jasno da je u njegovu slučaju izrazito teško govoriti ne samo o tekstu u kojemu su obilježja stanovitoga žanra preuzela dominantnu ili makar dominantniju ulogu, nego i o djelu koje je po većini svojih žanrovskih karakteristika podudarno određenome skupu sedamnaestostoljetnih, pa i ne samo sedamnaestostoljetnih književnih tekstova sa zajedničkim generičkim identitetom. Time se, dakako, nipošto ne želi sugerirati kako Vitezovićeva „zrinijada“ ne ostvaruje generičke veze s drugim, žanrovski nejednako realiziranim djelima iz

\footnotetext{
${ }^{1077}$ Vrlo pregledno o generičkim posebnostima epskoga pjesništva u 18. st. npr. u: Dukić 2002: 167-182. 1078 Usp. npr. Todorov 1987: 11.
} 
svoga i ranijih književnopovijesnih razdoblja, no ono čega bismo svakako trebali biti svjesni jest to da se spomenute generičke veze - s Ritterove strane - većinom svode na mjestimična posezanja za pojedinim „karakterističnim“ obilježjima čitava niza (sekundarnih) žanrova u kojima su ta djela ostvarena, a nipošto na ustrajno slijeđenje konkretnoga odabranog žanrovskog uzora ili, možebitno, nešto većega broja njih.

Maločas utvrđena i potvrđena spoznaja kako Odiljenje nije imalo žanrovskoga uzora $\mathrm{u}$ punom smislu riječi stoga bi nas - posve opravdano - trebala potaknuti na to da mu pokušamo prići kao potencijalnoj generičkoj inovaciji, odnosno s pretpostavkom kako se u njegovu slučaju zapravo ne radi ni o čemu drugome no o inauguraciji jednoga novog, dotad neiskušanoga žanrovskog rješenja, i to ne samo u okvirima domaće barokne književnosti, nego i u onima čitavoga ranonovovjekovnog, pa i ne samo ranonovovjekovnoga europskog literarnog stvaralaštva. Imajući u vidu njegovu višedijelnu strukturu, satkanu od niza žanrovski nejednako ostvarenih (lirsko)pjesničkih tekstova, sama od sebe nametat će nam se pomisao kako bi Vitezovićev hrvatski književni prvijenac trebao biti najbliži onom tipu novoosmišljenih generičkih rješenja što nastaju preoblikovanjem stanovitog broja drugih, $\mathrm{u}$ njih utkanih žanrova, točnije uslijed procesa kojemu su pojedini recentni teoretičari žanra u svojim studijama nadjenuli naziv „grupiranje“. Shodno definiciji koju je u svojoj knjizi Kinds of Literature iznio škotski genolog Alaistar Fowler, grupiranje bi tako bilo ništa drugo no jedan od devet mogućih procesa (pre)oblikovanja književnih žanrova, uslijed kojega se „nekoliko cjelovitih kratkih djela grupira u skupnu zbirku“ (primjerice, pjesnički tekstovi u zbirku pjesama), pri čemu se takav sklop na koncu ispostavlja kao posve ,žanrovski različit podjednako od svojih komponenata i neporedanih zbirki“ (Fowler 1982: 171-172). Tomu, pojašnjava Fowler, obično biva tako iz razloga što proces grupiranja posjeduje snažan transformacijski učinak i neizbježno dovodi do toga da ti okupljeni ili kompilirani tekstovi na koncu u potpunosti dospiju nadići žanrove od obilježja iz čijih su repertoara skrojeni, što će reći da dana zbirka u cijelosti samim okupljanjem tih tekstova u konačnici uspijeva postići temeljitu preobrazbu izvornih im žanrovskih identiteta, a sve u korist njihove preoblikovanja ili podvrgavanja svome „krovnom“ generičkom identitetu ili (inovativnom) sekundarnom žanru koji se tim i takvim grupiranjem začinje. ${ }^{1079}$

Pretpostavimo li da je u slučaju Ritterove ,zrinijade“ na djelu doista bio spomenuti

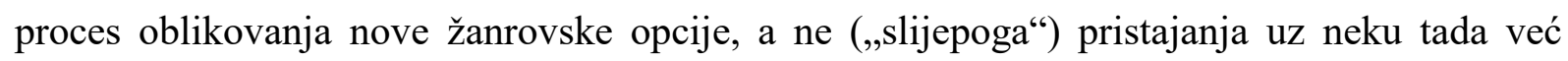
postojeću, kao neizbježan će se korak u pokušaju „dešifriranja“ stvarnoga joj generičkog

1079 Detaljnije o grupiranju kao jednom od nekoliko procesa što rezultiraju pojavom novih žanrova u: Fowler 1982: 171-172. 
identiteta pred nas postaviti nužnost njezina omjeravanja o prostorno i vremenski bliske primjerke drugih (inovativnih) žanrova također proizišlih iz procesa grupiranja, kojih u okvirima naše sedamnaestostoljetne književnosti - kao što smo već vidjeli - nipošto nije manjkalo. U prvome se redu tu, dakako, misli na korpus onodobnih domaćih kompilacijskih ostvarenja ili djela tzv. ,zborničkoga tipa“, među kojima se brojnošću generičkih paralela što ih dijeli s Odiljenjem izdvaja upravo Adrijanskoga mora Sirena Petra Zrinskog, no osim sa svojim uvjerljivo najvećim (glavninom sadržajnim i formalnim) literarnim uzorom, Vitezovićeva se „zrinijada“ u pogledu svoga žanrovskog identiteta - podsjetimo - pokazuje donekle srodnom i većini drugih, generički izrazito hibridnih sedamnaeostostoljetnih zbornika poput Kite cvitja razlikova Ivana Ivaniševića ili, pak, (prepjevanoga) Zvončaca Matijaša Magdalenića. Ritterovu bi hrvatskom književnom prvijencu po svojoj kompiliranosti tematski „kompatibilnih“, no istodobno i žanrovski raznoliko ispjevanih tekstova u određenoj mjeri generički bile bliske čak i sjevernohrvatske rukopisne pučke pjesmarice, u koje su upisivane mahom anonimne religiozne i tek gdjekoja ljubavna pjesma, iako ni one pritom najčešće nisu sve redom proizlazile iz jedinstvene ,provodne“ teme ili motiva, čemu razlog treba tražiti u činjenici da je riječ o tekstovima bilježenima od strane različitih zapisivača kroz prilično dugo vremensko razdoblje. S druge strane, iako važnu ulogu u njemu igraju i obilježja nekih od onih žanrova čiji su primjerci tada počesto bili okupljani u zasebnim (autorskim) lirskopjesničkim zbirkama (ponajprije heroide, epitafa, pa i lamentacije), Odiljenje sigetsko po većini svojih generičkih posebnosti ipak vidno odudara od sekundarnoga žanra barokne zbirke lirskih pjesama, ${ }^{1080}$ koji je, prisjetimo se, u najvećem broju slučajeva podrazumijevao kompilaciju žanrovski podudarnih pjesničkih tekstova usredotočenih na opjevavanje ne samo idejno srodnih sadržaja, nego gdjekad i iznimno širokoga kruga tema, čije su varijacije i provocirale ,aktiviranje“ različitih generičkih varijanata žanra lirske pjesme (religiozna pjesma, ratnička pjesma, ljubavna dijaloška pjesma, mjestimice čak i pastorala itd.).

S obzirom na pojedine svoje žanrovske slojeve, Odiljenje sigetsko također se ukazuje i kao tekst čiji bi generički identitet uvelike trebao biti na tragu sekundarnoga žanra u kojemu je realiziran (i) ranije već spomenuti parcijalni prijepis, odnosno rukopisni odabir iz Adrijanskoga mora Sirene svojedobno pronađen u ostavštini obitelji Drašković, za kojega se može reći kako je s Vitezovićevom „zrinijadom“ - do neke mjere - usporediv po svojoj

\footnotetext{
1080 Doduše, činjenica da je riječ o ostvarenju razbijene strukture, čiji lirskopjesnički tekstualni segmenti opjevavaju zajedničku temu - raznolike kršćanske (čitaj: hrvatske) oproštaje potaknute nepovoljnim ishodom bitke za Siget - pojedine je ,ritterologe“ ipak naveo na pomisao da se i u pogledu Odiljenja zapravo radi o „punokrvnoj“ baroknoj zbirci lirskih pjesama, što je generičko određenje s kojim bi se - shodno svemu dosad rečenom - itekako moglo i moralo polemizirati. Detaljnije o Odiljenju kao zbirci lirskih pjesama u: Kolumbić 2005: 327-353 i Pavličić 2007: 253-284.
} 
kompiliranosti i žanrovskoj heterogenosti, ali ne i po sadržajnoj raznolikosti, proistekloj iz nešto širega raspona ondje zahvaćenih tema. Naime, nalik rečenim odabirima iz opsežnijih književnih ostvarenja, kojih je u Vitezovićevo vrijeme u nas jamačno sastavljen i znatno veći broj od tek jednoga do danas sačuvanoga njegova primjerka, i Odiljenje sigetsko - barem u svome prvom i fiktivnomu „drugom“ izdanju - bilo je prezentirano kao „,nepotpun“, točnije „,nedovršen“ tekst kompilacijskoga tipa, koji je svojom formalnom, sadržajnom, pa i žanrovskom fragmentarnošću ostavljao dojam popabirčenosti iz neke daleko zamašnije tekstualne cjeline čije je (fingirano) dovršavanje i objelodanjivanje ovisilo o interesu čitatelja, a naročito potencijalnih pokrovitelja voljnih da financijski potpomognu njegovo buduće cjelovito tiskano izdanje. Osim težnje privlačenju pozornosti šire publike i mecena, Odiljenje je sa spomenutim odabirima, pa tako i nepotpunim prijepisom Petrove Sirene, dijelilo i nakanu da se nametne kao „punokrvna“ lektira prilagođena očekivanjima i potrebama raznolikih tipova recipijenata, naročito onih slabije učenih, a time i (sve brojnijem) ženskom čitateljstvu, što će reći da i u njegovu slučaju svjedočimo očitom primjeru kompilacijskoga štiva koje podilazi ukusima vrlo široke publike, a sve u cilju ispunjavanja bitnih kontekstualnih ciljeva, koji se nipošto nisu svodili samo i isključivo na „snubljenje“ potencijalnih financijera najavljenoga ,cjelovitog“ izdanja. Napritiv, do što raznolikijega čitateljstva Vitezovićeva je ,zrinijada“ trebala doprijeti ponajprije poradi sadržajne svoje važnosti, odnosno činjenice da progovara o jednom od ključnih događaja iz hrvatske povijesti, jasno pritom ukazujući na memorijalnu važnost lokaliteta na kojemu se spomenuti događaj zbio te neodgodivu potrebu njegova oslobađanja i obnove, a sve to $u$ četverodijelnomu pjesničkom sastavku ispjevanom tronarječnom inačicom hrvatskoga jezika kao idealnim rješenjem zajedničkoga, svehrvatskog jezika buduće ujedinjene, ,cjelovite“ Hrvatske.

Silna želja da privuče izuzetno široku publiku Rittera je, između ostalog, nagnala i na to da svoj vernakularni literarni prvijenac - koji, u generičkom smislu, podosta toga dijeli sa žanrom izbora iz obimnijih tekstova - opskrbi obiljem usmenoknjiževnih (žanrovskih) karakteristika, kojima u isti mah dospijeva ne samo aludirati na širinu odjeka što ga je isprovociralo osmanlijsko zauzeće Sigeta (podjednako zanimljivo autorima pisanoknjiževnih ostvarenja i anonimnim folklornim i pučkim stvarateljima), a neukijim čitateljima i čitateljicama zadojenima na ,narodnoj“ književnosti učiniti tekst pristupačnijim i ,pitkijim“, nego i recipijentima iz različitih društvenih slojeva olakšati razumijevanje sastavka generički donekle bliskog djelomičnom prijepisu Adrijanskoga mora Sirene iz ostavštine obitelji Drašković i drugim (nažalost, nesačuvanim) primjercima istoga žanra, koji je dotad - kako se čini - bio „rezerviran“ (gotovo) isključivo za publiku iz redova društvene elite, odnosno u 
potpunosti namijenjen cirkuliranju među pripadnicima aristokratskoga sloja. ${ }^{1081}$ Iako mu po pojedinim svojim značajkama nalikuje ono samo vrlo rubno i stoga ga nipošto nije utemeljeno proglasiti njegovim pripadnikom, pa čak ni bliskijim generičkim srodnikom, Odiljenju sigetskom svakako ipak valja priznati zasluge za "spuštanje“ određenih karakteristika svojstvenih (i) izborima iz duljih (pjesničkih) ostvarenja u pučku književnost, zahvaljujući kojemu i žanr odabira u cijelosti napokon dospijeva izgubiti onu svoju prepoznatljivu ,auru“ ekskluzivno elitnoknjiževnoga generičkog rješenja. ${ }^{1082}$

Bilo kako bilo, (pre)često se ne obazirući na to s primjercima kojega je konkretnog žanra ono uspostavljalo poveznice, odnosno od obilježja iz kojih je konkretnih generičkih repertoara sazdan njegov sekundarni žanr, dosadašnji se proučavatelji taj prilično nejasan i krajnje dvojben generički identitet Odiljenja sigetskog - kako je ranije već utvrđeno - u svojim prikazima i studijama nisu ustručavali označiti kojekakvim, često i krajnje disparatnim žanrovskim odrednicama, počevši od onih (povijesnoga) epa, „spjeva“ i zbirke lirskih pjesama, pa sve do onih poput (i ovdje učestalo korištene) „zrinijade“, baroknoga zbornika te „pjesništva graničnih utvrda“ (Grenzfestungen-Dichtung), koju mu je svojedobno pridao Andreas Angyal. Što se, međutim, ove njegove potonje (implicitne) žanrovske kategorizacije tiče, na umu bismo svakako morali imati da je riječ ne samo o „umjetno“, dake teorijski stvorenoj žanrovskoj, točnije nadžanrovskoj oznaci koja je proizišla iz naknadnih književnopovijesno-teorijskih pokušaja generičkoga razvrstavanja stvaralačke produkcije baroknoga razdoblja (dakle, ne iz rezultata eventualne rekonstrukcije izvornoga žanrovskog sustava - angyalovski rečeno - slavenskoga baroknog svijeta), nego i o (nad)generičkomu konstruktu čijem se (provizornom) „repertoaru“ Odiljenje približava isključivo svojim sadržajno-idejnim karakteristikama, odnosno tematsko-motivskim sklopom podudarnim ostatku korpusa „pjesništva graničnih utvrda“, a gotovo nimalo formalno-generičkim svojim

${ }^{1081} \mathrm{Za}$ podrobnije obavijesti o strukturi aristokratskoga sloja u sedamnaestostoljetnomu hrvatskom društvu usp. Maleković 1993: 18-20.

1082 Nezanemarive podudarnosti na generičkoj razini između odabira iz duljih tekstova i Odiljenja pritom bi, štoviše, lako mogle sugerirati i da je jednu od najranijih inačica svoje „zrinijade“ - na koju očito i misli u predgovoru prvoga njezina izdanja, u kojemu otkriva kako je bila ona ispjevana još ,pred petimi leti“ (Ritter Vitezović 1684) - naš autor možda i bio zamislio i realizirao upravo kao svojevrsno proširenje izabranih odsječaka iz Sirene, i to bez ikakve prvotne namjere da tu i takvu svoju rukopisnu kompilaciju objelodani kao autorsko djelo. Prihvatimo li da je tomu možda doista i bilo tako, u tom bi smislu tu ranu inačicu Odiljenja valjalo poimati kao ništa drugo no tek jedan iz (pretpostavljenoga) niza parcijalnih prijepisa, točnije odabira iz Petrove „zrinijade“, koji je izvorno - nalik izboru iz Sirene iz Arhiva Drašković - i trebao ostati u rukopisu kao svojevrsno štivo za „osobnu uporabu“, no budući da je predstavljao (ne samo sadržajnu) doradu izabranih segmenata prethodnikova ostvarenja te da je u narednim godinama pretrpio podosta tekstualnih preinaka, Pavao ga se Vitezović - potaknut odgovarajućim društvenopovijesnim okolnostima (ponajprije slabljenjem turske moći nakon katastrofalnoga poraza pod Bečom 1683.) te činjenicom da mu je pošlo za rukom upoznati potomka slavnoga sigetskog kapetana, u kojemu je vidio zaštitnika i pokrovitelja svojega budućeg stvaralaštva - u proljeće 1684. naposljetku ipak odvažio dati u tisak, zadržavši u njegovoj konačnoj verziji podosta značajki svojstvenih (i) žanru izvora iz kompleksnijih i uopće opsežnijih ostvarenja. 
posebnostima, po kojima osjetnije odskače od gotovo u potpunosti epskopjesničkoga žanrovskog ,„profila“ ostvarenja iz ove kategorije. ${ }^{1083}$

$\mathrm{S}$ druge strane, Vitezovićevu hrvatskom književnom prvijencu namijenjenom različitim tipovima publike ne pristaje u potpunosti čak ni žanrovska odrednica baroknoga zbornika, pod kojom se obično podrazumijevalo pisanoknjiževna i/ili pučkoknjiževna sedamnaestostoljetna ostvarenja kompilacijskoga tipa, u kojima je izrazitu žanrovsku hibridnost obično u stopu pratila i ona tematska (kao što to, uostalom, posvjedočiti može i primjer Petrove Sirene, sastavljene od povijesnoga epa te niza nabožnih, ljubavnih i mitoloških lirskih pjesama i nadgrobnica), pri čemu se čak ni za tu odrednicu ne može sa sigurnošću (u)tvrditi da je doista postojala i u svijesti onodobnih autora, odnosno da se odnosi ona na povijesni žanr za kojim su tadašnji književnici posezali svjesni posebnosti repertoara njezinih obilježja nasuprot onih drugih tada dostupnih generičkih rješenja. Štoviše, tu samo djelomičnu uklopivost Odiljenja u krug žanrovski slično koncipiranih onodobnih ostvarenja još nam uvjerljivije potvrditi može njegova usporedba s višežanrovskim kompilacijama što su ih tijekom 17. stoljeća sastavljali i pisci iz drugih europskih sredina, osobito oni njemački, ${ }^{1084}$ koji su - barokistički neskloni generički „,čistim“ tekstovima - neobično velik broj svojih djela realizirali upravo kao žanrovski mješovite zbornike, u kojima su uz primjerke različitih lirskopjesničkih žanrova obično skladno koegzistirali i (mahom) kraći epskopjesnički, pa čak i dramski sastavci. Pritom je, dakako, i u njihovu slučaju - baš kao i u onom, primjerice, Petrove Sirene ili Ivaniševićeve Kite - redovito bila riječ o sadržajno šarolikom štivu, u kojemu se počesto i izrazito velikim rasponom tema (raznolika religijska pitanja, filozofskodidaktičke preokupacije, pastoralno-mitološki momenti, ljubavne situacije, prigodničkopohvalničke intencije itd.) obrađenih u žanrovski kojekako ostvarenim okvirima svjesno i ciljano prkosilo dotad uvriježenoj praksi jednostranoga generičkog svrstavanja literarnih djela u unaprijed zadanu „ladicu“ nekog iz palete tradicionalnih, „čistih“ (književnih) žanrova.

Pridodamo li ovim konstatacijama još i ranije zapažanje kako Odiljenje nije moguće u potpunosti uklopiti ni u definicije drugih (baroknih) žanrova - povijesnoga epa, poeme, zbirke lirskih pjesama, postajne drame itd. - iz vizure kojih su ga nastojali protumačiti pojedini njegovi dosadašnji proučavatelji, redom pritom zanemarujući činjenicu da se u njemu prisutna

\footnotetext{
1083 O značajkama djela iz korpusa tzv. ,pjesništva graničnih utvrda“ znatno opsežnije u: Angyal 1961: 228-263.

1084 U njemačkoj književnosti 17. stoljeća, konkretno, izuzetno je velik broj književnih ostvarenja otpadao upravo na one sastavke koji bi se - promatrani iz današnje perspektive - mogli podvući pod (teorijsku) generičku odrednicu tekstova zborničkoga ili kompilacijskog tipa, što treba zahvaliti naročitoj sklonosti onodobnih njemačkih autora spram sljubljivanja raznolikih žanrova, među kojima su granice u to vrijeme ionako bile izrazito fluidne. Znatno detaljnije o zborničkoj produkciji u njemačkoj književnosti 17. stoljeća, pa tako i o Hoffmannswaldauovoj intrigantnoj kompilaciji u: Hess 2007: 422-434.
} 
njihova karakteristična obilježja ipak nisu dospjela prometnuti u dominantna, neće nam preostati ništa drugo no ustvrditi kako se u njegovu slučaju susrećemo s književnim ostvarenjem čiji generički identitet nije oblikovan ugledanjem u neki konkretan žanrovski predložak, ali također i nije - kao takav - uspio privući niti jednoga jedinog imitatora ili nasljednika, koji bi ga „prepisivanjem“ njegova generičkog „obrasca“, odnosno povođenjem za njemu svojstvenom kombinacijom tekstualnih obilježja - dakako, potaknutim i nekim identičnim ili vrlo sličnim kontekstualnim okolnostima - jednom za svagda potvrdio kao punopravni (barokni) sekundarni žanr. Polazeći, drugim riječima, od možda i ključnog preduvjeta za proglašavanje nekog spleta značajki žanrom - onoga da se u povijesti književnosti pojavilo još najmanje jedno djelo realizirano (gotovo) identičnom kombinacijom obilježja, koje pritom odgovara i na istu ili makar otprilike istu izvantekstualnu situaciju kao i njegov uzor, odnosno generički „prototip“1085 - Odiljenje sigetsko bit ćemo prisiljeni percipirati kao svojevrsni žanrovski eksces, tj. kao tekst koji ne samo što se nije našao u ulozi generičkoga nasljednika, nego i koji ni sam ,pravih“ generičkih nasljednika nije imao, slijedom čega ni o njegovoj vrlo kompleksnoj i žanrovski izrazito slojevitoj tekstualnoj fakturi, satkanoj od karakteristika probranih iz repertoara maločas utvrđenih književnih i ne samo književnih žanrova, zapravo nemamo nikakva razloga nastaviti govoriti kao o primjerku konkretnoga sekundarnog žanra kojega nam tek predstoji „,dešifrirati“. Kao krajnje osebujno i neponovljivo presjecište raznolikih žanrovskih karakteristika, tekst Odiljenja ne ispunjuje bazične kriterije za stjecanje statusa književnoga žanra, pa tako ni onaj prema kojemu je zbog nemogućnosti da bude definiran sam po sebi - svakom žanru nužan „barem još jedan žanr od kojega se može razlikovati““ (Cohen 1991: 97), tim više što mu zbog odsustva uzora i/ili nastavljača nedostaje čak i osnova za generičko utemeljenje, a uz to je još i riječ o ostvarenju koje je apsorbiralo elemente nevjerojatno širokog raspona - pisanoknjiževnih, folklornoknjiževnih, pučkoknjiževnih, poluknjiževnih, pa i izvanknjiževnih - žanrova, zahvaljujući kojima mu je u okvirima barokne književnosti vrlo teško, ako ne i nemoguće iznaći generičko rješenje s kojim ne dijeli makar pokoju značajku. Za razliku, dakle, od drugih žanrovski manje ili više hibridnih onodobnih sastavaka, koji su se - kao svojevrsne karike u lancima ponavljanja i postupnoga modificiranja poodavno već iznađenih i

\footnotetext{
${ }^{1085}$ U suvremenoj je genologiji, naime, prevladalo mišljenje kako je o žanru moguće govoriti samo ukoliko se utvrdi postojanje više djela sa zajedničkim - identičnim ili makar otprilike podudarnim - generičkim obilježjima, dočim - s druge strane - za izdvojeni model ili generički predložak, kojem nije pošlo za rukom privući potencijalne imitatore, nipošto nije opravdano konstatirati kako mu pripada status žanra (usp. npr. Guillén 2005: 145-147). Iako, međutim, moderni teoretičari žanrova pritom obično drže kako je dovoljno da generički prototip stekne barem jednoga nasljednika kako bi se mogao pojmiti žanrom, neki od njih ipak tvrde da bi trebao on uroditi i znatno većim brojem primjeraka, odnosno čitavim nizom djela što nose srodne karakteristike kako bi uopće bilo opravdano govoriti o pojavi konkretnoga novog žanrovskog rješenja (usp. Cohen 1991: 88).
} 
prihvaćenih generičkih opcija - uspjeli potvrditi kao nositelji stanovitih generičkih identiteta, odnosno kao reprezentanti konkretnih sekundarnih žanrova, „ekscentrično“ Vitezovićevo Odiljenje svojim se izrazito kompleksnim žanrovskim „sastavom“, pomalo paradoksalno, nameće kao djelo kojemu je u domaćim i ne samo domaćim književnim okvirima izlišno tražiti premca, što ujedno znači i da, unutarnjoj generičkoj mnoštvenosti usprkos, na razini teksta kao cjeline naprosto nije ni dobilo priliku naći se u svojstvu pripadnika određenoga (baroknog) sekundarnog žanra.

U prilog ovoj posve neočekivanoj definiciji Odiljenja sigetskog kao generički „unikatnog“ teksta koji se nije dospio potvrditi ni kao predstavnik, a još manje kao prototip stanovitoga žanra zasigurno bi najsnažnije trebala govoriti upravo činjenica da ni nakon višedesetljetnih raspredanja o njegovu generičkom identitetu domaći književni povjesnici i „ritterolozi“ još uvijek nisu načisto s time za koji se književni žanr s punim pravom može ustvrditi da mu ono u potpunosti pripada, odnosno da u njemu - „derridaovski“ kazano - i samo participira. Usuglašavanja proučavatelja oko pitanja generičke mu pripadnosti, na kraju krajeva, dosad nije bilo niti može biti jer - kao književno djelo bez (potvrđenoga) žanrovskog identiteta - Odiljenje izmiče svakom pokušaju strogoga, jednoznačnog svrstavanja, no u isti mah svojom generičkom mozaičnošću dospijeva privući recipijente $s$ nejednakim predznanjem, ukusima, a time i žanrovskim očekivanjima, kojima upravo zahvaljujući toj svojoj hibridnosti i fluidnosti odreda na koncu i dospijeva udovoljiti. Iako, dakle, lišen pripadnosti konkretnomu sekundarnom žanru, Vitezovićev je hrvatski prvijenac svojom generičkom višeslojnošću bio u stanju - kao što smo se i imali prilike uvjeriti - različite tipove čitatelja navesti i na posve različitu generičku percepciju, omogućujući im da u njemu vide upravo ono što su i očekivali vidjeti, odnosno da se u njihovim očima nada kao primjerak baš onoga žanra za kojega su i bili uvjereni da mu u potpunosti pripada ili da bi mu, zbog posjedovanja njemu svojstvenih obilježja, generički nekako i trebao biti najbliži.

Ciljano ga osmislivši i realiziravši kao žanrovski kompleksan sastavak, koji je doslovno svakomu pojedinačnom potencijalnom čitatelju - u generičkom pogledu - mogao, predstavljati nešto drugo, Pavao je Ritter Odiljenju tako zapravo uskratio jednoznačno odrediv generički identitet, čime se i definiranje onoga što suvremeni genolozi nazivaju sekundarnim žanrom u njegovu slučaju svelo na ,tek“ konstatiranje činjenice kako je riječ o višežanrovskom ostvarenju, koje je ,aktiviranjem“ značajki karakterističnih za čitav niz književnih i ne samo književnih žanrova nastojalo (i uspjelo) izmamiti zanimanje vrlo raznolike publike, koje se i trebala ticati potreba oslobođenja i obnove Sigeta kao važnoga hrvatskog mjesta sjećanja, ali i usvajanja naddijalektalnoga hrvatskog jezika kao temelja 
budućega svehrvatskog zajedništva. Dapače, taj žanrovski „kolaž“, koji onemogućuje precizno generičko „pozicioniranje“ Odiljenja, a u isti ga mah čini i podložnim kojekakvim subjektivnim predodžbama o žanrovskoj mu ,pripadnosti“, pokazao se ujedno i kao učinkovita strategija distanciranja od politički ,inkriminiranoga“ prethodnika i nimalo poželjnoga žanra povijesnoga epa, koji je do toga trenutka slovio kao najprimjerenija generička podloga za obradu teme herojske pogibije hrvatskih branitelja Sigeta, sada ništa manje uvjerljivo opjevane $\mathrm{u}$ daleko nekonvencionalnijim žanrovskim okvirima, koji su Vitezoviću ujedno omogućili i da na vrlo suptilan način iznese svoj afirmativni stav o obitelji Zrinski, a da se tim činom istodobno ne zamjeri političkoj eliti s bečkoga dvora.

Računajući upravo s raznolikim tipovima čitatelja, Pavao je Vitezović svoj književni prvijenac ciljano i oblikovao tako da se - iznimnom generičkom mnoštvu okupljenom na relativno malom tekstualnom prostoru usprkos - ta njegova hibridnost ni visokoobrazovanim, a još manje jedva opismenjenim recipijentima nije mogla doimati pretjeranom, odnosno ispjevao ga na način da ,aktivirana“ generička obilježja pisanoknjiževnih, folklornoknjiževnih, pučkoknjiževnih, pa i rubno književnih te neknjiževnih žanrova od prvoga do posljednjeg njegova stiha teže međusobnom (ponajprije sadržajnom, ali i formalnom) nadopunjavanju i uopće semantičkom „podupiranju“. Ipak, činjenica da u žanrovski jednoznačno posve neodredivim tekstualnim okvirima Odiljenja tako skladno supostoje, primjerice, filozofsko-ideološki jasno utemeljene pouke i poslovičke koncentracije „narodne“ mudrosti, odnosno da se - između ostalog - u drugome njegovu „dilu“ dijaloška pjesma s pokojim folklornoknjiževnim motivom $\mathrm{u}$ jednom trenutku efektivno dospijeva „preobraziti“ u gotovo punokrvnu „,narodnu““ naricaljku nad netom poginulim zaručnikom, nipošto ne znači da se dionice napučene obilježjima žanrova različita porijekla kontinuirano pretapaju jedna u drugu bez ikakvih primjetnih „šavova“, nego „samo“ to da ih nerazdruživo povezuju jedinstven tematsko-motivski kompleks te važne izvanknjiževne zadaće što ih je trebao izvršiti čitav tekst, kojim je naš autor uvjerljivo pokazao i dokazao da je tema na koju je dotad gotovo „ekskluzivno“ pravo bio polagao žanr povijesnoga epa ne samo prikladna za obradu i u čitavom nizu drugih, „neepskih“ generikih rješenja, nego i itekako uklopiva u višežanrovsko ostvarenje lišeno konkretnoga generičkog identiteta, u sklopu kojega je (tada) lako mogla doprijeti kako do (većinom učenije) publike sklone epskopjesničkom štivu, tako i do one koja s identično generički realiziranim (pisanoknjiževnim) djelima nije imala posebno velikih iskustava.

Drugim riječima, bez obzira na to što je izrazita težnja za tim da se tema turskoga zauzeća Sigeta i njegovih neposrednih posljedica „provuče“ kroz generički kojekako 
realizirane tekstualne segmente rezultirala sastavljanjem možda i „najekstremnije“ domaće inačice barokne mješavine žanrova, za kojom se neće povesti niti jedan potencijalni generički imitator, vernakularni literarni prvijenac Pavla Rittera nipošto ipak nije predstavljao usamljen slučaj po pitanju svoje žanrovske jedinstvenosti, tim više što su se - kako je u barokološkim studijama već poodavno upozoreno - i u nas, ali i diljem Europe kroz čitavo barokno razdoblje pojavljivali „tekstovi bez jasne žanrovske pripadnosti“ (Pavličić 1979b: 39), čiji književni karakter i usprkos tomu i takvom „,nedostatku“ ni u jednome trenutku nije dolazio u pitanje. Neovisno, dakle, od činjenice da bi zbog svoje nepripadnosti niti jednomu sekundarnom žanru Odiljenje sigetsko doista moglo i moralo kotirati kao izuzetno djelo u okvirima hrvatske, pa i ne samo hrvatske (ranonovovjekovne) književnosti, njegov „,izvangenerički“ identitet koji se opire svakom pokušaju jednoznačnoga svrstavanja u isti bi se mah trebao poimati i kao „tek“ jedna od najizrazitijih posljedica sveopće barokne sklonosti „onečišćavanju“, tj. hibridizaciji žanrova, potpuno nesumjerljive s renesansnim inzistiranjem na njihovu - poetičkom i praktičnom - jasnom i nedvosmislenom razlučivanju, a onda i krajnje preciznom klasificiranju samih tekstova u „ladice“ poetički normiranih i tradicijom potvrđenih žanrova.

Uzmemo li, međutim, u obzir da su i (pojedina) djela iz korpusa baroknih generičkih hibrida status predstavnika konkretnih sekundarnih žanrova mogla osigurati isključivo posredstvom činjenice da svoj generički identitet dijele barem s još jednim literarnim ostvarenjem, postojanje drugih njima žanrovski (gotovo) identičnih tekstova značit će pritom ništa drugo nego da je danomu žanru kojem pripadaju (ili u kojemu ,participiraju“) pošlo za rukom ne samo steći, nego i višestruko potvrditi svrhovitost u određenome kontekstualnom ili situacijskom okružju, odnosno da je sebi svojstvenim repertoarom tekstualnih značajki na ispravan način on dospio opetovano (retorički) odgovoriti na stanovitu ponovljivu izvanknjiževnu situaciju. Budući da je, shodno tumačenju Carolyn Miller, temeljni preduvjet izvantekstualne (društvene) funkcionalnosti bilo kojega - ne samo književnog - žanra taj da se u njemu dospjela postići potpuna fuzija ili stapanje (karakteristične) forme i (karakterističnog) sadržaja, ${ }^{1086}$ Vitezovićevo Odiljenje sigetsko ukazuje nam se kao generički višeslojno sedamnaestostoljetno pjesničko ostvarenje u kojemu - nezanemarivu čitateljskom interesu što ga je izaz(i)valo usprkos - do potpune fuzije jedinstvenoga sadržaja i prilično raspršene forme ipak nije uspjelo doći, u čemu bi i trebao ležati razlog kako neuspjeha u ispunjavanju dodijeljenih mu izvantekstualnih zadataka (širenje trodijalektalnoga hrvatskog

1086 Jer, kako pojašnjava ona u nastavku, samo žanr čija se forma i sadržaj upotpunjuju doista i može steći značenje u nekome društveno-kulturnom kontekstu, odnosno uslijed neke situacije. O tome znatno detaljnije u: Miller 1984: 151-167. 
jezika, iniciranje duhovne i fizičke obnove Sigeta kao memorijalnoga lokaliteta itd.), tako i činjenice da ,pravih“ generičkih nastavljača (odnosno imitatora) nije ono uopće ni imalo, što je u konačnici i dovelo do toga da se kao pripadnik (tj. prototip) potencijalnoga sekundarnog žanra nije niti dobilo prilike potvrditi.

S druge strane, kao djelo koje se laća (dotad) „tipično“ epskopjesničke tematike, obrađujući je pritom u formi koju je moguće prozvati „epskom“ samo u naznakama, Odiljenje se istodobno ne dospijeva potvrditi ni kao primjerak žanra barokne povijesne epske pjesme, tim više što, osim (neostvarenom) spregom „karakterističnoga“ sadržaja i „primjerene“ forme, oskudijeva i prepoznatljivo epskopjesničkim jasnim ideološkim usmjerenjem, odnosno naglašenom političnošću, kojom su barokni (i ne samo barokni) epovi iskazivali svoje prilično snažne ambicije da djeluju u izvanknjiževnoj zbilji. Iako je, doduše, ne tako rijetkim posezanjem za prepoznatljivo epskopjesničkim elementima pojedine svoje čitatelje želio navesti na to da mu pristupe s očekivanjem kako je i u slučaju njegova hrvatskog književnog prvijenca riječ o - žanrovski izrazito hibridiziranom - epu o padu Sigeta, Pavao Ritter u Odiljenju je, kako se čini, ipak posve ciljano težio izbjeći fuziju „,epskoga“ sadržaja i „epske“ forme, i više nego svjestan kako bi svojim opredjeljenjem za žanr koji je pretpostavljao nužnu ideološku nadgradnju mogao isprovocirati ne samo sumnju na sadržajno-generičko, nego i na političko pristajanje uz „ozloglašenu“, protuhabsburški nastrojenu Obsidu sigecku Petra Zrinskoga, a time i steći poprilično lošu reputaciju u očima tadašnje političke elite koja je „stolovala“ na dvoru u Beču. Da bi izbjegao takav „scenarij“, naš je autor u potpunosti odustao od „kompromitirajućega“ žanrovskog oblikovanja teksta posvećenog junaštvima najslavnijega pripadnika obitelji Zrinski, odvaživši se, umjesto toga, na krajnje neočekivan, a time i prilično riskantan - no ujedno i politički posve korektan - generički potez, tj. za takvu žanrovsku „izvedbu“ koja je rezultirala našom prvom ranonovovjekovnom „zrinijadom“ skrojenom tako da ne podilazi samo ukusima visokoobrazovane i književno iskusnije publike, nego i potrebama i očekivanjima literarnih nevježa, odnosno koja je - upravo zahvaljujući svome fluidnom, jednoznačno neodredivom generičkom identitetu - u stanju podjednako uspješno funkcionirati kako na pučkoknjiževnom ,terenu“ (kojemu su više naginjala prva dva njegova tiskana izdanja), tako i na onomu „elitne“ pisane književnosti, na kojemu se ponajprije trebalo pozicionirati njegovo zagrebačko izdanje. Doduše, svojim opredjeljenjem za žanrovski „mozaičan“ tip oblikovanja - umjesto za uklapanje teksta u već postojeće (više ili manje hibridne) okvire odabranoga sekundarnog žanra - Vitezović je stvorio djelo koje se, iako ispjevano usred književnoga razdoblja posebno sklonog generičkim poigravanjima, daleko najbolje ipak uklapalo u onaj književnostvaralački kontekst u kojemu kategorija žanra 
i žanrovska pripadnost ni prilikom čina sastavljanja, a još manje u procesu recepcije nisu igrali ni približno toliko važnu ulogu kao u „visokoj“ ili umjetničkoj pisanoj književnosti, a to znači ni manje ni više nego upravo u kontekst pučke književnosti, što je spoznaja koja nam ujedno daje za pravo da ga tretiramo kao ponajprije pučko ,izvanžanrovsko“ ostvarenje, ne smećući pritom s uma kako su kroz čitavo ranonovovjekovlje, pa tako i u 17. stoljeću, za vernakularnim pučkoknjiževnim štivom počesto bili posezali i pripadnici aristokracije.

Što se, međutim, dosadašnjega proglašavanja Vitezovićeve „zrinijade“ izvanžanrovskim, a mjestimice čak i nežanrovskim pjesničkim djelom tiče, nužno je osvijestiti kako se radi o oznakama gotovo u potpunosti nespojivima s idejnim polazištima moderne teorije žanrova, shodno kojima bi - podsjetimo - tekst bez ikakva žanrovskog identiteta bio ništa drugo no u praksi posve neostvariva zamisao. Iako je, naime, o njegovu sekundarnom žanru zbog nepostojanja drugih generički identično realiziranih tekstova doista bespredmetno raspravljati, ni Odiljenje sigetsko - kao što smo se i sami imali prilike uvjeriti nipošto nije tekst u pogledu kojega se ne može govoriti čak ni o žanrovskoj obilježenosti pojedinih mu dionica, odnosno četiriju njegovih „dilova“, zasebnih pjesama od kojih su oni sastavljeni, pa čak i kraćih odsječaka tih lirskopjesničkih tekstualnih komponenata. Naprotiv, s obzirom na njegove generički doista kojekako ostvarene pojedinačne (kraće ili dulje) segmente Odiljenje bi daleko ispravnije bilo definirati ne kao „nežanrovsko“, već - naprotiv kao „svežanrovsko“ književno ostvarenje, dakle kao tekst čiji žanrovski identitet nalikuje mozaiku sastavljenom od sitnijih (pojedinačna raspršena obilježja) i krupnijih (žanrovski raznoliko ispjevane pjesmovne dionice) generičkih sastavnica, a ne homogenoj cjelini u kojoj dominiraju prepoznatljive značajke jednoga žanra i koju je iz toga razloga moguće prilično lako i točno opisati jednoobraznom generičkom odrednicom.

Prihvatimo li netom izneseno zapažanje kao činjenicu koju mogu potvrditi gotovo sva dosad detektirana generička njegova svojstva, kao jedini logičan i opravdan zaključak po pitanju (ne)ispravnosti raznolikih generičkih percepcija, a onda i (ne)mogućnosti konkretnoga žanrovskog određenja Vitezovićeva Odiljenja nametnut će nam se taj da baš svaka potencijalna žanrovska odrednica koja mu se - na temelju konkretnih u njemu zastupljenih generičkih značajki - može dodijeliti u isti mah predstavlja podjednako točnu i podjednako pogrešnu definiciju izrazito mu kompleksnoga žanrovskog identiteta. Za posve različite predodžbe o njegovoj generičkoj pripadnosti, a onda i kojekakve dosadašnje pokušaje njegova jednoznačnog žanrovskog svrstavanja najodgovornijim bi, podsjetimo, pritom valjalo držati nikoga drugog no samog autora, koji je nejednaka poimanja njegova žanrovskog identiteta isprovocirao upravo svojom odlukom da ga realizira kao višežanrovsko ostvarenje koje ne 
slijedi niti jedan tada znani generički obrazac, a sve s ciljem da ga time učini pristupačnijim i interesantnijim čitateljima s različitim predznanjem, recipijentskim iskustvima i književnim ukusima, odnosno da na taj način svakome od njih omogući da - iščitavajući ga na podlozi vlastitih očekivanja i potreba - u nj „učita“ upravo onu generičku predodžbu koja mu se u danom trenutku i iz danoga gledišta čini(la) najispravnijom. Po toj težnji podilaženju ciljanoj publici, međutim, Odiljenje sigetsko nipošto ne predstavlja usamljen slučaj u bogatu i (žanrovski) razvedenom stvaralačkom opusu našega autora, kontinuirano zaokupljenog sastavljanjem iznimno prilagodljivih ostvarenja što su provocirala raznovrsna (između ostalog, i generička) tumačenja, odnosno čija je polisemantičnost bila produkt nastojanja da se $\mathrm{u}$ potpunosti ona usklade s posebnostima različitih kontekstualnih okružja u koja su trebala doći, a time i da udovolje nejednakim ukusima ciljanih čitatelja, koji su pri susretu s njim aktivirali više ili manje različite „horizonte očekivanja“.

Želja za prilagođavanjem zahtjevima ne samo jednoga konteksta prilično se jasno tako očituje, između ostalog, i u pet dobro nam već znanih Ritterovih latinskih spomenica iz tzv. postkarlovačkoga ciklusa (nastalih između 1699. i 1701.), koje - iako sve redom polaze od istih ideoloških ishodišta te ih zaokupljaju posve identična historiografska i pravnopovijesna pitanja - donose pet bitno različitih predodžbi o teritorijalnoj protežnosti, odnosno zemljopisnom opsegu buduće „cjelovite“ ili „oživljene“ Hrvatske, čemu razlog treba tražiti u činjenici da je svaka od njih bila namijenjena drugom adresatu ili čitateljskom krugu, a samim time i posvećena izvršavanju drugačijih funkcija unutar danoga izvantekstualnog okvira. Primjer potonjih spomenica stoga nam otkriva jedan od načina na koji se Ritterova „ideološka konstrukcija zbog svojih strukturalnih karakteristika mogla efikasno mijenjati i prilagođavati različitim kontekstualnim datostima i potrebama“, pri čemu je upravo iz te njezine polisemantičnosti na koncu i proizišlo ,više mogućnosti različitih današnjih interpretativnih otčitavanja Vitezovićeve ideološke koncepcije: u rasponu od habsburške imperijalne publicistike, do staleškog političkog programa i formulacije nacionalnog identiteta“ (Blažević 2002: 161). ${ }^{1087} \mathrm{~S}$ otprilike istom strategijom, koja je u konačnici rezultirala još raznolikijim poimanjem generičke njegove pripadnosti, susrećemo se - dakako - i u pogledu samoga Odiljenja, no s tom razlikom što je u njegovu slučaju riječ o polisemantičnosti unutar granica jednoga jedinog teksta, lucidno realiziranoga kao žanrovski izrazito slojevit uradak, koje tim svojim mnoštvom generičkih značajki različita porijekla teži uklopiti se u više različitih kontekstualnih okvira, odnosno doprijeti do različitih tipova publike iz svih hrvatskih regija.

1087 Detaljnije o polisemantičnosti Vitezovićevih (glavninom povijesno-političkih) djela kao strategiji prilagođavanja zahtjevima različitih kontekstualnih okružja u: Blažević 2002: 152-162. 
S obzirom na njegovu žanrovski naglašeno heterogenu „izvedbu“, koja je čitatelje od 17. stoljeća do danas navodila na razne, u isti mah točne i netočne generičke predodžbe, a onda i na svakojake, uglavnom (uvjerljivim) argumentima potkrijepljene pokušaje njegove žanrovske kategorizacije, niti jedno od dosadašnjih eksplicitnih određenja Odiljenja sigetskog ne bi se stoga smjelo otpisati kao u potpunosti pogrešno i nelegitimno, ali još manje isticati kao apsolutno točno i sveobuhvatno, a samim time i primjenjivo na baš sve njegove dionice. Ne smećući s uma i više nego očite klasifikacijske manjkavosti i djelomičnosti takvih definicija, Vitezovićev hrvatski prvijenac u tom bi smislu posve legitimno bilo definirati kao što se to, uostalom, i dosad u nekoliko navrata činilo - i kao predstavnika žanra (junačke) epske pjesme, i kao primjerak zbirke lirskih pjesama, i kao ostvarenje iz korpusa baroknih pjesničkih zbornika itd., tim više što mu se na taj način, kao „svežanrovskom“ (pučkom) djelu, zapravo ne oduzima ništa od njegova kompleksnog i višeslojnog žanrovskog identiteta, već upravo potvrđuje kao tekst koji je i skrojen tako da provocira nejednake generičke predodžbe i raznolike, no uvijek manjkave pokušaje (jednoznačnoga) svrstavanja. Stoga se ni sama činjenica da je u razmišljanjima o njegovoj žanrovskoj pripadnosti od 18. stoljeća dominiralo uvjerenje da se radi o epskopjesničkom ili makar samo „epskom“ djelu, koje se, uostalom, i hvata u koštac s jednom od najepskijih tema u hrvatskoj književnosti, ${ }^{1088}$ nipošto ne bi trebala uzimati kao primjer pogrešne i neutemeljene generičke predodžbe o njemu, već prihvatiti kao jedno od posve legitimnih njegovih određenja koje ne eliminira sva ostala, no isključivo pod uvjetom da se ni ta ina određenja - odnosno svijest o postojanju drugih, „neepskih“ njegovih žanrovskih slojeva - ni u jednome trenutku ne smetnu s uma. Iz toga bi razloga $\mathrm{i}$ ovo istraživanje ukazivanjem na prisutnost tih raznolikih generičkih slojeva $\mathrm{u}$ Ritterovu književnom prvijencu i podsjećanjem na šarolikost njegovih dosadašnjih žanrovskih određenja trebalo pridonijeti tomu da se u budućim pokušajima njegova generičkog svrstavanja i na njih ozbiljno računa ili da ih se ima makar u vidu prilikom takvih (često i neizbježnih) jednoznačnih definiranja žanrovskoga mu identiteta, osobito stoga što je - kako nas uči suvremena genologija - baš svako određenje nekoga teksta bitno i zato ga nipošto pri generičkim razmatranjima bilo kojega djela ne bi trebalo ostaviti po strani odbacujući ga kao zastarjelo, pa i usprkos činjenici što vrlo često ono odzrcaljuje upravo shvaćanje književnosti u nekome vremenskom trenutku te ukazuje na izvanknjiževnu situaciju koja je iziskivala da se to djelo žanrovski percipira upravo na taj i takav način.

1088 Podsjetimo, i u najrecentniju, obljetničku antologiju (epskopjesničkih) tekstova posvećenih bitci za Siget Sigetski boj u hrvatskoj epici (Zagreb, 2016.) Vitezovićevo Odiljenje uvršteno je upravo kao primjerak „zrinijade“ generički realizirane kao povijesna epska pjesma (usp. Pranjić 2016: 105-202). 
Na kraju krajeva, ni neumorno ustrajanje na označavanju Odiljenja ,zrinijadom“ kako u sklopu ovoga razmatranja, tako i u čitavu nizu književnopovijesnih i „ritteroloških“ studija ispisanih u posljednjih dvadesetak godina - u tom smislu nipošto ne bi trebalo odveć strogo proglasiti (još jednim manjkavim) pokušajem prisilnoga mu nametanja homogenog žanrovskog identiteta jer je, u suštini, riječ ni o čemu drugome no o predodžbi utemeljenoj na posve legitimnom analitičkom pristajanju uz jednu od mnogobrojnih njegovih dosad već iskušanih generičkih kvalifikacija, i to, u ovome slučaju, onoj koja podrazumijeva njegovu „pripadnost“ jednomu teorijskom žanru, koji ne samo što - kao generička opcija - nije postojao ili makar kao žanr nije bio prepoznat u Vitezovićevo vrijeme, nego se po prvi put pojavio tek u književnopovijesnim, barokološkim studijama napisanima u drugoj polovini 20. stoljeća. Ipak, usprkos činjenici što se (i) u ovome slučaju radi o posezanju za „čisto“ teorijskim određenjem smišljenim stoljećima nakon objelodanjivanja izvornoga teksta, treba znati da svaki put kada Odiljenje (ili bilo koje drugo književno ostvarenje iz ranijih epoha) okrstimo generičkom oznakom suvremen(ij)e provenijencije - dakle, ne nekom iz palete onih koja bi ih povezivala s konkretnim žanrom iz tadašnjega generičkog sustava, kojega su (pre)poznavali kako autor i onodobna publika, tako i drugi sudionici na književnom „polju“ toga vremena (tiskari, knjižari, financijeri izdanja itd.) - mi zapravo činimo jedan posve novi korak u njegovoj identifikaciji, $\mathrm{i}$ to onaj na koji nas je pritom u potpunosti naveo današnji izvanknjiževni kontekst, odnosno tom kontekstu „pripadajuća“ situacija, iz vizure koje ga neizbježno i motrimo. Drugim riječima, ta i takva suvremena (tj. teorijska) generička određenja nepogrešivo nam stoga - čak i u slučajevima kada se radi o posve promašenim, dakle književnopovijesno neutemeljenim pokušajima njegova svrstavanja - ukazuju na to kako dano djelo percipiraju njegovi kasniji čitatelji, odnosno kakvo mu značenje pridaju oslanjajući se na (tada) dominantno shvaćanje književnosti, ali se istodobno ona promeću i u možda najuvjerljiviju izvantekstualnu potvrdu njegove generičke slojevitosti budući da je samo takvo ostvarenje - kao što to svojim primjerom to bjelodano potvrđuje i samo Odiljenje - tijekom svoga višestoljetnog književnopovijesnog trajanja jedino i bilo u stanju isprovocirati višestruke, međusobno različite žanrovske kategorizacije.

$\mathrm{Pa}$, ipak, unatoč činjenici da je i za njega ovdje utvrđeno da se radi o generički izrazito slojevitom - $\mathrm{u}$ isti mah nežanrovskom i svežanrovskom - književnom sastavku, nužno je naglasiti kako je iznimno važnu, ako ne i presudnu ulogu u toj i takvoj percepciji Vitezovićeva hrvatskog književnog prvijenca odigralo (i) odabrano teorijsko polazište, koje je uvelike doprinijelo tomu da temeljni fokus ovoga istraživanja bude upravo na njegovoj generički šarolikoj „prirodi“. Inzistiranje na žanrovski heterogenomu karakteru Odiljenja kao 
njegovoj možda i najvǎnijoj značajci, odnosno elementu u kojemu bi se mogao i morao kriti ključ razumijevanja ove uvjerljivo najosebujnije ,zrinijade“ u povijesti hrvatske književnosti, u velikoj se mjeri tako ispostavlja kao posljedica odlučnoga pristajanja uz zamisli moderne teorije žanra, ponajprije uz Bahtinovu teoriju govornih žanrova, ali i njegovim idejama bitno usmjerena poststrukturalistička genološka gledišta, odnosno „shvaćanja o heterogenom karakteru teksta“, prema kojima je moguće, „u okviru istog teksta ili grupe tekstova pronaći elemente koji dozvoljavaju i druga/drukčija generička pridruživanja“ (Blažević 2002: 102). U tom smislu, budući da je i u ovoj analizi (najavljeni) povijesni pristup generičkom identitetu Odiljenja sigetskog tako ostao presudno usmjeren subjektivno izabranim književnoteorijskim ishodištem, ni krajnji rezultat $\mathrm{u}$ vidu njegova definiranja istodobno negeneričkim i svegeneričkim ostvarenjem lišenim pripadnosti konkretnomu sekundarnom žanru stoga se ipak nipošto ne može proglasiti u potpunosti „objektivnim“, a time ni „povijesnim“, tim više što nam zbog neizbježne ograničenosti danoga teorijskog utemeljenja možda ipak nije pošlo za rukom prepoznati stanovite tekstualne signale njegove stvarne žanrovske pripadnosti, slijedom čega nam se i svako od njegovih dosadašnjih, pa i potencijalnih određenja - u tipično poststrukturalističkom ključu - u konačnici (u)činilo podjednako točnim i pogrešnim.

\section{ZAKLJUČAK}

Da mijene shvaćanja književnosti što su ih zastupali predstavnici različitih književnoteorijskih pravaca i škola neposredno utječu i na postupnu promjenu analitičkoga fokusa u (književno)povijesnim tumačenjima samih literarnih ostvarenja, odnosno na odabir istraživačkoga pristupa izraslog iz novih predodžbi o književnom tekstu kao takvom, i više nego uvjerljivo - bez obzira na nemale svoje nedostatke - potvrditi nam može upravo ovo genološko razmatranje Vitezovićeva Odiljenja sigetskog. Naime, kao tumačenje koje je njegovim žanrovskim specifičnostima nastojalo prići iz pretežno književnopovijesne perspektive, trudeći se sagleda(va)ti ih ponajprije u kontekstu sedamnaestostoljetne hrvatske i ne samo hrvatske književnosti, ovo čitanje Vitezovićeva vernakularnog literarnog prvijenca u potpunosti se tako nameće kao „plod“ uvažavanja nekih od danas najutjecajnijih književnoteorijskih, točnije genoloških zamisli, na koje se ranije „ritterološke“ interpretacije nisu oslanjale ne samo zato što je u domaćim književnoznanstvenim okvirima sve do nedavno prevladavala sveopća fascinacija strukturalističkim favoriziranjem isključivo tekstualne dimenzije književnoga ostvarenja, već i stoga što su mnoge od tih inovativnih genoloških predodžbi punu važnost u suvremenoj književnoj teoriji stekle tek unatrag posljednjih 
nekoliko desetljeća. U tom smislu, neće biti nimalo slučajno to što se inzistiranje na shvaćanju žanrovskog identiteta Odiljenja kao (pretežno) „posljedice“ ispunjavanja stanovitih izvantekstualnih imperativa u potpunosti poklapa s aktualnom - poststrukturalističkom teorijskom percepcijom (književnoga) žanra kao kategorije čije se postojanje svodi na neprekidno prilagođavanje situacijskom okružju, i to nipošto samo onomu užem, književnokulturnom, već i daleko obuhvatnijemu društvenopovijesnom kontekstu, koji se i ispostavlja kao temeljno izvorište (,govornih“) žanrova iz svih komunikacijskih sfera. Opredjeljenje za tu i takvu teorijsku perspektivu i u slučaju pretresanja generičkih specifičnosti Vitezovićeva teksta nužno je stoga podrazumijevalo ne samo sagledavanje u njemu detektiranih žanrovskih obilježja kao „posuđenica“ iz repertoara značajki pojedinih povijesnih (baroknih) žanrova dakle kao karakteristika svojstvenih danim žanrovskim rješenjima što su egzistirala $u$ stanovitomu kronotopu, odnosno na konkretnomu prostoru u konkretnomu vremenskom trenutku, a ne kao „trajnih“ žanrovskih posebnosti „otpornih“ na protok vremena i periodične mijene književnih poetika - nego i pristup njegovu (hibridnom) žanrovskom identitetu, odnosno potencijalnomu sekundarnom žanru kao situacijskim čimbenicima također uvjetovanu aspektu, zahvaljujući kojemu se u konačnici i došlo do spoznaja kojima prethodni njegovi tumači - poradi uvažavanja isključivo unutartekstualnih njegovih datosti - većinom nisu bili ni na tragu.

Doduše, usprkos težnji da se spomenutim generičkim obilježjima pristupa kao elementima baštinjenima iz repertoara konkretnih povijesnih - pretežno, dakako, sedamnaestostoljetnih - žanrova, pri utvrđivanju pojedinih žanrovskih slojeva Odiljenja sigetskog nije se ipak moglo izbjeći njihovo omjeravanje o teorijske generičke opise, tj. o definicije onih žanrova koje ne poznajemo iz njihovih povijesnih ,inkarnacija“, već isključivo kao teorijske entitete s „trajnim“ skupom njima „tipičnih“ tekstualnih obilježja. Uvažavanje (književno)teorijskih predodžbi o konkretnim povijesnim žanrovima, kao ni uzimanje u obzir pojedinih „,izvorno“ teorijskih žanrova (poput, primjerice, ovdje počesto apostrofirane „zrinijade“) pritom nipošto ne bi trebalo držati neobičnom, a kamoli usamljenom pojavom u recentni(ji)m genološkim istraživanjima, tim više što čak ni interpretacije u cijelosti bazirane na najaktualnijim genološkim spoznajama o situacijskoj ukorijenjenosti žanrova ne raspolažu dovoljno detaljnim ni pouzdanim podacima o stvarnome povijesnom tretmanu apsolutno svih žanrovskih opcija iz generičkoga sustava odabranoga povijesnog razdoblja, a uz to nisu u stanju doskočiti ni neizbježnom manjku analitičke (književnopovijesne) objektivnosti, koji proizlazi iz činjenice da ,govoreći o djelima prijašnjih epoha, mi nikako ne možemo odbaciti i zanemariti svoje vlastito, današnje književno iskustvo“ (Pavličić 1979a: 146), što u baš svako 
razmatranje (književno)povijesnih momenata unosi nezaobilazan moment subjektivnosti, dakle potrebu „teorijskoga“ domišljanja nepotpunih spoznaja o žanrovskim rješenjima iz prošlosti. Osnovni je to razlog zbog kojega je apsolutno svaki govor o povijesnim žanrovima uvijek i nužno - makar nakratko - prisiljen skrenuti na „stranputicu“ njihova tumačenja iz suvremene vizure, odnosno što čak i najuvjerljiviji pokušaj rekonstruiranja povijesne poetike bilo kojega žanra mora uključivati i pokoju teorijsku intervenciju, pri čemu ne treba smetnuti s uma kako toj isprepletenosti povijesne i teorijske percepcije žanrovskoga „materijala“ $u$ prilog dodatno govori i činjenica da je čak i teorijski žanr ujedno ništa drugo no također i povijesna kategorija budući da se čak ni u njegovu slučaju ne radi, u suštini, ni o čemu drugome no o definiciji žanra proizišloj iz nekoga situacijskog, dakle vremensko-prostornog konteksta. Na tu tijesnu isprepletenost povijesne i teorijske dimenzije apsolutno svakoga (književnog i ne samo književnog) žanra i više nam nego bjelodano stoga ukazuje i istraživanje generičkih značajki Ritterova neobičnog literarnog prvijenca, koje nam također naporima da se ta teorijska komponenta u njemu pokuša svesti na minimum usprkos potvrđuje da razmatranje žanra iz povijesne perspektive nije moguće lišiti makar i same svijesti i o njegovoj teorijskoj utemeljenosti, koja je i dijelom ovoga čitanja najčešće postajala zapravo posve nesvjesno.

Uzimajući, međutim, u obzir sve dosad iznijete konstatacije o Odiljenju sigetskom, s punim pravom moći ćemo ustvrditi kako je to i takvo generičko čitanje ipak dospjelo iznjedriti čitav niz prilično zanimljivih, primjenom teorijske aparature suvremene (književne) genologije dosegnutih zapažanja, koji bacaju neko posve novo svjetlo na ovaj po mnogočemu osebujan, no u našoj književnoj povijesti počesto pogrešno tumačen i uopće nedovoljno valoriziran pjesnički sastavak Pavla Rittera Vitezovića. Kao možda i najvažniji doseg ovoga istraživanja pritom bi se, bez ikakve dvojbe, nametala činjenica da mu je u Odiljenju motreći ga iz daleko modernije analitičko-teorijske perspektive - pošlo za rukom detektirati nezanemariv broj dosad neprimijećenih generičkih obilježja, preuzetih iz repertoara upravo onih žanrova koji su (i) u okvirima hrvatske, ali i - još više - onima europske sedamnaestostoljetne književnosti bili među tada najeksploatiranijim generičkim rješenjima, $\mathrm{i}$ to neovisno od toga što se ni za jednoga od njih ne može kazati da je bio izvorno baroknoga podrijetla. Pa, ipak, njihova je baroknost - osim iz uvažavanja nekih „tipično“ baroknih tekstualnih značajki - glavninom proizlazila već iz same činjenice da su svi oni redom imali „zacementirano“ mjesto u (provizornome) žanrovskom sustavu onodobne književnosti, pri čemu bi počesto posezanje (domaćih i osobito stranih) pisaca za repertoarima njihovih obilježja ujedno trebalo nepogrešivo upućivati na to da su oni, iako nebaroknoga porijekla, 
bili itekako usklađeni s tadašnjim kontekstom ili situacijskim okružjem, unutar kojega su i vršili stanovite izvantekstualne zadaće. $U$ tom smislu, razmatranje žanrovske dimenzije Odiljenja sigetskog bjelodano je potvrdilo da se radi (i) o generički izrazito modernom, a ne kako su to pojedini proučavatelji težili dokazati - staromodnom ostvarenju, pa iako se i u njegovoj fakturi mogu zateći ponešto tradicionalniji, zaista staromodniji žanrovski slojevi, redom je riječ o značajkama preuzetima iz žanrova koji su imali svoje čvrsto mjesto u sustavu barokne književnosti, slijedom čega ih se nipošto ne bi trebalo ni smjelo označavati kao (u tom vremenskom kontekstu) ,arhaična“, a kamoli regresivna žanrovska rješenja.

Modernost Vitezovićeva hrvatskog književnog prvijenca pritom se možda i ponajbolje ogleda upravo u njegovu - baroknim ostvarenjima i više nego svojstvenom - nastojanju da se oblikuje kao neka varijanta žanrovski hibridnog teksta, odnosno kao jednoznačno teško odrediv generički mozaik ili kolaž, zamišljen i realiziran tako da bi lakše bio u stanju ispuniti čitav niz kako unutartekstualnih, tako i izvantekstualnih funkcija i zadaća. Ponajprije, naš je autor za obilježjima iz različitih generičkih repertoara u Odiljenju tako posezao ne samo u želji da ispiše moderno, žanrovski „nečisto“ djelo kojim će se etablirati kao „punokrvni“ barokist, nego i da njime pokuša privući potencijalnu publiku iz svih hrvatskih regija, točnije iz svih četiriju tadašnjih književno-kulturnih krugova, počevši od onoga ozaljskog, preko sjevernohrvatsko-kajkavskog i slavonskog, pa sve do - daleko najrazvijenijega - dubrovačkodalmatinskog baroknog kruga. Osim što se pritom, računajući na takvo raznoliko čitateljstvo, u svojoj trodijalektalno ispjevanoj „zrinijadi“ ciljano oslanjao na repertoare upravo onih žanrova koji su, kao što smo vidjeli, u (zamišljenim) generičkim sustavima svakog od tih baroknih književnih krugova imali posebno važno mjesto, ujedno je on značajke različitih (ne samo pisanoknjiževnih i ne samo književnih) žanrova težio ,aktivirati“ i ne bi li se lakše približio kako „horizontalno“ (regionalno) šarolikoj, tako i „,vertikalno“ raznolikoj publici, što će reći podjednako recipijentima koji su stekli prvorazredno obrazovanje i posjedovali zavidno književno iskustvo te znatno skromnije obrazovanim i literarno neiskusnijim čitateljima, koji su svoju predodžbu o književnosti pretežno temeljili na recepciji folklornoknjiževnih i pučkoknjiževnih sastavaka.

U želji da udovolji literarnim ukusima, očekivanjima, pa i potrebama jednih i drugih a sve ne bi li tako što većem broju sunarodnjaka dospio predstaviti svoju viziju svehrvatskoga jezika kao temelja buduće (i teritorijalno) ujedinjene Hrvatske te ih ujedno i potaknuo na to da se uključe u oslobađanje i obnovu Sigeta kao (pre)važnoga memorijalnog lokaliteta za hrvatski narod - Pavao Ritter Odiljenje premrežuje obiljem značajki svojstvenih različitim pisanoknjiževnim, ali i usmenoknjiževnim, pučkoknjiževnim, rubno književnim i 
neknjiževnim žanrovima, kojima - sljubljujući ih s posebno intrigantnim formalnim rješenjima poput metričkih i strofičkih varijacija, homonimskih rima, kronograma i dr. uspješno dospijeva otkloniti moguću „opasnost“ od upadanja u monotoniju koja bi mogla proizići iz činjenice da se laća višestruko već obrađene teme, odnosno postiže bitno veću dinamičnost i zanimljivost teksta kao jamstvo da će uspjeti ono pobuditi interes (i) među književno neiskusnijom i uopće neukijom publikom, koja je od pisanoga štiva očekivala „izvući“ neku praktičnu korist i zabavu. S druge strane, budući da je tom istom paletom značajki i formalnih postupaka paralelno on dospio privući i zanimanje (visoko)obrazovane publike iz redova tadašnje društvene elite, u čijim se očima njegovo generički višeslojno ostvarenje protkano kojekakvim formalnim dosjetkama ispostavljalo kao i više nego moderan i estetski uspio literarni produkt, u kojemu su važnu ulogu igrala obilježja nekih od tada najeksploatiranijih i najcjenjenijih žanrova (povijesni ep, heroida, epitaf, panegirik, poslovica i dr.), slučaj njegova hrvatskog književnog prvijenca nametao bi se kao jedan od možda i ponajboljih dokaza činjenice kako naši ranonovovjekovni - pa tako ni barokni - pisci „nisu svoje tekstove napisali upravo na taj način na koji su ih napisali zato što su mislili da je tako najbolje, nego zato što su, dobro razmislivši i odvagnuvši sve razloge - ocijenili da je tako najprimjerenije zajednici kojoj se obraćaju“ (Pavličić 2006: 194). Pritom, međutim, ne treba smetnuti s uma kako tom i takvom svojom ,zrinijadom“ Vitezović nipošto nije ciljao samo i isključivo na muške recipijente iz redova aristokracije i nižih drušvenih slojeva, već mu je podjednako važan bio i interes opismenjenih čitateljica, mahom, dakako, pripadnica (visokoga) plemstva, ${ }^{1089}$ kojima je na ovaj način također želio prezentirati novu inačicu zajedničkoga hrvatskog jezika, ali i osvježiti sjećanje na junaštva sigetskih branitelja predvođenih Nikolom Šubićem Zrinskim, posve svjestan kako bi u širenju novoga jezika i održavanju sjećanja na jedan od najvažnijih događaja iz domaće povijesti od nezanemarive važnosti mogla i morala biti (i) uloga žena, koje su ponajprije muškim članovima svojih obitelji, a onda i vlastitoj djeci trebale pomoći da te posve nove i nove-stare vrijednosti usvoje (i) u kućnomu, dakle obiteljskom okružju.

Osim, dakle, u želji da stvori djelo zanimljivo raznolikim tipovima publike, Pavao Ritter Vitezović u svome je vernakularnom književnom prvijencu pribjegao strategiji generičkoga kolažiranja i s razloga ,čisto“ žanrovske prirode, odnosno s nakanom da ga udalji od politički tada izuzetno kompromitiranoga žanra povijesnog epa (tj. epskopjesničke „zrinijade“), iz čijega generičkog repertoara i odabire tek nekolicinu „tipičnih“ obilježja,

1089 Detaljnije o Vitezovićevu paralelnom obraćanju učenijim i slabije učenim potencijalnim čitateljima $u$ Odiljenju sigetskom u: Pavličić 2007: 279-283. 
raspršujući ih duž teksta bez ikakve namjere da ispjeva „punokrvno“ epskopjesničko ostvarenje žanrovski podudarno toliko mu dragoj, iako ideološki spornoj Obsidi sigeckoj Petra Zrinskog, a opet - po nekim sadržajnim i formalnim karakteristikama - istodobno i dovoljno „epsko“ da pojedine svoje čitatelje ipak može navesti na pomisao kako se i u njegovu slučaju susreću s ,pravim“ epskopjesničkim sastavkom. S obzirom na njegovo višestruko već utvrđeno i potvrđeno - kreativno uvažavanje tematsko-motivskih posebnosti Petrove „zrinijade“, neće biti upitno da je upravo iz njezina epskopjesničkog segmenta u najvećoj mjeri on i preuzeo spomenute prepoznatljivo barokne „epske“ sadržajne momente, počevši od težnje proširivanju povijesnih sadržaja kvazipovijesnim, eshatološkim i romantičnim (,tassovskim“) motivima, ${ }^{1090}$ odnosno ispreplitanju vojno-povijesnih, ljubavnih i religijskih sadržajnih preokupacija, preko kontinuiranoga evociranja „tradicionalno“ lirskopjesničkih sadržajnih preferencija (osobito one isticanju duševnih stanja i uopće stvaranju povišeno emocionalnog ozračja), pa sve do mjestimičnih narativnih „uobličavanja“ dionica pojedinih pjesama, čija razvodnjenost i raspršenost možda i ponajbolje svjedoči o Vitezovićevu svjesnom razbijanju (tada) uvriježenoga epskopjesničkog okvira - koji je podrazumijevao pripovjednu obradu kronologije tematiziranoga događaja $u$ izrazito epizodičnoj strukturi što se proteže kroz veći broj (duljinom nimalo skromnih) pjevanja - na koje se odvažio ponajprije iz razloga što se pribojavao da bi ta i takva, „punokrvno“ epskopjesnička generička „izvedba“, posvećena veličanju junaštva najistaknutijega pripadnika porodice Zrinski i njegovih sigetskih suboraca, ,automatski“ mogla sugerirati protuhabsburško ideološko opredjeljenje, na kakvom je inzistirao i njegov neposredni prethodnik i ujedno najveći mu literarni uzor.

Nipošto ne želeći izaz(i)vati sumnju javnosti, a ponajmanje tadašnje habsburške političke elite - koju bi žanrovska „vanjština“ Odiljenja lako mogla navesti na ishitrene zaključke o njegovoj političkoj orijentaciji - naš autor ne samo što je prepoznatljivo „epska“ obilježja odlučio svesti na „tek“ mjestimične evokacije „tipično“ epskopjesničkih sadržajnih momenata (teme, motiva, situacija i likova), nekolicinu (ne odveć opsežnih) narativnih odsječaka te formalnu dominaciju dvostruko rimovanoga dvanaesterca kao jednog od „najepskijih“ stihova naše ranonovovjekovne književnosti, nego je ujedno - kao što je primijećeno - poprilično ,utišao“ napadno barokno ustrajanje na pretjerano bujnim i ingenioznim figuralno-stilskim rješenjima, kakvome su bili skloni tadašnji epski pjesnici, a uz to još i modernost teksta bitno ublažio (pre)čestim posezanjima za (izvorno) renesansnim (motiv vile, četverodijelna struktura itd.), ali i srednjovjekovnim elementima (topos memento

${ }^{1090}$ Usp. o tome u: Kravar 1993: 104-125 i Fališevac 1997: 161-175. 
mori, žanr dijaloške lirike i sl.), kojima napučuje sva četiri dijela svoje „zrinijade“. Govoreći, međutim, o Vitezovićevu hotimičnom olabavljivanju (tradicionalno) čvrstih epskopjesničkih žanrovskih okvira i uopće generički disperziranoj realizaciji Odiljenja kao svojevrsnim strategijama distanciranja od (kompromitiranoga) žanra barokne povijesne epske pjesme, ono što nikako ne bi trebalo smetnuti s uma kada se govori o epskopjesničkoj produkciji seicenta jest - u barokološkim studijama već poodavno iznesena - činjenica kako su upravo u 17. stoljeću epski pjesnici diljem Europe (pa tako i u nas) počeli pokazivati sve veću sklonost sastavljanju krajnje neobičnih „epskih“ žanrovskih hibrida, kojima su se radikalno suprotstavljali uvriježenim (naoko poprilično neumoljivim) epskopjesničkim konvencijama glavninom naslijeđenima iz prethodnih stoljeća, i to usprkos tomu što su ih se - u teorijskom, odnosno poetičkom smislu - deklarativno još uvijek trudili poštivati, između ostalog i stoga što su i dobar dio „epskih“ žanrova prisutnih u generičkom sustavu svoje epohe baštinili upravo iz šesnaestostoljetne književnosti. U tom smislu, znamo li da se u baroknoj epskoj poeziji - namjesto dotad uobičajene objektivnosti i ,jake“, dosljedno izvedene naracije - sve veća važnost počela pridavati ne samo opisnosti, dramatičnosti, patetičnosti i elegičnosti, nego i izrazito učestalim izlaganjima enciklopedijskoga znanja, kojima se nepovratno oslabljivala njezina pripovjedna „osnovica“ (ionako već uvelike „,nagrižena“ pretjeranim posvećivanjem pažnje ingenioznim stilskim rješenjima - radiklanim metaforama, igrama riječi, concettima - najčešće ,aktiviranima“ bez ikakva konkretnog sadržajnog povoda), a samim time i njezin herojski ,učinak“ uopće, ${ }^{1091}$ i Odiljenje sigetsko na podlozi tih i takvih se onodobnih pjesničkih ostvarenja itekako moglo nametnuti kao svojevrsno „epsko“ djelo, pa makar samo u očima onih recipijenata koji su posjedovali iskustvo čitanja najsuvremenijega tadašnjeg „epskog“" stvaralaštva.

I sam izvrsno upoznat sa sedamnaestostoljetnom epskopjesničkom produkcijom, Pavao je Ritter vrlo dobro znao koliko daleko smije otići s asimiliranjem obilježja iz generičkoga repertoara (barokne) povijesne epske pjesme, a da njegova literarna vizija pada Sigeta pritom ipak u potpunosti ne „sklizne“ u sekundarni žanr ,punokrvnoga“ baroknog junačkog epa. Dapače, kao politički korektan generički „konglomerat“ prošaran prepoznatljivo „epskim“ karakteristikama, Odiljenje je u njegovo vrijeme zapravo bilo u stanju doslovno tek zanemarivom broju literarno iskusnijih recipijenata pobuditi dojam da je riječ o (pretežno) epskopjesničkom sastavku, zbog čega ne čudi da će ga kao „epsko“ ostvarenje znatno učestalije percipirati „tek“ čitatelji iz sljedećih stoljeća, kada i dolazi do

1091 O ovim i drugim specifičnostima sedamnaestostoljetnoga epskopjesničkog stvaralaštva u: Warnke 1972: 158-186. 
daljnjega rastakanja poetike povijesnoga epa, odnosno ublažavanja, a onda i napuštanja njegovih dotad neprikosnovenih generičkih normi. Za razliku, naime, od velike većine Vitezovićevih suvremenika, koje je od pristupanja Odiljenju kao epskopjesničkoj „zrinijadi“ usprkos sve izrazitijem udaljavanju onodobnih epskih djela od ustaljenih konvencija povijesnoga epa - odvraćala upravo činjenica da je riječ o žanrovski fragmentarnom ostvarenju bez jasnoga ideološkog opredjeljenja, kakvim su se mogli podičiti gotovo svi dotadašnji primjerci epa, počevši od Tassova Oslobođenog Jeruzalema, pa sve do Gundulićeva Osmana i Obside sigecke Petra Zrinskog, u očima mnogih osamnaestostoljetnih, pa i znatno kasnijih čitatelja (osobito onih iz redova književnih praktičara i proučavatelja) Odiljenje se ispostavljalo kao „punokrvna“ epska pjesma, što je bila posljedica ne samo širenja njegove (književno sve upućenije i iskusnije) publike, nego i nezaustavljivoga procesa razvodnjavanja poetičkih uporišta povijesnoga epa, odnosno olabavljivanja njegovih tradicionalnih generičkih okvira i temeljitoga pretresanja uvriježenoga mu generičkog repertoara, koje je rezultiralo osjetnim kraćenjem „epskih“ tekstova i njihovim napučivanjem raznoraznim formalnim postupcima i značajkama čitavog niza „neepskih“ žanrova.

Zamislivši ga, dakle, kao u isti mah i „elitni“ i pučki književni prikaz kršćanskoga poraza pod zidinama Sigeta i njegovih reperkusija, Pavao Ritter Vitezović nije imao drugoga izbora no upustiti se u generički fluidno oblikovanje svoje „zrinijade“, kojim je doslovno svakomu pojedinačnom čitatelju - neovisno od njegove učenosti i prethodnih čitateljskih iskustava - omogućio da u njemu prepozna upravo ono što je želio i/ili bio u stanju prepoznati. Njegove su temeljne nakane, krajnje pojednostavljeno govoreći, pritom zapravo bile dvojake, pa dok je žanrovski šarolikom realizacijom Odiljenja u pučkih recipijenata želio „samo“ pobuditi i zadržati čitateljsko zanimanje, dotle se u očima visokoobrazovanih književnih sladokusaca tim istim hibridom u kojemu su dominirala ni manje ni više nego upravo obilježja nekih od najučestalijih i najcjenjenijih pisanoknjiževnih baroknih žanrova (povijesni ep, heroida, lirski panegirik, epitaf i dr.) nastojao potvrditi kao pjesnik „od zanata“, odnosno kao (visoko)obrazovan i kompetentan pisac upućen u najrecentnija zbivanja na europskoj književnoj „sceni“. Imajući, drugim riječima, u vidu (i) potencijalne visokoobrazovane čitatelje iz redova onodobnoga plemstva, Vitezović je dobro znao da, želi li im se u svome tekstu prezentirati kao učen i upućen pjesnik koji suvereno vlada stihotvoračkom vještinom, nipošto u (n)ovoj literarnoj obradi dotad već višestruko obrađene teme ne smije poći (generičkim) putovima svojih prethodnika, što je i bio jedan od presudnih razloga njegova ustrajanja na estetizaciji teksta u cijelosti, odnosno na artificijelizaciji svih 
njegovih razina, ${ }^{1092}$ pa tako $\mathrm{i}$ one žanrovske, na kojoj su se variranja obilježja raznolikoga generičkog podrijetla također ispostavljala kao jedna od mnogih strategija za potvrđivanje autorova pjesničkog umijeća, a time i modernosti, pa onda i „elitnoga“ statusa njegova djela. $\mathrm{Na}$ kraju krajeva, takva „napadna“ artificijelizacija književnih tekstova namijenjenih (visoko)obrazovanim recipijentima predstavljala je u 17. stoljeću gotovo redovitu pojavu, pri čemu se - kako ističe Dukić - kao jedan od njezinih najčešćih povoda nameće upravo slučaj „kad se književnik, koji je čak donekle to bio i po profesiji, uhvati u koštac s već obrađenom svjetovnom temom i stvara svoje djelo kao varijaciju već postojećeg teksta“, uslijed kojega se i „posao prikazivanja književne vještine čini samorazumljivim“ (Dukić 2002: 69).

Detektiranje raznolikih (primarnih i sekundarnih) generičkih slojeva Odiljenja sigetskog, koje smo - u cilju utvrđivanja njegova sekundarnog žanra - proveli na stranicama ovoga istraživanja, presudno je tako usmjerilo naša razmišljanja o izvantekstualnom statusu ove generički uvjerljivo najneobičnije ,zrinijade“ u povijesti hrvatske književnosti, ukazavši nam ne samo na (vrlo vjerojatne) razloge poradi kojih se Pavao Ritter odlučio ispjevati baš ovako „uobličen“ tekst o herojskoj obrani Sigeta, nego nas istodobno suočivši i s činjenicom kako u tom poslu nije on slijedio nikakav konkretan žanrovski uzor, što mu i jest omogućilo da iznjedri inovativni generički „križanac“ kojemu u narednim godinama ni samom neće poći za rukom naći se u ulozi žanrovskoga uzora, odnosno predloška ili matrice, a time ni potvrditi svoj izvorni generički identitet kao sekundarni žanr. Osim što je potonju spoznaju - da je Odiljenju teško pronaći žanrovski pandan kako u okvirima hrvatske, tako i u onima europske sedamnaestostoljetne književnosti, pa čak i među tekstovima i žanrovima s kojima dijeli stanovit broj (većinom formalnih i strukturno-kompozicijskih) osobina (pučkoknjiževne višežanrovske kompilacije, autorski epsko-lirski zbornici, rukopisni izbori iz opsežnijih tekstova, donekle čak i Biblija itd.) - pritom moguće izdvojiti kao možda i najprepoznatljiviju karakteristiku ove literarne vizije sigetske katastrofe, $\mathrm{u}$ isti mah valjalo bi u njoj vidjeti i očit rezultat Vitezovićeva i više nego oduševljenog prihvaćanja barokne „mode“ sastavljanja tekstova baziranih na generičkoj „kombinatorici“ - tj. proizišlih ili iz svjesne težnje za „onečišćavanjem“ postojećih žanrovskih rješenja ili, pak, za „otkrivanjem“ posve novih (dakako, hibridnih) generičkih opcija satkanih od obilježja deriviranih iz više različitih žanrovskih repertoara - slijedeći koju je dospio on demonstrirati izvrsno poznavanje „poetike“ nemalog broja književnih i ne samo književnih (baroknih) žanrova, a uz to i nevjerojatnu okretnost $u$,žongliranju“ njima svojstvenim obilježjima te njihovu stapanju, odnosno efikasnom pretakanju u posve novu - svežanrovsku - literarnu cjelinu, koja se

${ }^{1092}$ O artificijelnosti Odiljenja sigetskog naročito u: Dukić 2002: 69-70. 
(prividnoj kaotičnosti i razbijenosti usprkos) tako promeće u uvjerljivu potvrdu onoga što bismo mogli nazvati njegovom neupitnom „književnom kompetencijom“. Pa iako su mu, pravdajući svoje sudove ponajviše uvjerenjem o generičkoj „nabacanosti“ Odiljenja sigetskog, tu kompetenciju pokuša(va)li osporiti mnogi dosadašnji povjesničari hrvatske književnosti, ne treba zaboraviti da bez prethodnoga čitateljskog i praktičnog (književnostvaralačkog) iskustva uvelike proizišlog iz kvalitetne literarne naobrazbe Vitezović nipošto ne bi bio u stanju ispjevati djelo koje je - kako to izvrsno poentira Pavao Pavličić - „po svojim formalnim osobinama, a i po načinu na koji tekst funkcionira - zapravo jedinstveno, ne samo i krilu hrvatske književnosti, nego i u mnogo širem literarnom kontekstu“ (Pavličić 2007: 253), iz kojega „strši“ kao možda i jedino ostvarenje koje je svojim fluidnim, višežanrovskim identitetom bilo u stanju privući posve različite tipove čitatelja s gotovo čitava prostora onodobne Hrvatske.

Ciljano, dakle, realiziravši svoju „zrinijadu“ kao generički heterogen tekst koji je nemoguće bez „ostatka“ podvesti pod isključivo jednu žanrovsku odrednicu, Pavao se Ritter istovremeno uspio potvrditi i kao pisac koji uvažava najmodernije stvaralačke principe autorske (,elitne“) književnosti svoga vremena - u kojoj su povlašten status uživali upravo generički hibridi - i kao pjesnik koji se za „strategiju“ sljubljivanja čitavog niza primarnih i sekundarnih žanrova i njima svojstvenih obilježja odlučio ne bi li zaokupio pažnju što je moguće većeg broja recipijenata nejednakoga čitateljskog profila, međusobno različitih kako po dosegnutom stupnju obrazovanja, tako i po prethodnim literarnim iskustvima, na kojima se ponajvećma i temeljila njihova predodžba o književnosti „zaslužna“ (i) za nejednaka (ne samo žanrovska) očitovanja s kojima su pristupali njezinim ,produktima“. Dapače, da Vitezović nipošto nije računao isključivo s učenijom publikom, koja je živo pratila zbivanja na tadašnjoj domaćoj i (srednjo)europskoj književnoj sceni, već i s nerijetko tek jedva opismenjenim „nevježama“, za koje su „pojam“ literarnoga djela predstavljale foklornoliterarne kreacije i pučko štivo, potvrditi nam - pored detektiranoga obilja utkanih autohtono usmenoknjiževnih i pučkoknjiževnih žanrovskih obilježja - mogu i brojni drugi paratekstualni i tekstualni signali u Odiljenju sigetskom, između ostalih i njegovo odlučno opredjeljenje za vernakularnu jezičnu „izvedbu“, kojom je učinio oštar zaokret od svoga dotadašnjeg pretežno (novo)latinskog stvaralaštva u potpunosti namijenjenog obrazovanijem čitateljstvu unutar i onkraj granica tadašnje Hrvatske.

U silnoj želji da oko svoga literarnog prvijenca okupi i književne sladokusce i neukiju publiku, odnosno kako pripadnike društvene elite, tako i bazično obrazovan puk iz svih hrvatskih regija, Vitezović ispisuje tekst na trodijalektalnoj jezičnoj stopljenici, koju 
izrijekom predstavlja kao idealno rješenje za budući (sve)hrvatski standard, odzrcaljujući njome ponajprije izrazitu šarolikost generičke razine teksta - opskrbljene karakteristikama iz repertoara žanrova zastupljenih u (zamišljenim) generičkim sustavima svih četiriju onodobnih domaćih književnih krugova - ali i bogatstvo formalnih (prisutnost ne samo stihova baštinjenih iz južnohrvatske i sjevernohrvatske pisane književnosti, već i onih svojstvenih isključivo folklornoknjiževnom stvaralaštvu), donekle i stilskih, pa i motivskih rješenja i postupaka raznolikoga porijekla, uklopljenih u okvire djela posvećenog tematiziranju događaja što je u gotovo podjednakoj mjeri odjeknuo u tadašnjem (ne samo pisanom) književnom stvaralaštvu svih hrvatskih regija. Takvim stvaralačkim postupkom, baziranim na sprezanju literarnih elemenata „izvučenih“ iz međusobno različitih, regionalno razdijeljenjih „odvojaka“ domaće ranonovovjekovne književnosti, naš se autor zapravo potvrdio kao „prvi hrvatski pisac koji se oslanjao na sve raznorodne regionalne tradicije hrvatske književnosti (...) težeći ih sve uliti u jedan tok“ (Fališevac 2013: 12), što ga i jest nagnalo na to da između ostalog - u Odiljenju osobito naglasi upravo pučkoknjiževnu dimenziju, odnosno da ga od korica do korica premreži obilježjima „tipičnima“ za čitav niz pučkih žanrova, koji su se s jednakom učestalošću bili tada sastavljali kako u okrilju južnohrvatske književnosti, tako i na našem sjeveru, što će reći da ih je lakoćom mogla i morala (pre)poznavati potencijalna publika iz svih četiriju ranonovovjekovnih književno-kulturnih krugova.

Bez obzira na njegovu izrazitu žanrovsku slojevitost, odnosno prisutnost elemenata iz različitih književnih tradicija u kompleksnoj mu tekstualnoj fakturi, Vitezovićevo se Odiljenje sigetsko - utvrdili smo - nadaje ipak kao itekako kompaktno i planski strukturirano ostvarenje, čiji su generički raznoliko ispjevani segmenti čvrsto „saliveni“ u jedinstvenu, ali ne i žanrovski jednoznačno odredivu književnu cjelinu sadržajno posvećenu herojskoj obrani Sigeta i njezinim neposrednim reperkusijama. Iako bi, međutim, suviše doslovno (i književnopovijesno neosviješteno) pridržavanje genoloških predodžbi na kojima počiva Bahtinova teorija govornih žanrova - iz vizure kojih bi se u ovome slučaju radilo „tek“ o skupu primarnih i sekundarnih žanrova što ne uspijevaju formirati (novi) sekundarni žanr nedvojbeno rezultiralo zaključkom kako generički nejednako ostvarene pjesmovne odsječke Odiljenja što ih izriču različiti govornici nipošto nije moguće prihvatiti kao sastavnice žanrovski zaokruženoga, koherentnog djela, takvom prosudbom u potpunosti bi se zamaglila činjenica da baš sve njegove dijelove, točnije baš svaku pojedinačnu pjesmu svih četiriju mu „dilova“ prožima i nerazdruživo povezuje posve identična sadržajna orijentiranost temi sigetske katastrofe i njezinih odjeka. Štoviše, inzistiranje na (is)toj bi konstataciji ujedno značilo i negiranje ne samo - maločas već navedene - spoznaje kako pjesme Ritterove 
„zrinijade“ u velikoj mjeri na okupu drži i to što su redom one skrojene od obilježja pjesničkih žanrova od kojih su mnogi već i ranije bili evocirani u svrhu opjevavanja opsade i pada Sigeta i/ili makar nekih pojedinačnih aspekata ili momenata toga događaja, nego ujedno i (opetovano isticane) činjenice kako baš sve (lirsko)pjesničke komponente Odiljenja u većoj ili manjoj mjeri sadržajno, pa i donekle formalno i generički ovise od Vitezoviću posebno omiljene i žanrovski također disperzirane Adrijanskoga mora Sirene, u kojoj Petar Zrinski ne zaboravimo - poseže za čitavim nizom žanrova što će ih (nipošto nevezano od svoga najvećeg literarnog uzora) dva i pol desetljeća kasnije iznova „aktivirati“ naš autor pri sastavljanju vernakularnoga književnog prvijenca.

Konačno, i netom spomenuto kontinuirano prizivanje karakteristika pučke književnosti - u kojoj su žanrovska pretapanja predstavljala nezaobilaznu pojavu - također bi se moglo i moralo izdvojiti kao jedan od tekstualnih čimbenika koji su doprinosili kompaktnosti Odiljenja, osobito u očima slabije obrazovanoga čitateljstva, ali i literarno iskusnije publike iz viših društvenih slojeva, koja se zgodimice također nije ustručavala „Zaviriti“ i u djela takva tipa i namjene. Iako su pritom među „konzumentima“ pučkoknjiževnih ostvarenja iz redova aristokracije glavninom bile majke, sestre i supruge magnata i drugih onodobnih velikaša, muški dio „elitne“ publike u neizbježan je kontakt s karakteristikama svojstvenima upravo pučkom štivu dolazio već i posredstvom pisanoknjiževnih ostvarenja protkanih mnoštvom tih i takvih ,pučkih“ elemenata, među kojima su se posebno izdvajala dobro nam već znana (autorska) djela „zborničkoga tipa“ poput Sirene, ali i rukopisni izbori iz opsežnijih literarnih ostvarenja kao što je bio onaj iz Petrove „zrinijade“, pri čemu ne treba smetnuti s uma ni to da su svoju itekako dobru predodžbu o žanrovski „,neurednim“, tj. kompilacijskim pučkoknjiževnim tekstovima ti isti čitatelji uvelike dugovali recepciji tadašnjega religiozno-liturgijskog štiva, a ponajprije Biblije kao također zbornički uobličena sastavka. U tom bi se smislu s punim pravom moglo pretpostaviti kako je Pavao Ritter u najvećoj mjeri i računao upravo na to da potencijalni čitatelji iz aristokratskih krugova posjeduju (,barem“) iskustvo čitanja onodobnih pisanoknjiževnih i religioznih kompilacijskih ostvarenja te svakako Biblije, na podlozi kojega će (ili bi barem trebali) biti u stanju prepoznati (i) pučkoknjiževnu dimenziju kao jedan od činitelja kompaktnosti višedijelnoga Odiljenja „razbijenog“ u niz žanrovski raznoliko ostvarenih tekstualnih ,jedinica“, odnosno pojedinačnih pjesama. ${ }^{1093}$

1093 Imamo li na umu to Vitezovićevo nastojanje da „komprimira“ izuzetno velik broja generičkih obilježja raznolike provenijencije, odnosno stopi žanrovski kojekako ostvarene pjesničke dionice u jednu kompaktnu tekstualnu cjelinu, ni najmanje nas ne bi trebali čuditi rezultati analize frekvencijara ili čestotnika Odiljenja sigetskog što ju je svojedobno bio proveo Milan Moguš, koji su pokazali kako je - između sveukupno 16220 
Opetovano isticanje osebujnosti Odiljenja sigetskog, odnosno njegove neupitne žanrovske posebnosti i unikatnosti, itekako bi nas lako pritom moglo zavarati i navesti na iskrivljenu njegovu percepciju kao jednog od rijetkih ili možda čak i jedinoga literarnog ostvarenja čiji se generički identitet nameće kao specifikum u kontekstu hrvatske i ne samo hrvatske (ranonovovjekovne) književnosti. Naprotiv, da u pogledu svoje generičke izdvojenosti ono nipošto nije predstavljalo usamljen, a kamoli neobičan slučaj u povijesti naše književnosti ponajbolje nam mogu potvrditi rezultati pojedinih genoloških studija novijega datuma, koji ukazuju na to da su se u hrvatskoj književnosti kroz njezino višestoljetno povijesno trajanje povremeno pojavljivali žanrovi, točnije žanrovski tako realizirani tekstovi kojima je vrlo teško, a najčešće i posve nemoguće pronaći generičke srodnike u drugim nacionalnim književnostima. Motreći njezinu povijest kao periodičko smjenjivanje poetički „reguliranih“ žanrovskih sustava, na tu je pojavu u hrvatskoj književnosti među prvima ukazao Pavao Pavličić, koji primjećuje kako su se baš svi (pisano)književni žanrovi evocirani u domaćim okvirima u razdoblju između početka renesanse i konce 20. stoljeća „bilo po svojim obilježjima bilo po svojoj funkciji razlikovali od svojih parnjaka u ostalim europskim literaturama“" (Pavličić 1999: 53), pri čemu se te razlike nisu očitovale isključivo na nivou pojedinačnih žanrovskih rješenja (kao nepodudarnosti u repertoarima njihovih obilježja), nego i na onom čitavih žanrovskih sustava pojedinačnih književnih epoha, čije su domaće „varijante“ po svojim sastavima i funkcijama uvelike odskakale od generičkih sistema inozemnih (rano)novovjekovnih književnosti, čemu je razlog ležao, uvjeren je Pavličić, u kontinuirano snažnoj potrebi domaćih autora iz svih razdoblja da književnošću djeluju u izvanknjiževnoj stvarnosti.

Usredotočimo li se, međutim, isključivo na epohu baroka, uvidjet ćemo kako u njegovu (zamišljenom) žanrovskom sustavu - kao što detektira i sam Pavličić - ne samo što se nije našlo mjesta za mnoge od onih žanrova koji su u generičkim sistemima većine drugih

\footnotetext{
riječi od kojih se ono „sastoji“ - uvjerljivo najfrekventnija riječ ni manje ni više nego veznik ,i“ (usp. Moguš 1986: 150). Učestalošću veznika „i“ na ,čisto“ jezičnoj razini teksta, naime, naš autor kao da je želio dodatno naglasiti specifičnu „prirodu“ svoga književnog prvijenca, realiziranog „strategijom“ sprezanja mnogih međusobno različitih komponenata, ponajprije onih žanrovskih, među kojima su se - između ostalih - tako našla ,¡“ obilježja baroknoga povijesnog epa, ,i“ značajke iz generičkoga repertoara barokne heroide, ,i“ karakteristike svojstvene (sedamnaestostoljetnoj) lamentaciji, „““ primjerci žanra epitafa, „i“ prepoznatljive elementi čitava niza folklornoknjiževnih, pučkoknjiževnih, ali i rubno književnih, pa čak i izvanknjiževnih (govornih) žanrova. Količinska prevlast veznika „i“, drugim riječima, ispostavljala bi se tako kao očita jezična manifestacija Vitezovićevih sintetizirajućih ,aspiracija“, s kojima je pristupio sastavljanju Odiljenja sigetskog, silno se pritom trudeći na njegovu nevelikome tekstualnom prostoru obuhvatiti nevjerojatno širok spektar književnih postupaka, rješenja i uopće generičkih obilježja raznolike provenijencije, a sve ne bi li se takvim „konglomeratom“ dospio približiti što većem broju potencijalnih čitatelja različita profila: kako onima iz aristokratskih krugova, tako „,““ onima iz redova nižega plemstva, ali ,i“ tek bazično obrazovanima, pa čak ,i“ jedva opismenjenim recipijentima, „i“ čitateljicama iz nešto viših slojeva što su „konzumirale“ većinom pučko štivo, „i“" publici sa sjevera Hrvatske, ali „i“ onoj iz južnijih njezinih krajeva itd.).
} 
onodobnih nacionalnih književnosti igrali sve važniju ulogu (ponajprije za roman i komediju), nego je u njemu, osim toga, naglo (po)rastao i značaj upravo onih generičkih rješenja (osobito poeme, tada ostvarivane u čak dvije različite varijante: religioznoj i komičnoj), koja u tim istim „,inozemnim“ žanrovskim sustavima nisu uživala ni približno jednaku važnost. Žanrovski „obrasci“ što ih je, s druge strane, hrvatski barok dijelio s ostalim europskim književnim kulturama bili su, pak, podvrgnuti dubinskim modifikacijama, što se - između ostalog - manifestiralo i u činjenici da je žanr povijesne epske pjesme u nas tada većinom bio posvećen opjevavanju suvremenih događaja, i to u tekstualnim okvirima redovito nabijenima snažnim ideološko-političkim silnicama (kakvima je, na primjer, i svoga Osmana premrežio Ivan Gundulić), potom u praksi pojedinih onodobnih epika koji su svoje osobne doživljaje suočeni s nepostojanjem prikladnijega generičkog rješenja za obradu memoarskih sadržaja u Žanrovskom sustavu domaćega baroka - iznosili ni manje ni više nego u epskopjesničkom obliku (kao što je to, primjerice, u svome Dubrovniku ponovljenom učinio i Jaketa Palmotić Dionorić), ali i u pojavi ostvarenja poput samoga Vitezovićeva Odiljenja, kojemu Pavličić (tada) pristupa kao izrazitoj strukturnoj inovaciji u žanru barokne epske pjesme naglašavajući pritom kako je u njegovu slučaju zapravo riječ o „spjevu“ koji ne samo što pretresa (u tom trenutku) još uvijek ,svježu“ temu iz nacionalne povijesti, nego to ujedno čini u osebujno strukturiranu tekstu u kojemu ne postoje likovi i u kojemu se od čitatelja očekuje da kronologiju opsade i pada Sigeta poznaje iz nekoga ranijeg izvora. Prisjetimo li se $-\mathrm{s}$ tim u vezi - kako se književnost našega 17. stoljeća poprilično „osjećala obaveznom prema zbilji, a jedino sredstvo da na tu obavezu odgovori bile su joj tradicionalne književne vrste“, tada nam se ni najmanje ne bi smjeli neobičnima činiti razlozi poradi kojih su i mnogi žanrovi, odnosno vrste u razdoblju baroka u nas i ,doživljavale modifikacije, postajale atipične“ (Isto: 55), u pojedinim slučajevima čak i zamjetnije.

Ne samo kada je riječ o literarnom stvaralaštvu našega baroka, nego i o onom (većine) drugih razdoblja hrvatske književnosti, bez ikakve bi se dvojbe - ističe Pavličić - moglo ustvrditi kako za učestalost generičkih eksperimenata, odnosno za sve specifične ,pojave“ u njihovim žanrovskim sustavima daleko najveću „odgovornost““ snosi karakterističan, granični položaj hrvatske kulture, zaslugom kojega je počesto ona bila izložena vrlo nepovoljnim društvenopovijesnim okolnostima što su nepovratno obilježile sve njezine produkte. Od svojih početaka egzistirajući „na granici među svjetovima“, (i) hrvatska je književnost „gotovo stalno bila u prilici da se pita o vlastitom identitetu i da taj identitet svagda iznova potvrđuje“ (Isto: 58), pri čemu je upravo iz razloga što joj je zbog te granične pozicije kontinuirano prijetila opasnost od utapanja u druge kulture i potpunoga nestanka i bila prisiljena na 
neprekidna (re)definiranja kojima se štitila od moguće propasti. U tom poslu trajnoga definiranja i redefiniranja vlastita identiteta naša se književnost u najvećoj mjeri oslanjala na svoj europski kontekst, odnosno na one iste književne žanrove koji su egzistirali i u generičkim sustavima većine sedamnaestostoljetnih europskih književnosti, uz pomoć kojih je najbolje mogla konceptualizirati problematičnu stvarnost i na taj joj način podariti smisao (dakle, ,primijeniti“ ih u konkretnom kontekstu ili situaciji koja ju je okruživala), a time ujedno i obraniti svoj vlastiti identitet od mogućih „,pretenzija“ susjednih kultura. Budući da domaći pisci to, dakako, nisu bili u stanju učiniti bez nužnih prilagođavanja, odnosno bez manjih ili većih modifikacija tih inozemnih generičkih opcija, kao nezaobilazna posljedica te $\mathrm{i}$ takve prakse pojavio se niz žanrovski neobičnih, gdjekad i posve atipičnih rješenja, u kojima je tijekom povijesnoga trajanja hrvatske književnosti - točnije, zaključno s početkom 20 . stoljeća, kada se ona napokon dospjela u potpunosti osamostaliti kao književna institucija ostvaren i više nego respektabilan broj primjera. ${ }^{1094}$

Netom iznesena zapažanja u tom bi smislu valjalo prihvatiti kao i više nego uvjerljiv prikaz situacijskih okolnosti, točnije književno-kulturnoga i uopće društvenopovijesnog konteksta koji je iznjedrio ne samo Odiljenje sigetsko, nego i nezanemariv broj žanrovski izuzetno intrigantnih ostvarenja čiji se generički identitet teško može dovesti u vezu s onim drugih ( $u$ istom periodu nastalih) inozemnih, a pokatkad čak i domaćih književnih djela. Motrimo li je, drugim riječima, upravo iz njihove vizure, pokazat će se da je „zrinijada“ poput one što ju je ispjevao Pavao Ritter Vitezović danje svjetlo mogla ugledati samo i isključivo u okrilju hrvatske (ranonovovjekovne) književnosti, koja je egzistirala kao granična pojava u graničnoj kulturi naroda što je obitavao na geografski i politički graničnom prostoru te koja je upravo toj unutarnjoj i izvanjskoj graničnosti i dugovala svoj prilično širok raspon generičkih opcija, od kojih su mnoge bile posve neprispodobive onima za kojima su posezali pisci iz (većine) drugih europskih književnih kultura. Štoviše, višežanrovski je sastavak poput Odiljenja sigetskog - kojega je ne samo teško, nego i posve nemoguće jednoznačno žanrovski kategorizirati - na domaćem tlu i mogao „niknuti“ ne samo stoga što je ranonovovjekovna hrvatska književnost sama po sebi bila granična pojava, nego i - još više - zato što je onodobna hrvatska kultura kao (zamišljena) cjelina unutar sebe bila presječena mnogobrojnim - kako zemljopisnim, tako i povijesno-političkim - granicama, ${ }^{1095}$ iz čega proizlazi da bi (i) Ritterov vernakularni prvijenac tako zapravo trebalo percipirati kao samo jedan u nizu literarnih produkata „specifičnoga konteksta hrvatske kulture rastegnute između europskoga

\footnotetext{
1094 Znatno detaljnije o ovim pitanjima u: Pavličić 1999: 53-59.

1095 O višestruko graničnoj „prirodi“ naše „starije“ ili dopreporodne književnosti detaljno u: Pavličić 2007: 7-19.
} 
zapada i turskih posjeda, ali i iznutra presječene razlikama srednjoeuropske i mediteranske geografsko-kulturne sfere“ (Budišćak 2016a: 272), odnosno regionalno rascjepkane u više zasebnih (i idiomski razlučenih) kulturno-književnih krugova, od kojih je svaki - kao što smo utvrdili - razvio i zaseban sustav književnih žanrova, baziran na u njemu dominantnoj predodžbi o književnoj djelatnosti kao takvoj.

Osim što svojom žanrovski mješovitom ,izvedbom“ Odiljenje sigetsko - kao djelo namijenjeno publici s prostora čitave Hrvatske - povezuje sve (onodobne) domaće književne krugove, ono ujedno na taj način zapravo zrcali kreativni opus Pavla Rittera Vitezovića u cijelosti, namećući se kao svojevrsno presjecište svih njegovih stvaralačkih interesa, ${ }^{1096} \mathrm{i}$ to neovisno od činjenice da je ispjevano i objelodanjeno ni manje ni više nego u ranim tridesetim godinama njegova života, dakle „tek“ na polovici životnoga mu i stvaralačkog „puta“. Težeći sljubiti idejne silnice iz apsolutno svih područja njegove - (do)tadašnje i buduće - kreativne zaokupljenosti (književnosti, historiografije, jezikoslovlja, enigmatike itd.), Odiljenje redom upošljava (i) karakteristična obilježja iz repertoara upravo onih žanrova u kojima je naš autor već pretresao ili se tek spremao pretresati neka njemu intrigantna pitanja iz pobrojanih područja (poslanice, epske pjesme, panegirika, pučkoga kronikalnog prikaza, jezikoslovne rasprave, poslovice, kronograma itd.), čime se potvrđuje kao svojevrsni idejni i žanrovski „sažetak“ silno mu razvedena stvaralačkog opusa, odnosno kao uradak u kojemu istodobno demonstrira neupitnu umješnost u sastavljanju žanrovskih oblika kojih se povremeno već bio laćao u prijašnjim godinama, ali i u kojemu se okušava u žanrovima za kojima će daleko učestalije posezati tek u (bližoj) budućnosti - poglavito u svojim pučkim vernakularnim tekstovima, potom u latinskoj lirici, stihovanoj kronici Plorantis Croatiae saecula duo itd. što bi značilo da ta neobična „zrinijada“ u isti mah svjedoči kako o golemom mu književnom (pred)znanju, tako i o punoj širini njegovih stvaralačkih interesa, zahvaljujući kojima mu se mnogi „ritterolozi“ neće ustručavati dodijeliti epitet „najsvestranije ličnosti hrvatske književne kulture“ (Dukić 2003: 497). Dapače, da se u Odiljenju doista zrcali značajan dio Vitezovićeva idejno, pa time i generički raznovrsnoga stvaralačkog opusa može se naslutiti i iz činjenice kako ono ne samo što nije jedino njegovo generički „nečisto“ ostvarenje, nego nije ujedno ni jedini njegov (književni) tekst čiji je fluidan žanrovski identitet počesto izazivao prijepore proučavatelja po pitanju definiranja žanrovske mu pripadnosti, što nam između ostalih - možda i ponajbolje posvjedočuje „slučaj“ dobro nam već znanoga latinskog mu (epsko)pjesničkog teksta Dva stoljeća uplakane Hrvatske, oko čijega se sekundarnog žanra već desetljećima „lome koplja“ povjesničara hrvatske književnosti, klasičnih filologa i 
historičara. ${ }^{1097}$ Ova stihovana kronika s naoko jakom epskopjesničkom podlogom - koju su zbog odsustva većine „ključnih epskih“ značajki (,protežne“ fabularne okosnice, instance sveznajućeg pripovjedača, figure protagonista, čvrstoga vremenskog i prostornog okvira, formalno-kompozicijske kompaktnosti itd.) pojedini proučavatelji već dovodili u vezu s njegovim hrvatskim književnim prvijencem ${ }^{1098}$ - pritom se ispostavlja kao Odiljenju Žanrovski možda i najbliskije ostvarenje u cjelokupnom Vitezovićevu opusu, ispjevano kao izrazit hibrid koji se opravdano može svrstati u nekoliko žanrovskih „ladica“ (epske pjesme, kronike u stihovima, heroide itd.), iako ni jednoj od njih zapravo ne „pripada“ u cijelosti. ${ }^{1099}$

Kako bilo, ostvarenja poput Dva stoljeća uplakane Hrvatske i Odiljenja sigetskog nadaju se tako kao i više nego uvjerljiv pokazatelj Vitezovićeve ne samo u potpunosti svjesne, nego i kontinuirane težnje za sastavljanjem jednoznačno teško odredivih (književnih) tekstova „razbijenih“ u mnoštvo različitih žanrova, čijom je inovativošću, satkanošću od otprije dobro poznatih generičkih obilježja, a opet neusporedivošću sa sekudarnim žanrom bilo kojega dotad ispisanog djela pokušao „osvježiti“ (provizorni) generički sustav hrvatskoga književnog baroka (tj. njegovih regionalnih odvjetaka) - koji je, kao što smo vidjeli, ionako neprekidno obogaćivao „presađujući“ u nj žanrove što su u to vrijeme cirkulirali u srednjoeuropskome kulturnom krugu - znajući da će ih takvom generičkom „,izvedbom“ najbolje „osposobiti“ za to da budu u stanju funkcionirati na različite načine, odnosno da različitim tipovima čitatelja ne samo u generičkom smislu - znače i posve različite stvari. Kao tipični čovjek svoga vremena, osobito sklonog generičkim poigravanjima i žanrovskim hibridima, Pavao je Ritter od samoga početka stvaralačkog djelovanja konstantno i do krajnosti iskušavao goleme mogućnosti što su ih tadašnjim piscima ostavljale gotovo u potpunosti odriješene ruke po pitanju žanrovskoga uobličavanja literarnih i ne samo literarnih tekstova, što je rezultiralo (i) time da se njegov književni hrvatski prvijenac kao tipično „vitezovićevsko“ djelo ispostavlja glavninom po tome što svojom (ponajprije) generičkom heterogenošću nalikuje svim ostalim djelima proizišlima ispod njegova pera, među kojima bi se tek rijetko koje - uzimajući u obzir njihovu tematsko-motivsku, formalnu, često i ideološku, stilsku, a iznad svega žanrovsku slojevitost - uopće moglo u potpunosti i bez ostatka podvesti pod samo jednu generičku odrednicu. Baš kao što je to činio u ranijim i kao što će to nastaviti činiti i u kasnijim svojim ostvarenjima, naš je autor asimiliranjem počesto i posve disparatnih generičkih elemenata, odnosno ,aktiviranjem“ i preplitanjem značajki svojstvenih kako „epskim“, tako i „lirskim“ te

${ }^{1097} \mathrm{O}$ nekim nedoumicama u pogledu njegova žanrovskog identiteta, u koje je proučavatelje dovodila šarolika generička ,izvedba“ Dva stoljeća uplakane Hrvatske, vrlo pregledno u: Stepanić 2005: 115-116, Knezović 2016: 229-241 i Blažević 2019: 5-21.

1098 Usp. Stepanić 2005: 133-134.

${ }^{1099}$ Opširnije o žanrovima čijim su značajkama protkana Dva stoljeća uplakane Hrvatske u: Blažević 2019: 5-21. 
„dramskim“ žanrovima u Odiljenju sigetskom tako samo (još jednom) potvrdio svoju „tipično“ baroknu „ćud“, skrojivši ga na način da se u potpunosti podudara sa svojim kontekstualnim okružjem, tj. da izvrsno pristaje u barokno doba ,janusovske raspolućenosti u kojem su harmonično koegzistirali i pretapali se proturječni koncepti, ideologije i paradigme“" (Blažević 2002: 200) i u kojemu ni najmanje stoga nije bilo neobično susresti (i) književne žanrove stopljene od generičkih komponenata izvučenih iz posve oprečnih žanrovskih opcija poput, primjerice, tragikomedije.

Slijedeći (književno)stvaralačku praksu svoga vremena, i Pavao Ritter Vitezović u velikoj će većini vlastitih tekstova pribjegavati „strategiji“ sljubljivanja dotad posve nespojivih momenata, zbog čega ne treba čuditi to što se i na primjeru samoga Odiljenja sigetskog možemo osvjedočiti kako je „laka koegzistencija racionalnoga s fantastičnim“ kotirala kao jedno od najprepoznatljivijih obilježja „sedamnaestostoljetnoga učenog uma“ (Simpson 1991: 42). Obratimo li, naime, malo veću pozornost na sam Ritterov odabir žanrova iz vizure kojih motri herojsku obranu i pad Sigeta te njegove neposredne posljedice, uvidjet ćemo kako - posve ravnopravno - uz bok onim žanrovima (točnije, njima svojstvenim značajkama) čiji je pristup stvarnim događajima glavninom proizlazio iz oslanjanja na konkretne povijesne činjenice (povijesni ep, epitaf) u Odiljenju stoje ne samo oni u kojima se povijesna zbivanja fikcionaliziraju do te mjere da o njima progovaraju poodavno već izginuli ili neživi govornici (heroide, lamenti, eho-pjesma), nego i oni koji na „izraslost“ toga (društvenopovijesno izrazito važnog) događaja iz same življene svakodnevice podsjećaju ili evociranjem nekoga - iz njega proisteklog - emotivnog, odnosno širega životnog iskustva (naricaljka, poslovica), ili, pak, ludičkim momentom povezanim s enigmatsko-zagonetačkim nakanama kojima kao da žele aludirati na to da je i sigetska katastrofa bila ništa drugo no posljedica „igre sudbine“ i uopće hirovite sreće, a ujedno i dati do znanja kako su njezin odjek, a time i značaj u kolektivnoj memoriji hrvatskoga naroda toliki da se s punim pravom na nju mogu i moraju referirati čak i „manje važna“ primarna, odnosno jednostavnija $\mathrm{i}$ svakodnevnija žanrovska rješenja poput zagonetke i kronograma. Tim i takvim, neobično šarolikim ,arsenalom“ evociranih žanrova, miješanjem prepoznatljivih obilježja kojih je želio postići otvaranje svoje „zrinijade“ čitateljima s različitim (književnim) predznanjem iz svih slojeva društva, Vitezović je tako zapravo dospio „skrojiti“ djelo u tipično baroknom „duhu“ zbližavanja proturječja, koji se - između ostalog - očituje i u njegovoj težnji da vlastite historiografske i druge znanstvene spise napuči međusobno oprečnim tvrdnjama i drugim 
sadržajnim (pa i ne samo sadržajnim) nedosljednostima, ${ }^{1100}$ kao i u nakani da svoje ozbiljno, znanstveno utemeljeno zanimanje za astronomiju „nadogradi“ povremenom praksom sastavljanja (natalnih) horoskopa za prijatelje i/ili neke društvene uglednike, odnosno da poput mnogih svojih suvremenika - bavljenje znanošću kombinira s praznovjerjem.

Svjesni ove unutarnje generičke fragmentiranosti Odiljenja sigetskog, koja je u isti mah rezultirala njegovom žanrovskom neodredivošću i ,sveodredivošću“, odnosno sveopćom konfuzijom što su je izazvali dosadašnji književni povjesnici i „ritterolozi“ u svojim neumornim pokušajima da iznađu najadekvatniju generičku „ladicu“ u koju bi ga jednom za svagda i bez ostatka mogli svrstati, (n)i u ovome se istraživanju nismo ustručavali posve ga namjerno obilježavati kojekakvim (više ili manje preciznim) žanrovskim oznakama, počevši od one - daleko najučestalije - ,zrinijade“, preko „spjeva“ i „hibridnoga (književnog) djela“, pa sve do „djela zborničkoga tipa“, „kompilacije“ i primjer(k)a „pjesništva graničnih utvrda“, pazeći pritom da u tim i takvim kvalifikacijama većinom rabimo što općenitije odrednice mahom uvriježene u recentnijim prikazima i „ritterološkim“ studijama. Pored već utvrđene spoznaje kako - radi njegove nepripadnosti niti jednomu (poznatom) sekundarnom žanru nijedna u dosadašnjoj sekundarnoj literaturi već uporabljena ili potencijalna generička oznaka nije dovoljno obuhvatna ni precizna da bi bila u stanju posve točno definirati hibridan žanrovski identitet Odiljenja, na takvu praksu navela nas je i namjera da na primjeru vlastita genološkog čitanja Vitezovićeva žanrovski (pre)bujnoga hrvatskog književnog prvijenca ukažemo na neizbježne nedoumice s kojima je bio i bit će prisiljen suočavati se baš svaki pokušaj pobližega (čitaj: jednoznačnog) definiranja njegova generičkog okvira, osmišljenog i realiziranog bez oslanjanja na možebitne konkretne žanrovske uzore. Ne samo posezanjem za raznolikim određenjima Odiljenja, nego i evociranjem svih dosadašnjih njegovih generičkih identifikacija - povrh toga - ujedno se željelo udovoljiti i ovdje već spomenutom glasnom inzistiranju suvremene teorije žanra na interpretativnom uvažavanju prethodnih žanrovskih kategorizacija svakoga (književnog) teksta, iz kojih je štošta moguće zaključiti i o samom statusu što ga je navedeni tekst u danom (vremenskom i/ili mjesnom) kontekstu uživao, odnosno o načinu na koji je on funkcionirao ili barem mogao funkcionirati unutar pojedinoga situacijskog okružja ili kronotopa.

Snažno nastojanje da se uzmu u obzir generičke značajke prisutne na baš svim tekstualnim, pa i paratekstualnim razinama Vitezovićeve „zrinijade“, a onda i da se njihovo prisustvo razmotri na podlozi konteksta autorova cjelokupnog stvaralačkog opusa, potom sedamnaestostoljetne - domaće i ne samo domaće - književne kulture, ali i općega 
situacijskog (društvenopovijesnog) okružja u koji je ona stupila s nakanom da privuče što veći broj čitatelja iz svih društvenih slojeva i više bi nego jasno pritom trebalo dati do znanja kako se ovo tumačenje temelji na predodžbama što ih je zastupalo više teorija književnih žanrova iz (mahom) druge polovine prošloga stoljeća, koje su u ovome slučaju okupljene oko teorijske „baze“ u obliku utjecajne Bahtinove teorije govornih žanrova, čije su ideje ionako poslužile kao ishodište velike većine najaktualnijih (poststrukturalističkih) genoloških pristupa. Govoreći iz „čisto“ genološkoga gledišta, kao jedan od možda i najvažnijih rezultata ovako teorijski utemeljenoga i provedenog istraživanja pritom se svakako nameće (još jedna) empirijska potvrda u suvremenoj teoriji žanrova često isticana uvjerenja kako je pitanje žanra, odnosno generičkoga identiteta svakoga pojedinačnog teksta nerješivo bez uvida kako u sve njegove tekstualne aspekte, tako i u mnogostruke kontekstualne okvire unutar kojih je ono egzistiralo i obnašalo stanovite (izvan)književne zadaće. Problematiziranje generičke „pripadnosti“ danoga teksta, odnosno preciziranje njegova žanrovskog „sastava“ ili slojeva na taj način, kao što je to i demonstrirala ova analiza, otvara i mogućnost preciznijeg definiranja njegove književnopovijesno-poetičke, ali i ideološke, recepcijske i uopće izvantekstualne određenosti, iz čega proizlazi da je upravo pretresanjem žanrovskih „silnica“ moguće steći daleko najpotpuniji uvid ne samo u (unutarnju) višedimenzionalnost svakoga ostvarenja, nego i u način na koji je ono funkcioniralo i bilo percipirano u vrijeme svoga nastanka, što ukazuje (i) na to da bi upravo od detektiranja njegovih generičkih „komponenata“ i utvrđivanja (eventualnoga) sekundarnog mu žanra trebalo poći svako iole ambicioznije književnopovijesno čitanje bilo kojega literarnog sastavka.

Iako bi, međutim, naša analiza $u$ tom smislu trebala biti svojevrstan poticaj $\mathrm{i}$ smjerokaz svim budućim interpretacijama koje namjeravaju poći od žanrovske dimenzije književnoga teksta, istovremeno se ona promeće i u dokaz nezanemarive analitičke ograničenosti najsuvremenijih genoloških predodžbi, koja osobito dolazi do izražaja prilikom njihove primjene na (pisano)književno štivo starijih datuma - u kakvo se, dakako, ubraja i Odiljenje sigetsko - uslijed koje nipošto nije moguće u potpunosti ispoštovati imperativ „čistoga“" povijesnog pristupa koji bi učinkovito eliminirao i najmanju potrebu uplitanja znatno suvremenijih genoloških sudova, odnosno ,nadograđivanja“ predodžbe o konkretnim povijesnim žanrovima utemeljene na poznavanju njihove trenutačne poetike teorijskim opisima nastalima „taloženjem“ poetički izmjenjivih određenja tih istih žanrova što su bila na snazi kroz znatno dulje vremensko razdoblje. Doduše, znamo li da je apsolutno povijesni pristup literarnim tekstovima kakvoga zagovaraju moderne književne teorije u praksi neprovediv čak i kada se radi o ostvarenjima „starima“ svega nekoliko desetljeća ili samo i 
godina, analize poput ove imale bi za svoju svrhu ništa drugo no ukazati na širinu uvida koje je moguće postići napuštanjem - u našim književnopovijesnim istraživanjima još uvijek suviše čestih - teorijskih poimanja književnih žanrova, odnosno razvijanjem svijesti (i) o neizbježnoj kontekstualnoj uvjetovanosti baš svakoga generičkog odabira, pa tako i onoga što ga je - nipošto slijedeći samo svoju volju - učinio autor promatranoga književnog sastavka.

Ono što je, međutim, netom provedeno istraživanje u najvećoj ipak mjeri dospjelo pokazati i dokazati jest činjenica kako baš svaki genološki pristup nekomu određenom tekstu presudno ovisi o samoj poziciji onoga koji se laća njegova čitanja, a koji se i sam nalazi pod utjecajem neke (privremene) situacije te tekstu stoga neizbježno prilazi iz perspektive raznolikih konteksta - društvenopovijesnog, kulturnog, književnoteorijskog, uopće iskustvenog itd. - karakterističnih upravo za tu situaciju. U toj bi spoznaji, uostalom, i trebalo tražiti razlog poradi kojega je (i) ova analiza urodila ni manje ni više nego zapažanjima iznijetima na prethodnim stranicama, u kojima se tako neminovno zrcale ne samo književnoteorijske preferencije (ili naprosto teorijska pomodnost), odnosno institucionalno nametnuto uvažavanje idejnih polazišta, a time i analitičke aparature neke konkretne teorijske struje, nego i razina (ne)znanja, čitateljsko (ne)iskustvo, uvjerenja i predrasude o književnosti kao takvoj, pa čak i sam životni svjetonazor osobe analitičara „odgovornog“ za netom provedeno čitanje, što ujedno znači i kako bi promjena analitičke perspektive, točnije samoga tumača zaduženog za genološku interpretaciju (is)toga teksta, nedvojbeno rezultirala i bitno drugačijim zapažanjima o žanrovskim obilježjima Vitezovićeve „zrinijade“, u kojima bi možebitno u prvi plan iskočio (i) neki sasvim drugi - na ovome mjestu možda i posve zapostavljen - sloj ili aspekt njezina generičkog identiteta. Svijest o tome kako će predstojeća genološka i ne samo genološka čitanja Odiljenja, poduzimana od strane budućih analitičara uslijed nekih bitno drugačijih situacijskih okolnosti, stoga (vrlo vjerojatno) značajno produbiti i temeljito revidirati ovdje iznesene zaključke u tom se smislu ispostavlja kao dodatna potvrda gotovo ,papagajski“ ponavljane predodžbe suvremene genologije o žanrovima kao (primarno) kontekstualnim konstruktima čija su (privremena) poetika i način funkcioniranja (pred)određeni situacijskim imperativima, a time i uvelike obilježeni dotadašnjim poetičkim normiranjima i samim analitičkim genološkim prosudbama, zbog čega se i inzistiranje na njihovim „svevremenskim“ definicijama pokazuje ne samo posve pogrešnim, nego i u praksi neizvedivim jer počiva na pretpostavci o postojanju konkretnoga žanra kao izvanpovijesne, za svagda „okamenjene“ kategorije. Iz toga bi se razloga činjenica kako je baš svaki odabrani pristup ili analitičko (genološko) motrište rezultat ,djelovanja“ krajnje subjektivnih čimbenika presudno uvjetovanih neprekidno mijenjajućim situacijskim datostima te stoga može iznjedriti 
isključivo privremena - neizbježno ograničena i manjkava - tumačenja, od kojih svako predstavlja samo jednu od bezbrojnih mogućnosti razumijevanja konkretnoga teksta, napokon trebala osvijestiti i prihvatiti kao neminovna realnost i u okvirima hrvatske znanosti o književnosti, čemu bi i ovo istraživanje svakako željelo biti kakav-takav primjer i poticaj.

Prevlast novih - poststrukturalističkih - genoloških shvaćanja u recentnoj književnoj teoriji, odnosno naša težnja da, usprkos (još uvijek) ne odveć im naklonjenoj domaćoj znanosti o književnosti, njihovu praktičnu primjenjivost iskušamo upravo u okvirima razmatranja žanrovskih posebnosti Odiljenja sigetskog, nije tako mogla dovesti ni do čega drugog no spoznaje o kronotopski (čitaj: situacijski) ograničenoj ,prirodi“ svake žanrovske kategorizacije, u potpunosti ovisne o kontekstualnim okolnostima i uopće specifičnom (i neponovljivom) polazištu samoga genologa, koja se daleko najjasnije očituje u nakani kasnijih tumača da prethodno već klasificiran tekst podvrgnu više ili manje temeljitoj genološkoj reviziji u cilju redefiniranja njegova žanrovskog identiteta. Polazeći od spoznaje moderne genologije kako se ,nijedan akt generičke identifikacije ne obavlja jednom za svagda“" (Novaković 1986: 336) i sami smo tako (prešutno) pristali iz ove analize izvući tek privremene sudove o žanrovskom identitetu Vitezovićeva vernakularnog književnog prvijenca, u potpunosti pritom svjesni kako (i) oni neizbježno podliježu reviziji, odnosno kako će i sami u (nadajmo se, što bliskijoj) budućnosti postati predmetom dubinskog preispitivanja s ciljem da se ovomu po mnogočemu iznimnom ostvarenju u povijesti hrvatske književnosti iznađe još primjerenija i preciznija generička oznaka. Dapače, svojim pomalo neočekivanim, no nipošto neargumentiranim konstatacijama o žanrovskoj (ne)pripadnosti Odiljenja ovo čitanje i ostavlja dojam ponešto nedorečena razmatranja koje kao da svjesno teži isprovocirati dodatna genološka pretresanja, pa onda i korjenito žanrovsko redefiniranje Ritterove „Zrinijade“, tim više što je i ono samo zamišljeno upravo kao „reakcija“ na prethodna njezina generička svrstavanja, $\mathrm{i}$ to ponajprije $\mathrm{u}$ vidu njihova korigiranja, proširivanja i uopće osuvremenjivanja, o čemu možda i ponajbolje svjedoči „aktiviranje“ generičkih odrednica novi(ji)h datuma, za kojima ne samo što gotovo uopće nisu posezali čak ni najrecentniji proučavatelji, nego o njima, dakako, ništa nisu znali (ni mogli znati) književni teoretičari, a još manje praktičari Vitezovićeva vremena. Uporaba „svježih“ žanrovskih oznaka tako bi se nametnula kao možda i najuočljiviji signal popriličnoga zaokreta u teorijsko-analitičkom pristupu Odiljenju sigetskom, koji je urodio i prijedlogom nove njegove generičke (ili, preciznije kazano, negeneričke) definicije, proizišle iz detektiranja čitava spektra ranije neprepoznatih ili hotimice prešućivanih žanrovskih mu sastavnica, otkrivanje kojih tako istovremeno osvjetljuje ne samo njegovu punu generičku slojevitost, nego ujedno i situacijski 
uvjetovanu subjektivnu perspektivu analitičara kao jednog u nizu odreditelja njegova žanrovskog identiteta. Pretresajući njegove generičke posebnosti s nakanom detektiranja eventualne mu pripadnosti nekomu sekundarnom žanru baš svi su dosadašnji tumači Odiljenja tako dospjeli iznjedriti „samo“ žanrovska mu određenja relativno kratkoga vijeka, u red kojih će definitivno ići i netom provedeno istraživanje, čiji će pokušaj njegove žanrovske definicije svakako vrijediti (najmanje) do pojave novoga njegova genološkog čitanja, iako će ono i nakon toga nastaviti trajno egzistirati kao analitička potvrda u potpunosti subjektivne i privremene ,prirode“ žanra. Po tomu svom svojstvu, na kraju krajeva, žanr neodoljivo i nalikuje svojim vlastitim praktikantima i čitateljima jer - kao takav - on i nije ništa drugo nego upravo - čitatelj sam.

Usprkos tomu što (ni) ovom istraživanju stoga nije pošlo - niti je uopće moglo poći za rukom podastrijeti konačan, trajno važeć odgovor o žanrovskoj pripadnosti Odiljenja sigetskog, kao njegov možda i najveći doprinos generičkim interpretacijama ne samo ovoga Ritterova višežanrovskog ostvarenja svakako bi trebalo izdvojiti činjenicu da je ono dospjelo ukazati barem na one njegove žanrovske komponente koje je, pristupajući mu iz navedene subjektivno-situacijske perspektive, bio u stanju prepoznati sam genolog-analitičar, a time i donekle „pripremiti teren“ za eventualna buduća istraživanja koja bi (is)tom ili nekom drugom književnom tekstu željela pristupati iz istoga, srodnog, odnosno nekoga još modernijeg (teorijsko-analitičkog) gledišta. Ne mogavši, drugim riječima, iznjedriti ništa drugo nego (,tek“) privremenu žanrovsku definiciju Odiljenja - svedenu na pretpostavku da je decidiran i jednoznačan sud o njegovu generičkom identitetu nemoguće donijeti bez nijekanja svežanrovske mu prirode - naša bi analiza svakako željela poslužiti kao primjer empirijskoga prakticiranja uvjerenja što ih zagovaraju poststrukturalističke teorije žanra, odnosno kao pokazatelj da bez analitičkoga pristupa utemeljenog na relevantnim genološkim spoznajama ne može biti ni ispravnoga razumijevanja nemalog broja višežanrovskih, odnosno žanrovski upitnih djela prisutnih u svim razdobljima hrvatske književne povijesti. Skrećući pozornost nedovoljno osviještene domaće književnoznanstvene zajednice na činjenicu da se u posljednjih nekoliko desetljeća (književna) genologija od morfološko-esencijalističke naglo preobrazila u „spekulativno-empirijsku disciplinu“ (Turković 2010: 13) zaokupljenu ponajprije kontekstualnom uvjetovanošću generičkih odabira i kategorizacija, ovo čitanje željelo je ukazati na vrlo visok ,stupanj“ praktične uporabljivosti i korisnosti tih najsuvremenijih uvida teorije žanra, ispravna primjena kojih bi, kao što je pokazano, tumača mogla $\mathrm{i}$ morala natjerati (i) na to da u svojoj interpretaciji uzme u obzir $\mathrm{i}$ one aspekte 
žanrovskoga identiteta promatrana teksta koji bi uslijed pridržavanja isključivo tradicionalnih genoloških uvjerenja gotovo u potpunosti ostali zanemareni.

Dapače, itekako bi snažan poticaj za „osvježavanje“, tj. moderniziranje genoloških analitičkih motrišta recentnim analitičarima trebao doći ne samo s ,područja“ (poodavno već teorijski osuvremenjene) inozemne književne znanosti, nego i iz samih svjetonazorskih i društvenopovijesnih „okolnosti““ suvremenoga doba, satkanoga od oštrih proturječja na svim razinama življene svakodnevice, koja bi trebala bitno olakšavati i razumijevanje nešto starijih ostvarenja poput Odiljenja sigetskog, u kojemu - jedne uz druge - također koegzistiraju razne, ne samo žanrovske suprotnosti, kao, uostalom, i u neobično šarolikomu, „tipično“ baroknom stvaralačkom opusu Pavla Rittera Vitezovića u cijelosti. Ako je, drugim riječima, sastavljajući svoj hrvatski književni prvijenac kao generički disperziran tekst koji može ispuniti doslovno bilo koje žanrovsko očekivanje te tako privući zanimanje recipijenata raznolikih čitateljskih profila naš autor ujedno dospio i (neizravno) odraziti duh svoga vremena, obilježenog neprekidnim (ne samo ratnim) sukobima, društvenim prevratima, nemirima, a onda i kulturnim višeglasjem proizišlim iz (društvenopovijesno također potaknute) sklonosti onodobnih stvaratelja sprezanju disparatnih kreativnih praksi, onda će i sama genološka istraživanja Odiljenja i njemu sličnih djela iz bliže ili dalje književne povijesti nužno upućivati i na ništa manje proturječan karakter suvremenoga vremenskog trenutka, koji se - između ostalog - manifestirao i u pojavi novih genoloških pristupa, zaslužnih i za porast analitičkog zanimanja (i) za žanrovski teško odrediva te dosad manjkavo definirana literarna ostvarenja. Na taj način, genološko tumačenje nekoliko stoljeća „starog“ ostvarenja istovremeno se promeće i u implicitno (raz)otkrivanje sadašnjeg trenutka, ali i samoga analitičara kao dionika tog trenutka, u potpunosti ,inficiranog“ općom suvremenom sklonošću za generičke „križance“ i uopće raznolike, gdjekad i međusobno isključujuće književne i ine umjetničke, dakle šire kulturne prakse.

Na koncu, nužno je primijetiti i kako ovo (i ovako izvedeno) genološko ispitivanje žanrovskih osobitosti jednoga od najosebujnijih tekstova u povijesti hrvatske književnosti nipošto ne odražava jedino preferencije suvremenoga doba spram generičkih hibrida, koje se uvelike poklapaju i s čitateljskim sklonostima samoga tumača, nego i već poduboko ukorijenjenu modernu naviku podastiranja krajnje pojednostavljenih, polovičnih odgovora na pitanja od krucijalne važnosti, koja u mnogim slučajevima i jest „,najzaslužnija“ za pojavu generički „nedorečenih“, mozaičnih ostvarenja. Da bi ga, naime, i u tom pogledu valjalo percipirati kao znak svoga vremena ponajbolje se može uvidjeti upravo iz činjenice kako većina dilema vezanih uz generičke osobitosti Ritterove ,zrinijade“ - kako njegove primarne i 
sekundarne žanrovske sastavnice, tako i kompleksan mu žanrovski identitet u cijelosti - i nakon njega ostaje jedva djelomično razriješena, odnosno kako se (i) ovom prilikom njihovo razmatranje svelo na nizanje često i nedovoljno argumentiranih, a svakako ni najmanje zadovoljavajućih pretpostavki o žanrovski jedinstvenoj prirodi Odiljenja sigetskog. Pritom bi, dakako, i tom nedostatku razloge valjalo tražiti ponajprije u situacijskim okolnostima na podlozi kojih je i provedeno ovo istraživanje, točnije tim istim kontekstualnim okvirom snažno uvjetovanoj subjektivnoj perspektivi njegova autora-analitičara, na koju je tako - u jednakoj mjeri - presudno djelovala ne samo iznimna širina odabrane teme, već i nametnuto prostorno ograničenje (poželjan opseg žanra doktorske disertacije), potom osjetan manjak sekundarne literature o istom ili srodnom problemu ( $\mathrm{tj}$. neprovedene nužne predradnje za genološko istraživanje ovakva tipa), poprilično „deficitarni“ povijesni i književnopovijesni podaci, a u konačnici i sama autorova nemuštost da pretresanju odabrana problema pristupi jezgrovito i bez zahvaćanja pitanja na koja - uglavnom radi vlastita nedostatnog znanja zadovoljavajuće odgovore nije ni bio u stanju podastrijeti. U tom smislu ne preostaje ništa drugo nego zaključiti kako temeljito razmatranje žanrovskih obilježja Odiljenja sigetskog, koje će uzeti u obzir sve one aspekte kojima je na ovom mjestu posvećeno malo ili čak gotovo i nimalo pozornosti, još uvijek ostaje zadaćom koja zapravo tek predstoji, pa autoru ovoga pokušaja njegova genološkog čitanja stoga ostaje tek nadati se da - ako njome nije već dospio iznjedriti nikakve nove spoznaje - svojom nepotpunom, uopće nevješto izvedenom i neizbježno subjektivnom interpretacijom u sveukupni korpus dosadašnjih istraživanja lika i djela Pavla Rittera Vitezovića ili tzv. „ritterološki interpretacijski kompleks“ (Blažević 2002: 32, bilješka 61) nije barem unio samo još veću zbrku i štetu. 


\section{LITERATURA}

\section{PRIMARNA}

1. Baraković, Juraj. 2000. Vila Slovinka. Prir. Franjo Švelec. SHK. Zagreb: Matica hrvatska.

2. Črnko, Ferenac. 1971. Podsjedanje i osvojenje Sigeta i popratni tekstovi. Ur. Milan Ratković. Zagreb: Liber.

3. Frankopan, Fran Krsto. 1999. Djela. 2. izdanje. Prir. Josip Vončina. SHK. Zagreb: Matica hrvatska.

4. Ivanišević, Ivan. 1642. Kitta cvitya razlikova. Venecija.

5. Kanižlić, Antun, Antun Ivanošić i Matija Petar Katančić. 1940. Pjesme Antuna Kanižlića, Antuna Ivanošića i Matije Petra Katančića. Prir. Tomo Matić. SPH 26. Zagreb: Jugoslavenska akademija znanosti i umjetnosti.

6. Kaštelan, Jure i Bonaventura Duda (gl. ur.). 2003. Biblija: Stari i Novi zavjet. Prev. Antun Sović, Silvije Grubišić, Filibert Gass i Ljudevit Rupčić. Zagreb: Kršćanska sadašnjost.

7. Ovidije Nazon, Publije. 1849. Pub. Ovidia Nazona Heroidah. Prev. Jozip i Jakob Betondić. Dubrovnik.

8. Ritter Vitezović, Pavao. 1684. Oddilyenje sigetsko. Linz.

9. Ritter Vitezović, Pavao. 1685. Oddilyenja sigetskoga perva csetiri dila. Beč.

10. Ritter Vitezović, Pavao. 1695. Oddilyenje sigetsko. Zagreb.

11. Ritter Vitezović, Pavao. 1836. Oddiljenja sigetskoga četiri děla. Zagreb.

12. Ritter Vitezović, Pavao. 1994. Izbor iz djela. Prir. Josip Bratulić. Zagreb: Erasmus naklada.

13. Ritter Vitezović, Pavao. 1999. Izbor iz djela. Prir. Marko Samardžija. Vinkovci: Riječ.

14. Ritter Vitezović, Pavao. 2009. Lexicon Latino-Illyricum. Svezak treći: hrvatsko-latinski rječnik. Prir. Nada Vajs i Zrnka Meštrović. Zagreb: ArTresor naklada i Institut za hrvatski jezik i jezikoslovlje.

15. Ritter Vitezović, Pavao. 2010. Lexicon Latino-Illyricum. Svezak drugi: prijepis i obrada. Prir. Bojan Marotti. Zagreb: ArTresor naklada.

16. Ritter Vitezović, Pavao. 2015. Kronika aliti spomen vsega svieta vikov. Prir. Alojz Jembrih. Zagreb: ArTresor naklada.

17. Ritter Vitezović, Pavao. 2019. Dva stoljeća uplakane Hrvatske / Plorantis Croatiae saecula duo. Prir. Zrinka Blažević i Bojan Marotti. Prev. Zrinka Blažević. Zagreb: Matica hrvatska. 
18. Ritter Vitezović, Pavao. 2019. Epistolae metricae. Prir. Violeta Moretti i Gorana Stepanić. Split: Književni krug.

19. Zoranić, Petar, Barne Karnarutić i Šime Budinić. 2002. Planine / Djela / Izabrana djela. Prir. Franjo Švelec. SHK. Zagreb: Matica hrvatska.

20. Zrinski, Katarina. 2006. Putni tovaruš: transkripcija. Prir. Zvonimir Bartolić. Čakovec Zagreb: Ogranak Matice hrvatske, Zrinski i Nacionalna i sveučilišna knjižnica.

21. Zrinski, Ana Katarina. 2014. Pjesmarica Ane Katarine Zrinske. Prir. Josip Bratulić. Zagreb: Matica hrvatska.

22. Zrinski, Petar. 1957. Adrijanskog mora Sirena. Prir. Tomo Matić. SPH 32. Zagreb: Jugoslavenska akademija znanosti i umjetnosti.

23. Zrinski, Petar. 2016. Adrijanskoga mora sirena \& Obsida sigecka. Prir. Josip Bratulić. Zagreb: Matica hrvatska.

24. Zrinski, Petar, Fran Krsto Frankopan i Pavao Ritter Vitezović. 1976. Izabrana djela. Prir. Josip Vončina. PSHK 17. Zagreb: Zora i Matica hrvatska.

\section{SEKUNDARNA}

1. Agrell, Beata. 2015. „Consolation of Literature as Rhetorical Tradition: Issues and Examples“. U: LIR.journal 4: 11-35.

2. Anđelić, Đorđe. 1933. Istorija jugoslovenske književnosti. 3. izdanje. Beograd: Izdavačko i knjižarsko preduzeće Geca Kon.

3. Angyal, Andreas. 1961. Die slawische Barockwelt. Leipzig: VEB E. A. Seemann.

4. Angyal, Andrija. 1964. „Aspekti književnog baroka“. U: Zadarska revija 13, 2: 97-118.

5. Avsenik Nabergoj, Irena. 2011. Literarne vrste in zvrsti: stari Izrael, grško-rimska antika in Evropa. Ljubljana: Cankarjeva založba.

6. Bačić-Karković, Danijela i Adriana Car-Mihec. 2000. Uvod u genologiju. Rijeka: Filozofski fakultet.

7. Badalić, Hugo. 1892. Hrvatska antologija. Zagreb: Matica hrvatska.

8. Bagić, Krešimir. 2012. Rječnik stilskih figura. Zagreb: Školska knjiga.

9. Bahtin, Mihail Mihailovič. 1980. „Problem govornih žanrova“. Prev. Mitar Popović. U: Treći program Radio Beograda 47: 233-270.

10. Bahtin, Mihail Mihailovič. 1986. Speech Genres and Other Late Essays. Prev. Vern W. McGee. Austin: University of Texas Press.

11. Bahtin, Mihail Mihailovič. 1989. O romanu. Prev. Aleksandar Badnjarević. Beograd: Nolit. 
12. Bahtin, Mihail Mihailovič. 2000. Problemi poetike Dostojevskog. Prev. Milica Nikolić. Beograd: Zepter Book World.

13. Banac, Ivo. 1996. „Uskrsnula Hrvatska Pavla Rittera Vitezovića“. U: Kolo 5, 2: 5-18.

14. Barac, Antun. 1963. Jugoslavenska književnost. 3. izdanje. Zagreb: Matica hrvatska.

15. Bartolić, Zvonimir. 1985. Sjevernohrvatske teme. Knjiga 3: „Književno djelo Jurja Habdelića u svjetlu suvremene barokologije“. Čakovec: Zrinski.

16. Batušić, Nikola. 1978. Povijest hrvatskoga kazališta. Zagreb: Školska knjiga.

17. Bawarshi, Anis. 2000. „The Genre Function“. U: College English 62, 3: 335-360.

18. Bawarshi, Anis S. i Mary Jo Reiff. 2010. Genre: An Introduction to History, Theory, Research, and Pedagogy. Indiana: Parlor Press i The WAC Clearinghouse.

19. Bene, Sándor. 2012. „Nikola Zrinski“. U: Hrvatska književna enciklopedija. Svezak 4: SŽ. Gl. ur. Velimir Visković. Zagreb: Leksikografski zavod Miroslav Krleža: 548-550.

20. Bene, Sándor, Gábor Hausner i Zoran Ladić. 2012. „Predgovor“. U: Susreti dviju kultura. Obitelj Zrinski u hrvatskoj i mađarskoj povijesti. Prir. Sándor Bene, Zoran Ladić i Gábor Hausner. Zagreb: Matica hrvatska: 7-14.

21. Bennett, Tony. 2005. Outside Literature. London i New York: Routledge.

22. Biti, Vladimir. 2000. Pojmovnik suvremene književne i kulturne teorije. Zagreb: Matica hrvatska.

23. Bitskey, István. 2012. „Pogled na povijest i slika nacije u epu Nikole Zrinskog“. Prev. Boris Nikšić. U: Susreti dviju kultura. Obitelj Zrinski u hrvatskoj i mađarskoj povijesti. Prir. Sándor Bene, Zoran Ladić i Gábor Hausner. Zagreb: Matica hrvatska: 229-250.

24. Blažević, Zrinka. 1997. „Croatia rediviva Pavla Rittera Vitezovića u suvremenom europskom kontekstu“. U: Pavao Ritter Vitezović. Oživljena Hrvatska. Prev. Zrinka Blažević. Zagreb: Latina et Graeca, Hrvatski institut za povijest i Zavod za hrvatsku povijest Filozofskog fakulteta Sveučilišta u Zagrebu: 13-59.

25. Blažević, Zrinka. 1999. „Primjerak Vitezovićeva djela Oživljena Hrvatska iz ostavštine grofa L. F. Marsiglija“. U: Senjski zbornik 26: 179-228.

26. Blažević, Zrinka. 2002. Vitezovićeva Hrvatska između stvarnosti $i$ utopije: ideološka koncepcija u djelima postkarlovačkog ciklusa Pavla Rittera Vitezovića (1652. - 1713.). Zagreb: Barbat.

27. Blažević, Zrinka. 2003. „Miserrima facies Croatiae: percepcija prirodne okoline tromeđe u djelu Plorantis Croatiae saecula duo Pavla Rittera Vitezovića“. U: Triplex Confinium (1500-1800): ekohistorija. Ur. Drago Roksandić, Ivan Mimica, Nataša Štefanec i Vinka 
Glunčić-Bužančić. Split - Zagreb: Književni krug i Zavod za hrvatsku povijest Filozofskog fakulteta Sveučilišta u Zagrebu: 201-211.

28. Blažević, Zrinka. 2005. „Plorantis Croatiae saecula duo: diskurzivne adaptacije i performativne funkcije marijanskog toposa“. U: Umjetnost riječi 49, 1: 37-47.

29. Blažević, Zrinka. 2007. „Ideae magnanimitatis Illyricae et Pannonicae: (de)konstrukcija autopredodžbi i heteropredodžbi u diskursu baroknog heroizma“. U: Umjetnost riječi 51, 3-4: 249-264.

30. Blažević, Zrinka. 2008a. „Dva stoljeća uplakane Hrvatske“. U: Leksikon hrvatske književnosti. Djela. Ur. Dunja Detoni-Dujmić, Dunja Fališevac, Ana Lederer i Tea Benčić-Rimay. Zagreb: Školska knjiga: 150-151.

31. Blažević, Zrinka. 2008b. Ilirizam prije ilirizma. Zagreb: Golden marketing - Tehnička knjiga.

32. Blažević, Zrinka. 2008c. „Rodne subverzije herojske matrice u djelu Adrianskoga mora sirena Petra Zrinskog“. U: Teorije i politike roda. Rodni identiteti u književnostima $i$ kulturama jugoistočne Evrope. Ur. Tatjana Rosić. Beograd: Institut za književnost i umetnost: 329-342.

33. Blažević, Zrinka. 2011. „Odiljenje sigetsko“. U: Hrvatska književna enciklopedija. Svezak 3: Ma-R. Gl. ur. Velimir Visković. Zagreb: Leksikografski zavod Miroslav Krleža: 252253.

34. Blažević, Zrinka. 2012. „Pavao Ritter Vitezović“. U: Hrvatska književna enciklopedija. Svezak 4: S-Ž. Gl. ur. Velimir Visković. Zagreb: Leksikografski zavod Miroslav Krleža: 435-437.

35. Blažević, Zrinka. 2014a. „Kulturni posrednici i kulturni transferi u ranom novom vijeku Janez Vajkard Valvasor i Pavao Ritter Vitezović“. U: Ascendere historiam. Zbornik u čast Milana Kruheka. Prir. Marija Karbić, Hrvoje Kekez, Ana Novak i Zorislav Horvat. Zagreb: Hrvatski institut za povijest: 279-299.

36. Blažević, Zrinka. 2014b. Prevođenje povijesti. Teorijski obrati i suvremena historijska znanost. Zagreb: Srednja Europa.

37. Blažević, Zrinka. 2016. „Genius grandibus aptus: historiografska produkcija Pavla Rittera Vitezovića“. U: Pavao Ritter Vitezović i njegovo doba (1652 - 1713). Prir. Alojz Jembrih i Ivana Jukić. Zagreb: Hrvatski studiji Sveučilišta u Zagrebu: 149-163.

38. Blažević, Zrinka. 2018. „Pavao Ritter Vitezović: Dva stoljeća uplakane Hrvatske“. U: Forum 57, 7-9: 731-736. 
39. Blažević, Zrinka. 2019. „Rađanje nacionalnoga epa: Dva stoljeća uplakane Hrvatske“. U: Pavao Ritter Vitezović. Dva stoljeća uplakane Hrvatske / Plorantis Croatiae saecula duo. Prir. Zrinka Blažević i Bojan Marotti. Prev. Zrinka Blažević. Zagreb: Matica hrvatska: 521.

40. Blažević, Zrinka i Suzana Coha. 2008. „Zrinski i Frankopani - strategije i modeli heroizacije u književnom diskursu“". U: Radovi Zavoda za hrvatsku povijest Filozofskoga fakulteta Sveučilišta u Zagrebu 40: 91-117.

41. Boban, Vjekoslav. 2008. „Molitva kao pjesnička vrsta“. U: Molitvenik hrvatskih pjesnika. Vijenac molitava. Prir. Josip Brkić. Zagreb: Altagama: 367-377.

42. Bogdan, Tomislav. 2012. Ljubavi razlike. Tekstualni subjekt u hrvatskoj ljubavnoj lirici 15. i 16. stoljeća. Zagreb: Disput.

43. Bogdanović, David. 1932. Pregled književnosti hrvatske i srpske. Knjiga prva: „Hrvatska i srpska književnost od najstarijih vremena do Narodnoga preporoda“. 3. izdanje. Zagreb: vlastita naklada.

44. Bogdanović, Tomislav. 2011. „Prilozi poznavanju obitelji i posjeda Nikole Makara“. U: Cris 13, 1: 27-40.

45. Bogišić, Rafo. 1991. „Hrvatski barokni slavizam“. U: Hrvatski književni barok. Ur. Dunja Fališevac. Zagreb: Zavod za znanost o književnosti Filozofskog fakulteta Sveučilišta u Zagrebu: 9-38.

46. Bogišić, Rafo. 1993. „Hrvatske kajkavske pjesmarice 16.-18. stoljeće“. U: Dani Hvarskog kazališta. Knjiga 19: „Hrvatsko kajkavsko pjesništvo do preporoda“. Ur. Nikola Batušić i sur. Split: Književni krug: 77-91.

47. Bogišić, Rafo. 1995. „Pavao Vitezović kao kroatist“. U: Senjski zbornik 22: 191-200.

48. Bogišić, Rafo. 2007. Patnje mladoga Džore. (Rasprave i studije). Zagreb: Matica hrvatska.

49. Bogišić, Vlaho, Lada Čale Feldman, Dean Duda i Ivica Matičević. 1998. Leksikon hrvatske književnosti. Zagreb: Naprijed.

50. Bogović, Lidija i Jasmina Pavić. 2016. „Vitezovićeva Hërvatkinga i Dolmacia - identiteti identiteta“. U: Pavao Ritter Vitezović i njegovo doba (1652 - 1713). Prir. Alojz Jembrih i Ivana Jukić. Zagreb: Hrvatski studiji Sveučilišta u Zagrebu: 243-261.

51. Bošković-Stulli, Maja. 1978. „Usmena književnost““. U: Povijest hrvatske književnosti. Knjiga 1. Zagreb: Liber i Mladost: 7-353.

52. Bošković-Stulli, Maja. 1983. Usmena književnost nekad i danas. Beograd: Prosveta. 
53. Bošković-Stulli, Maja. 2011. „Pučka književnost“. U: Hrvatska književna enciklopedija. Svezak 3: Ma-R. Gl. ur. Velimir Visković. Zagreb: Leksikografski zavod Miroslav Krleža: 499-501.

54. Botica, Stipe. 1995. Biblija i hrvatska kulturna tradicija. Zagreb: vlastita naklada.

55. Botica, Stipe. 2011. Biblija i hrvatska tradicijska kultura. Zagreb: Školska knjiga.

56. Botica, Stipe. 2013. Povijest hrvatske usmene književnosti. Zagreb: Školska knjiga.

57. Botica, Stipe. 2016. „Epitafska praksa na hrvatskome području“. U: Forum 55, 1-3: 207231.

58. Brajović, Tihomir. 1995. Poetika žanra. Beograd: Narodna knjiga i Alfa.

59. Bratulić, Josip. 1990. Sjaj baštine. Split: Književni krug.

60. Bratulić, Josip. 1994. „Pavao Ritter Vitezović, književnik“. U: Pavao Ritter Vitezović: Izbor iz djela. Prir. Josip Bratulić. Zagreb: Erasmus naklada: 5-17.

61. Bratulić, Josip (prir.). 1996. Hrvatska propovijed: od svetoga Metoda do biskupa Strossmayera. Zagreb: Erasmus naklada.

62. Bratulić, Josip. 1997. „Oživjela Hrvatska u obzoru života i djela Pavla Rittera Vitezovića“. U: Pavao Ritter Vitezović: Oživjela Hrvatska. Prev. Zlatko Pleše. Zagreb: Golden marketing i Narodne novine: 9-40.

63. Bratulić, Josip. 2003. „Propovjedna i hagiografska književnost““. U: Hrvatska i Europa. Kultura, znanost i umjetnost. Svezak 3: Barok i prosvjetiteljstvo (XVII.-XVIII. stoljeće). Ur. Ivan Golub. Zagreb: Školska knjiga i HAZU: 533-549.

64. Bratulić, Josip. 2011. „Tronarječni tip hrvatskoga književnog jezika“. U: Povijest hrvatskoga jezika. 2. knjiga: 16. stoljeće. Gl. ur. Ante Bičanić. Zagreb: Croatica: 229-273.

65. Bratulić, Josip. 2014. „Pjesnikinja Ana Katarina Zrinska i pjesme u njezinoj Pjesmarici“. U: Ana Katarina Zrinski: Pjesmarica Ane Katarine Zrinske. Prir. Josip Bratulić. Zagreb: Matica hrvatska: 277-319.

66. Bratulić, Josip. 2016a. „Petar Zrinski - pjesnik hrvatske 'Zrinijade'“،. U: Petar Zrinski. Adrijanskoga mora sirena \& Obsida sigecka. Prir. Josip Bratulić. Zagreb: Matica hrvatska: 5-58.

67. Bratulić, Josip. 2016b. „Sigetska epopeja u hrvatskoj književnosti“. U: Nikola Šubić Zrinski u hrvatskom stihu. Prir. Josip Bratulić, Vladimir Lončarević i Božidar Petrač. Zagreb: Društvo hrvatskih književnika: I-XXV.

68. Bratulić, Josip. 2018. „Misao i djelo Pavla Rittera Vitezovića među hrvatskim preporoditeljima“. U: Tragovi tradicije, znakovi kulture. Zbornik u čast Stipi Botici. Ur. 
Evelina Rudan, Davor Nikolić i Josipa Tomašić. Zagreb: Hrvatska sveučilišna naklada, Hrvatsko filološko društvo i Matica hrvatska: 67-72.

69. Brešić, Vinko. 2015. Hrvatska književnost 19. stoljeća. Zagreb: Alfa.

70. Brezak-Stamać, Dubravka. 2012. „Književno-povijesni pregled poslanica u stihu i prozi u povijesti europskoga pjesništva od antike do renesanse“. U: Croatica et Slavica Iadertina 8, 2: 403-438.

71. Brezak-Stamać, Dubravka. 2016. Pisma iz renesanse: poetika poslanice $u$ stihu $u$ hrvatskoj književnosti 15. i 16. stoljeća. Zagreb: Školska knjiga.

72. Budak, Neven. 2007. Hrvatska i Slavonija u ranome novom vijeku. Zagreb: Leykam international.

73. Budišćak, Vanja. 2013a. „Dečko s periferije. Što je nama danas Pavao Ritter Vitezović? (Povodom 300. obljetnice smrti)“. U: Zarez 15, 356: 36-37.

74. Budišćak, Vanja. 2013b. „Poganska sila: slika Turaka u Vitezovićevu Odiljenju sigetskom“. U: Senjski zbornik 40: 343-362.

75. Budišćak, Vanja. 2015. „Pučka kao popularna književnost: teorijsko razmatranje“. U: Jat 2, 2: 154-169.

76. Budišćak, Vanja. 2016a. „Tamo gdje putovi staju: Vitezovićevo Odiljenje sigetsko“. U: Pavao Ritter Vitezović i njegovo doba (1652 - 1713). Prir. Alojz Jembrih i Ivana Jukić. Zagreb: Hrvatski studiji Sveučilišta u Zagrebu: 263-278.

77. Budišćak, Vanja. 2016b. „Treće Vitezovićevo izdanje Odiljenja sigetskog (1695.)“. U: Kaj 49, 5-6: 82-104.

78. Budišćak, Vanja. 2019. „Poslovice u Vitezovićevu Odiljenju sigetskom“. U: Narodna umjetnost 56, 2: 143-155.

79. Burke, Peter. 1991. Junaci, nitkovi i lude: narodna kultura predindustrijske Evrope. Prev. Borko Auguštin i Dunja Rihtman-Auguštin. Zagreb: Školska knjiga.

80. Cavitch, Max. 2012a. „Genre“. U: The Princeton Encyclopedia of Poetry and Poetics. Prir. Roland Greene i Stephen Cushman. 4. izdanje. Princeton i Oxford: Princeton University Press: 551-554.

81. Cavitch, Max. 2012b. „Lament“. U: The Princeton Encyclopedia of Poetry and Poetics. Prir. Roland Greene i Stephen Cushman. 4. izdanje. Princeton i Oxford: Princeton University Press: 781-782.

82. Cherci, Paolo, Albert N. Mancini i David Kimbell. 2008. „The Seicento“. U: The Cambridge History of Italian Literature. Prir. Peter Brand i Lino Pertile. Cambridge: Cambridge University Press: 299-340. 
83. Coe, Richard i sur. 2002. „Genre as Action, Strategy and Differance: An Introduction“. U: The Rhetoric and Ideology of Genre. Strategies for Stability and Change. Prir. Richard Coe, Lorelei Lingard i Tatiana Teslenko. Cresskill: Hampton Press: 1-10.

84. Coha, Suzana. 2017. „(Ne)održivost koncepta žanra i ideje žanrovskoga sustava - primjeri iz hrvatske preporodne književnosti“. U: Komparativna povijest hrvatske književnosti. Zbornik radova XIX: „Vrsta ili žanr“. Ur. Vinka Glunčić-Bužančić i Kristina Grgić. Split - Zagreb: Književni krug i Odsjek za komparativnu književnost Filozofskog fakulteta Sveučilišta u Zagrebu: 64-83.

85. Cohen, Ralph. 1991. „Genre Theory, Literary History, and Historical Change“. U: Theoretical Issues in Literary History. Prir. David Perkins. Cambridge i London: Harvard University Press: 85-113.

86. Culler, Jonathan. 1990. Strukturalistička poetika. Prev. Milica Mint. Beograd: Srpska književna zadruga.

87. Curtius, Ernst Robert. 1998. Europska književnost $i$ latinsko srednjovjekovlje. Prev. Stjepan Markuš. 2. izdanje. Zagreb: Naprijed.

88. Čubelić, Tvrtko. 1988. Povijest $i$ historija usmene narodne književnosti. Zagreb: vlastita naklada.

89. Derrida, Jacques. 1988. „Zakon žanra“. Prev. Borislav Knežević. U: Rival 3-4: 132-144.

90. Devitt, Amy J. 2004. Writing Genres. Carbondale: Southern Illinois University Press.

91. Dijk, Teun Adrianus van. 1985. „Introduction. The Common Roots of the Studies of Literature and Discourse“. U: Discourse and Literature. New Approaches to the Analysis of Literary Genres. Prir. Teun Adrianus van Dijk. Amsterdam i Philadelphia: John Benjamins Publishing Company: 1-9.

92. Divković, Mirko. 2006. Latinsko-hrvatski rječnik. Bjelovar: Dunja.

93. Dobronić, Lelja. 1994. „Vitezovićeva tiskarska djelatnost u Zagrebu“. U: Senjski zbornik 21: $117-126$.

94. Dobronić, Lelja. 1995. „Pavao Ritter Vitezović u Zagrebu“. U: Senjski zbornik 22: 171178.

95. Duda, Bonaventura. 2003. „Opći uvod u Bibliju“. U: Biblija: Stari i Novi zavjet. Gl. ur. Jure Kaštelan i Bonaventura Duda. Prev. Antun Sović, Silvije Grubišić, Filibert Gass i Ljudevit Rupčić. Zagreb: Kršćanska sadašnjost: 1169-1176.

96. Duff, David. 2000. „Introduction“. U: Modern Genre Theory. Prir. David Duff. Harlow: Longman: 1-24. 
97. Dukat, Vladoje. 1915. „Pater Gregur kapucin (Juraj Malevac), kajkavski književnik XVIII. vijeka“. U: Rad JAZU 207: 137-261.

98. Dukić, Davor. 2002. Poetike hrvatske epike 18. stoljeća. Split: Književni krug.

99. Dukić, Davor. 2003. „Hrvatska književnost. Neke temeljne značajke“. U: Hrvatska $i$ Europa. Kultura, znanost i umjetnost. Svezak 3: Barok i prosvjetiteljstvo (XVII.-XVIII. stoljeće). Ur. Ivan Golub. Zagreb: Školska knjiga i HAZU: 487-499.

100. Dukić, Davor. 2004a. „Predgovor“. U: Usmene epske pjesme I. Prir. Davor Dukić. Stoljeća hrvatske književnosti. Zagreb: Matica hrvatska: 9-59.

101. Dukić, Davor. 2004b. Sultanova djeca: predodžbe Turaka u hrvatskoj književnosti ranog novovjekovlja. Zadar: Thema.

102. Dukić, Davor i Jasmina Lukec. 2017. „Pjesme Ane Katarine Zrinski - poetika i kontekst“. U: Croatica 61: 273-294.

103. Eickmeyer, Jost. 2014. „Imitating Ovid to the Greater Glory of God: Jesuit Poets and Christian Heroic Epistles (1514 - 1663)“. U: Journal of Jesuit Studies 1, 3: 419-442.

104. Endstrasser, Vilko. 1997. Književni i izvanknjiževni žanrovi (Aspekt teorije govornih žanrova). Doktorska disertacija. Zagreb: Filozofski fakultet Sveučilišta u Zagrebu.

105. Endstrasser, Vilko. 2000. „Govorni žanrovi u Gjalskijevu djelu Pod starim krovovima u kontekstu povijesnih, političkih i ekonomskih zbivanja“. U: Narodna umjetnost 37, 2 : 163-180.

106. Fališevac, Dunja. 1995. Smiješno \& ozbiljno u staroj hrvatskoj književnosti. Zagreb: Hrvatska sveučilišna naklada.

107. Fališevac, Dunja. 1997. Kaliopin vrt: studije o hrvatskoj epici. Split: Književni krug.

108. Fališevac, Dunja. 2003. „Epika“. U: Hrvatska i Europa. Kultura, znanost i umjetnost. Svezak 3: Barok i prosvjetiteljstvo (XVII.-XVIII. stoljeće). Ur. Ivan Golub. Zagreb: Školska knjiga i HAZU: 501-511.

109. Fališevac, Dunja. 2007a. Dubrovnik - otvoreni i zatvoreni grad. Studije o dubrovačkoj književnoj kulturi. Zagreb: Naklada Ljevak.

110. Fališevac, Dunja. 2007b. Stari pisci hrvatski i njihove poetike. 2. izdanje. Zagreb: Hrvatska sveučilišna naklada.

111. Fališevac, Dunja. 2010a. „Barokni slavizam“. U: Hrvatska književna enciklopedija. Svezak 1: A-Gl. Gl. ur. Velimir Visković. Zagreb: Leksikografski zavod Miroslav Krleža: 116.

112. Fališevac, Dunja. 2010b. „Ep“. U: Hrvatska književna enciklopedija. Svezak 1: A-Gl. Gl. ur. Velimir Visković. Zagreb: Leksikografski zavod Miroslav Krleža: 484-488 
113. Fališevac, Dunja. 2013. „Veliki prethodnik hrvatskih preporoditelja“. U: Vijenac 21, 503: 12.

114. Fowler, Alaistar. 1982. Kinds of Literature. An Introduction to the Theory of Genres and Modes. Oxford i New York: Oxford University Press.

115. Frangeš, Ivo. 1987. Povijest hrvatske književnosti. Zagreb - Ljubljana: Nakladni zavod Matice hrvatske i Cankarjeva založba.

116. Freedman, Aviva i Peter Medway. 2005. „Locating Genre Studies: Antecedents and Prospects“. U: Genre and the New Rhetoric. Prir. Aviva Freedman i Peter Medway. London: Taylor \& Francis: 2-18.

117. Frndić, Nasko. 1993. „Svjetovne pjesme u hrvatskokajkavskim prekomurskim pjesmaricama od 16. do 18. stoljeća“. U: Dani Hvarskog kazališta. Knjiga 19: „Hrvatsko kajkavsko pjesništvo do preporoda“. Ur. Nikola Batušić i sur. Split: Književni krug: 92105.

118. Frow, John. 2015. Genre. 2. izdanje. New York: Routledge.

119. Frye, Northrop. 2000. Anatomija kritike. Prev. Giga Gračan. Zagreb: Golden marketing.

120. Gaj, Velimir. 1875. Knjižnica Gajeva, ogled bibliografijskih studija. Zagreb: vlastita naklada.

121. Gazda, Grzegorz i Słowina Tynecka-Makowska (ur.). 2015. Rečnik književnih rodova i vrsta. Prev. Ivana Đokić Saunderson. Beograd: Službeni glasnik.

122. Genette, Gérard. 1980. Narrative Discourse. Prev. Jane E. Levin. New York: Cornell University Press i Ithaca.

123. Genette, Gérard. 1985. Figure. Prev. Mirjana Miočinović. Beograd: Vuk Karadžić.

124. Genette, Gérard. 1997. Paratexts: Thresholds of Interpretation. Prev. Jane E. Levin. Cambridge: Cambridge University Press.

125. Genette, Gérard. 2002. Figure V. Prev. Vladimir Kapor. Novi Sad: Svetovi.

126. Georgijević, Krešimir. 1969. Hrvatska književnost od 16. do 18. stoljeća u sjevernoj Hrvatskoj i Bosni. Zagreb: Matica hrvatska.

127. Goldstein, Ivo. 2008. Hrvatska povijest. Zagreb: Europapress holding.

128. Golub, Ivan. 2003. „Počeci slavenske misli“. U: Hrvatska i Europa. Kultura, znanost $i$ umjetnost. Svezak 3: Barok i prosvjetiteljstvo (XVII.-XVIII. stoljeće). Ur. Ivan Golub. Zagreb: Školska knjiga i HAZU: 123-140. 
129. Gorp, Hendrik van i Ulla Musarra-Schroeder. 2000. „Introduction: Literary Genres and Cultural Memory“. U: Genres as Repositories of Cultural Memory. Prir. Hendrik van Gorp i Ulla Musarra-Schroeder. Amsterdam - Atlanta: Rodopi: I-IX.

130. Grgec, Petar. 1944. Razvoj hrvatskog narodnog pjesničtva. Zagreb: Hrvatska školska knjižnica.

131. Grmača, Dolores. 2015. Nevolje s tijelom. Alegorija putovanja od Bunića do Barakovića. Zagreb: Matica hrvatska.

132. Grübel, Rainer. 2015. „Bakhtin's Theory of Speech Genres and the Addressivity in Cultural Pragmatics of Genres in Literature: »Genus« vs. »Genre«“. U: Umjetnost riječi 59, 3-4: 215-238.

133. Guillén, Claudio. 1982. Književnost kao sistem. Prev. Tihomir Vučković. Beograd: Nolit.

134. Guillén, Claudio. 2005. Entre lo uno y lo diverso. Introducción a la Literatura Comparada (Ayer y hoy). Barcelona: Tusquets Editores.

135. Hausner, Gábor. 2012. „Posljednji junak obitelji Zrinski: grof Adam Zrinski (1662 1691)“. Prev. Kristina Katalinić. U: Susreti dviju kultura. Obitelj Zrinski u hrvatskoj i mađarskoj povijesti. Prir. Sándor Bene, Zoran Ladić i Gábor Hausner. Zagreb: Matica hrvatska: 447-461.

136. Helmridge-Marsillian, Veronique. 1991. The Heroism of Love in Hoffmannswaldau's „Heldenbriefe“. Tübingen: Max Niemeyer Verlag.

137. Hercigonja, Eduard. 1975. „Srednjovjekovna književnost“. U: Povijest hrvatske književnosti. Knjiga 2. Zagreb: Liber i Mladost.

138. Hernadi, Paul. 1972. Beyond Genre. New Directions in Literary Classification. Ithaca i London: Cornall University Press.

139. Hess, Peter. 2007. „Poetry in Germany 1450 - 1700“. U: Camden House History of German Literature. Svezak 4: „Early Modern German Literature 1350 - 1750“. Prir. Max Reinhart. Rochester: Camden House: 395-465.

140. Hirsch, Eric Donald. 1983. Načela tumačenja. Prev. Tihomir Vučković. Beograd: Nolit.

141. Hoffman, Daniel. 2012. „Proverb“. U: The Princeton Encyclopedia of Poetry and Poetics. Prir. Roland Greene i Stephen Cushman. 4. izdanje. Princeton i Oxford: Princeton University Press: 1122-1123.

142. Holquist, Michael. 1986. „Uvod“. U: Mihail Mihailovič Bahtin. Speech Genres and Other Late Essays. Prev. Vern W. McGee. Austin: University of Texas Press: IX-XXIII. 
143. Honko, Lauri. 1989. „Folkloristic Theories of Genre“. U: Studia Fennica 33: 13-28.

144. Hornsby, Roger A. i Terry V. F. Brogan. 2012. „Verse epistle“. U: The Princeton Encyclopedia of Poetry and Poetics. Prir. Roland Greene i Stephen Cushman. 4. izdanje. Princeton i Oxford: Princeton University Press: 1513-1514.

145. Hoško, Franjo Emanuel i Mijo Korade. 2003. „Školstvo i crkveni redovi“. U: Hrvatska i Europa. Kultura, znanost i umjetnost. Svezak 3: Barok i prosvjetiteljstvo (XVII.-XVIII. stoljeće). Ur. Ivan Golub. Zagreb: Školska knjiga i HAZU: 187-201.

146. Hranjec, Stjepan. 2011. „Zrinski i Frankopani kao književna tema“. U: Politička, kulturna i društvena djelatnost Zrinskih i Frankopana u Hrvatskoj. Gl. ur. Juraj Kolarić. Čakovec: Zrinska garda Čakovec: 91-108.

147. Hranjec, Stjepan. 2016. „Sigetsko 'odiljenje' kao književna tema“. U: Hrvatski kajkavski kolendar 2016. Gl. ur. Stjepan Hranjec. Čakovec: Ogranak Matice hrvatske u Čakovcu: 22-32.

148. Hrgić, Danijel. 2015. Kultura medija i medij kulture: kalendari Pavla Rittera Vitezovića. Diplomski rad. Zagreb: Filozofski fakultet Sveučilišta u Zagrebu.

149. Jameson, Fredric. 1984. Političko nesvesno. Prev. Dušan Puhalo. Beograd: Rad.

150. Janković, Valentina. 2016. „Živjeti kao plemić: Pavao Ritter Vitezović u Zagrebu na prijelazu 17. u 18. st.“. U: Pavao Ritter Vitezović i njegovo doba (1652 - 1713). Prir. Alojz Jembrih i Ivana Jukić. Zagreb: Hrvatski studiji Sveučilišta u Zagrebu: 97-120.

151. Jauss, Hans Robert. 1970. „Teorija rodova i književnost srednjega vijeka“. Prev. Zdenko Škreb. U: Umjetnost riječi 14, 3: 327-352.

152. Jauss, Hans Robert. 1978. Estetika recepcije. Prev. Drinka Gojković. Beograd: Nolit.

153. Jelčić, Dubravko. 2002. „Pavao Vitezović između povijesti i sna“. U: Forum 41, 1012: 1173-1177.

154. Jelčić, Dubravko. 2004. Povijest hrvatske književnosti. Tisućljeće od Baščanske ploče do postmoderne. 2. izdanje. Zagreb: Naklada Pavičić.

155. Jembrih, Alojz. 2008. „Stjepan Moyses i ponovljeno izdanje Oddiljenja sigetskoga (Linz, 1684. - Zagreb, 1836.) Pavla Vitezovića senjskoga zlatoga viteza“. U: Gazophylacium 13, 1-2: 41-58.

156. Jembrih, Alojz. 2011. „Doprinos zrinsko-frankopanskoga književno-jezičnoga kruga hrvatskoj književnosti i leksikografiji 17. stoljeća“. U: Politička, kulturna i društvena djelatnost Zrinskih i Frankopana u Hrvatskoj. Gl. ur. Juraj Kolarić. Čakovec: Zrinska garda: $109-123$. 
157. Jembrih, Alojz. 2015. „Pavao Ritter Vitezović i njegova Kronika (1696.)“. U: Pavao Ritter Vitezović: Kronika aliti spomen vsega svieta vikov. Prir. Alojz Jembrih. Zagreb: ArTresor naklada: 489-612.

158. Jembrih, Alojz. 2016a. „O Pavlu Ritteru Vitezoviću - iznova“. U: Pavao Ritter Vitezović i njegovo doba (1652 - 1713). Prir. Alojz Jembrih i Ivana Jukić. Zagreb: Hrvatski studiji Sveučilišta u Zagrebu: 13-81.

159. Jembrih, Alojz. 2016b. Tragom života i rada Stjepana Moysesa u Zagrebu (1829. 1851.). Zagreb: Hrvatsko književno društvo Sv. Jeronima.

160. Jembrih, Alojz. 2017a. „Fodrocijevo izdanje Vazetja Sigeta grada (1661.) Barne Karnarutića“. U: Studia lexicographica 10-11, 19-20: 35-62.

161. Jembrih, Alojz. 2017b. Pavao Ritter Vitezović (1652 - 1713). Zagreb: Družba »Braća Hrvatskoga Zmaja«.

162. Ježić, Slavko. 1993. Hrvatska književnost od početka do danas (1100. - 1941.). 2. izdanje. Zagreb: Grafički zavod Hrvatske.

163. Johnson, Christopher. 2012. „Baroque“. U: The Princeton Encyclopedia of Poetry and Poetics. Prir. Roland Greene i Stephen Cushman. 4. izdanje. Princeton i Oxford: Princeton University Press: 121-126.

164. Jolles, André. 2000. Jednostavni oblici. Prev. Vladimir Biti. Zagreb: Matica hrvatska.

165. Jovanović, Neven. 1998. „De consolatione“ Nikole Modruškog. Magistarski rad. Zagreb: Filozofski fakultet Sveučilišta u Zagrebu.

166. Jovanović, Neven. 2002. „Ter tužnih konsolaj: Marulićeva Utiha nesriće i PseudoSenekina konzolacijska zbirka De remediis fortuitorum“. U: Colloquia Maruliana 11: 413-442.

167. Jukić, Ivana. 2016. „Vitezovićevo zaleđe i Klaićevi putokazi“. U: Pavao Ritter Vitezović i njegovo doba (1652 - 1713). Prir. Alojz Jembrih i Ivana Jukić. Zagreb: Hrvatski studiji Sveučilišta u Zagrebu: 83-95.

168. Jurišić, Hrvatin Gabrijel. 1995. „Pavao Vitezović kao latinist. (Osvrt na neka Vitezovićeva latinska djela)“. U: Senjski zbornik 22: 201-224.

169. Juvan, Marko. 2006a. „Kulturni spomin in literarni žanri: primer slovenskega soneta“. U: Slavica litteraria 55, 9: 195-205.

170. Juvan, Marko. 2006b. Literarna veda v rekonstrukciji: uvod v sodobni študij literature. Ljubljana: Literarno-umetniško društvo „Literatura“.

171. Karpatský, Dušan. 2008. „Hrvatsko pjesništvo kroz stoljeća“. Prev. Dubravka Sesar. U: Kolo 18, 3-4: 603-661. 
172. Katičić, Radoslav. 2013. „Hrvatski jezik u 17. i 18. stoljeću obuhvaćen jednim pogledom“. U: Povijest hrvatskoga jezika. 3. knjiga: 17. i 18. stoljeće. Gl. ur. Ante Bičanić. Zagreb: Croatica: 9-75.

173. Kekez, Josip. 1984. Poslovice i njima srodni oblici. Zagreb: Zavod za znanost o književnosti Filozofskog fakulteta Sveučilišta u Zagrebu.

174. Kekez, Josip. 1987. Usmeno-pisani književni suodnosi. Nikšić: Univerzitetska riječ.

175. Kekez, Josip. 1992. Hrvatski književni oikotip. Zagreb: Zavod za znanost o književnosti Filozofskog fakulteta Sveučilišta u Zagrebu.

176. Kekez, Josip. 1998. „Usmena književnost“. U: Uvod u književnost. 5. izdanje. Prir. Zdenko Škreb i Ante Stamać. Zagreb: Nakladni zavod Globus.

177. Kekez, Josip. 2000. Predgovor. U: Bugaršćice: starinske hrvatske usmene pjesme. Prir. Josip Kekez. Zagreb: Organizator: 5-63.

178. Klaić, Vjekoslav. 1914. Život i djela Pavla Rittera Vitezovića (1652. - 1713.). Zagreb: Matica hrvatska.

179. Klaić, Vjekoslav. 1915. „Obrana Pavla Rittera Vitezovića od g. 1710“. U: Građa za povijest književnosti hrvatske 8: 375-394.

180. Knezović, Pavao. 2016. „Plorantis Croatiae saecula duo carmine descripta P. R. Vitezovića (žanr?)“. U: Pavao Ritter Vitezović i njegovo doba (1652 - 1713). Prir. Alojz Jembrih i Ivana Jukić. Zagreb: Hrvatski studiji Sveučilišta u Zagrebu: 229-241.

181. Kolanović, Josip. 2012. „Stemmatographia, sive Armorum Illyricorum delineatio, descriptio, et restitutio (Stematografija ili nacrt, opis i obnova ilirskih grbova)“. U: Hrvatska književna enciklopedija. Svezak 4: S-Ž. Gl. ur. Velimir Visković. Zagreb: Leksikografski zavod Miroslav Krleža: 146-147.

182. Kolumbić, Nikica. 1971. „Pjesničke vrednote Vitezovićeva spjeva Odiljenje sigetsko“. U: Opsada Sigeta. Prir. Milan Ratković. Zagreb: Liber: 85-92.

183. Kolumbić, Nikica. 1991. „Neke osobitosti žanrova hrvatskoga književnog baroka“. U: Hrvatski književni barok. Ur. Dunja Fališevac. Zagreb: Zavod za znanost o književnosti Filozofskog fakulteta Sveučilišta u Zagrebu: 39-51.

184. Kolumbić, Nikica. 2005. Poticaji i nadahnuća: studije $i$ eseji iz starije hrvatske književnosti. Zagreb: Dom i svijet.

185. Kombol, Mihovil. 1961. Povijest hrvatske književnosti do narodnog preporoda. 2. izdanje. Zagreb: Matica hrvatska. 
186. Kombol, Mihovil i Slobodan Prosperov Novak. 1995. Hrvatska književnost do Narodnog preporoda. Priručnik za učenike, studente i učitelje književnosti. 3. izdanje. Zagreb: Školska knjiga.

187. Konstantinović, Zoran. 1985. „Preobražaji rodovskih struktura“. U: Književna kritika 16, 5: 22-36.

188. Kosić, Ivan. 2013. Pavao Ritter Vitezović u Zbirci rukopisa i starih knjiga Nacionalne i sveučilišne knjižnice u Zagrebu. Zagreb: Nacionalna i sveučilišna knjižnica.

189. Kovač, Tita. 1973. Spomini barona Valvasorja. Ljubljana: Cankarjeva založba.

190. Kravar, Miroslav. 1986. „Čakavsko-hrvatski heksametar u Vitezovićevu Odiljenju sigetskom“. U: Zadarska revija 35, 2: 129-144.

191. Kravar, Zoran. 1975. Studije o hrvatskom književnom baroku. Zagreb: Nakladni zavod Matice hrvatske.

192. Kravar, Zoran. 1978. „Stil hrvatskoga književnog baroka“. U: Hrvatska književnost u evropskom kontekstu. Prir. Aleksandar Flaker i Krunoslav Pranjić. Zagreb: Zavod za znanost o književnosti i Liber: 223-241.

193. Kravar, Zoran. 1984. „Zapažanja o genološkoj teoriji Pavla Pavličića“. U: Umjetnost riječi 28, 1-2: 133-142.

194. Kravar, Zoran. 1991. Das Barock in der kroatischen Literatur. Köln - Weimar Wien: Böhlau Verlag.

195. Kravar, Zoran. 1993. Nakon godine MDC. Dubrovnik: Matica hrvatska.

196. Kravar, Zoran i Darko Novaković. 2000. „Vitezović Ritter, Pavao“. U: Leksikon hrvatskih pisaca. Ur. Dunja Fališevac, Krešimir Nemec i Darko Novaković. Zagreb: Školska knjiga: 766-769.

197. Kravar, Zoran. 2003a. „Lirika“. U: Hrvatska i Europa. Kultura, znanost i umjetnost. Svezak 3: Barok i prosvjetiteljstvo (XVII.-XVIII. stoljeće). Ur. Ivan Golub. Zagreb: Školska knjiga i HAZU: 513-520.

198. Kravar, Zoran. 2003b. „Svjetonazori i ideje“. U: Hrvatska i Europa. Kultura, znanost $i$ umjetnost. Svezak 3: Barok i prosvjetiteljstvo (XVII.-XVIII. stoljeće). Ur. Ivan Golub. Zagreb: Školska knjiga i HAZU: 117-121.

199. Kravar, Zoran. 2010. „Barok“. U: Hrvatska književna enciklopedija. Svezak 1: A-Gl. Gl. ur. Velimir Visković. Zagreb: Leksikografski zavod Miroslav Krleža: 110-115.

200. Kravar, Zoran i Tonko Maroević. 2010. „Lirika“. U: Hrvatska književna enciklopedija. Svezak 2: Gl-Ma. Gl. ur. Velimir Visković. Zagreb: Leksikografski zavod Miroslav Krleža: 516-524. 
201. Krmpotić, Branko. 1970. „Vitezovićeva senjska i pomorska tematika“. U: Pomorski zbornik 8: 613-632.

202. Kühlmann, Wilhelm. 2007. „Neo-Latin Literature in Early Modern Germany“. Prev. Michael Swisher. U: Camden House History of German Literature. Svezak 4: „Early Modern German Literature 1350 - 1750“. Prir. Max Reinhart. Rochester: Camden House: 281-329.

203. Lešić, Zdenko. 2008. Teorija književnosti. Beograd: Službeni glasnik.

204. Lőkös, István. 2008. Croatohungarica. Hrvatsko-mađarske književnopovijesne teme. Zagreb: Matica hrvatska.

205. Lopašić, Radoslav. 1897. „Pavao Ritter-Vitezović“. U: Građa za povijest književnosti hrvatske 1: 39-55.

206. Lotman, Jurij Mihajlovič. 2001. Struktura umjetničkog teksta. Prev. Sanja Veršić. Zagreb: Alfa.

207. Lozica, Ivan. 1990. „Favorizirani i zanemareni žanrovi u usmenoj tradiciji“. U: Narodna umjetnost 27, 1: 111-119.

208. Lozovina, Vinko. 1936. Dalmacija u hrvatskoj književnosti. Zagreb: Matica hrvatska.

209. Luetić, Andrea i Tamara Tvrtković. 2016. „Povijesni kontekstualni okvir anagrama: kako u Rittera slavna pjesma goni k novíni“. U: Pavao Ritter Vitezović i njegovo doba (1652 - 1713). Prir. Alojz Jembrih i Ivana Jukić. Zagreb: Hrvatski studiji Sveučilišta u Zagrebu: $317-332$.

210. Ljubić, Lucija i Martina Petranović. 2012. „Deskriptivna obrada važnijih predstava na hrvatskom jeziku i izvedbi na stranim jezicima hrvatskih izvođača do 1840. godine“. Repertoar hrvatskih kazališta. Knjiga peta. Ur. Branko Hećimović. Zagreb: Hrvatska akademija znanosti i umjetnosti i AGM.

211. Ljubić, Šime. 1869. Ogledalo književne poviesti jugoslavjanske na podučavanje mladeži. Knjiga II. Rijeka: Riečki Emidija Mohovića Tiskarski Kamen. Zavod.

212. Ljubović, Enver. 2002. „Heraldika u djelima Pavla Vitezovića“. U: Forum 41, 10-12: 1190-1196.

213. Macan, Ivan. 2016. „Poslijetridentska obnova školstva. Isusovački Ratio et institutio studiorum (1599)“. U: Tridentska baština. Katolička obnova i konfesionalizacija u hrvatskim zemljama. Ur. Zrinka Blažević i Lahorka Plejić Poje. Zagreb: Matica hrvatska, Katolički bogoslovni fakultet i Filozofski fakultet Družbe Isusove: 429-440. 
214. Maleković, Vladimir. 1993. „Od svagdana do blagdana. Ka prepoznavanju duha baroka u Hrvatskoj“. U: Od svagdana do blagdana: barok u Hrvatskoj. Ur. Vladimir Maleković. Zagreb: Muzej za umjetnost i obrt: 12-30.

215. Marković, Mirko. 1987. „Prilog poznavanju djela objavljenih u zagrebačkoj tiskari Pavla Rittera Vitezovića“. U: Starine JAZU 60: 71-99.

216. Maruševski, Olga. 1993. „Sadržaji i iskazi života hrvatskog društva u 17. i 18. stoljeću“. U: Od svagdana do blagdana: barok u Hrvatskoj. Ur. Vladimir Maleković. Zagreb: Muzej za umjetnost i obrt: 32-91.

217. Matagić, Zvonimir. 1966. „Nikola Šubić Zrinski i sigetska bitka u književnosti, umjetnosti i politici“. U: Riječka revija 15, 10: 906-918.

218. Matanović, Julijana. 1992. Barok iz suvremenosti gledat (Primarna i sekundarna generička obilježja u Đorđićevim ,Uzdasima Mandalijene pokornice“). Osijek: Revija.

219. Matić, Tomo. 1957. Predgovor. U: Petar Zrinski: Adrijanskog mora Sirena. Prir. Tomo Matić. SPH 32. Zagreb: Jugoslavenska akademija znanosti i umjetnosti: 5-18.

220. Matić, Tomo. 1968. „Vitezovićevo Odiljenje sigetsko i Sejnčica“. U: Građa za povijest književnosti hrvatske JAZU 29: 103-108.

221. Matvejević, Predrag. 1986. „Prigodna pesma“. U: Rečnik književnih termina. Gl. ur. Dragiša Živković. Beograd: Nolit: 602-603.

222. Mažuran, Ive. 1998. Hrvati i Osmansko Carstvo. Zagreb: Golden marketing.

223. Meić, Perina. 2017. „Koje je vrste Pavličićeva Književna genologija?“. U: Komparativna povijest hrvatske književnosti. Zbornik radova XIX: „Vrsta ili žanr“. Ur. Vinka Glunčić-Bužančić i Kristina Grgić. Split - Zagreb: Književni krug i Odsjek za komparativnu književnost Filozofskog fakulteta Sveučilišta u Zagrebu: 23-37.

224. Mijatović, Anđelko. 2010. Obrana Sigeta. 2. izdanje. Zagreb: Školska knjiga.

225. Mikić, Pavao i Vjekoslav Suzanić. 1994. Biblijske poslovice u Hrvata. Zagreb Zadar: Školska knjiga i Hrvatski institut za liturgijski pastoral.

226. Miller, Carolyn R. 1984. „Genre as Social Action“. U: Quarterly Journal of Speech 70: 151-167.

227. Miller, Carolyn R. 2005. „Rhetorical Community: The Cultural Basis of Genre“. U: Genre and the New Rhetoric. Prir. Aviva Freedman i Peter Medway. London: Taylor \& Francis: 57-66.

228. Miller, Carolyn R. 2015. „Genre as Social Action (1984), Revisited 30 Years Later (2014)“. U: Letras \& Letras 31, 3: 56-72. 
229. Milutinović, Dejan. 2009. „Žanr - pojam, istorija, teorija“. U: Philologia Mediana 1, 1: 11-37.

230. Moguš, Milan. 1974. „Pavao Vitezović kao jezikoslovac“. U: Zbornik Zagrebačke slavističke škole. Knjiga 2. Ur. Franjo Grčević i Mladen Kuzmanović. Zagreb: Međunarodni slavistički centar SR Hrvatske: 73-79.

231. Moguš, Milan. 1986. „Napomene o Vitezovićevu jeziku“. U: Zadarska revija 35, 2: 145-153.

232. Moguš, Milan. 2009. Povijest hrvatskoga književnoga jezika. 3. izdanje. Zagreb: Nakladni zavod Globus.

233. Moretti, Violeta. 2013. „Figura Turcae u Vitezovićevim stihovanim pismima“. U: Susret kultura. Knjiga II. Ur. Ivana Živančević Sekeruš. Novi Sad: Univerzitet u Novom Sadu, Filozofski fakultet: 1139-1148.

234. Moretti, Violeta. 2014. Jezik i stil pjesničkih poslanica Pavla Rittera Vitezovića. Doktorska disertacija. Zagreb: Filozofski fakultet Sveučilišta u Zagrebu.

235. Moretti, Violeta i Gorana Stepanić. 2019. „Usud ga nije volio. Latinske pjesničke poslanice Pavla Rittera Vitezovića (1652-1713)“. U: Pavao Ritter Vitezović. Epistolae metricae. Prir. Violeta Moretti i Gorana Stepanić. Split: Književni krug: 9-116.

236. Novaković, Darko. 1986. „Rodovi i vrste na stranicama Umjetnosti riječi“. U: Umjetnost riječi 30, 4: 323-339.

237. Novaković, Darko. 2003. „Hrvatski latinizam u XVII. stoljeću“. U: Hrvatska $i$ Europa. Kultura, znanost i umjetnost. Svezak 3: Barok i prosvjetiteljstvo (XVII.-XVIII. stoljeće). Ur. Ivan Golub. Zagreb: Školska knjiga i HAZU: 551-563.

238. Novaković, Darko. 2010. „Vitezovićevo ljubavno pjesništvo na latinskom“. U: Latina et Graeca 16: 39-54.

239. Novalić, Đuro. 1967a. „Književni krug oko braće Nikole i Petra Zrinjskog“. U: Kolo 5, 3: 212-221.

240. Novalić, Đuro. 1967b. Mađarska i hrvatska „Zrinijada“. Zagreb: Filozofski fakultet Sveučilišta u Zagrebu.

241. Novalić, Đuro. 1968. „O dvojstvu hrvatskoga književnog baroka“. U: Forum 7, 4: 712-730.

242. Oblučar, Branislav. 2013. „Pjesma u prozi kao žanr - pokušaji određenja“. U: Književna smotra 45, 1: 3-15.

243. Oestreich, Gerhard. 2008. Neostoicism and the Early Modern State. Prev. David McLintock. Cambridge: Cambridge University Press. 
244. Oraić Tolić, Dubravka. 2011. Akademsko pismo. Strategije i tehnike klasične retorike za suvremene studentice $i$ studente. Zagreb: Naklada Ljevak.

245. Pajur, Franjo. 2014. „Ozaljski jezično-književni krug ili zrinsko-frankopanski književni krug“. U: Kaj 47, 3-4: 55-68.

246. Palotás, György. 2014. „Politics and Literature in the Elegies of Michael Verancius in 1528“. U: Colloquia Maruliana 23: 55-83.

247. Paré, Anthony, Doreen Starke-Meyerring i Lynn McAlpine. 2009. „The Dissertation as Multi-Genre: Many Readers, Many Readings“. U: Genre in a Changing World. Ur. Charles Bazerman, Adair Bonini i Debora Figueiredo. Colorado - Indiana: The WAC Clearinghouse i Parlor Press: 179-193.

248. Pavličić, Pavao. 1979a. „Metodološki problemi književne genologije“. U: Umjetnost riječi $23,3: 143-172$.

249. Pavličić, Pavao. 1979b. Rasprave o hrvatskoj baroknoj književnosti. Split: Čakavski sabor.

250. Pavličić, Pavao. 1983. Književna genologija. Zagreb: Sveučilišna naklada Liber.

251. Pavličić, Pavao. 1987. „Pučka, trivijalna i masovna književnost““. U: Trivijalna književnost. Prir. Svetlana Slapšak. Beograd: Radionica SIC: 74-83.

252. Pavličić, Pavao. 1995. Barokni stih u Dubrovniku. Dubrovnik: Matica hrvatska i Međunarodno središte hrvatskih sveučilišta.

253. Pavličić, Pavao. 1998. „Epsko pjesništvo“. U: Uvod u književnost. 5. izdanje. Prir. Zdenko Škreb i Ante Stamać. Zagreb: Nakladni zavod Globus: 413-439.

254. Pavličić, Pavao. 1999. „Razvoj žanrova u hrvatskoj književnosti“. U: Introduzione allo studio della lingua, letteratura e cultura croata. Prir. Fedora Ferluga Petronio. Udine: Forum: 53-59.

255. Pavličić, Pavao. 2003. Barokni pakao: rasprave iz hrvatske književnosti. Zagreb: Naklada Pavičić.

256. Pavličić, Pavao. 2006. Skrivena teorija. Zagreb: Matica hrvatska.

257. Pavličić, Pavao. 2007. Epika granice. Zagreb: Matica hrvatska.

258. Pavličić, Pavao. 2008a. „Adrijanskoga mora Sirena“. U: Leksikon hrvatske književnosti. Djela. Ur. Dunja Detoni-Dujmić, Dunja Fališevac, Ana Lederer i Tea Benčić-Rimay. Zagreb: Školska knjiga: 2-3.

259. Pavličić, Pavao. 2008b. „Odiljenje sigetsko“. U: Leksikon hrvatske književnosti. Djela. Ur. Dunja Detoni-Dujmić, Dunja Fališevac, Ana Lederer i Tea Benčić-Rimay. Zagreb: Školska knjiga: 535-536. 
260. Pavličić, Pavao. 2017a. „Književna genologija u teoriji i praksi“. U: Komparativna povijest hrvatske književnosti. Zbornik radova XIX: „Vrsta ili žanr“. Ur. Vinka GlunčićBužančić i Kristina Grgić. Split - Zagreb: Književni krug i Odsjek za komparativnu književnost Filozofskog fakulteta Sveučilišta u Zagrebu: 11-22.

261. Pavličić, Pavao. 2017b. „Pučka i popularna književnost: jedno ili dvoje?“. U: Dani Hvarskoga kazališta. Knjiga 43: „Pučko i popularno“. Ur. Boris Senker i Vinka GlunčićBužančić. Zagreb - Split: Hrvatska akademija znanosti i umjetnosti i Književni krug: 5-17

262. Peleh, Slavko. 1973. „Vitezovićev prilog zagonetaštvu“. U: Senjski zbornik 5: 397402.

263. Peternai Andrić, Kristina. 2018. „Skica za pojam popularne književnosti“. U: Dani Hvarskoga kazališta. Knjiga 44: „Pučko i popularno II“. Ur. Boris Senker i Vinka Glunčić-Bužančić. Zagreb - Split: Hrvatska akademija znanosti i umjetnosti i Književni krug: 152-170.

264. Petrović, Svetozar. 1968. „Problem soneta u starijoj hrvatskoj književnosti. (Oblik i smisao)“. U: Rad JAZU 350: 5-304.

265. Plejić Poje, Lahorka. 2016. „Kako jedno zrcalo pričisto: Bartol Kašić i poslijetridentska prozna hagiografija“. U: Tridentska baština. Katolička obnova $i$ konfesionalizacija u hrvatskim zemljama. Ur. Zrinka Blažević i Lahorka Plejić Poje. Zagreb: Matica hrvatska, Katolički bogoslovni fakultet i Filozofski fakultet Družbe Isusove: 363-376.

266. Popov, Jovan. 2003. „O upotrebi termina žanr u novijoj srpskoj i hrvatskoj teoriji književnosti“. U: Zbornik Matice srpske za književnost i jezik 51, 3: 457-471.

267. Popović, Pavle. 1999. Jugoslovenska književnost. 2. izdanje. Beograd: Zavod za udžbenike i nastavna sredstva.

268. Posavac, Zlatko. 1994. „Hrvatska estetika 17. stoljeća“. U: Filozofska istraživanja 14, 53-54: 507-541 (1. dio) i 55: 849-886 (2. dio).

269. Potočnjak, Saša. 2015. „Fran Krsto Frankopan i bečko-furlansko pjesništvo 17. stoljeća“. U: Slavistična revija 63, 1: 119-134.

270. Pranjić, Ivan (prir.). 2016. Sigetski boj u hrvatskoj epici. Čakovec: Ogranak Matice hrvatske u Čakovcu.

271. Prosperov Novak, Slobodan. 1999. Povijest hrvatske književnosti. 3. knjiga: „Od Gundulićeva 'poroda od tmine' do Kačićeva 'Razgovora ugodnog naroda slovinskog' iz 1756.“. Zagreb: Izdanja Antibarbarus. 
272. Pšihistal, Ružica. 2014. „Uvod u alegoriju: aliud verbis, aliud sensu“. U: Anafora 1, 1: 95-117.

273. Puškadija Ribkin, Tatjana. 2000. „Prilog bibliografiji djela Pavla Rittera Vitezovića“. $\mathrm{U}: \operatorname{Kaj} 33,3-4:$ 61-66.

274. Putanec, Valentin i dr. (prir.). 1952. Djela Pavla Vitezovića (1652 - 1952). Zagreb: JAZU.

275. Putanec, Valentin. 1986. „Lingvistički rad Pavla Vitezovića (1652 - 1713). (Sintetski prikaz)“. U: Forum 25, 3-4: 349-356.

276. Quint, David. 1993. Epic and Empire: Politics and Generic Form from Virgil to Milton. Princeton: Princeton University Press.

277. Rafolt, Leo. 2016. „Sala declamationum: isusovačka tragedija u Dubrovniku“. U: Tridentska baština. Katolička obnova $i$ konfesionalizacija u hrvatskim zemljama. Ur. Zrinka Blažević i Lahorka Plejić Poje. Zagreb: Matica hrvatska, Katolički bogoslovni fakultet i Filozofski fakultet Družbe Isusove: 377-392.

278. Rasmussen, Anders Juhl. 2015. „Genre and Paratext“. U: Genre and.... Prir. Sune Auken, Palle Schantz Lauridsen i Anders Juhl Rasmussen. Copenhagen: Forlaget Ekbátana: 125-152.

279. Rapacka, Joanna. 2005. „Centri i periferije starije hrvatske književnosti“. Prev. Ivana Vidović Bolt. U: Hrvatska književna baština. Knjiga 4. Ur. Dunja Fališevac, Josip Lisac i Darko Novaković. Zagreb: Ex libris: 359-373.

280. Ratković, Milan. 1971. „Ferenac Črnko i njegov opis podsjedanja i pada Sigeta“. U: Ferenac Črnko. Podsjedanje i osvojenje Sigeta i popratni tekstovi. Ur. Milan Ratković. Zagreb: Liber: 27-34.

281. Ravlić, Slaven (gl. ur.). 2009. Hrvatska enciklopedija. Svezak 11 ( $\mathrm{Tr}-$ Ž). Zagreb: Leksikografski zavod Miroslav Krleža.

282. Rendić-Miočević, Duje. 1987. Carmina epigraphica. Split: Književni krug.

283. Rosenberg, Bruce A. 1978. „The Genres of Oral Narrative“. U: Theories of Literary Genre. Prir. Joseph P. Strelka. University Park i London: The Pennsylvania State University Press: 150-165.

284. Rosmarin, Adena. 1985. The Power of Genre. Minneapolis: University of Minnesota Press.

285. Salomon, Herman P. 1978. „Observations on the Definition, Evolution, and Separation of Genres in the Study of French Literature“. U: Theories of Literary Genre. Prir. Joseph P. Strelka. University Park i London: The Pennsylvania State University Press: 209-228. 
286. Samardžija, Marko. 1999. „Predgovor“. U: Pavao Ritter Vitezović. Izbor iz djela. Prir. Marko Samardžija. Vinkovci: Riječ: 7-12.

287. Schaeffer, Jean-Marie. 1989. „Literary Genres and Textual Genericity“. Prev. Alice Otis. U: The Future of Literary Theory. Prir. Ralph Cohen. London i New York: Routledge: 167-187.

288. Segel, Harold B. 1974. The Baroque Poem. New York: Dutton \& Co.

289. Seitel, Peter. 2012. „Three Aspects of Oral Textuality“. U: A Companion to Folklore. Prir. Regina F. Bendix i Galit Hasan-Rokem. Oxford: Wiley-Blackwell: 75-93.

290. Serdarević, Seid. 1995. „Slovački ep o Sigetu“. U: Književna smotra 27, 1: 71-78.

291. Shuman, Amy i Galit Hasan-Rokem. 2012. „The Poetics of Folklore“. U: A Companion to Folklore. Prir. Regina F. Bendix i Galit Hasan-Rokem. Oxford: WileyBlackwell: 55-74.

292. Simčič, Miha. 2008. Analiza komunikacijskih žanrov podjetniških spletnih mest. Magistarski rad. Ljubljana: Fakulteta za družbene vede.

293. Simpson, Catherine Anne. 1991. Pavao Ritter Vitezović: Defining National Identity in the Baroque Age. Doktorska disertacija. London: The School of Slavonic and East European Studies, The University of London.

294. Slamnig, Ivan. 1965. Disciplina mašte. Zagreb: Matica hrvatska.

295. Slamnig, Ivan. 1981. Hrvatska versifikacija. Zagreb: Sveučilišna naklada Liber.

296. Slavić, Dean. 2016. Biblija kao književnost. Zagreb: Školska knjiga.

297. Smičiklas, Tadija. 1879. Poviest hrvatska. Dio drugi: od godine 1526.-1848. Zagreb: Matica hrvatska.

298. Solar, Milivoj. 1971. Pitanja poetike. Zagreb: Školska knjiga.

299. Solar, Milivoj. 1996. Teorija književnosti. 17. izdanje. Zagreb: Školska knjiga.

300. Solar, Milivoj. 2011. Književni leksikon. 2. izdanje. Zagreb: Matica hrvatska.

301. Solar, Milivoj. 2014. Književnost. Vrlo kratak uvod u njezinu teoriju, povijest i kritiku. Zagreb: Politička kultura.

302. Sršen, Andreja i Davor Piskač. 2016. „Vitezović i njegov doprinos u oblikovanju hrvatskoga nacionalnoga identiteta“. U: Pavao Ritter Vitezović i njegovo doba (1652 1713). Prir. Alojz Jembrih i Ivana Jukić. Zagreb: Hrvatski studiji Sveučilišta u Zagrebu: 207-225.

303. Staiger, Emil. 1996. Temeljni pojmovi poetike. Prev. Ante Stamać. Zagreb: Ceres. 
304. Stepanić, Gorana. 2005. Hrvatsko pjesništvo na latinskom u sedamnaestom stoljeću: stilske tendencije $i$ žanrovski inventar. Doktorska disertacija. Zagreb: Filozofski fakultet Sveučilišta u Zagrebu.

305. Stepanić, Gorana. 2010. „Lica humanizma: mijene u poetici novolatinskih književnosti i pitanje njihove periodizacije“. U: Komparativna povijest hrvatske književnosti. Zbornik radova XII: „Istodobnost raznodobnog. Tekst i povijesni ritmovi“. Ur. Cvijeta Pavlović, Vinka Glunčić-Bužančić i Andrea Meyer-Fraatz. Split - Zagreb: Književni krug i Odsjek za komparativnu književnost Filozofskog fakulteta Sveučilišta u Zagrebu: 60-75.

306. Stepanić, Gorana. 2016. „Formalni eksperimenti u latinskom pjesništvu Pavla Rittera Vitezovića (1652-1713)“. U: Pavao Ritter Vitezović i njegovo doba (1652 - 1713). Prir. Alojz Jembrih i Ivana Jukić. Zagreb: Hrvatski studiji Sveučilišta u Zagrebu: 333-348.

307. Stipčević, Aleksandar. 1995. „O strukturi tiskopisa iz Vitezovićeve tiskare u Zagrebu“. U: Senjski zbornik 22: 187-190.

308. Stipčević, Aleksandar. 2003. „Knjige i knjižnice“. U: Hrvatska i Europa. Kultura, znanost i umjetnost. Svezak 3: Barok i prosvjetiteljstvo (XVII.-XVIII. stoljeće). Ur. Ivan Golub. Zagreb: Školska knjiga i HAZU: 285-296.

309. Stipčević, Aleksandar. 2005. Socijalna povijest knjige u Hrvata. Knjiga II: „Od glagoljskog prvotiska (1483) do hrvatskoga narodnog preporoda (1835)“. Zagreb: Školska knjiga.

310. Stojan, Slavica. 2015. „Poetika katastrofe - pjesnici o Velikoj trešnji 1667. godine u Dubrovniku i okolici“. U: Anali Zavoda za povijesne znanosti HAZU u Dubrovniku 53, 1: 113-148.

311. Szondi, Peter. 2001. Teorija moderne drame 1880 - 1950. Prev. Ivan Katić. Zagreb: Hrvatski centar ITI-UNESCO.

312. Šegvić, Cherubin. 1911. Kratka povijest hrvatske (srpske) književnosti od prvih početaka do god. 1900. Zagreb: Tisak i naklada Knjižare L. Hartmana (St. Kugli).

313. Šenoa, August. 1876. Antologija pjesničtva hrvatskoga i srbskoga. Zagreb: Matica hrvatska.

314. Šenoa, August. 1879. „Hrvatske novine u stihovih“. U: Vienac: zabava i pouci 11, 45: 719-720 (1. dio) i 46: 738-739 (2. dio).

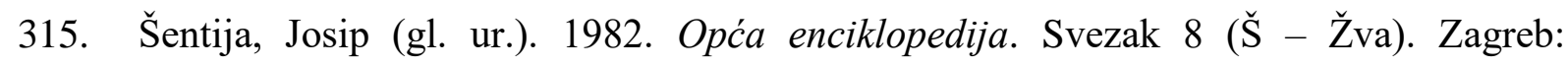
Jugoslavenski leksikografski zavod.

316. Šimundža, Drago. 2010. „Književni rodovi i vrste u Bibliji“. U: Biblija - knjiga Mediterana par excellence. Ur. Marijan Vugdelija. Split: Književni krug: 279-296. 
317. Škopljanac, Lovro. 2015. „Sižejna izgradnja poeme u starijoj hrvatskoj književnosti““. U: Komparativna povijest hrvatske književnosti. Zbornik radova XVII: „Poema u hrvatskoj književnosti: problem kontinuiteta“. Ur. Cvijeta Pavlović, Vinka GlunčićBužančić i Andrea Meyer-Fraatz. Split - Zagreb: Književni krug i Odsjek za komparativnu književnost Filozofskog fakulteta Sveučilišta u Zagrebu: 34-45.

318. Škreb, Zdenko. 1976. Studij književnosti. Zagreb: Školska knjiga.

319. ŠKkreb, Zdenko. 1982. „Književna vrsta“. U: Umjetnost riječi 26, 1-2: 85-90.

320. Škreb, Zdenko. 1985. „O problemu osnovne sheme podjele na rodove i vrste“. U: Književna kritika 16, 5: 11-21.

321. Šojat, Olga (prir.). 1977a. Hrvatski kajkavski pisci. Knjiga I: „Druga polovina 16. stoljeća“. PSHK 15. Zagreb: Matica hrvatska i Zora.

322. Šojat, Olga (prir.). 1977b. Hrvatski kajkavski pisci. Knjiga II: „17. stoljeće“. PSHK 15. Zagreb: Matica hrvatska i Zora.

323. Šrepel, Milivoj. 1902. „Sigetski junak u povijesti hrvatskoga pjesništva“. U: Rad JAZU 148: 81-173.

324. Šundalić, Zlata. 2002. „Sekundarni žanr(ovi) u Marulićevoj Juditi“. U: Colloquia Maruliana 11: 57-82.

325. Šundalić, Zlata. 2005. „Čime se poigrava Gazarović u Muratu gusaru“. U: Dani Hvarskoga kazališta. Knjiga 31: „Igra i svečanost u hrvatskoj književnosti i kazalištu“. Ur. Nikola Batušić i sur. Zagreb - Split: Hrvatska akademija znanosti i umjetnosti i Književni krug: 34-61.

326. Šundalić, Zlata i Anela Mateljak Popić. 2018. „Jeka - o jednom rubnom motivu u staroj hrvatskoj književnosti““. U: Anafora 5, 1: 21-63.

327. Šurmin, Đuro. 1898. Povjest književnosti hrvatske i srpske. Zagreb: Knjižara Lav. Hartmanna (Kugli i Deutsch).

328. Šurmin, Đuro. 1902. „Bilješke za literarnu istoriju i bibliografiju“. U: Nastavni vjesnik 10: 531-538.

329. Švelec, Franjo. 1974. „Hrvatska književnost sedamnaestog stoljeća“. U: Povijest hrvatske književnosti. Knjiga 3. Zagreb: Liber i Mladost: 175-292.

330. Švelec, Franjo. 1990. Iz naše književne prošlosti. Split: Književni krug.

331. Švelec, Franjo. 2002. „Barne Karnarutič“. U: Petar Zoranić, Barne Karnarutić i Šime Budinić. Planine / Djela / Izabrana djela. Prir. Franjo Švelec. SHK. Zagreb: Matica hrvatska: 197-213. 
332. Teskey, Gordon. 2012. „Allegory“. U: The Princeton Encyclopedia of Poetry and Poetics. Prir. Roland Greene i Stephen Cushman. 4. izdanje. Princeton i Oxford: Princeton University Press: 37-40.

333. Todorov, Tzvetan. 1987. Uvod u fantastičnu književnost. Prev. Aleksandra MančićMilić. Beograd: Rad.

334. Todorov, Tzvetan. 1990. Genres in Discourse. Prev. Catherine Porter. Cambridge: Cambridge University Press.

335. Tomašić, Josipa. 2015. „Recipijenti pučke književnosti kao polazište za razumijevanje pučke poetike“. U: Narodna umjetnost 52, 2: 179-194.

336. Turković, Hrvoje. 2010. Nacrt filmske genologije. Zagreb: Matica hrvatska.

337. Tvorić, Alojzija. 2013. Žene autorice i čitateljice hrvatskih molitvenika od 16. do 19. stoljeća. Doktorska disertacija. Zagreb: Filozofski fakultet Sveučilišta u Zagrebu.

338. Ujević, Mate. 2009. Hrvatska književnost. Pregled hrvatskih pisaca i knjiga. 2. izdanje. Zagreb: Ex libris.

339. Ušković Croata, Petar. 2015. „Musae alumnus Illyricae. Lik i djelo Pavla Rittera Vitezovića“". U: Pavao Ritter Vitezović. Vita et martyrium beati Vladimiri Croatiae regis (Život $i$ mučeništvo hrvatskog kralja blaženog Vladimira). Prir. Petar Ušković Croata. Zagreb: Biakova: 7-13.

340. Užarević, Josip. 2012. Književni minimalizam. Zagreb: Disput.

341. Vajs, Nada i Zrnka Meštrović. 2009. „Pavao Ritter Vitezović - čovjek ispred svojega vremena“. U: Pavao Ritter Vitezović. Lexicon Latino-Illyricum. Svezak treći: hrvatskolatinski rječnik. Prir. Nada Vajs i Zrnka Meštrović. Zagreb: ArTresor naklada i Institut za hrvatski jezik i jezikoslovlje: V-LXIII.

342. Valentić, Mirko. 2002. „Hrvatska u vrijeme Pavla Vitezovića“. U: Forum 41, 10-12: 1167-1172.

343. Vanino, Miroslav. 1969. Isusovci i hrvatski narod. Knjiga I: „Rad u XVI. stoljeću. Zagrebački kolegij“. Zagreb: Filozofsko-teološki institut Družbe Isusove.

344. Vaupotić, Miroslav. 1969. „Sigetski junak u novijoj hrvatskoj književnosti (kratki povijesni pregled)“. U: Revija 9, 2: 44-62.

345. Veljković, Momir i Miloš Savković. 1932. Jugoslovenska književnost. Prvi deo: „Srednji vek. Renesansa i reformacija. Katolička reakcija. Pećka patrijaršija. Prelazno doba“. Beograd: Zadruga Profesorskog društva.

346. Vodnik, Branko. 1913. Povijest hrvatske književnosti. Knjiga I: „Od humanizma do potkraj XVIII. stoljeća“. Zagreb: Matica hrvatska. 
347. Vončina, Josip. 1968. „Ozaljski jezično-književni krug“. U: Zbornik radova Zavoda za slavensku filologiju 10: 195-205.

348. Vončina, Josip. 1973. „Jezični razvoj ozaljskoga kruga“. U: Filologija 7: 203-237.

349. Vončina, Josip. 1976a. „Pavao Ritter Vitezović“. U: Petar Zrinski, Fran Krsto Frankopan i Pavao Ritter Vitezović. Izabrana djela. Prir. Josip Vončina. PSHK 17. Zagreb: Zora i Matica hrvatska: 337-351.

350. Vončina, Josip. 1976b. „Petar Zrinski“. U: Petar Zrinski, Fran Krsto Frankopan i Pavao Ritter Vitezović. Izabrana djela. Prir. Josip Vončina. PSHK 17. Zagreb: Zora i Matica hrvatska: 7-20.

351. Vončina, Josip. 1977. Analize starih hrvatskih pisaca. Split: Čakavski sabor.

352. Vončina, Josip. 1986. „O jezičnim kontaktima u Karnarutićevu Vazetju Sigeta grada“. U: Zadarska revija 35, 2: 119-127.

353. Vončina, Josip. 1988. Jezična baština. Split: Književni krug.

354. Warnke, Frank J. 1972. Versions of Baroque. New Haven i London: Yale University Press.

355. Wellek, René i Austin Warren. 1974. Teorija književnosti. Prev. Aleksandar I. Spasić i Slobodan Đorđević. Beograd: Nolit.

356. Winner, Thomas G. 1978. „Structural and Semiotic Genre Theory“. U: Theories of Literary Genre. Prir. Joseph P. Strelka. University Park i London: The Pennsylvania State University Press: 254-268.

357. Zečević, Divna. 1972. „Odjek pogibije Petra Zrinskoga i Frana Krste Frankopana u pučkim pjesmama njihova doba“". U: Narodna umjetnost 9, 1: 41-54.

358. Zečević, Divna. 1978. „Pučki književni fenomen“. U: Povijest hrvatske književnosti. Knjiga 1. Zagreb: Liber i Mladost: 357-638.

359. Zlatar, Andrea. 2010. „Alegorija“. U: Hrvatska književna enciklopedija. Svezak 1: AGl. Gl. ur. Velimir Visković. Zagreb: Leksikografski zavod Miroslav Krleža: 13-14.

360. Zvonar, Ivan. 2008. „Dva neposredna viđenja Sigetske tragedije (u povodu 500. obljetnice rođenja Nikole Zrinskoga Sigetskog)“. U: Gazophylacium 13, 1-2: 21-39.

361. Zvonar, Ivan. 2016. „Sigetska tragedija u očima jednog komornika i jednog vojnika (U povodu 450. obljetnice opsade i pada Sigeta)“. U: Kaj 49, 5-6: 57-81.

362. Živković, Dragiša (gl. ur.). 1986. Rečnik književnih termina. Beograd: Nolit. 


\section{ŽIVOTOPIS AUTORA}

Vanja Budišćak rođen je 1988. u Zagrebu, gdje je i završio osnovnu i srednju ekonomsku školu. 2006. upisuje jednopredmetni preddiplomski, a tri godine kasnije i diplomski Studij komparativne književnosti na Filozofskom fakultetu Sveučilišta u Zagrebu, na kojemu 2011. stječe diplomu obranivši rad na temu Impresionizam u poeziji Dragutina Domjanića. Iste je godine upisao i Poslijediplomski doktorski studij hrvatske kulture, u sklopu kojega i radi na disertaciji posvećenoj žanrovskim posebnostima Vitezovićeva Odiljenja sigetskog. Dosad je objavio niz znanstvenih i drugih tekstova u raznim domaćim časopisima te sudjelovao na nekoliko domaćih stručnih skupova. U svome znanstvenom radu ponajviše je zaokupljen poredbenom poviješću (rano)novovjekovne hrvatske književnosti, međuodnosom pisane, usmene i pučke književnosti te suvremenim teorijama (književnih) žanrova. Trenutno je zaposlen u Zavodu za povijest hrvatske književnosti, kazališta i glazbe Hrvatske akademije znanosti i umjetnosti. Član je Kajkavskoga spravišča te Matice hrvatske.

\section{POPIS JAVNO OBJAVLJENIH RADOVA}

\section{ZNANSTVENI RADOVI U ČASOPISIMA:}

Budišćak, Vanja. 2019. „Poslovice u Vitezovićevu Odiljenju sigetskom“. U: Narodna umjetnost 56, 2: 143-155.

Budišćak, Vanja. 2016. „Privatni verlibrizam: slobodni stih u Benešićevim Istrgnutim listovima“. U: Forum 55, 4-6: 592-615.

Budišćak, Vanja. 2016. „Treće Vitezovićevo izdanje Odiljenja sigetskog (1695.)“. U: Kaj 49, 5-6: 82-104.

Budišćak, Vanja. 2015. „Pučka kao popularna književnost: teorijsko razmatranje“. U: Jat 2, 2: 154-169.

Budišćak, Vanja. 2014. „Impresionizam u Matoševu pjesništvu“. U: Kolo 24, 3: 77-89.

Budišćak, Vanja. 2014. „San Edipova buđenja: incest i ženskost u Begovićevoj Myrrhi“. U: Fluminensia 26, 1: 59-71.

Budišćak, Vanja. 2013. „Impresionistički epiteti u pjesništvu Dragutina Domjanića“. U: Kaj 46, 3: 19-43.

Budišćak, Vanja. 2013. „Lica u suncu i lica u sjeni: lirski subjekt u pjesništvu Dragutina Domjanića“. U: Umjetnost riječi 57, 3-4: 249-271. 
Budišćak, Vanja. 2013. „Pesme horvatske Katarine Patačić: rokoko na domače“. U: Kaj 46, 4-5: 39-65.

Budišćak, Vanja. 2013. „Poganska sila: slika Turaka u Vitezovićevu Odiljenju sigetskom“. U: Senjski zbornik 40: 343-362.

Budišćak, Vanja. 2012. „Što je Matošu Mòra?“. U: Balkan Express 4, 5: 17-37.

\section{RADOVI U ZBORNICIMA SA ZNANSTVENIH SKUPOVA:}

Budišćak, Vanja. 2016. „Matošev (proto)ekspresionizam“. U: Šesti hrvatski slavistički kongres: zbornik radova. Prvi svezak. Prir. Stipe Botica, Davor Nikolić, Josipa Tomašić i Ivana Vidović Bolt. Zagreb: Hrvatsko filološko društvo: 451-457.

Budišćak, Vanja. 2016. „Tamo gdje putovi staju: Vitezovićevo Odiljenje sigetsko“. U: Pavao Ritter Vitezović i njegovo doba (1652-1713). Prir. Alojz Jembrih i Ivana Jukić. Zagreb: Hrvatski studiji Sveučilišta u Zagrebu: 263-278.

\section{PRIKAZI:}

Budišćak, Vanja. 2016. „Kritičko izdanje Vitezovićeve Kronike“. U: Kolo 26, 1: 202-206.

Budišćak, Vanja. 2016. „Put koji treba slijediti“. U: Marulić 49, 3: 143-147.

Budišćak, Vanja. 2016. „Štokavskije čitanje barda kajkavske poezije“. U: Kaj 49, 3-4: 139141.

Budišćak, Vanja. 2016. „Tradicija koja se nastavlja“. U: Kaj 49, 1-2: 129-130.

Budišćak, Vanja. 2016. „Zrinka Blažević, Prevođenje povijesti. Teorijski obrati i suvremena historijska znanost (Zagreb: Srednja Europa, 2014), 192 str.“. U: Časopis za suvremenu povijest 48, 1: 225-227.

Budišćak, Vanja. 2015. „Izvrsna knjiga kazališnih sjećanja“. U: Kolo 25, 1: 220-224.

Budišćak, Vanja. 2014. „'Alka je vječna, mi smo prolazni'“. U: Mogućnosti 61, 4-6: 158-160.

Budišćak, Vanja. 2014. „Oživljeni Vitezović“. U: Marulić 47, 5-6: 207-211.

Budišćak, Vanja. 2014. „Povratak usmenoj književnosti““. U: Marulić 47, 1-2: 185-188. 


\section{POPULARNI RADOVI:}

Budišćak, Vanja. 2013. „Dečko s periferije. Što je nama danas Pavao Ritter Vitezović?“،. U: Zarez 15, 356 (11. travnja): 36-37.

Budišćak, Vanja. 2013. „Samo popevke, molim!“. U: Zarez 15, 363-364 (18. srpnja): 48-49.

Budišćak, Vanja. 2013. „Više od kajkavskog pjesnika“. U: Vijenac 21, 505-507 (11. srpnja): 21.

\section{SUDJELOVANJA NA ZNANSTVENIM SKUPOVIMA:}

Sedmi hrvatski slavistički kongres. Domaći znanstveni skup. Šibenik: Hrvatsko filološko društvo. 25. 09. 2019. - 28. 09. 2019. (Usmeno priopćenje: „Mediteranske značajke Vitezovićeva Odiljenja sigetskog“)

1. znanstveni susreti na Sjeveru: Jezik književnosti, znanosti $i$ medija. Međunarodni znanstveni skup. Koprivnica: Sveučilište Sjever, 21. 10. 2016. - 22. 10. 2016. (Usmeno priopćenje: „Poslovice u Vitezovićevu Odiljenju sigetskom“)

Šesti hrvatski slavistički kongres. Domaći znanstveni skup. Vukovar i Vinkovci: Hrvatsko filološko društvo, 10. 09. 2014. - 13. 09. 2014. (Usmeno priopćenje: „Matošev (proto)ekspresionizam")

Znanstveno-stručni skup o Antunu Gustavu Matošu. Domaći znanstveni skup. Zagreb: Matica hrvatska, 13. 06. 2014. - 13. 06. 2014. (Usmeno priopćenje: „Impresionizam u Matoševu pjesništvu")

Treća međunarodna kroatološka konferencija: Pavao Ritter Vitezović i njegovo doba. Međunarodni znanstveni skup. Zagreb: Hrvatski studiji Sveučilišta u Zagrebu, 26. 09. 2013. 28. 09. 2013. (Usmeno priopćenje: „Tamo gdje putovi staju: Vitezovićevo Odiljenje sigetsko") 